


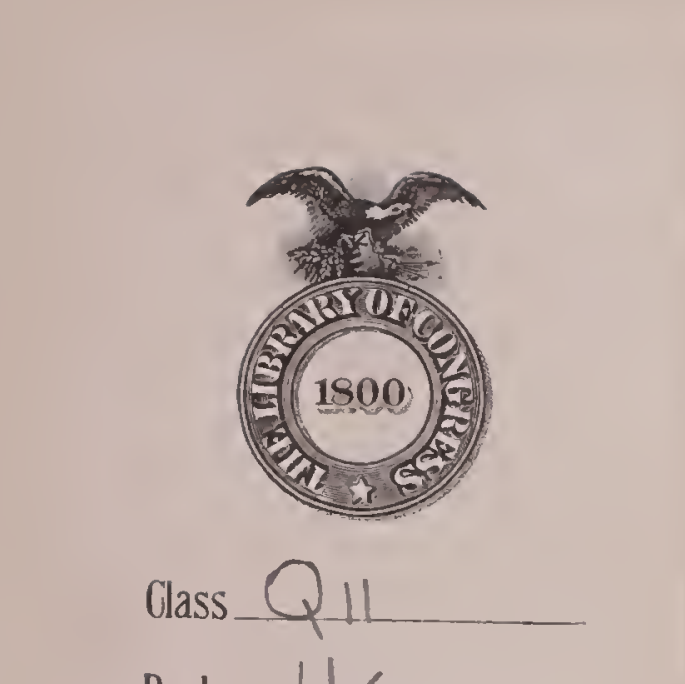






SMITHSONLAN INSTITUTION

UNITED STATES NATIONAL MUSEUM

Bulletin 125

\title{
NORTH AMERICAN LATER TERTIARY AND QUATERNARY BRYOZOA
}

\author{
BY \\ FERDINAND CANU \\ Versailles, France \\ AND \\ RAY S. BASSLER \\ Washington, District of Columbia
}

$25-26786$

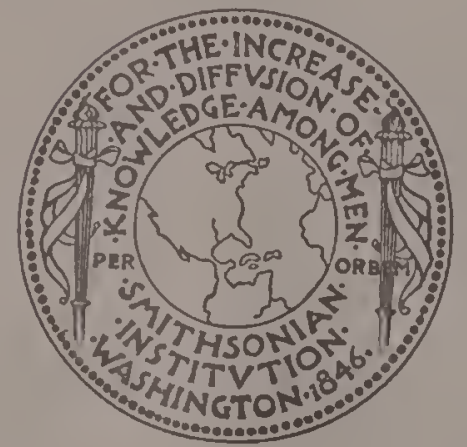

WASHINGTON

GOVERNMENT PRINTING OFFICE 1923 

SMITHSONIAN INSTITUTION

UNITED STATES NATIONAL MUSEUM

Bulletin 125

\title{
NORTH AMERICAN LATER TERTIARY AND QUATERNARY BRYOZOA
}

\author{
BY \\ FERDINAND $\mathrm{CANL}_{3 \mathrm{i}}$ \\ Versailles, France \\ AND \\ RAY S. BASSLER \\ Washington, Distlict of Columbia
}

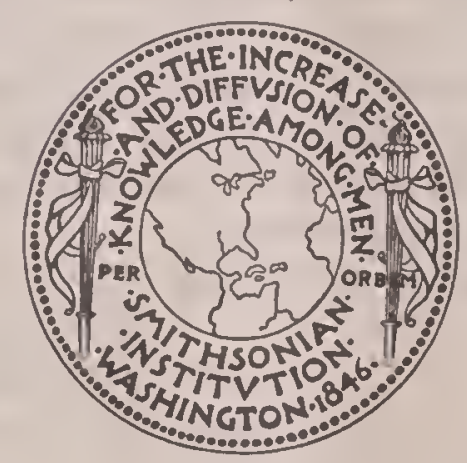

WASHINGTO:

GOVERNMENT PRINTING OFFICE 


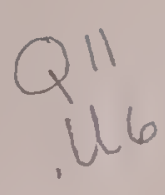

\section{ADVERTISEMENT.}

The scientific publications of the United States National Museum consist of two series, the Proceedings. and the Bulletins.

The Proceedings, the first volume of which was issued in 1S7S, are intended primarily as a medium for the publication of original, and usually brief, papers based on the collections of the National Museum, presenting newly-acquired facts in zoology, geology, and anthropology, including descriptions of new forms of animals, and revisions of limited groups. One or two volumes are issued annually and distributed to libraries and scientific organizations. A limited number of copies of each paper, in pamphlet form, is distributed to specialists and others interested in the different subjects as soon as printed. The date of publication is printed on each paper, and these dates are also recorded in the tables of contents of the volumes.

The Bulletins, the first of which was issued in 1S75, consist of a series of separate publications comprising chiefly monographs of large zoological groups and other general systematic treatises (occasionally in several volumes), faunal works, reports of expeditions, and catalogues of type-specimens, special collections, etc. The majority of the volumes are octavos, but a quarto size has been adopted in a few instances in which large plates were regarded as indispensable.

Since 1902 a series of octavo volumes containing papers relating to the botanical collections of the Museum, and known as the Contributions from the National Herbarium, has been published as bulletins.

The present work forms No. 125 of the Bulletin series.

William deC. Ravenel, Administrative Assistant to the Secretary, In charge of the United States National Museum.

Washington, D. C., May 14, 1923.

II

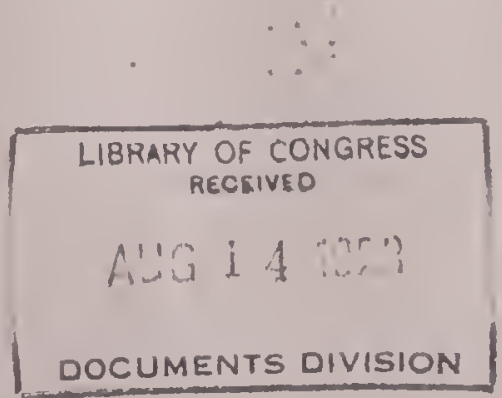




\section{TABLE OF CONTENTS.}

Page.

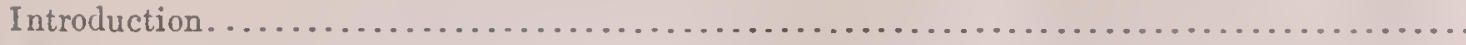

Catalogue of papers of American Later Tertiary and Quaternary Bryozoa..................

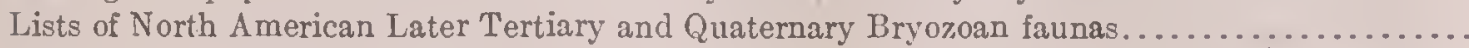

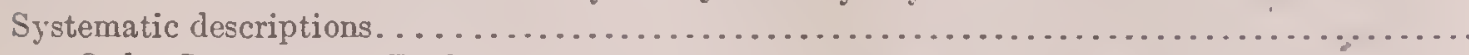

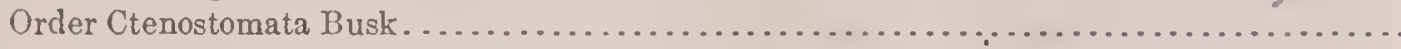

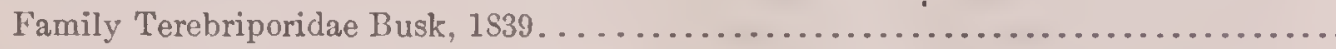

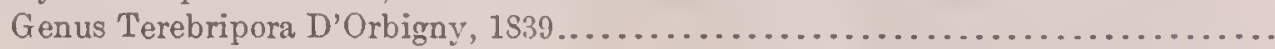

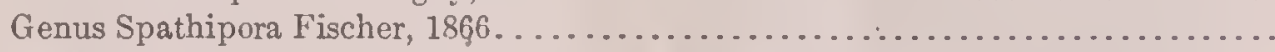

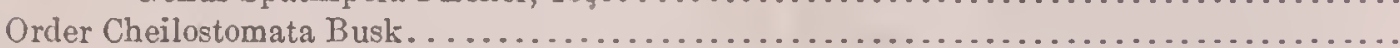

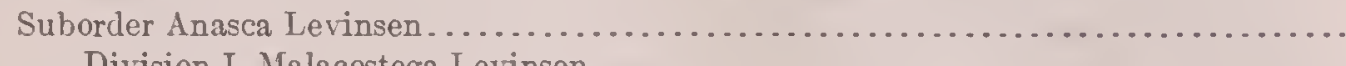

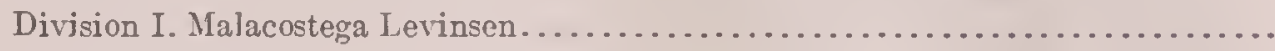

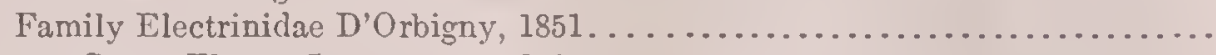

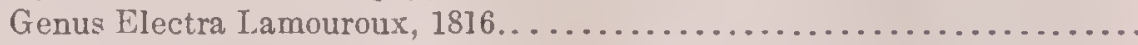

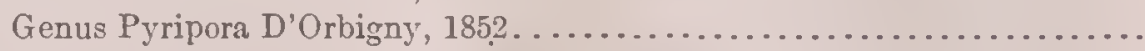

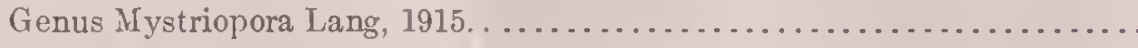

Genus Membranipora Blainville, $1834 \ldots \ldots \ldots \ldots \ldots \ldots \ldots \ldots \ldots \ldots \ldots . . . \ldots \ldots$

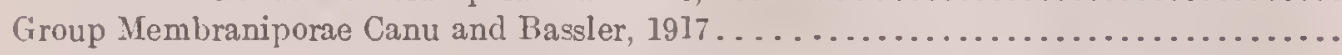

Section I. No ovicell. . . . . . . . . . . . . . . . . . . . . . . . . . . . . . . .

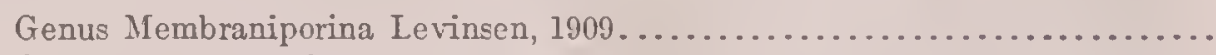

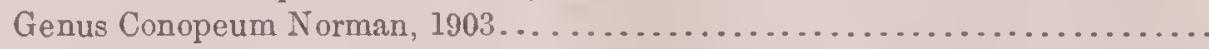

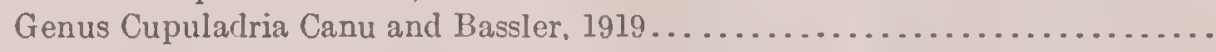

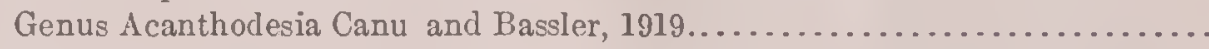

Section II. Membraniporae with endozooecial ovicell. . . . . . . . . . . . . . . . .

Genus Vibracellina Canu and Bassler, $1917 \ldots \ldots \ldots \ldots \ldots \ldots \ldots \ldots \ldots \ldots \ldots \ldots \ldots \ldots \ldots$

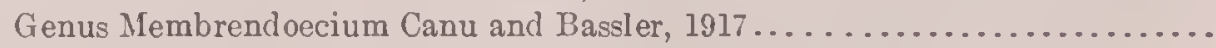

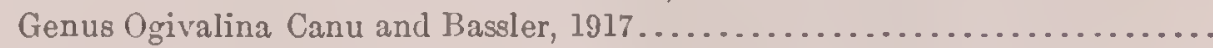

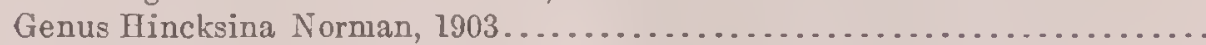

Section III. Ovicell hyperstomial, al ways closed by the operculum. . . . . . . . .

Genus Membraniporidra Canu and Bassler, $1917 \ldots \ldots \ldots \ldots \ldots \ldots \ldots \ldots \ldots$

Section IV. Oricell never closed by the operculum.....................

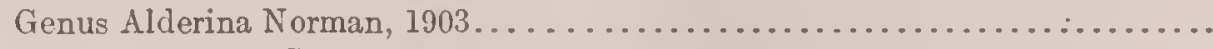

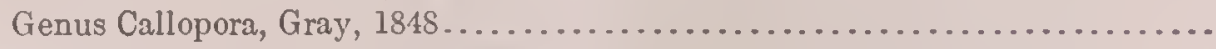

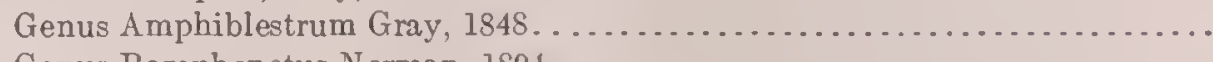

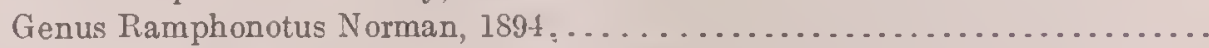

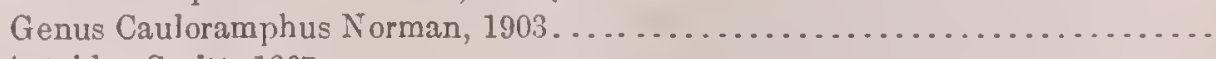

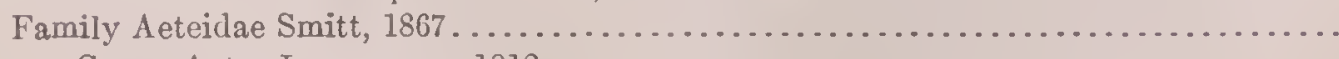

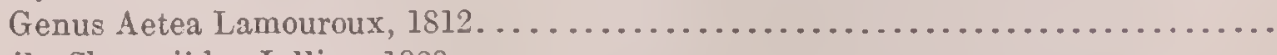

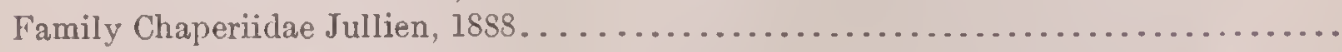

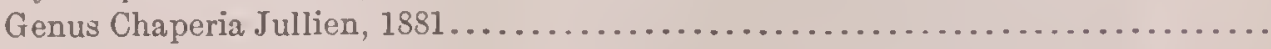

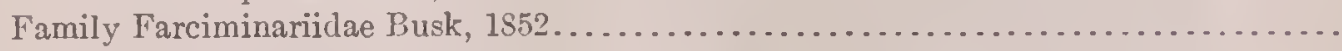

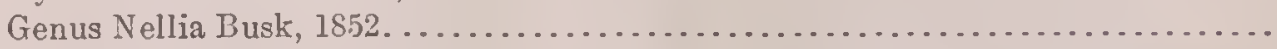

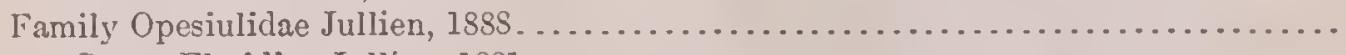

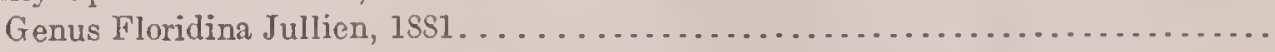

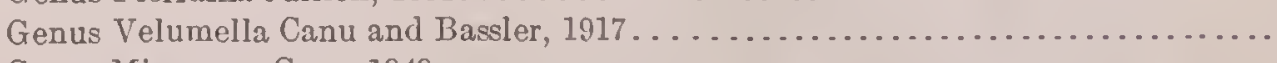

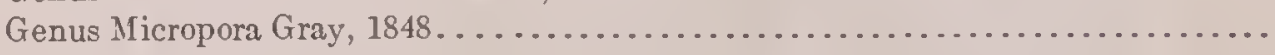

Genus Selenaria Busk, 1854 . 
Systc matic descriptions-Continucd .

Order Chcilostomata Busk-Continued.

Page.

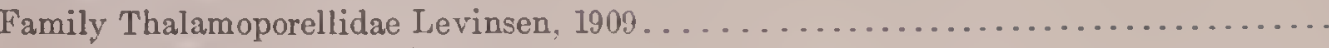

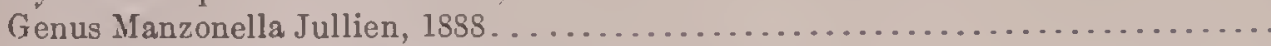

Genus Woodipora Jullien, 18ss. . . . . . . . . . . . . . . . . . . . . . . . .

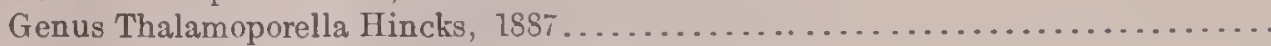

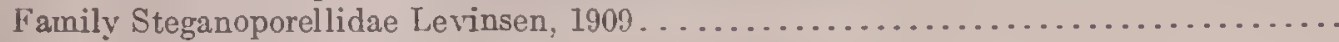

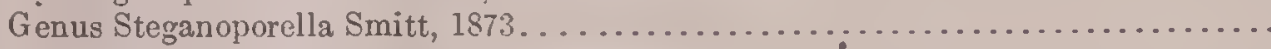

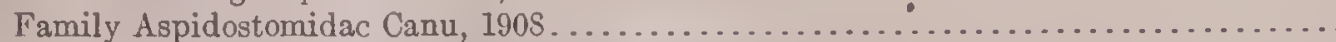

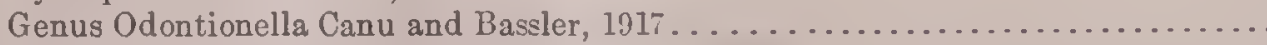

Genus Foraminella Levinsen, 1909. . . . . . . . . . . . . . . . . . . . . . . .

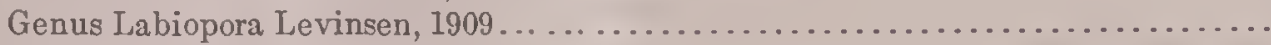

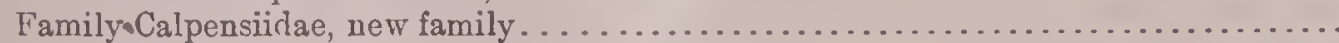

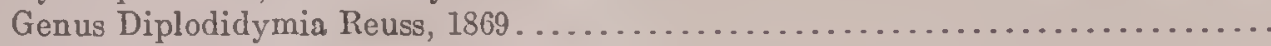

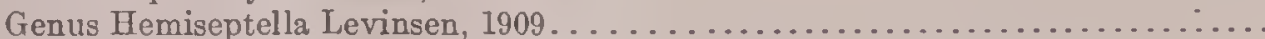

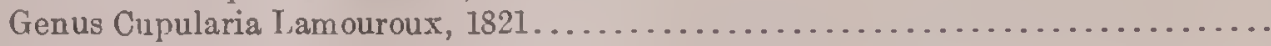

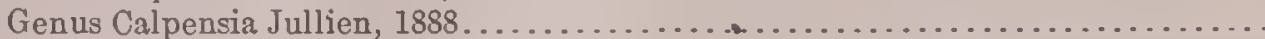

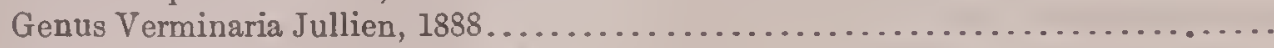

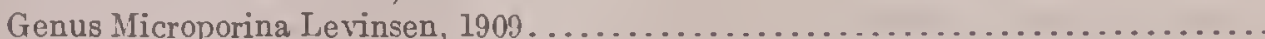

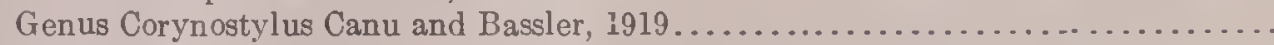

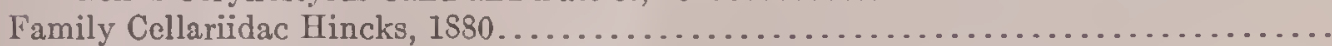

Genus Cellaria Authors. . . . . . . . . . . . . . . . . . . . . . . . . . . . . .

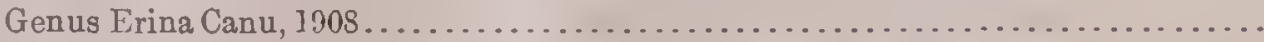

Genus Melicerita Milne-Edwards, $1836 \ldots \ldots \ldots \ldots \ldots \ldots \ldots \ldots \ldots \ldots \ldots \ldots$

Genus Euginoma Jullien, $1882 \ldots \ldots \ldots \ldots \ldots \ldots \ldots \ldots \ldots \ldots \ldots \ldots \ldots \ldots \ldots \ldots \ldots \ldots$

The Costulae (Family Cribrilinidae Hincks, 18s0) . . . . . . . . . . . . . . . . .

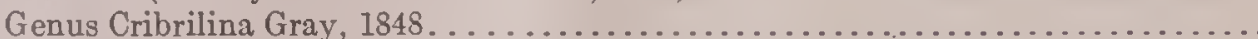

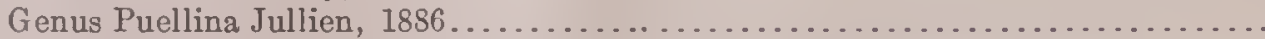

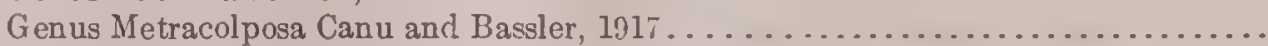

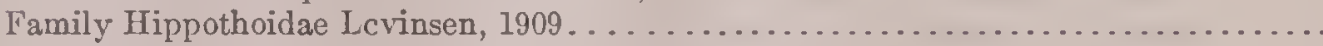

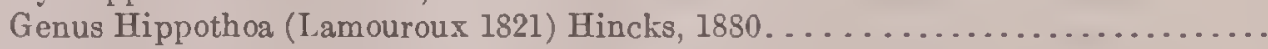

Genus Trypostega Levinsen, $1909 . \ldots \ldots \ldots \ldots \ldots \ldots \ldots \ldots \ldots \ldots \ldots \ldots . . . \ldots$

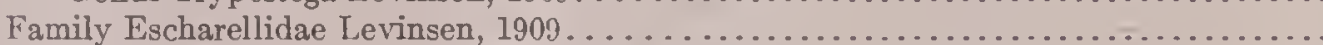

Group 1. Schizoporellae Canu and Bassler, 1917.......................

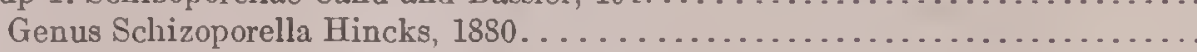

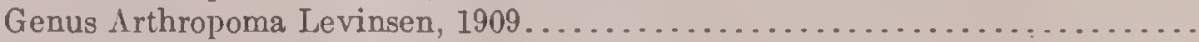

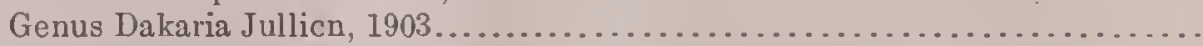

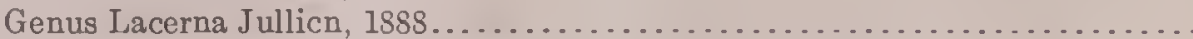

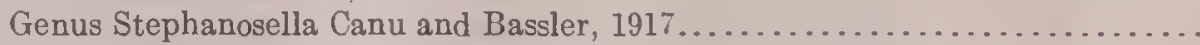

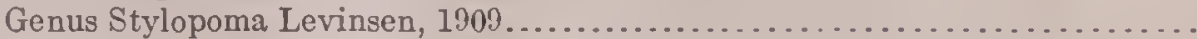

Genus Schizopodrella Canu and Bassler, 1917.......................

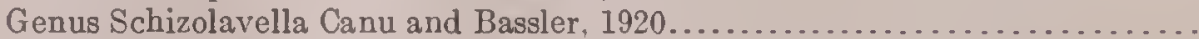

Genus Schizomavella Canu and Bassler, 1920.......................

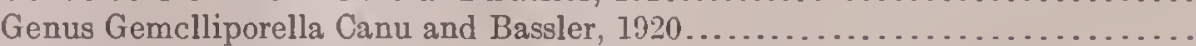

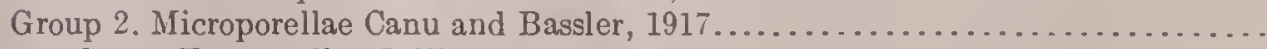
Genus Fenestrulina Jullien, $1888 \ldots \ldots \ldots \ldots \ldots \ldots \ldots \ldots \ldots \ldots \ldots \ldots \ldots$

Genus Microporella Hincks, $1877 \ldots \ldots \ldots \ldots \ldots \ldots \ldots \ldots \ldots \ldots \ldots \ldots \ldots \ldots . . . \ldots \ldots$

Genus Diporula Hincks, $1879 . \ldots \ldots \ldots \ldots \ldots \ldots \ldots \ldots \ldots \ldots \ldots \ldots \ldots \ldots . \ldots \ldots \ldots$

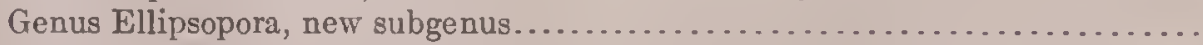

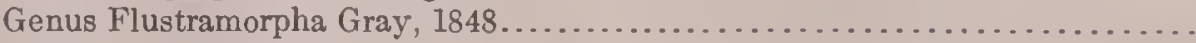

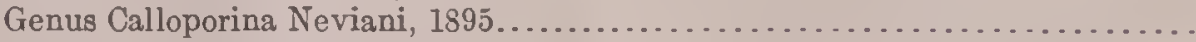

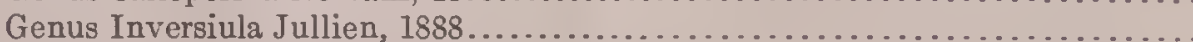

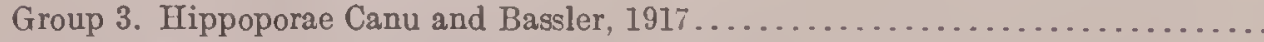

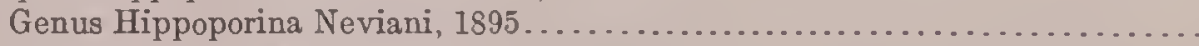

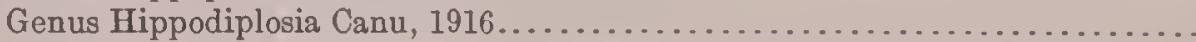

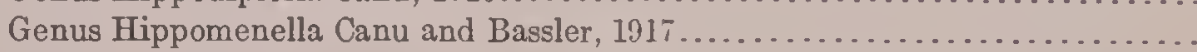

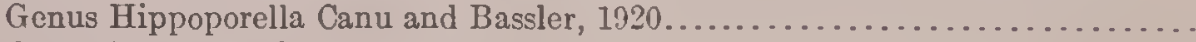

Genus Lepralia Jolınston, 1847

60

60

61

61

62

$6 ?$

61

64 
Systematic descriptions-Continued.

Order Cheilostomata Busk-Continued.

Family Escharellidae Levinsen, 1909-Continued.

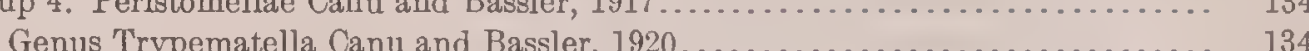

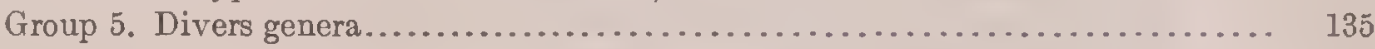

Genus Cyclocolposa Canu and Bassler, 1920.......................... 135

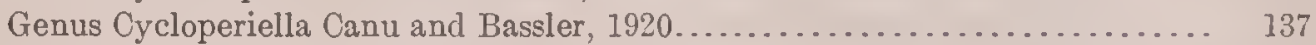

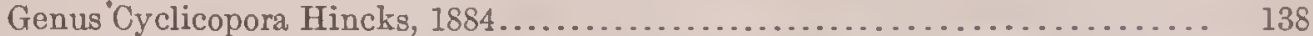

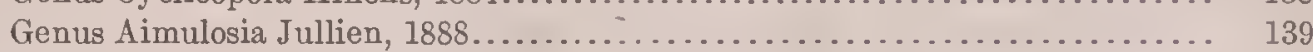

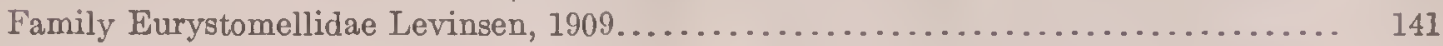

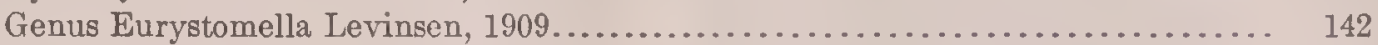

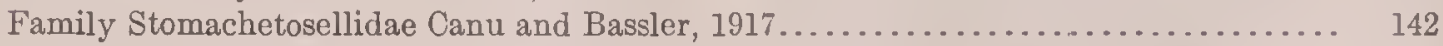

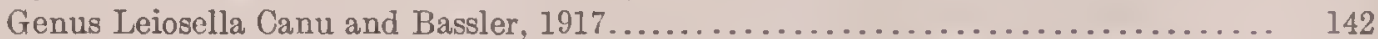

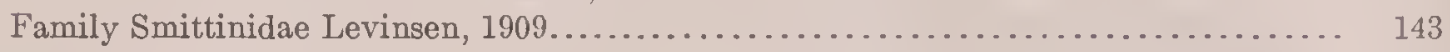

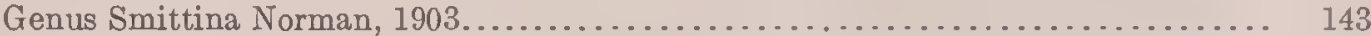

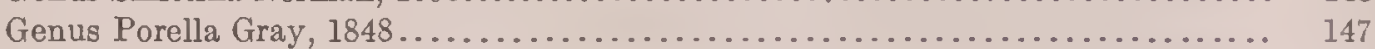

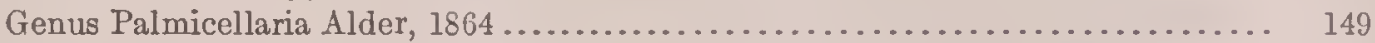

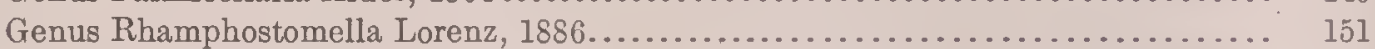

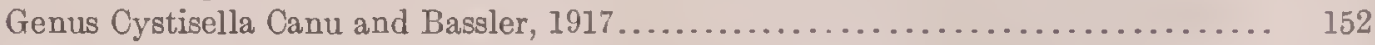

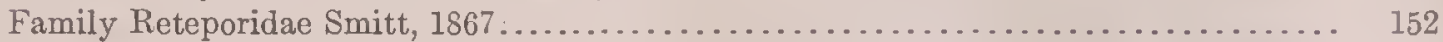

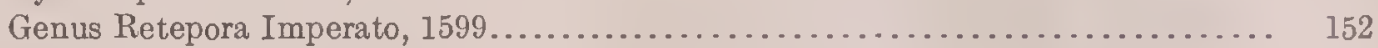

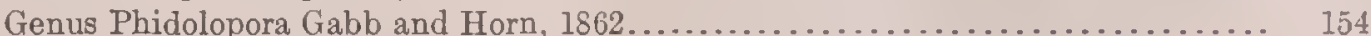

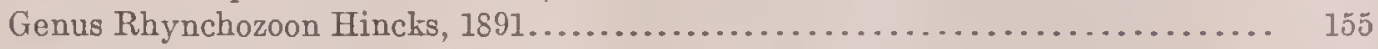

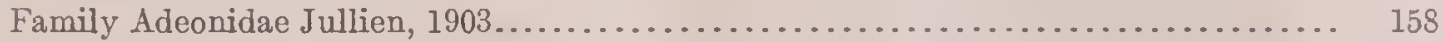

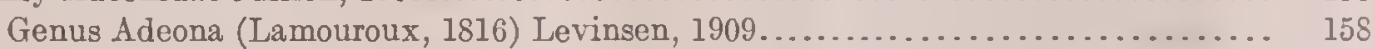

Genus Bracebridgia MacGillivray, $1886 \ldots \ldots \ldots \ldots \ldots \ldots \ldots \ldots \ldots \ldots \ldots \ldots . . \ldots \ldots$

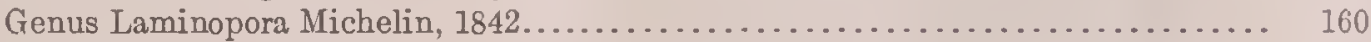

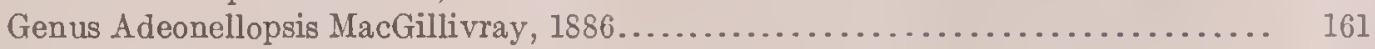

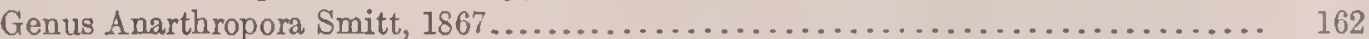

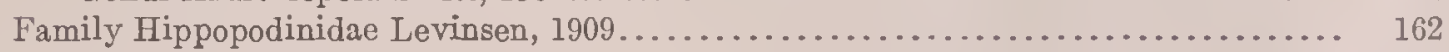

Genus Metrarabdotos Canu, 1914.................................... 162

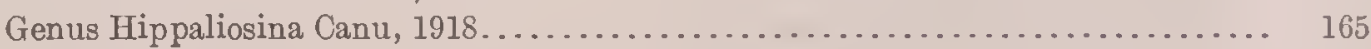

Genus Tremogasterina Canu, $1911 \ldots \ldots \ldots \ldots \ldots \ldots \ldots \ldots \ldots \ldots \ldots \ldots \ldots \ldots \ldots \ldots \ldots \ldots$

Genus Cheiloporina, new genus..................................... 168

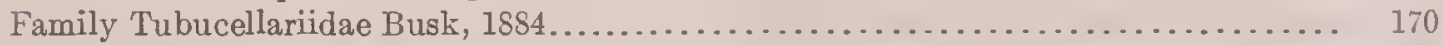

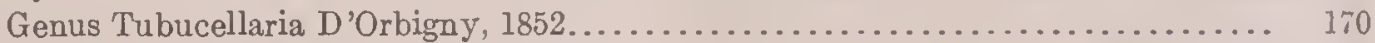

Family Phylactellidae Canu and Bassler, 1917......................... 170

Genus Phylactella Hincks, $1880 \ldots \ldots \ldots \ldots \ldots \ldots \ldots \ldots \ldots \ldots \ldots \ldots \ldots . . . \ldots \ldots$

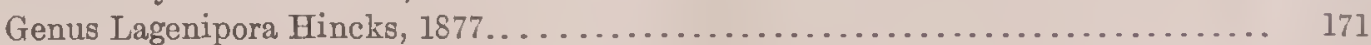

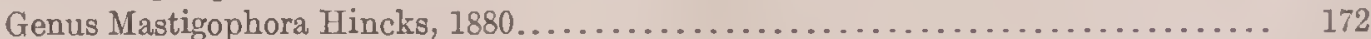

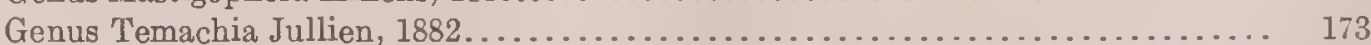

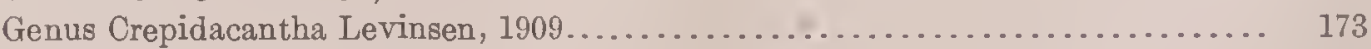

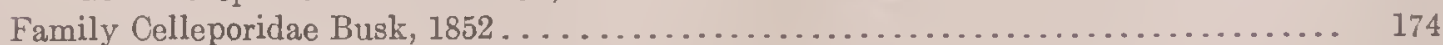

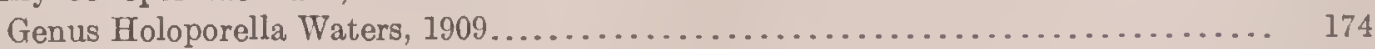

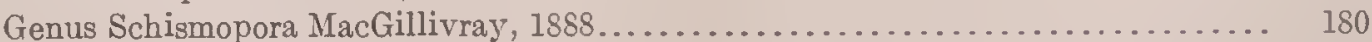

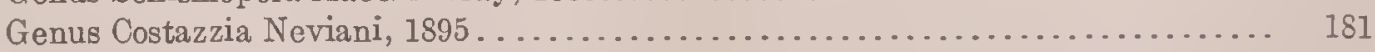

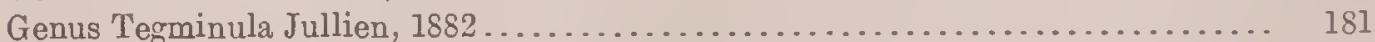

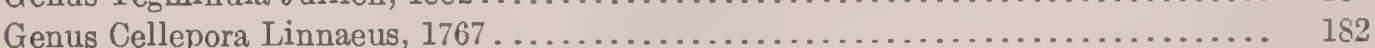

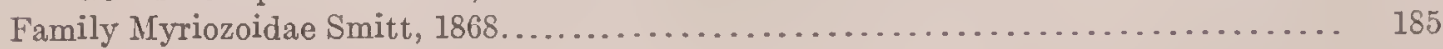

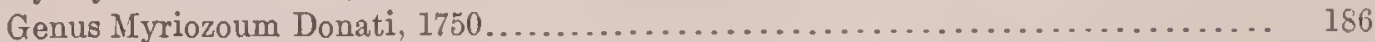

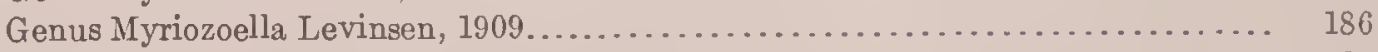

Family Orbituliporidae, new family ................................... 186

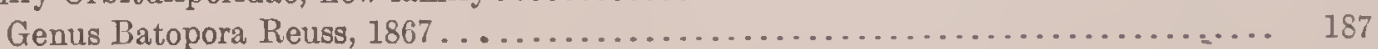

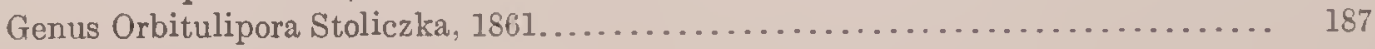


Systematic descriptions-Continued.

Order Cheilostomata Busk-Continued.

Family Orbituliporidae, new family-Continued. Page.

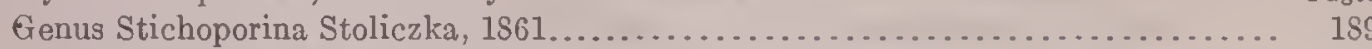

Genus Sphaerophora Haswell, 1881............................... 190

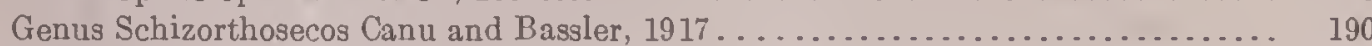

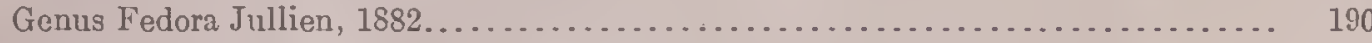

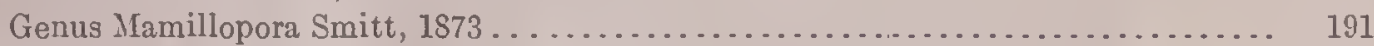

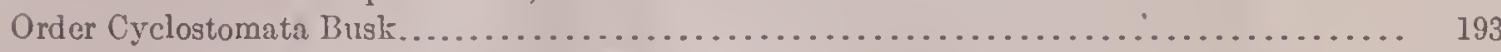

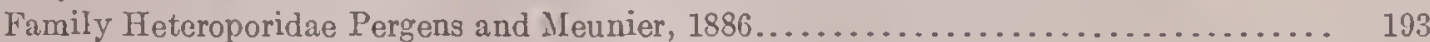

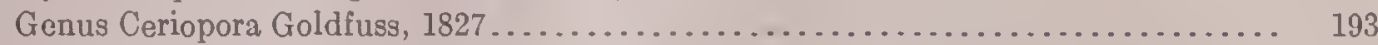

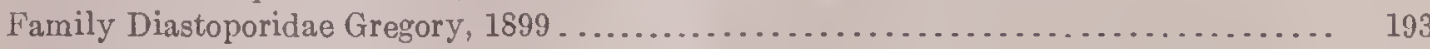

Genus Proboscina Audouin, 1826 ................................... 193

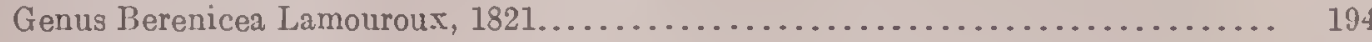

Genus Ätelesopora, new genus.................................. 194

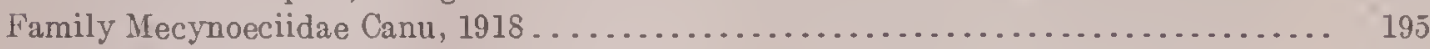

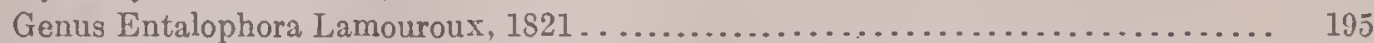

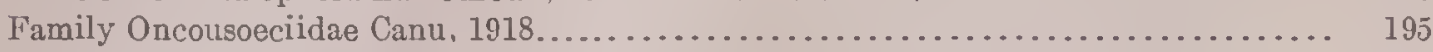

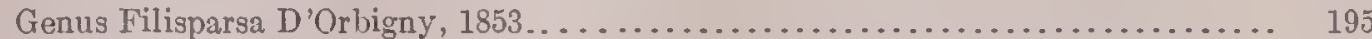

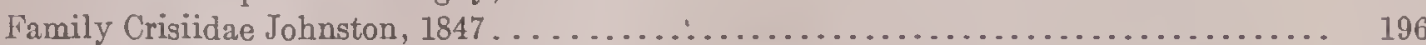

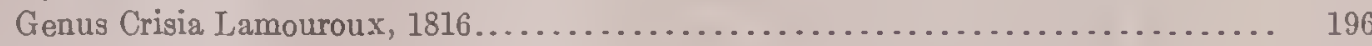

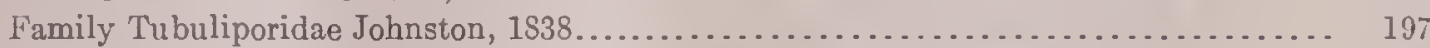

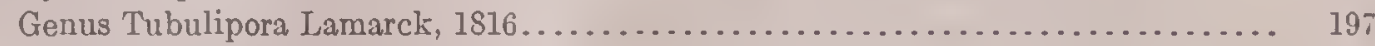

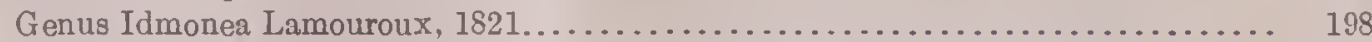

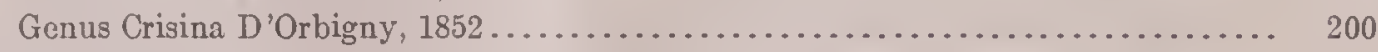

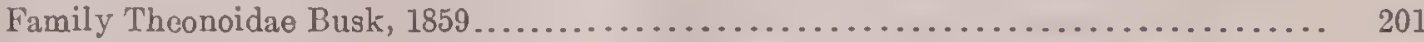

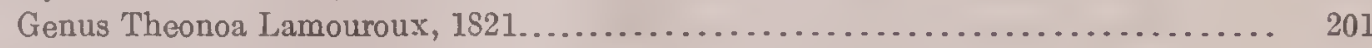

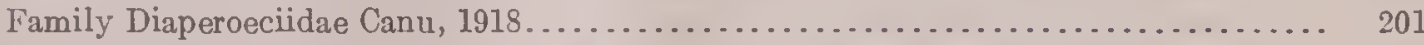

Genus Stathmepora Canu and Bassler, 1922........................... 201

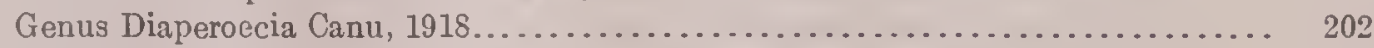

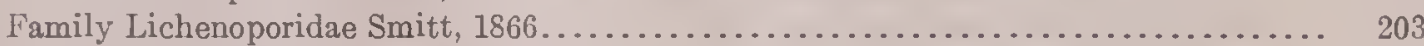

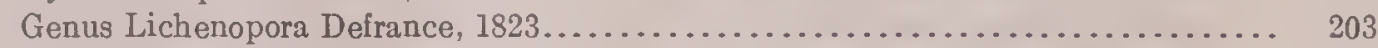

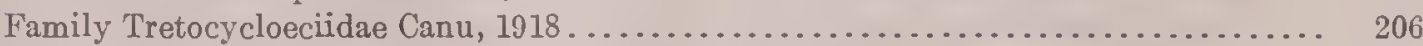

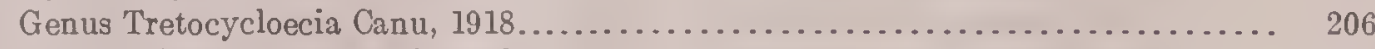

Genus Psilosolen Canu and Bassler, 1922........................... 207

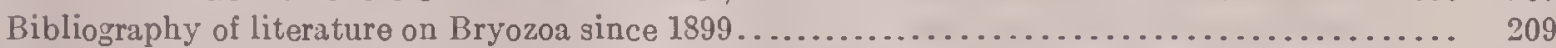

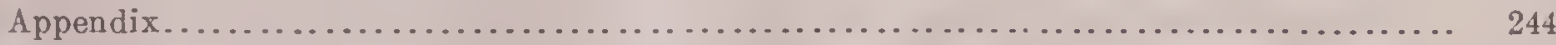

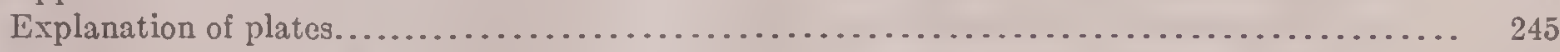

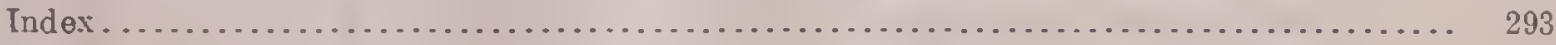




\section{LIST' OF ILLUSTRATIONS. ${ }^{1}$}

TEXT Figures.

FIG. 1. Genera of the family Electrinidae D'Orbigny, 1851........................... Pago

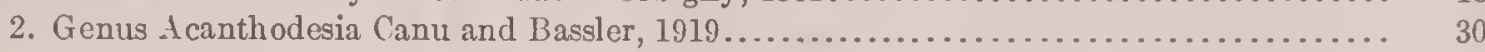

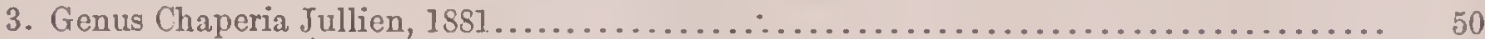

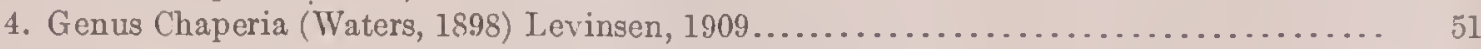

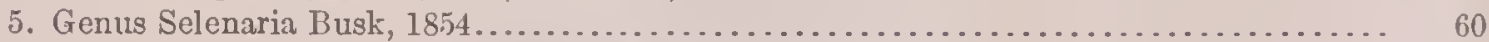

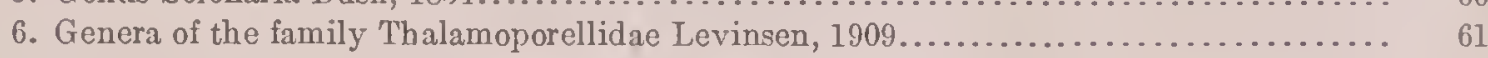

7. Genera of the family Steganoporellidae Levinsen, $1909 \ldots \ldots \ldots \ldots \ldots \ldots \ldots \ldots \ldots \ldots$

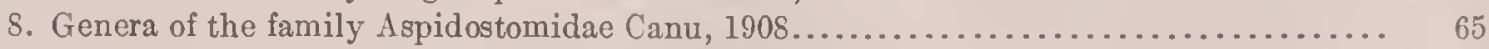

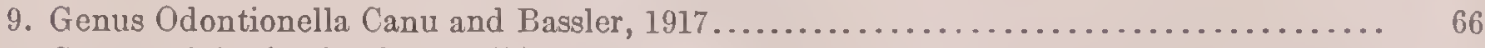

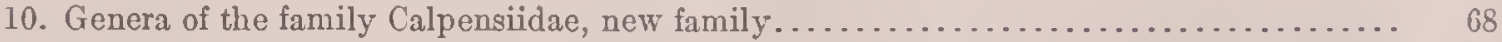

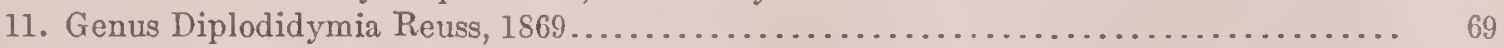

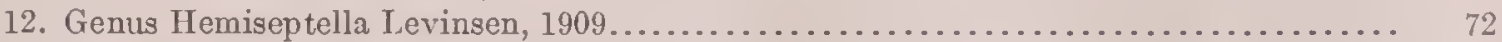

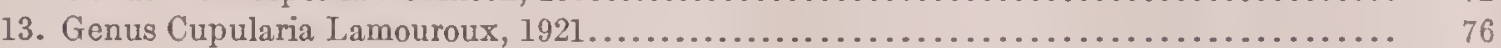

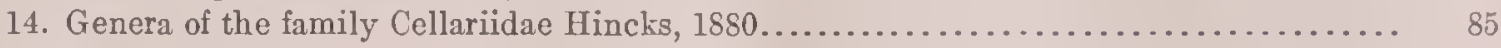

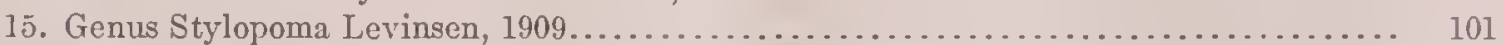

16. Genus Schizolavella Canu and Bassler, $1920 \ldots \ldots \ldots \ldots \ldots \ldots \ldots \ldots \ldots \ldots \ldots \ldots \ldots \ldots . \ldots \ldots$

17. Genera of the Microporellae........................................... 112

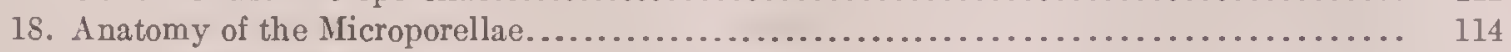

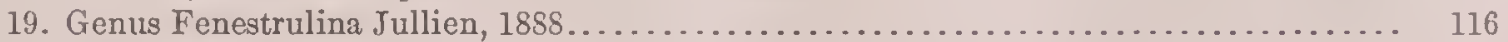

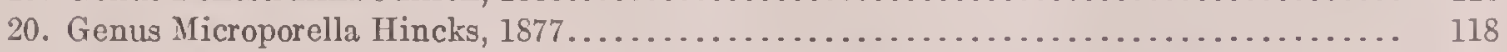

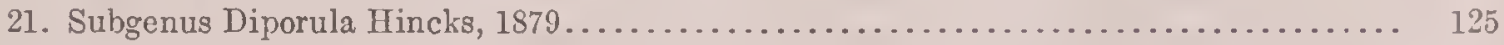

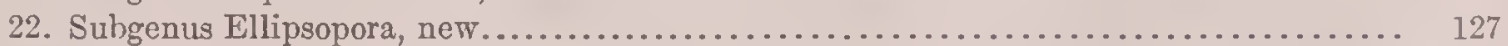

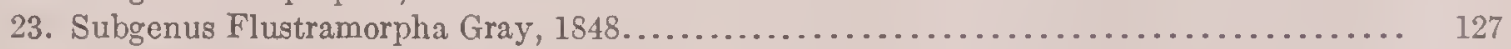

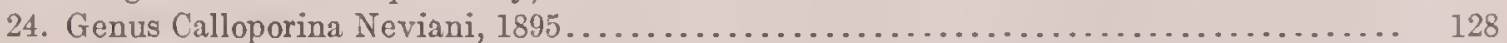

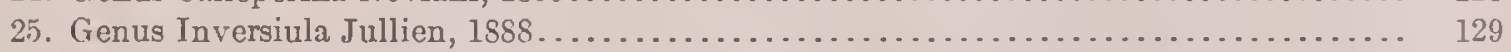

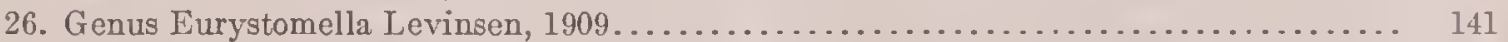

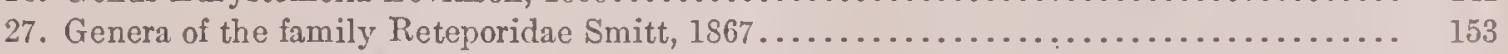

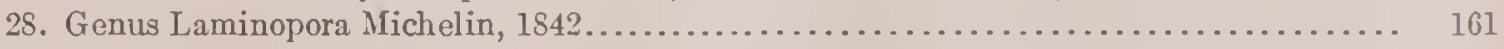

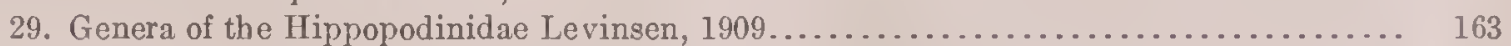

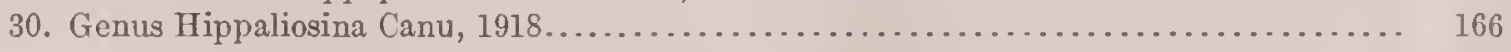

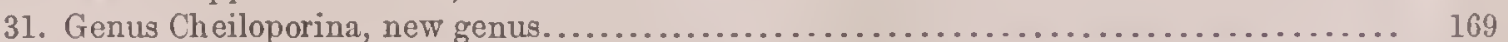

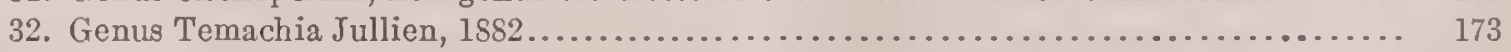

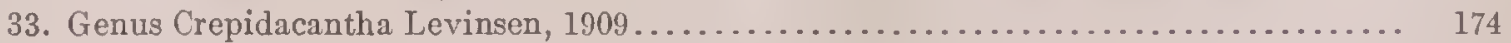

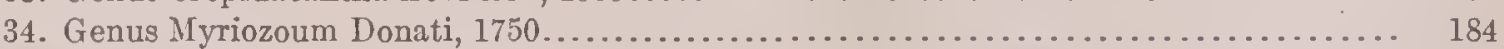

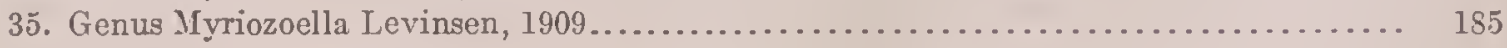

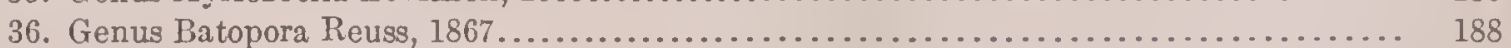

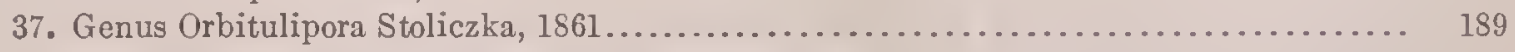

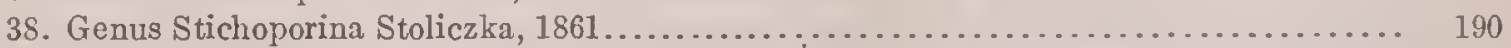

2 The 47 plates of this rolume, with their accompanying explanations, begin on page 245 . 



\title{
NORTH AMERICAN LATER TERTIARY AND QUATERNARY BRYOZOA.
}

\author{
By Ferdinand Canu, \\ of Versailles, France, \\ AND \\ RAY S. BASSLER, \\ of Tashington, District of Columbia.
}

\section{INTRODUCTION.}

The present volume contains the results of researches upon the Post-Oligocene fossil bryozoa of North America and forms the concluding part of our studies upon the Tertiary and Quaternary faunas, those of the Eocene and Oligocene epochs having been published in 1920 under the title of North American Early Tertiary Bryozoa. ${ }^{1}$ The present work, like the companion volume on the Early Tertiary faunas, was undertaken under the joint auspices of the United States Geologica Survey and the United States National Museum. Almost without exception all the type specimens described and illustrated in the present volume are contained in the paleontological collections of the United States National Museum.

The authors are deeply indebted to Dr. Charles D. Walcott, Secretary of the Smithsonian Institution, and Mr. W. deC. Ravenel, Administrative Assistant in charge United States National Museum, who have arranged for the publication of the work and have extended various courtesies to us during its preparation. Dr. T. Wayland Vaughan, of the United States Geological Survey, has likewise spared no effort in assisting us to bring the work to a successful conclusion and we are greatly indebted to him, as well as to other members of the Federal Survey, particularly Mr. Wendell C. Mansfield, Mr. R. D. Mesler, and Mr. I. B. Milner.

We are under many obligations to Mr. F. Julius Fohs, chief geologist of the Humphreys Mexia Oil Company at Mexia, Texas, who has rery generously assisted us financially in the preparation and illustration of the volume, and who has thus shown his appreciation of the value of the bryozoa in stratigraphic and economic work.

Through several grants from the Marsh Fund of the National Academy of Sciences and from the American Association for the Adrancement of Science we have been able to carry on supplementary studies of other fossil and recent bryozoan faunas which were quite necessary in the preparation of this rolume. For this assistance we are highly grateful, as we have thus been enabled to pursue our researches on a larger scale and to secure more definite and lasting results. 
Our hearty thanks are due to Dr. F. C. Clark, of Los Angeles, California, and Dr. Ralph Arnold, of Pasadena, California, who have supplied us with practically all of the faunas described from the Pleistocene of California.

The methods of study of the bryozoa and various other subjects relating to them in general have been described in our Early Tertiary volume, to which the reader is referred. We have, however, added to the present volume a bibliography of bryozoan literature published since 1899, the list of literature up to this date being contained in the work by Nickles and Bassler of $1900 .^{2}$

Although the present work deals primarily with North American Post-Oligocene fossil Bryozoa, the descriptions of a few small faunas from the Oligocene rocks of the West Indies and of several miscellaneous Eocene species are added for various reasons.

\section{CATALOGUE OF PAPERS OF AMERICAN LATER TERTIARY AND QUATERNARY BRYOZOA.}

[A few papers by Canu, Ulrich, and Bassler, published since 1900, are not listed here because their contents are reproduced in the present work.]

\section{1.}

Conrad, T. A. Observations on the Secondary and Tertiary formations of the southern Atlantic States, by James T. Hodge. With an appendix by T. A. Conrad. (Amer. Journ. Sci., ser. 1, vol. 41, 1841, pp. 344-348.)

The bryozoa in the paper are:

Lunulites denticulata, p. 348.

Lunulites depressa, p. 348.

1845.

Lonsdale, Williaß. Report on the Corals from the Tertiary formations of North America. (Quart. Journ. Geol. Soc. London, vol. 1, 1845, pp. 495-509.)

Heteropora? tortilis, new species, p. 500. Miocene: Williamsburg, Petersburg.

Escharina tumidula, new species, p. 502. Miocene: Petersburg.

Lunulites denticulata Conrad, p. 503. Miocene: Petersburg.

Cellepora informata, new species, p. 505. Miocene: Petersburg, Virginia.

Cellepora umbilicata, new species, p. 507. Miocene: Petersburg.

Cellepora quadrangularis, new species, p. 508. Miocene: Williamsburg, Evergreen.

Cellepora similis, new species, p. 509. Miocene: Williamsburg.

1855.

Conrad, T. A. Note on the Miocene and Post-Pliocene deposits of California, with descriptions of two new fossil corals. (Proc. Acad. Nat. Sci. Philadelphia, vol. 7, 1855, p. 441.)

Idmonea californica, p. 441. Miocene: Santa Barbara, California.

Lichenopora californica, p. 441. Miocene: Santa Barbara, California.

1857.

Tuomer, M., and Holmes, F. S. Pleiocene Fossils of South Carolina. Charleston, 1857, xvi+ $152 \mathrm{pp} ., 30 \mathrm{pls}$.

The bryozoa are:

Lunulites denticulata Conrad, p. 11, pl. 4, figs. 1-5. Darlington district, South Carolina.

Cellepora tessellata, new species, p. 13, pl.4, fig. 7. Giles Bluff, Peedee River.

Cellepora radiata, new species, p. 13, pl. 4, fig. 8. Smith's, Goose Creek.

Cellepora depressa, new species, p. 14, pl. 4, fig. 9. Smith's, Goose Creek.

Membranipora lacinia, new species, p. 14, pl. 4, fig. 10. Smith's, Goose Creek.

2A Synopsis of American Fossil Bryozoa, including Bibliography and Synonymy. Bull. No. 173, United States Geo logical Survey. 
Reptocelleporaria informata (Lonsdale), p. 15, pl. 4, figs. 11, 12. Darlington district.

Reptocclleporaria similis (Lonsdale), p. 16, pl. 4, figs. 13, 14. Darlington district, South Carolina; Petersburg, Virginia.

Hetero pora tortilis Lonsdale, p. 16, pl. 4, figs. 15, 16. Smith's, Goose Creek.

1858.

Emmons, Ebenezer. Report of the North Carolina Geological Survey. Raleigh, 1858. Paleontology, pp. 193-314.

Lunulites denticulata, p. 311, figs. 248, 249. Mfiocene: Bcds on Neuse and Cape Fear rivcrs.

Lunulites oblongus, new species, p. 312 , figs. 252, 253. Locality not given.

Disco porella umbellata,.p. 312, figs. 254, 255. Locality not given.

1860.

Holares, Francis S. Postpliocene fossils of South Carolina. Charleston, 1860. $x \ddot{i}+r+122$ pu., 28 pls.

The bryozoa described arc:

Reptocelleporaria informata (Lonsdale), p. 6, pl. 1, fig. 5. Charleston, South Carolina.

Lunulites denticulata Conrad, p.6, pl. 2, figs. 4-4b. Simmons'; Abbapoola; St. Andrew's.

1862.

Gabb, William M., and Horx, George H. Monograph of the fossil Polyzoa of the Sccondary and Tertiary formations of North America. (Journ. Acad. Nat. Sci. Philadelphia, ser. 2, vol. 5, 1862, pp. 111-178, pls. 19-21.)

Eschara? fragilissima, new species, p. 118, pl. 19, 3. Miocenc: St. Mary's Rivcr, Maryland.

Lunulites oblonga Emmons, p. 121. Miocene(?): North Carolina.

Cellepora tumidula D'Orbigny, p. 127. Miocene: Petersburg, Virginia.

Cellepora formosa Tuomey and Holmes, p. 129. Miocene (?Pliocene): Darlington district, South Carolina.

Cellepora tessellata Tuomey and Holmes, p. 129. Miocene (?Pliocene): Giles Bluff, Peedee River, South Carolina.

Cellepora radiata Tuomey and Holmes, p. 129. Miocene (?Pliocene): Goose Creek, South Carolina. Cellopora depressa Tuomey and Holmes, p. 129. Miocene (?Pliocene): Goose Creek, South Carolina. Cellepora californiensis, new species, p. 130, pl. 19, fig. 12. Postpliocene: Santa Barbara, California. Cellepora bellerophon, new species, p. 130, pl. 19, fig. 13. Postpliocene: Santa Barbara, California.

Reptocelleporaria informata D'Orbigny, p. 132. Miocene: Petersburg, Virginia; and South Carolina. Reptocelleporaria quadrangularis D'Orbigny, p. 132. Locality not given.

Reptocelleporaria similis D'Orbigny, p. 133. Miocene (?Pliocenc): Virginia and South Carolina. Reptescharella hermannii, new spccies, p. 137, pl. 19, fig. 20. Postpliocene: Santa Barbara, California. Reptescharella plana, new species, p. 137, pl. 19, fig. 19. Postpliocene: Santa Barbara, California. Phidolopora labiata, new species, p. 13S, pl. 19, fig. 21. Postpliocene: Santa Barbara, California. Ennallipora quadrangularis, new spccies, p. 141, pl. 20, fig. 24. Miocene: Petersburg, Virginia.

Discoporella denticulata (Conrad), p. 142, pl. 20, fig. 25. Mioccne: Generally distributed from New Jersey to South Carolina.

Reptoporina eustomata, new species, p. 144, pl. 20, fig. 26. Postpliocene: Santa Barbara, California. Multiporina umbilicata (Lonsdale), p. 145, pl. 20, fig. 27. Miocene: Petersburg, Virginia.

Reptescharellina disparilis, new species, p. 147, pl. 20, fig. 29. Postpliocene: Santa Barbara, California. Reptescharcllina? hermannii, new species, p. 147, pl. 20, fig. 30. Postpliocene: Santa Barbara, California.

Reptescharellina cornuta, new species, p. 147, pl. 20, fig. 31. Postpliocene: Santa Barbara, California. Siphonella multipora, new spccies, p. 154, pl. 20, fig. 38. Postpliocene: Santa Barbara, California.

Membranipora sexpunctata, new species, p. 159, pl. 20, fig. 44. Miocene or Eocene: Locality unknown. Membranipora speciosa (Gabb and Horn), p. 159, pl. 20, fig. 45. Miocene(?): Chiriqui, Central America. 
Membranipora californica, new species, p. 160, pl. 20, fig. 46. Postpliocene: Santa Barbara, California. Membranipora barbarensis, new species, p. 160, pl. 20, fig. 47. Postpliocene: Santa Barbara, California.

Reptoflustrella tubulata, new species, p. 162, pl. 20, fig. 51. With .Membranipora sexpunctata. Locality unknown, probably from the Virginia Miocene.

Pyriflustrella tuberculum D'Orbigny, p. 163. Locality not given.

Idmonea californica Conrad, p. 168, pl. 21, fig. 56. Postpliocene: Santa Barbara, California.

Semitubigera tuba, new species, p. 169, pl. 21, fig. 57. Postpliocene: Santa Barbara, California.

Entalophora punctulata, new species, p. 171, pl. 21, fig. 61. Postpliocene: Santa Barbara, California.

Crisina serrata, new species, p. 174, pl. 21, fig. 66. Postpliocene: Santa Barbara, California.

Lichenopora californica Conrad, p. 176, pl. 21, fig. 68. Postpliocene: Santa Barbara, California.

Multicrescis tortilis (Lonsdale), p. 178. Miocene: Virginia and South Carolina.

LISTS OF NORTH AMERICAN LATER TERTIARY AND QUATERNARY BRYOZOAN FAUNAS

$[\mathrm{c} .=$ common; $\mathrm{v}$. $\mathrm{c} .=$ very common; $\mathrm{r} .=$ rare; $\mathrm{r} . \mathrm{r} .=$ tery rare.]

OLIGOCENE.

Oligocene (Antigua formation): Rifle butts, Antigua, Leerrard Islands (loc. No. 6854)-

Floridina fusifera Canu and Bassler, 1919. (

Floridina pyripora Canu and Bassler, 1919. (r.)

Hippoporina lata Smitt, 1862. (r.)

Porella bella Busk, 1860 . (r.)

Puellina radiata carolinensis Gabb and Horn, 1862. (r.)

Oligocene (Antigua formation): Carlisle marl pit, Antigua, Leerard Islands (loc. No. 6873)Calpensia impressa Moll, 1803. (r.)

Oligocene (Anguilla formation): Southwest side of Crocus Bay and vicinity, Anguilla, Leerrard IslandsCallopora dumerilli Savigny-Audouin 1826. (r.)

Floridina pyripora Canu and Bassler, 1919. (r.)

Holoporella albirostris Smitt, 1872. (r.)

Ogivalina mutabilis Canu and Bassler, 1919. (r.)

Pucllina radiata carolinensis Gabb and Horn, 1862. (r.)

Stephanosella biaperta Michelin, 1842. (r.)

Stylopoma spongites Pallas, 1766. (r.)

Oligocene (Emperador limestone): one-third mile north of west of Empire, Panama Canal Zone (loc. No. 6016)-

Holoporella albirostris Smitt, 1872. (r.)

Ogivalina mutabilis Canu and Bassler, 1919. (r.)

LOWER MHOCENE FALNAS.

Lower Miocene (Bowden horizon): Rio Cana, Santo Domingo-

Cupuladria canariensis Busk, 1859. (r.)

IVamillopora tuberosa Canu and Bassler, 1919. (c.)

. Yetrarabdotos colligatum Canu and Bassler, 1919. (c.)

Thalamoporella biperforata Canu and Bassler, 1919. (c.)

Lower Miocene (Bowden horizon): Rio Gurabo, Santo Domingo-

Cupuladria canariensis Busk, 1859. (c.)

Cupuladria umbellata Defrance, 1823. (c.)

Labiopora miocenica Canu and Bassler, 1919. (r.)

Mamillopora tuberosa Canu and Bassler, 1919. (c.)

Thalamoporella biperforata Canu and Bassler, 1919. (c.)

Thalamoporella granulata Levinsen, 1909. (r.) 
Lower Miocene (Bowden horizon): Santo Domingo-

Cupuladria biporosn. new species. (r.)

Laminopora miocenica, new species. ( $v$. r.)

Palmicellaria c/r. inermis Jullien. (r.)

Rhynchozoon curtum, new species, (v.r.)

Stylopoma magniporosa, new species. (r.)

Tremogasterina truncatorostris, new species. (v.r.)

Lower Miocene (Bowden horizon): Cercado de Mao, Santo Domingo-

Acanthodesia savarti forma monilifera Canu and Bassler, 1919. (r.)

Adeona porosa Canu and Bassler, 1919. (r.)

Aimulosia brevis, new species. (r.)

Corynostylus ellipticus Canu and Bassler, 1919. (r.)

Corynostylus labiatus Canu and Bassler, 1919. (c.)

Cupuladria canariensis Busk, 1859. ( $\mathrm{r}$.)

Cupularia umbellata Defrance, 1823. (c.)

Diaperoecia milneana D’Orbigny, 1839. (r.)

Hemiseptella lata Canu and Bassler, 1919. (

Hippomenella infratelum Canu and Bassler, 1919. ( $r$. r.)

Mamillopora tuberosa Canu and Bassler, 1919. (c.)

Membranipora vaughani Canu and Bassler, 1919. (r. r.)

Metrarabdotos colligatum Canu and Bassler, 1919. (c.)

Nellia oculata Busk, 1852. (v. c.)

Rhynchozoon vaughani Canu and Bassler, 1919. (v. r.)

Schizopodrella (?) mutabilis Canu and Bassler, 1919. (r.)

Smittina (?) brevis Canu and Bassler, 1919. (r.)

Steganoporella parvicella Canu and Bassler, 1919. (c.)

Thalamoporella biperforata Canu and Bassler, 1919. (c.)

Lower Miocene (Bowden marl): Bowden, Jamaica-

Acanthodesia savarti forma texturata Reuss, 1847. (

Adeona heckeli Reuss, 1847. (r.)

Aimulosia brevis, new species. (c.)

Bracebridgia deformis Canu and Bassler, 1919. (r.)

Callopora dumerillii Savigny-Audouin, 1826. (r.)

Conopeum lacroixii Busk, 1S72. (r.)

Conopeum ovale, new species. ( $v$. r.)

Cupuladria canariensis Busk, 1859. (r.)

Cupularia umbellata Defrance, 1823. (c.)

Cycloperiella rubra, new species. (v. r.)

Gemelliporella punctata Canu and Bassler, 1919. (r.)

Hemiseptella grandicella, new species. (r.)

Hippodiplosia baccata Canu and Bassler, 1920. (r.)

Holoporella albirostris Smitt, 1872. (v. c.)

Holoporella hemispherica, new species. (r.)

Mamillopora tuberosa Canu and Bassler, 1919. (c.)

Mastigophora granulosa, new species. (v. r.)

Membranipora osburni, new species. (r.)

Membranipora tenella Hincks, 1880. (r.)

Membrendocium parvicapitatum, new species. (r.)

Metrarabdotos lacrymosum Canu and Bassler, 1919. (c.)

Rhamphostomella granulosa, new species. (v. r.)

Rhamphostomella laticella Canu and Bassler, 1919. (

Rhynchozoon verruculatum Smitt, 1872. (r.)

Schizo podrella unicornis Johnston, 1847. (r.)

Smittina ophidiana Waters, 1878 . (v.r.)

Steganoporella parvicella Canı and Bassler, 1919. (c.) 
Lower Miocene (Bowden marl): Bowden, Jamaica-Continued.

Stephanosella biaperta Michelin, 1841. (r.)

Stylopoma minuta, new species. (r.)

Terebripora clongata, new species. (r.)

Tercbripora sinefilum, new species. (r.)

Thalamoporella biperforata Canu and Bassler, 1919. (c.)

Lower Miocene (Gatun formation): Banana River, Costa Rica-

Cupuladria canariensis Busk, 1859. (r.)

Cupularia umbellata Defrance, 1823. (c.)

Mamillopora tuberosa Canu and Bassler, 1919. (c.)

Lower Miocene (Chipola marl): Chipola River, Calhoun County, Florida-

Adeonellopsis coccinella, new species. (r.)

Callopora dumerilii Savigny-Audouin, 1826.

Cupularia umbellata Defrance, 1S23. (c.)

Gcmelliporella vorax, new species. (r.)

Leiosella edax, new species. (r.)

MIOCENE OF MARTIAND.

Miocene (Choptank formation): Cordova, MarylandAcanthodesia savarti forma bifoliata Ulrich and Bassler, 1904. (c.) Microporella bifoliata Ulrich and Bassler, 1904. (r.)

Miocene (Choptank formation): Governor Run, MarylandAcanthodesia oblongula Ulrich and Bassler, 1904. (r.) Schizopodrella unicornis Johnston, 1847. (r.)

Miocene (Choptank formation): Greensboro, MarylandHoloporella massalis Ulrich and Bassler, 1904.

Miocene (Choptank formation): Pawpaw Point, MarylandConopeum? nitidulum Ulrich and Bassler, 1904. (r.)

Miocene (Choptank formation): Dover Bridge, MarylandAcanthodesia oblongula Ulrich and Bassler, 1904. (r.) Conopeum germanum Ulrich and Bassler, 1904. (v. r.) Retepora doverensis Ulrich and Bassler, 1904. (c.) Schizopodrella doverensis Ulrich and Bassler, 1904. (r.)

Miocene (Choptank formation): Jones Wharf, MarylandAcanthodesia oblongula Ulrich and Bassler, 1904. (r.) Acanthodesia savarti forma bifoliata Ulrich and Bassler, 1904. (c.) Chaperia caminosa Ulrich and Bassler. (r.) Crisina striatopora Ulrich and Bassler, 1904. (r.) Microporella ciliata Linnaeus, 1759. (r.) Retepora doverensis Ulrich and Bassler, 1904. (c.) Schizoporella cumulata Ulrich and Bassler. (r.) Schizoporella latisinuata Ulrich and Bassler, 1904. (r.)

Miocene (Calvert formation): Reed's, MarylandAcanthodesia oblongula Ulrich and Bassler, 1904. (c.) Cellepora cribrosa Ulrich and Bassler, 1904. (v. r.) Conopeum lacroixii Busk, 1852. (r.)

Cyclicopora mansfieldi, new species. (v.r.) Membranipora fossulifera Ulrich and Bassler, 1904. ( Ogivalina parvula Ulrich and Bassler, 1904. (r.) Porella convoluta Ulrich and Bassler, 1904. (r.) Porella punctata Ulrich and Bassler, 1904. (v. r.)

Miocene (Calvert formation): Plum Point, MarylandAcanthodesia oblongula Ulrich and Bassler, 1904. (c.) Cellepora maculata Ulrich and Bassler, 1904. (c.) Holoporclla massalis Ulrich and Bassler, 1904. (r.) 
Miocene (Calvert formation): 1 mile south of Parkers Creek, Calvert County, MarylandCallopora parvirostris, new species. (v. r.) Cribrilina ligulata, new species. (v. r.)

Miocene (Calvert formation): Chesapeake Beach, MarylandAcanthodesia oblongula Ulrich and Bassler, 1904. (c.) Holoporella massalis Ulrich and Bassler, 1904. (r.)

Miocene (St. Mary's formation): St. Mary's River, MarylandCupularia denticulata Conrad, 1841. (r.) Hemiseptella fistula Ulrich and Bassler, 1904. (v. r.) Holoporella massalis Ulrich and Bassler, 1904. (r.) Lepralia montifera Ulrich and Bassler, 1904. (v. r.) Theonoa glomerata Ulrich and Bassler, 1904. (r.)

Miocene (St. Mary's formation): Cove Point, MarylandAmphiblestrum constrictum Ulrich and Bassler, 1904. (r.) Conopeum germanum Ulrich and Basisler, 1904. (v. r.) Cribrilina punctata Hassall, 1841. (r.) Idmonea expansa Ulrich and Bassler, 1904. (r.) Mrembranipora tuberimargo, new species. (v. r.) Microporella ciliata Linnaeus, 1759. (r.) Porella reversa Ulrich and Bassler, 1904. (r.) Ramphonotus agellus Ulrich and Bassler, 1904. (r.) Schizoporella cumulata Ulrich and Bassler, 1904. (r.)

MOCENE OF VIRGINIA.

Miocene (St. Mary's formation): Bowlers wharf, 18 miles above Urbana, Middlesex County, VirginiaAcanthodesia savartii formatypica. (r.)

Conopeum lacroixii Busk, 1852. (r.)

Membraniporina baccata, new species. (r.)

Ramphonotus agellus UIrich and Bassler, 1904. (r.)

Schizopodrella unicornis Johnston, 1847. (r.)

Spathipora longicauda, new species. (v. r.)

Miocene (Yorktown formation): Yorktown, Virginia-

Cellepora maculata Ulrich and Bassler, 1904. (r.)

Dakaria grandis, new species. (r.)

Floridina regularis, new species. (r.)

Gemelliporella vorax, new species. (r.)

Hippaliosina rostrigera Smitt, 1872. (c.)

Hippoporella spinosa, new species. (r.)

Holoporella (?) echinata, new species. (v.r.)

Ifembranipora flabellata Canu, 1906. (r.)

Microporella fissurifera, new species. (v. r.)

Ramphonotus asperus, new species. (r.)

Stylopoma spongites Pallas, 1766. (c.)

Terebripora parvicella, new species. (r.)

Tretocycloecia tortilis Lonsdale, 1845. (c.)

Miocene (Yorktown formation): 1 mile northeast and 1 mile west of Suffolk, Virginia-

Acanthodesia savarti forma typica. (r.)

Atelesopora reptans, new species. (r.)

Ceriopora virginiana, new species. (v. r.)

Cycloperiella rubra, new species.

Gemelliporella vorax, new species. (r.)

Hippaliosina rostrigera Smitt, 1872. (c.)

Membranipora flabellata Canu, 1906. (r.)

Microporella fissurifera, new species. (r.)

Ramphonotus asperus, new species. (r.) 
Upper Miocene (Yorktown formation): 3 miles southwest of Petersburg, TirginiaAcanthodesia rectangularia, new species. (

Adeona heckeli Reuss. (c)

Amphiblestrum constrictum Ulrich and Bassler, 1904. (r.)

Ateleso pora reptans, new species. (r.)

Berenicea flabellum? Reuss, 1847. (r.)

Callopora lanceolata, new species. (v. r.)

Cycloperiella rubra, new species. (c.)

Dalaria torquata D'Orbigny, 1839. (v. r.)

Gemelliporella vorax, new species. (r.)

Hippaliosina rostrigera Smitt, 1872. (c.)

Hippodiplosia bigibbera, new species. (r.)

Membraniporina vincularina, new species.

Microporella fissurifera, new species. (r.)

Ramphonotus asperus, new species. ( $r$ )

Stylopoma spongites Pallas, 1766. (c.)

Tretocycloecia tortilis Lonsdale, 1845. (c.)

Miocene (Yorktown formation): 1 mile west of Fort Nonsense, Gloucester County, VirginiaAtelesopora reptans, new species. (r.)

Cyclocopora spinifera, new species. (r.)

Gemelliporella vorax, new species. (r.)

Microporella fissurifcra, new species. (r.)

Ramphonotus asperus, new species. (r.)

Schizopodrella unicornis Jolnston, 1842.

Trypostega venusta Norman, 1864. (r.)

Miocene (Yorktown formation): 1 mile south of Cash, Gloucester County, Virginia-

Atelesopora reptans, new species. (r.)

Cyclocolposa spinifera, new species. (r.)

Ramphonotus asperus, new species. ( $\mathrm{r}$.)

Miocene (Yorktown formation): 2 miles southwest of Cash, Gloucester County, Virginia-

Cyclocolposa spinifera, new species. (r.)

Cycloperiella rubra, new species. (c.)

Dakaria torguata D'Orbigny, 1839. (r.)

Ramphonotus asperus, new species. (r.)

Stylopoma spongites.Pallas, 7766 . (c.)

Tretocycloecia avellana, new species. (r)

Miocene (Yorktown formation): Near Powcan, King and Queen County, Virginia (loc. No. 8205)-

Adeona heckeli Reuss, 1847. (r.)

Berenicea flabellum? Reuss. (r.)

Cycloperiella rubra, new species. ( $\mathrm{r}$.)

Cyclocolposa spinifera, new species. (r.)

Gemelliporella vorax, new species. (r.)

Miocene (Yorktown formation): Beulahland, King and Queen County. Tirginia (loc. No. 8229)-

Atelesopora reptans, new species. (r.)

Berenicea flabellum? Reuss, 1847. (r.)

Callopora lanceolata, new species. (r.)

Cyclocolposa spinifera, new species. (r.)

Cyclopericlla rubra, new species. (r.)

Ramphonotus asperus, new species. (r.)

Schizopodrella unicornis Jolnnston, 1847. (r.)

Miocene (Yorktown formation): One-third mile north of Macedonia Church, Essex County, Virginia (loc. No. 8208)-

Atelesopora reptans, new species. (r.)

Vicroporella fissumfera, new species. (v.r.)

Ramphonotus asperus, new species. (r.) 
Miocene (Yorktown): York River, VirginiaCupularia denticulata Conrad, 1841. (r.) Hemiseptella flimargo, new species. (v. r.)

Holoporella rostrifera, new species. (v. r.)

Miocene (Yorktown formation): Williamsburg, VirginiaCupularia denticulata Conrad, 1841. (r.) Tretocycloecia tortilis, Lonsdale, 1845. (c.)

Miocene (Yorktown formation): $1 \frac{1}{2}$ miles southwest of Reed's Ferry, VirginiaCyclicopora? mansfieldi, new species. (v. r.)

\section{MIOCENE OF NORTH CAROLINA.}

Miocene (Duplin marl): Natural Well, 2 miles southwest of Magnolia, Duplin_County, North CarolinaAdeona heckeli Reuss, 1847. (r.)

Aimulosia aculeata, new species. (c.) Alderina cesticella, new species. (r.)

Atelesopora reptans, new species. (r.)

Cellepora maculata Ulrich and Bassler, 1904.

Cupularia denticulata Conrad, 1841. (r.)

Cupularia umbellata De France.

Cycloperiella rubra, new species. (c.)

Floridina minuta, new species. (r.)

Floridina regularis, new species. (c.)

Gemelliporella vorax, new species. (c.)

Hippaliosina rostrigera Smitt, 1872. (c.)

Puellina radiata-scripta Reuss.

Schizopodrella unicornis Johnson, 1847.

Stylopoma spongites Pallas, 1766 . (c.)

Terebripora parvicella, new species. (r.)

Velumella elongata, new species. (r.)

Vibracellina pusilla, new species. (r.)

Vibracellina simplex, new species. (r.)

Miocene: Kuhns, Carteret County, North Carolina-

Lagenipora brevicollis, new species. (r.)

Membranipora fossulifera Ulrich and Bassler, 1904. (r.)

Membranipora spiculata, new species. (r.)

Iicroporella ciliata Linnaeus, 1759. (r.)

Porella reversa Ulrich and Bassler ,1904. (r.)

Pyripora brevicauda, new species.

Miocene (Duplin marl): Lake Waccamaw, North Carolina-

Schizo podrella floridina Osburn, 1914. (r.)

Miocene (Duplin marl): Snow Hill, Green County, North CarolinaMembranipora flabellata Canu, 1906. (r.)

Miocene (Duplin marl): $2 \frac{1}{2}$ miles northwest of Chocowinity, North CarolinaMembranipora flabellata Canu, 1906. (r.)

Miocene (Duplin): 10 miles south of Greenville, North CarolinaCycloperiella rubra, new species. (c.)

Microporella fissurifera, new species. (r.)

Tretocycloecia avellana, new species. (r.)

Miocene (Duplin marl): 28 miles northwest of Wilmington, North[Carolina-

Holoporella parvula, new species. (r.)

Holoporella subturrita, new species. (v. r.)

Miocene (Duplin marl): Wilmington, North Carolina-

Adeona heckeli Reuss, 1847. (c.)

Aimulosia aculeata, new species. (r.)

Callopora dumerilii Savigny-Audouin, 1826. (r.)

$$
\text { 12181-23-Bull. 125-—2 }
$$


Miocene (Duplin marl): Wilmington, Nortli Carolina-Continued.

Cellepora minuta, new species. (r.)

Cupularia denticulata Conrad, 1841. (v. c.)

Cupularia doma D'Orbigny, 1851.

Cupularia umbellata Defrance, 1823. (c.)

Cycloperiella rubra, new species. (c.)

Floridina regularis, new species. (c.)

Gemelliporella vorax, new species. (c.)

Hemiseptella rectangulata, now species. (r.)

Hippoporina gibbosa, new species. (r.)

Holoporella orbifera, new species. (r.)

Holoporella subturrita, new species. (r.)

Lacerna mucronata Smitt, 1872. (v. r.)

Membrendoecium grande, new species. (v. r.)

Proboscina mesleri, new species. (r.)

Puellina radiata forma scripta Reuss, 1847. (r.)

Schizopodrella floridina Osburn, 1915. (v. r.)

Schizopodrella unicornis Johnston, 1847. (c.)

Smittina trispinosa Johnston, 1838. (c.)

Stephanosella biaperta Michelin, 1841. (r.)

Stylopoma spongites Pallas, 1766. (c.)

Trypostega venusta Norman, 1864. (v. r.)

MIOCENE OF SOUTH CAROLINA, FLORIDA, AND CUBA.

Miocene (Duplin marl): Muldrows Mills, 5 miles south־of Mayville, Sumter County, South CarolinaAimulosia aculeata, new species. (r.)

Atelesopora reptans, new species. (r.)

Cellepora maculata Ulrich and Bassler, 1904. (r.)

Gemelliporella vorax, new species. (r.)

Schizopodrella unicornis Johnston, 1847. (v. r.)

Stylopoma spongites Pallas, 1766. (r.)

Miocene (Duplin marl): Darlington, South Carolina-

Microporella hexagona, new species. (r.)

Stylopoma spongites Pallas, 1766. (r.)

Miocene: Giles Bluff, Peedee River, South CarolinaMicroporella tessellata Tuomey and Holmes.

Miocene: Smith's, Goose Creek, South CarolinaHemiseptella lacinia Tuomey and Holmes.

Tretocycloecia tortilis Lonsdale, 1845.

Miocene: Charleston, South Carolina-

Hemiseptella granulosa, new species. (v. r.)

Miocene Harvey's Mills, Leon County, Florida-

Aimulosia aculeata, new species. (r.)

Cellepora maculata Ulrich and Bassler, 1904. (v. r.)

Cyclocolposa tenuiparietis, new species. (r.)

Holoporella orbifera, new species. (r.)

Miocene: Santiago, Cuba-

Cribrilina cuspidata, new species. (v.r.)

Miocene (Choctawhatchee marl): Jackson's Bluff, OcklockoneejRiver, Leon County, 25 miles southwest of Tallahassee, Florida-

Acanthodesia savarti forma delicatula Busk, 1859. (r.)

Amphiblestrum tenuiparietis, new species. (r.)

Arthropoma cornuta, new species. (r.)

Cellepora maculata Ulrich and Bassler, 1904. (v. r.)

Chaperia parvispina, new species. (v. r.)

Cupuladria canariensis Busk, 1859. (r.) 
Miocene (Choctawhatchee marl): Jackson's Bluff, Ocklockonee River, Leon County, 25 miles south. west of Tallahassee, Florida-Continued.

Cupularia denticulata Conrad, 1841. (c.)

Gemelliporella asper, new species. (r.)

Gemelliporella vorax, new species. (r.)

Hippoporella? papulifera, new species. (v. r.)

Hippoporina (?) vcstita, new species. (r.)

Idmonea planula, new species. (v.r.)

Membraniporidra parca, new species. ( $r . r_{\text {.) }}$

Membraniporina vincularina, new species. (r.)

Membrendoecium parvicapitatum, new species. (r.)

Microporella ciliata Linnaeus, 1759. (r.)

Puellina innominata Couch, 1844. (v. r.)

Schizopodrella floridina Osburn, 1914. (r. r.)

Schizopodrella pusilla, new species. (r.)

Steganoporella magnilabris Busk, 1854. (v. r)

Tremogasterina horrida, new species. ( $\mathrm{r}_{\mathrm{o}}$ )

Vibracellina simplcx, new species. (v. r.)

PLIOCENE OF SOUTH CAROLINA AND FLORIDA.

Pliocene (Waccamaw marl): Waccamaw River, Horry County, South Carolina-

Aimulosia aculeata, new species. (r.)

Amphiblestrum constrictum Ulrich and Bassler, 1904. (r.)

Cellepora minuta, new species. (r.)

Cupularia denticulata Conrad, 1841. (v. c.)

Cyclocolposa perforata, new species. (v. c.)

Cycloperiella rubra, new species. (c.)

Dakaria parviporosa, new species. (v. r.)

Electra monostachys Busk, 1875. (r.)

Floridina parvicclla, new species. (v. r.)

Gemelliporella asper, new species. (v.)

Gemelliporella vorax, new species. (c.)

Herniseptclla planulata, new species. (r.)

Holoporella bicornis, new species. (r.)

Holoporella ortifera, new species. (c.)

Iembranipora lacroixii Audouin, 1826. (r.)

Membrendocium grande, new species. ( $\mathrm{r}$.)

Metrarabdotos auriculatum, new species. (c.)

Microporella tessellata Tuomey and Holmes, 1857. (r.)

Puellina crassilabiata, new species. (r.)

Schizopodrella aculeata, new species. (v.r.)

Schizopodrella marginata, new species. ( $\mathrm{r}_{\mathrm{.}}$ )

Smittina trispinosa Johnston, 1838. (r.)

Spathipora longirima, now species. (r.)

Tretocycloecia avellana, new species. (v. r.)

Pliocene (Caloosahatchie marl): Shell Creek, De Soto County, Florida-

Adeona heckeli Reuss, 1847. (c.)

Aimulosia brevis, new species. (r.)

Aimulosia radiata, new species. (v. r.)

Gemelliporella vorax, new species. (r.)

Metrarabdotos auriculatum, new species. (v. c.)

Rhynchozoon verruculatum Smitt, 1872. (r.)

Schismopora brevincisa, new species. (c.)

Schizoporella doverensis Ulrich and Bassler, 1904. (v. r.)

Smittina maleposita, new species. (v.r.) 
Pliocene (Caloosahatchie marl); Shell Creek, De Soto County, Florida-Continued. Smittina trispinosa Johnston, 183S. (c.) Stylopoma spongites Pallas, 1766. (c:)

Vibracellina pusilla, new species. ( $v$. r.)

Holoporella albirostris Smitt. (v. c.)

Pliocene (Caloosahatchie marl): Monroe County, Florida-

Cupuladria canariensis Busk, 1859. (r.)

Cupularia denticulata Conrad, 1S41. (ง. c.)

Gemelliporella vorax, new species. (c.)

Hippaliosina rostrigera Smitt, 1872. (r.)

Holoporella albirostris Smitt, 1872. ( $v$. c.)

Ifetrarabdotos auriculatum, new species. (v. c.)

Schizopodrella unicornis Johnston, 1847. (r.)

Smittina trispinosa Johnston, 1833. (c.)

Steganoporella magnilabris Busk, 1854. (v. r.

Stylopoma spongites Pallas, 1766. (c.)

PLEISTOCENE OF THE ATLANTIC COAST.

Pleistocene: Simmons Bluff, Yonges Island, Charleston County, South Carolina-

Hemiseptella tubcrosa, new species. (r.)

Rhynchozoon verruculatum Smitt, 1872. (v. r.)

Schizopodrella unicornis Johnston, 1847. (r.)

Smittina trispinosa Johnston, 183S. (c.)

Stylopoma spongites Pallas, 1766. (r.)

Pleistocene or Recent: Vero, Florida-

Acanthodesia savarti forma texturata Reuss, 1847. (r.)

Acanthodesia savarti forma typica. (c.)

Smittina maleposita, new species. (r.)

Smittina trispinosa Johnston, 1838. (r.)

Stephanosella biaperta Michelin, 1842. (r.)

Stylopoma spongitcs Pallas, $1766 . \quad\left(r_{0}\right)$

Pleistocene: Daytona, Florida-

Schizopodrella unicornis Johnston, 1847. (r.)

Smittina trispinosa Johnston, 1838. (r.)

Pleistocene: Los Angeles, California-

Cellaria diffusa Robertson, 1905. (r.)

Cellaria mandibulata Hincks, 18s2. ( $\mathrm{r}$. c.)

Mippothoa hyalina Linnaeus, 1768. (r.) Stephanosella biaperta Michelin, 1842. (r.)

Pleistocene: Mount IIope, Panama Canal ZoneCallopora filum Jullien, 1903. (r.)

Callopora guernei Jullien, 1903. (v. r.)

Cyclicopora multilamellosa, new species. (r.)

Dakaria chevreuxi Jullien, 1903. (r.)

Hippoporella costulata, new species. (

Hippoporina pusilla, new species. (v.r.)

Holoporella aviculifera, new species. (r.)

Holoporella mucronata, new species. ( $v .1$.)

Holoporella turrita Smitt, 1873. (v. r.)

Jastigophora pesanseris Smitt, 1872. (r.

Membranipora osburni, new species. (r.)

Porella (Palmicellaria) costulata, new species. ( $r$.)

Rhynchozoon (?) levigatum, new species. ( $r . \mathrm{r}$.

Schizoporella magniporosa, new species. $\quad \checkmark . r$.

Stylopoma projecta, new species. (r.)

Stylopoma spongites Pallas, 1766. (r.) 
PLEISTOCENE OF THE PACIFIC COAST.

Pleistocene: Santa Barbara, California-

Callopora crassospina, new species. (r.)

Callopora horrida Hincks, 1880. (r.)

Callopora (?) multipora Gabb and IIorn, 1862.

Cauloramphus porosus, new species. (r.)

Cauloramphus triangularis, new species. (r.)

Chaperia galeata Busk, 1852. (v. r.)

Conopeum barbarensis Gabb and Horn, 1862. (r.)

Crisia serrata Gabb and IIorn, 1862. (v. c.)

Cystisella aviculifera, new species. (r.)

Electra monostachys Busk, 1875. (r.)

Fenestrulina malusi Savigny-Audouin, 1826. (c.)

Fitisparsa clarki, new species. (r.)

Filisparsa clarki, var. parvula, new variety. (r.)

Hincksina multispinata, new species. (v. r.)

Hippothoa hyalina Linnaeus, 1768. (r.)

Hippothoa hyalina, var. rugosa, new variety. (v. r.)

Holoporella umbonata, new species. (r.)

Idmonea californica D'Orbigny, 1852. (v. c.)

Lichenopora californica Conrad, 1855. (r.)

Lichenopora hispida Fleming, 1828. (r.)

Membraniporina californica Gabb and Horn.

Mctracolposa mucronata, new species. (r.)

Micropora coriacea Esper, 1794. (r.) '

Nicroporella californica Hincks, 1882. (c.)

Microporella ciliata Linnaeus, $1759 . \quad$ (r.)

Microporella eustomata Gabb and Horn, 1862.

Vicroporella heermani Gabb and IHorn, 1862.

Microporella umbonata IIincks, 1882. (v. r.)

Microporella vibraculifera Hincks, 1882. (v. r.)

Phidolopora labiata Gabb and Horn, 1862. (v. c.)

Poretla collifera Robertson, 1908. (c.)

Psilosolen capitiferax, new species. (v. c.)

Puellina heermanni Gabb and Horn, 1862. (v. r.)

Puellina radiata forma scripta Reuss, 1847. (r.)

Ramphonotus multispinatus, new species. (r.)

Schismopora abrupta, new species. (r.)

Schizolavella vulgaris Moll, 1803. (v. r.)

Schizomavella longirostrata Hincks, 1883. (r.)

Smattina californiensis Robertson, 1908. (r.)

Stathmepora flabellata, new species. (c.)

Tubucellaria punctata Gabb and Horn, 1862. (v. c.)

Tubucellaria punctata, var. minor, new variety. (r.)

Tubulipora fasciculifera Hincks, 1884. (r.)

Tubulipora tuba Gabb and Horn, 1862. (r.)

Pleistocene: Santa Monica, California.

Callopora circumclathrata Hincks, 1881. (r.)

Cellaria diffusa Robertson, 1905. (r.)

Cellaria fissurifera, new species. ( $\mathrm{r}$.)

Costazia robertsoniae, new species. (r.)

Crisia serrata Gabb and Horn, 1862. (v. c.)

Cupularia robertsoniae, new species. (r.)

Cyclicopora (?) gigantea, new species. (r.)

Cystisella aviculifera, new species. (r.)

Diaperocia flabellata, new species. (r.) 
Pleistocene: Santa Monica, California-Continued.

Entalophora fasciculifera, new species. (r.)

Fenestrulina porosa, new species. (r.)

Hincksina quadrispinosa, new spécies. (r.)

Hippothoa hyalina Linnaeus, 1768. (r.)

Holoporella umbonata, new species. (v. r.)

Idmonca californica D'Orbigny, 1852. (r.)

Idmonea dispar, new species. (c.)

Lepralia cribrosa (?) Maplestone, 1900. (v. r.)

Lichenopora radiata Savigny-Audouin, 1826. (r.)

Lichenopora vcrrucaria Fabricius, 1780. (v. r.)

Membranipora tubcrculata Bosc, 1802. (r.)

Microporella californica Hincks, 1882. (r.)

Microporella ciliata Linnaeus, 1759. (r.)

Microporclla eustomata Gabb and Horn, 1862. (r.)

Microporella gibbcra, new species. (v. r.)

Microporella heermanni Gabb and Horn, 1862. (r.)

IVicroporella umbonata Hincks, 1882. (r.)

Microporella vibraculifera Hincks, 1883. (r.)

Mystriopora (?) areolata, new species. (v. r.)

Phidolopora labiata Gabb and Horn, 1862. (c.)

Phidolopora pacifica Robertson, 1908. (r.)

Phylactella spinosissima, var. major Hincks, 1884. (r.)

Porella collifera Robertson, 1908. (r.)

Porella cyclopea, new species. (r.)

Puellina radiata forma rarecosta Reuss, 1847. (r.)

Rhynchozoon grandicella, new species. (r.)

Schismopora lanceolata, new species. (r.)

Smittina discoidea, new species. (c.)

Smittina grandicclla, new species. (r.)

Smittina porifera Hincks, 18S4. (r.)

Stathmepora flabellata, new species. (r.)

Stephanosella biaperta Michelin, 1841. (r.)

Trypematella papulifera, new species. (r.)

Tubucellaria punctata Gabb and Horn, 1862. (r.)

Tubucellaria punctata, var. minor, new variety. (r)

Tubulipora tuba Gabb and Horn, 1862. (r.)

Pleistocene: Dead Mans Island, off San Pedro, California.-

Diaperoccia flabcllata, new species. (v. r.)

Entalophora fasciculifera, new species. (v. r.)

Eurystomclla bilabiata Hincks, 1884. (r.)

Fenestrulina malusi Savigny-Audouin, 1826. (v. r.)

Hippothoa hyalina Linnacus, 1768. (r.)

Idmonea californica D'Orbigny, 1852. (v. c.)

Idmonea clarki, new species. (r.)

Lagenipora spinulosa Hincks, 1884. (r.)

Microporella californica Hincks, 1884. (r.)

Microporella ciliata Iinnaeus, 1759. (r.)

Microporella umbonata Hincks, 1882. (v. r.)

Microporella vibraculifera Hincks, 1883. (r.)

Phidolopora labiata Gabb and Horn, 1862. (r.)

Phidolopora pacifica Robertson, 1908. (r.)

$P$ silosolen capitiferax, new species. ( $r$.)

Stephanosella biaperta Michelin, 1841. (v. r.)

Terebripora pacifica, new species (r.) (San Pedro.)

Tubucellaria punctata Gabb and Horn, 1862. (r.)

Tubulipora tuba Gabb and Horn, 1862. (r.) 
SYSTEMATIC DESCRIPTIONS.

\section{Class BRYOZOA Ehrenberg.}

Order CTENOSTOMATA Busk. .

Family TEREBRIPORIDAE Busk, 1839.

Genus TEREBRIPORA D'Orbigny, 1839.

(For description see Bulletin 106, United States National Museum, p. 842.)

TEREBRIPORA PARVICELLA, new species.

Plate 27, figs. 15, 16.

Description.-The canalicules are very thin and branch almost at a right angle. The zooecia are very small, arranged somewhat obliquely on the canalicules.

Occurrence.-Miocene (Yorktown formation): Yorktown, Virginia (rare). Miocene (Duplin marl) : Natural Wells, 2 miles southwest of Magnolia, North Carolina (rare).

Holotype.-Cat. No. 68389, U.S.N.M.

TEREBRIPORA SINEFILUM, new species.

Plate 3, figs. 14, 15.

Description.-The canalicules are very thin; they branch obliquely and disappear on the adult zooecia. The young zooecia are small and united among themselves; the old zooecia are large and not united.

Structure.-Our specimens show no zooecia intact and the perforations alone are visible. The cavity containing the cellule alone persists. It is quite remarkable that the canalicules disappear when the cavities are deep. These two sorts of perforations are moreover visible on the same zoarium.

Occurence.-Miocene (Bowden marl); Bowden Jamaica (rare).

Cotypes.-Cat. No. 68390, U.S.N.M.

\section{TEREBRIPORA ELONGATA, new species.}

Plate 3, figs. 16, 17.

We know this species only from the perforations left in shells and are therefore not able to give a complete description. The canalicules branch almost at a right angle. The distance between the zooecia is equal to their length. The zooecia are much larger than those of Terebripora falunica Fischer, 1866, which is found in Europe at the corresponding geological horizon.

Occurence.-Miocene (Bowden marl): Bowden, Jamaica (rare).

Holotype.-Cat. No. 68391, U.S.N.M.

\section{TEREBRIPORA PACIFICA, new species.}

Plate 46, fig. 13.

This species is known only from the perforations left by it, but these are so distinct that it can easily be recognized. The zooecia appear small, pyriform approaching each other from one to two times their length. The ternary axes are 
deprived of zooecia but they bear unicellular ramifications. In this character this new species is close to Terebripora irregularis D'Orbigny, 1839, but it differs from it in that the distance between the zooecia is much less than fire or six times their length.

Occurrence.-Pleistocene: San Pedro, California (rare).

Holotype.-Cat. No. 68392. U.S.N.M.

\section{Genus SPATHIPORA Fischer, 1866.}

\section{SPATHIPORA LONGICAUDA, new species.}

Plate 27, figs. 12,13.

Description.-The principal axes are linear and do not bear zooecia; they intersect each other at about an angle of $90^{\circ}$. The zooecia are attached to them and are arranged alternately; they are thin, elongated, fusiform and are prorided with a long peduncle; the angle of insertion is about $45^{\circ}$.

Affinities.-This species differs from Spathipora sertum Fischer, 1S63, wide spread in the Helvetian faluns of France, in the great length of the peduncle of insertion.

Occurrence.-Miocene (St. Marys formation): 18 miles abore Urbana, Middlesex County, Virginia (very rare).

Holotype-Cat. No. 68393, U.S.N.M.

\section{SPATHIPORA LONGIRIMA, new species.}

Plate 47, fig. 3.

Description.-The canalicules are delicate, rectilinear, branching at an angle varying from $45^{\circ}$ to $90^{\circ}$. The zooecia are conical, attached directly to the canalicules, without a peduncle. The apertura is terminal, orbicular, with a rery long rimule prolonged over almost all the frontal.

Affnities.-This species differs from Spathipora cucullata in which the form is identical, in its very long rimule. It differs from Spathipora longicauda in the absence of a peduncle to the zooecia.

Occurrence.-Pliocene (Waccamaw marl): Waccamaw, Rirer, Horry County South Carolina (rare).

Holotype.-Cat. No. 68394, U.S.N.M.

\section{SPATHIPORA CUCULLATA, new species.}

Plate 27, fig. 14.

Description.-The canalicules are delicate, deeply buried in the surface of shells; the ramifications are little oblique. The zooecia are conical, in the form of a cornet of paper; their apertura is at the level of the shell, and their peduncles, attached to a canalicule, are deeply buried and rery short.

Affinities.-Of the preceding species, Spathipora longicauda, we know only the perforations left by the zooecia. In the present one, on the contrary, the zooecium is entire because it is entirely embedded in the shell substance. We hare no knowledge of the mechanism employed by this species in perforating the shell.

Occurence.-Miocene (Yorktown formation): Beulahland, King and Queen County, Virginia (rare).

Holotype.-Cat. No. 68395, U.S.N.M. 
Order CHEILOSTOMATA Bưsk.

Suborder ANASCA Levinsen.

\section{Division I. MALACOSTEGA Levinsen}

\section{Family ELECTRINIDAE D'Orbigny, 1851.}

Genus ELECTRA Lamouroux, 1816.

(For description, see Bulletin 106, U. S. National Museum, p. 76.)

ELECTRA MONOSTACHYS Busk, 1854.

Plate 29, figs. 1-3.

1854. Membranipora monostachys Busk, Catalogue marine Polyzoa in British Mfuseum, pt. 2, Cheilostomata, p. 61, pl. 70, figs. 1-4.

1859. Membranipora monostachys Busk, Monograph fossil Polyzoa of the Crag, Publications Paleontographical Society, London, vol. 14, p. 31, pl. 2, fig. 2.

1880. Membranipora monostachys Hincks, British Marine Polyzoa, p. 131, pl. 17, figs. 3, 4; pl. 18, figs. $1-4$.

1889. Membranipora monostachys JeLLx, A Synonymic Catalogue of Marine Bryozoa, p. 1555 (Cites bibliography).

1896. Membranipora monostachys Calvet, Bryozoaires: Résultats scientifiques de la Campagne du "Cauden" danș le Golfe de Gascogne, Annales de l'Université de Lyon, vol. 26, p. 253.

1900. Membranipora monostachys Waters, Bryozoa from Franz-Josef Land, Journal Linnean Society London, vol. 28, p. 59, pl. 8 , fig. 3.

1904. Membranipora monostachys CAlvet, Bryozoen: Ergebnisse der Hamberger Magalhaensiche Sammelreise, p. 13.

1911. Membranipora monostachys GuérIN-Ganivet, Bryozoaires de l'expedition des Jacques Cartier, Bulletin de l'Institut oceanigraphique, no. 207, p. 9.

1912. Electra monostachys NordaAard, Revision av Universitetsmuseets samling ar norske Bryozoer, Kgl. norske Videnskabers Selskabs Skriften, 1911, no. 3, pp. 1-19.

1912. Mcmbranipora monostachys OsBurn, The Bryozoa of the Woods Hole Region, Bulletin Bureau Fisheries, vol. 30, 1910, p. 227, pl. 22, fig. 29; pl. 39, fig. 87.

1914. Electra monostachys Canu, Contribution a l'etude des Bryozoaires fossiles, Les Bryozoaires du Stampien, XIV, Bulletin Société Géologique de France, ser. 4, vol. 14, p. 147, pl. 4, fig. 1.

Measurements.-Opesia $\left\{\begin{array}{l}h_{0}=0.26-0.34 \mathrm{~mm} . \\ l_{0}=0.28 \mathrm{~mm} .\end{array} \quad\right.$ Zooecia $\left\{\begin{array}{l}L_{z}=0.40-0.4 \mathrm{~S} \mathrm{~mm} . \\ l_{z}=0.24-0.26 \mathrm{~mm} .\end{array}\right.$

Variations.-Our specimens agree with the figures giren by Hincks in 1880 and by Busk in 1859. The variety with large gymnocyst noted by Waters in 1900 probably constitutes a distinct species, perhaps identical with Membranipora arcuata Canu, 190s, from the Post-Pampean of Argentina.

This species extends scarcely beyond the Tropics and it has remained fixed in the Frigid and Temperate Zones. Its occurrence in the Pliocene of South Carolina indicates a great contraction of the equatorial zone and the position of the Tropic of Cancer toward the thirty-third parallel. Other species confirm this phenomenon.

There are 10 tentacles according to Waters.

Occurrence.-Pliocene (Waccamaw marl): Waccamaw Rirer, Horry County, South Carolina (rare). Pleistocene: Santa Barbara, California (rery rare); Waies Bluff, near Cornfield Harbor, St. Marys County, Maryland (rare). 
Geological distribution.-Stampian, environs of Paris (Canu); Helvetian of Touraine (Collection Canu); Astian of England (Busk).

Habitat.-Arctic Ocean: Franz Josef Land (16-205 meters) (Waters), Barentz Sea. Eastern Atlantic: English Channel, North Sea off Germany, Denmark, England, Norway (19-24 meters), Gulf of Gascony (17-180 meters), mouth of the Tagus, Cape Verde Islands. Western Atlantic: Woods Hole (3-30 meters), Panama. This species lives principally at the mouth of streams and large rivers.

Plesiotypes.-Cat. Nos. 68396-68398, U.S.N.M.

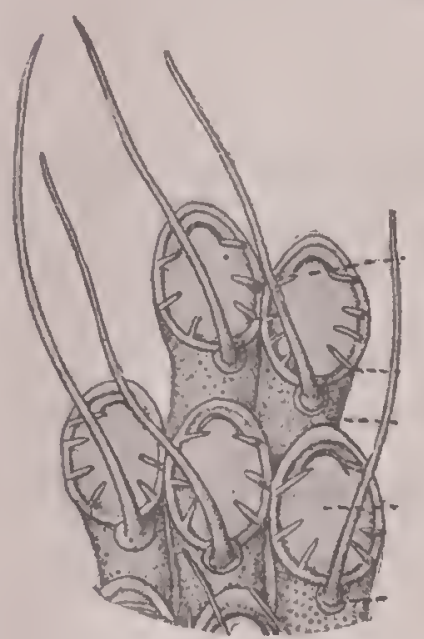

A. Electra

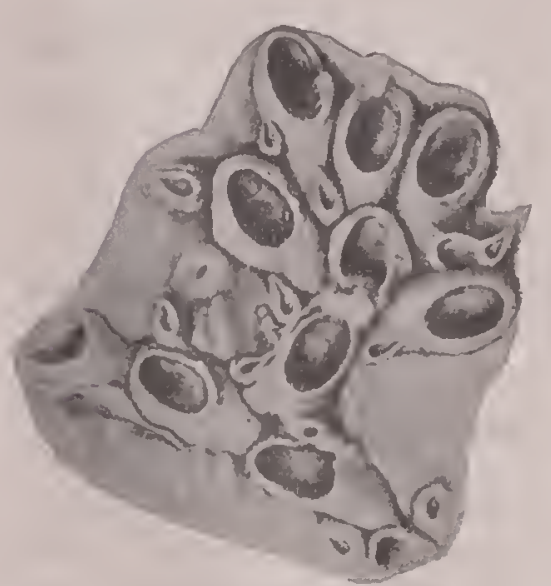

D. Mystriopora
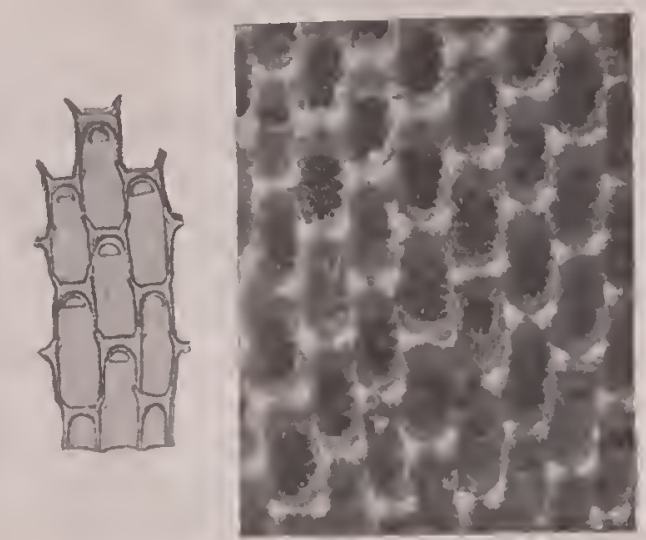

B. Membranipora

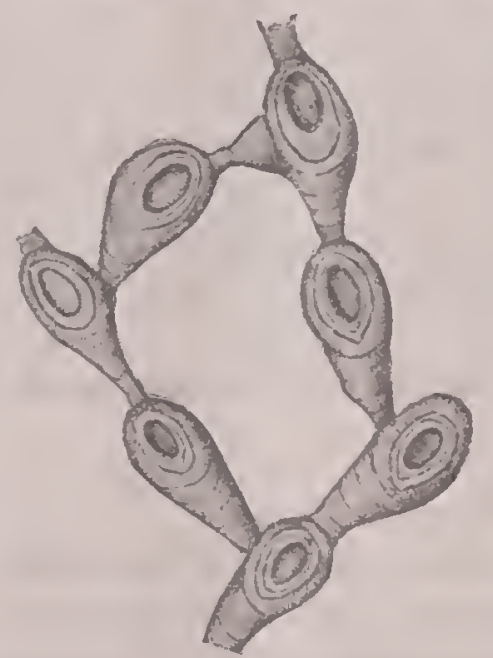

E.Pyripora

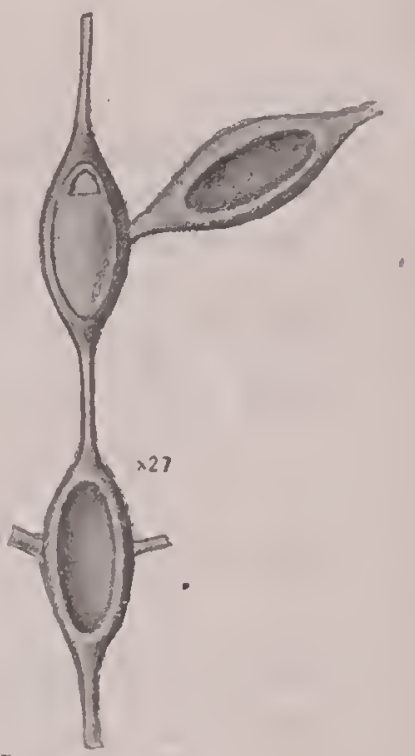

c. Herpetopora

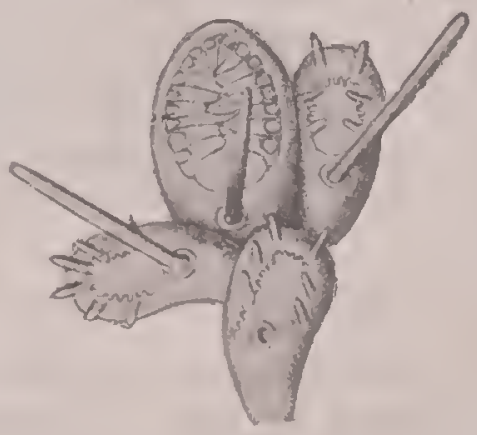

F. Heterooecium

Fig. 1.-Genera of the family Electrinidae D'Orbignv, 1851.

A. Electra Lamouroux, 1816. E. pilosa Linnaeus, $1758, \times 46$. Recent.

B. Membranipora Blainville, 1834. M. membranacea Linnaeus, $1758, \times 15$ (left) and M. tuberculata Bosc, 1802, X 20. Recent.

C. Herpetopora Lang, 1914. H. anglica Lang, 1914, $\times 27$. Cretaceous (after Lang, 1914).

D. Mystrio pora Lang, 1915. If. möckleri Lang, 1915, X 26. Cretaceous of England. 1880.)

E. Pyripora D'Orbigny, 1852. P. catenularia Jameson, 1914, X 25. Recent. (A E., after Hincks, 1909.)

F. Heterooecium Hincks, 1892. H. amplectens Hincks, 1892, X 55. Recent. (After Levinsen, 
NORTH AMERICAN LATER TERTIARY AND QUATERNARY BRYOZOA.

Genus PYRIPORA D'Orbigny, 1852.

(For description see Bulletin 106, U. S. National Museum, p. 78.)

PYRIPORA BREVICAUDA, new species.

Plate 9, figs. 2-4.

Description.-The zoarium encrusts Cellepore bryozoa. The zooecia are pyriform, little narrowed behind, elongated, distinct, separated by a furrow; the gymnocyst is convex and very short. The opesium is elliptical or oval, anterior.

Measurements. ${ }^{3-}$-Opesia $\left\{\begin{array}{l}h_{0}=0.20 \mathrm{~mm} . \\ l_{0}=0.12 \mathrm{~mm} .\end{array} \quad\right.$ Zooecia $\left\{\begin{array}{l}L_{z}=0.40 \mathrm{~mm} . \\ l_{z}=0.22 \mathrm{~mm} .\end{array}\right.$

Variations.-This small species is of a disconcerting irregularity, especially since the substratum itself is very irregular. The calcified zooecia bear a large elliptical pore. The heterozooecia are numerous and generally fusiform. The zoarial expansions appear to be flabelliform.

Occurrence.-Miocene: Kuhns, Carteret County, North Carolina (rare).

Cotypes.-Cat. No. 68399, U.S.N.M.

\section{Genus MYSTRIOPORA Lang, 1915.}

1915. Nystriopora Lang, New Uniserial Cretaceous Cheilostome Polyzoa, Geological Magazine ser. 6, vol. 2, p. 502 .

MYSTRIOPORA (?) AREOLATA, new species.

Plate 33, figs. 1, 2.

Description.-The zoarium is incrusting. The zooecia are distinct, separated by a doep furrow, elongated, pyriform; the gymnocyst is short, convex, smooth, much narrowed. The mural rim is thin, garnished all around with hollow spines; the opesium is large, oval, anterior; between the zooecia.are some zooeciules whose opesium is also garnished with some spines. The zooecia are separated from each other by rectangular areolar spaces. Dietellae are present.

Measurements. ${ }^{3}$-Opesia $\left\{\begin{array}{l}h o=0.45 \mathrm{~mm} . \\ l_{0}=0.25 \mathrm{~mm} .\end{array}\right.$ Zooecia $\left\{\begin{array}{l}L z=0.60 \mathrm{~mm} . \\ l_{z}=0.50 \mathrm{~mm} .\end{array}\right.$

Affinities.-The Cretaceous genus Mystriopora Lang, 1915, shows also zooeciules (although the English authors thought them to be more in the nature of avicularia) and areal spines, but it did not have areolar spaces between the zooecia. Our specimens appear, therefore, to belong to a new genus, although we prefer to employ Lang's name provisionally because the rarity of specimens has not permitted us to make a tangential section in order to discover the dietellae and to establish the nature of the areolar spaces. We have observed cases of double and triple regeneration of the polypide.

This species differs from Membranipora pedunculata Hincks, 1881, also provided with zooeciules, by the absence of spines and by the presence of areolar spaces.

Occurrence.-Pleistocene: Santa Monica (Long Wharf Canyon), California (rare).

Cotypes.-Cat. No. 68400, U.S.N.M.

3 In the citation of measurements $h o$ is the length and $l_{0}$ the width of the opesia, $L z$ and $l_{2}$ similarly the length and width of the zooecia, $L v$ and $l v$ the same for the vibraculum, Lon and lon for the onychocellaria, $h a$ and $l a$ for the apertura, otc. 


\section{Genus MEMBRANIPORA Blainville, 1834.}

(For description see Bulletin 106, U. S. National Museum, p. 77.)

MEMBranipora flabellata Canu, 1904.

Plate 10, figs. 10-14.

1904. Icmbranipora flabellala CANu, Les Bryozoaires du Patagonien echelle des Bryozoaires pour les terrains tertiares, Memoires Société Géologique de France, Paleontologie, vol. 12, p. 7, pl. 1, fig. 8 .

1908. Membranipora flabellata CANv, Iconographie des Bryozoaires fossiles de l'Argentine, Anales del Museo Nacional de Buenos Aires, vol 17, p. 249, pl. 1, figs. 1-5.

$$
\text { Measurements.-Opcsia }\left\{\begin{array} { l } 
{ h o = 0 . 2 6 \mathrm { mm } . } \\
{ l o = 0 . 1 6 \mathrm { mm } . }
\end{array} \quad \text { Zooecia } \left\{\begin{array}{l}
L z=0.36-0.40 \mathrm{~mm} . \\
l z=0.26 \mathrm{~mm} .
\end{array}\right.\right.
$$

Structure.-The zoarium incrusts shells and algae over large surfaces forming many superposed lamellae. The tubercles of the intcrzooecial angles are well preserred only on the inner lamellae, the outermost lamellae being deprired of them. The zooecia are very deep, the mural rim is quite thick, and the opesium is crenulated. The superior lamellae arc formed of zooccia dereloped around pseudoancestrulac. The latter do not arise from the development of a larra, but thcy are produced by the gemmation of an inferior zooecium.

Variations.-One of our species from Yorktown, Virginia, is exactly similar to the typical Argentina specimens, but our other examples present variations not noted in the types. The rariations are due evidently to the dircrsity of conditions under which the species existed, as its gcographic distribution appears very great.

The tubercles are rery inconstant (fig. 10) and entire colonies are deprived of them (fig. 12). The young zooecia harc thin mural rims (fig. 12) which gives them an aspect similar to that of Acanthodesia savarti Audouin, 1826, but old zooecia are normal and there are never large zooecia giring risc to new rows. Sometimes the two distal tubercles are joined together (fig. 13). The tubercles are often replaced by interopesial cavities (fig. 11) on the much expanded zoaria, but the presence of normal tuberose zooecia rereals the true naturc of these sorts of specimens.

Affinities.--The exterior aspect much recalls Acanthodesia oblongula Ulrich and Bassler, 1904, but the present species differs in its smaller measurements (ho< $<0.30$ $\mathrm{mm}$.) in the absence of opesial spicules and in its multilamellar colonies.

Occurrence.-Miocene (Yorktown formation): Yorktown, Bellfield and Suffolk, Virginia (rarc). Miocene (Duplin marl) : $2 \frac{1}{2}$ miles northwest of Chocowinity and at Snow Hill, North Carolina (rare).

Geological distribution.-Patagonian, Pampean and Post Pampean of Argcntina (Canu).

Plesiotype.-Cat. Nos. 68401, 68402, U.S.N.M.

\section{MEMBRANIPORA FOSSULIFERA Utrich and Bassler, 1904.}

Plate 9 , figs, 6,7 .

1904. Membranipora fossulifcra ÜLrich and BAssler, Bryozoa, Maryland Geological Survey", Miocene, p. 408, pl.110, fig. 1.

The original description is as follows:

Description.-Zoarium forming a thin expansion upon foreign bodies. Zooecia oblong, subquadrate, sometimes obscurely hexagonal, arranged in regular longitudinal and diagonally intersecting rows, with about 11 in $5 \mathrm{~mm}$., measuring lengthwise, 9 to 10 in $3 \mathrm{~mm}$., diagonally, and 11 to 13 of the longi- 
tudinal rows in $3 \mathrm{~mm}$. Opesium elongate oval, generally about twice as long as wide. Walls nearly always a little less than half the width of the opesium, with a median channel, the ring-like elevation enclosing the opesium uniformly elevated except across the anterior end where it is higher and obliquely arched and elevated beneath, probably to form a cover for an ooecium, and is usually surmounted by a transverse rib terminating at each end in a small rounded prominence. Rarely the space of an ordinary zooecium is taken up by a cell having a thicker wall and a smaller aperture varying from elongate to nearly circular, while in one instance, a small cell with an oblique opening, narrowed distally, is wedged in between three zooecia.

$$
\text { Measurements.-Opesia }\left\{\begin{array} { l } 
{ h _ { 0 } = 0 . 3 6 \mathrm { mm } . } \\
{ l _ { 0 } = 0 . 2 0 \mathrm { mm } . }
\end{array} \quad \text { Zooecia } \left\{\begin{array}{c}
L z=0.50 \mathrm{~mm} . \\
l_{z}=0.32 \mathrm{~mm} .
\end{array}\right.\right.
$$

Variations.-Our micrometric measurements represent the average; in reality as in all the Membranipores the variations are considerable. The mural rim is always somewhat wider in the proximal portion; the separating furrow is deep; the opesium is finely crenulated. The two distal tubercles are placed generally on the termen of the mural rim, but frequently they are attached to the exterior slope and appear there as inserted in the interzooecial angles. We have not yet discovered regenerated zooecia.

We present a new photograph of the type of this species which brings out the surface ornament and especially the tubercles more clearly. The species has resemblance to both Conopeum and Membranipora, but the apparent absence of the two impressions on the dorsal wall of the zooecium, characteristic of Conopeum, and the presence of the spines of Membranipora cause us to refer the species to Membranipora in its restricted sense.

Occurrence.-Miocene (Calvert formation): Reed's, Maryland (very rare). Miocene: Kuhns, Carteret County, North Carolina (rare).

Plesiotype.-Cat. No. 68403, U.S.N.M.

\section{MEMBRANIPORA SPICULATA, new species.}

Plate 9, fig. 1.

Description.-The zoarium encrusts species of Cellepora. The zooecia are distinct, separated by a deep furrow, elliptical, elongated; the mural rim is thin, salient, flat, bearing two distal tuberosities and two pairs of lateral spicules which are conical and very salient. The opesium is of the same form as the zooecium.

$$
\text { Measurements.-Opesia }\left\{\begin{array} { l } 
{ h o = 0 . 3 2 \mathrm { mm } . } \\
{ l o = 0 . 1 8 \mathrm { mm } . }
\end{array} \text { Zooecia } \left\{\begin{array}{l}
L z=0.40 \mathrm{~mm} . \\
l z=0.30 \mathrm{~mm} .
\end{array}\right.\right.
$$

Affinities.-In its lateral spicules this species has much resemblance to Spiralaria denticulata Busk, 1852, but it differs from it in the absence of an endozooecial ovicell and in the presence of two lateral pairs of spicules. Hincksina serrata MacGillivray, 1881, also has a similar aspect, but in the present species we have not observed either the ovicell or interzooecial avicularia. The spicules are rarely erect; they are more or less curved in the form of a claw. The distal tuberosities are often transformed into spicules. It is therefore rather probable that this species bears an ovicell. But a single specimen has been found.

Occurrence.-Miocene: Kuhns, Carteret County, North Carolina (rare).

Holotype.-Cat. No. 68404, U.S.N.M. 


\section{MEMBRANIPORA LACROIXII Audouin, 1826.}

Plate 29, fig. 4.

1826. Flustra lacroixii Audour, Explication des planches de Polypes de l'Egypte. . . In Savigny's Description de L'Egypte, Historie Naturelle, vol. 1, 1809, pt. 3, p. 240, pl. 10, fig. 9 (not Busk, Hincks, Canu).

$$
\begin{array}{r}
\text { Measurements.-Ordinary zooecia: Opesia }\left\{\begin{array}{l}
h o=0.40 \mathrm{~mm} . \\
l_{0}=0.22 \mathrm{~mm} .
\end{array}\right. \\
\text { Zooecia }\left\{\begin{array}{l}
L z=0.50 \mathrm{~mm} . \\
l_{z}=0.32-0.34 \mathrm{~mm} .
\end{array}\right.
\end{array}
$$

First zooecia of a row:

$$
\begin{aligned}
& \text { Opesia }\left\{\begin{array}{l}
h_{0}=0.40 \mathrm{~mm} . \\
l_{0}=0.24-0.28 \mathrm{~mm} .
\end{array}\right. \\
& \text { Zooecia }\left\{\begin{array}{l}
L_{z}=0.50-0.56 \mathrm{~mm} . \\
l_{z}=0.40 \mathrm{~mm} .
\end{array}\right.
\end{aligned}
$$

Variations.-The mural rim is flat and finely striated. There is a constant tubercle at each interzooecial angle. The zooecium giving rise to two or more series is much larger. Our specimen is exactly like Audouin's figure of 1826 .

Affinities.-Years ago Waters noted that the Membranipora lacroixi of Busk and Hincks was probably not Audouin's species. Canu, sharing this opinion, has carefully revised the synonymy." The unexpected discovery in America of Andouin's species confirms therefore the idea of both Waters and Canu. There is no necessity of a new name, since our specimen appears to indicate Membranipora more than Conopeum.

This species differ from Membranipora fossulifera Ulrich and Bassler, 1904, in the presence of tubercles at the interzooecial angles. It is much larger than Biflustra savarti Smitt, 1872, which belongs moreover to another genus.

Occurrence.-Pliocene (Waccamaw marl): Waccamaw River, Horry County, South Carolina (rare).

Habitat.-Red Sea or Mediterranean (Audouin):

Plesiotype.-Cat. No. 68405, U.S.N.M.

MEMBRANIPORA TUBERCULATA Bosc, 1802.

Plate 33 , figs. 3-5.

1802. Flustra tuberculata Bosc, Histoire naturelle des Vers, vol. 3, p. 118.

1839. Flustra tehuelca D'Orbigny, Voyage dans l'Amerique-Mréridionale, vol. 5, pt. 4, Zoophytes, p. 17, pl. 8, fig. 10-14.

1858. Membranipora tuberculata Busk, Zoophytology: On some Madeiran Polyzoa, Quarterly Journal of Microscopical Science, vol. 6, p. 126, pl. 18, fig. 4.

1898. Membranipora tehuelca WATERs, Observations on Membraniporidae, Journal of the Linnean Society, Zoology, vol. 26, p. 674, pl. 48, fig. 6-8.

1908. Membranipora tehuelca RóBertson, The incrusting Cheilostomatous Bryozoa of the West Coast of North America, University of California Publications, Zoology, vol. 4, no. 5, p. 265 , pl. 15, fig. 16, 17; pl. 16, fig. 18 .

1909. Membranipora tuberculata Norman, The Polyzoa of Madeira and neighboring Islands, Journal Linnean Society London, Zoology, vol. 30, p. 286.

4 See North American Early Tertiary Bryozoa, p. 89. 
1911. Membranipora tehuelca Guerin-Ganivet, Contributions a l'etude des Bryozoaires des cotes Armoricaines II, Bryozoaires provenant de la rade de Brest, et recueilles par les freres Crouan, Travaux scientifiques du Laboratoire de Zoologie de Concarneau, vol. 3, fasc. 5, p. 6, fig. 3 .

1912. Membranipora tehuelca Osburn, The Bryozoa of the Woods Hole Region, Bulletin Bureau Fisheries, vol. 30, 1910, p. 231, pl. 24, fig. 40.

We agree with Norman that this species is indeed that of Bosc, who indicated it as very abundant on the algae of the Sargossa Sea. 'These algae, swept along by the equatorial current, have transported to America a considerable number of European species. This particular one has made the tour of America. One of our fossil specimens still retains its ectocyst and its corneous opercular valve.

Occurrence.-Pleistocene: Santa Monica (Rustic Canyon), California (rare).

Habitat.-Eastern Atlantic off France, Senegal, Madeira, and Angola. Western Atlantic: United States, Chagos Isles, Pernambuco, Rio Janeiro, Patagonia. Pacific: Kursachee and California.

Plesiotype.-Cat. No. 68406, U.S.N.M.

\section{MEMbranipora vaUghaNi Canu and Bassler, 1919.}

Plate 2, fig. 1.

1919. Membranipora vaughani CANU and BASSLER, Geology and paleontology of the West Indies, Bryozoa, Publications of the Carnegie Institution of Washington, no. 291, p. 77, pl. 2, fig. 1.

Description.-The zoarium incrusts shells. The zooecia are little distinct, united among themselves by their mural rim, elongated, hexagonal; the mural rim is flat, granular, everywhere of equal width. The opesium is elliptical or oval, finely crenulated. Between the zooecia at the angles of junction large rounded tubercles occur.

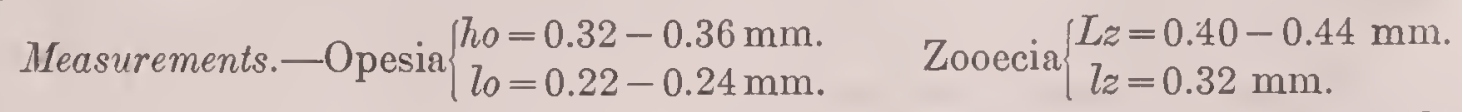

Affinities.-A single specimen has been found and its zooecia are somewhat deformed by the substratum. The species differs from Membranipora tuberculata Busk, 1859, from the English Crag in its much larger micrometric measuremcnts. It differs from Membranipora tuberculata Bosc, 1802 (not Busk, 1859) in the much more reduced and very different form of its interzooecial tuberosites.

Occurrence.-Lower Miocene (Bowden horizon): Cercado de Mao, Santo Domingo (very rare).

Holotype.-Cat. No. 68407, U.S.N.M.

MEMBRANIPORA(?) TURERIMARGO, new specles.

Plate 9, fig. 12.

Description.-The zoarium incrusts shells. The zooecia are distinct, separated by a deep furrow, elongated, elliptical. The mural rim is thin, rounded, a little enlarged at the base; it bears one pair of distal and two pairs of lateral tuberosities. The opesium is large, anterior, elliptical.

$$
\text { Measurements.-Opesia }\left\{\begin{array} { l } 
{ h _ { 0 } = 0 . 4 0 - 0 . 4 5 \mathrm { mm } . } \\
{ l _ { 0 } = 0 . 2 5 - 0 . 3 0 \mathrm { mm } . }
\end{array} \text { Zooecia } \left\{\begin{array}{c}
L z=0.45 \mathrm{~mm} . \\
l_{z}=0.35-0.40 \mathrm{~mm} .
\end{array}\right.\right.
$$


Variations.-Our micrometric measurements hare been made as far as possible from the ancestrula on our single specimen. The opesium of the small ancestrular zooecia measures only 0.30 by $0.20 \mathrm{~mm}$. The number and size of the tubercles is rery irregular. They are hollow.

This species differs from Membranipora osburni in its larger dimensions, and in the presence of two pairs of lateral tuberosities. rare).

Occurrence.-Miocene (St. Mary's formation): Core Point, Maryland (very

Holotype.-Cat. To. 68408, U.S.N.M.

MEMBRANIPORA OSBURNI, new species.

Plate 46, figs. 11, 12.

Description.-The zoarium incrusts sponges. The zooecia are distinct, separated by a furrow, elongated hexagonal; the mural rim is thin, rounded, rery finely crenulated, salient, ornamented with two distal tubercles; the proximal cryptocyst is concare and very small. The opesium is elliptical.

Measurements.-Opesia $\left\{\begin{array}{l}h_{0}=0.30 \mathrm{~mm} . \\ l_{0}=0.20 \mathrm{~mm} .\end{array} \quad\right.$ Zooecia $\left\{\begin{array}{l}L z=0.35 \mathrm{~mm} . \\ l z=0.28 \mathrm{~mm} .\end{array}\right.$

Affinities.-The micrometric mensurements are smaller than Membranipora vaughani, but the species is quite close to Membranipora tuberculata Busk, 1859, in its two distal tubercles. It is distinguished from the latter by its cryptocyst placed only in the proximal portion of the zooecium, by its larger micrometric measurements ( $L z=0.35 \mathrm{~mm}$. and not $0.30 \mathrm{~mm}$.), and in its much thinner mural rim.

We dedicate this interesting species to Dr. Raymond C. Osburn, of the Ohio State University, in honor of his important researches upon American recent bryozoa.

Occurrence.-Pleistocene: Mount Hope, Panama Canal Zone (rare). Miocene (Bowden marl): Bowden, Jamaica (rare).

Holotype.-Cat. No. 68409, U.S.N.M.

Group MEMBRANIPORAE Canu and Bassler, 1917.

SECTION I. NO OVICELL.

Genus MEMBRANIPORINA Levinsen, 1909.

(For description see Bulletin 106, U. S. National Museum, p. 94.)

MEMBRANIPORINA TENELLA Hincks, 1880.

Plate 5, figs. 10, 11.

1S50. Membranipora tenella HrNcks, Contributions History Marine Polyzoa, Foreign Membraniporina II, Annals Magazine Natural History, ser. 5, vol. 6, p. 376, pl. 16, fig. 7.

1S89. Membranipora tenella JeLLY, Synonymic catalogue of recent marine Bryozoa, p. 167.

1919. Callopora tenella CANu and BASsler, Geology and Paleontology of the West Indies, Bryozoa, Publication of the Carnegie Institution at Washington, No. 291, p. S1, pt. 5, fig. 10.

Affinities.-This species is quite easily recognized by its very thin mural rim and especially by its small tubercles arranged more or less symmetrically on the gymnocyst. These tubercles appear to be hollow. 
The species may perhaps be confused with Callopora dumerilli Sarigny-Audouin, 1826, in which the exterior aspect is quite similar; it differs from it in the presence of nodules instead of avicularia placed on the gymnocyst (and not between the opesia).

Occurrence.-Lower Miocene (Bowden marl): Bowden, Jamaica (rare).

Habitat.-Florida (Hincks).

Plesiotypes.-Cat. No. 68t10, U.S.N.M.

\section{MEMBRANIPORINA BACCATA, new species.}

Plate 9, fig. 14.

Description.-The zoarium is incrusting, unilamellar. The zooecia are distinct, separated by a deep furrow, much elongated, elliptical or irregular. The mural rim is thin, regular, salient, rounded, corered with large granules. The opesium has the same form as the zooecium.

$$
\text { Measurements.-Opesia }\left\{\begin{array} { l } 
{ h _ { 0 } = 0 . 5 0 \mathrm { mm } . } \\
{ l _ { 0 } = 0 . 2 2 \mathrm { mm } . }
\end{array} \quad \text { Zooecia } \left\{\begin{array}{l}
L z=0.60 \mathrm{~mm} . \\
l z=0.35 \mathrm{~mm} .
\end{array}\right.\right.
$$

I'ariations.-The zooecia giring rise to new series are much larger; they- are numerous, and when the zoarium is not perfectly regular the smaller zooecia which they emit have not sufficient place for derelopment and thus become deformed.

We hare noted traces of spicules, so that this species could possibly belong to the genus Acanthodesia. Howerer, it is imprudent to pronounce on this point from a single specimen. The ensemble of the large granules of the mural rims give to this species the aspect of a chain of pearls.

Occurrence.-Miocene (St. Mary's formation): Bowler's wharf, 18 miles abore Urbana, Middlesex County, Virginia (rare).

Holotype.-Cat. No. 68411 , U.S.N.M.

\section{MEMBRANIPORINA CALIFORNICA Gabb and Horn, 1862}

Plate 33, fig. 6.

1862. Membranipora californica GAвв and Horn, Monograph Polyzoa Secondary and Tertiary formations of North America, Journal Academy Natural Sciences of Philadelphia, ser. 2 vol. 5, p. 160, pl. 20, fig. 46

The original description is as follows:

Colony encrusting, cellules arranged in lines, not always in regular quincunx. Cellules pyriform, sometimes continued behind, often abruptly truncated. Opening large, occupring two-thirds or more of the cellules; varying from rounded triangular to oval, usually narrowest in front, never sharply acuminate. Surface sometimes rounded about the oval opening, at others carinate, midway between the aperture and the margin of the cellule, from which line the surface slopes downwards, convexly in botll directions. Behind the opening the surface is convex, often narrow. No abortive cellules nor ovarian vescicles were observerl.

We hare been unable to find specimens of this species and we therefore reproduce the original description and figures for the benefit of future students.

Occurrence.-Pleistocene: Santa Barbara, California.

$1218+2-3-$ Rul1. 12.7-3 
Plate 9, figs. 8-10.

Description.-The zoarium is free, vincular, formed of two lamellae back to back, composed of four to eight longitudinal rows of zooecia. The zooecia are elliptical, distinct, separated by a deep furrow; the mural rim is wide, rounded, tuberose somewhat wider in the proximal portion; the opesium is regular, elongated, elliptieal.

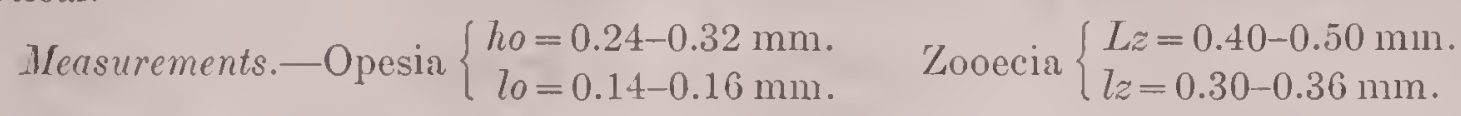

Affinities. - We hare not yet discovered an oricell on any of our specimens. The quadrangular zoaria have much resemblance to Farcimia, but their zooecia are identical with those of the multiserial colonies.

Occurrence.-Miocene (Choctawhatchee marl): Jackson Bluff, Ocklocknee River, 25 miles southwest of Tallahassee, Florida (rare). Miocene (Yorktown formation): 3 miles southwest of Petersburg, Virginia (very rare).

Cotypes.-Cat. Nos. 68412, 68413, U.S.N.M.

\section{Genus CONOPEUM Norman, 1903.}

(For description see Bulletin 106, U. S. National Museum, p. S6.)

\section{CONOPEUM LACROIXII Busk, 1852.}

Plate 1, fig. 6.

1919. Conopeum lacroixii CANU and BAssler, Monograph Early Tertiary Bryozoa of North America, Bull. 106, T. S. National Museum, p. 89, pl. 13, fig. 9. (Bibliography, history and distribution.)

Measurements.-Opesia $\left\{\begin{array}{l}h o=0.40 \mathrm{~mm} . \\ l_{0}=0.20 \mathrm{~mm} .\end{array} \quad\right.$ Zooecia $\left\{\begin{array}{r}L z=0.50 \mathrm{~mm} . \\ l_{z}=0.28 \mathrm{~mm} .\end{array}\right.$

Although we have had the good fortune to discorer the true Membranipora lacroixii Audouin, 1826 (see p. 22, pl. 29, fig. 4), it is evident that the present species ought henceforth to be classed under Busk's name of 1852 . We have no new obserrations to add to our previous description of this species, for the Miocene specimens are very rare.

Occurrence.-Miocene (St. Mary's formation): Bowler's wharf, 18 miles abore Urbana, Middleséx County, Virginia (rare). Miocene (Calrert formation): Reeds, Maryland (1'are). Mioeene (Bowden marl): Bowden, Janıica (rare).

Plesiotype.-Cat. No. 68414, U.S.N.M.

CONOPEUM OVALE Canu and Bassler, 1919.

Plate 5, fig. 6 .

1919. Conopeum ovale CANu and BAssler, Geology and Paleontology of the West Indies Bryozoa, Pub. Carnegie Institution of Washington, No. 291, p. 77, pl. 5, fig. 6.

Description.-The zoarium incrusts shells. The zooecia are distinct, elongated, oral, the point above, separated by a deep furrow; the mural rim is thin, oblique, flat; the opesium is entire, oral. There are two orbicular impressions at the base of the zooecia. The interopesial carities are irregular and rare.

$$
\text { Measurements.-Opesia }\left\{\begin{array} { l } 
{ h o = 0 . 3 0 \mathrm { mm } . } \\
{ l o = 0 . 1 5 \mathrm { mm } . }
\end{array} \quad \text { Zooecia } \left\{\begin{array}{rl}
L z=0.35 \mathrm{~mm} . \\
l z=0.25 \mathrm{~mm} .
\end{array}\right.\right.
$$


Affinities.-The primoserial zooecia are small and ealcified. The figured specimen alone has been found. We know no equatorial species with which to compare the present one.

Occurrence.-Lower Miocene (Bowden marl): Bowden, Jamaiea (very rare). Holotype.-Cat. No. 68415 , U.S.N.M.

\section{CONOPEUM GEIRMANUM Ulrich and Bassler, 1904.}

Plate 10, fig. 8 .

1901. Membranipora germana UlRICH and BASSLER, Bryozoa: Maryland Geological Survey, Miocene, p. 410, pl. 111, fig. 29.

The original description is as follows:

Zoarium forming a delicate crust upon foreign bodies, the largest seen being less than $1 \mathrm{~cm}$. in diameter. Zooecia shallow, arranged in curved radiating lines in which about 6 occur in $3 \mathrm{~mm}$.; measuring transversely, 11 to 12 of the rows in the same space. Opesia large, more or less elongate-ovate, the length and width usually as 3 is to 2, separated laterally from their neighbors by about half their width, enclosed by a ring-like thickening formed by a furrow separating adjoining zooecia. At somewhliat irregular intervals, the interzooecial space widens and is occupied by a rounded cell that may have lodged some kind of avicularium. These cells vary greatly in size but are always considerably smaller than the true zooecia. Occasionally the front margin of the zooecium is more elerated than the rest of the circumference. No ovicells observed.

The deseription quoted above gires all the essential features of this species.

Occurrence.-Miocene (St. Mary's formation): Cove Point, Maryland (very rare). Miocene (Choptank formation): Dorer Bridge, Maryland (very rare).

Holotype.-Cat. No. 68416 , U.S.N.M.

CONOPEUM? NITIDULUM Utrich and Bassler, 1904.

Plate 9, fig. 5 .

1904. Membranipora nitidula Ulrich and BASsLer, Bryozoa: Maryland Geological Survey, Miocene, p. 412, pl. 112, fig. 1.

The original deseription is as follows:

Zoarium apparently erect, bifoliate. Zooecia oblong, subquadrate, the length twice the width, arranged rather regularly in longitudinal and diagoually intersecting series, rarely four, usually five in three $\mathrm{mm}$. Iengthwise, about seven diagonally, and ten or eleven transversely in the same spare. Opesia elongate-elliptical, separated transversely by an obtusely ridge-shaped wall generally equalling about half their width; longitudinal interspaces about twice as great as the transverse, medially ridged with a crescentic ovicellar excavation below (that is, in front of each opesium) and usually a small pore-like depression at each end of the ridge. Very minute spines or granules on inner slope of walls.

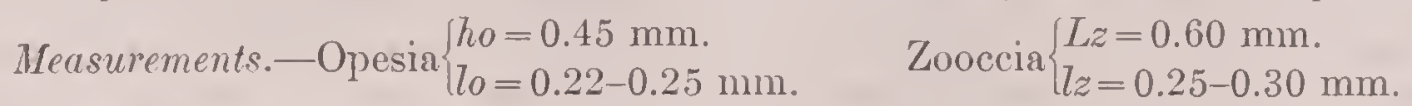

Affinities. - A restudy of the type specimen shows that the original illustration of the species was inverted. At the bottom of each zooecium there is a small flat cryptocyst more or less dereloped. The interopesial spaces are triangular. The opesium is finely crenulated.

This species is rery close to Conopeum lacroixii Authors, but it differs in its larger mierometric measurements and in the presence of a small proximal cryptocyst. Nerertheless, as the figured example alone has been found, we ean not affirm the constaney of this latter characteristic.

Occurence.-Miocene (Choptank formation): Pawpaw Point, Maryland (rare). Holotype.-Cat. No. 68417 , U.S.N.M. 
Plate 33, figs. $;-9$.

1562. Membranipora barbarensis GABB and Horx, Monograph Polyzoa Secondary and Tertiary iormations of Yorth America. Journal Icademy Natural Sciences of Philadelphia. ser. 2. p. $60^{\circ}$, pl. 20, fig. 47 .

Description.-The zoarium incrusts bryozoa. The zooecia are distinct, irregular, elliptical or oral: the mural rim is thin, flat, trenchant; the opesium is large, elliptical or oral. The axis of the aricularium is always in the axis of the proximal zooecium.

$$
\text { Measurements.-Opesia } \begin{aligned}
& h_{0}=0.32 \mathrm{~mm} . \\
& l_{0}=0.16 \mathrm{~mm} .
\end{aligned} \quad \text { Zooecia }\left\{\begin{array}{l}
L z=0.40 \mathrm{~mm} . \\
l z=0.2 S \mathrm{~mm} .
\end{array}\right.
$$

Affinities.-There are two muscular impressions as in the genus Conopeum. The aricularium (?) is not constant; it only appears from place to place; it is elliptical. We are not certain of its nature for only the figured specimens hare been found.

This species differs from Ellisina (Membranipora) levata Hincks, 1SS2, from the Queen Charlotte Islands, in its thinner mural rim, and in the aricularium, always placed in the axis of the proximal zooecium (and not in all directions).

Occurrence.-Pleistocene: Santa Barbara, California (rare).

Plesiotypes.-Cat. No. 6841S, C.S.N.M.

\section{Genus CLPUlADRIA Canu and Bassler, 1919.}

1919. Cupuladria CANC and Bassler, The Geology and Paleontology of the Test Indies, Bryozoa, Publications Carnegie Institution of Tashington, No. 291, p. $i$.

No oricell. The zoarium bears ribracula. No grmnocyst. Recent.

Genotype.-Cupuladria (Cupularia) canariensis Busk, 1\$59. Range: Miocene-

The genotype does not belong at all to Cupularia as we now understand this genus and as it is defined by its type species. There are neither opesiules nor cryptocrst. Preriously, Smitt in 1Si2 classified the genotype more correctly in Membranipora as this genus was then understood. It can not, howerer, be maintained in this genus since its significance has been more restricted. We were therefore obliged to create the new genus characterized by the presence of ribracula, although these organs of zoarial adaptation may not logically furnish good generic characters. We only add a letter to the primitive term to modify the long srnonymr of this species as little as possible.

This genus differs from Helindoma Calret, $190 \bar{\tau}$, in the absence of a grmnocyst. The absence of an endozooecial oricell does not permit it to be confused with either ribracellina Canu and Bassler, 1917, or Setosellina Calret, 1907.

CLPLLADRIA CANARIENSIS Busk, 1859.

Plate 1, figs. 7-9.

1559. Cupularia canariensis Busk, Monograph fossil Polyzoa of the Crag. Publications Paleontographical Society. London, vol. 14, p. 8i, pl. 13. fig. 2 
1872. Membranipora canariensis SurTr, Floridan Bryozoa, collected by Count I. F. de Pourtales, pt. 1, Kongl. Svenska Vetenskaps-A kademiens Handlingar, vol. 10, No. 11, p. 10.

1908. Cupularia canariensis CANu, Iconographie des Bryozoaires fossiles de L'Argentine, Anales del Iruseo Nacional de Buenos Aires, vol. 17, p. 275, pl. 5, figs. 8-10 (gives bibliography).

1909. Cupularia guineensis Noryan, The Polyzoa of Madeira and neighboring Islands, Journal Linnean Society London, Zoology, vol. 30, p. 289, pl. 37, figs. 2-6.

1913. Cupularia canarionsis CANU, Contributions a l'etude des Bryozoaires fossiles, IV, Pliocene d'Alger, Bulletin Société Géologique de France, ser. 4, vol. 13, pp. 124, 128.

1914. Cupularia guiniensis OsBurs, The Bryozoa of the Tortugas Islands, Florida, Publication Carnegie Institution of Washington, No. 182, 1). 194.

1916. Cupularia canariensis Cand, Bryozoaires fossiles des Terraines du Sud-Ouest de la France, 9, Aquitanien, Bulletin de la Société Géologirque de France, ser. 4 vol. 16, p. 137, pl. 3, figs. 4-6.

1919. Cupuladria canariensis CANu and B.Assler, Geology and Paleontology of the West Indies, Bryozoa, Publication Carnegie Institution of Washington, no. 291, p. 78, pl. 1, figs 8-10.

This abundant, well-known fossil and recent species, distinguished by its free, cupuliform zoarium with the zooecia on the conrex side haring a membraniporoid opesium and ribracula and with the concare side marked by distinct polygonal areas pierced by a few large pores, has been found fossil at number of American localities starting in the Lower Miocene and continuing to the present time. In its geological occurrence it agrees with Cupularia umbellata Defrance, 1823, which likewise begins in the Lower Miocene.

Occurrence.-Lower Miocene (Chipola marl): 1 mile below Baileys Ferry, Chipola Rirer, Florida (rare). Lower Miocene (Bowden horizon): Bowden, Jamaica (rare); Rio Gurabo, Rio Cana, and Cercado de Mao, Santo Domingo (rare); and Port Limon, Costa Rica (common). Lower Miocene (Gatun formation): Banana River, Costa Rica (rare). Miocene (Choctowatchee marl) Jackson Bluff, Ocklocknee River, 25 miles southwest of Tallahassee, Florida (rare). Pliocene (Caloosahatchee marl): Monroe Countr, Florida (rare).

Geological distribution.-Burdigalian of Bordeaux (Canu collection); Helretian of France (Canu) and Spain (DeAngelis); Tortonian of Austria-Hungary (Reuss) and Italy (Seguenza); Plaisancian of Italy (Manzoni), England (Busk), Spain (DeAngelis) and Algeria (Canu); Astian of Italy (Neviani, Canu); Sicilian of Rhodes (Manzoni) and Italy (Neriani); Quaternary of Italy (Neviani) and Argentina (Canu); Miocene of Australia? (Waters).

Plesiotypes.-Cat. No. 68419-68424, U.S.N.M.

CUPULADRIA BIPOROSA, new species.

Plate 47 , figs. 1,2 .

Description.-The zoarium is orbicular. The zooecia are distinct, large, elongated or transrerse, large or small, generally rhomboidal; the opesium is regular, oral, variable in form in the wide zooecia. The interzooecial ribraculum is rery large and auriculate. On the inner face the zooecia are rectangular and each one bears two large pores.

Affinities.-This interesting new species differ's from Cupuladria canariensis Busk, 1852, in its larger zooecia, which bear on the inner face only two large pores. 
It is also very well characterized by the presence of wider zooecia in the vicinity of the zoarial margins.

Occurrence.-Miocene (Bowden marl): Santo Domingo.

Cotypes.-Cat. No. 68425, U.S.Y.M.

Genus ACANTHODESIA Canu and Bassler, 1919.

1919. Acanthodesia Caxu and Bassler, Gejology and Paleontology of the West Indies, Bryozoa, Publications of the Carnegie Institution of Washington, No. 291, p. 79.

No ovicell. The opesium is garnished laterally by small spinous processes and inferiorly by a serrate denticle. Fifteen tentacles.

Genotype.-Acanthodesia (Flustra) savarti Savigny-Audouin, 1826.

Range.-Lutetian-Recent.
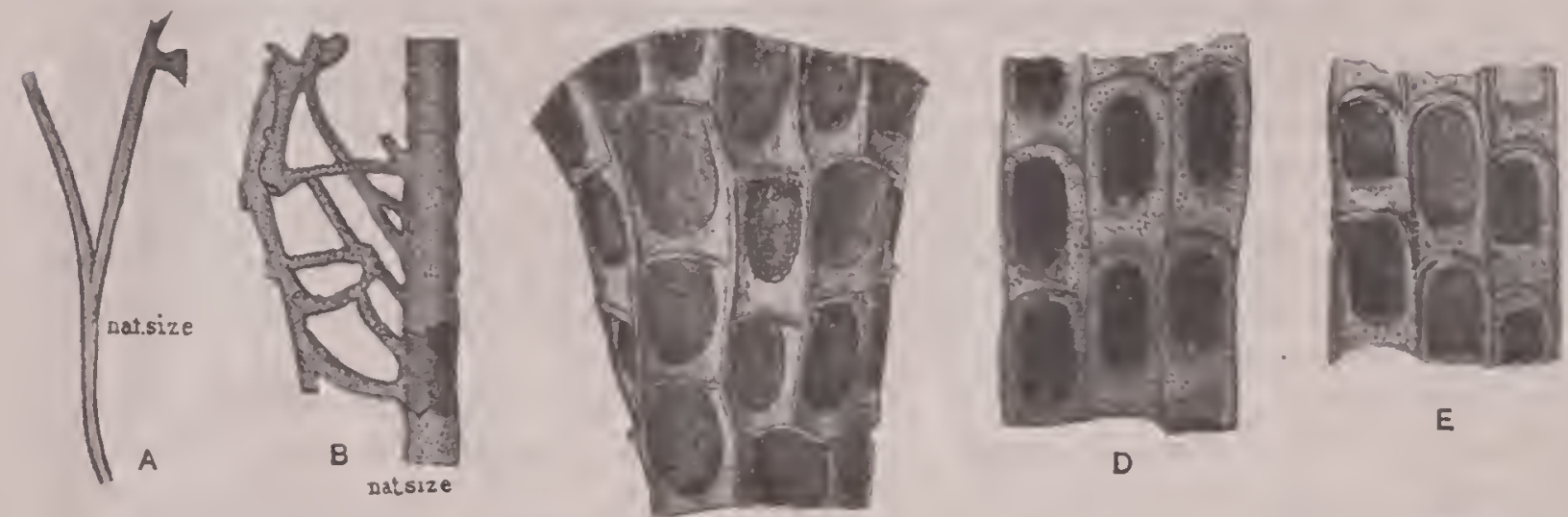

E

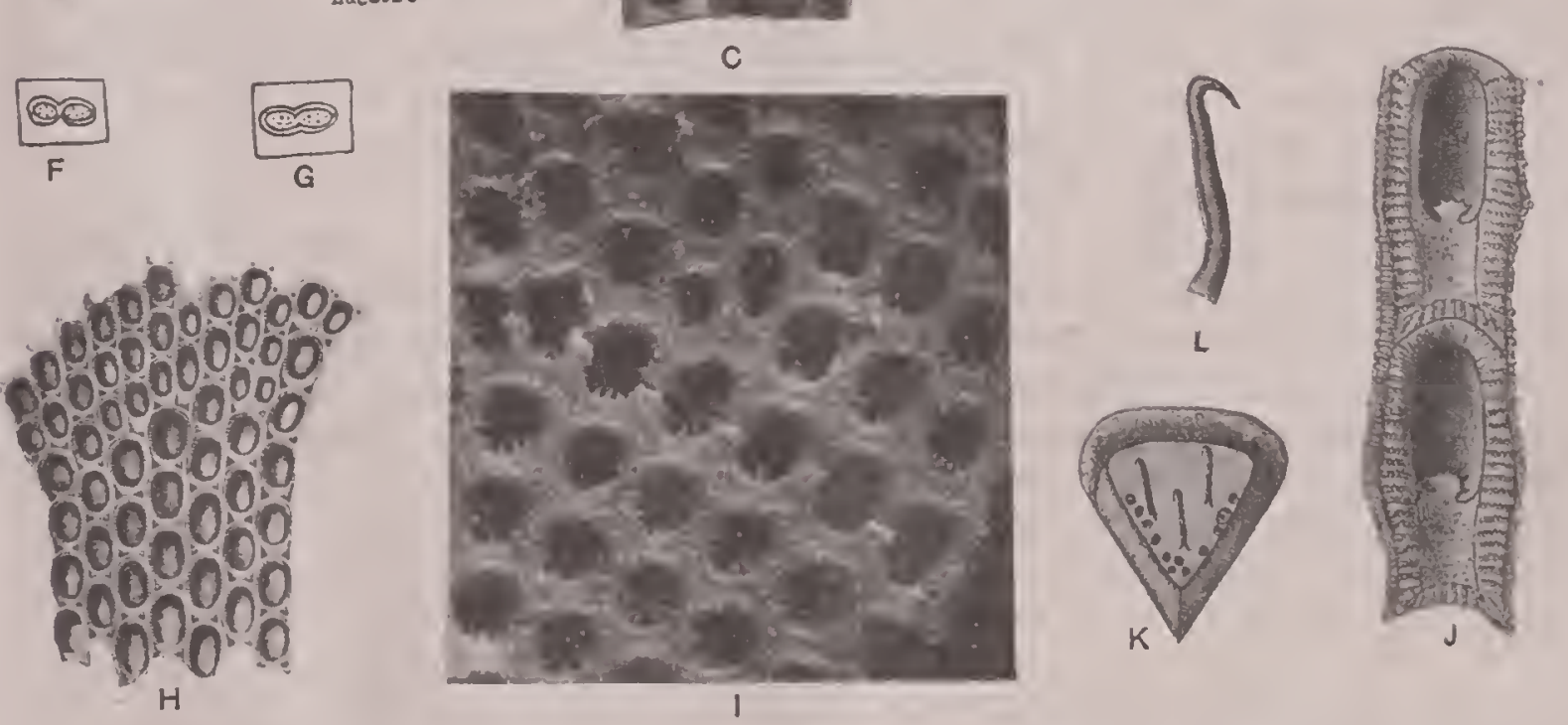

Fig. 2.-Genus Acanthodesia Canu and Bassler, 1919.

Figs. A-I. Acanthodesia satartii Savigny-Audouin, 1826. A and B. Zoaria of recent specimens natural size. C. Young zooecia, $\times 25$. D. Older zooecia, $X 25$, showing small proximal denticles. E. Older zooecia, $X 25$, with a serrate denticle directed inward toward the basal wall. F, G. Distal septular plates, $X 250$ (A-G, after Waters, 1908). II. Zoarial fragment, $X 12$ (after Audouin, 1826). I. $\Lambda$ fossil specimen, $\times 20$, showing zooecia with spicules.

Figs. J-L. Acanthodesia (Membranipora) limosa, Waters, 1908. J. Two zooecia, X 55. K. Distal wall, $X 55$, with the peculiar spine-like processes. L. A spine-like process more highly magnified, $\times 200$. (Figs. J-L, after Levinsen, 1909.) 
ACANTHODESIA SAVARTI Savigny-Audouin, 1826.

1812. Flustra savarti SAvignY, Description de l'Egypte, Polypes, pl. 10, fig. 10.

1826. Flustra savarti Audour, Explication sommaire des planches de Polypes de l'Egypte et de la Syrie, p. 240.

The rariations in form and size of this species are extraordinary. We group them around some principal forms, but it is erident that the same zoarium may exhibit all of them. These forms are as follows:

1. Forma typica. The opesium is crenulated and elongated; the large zooecia have a cryptocyst. The zoarium is incrusting, unilamellar or bilamellar.

2. Forma texturata. The cryptocyst is developed on all the zooecia. No areal spines. No tubercles. The zoarium is unilamellar and subcylindrical.

3. Forma reyti. The zooecia are irregular. There are areal spines. No cryptocyst. No tubercles. The opesium is denticulated and not crenulated. The zoarium is unilamellar and subcylindrical.

4. Forma monilifera. Like typica, but the mural rim is beaded. The zoarium is unilamellar and subcylindrical.

5. Forma delicatula. The cryptocyst is short. There are areal spines. The zonrium is bilamellar.

6. Forma bifoliata. There are areal spines. The opesium is surrounded by a sort of salient collar. The zoarium is bilamellar. Tubercles at the angles.

These rarious forms and occurrences are noted under the following headings:

\section{ACANTHODESIA SAVARTI forma TYPICA.}

Plate 11, figs. 1-3.

The opesium is crenulated and elongated; the large zooecia have a cryptocyst. The zoarium is encrusting, unilamellar or bilamellar.

Our few American specimens are encrusting. The zooecia are less elongated than in the forma monitifera and less spinous than the forma reyti. The micrometric variations are very great. The granulations are as beautiful as in the other two forms.

Occurrence.-Miocene (St. Mary's formation): Bowler's wharf, Rappahannock Rirer, 18 miles above Urbana, Middlesex County, Virginia (rare). Miocene (Yorktown formation): Near Suffolk Virginia (rare). Pleistocene: Vero, Florida (common).

Plesiotypes.-Cat. No. 68426, U.S.N.M.

\section{ACANTHODESIA SAVARTI forma REYTI Canu, 1909.}

1909. Membranipora reyti Caxu, Les Bryozoaires fossiles des Terraines du Sud-Ouest de la France; III Burdigalien, Bulletin de la Société Géologique de France, ser. 4, vol. 9, p. 443, pl. 15, fig. 2.

1909. Membranipora savarti C.Avu, Les Bryozoaires fossiles des Terraines du Sud-Ouest de la France; III Burdigalien, Bulletin de la Société Géologique de France, ser. 4, vol. 9, p. 444, pl. 15, fig. 3 .

Measurements.-Opesia $\left\{\begin{array}{l}h_{0}=0.34-0.50 \mathrm{~mm} . \\ l_{0}=0.20-0.30 \mathrm{~mm} .\end{array}\right.$ Zooecia $\left\{\begin{array}{l}L z=0.50 \mathrm{~mm} . \\ l_{z}=0.40 \mathrm{~mm} .\end{array}\right.$ 
There are some long and some wide zooecia. The opesium is rery finely denticulated and bears areal spines. The mural rim is granulated on the better preserved specimens, which then r'esemble forma monilifera from Cercado de Mao, Santo Domingo. There are in the Canu collection specimens almost as beautiful as the Santo Domingo form.

Occurrence.-Miocene (Aquitanian): Léognan (LeThil), St. Médard-Gajac (Gironde) and St. Arit (Landes), France. Miocene (Burdigalian): Saucats (LePeloua), Léognan and Pontiac (Gironde) France.

\section{ACANTHODESIA SAVARTI forma MONILIFERA Canu and Bassler, 1919.}

Plate 2, figs. 2, 3 .

1919. Acanthodesia savarti forma monilijera CAxu and BAssler, Geology and Paleontology of the West Indies, Bryozon, Publication of the Carnegie Institution of Washington, No. 291, p. 79, pl. 2, figs. $2,3$.

Like typica, but the mural rim is beaded. The zoarium is unilamellar and subcylindrical.

This form is intermediate between forma reyti and forma typica. It is evidently the first representative in the American Basin.

Occurrence.-Lower Miocene (Bowden horizon): Cercado de Mao, Santo Domingo (rare.)

Holotype.-Cat. No.68427, U.S.N.M.

ACANTHODESIA SAVARTI forma TEXTURATA IReuss, 1847.

Plate 5, figs. 1-5: plate 46 , figs. $8,9$.

1847. Flustrcllaria texturata Reuss, Die fossilen Polyparien des Wiener-Tertiärbeckens, Haidinger's naturwissenschaftliche Abhandlungen, vol. 2, p. 73, pl. 9, fig. 1.

1872. Biflustra savarti Sirts, Floridan Bryozoa, collected by Count L. F. de Pourtales, Part I, Kongl. Srenska Vetenskaps-Akademiens Handlingar, rol. 10, No. 11, p. 20, pl. 4, figs. 92-95.

1877. Flustrellaria texturata Maxzoxi, I, Briozoi fossili del Mriocene d'Austria ed Lngheria, II Parte, Denkschriften der math. natur. Classe der k. Akademie der Wissenschaften, vol. 37, Abtheil. 2, p. 67, pl. 13, fig. 45 .

1917. Acanthodesia sararti forma texturata CANu and BAssler, Geology and Paleontology of the West Indies, Bryozoa, Publication of the Carnegie Institution of Washington, No. 291, p. 79, pl. 5 , figs. 1-5.

The cryptocyst is dereloped on all the zooecia. No spinous processes. No tubercles. The zoarium is unilamellar and subcylindrical.

$$
\text { Measurements.-Opesia }\left\{\begin{array} { l } 
{ h _ { 0 } = 0 . 3 5 \mathrm { mm } . } \\
{ l _ { 0 } = 0 . 2 0 \mathrm { mm } . }
\end{array} \quad \text { Zooecia } \left\{\begin{array}{l}
L_{z}=0.50 \mathrm{~mm} \text {. } \\
l_{z}=0.28 \mathrm{~mm} .
\end{array}\right.\right.
$$

Variations. - The zoarium incrusts fine algae at their bifurcation; it is therefore unilamellar and subcylindrical. The zooecia are elongated, ogival, distinct; the mural rim is striated, salient only in the distal portion; the cryptocyst is large and concave. The opesium is elliptical, rery finely denticulated; anteriorly it often bears thin and short spinous processes.

Smitt figured the serrate denticle on the recent specimens; it never persists on the fossil examples. On the inner face the zooecia are rectangular. 
Affinities.--The presence of the spinous processes differentiates our specimens from Flustrellaria texturata from the European Tortonian which, according to the figures, does not bear them.

Occurrence.-Lower Miocene (Bowden horizon): Bowden, Jamaica (very common). Pleistocene or Recent: Vero, Florida (rare).

Geologic distribution.-Tortonian of Austria Hungary (Manzoni).

Habitat.-Recent, off Florida (Smitt).

Plesiotypes.-Cat. Nos. 68428, 68429, U.S.N.M.

\section{ACANTHODESIA SAVARTI forma DELICATULA Busk, 1859.}

Plate 11, figs. 5-9.

1859. Biflustra delicatula Busk, Monograph fossil Polyzoa of the Crag, Publications Paleontographical Society, London, vol. 14, p. 72, pl. 1, figs. 2, 4; pl. 2, fig. 7.

1869. Biflustra delicatula Manzoxr, Bryozoi fossili italiani, Terza contribuzione, sitzungsberichte der kaiserlichen Akademie der Wissenschatten, vol. 60, Abtheil. 1, p. 4, pl. 1, fig. 5.

$$
\text { Measurements.-Opesia }\left\{\begin{array}{l}
h o=0.40 \mathrm{~mm} . \\
l o=0.20 \mathrm{~mm} .
\end{array} \quad \begin{array}{l}
\text { Zooecia } \\
\text { (first of series) }
\end{array}\right) \begin{aligned}
& L z=0.60 \mathrm{~mm} . \\
& l z=0.40 \mathrm{~mm} .
\end{aligned}
$$

Our specimens have very narrow fronds. The mural rim is thick and finely tuberous. The cryptocyst is sometimes short, sometimes long. The traces of spinous processes are quite frequent.

The bilamellar form commences in the Helretian. The rariation with large cryptocyst is abundant in the Mediterranian Pliocene.

Occurrence.--Miocene (Choctawhatchee marl: :) Jackson Bluff, Ocklocknee Rirer, 25 miles southwest of Tallahassee, Florida (rare). Miocene (St. Marrs formation): Bowler's wharf, 18 miles abore Urbana, Middlesex County, Virginia (rare).

Geologic distribution.-Helretian of St. Arit and Salles (Gironde), of the faluns of Touraine (Canu collection). Pliocene (Astian) of England (Busk) and of Italy (Manzoni).

Plesiotypes.-Cat. Nos. 68430,68431 , U.S.N.M.

ACANTHODESIA SAVARTi forma BIFOLIATA Uirich and Bassler, 1904.

Plate 11, fig. 4.

1904. Membranipora bifoliata ULrich and BAs er, Bryozon, Maryland Geological Survey, Miocene, p. 411, pl. 112, figs. 2, 3, 4 .

There are areal spines. The opesium is surrounded by a sort of salient collar. The mural rim is thin. The zoarium is bilamellar. Tubercles at the angles.

This form is much like forma delicatula and differs only in the absence of the cryptocyst and in its thin mural rim. The collar-like structure which surrounds the opesium is not constant; it exists sometimes in the unilamellar forms.

Occurrence.-Miocene (Choptank formation): Jones wharf and Cordova, Maryland (common).

Cotypes.-Cat. No. 68432 , U.S.N.M. 
Plate 10, figs. 1-3.

1904. Membranipora oblongula Ulrich and Bassler, Bryozoa, Maryland Geological Survey, Miocene, p. 407, pl. 110, figs. 2-5.

Description.-The zoarium incrusts shells. The zooecia are distinct, separated by a furrow of little depth, elongated, rectangular; the mural rim is rounded, regular, granular, ornamented by two large distal tubercles. The opesium is entire, elliptical, finely denticulated and provided with spicules of greater or less length.

$$
\text { Measurements. O Opesia }\left\{\begin{array} { l } 
{ h o = 0 . 4 0 \mathrm { mm } . } \\
{ l o = 0 . 1 5 \mathrm { mm } . }
\end{array} \quad \text { Zooecia } \left\{\begin{array}{l}
L_{z}=0.45-0.50 \mathrm{~mm} . \\
l_{z}=0.25-0.30 \mathrm{~mm} .
\end{array}\right.\right.
$$

Tariations.-The figures of Ulrich and Bassler are incomplete as the tubercles hare not been restored fully enough. On Plate 10 we reproduce a better photograph of the type (fig. 1). Sometimes the tubercles are joined and form a single large distal tuberosity (fig. 2). The micrometric measurements vary according to the spccimens and even on the same specimen they are irregular. The zooecia giving rise to a new series are larger according to the rule in the genus.

Affinities.-This species differs from Membranipora flabellata Canu, 1904, in the presence of spicules and in the larger micrometric measurements. It differs from Acanthodesia savarti Audouin, 1S26, in the presence of large distal tubercles.

Occurrence.-Miocene (Calrert formation): Plum Point, Reeds, and Chesapeake Beach, Maryland (common). Miocene (Choptank formation): Jones wharf, Pawpaw Point, Dorer Bridge, etc., Maryland (rare).

Plesiotype.-Cat. No. 68t33, U.S.N.M.

\section{ACANTHODESIA RECTANGULARIA, new species.}

Plate 9, fig. 11.

Description.-The zoarium incrusts oyster shells. The zooecia are distinct, elongated, rectangular; the mural rim is thin, salient; the cryptocyst is deep, short, a little convex. The opesium is large, oval, terminal.

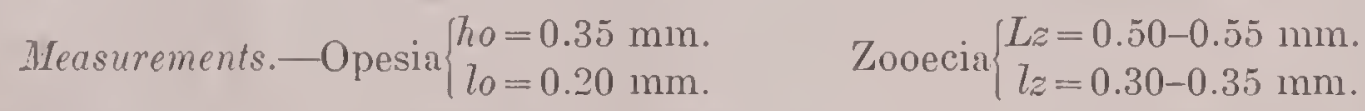

Affinities.-On certain isolated zooecia we have been able to observe some spines and eren traces of the serrate proximal denticle. In spite of appearances of our figure, which is incomplete because of the disappearance of the spines, this species belongs really to the genus Acanthodesia. It is well characterized by the rectangular form of its zooecia.

Occurrence.-Miocene (Torktown formation) : 3 milcs southwest of Petersburg, Virginia (rare).

Holotype.-Cat. No. 68434 , U.S.N.M. 
SECTION II. MEMBRANIPORAE WITH ENDOZOOECIAL OVICELL.

Genus VIBRACELLINA Canu and Bassler, 1917.

(For description see Bulletin 106, U. S. National Museum, p. 110.)

VIBRACELlina pUSILla, new species.

Plate 10, figs. $4,5$.

Description.-The zoarium incrusts shells. The zooecia are small, oval, a little elongated, distinct, separated by a deep furrow; the mural rim is thin, rounded, salient, much enlarged at the base into a concave cryptocyst. The opesium is anterior, oval, regular. The ovicell is very small and endozooecial. The vibracula are small, salient, elliptical, auricular.

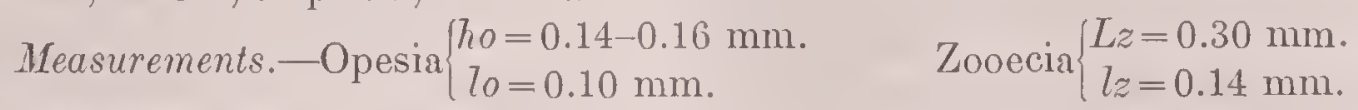

Affinities.-According to the rule in this genus, the ancestrular zooecia are smaller and frequently calcified. The ancestrula cngenders five normal zooecia and three vibracular ones. In the proximal portion of the zooccia there is often a very short gymnocyst.

This species differs from Membrendoecium rectum Canu and Bassler, 1920, from the Vicksburgian in its slightly smaller dimensions, its concave and not flat cryptoeyst and in its nonsalient mural rim.

Occurrence.-Pliocene (Caloosahatchee marl): Shell Creek, De Soto County, Florida (very rare). Miocene (Duplin marl): Natural well, 2 miles southwest of Magnolia, North Carolina (rare).

Cotypes.-Cat. Nos. 68435,68436 , U.S.N.M.

\section{VIBRACELLINA SIMPLEX, new species.}

Plate 10, figs. 6, 7 .

Description.-The zoarium incrusts shells. The zooecia are distinct, separated by a furrow, elongated, pyriform; the gymnocyst is smooth, convex, rather short: the termen is sharp. The opesium is oval, the point above. The ovicell is very small and endozooecial. The vibracula are rare, very small, auriculated. The ancestrula is calcified and presents a small semilunar aperture.

$$
\text { Measurements.-Opesia }\left\{\begin{array} { l } 
{ h _ { 0 } = 0 . 2 0 \mathrm { mm } . } \\
{ l _ { 0 } = 0 . 1 3 - 0 . 1 5 \mathrm { mm } . }
\end{array} \text { Zooecia } \left\{\begin{array}{l}
L z=0.35-0.40 \mathrm{~mm} . \\
l z=0.25 \mathrm{~mm} .
\end{array}\right.\right.
$$

Structure.-The rarety of vibracula give to this species an aspect of great simplicity. The heterozooecin appear to be zooccia in which the development has been arrested by adjacent zooecia. The ancestrula and three ancestrular zooecia arc calcified. The hexagonal symmetry in the arrangement of the ancestral zooecia is remarkable. Nererthelcss, there are really only five zooecia issuing from the ancestrula according to the rule, and no vibracula. We have observed calcified zooecia and also regenerated zodecia in vicinity of the ancestrula.

This species differs from Tribracellina pusilla in its larger micrometric dimensions and in the very great rarity of the vibracula.

Occurrence.-Miocene (Choctowhatchee marl): Jackson Bluff, Ocklocknee River, 25 miles southwest of Tallahassee, Florida (very rare). Miocene (Duplin marl): Natural well, 2 miles southwest of Magnolia, North Carolina (rare).

Cotypes.-Cat. Nos. 68437, 68438, U.S.N.M. 
Genus MEMBRENDOECIUM Canu and Bassler, 1917.

(For description see Bulletin 106, U. S. National IIuseum, p. 119.)

MEMBRENDOECIUM PARVICAPITATUM, new species.

Plate 12, figs. 1, 2.

Description.-The zoarium enerusts shells. The zonecia are distinet, separated by a deep furrow, elongated, elliptical; the mural rim is thin and rounded. The opesium is of the same form as the zooeeium. The oricell is very small, transverse, endozooeeial, searcely salient. A rery small triangular arieularium appears sometimes between the zooeeia.

$$
\text { Measurements.-Opesia }\left\{\begin{array} { l } 
{ h o = 0 . 3 6 \mathrm { mm } . } \\
{ l o = 0 . 2 6 \mathrm { mm } . }
\end{array} \quad \text { Zooecia } \left\{\begin{array}{l}
L z=0.44 \mathrm{~mm} . \\
l z=0.32-0.34 \mathrm{~mm} .
\end{array}\right.\right.
$$

Variations.-The measurements are very irregular. The regeneration of the polypide is rery frequent and our figure shows an orarian zooeeium replaced by an ordinary one. The mural rim is rery finely granulated. The small avicularium is quite rare. Aceording to the rule in this genus it is deprived of pirot.

All of the resemblanees of this speeies are with Callopora guemei, Jullien, 1904, and it is close to this latter species that we would have to refer the present new speeies in case additional specimens should show that the small distal elevation of the mural rim is not an endozooecial ovicell.

Occurrence.-Miocene (Choctowhatehee marl); Jackson Bluff, Ocklocknee River 25 miles southwest of Tallahassee, Florida (rare). Mineene (Bowden marl) : Bowden, Jamaica (rare).

Holotype and paratype.Cat. Nos. 68439,68440 , U.S.N.M.

MEMBRENDOECIUM GRANDE, new species.

Plate 11. figs. 10-12.

Description.-The zoarium inerusts shells. The zooeeia are distinct, separated by a furrow of little depth, elongated, large, irregular; the mural rim is thin, bevelled, with a sharp termen. The opesium is large, entire, of the same form as the zooecium. The oricell is endozooeeial, small, little salient, transverse.

$$
\text { Measurements.-Opesia }\left\{\begin{array} { l } 
{ h o = 0 . 5 6 \mathrm { mm } . } \\
{ l o = 0 . 4 0 \mathrm { mm } . }
\end{array} \quad \text { Zooeeia } \left\{\begin{array}{c}
L z=0.70 \mathrm{~mm} . \\
l z=0.50 \mathrm{~mm} .
\end{array}\right.\right.
$$

Affinities.-This speeies has the aspeet of Membranipora irregularis Manzoni, 1875, of the Italian Plioeene, but differs in its larger dimensions $(L z=0.70$ and not $0.60 \mathrm{~mm}$.) and in the absenee of a distal thickening in the form of a turret. It has also the general aspect of the reeent Membranipora irregularis Smitt, 1872; but we hare noted (see p. 142 of Bulletin 106, U. S. National Museum) that the latter is a charaeteristie Alderina; there is therefore a fundamental differenee in the orieell.

Occurrence.-Mioeene (Duplin marl): Wilmington, North Carolina (very rare). Plioeene (Waeeamaw marl): Waecamaw River, Horry County, South Carolina (rare). Reeent: Various loealities in the Gulf of Mexico.

Cotypes.-Cat. Nos. 6S441,6S442, U.S.N.M. 
Genus OGIVAliNA Canu and Bassler, 1917.

(For description see Bulletin 106, U. S. National Museum, p. 117.)

OGIVAliNA MUTABILIS Canu and Bassler, 1919.

Plate 1, fig. 3.

1919. Ogivalina mutabilis Caxu and Bassler, Geology and Paleontology of the West Indies, Bryozoa, Publicatiou Carnegie Institution of Washington, No. 291, p. 80, pl. 1, fig. 4.

Description.-The zoarium is incrusting. The zooecia are elongated, oval, distinct, separated by a deep furrow; the mural rim is thin, smooth, rounded; there is often a small gymnocyst. The opesium is rery large, irregular, more often oral. The ovicell is endozooecial, small, little convex. Sometimes there is a small interzooecial fusiform aviculariun (?)

Measurements.-Opesia $\left\{\begin{array}{l}h o=0.60-070 \mathrm{~mm} . \\ 70=0.30-045 \mathrm{~mm} .\end{array}\right.$ Zooecia $\left\{\begin{array}{c}L z=0.75-0.95 \mathrm{~mm} . \\ l z=0.50-0.70 \mathrm{~mm} .\end{array}\right.$

The great irregularity of form and zooecial dimensions of this species occasions its name. There are some variations which recall those of Membranipora irregularis Manzoni, $1875,{ }^{5}$ which possesses a mural rim enlarged at the base and also some large interzooecial aricularia.

The present species differs from the splendid Ogivalina eximipora Canu and Bassler, 1917, from the Middle Jacksonian in its smaller dimensions, in the absence of cryptocyst and in the presence of a gymnocyst. The avicularium (?) is idcntical in form and position.

Occurrence.--Upper Oligocene (Emperador limestone): Old quarry, one-third mile north of west of Empire, Panama Canal zone (rare). Upper Oligocene (Anguilla formation): Southwest side Crocus Bay Hill, Anguilla, Leward Islands (rare).

Holotype.-Cat. No. 68443 , U.S.N.M.

\section{OGIVAliNa PARUULA Ulrich and Bassler, 1904.}

Plate 12, fig. 6 .

1904. Membranipora parmla ULrich and Bassler, Bryozoa, Maryland Geological Survey, Miocene, p. 310, pl. 111, fig. 1, 2.

The original description of this species is as follows:

In its general zoarial and zooecial characters this species resembles Membranipora germana Ulrich and Bassler, 1904 and I. plebeia Gabh and Horn. but it is readily distinguished by the smaller size and less elongate form of its zooecia. The walls are also relatively thicker while the longitudinal arrangement of the zooecia is more pronounced. Ifeasuring longitudinally, $\mathrm{S}$ zooecia occur in $3 \mathrm{~mm}$. and transversely 12 may be counted in the same space.

To the above we would add that there is a small gymnocyst and that the ovicell is endozooecial and the avicularium is interzooecial.

Occurrence-Miocene (Calvert formation): Reed's Maryland (rare.)

Holotype.-Cat. No. 68444 , L.S.N.M.

\footnotetext{
5 Briozoi del plioceue antico di Castrocaro Bologna, 1875, p. 10, pl. 1, figs. 3 , \&.
} 
Genus HINCKSINA Norman, 1903.

(For description, sce Bulletin 106, U. S. National Museum, p. 111.)

HINCKSINA QUADRISPINOSA, new species.

Plate 33, fig. 10.

Description.-The zoarium incrusts shells. The zooecia are distinct, separated - by a very deep furrow, large, elongated, elliptical; the mural rim is convex, thin, granulated, ornamented with four distal, hollow spines. The opesium has the same form as the zooecium. The ovicell is endozooccial, very small, scarcely salient.

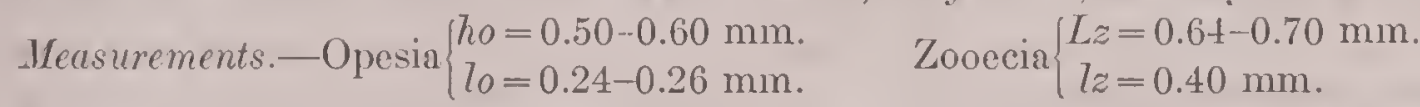

Affinities. - The total regcneration of the polypide is frequent and manifests itself, as is customary by a double mural rim. This species differs from Membrendoecium grande in the prescnce of four distal spines. It differs from Membranipora echinata D'Orbigny, 1839, in the presence of four (and not six) distal spines and in a much smaller ovicell. It differs from Membranipora irregularis D'Orbigny, 1839, of which it has the zooecial form, in its endozooecial and very small ovicell. Our specimen which showed the ovicell was not in a condition to be photographed.

Occurrence.-Pleistocene: Santa Monica (Rustic Canyon), California (rare).

Holotype.-Cat. No. 68445 . U. S. N. M.

\section{hiNCKSINA MULTISPINATA, new species.}

Plate 33, fig. 11.

Description.-The zoarium incrusts shells. The zooecia are distinct, separated by a deep furrow, elongated, oval or pyriform, provided with a small convex and smooth gymnocyst; the mural rim is thick, round, salient and bears 16 to 18 large, hollow spincs; the opcsium is anterior, oval, entire.

$$
\text { Measurements.-Opesia }\left\{\begin{array} { l } 
{ h _ { 0 } = 0 . 2 4 - 0 . 2 6 \mathrm { mm } . } \\
{ l _ { 0 } = 0 . 1 4 - 0 . 1 6 \mathrm { mm } . }
\end{array} \quad \text { Zooecia } \left\{\begin{array}{l}
L z=0.40 \mathrm{~mm} . \\
l_{z}=0.28-0.34 \mathrm{~mm} .
\end{array}\right.\right.
$$

Affinities.-The four distal spines are sometimes smaller and more crowded; the others are regularly distributed around the opesium. The figured specimen only having been found, we have not been able to verify whether the ovicell is really endozooecial; a single zooecium shown in our figure appears to have this character. We have observed a case of total regeneration of the polypide.

This species differs from Mcmbranipora variegata Hincks, 1881, in having more than thirteen spines. It differs from Membranipora echinus Hincks, 1884, in the possession of more than two spines in the distal third of the zooecium. It differs from Membranipora echinata D'Orbigny, 1839, in having more than six spines. It differs from Membranipora pyrula Hincks, 1881, in its smaller dimensions and in the presence of a greater number of spines.

Occurrence.-Pleistocene: Santa Barbara, California (very rare).

IIolotype.-Cat. No. 68446, U.S.N.M. 
SECTION III. OVICELL HYPERSTOMIAL ALWAYS CLOSED BY THE OPERCULUM.

Genus MEMBRANIPORIDRA Canu and Bassler, 1917.

(For description, see Bulletin 106, U. S. National Museum, p. 133.)

membraniporidra Parca, new species.

Plate 12, fig. 7.

Description.-The zoarium incrusts shells. The zooecia are distinct, separated by a deep furrow, regularly elliptical; the frontal is formed of a convex gymnocyst principally developed in the inferior part of the zooecium. The opesium is regularly elliptical and bears a distal indentation in which the operculum is placed. The oricell is conrex, smooth, transverse, placed on the gymnocyst of the distal zooccium; it is always closed by the operculum.

$$
\text { Measurements.-Opesia }\left\{\begin{array} { l } 
{ h _ { 0 } = 0 . 3 0 \mathrm { mm } . } \\
{ l o = 0 . 2 2 \mathrm { mm } . }
\end{array} \text { Zooecia } \left\{\begin{array}{l}
L z=0.50 \mathrm{~mm} . \\
l z=0.30 \mathrm{~mm} .
\end{array}\right.\right.
$$

Tariations.-It is rery difficult to interpret the operation of the operculum on the fossils. Here the oricell is indeed separated from the opesium by the mural rim, but the superior indentation of the opesium which corresponds to the operculum is of exactly the same form as the orifice of the ovicell. It is therefore rery probable that our generic assignment is exact.

This species rests directly upon the shell and does not secrete a calcareous dorsal. This economy of calcite is rather rare in the strata which are not exclusively arenaceous.

Occurrence.-Miocene (Choctowhatchee marl): Jackson Bluff, Ocklocknee River, 25 miles southwest of Tallahassee, Florida (very rare).

Holotype.-Cat. No. 68447 , U.S.N.M.

\section{DIVISION IV. OVICELL NEVER CLOSED BY THE OPERCULUM.}

Genus ALDERINA Norman, 1903.

(For description, see Bulletin 106, U. S. National Museum, p. 140.)

ALDERINA CESTICELLA, new species.

Plate 12, figs. 4, 5 .

Description.-The zoarium incrusts oysters. The zooecia are distinct, elongated, oval, separated by a deep furrow, ornamented by a short gymnocyst; the mural rim is thin; enlarged behind in the form of a cryptocyst, rounded, salient, garnished with six to eight large distal spines; the opesium is anterior, oral, surrounded by a salient and fincly wrinkled collar. The oricell is large, salient, globular, hemispherical, bearing a large, inferior collar, transverse and linear. The ancestrula bears an opesial sinus.

$$
\text { Measurements.-Opesia }\left\{\begin{array} { l } 
{ h o = 0 . 2 0 - 0 . 2 5 \mathrm { mm } . } \\
{ l o = 0 . 1 5 - 0 . 2 2 \mathrm { mm } . }
\end{array} \quad \text { Zooecia } \left\{\begin{array}{l}
L z=0.40-0.50 \mathrm{~mm} . \\
l z=0.25-0.30 \mathrm{~mm} .
\end{array}\right.\right.
$$

Affinities.-This species is irregular in its micrometric measurements, but the zooecial form remains always pyriform. The ancestrula is quite remarkable. It is elliptical and deprived of spines. It engenders two large and three small zooecia. Its opesium bears a deep sinus, the significance of which is unknown. The marginal 
zooccia are larger and become almost triangular. Regenerated zooecia are quite frequent. Although the ovicell projects much on the opcsium, we think, however, that it does not become closed by the operculum. Horeorer, the zooecial form is that of Alderina imbellis Hincks, 1860.

This species differs from Membranipora galeata Busk, $185 t$, in the presence of six to eight distal spines (and not four) and in the absence of a triangular area on the ovicell.

Occurrence.-Niocene (Duplin marl): Natural well, 2 miles southwest of Magnolia, Duplin County, North Carolina (rare).

Holotype.-Cat. No. 6St4S, U.S.N.M.

\section{Genus CALLOPORA Gray, 1848.}

(For description see Bulletin 106, U. S. National Museum, p. 145.)

CALLOPORA DUMERILII Savigny-Audouin, 1826.

Plate 1, fig. 2; plate 2, fig. 23; plate 12, fig. 12

1826. Flustra dumerilii AUdor's, Explication Savigny's Egypte, Polypes, pl. 10, fig. 12.

1591. Kembranipora dumerilii Waters, North Italian Bryozoa, Quarterly Journal Geological Society of London, vol. 47, p. 12, pl. 2, fig. 4.

1S 14. Membranipora dumerilii Levissex, Mosdyr, Zoologica Danica, Hefte 9, p. 57, pl. 4, figs. 22-25.

1907. Iembranipora dumerilii CaLvet, Bryozoailes Expedition scientifique du Travailleur (1881-82) et du Talisman (1SS3), p. 395 (bibliography).

1909. Callopora dumerilii Norsas, On the polyzoa of Madeira and neighboring islands, Linnean Society Journal, Zoology, rol. 30, p. 2Si.

1912. Membranipora dumerilii CANu, Etude des Bryozoaires Helvetiens de l'Egypt, Memoires de l'Institute Egyptien, vol. 6, p. 196, pl. 10, fig. T (sce for complete bibliography).

1919. Callopora dumerilii, var. lata CANU and BAssLer, Geology and Paleontology of the West Indies, Bryozoa Publication Carnegie Institution of Washington, No. 291, p. 81, pl, 1, fig. 1.

1920. Callopora dumerilii CANu and BAsscer, North American Early Tertiary Bryozoa, Bulletin 106. L. S. National Museum, p. 148, pl. 3, fig. 15. (see for zoological and paleontological bibliograplì).

This species presents two different aspects. Very frequently the zooecium is almost elliptical and there are two symmetrical frontal aricularia (as figured by Taters, Levinsen, and Busk). More rarely the zooecium is oral and there is only a single small interopesial aricularium (as figured by Hincks and Jullien). One specimen from Anguilla has this second aspect which appears to be that of zooecia in the ricinity of the ancestrula (pl 1, fig. 2). In 1919 we separated this second form as a new rariety, rar. lata, but until more specimens are collected we now prefer to leare the symonrmy as abore.

We refer doubtfully to this species two specimens incrusting a shell from the lower Miocene of Florida which appear to agree with Busk's figure of 1850 (pl. 12, fig. 12).

American sccurrence.-Oligocene (Anguilla formation): Southwest side of Crocus Bay.bluffs, uppermost horizon, 125 feet abore sea lerel, Anguilla, Leeward Islands (rare). Jacksonian (Castle Hayne limestone): Wilmington, North Carolina (rare). Miocene (Bowden marl); Bowden Jamaica (rare). Miocene (Chipola marl): Chipola Rirer, Calhoun County, Florida (rare).

Habitat.-Dredged to a depth of 280 meters.

Plesiotypes.-Cat. Nos. 68449,68450, U.S.N.MI. 
CALlopora PARVIROSTRIS, new species.

Plate 12, fig. 3.

Description.-The zoarium incrusts the shell of a Pecten. The zooecia are distinct, separated by a deep furrow, somewhat elongated, ovoid but with irregular contours; the mural rim is salient, thin, granular, somewhat enlarged at the base. The opesium is of the same form as the zooecium. The ovicell is small, very globular, smooth, opening below the operculum by a very small orifice. The interzooecial aricularium is triangular, suberect, very small with two large condyles for pivots.

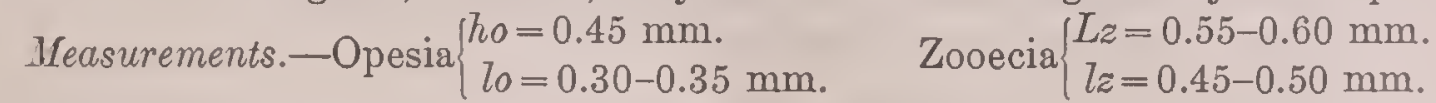

Affinities.-This species belongs to the C. tenuirostris group in the presence of its interzooecial avicularium. It differs from the genotype in its much larger micrometric dimensions and in its very small avicularium.

Occurrence.-Miocene (Calvert formation): 1 mile south of Parkers Creek, Calvert County, Maryland (very rare).

Holotype.-Cat. No. 68451, U.S.N.M.

\section{CALLOPORA LANCEOLATA, new species.}

Plate 12 fig. 11.

Description.-The zoarium incrusts oysters. The zooecia are distinct, elongated, fusiform, adjacent to each other by their mural rim; the mural rim is very thin, rounded; a little enlarged at the base; the opesium is elliptical, regular; traces of three pairs of spines are visible. The ovicell is large, salient, rectangular, garnished in front by a large convex area. The avicularium is placed at the base of each opesium; it is large, lanceolate; the beak is very salient and directed toward the base.

Measurements.-Opesia $\left\{\begin{array}{l}h_{0}=0.35 \mathrm{~mm} . \\ l_{0}=0.20-0.25 \mathrm{~mm} .\end{array}\right.$ Zooecia $\left\{\begin{array}{l}L z=0.60-0.70 \mathrm{~mm} \text {. } \\ l z=0.35 \mathrm{~mm} .\end{array}\right.$

Affinities.-Above the ovicell the avicularium is frequently divided into two smaller, symmetrical avicularia.

This species differs from Amphiblestrum constrictum Ulrich and Bassler, 1904, in its much larger avicularia, more elongated zooecia, and in the absence of two prominent condyles for the articulation of the operculum.

Occurrence:-Upper Miocene (Yorktown formation): 3 miles southwest of Petersburg (rare) and Beulahland, King and Queen County, Virginia (rare).

Holotype.-Cat. No. 68452, U.S.N.M.

\section{CALLOPORA CRASSOSPINA, new species.}

Plate 33, fig. 13.

Description.-The zoarium incrusts bryozoa. The zooecia are distinct, separated by a furrow, elongated, oval; the mural rim is thin, round, little salient and bears distally six large, hollow spines; the opesium is large, oval, entire. The avicularium is interzooecial, long, fusiform, with pointed and salient beak. The oricell is globular, salient, smooth.

$$
\text { 12184-23-Bull. 12j- } 4
$$




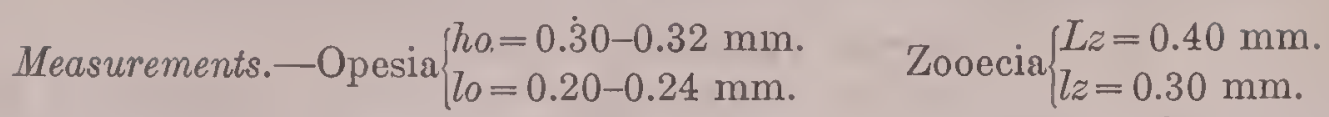

Affinities.-Our ovicelled specimen was not in a condition for photography, but it is well preserved and our generic determination is exact. We have observed some calcified and perforated zooecia.

In the number of spines this species much resembles Membranipora echinata D'Orbigny, 1839. It differs from it in its oval opesia and in the presence of the interzooecial avicularium. It belongs to the group of Callopora tenuirostris.

Occurrence.-Pleistocene: Santa Barbara, California (rare).

Holotype.-Cat. No. 68453, U.S.N.M.

CALlopora Guernei Jullien, 1903.

Plate 45 , figs. 3,4 .

1903. Membranipora guernei Jullien, Bryozoaires provenant des Campagnes de l' Hirondelle (18861883), Resultats des Campagnes scientifiques du Prince de Monaco, fasc. 23, p. 40, pl. 5, fig. 3 .

Measurements.-Opesia $\left\{\begin{array}{l}h_{0}=0.33 \mathrm{~mm} . \\ l o=0.20-0.25 \mathrm{~mm} .\end{array} \quad\right.$ Zooecia $\left\{\begin{array}{l}L z=0.45-0.50 \mathrm{~mm} . \\ l z=0.30-0.38 \mathrm{~mm} .\end{array}\right.$

Affinities. -The micrometric measurements noted on Jullien's figures are a little larger than ours; but as these are drawings and not photographs an error is always possible. Our specimens have the regularly oval zooecia shown in the figures of the French zoologist. Moreover, the interzooecial avicularia are identical with those described by Calvet in the same publication, "ils sont de forme ovoide a mandibule arrondie, et disposés soit obliquement, soit transrersalement par rapport au grand axe de zooécies."

Occurrence.-Pleistocene: Mount Hope, Panama Canal Zone (rery rare).

Habitat.--Gulf of Gascony at 135 meters.

Plesiotypes.-Cat. No. 6\$454, U.S.N.M.

CALLOPORA FILUM Jullien, 1903.

Plate 45 , fig. 5 .

1907. Membranipora filum Calvet, Bryozoaires, Expédition Scientifique du Travailleur et du Talisman, p. 386 (bibliography).

The ovicell of this species has not yet been described exactly, but Calvet writes that there are many ovicells which have the peculiarity of being operculated; that they are rather salient, have a semicircular basal contour and are provided with a semicircular orifice placed below the zooecial orifice. We believe that there is, therefore, no doubt in assigning the species to the genus Callopora, although the figure of Smitt, 1872, suggested an endozooecial ovicell. Our specimens are encrusting a coral.

Occurrence.-Pleistocene, Mount Hope, Panama Canal Zone (rare).

Habitat.-Northeast of Morocco (714 meters), Cape Verde Islands (110-180 meters), Azores (80-318 meters), Corse and Florida (21-97 meters).

Plesiotype.-Cat. No. 68455 , U.S.N.M. 
CALLOPORA HORRIDA Hincks, 1880.

Plate 33, figs. 18, 19.

1880. Membranipora horrida Hrveks, Contributions towards a general history of the marine Polyzoa, Annals and Magazine of Natural History, ser. 5, vol. 6, p. 82, pl. 10, fig. 6.

1908. Membranipora horrida RoBertson, The incrusting Cheilostomatous Bryozoa of the West Coast of North America, University of California Publications, Zoology, vol. 4, No. 5, p. 260, pl. 4, figs. 3,4 .

1898. ? Membranipora californiensis Waters, Observations on Membraniporidae, Journal Linnean Society Zoology, vol. 26, p. 681, pl. 49, fig. 14.

Measurements.-Opesia $\left\{\begin{array}{l}h o=0.28-0.30 \mathrm{~mm} . \\ L_{0}=0.16-0.18 \mathrm{~mm} .\end{array}\right.$ Zooecia $\left\{\begin{array}{l}L z=0.50 \mathrm{~mm} . \\ l z=0.30-0.40 \mathrm{~mm} .\end{array}\right.$

Our specimens have two areal spines, sometimes four. They present micrometric measurements a little different from those noted on Miss Robertson's figure; it is difficult, however, to admit two distinct species, the other characters being very similar. In studying a recent specimen of this species we have been convinced that the orifice of the ovicell is very small and can not be closed by the operculum.

Membranipora californiensis Waters, 1898, presents six articulated areal spines; our form is therefore intermediate between Waters' species and that of Hincks.

This species differs from Membranipora occultata Robertson, 1908, in shorter opesium, and in its larger and differently placed avicularium.

Occurrence.-Pleistocene: Santa Barbara, California (rare).

Habitat.-Eastern Pacific: Pacific Grove (Robertson) and the Queen Charlotte Islands (Hincks).

Plesiotype.-Cat. No. 68456, U.S.X.M.

CALlOPORA CIRCUMClathrata Hincks, 1881.

Plate 34 , figs. 1-3.

1881. Membranipora circumclathrata Hincks, Contribution general history of Marine Polyzoa 7 , Foreign Membranipora, Annals and Magazine Natural History, ser. 5, vol. 8, p. 131 (sep. 72), pl. 5, fig. 1.

1908. Membranipora circumclathrata RoBERTSON, The incrusting Cheilostomatous Bryozoa of the West Coast of North America, University of California Publications, Zoology, vol. 4, p. 259, pl. 14, figs. 1, 2.

Structure.-In this species the oricell is not closed by the operculum. Not only is this quite visible on the fossils but we have been able to verify it on a recent specimen dredged off Santa Monica. Sometimes a triangular pore is visible in the separating furrow of two zooecia; it is clearly attached to one of the mural rims and it is perhaps the base of a pedunculate avicularium as is the genus Cauloramphus. We have not observed these pores on our recent specimens. At the base of each opesium there is a small triangular avicularium with salient beak placed on the median zooecial axis. It sometimes becomes very large and is developed obliquely as in Callopora horrida Hincks, 18s0. Nevertheless, the presence of wide-spaced areolar pores differentiates the two species clearly.

Occurrence.-Pleistocene: Santa Monica (Long Wharf Canyon), California (rare).

Habitat.-Pacific coast of California.

Plesiotypes.-Cat. No. 68457, U.S.N.M. 
CALLOPORA (?) SPECIOSA Gabb and Horn, 1862.

Plate 9, fig. 13.

1862. Membranipora speciosa GAB B and Hors, Monograph Polyzoa Secondary and Tertiary formations of North America, Journal Academy Natural Sciences, Philadelphia, ser. 2, vol. 5, p. 159 , pl. 20 , fig. 45 .

The original description is as follows:

Colony encrusting in irregular patches, composed of elongated, oval cells, often crowded out of their normal shape. Cells arranged in longitudinal lines and in somewhat irregular quincunx. often assuming a transverse arrangement; aperture occupying the whole of the surface, cell walls plain. angular, at their edge or slightly rounded. Interior of the cell, regularly concave, with the sides of the concavity reaching almost to the top of the walls; in new cellules the germinal plate only is seen. This germinal plate often extends for a considerable distance beyond the colony (half an inch) and is marked by irregular longitudinal lines, frequently bent suddenly in an oblique direction and then continued longitudinally as before. Between the cellules are frequently open angular spaces, caused by the inaccurate apposition to the cellules.

\section{Occurrence.-Miocene: Chiriqui, Central America.}

\section{CALlopora (?) MULTiPORA Gabb and Horn, 1862.}

\section{Plate 33, fig. 12.}

1862. Siphonella (Flustrellaria) multipora GABB and HoRN, Monograph Polyzoa Secondary and Tertiary formations of North America, Jourual Academy Natural Sciences, Philadelphia, ser 2, vol. 5, p. 154, pl. 21, fig. 3S.

The original description follows:

Colony free (arranged in a tube in the only specimen we have seen), cellules outside, back, or inside of the tube showing the outline of the cellules. Cellules oval, juxtaposed, placed in irregular quincunx. Opening larger, occupying nearly the whole surface of the cellule; usually of the same shape as the cellule, sometimes having the proximal end wider than the distal end. Cell walls convex or flattened; marked by a variable number of pits often surrounded each by a distinct elevation or wall. The mouth is sometimes constricted by a small rim, parallel with the ordinary wall, placed inside of, and below it. This rim is ornamented in the same manner as the larger one.

\section{Occurrence.-Pleistocene: Santa Barbara, California.}

Genus AMPHIBLESTRUM Gray, 1848.

(For description see Bulletin 106, U. S. National Mruseum, p. 156.)

AMPHIBLESTRUM CONSTRICTUM Urich and Bassler, 1904.

Plate 13, figs. 1-6.

1904. Amphiblestrum constrictum Ulrich and Bassler, Bryozoa, Maryland Geological Survey, Miocene, p. 413, pl. 115, figs. 6. 7; pl. 11S, fig. 15.

The original description is as follows:

Zoarium forming crusts of small extent upon shells, the types growing on a Pecten. Zooecia arranged in rather irregular rows, 6 to 8 in $3 \mathrm{~mm}$. Aperture subovate, more or less constricted in front of the midlength, enclosed a sloping and fnely striated border, widest posteriorly. Frontal lamina very little developed forming the sloping and transversely striated border just mentioned. Oricells abundant, large, moderately convex, the middle portion distinguished by being minutely pitted or porous. Avicularia of moderate size, usually one, rarely two to each zooecium, of the same type as in A. flemingi but with the apex more prominent. 
This species is closely related to $A$. flemingi Busk, 1854, and $A$. trifolium Wood, both living in the seas of to-day and known also as fossils from late Tertiary beds of England and Italy. It is distinguished from both by the lesser development of the frontal lamina. The constriction of the aperture is usually more pronounced in $A$. constricta.

$$
\text { Ieasurements.-Opesia }\left\{\begin{array} { l } 
{ h _ { 0 } = 0 . 3 0 \mathrm { mm } . } \\
{ l _ { 0 } = 0 . 2 2 \mathrm { mm } . }
\end{array} \quad \text { Zooecia } \left\{\begin{array}{l}
L z=0.52-0.54 \mathrm{~mm} . \\
l z=0.36 \mathrm{~mm} .
\end{array}\right.\right.
$$

Variations.-The cryptocyst is very little developed; it is more like a proximal enlargement of the mural rim. By abrasion of the surface, the five dietellae are easily visible. The beak of the avicularium is salient and rounded. The two salient condyles arranged symmetrically in the opesium are intended to support the articulation of the operculum. The ancestrula is orbicular, without spines. It engenders one large and three small zooecia; the two groups are separated by two large zooecia derived from the small ones. We have observed some calcified zooecia perforated by a small median pore. Regenerated zooecia are rare.

Affinities.-In a recent letter, Mr. Waters remarks that the differences between this species and Amphiblestrum flemingi Busk, 1854, are not sufficient to separate the two species. It is evident that we have here a difficult problem in specific determination and that we are not yet able to distinguish the true characters of the species from those of a variety. The problem is further complicated by the great zooecial rariations.

The micrometric measurements taken on the recent specimens and on those from the Helvetian of Touraine and the Tortonian of Eisenstadt, Hungary, are always smaller than those of $A$. constrictum, a character which may be sufficient to maintain the American species. The American specimens also appear deprived of oral spines. However, the specific name is a small matter if the illustrations are good for careful comparisons.

Occurrence.-Miocene (St. Mary's formation): Cove Point, Maryland (rare). Miocene (Yorktown formation): 3 miles southwest of Petersburg, Virginia (rare). Pliocene (Waccamaw marl): Waccamaw River, Horry County, South Carolina (rare).

$$
\text { Plesiotypes.-Cat. Nos. } 68456,68459 \text {, U.S.N.M. }
$$

\section{AMIPHIBLESTRUM TENUIPARIETIS, new species.}

Plate 13, fig. 7.

Description.-The zoarium incrusts shells. The zooecia are distinct, separated by a deep furrow, hexagonal, rounded above; the mural rim is very thin, rounded, very finely granulated; the cryptocyst is of little depth, concave, granular; the opesium is oval, narrowed laterally by two condyles serving for articulation of the opercular valve; it bears a concave or undulated proximal border. The avicularium is elliptical, salient, with pointed beak directed below.

$$
\text { Measurements.-Opesia }\left\{\begin{array} { l } 
{ h o = 0 . 3 0 \mathrm { mm } . } \\
{ l _ { 0 } = 0 . 4 0 \mathrm { mm } . }
\end{array} \text { Zooecia } \left\{\begin{array}{l}
L z=0.55 \mathrm{~mm} . \\
l_{z}=0.45 \mathrm{~mm} .
\end{array}\right.\right.
$$

Affinities.-The ancestrula is orbicular, garnished with very small spines, it engenders three small and two large zooecia.

This species is quite close to Amphiblestrum flemingi Busk, 1854; it differs from it in the absence of gymnocyst, and in the larger ancestrular zooecia. It 
appears to be the equatorial equivalent. Amphiblestrum flemingi is a species from the cold and temperate regions; it occurs from the polar circle to the forty-fourth parallel in depths where the temperature is from $3.1^{\circ}$ to $6.7^{\circ} \mathrm{C}$. Our American species represent, therefore, the simplification which the warmth of the waters may provoke in a species.

Occurrence.-Miocene (Choctawhatchee marl): Jackson Bluff, Ocklocknee River, 25 miles southwest of Tallahassee, Florida (rare).

Holotype.-Cat. No. 68460 , U.S.N.M.

\section{Genus RAMPHONOTUS Norman, 1894.}

(For description, see Bulletin 106, U. S. National Nuseum, p. 163.)

RAMPHONOTUS ASPERUS, new species.

Plate 13, figs. 11-13.

Description.-The zoarium incrusts shells and masses of Stylopoma spongites. The zooecia are elongated, distinct, oval, much enlarged at the base; the mural rim is thin, much enlarged in the lower part of the cryptocyst, and bears two large areal spines and generally four smaller ones; the opesium is anterior, oval, trifoliated, narrowed laterally by two little salient condyles on which articulates probably the opercular valve. The ovicell is hyperstomial, salient, globular, ornamented by a small transverse area. The avicularium is large, salient, transverse, triangular, with beak pointed and thin and placed regularly below each opesium.

Elongate zooecia:

$$
\begin{gathered}
\text { Measurements. Opesia }\left\{\begin{array}{l}
h_{0}=0.24 \mathrm{~mm} . \\
l_{0}=0.20 \mathrm{~mm} .
\end{array}\right. \\
\text { Transverse (short) zooecia :. } \\
\text { Opesia }\left\{\begin{array} { l } 
{ h o = 0 . 1 8 - 0 . 2 0 \mathrm { mm } . } \\
{ l _ { 0 } = 0 . 2 0 \mathrm { mm } . }
\end{array} \quad \text { Zooecia } \left\{\begin{array}{l}
L z=0.50 \mathrm{~mm} . \\
L_{z=0}=0.44 \mathrm{~mm} . \\
l_{z=0}=0.40 \mathrm{~mm} .
\end{array}\right.\right.
\end{gathered}
$$

Variations.-The zooecia are often short and wide. The number of spines is variable and may be eight, but there are always two large hollow spines on the ovicelled zooecia. The calcified and perforated zooecia and regenerated zooecia are not rare. All of the avicularia are not large and transverse; they are sometimes much reduced and orbicular, especially in the vicinity of the ancestrula. The walls are fragile and fossilization gives the species quite variable and curious aspects (fig. 12). The dietellae are arranged as in Callopora (fig. 13).

The presence of species of this genus seems to indicate that in the localities where they lived the waters were calm and little rich in diatoms.

Affinities.-This species differs from Ramphonotus agellus Ulrich' and Bassher, 1904 , in its triangular avicularium placed transversely. It differs from Ramphonotus rhynchota Busk in its very different dimensions and in the presence of more than two spines.

Occurrence.-Miocene (Yorktown formation): 3 miles southwest of Petersburg, Yorktown, Beulahland, King and Queen County, 1 mile northeast of Suffolk, and other localities in Virginia (rare).

Cotypes.-Cat. No. 68461, U.S.N.M. 
RAMPHONOTUS MULTISPINATUS, new species.

Plate 34, fig. 4.

Description.-The zoarium incrusts shells. The zooecia are oval or elliptical, elongated, distinct; separated by a deep furrow; the mural rim is wide, salient, round, and bears four small distal spines, two large hollow spines at the level of the condyles, and a variable number of areal spines; the opesium is anterior, oval, trifoliated. On the gymnocyst there is a large avicularium.

Measurements.-Opesia $\left\{\begin{array}{l}h_{0}=0.24 \mathrm{~mm} . \\ l_{0}=0.16-0.18 \mathrm{~mm} .\end{array}\right.$ Zooecia $\left\{\begin{array}{l}L_{z}=0.40-0.50 \mathrm{~mm} \\ l_{z}=0.28-0.40 \mathrm{~mm} .\end{array}\right.$

Affinities.-The two large spines are fixed at the level of the condyles which narrow the opesium and which serve for the articulation of the opercular valve.

This species differs from Ramphonotus asperus in its spines, which are more numerous and of two kinds.

Occurrence.-Pleistocene: Santa Barbara, California (rare).

Holotype.-Cat. No. 68462, U.S.N.M.

RAMPHONOTUS AGELLUS Ulrich and Bassler, 1904.

Plate 13, figs. 8-10.

1904. Amphiblestrum agellus Ulrich and BassLer, Bryozoa, Maryland, Geological Survey, Miocene, p. 414, pl. 112, figs. $7 a, 7 b$; pl. 118, fig. 14.

Description.-The zoarium incrusts shells. The zooecia are distinct, separated by a deep furrow, ovoid, much enlarged at their base; the mural rim is thin and sharp; the cryptocyst is short, oblique, concave. The opesium is transverse, trifoliate, much narrowed at the level of two large spines and of the hinge of the opercular valve. The ovicell is quite salient, globular, smooth, formed of two calcareous lamellae the superior one of which is incomplete and limits a small semilunar frontal area. The gymnocyst bears a large very salient oblique avicularium with its beak turned toward the base.

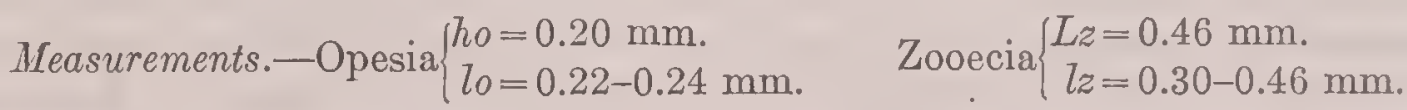

Variations.-The original type of the species is incomplete and formed of ancestrular zooecia, which in this genus are always much smaller than the normal zooecia. Other specimens found at the same horizon in Virginia appear to represent the true form of the species. The avicularium is triangular and very salient. On account of its oblique arrangement it is very fragile and is not well preserved in fossilization. The opesium is elongated in the ancestrular zooecia but transverse in the other.

Affinities.-This species' differs from Ramphonotus minax Busk, 1864, in its trifoliate opesium and in its avicularium oriented in the zooecial axes. It differs from $R$. asperus in the presence of two large spines instead of six and in its avicularium not arranged transversely. The worn or broken forms of this species are very difficult to distinguish.

Occurrence.-Miocene (St. Mary's formation): Cove Point, Maryland (rare); Bowler's wharf, 18 miles above Urbana, Middlesex County, Virginia (rare).

Plesiotype-Cat. No. 68463, U.S.N.M. 
Genus CAULORAMPHUS Norman, 1903.

(For description, see Bulletin 106, U. S. National Museum, p. 174.)

CAULORAMPHUS POROSUS, new species.

Plate 33, fig. 17.

Description.-The zoarium incrusts shells and bryozoa. The zooecia are large, distinct, separated by a deep furrow, irregularly elliptical; the mural rim is thin flat, finely striated, very little enlarged at the base; the opesium is large of the same form as the zooecium. Between the mural rims in the separating furrow there are numerous pores ( 8 to 10) which are bases of pedunculate and articulate aricularia.

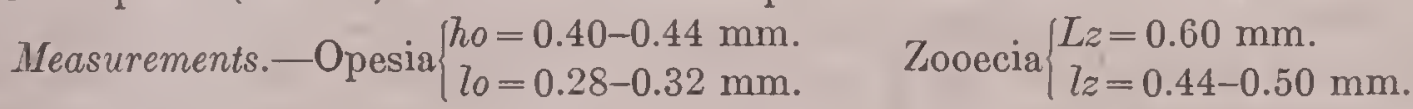

Affinities.-It should be remarked that the pores are not arranged on the mural rim where the termen is sharp. There are therefore no hollow spines; but they form the base, the place of attachment of pedunculate aricularia which surmount them. It is therefore in the genus Cauloramphus that this remarkable species must be classified.

The avicularia being organs of oxygenation we suppose that this species must live in absolutely calm waters little rich in diatoms. The incessant agitation of the mandibles appears to be intended to renew the impure water and to thus carry oxygen and nourishment.

Occurrence.-Pleistocene: Santa Barbara, California (rare).

Holotype.-Cat. No. 68464, U.S.N.M.

CaUloramphus triangularis, new species.

Plate 33, figs. 14-16.

Description.-The zoarium incrusts shells and bryozoa. The zooecia are distinct, separated by a wide and deep furrow, elongate, elliptical, with a rery short proximal gymnocyst; the mural rim is wide, rounded, salient and bears two small distal and eight large areal hollow spines placed in the distal half of the zooecium; the opesium is elliptical or oval according to the form of the zooecium. The oricell is hyperstomial, globular, ornamented by a semicircular area. In the separating furrow with each zooecium there is a small triangular pore which is the base of the articulation of a pedunculate and articulate avicularium.

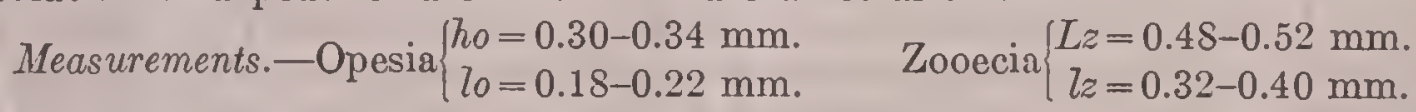

Affinities.-The presence of the small exterior avicularium at the line of the spines seems to indicate Membranipora (Cauloramphus) corniculifera Hincks, 1882, from the Queen Charlotte Islands. It differs from it in a smaller number of spines (less than 18) and in the very different arrangement of distal and areal spines. It differs from Cauloramphus spiniferum Johnston in the larger micrometric measurements $(L z>0.43 \mathrm{~mm}$.), in the presence of less than 12 spines and in the triangular form of the pore of the pedunculate aricularium. The two species are evidently very close.

The ancestrular zooecia are smaller than the others. The ancestrula is oral. garnished by 12 spines; it engenders three large and three small zooecia. 
This is the sixth species with large spines found at Santa Barbara, California. We are ignorant of the true function of these spines, but there is reason to believe that their ensemble forms a trap for diatoms the usual food of bryozoa. The very calm waters off California, therefore, obliged these animals to multiply their means of capture.

Occurrence.-Pleistocene: Santa Barbara, California (rare).

Cotypes.-Cat. No. 68465, U.S.N.M.

\section{Family AETEIDAE Smitt, 1867.}

Genus AETEA Lamouroux, 1812.

(See Bulletin 106, U. S. National Museum, p. 179, for discussion.)

AETEA ANGUINA? Linnaeus, 1758.

Plate 24, fig. 15.

To this recent species we have referred doubtfully the creeping network of a bryozoan from the Pliocene of South Carolina. Without a more complete zoarium it is impossible to make a more definite identification, but we figure the specimen in order to call attention to fossil bryozoa of this type of structure. The geological distribution and other features of this species have been given in our Monograph on North American Early Tertiary Bryozoa.

Occurrence.-Pliocene (Waccamaw marl): Waccamaw River, Horry County, South Carolina.

Plesiotype.-Cat. No. 68466, U.S.N.M.

Family CHAPERIIDAE Jullien, 1888.

1888. Chaperiidae Jullien, Mission scientifique du Cap Horn, VI, Zoologie, Bryozoaires, p. 61.

The orifice is semilunar, or subcircular, very large, entirely closed by the operculum, provided interiorly with one or more calcareous plates serving for the insertion of the retractor muscular fibers of the operculum; the frontal is deprived of pores. The ancestrula, of the same form as the zooecia, is oval and bears some articulated spines on the border. (Translated after Jullien.)

\section{Genus CHAPERIA Jullien, 1881 (first group).}

1881. Chaperia Jullien, Remarques sur quelques Espèces de Bryozoaires Cheilostomiens, Bulletin Société zoologique de France, vol. 6, p. 61.

Two internal calcareous plates, with extremities fixed and serring for the insertion of the retractor muscular fibers of the operculum. (Translated, after Jullien.)

Type-Chaperia (Flustra) acanthina Quoy and Gaymard, 1824. Range: Miocene-Recent.

The species of this genus corresponding exactly to Jullien's definition are: Chaperia (Flustra) acanthina Quoy and Gaymard, 1824;C. (Amphiblestrum) spinosa MacGillivray, 1881; and C. spinosissima Calvet, 1904.

The ovicell of these forms has never been figured. Jullien alone affirmed (but he has given no figure) that the operculum does not close the ovicell. Waters and Calvet classify in the same genus a certain number of other forms with concare 

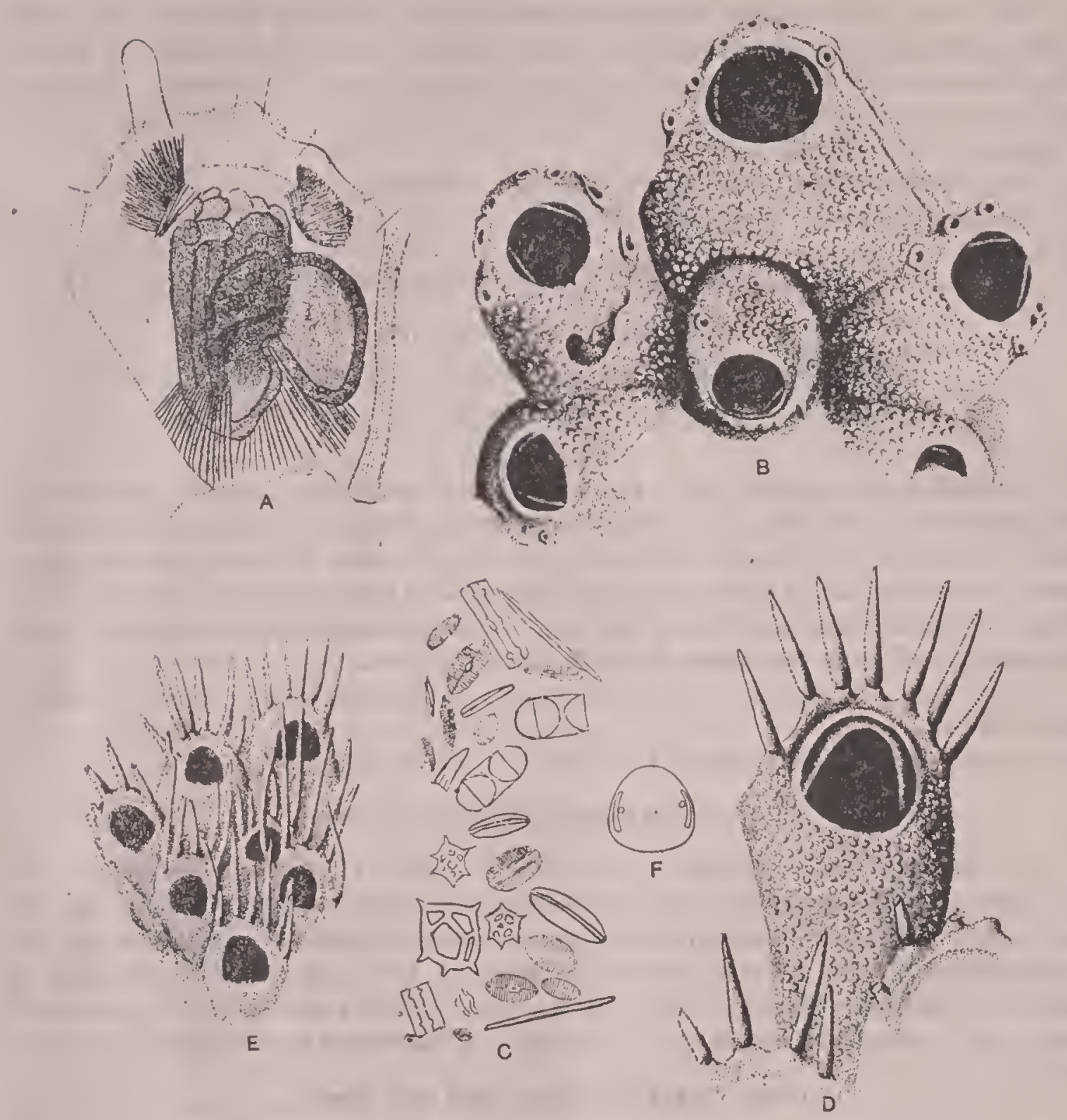

Fig. 3.-Genus Chaperia Jullien, 1881.

Figs. A-G. Chaperia acanthina Quoy and Gaymard, 1824.

A. Interior of a zooecium showing the polypide and the retractor muscles of the operculum. These are the two enormous unuscular bundles which characterize the family Chaperiidae, determining in the zooecia the formation of the calcareous lateral plates situated below the orifice. Such plates are the most characteristic remains of this anatomical arrangement which existed as far back as the Cretaceous period.

B. A young colony, $\times 70$, treated with "eau de jarelle," slowing the ancestrula with the base of the spine of the circumference. In this ancestrula the two lateral funnels which serve for the insertion of the retractor muscles of the operculum, can be seen.

C. Diatoms and radiolaria found in the digestive apparatus of this species, $\times 216$. The radiolarian is Dyctioca speculum Elirenberg, a species encountered in many other bryozoa.

D. Very young zooecium bearing spines and in the orifice of which the funnels in process of formation, still unseparated, can be seen. 1888.)

E. Zooecia covered over by the ectocyst and bearing marginal spines. (Figs. A-E, after Jullien,

F. Operculum (after Kirkpatrick, 1890). 
frontal and characterized by the samc calcareous lamellae. With our present poor state of knowledge of the larva we can not be absolutely certain that this single anatomical peculiarity is sufficient to characterize a family. We think, thereforc, that it is prcferablc to group in a distinct section these species with concave frontal under the same name but placed under the authority of Waters.

The Cretaceous forms figurcd by D'Orbigny and Hagenow have already been separatcd under tha name of Hagenowinella Canu, 1900.

Jullien, who has studied and figured Membranipora galeata Busk, 1852, has not classified it in his genus.

Genus CHAPERIA (Waters, 1898) Levinsen, 1909 (second group).

1909. Chaperia Levinsev, Morphological and Systematic Studies on the Cheilostomatous Bryozoa p. 115.

The original description of this genus by Levinsen follows:

The distal part of the zooecium is furnished internally with two lateral spaces open towards the frontal surface (sometimes coalesced to a single horseshoe shaped one), formed by two plates which project from the side walls and converge towards the distal wall. Each distal wall has two multiporous

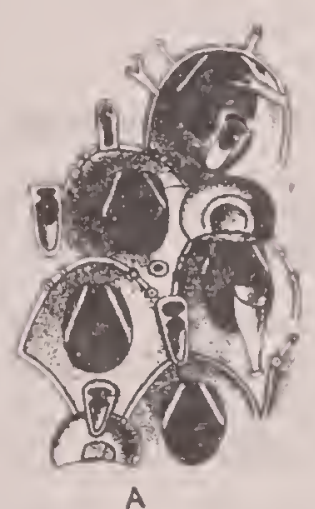

A

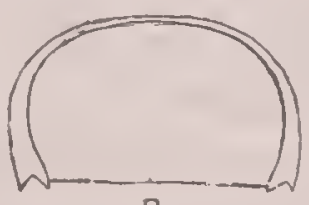

B

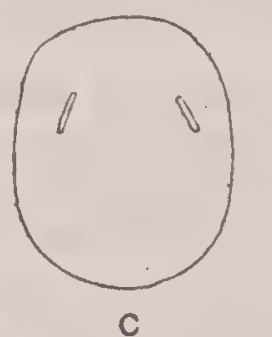

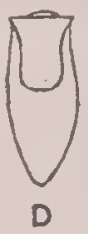

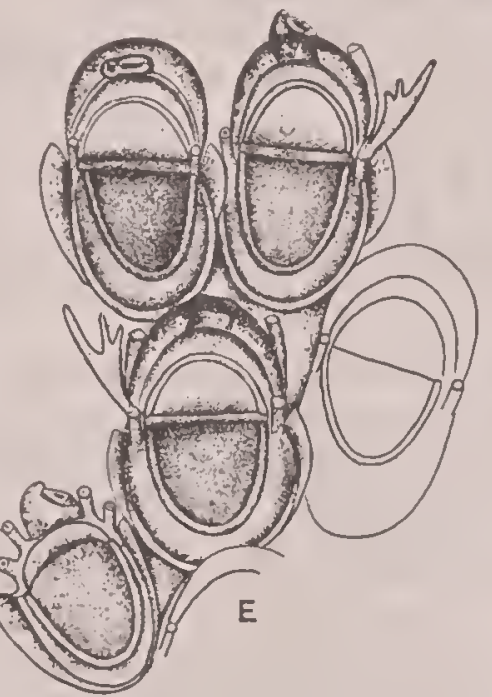

FIg. 4.-Genus Chaperia (Waters, 1895) Levinsen, 1909.

Figs. A-D. Chaperia bilamellata Waters, 1898. A. Specimen, $\times 25$, from Port Elizabeth, South Africa, showing the principal variations of the avicularia, etc. B. Operculum of the orifice of the ovicell, $\times 85$. ${ }^{\circ}$ C. Operculum of the aperture, $\times 85$. D. Mandible of the avicularium, $\times 85$. (Figs. AD, after Waters, 1898.)

Fig. E. Chaperia cervicornis Busk, 1852. Zooecia showing the operculum of the aperture and that of the ovicell in position (after Hincks, 1881).

rosette plates [septular plates] and the distal half of each side wall a single one. Hyperstomial free ooecia with a completely calcified ectooecium [and a special operculum]. The zooecia, which may sometimes have a membraneous opercular valve, sometimes a chitinous compound operculum, are generally strongly provided with spines and have often a well-developed [concave] cryptocyst. Avicularia sometimes trumpet shaped, not always present. The colonies are generally incrusting.

Type-Chaperia bilamellata Waters, 1898.

To this genus bclong the following species:

Chaperia (Amphiblestrum) cristata Busk, 1884. 
Chaperia (Membranipora) annulus Manzoni, 1875 (Chaperia galeata Busk,

Chaperia (Membranipora) cervicornis Bush, 1852.

Chaperia (Electra) cylindracea Busk, $18 \$ 4$.

Chaperia (Membranipora) albispina MacGillirray, $18 \$ 2$.

Chaperia (Amphiblestrum) capensis Busk, $18 S 4$.

Chaperia palulosa Waters, 1904.

Chaperia tropica Waters, 1909.

Chaperia galeata Busk, 1852.

Chaperia bilamellata Waters, 1898.

In this list given by Levinsen there is not a single species recognized as identical with the genotype of Jullien. The best known species of this group is Chaperia galeata Busk, 1852. The best figures hare been drawn from the fossils. The only good figures of the recent specimens hare been given by Jullien, 1888, which have not the characteristic lamellae. On the contrary, Chaperia bilamellata Waters, 189 , has been perfectly drawn with its chitinous appendages. Levinson classified this genus in the Bicellariidae.

CHAPERIA GALEATA Busk, 1852.

Plate 34, figs. 8-10.

1852. Membranipora galeata Busk, Catalogue of Marine Polyzoa in British Museum, Cheilostomata, pt. 2, p. 62, pl. 65, fig. 5.

1870. Membranipora annulus Manzoni, Briozoi fossili Italiani, Quarta contribuzione, Sitzungsberichte der kaiserlichen Akademie der Wissenschaften, Wien, vol. 61, Abth. 1, p. 7, pl. 1 , fig. 6.

1875. Membranipora annulus Manzoni, I Briozoi del pliocene antico di Castrocaro, p. 12, pl. l, fig. 9.

1877. Membranipora annulus Mfanzoni, Bryozoaires du pliocéne supérie:ir, de l'ile de Rhodes, Memoirs de la Société Géologique de France, ser. 3, vol. 1, Mem. No. 2, p. 62.

1879. Membranipora galeata Busk, Polyzoa from Kerguelen Island, Philosophical Transactions Royal Society London, vol. 168, p. 195.

1879. Membranipora annulus Seguenza, Le formazioni terziarie nella Provincia di Reggio (Calabria), Reale Accademia dei Lincei, Memorie della Classe di Scienze Fisiche, Matematiche e Naturali, ser. $\Im$, vol. 6, pp. 80, 198, 294, 328.

1882. Membranipora dentata Waters, Fossil Bryozoa from Mount Gambier, South Australia, Quarterly Journal Geological Society London, vol. 38, p. 263, pl. 8, fig. 14.

1884. Membranipora galeata Busk, Report on the Polyzoa collected by H. M. S. Challenger (18731876), Pt. I, vol. 10, pt. 30, p. 64.

1884. Amphiblestrum cristatum Busk, Report on the Polyzoa collected by II. MI.' S. Challenger (1873-1876), Pt. I, vol. 10, pt. 30, p. 63, pl. 15, fig. 1.

1887. Membranipora annulus WATERs, Tertiary Chilostomatous Bryozoa from New Zealand, Quarterly Journal Geological Society, vol. 43, p. 47, pl. 6, figs. 2, 5, 9.

1887. Membranipora annulus Peraens, Pliocäne Bryozoen von Rhodes, Annalen des $k . k$. naturhistorischen Hofmuseums, vol. 2, p. 17.

1888. Membranipora galeata Jullien, Mission scientifique du Cap Horn, VI, Zoologie, Bryozoaires, p. 75, pl. 5 , figs. 6,8 .

1891. Membranipora annulus Neviani, Briozoi postpliocenici del sotto suolo di Iivorno, Bollettino della Societia Geologica Italiana, vol. 10, p. 116.

1895. Amphiblestrum annulus MacGillivray, Monograph of Tertiary Polyzoa of Victoria, Transactions Royal Society Victoria, vel. 4, p. 43, pl. 6, fig. 3.

1895. Membranipora galeata Neviani, Briozoi fossili della Farnesina e Monte Ifario presso Roma, Palaeontographica Italica, vol. 1, p. 96 (sep. 20), no. 10. 
1895. Membranipora galeata Neviani, Briozoi neozoici di alcune localita d'Italia, Bollettino della Società Romana per gli Studi Zoologici, vol. 4, pt. 2, p. 233 (sep. 9), 1896; vol. 5, pt. 3, p. 121 (sep. 20).

1896. Membranipora galeala Neviavi, Briozoi Postpliocenici di Spilinga (Calabria), Atti Accademia Gioenia di Scienze Naturali in Catania, ser. 4, vol. 9, p. 14.

1898. Membranipora galeata Nevian1, Briozoi neozoici di alcune localita d'Italia, Bollettino de la Societa Romana per gli Studi Zoologici, vol. 7, pt. 4, p. 4; pt. 5, pp. 4, 6, 13 (sep.); 1900, pt. 6 , p. 66 .(sep. 9).

1898. Chaperia annulus WATERs, Observations on Membraniporidae, Journal Linnean Society Zoology, vol. 26, p. 673

1898. Chaperia annulus, variety bilaminata WATERs, Observations on Membraniporidae, Journal Linnean Society, Zoology, vol. 26, p. 673, pl. 47, figs. 5. 8, 9.

1901. Membranipora galeata Nevian1, Bryozoi neogenici delle Calabrie, Paleontographia italica vol. 6, p. 152.

1904. Membranipora galeata CALvet, Bryozoen, Ergebnisse der Hamberger Magalhaensiche Sammelreise, 1892, 1893, vol. 3, p. 10.

1908. Chaperia galeata CANr, Iconographie des Bryozoaires fossiles de l'Argentine, Pt. I, Anales del Museo Nacional de Buenos Aires, vol. 17, p. 262, pl. 3, figs. 13, 14.

1909. Chaperia galeata Calver, Bryozoaires, Expédition Antarctique Francaise, Sciences Naturelles, p. 17.

Historical.-Waters cleared up the principal characters of this species; he made known its structure and showed its identity. with the fossil Membranipora annulus Manzoni of the Miocene. The complete bibliography which we give above, resulted from his work.

The name galeata is the oldest, but from the description and figure in the British Museum Catalogue identification has not been made, and I should not have recognized it as a synonym without an examination of the Museum specimen. (Waters, 1908.)

However, in 1888 Jullien believed he had rediscovered Busk's species; he gave an excellent figure, but he did not classify it in his genus Chaperia. Jullien appeared to be mistaken, since Waters did not cite his work at all in the synonymy. On the other hand, Calvet, 1904, who had studied numerous specimens, rectified the omission of Waters. The fossil specimens of the Canu collection have never the aspect shown in Jullien's figures.

Affinities.-The number of spines varies from four to six. The zooecia in a circle are the ancestrular zooecia. It is remarkable that the genus Chaperia widespread in both hemispheres since the Miocene has emigrated into the Southern Hemisphere.

We do not believe that the entire synonymy adopted above is exact; there are certainly many species confounded under this name. Even in Italy under the name of Chaperia annulus the authors appear to have confused at least two species. Notably our specimens from Farnesina are absolutely distinct from those (and they are quite numerous) which we have collected in the Pleistocene of Palermo. But all these species are so variable that it is very difficult to find constant characters.

Occurrence.-Pleistocene: Santa Barbara, California (very rare). Santa Monica (Rustic Canyon), California (very rare).

Geological distribution.-Helvetian of Italy (Seguenza); Zanclean of Italy (Seguenza); Entrerrian of Patagonia (Canu); Miocene of Australia (Waters); Pliocene of New Zealand (Waters); Plaisancian of Italy (Manzoni, Neviani); 
Astian of Italy (Seguenza, Neriani); Sicilian of Italy (Seguenza, Neviani); Post Pliocene of Italy (Neviani).

Habitat.-Kerguelen Islands (42 mcters); Malouines Islands (6 to 16 meters); Bare Orange, Smiths Strait (12 to $27^{\circ}$ meters); Straits of Magellan (16 meters); Southern Tierra delle Fuego (11 meters); Port Charcot (40 meters); Booth Wandel Island (30 meters); station 320 of the Challenger, near Montevideo (960 meters). The varieties bilaminata and multifida have been found in the Indian Ocean and at the Cape of Good Hope, the latter at a depth of 720 meters.

Plesiotype.-Cat. No. 68467, U.S.N.M.

CHAPERIA CAMINOSA Ulrich and Bassler, 1904.

Plate 14, figs. 2-4.

1904. Membranipora caminosa Ulrich and BAsster, Bryozoa, Maryland Geological Survey, Miocene, p. 409, pl. 111, figs. 3, 4.

Ulrich and Bassler's original description follows:

Zoarium adnate, forming a thin, single sheet of indefinite extent. Zooecia arranged quincuncially, $6 \frac{1}{2}$ measuring longitudinally and $7 \frac{1}{2}$ to $8 \frac{1}{2}$ diagonally, in $3 \mathrm{~mm}$. Opesia subcircular, separated by onehalf to two-thirds their diameter; when the ooecium is wanting, a rim-like border encloses the anteriohalf of the opening. Ooecia very high, with a rib across the top, and just in front of the latter a prominent chimney-like tube or hollow spine projecting obliquely over the zooecium next above. When the ooecium is broken away a semiovate or quadrangular concave space is uncovered between the ends of following zooecia. The hollow tubule behind the zooecial aperture is always present, but it is usually worn down so as to appear as merely a thick-rimmed pore. Where the zooecial arrangement is irregular or changed, a second or even a third tubule, each directed forward, may occur between the three zooecia.

This species is a perfectly characterizcd Chaperia. We reproduce figures of the types correctcd with more carc. Above each zooecium there is a very constant, small, erect, triangular avicularium with its beak above. A large pedunculate avicularium appears in a corncr of the cryptocyst; it is almost always broken and appears only as a very irregular pore. There are four large distal articulated spines. We have from the Pleistocene of Palermo (Sicily) a variety of Chaperia annulus Manzoni, 1875, very close and which presents also a very constant, small, distal, triangular avicularium. The present species differs from it in the presence of the large, pedunculate aricularium, and its ovicell not smooth and formed of two thick, separable calcareous layers and in the triangular avicularium placed on the ovicell.

Occurrence.-Miocene (Choptank formation): Jones Wharf, Maryland (rare). Cotypes.-Cat. No. 68469, U.S.N.M.

\section{CHAPERIA PARVISPINA, new species.}

Plate 14, fig. 1.

The figured specimen is the only one which has been found. It incrusts an oyster shell and is too incomplete to permit an exact description. However, the complete absence of large distal articulated spines is a specific character which amply justifies the establishment of a new species. They are replaced by a variable number of minute and very frngile spines. 
Measurements.-Opesia $\left\{\begin{array}{l}h o=0.30 \mathrm{~mm} . \\ l o=0.26 \mathrm{~mm} .\end{array} \quad\right.$ Zooecia $\left\{\begin{array}{l}L z=0.40-0.50 \mathrm{~mm} . \\ l z=0.40 \mathrm{~mm} .\end{array}\right.$

Occurrence.-Miocene (Choctawhatchee marl): Jackson Bluff, Ocklocknee River, 25 miles southwest of Tallahassee, Florida (very rare).

Holotype.-Cat. No. 68470 , U.S.N.M.

\title{
Family FARCIMINARIIDAE Busk, 1852.
}

\section{Genus NELLIA Busk, 1852.}

(For description, see Bulletin 106, U. S. National Museum, p. 195.)

\author{
NELLIA OCULATA Busk, 1852.
}

Plate 2, figs. 5-7.

1816. Farcimia tenella LAмАвск, Histoire naturelle des animaux sans vertebres, vol. 2, pl. 2, figs. $26,27$.

1816. Cellaria tenella LamarcK, Histoire naturelle des animaux sans vertèbres, ed. 1, p. 135.

1834. Cellaria tenella Blarnville, Manuel d'Actinologie ou de Zoophytologie, p. 455.

1850-1852. Cellaria tenella D'Orbigny, Paleontologie Francaise: Terrain Crétace, vol. 5, p. 28.

1852. Nellia oculata Busk, Catalogue Marine Polyzoa, British Museum, Pt. I, Cheilostomata, p. 18, pl. 64 , fig. 6 ; pl. 65, fig. 4 .

1873. Nellia oculata Surtw, Floridan Bryozoa, Pt. II: Kongl. Svenska Vetenskaps-Akademiens Handlingar, vol. 10, no. 11, p. 3, pl. 1, figs. 53, 54 .

1880. Nellia oculata MacGillivray in McCoy's Prodomus of the Zoology of Victoria, vol. 1, decade 5, p. 51 , pl. 49 , fig. 5 .

1881. Nellia oculata Haswell, On some Polyzoa from the Queensland coast, Proceedings Linnean Society New South Wales, vol. 5 , p. 36.

1884. Nellia oculata Busk, Report on Polyzoa collected by the Challenger, vol. 10, pt. 30, p. 27.

1887. Nellia oculata Hincks, On the Polyzoa and Hydroida of the Mergui Archipelago, Journal Linnean Society, Zoology, vol. 21, p. 121.

1887. Farcimia oculata WAters, Bryozoa from New South Wales, etc., Annals and Magazine Natural History, ser. 5, vol. 20, p. 92.

1909. Nellia tenella Levinsen, Morphologic and Systematic Studies on the Cheilostomatous Bryozoa, p. 120, pl. 1, fig. 13 (ovicell).

1919. Nellia oculata CANU and BAssler, Geology and Paleontology of the West Indies, Bryozoa, Publication Carnegie Institution of Washington, No. 291, p. 82, pl. 2, figs. 5-7.

1920. Nellia oculata Canu and Bassuer, Monograph North American Early Tertiary Bryozoa, Bulletin 106, U. S. National Museum, p. 196, pl. 82, figs. 6-10.

Small fragments of this delicate bryozoan occurring in the Bowden horizon of Santo Domingo are quite sufficient for the determination of the species in the American Miocene. The dimensions of the opesium are not equal on the four sides, one of which is often larger than the others. The authors are not in accord as to the name which should be given to this species. We have adopted that of Busk. The species is discussed on page 196 of our monograph on North American Early Tertiary Bryozoa, where a more detailed bibliography is given the above references being additional ones.

Occurrence.-Lower Miocene (Bowden horizon): Cercado de Mao, Santo Domingo (rare).

Geological distribution.-Vicksburgian of Mississippi; Lutetian of the environs of Paris (Canu); Helvetian of Egypt (Canu); Miocene of Australia (Waters).

Plesiotypes.-Cat. No. 68471, U.S.N.M. 
Family OPESIULIDAE Jullien, 1888.

Genus FLORIDINA Jullien, 1881.

(For description, see Bulletin 106, U. S. National Nuseum, p. 219.)

FLORIDINA PYRIPORA Canu and Bassler, 1919.

Plate 1, fig. 1.

1919. Floridina pyripora CANU and BAssLer, Geology and Paleontology of the West Indies, Bryozoa Publications Carnegie Institution of Washington, No. 291, p. 82 , pl. 2, fig. 2.

The few specimens of this incrusting species which have been collected in the Leeward Islands seem hardly sufficient for the description of a new Floridina, because polymorphism is the rule in this genus; but we believe more specimens will prove this to be a good species. The polypidian convexity is little salient; the opesiules are large and poorly defined; the lateral apophyses are very little salient; the general aspect of the opesium is pyriform. The ovicell is endozooecial, smooth, and salient.

$$
\begin{gathered}
\text { Measurements.- Opesia (including opesiules) }\left\{\begin{array}{l}
h_{o}=0.20 \mathrm{~mm} \\
l_{0}=0.22 \mathrm{~mm}
\end{array}\right. \\
\text { Zooecia }\left\{\begin{array}{c}
L z=0.48-0.50 \mathrm{~mm} . \\
l z=0.40-0.44 \mathrm{~mm} .
\end{array}\right.
\end{gathered}
$$

Floridina antiqua Smitt, 1872, a recent species in the Gulf of Mexico, is marked by large lateral denticles and by small opesiules, giving it a quite different aspect.

Occurrence.-Oligocene (Antigua formation): Rifle Butts, Antigua, Leeward Islands (rare). Oligocene (Anguilla formation): Southwest side of Clocus Bay, Anguilla, Leeward Islands (rare).

Holotype.-Cat. No. 68472,68473, U.S.N.M.

\section{FLORIDINA FUSIFERA Canu and Bassler, 1919.}

Plate 1, fig. 5.

1919. Floridina fusifera Canu and Bassler, Geology and Paleontology of the West Indies, Bryozoa. Publications Carnegie Institution of Washington, No. 291, p. 83, pl. 1, fig. 3.

Description.-The zoarium is incrusting. The zooecia are hexagonal; the cryptocyst is larger than the opesium; it is of little depth and is finely granulated; the opesium is trifoliate; the lateral apophyses are very salient; the opesiules are large and rounded; the polypidian convexity is very salient and convex. The onychocellarium is large, somewhat constricted laterally, and is provided with a very large orifice. Here and there are small fusiform avicularia.

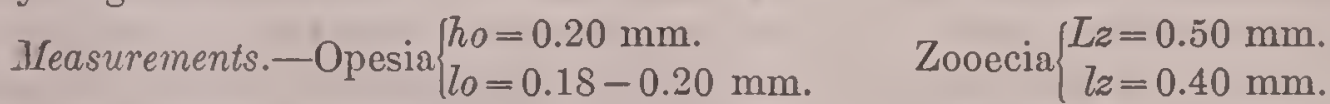

$$
\begin{aligned}
& \text { Onychocellaria }\left\{\begin{array}{l}
\text { Opesium }=0.30 \text { by } 0.20 \mathrm{~mm} . \\
\text { Zooecium }=0.60 \text { by } 0.36 \mathrm{~mm}
\end{array}\right.
\end{aligned}
$$

There are only four zooecia intact on the single zoarium obtained. The presence of small fusiform avicularia has appeared to us sufficient to justify the creation of this species, this feature never having been observed in the genus.

Occurrence.-Oligocene (Antigua formation): Rifle Butts, Antigua, Leeward Islands (very rare).

Holotype.-Cat. No. 68474, U.S.N.M. 
FLORIDINA REGULARIS, new species.

Plate 14, fig. 7,8 .

Description.-The zoarium incrusts shells and consists of one or two superposed lamellae. The zooecia are distinct, separated by a furrow, little elongated, hexagonal, regular; the cryptocyst is smooth, somewhat concave, limited laterally by two conrergent groores which end at the opesiules. The apertura is orbicular and forms the distal part of the trifoliate opesium; the polypidian convexity is limited laterally by two linear opesiules. The oricell is little salient and endozooecial. The onychocellarium is fusiform; its beak is rery salient on the zooecial plane; its opesium is anterior.

Measurements (maximum).-Opesia $\left\{\begin{array}{l}h o=0.15 \mathrm{~mm} . \\ l o=0.12 \mathrm{~mm} .\end{array}\right.$ Zooecia $\left\{\begin{array}{l}L z=0.40 \mathrm{~mm} . \\ l z=0.35 \mathrm{~mm} .\end{array}\right.$

Affinities.-The marginal zooecia are elongated; the central zooecia are transrerse.

This species differs from Floridina antiqua Smitt, 1872, in its onychocellarium with salient beak of a different form, It differs from Floridina parvicella in its larger micrometric measurements.

Occurrence--Miocene (Duplin marl): Wilmington, North Carolina (common). Natural Well, 2 miles southwest of Magnolia, Duplin County, North Carolina (common). Miocene (Yorktown formation): Yorktown, Virginia (rare).

Holotype and paratype.-Cat. Nos. 68475, 68476, U.S.N.M.

\section{FLORIDINA PARVICELILA, new species.}

Plate 31, fig. 12

Description.-The zoarium incrusts oysters. The zooecia are small, hexagonal, little elongated, distinct but with adjacent mural rims; the opesium is trifoliate; the anterior part of aperture is elongate or elliptical; the polypidian convexity is wide and limits two linear and transrerse opesiules.

$$
\text { Measurements. Opesia }\left\{\begin{array} { l } 
{ h o = 0 . 1 0 \mathrm { mm } . } \\
{ l o = 0 . 0 7 \mathrm { mm } . }
\end{array} \text { Zooecia } \left\{\begin{array}{l}
L_{z}=0.38 \mathrm{~mm} . \\
l z=0.30 \mathrm{~mm} .
\end{array}\right.\right.
$$

Affinities.-This species is sufficiently characterized by its small dimensions. It differs again from Floridina regularis in the absence of a furrow separating the zooecia.

The genus Floridina has been obserred in the Cretaceous formations of northern Europe. It has, therefore, in the course of the geologic ages migrated slowly toward the Equator. The Waccamaw marl is its last known stage in America.

Occurrence.-Pliocene (Waccamaw marl): Waccamaw River, Horry County, South Carolina (very rare).

Holotype.-Cat. No. 68477, U.S.N.M.

\section{FLORIDINA MINIMA, new species.}

Plate 14, fig. 6.

Description.-The zoarium incrusts shells. The zooecia are distinct, separated by a furrow, very small, hexagonal or ogival; the mural rim is wide, convex, little salient, very finely granulated; the cryptocyst is of little depth, somewhat convex $12184-23-$ Bull. 125- -5 
and finely granulated. The opesium is elliptical, elongatcd; the opesiular indentations are large, rectilinear, oblique, limited by a concave proximal border. The ancestrula is very small.

$$
\text { Measurements.-Opesia }\left\{\begin{array} { l } 
{ h o = 0 . 1 2 \mathrm { mm } . } \\
{ l o = 0 . 0 7 \mathrm { mm } . }
\end{array} \quad \text { Zooecia } \left\{\begin{array}{l}
L z=0.35 \mathrm{~mm} . \\
l z=0.30 \mathrm{~mm} .
\end{array}\right.\right.
$$

Affinitics.-On our type specimen we have obscrved neither onychocellaria nor oricells. This is the smallest species of Floridina known. It differs from Floridina parvicella in its zooecia separated by a deep furrow and in its smaller opesial dimensions.

Occurrence.--Miocene (Duplin marl): Natural Well, 2 miles southwest of Magnolia, Duplin County, North Carolina (rare).

Holotype.-Cat. No. 68478 , U.S.N.M.

Genus VELUMELLA Canu and Bassler, 1917.

(For description, see Bulletin 106, U. S. National Museum, p. 213.)

VELUMELLA ELONGATA, new species.

Plate 14, fig. 5.

Description.-The zoarium incrusts shells. The zooecia are distinct, separated by a furrow, large, elongated, ogiral; the mural rim is thin, rounded, granulated, salient; the cryptocyst is shallow, flat, granulated. The opesium is large, semilunar; the opesiular indentations are of little depth, rounded, almost symmetrical. The onychocellarium is large, elongated, straight, acuminate or elliptical; its opesium. is median, elongated, elliptical.

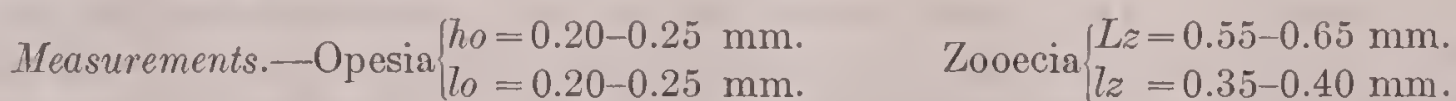

$$
\begin{aligned}
& \text { Opesium of } 7 l n=0.35 \mathrm{~mm} . \quad \text { Onychocellarium }\left\{\begin{array}{l}
\text { Lon }=0.55-0.65 \mathrm{~mm} . \\
\text { lon }=0.35 \mathrm{~mm} .
\end{array}\right.
\end{aligned}
$$

Affinities.--In its general aspect, the relations of its dimensions and its frontal granulations, this species much resembles Vincularia abyssicola Hincks, 1881 (not Smitt, 1872), from Singapore or the Philippines. It differs from it simply in the absence of lateral facets to the cryptocyst; that is to say, in the peculiarity characterizing Smittipora. The onychocellaria are not fusiform as in Rectonychocella and Diplopholeos.

Occurrence.-Miocene (Duplin marl): Natural Well, 2 miles southwest of Magnolin, North Carolina (rare).

Holotype.-Cat. No. 68479, U.S.N.M.

Genus MICROPORA Gray, 1848.

(For description, see Bulletin 106, U. S. National Museum, p. 234.)

MICROPORA CORIACEA Esper, 1794.

1862. Reptescharcllina disparilis GABB and Hors, Monograph Polyzoa Secondary and Tertiary formations of North America, Journal Academy Natural Sciences Philadelphia, ser. 2, vol. 5 , p. 147, pl. 20, fig. 29.

1912. Micropora coriacea Barroso, Briozoos de la Estacion de Biologia maritima cle Santander, Instituto nacional de Ciencias Fisico naturales, p. 21. 
1917. Micropora coriacea CANu, Bryozoaires fossiles des Terrains du Sud-Ouest de la France, Bulletin de la Société Géologique de France, ser. 4, vol. 16, p. 135 (cites bibliography).

1920. Micropora coriacea CANU and Bassler, Monograph Early Tertiary Bryozoa of North America, Bulletin 106, U. S. National Iluseum, p. 235, pl. 4, figs. 20-22.

The only known occurrence in American post Oligocene strata of this wellknown recent and fossil bryozoan is in the Pleistocene rocks of California, where it receired the name of Reptescharellina disparilis Gabb and Horn, 1862. The species is discussed on page 235 of our rolume on the North American Early Tertiary Bryozoa, where a more complete bibliography is giren.

Occurrence.-Midwayan, Jacksonian, and Vicksburgian of the United States Pleistocene: Santa Barbara, California (rare).

Plesiotype.-Cat. No. 68480, U.S.N.M.

\section{Genus SELENARIA Busk, 1854.}

1854. Selenaria Busז, Catalogue marine Polyzoa, pt. 2, p. 101.

The oricell is endozooecial; it appears on the surface of the colony as low, rounded, pent-roof shaped swellings. The cryptocyst is perforated by the opesiules or limited by the opesiular indentations. The opesium is irregular. The opercular ralre is limited by the distal part of the zooecial mural rim. Porous vibracula are disseminated among the zooecia. The zoarium is discoid and cupuliform; its inner surface is perforated by numerous pores. No spines.

Genotype.-Selenaria maculata Busk, 1854.

Range-Claibornian to Recent.

According to Levinsen, who wrote in 1909:

The ribracula are an arched frontal surface perforated by numerous pores or by slits. A high ribbonshaped lamina issuing from the one lateral margin in the distal part of the vibracularian chamber stretches over toward the opposite margin and not far from this bends inward toward the basal surface. It serves no doubt for the attachment of the flagellum. Distal wall with two multiporous septules, and the distal half of each lateral wall with a single one. Lateral walls are common to the contiguous neighboring zooecia.

SELENARIA AURICULARIA, new species.

Description.-The zoarium is a Lunulites form of $6 \mathrm{~mm}$. in diameter. The zooecia are distinct, separated by a salient and wide mural rim, hexagonal, regular or transverse; the cryptocyst is deep, flat, smooth, and perforated by two large equal opesiules symmetrically arranged. The apertura is elliptical and transverse. The ribracula are very large, auriform, terminated by a short, hooked, small canal. The inner side is perforated by numerous pores regularly arranged on the inner layer and rery irregularly disposed on the outer central layer.

Variations.-The zooccia are very irregular in size and we have not been able to discorer any constant micrometric measurements. The apertura is likewise irregular in its measurements. The ribracula nre larger at the periphery than at the center. The opesiules alone are of the same diameter on all the zooecia.

Affinities.-The form of the opesiules is quite variable in the genus Selenaria. They are perforated (as in our American species) in S. parvipunctata Maplestone, 1904; S. bimorphocella Maplestone, 1904; and S. magnipunctata Maplestone, 1904. They are formed by deep lateral indentations in S. maculata Busk, 1862. They 
are transformed into simple, lateral, irregular sinuosities in S. cupola Tenison Woods, 1879; S. concinna Tenison Woods, 1879; S. marginata Tenison Woods, 1879; and S. otwayensis Maplestone, 1904. They are very little visible in S. nitida. Maplestone, 1909, and S. flagellifera Maplestone, 1910. The inner face of all the species is porous except in $S$. marginata Tenison Woods, 1879.

Our American species differs from the known forms only in the auriculate form of vibracula. 'This difference can not form a generic character; first, because the function is the same: second, because porous and cribriform ribracula have been observed in the genus Coscinopleura Marsson, 1885, which belongs to anotler quite distinct family; third, because auriform vibracula analogous to those of our species may be observed in the genus Otionella Canu and Bassler, 1917, which does not appear to be opesiulated; fourth, because the large auriform vibracula are possibly porous vibracula which have lost their frontal. There are specimens of Sele-
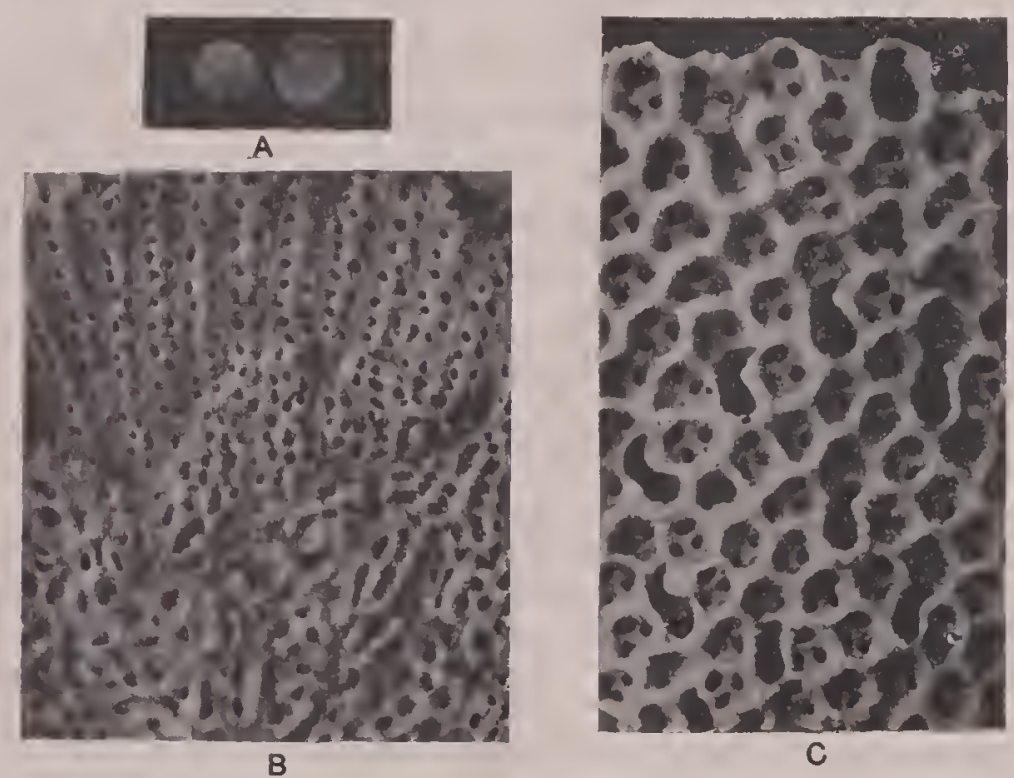

Fig. 5.-Genus Selenaria Busk, 1854.

A-C. Selenaria auricularia, new species.

A. Zoaria, natural size.

B, C. Noncelluliferous and celluliferous sides, $\times 20$.

Eocene (Claibornian); Claiborne, Alabama.

naria maculata in the National Museum Collections provided with analogous auriculate vibracula.

Occurrence.-Eocene (Claibornian) Gosport sand; Claiborne, Alabama (rare). Cotypes.-Cat. No. 68481, U.S.N.M.

Family THALAMOPORELLIDAE Levinsen, 1909.

Genus MANZONELLA Jullien, 1888.

1888. Manzonella Julutes, Mission scientifique du Cap Horn, VI, Zoologie, Bryozoaires, p. 79.

Opesiules well formed, sometimes multiple. Opesium terminal in the form of an orifice. (After Jullien.)

Genotype.-Manzonella (Membranipora) exilis Manzoni, 1869, Pliocene. 


\section{Genus WOODIPORA Jullien, 1888.}

1839. Woolipora Juluiex, Mission scientifique du Cap Horn, VI, Zoologie, Bryozoaires, p. 79.

Cryptocyst entirely developed; two regular opesiules; opesium with rounded contour. (After Jullien.)

Genotype.- Toodipora (Membranipora) holostoma (IVood), Pliocene.

Genus THALAMOPORELLA Hincks, 1887.

(For description, see Bulletin 106, U. S. National Museum, p. 269.)

THALAMOPORELLA GRANULATA Levinsen, 1909.

Plate 2, fig. 14

1909. Thalamoporella granulata Levinsen, Morphological and Systematic Studies on the Cheilostomatous Bryozoa, p. 188, pl. $6 a$, figs. 1, 2; pl. 6, fig. 5 .

1914. Thalamoporella gramuluta OsBurs, The bryozoa of the Tortugas Islands, Florida, Publication Carnegie Institution of Washington, No. 182, p. 197, fig. S.

1919. Thalamoporella granulata $\mathrm{CANU}$ and BAssler, Geology and Paleontology of the Test Indies, Bryozoa, Publications Carnegie Institution of Washington, .No. 291, p. \$8, pl.2, fig.14.
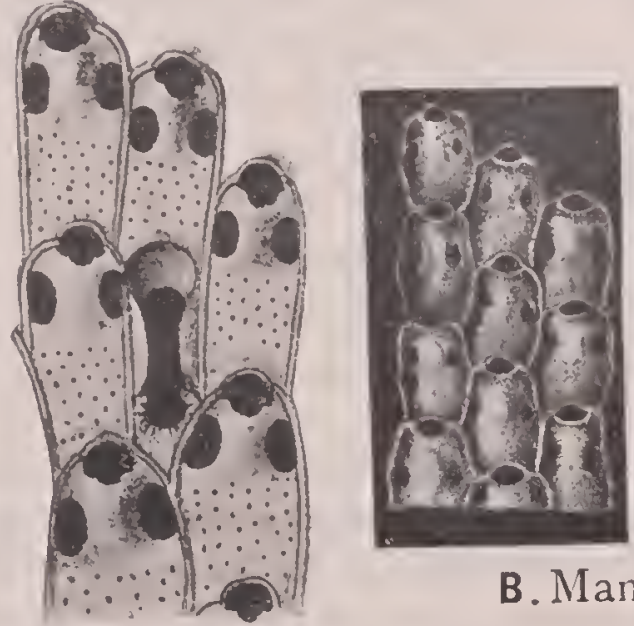

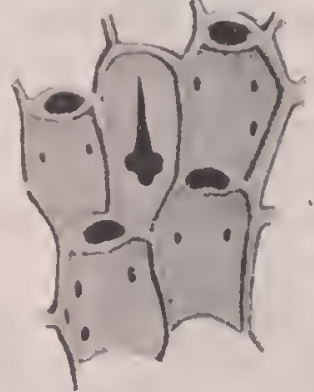

B. Manzonella

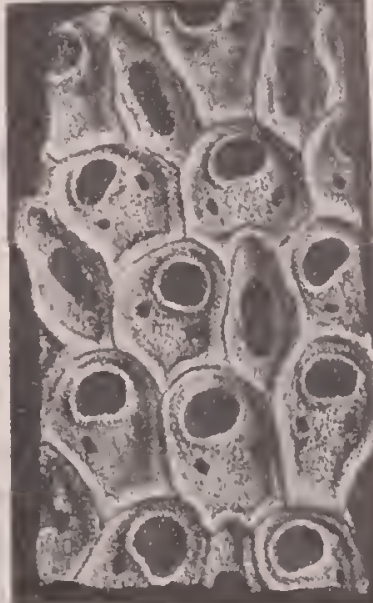

C. Woodipora

\section{A. Thalamoporella}

Fig. 6.-Genera of the family Thalamoporellidae Levinsen, 1909.

A. Thalamoporella rozieri A udouin, 1826, $\times 25$ (after Waters, 1908).

B. Manzonella exilis Manzoni, 1870 (after Manzoni, 1870, and Neviani, 1995).

C. Woodipora holostoma Busk, $1859, \times 25$.

$$
\text { Measurements.-Opesia }\left\{\begin{array} { l } 
{ h _ { 0 } = 0 . 1 6 - 0 . 1 8 \mathrm { mm } . } \\
{ l o = 0 . 1 6 - 0 . 1 8 \mathrm { mm } . }
\end{array} \quad \text { Zooecia } \left\{\begin{array}{l}
L z=0.80 \mathrm{~mm} . \\
l_{z}=0.50 \mathrm{~mm} .
\end{array}\right.\right.
$$

Affinities. - We possess only a small fragment consisting of two zooecia; we are not certain therefore of our determination, as this has been made almost entirely on the micrometric measurements. The opesium is oral, the point abore; the cryptocyst is granulated; the mural rim has a width of $0.08 \mathrm{~mm}$. and is granulated transversally.

Occurrence.-Lower Miocene (Bowden horizon): Rio Gurabo, Santo Domingo (rare).

Habitat.-Andaman or Nicobar Islands? (Lerinsen); Tortugas Islands, Florida (Osbuin).

Plesiotype.-Cat. No. 68482, T.S.N.M. 


\section{THALAMOPORELLA BIPERFORATA Canu and Bassler, 1919.}

Plate 6, figs. 10-15.

1919. Thalamoporella biperforata CANu and BAssler, Geology and Paleontology of the West Indies, Bryozoa, Publication Carnegie Institution of Washington, No. 291, p. S8, pl. 6, figs. 10-15,

Description.-The zoarium is bilamellar. The zooecia are elongate, distinct rectangular; the mural rim is thin, salient, berelled, and bears two hollow tubercles on each side of the apcrture. The cryptocyst is deep, flat, ornamented with large widely spaced pores and with numerous small pores closely placed together; the opcsiules are very large, far distant from the apertura, placed symmetrically, but very unequal in size. The apertura is transrerse, oval; the proximal border is always concare and the polypidian tube is limited by two small lateral indentations. The reticulocellarium is large, quite elongate; its cryptocyst is perforated by two opesiules; the opesium bears two lateral denticles serving as pivot to the corneous mandible.

Measurements.-Opesium of zooecium ..... $\left\{\begin{array}{l}h_{0}=0.10-0.12 \mathrm{~mm} . \\ l_{0}=0.14 \mathrm{~mm} .\end{array}\right.$

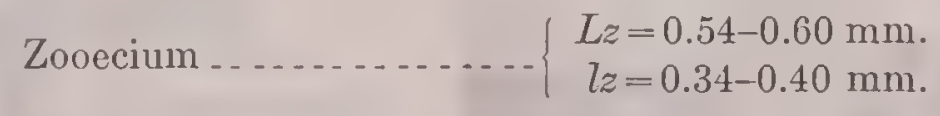

Opesium of onychocellarium $\left\{\begin{array}{l}h o n=0.24 \mathrm{~mm} . \\ l o n=0.12 \mathrm{~mm} .\end{array}\right.$

Onychocellarium........... $\left\{\begin{array}{l}L m n=0.90 \mathrm{~mm} \text {. } \\ l o n=0.30 \mathrm{~mm} \text {. }\end{array}\right.$

Affinities.-The oral tuberosities are quite variable in size; they are often replaced by two fosscttes.

This species is characterized by its onychocellarium, which resembles that of Thalamoporella granulata Levinsen, 1909, figured by Osburn, 1914. It differs, howerer, in the very different oval form of its apertura and in the presence of oral tuberosities. In its tuberosities this species is quite close to Thalamoporella rozieri Sarigny-Audouin, 1826. It differs from it in the form of its onychocellarium provided with two opesiules, which are not figurcd by Levinsen in the numerous drawings which he has given.

Occurrence.-Lower Miocene (Bowden horizon) : Cercado de Mao, Rio Cana and Rio Gurabo, Santo Domingo; and Borden, Jamaica (common).

Cotypes.-Cat. No. 68483, 68484, U.S.N.M.

Family STEGANOPORELLIDAE Levinsen, 1909.

Genus STEGANOPORELLA Smitt, 1873.

(For description see Bulletin 106, U. S. National Juseum, p. 259.)

STEganoporella PARvicella Canu and Bassler, 1919.

Plate 6, figs. 6-9.

1919. Steganoporella parvicella CANu and BAssLer, Geology and Paleontology of the Tiest Indies, Bryozoa, Publication of the Carnegie Institution No. 291, p. 89, pl. 6, figs. 6-9.

Description.-The zoarium is unilamellar incrusting algae or bryozoa. The zooecia are distinct, elongate, separated by a shallow furrow; the mural rim is thin, 
salient, finely granular. The cryptocyst is finely porous; the opesium is irregular or semilunar, a little elongate; the polypidian tube forms a rectangular surface, salient and excentric between the two dissimilar opesiular indentations. The large zooecia (B) are prorided with $a$ wide distal floor, and the polypidian tube is almost median.

$$
\begin{aligned}
& \text { Measurements.-Opesium of small (a) zooecia }\left\{\begin{array}{l}
h_{0}=0.34-0.36 \mathrm{~mm} . \\
l_{0}=0.16-0.30 \mathrm{~mm} .
\end{array}\right. \\
& \text { Small (a) zooecia............. }\left\{\begin{array}{l}
L z=0.50-0.76 \mathrm{~mm} \text {. } \\
l z=0.50 \mathrm{~mm} .
\end{array}\right.
\end{aligned}
$$

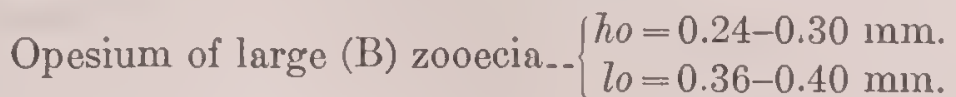

$$
\begin{aligned}
& \text { Large (B ) zooecia ............. }\left\{\begin{array}{l}
L z=1.00-1.10 \mathrm{~mm} . \\
l z=0.44-0.56 \mathrm{~mm} .
\end{array}\right.
\end{aligned}
$$

Affinities. - The dimensions are quite variable, but they are always smaller than those of Steganoporella magnilabris Busk, 1854, which this species resembles in all its other characters.
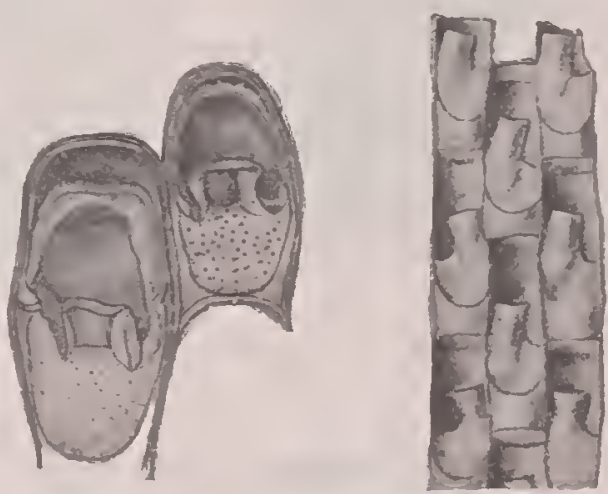

\section{A. Steganoporella B. Siphonoporella}

FIG. 7.-Genera of the family Steganoporellidae Levinsen, 1909.

A. Steganoporella Smitt, 1873. S. magnilabris Busk, 1852. Recent. (After Harmer, 1900.)

B. Siphonoporella Hincks, 1880. S. delicatissima Busk, 1840, $\times 40$. Recent. (After Levinsen, 1909.)

Occurrence.-Lower Miocene (Bowden horizon): Cercado de Mao, Santo Domingo (rare) and Bowden, Jamaica (common).

Cotypes.-Cat. Nos. 68485, 68486, U.S.N.M.

\section{STEGanoporella MaGNilabris Busk, 1854.}

Plate 14, figs. 12, 13

1854. Membranipora magnilabris Busk, Catalogue Marine Polyzoa, British Museum, pt. 2, Cheilostomata, p. 62, pl. 65, fig. 4 .

1872. Steganoporella elegans SuIт, Floridan Bryozoa, collected by Count Pourtales, Pt. I, Kongl. Şrenska Vetenskaps-Akademiens Handlingar, vol. 10, \o. 11, p. 15, pl. 4, figs. 96-101.

1590. Steganoporella magnilabris HARMer, A revision of the Genus Steganoporella, Quarterly Journal Microscopical Science, vol. 43, p. 279, pl. 12, fig. 10; pl. 31, figs. 44-46 (cites bibli ography).

1909. Steganoporella magnilabris Levinsen, Morphological and Systematic Studies on the Cheilo. stomatous Bryozoa, pp. 167, 168. 
1913. Sleganoporella magnilabris Waters, Bryozoa from Zanzibar, Proceedings Zoological Society, London, p. 498, pl. 72, figs. 12-20 (cites bibliography).

1914. Steganoporella magnilabris Osburn, The bryozoa of the Tortugas Islands, Florida, Publication Carnegie Institute, Washington, No. 182, p. 196.

$$
\begin{aligned}
& \text { Measurements.-A pertura of small (a) zooecia. . }\left\{\begin{array}{l}
h a=0.42-0.44 \mathrm{~mm} \text {. } \\
l a=0.40 \mathrm{~mm} .
\end{array}\right.
\end{aligned}
$$

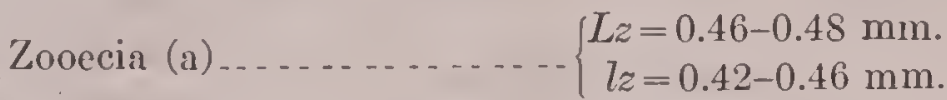

$$
\begin{aligned}
& \text { Apertura of large (B) zooecia }-\left\{\begin{array}{l}
h a=0.46-0.48 \mathrm{~mm} \text {. } \\
l a=0.42-0.46 \mathrm{~mm} \text {. }
\end{array}\right. \\
& \text { Zooecia (B) . . . . . . . . }\left\{\begin{aligned}
L z & =1.20 \mathrm{~mm} . \\
l z & =0.60 \mathrm{~mm} .
\end{aligned}\right.
\end{aligned}
$$

The zoaria are bilamellar; the two lamellae are easily separated. The micrometric measurements given by Harmer are quite variable; ours are more constant and always greater than those in Steganoporella parvicella.

Occurrence.-Miocene (Choctawhatchee marl): Jackson Bluff, Ocklocknce River, 25 miles southwest of Tallahassee, Florida (very rare). Pliocene (Caloosahatchee marl); Monroe County, Florida (very rare).

Habitat.-Western Atlantic: Off Florida (24-59 meters), Jamaica (16-19 meters), St. Vincent, Brazil (32 meters). Western Pacific: Off Japan (324 meters), China Sea (43 meters), Philippines (29 meters), Singapore to Honolulu (32-64 meters), Queensland (19-32 meters). Indian Ocenn: Trincomalie, Admirality Islands (32-40 meters), East Africa (3-16 meters).

Plesiotypes.—Cat. No. 68487, U.S.N.M.

\section{Family ASPIDOSTOMIDAE Canu, 1908.}

\section{Genus ODONTIONELLA Canu and Bassler, 1917.}

1917. Odontionella Canu and Bassler, A Synopsis of American Early Tertiary Cheilostome Bryozoa, U. S. National Museum, Bull. 96, p. 12

1920. Odontionella Canu and Bassuer, Monograph North American Early Tertiary Bryozoa, Bull. 106, U. S. National Museum, p. 256.

Ovicell hyperstomial. No condyle for the opercular valve. The opesium is not symmetrical. The proximal border of the opesium bears irregular spinous processes, short, flat, more or less wide. The opesiular indentations are dissymmetrical. The operculum projects beyond the ridge. Sixteen tentacles. The avicularium is placed on the gymnocyst.

Genotypes.-Odontionella (Membranipora) hians Hincks, 18s5, and Odontionella (Membranipora) occultata Waters, 1887. Range: Pliocene-Recent.

In 1917 we gave the generic definition of Waters's M. hian's group. Later studies have permitted us to gain a better knowledge of the structure of this remarkable genus, which must be definitely placed in the Aspidostomidae on account of the nature of the ovicell. The genus differs from Hemiseptella Levinsen, 1912, also deprived of condyles in the nature of the opercular valve, in the presence of a gymnocyst and of a sort of vestibular arch, in the rarity of the lateral processes, and in 
the presence of an ovicell. The retractor muscles of the polypicle are attached in one of the zooecinl angles. This results in a clissymmetry of the opesium and of the opesiules as in Steganoporella, Onychocella, etc.

Like Waters, 1899, we have thought that Membranipora savartii Audouin, 1826 , belonged to this group of species. It is in fact also prorided with spinous processes and rather frequently with a proximal denticular plate. But this analogy is not sufficient; for, first, the opesium is symmetrical; second, we do not know whether there are opesiules in the chitinous cryptocyst; third, the operculum is totally different; and, fourth, there are only 15 tentacles.

The characteristics of this genus are much more risible on Membranipora occultata Waters, 1S87, wherefore we believe it wise to add it as a second genotype.

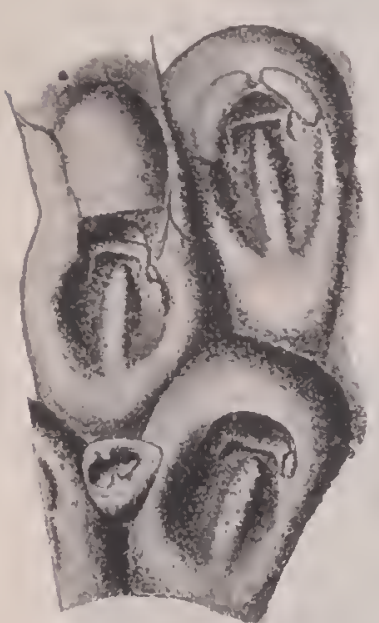

A. Aspidostoma

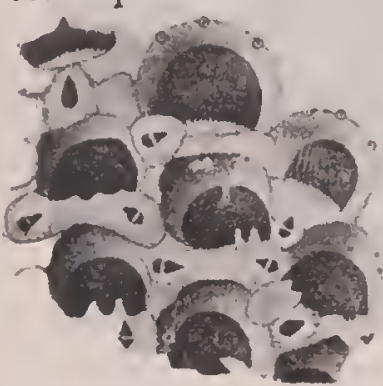

E. Odontionella

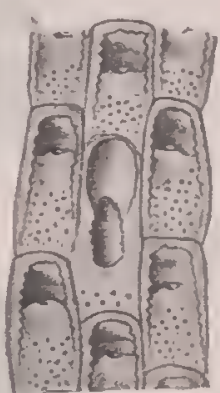

B. Labiopora

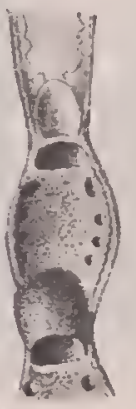

F. Foraminella
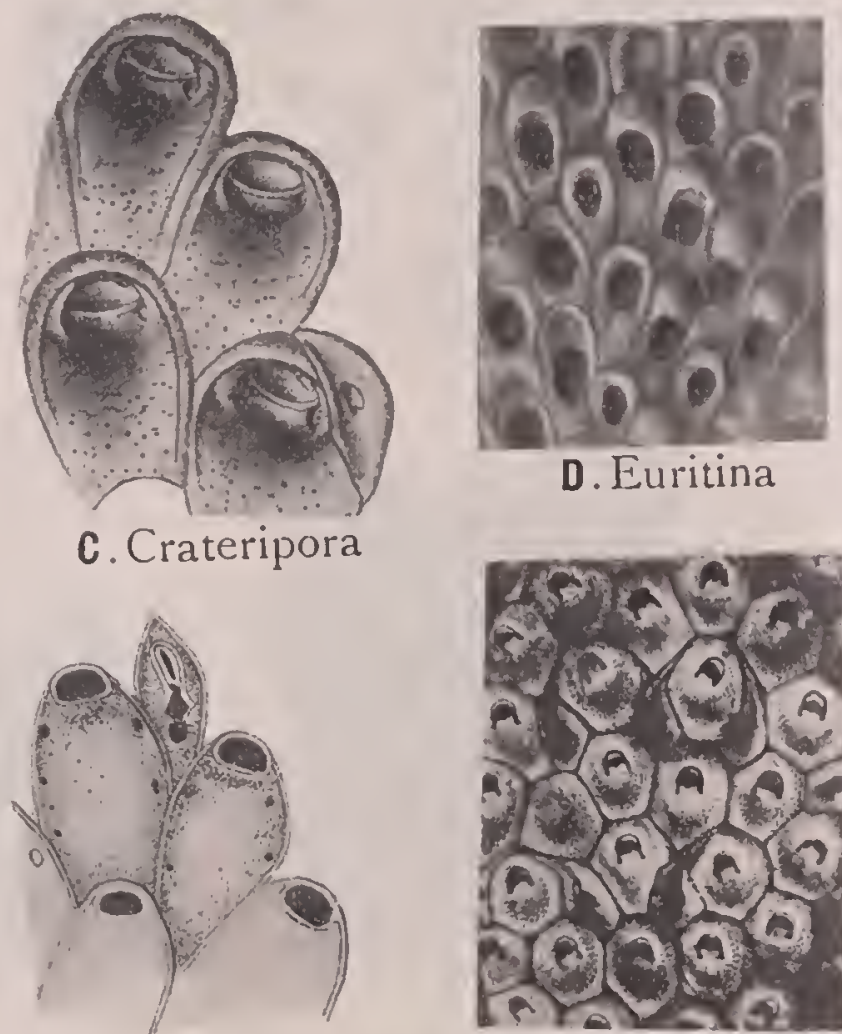

G. Rhagasostoma

FIG. 8.-Genera of the family Aspidostomidae Canu, 1908.

A. Aspidostoma, Hincks, 1881. A. giganteum Busk, $1884, \times 25$. Recent.

B. Labiopora Levinsen, 1909. L. crenulata Levinsen, 1909, X 23. Recent.

C. Crateropora Levinsen, 1909. C. falcata Levinsen, 1909, $\times 23$. Recent. (A-C after Levinsen, 1909.)

D. Euritina Canu, 1900. E. eurita D'Orbigny, $1852, \times 20$. Cretaceous.

E. Odontionella Canu and Bassler, 1917. O. occultata Waters, 1887. (After Waters, 1887.)

F. Foraminella Levinsen, 1909. F. lepida Hincks, 1881, X 25. Recent. (After Hincks, 1881.)

G. Rhagasostoma Koschinsky, 1885. R. hexagonum Koschinsky, 1885, X17. Eocene. (After Koschinsky, 18s5.) 


\section{Genus FORAMINELLA Lerinsen, 1909.}

1909. Foraminella Levinsen, Morphological and Systematic Studies on the Cheilostomatous Bryozoa, p. 165 .

The somewhat arched frontal wall has no pores, but on each side a longitudinal series of (1-5) foramina (opesiules). $\Lambda$ membranous opercular valve. Independent avicularia without crossbar, with an elongate mandible, on the one side furnished with a wing-like expansion. Hyperstomial ovicell with a membraneous ectooecium. Dietellae (Levinsen).

Genotype.-Foraminella (Monoporella) lepida Hincks, 1881. Recent.
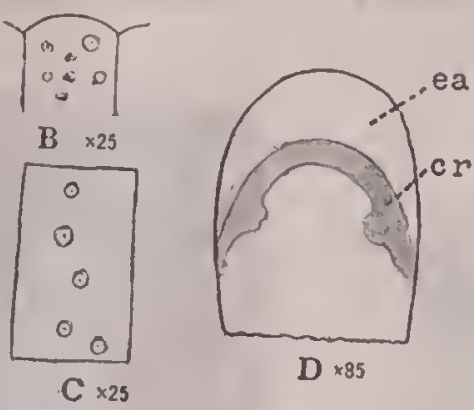

$\mathrm{D} \times 85$

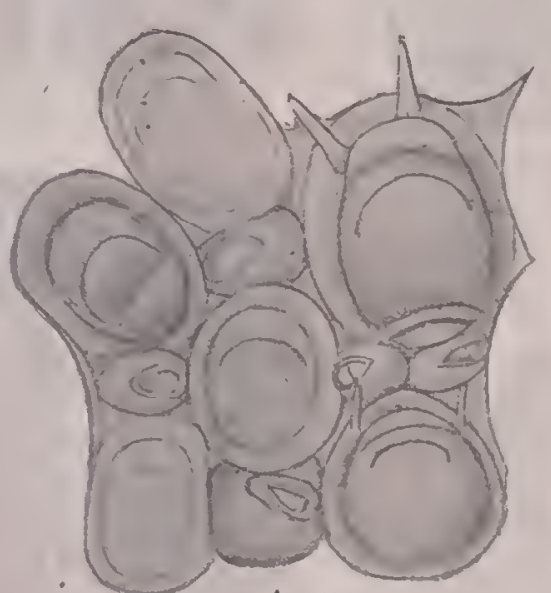

A $\times 75$
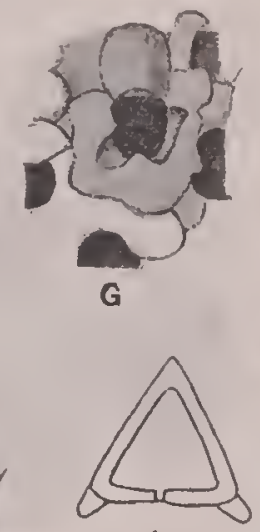

1

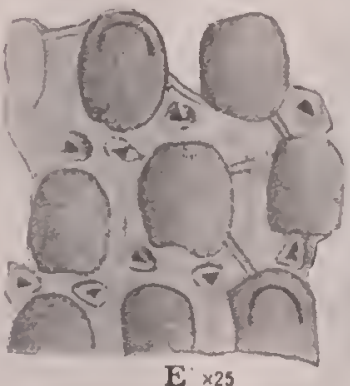

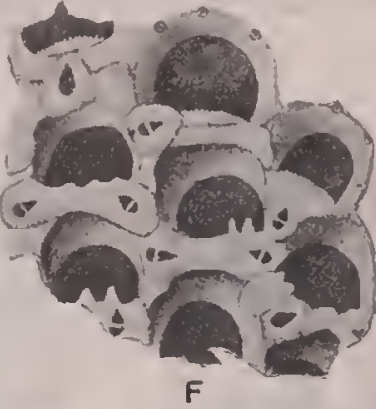

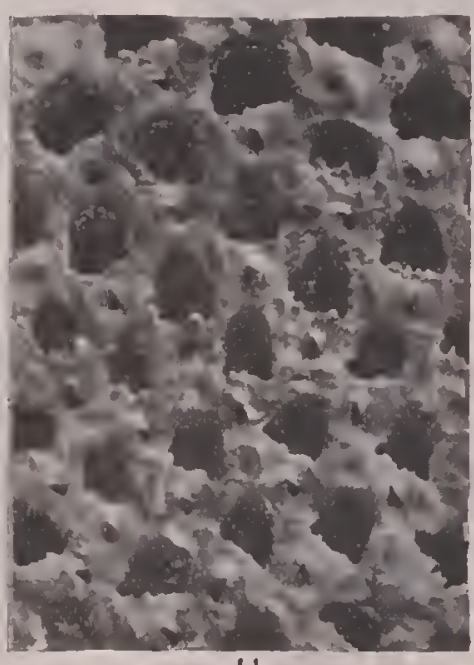

H

Fig. 9-Genus Odontionella Canu and Bassler, 1917.

A-E. Odontionella (Membranipora) hians Hincks, 1885.

A. Zooecia, $\times 75$. (After Hincks, 1885.) B. Distal wall with septulae, $\times 25$. C. Lateral wall with septulae, $\times 25$. D. Operculum, $\times 85$, showing chitinous ridge $(c r)$ and expansion $(e a)$. E. Zooecia $\times$ 25. (B-E after Waters, 1898.)

F, G, I. Odontionella occultata Waters, 1887.

F. Specimen from recent seas with its avicularia. G. Example from the Tertiary rocks of New Zealand showing a thick calcareous deposit between the zooecia. I. Avicularian mandil)le, $\times 250$.

J, Tr. Opercula of another species (introduced by error.).

H. Photograph of a specimen of Odontionella hians Hincks from New Zealand showing the disymmetry of the opesiular indentations, $\times 20$. 
Genus LABIOPORA Levinsen, 1909.

(For description, see Bulletin 106, U. S. National Museum, p. 258.)

LABIOPORA MIOCENICA Canu and Bassler, 1919.

Plate 6, fig. 1.

1919. Labiopora miocenica CANU and Bassler, Geology and Paleontology of the West Indies, Bryozoa, Publication of the Carnegie Institution of Washington, No. 291, p. \$9, pl. 6, fig. 1.

Description.- The zoarium is unilamellar. The zooecia are elongate, distinct, rectangular; the mural rim is quite thin, round. The cryptocyst is little deep, flat, and formed of a tremocyst superposed on an olocyst perforated with corresponding pores. The opesium is tranverse, terminal or placed at the base of a funncl, formed by the much developed vestibular arch. The polypidian tube is visible, wide, median.

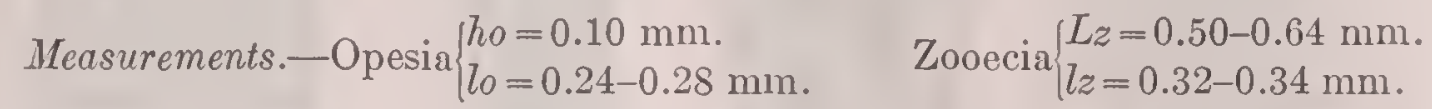

Affnities.-This new species diffcrs from Labiopora crenulata Levinscn, 1909, in the wide form of the zooecia and in its transverse opesium. (rare).

Occurrence.-Lower Miocene (Bowden horizon): Rio Gurabo, Santo Domingo

Holotype-Cat. No. 68488, U.S.N.M.

\section{CALPENSIIDAE, new family.}

No ovicell. The cryptocyst is perforated by one or two opcsiules.

We suppose that the ovicell is formed by an internal sac placed in the vicinity of the opcrcular region as in the genus Diplodidymia Reuss, 1869. The different gencra which we classify here belong perhaps to distinct families; but as we are ignorant of the larva, it is preferable to group them provisionally under the same name. They may be classified in three groups.

1. A single opesiule. Diplodidymia Reuss, 1869.

2. Cryptocyst with spinous processes. Hemiseptella Levinsen, 1909; Cupularia Lamouroux, 1821.

3. Complete cryptocyst. Calpensia Jullien, 1888; Verminaria Jullien, 1888; Microporina Lcvinsen, 1909; Corynostylus Canu and Basslcr, 1919.

\section{Genus DIPLODIDYMIA Reuss, 1869.}

1869. Diplodidymia Reuss, Zur fossilen Fauna der Oligocänschichten von Gaas, Sitzungsherichte der k. Akademie der Wissenschaften, Wien, vol. 59, Abth. 1, p. 469.

The zoarium is articulatcd and radicelled. Each segment is formed of four rows of zooecia placed diagonally. No ovicell. Two very small pores are placed on each side beforc the apertura. The cryptocyst is perforated laterally by a long linear opesiule; it gives passage to the wide muscles attached to the cctocyst in a scelerity (=chitinous thickening). The avicularium is by the side of the apertura 
and the mandible is triangular. The avicularian chamber bears a radicular perforation. Eleven to twelve tentacles.

Genotype:-Diplodidymia complicata Reuss, 1869. Range: Montian-Recent.

A detailed study of this genus was made by Waters, 1913. The ovicell is a sae hanging from the opercular region; the egg evolves there until the formation of the larva. Reuss classified this genus in a special family.
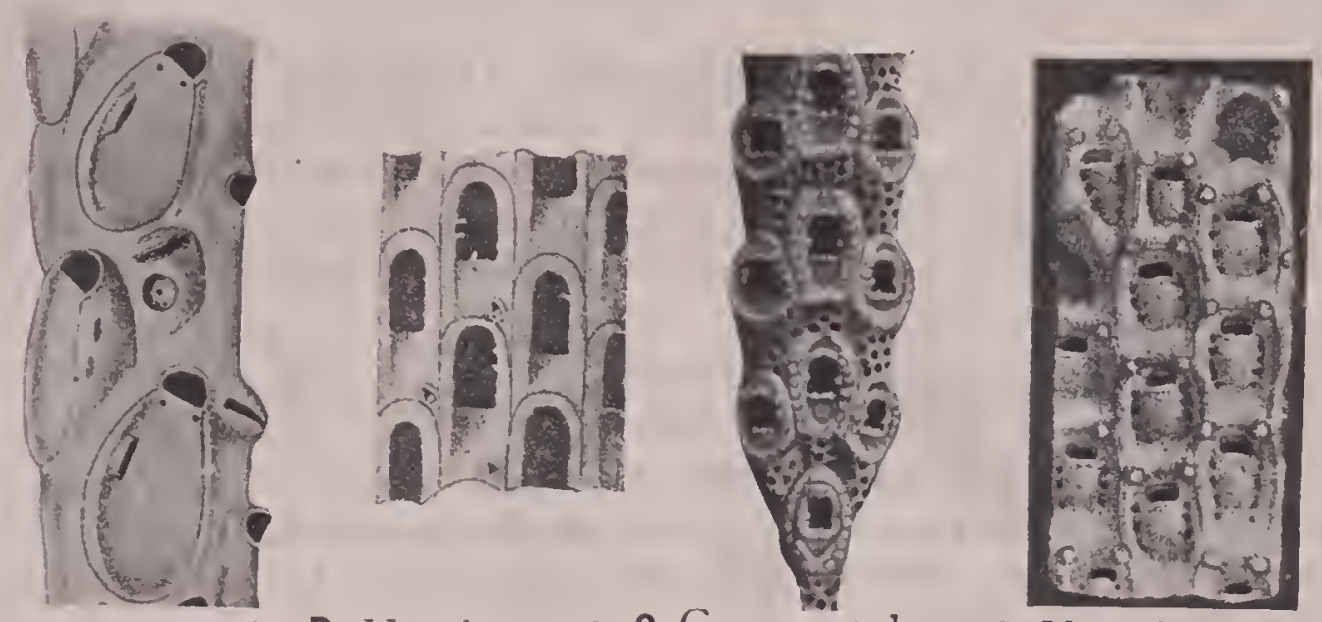

A. Diplodidymia B. Hemiseptella C.Corynostylus

D. Verminaria

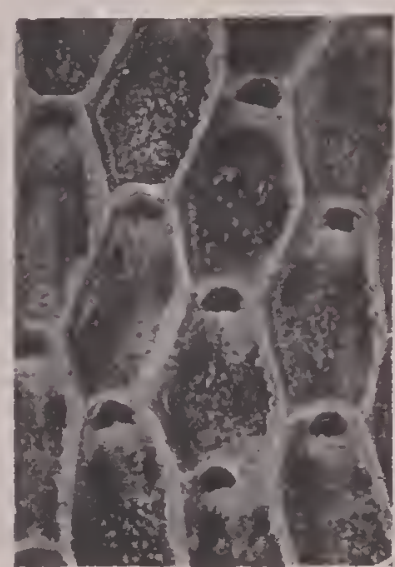

E. Calpensia

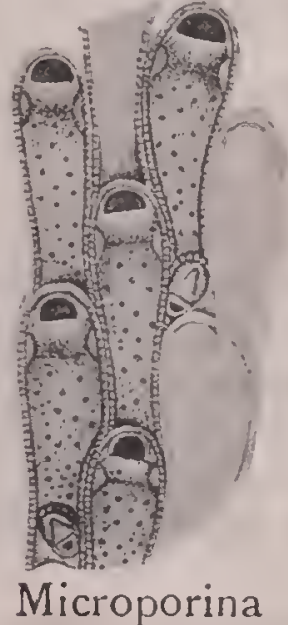

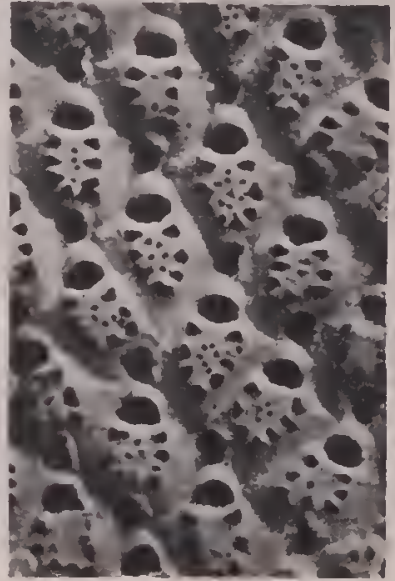

G. Cupularia

FIG. 10.-Genera of the family Calpensiidae, new family.

A. Diplodiflymia Reuss, 1869, D. complicata Reuss, 1869, X 85. Recent, Africa. (After Waters, 1913.) 1895.)

B. Hemiseptella Levinsen, 1909, II. labiata Busk, 1884, $\times$ 12. Recent, Cape Horn. (After Waters,

C. Corynostylus Canu and Bassler, 1919, C. labiatus Canu and Bassler, 1919, $\times 20$. Miocene.

D. Verminaria Jullien, 1885, V. oblonga Busk, 1859. Crag of England. (After Busk, 1859.)

E. Calpensia Jullien, 1888, C. impressa Moll, 1803, X 25. Recent, Atlantic. (After GuerinGanivet.)

F. Microporina Levinsen, 1909, M. elongata Hincks, $1880 \times 25$. Recent, Australia. (After Hincks, 1801.)

G. Cupularia Lamouroux, 1821. C. umbellata Defrance $1823, \times 20$. 


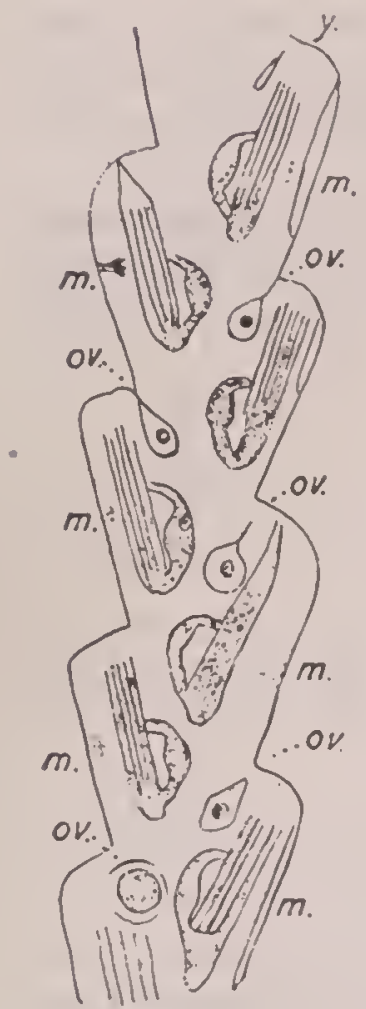

A
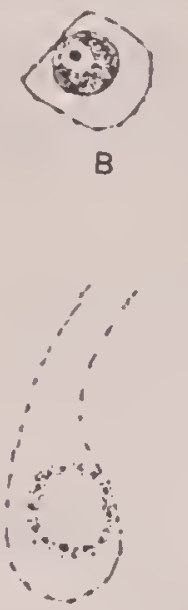

C
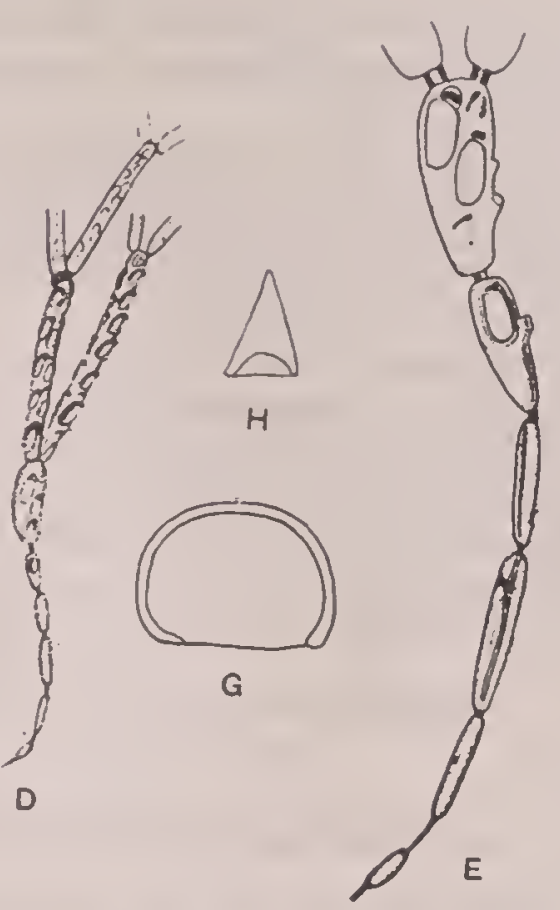

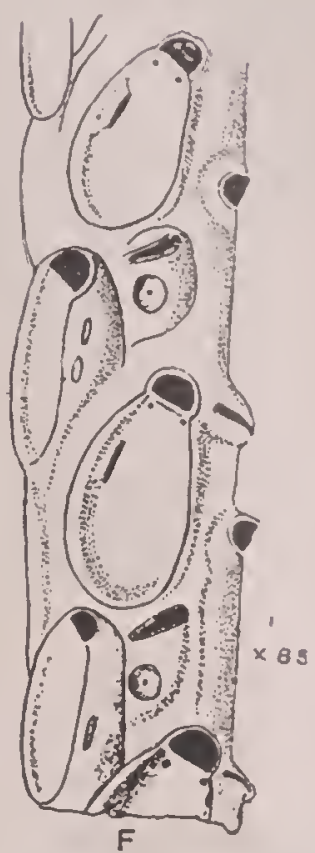

FIG. 11.-Genus Diplodidymia Reuss, 1869.

Figs. A-H. Diplodidymia complicata Reuss, 1869.

A. Sketch, $\times 50$ showing small sacs hanging from the opercular region, and in each an ovum grows (ov). At $y$. there seems as yet no ovum in the small sac; $m$., the muscles of the opesium. B. Section showing an orum in the small sac, $\times 750$. C. Section, $\times 750$, in which the ovum has segmented and a blastula has formed. D. Colony from Chuaka, Africa, $\times 6$. E. Lower part of colony, $\times 25$. F. Portion of zoarium, $\times 85$, showing the structure of the zooecia and avicularia. G. Operculum, $\times 250$. H. Mandible of the avicularium, $\times 250$. (A-H, after Waters, 1913.)

\section{Genus HEMISEPTELLA Levinsen, 1909.}

1909. Hemiseptella Levinsen, Morphological and Systematic Studies on the Cheilostomatous Bryozoa, p. 164.

No ovicell. The distal extremity of the cryptocyst plunges into the zooecium. The dissymmetric opesium bordered laterally and inferiorly by spines. The two opesiules, distinct or not are limited sometimes by the cryptocyst, sometimes by the spinous processes. The opercular valve is garnished superiorly by an opercular arch strongly chitinized. Small avicularium. Twenty-six tentacles.

\section{Recent.}

Genotype.-Hemiseptella (Vincularia) labiata Busk: 1884. Range: Miocene-

Structure.-We have chosen Vincularia labiata as the genotype because it presents two sorts of spinous processes, the larger of which can unite in order to form a bridge intended to support the hinge of the opercular valve. But this bridge is only a secondary character. The cryptocyst covers the spinous processes. Levinsen attributed to this genus a certain number of species from the Cretaceous figured by D'Orbigny. This is an error; these species belong to the genus Floridina, for their ovicell is endozooecial and they bear onychocellaria. 
One must not confuse the spinous processes or spinules with the spines. Their structure is not similar and their physiologic rôle is absolutely distinct. The spinous processes arc here only internal apparatus for support, probably intended to limit the movements of the hypostege.

The large retractor muscle of the polypide is inserted in a corner of the zooecium as in Onychocella, Odontionella, and Steganoporella. It results in a great dissymmetry of the opesium especially on its proximal border.

The known species of this genus arc:

Hemiseptella (Vincularia) labiata Busk, 1884.

Hemiseptella (Vincularia) steganoporoides Goldstein, 1582.

Herniseptella (Thalamoporella) michaelseni Calvet, 1904.

Hemiseptella (Biflustra) denticulata Smitt, 1872.

Hemiseptella (Membranipora) tenuis Desor, 1848.

Hemiseptclla (Membranipora) lacinia Tuomey and Holmes, 1857.

Hemiseptclla (Membranipora) minor Canu, 1908 ( M. sulcata, var. minor Canu).

HeMiseptella LATA Canu and Bassier, 1919.

Plate 2, fig. 4.

1919. Itemiseptella lata CANu and Bassler, Geology and Paleontology of the West Indies, Bryozoa Publication of the Carnegie Institution of Washington, No. 291, p. 35, pl. 2, fig. 4 .

Description.-The zonrium incrusts fronds of the bryozoan Metrarabdotos. The zooecia are distinct, little elongated, wide, subrectangular; the mural rim is thin. The opesium is elliptical or orbicular, never symmetrical; the cryptocyst is short, little deep, irregular; the opesiular indentations are represented by two lateral dissymmetric concavities and are oftcn scparated by a wide and serrate denticle.

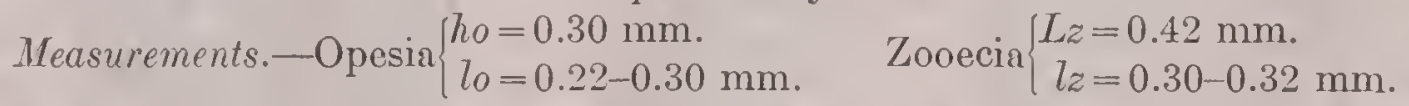

Affinities.-It is always difficult to charactcrize a species from the study of a single specimen. Extcriorly the zooecia hare the form of certain zooccia observed in Acanthodesia savartii Savigny-Audouin, 1826; it differs from it in its nonsymmetric opesium and in two opesiular sinuosities.

This species differs from Biflustra savarti Smitt, 1872, which is not perhaps the species of Audouin, in the more constant derelopment of its cryptocyst and in the nature of its zoarium, which does not incrust algae. The proximal denticle has been clearly observed on three zonecia.

Occurrence.-Lower Miocene (Bowden horizon): Cercado de Mao, Santo Domingo (vert rne).

Holotype.-Cat. No. 68498, U.S.N.M.

HEMisePtella? LACINIA Tuomey and Holmes, 1857.

Plate 14. fig. 10.

1857. Membranipora lacinia Tuomey and Holmes, Pleiocene Fossils of South Carolina, p. 14, pl. 4, fig. 10.

We have been unable to find any specimens corresponding to the figure of Membranipora lacinia, which, moreover, is somewhat confusing, al though probably indicating the genus IIemiseptella. We reproducc the original figure in the lope that some future student will rediscorer the species.

Occurrencc.-Miocene?: Smith's, Goose Creek, South Carolina. 
HEMisEPTELLA GRANDICELLA Canu and Bassler, 1919.

Plate 5, fig. 12.

1919. Hemiseptella grandicella CANU and BAssLer, Geology and Paleontology of the West Indies, Bryozoa, Publications of the Carnegie Institution of Washington, No. 291, p. 84, pl. 5, fig.'11.

Description.-The zoarium incrusts shells. The zooecia are large, elongate, ogival, distinct, separated by a furrow of little depth; the mural rim is narrow, little salient, round, finely granulater; the cryptocyst is large, flat, granulated; the opesium is elongated, elliptical, irregular and nonsymmetrical in the proximal portion.

$$
\text { Measurements. Opesia }\left\{\begin{array} { l } 
{ h o = 0 . 4 0 \mathrm { mm } . } \\
{ l _ { 0 } = 0 . 2 5 \mathrm { mm } . }
\end{array} \text { Zooecia } \left\{\begin{array}{c}
L z=0.65-0.70 \mathrm{~mm} . \\
l_{z}=0.35 \mathrm{~mm} .
\end{array}\right.\right.
$$

Affinities.-The group of inferior opesiular spines was certainly dissymmetrical; trace of the lateral spines is scarcely visible on our specimens.

This species differs from Hemiseptella denticulata Smitt, 1872, in the absence of nodosities in the interzooecial angles and in the nontrifoliate opesium. It differs from Hemiseptella tenuis Desor. 1848, in the larger micrometric measurements and in the more fragile and less numerous spines.

Occurrence.-Lower Miocene (Bowden marl): Bowden, Jamaica (rare).

Holotype.-Cat. No. 68490, U.S.N.M.

HEMISEPTELLA FILIMARGO, new species.

Plate 10, fig. 9.

Description.-The zoarium incrusts shells. The zooecia are distinct, separated by a rery thin salient thread, elongated, subhexagonal; the mural rim is very thin, filiform, salient; the cryptocyst is large, flat, shallow. The opesium is semielliptical, transverse, with an irregular proximal border, two large lateral spicules and many spicules placed inferiorily.

$$
\text { Measurements.-Opesia }\left\{\begin{array} { l } 
{ h o = 0 . 1 2 - 0 . 1 8 \mathrm { mm } . } \\
{ l o = 0 . 1 5 - 0 . 2 0 \mathrm { mm } . }
\end{array} \quad \text { Zooecia } \left\{\begin{array}{l}
L z=0.40-0.50 \mathrm{~mm} . \\
l z=0.25-0.30 \mathrm{~mm} .
\end{array}\right.\right.
$$

Variations. - The micrometric mensurements are very irregular. Interzooecial tubercles are sometimes present. On our single specimen the spicules are badly preserved. The extreme thinness of the mural rim well characterizes this species. Cases of regenerated zoocia have been observed.

Occurrence.-Miocene (Yorktown formation): York River, Virginia (rery rare).

Holotype.-Cat. No. 68491, U.S.N.M.

$$
\text { HEMISEPTELLA TUBEROSA, new species. }
$$

Plate 46, fig. 10.

Description.-The zoarium incrusts shells. The zooecia are distinct, elongated, rectangular, ornamented with large interzooecial tubercles; the mural rim is thick, rounded, granulated; the cryptocyst is much reduced, deep, granulated. The opesium is elongated, elliptical, with an irregular proximal border.

$$
\text { Measurements.-Opesia }\left\{\begin{array} { l } 
{ h _ { 0 } = 0 . 2 5 \mathrm { mm } . } \\
{ l _ { 0 } = 0 . 1 5 \mathrm { mm } . }
\end{array} \text { Zooecia } \left\{\begin{array}{l}
L_{z}=0.35 \mathrm{~mm} . \\
l_{z}=0.25 \mathrm{~mm} .
\end{array}\right.\right.
$$

Variations.-On our type specimen there are very few spicules risible. The micrometric measurements are very irregular. 

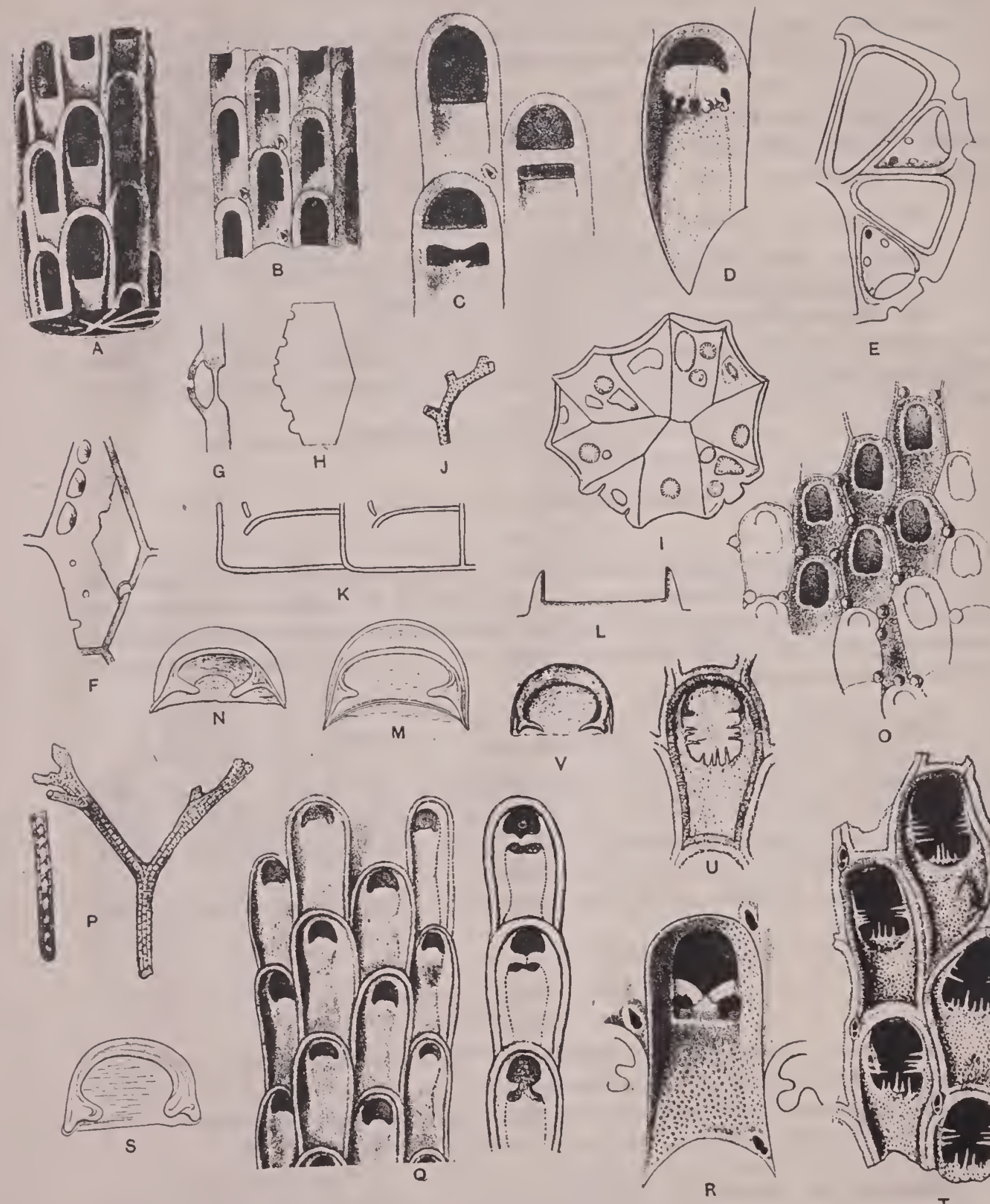

FIG. 12.-Genus Hemiseptella Levinsen, 1909. 
FIa. 12.-Genus Hemiseptella Lcrinsen, 1919.

Figs. A-N. Hemiseptella labiata Busk, 1884.

A. A branch of the form Vincularia elegans (after D'Orbigny, 1839). B. A branch from Cape Horn, $\times 12$. A few minute denticles or hooks occur on thc bordcr of the opesium. C. Several zooecia of the type of Vincularia elegans preserved at the Museum of Paris. A growth from each side forms a calcareous bridge over thc opesium. It is placed under the membraneous cctocyst. D. A calcined zooecium of a specimen from the Atlantic (Challenger collection), $\times 25$. E. Transverse section, $\times 25$. $\mathrm{F}$. Calcareous section diagonally through a zooeciun, thus showing the projecting rosette plates (septulae), $\times 25$. G. Section through the dietcllae, $\times 250$. H. Diagrammatic section showing the position of the septulae, $\times 25$. I. Transverse, decalcificd section, $\times 25$. J. A branch, natural size (after D'Orbigny, 1839). K. Section in the zooecia, $\times 25$. Besides the lip which projects upward, the front wall of the zooecium is directed downward thus contracting the zooecium near the aperture. (Figs. D-H, K, (after Waters, 1889). L. Transverse section in operculum, $\times 85$ (B, C, I, L, after Waters, 1895). M., N. Operculum (after Busk 1884).

FIG. O. Hemiseptella denticulata Smitt 1872. A zoarium from Florida. The unshaded zooecia are covered by the ectocyst. They show the chitinous arcli of the opercular valve.

Fig. P-S.-Hemiseptella stcganoporoides MacGillitray, 1881. P. A zoarium, natural size, from Prince Edward Island. Q. Zooecia with their opesiular in dentations and occasionally the bridge, $\times 25$ (forma Vincularia gothica). R. A zooecium showing the sutures between the three processes and the avicularium (aftcr Waters, 1889). S. Operculum, $X 85$ (figs. P, Q and S, after Busk, 1884).

Figs. T-V.-Hemiseptella michaelseni Calvet, 1904. T. Zooecia, $X 25$, showing the three groups of spinous processes bordering the opesium. U. A zooecium covered by its membranous transparent ectocyst under which the spinous processcs are seen. V. Operculum, X 85 (T-V, aftcr Calvet, 1907).

This species is much smaller than Hemiseptella rectangulata, in which the form of the zooecia is identical but which is deprived of tubercles.

Occurrence.--Pleistocene: Simmons Bluff, Yonges Island, Charleston County, South Carolina (rare).

Holotype.-Cat. No. 68492, U.S.N.M.

HEMISEPTELLA FISTULA Ulrich and Bassler, 1904.

Plate 14, fig. 9.

1904. Membranipora fistulu Ulrich and BAssler, Bryozoa: Maryland Geological Survey, Miocene, p..413, pl. 112, fig. 5 .

The original description is as follows:

Zoarium so far as observed forming small, hollow, subcylindrical stems, about $1.5 \mathrm{~mm}$. in diameter, composed of twelve to fifteen longitudinal rows of zooecia. Walls about as wide as the zooecial opcnings, obtusely carinate, the carinae betwcen the ends of the cells high and bent forward so as to impart a slightly imbricating appearance to successive cells. Opesial opening elongate elliptical; immediatcly behind it a minute pore is occasionally noticeable. Measuring longitudinally about 8 zooecia in $5.0 \mathrm{~mm}$. No avicularian nor vibracular cells observed.

The original description of this slender rod-like bryozoan gives an adequate idea of the species, of which unfortunately no more specimens have been discovered. We reproduce a new illustration of the type specimen which shows spines irregularly distributed on the proximal border of the opesium, thereby causing the species to be referred to Hemiseptella.

Occurrence.-Miocene (St. Mary's formation): St. Mary's River, Maryland (very rare).

Holotype.-Cat. No. 68493, U.S.N.M.

12184-23-Bull. $125-6$ 
Plate 14, fig. 11.

Description.-The zoarium incrusts shells. The zooecia are distinct, adjacent, elongated, rectangular, with rounded distal border. The cryptocyst is deep, granular, flat; the opesium is elliptical, elongated with a proximal border irregular and without symmetry; the spinous processes are short, fragile, thin, numerous. No dietellae.

$$
\text { Measurements.-Opesia }\left\{\begin{array} { l } 
{ h _ { 0 } = 0 . 3 0 \mathrm { mm } . } \\
{ l _ { 0 } = 0 . 2 0 \mathrm { mm } . }
\end{array} \text { Zooecia } \left\{\begin{array}{l}
L_{z}=0.47 \mathrm{~mm} . \\
l_{z}=0.22 \mathrm{~mm} .
\end{array}\right.\right.
$$

The spinous processes are very fragile; they little resist fossilization, but their vestiges are easily observed.

Affinities.-This species differs from Hemiseptella granulosa in its smooth mural rim and its smaller micrometric measurements. It differs from Hemiseptella grandicella in its deep cryptocyst and its smaller micrometric measurements.

Occurrence.-Miocene (Duplin marl): Wilmington, North Carolina (rare).

Holotype.-Cat. No. 68494, U.S.N.M.

HEMISEPTELla GRANULOSA, new species.

Plate 29, fig. 8.

Description.-The zoarium is unilamellar. The zooecia are distinct, separated by a furrow of little depth, elongated, rectangular; the mural rim is thin convex, granular; the cryptocyst is of little depth, flat, slightly granular. The opesium is elliptical, irregular on its proxial border which is never symmetrical; the spinous processes are distributed in the lower half and the proxial bundle is wider and more salient.

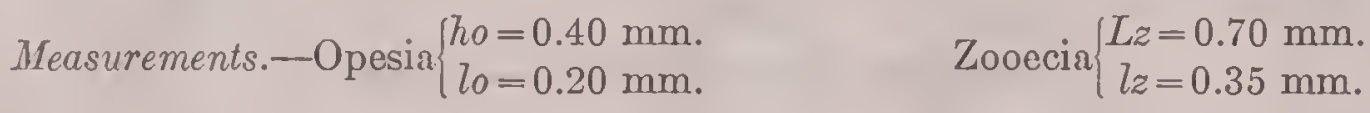

Affinities.-The micrometric measurements are quite variable, even on a simple zoarium; but the relationship of one-half between the two dimensions remain rather constant.

This species differs from Hemiseptella planulata, in which the cryptocyst is also very superficial in its granulated mural rim and in its crenulated opesium. It differs from Hemiseptella grandicella in its micrometric measurements, generally smaller, and in its granular mural rim.

The spinous processes are rather fragile; only their base resists fossilization, and they appear to be grouped into three bundles. The lowest one is wide and vigorous. The asymmetry of the proximal border of the opesium seems to indicate that the large retractor muscle of the polypide was inserted, not in the median axis of the zooecium, but in a lower corner, as in Onychocella and Steganoporella.

Occurrence.-Miocene: Near Charleston, South Carolina (very rare).

Holotype.-Cat. No. 68495 , U.S.N.M.

HEMISEPTELLA PLANULAta, new species.

Plate 29, figs. 5, 6.

Description.-The zoarium incrusts shells (Pectunculus). The zooecia are distinct, elongated, with adjacent mural rims, hexagonal, ogival; the mural rim is thin, little salient; the cryptocyst is little deep, large, flat. The opesium is ogival or 
subtrifoliate; the mural rim is thin, little, salient; the cryptocyst is little deep, large, flat. The spinous processes are very fragile and are distributed into five principal bundles; the lower bundle is salient and placed without symmetry on the proximal border of the opesium.

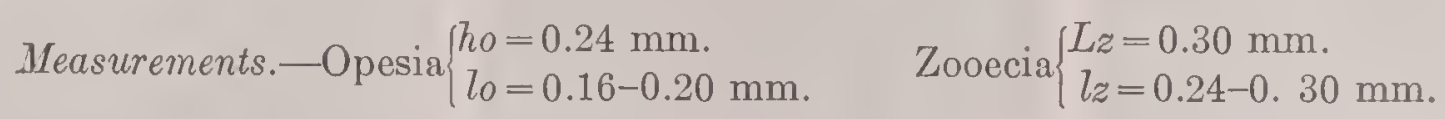

Affinities.-The walls of this species are very fragile and are easily worn; the zooecia are then scarcely distinct, and certain zooecia bear tubercles at the angles.

This species is quite close to Hemiseptella denticulata Smitt, 1872, which also presents tubercles. It differs from it in its less deep cryptocyst and in the inconstancy of the tubercles. However, we possess no specimen of this species and our comparisons are made only from the figures. It differs from Hemiseptella granulata in the absence of granules on the mural rim and in its subtrifoliate opesium.

Occurrence.-Pliocene (Waccamaw marl): Waccamaw River, Horry County, South Carolina (rare).

Cotypes.-Cat. No. 68496, U.S.N.M.

\section{Genus CUPULARIA Lamouroux, 1821.}

1821. Cupularia Lamouroux, Exposition methodique des genres de l'ordre des Polypiers, p. 44.

The zoarium is a more or less expanded cup; it is provided-with a special hydrostatic system accompanied by vibracula. The opesium is fringed with spinous processes which are flat, free, or joined together; the two distal processes are symmetrically placed and serve as support to the opercular valve. The two distal opesiules are always rounded. No oviccll. Vestibular arch present.

Genotype.-Cupularia umbellata Defrance, 1823. Range: Miocene-Recent.

Affinities.-The genus Cupularia is identical in its frontal with the genus Hemiseptella Levinsen, 1909. It differs from it in its cup-shaped zoarial form, in the presence of vibracula, the flat form of the spinous processes, and in the union of the latter.

Cupularia lives like Lunularia, of which we have explained the hydrostatic zoarial mechanism. (See North American Early Tertiary Bryozoa, p. 238). The cellular or external face is the inferior face; the noncellular or internal face is the superior face. The ancestrular zooecia are often calcified, indeed only the opercular valve may be visible there; these are the hydrostatic zooecia (aborted of D'Orbigny); they are never radicular as in the genus Lunularia. The larvae probably devclop in an oral sac, as in the genus Diplodidymia Ruess, 1869.

The union of the spines is not a generic character. In fact it may be accidental (as in Cupularia denticulata), partial (C. reussiana), almost complete (C. umbellata). This union of the spinous processes forms a clyptocyst.

Smitt, 1872, recognized that this genus ought to be classed in the Microporidae. This was correct, as the opesiules or opesiular slits are always clearly visible. In order to show the character of the genus in more detail we have introduced descriptions of a few European species. 


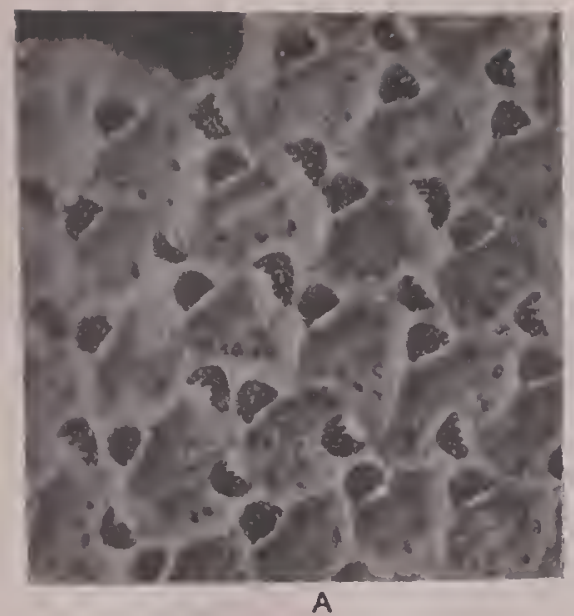

A

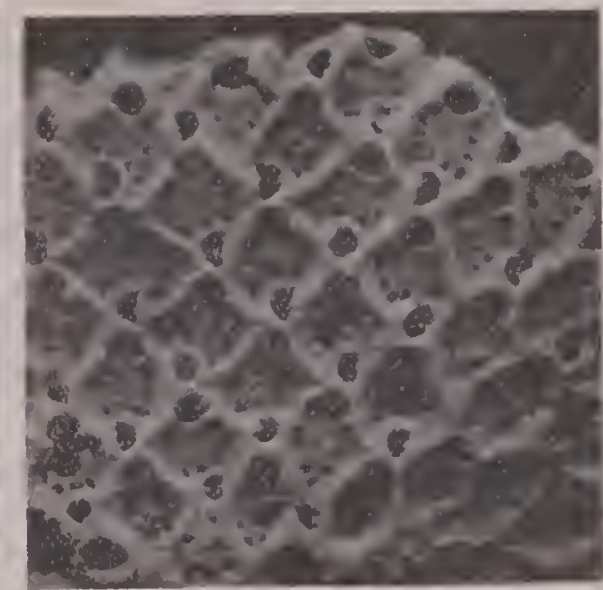

B

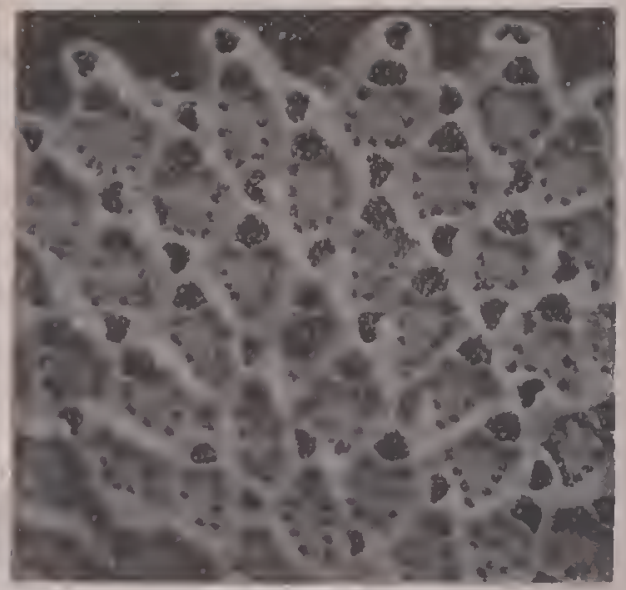

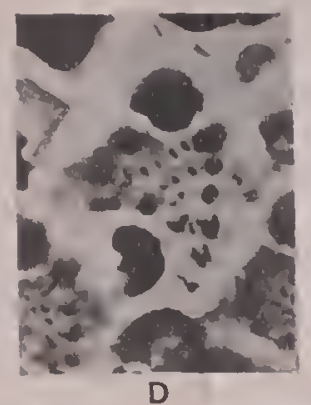
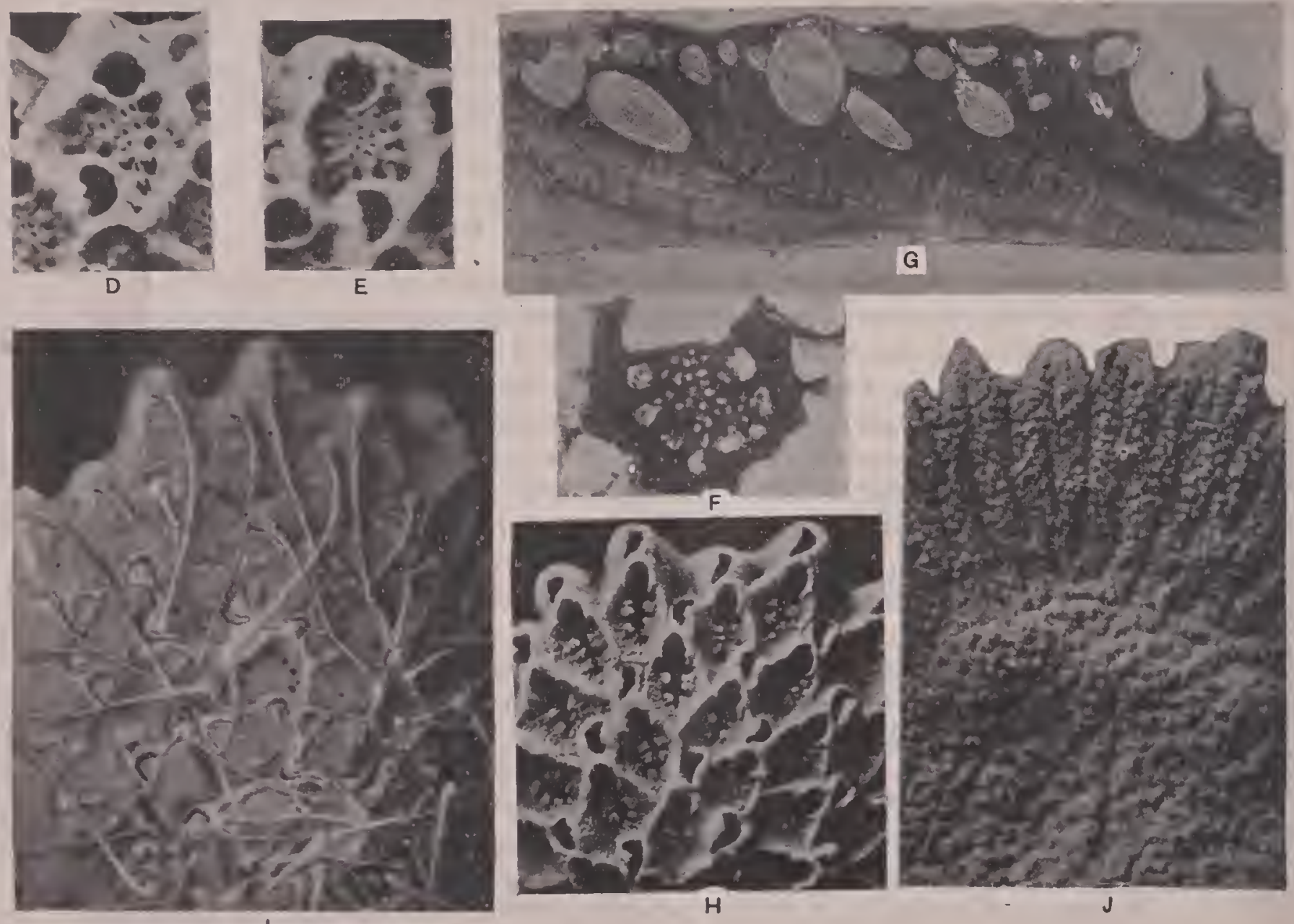

Fic. 13.-Genus Cupulavia I,amouroux, 1921.

A-F. Cupularia umbellata Defrance, 1923.

A. Zooecia, $\times 2$; of specimen dredged in the Mediterranean at Oran (Algeria). B. An example, $\times 25$, with small, wide zooecia. C. Specimen with small, long zooecia, $\times 25$. D, E. Zooecia enlarged $X 50$ ) slowing the formation of the cryptocyst by the partial union of spinous processes. F. Tangential thin section of the frontal, $X 75$, showing the successive ramifications of the lateral spinous processes.

G. Longitudinal thin section, $\times 75$, showing the successive zones of calcification.

J. Internal face (superior) of a zoarium, $\times 25$. (B-G, J) Burdigalian of Merignac, Gironde France.

H, I. Cupularia multispinala, new species.

II. Portion of a zoarium deprived of its ectocyst, $\times 25$. I. Zoarium $\times 25$, provided with its ectocyst, and its vibracula, Mediterranean at Oran (Algeria) 
CUPULARIA HAIDINGERI Reuss, 1847.

Plate 1, figs. 13-17.

1847. Lunulites haidingeri Reuss, Die fossilen Polyparien des Wiener Tertiarbeckens, Haidinger's naturwissenschaftliche Abhandlungen, vol. 2, p. 58, pl. 7, fig. 26, 27.

1859. Cupularia denticulata Busk, Monograph Fossil Polyzoa of the Crag, Publications Paleontolographical Society, p. 85 , pl. 13, fig. 1 .

1877. Cupularia haidingeri Manzonı, I Briozoi fossili del Miocene d'Austria ed Ungheria, parte 2, Denkschriften der k. Akademie der Wissenschaften, Wien, vol. 37, p. 73, pl. 16, fig. 54 .

1880. Cupularia haidingeri Seguesza, La formazioni tergiarie nella Provincia di Reggio (Calabria), Reale Accademia dei Lincei, Memorie della Classe di Scienze Fisiche, Matematiche e Naturali, ser. 3, vol. 6, pp. 84, 131 .

Measurements.-Large zooecia $\left\{\begin{array}{l}L z=0.60 \mathrm{~mm} . \\ l z=0.36-0.40 \mathrm{~mm} .\end{array}\right.$

Variations.-The place of the opercular valve is clearly indicated by a distal arch limited by two symmetrical apophyses or condyles. The spinous processes are flat, often very wide, claviform or finely denticulated; their number is five (which inclucles the two oral apophyses). Their form is inconstant, and we figure some interesting rariations. Our determination of the species has been verified by specimens from Porzteich, Austria-Hungary. The internal face bears radial, bifurcated, and tuberous ribs.

Affinities.-This species differs from Cupuladria canariensis, Busk, 1859, in the presence of spinous processes and in the absence of the large pores of the internal face. It differs from Cupularia denticulata Conrad, 1841, in its larger and flatter zoarial form, its larger zooecia, and in the larger tuberosities of the internal face.

Geological distribution.-Helvetian of Italy (Seguenza); Tortonian of Italy (Seguenza), of Austria-Hungary (Reuss); Redonnian of France (Canu); Plaisancian of England (Busk).

CUPULARIA DOMA D'Orbigny, 1851.

Plate 1, fig. 18; plate 15, figs. 1-5.

1851. Discoflustrcllaria doma D'Orbigny, Paléontologie francaise, Terrain Crétacé, vol. 5, Bryo. zoaires, p. 561.

185̣.9. Cupularia johnsoni Busk, Zoophytology: On some Madeiran Polyzoa, Quarterly Journal Ilicroscopical Science, vol. 7, p. 67, pl. 23, figs. 1-6.

1872. Cupularia doma Smitr, Floridan Bryozoa, collected by Count Pourtales, Kongl. Svenska, Vetenskaps-A kademiens Handlingar, pt. 2, vol. 11, No.4, p. 15, pl. 3, figs. 81-84 (not Busk, 1859).

1877. Cupularia reussiana Manzon, Bryozoaires du pliocene superieur de l'Ile de Rhodes, Memoires de la Société Géologique de France, ser. 3, vol. 1, p. 67.

1909. Cupularia johnsoni Norman, Polyzoa of Madeira and neighboring islands, Journal Linnean Society London, Zoology, vol. 30, p. 290, pl. 38, figs. 1-6.

Variations.-The spinous processes are flat or acuminate; there are even some which are spatulate and some fimbriated. The two superior ones form two symmetrical condyles serving as pirot to the opercular valve. The others are three in number; they are dissymmetrical, irregularly placed, without definite and constant form, never joined. The cryptocyst is more or less developed and its presence considerably modifies the aspect of the opesium. The internal face bears hydrostatic tuberosities (as usual), very inconstant in their size; they are generally very large, but may disappear almost totally. The zoarium is conical, higher than wide. The two opesiules are formed by two rounded indentations symmetrically placed below the condyles. 
Affnities.-Smitt has confused this species with Cupularia reussiana Manzoni, 1869. He saw D'Orbigny's type in Paris. Manzoni and Norman have adopted the same synonymy. For all these authors the essential character was the absence of a complete calcareous pivot for the opercular valve, as in Cupularia umbellata Defrance, 1823. In reality all the denticulata group possess this character and the species are differentiated from each other not only in their zoarial form but also by the number and nature of their spinous processes and in the form of their hydrostatic tubercles.

This species differs from Cupularia multispinata, new species, in the presence of three (and not five) spines, and in the conical form of the zoarium. It differs from Cupularia denticulata Conrad, 1841, which has the same number of spinous processes, in the more conical form of the zoarium, and in the presence of large hydrostatic tuberosities on the internal face. It differs from Cupularia reussiana Manzoni, 1869, in the more conical form of the zoarium and in its spinous processes never joined together.

Occurrence.-Sicilian of Rhodes (Manzoni). Miocene (Duplin marl): Wilmington, North Carolina.

Habitat.-Mediterranean: Shores of Algeria (72 meters), Oran (81-103 meters). Atlantic: Madeira (64-113 meters). Gulf of Mexico: Florida (Smitt).

\section{CUPUlaria multispiNata, new species.}

Description.-The zoarium is discoidal, thin, very convex, much less high than wide. The zooecia are elongated, distinct, hexagonal; the mural rim is thin, little salient; the cryptocyst is more or less developed laterally. The opesium is ornamented by at least five flat spinous processes nonsymmetrical, rather wide, finely denticulated. Two symmetric salient condyles limit the apertura. A vestibular arch is present. The vibracula are large and auriform.

$$
\text { Measurements.-Large zooecia }\left\{\begin{array}{l}
L_{z}=0.48 \mathrm{~mm} . \\
l z=0.32 \mathrm{~mm} .
\end{array}\right.
$$

Affinities.-This species bears the most numerous spinous processes and this character is amply sufficient to differentiate it from Cupularia reussiana Manzoni, 1869 ; C. doma D'Orbigny, 1851; and from C. denticulata Conrad, 1841. The hydrostatic zooecia have their cryptocyst entirely calcified.

Mabitat.--Mediterranean: Gulf of Oran (105 meters).

\section{CUPUlaria REUSSIANA Manzoni, 1869.}

Plate 1, figs. 19-22.

1869. Cupularia reussiana MAanzoni, Bryozoi Pliocenici Italiani, Sitzungsberichte der kaiserlichen Akademie der Wissenschaften, Wien, vol. 59, p. 27, pl. 2, fig. 19.

1895. Cupularia reussiana Neviani, Briozoi fossili della Farnesina e Monte Mario presso Roma, Palaeontographia Italica, vol. 1, p. 102 (sep. 26).

1895. Cupularia reussiana Neviani, Briozoi neozoici di alcune localita d'Italia, Bollettino della Socicte Romana per gli Studi Zoologici, parte 1, vol. 4, p. 45 (sep. 7); parte 2, p. 243 (sep. 19); parte 5, vol. 7, p. 101 (sep. 4), p. 103 (sep. 6).

1900. Cupularia reussiana Neviani, Briozoi neogenici delle Calabrie, Paleontologia italica, vol. 6, p. 169 (55) (regional bibliography). 
1900. Cupularia reussiana Neviani, Briozoi Terziari della Toscana, Bollettino Sociètá geologica italiana, vol. 19, p. 19 (sep.).

1913. Cupularia reussiana CANU, Contributions a I'Etude des Bryozoaires fossiles: IV. Pliocene d'Alger, Bulletin Société Géologique de France, ser. 4, vol. 13, p. 126.

1913. Cupularia haidingeri Canu, Bulletin Société Géologique de France, ser. 4, vol. 13, p. $12 S$.

Historical.-Manzoni's figures of 1869 are exact, although the zoarium is much less conical and almost cupuliform. As the figure of the cellular face has served for the determination by Seguenza, Canu, and Neviani we can hold as exact the synonymy given, moreover partially verified by Canu.

Variations.-The apertural arch is constant; it forms with the two wide, lateral opesiular indentations a trifoliate opesium. The inferior spinous processes are partially united and separated at their base by three large pores which are perhaps secondary opesiules. This character is specific. The vestibular arch is very large; the internal face is covered with large tuberosities.

Affinities.-All the authors, on the authority of Smitt, have confused this species with Cupularia doma D'Orbigny, 1851, the examination of the zoarial form having been judged sufficient. It differs much from it in its cupuliform zoarium (and not very conical) and in the union of the spinous processes occasioning the formation of three large frontal pores.

This species differs from Cupularia umbellata Defrance, 1823, in the presence of three frontal pores only, and in its opesiules not separated from the apertura and reduced to the state of indentations.

Geological distribution.-Tortonian of Italy (Seguenza, Neviani); Zanclean of Italy (Seguenza); Plaisancian of Italy (Neviani); Astian of France and Italy (Canu); Sicilian of Italy (Waters, Seguenza).

This species has not yet been found in the Mediterranean dredgings carried out by Canu. Waters did mention it at Naples.

CUPUlaria DENTICUlata Conrad, 1841:

Plate 15, figs. 6-10.

1841. Lunulites denticulata Conrad (in Hodge), Observations on the Secondary and Tertiary formations of the southern A tlantic States, American Journal Science and Arts, ser. I, vol.41, p. 348.

1845. Lunulites denticulata LonsDale, Report on the Corals from the Tertiary formations of North America, Quarterly Journal Geological Society, London, vol. 1, p. 503.

1857. Lunulites denticulata Tuomey and Holmes, Pleiocene Fossils of South Carolina, p. 11, pl. 4, figs. 1-5.

1904. Cupularia denticulata Ulrich and Bassler, Maryland Geological Survey, Miocene, p. 414, pl. 112 , fig. 6 .

Measurements. - Large zooecia $\left\{\begin{array}{r}L z=0.30-0.40 \mathrm{~mm} . \\ l z=0.20-0.24 \mathrm{~mm} .\end{array}\right.$

Variations.-The hydrostatic zooecia are thin, calcified, probably deprived of polypide, garnished with a complete cryptocyst; their apertura is small and serves probably as passage for a more or less long bristle; they surmount the grain of sand on which the larva is fixed. The internal face is flat or curved; the radiating ribs are generally smooth, but small tuberosities are not rare. The two condyles are not always exactly symmetrical. The spinous processes are acuminate or flat, 
short, finely denticulated, numbering three or four; they are irregular and their position never symmetrical. The zoarium is rather variable. The small specimens are always wider than high. The large specimens are cupuliform but always very convex.

-This species differs from Cupularia haidingeri Reuss, 1847 (=C. denticulata Busk, 1859), in the smaller micrometric measurements and in the absence of the large hydrostatic tuberosities of the internal face. It differs from Cupularia reussiana Manzoni, 1869, in its spinous processes never united. It differs from Cupularia doma D'Orbigny, 1851, which it most resembles in its large, thin, cupuliform zoarium and in the absence or attenuation of the large tuberosities of the internal face.

Occurrence.-Miocene (Duplin marl) : Natural Well, 2 miles southwest of Magnolia, Duplin County, North Carolina (type locality); Wilmington, and many other localities in North and South Carolina. Miocene (Choctowhatchee marl): Jackson Bluff, Ocklocknee River, 25 miles southwest of Tallahassee, Florida (common). Miocene (St. Mary's formation): St. Marys River, Maryland (rare). Miocene (Yorktown formation): Williamsburg, York River, and other localities in Virginia (rare). Pliocene (Waccamaw marl): Waccamaw River, Horry County, South Carolina (very common). Pliocene (Caloosahatchee marl): Monroe County, Florida (very common).

Plesiotypes.-Cat. Nos. 68497-68505, U.S.N.M.

CUPUlaria umbellata Defrance, 1823.

Plate 2, figs. 15-19.

1823. Lunulites umbellata Defrance, Dictionnaire du Sciences Naturelles, vol. 27, p. 361.

1862. Discoporella denticulata Gaвb and Horx, Monograph of the fossil Polyzoa of the Secondary and Tertiary formations of North America, Journal Academy of Natural Sciences of Philadelphia, ser. 2 , vol. 5 , p. 142 , pl. 20, fig. 25.

1872. Cupularia umbellata SмrтT, Floridan Bryozoa, Kongl. Svenska Vetenskaps-Akadlemiens Handlingar, vol. 11, p. 14, pl. 3, figs. 75-S0.

1889. Cupularia umbellata Jelly, A synonymic Catalogue of marine Bryozoa, p. 79 (general bibliography).

1895, 1900. Cupularia umbellata Neviani, Briozoi, neozoici di alcune localita d'Italia, Bollettino della Società Romana per gli Studi Zoologici, pt. 2, vol. 4, 1895, pp. 237, 243; pt. 4, vol. 7, 1898 , p. 38 ; pt. 5 , vol. 8,1898 , pp. $98,100,106$; pt. $6,(2)$, vol. 1, p. 60.

1896. Cupularia umbellata Neviani, Briozoi fossili della Farnesina, Palaeontographia I talica, vol. 1, p. 101 (sep. 25).

1900. Cupularia umbellata Neviani, Bryozoi, terziari et posterziari della Toscana, Bolletino della Società geologica Italiana, vol. 19, p. 362 (sep. 18).

1900. Cupularia umbellata Neviani, Brioizoi neogenici della Calabrie. Palaeontographia Italica vol. 6, p. 168 (regional bibliography).

1908. Cupularia umbellata Canu, Iconographie des Bryozoaires fossiles de l'Argentine, Anales del Ifuseo Nacional de Buenos Aires, vol. 17, p. 274, pl. 5, figs. 4, 5 (bibliography).

1909. Cupularia umbellata CANu, Bryozoaires fossiles du Sud-Ouest de la France, Bulletin de la Société Geologique de France, ser. 4, vol. 9, pp. 448, 454, pl. 16, figs. 16, 17 (regional bibliography).

1909. Cupularia lowei Normas, On the Polyzoa of Madeira, Journal Linnean Society, vol. 30, p. 290, pl. 37 , figs. $7-12$.

1913. Cupularia umbellata CANu, Etude comparée des Bryozoaires Helvetiens de l'Egypte arec les Bryozoaires vivants de la Mediterranée et de la Mer Rouge: Mémoire de l'Institut Egyptien, vol. 6, fasc. 3, p. 205. 
1913. Cupularia umbellata CANu, Contributions à l'étude des Bryozoaires fossiles, Bulletin Société Géologique de France, ser. 4, vol. 13, pp. 125, 127.

1914. Cupularia lowei OsBurn, The Bryozoa of the Tortugas Islands, Florida, Publication No. 182 of the Carnegie Institution of Washington, p. 194.

1916. Cupularia umbellata Cand, Bryozoaries fossiles du Sud-Ouest de la France, Bulletin Société Géologique de France, ser. 4, vol. 15, p. 322.

1919. Cupularia umbellata GANU and Bassler, Geology and Paleontology of the West Indies, Bryozoa, Publications Carnegie Institution of Washington, No. 291, p. 85, pl. 1, figs. 5-7; pl. 2, figs. 17-21.

We are ignorant as to why Norman, who is a great lover of archaic names, has not preserved the name of Defrance. The figures published by this author and by D'Orbigny are excellent and leave no doubt as to the identity of the species. The fossils which are identified as above are rather well preserved and their determination is easy. The pores of the hydrostatic zooecia are not radicular.

Variations.--In this species the two oral condyles are developed and united in a manner to produce a pivot serving as a support to the hinge of the opercular valve. The spinous processes number from seren to eight; they are united on the greater part of their length and form a false cryptocyst perforated with very irregular holes; at their base there is no union' and they thus limit a certain number of opesiules arranged all over the zooecium.

As Smitt thought in 1872, this species differs only from the species of the denticulata group in a greater calcification and in a more complete development of the spinous processes. In spite of its superficial appearance it therefore belongs to the same genus.

The specimens from Santo Domingo, where the species had been noted by Busk in 1859 , are quite vigorous. They represent a variation that is remarkable in the size of the zooecia and in the aspect of the inner side. The latter does not show the usual tuberose ribs and the tuberosities are equally distributed on the zoarial surface. The ancestrula is not always visible; it is often covered over by a normal zooecium or replaced by a special region in which the zooecia are arranged in contrary order.

$$
\text { Measurement. O Opesia }\left\{\begin{array} { l } 
{ h o = 0 . 1 2 \mathrm { mm } . } \\
{ l o = 0 . 1 6 \mathrm { mm } . }
\end{array} \quad \text { Zooecia } \left\{\begin{array}{l}
L z=0.44-0.50 \mathrm{~mm} . \\
l z=0.34 \mathrm{~mm} .
\end{array}\right.\right.
$$

Occurrence.-Lower Miocene (Gatun formation): Banana River, Costa Rica (common). Lower Miocene: Chipola River, Calhoun County, and Shoal River, Walton County, Florida (common). Lower Miocene: (Oak Grove); Oak Grove, Yellow River, Florida (common). Lower Miocene (Bowden horizon): Bowden, Jamaica: Cercado de Mao, Rio Cana, and Rio Gurabo, Santo Domingo (common). Miocene (Duplin marl): Wilmington and other localities in North Carolina and South Carolina (common). Pliocene of South Carolina and Florida.

This species is almost always associated with Cupuladria canariensis Busk, 1859. Like the latter it commences in the Lower Miocene and continues through the latter Miocene and Pliocene of the United States.

Geological distribution.-Aquitanian of Italy (Seguenza, Neviani), of Bordeaux (Canu); Burdigalian of Italy (Seguenza, Canu), of Bordeaux (Canu); Helvetian of Egypt, Bordeaux, and Touraine; Tortonian of Provence (Canu), of Italy (Seguenza); Plaisancian of England (Busk), of Italy (Manzoni); Astian of Italy (Neviani, 
Canu), of Provence (Canu); Sicilian of Italy (Neviani); Quaternary of Italy (Seguenza), of Argentina (Canu).

Habitat.-Mediterranean; Atlantic, Canary Islands, and Florida. It is common in the Gulf of Gascony in the Miocene, but it has now disappeared from this region. The species has been dredged at a depth of 11 to 48 meters in America and from 81 to 113 meters at Madeira.

Plesiotypes.—Cat. Nos. 68506-68511, U.S.N.M.

CUPULARIA ROBERTSONIAE, new species.

Plate 34, figs. 5-7.

1908. Cupularia canariensis RoBertson, The incrusting Cheilostomatous Bryozoa of the West Coast of North America, University of California Publications 11, Zoology, vol. 4, no. 5, p. 314 , pl. 24, figs. $90,91$.

Description.-The zoarium is discoid, little convex. The zooecia are distinct, much elongated, lozenge shaped; their mural rim is thin, sharp. The cryptocyst is deep, flat, perforated in the middle by some irregular pores and laterally by seven large opesiules; the opesium is ogival, transverse, with a proximal concave border. The vibraculum is large, salient, auriform and provided with a very large opesium.

$$
\text { Measurements.-Apertura }\left\{\begin{array} { l } 
{ h a = 0 . 1 0 \mathrm { mm } . } \\
{ l a = 0 . 1 5 \mathrm { mm } . }
\end{array} \quad \text { Zooecia } \left\{\begin{array}{l}
L z=0.60 \mathrm{~mm} . \\
l z=0.30-0.35 \mathrm{~mm} .
\end{array}\right.\right.
$$

Affinities.-The few fossil fragments in our collections appear to agree with Cupularia canariensis Robertson, 1908, dredged in the Pacific off the shores of California. This species is very close to Cupularia umbellata Defrance, 1828; but differs in its larger and less numerous opesiules and in its smaller zoarium. It differs from Cupularia reussiana Manzoni, 1869, in its more numerous and smaller opesiules and in its flatter zoarium.

Occurrence.-Pleistocene: Santa Monica (Long Wharf Canyon), California (rare).

Habitat.-Pacific, off San Pedro (6 meters) and island of Santa Catalina, California.

Cotypes.-Cat. No. 68512, U.S.N.M.

Genus CALPENSIA Jullien, 1888.

18ss. Calpensia Juluien, Mission scientifique du Cap Horn, VI, Zoologie, Bryozoaires, p. 78.

The cryptocyst is entirely developed; it bears two distinct secondary opesia [opesiules]. The operculum is semilunar. (After Jullien.)

The opesiular outgrowths join the lateral walls, forming a closed hollow on each side. A simple, feebly chitinized operculum. Numerous pores, but no spines. No ovicell. No avicularia. The distal wall consists of a basal horizontal and a frontal ascending part, the former being furnished with a narrow transverse group of small uniporous rosette plates [= septulae]. The distal half of each distal wall with a single multiporous plate. (Levinsen.) Recent.

Genotype.-Calpensia (Flustra) impressa Moll, 1803. Range: Auversian, 
CALPENSIA IMPRESSA Moll, 1803.

Plate 1, fig. 4 .

1803. Eschara impressa Mold, Die Seerinde aus der Ordnung der Planzenthiere, Wien, p. 57, pl.11, fig. 9.

1847. Eschara nobilis MicheuIs, Iconographie zoophytologique, p. 329, pl. 79, fig. 1.

1854. Membranipora calpensis Busk, Catalogue of the Marine Polyzoa, British Museum, Cheilostomata, pt. 2, p. 60, pl. 104, fig. 5, 6.

1879. Micropora impressa Waters, On the Bryozoa of the Bay of Naples, Annals Magazine Natural History, ser. 5, vol. 3 , p. 1230.

1902. Ificropora impressa Calvet, Bryozoaires marins des cotes de Corse, Travaux de l'Institut de Zoologie de l'Universite de Montpellier, ser. 2, mem. 12, p. 17.

1910. Micropora impressa Canu, Bryozoairs fossiles de terrains du Sud. Ouest de la France, Bulletin Société Géologique de France, ser. 4, vol. 10, p. 844, pl. 16, fig. 6 (variety).

1911. Ificropora impressa Mue. Guerin-Ganiver, Contribution a l'etude des Bryozoaires des cotes Armoricaines, I, Travaux scientifique du Laboratoire de Concarneau, vol. 3, p. 5, pl. 1

1919. Calpensia impressa Canu and Bassler, Geology and Palentology of the West Indies, Bryozoa, Publication of the Carnegie Institution of Washington, No. 291, p. 84, pl. 1, fig. 11.

The discovery of this species in America was a great surprise, since it has heretofore been noted only in the Mediterranean area, where its zoaria occur in great abundance, especially along the African coast. Our determination is nevertheless an exact one, as we possess so many specimens for comparison that we should not be mistaken.

The bibliography of this species given by Pergens, Jelly, and Waters is incorrect, for they have confounded many distinct species. Canu noted five of them in 1911. In spite of its antiquity there are no unquestioned references to the species other than those we have given above.

The zoarium may be incrusting or Eschara-like. We have never observed an ovicell-indeed, the species may have none.

Occurrence.-Oligocene (Antigua formation): Carlisle marl pit, Antigua, Leeward Islands (rare).

Geological distribution.-Helvetian of Brittany, France (Michelin); Sahelian of Oran (Canu collection); Sicilian of Italy (Neviani).

Habitat.-Mediterranean: Gibraltar, Corsica, Tuscany, Naples, Adriatic, Aegean Sea, Tunis, Algeria, Morocco; Atlantic off Brittany. It abounds at a deptl of 25-30 meters and is very common at the depths of 75-100 meters.

Plesiotype.-Cat. No. 68513, U.S.N.M.

\section{Genus VERMINARIA Jullien, 1888.}

1888. Verminaria Julliex, Mission scientifique du Cap Horn. VI, Zoologie, Bryozoaires, p. 78.

The cryptocyst bears many opesiules on each side. The opesium is subterminal. (After Jullien.)

Genotype.-Verminaria (Membranipora) oblonga Busk, 1859. Pliocene.

Genus MICROPORINA Levinsen, 1909.

1909. Microporina Levinsen, Morphological and Systematic Studies on the Cheilostomatous Bryozoa, p. 162.

The two opesiulae, which, however, are sometimes filled up, appear as simple perforations. Numerous pores. No ovicell, but avicularia with crossbar occur. 
Each distal wall and the distal half of each lateral wall with a row (6-8) of one or two pored rosette plates [septulae]. A longitudinal series of parietal muscles is placed on each side between the cryptocyst and the covering membrane.

Genotype.-Microporina (Cellaria) borealis Busk and Microporina (Micropora) elongata Hincks, 1880 . Range: Campanian, Recent.

Homalostega amphora Marsson, 1887, from the Campanian of Rügen, also belongs to this genus.

\section{Genus CORYNOSTYLUS Canu and Bassler, 1919.}

1919. Corynostylus Canu and Bassler, Geology and Paleontology of the West Indies, Bryozoa, Publication of the Carnegie Institution of Washington, No. 291, p. 86.

No oricell. The opercular valve articulates on two condyles. The zooecia are club shaped and provided with a gymnocyst. The zoarium is articulated.

Genotype.-Corynostylus labiatus Canu and Bassler, 1919. Miocene.

This genus has no recent equivalent but its structure is easy to interpret. The two condyles serve as a hinge for the strongly chitinized opercular valve. The lower part of the opesium placed below served evidently as passage for the opesiular fibers attached to the ectocyst. The deep cavity of the cryptocyst served as a hydrostatic apparatus for the entrance and exit of the polypide. Like most of the articulated genera, the zoarium in this one probably was fastened on large mobile algae.

\section{CORYNOSTYLUS LABIATUS Canu and Bassler, 1919.}

Plate 2, figs. 11-13.

1919. Corynostylus labiatus CANU and BAssler, Geology and Paleontology of the West Indies. Bryozoa, Publications Carnegie Institution of Washington, No. 291, p. 87, pl. 2, figs. 11-13.

Description.--The zoarium is articulated and formed of long regular segments. The segments are compressed, bilamellar, formed of three longitudinal rows of zooecia on each side. 'The zooecia are elongate, oval, distinct, rounded in front, narrowed behind and are provided with a convex gynuocyst with large pores; the mural rim is thick, regular, granular. The opesium is elongate, oval, provided with a proximal, salient lip placed between two rounded opesiular indentations. The two condyles are quite salient. The cryptocyst is deep and smooth.

$$
\text { Measurements.-Opesia }\left\{\begin{array} { l } 
{ h o = 0 . 1 2 \mathrm { mm } . } \\
{ l o = 0 . 1 0 \mathrm { mm } . }
\end{array} \text { Zooecia } \left\{\begin{array}{l}
L z=0.50 \mathrm{~mm} . \\
l z=0.26-0.28 \mathrm{~mm} .
\end{array}\right.\right.
$$

Affinities.--The first zooecium of eacl segment is radicular; it gives rise to three polypidian zooecia.

Occurrence.-Lower Miocene (Bowden horizon): Cercado de Mao, Santo Domingo (common).

$$
\text { Holotype--Cat. No. 68514, U.S.N.M. }
$$

\section{CORYNOSTYLUS ELLIPTICUS Canu and Bassler, 1919}

Plate 2, figs. 8-10.

1919. Corynostylus ellipticus Canu and Bassler, Geology and Paleontology of the West Indies, Bryozoa, Publications of the Carnegie Institution of Washington, No. 291, p. 87, pl. 2, figs. 8-10.

Description.-The zoarium is articulated. The segments are formed of two longitudinal rows of zooecia placed only on one side of the zoarium. The zooecia 
are distinct, club shaped, with long, convex, and porous gymnocyst. The mural rim is thin and granular. The opesium is elliptical, elongate, surrounded by a salient rim: the two condyles are large and median. The cryptocyst is deep, smooth, and small.

$$
\text { Measurements.-Opesia }\left\{\begin{array} { l } 
{ h o = 0 . 1 4 \mathrm { mm } . } \\
{ l o = 0 . 1 0 \mathrm { mm } . }
\end{array} \text { Zooecia } \left\{\begin{array}{l}
L z=0.50 \mathrm{~mm} . \\
l z=0.20-0.22 \mathrm{~mm} .
\end{array}\right.\right.
$$

Affinities.-This species differs from Corynostylus labiatus in its unilamellar segments with only two zooecial rows and in the absence of a salient lip proximal to the opesium. Only the fragments figured have been found; they are extremely fragile.

Occurrence.-Lower Miocene (Bowden horizon): Cercado de Ma, Santo Domingo (rare).

Cotypes.-Cat. No.68515, U.S.N.M.

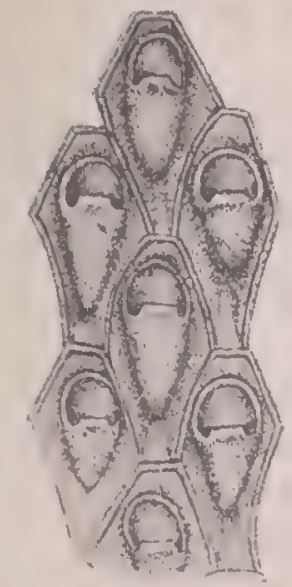

A. Cellaria

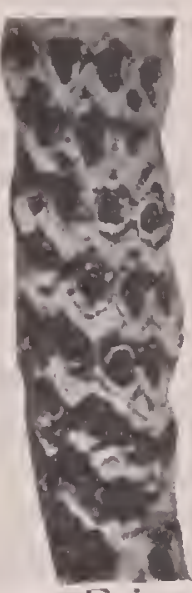

B. Erina

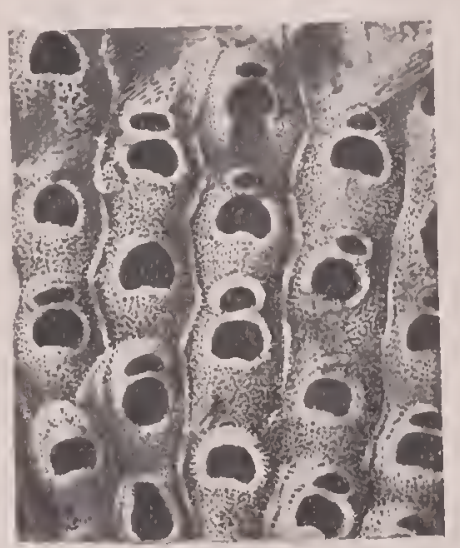

c. Cianotremella
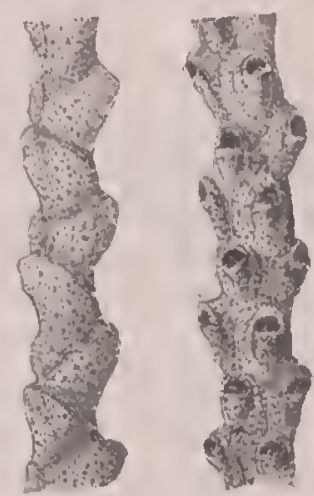

D. Euginoma

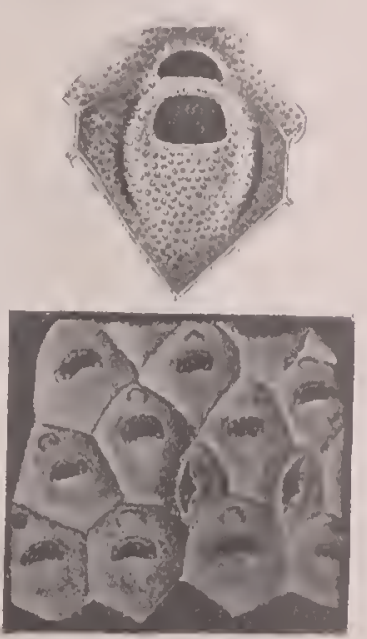

E. Melicerita

Fig. 14.-Genera of the family Cellariidae Hincks, 1880.

A. Cellaria Authors. C. sinuosa Hassall, 1841. $\times 50$. Recent. (After Hincks, 1850.)

B. Erina Canu 1908. E. patagonica Canu, 1908. Cretaceous. (After Canu, 1908.)

C. Cianotremella Canu, 1911. C. gigantea Canu, 1911. Cretaceous. (After Canu, 1911.

D. Euginoma Jullien, 1882. E. vermiformis Jullien, 1882. $\times 21$. Recent. (After Jullien, 1852.) Upper right-hand figure, zooecium enlarged, showing ovicell.

E. Melicerita Milne-Edwards, 1838. M. charlesworthi Busk, 1859. X 25. Pliocene. (After Busk, 1859.)

\section{Family CELLARIIDAE Hincks, 1880.}

Genus CELLARIA Authors.

(For description see Bulletin 106, U. S. National Museum, 1. 272.)

\section{CELLARIA FISSURIFERA, new species.}

Plate 34, figs. 15-18.

Description.--The segments are cylindrical, slender at the base. The zooecia are rhomboidal, distinct, adjacent or partially separated by a very deep furrow; the mural rim is thin, salient, sharp, and ornamented with small tuberosities; the cryptocyst is smooth, deep, scarcely convex. The apertura is semilunar, sur- 
rounded by a thin and salient peristome; the proximal lip is very convex and bears two very small lateral denticles. The orifice of the oricell, which is cndotoichal, is small. The zooecia bcaring branches are narrow, with an elliptical elongate orifice. The interzooecial aricularium is clliptical or subrectangular; its opesium is irregular.

$$
\text { Measurements.-Apertura }\left\{\begin{array} { l } 
{ h a = 0 . 1 5 \mathrm { mm } . } \\
{ l a = 0 . 1 7 \mathrm { mm } . }
\end{array} \text { Zooecia } \left\{\begin{array}{c}
L z=0.85 \mathrm{~mm} . \\
l z=0.30 \mathrm{~mm} .
\end{array}\right.\right.
$$

Affinities.-In the determination of Cellaria, one must take into consideration the zooecin bearing branches which arc somewhat equivalent to the "basis ramae" of Crisia. Their orifice serves as a placc for a horny cylindrical joint.

This species differs from Cellaria mandibulata Hincks, figured by Miss Robertson, 1905, in the small round orifice of the ovicell and in the form and size of its zooecia bcaring branches, which are narrow and provided with an elongate orificc and not transverse, and in the absence of large avicularian zooccia.

Occurrence.-Pleistocene: Santa Monica, California (rare).

Cotypes.-Cat. No. 68516, U.S.N.M.

CELlaria MaNdibULATA Hincks, 1882.

Plate 34, figs. 11-14.

1852. Cellaria mandibulata Hincks, Polyzoa of the Queen Charlotte Islands, Annals and Magazine Natural History, ser. 5 , vol. 10, p. 462; 1884, ser. 5, vol. 13, p. 203, p. 9, fig. 7 .

1905. Cellaria mandibulata RoBertson, Nonincrusting Cheilostomatous Bryozoa of the IVest Coast of North America, University of California Publications, Zoology, vol. 4, no. 5, p. 288, pl. 15, figs. 87,89 ; pl. 16, fig. 103.

Measurements.-Apertura $\left\{\begin{array}{l}h a=0.07 \mathrm{~mm} \\ 7 a=0.14 \mathrm{~mm} .\end{array} \quad\right.$ Zooecia $\left\{\begin{array}{l}L z=0.60 \mathrm{~mm} \\ l z=0.39 \mathrm{~mm} .\end{array}\right.$

Variations.-The orifice of the ovicell is quitc rariable; sometimes it is an ellipsc, elongate and narrow: more often it is an orbicular orifice. The two forms may exist on the same segment. The aricularian zooecin are enormous and comparable to those which are observed on the recent specimens. The reader will comprchend their function by studying Miss Robertson's figure 88. The orifice of the zooecia bearing branches is round, surrounded by a salient peristome.

Occurrence.-Pleistocene: Los Angeles, California (very common).

Habitat.-Pacific Ocean off San Pedro and San Diego, California.

Plesiotypes.-Cat. No. 68517, U.S.N.M.

\section{CELlaria Diffusa Robertson, 1905.}

Plate 34, figs. 19, 20.

1905. Cellaria diffusa Robertson, Nonincrusting Cheilostomatous Bryozoa of the West Coast of North America, University of California Publications, Zoology, rol. 4, no. 5, p. 289, pl. 15, fig. 90 ; pl. 16, fig. 104.

We have found very few fragments of this large and superb species. We have observed the same proximal tongue in the orifice of the ovicell, the same proximal convexity of the apertura, and the same rectangular interzooecial aricularium. Our micrometric measurcments would be slightly larger if the scale of Miss Robertson be exact.

Occurrence.-Pleistocene: Santa Monica (Rustic Canyon) and Los Angeles, California (rare).

Habitat.-Pacific Ocean off California.

Plesiotype-Cat. No. 68518, U.S.N.M. 


\section{Genus ERINA Canu, 1908.}

1908. Erina CANU, Iconographie des Bryozoaires fossiles de l'Argentine, pt. 1, Anales del Museo Nacional de Buenos Aires, vol. 17, p. 273.

The opesium is round, without oral denticles. Genotype.-Erina patagonica Canu, 1908. Patagonian.

\section{Genus MELICERITA Milne-Edwards, 1836.}

1836. Melicerita MrLne-EDwards, Recherches anatomiques sur les Eschares, Annales des Sciences Naturelles, Zoologie, ser. 2, vol. 6, p. 26.

The zoarium is bilamellar and not articulated. Genotype.-Melicerita charlesworthi Milne-Edwards, 1836. Astian.

\section{Genus EUGINOMA Jullien, 1882.}

1882. Euginoma Jullien, Dragages du Travailleur: Bryozoaires, Bulletin Société Zoologique de France, vol. 7, p. 520.

The zooecia are all turned forward and arranged in longitudinal rows; they are hexagonal, limited by a suture in relief; the orifice is semicircular, deprived of spines; the ovicell is formed by the raising of the wall of two zooecia superior to that which bears it; it is divided into two halves by the sutural line of these zooecia; its opening, like a policeman's helmet, is entirely above and in front of the orifice. Dorsal face of the zoarium is divided into trapezoidal areas which are the dorsal faces of two zooecia. (After Jullien.)

Genotype.-Euginoma vermiformis' Jullien, 1882. Recent.

THE COSTULAE.

\section{Family CRIBRILINIDAE Hincks, 1880. \\ Genus CRIBRILINA Gray, 1848.}

(For description see Bulletin 106, U.S. National Museum, p. 290.)

\section{CRIBRILINA PUNCTATA Hassall, 1841.}

Plate 15, fig. 11.

1841. Lepralia punctata HASSALl, Supplement to Catalogue of Irish Zoophytes, Annals and Magazine Natural History, vol. 7, p. 368, pl. 9, fig. 7.

1889. Cribrilina punctata JELlY, A Synonymic Catalogue of the Recent Marine Bryozoa, p. 67 (synonymy).

1901. Cribrilina (Arachnopusia) punctata Neviani, Briozoi neogenici della Calabrie, Paleontographia Italica, vol. 6, p. 174 (local bibliography).

1904. Lepralia marylandica Ulrich and BAssler, Maryland Geological Survey, Miocene, p. 425, pl. 117, fig. 2.

1905. Cribrilina (Arachnopusia) punctata Neviani, Briozoi fossili di Carrubare (Calabria), Bollettino Societa Geologica Italiana, vol. 23, p. 523.

1907. Cribrilina punctata Calver, Bryozoaires, Expedition. scientifique du Travailleur et du Talisman, p. 398 (bibliography).

1912. Cribrilina punctata Osburn, The Bryozoa of the Woods Hole Region, Bulletin Bureau Fisheries, vol. 30, 1910, p. 232, pl. 24, fig. 41 (bibliography). 
This species lives mainly in the temperate and frigid regions and does not approach the Tropics. Its presence in the Miocene at Core Point, Maryland, where it was described as Lepratia marylandica by Ulrich and Bassler, is very remarkable and would indicate the existence of a rery cold boreal current.

Occurrence.-Miocene (St. Mary's formation): Core Point, Maryland (rare).

Geological distribution.-Pliocene and Quaternary of Austria-Hungary (Busk, Bell) and of Italy (Seguenza).

Habitat.-Arctic Ocean: Jean Mayen (140-180 meters), Franz Joseph Land (210 meters); Sea of Kara; North Sea; Norway; Germany; Denmark (9-25 meters). Eastern Atlantic off England in the English Channel, in the Gulf of Gascony. Mediterranean (57-77 meters) and Adriatic. Madeira Islands. Western Atlantic from the St. Laurence to the Woods Hole Region.

Plesiotype.-Cat. No. 68519, U.S.N.M. (Holotype of Lepralia marylandica Ulrich and Bassler.)

CRIBRILINA LIGULATA, new species.

Plate 15, fig. 14.

Description.-The zoarium is encrusting a Pecten. The zooecia are distinct, separated by a deep furrow, elongated, regularly elliptical; the frontal is convex and bears 15 narrow, little salient costules; the lacunae are rectangular and larger on the margin than on the median zooecial axis. The apertura is large, tranverse, semilunar but with a concare proximal border; the peristome is wide, smooth, little salient; it bears four spines which can be transformed into two or three tongues by coalescence. The ancestrula is membraniporoid.

$$
\text { Measurements.-Apertura }\left\{\begin{array} { l } 
{ h a = 0 . 1 0 \mathrm { mm } . } \\
{ l a = 0 . 1 2 \mathrm { mm } . }
\end{array} \text { Zooecia } \left\{\begin{array}{l}
L z=0.50 \mathrm{~mm} . \\
l z=0.30-0.32 \mathrm{~mm} .
\end{array}\right.\right.
$$

Affinities.-In its exterior aspect this species much resembles Lepralia manzonii Reuss, 1874, from the Tortonian of Austria-Hungary, but it differs in the presence of its liguliform spines. Normally there are only four large spines, but they become thickened easily and joined together to form two or three very salient tonguelike plates.

Occurrence.-Miocene (Calvert formation): 1 mile south of Parkers Creek, Calvert County, Maryland (very rare).

Holotype.-Cat. No. 68520, U.S.N.M.

CRIBRILINA CUSPIDATA, new species.

Plate 15, fig. 15.

Description.-The zoarium incrusts shells. The zooecia are distinct, separated by a deep furrow; large, elongate; the frontal is very convex; it is surrounded by a line of small lacunae and ornamented with 5 or 6 large lacunae in the form of a crescent. The lumen is not visible. The apertura is semilunar; the anter is very large and the poster is concare. The ovicell is hyperstomial. Between the zooecia are large triangular avicularia in the form of the head of a lance; the beak is rounded and turned toward the top.

$$
\text { Measurements.-Apertura }\left\{\begin{array} { l } 
{ h a = 0 . 1 7 \mathrm { mm } . } \\
{ 7 a = 0 . 2 0 \mathrm { mm } . }
\end{array} \quad \text { Zooecia } \left\{\begin{array}{l}
\mathrm{L} z=0.85 \mathrm{~mm} . \\
l z=0.35-0.50 \mathrm{~mm} .
\end{array}\right.\right.
$$


Affinities.-This species is very little distinct from Escharipora mucronata Smitt, 1872 , formerly dredged in the waters off Florida. It is distinguished from it in its larger and less salient mucro and in having more than three lacunae on the frontal.

The species of Smitt has not yet been rediscovered; we are ignorant, therefore, of its variations. It is hardly probable that the frontal pores would always be so constant as they are drawn on Smitt's figures, but as we are not able to judge the nature of the variations we are obliged to create a new species which will become perhaps in the future simply a variety. Only the figured specimen has been found.

Occurrence.-Miocene: Santiago, Cuba (very rare).

Holotype.-Cat. No. 68521, U.S.N.M.

\section{Genus PUELLINA Jullien, 1886.}

(For description see Bulletin 106, U. S. National Museum, p. 293.)

PUELLINA HFRRMANNI Gabb and Horn, 1862.

Plate 35 , figs. 2, 3 .

1862. Reptescharella herrmanni GABB and Horn, Monograph Fossil Polyzoa of the Secondary and Tertiary formations of North America, Journal Academy of Natural Sciences, Philadelphia, ser. 2, vol. 5, p. 137, pl. 19, fig. 20

Description.-The zoarium incrusts shells. The zooecia are large, elongate, elliptical, distinct, separated by a furrow and little convex. The costules are wide, flat, numbering from eight to ten; the lacunae are small and increase in size from the talon toward the zooecial axis. The apertura is semilunar, transverse, with a rectilinear proximal border.

$$
\text { Measurements.-Apertura }\left\{\begin{array} { l } 
{ h a = 0 . 1 0 \mathrm { mm } . } \\
{ l a = 0 . 2 0 \mathrm { mm } . }
\end{array} \quad \text { Zooecia } \left\{\begin{array}{l}
L z=0.60 \mathrm{~mm} . \\
l z=0.40 \mathrm{~mm} .
\end{array}\right.\right.
$$

Affinities.-The trace of the five oral spines as figured by Gabb and Horn is sometimes visible. In its exterior aspect and the width of the costules, this species is similar to Cribritina reniformis Ortmann, 1890, and it differs from it only in the micrometric measurements if the magnification indicated by this author is exact.

Occurrence.-Pleistocene: Santa Barbara, California (very rare).

Plesiotype.-Cat. No. 68522, U.S.N.M.

\section{PUELLINA RADIATA forma SCRIPTA Reuss, 1847.}

Plate 15 , fig. 12 ; plate 35 , fig. 1 .

1847. Cellepora scripta Reuss, Die fossilen Polyparien des Wiener Tertiärbeckens, Haidinger's Naturwissenschaftliche Abhandlungen, vol. 2 , p. 82 , pl. 9, fig. 28 .

$$
\begin{gathered}
\text { Measurements.-Apertura }\left\{\begin{array} { l } 
{ h a = 0 . 0 6 \mathrm { mm } . } \\
{ l a = 0 . 0 8 \mathrm { mm } . }
\end{array} \quad \text { Zooecia } \left\{\begin{array}{l}
L z=0.46-0.50 \mathrm{~mm} . \\
l z=0.24-0.30 \mathrm{~mm} .
\end{array}\right.\right. \\
\text { Apertura of ovicelled zooecia }\left\{\begin{array}{l}
h a=0.08 \mathrm{~mm} . \\
l a=0.10 \mathrm{~mm} .
\end{array}\right.
\end{gathered}
$$

Variations.-The variations figured by the authors are very great; they depend on the number of the costules and on their width and also on the size of the avicularia. The photographs of our specimens are quite similar to the figures of Reuss 12184-23-Bull. 125- 7 
and Manzoni; but the dimensions are generally larger than in Eocene examples; all of them corresponding to specimens dredged in the Mediterranean.

The operculum closes the ovicell. The latter is often keeled. The apertura of the ovicelled zooecia is always larger. The number of costules is never greater than 12 to 14 . There are always firo spines.

Occurrence.-Miocene (Duplin marl): Wilmington, North Carolina (rare). Miocene (Yorktown formation): 1 mile west of Fort Nonsense, Gloucester County, Virginia (rare). Pleistocene: Santa Barbara, California (rare).

Plesiotype.-Cat. Nos. 68523-68525, U.S.N.M.

PUELliNa RADIATA forma RARECOSTA Reuss, 1847.

1847. Cellepora rarecosta Reuss, Die fossilen Polyparien des Wiener Tertiärbeckens, Haidinger's Naturwissenschaftliche Abhandlungen, vol. 11, p. \$2, pl. 10, fig. 4.

This form is recognizable by the small number and prominence of the costules. It accompanies the typical form of the species at many recent and fossil localities.

Occurrence.-Pleistocene: Santa Monica, California (rare).

Plesiotypes.-Cat. No. 68526, U.S.N.M.

PUElliNa RADIATA CAROLINENSIS Gabb and Horn, 1862.

Plate 1, fig. 10.

1862. Reptescharella carolinensis GABв and Horn, Monograph Polyzoa Secondary and Tertiary formations of North America, Journal Academy Natural Sciences Philadelphia, vol. 5, p. 136, pl. 19 , fig. 18 .

1919. Puellina radiata carolinensis CANU and BASSLer, Geology and Paleontology of the West Indies, Bryozoa, Publications of the Carnegie Institution of Washington, No. 291, p. 90, pl. 1, fig. 12.

1920. Puellina radiata carolinensis CANu and Bassler, Mongraph North American Early Tertiary Bryozoa, Bulletin 106, U. S. National Museum, p. 297, pl. 41, fig. 19.

This variety is characterized by its smooth peristome, without tuberosities, and by the small canal of the avicularium, which is larger than in the type.

In reality the spines have not disappeared; on the perfect specimens they are still visible, but they never have the size and importance of those which decorate the type. The zooecia are a little larger and have 16 costules.

Occurrence.-Jacksonian of South Carolina and Alabama; Vicksburgian of Alabama. Oligocene (Anguilla formation): Southwest side of Crocus Bay Bluff, 125 feet above sea level, Anguilla, Leeward Islands (rare). Oligocene (Antigua formation): Rifle Butts, Antigua, Leeward Islands (rare).

Plesiotype-Cat. No. 68527, U.S.N.M.

PUELLINA INNOMINATA Couch, 1844 .

Plate 15, fig. 13.

1844. Lepralia innominata Couch, Cornish Fauna, pt. 3, p. 114.

1900. Cribrilina radiata, var. innominata Nevianı, Briozoi neogenici della Calabrie, Palaeontographia Italica, vol. 6, p. 171 (regional bibliography).

1905. Cribrilina radiata, var. innominata Nevianı, Briozoi fossili di Carrubare, Bollettino della Societa Geologica Italiana, vol. 23, p. 523 (sep. 21).

1909. Puellina innominata Normax, The Polyzoa of Madeira, Journal Linnean Society London, Zoology, vol. 30, p. 291 (zoological bibliography). 
Variations.--The genus Puellina as limited by Jullien, 1886, and Levinsen, 1909, does not appear to us as well characterized as it is based on the presence of papillae whose physiologic function is not very evident. The relationship of the operculum to the ovicell constitutes for us generic characters of a greater importance in the Costulae as in the other Cheilostomata. It is in this feature that the present species is quite different from Puellina (Cribrilina) radiata, for the ovicell is never closed by the operculum. According to our views of classification it will be necessary to form a new genus for this type.

On our specimen the suboral pore is often replaced by a tubercle. The costules are fine and the lacunae are arranged in concentric series.

Occurrence.--Miocene (Choctawhatchee marl): Jackson Bluff, Ocklocknee River, 25 miles southwest of Tallahassee, Florida (very rare).

Geological distribution.-Helvetian of Italy (Seguenza); Astian of Italy (Seguenza); Sicilian of Italy (Seguenza, Neviani); Quaternary of Italy (Waters, Seguenza, DeStefani).

Habitat.--England, Mediterranean, Florida.

Plesiotype.-Cat. No. 68528, U.S.N.M.

PUELLINA CRASSILABIATA, new species.

Plate 29, fig. 7.

Description.-The zoarium incrusts oysters. The zooecia are elliptical, regular, very little elongated, distinct, convex, separated by a furrow; the radial costules number 12 and taper toward the center, they are garnished with three large lumen pores and separated by four lacunae of diminishing size. The aperture is semilunar; the peristome is salient, very thin, and bears three hollow spines; a thick transverse lip bordcrs the proximal edge of the apertura, between the two small oral avicularia. The ovicell is large, globular, salient, punctured by small, scattered pores; it opens by a special orifice in front of the oral lip.

Measurements.-Apertura $\left\{\begin{array}{l}h a=0.12 \mathrm{~mm} . \\ l a=0.10 \mathrm{~mm} .\end{array} \quad\right.$ Zooecia $\left\{\begin{array}{l}L z=0.50 \mathrm{~mm} . \\ l z=0.35 \mathrm{~mm} .\end{array}\right.$

Affinities.-The apertura of the ovicelled zooecia is wider and measures $0.12 \mathrm{~mm}$. in width. The ovicell is not closed by the operculum and the passage of the eggs is protected by the wide oral mucro. This species does not belong, therefore, to the genus Puellina, since the two functions of the passage of the eggs and the escape of the larva operate in an absolutely different fashion than in Puellina radiata Moll, 1803. There are six dietellae.

In the presence of two small oral avicularia, it resembles the following species: It differs from Puellina puncturata Busk, 1859, in its elongate and nontransverse ovicell. It differs from Puellina calomorpha Reuss, 1866, in its apertura nontransverse and garnished with less than five spines. It differs from Puellina parisiensis Canu, 1917, in its thin nontransverse peristome, garnished with three spines and not with two tuberosities.

Occurrence.-Pliocene (Waccamaw marl): Waccamaw River, Horry County, South Carolina (rare).

Holotype-Cat. No. 68529, U.S.N.M. 
Plate 35, fig. 4.

Description.-The zoarium incrusts shells. The zooecin are large, elongate, elliptical, distinct, convex, separated by a deep furrow. The costules, numbering 10 to 12 , are wide, robust, convex, and bear some lumen pores; the lacunae are 4 in number and are small and orbicular. The apertura is oblique, elliptical, transverse; its proximal border bears a bifid, salient mucro. The ovicell is large, salient, convex; keeled, sunken in the distal zooecium; it opens in front of the mucro and can not be closed by the operculum.

$$
\begin{array}{cc}
\text { Measurements. - Apertura }\left\{\begin{array}{l}
h a=0.10 \mathrm{~mm} . \\
l a=0.18 \mathrm{~mm} .
\end{array}\right. & \text { Zooecia }\left\{\begin{array}{l}
L z=0.40-0.46 \mathrm{~mm} . \\
l z=0.34-0.36 \mathrm{~mm} .
\end{array}\right. \\
\text { Apertura of ovicelled zooecium }\left\{\begin{array}{l}
h a=0.15 \mathrm{~mm} . \\
l a=0.22 \mathrm{~mm} .
\end{array}\right.
\end{array}
$$

Affinities.-The genus Afetracolposa was discovered in the American Eocene formations, where it is widely represented by vigorous, bilamellar species. Its presence in the zone of the Pacific seems to indicate a great geographic extension in geologic time. Its presence even in the recent seas is quite probable. We should recall that the mucro of the Cheilostomatous zooecia is an apparatus of protection for the passage of the eggs.

Occurrence.-Pleistocene: Santa Barbara, California (rare).

Holotype.-Cat. No. 68530 , U.S.N.M.

\section{Family HIPPOTHOIDAE Levinsen, 1909.}

Genus HIPPOTHOA (Lamouroux, 1821) Hincks, 1880.

(For description, see Bulletin 106, U. S. National Museum, p. 326.)

HIPPOTHOA HYALINA Linnaeus, 1768.

Plate 35, figs. 5-8.

1768. Cellepora hyalina LinNaEus, Systema Naturae, ed. 12, p. 1286.

1859. Lepralia hyalina Busk, Monograph Fossil Polyzoa of the Crag, Publications Paleontographical Society, London, vol. 14, p. 52, pl. 5, fig. 1.

1880. Schizoporella hyalina Hincks, British Marine Polyzoa, p. 271, pl. 18, figs. 8-10.

1889. Schizoporella hyalina JeLry, A synonymic Catalogue Recent Marine Bryozoa, p. 227 (bibliography).

1894. Schizoporella hyalina Levinsen, Mosdyr. Zoologica Danica (Danske Dyr), Hefte 9, p. 66, pl. 5, figs. 45-47.

1896. Celleporella hyalina NordgaArd, Systemetisk fortegnelse over de i Norge hidtil observer de, arter af marine polyzoa, I, Cheilostomata, Bergen's Musuem Aarbog for 1894-95, No. 2, p. 23.

1900. Hippothoa hyalina Waters, Bryozos from Franz-Josef Land, Journal Linnean Society London, vol. 18 , p. 70 , pl. 8, figs. 16-18.

1900. Celleporella hyalina NordgaArd, Den Norske Nordnays-Expedition, Zoology no., vol. 17, p. 10.

1902. Schizoporella hyalina Calvet, Bryozoaires marins de la region de Cette, Travaux de l'Institut Zoologie, Université Montpel lier, ser. 2, Memoire XI, p. 44. 
1903. Hippothoa hyalina Norman, Notes on the Natural History of East Finnmark, Annals Magazine Natural History, ser. 7, vol. 12, Polyzoa, p. 108.

1904. Schizoporella hyalina CALvet, Bryozoen, Ergebnisse der Hamberger Magalhaensiche Sammelreise, p. 25 .

1905. Hippothoa hyalina NoRdGaARD, Hydrographical and biological investigations in Norwegian fiords, Bergen Museum, p. 165.

1906. Hippothoa hyalina WATERS, Bryozoa from Chatham Island and d'Urville Island, New Zealand. Annals Magazine Natural History, ser. 7, vol. 17, p. 19.

1906. Celleporella hyalina Nordgand, Die Bryozoen des westlichen Norwegens, Bergen Musuem Meeres-fauna von Bergen, p. 87.

1907. Schizoporella hyalina Calvet, Bryozoaires, Expédition scientifiques Travailleur et Talisman, p. 415.

1907. Hippothoa hyalina NordgaArd, Campagne arctique de 1907 de Duc D'Orleans. Bryozoaires, p. 9.

1908. Schizoporella hyalina RoBertson, Incrusting Cheilostomatous Bryozoa of the West Coast of North America, University of California Publications, Zoology, vol. 4, No. 5, p. 289, pl. 19, fig. 43-45 (not synonomy).

1911. Schizoporella hyalina Gứrin-Ganivet, Contributions a l'étude des Bryozoaires des cotes Armoricaines, II, Bryozoaires provenant de la rade de Brest, Travaux du Laboratoire de Zoologie de Concarneau, vol. 3, p. 2.

1912. Hippothoa hyalina OsBunn, The Bryozoa of the Woods Hole Region, Bulletin Bureau Fisheries, vol. 30, 1910, p. 235, pl. 24, fig. 47 (American bibliography).

1912. Hippothoa hyalina NordgaARD, Revision av norske Bryozoer, Kgl. norske Videnskabers Selskabs Skriften, 1911, no. 3, p. 20.

1912. Schizoporella hyalina Gứrin-Ganivet, Contributions a l'étude des Bryozoaires des cotes Armoricaines, III, Bryozoaires de la region de Concarneau, Travaux scientifiques du Laboratoire de Zoologie de Concarneau, vol. 4, p. 14.

1912. Schizoporclla hyalina Barroso, Briozoos de la estacion maritima de Santander, Trabajos del Museo de ciencias naturales, no. 5, p. 16.

1913. Schizoporella hyalina GứRin-GanIVET, Bryozoaires de la Mission arctique, Société d'oceanographique de Golfe de Gascogne, fasc. 7, p. 26.

A number of varielies of this widespread recent and fossil species have been described. Their present day arrangement is as follows:

Variety bougainvillei D'Orbigny, 1839, is a distinct species.

Variety discreta Busk, 1852, is Diazeuxia reticulans Jullien, 1888.

Variety muricata Busk, 1852, is Diazeuxia kerguelenensis Jullien, 1888.

Variety cornuta Hincks, 1880, from Australia belongs to another genus.

Variety cornuta Hincks, 1880, from Natal is another species.

Variety from Santa Cruz (Hincks, 1880) is a distinct species.

Variety from Australia (MacGillivray) is a distinct species.

Measurements.-Ordinary zooecia: Apertura $\left\{\begin{array}{l}h a=0.10 \mathrm{~mm} \text {. } \\ l a=0.10 \mathrm{~mm} \text {. }\end{array}\right.$

$$
\text { Zooecia }\left\{\begin{aligned}
L z & =0.40 \mathrm{~mm} \\
l z & =0.14 \mathrm{~mm}
\end{aligned}\right.
$$

Ovicellcd zooecia: Apertura $\left\{\begin{array}{r}h a=0.06 \mathrm{~mm} . \\ l a=0.08 \mathrm{~mm} .\end{array}\right.$

Zooecia $\left\{\begin{aligned} L z & =0.40 \mathrm{~mm} \text {. } \\ l z & =0.20 \mathrm{~mm} \text {. }\end{aligned}\right.$

Male zooecia:

Apertura $\left\{\begin{array}{r}h a=0.04 \mathrm{~mm} . \\ l a=0.04 \mathrm{~mm} .\end{array}\right.$

Zooecia $\left\{\begin{aligned} L z & =0.24 \mathrm{~mm} . \\ l z & =0.12 \mathrm{~mm} .\end{aligned}\right.$ 
Variations.-The ordinary zooecia and the ovicelled zooecia develop on the same plane. The male zooecia havc no fixed placc and lap over very often on the others; when they are numerous and erect they give to the zoarium an aspect of Cellepora, which explains its generic name of Celleporella given by certain authors. The presence of three sorts of zooecia renders this species easy to determine; however, it is not rare to find zoaria uniquely formed of ordinary zooecia, in which case the determination is more difficult.

This specics generally lives on algae and the depths indicated by the dredgings gives only information of secondary importance when the substratum is unknown. This is a species of the cold boreal zone and it never goes farther south than the forty-second parallel. We have found in the Plioccne of Monroe County, Florida, a mediocre specimen of a very closely related species. We will only give it a name if we have the chance to find better specimens. Generally its micrometric measurements are more reduced.

Measurements.-Ordinary zooecia: Apertura $\left\{\begin{array}{l}h a=0.08 \mathrm{~mm} . \\ l a=0.08 \mathrm{~mm} .\end{array}\right.$

$$
\begin{aligned}
& \text { Male zooecia: } \text { Zooecia }\left\{\begin{array}{l}
L z=0.30 \mathrm{~mm} . \\
l z=0.20 \mathrm{~mm} .
\end{array}\right. \\
& \text { Apertura }\left\{\begin{array}{l}
h a=0.04 \mathrm{~mm} . \\
l a=0.04 \mathrm{~mm} .
\end{array}\right. \\
& \text { Zooecia }\left\{\begin{array}{l}
L z=0.16-0.20 \mathrm{~mm} . \\
l z=0.12 \mathrm{~mm} .
\end{array}\right.
\end{aligned}
$$

Occurrence.-Pleistocene: Santa Barbara (rare); Dead Man's Island off San Pedro (rare); Los Angeles and Santa Monica, California (rare).

Geological distribution.-Plaisancian of England (Busk).

Habitat.-Arctic Ocean: Iceland (162 meters); Franz Joseph Land (12-150 meters); Barents Sea (106 meters); Jean Mayen; Spitzberg; Greenland (4-48 meters); Sea of Kara; Nova Zembla (3-32 meters). North Sea: Norway; Germany; Denmark (8-27 meters). Enstern Atlantic: Off England, English Channel, Gulf of Gascony. Western Atlantic: Labrador, Woods Hole region. Eastern Pacific: Alaska, California.

Plesiotypes.-Cat. Nos. 68531, 68532, U.S.N.M.

HIPPOTHOA HYALINA, var. RUGOSA, new variety.

Plate 35 , fig. 9.

Only the figured specimen has been found; it perhaps forms a distinct species. The large transverse wrinkles of the frontal are very characteristic. The species differ from Hippothoa bougainvillei D'Orbigny, 1839, in the absence of two largo frontal beaks.

Occurrence.-Pleistocenc: Santa Barbara, California (very rare),

Holotype.-Cat. No. 68533,U.S.N.M. 
Genus TRYPOSTEGA Levinsen, 1909.

(For description, see Bulletin 106, U. S. National Mfuseum, p. 327.)

TRYPOSTEga Venusta Norman, 1864.

Plate 16, fig. 1.

1920. Trypostega venusta CANu and Bassler, Monograph North American Early Tertiary Bryozoa, Bulletin 106, U. S. National Museum, p. 330 p. 85, figs. 15, 16 (bibliography and description.).

The earliest appearance of this recent species in the Tertiary rocks of America is in the Vicksburgian of Mississippi and Alabama, where it is quite rare. "The Miocene deposits of North Carolina have furnished a very few specimens which differ in no appreciable respect from the typical form.

Occurrence.-Miocene: (Duplin marl) Wilmington, North Carolina (very rare). Miocene (Yorktown formation): 1 mile west of Fort Nonsense, Gloucester County, Virginia (rare).

Geological distribution.-Miocene of Australia (Waters); Vicksburgian of the United States (Canu and Bassler).

Habitat.-Eastern Atlantic: English Channel, Madeira, Azores, Cape Verde Islands. Pacific: Lifu, Loyalty Island, Torres Straits. China Sea, Tozar Bank (43 meters). Indian Ocean: Saya de Malha (46-202 meters); Mauritius; Wasin, British East Africa (162 meters).

Plesiotype.-Cat. No. 68534, U.S.N.M.

Family ESCHARELLIDAE, Levinsen, 1909.

Group, SCHIZOPORELLAE Canu and Bassler, 1917.

Genus SCHIZOPORELLA Hincks, 1880.

As employed in our Monograph on the North American Early Tertiary Bryozoa, Schizoporella is retained for species showing no ovicell and which therefore can not be grouped in their proper place in the Schizoporellae.

\section{SCHIZOPORELLA MAGNIPOROSA, new species.}

Plate 45, figs. 1, 2.

Description.-The zoarium incrusts sponges. The zooecia are distinct, separated by a furrow, irregularly hexagonal; the frontal is little convex, porous, perforated by large, scattered tremopores. The apertura is formed of a semicircular anter and of a wide rounded rimule. Near the apertura there are one or two small setiform avicularia.

$$
\text { Measurements. Apertura }\left\{\begin{array} { l } 
{ \hbar a = 0 . 1 8 \mathrm { mm } . } \\
{ l a = 0 . 1 2 \mathrm { mm } . }
\end{array} \text { Zooecia } \left\{\begin{array}{l}
L z=0.65 \mathrm{~mm} . \\
l z=0.50-0.55 \mathrm{~mm} .
\end{array}\right.\right.
$$

Affinities.-Only the figured specimens have been found, and as they are incomplete and bear no ovicell it is impossible as yet to classify the species generically. The presence of small, oral, vibraculoid avicularia seems to indicate that this species belongs in reality to the genus Mastigophora.

The ancestrular zooecia are much smaller. The ancestrula bears a large elliptical aperture occupying almost all its frontal. 
This species differs from Mastigophora porosa Smitt, 1872, in its larger tremopores and in the smaller apertura.

Occurrence.-Pløistocene: Mount Hope, Panama Canal Zone (rare).

Cotypes.-Cat. No. 68535, U.S.N.M.

SCHIZOPORELla LATISiNuata Ulrich and Bassler, 1904.

Plate 18, fig. 4.

1901. Schizoporella latisinuata Ulrich and Bassler, Bryozoa: Maryland Gcological Survey, Miocene, p. 421, pl. 119, fig. 2-4.

Description.-Zoarium forming thin parasitic expansions over foreign bodies. Zooecia sharply distinguished from each other, rather irregularly arranged, often subrhomboidal, four or five in $2 \mathrm{~mm}$.; surface coarsely punctate. Orifice terminal, directed somewhat obliquely forward, subcircular, broadly sinuate proximally, enclosed by a slightly elevated peristome. Avicularia rather small, prominent, one on either or both sides of the orifice, rarely wanting, situated close to the peristome; apparently not divided by a septum. Ovicells not observed. (Ulrich and Bassler.)

$$
\begin{gathered}
\text { Measurements.-Apertura }\left\{\begin{array} { l } 
{ h a = 0 . 1 0 \mathrm { mm } . } \\
{ l a = 0 . 1 0 \mathrm { mm } . }
\end{array} \text { Short zooecia } \left\{\begin{array}{l}
L z=0.40-0.45 \mathrm{~mm} \text {. } \\
l z=0.40 \mathrm{~mm} .
\end{array}\right.\right. \\
\text { Long zooecia }\left\{\begin{array}{l}
L z=0.60 \mathrm{~mm} . \\
l z=0.30 \mathrm{~mm} .
\end{array}\right.
\end{gathered}
$$

Affinities.-The aperture is as high as wide and buried at the base of a small peristome. The avicularium is infraoral; its beak is directed toward the median axis of the zooecia. The species has the exterior aspect of Stylopoma isabelleana Smitt, 1872, but differs in its larger a vicularium and in the wider rimule of the aperture. We have not discovered the ovicell and are therefore not able to classify the species generically.

Occurrence.-Miocene (Choptank formation): Jones Wharf, Maryland (rare).

Holotype.-Cat. No. 68536, U.S.N.M.

\section{SCHIzOPORELLA CUMULATA Ulrich and Bassler, 1904.}

Plate 16, fig. 10.

1904. Schizoporella cumulata ULRIch and BAssler, Maryland Gcological Survey Miocene, p. 422, pl. 17 , fig. 7.

The original description is as follows:

Zoarium probably massive, composed of layers of zooecia arranged very irregilarly and piled upon each other much as in Cellepora. Zooecia of irregular shapes, often broad ovate, convex, large, $0.5 \mathrm{~mm}$. or $0.6 \mathrm{~mm}$. in length and nearly $0.5 \mathrm{~mm}$. in width. Orifice rounded, slightly transverse, the proximal side broadly notched; peristome somewhat elevated, thick. Surface distinctly and abundantly punctate. Avicularia rather variable in size, situated on only one or on both sides of the orifice, the acuminate end of the aperture elevated and turned outwardly. Ovicells not observed.

The general aspect of this bryozoan is decidedly like that of a Cellepora, and we can scarcely doubt that it is related to some of the species still referred to that genus. We have placed it under Schizoporella, not because we are satisfied that it really belongs there, but for the reason that its zooecial orifices and the avicularia are almost exactly as in other species (e. g., S. subquadrata and S. latisinuata) that we have referred to this genus. From these it is distinguished principally by the extremely irregular arrangement and piling up of the zooecia. 
In the absence of ovicells on the few specimens found we are unable to classify this species in the correct division of the Schizoporellae.

Occurrence.-Miocene (Choptank formation): Jones Wharf, Maryland (very rare). Miocene (St. Mary's formation): Cove Point, Maryland (rare).

Holotype.-Cat. No. 68537, U.S.N.M.

\section{Genus ARTHROPOMA Levinsen, 1909.}

(For description see Bulletin 106, U. S. National Museum, p. 351.)

ARTHROPOMA CORNUTA, new specles.

Plate 16, fig. 3.

Description.-The zoarium incrusts shells. The zooecia are distinct, separated by a deep furrow, little elongate, swollen; the frontal is convex covered by large tremopores and ornamented by a small salient median protuberance. The apertura is semilunar, transverse and bears on its rectillinear, proximal border a very small sinus.

$$
\text { Measurements. -Apertura }\left\{\begin{array} { l } 
{ h a = 0 . 1 0 \mathrm { mm } . } \\
{ l a = 0 . 1 4 \mathrm { mm } . }
\end{array} \quad \text { Zooecia } \left\{\begin{array}{l}
L z=0.70 \mathrm{~mm} . \\
l z=0.50 \mathrm{~mm} .
\end{array}\right.\right.
$$

Affinities. - The form of the rimule leaves no doubt regarding the arrangement of this species in the genus Arthropoma. It differs from the genotype Arthropoma ceciti Audouin, 1826, only in the presence of the small frontal protuberance.

Occurrence.--Miocene (Choctawhatchee marl) : Jackson Bluff, Ocklocknee River, 25 miles southwest of Tallahassee, Florida (rare).

Holotype.-Cat. No. 68538, U.S.N.M.

\section{Genus DAKARIA Jullien, 1903.}

(For description see Bulletin 106, U. S. National Museum, p. 359.)

DAKARIA CHEVREUXI Jullien, 1903.

Plate 45 , fig. 7.

1903. Dakaria chevreuxi Jullien, Bryozoaires provenant des campagnes de l'Hirondelle (1886-1888), Résultats des Campagnes scientifiques du Prince de Monaco, fasc. 23, p. 90, pl. 9, fig. 6.

We have found only a single specimen which is incrusting a coral, but in spite of its mediocre preservation we believe our determination to be exact. Each tremopore is surrounded by a small salient peristome. The oral avicularia are not constant. The proximal lip of the aperture ends in two condyles.

Occurrence.-Pleistocene: Mount Hope, Panama Canal Zone (rare).

Habitat.-Shores of Graciosa Isle, Azores.

Plesiotype.-Cat. No. 68539, U.S.N.M.

\section{DAKARIA GRANDIS, new species.}

Plate 20, fig. 16.

Description.-The zoarium incrusts shells. The zooecia are large, distinct, elongated, elliptical, separated by a deep furrow; the frontal is convex, ornamented with numerous small tremopores and minute granulations. The apertura is orbicular or somewhat transverse; two strong condyles placed in the lower third limit the broad rounded sinus; the peristome is entire, thin, salient, finally denticulated. 
Measurements.-Apertura $\left\{\begin{array}{l}h a=0.25 \mathrm{~mm} . \\ l a=0.25 \mathrm{~mm} .\end{array} \quad\right.$ Zooecia $\left\{\begin{array}{l}L z=0.95 \mathrm{~mm} . \\ l z=0.55-0.60 \mathrm{~mm} .\end{array}\right.$

Affinities.- This species is rery close to the genotype Dakaria chevreuxi Jullien, 1904 , but it differs in the absence of salient threads between the zooecia, which are also more elongated and especially in the larger micrometric dimensions ( $L z=0.75$ min.).

Occurrence.-Wiocene (Yorktown formation): Yorktown, Virginia (rare).

Holotype-Cat. No. 68540, U.S.N.M.

\section{DAKARIA TORQUATA D’Orbigny, 1839.}

Plate 12, figs. 8, 9 .

1839. Escharina torquata D'Orbigny, Voyage dans l'Amerique-Mcridionale, vol. 5, pt. 4, Zoophytes, p. 11, pl. 4, figs. 1-4.

1845. Escharina tumidula Lonsdale, Report on the Corals from the Tertiary formations of North America, Quartcrly Journal Geological Society, London, vol. 1, p. 502. (Not Flustra torquata Lamouroux, 1827, Encyclopedie Méthodique, vol. 14, p. 407.)

1851. Cellepora subtorquata D'Orbigsy, Paleontologie francaise, Terrain Cretace, vol. 5, Bryozoaircs, p. 399.

1905. Cellepora -subtorquata Waters, Notes on some Recent Bryozoa in D'Orbigny's Collection, Annals Magazine Natural History, ser. 7, vol. 15 , p. 6.

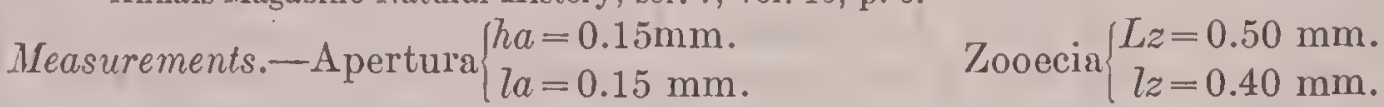

Affinities.-In 1851 D'Orbigny having noted that his Escharina torquata was not Flustra torquata Lamouroux, 1827, changed its name. Examining the type of the species Waters, 1905, wrote "D'Orbigny's figure is good, but the lateral wings by the side of the sinus project more than is figured." In 1884 Hincks believed he had found D'Orbigny's species in the Pacific off California, but his good figure would not really permit this identification; the primitive name of Schizoporella dawsoni Hincks, 1883, applied by him to this species must therefore be preserved. The description and figure of Lonsdale leaves no doubt; we have indeed rediscorered his Escharina tumidula and in the same locality, namely, Petersburg, Virginia. D'Orbigny's figure of the species is much better than that of Lonsdale. This species differs from Schizobrachiella sanguinea Norman, 1868, and Dakaria chevreuxi Jullien, 1903, in a larger rimule and in the smaller micrometric dimensions. It incrusts shells and has no dietellae.

Occurrence.-Miocene (Yorktown formation): 3 miles southwest of Petersburg (rare) and 2 miles southwest of Cash, Gloucester County, Virginia (rare).

Habitat.-Atlantic: Bay of Rio de Janeiro, Brazil.

Plesiotypes.-Cat. No. 68541, U.S.N.M.

\section{DAKaria PARVIPOROSA, new species.}

Plate 30, fig. 1.

Description.-The zoarium inclusts oysters. The zooecia are distinct, long, separated by a furrow; the frontal is convex and formed by a tremocyst with rery small pores. The apertura is large, orbicular with a very wide rimule of little depth.

$$
\text { Measurements.-Apertura }\left\{\begin{array} { l } 
{ h a = 0 . 1 6 \mathrm { mm } . } \\
{ l a = 0 . 1 6 \mathrm { mm } . }
\end{array} \quad \text { Zooecia } \left\{\begin{array}{l}
L_{z}=0.50-0.60 \mathrm{~mm} . \\
l z=0.36-0.40 \mathrm{~mm} .
\end{array}\right.\right.
$$


Affinities.--This species differs from Schizoporella insculpta Hincks, 1883, only in the absence of the oral armature of the rimule and in the absence of a furrow near the apertura. The figured specimen is the only one that has been found; it lacks the ovicell and we can not make any close comparisons.

Occurrence.-Pliocene (Waccamaw marl): Waccamaw River, Horry County, South Carolina (very rare).

Holotype.-Cat. No. 68542, U.S.N.M.

Genus LACERNA Jullien, 1888.

(For description see Bulletin 106, U. S. National Museum, p. 345.)

LACERNA MUCRONATA Smitt, 1872.

Plate 16, fig. 2.

1872. Hippothoa mucroneta Ssrrt , Floridan Bryozoa, pt. 2, Kongl. Svenska Vetenskaps-Akademiens Handlingar, vol. 11, no. 4, p. 45, pl. 8, fig. 169.

Our determination of the American specimens is exact. We can observe on our specimens the same costules, the six spines, the wide rimule and the complete peristome indicated on Smitt's figure.

Occurrence.-Miocene (Duplin inarl): Wilmington, North Carolina (very rare).

Habitat.-Florida (47 meters).

Plesiotype.--Cat. No. 68543, U.S.N.M.

Genus STEPHANOSELLA Canu and Bassler, 1917.

(For description see Bulletin 106, U. S. National Museum, p. 343.)

STEPHANOSElLA BIAPERTA Michelin, 1842.

Plate 16, figs. 4-9.

Zoological bibliography.

1889. Schizoporella biaperta JeLly, Synonymic Catalogue Recent Marine Bryozoa, p. 223 (bibliography).

1901. Schizoporella biaperta Whrteaves, Catalogue of the Marine Invertebrata of Eastern Canada, Geological Survey of Canada, Bull. no. 722, p. 100.

1907. Schizoporella biaperta Calvet, Expedition scientifique Travailleur et Talisman, p. 419 (bibliography).

1908. Schizoporella biaperta Roвertson, The Incrusting Chilostomatous Bryozoa of the West Coast of North America, University of California Publications, Zoology, vol. 4, p. 287, pl. 19, fig. 41 .

1909. Schizoporella biaperta Norman, The Polyzoa of Maderia and neighboring Islands, Journal Linnean Society London, Zoology, vol. 30, p. 303, pl. 40, figs. 3, 4 (var. divergens).

1912. Schizoporella biaperta OsBurs, The Bryozoa of the Woods Hole Region, Bulletin Bureau Fisheries, vol. 30, p. 237, pl. 29, fig. 49.

1912. Schizoporella biaperta Guerin-Ganivet, Contributions a l'étude des Bryozoaires des cotes Armoricaines, III, Bryozoaires de la region de Concarneau, Travaux scientifiques du Laboratoire de Zoologie de Concarneau, vol. 4, p. 13.

1912. Schizoporella biaperta NordgaARD, Campagne arctique de 1907, de Duc d'Orleans, Bryozoaires p. 40 .

1912. Schizoporella biaperta Barroso, Briozoos de la Estacion de Biologia maritima de Santander, Trabajos del Museo de Ciencias naturales, no. 5, p. 40.

1914. Schizoporella biaperta Osburn, The Bryozoa of the Tortugas Islands, Publication Carnegie Institution of Washington, no. 182, p. 207. 
Paleontological bibliography.

1842. Eschara biaperta Michelin, Iconographie zoophytologique, p. 330, pl. 79, fig. 3.

1859. Lepralia biaperta Busk, Monograph Fossil Polyzoa of the Crag, Publications Paleontographical Society, London, vol. 14, p. 47, pl. 7, fig. 5 .

1862. Reptcscharcllina cornuta GABB and Horn, Monograph Polyzoa Sccondary and Tertiary formations of North America, Journal Academy Natural Sciences of Philadelphia, ser. 2, vol. 5 , p. 147 , pl. 20 , fig. 31 .

1875. Lepralia biaperta Manzoni, I Briozoi del pliocene antico di Castrocaro, p. 21, pl. 2, fig. 28.

1878. Lepralia biaperta WATEns, Bryozoa (Polyzoa) from the Pliocenc of Bruccoli (Sicily), Transactions Manchester Geological Society, vol. 14, p. 13, fig. 8.

1879. Lepralia biaperta Seguenza, Le formazioni terziaric nella Provincia di Reggio (Calabria), Reale Accademia dei Lincei, Memorie della Classe di Scienze Fisiche, Matcmatiche e Naturali, scr. 3, vol. 6, pp. 81, 202.

1887. Lepralia biaperta Waters, On Tcrtiary Bryozoa from New Zealand, Quarterly Journal Geological Society, London, vol. 43, p. 65.

1895. Schizoporella biaperta MacGuluvray, Monograph Tcrtiary Polyzoa of Victoria, Transactions Royal Society of Victoria, vol. 4, p. 85, pl. 11, fig. 20.

1895. Schizoporella biaperta Neviani, Briozoi fossili della Farnesina c Monte Mario presso Roma, Paleontographica Italica, vol. 1, p. 110 (sep. 34).

1896. Schizoporella biaperta Neviani, Briozoi Postpliocenici di Spilinga (Calabria), Atti Accademia Gioenia di Scienze Naturali in Catania, ser. 4, vol. 9, p. 33, fig. 16.

1896-1898. Schizoporella biaperta Neviani, Briozoi ncozoici di alcune localita d'Italia, Bollettino dclla Societa Romana per gli Studi Zoologica, pt. 3, p. 111 (sep. 10); pt. 5, pp. 4, 7.

1897. Schizoporella biaperta Neviani, Corallari e Briozoi neogenici di Sardigna, Bolletino della Società Gcologica Italiana, vol. 15, p. 588 (sep. 20).

1901. Schizoporella biaperta Nevisni, Briozoi neogenici della Calabric Paleontographia Italiana, vol. 6, p. 195 (scp. 8) (regional bibliography).

1905. Schizoporclla biaperta Neviani, Briozoi fossili di Carrubarc (Calabria), Bollettino Societa Geologica Italiana, vol. 23, p. 532 (sep. 30).

1919. Stephanosella biaperta CANU and Bassler, Geology and Paleontology of the West Indies, Paleontology, Publications Carnegie Institution of Washington, no. 292, p. 91, pt. 1, figs. 16-18.

1920. Stephanosella biaperta CAnU and Bassler, North American Early Tertiary Bryozoa, Bull. 106, U. S. National Museum, p. 344.

$$
\text { Measurements.-Apertura }\left\{\begin{array} { l } 
{ h a = 0 . 1 0 \mathrm { mm } . } \\
{ l a = 0 . 1 0 - 0 . 1 2 \mathrm { mm } . }
\end{array} \quad \text { Zooecia } \left\{\begin{array}{l}
L_{z}=0.40 \mathrm{~mm} . \\
l z=0.30 \mathrm{~mm} .
\end{array}\right.\right.
$$

Variations.-This species is quite variable in its external aspcets and in its micrometric measurements. The ovicelled zooecia are oriented in all directions; this absolutely inexplicable phenomenon charactcrizes this species and contributes much to making it often absolutely unrecognizable.

We give figures of specimens chosen from different formations which will suffice to enable the rcader to avoid errors of determination. The specimens with large tremopores should possibly be separated as a variety, in which case Gabb and Horn's name of cornuta would be available. 'This is one of the few species common to botlı the Atlantic and Pacific.

Occurrence.-Miocene (Bowden marl): Bowden, Jamaica (rare). Miocene (Duplin marl): Wilmington, North Carolina (rare). Pleistocene: Los Angeles (rare). Dead Mans Island off San Pedro (very rare), and Santa Monica, California (rare); Vero, Florida (rare).

Geological distribution.-Miocene of Australia (MacGillivray); Helvetian of France (Michelin), of Sardinia (Neviani), and Italy (Seguenza); Zanclean of Italy (Seguenza, DeStefani); Sahelian of Oran (Collection Canu); Plaisancian of England 
(Busk), of Italy (Manzoni); Sicilian of Italy (Neviani, Waters); Quaternary of Italy (Neviani); Pliocene of New Zealand (Waters).

Habitat.-Arctic Ocean: Kara Sea, Spitzberg, Greenland, Jean Mayen (160-180 meters), Alaska (circumpolar species). Eastern Atlantic: North Sea, English Channel, England, Brittany, Gulf of Gascony (166 meters), Spain, Madeira (48 meters), Azores (130 meters). Western $\Lambda$ tlantic: Woods Hole region (5-32 meters), Florida (14-97 meters). Eastern Pacific: Queen Charlotte Islands, California (213 meters). Western Pacific: Japan. Southern Pacific: Australia, New Zealand. Mediterranean: Nice, Naples, Corse (22-110 meters), Ajaccio (280 meters), Bonifacio (55-77 neters), Algeria (121 meters), and north of Morocco (370 meters).

Plesiotypes.-Cat. Nos. 68544-68546, U.S.N.M.

\section{Genus STYLOPOMA Levinsen, 1909.}

1909. Stylopoma Levinsen, Morphological and Systematic Studies on the Cheilostomatous Bryozoa, pl. 18 (name only).

1920. Stylopoma CANU and Basster, Monograph North American Early Tertiary Bryozoa, Bull. 106, U. S. National Museum, p. 359.

The ovicell is hyperstomial; it covers the apertura and the avicularia entirely. The frontal is a tremocyst. The apertura is provided with a small linear rimule.

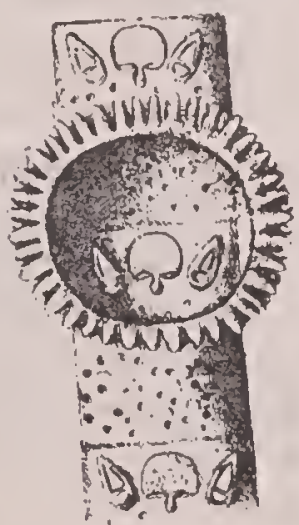

A

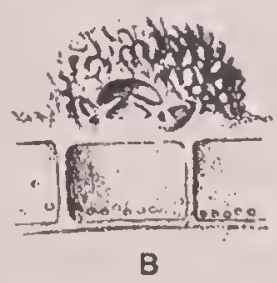

B
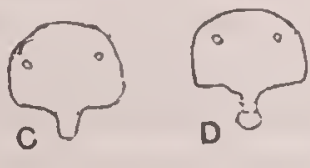
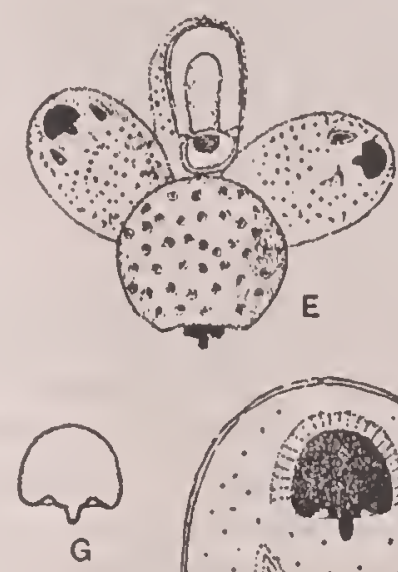

Fra. 15.-Genus S tylopoma Levinsen, 1909.

A.-H. Stylopoma spongites Pallas, 1766. A. Zooecium, $\times 40$, with an ovicell, the frontal half of which is cut away. B. drawing, $\times 6$, showing an ovicell from the proximal end and distal walls with septulae. C, D. Opercula, $\times 100$. (A-D, after Levinsen, 1909.) E. Zooecia, $\times 25$, showing ovicell and vicarious avicularium. F. A zooecium, $\times 85$, showing the oral denticles from the front. G. Operculum, $\times$ 85. (E-G, after Waters, 1918.) Recent.

Genotype.-Stylopoma (Eschara) spongites Pallas, 1766. Range: Miocene-

Levinsen proposed this genus for Eschara spongites and Schizoporella longirostris Hincks, 1886, but having recognized that the size of the rimule upon which he based it is not a generic character, he suppressed the name. We reestablish the genus, basing it upon the function of the passage of the eggs, which operates in a very different manner from that in Schizopodrella, where the species would otherwise have been placed. The great development of the ovicell above the aperture assures this function. Schizoporella longirostris Hincks, 1886, has the same type of orifice, but not being provided with this ovicell it must be classified in Schizopodrella. 
1766. Eschara spongites PaLLAs, Elenchus Zoophytorum, p. 45.

1797. Cellepora spongites Esper, Die Pflanzenthiere, p. 242, pl. 111.

1803. Eschara spongitcs Molı, Die Seerinde aus der Ordnung der Pflanzenthiere, Wien, pl., figs. $3 A$, $3 \mathrm{~B}$.

1821. Cellepora spongites Lamouroux, Exposition methodique des genres de Bolypiers, p.41, fig. 3.

1845. Ccllepora informata LoNsDALE, Report on the Corals from the Tertiary formations of North America, Quarterly Journal Geological Society London, vol. 1, p. 505 (text fig.).

1857. Reptocelleporaria informata Tuoney and Holses, Pliocene Fossils of South Carolina, p. 15, pl. 4, figs. 11, 12.

1862. Reptocelleporaria informata GAB and Horn, Monograph Polyzoa Secondary and Tcrtiary formations of North America, Journal Academy Natural Sciences of Philadelphia, scr. 2, vol. 5, p. 132.

1872. Hippothoa spongites Smurt, Floridan Bryozoa, pt. 2, Kongl. Svenska Vetenskaps-Akademiens Handlingar, vol. 11, no. 4, p. 42, pl. 8, figs. 161-163.

1889. Schizoporella spongites JELLY, Synonymic Catalogue of Marine Bryozoa, p. 234 (bibliography).

1904. Schizoporella informata Ulrich and Basster, Bryozoa, Maryland Geological Survey, Miocene, p. 419 , pl. 114, figs. 6-10.

1909. Schizoporella spongites Levinsen, Morphological and Systematic Studies on the Cheilostomatous Bryozoa, p. 323, pl. 18, figs. 3, 4 (Stylopoma spongites on plate).

1914. Schizoporella spongites OsBurn, The Bryozoa of the Tortugas Islands, Publication Carnegie Institution of Washington, no. 182, p. 207.

1919. Stylopoma spongites CANU and Bassler, Geology and Paleontology of the West Indies, Bryozoa, Publications of the Carnegie Institution of Washington, no. 291, p. 91, pl. 1, fig .13.

$$
\text { Measurements. - Apertura }\left\{\begin{array} { l } 
{ h a = 0 . 1 4 \mathrm { mm } . } \\
{ l a = 0 . 1 0 \mathrm { mm } . }
\end{array} \quad \text { Zooecia } \left\{\begin{array}{l}
L z=0.50 \mathrm{~mm} . \\
l z=0.36 \mathrm{~mm} .
\end{array}\right.\right.
$$

Historical.-The bibliography published by Miss Jelly in 1889 was determined by Smitt, 1872, and appears inexact to us. This species is absolutely restricted to the Gulf of Mexico. By what chance could it have fallen into the hands of the eighteenth century authors? Certainly the species which they figured is the Schizopodrella unicornis Johnston, 1847, or Schizopodrella longirostris Hincks, 1886, which also present large multilamellar and spongy zoaria. We believe that the name of Lonsdale, 1845 , would be preferable.

Variations.-The ovicell of this species is quite remarkable; a superb study was made by Levinsen, 1909. An ordinary polypide forms the zooecium. It degenerates and is replaced by a female polypide which forms the ovicell above the distal zooecium and the apertura. It is deprived of tentacles which could scarcely issue from the special orifice of the ovicell. The passage of the eggs is thus assured in a positive fashion. The escape of the larvae operates as in the species of the genus Schizopodrella by the rupture of the membrane which closes the ovicell.

The variations of this species are extraordinary. The avicularium is present or absent, large or small. The zooecia are long or short, narrow or swollen, even transverse. Frequently they are oriented in all directions.

The zoaria contain a large number of lamellae piled one on another; their dimensions reach a length of 5 centimeters. The larvae are fastened on shells, on other bryozoa, and more frequently on the fronds of small algae. 
Occurrence.-Miocene (Yorktown formation): Yorktown and 3 miles southwest of Petersburg, Virginia (common). Miocene (Duplin marl): Wilmington, and other localities in North Carolina (common); Darlington, Muldrows Mills, 5 miles south of Maysville, and other localities, South Carolina (rare). Pliocene (Caloosahatchee marl): Shell Creek, De Soto County and Munroe County, Florida (common). Pleistocene: Simmons Bluff, Yonge's Island, Charleston County, South Carolina (rare); Mount Hope, Panama Canal Zone (rare). Pleistocene or Recent: Vero, Florida (rare).

Habitat.-Gulf of Mexico off Elorida (21-56 meters), Tortugas (29 meters), Bermuda, St. Thomas, St. John, and perhaps at Malacca (Lerinsen).

Plesiotypes.-Cat. Nos. 68547-68553, U.S.N.M.

\section{STYLOPOMA PROJECTA, new species.}

Plate 45 , fig. 6.

Description.-Zoarium incrusting. Zooecia distinct, separated by a furrow, regularly oriented, sub-rectangular; frontal convex and garnished with numerous tremopores. Aperture small, transverse, with a small, narrow rimule; rounded at its extremity; peristome thick, salient, smooth. A small oral avicularium with pointed and very salient beak is adjacent to the rimule and to the aperture. The ovicell is enormous, globular ornamented with tremapores; it hides the aperture. The interzooecial aricularium is large, convex, with rounded and somewhat enlarged beak.

$$
\text { Measurements. A Aperture }\left\{\begin{array} { l } 
{ h a = 0 . 1 0 \mathrm { mm } . } \\
{ l a = 0 . 1 1 \mathrm { mm } . }
\end{array} \quad \text { Zooecia } \left\{\begin{array}{l}
L z=0.50-0.55 \mathrm{~mm} . \\
l z=0.30-0.40 \mathrm{~mm} .
\end{array}\right.\right.
$$

Affinities.-This species is very well characterized by its small oral avicularium arranged to the right or to the left of the rimule, an arrangement not observed in other known species.

Occurrence.-Pleistoccne: Mount Hope, Panama Canal Zone (rare).

Plesiotype.-Cat. No. 68554, U.S.N.M.

\section{STYLOPOMA MAGNIPOROSA, new species,}

Plate 47, fig. 4.

Description.-The zoarium is bilamellar. The zooecia are large, elongated, distinct, separated by a furrow, elliptical; the frontal is convex and perforated by large expanded tremopores. The apertura is elongated; the anter is orbicular and very large; the poster is formed by a small narrow rectilinear rimule; the peristome is thick, little salient, smooth. On each side of the apertura there are two triangular oblique avicularia with the beak directed toward the base. The ovicell is enormous, globular, placed on the distal zooecium, covering and hiding the aperture.

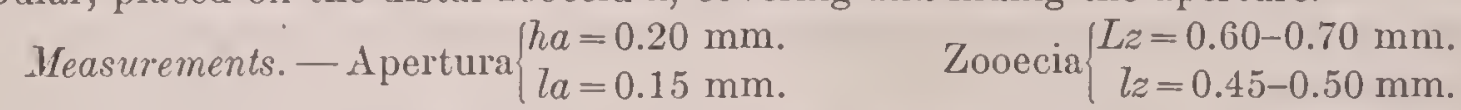

Affinities. - This species differs from Stylopoma isabelleana D'Orbigny in its large frontal tremopores and in the beak of the aricularia directed toward the base. We have observed a giant aperture corresponding probably to a spccial or abnormal mandible.

Occurrence.-Miocene (Bowden horizon): Santo Domingo.

Holotype.-Cat. No. 68555, U.S.N.M. 
Plate 3, fig. 8.

Description.-The zonrium incrusts shells. The zooecia are distinct, separated by deep furrows, elongated, small; the frontal is convex and provided with small tremopores. The apertura is small, transverse, semiclliptical with a narrow rectangular rimule on the proximal, rectilinear border; the peristome is thin, sharp, salient. The ovicell is very large, globular, provided with protuberances and entirely covers the apertura. In the vicinity of the apertura there is a small triangular a vicularium with pivot, the beak of which is turned obliquely toward the top.

Measurements.-Apertura $\left\{\begin{array}{l}h a=0.05 \mathrm{~mm} . \\ l a=0.07 \mathrm{~mm} .\end{array}\right.$ Zooecium $\left\{\begin{array}{l}L z=0.40-0.45 \mathrm{~mm} . \\ l z=0.25-0.30 \mathrm{~mm} .\end{array}\right.$

This is the smallest known species of the genus Stylopoma.

Occurrence.-Miocene (Bowden marl) : Bowden, Jamaica (rare).

Holotype-Cat. 68556, U.S.N.M.

Genus SCHIZOPODRELLA Canu and Bassler, 1917.

(For description, see Bulletin 106, U. S. National Museum, p. 338.)

SCHIZOPODRELLA ACULEATA, new species.

Plate 31 , figs. 13, 14.

Description.-The zoarium is massive, very large and formed of many superposed lamellae. The zooecia are little distinct, elongated, separated by an irregular furrow, elliptical or rectangular; the frontal is a tremocyst with largc, widened pores. The apertura is suborbicular and bears a wide, rounded rimule of little depth; the peristome is thin, complete and salient on the zooecia of the internal lamellae. The ovicell is globular, salient, covered with tremopores. The aricularium with pivot is placed in the vicinity of the apertura; it is very long and terminates in a point.

$$
\text { Measurements.-Apertura }\left\{\begin{array} { l } 
{ h _ { 0 } = 0 . 1 5 \mathrm { mm } . } \\
{ l _ { 0 } = 0 . 1 2 - 0 . 1 5 \mathrm { mm } . }
\end{array} \quad \text { Zooecia } \left\{\begin{array}{l}
L z=0.45 \mathrm{~mm} . \\
l_{z}=0.25 \mathrm{~mm} .
\end{array}\right.\right.
$$

Affinities. - This species differs from Schizoporella cumulata Ulrich and Bassler, 1904 , in the length of its avicularium $(L=0.40 \mathrm{~mm}$.). It differs from Schizopodrella longirostris Hincks, 1886, which also bears a large avicularium, in the much greater width of its rimule. When the large avicularium is not much dereloped $S$. aculeata much resembles Stylopoma spongites Pallas, 1766; it differs from it in its rimule which is wide and concare and not small and rectangular and also in the different form of the ovicell. It differs from Schizopodrella unicornis Johnston, 1847 , in which the apertura is identical, in the presence of a single very large avicularium.

Occurrence.-Pliocene (Waccamaw marl): Waccamaw River, Horry County, South Carolina (very rare).

Cotypes.-Cat. No. 68557, U.S.N.M. 
SChizopodrella MUTABILIS Canu and Bassler, 1919.

Plate 6, figs. 3-5.

1919. Schizopodrella? mutabilis CANU and BASSLER, Geology and Paleontology of the West Indies, Bryozoa, Publications of the Carnegie Institution of Washington, no. 291, p. 90, pl.6, figs. 3-5.

Description.-The zoarium is unilamellar, tubular; it incrusts the fine radicells of algae. The zooecia are little distinct, elongate, elliptical; the frontal is little convex, surrounded by areolar pores and garnished with some large tremopores. The apertura is elongate, oval, with a wide rimule separated from the anter by two salient condyles.

Measurements.-Apertura $\left\{\begin{array}{l}h a=0.18-0.20 \mathrm{~mm} . \\ l a=0.12 \mathrm{~mm} .\end{array} \quad\right.$ Zooecia $\left\{\begin{array}{l}L z=0.70 \mathrm{~mm} . \\ l z=0.34 \mathrm{~mm} .\end{array}\right.$

Affinities.-The very thick incrustation of the tremocyst renders the aspect of this species quite changeable and sometimes absolutely unrecognizable. We have not discovered the ovicell, so the classification naturally remains doubtful. It is possible that our specimens represent the incrusting base of some branching form like Gemelliporella punctata Canu and Bassler, 1919, but until the discovery of more specimens this point must remain in doubt.

Occurrence.-Lower Miocene (Bowden horizon): Cercado de Mao, Santo Domingo (rare).

Holotype.-Cat. No. 68558, U.S.N.M.

SCHIZOPODRELLA UNICORNIS Johnston, 1847.

Plate 17, figs. 13, 14.

1847. Lepralia unicornis Jornston, History of British Zoophytes, ed. 2, p. 320, pl. 57, fig. 1.

1850. Schizo porclla unicornis Hincks, British Marine Polyzoa, p. 238, pl. 35, figs. 1-5.

1889. Schizoporella unicornis JeLly, Synonymic Catalogue of Marine Bryozoa, p. 236 (general bibliography).

1904. Schizoporella subquadrata Ulrich and Bassler, Maryland Geological Survey, Miocene, p. 420 , pl. 114, fig. 1 ; pl. 118, figs. 5,6 .

1906. Schizo porella unicornis CANu, Bryozoaires fossiles des Terrains du Sud-Ouest de la France, I Aquatanien, Bulletin de la Société géologique de France, p. 516 (biliography).

1907. Schizoporella unicornis CALvet, Expéditions scientifiques du Travailleur et du Talisman, vol. 8 , p. 417 (bibliography).

1914. Schizoporella unicornis Osburn, The Bryozoa of the Tortugas Islands, Publications Carnegie Institute of Washington, No. 182, p. 205 (American bibliography).

1918. Schizoporella unicornis Waters, Marine Fauna fo the Cape Verde Islands, Linnean Society's Journal Zoology, vol. 34, p. 14, pl. 2, figs. 14-17, 22 (bibliography).

1919. Schizopodrella unicornis CANU and BAssler, Geology and Paleontology of the West Indies, Bryozoa, Publication of the Carnegie Institution of Washington, no. 291, p. 90.

This species may easily be confused with Stylopoma spongites Pallas, 1766; it is distinguished from it by the wide, proximal sinus of its apertura and by the quite different form of its ovicell.

S. unicornis is quite diffused through the European Tertiary formations, but on the contrary is quite rare in America, although its geologic distribution here appears to be almost identical.

Occurrence.--Lower Miocene: (Bowden formation): Bowden, Jamaica (rare). Miocene (Choptank formation): Governor Run, Maryland (rare). Miocene (Duplin 12184-23-Bull. 125--S 
marl): Muldrows Mills, 5 miles south of Maysville, South Carolina (very rare); Wilmington, Natural Well, 2 miles southwest of Magnolia, etc., North Carolina (rare). Miocene (Yorktown formation) : 1 mile west of Fort Nonsense, Gloucester County and other localities in Virginia (rare). Miocene (St. Mary's formation): Bowler's wharf, 18 miles above Urbana, Middlesex County, Virginia (rare). Pliocene (Caloosahatchee marl) : Monroe County, Florida (rare). Pleistocene:Simmons Bluff, Younges Island, Charleston County, South Carolina; Daytona, Florida (rare).

Geologic distribution.-In Europe since the Stampian.

Habitat.-Atlantic, Mediterranean, and boreal seas.

Plesiotype.-Cat. Nos. 68559-68565, U.S.N.M.

\section{SCHIZOPODRELLA FLORIDINA Osburn, 1914.}

Plate 16, figs. 11-15.

1914. Schizoporella floridina OsBurn, The Bryozoa of the Tortugas Islands, Florida, Publications Carnegie Institute of Washington, No. 182, p. 206, text figs. 17, 18.

Variations. -The zoarium is massive and formed of a number of superposed lamellae. Sometimes the zooecia are not oriented and are distributed in all directions. The large avicularium is very fragile and easily altered by fossilization. The aperture in our fossil specimens is not exactly similar to that figured by Osburn differing slightly in its rimule not placed at the level of the frontal. We have not observed moreover the large interzooecial avicularium.

Occurrence.-Miocene (Duplin marl) : Wilmington and Lake Waccamaw, North Carolina (rare). Miocene (Choctawhatchee marl): Jackson Bluff, Ocklockonee River, 25 miles southwest of Tallahassee, Florida (very rare).

Cotypes.-Cat. Nos. 68566, 68567, U.S.N.M.

SCHIZOPODRELLA PUSILLA, new specles.

Plate 17, figs 18, 19.

Description.-The zoarium is free and bilamellar or incrusting. The zooecia are small, little distinct, elongated, claviform; the frontal is somewhat convex, perforated by some large tremopores. The apertura is as high as wide; the rimule is wide, rounded, little deep. The ovicell is globular, hyperstomial. There are generally two small triangular avicularia with very salient beak placed on each side of the apertura.

$$
\text { Measurements.-Apertura }\left\{\begin{array} { l } 
{ h a = 0 . 1 0 - 0 . 1 2 \mathrm { mm } . } \\
{ l a = 0 . 1 0 \mathrm { mm } . }
\end{array} \quad \text { Zooecia } \left\{\begin{array}{l}
L z=0.54 \mathrm{~mm} . \\
l z=0.24 \mathrm{~mm} .
\end{array}\right.\right.
$$

Affinities. - This spe.ies has much resemblance to Schizopodrella patagonica Waters, 1905, in the arrangement of its avicularia; it differs from it in its larger avicularia, placed lower, salient and always inclined toward the aperture. The zooecia, although usually plain, are sometimes margined by a slightly salient thread.

Occurrence.-Miocene (Choctowhatchee marl): Jackson Bluff, Ocklockonee River, 25 miles southwest of Tallahassee, Florida (rare).

Holotype-Cat. No. 68568, U.S.N.M. 
NORTH AMERICAN LATER TERTIARY AND QUATERNARY BRYOZOA.

SCHIZOPODRELLA MARGINATA, new species.

Plate 30, figs. 4, 5.

Description.--The zoarium incrusts oysters. The zooecia are distinct, oval, wide, bordered by a wide thread, little salient joined to the peristome; the frontal is little convex and ornamented with large tremopores. The apertura is orbicular; the rimule is wide, of little depth, triangular. The ovicell is little salient, much embedded in the distal zooecium with a frontal area. On each side of the apertura there are two small round avicularia without pivot.

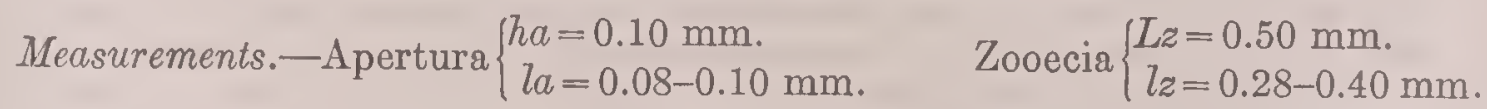

Affinities.--This small species is quite well characterized and easy to determine. It differs from Schizopodrella pusilla, new species, in its great zooecial width and in the triangular form of the rimule.

Occurrence.-Pliocene (Waccamaw marl): Waccamaw River, Horry County, South Carolina (rare).

Holotype.-Cat. No. 68569 , U.S.N.M.

\section{SCHIZOPODRELLA DOVERENSIS Ulrich and Bassler, 1904.}

Plate 18, figs. 1-3.

1904. Schizopodrella doverensis UlRICH and BASSLER, Bryozoa, Geological Survey Maryland, Miocene, p. 421, pl. 117, fig. 1 .

Description.-Zoarium a thin sheet on foreign bodies, the figured specimen growing on the reverse of Retepora doverensis. Zooecia well distinguished from each other but with the surface rather flat; irregularly arranged, though their elongate form gives some prominence to the longitudinal rows; average length $0.6 \mathrm{~mm}$., width 0.35 to $40 \mathrm{~mm}$. Orifice terminal, slightly transverse, broadly notched on the proximal side, on the whole nearly circular. Surface reticulate, only slightly convex, the central portion appearing flattened. Avicularia rather small, prominent, one on either or both sides of the orifice, rarely wanting, situated close to the peristome; apparently both divided by a septum. Ovicells not observed. (Ulrich and Bassler.)

Affinities.-The zooecia are not always regularly oriented. The zoarium incrusts shells or other bryozoa.

This species differs from Schizopodrella unicornis Johnston; 1847, whose apertura is identical, in its larger dimensions and in the absence of the frontal protruberance. It differs from Schizobrachiella (Escharella) sanguinea Smitt, 1872, in its single very large avicularium and in the smaller and more numerous tremopores. It differs from Stylopoma (Hippothoa) isabelleana Smitt, 1872, in the place of its avicularium not situated below the apertura.

Occurrence.-Miocene (Choptank formation): Dover bridge, Maryland (rare). Pliocene (Caloosahatchee marl): Shell Creek, De Soto County, Florida (very rare). Plesiotypes.-Cat. No.68570, U.S.N.M. 


\section{Genus SCHIZOLAVELLA Canu and Bassler, 1920.}

1920. Schizolavella CANU and BAssler, North American Early Tertiary Bryozoa, Bulletin 106, U. S. National Museum, p. 358.

SCHIZOLAVELLA VULGARIS Moll, 1803.

Plate 35 , fig. 10.

1803. Eschara vulgaris MoL, Die Seerinde, p. 55, pl. 3, fig. 10.

1867. Lepralia botterii Heller, Die Bryozoen des Adriatischen Meeres, Verhandlungen der k. k. zoologisch-botanischen Gesellschaft in Wien, vol. 7, p. 30, pl. 2, fig. 4.

1880. Schizoporclla vulgaris Hincks, British Marine Polyzoa, p. 244, pl. 37, fig. 7; pl. 40, figs. 5, 6.

1880. Lepralia vulgaris Sequenza, Le formazioni terziarie della Provincia di Reggio (Calabria), Reale Accademia dei Lincei, ser. 3, vol. 6, pp. 202, 295, 369, (not Lepralia otophora of the same author).

?1885. Pachykraspedon otophorum Koscuinsкy, Ein Beitrag zur Kenntnis der Bryozoenfauna der älteren Tertiärschichten des südlichen Bayerns, Paleontographica, vol. 32, p. 44.

1889. Schizoporella vulgaris Jelly, A Synonymic Catalogue of Recent Marine Bryozoa, p. 238 (bibliography) (not Lepralia cognata Reuss).

1889. Schizoporclla vulgaris Pergens, Notes succinctes sur les Bryozoaires, du Miocène de la Russie méridionale, Bulletin des Séances de la Société Royale Malacologique de Belgique, vol. 24, p. 5 .

1895. Schizoporella vulgaris Neviani, Briozoi fossili della Farnesina, Palaeontographica Italica, vol. 1, p. 113 (3), pl. 6, fig. 13.

1896. Schizoporella vulgaris Neviani, Briozoi Postpliocenici di Spilinga (Calabria), Atti Accademia Gioenia di Scienze Naturali in Catania, ser. 4, vol. 9, p. 32.

1896. Schizoporella vulgaris Calvet, Campagne du Caudan, Bryozoaires, Annales de l'Université de Lyon, p. 258.

1898-1900. Schizoporella vulgaris Neviani, Briozoi neozoici di alcune localita d'Italia, Bolletino della Società Romana per gli Studi Zoologici, pt. 4, vol. 5, p. 11; pt. 5, vol. 7, pp. 4, 7, 13; pt. 6 , vol. S, p. 67 (sep. 10), 1900

1899. Schizoporella vulgaris Waters, Bryozoa from Madeira, Journal Royal Microscopical Society, pp. 11, 16, pl. 3, figs. 9-11.

1900. Schizoporella vulgaris Neviani, Briozoi neogenici della Calabria, Palaeontographia Italica, vol. 6, p. 196 (sep. 82) (Bibliography regional).

1902. Schizoporclla vulgaris Calvet, Bryozoaires marins des cotes de Corse, Travaux de l'Institut Zoologique de Montpellier, ser. 2, mem. 12, p. 21.

1902. Schizoporella vulgaris CALvet, Bryozoaries marins de la region de Cette, Travaux de l'Institut Zoologique de Montpellier, ser. 2, mem. 8, p. 41.

1903. Schizoporella vulgaris Jullien, Bryozoaires provenant des Campagnes de l'Hirondelle, pp. $79,136$.

1905. Schizoporclla vulgaris Neviani, Briozoi fossili di Carrubare (Calabria), Bollettino della Societì Geologica I talica, vol. 21, pt. 1, p. 533 (sep. 31), fig. 12.

1907. Schizoporella vulgaris Calvet, Expédition scientifiques du Trarailleur et du Talisman, p. 417 (bibliography).

1909. Escharina vulgaris Norsan, Polyzoa of Madeira, Linnean Society's Journal, vol. 30, p. 302.

1912. Schizoporella vulgaris CANu, Etude comparée des Bryozoaires Helvétians de l'Egypte avec les Bryozoaires vivan ts de la Méditerranée et de la mer Rouge, Memoires de l'Institut Egyptien, vol. 6, p. 213, pl. 11, fig. 6 (palaeontological, illustrated bibliography)

This species has never been noted except in the eastern Atlantic from the English Channel to the Cape Verde Islands and in the Mediterranean. It is not known in the Pacific. However, Waters has noted the fossil form in the Miocene of Australia. Our specimen from the Pleistocene is undoubtedly of this species. 
It is therefore probable that its geographic extension is greater than we had supposed hitherto.

Occurrence.-Pleistocene: Santa Barbara, California (very rare).

Geological distribution.-Stampian of Germany (Reuss); Casselian of Germany (Reuss); Miocene of Australia (Waters); Burdigalian of Gard (Canu collection); Helvetian of Italy (Seguenza, Neviani), of Gard, of Herault, and of Touraine (Canu collection); Tortonian of Italy (Seguenza), of Austria-Hungary (Reuss); Sahelian of Oran (Canu collection); Zanclean of Italy (Seguenza); Plaisancian of Italy (Manzoni, Neviani); Astian of Italy (Seguenza); Sicilian of Italy (Neviani, Waters); Quaternary of Italy (Neviani, Seguenza).

Habitat.-Eastern Atlantic; English Channel, Gulf of Gascony (155-180 meters) Madeira, Cape Verde Islands, Azore Islands (89-130 meters). Mediterranean, Black Sea, Adriatic, Corse (5-77 meters), Cette (20-40 meters), Oran (75-121 meters).

Plesiotype.-Cat. No. 68571, U.S.N.M.
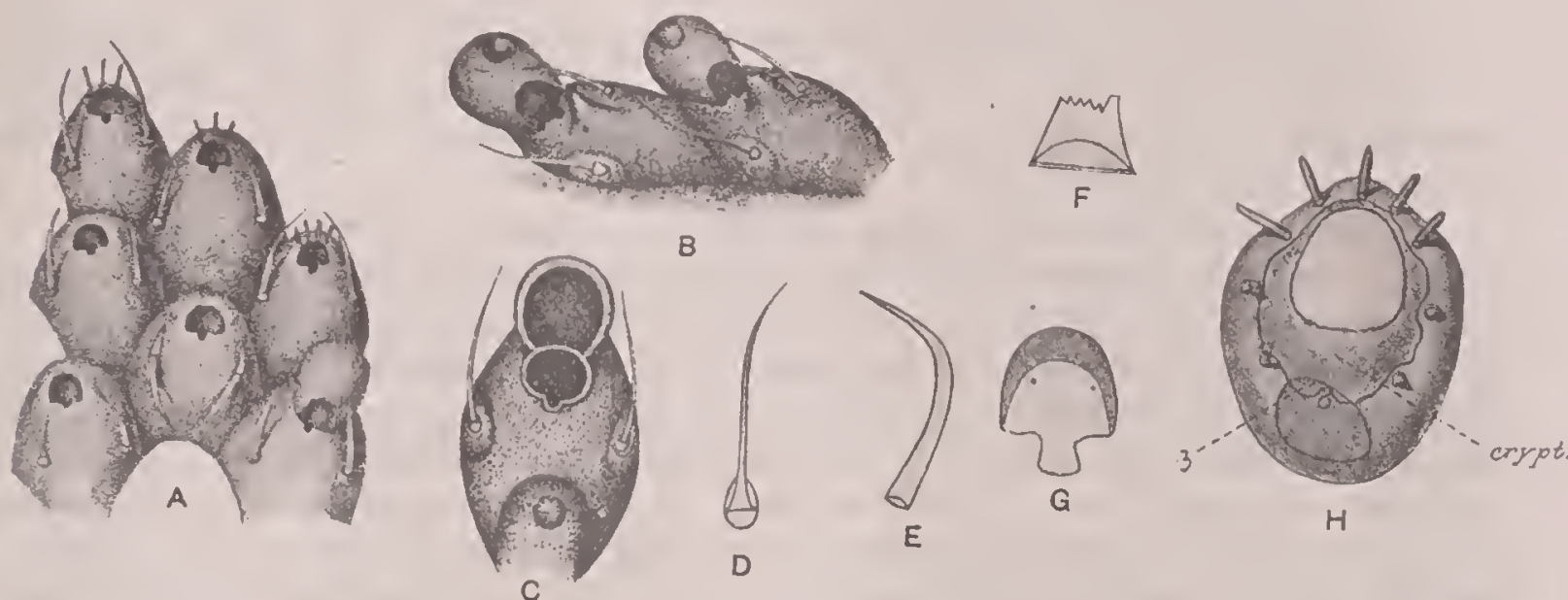

FIG. 16.-Genus Schizolavella Canu and Bassler, 1920.

A-H. Schizolavella vulgaris Mfoll, 1S03. A. Portion of zoarium with an ovicelled zooecium $\times 25$. B. Two zooecia, $\times 40$, showing the umbonate ovicell and a mucro on the front wall. C. A zooecium, $X 40$, showing structure. D. Avicularian mandible. ( $\Lambda-D$, after Hincks, 1850.) E. Avicularian mandible, $\times 85$. F. Base of the avicularian mandible, $\times 250$. G. Operculum, $\times 85$. (E-G, after Waters, 1898.) H. Ancestrula. The region inside the marginal spines is partly occupied by a calcareous plate (crypt) which is probably a cryptocist; $b$. brown body (after Harmer, 1902).

Genus SCHIzOMAVELLA Canu and Bassler, 1920.

(For description see Bulletin 106, U. S. National Museum, p. 353.)

SCHIZOMAVELLA LONGIROSTRATA Hincks, 1883.

Plate 35 , fig. 11 .

1883. Schizoporella longirostrata Hricks, Report on the Polyzoa of the Queen Charlotte Islands, Annals Magazine Natural History, ser. 5, vol. 11. p. 447, pl. 17, fig. 4 (not Robertson, 1908).

Measurements.-Apertura $\left\{\begin{array}{l}h a=0.16 \mathrm{~mm} . \\ l a=0.14 \mathrm{~mm} .\end{array}\right.$ Zooecia $\left\{\begin{array}{l}L z=0.56 \mathrm{~mm} . \\ l z=0.36-0.40 \mathrm{~mm} .\end{array}\right.$ 
Variations.-The rimule bears two salient condyles on which are supported the small proximal tongue of the operculum. The ovicell is globular, elongated, large; it bears in front a small concavity; it bears small trcmopores like the frontal, it is closed by the operculum.

The large avicularium is not median; it is eccentric and curved.

The species which Miss Robertson has figured under the same name appcars to be different for the apertura of the ovicelled zooecia is much larger than that of the ordinary zooecia. This is not the case in the figure of Hincks and of our specimen.

Occurrence.-Pleistocene: Santa Barbara, California (rare).

Habitat.-Queen Charlotte Islands.

Plesiotype.-Cat. No. 68572, U.S.N.M.

Genus GEMELLIPORELlA Canu and Bassler, 1920.

1920. Gemelliporella CANu and Bassler, North American Early Tertiary Bryozoa, Bulletin 106, U. S. National Museum, p. 372.

The ovicell is hyperstomial and deeply embedded in the distal zooecium. The operculum does not close the ovicell and operates in a locella. The form of the apertura is like a keyhole. The frontal is garnished with lateral areolar pores and with a granular pleurocyst.

Genotype.-Gemelliporella vorax, new species. Range: Pliocene.

The genus Gemellipora Smitt, 1872, founded solely on the aspect of the apertura, is not a natural one. The first species described, G. eburnea, has been selected by Levinsen, 1909, as the type of the genus and classified in his family Liriozoidae. Gemellipora striatula Smitt, 1872, is a synonym for Trypostega venusta Norman, 1869. Gemellipora glabra Smitt appears to have a smooth frontal, but it is nccessary to examine specimens anew. G. limbata Smitt is serial and appears to belong to the Phylactellidae. The keyhole form of the aperture does not appear to furnish a sufficient generic character because it does not correspond to an importani modification of the hydrostatic function. In establishing the new genus Gemelliporella we have employed the characters furnished by the ovicell and the frontal.

GEMELLIPORELLA ASPER, new species.

Plate 18, figs. 5, 6.

Description.-The zoarium incrusts oysters. The zooecia are little distinct, irregularly elliptical; the frontal is small, hardly convex, surrounded by large, crowded, areolar porcs. The apertura is deep, buried, elongate, shaped like a keyhole, with two lateral symmetrical condyles limiting the rimule; the peristomice is elliptical and bears a little salient mucro. The ovicell is globular, salient, punctate; its orifice is very large and can not be closed by the operculum. On each side of the apertura there are two large orbicular avicularia with pivot, very salient; the one between them is much developed and becomes onychocelliform; its pivot bears a wide rectangular denticle.

$$
\text { Measurements.-Apertura }\left\{\begin{array} { l } 
{ h a = 0 . 1 4 \mathrm { mm } . } \\
{ l a = 0 . 1 0 \mathrm { mm } . }
\end{array} \quad \text { Zooecia } \left\{\begin{array}{l}
L z=0.40-0.50 \mathrm{~mm} . \\
l z=0.30 \mathrm{~mm} .
\end{array}\right.\right.
$$

Affinities.-The avicularia by their saliency cover the zoarial surface with a grcat number of asperities which characterize this species, but which render it 
very irregular. The denticle placed on the pivot of the large avicularia is rather peculiar to this species, but it is not constant; it corresponds perhaps to a particular arrangement of the rachis. The known recent bryozoa never have this arrangement. The number and importance of the avicularia indicate calm waters.

Occurrence.-Miocene (Choctawhatchee marl) : Jackson Bluff, Ocklocknee River, 25 miles southwest of Tallahassce, Florida (rare). Pliocene (Waccamaw marl): Waccamaw River, Horry County, South Carolina (very rare).

Cotypes.-Cat. Nos. 68573, 68574, U.S.N.M.

\section{GEMELLIPORELLA VORAX, new species.}

Plate 19, figs. 1-9.

Description.-The zoarium incrusts shells, oysters, and bryozoa. The zooecia are little distinct, separated by a furrow, irregularly elliptical; the frontal is convex, surrounded by some large areolar pores which are scattered and covered over with a pleurocyst more or less granular. The apertura is deep, oval, the point below with rimule wide and notched; the peristomice is semilunar with a proximal mucro more or less developed. The ovicell is convex, little salient, deeply embedded in the distal zooecium; its orifice is very wide and can not be closed by the operculum. On each side of the apertura there is a round avicularium; very frequently the one between them becomes very long and fusiform.

$$
\text { Measurements.-Apertura }\left\{\begin{array} { l } 
{ h a = 0 . 1 0 \mathrm { mm } . } \\
{ l a = 0 . 0 8 \mathrm { mm } . }
\end{array} \quad \text { Zooecia } \left\{\begin{array}{l}
L z=0.40 \mathrm{~mm} . \\
l z=0.30 \mathrm{~mm} .
\end{array}\right.\right.
$$

Variations.-This species is exceedingly variable and takes the most fantastic aspects. The zooecia are only distinct on the small zoaria or on the margins of the large ones; at the center of the latter they are absolutely indistinct. The ancestrula is a small zooecium; it engenders two distal and four proximal zooecia. There are often interareolar costules. The reduction of its zooecial dimensions and the great development of the avicularia seems to indicate that this species required much oxygen.

It is remarkable that the species has disappeared from the recent Gulf of Mexico after its existence in the same region throughout the Miocene and Pliocene.

Occurrence.-Lower Miocene (Chipola marl): Chipola River, Calhoun County, Florida (rare). Miocene (Duplin marl): Wilmington and Natural Well, 2 miles southwest of Magnolia, Duplin County, North Carolina (common); Muldrows Mills, 5 miles south of Maysville, South Carolina (rare). Miocene (Choctawhatchee marl) : Jackson Bluff, Ocklocknee River, 25 miles southwest of Tallahassee, Florida (rare). Miocene (Yorktown formation): Yorktown, 3 miles southwest of Petersburg, and other localities in Virginia (rare). Pliocene (Waccamaw marl): Waccamaw River, Horry County, South Carolina (common). Pliocene (Caloosahatchee marl) : Shell Creek, De Soto County (rare), and Monroe County, Florida (common). Cotypes.-Cat. Nos. 68575-68580, U.S.N.M.

gemelliporella PUNCtata Canu and Bassler, 1919.

Plate 5, figs. 7-9.

1919. Gemelliporella punctata Canu and Bassler, Biology and Paleontology of the West Indies, Bryozoa. Publications of the Carnegie Institution of Washington, No. 291, p. 92, pl. 5, figs. $7-9$.

Description.-The zoarium is free, cylindrical, bifurcated. The zooecia are very little distinct, elongate, convex; the frontal is granular and surrounded with areolar 
pores and is sometimes corered with punctations of pleurocystal origin. The aperture is oval, elongate, formed of a large semilunar anter and of a wide proximal sinus. The ovicell is deeply embedded in the distal zooecium, little salient, closed by the operculum, ornamented by an orbicular and very fragile frontal area.

$$
\text { Measurements._Apertura }\left\{\begin{array} { l } 
{ h a = 0 . 1 5 \mathrm { mm } . } \\
{ l a = 0 . 1 2 \mathrm { mm } . }
\end{array} \text { Zooecia } \left\{\begin{array}{l}
L z=0.60 \mathrm{~mm} . \\
l z=0.40 \mathrm{~mm} .
\end{array}\right.\right.
$$

Affinities.-The punctations of the frontal are quite variable; there is not a single zooecium similar to another. In a better preserved state we think that each zooecium is surrounded with areolar pores irregular in size and spacing. The frontal is a thick and compact olocyst, covered by a pleurocyst which is granular or punctured with large pores which do not perforate the zooecial walls. Unfortunately we have not been able to confirm this exterior aspect by sections.

The possible relationship of this species to Schizopodrella mutabitis Canu and Bassler, 1919, has been mentioned under the discussion of that species.

Occurrence.-Lower Miocene (Bowden formation): Bowden, Jamaica (rare).

Cotypes.-Cat. No. 68581, U.S.N.M.

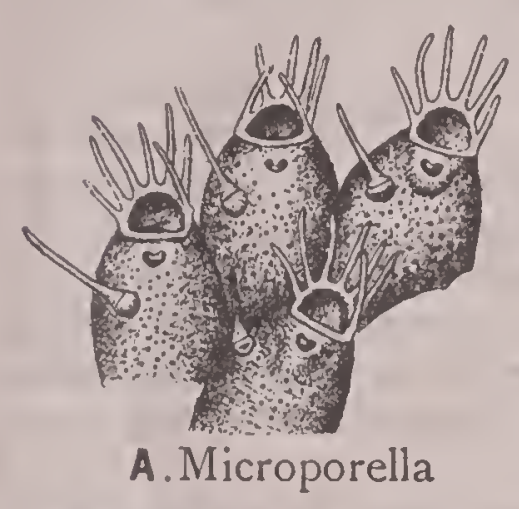

A. Microporella

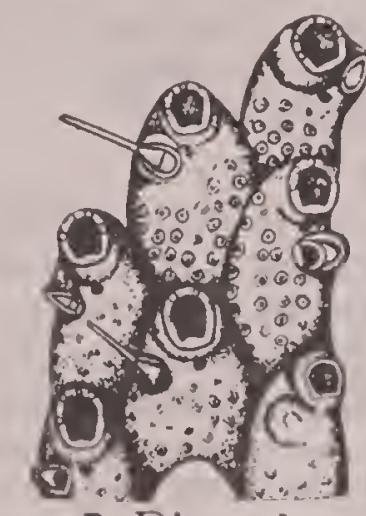

B. Diporula

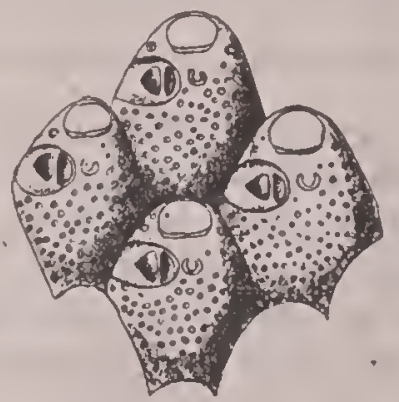

C. Ellipsopora

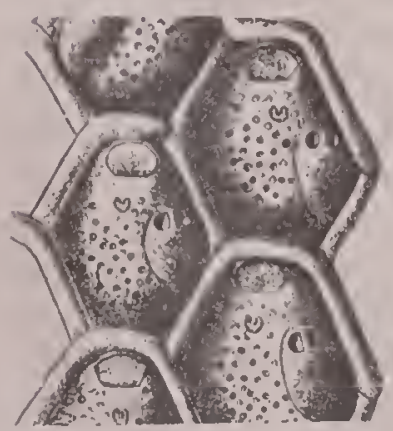

D. Flustramorpha

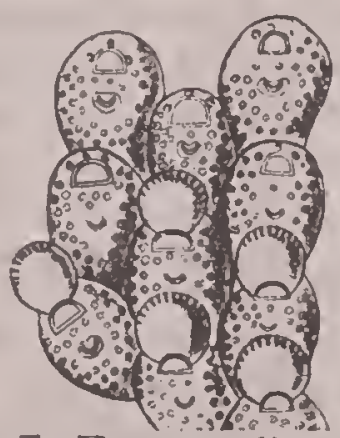

E. Fenestrulina

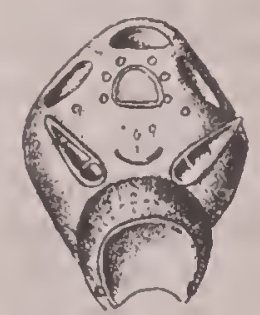

F. Calloporina

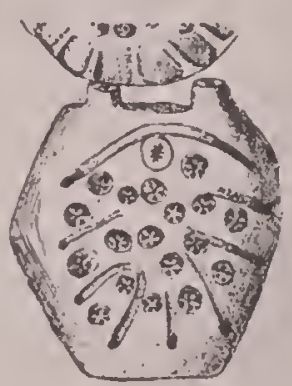

G. Inversiula

FIG. 17.-Genera of the Mricroporellae.

A. Microporella Hincks, 1887; M. ciliata Pallas, 1766, $\times$ 43. B. Subgenus Diporula Hincks, 18s0; D. verrucosa Peach, $1868, \times 25$. C. Subgenus Ellipsopora, new; E. flabellaris Busk, $1852, \times 40$. D. Subgenus Flustramorpha Gray, 1848; $F$. marginata Krause, $X$ 40. E. Fenestrulina Jullien, 1888; $F$. malusi Savigny-Audouin, 1826, $\times 20$. F. Calloporina Neviani, 1895; C. decorata Reuss. 1847, X 40. G. Inversiulu Jullien, 1888; $I$. inversa Waters, 1889, $\times 50$. 


\section{Group 2. MICROPORELLAE Canu and Bassier, 1917.}

(See Bulletin 106, U. S. National Museum, p. 417, for description and illustration).

In this group the orifice of the compensatrix (frontal pore, micropore or ascopore) is distinct and removed from the apertura. The ovicell is hyperstomial and always closed by the operculum. Dietellae are present.

Historical.- The presence of a frontal micropore was considered by Hincks as an important family character, but the study of the larvae does not permit the adoption of his conclusion. According to Jullien, the ascopore is the orifice of a horn-shaped body, allowing the exterior to communicate with the tentacular sheath. Harmer and Levinsen believed that this was an optical illusion and that the ascopore was really the orifice of the compensatrix.

Levinsen, 1909, did not recognize the different genera established by authors according to the form of the apertura. We again follow the same principles of generic distinction by considering the great rariations of the function of calcification. Many species considered at first to belong to the Microporellae have since been recognized as true representatives of the Adeonidae. According to the nature of the calcification and the form of the aperture, we class the following genera in this group:

Fenestrulina Jullien, 1888.

Microporella Hincks, 1877.

Calloporina Neviani, 1895.

?Inversiula Jullien, 1888.

\section{Genus FENESTRULINA Jullien, 1888.}

1888. Fenestrulina Jullien, Mission scientifique du Cap Horn, 1882-83, VI, Zoologie, Bryozoaires, p. 37.

The frontal is garnished with stellate tremopores. The operculum closes the ovicell. No avicularia. Fourteen to fifteen tentacles.

Genotype.-Fenestrulina (Cellepora) malusi Sarigny-Audouin, 1826.

Range.-Helvetian-Recent.

The known species belonging to this genus are:

Fenestrulina (Cellepora) malusi Audouin, 1826.

Fenestrulina (Microporella) proxima Waters, 1904.

Fenestrulina (Microporella) exigua Waters, 1904.

Fenestrulina (Microporella) parvipora Waters, 1904. 

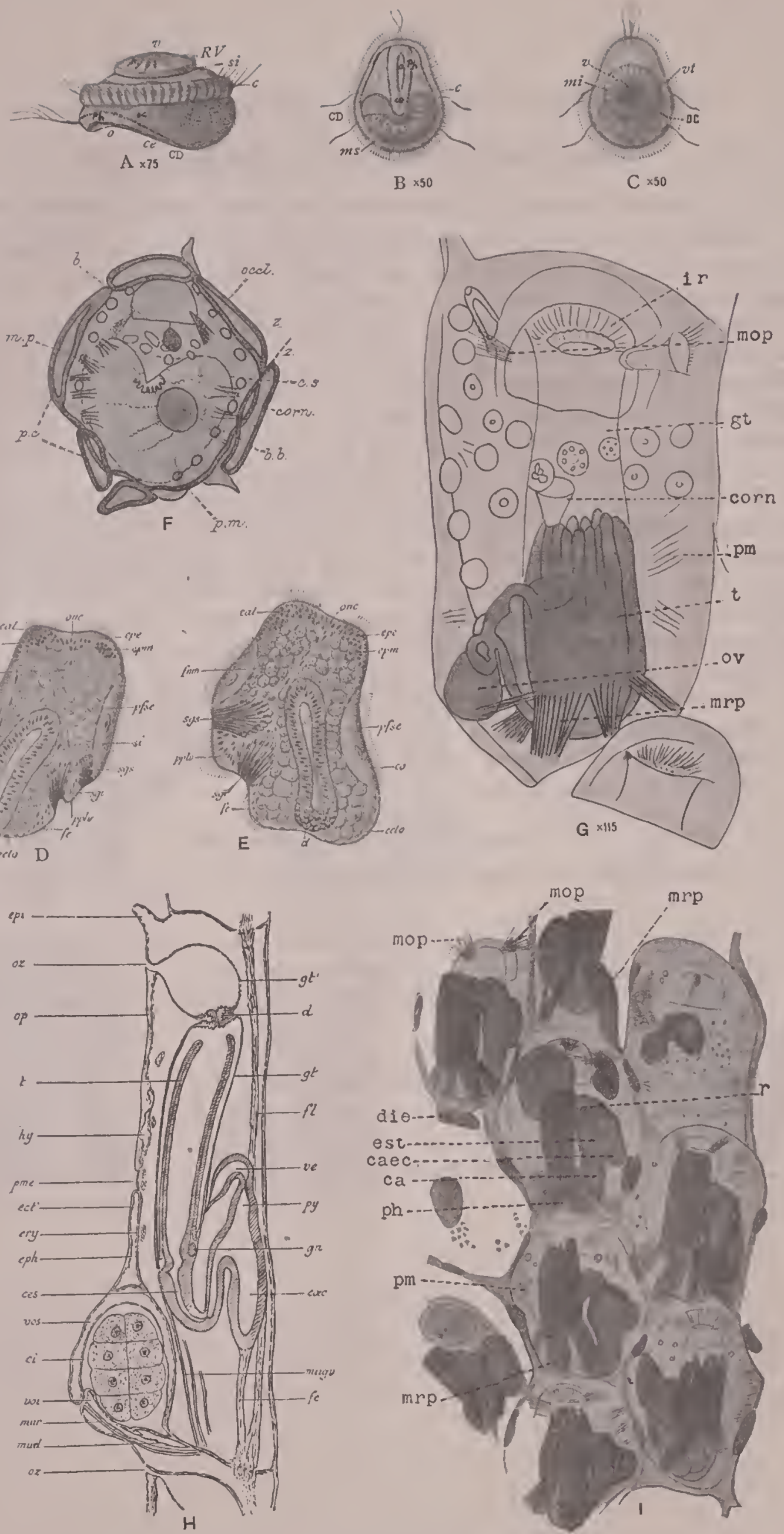

FIg. 18. - Anatomy of the Microporellae. 
Fig. 18.-Anatomy of the Microporellae.

A-D. Microporella ciliata Pallas, 1766. A. Profile view of free larva, $\times 75$. B. Free larva, oral view, showing the large radiating elements of the oral mesoderm, $X 50$. C. Free larva, aboral view, showing radiating aspect of the calotte, 50. (A-C after Barrois, 1877.) c, corona; cal, calotte (terminal bud); $C D$, digestive cavity; $c e$, obscure part between the two branches of the stomach; $m i$, aboral mesoderm; $m s$, oral mesoderm; $O$, ciliated cleft; oc, oculiform points; $p h$, pharynx; $R V$, border of the calotte. $D$. Median sagittal section of an cmbryo in one of the last stages of development. (After Calvet, 1900.)

E-I. Fenestrulina malusi Audouin, 1826. E. Median sagittal section of an embryo just before it emerges. (After Calvet, 1900.) In the course of the neuro-muscular bundles passing from the central nerve organs to the pyriform organ some cellules are seen. The internal sack has a simple form almost regularly cylindrical. $c$, mantle; cal, calotte (terminal bud); co, corona; $d$, tampon or inner sac; ecto, ectoderm; epe, ectoderm thickening; epm, mesoderm thickening; $f c$, ciliated cleft; fum, neuro-muscular bundle; onc, central nervous organ of the embryo; $p f s e$, sub-ectoderm nerve plexus; $p p l v$, papilla of the vibratile plume; si, internal sac; $s q s$, superior glandular system; sqi, inferior glandular system. F. Basal view of a zooecium which has lost its polypide. (After Harmer, 1902.) $b$, polypide bud; $b b$, brown body; corn, cornicula; cs. compensatrix opening by the ascopore ( $m$. p.); occl, opercr muscles; $p$. $c$, dietellae; $z$, neighboring zooecia. G. Anterior view of a zooecium containing only a young polypide, X 115. (after Jullien, 1888.) ca, cardiac region of the stomach; caec, caecum of the stomach; corn, cornicula; die, dietella; est, stomach; gt, tentacular sheath; $i r$, irisoid; mop, occlusor muscles of the operculum; mrp, large retractor muscles of the polypide; ov, ovary; $p h$, pharynx and esophagus; $p m$, parietal muscles; $r$, intestine and rectum; $t$, tentacles. H. Longitudinal section of a bryozoid. (After Calvet, 1900.) caec, stomachic caecum; ci, incubation cavity; cry, cryptocyst, or skeleton; diaphragm; eph, hypostegal epithelium; epi, spine; $f e$, central funicular cord; $\lambda$, lateral funicular cord; gn, nervous ganglion; $g t$, sub-diaphragm region of the tentacular sheath; $g t^{\prime}$, subdiaphragm region; $h y$, hypostege; mud, dilator muscles of the incubation cavity; mugr, large retractor muscles; mur, retractor muscles of the frontal walls of the lower ovicellarian vesicle; oes, esophagus; $o p$, operculum; $o z$, zooecial orifice; pme, median frontal pore; $p y$, pyloris; re, rectum; $t$, tentacles; voi, lower ovicellarian vesicle; vos, upper ovicellarian vesicle. I. Zoarium decalcified, seen posteriorly, $X 45$. (See G. for explanation of letters.)

\section{FENESTRULINA MALUSI Savigny-Audouin, 1826.}

Plate 36, figs. $2,3$.

1809. Cellepora malusii SAvigny, Description de l'Egypte, Polypes, pl. 8, fig. 8.

1826. Cellepora malusii Audourn, Explication des planches de Savigny, p. 239.

1862. Cellepora californiensis GaBb and HorN, Monograph of the fossil Polyzoa of the Secondary and Tertiary formations of North America, Journal Academy Natural Sciences Philadelphia, ser. 2, vol. 5 , p. 130, pl. 19, fig. 12 .

1895. Mficroporella malusi MAcGilurvay, Monograph of the Tertiary Polyzoa of Victoria, Transactions Royal Society of Victoria, vol. 4, p. 65, pl. 9, fig. I (regional bibliography).

1895. Microporella (Fenestrulina) malusi Neviani, Briozoi fossili delle Farnesina, Palaeontographia Italica, vol. I, p. 104 (sep. 28).

1895-1896. Microporella (Fenestmulina) malusi Neviani, Briozoi neozoici, di alcune localitia d'Italia, Bollettino della Societa Romana per gli Studi Zoologici, pt. I, p. 115 (sep. 7); pt. 2, p. 229 (sep. 5); pt. 3, p. 109 (sep. 8).

1898. Mricroporella malusi DE ANGELIs, Los primeros antozoos y briozoos miocenicos recogidos en Cataluña, p. 22

1901. Microporella (Fenestrulina) malusi Neviani, Briozoi neogenici della Calabrie, Palaeontographia italica, vol. 6, p. 175 (sep. 61) (Regional bibliography).

1904. Microporella malusi CANU, Les Bryozoaires du Patagonien, Memoires de la Societe geologique de France, vol. 12, No. 33, p. 11, pl. 3, fig. 27.

1905. Microporella (Fenestrulina) malusi Neviani, Bryozoi fossili de Carrubare (Calabrio), Bollettino delle Societa geologica italiana, vol. 23 , p. 524, fig. 8 .

1907. Microporella malusi Calvet, Expeditions scientifiques du Travailleur et du Talisman, p. 404 (bibliography).

1908. Microporella malusi CANu, Bryozoaires fossiles de l'Argentine, Anales del Museo Nacional de Buenos Aires, vol. 16, p. 280. 
1908. Microporella malusi RoBertson, The incrusting cheilostomatous Bryozoa of the west coast of North America, University of California Publications, Zoology, rol. 4, no. 5, p. 282, pl. 18 , figs. 35,36 .

1909. Fenestrulina malusi Norman, The Polyzon of Madeira, Journal Linnean Society, Zoology, vol. 30, p. 297.

1910. Microporella malusi Waters, Reports on the marine biology of the Sudanese Red Sea, Journal Linnean Society of London, Zoology, vol. 32, p. 168.

1912. Microporella malusi Barroso, Briozoos de la estacion maritima de Santander, Trabajos del Míuseo de ciencias naturales, no. 5, p. 27.

It is remarkable that this very cosmopolitan species has never been observed in the western Atlantic, fossil as well as recent.

Measurements.-Apertura $\left\{\begin{array}{l}h a=0.08-0.10 \mathrm{~mm} . \\ l a=0.16-0.18 \mathrm{~mm} .\end{array} \quad\right.$ Zooecia $\left\{\begin{array}{l}L_{z}=0.50 \mathrm{~mm} . \\ l_{z}=0.36 \mathrm{~mm} .\end{array}\right.$

Occurrence.-Pleistocene: Santa Barbara (common), and Dead Mans Island, off San Pedro, California (very rare).
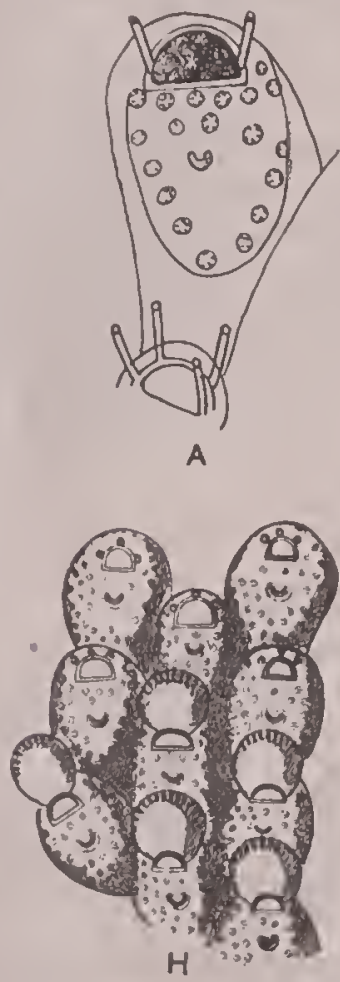
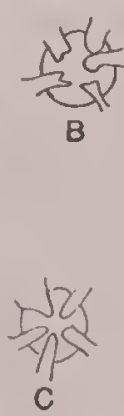

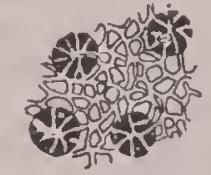

D

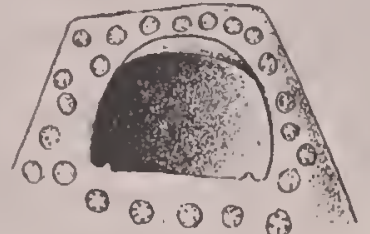

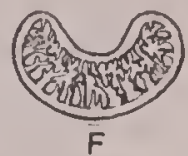

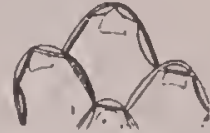

G

E
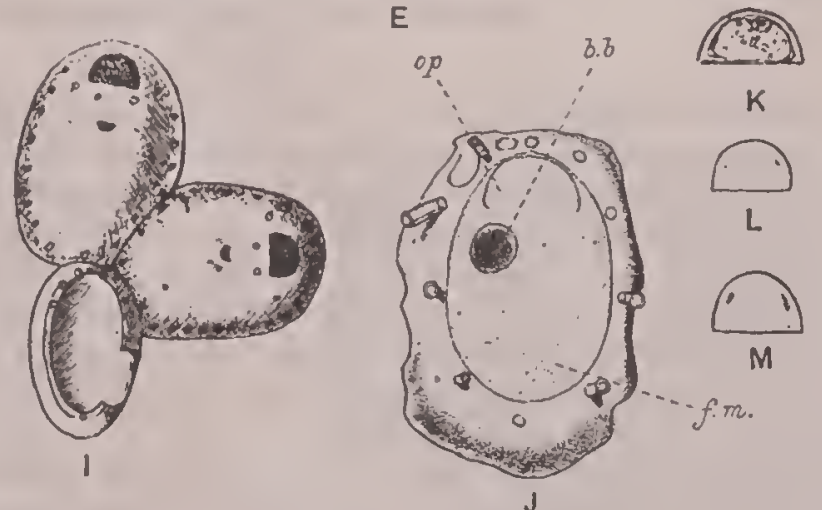

FIG. 19.-Genus Fenestrulina Jullien, 1888.

A-J. Fenestrulina malusi Savigny Audouin, 1826. A. A zooecium $\times 50$ showing all the characters. B, C. Stellate frontal pores, $\times 250$. (A-C, after Waters, 1903.) D. Portion of surface of a zooecium, $\times 175$. E. Aperture, $\times 100$. (After Levinsen, 1909.) F. Detailed structure of the ascopore (fenestrule of Jullien) $\times 175$. G. Dorsal face of the zooecia, showing the dietellae $\times 18$. H. Zooecia $\times 21$, several showing the ovicell. (D, F-H, after Levinsen, 1894.) I. Ancestrula and ancestrular zooecia, $X 25$. J. Ancestrula. The frontal membrane is typically Flustrine, its calcareous margin bearing ten spines, of which three are oral spines; op, operculum; $b . b$., brown body; $f . m$., frontal membrane (=ectocyst). (After Harmer, 1902.)

K. Operculum, $\times$ 85. (After Waters, 1877.) I. Fenestrulina parvipora Waters, 1903. Operculum, $\times$ 85. M. Fenestrulina proxima Waters, 1903. Operculum, $\times 85$. (I, L, M, after Waters, 1903 
Geological distribution.-Burdigalian of Catalogne (De Angelis); Patagonian of Argentina (Canu); Miocene of Australia (MacGillivray) and New Zealand (Waters); Plaisancian of England (Busk) and of Italy (Manzoni); Astian of Italy (Seguenza); Sicilian of Italy (Seguenza, Neviani); Quaternary of Italy (Seguenza, Neviani).

Habitat.-Arctic Ocean: Finmark (16-48 meters). North Sea: Norway, Denmark (29-45 meters), England. Eastern Atlantic: England, English Channel, Gulf of Gascony (10-180 meters), Madeira. Mediterranean: Cette, Corse, Naples, Oran. Adriatic (32-89 meters). Southern Atlantic: Tristan da Cunha (228-243 meters), Falkland Islands (8-34 meters). Eastern Pacific: Queen Charlotte Islands, California (32-48 meters). Southern Pacific: Tahiti, Australia (5-13 meters), New Zealand. Western Pacific: Japan, Cape Tizard (China Sea) (44 meters), Indian Ocean, Red Sea. Antartic Ocean: Cape Horn (5-300 meters), Malouines Islands, Terra del Fuego.

Plesiotypes.-Cat. No. 6S5S2, U.S.N.M.

FE.NESTRULINA POROSA, new species.

Plate 37, fig. 4.

Description.-The zoarium incrusts shells. The zooecia are distinct, separated by a deep furrow, very little elongated; the surface is convex, very porous and perforated in its middle portion by a crescentric ascopore. The apertura is semilunar, transverse, surrounded by a little salient, very thin peristome. The ovicell is globular, covered with scarcely visible tuberosities and surrounded by a salient ring.

$$
\text { Measurements.-Apertura }\left\{\begin{array} { l } 
{ h a = 0 . 1 3 \mathrm { mm } . } \\
{ l a = 0 . 2 6 \mathrm { mm } . }
\end{array} \text { Zooecia } \left\{\begin{array}{c}
L z=0.65 \mathrm{~mm} . \\
l z=0.50-0.65 \mathrm{~mm} .
\end{array}\right.\right.
$$

Affinities.-The peristome frequently bears two spines. The frontal is often covered with a double pellicule.

This species is very close to Fenestrulina malusi, but differs from it in its greater number of frontal pores and in its triple instead of double rows of pores present between the aperture and the ascopore.

Occurrence.-Pleistocene: Santa Monica (Long Wharf Canyon), California (rare).

Holotype.-Cat. No. 68583, U.S.N.M.

\section{Genus MICROPORELLA Hincks, 1877.}

1877. Microporella Hincks, On British Polyzoa, Annals Magazine Natural History, ser. 4, vol. 20, p. 526 .

The operculum closes the ovicell and is semielliptical. The frontal is an ordinary tremocyst. Avicularia are present. Thirteen to fourteen tentacles.

Genotype.-Microporella (Eschara) ciliata Linnaeus, 1759.

Range.-Miocene-Recent.

Under this well-known genus we recognize three subgenera, as follows:

Diporula Hincks, 1879, characterized by a horseshoe-shaped orifice, slightly contracted by two lateral projections.

Ellipsopora, new subgenus, characterized by a transverse, elliptical apertura. 
F' 'ustramorpha Busk, 1884, characterized by the presence of radicular fibers and vibracula.

The known species belonging to this genus and its subgenera are as follows:

Microporella ciliata Linnaeus, 1759.

Microporella flabelligera Levinsen, 1909.

Microporella divaricata Waters, 1903.

Microporella hyadesi Jullien, 1888.

Microporella personata Busk, 1852.

Microporella rudis McGillivray, 1895.

Microporella rugosa Maplestone, 1900.

Microporella marginata Maplestone, 1909.

Microporella coronata Audouin, 1896.

Microporella (Flustramorpha) marginata Krauss, 1837.

Microporella (Diporula) verrucosa Peach, 1868.

Microporella (Diporula) hastigera Busk, 1884.

Microporella (Ellipsopora) flabellaris Busk, 1852.

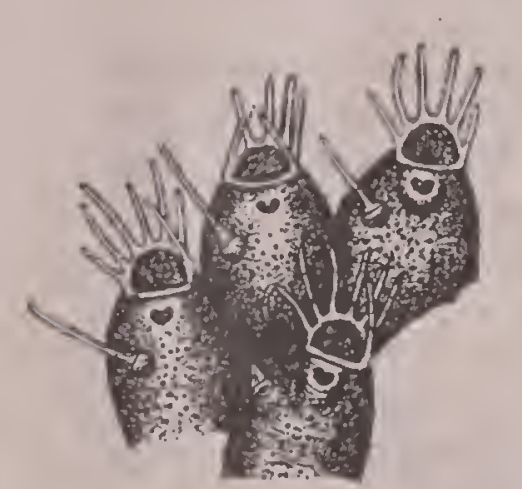

A

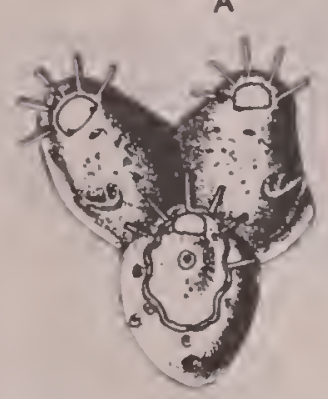

G

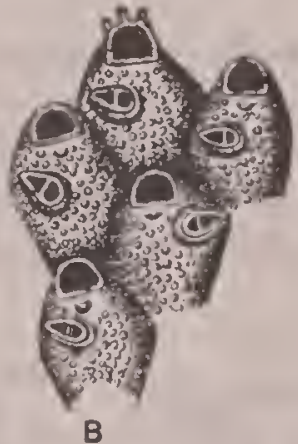

B

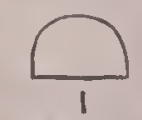

(1)

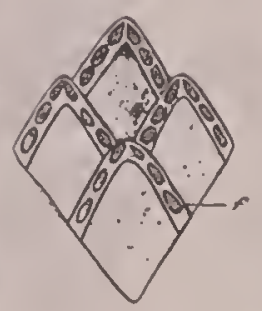

H

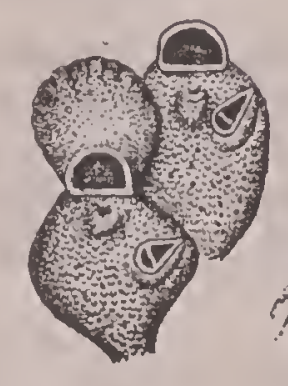

c

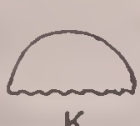

K

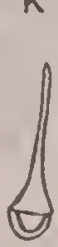

\&

$L$

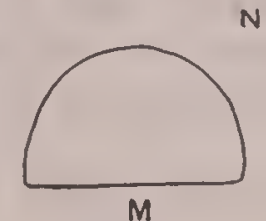

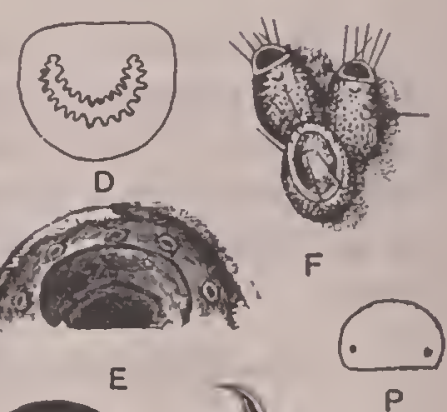

p

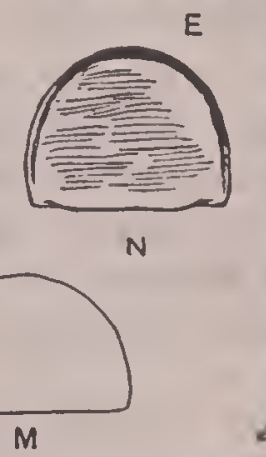

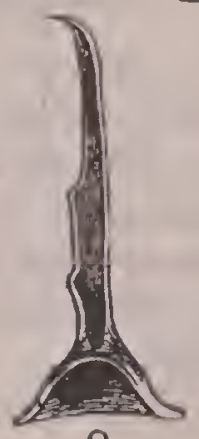

0

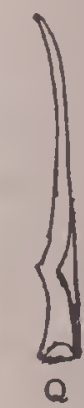

Fra. 20.-Genus Microporella Hincks, 1877.

A-I. Microporella ciliata Pallas, 1766. A. Zooecia with spines and mandible, $X 43$. B. Zooecia with avicularia, $X 29$. C. Ovicelled zooecia, $X 40$. E. Aperture, $\times 200$. F. Ancestrula and ancestrular zooecia, $\times 29$. (A-C, after Hincks, 1880.) G. The same part of the zoarium, $\times 55$. (E, F, after Levinsen, 1909.) H. Zooecia from the basal surface, $X 26$, showing the dietellae. (After Levinsen, 1894.) I. J, Opercula and mandibles. (After Waters, 1877, and Hincks, 1880.)

D. Structure of the ascopore of Aficroporella hyadesi Jullien, 1888.

K-Q. Opercula and mandibles. K, L. Mieroporella hyadesi Jullien, 188s. (After Waters, 1877.) M. Mieroporella divaricata Canu, 1902. (After Waters, 1903.) N, O. Aficroporella personata Busk, 1852. (After Busk, 1885.) P, Q. Mficroporella coronata Audouin, 1826. (After Waters, 1909.) 
Microporella CILIATA Linnaeus, 1759.

Plate 20, figs. 1-6; plate 36 , figs. 4, 5 .

1759. Cellepora ciliata Linnaeus, Systema Naturae, ed. 12, p. 1286.

1889. Mficroporella ciliata JELLY, A synonymic catalogue of marine Bryozoa, p. 179 (bibliography).

1891. Microporella ciliata Neviani, Briozoi postpliocenici di Livorno, Bollettino della Societa geologica italiana, vol. 10, p. 117 (sep. 21).

1895. Microporella (Fenestrulina) ciliata Neviani, Briozoi fossili della Farnesina Palaeontographia italica, vol. 1, p. 105 (sep. 29), pl. 5, fig. 25.

1895-1900. Mficroporella (Fenestrulina) ciliata Neviani, Briozoi neozoici di alcune localita d'Italia, Bollettino della Societa Romana per gli Studi Zoologici, pt. 1, vol. 4, p. 7; pt. 2, vol. 4, p. 234 (sep.10); pt. 3, vol. 5, p. 122 (sep. 21); pt. 5, vol. 7, pp. 13, 15; pt. 6, vol. 8, p. 3, 9, 10.

1896. Aficroporella (Fenestrulina) ciliata Nevians, Briozoi postpliocenici di Spilinga, Atti Academia Gioenia di Scienze Naturali in Catania, vol. 9, p. 22.

1900. Microporella (Fenestrulina) ciliata Neviani, Briozoi neogenici della Calabrie, Palaeontographia italica, vol. 6, p. 176 (sep. 62) (regional bibliography).

1900. Microporella (Fenestrulina) ciliata Neviant, Briozoi terziari et posterziari della Toscana, Bollettino della Societa geologica italiana, vol. 19, p. 368 (sep. 19).

1904. Microporella inflata Ulrich and Bassler, Maryland Geological Survey, Miocene, p. 416, pl. 110 , fig. 7.

1904. Microporella praciliata Ulrich and BAssler, Maryland Geological Survey, Miocene, p.415, pl. 110 , fig. 6 , pl. 113 , fig. 3 .

1905. Microporella (Fenestrulina) ciliata Nevia NI, Briozoi fossili di Carrubare (Calabria), Bollettino della Societa geologica italiana, vol. 23, p. 324 (sep. 22).

1907. Dicroporella ciliata CALvet, Expeditions scientifiques du Travailleur et du Talisman, p. 403, (regional bibliography).

1908. If icroporella ciliata WA ters, The Bryozoa of the Sudanese Red Sea, Journal Linnean Society, London, vol. 31, p. 143.

1911. If icroporella ciliata Guerin-Ganivet, Bryozoaires provenant de la Rade de Brest, Travaux du Laboratoire de Zoologie de Concarneau, p. 2.

1912. Mricroporella ciliata Guerin-Ganivet, Contributions a l'etude des Bryozoaires des côtes armoricaines, III, Travaux scientifiques du Laboratorie de Zoologie de Concarneau, p. 12.

1912. Aricroporella ciliata OsBunN, Bryozoa of Woods Hole Region, Bulletin Bureau of Fisheries, vol. 30 , p. 233, pl. 24, fig. 44; pl. 30, fig. 90 .

1912. Microporella ciliata BArRoso, Briozoos de la estacion de biologia maritima de Santander, Trabajos del museo de ciencias naturales, p. 26.

1912. Mficroporella ciliata OsBurn, Bryozoa from Labrador, Newfoundland, and Nova Scotia, Proceedings U. S. National Museum, vol. 43, p. 279.

1913. Microporella ciliata Guerin-Ganivet, Bryozoaires de la mission arctique commandee par Ch. Bénard, Société d'oceanographie du Golfe de Gascogne, vol. 7, p. 23.

1913. If icroporella ciliata CANU, Contribution a l'etude des Bryozoaires fossiles, IV, Pliocene d'Alger, Bulletin Société Geologique France, vol. 13, p. 125.

1915. Microporella ciliata Barroso, Contribucion al conocimiento de los Briozoos marinos de España, Boletin de la Sociedad española de Historia natural, vol. 15, p. 414.

1915. Microporella ciliata Waters, Marine biology of the Sudanese Red Sea, Journal Linnean Society, London, vol. 31, p. 443.

1917. Microporella ciliata Barroso, Notas sobre Briozoos, Boletin de la R. Sociedad española de Historia natural, vol. 17, p. 4.

The great variations in the calcification of the frontal in this species have been known for a long time. They have been carefully noted by the zoologists and depend solely on the nature of the water and the age of the zoarium. When the granulations are important, the tremopores appear very small and even may disappear leaving the frontal smooth (forma inflata). If the granulations are little 
developed, the tremopores appear large (forma praeciliata). A specimen from Carteret County, North Carolina, is very suggestive. The incrusting portion shows normal zooecia with granulations and tremopores (fig. 1); a bilamellar expansion shows, on the contrary, zooecia without granulations but with large tremopores (fig. 2). A specimen from Santa Barbara, California, has very small avicularia as in Microporella umbonata, but nevertheless its dimensions are absolutely identical with Microporella ciliata.

$$
\text { Measurements.-Apertura }\left\{\begin{array} { l } 
{ h a = 0 . 0 4 = 0 . 0 6 \mathrm { mm } . } \\
{ l a = 0 . 1 0 - 0 . 1 2 \mathrm { mm } . }
\end{array} \quad \text { Zooecia } \left\{\begin{array}{l}
L z=0.50 \mathrm{~mm} . \\
l z=0.30 \mathrm{~mm} .
\end{array}\right.\right.
$$

The coast of California is the Elysium of the genus Microporella, for a wealth of species occurs there. They are very closely related and their determination is not made without difficulty because of their polymorphism. It is necessary especially to take into consideration the reciprocal place occupied by the avicularium and the ascopore; the micrometric measurements are of value only in extreme cases.

Occurrence.-Miocene (Choctawhatchee marl): Jackson Bluff, Ocklockonee . River, 25 miles southwest of Tallahassee, Florida (rare). Miocene (St. Mary's formation): Cove Point, Maryland (rare). Miocene; Kuhns, Carteret County, North Carolina (rare). Miocene (Choptank formation); Jones Wharf, Maryland (rare). Pleistocene: Santa Monica (rare); Dead Mans Island, off San Pedro (rare); and Santa Barbara, California (rare).

Geological distribution.-Stampian of Germany (Schreiber); Chatian of Germany (Reuss); Miocene of Australia (Waters), ' of Tunis (Canu); Burdigalian of Gard in France (Canu collection); Helvetian of Italy (Seguenza Neviani), of France (Canu collection); Tortonian of Italy (Seguenza), of Austria-Hungary (Reuss); Sahelian of Oran (Canu collection); Zanclean of Italy (Seguenza); Pliocene of New Zealand (Waters); Plaisancian of Algeria (Canu), of Italy (Manzoni), of England (Busk); Astian of Italy (Seguenza); Sicilian of Italy (Seguenza, Manzoni, Neviani), of Rhodes (Manzoni); Quaternary of Italy (Waters, Seguenza, Neviani, De Stefani).

Habitat.-Cosmopolitan.

Plesiotypes.-Cat. Nos. 68584-68590, U.S.N.M.

MICROPORELLA HEXAGONA, new species.

Plate 20, figs. 14, 15.

Description.-The zoarium incrusts shells. The zooecı are little distinct, separated by a furrow, short, hexagonal,convex, gibbose; the frontal is convex, irregular, and formed of a tremocyst with large pores detachable from a subjacent, finely perforated olocyst. The apertura is deeply buried, semilunar; the peristome is somewhat salient, rery thin, and bears four to six large, hollow spines. The oricell is little salient and is covered by an incomplete tremocyst. The ascopore is large and is surrounded by a very. salient peristome. There are two small avicularia or a single one very large and salient.

$$
\text { Measurements.-Apertura }\left\{\begin{array} { l } 
{ h a = 0 . 0 7 \mathrm { mm } . } \\
{ l a = 0 . 1 2 - 0 . 1 5 \mathrm { mm } . }
\end{array} \text { Zooecia } \left\{\begin{array}{l}
L z=0.45-0.50 \mathrm{~mm} . \\
l z=0.45 \mathrm{~mm} .
\end{array}\right.\right.
$$


Affinities.-The intensity of the calcification is remarkable in this species and gives to it an aspect very characteristic and difficult to figure. The large avicularium is triangular, the beak pointing upward; the pivot is almost always broken. The distal border of the apertura is often denticulated by the rupture of the hollow spines much wider than the peristome. In spite of its double protective envelope the ovicell is often broken. The exterior aspect is absolutely unique. This species must have lived in a strong current. (rare).

Occurrence.-Miocene (Duplin marl): Darlington Courthouse, South Carolina

Holotype.-Cat. No.68591, U.S.N.M.

MICROPORELLA BIFOLIATA Ulrich and Bassler, 1904.

Plate 20, figs. 7-11.

1904. Microporella? bifoliata Ulrich and BAssler, Maryland Geological Survey, Miocene, p. 417, pl. 113, figs. 6-8.

The original description is as follows:

Zoarium erect, bifoliate, not known to branch. Zooecia subquadrate or hexagonal, arranged in regular longitudinal and diagonally intersecting series, four longitudinally and five diagonally in 2 $\mathrm{mm}$. Appearance of surface varying with age. In young examples the zooecia are more or less convex and separated, especially transversely, by an impressed line containing one or more rows of pores; the orifice is somewhat transverse and subovate with the proximal side straightened, the peristome but little elevated, the front sparsely punctated, the avicularia of which there is usually one to each zooecium placed some distance beneath and to one side of the orifice, rather large, subcircular and divided into two nearly equal parts by a thin partition. In old examples the oral part is sunken and the rest of the surface abundantly punctate, while the avicularia have been somewhat reduced in size. Immediately behind the orifice there is always a small (? peristomial) pore. Ovicells large, rather strongly convex, punctate.

$$
\text { Measurements.-Apertura }\left\{\begin{array} { l } 
{ h a = 0 . 1 1 \mathrm { mm } . } \\
{ l a = 0 . 1 2 \mathrm { mm } . }
\end{array} \quad \text { Zooecia } \left\{\begin{array}{l}
L z=0.55 \mathrm{~mm} . \\
l z=0.25-0.35 \mathrm{~mm} .
\end{array}\right.\right.
$$

We have nothing to add to the original description except to call attcntion to the fact that the ascopore is crescent shaped.

This species differ from Microporella ciliata Linnaeus, 1759, in the absence of frontal granules, in the presence of larger tremopores and in its nontransverse aperture which is almost as high as wide. The erect form of the zoarium is rather rare in the genus Microporella and it appears to form a good character for this species. Nevertheless we have observed bilamellar expansions in Microporella ciliata.

Occurrence.-Miocene (Choptank formation): Cordova, Maryland (rare).

Cotypes.-Cat. No. 68592, U.S.N.M.

MICROPORELLA FISSURIFERA, new species.

Plate 19, figs. 12-13.

Description.-The zoarium incrusts shells. The zooecia are distinct, separated by a deep furrow, elliptical, little elongated, wide; the frontal is convex and perforated by a large number of tremopores. The apertura is semilunar, transverse; it is surrounded by a thin peristome bearing four large spines. The ascopore is placed 12181-23-Bull. $125-9$ 
on a median prominence of the frontal. The avicularium is short, triangular, without pivot, with its beak turned toward the top. The dietellae are not entirely covered over, and appear between the zooecia in the form of small slits. The ovicell is large, globular, buried in the distal zooecium, covered with a tremocyst.

$$
\text { Measurements.-Apertura }\left\{\begin{array} { l } 
{ h a = 0 . 1 0 \mathrm { mm } . } \\
{ l a = 0 . 1 0 - 0 . 1 2 \mathrm { mm } . }
\end{array} \quad \text { Zooecia } \left\{\begin{array}{l}
L z=0.60 \mathrm{~mm} . \\
l z=0.50 \mathrm{~mm} .
\end{array}\right.\right.
$$

Variations.-In this genus, where the species are so difficult of determination, the present species is very well characterized by the dietellae not entirely covered over by the tremocyst. We are ignorant as to the cause of this remarkable peculiarity, which has been observed hitherto only in the Membraniporae. The distal diatellae are visible on the marginal zooecia. The two proximal spines are always larger and more salient than the distal spines. Our micrometric measurements are those of the larger zooecia for the variations are considerable.

Occurrence.-Miocene (Yorktown): Near Macedonia Church, Essex County, (very rare); 1 mile northeast of Suffolk, 3 miles southwest of Petersburg, and other localities in Virginia. Miocene (Duplin marl): 10 miles south of Greenville, North Carolina (rare).

Cotypes.-Cat. Nos. 68593, 68594, U.S.N.M.

MiCROPORELla TessellatA. Tuomey and Holmes, 1857.

Plate 30 , figs. $2,3$.

1857. Cellepora tesselata Tuomey and Holmes, Pliocene fossils of South Carolina, p. 13, pl. 4, fig. 7.

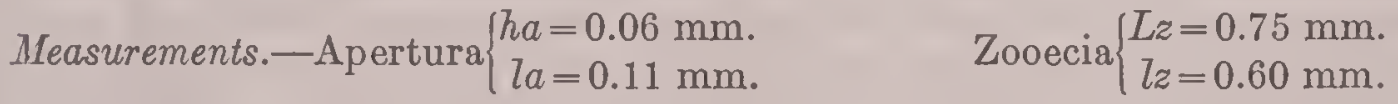

Variations.-There are often six very short and very inconstant spines. The vestibular arch is always visible. The apertura is relatively small for so large a species, which appears to indicate extremely fine tentacles. The frontal is perforated with rather large tremopores. The ascopore is surrounded by a salient peristome. In the vicinity of the ancestrula the avicularium is small and placed at the level of the ascopore. The large marginal zoeceia have their avicularia larger and placed in the wider part of the zooecium well below the ascopore. This character is quite visible on the figure of Tuomey and Holmes and we believe that it is sufficient to recognize this long-forgotten species of these American authors. There are six lateral and one distal dietellae.

Affinities.-This species differs from Microporella eustomata Gabb and Horn, 1862, and from Microporella vibraculifera Hincks, 1883, in its smaller avicularium, more distant from the zooecial axis and of a more irregular position. It differs from Microporella ciliata Linnaeus, 1759, in the large zooecial dimensions and its larger вvicularium.

Occurrence.-Pliocene (Waccamaw marl): Waccamaw River, Horry County, and Giles Bluff, Peedee River, South Carolina (Tuomey and Holmes).

Pleisotypes.-Cat. No. 68595, U.S.N.M. 
MICROPORELLA UMBONATA Hincks, 1882.

Plate 36, figs. 6, 7 .

1882. Microporella ciliata forma umbonata HrNcks, Report on the Polyzoa of the Queen Charlotte Islands, Aunals and Magazine of Natural History, ser. 5, vol. 2, p. 15, pl. 17, fig. 1.

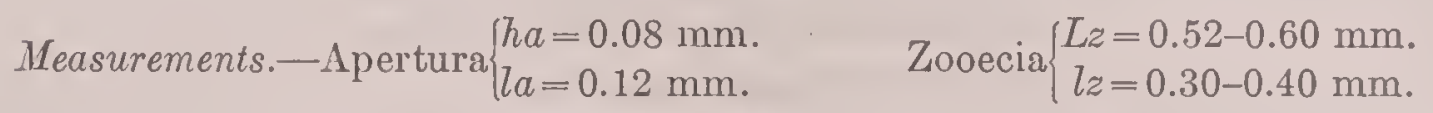

Variations.-There is one small oral avicularium (rarely two). The frontal is a tremocyst with small pores. The oviccll is costulated. The frontal gibbosity (umbo) is always placed below the ascopore. Our specimens bear no spines.

Affinities.-This spccies differs from Microporella ciliata Linnaeus, 1759, in the presence of the frontal umbo and in its larger micrometric dimensions. It differ's from Microporella fallax Canu, 1904 from the post-Pampean of Argentina, which also bears a frontal gibbosity, in its avicularium which is placednotmuch below the ascopore but always at the same lcrel with it.

Occurrence.-Pleistocene: Santa Monica (rare), Santa Barbara (very rare), and Dead Mans Island, off San Pedro (very rare), California.

Habitat.-Queen Charlotte Islands.

Plesiotype.-Cat. No. 68596, U.S.N.M.

\section{Microporella CALiforNica Hincks, 1883.}

Plate 36, figs. 8-10.

1858. Lepralia californica Busk, Zoophytology, Quarterly Journal Microscopical Science, vol. 4, p. 310 , pl. 11, fig. 6 .

1883. Microporella ciliata forma californica Hincks, Report on the Polyzoa of the Queen Charoltte Islands, Annals' and Magazine Natural History, ser. 5, vol. 2, p. 444, pl. 17, fig. 3.

1908. Microporella californica RoBertson, The incrusting chilostomatous Bryozoa of the west coast of North America, University of California Publications, Zoology, vol. 4, No. 5, p. 281, pl. 18, figs. 32-34.

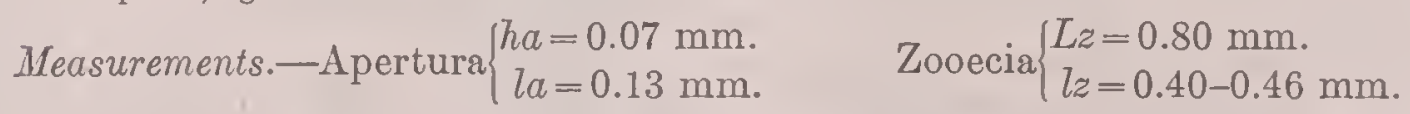

Variations.-Our specimens are somewhat larger than those living to-day off the coast of California. There are six spines but on our fossils only two, three, or four alone persist. The frontal is a tremocyst with large pores superposed on an olocyst perforated by very small corresponding pores; it is detachable.

The two avicularia are rather constant erect, rather long, very sharp, with a very fragile pivot; their slender beak is easily broken. In some cascs one avicularium is smaller than the other. There is a salient frontal gibbosity bearing the ascopore or placed below it. The ascopore is surrounded by a smooth peristone.

Hincks, 1883, thought that his specimens belonged to Busk's species, 1856. Waters, 1908, affirmed that Busk's species is Microporella coronata Savigny-Audouin, 1826.

Affinities.-This species much resemblcs Microporella coronata Savigny-Audouin, 1826 , in its costulate ovicell; it differs from it in the presence of six spines (and not four) and in its larger avicularia. It diffcrs from Microporella ciliata Linnaeus, 1759 , in the constant presence of two large avicularia, and in its frontal with large tremopores. 
Occurrence.-Pleistocene: Santa Monica (Long Wharf Canyon) (rare), Santa Barbara (common), and San Pedro (rare), California.

Habitat.-Queen Charlotte Islands and coast of California.

Plesiotypes.-Cat. Nos. 68597, 68598, U.S.N.M.

Microporella vibraculifera Hincks, 1883.

Plate 36 , figs. 11,12 .

1883. Microporella ciliata forma vibraculifera HiNcrs, Report on the Polyzoa of the Queen Charlotte Islands, Annals and Magazine of Natural History, ser. 5, vol. 11, p. 15, pl. 17, fig. 2.

1890. Microporclla ciliata, var. vibraculifera OrtMann, Die japanische Bryozoen-Fauna, Archiv für Naturgeschichte, vol. 50, pt. 1, p. 38, pl. 3, fig. 5 .

Measurements.-Apertura $\left\{\begin{array}{l}h a=0.06 \mathrm{~mm} . \\ l a=0.12 \mathrm{~mm} .\end{array} \quad\right.$ Zooecia $\left\{\begin{array}{l}L z=0.50-0.60 \mathrm{~mm} . \\ l z=0.34-0.40 \mathrm{~mm} .\end{array}\right.$

Variations.-There are six large hollow spines. The ovicell and the frontal bear large tremopores. The avicularium is large, salient, tuberous, placed laterally and lower than the ascopore; the mandible is placed transversally. The ovicell is costulate. The organ originally called vibraculum by Hincks is in reality an avicularium with very long and setiform mandible. There is often a pivot.

Affinities.-This species differs from Microporella ciliata Linnaeus, 1759 , in the presence of six large hollow spines and in larger micrometric measurements. It differs from Microporella fallax Canu, 1904, in its larger avicularium placed very near the ascopore. It differs from Microporella eustomata Gabb and Horn, 1862, in its transverse avicularium.

Occurrence.-Pleistocene: Santa Monica (Rustic Canyon) (rare), Dead Mans Island off San Pedro (rare), and Santa Barbara (very rare), California.

Habitat.-Queen Charlotte Islands and Japan (113-405 meters).

Plesiotypes.-Cat. Nos. 68599,68600, U.S.N.M.

Microporella EUSTOMATA Gabb and Horn, 1862.

Plate 36, fig. 13.

1862. Reptoporina customala GABB and Honn, Monograph of the fossil Polyzoa of the Secondary and Tertiary formations of North America, Journal Academy of Natural Sciences of Philadelphia, ser. 2 , vol. 5 , p. 144, pl. 20, fig. 26 .

Measurements.-Apertura $\left\{\begin{array}{l}h a=0.06 \mathrm{~mm} . \\ l a=0.12 \mathrm{~mm} .\end{array} \quad\right.$ Zooecia $\left\{\begin{array}{l}L z=0.60-0.80 \mathrm{~mm} . \\ l z=0.50 \mathrm{~mm} .\end{array}\right.$

Affinities.-Gabb and Horn's figure is very characteristic; the mandible of the avicularium is oblique in relation to the zooecial median axis so that the whole avicularium convexity appears bent toward this same axis. This is the exact case in our specimens. However, they bear only six large hollow spines instead of eight shown on the figures of the American authors. 'The frontal and the ovicell are garnished with large tremopores. The ovicell is preceded by a sort of tubular turret, at the base of which is buried the operculum. The avicularium is curved and always has a pivot.

This species differs from Microporella vibraculifera Hincks, 1883, in its oblique and nontransverse avicularium. It differs from all the other species of Microporella in its large avicularium.

Occurrence.-Pleistocene: Santa Monica (Rustic Canyon) (rare) and Santa Barbara, California (Gabb and Horn).

Plesiotype.-Cat. No. 68601, U.S.N.M. 
MICROPORELLA HEERMANNI Gabb and Horn, 1862.

Plate 37, figs. 1, 2.

1862. Reptescharellina heermanni Ganis and Honn, Monograph of fossil Polyzoa of the Secondary and Tertiary formations of North America, Journal Academy Natural Sciences of Philadelphia, ser. 2, vol. 5 , p. 147, pl. 20, fig. 30 .

Description.-The zoarium incrusts shells. The zooecia are large, elliptical, swollen, separated by a furrow, convex; the frontal is formed by a granular tremocyst perforated by numerous small pores. The apertura is semilunar, transverse; the peristome is thin, somewhat salient, deprived of spines resistant to fossilization.
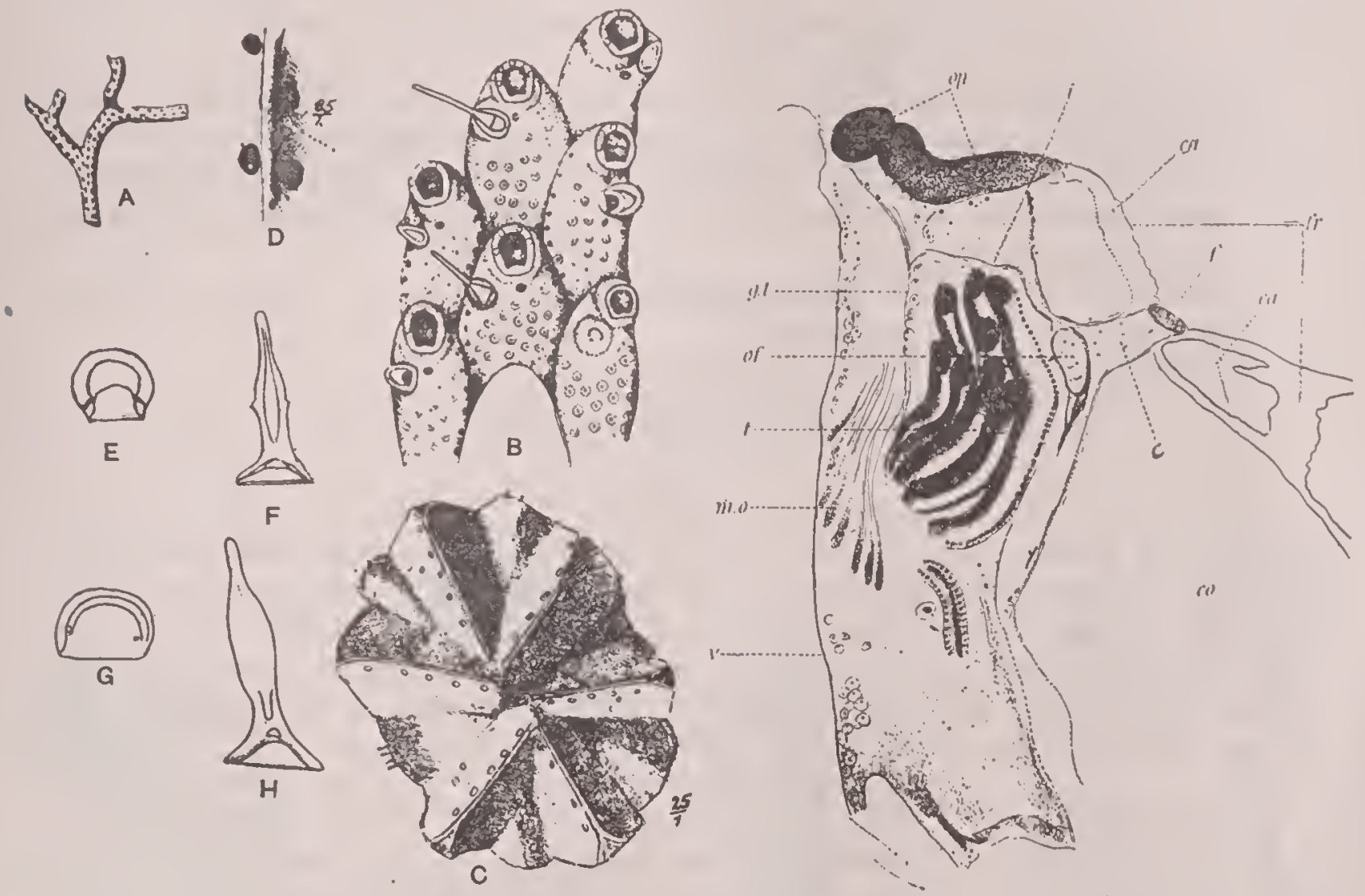

F1a. 21.-Subgenus Diporula Hincks, 1879.

A-F. Diporula verrucosa Peach, 1868. A. Zoarium, natural size. B. Zooecia with avicularia and mandibles, $\times 25$. (A, B, after Hincks, 1880.) C, D. Growing extremity of a zoarium. The ends of the last formed row of zooecia have a doublc slope, like the roof of a house with a raised, rounded, slightly overlapping ridge at the top. On each side of this arc usually five tubular holes and one or two lower down on the side. At the bottom of these tubes is a membrane which has one, two, or even more minute perforations. D shows the ridge of the roof and rosette pores, $X 85$. E. Operculum, $X 85$. (C-E, after Watcrs, 1878.) F. Mandible, $\times 85$. (After Waters, 1885.)

G-I. Diporula hastigera Busk, 1884. G. Operculum, $\times 85$. H. Mandible, $\times 85$. (After Waters, 1889.) I. Section of zooecium showing anatomical structure. (After Jullien, 1903.) av, avicularium; $c$, corniculum; $c a$, calcite; $c o$, compensatrix; $f$, fenestrulc (=ascopore); $f r$, frontal; gt, tentacular sheath; $i$, irisoid; mo, opercular muscles; of, inferior orifice of the corniculum; op, operculum; $t$, tcntacles; $v$, dorsal. The corniculum is not a tube allowing communication of the ascopore with the tentacular sheath as Jullien thought, but it is a simple fold of the compensatrix probably determined by the size of the tentacles. 
The ovicell is globular, placed on the distal zooecium, and of the same nature as the frontal. One or two small triangular oblique avicularia are located on each side of the ascopore.

$$
\text { Measurements.-Apertura }\left\{\begin{array} { l } 
{ h a = 0 . 1 0 \mathrm { mm } . } \\
{ l a = 0 . 1 6 \mathrm { mm } . }
\end{array} \text { Zooecia } \left\{\begin{array}{r}
L z=0.70-1.00 \mathrm{~mm} . \\
l z=0.50-0.60 \mathrm{~mm} .
\end{array}\right.\right.
$$

Affinities.-This large species is well characterized. It differs from Microporella californica Hincks, 1883, in its smaller tremopores, its avicularia twice as short, its granular frontal, and its larger dimensions. The vestibular arch is as large as in Microporella ciliata Linnaeus, 1759; it differs from it in its micrometric measurements, which are twice as large $(L z=1.00 \mathrm{~mm}$. and not $0.50 \mathrm{~mm}$.). It differs from Microporella gibbera in the regular form of its zooecia and in its small avicularia placed at the level of the ascopore.

Although we have not found this species at Santa Barbara, Gabb and Horn's type locality, we do not hesitate to compare our specimens with Reptescharella heermanni Gabb and Horn. Their figure resembles Microporella ciliata Linnaeus, 1759, as much as it does the present one, but we believe it best to adopt their name instead of suggesting a new one.

Occurrence.-Pleistocene: Santa Monica (Rustic Canyon) (rare), and Santa Barbara, California (Gabb and Horn).

Plesiotype.-Cat. No. 68602, U.S.N.M.

\section{MICROPORELLA GIBBERA, new species.}

Plate 37, fig. 3.

Description.-The zoarium is unilamellar. The zooecia are distinct, separated by a furrow, very irregular, gibbose; the frontal is convex and perforated by numerous and rather large spines. The apertura is semilunar, transverse; the peristome is thin, a little salient, deprived of spines, resistant to fossilization. The ascopore is very small and placed in the immediate vicinity of the apertura. The ovicell is large, very globular, irregular, of the same nature as the frontal. The two avicularia are very small and placed lower than the ascopore.

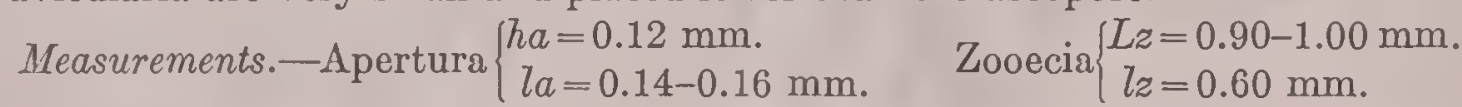

Affinities. - The two avicularia are not constant; there is often only a single one, somewhat a little larger. The form of the zooecia defies description.

This species differs from Microporella heermanni Gabb and Horn, 1862, in which the dimensions are close, in the irregularity of its zooecia and in its small avicularia placed below the ascopore.

Occurrence.-Pleistocene: Rustic Canyon, Santa Monica, California (very rare). Holotype.-Cat. No. 68603, U.S.N.M.

Subgenus Diporula Hincks, 1879.

1879. Diporula Hincks, On the classification of the British Polyzoa, Annals and Magazine Natural History, ser. 5, vol. 3, p. 156.

The operculum is semilunar and closes the ovicell. The frontal is a tremocyst. Avicularia are present. The apertura is horseshoe shaped and is slightly contracted by two lateral projections. The concavity of the ascopore is denticulated. Genotype.-Diporula (Eschara) verrucosa Peach, 1873.

Range.-Pliocene-Recent. 


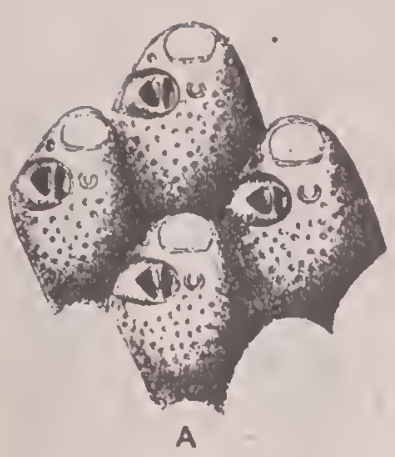

A

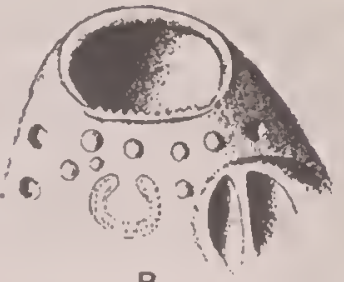

B

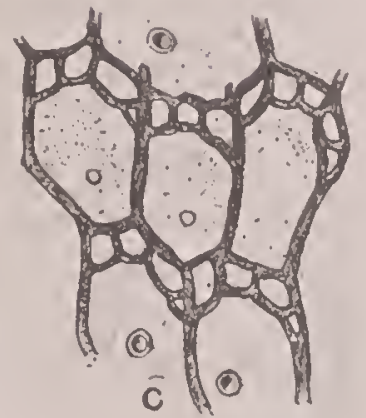

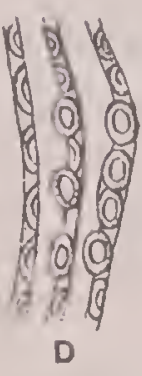
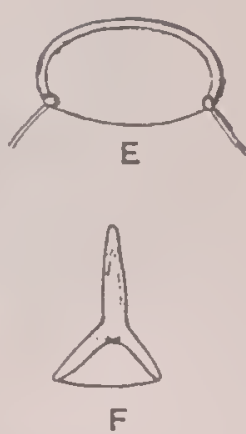

FrG. 22.-Subgenus Ellipsopora, new.

A-F. Ellipsopora (Nicroporella) fabellaris Busk, 1852. A. Zooecia with avicularia, $\times 40$. B. The distal end of a zooecium, $\times 100$. C. Zooecia from the basal surface, $\times 40$. Besides the basal wall of the dietellae, the small triangular basal surface of the vibracular chamber is seen lowest down to the right on the four zooecia. On some zooecia the basal surface shows a septula and on others an opening corresponding with a septula in an opposite zooecium. D. Radical fibers, $\times 140$. E. Operculum, $\times 140$. F. Mandible, $\times 55$. (A-F, after Levinsen, 1909.)

ElLIPSOPORA, new subgenus.

The aperture is transverse, elliptical. The operculum is elliptical and closes the ovicell. The frontal is a tremocyst. There is a vibraculum on each zooecium.

Genotype.-Ellipsopora (Eschara) flabellaris Busk, 1852. Recent.
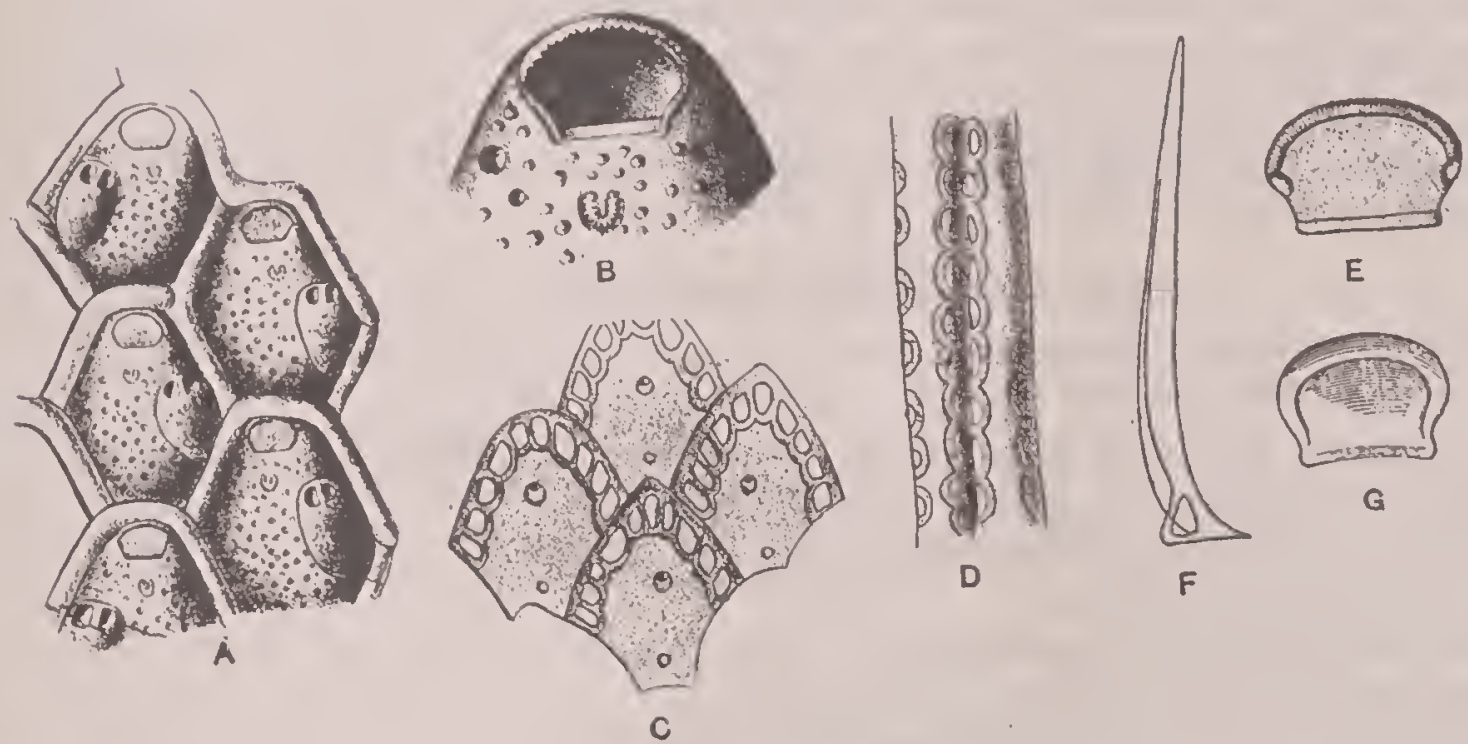

$E$

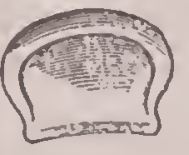

G

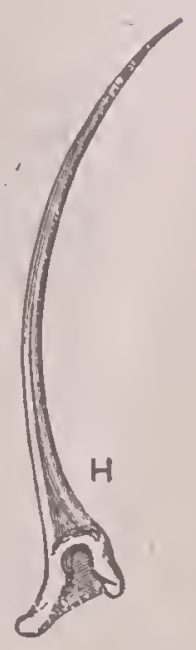

Fra. 23.-Subgenus Flustramorpha Gray, 1848.

A-H. Flustramorpha marginata Krauss, 1837. A. Zooecia with their avicularium, $\times 40$. B. The distal end of a zooecium, $\times 100$. C. Four zooecia, from the basal surface, $\times 40$. In addition to the marginal dietellae, each basal zooecial surface shows a rosette plate (=septula) and an opening for communication with zooecia in the opposite layer. D. Radical fibers, $\times 40$. E. Operculum, $\times 140$. F. Avicularian mandible, $\times 55$. (A-F, after Levinson, 1909.) G, H. Operculum and mandible. (After Busk, 1885.) 
Subgenus FuUstramorpha Gray, 1848.

1818. Flustramorpha GraY, List of British Animals in British Museum, pt. 1, Centroniae or Radiated animals.

The operculum closes the oricell; it is trapezoid. The zoarium is chitinous. "Zoarium erect, radicate, bilaminar, composed of irregular lobes, bordered and loosely connected by chitinous tubes; mouth coarctate; a lateral pouch-like vibracularium." (Busk.)

Genotype.-Flustramorpha (Flustra) marginata Krauss, 1837. Recent.

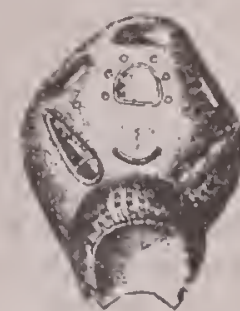

A

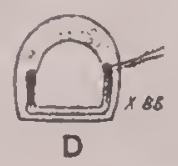

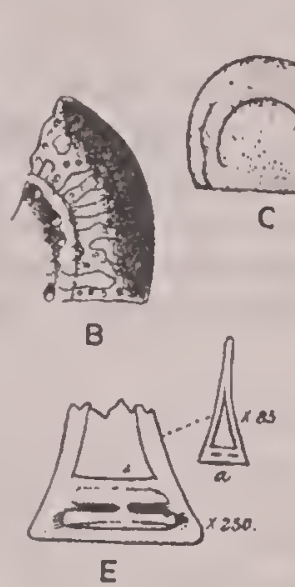

E

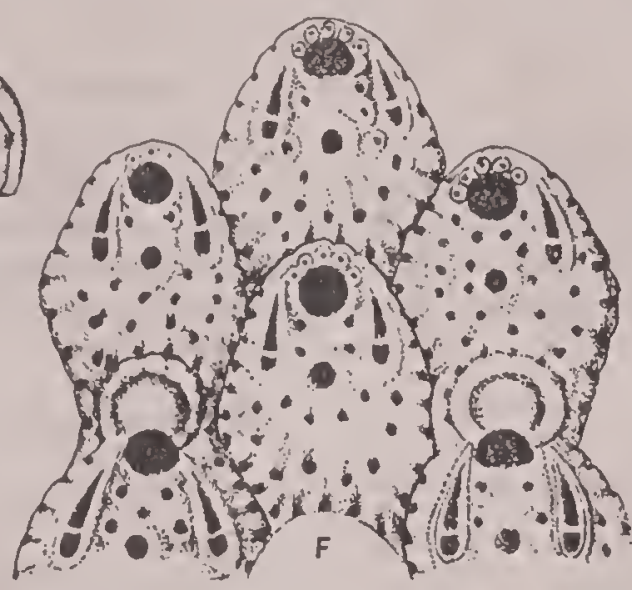

Frg. 24.-Genus Calloporina Neviani, 1895

A-F. Calloporina decorata Reuss, 1847. A. The zooecium is furnished with three distal dietellae, and the curved belts on the ovicell, at the base of which are seen the fine pores of the endooecium, are canal like cavities between the endooecium and the distal calcified part of the ectooecium. Between these canals, which open through a circle of pores, the two layers of the zooecium have united; $\times 40$. B. A portion of the zooecium, magnified $\times 75$. C. Operculum, $\times 100$. (A-C, after Levinsen, 1909.) D. Operculum, $\times 85$. E. Mandible, $\times 85$. (D, E, after Waters, 1887.) F. Portion of a fossil zoarium. (After Manzoni, 1875.)

\section{Genus CALLOPORINA Neviani, 1895.}

1895. Calloporina Neviani, Briozoi fossili della Farnesina e Monte Maria presso Roma Paleontographia Italica, Pisa, vol. 1, p. 107.

The frontal is garnished with lateral areolar pores. Costules and avicularia are present. The ascopore is circular.

Genotype.-Calloporina (Cellepora) decorata Reuss, 1847.

Range.-Helretian-Recent.

The known species of the genus are:

Calloporina (Cellepora) decorata Reuss, 1847.

Calloporina (Lepralia) diadema MacGillivray, 1868.

Calloporina (Microporella) renipuncta MacGillivray, 1882.

Calloporina (Microporella) scandens MacGillivray, 1884. 

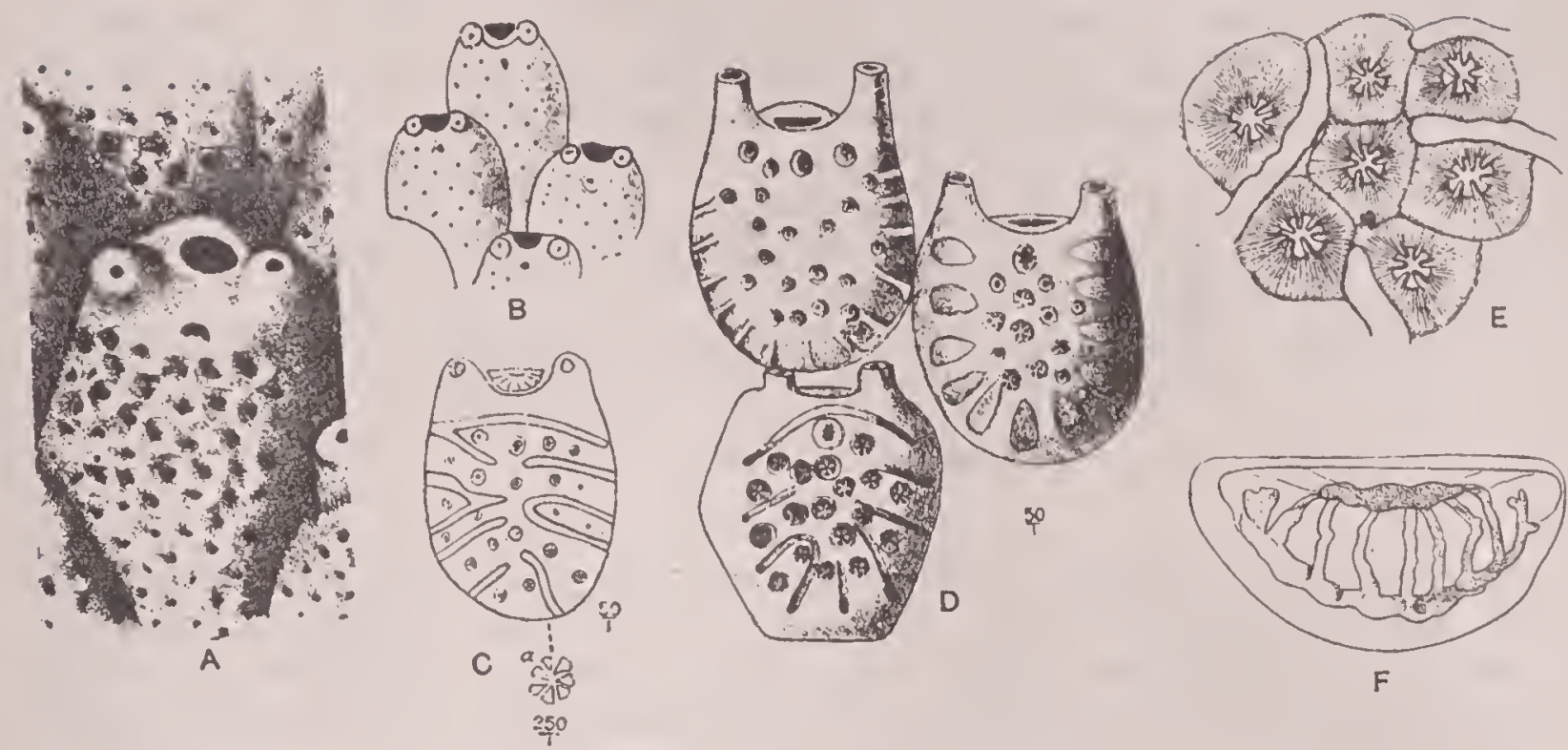

Fig. 25.-Genus Inversiula Jullien, 1888.

A. Inversiula nutrix Jullien, 1888. Zooecium. (After Jullien, 1888.)

B-F. Inversiula inversa Waters, 1889. B. Zooecia, $\times 25$. C. Decalcified zooecia, $\times 50$. Distinct tubes occupy the place of the grooves. The interior membrane of the zooecial wall is not perforated by the stellate pores. A stellate pore $\times 250$ is represented at $a$. D. Three stages of growth, $\times 50$. There are deep grooves between the stellate pores. (B-D, after Waters, 1889.) E. Structure of the stellate pores, $\times 200$. (After Levinsen, 1909.) F. Operculum, X 250. (After Waters, 1887.)

Genus INVERSIULA Jullien, 1888.

1888. Inversiula Jullien, Mission scientifique du Cap Horn. 1882-83, VI, Zoologie, Bryozoaires, p. 41.

No ovicell. The frontal is a tremocyst with stellate pores. The aperture is elliptical and transverse. The convexity of the ascopore is turned toward the aperture. Avicularia are present. No spines.

Genotype.-Inversiula nutrix Jullien, 1888.

Range.-Miocene-Recent.

The known species of this genus are:

Inversiula nutrix Jullien, 1888.

Inversiula (Microporella) inversa Waters, 1889.

Inversiula (Microporella) airensis Maplestone, 1910.

Inversiula (Microporella) quadricornis Maplestone, 1910.

Group 3. HIPPOPORAE Canu and Bassler, 1917.

Genus HIPPOPORINA Neviani, 1895.

(For description see Bulletin 106, U. S. National Museum, p. 374.)

HIPPOPORINA PUSILLA, new species.

Plate 45, figs. $8,9$.

Description.-The zoarium incrusts sponges and corals. The zooecin are distinct, separated by a furrow, small, elongate, elliptical; the frontal is an absolutely smooth olocyst. The apertura is very small, surrounded by a thick peristome which 
is salient tuberous, or garnished with six spines; two very small cardelles placed on the lower third separate the anter from the concave poster. The ovicell is globular, salient; it can not be closed by the operculum.

Measurements.-Apertura $\left\{\begin{array}{l}h a=0.07 . \\ l a=0.05 \mathrm{~mm} .\end{array} \quad\right.$ Zooecia $\left\{\begin{array}{l}L z=0.40 \mathrm{~mm} . \\ l z=0.25 \mathrm{~mm} .\end{array}\right.$

Affinities.-The saliency of its peristome and its small dimensions characterize this species quite well.

Occurrence.-Pleistocene: Mount Hope, Panama Canal Zone (very rare).

Holotype.-Cat. No. 68604, U.S.N.M.

\section{HIPPOPORINA GIBBOSA, new species.}

Plate 18, fig. 10.

Descriptions.-The zoarium incrusts shells. The zooecia are distinct, separated by a furrow of little depth, hexagonal, elongate; the frontal is s mooth, little convex, garnished with a frontal gibbosity. The apertura is elongate and formed of a large anter separated by two cardelles from a small poster with proximal border almost straight. The ovicell is large globular, widely open.

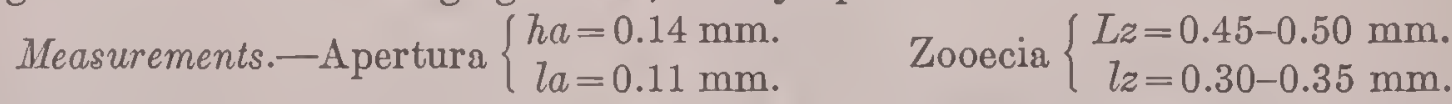

Variations.-No other known species of the genus Hippoporina presents a frontal gibbosity; it is"therefore easy to distinguish this one and no error is possible. The micrometric measurements of the zooecia are quite variable and our figure shows a zooecium measuring $0.60 \mathrm{~mm}$. in width. This irregularity is difficult to explain, for it is not occasioned only by calcification; it is real and easy to ascertain on the worn zooecia whose frontal is broken. In most of the other Cheilostomatous bryozoa the irregularity is more apparent than real and examination of the interiors reveals the zooecia to be practically equal.

Occurrence.-Miocene (Duplin marl): Wilmington, North Carolina (rare).

Holotype.-Cat. No. 68605, U.S.N.M.

\section{HIPPOPORINA(?) VESTITA, new species.}

Plate 18, figs. 7-9.

Description.-The zoarium incrusts oysters. The zooecia are distinct, hexagonal, separated by a furrow of little depth, with little convex frontal, smooth and covered by two or three superposed calcareous pellicles. The apertura is elliptical, elongate. The ovicell is little salient; it bears a very fragile frontal area.

Variation.-This is a strange species, the generic position of which is very uncertain; but we are unable to create a special genus for such incomplete specimens. The latter bear only broken ovicells and we can not obtain an exact idea of their nature. The exterior calcification is very remarkable. The deposit of two or three calcareous pellicles can only be explained by an endocystal covering, immediately adjacent to the ectocyst.

Occurrence.-Miocene (Choctawhatchee marl): Jackson Bluff, Ocklocknee River, 25 miles southwest of Tallahassee, Florida (rare).

Holotype.-Cat. No. 68606, U.S.N.M. 
HIPPOPORINA LATA(?) Smitt, 1872.

Plate 1, fig. 11.

1872. Gemellipora lata Surtr, Floridan Bryozoa, pt. 2, Kongl. Svenska Vetenskaps-Akademiens Handlingar, vol. 11, No. 4, p. 36, pl. 7, fig. 1557.

1919. Hippoporina lata CANU and BASsler, Geology and Paleontology of the West Indies, Bryozoa, Publications of the Carnegie Institution at Washington, No. 291, p. 93, pl. 1, fig. 14.

This recent species was described from specimens from the Floridan waters and the species itself is confined to this region. A very mediocre fossil specimen of doubtful determination has been found in the strata of Antigua.

Occurrence.-Oligocene (Antigua formation): Rifle Butts, Antigua, Leeward Islands (rare).

Plesiotype.-Cat. No. 68607, U.S.N.M.

Genus HIPPODIPLOSIA Canu, 1916.

(For description see Bulletin 106, U. S. National Museum, p. 393.)

HIPPODIPLOSIA BACCATA Canu and Bassler, 1920.

Plate 3, fig. 1.

1920. Hippodiplosia baccata CÁNu and BASsler, Monograph of the Early Tertiary Bryozoa of North America, Bulletin 106, U. S. National Museum, p. 397, pl. 87, figs. 5, 6.

This species, which was based on specimens from the Vicksburgian of Mississippi, is represented in Lower Miocene strata at Bowden, Jamaica. In these Miocene specimens the tremocyst is separable and the intensity of the calcification is very active in the ancestrular region.

Occurrence.-Miocene (Bowden marl): Bowden, Jamaica (rare).

Geologic distribution.-Vicksburgian of Mississippi.

Plesiotype.-Cat. No.68608, U.S.N.M.

HLPPODIPLOSIA BIGIBERRA, new species.

Plate 12, fig. 10.

Description.-The zoarium incrusts shells. The zooecia are distinct, separated by a furrow, elongated, subrectangular; the frontal is somewhat convex, perforated by a dozen of small tremopores and ornamented with two gibbosites symmetrically placed in the vicinity of the apertura, which they hide and partially deform. The apertura is elliptical, elongated; two small, deep cardelles separate a large anter from a small poster.

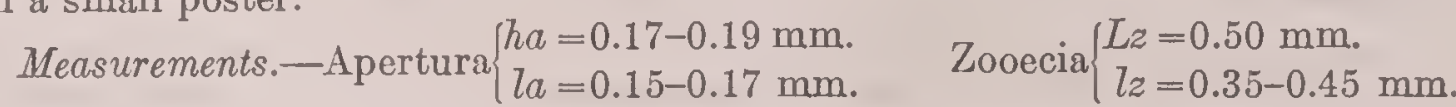

Structure.-The aspect of the apertura is very deceiving in a photograph. It appears to resemble that of Gemellipora, but this is an optical illusion arising from the projection on the same plane of the different zooecial elevations. In reality the apertura is elliptical, but its proximal portion is deformed by two frontal gibbosites which appear thus separated by a false rimule. By inclining specimens the true form of the apertura is visible.

Occurrence.-Miocene (Yorktown formation): 3 miles southwest of Petersburg, Virginia (rare).

Holotype.-Cat. No. 68609, U.S.N.M. 
Genus HIPPOMENELLA Canu and Bassler, 1917.

(For description see Bulletin 106, U. S. National Museum, p. 379.)

HIPPOMENELLA INFRATELUM Canu and Bassler, 1919.

Plate 6, fig. 2.

1919. Hippomenella infratelum CANU and Bassler, Geology and Paleontology of the West Indies Bryozoa, Publications of the Carnegie Institution of Washington, No. 291, p. 92, pl. 6, fig. 2.

Description.-The zoarium is a narrow Eschara borne on an cxpanded base. The zooccia are clongatc, distinct, elliptical; the frontal is convex, surrounded by a line of small areolar pores and formed of a pleurocyst very finely granulated. The apertura is elliptical, clongate, with two very small cardelles. The avicularium is salient, elliptical with pivot, placed on the line of pores in the lower part of the zooecium.

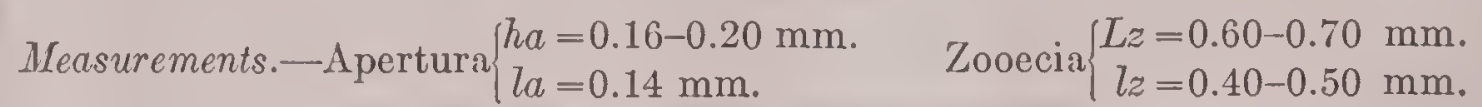

Affinities.-The only specimen found has been figured. The species is absolutely characterized by its elliptical a vicularium placed inferiorly, a character which does not exist in the other species of the genus. We have observed a rather rare case of regeneration of a zooecium by an avicularium $(z r)$.

Occurrence.-Lower Miocenc (Bowden marl) : Cercado de Mao, Santo Domingo (very rare).

Holotype.-Cat. No. 68610, U.S.N.M.

Genus HIPPOPORELLA Canu and Bassler, 1920.

(For description see Bulletin 106, U. S. National Museum, p. 377.)

HIPPOPORELLA SPINOSA, new species.

Plate 19, fig. 10.

Description.-The zoarium incrusts other bryozoa. The zooecia are distinct, separated by a deep furrow, somewhat elongate, elliptical; the frontal is smooth, very convex, garnished laterally with small areolar widely spaced pores. The apertura is elongate, the proximal border is almost straight; the two small cardelles arc placed very low; the peristome is little salient and bears six spines. There is a vestibular arch. The ovicell is large, globular, salient, never closed by the operculum.

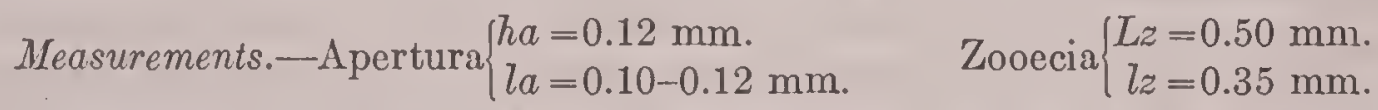

Variations.-The zooecia arc rather variable in aspect and measurements; however, the number of spines, the vestibular arch, and the place of the cardelles are very constant characters which permit no confusion with the species which we have described from the American Eocene.

Occurrence.-Miocene (Yorktown) : Yorktown, Virginia (rare).

Holotype.-Cat. No. 68611, U.S.N.M. 
hippoporella(?) PAPULIFERA, new species.

Plate 19, fig. 14

Description.-The zoarium incrusts shells. The zooecia are distinct, separated by a deep furrow, elongated, elliptical; the frontal is very convex, perforated by a double row of areolar pores, ornamented with little salient costules and covered by a more or less granular pleurocyst. The apertura is oblique, deep, located at the base of a peristomie, the peristome of which is spinous, very thin and little salient; the two cardelles are quite low. A hollow mucro in the form of a pimple hides the proximal part of the apertura.

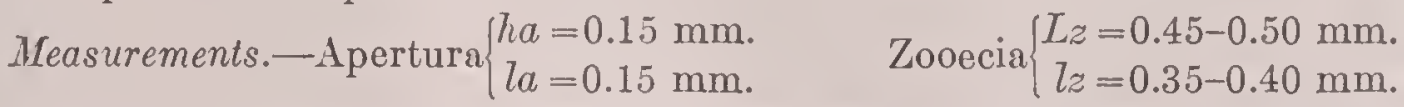

Affinities.-We have not discovered the ovicell of this species. The frontal granulations are rare or numerous according to the place of the zooecia. On account of the obliquity of the aperture the two cardelles are visible only when the specimen is inclined to an angle of $45^{\circ}$.

This species differs from Lepralia montifera Ulrich and Bassler, 1904, in its nontransverse aperture and from Hippoporella costulata in the absence of small adventitious avicularia.

Occurrence.-Miocene (Choctowhatchee marl): Jackson Bluff, Ocklocknee River, 25 miles southwest of Tallahassee, Florida (very rare).

Holotype-Cat. No. 68612, U.S.N.M.

hippoporella costulata, new species.

Plate 45, fig. 14.

Description.-The zoarium incrusts shells. The zooecia are distinct, separated by a deep furrow, hexagonal, widened; the frontal is convex and formed of an olocyst surmounted by a pleurocyst garnished laterally with areolar pores and with costules converging toward the oral mucro. The apertura bears two very small cardelles placed in the lower third; the proximal border is somewhat concave and denticulated. The ovicell is globular, smooth, little salient, much embedded in the distal zoecium; it is nerer closed by the operculum. On the line of pores there are small irregularly placed aricularia.

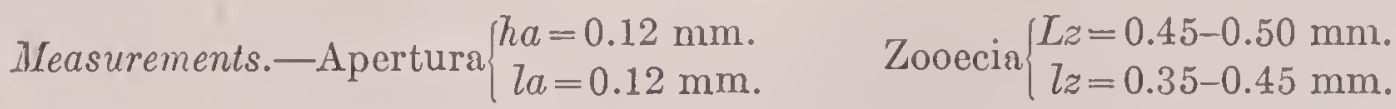

Variations.-The line of areolar pores is of ten doubled by another more interior one. The passage of the eggs, as in all the species of this genus, is assured by the embedding of the ovicell in the distal zooecium and in the presence of the oral mucro formed by the coalescence of the interareolar costules. In the vicinity of the ancestrula the zooecia have some large frontal pores. The species has neither peristome nor spines.

Occurrence.-Pleistocene: Mount Hope, Panama Canal Zone (very rare).

Holotype.-Cat. No. 68613, U.S.N.M.

\section{Genus LEPRALIA Johnston, 1847.}

The name Lepralia is retained for those species of the Hippoporae which show no ovicell and which cannot therefore be more definitely placed. 
LEPRALIA MONTIFERA Ulrich and Bassler, 1904.

Plate 18, fig. 11.

1904. Lepralia montifera Uurich and Bassler. Maryland Geological Survey, Miocene, p. 424, pl. 116, fig. 5.

The original description is as follows:

Zoarium parasitic, in one or more layers. Zooecia not regularly arranged, subovate, averaging $0.5 \mathrm{~mm}$. or a trifle more in length and about $0.35 \mathrm{~mm}$. in width. Orifice oblique, depressed in front, transversely subovate, broadly sinuate below; peristone scarcely thickened. Central portion of surface very high, the slopes traversed by rows of large punctures in radially disposed furrows. Ovicells not observed; nor avicularia, unless certain elongate-acuminate, curved depressions, with a pore at the broader lower extermity, that sometimes may be observed close to the rim of the orifice, are of that nature. This rather highly ornamented form reminds in certain respects of Cribrilina, but on the whole it agrees better with Lepralia. The strikingly monticular elevation and strongly puncto-radiate marking of the surface of the zooecia will, we believe, serve very well in distinguishing the species.

We are unable to classify this species generically on account of the absence of ovicell on the type and only specimen.

The interareolar costules are larger than in Hippoporella costulata, but the present species differs in the absence of a hollow infraoral mucro and of the small adventitious avicularia.

Occurrence.-Miocene (St Mary's formation): St. Marys River, Maryland (very rare).

Holotype.-Cat. No. 68614, U.S.N.M.

Lepralia Cribrosa? Maplestone, 1900.

Plate 36 , fig. 1.

1900. Lepralia cribrosa Maplestone, Further descriptions of the Tertiary Polyzoa of Victoria, pt. 6, Proceedings Royal Society, Victoria, vol 13, pt. 2, p. 210, pl. 35, fig. 16.

We are not certain of our determination, although the specimen studied is a superb one. If the magnification indicated by Maplestone be exact our species would be somewhat smaller. The absence of an ovicell does not allow the species to be classified generically. Two very small cardelles separate a large anter from a smaller poster.

Occurrence.-Pleistocene: Santa Monica, (Long wharf Canyon), California (very rare).

Geological distribution.-Miocene of Australia (Maplestone).

Plesiotype.-Cat. No. 68615, U.S.N.M.

\section{Group 4. PERISTOMELLAE Canu and Bassler, 1917.}

\section{Genus TRYPEMATELLA Canu and Bassler, 1920.}

1920. Trypematella Canu and Bassler, Monograph North American Early Tertiary Bryozoa, Bulletin 106, U. S. National Museum, p. 417.

The ovicell is hyperstomial and closed by the operculum for the passage of the eggs. The apertura is semilunar with proximal border a little concave. The frontal bears some lateral areolar pores (pleurocyst on olocyst). Two large lateral avicularia are placed below the apertura.

Genotype.-Trypematella papulifera, new species. Pleistocene. 
TRYPEMATELLA PAPULIFERA, new species.

Plate 35, figs. 12-14.

Description.-The zoarium is free and cylindrical; it incrusts fine algae. The zooecia are little distinct, short, wide; the frontal is little convex and perforated laterally by large areolar pores. The apertura is semielliptical; the peristome is salient and very thin with four distal spines; the ovicell is very large, placed on the distal zooecium, globular, salient, closed by the operculum for the passage of the eggs; it is costulate and granulated and bears a smooth prominence at its summit. On each side of the apertura there is a small round avicularium without pivot. Laterally, on the line of the areolar pores, on each side of the zoecium, there is a large triangular avicularium, with pivot, transverse or turned toward the top.

Measurements.-Apertura $\left\{\begin{array}{l}h a=0.09 \mathrm{~mm} . \\ l a=0.12 \mathrm{~mm} .\end{array}\right.$ Zooecia $\left\{\begin{array}{l}L z=0.40-0.45 \mathrm{~mm} . \\ l z=0.30-0.45 \mathrm{~mm} .\end{array}\right.$

(With the avicularia.)

Variations.-This fine species is very irregular in aspect on account of the irregularities of calcification. This is very active and gives a great thickness to the zooecial walls. The size and number of the avicularia, the organs of oxygenation, seem to indicate that the species lived in very calm waters.

Occurrence.-Pleistocene: Santa Monica (Rustic Canyon), California (rare).

Cotypes.-Cat. No. 68616, U.S.N.M.

\section{Group 5. DIVERS GENERA. .}

Genus CYCLOCOLPOSA Canu and Bassler, 1920.

1920. Cyclocolposa CANu and Bassler, Monograph North American Early Tertiary Bryozoa, Bulletin 106, U. S. National Museum, p. 431.

The apertura is suborbicular or elliptical without cardelles. The frontal is an olocyst, perforated by a double row of areolar pores, and covered by a granular, detachable pleurocyst. The ovicell is hyperstomial, never closed by the operculum, embedded in the distal zooecium.

Genotype.-Cyclocolposa perforata, new species.

Range.-Miocene-Pliocene.

In spite of appearances this genus is very different from Cyclicopora Hincks, 1884. The frontal pores are really areolar pores and not tremopores, for they are separated by short costules; the granulations reveal also the detachable pleurocyst, moreover, and are often visible on the altered zooecia. In Cyclicopora the operculum always closes the ovicell to assure the passage of the eggs; here this function is assured by the embedding of the ovicell in the distal zooecium, and in the great thickness of the frontal; the orifice is thus arranged in the locella in front of the tentacular sheath.

CYCLOCOLPOSA PERForata, new species.

Plate 30, figs. 6-14.

Description.-The zoarium incrusts oysters over large surfaces. The zooecia are distinct, separated by a furrow, elliptical or hexagonal, short, wide; the frontal is convex, surrounded by a double row of areolar pores, and formed of an olocyst supporting a granular and detachable pleurocyst. The apertura is oblique, subor- 
bicular, deeply embedded. The ovicell is globular, smooth, little salient, deeply embedded in the distal zooecium. The walls are very thick and perforated by a large number of dietellae. The ancestrula is small and reduced to only the apertura; it emits five zooecia.

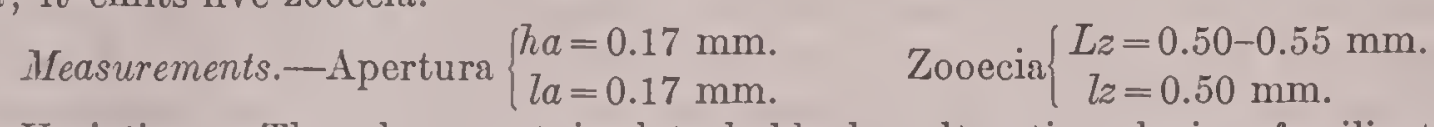

Variations.-The pleurocyst is detachable by alteration during fossilization (fig. 10). The ancestrula, normal in figure 8 , is often covered by the pleurocyst of the adjacent zooecia (fig. 9). Sometimes there are nonoriented zooecia. The calcified zooecia are provided with tremopores. The structure of the olocyst is that of Cyclicopora. The very thick walls with numerous dietellae characterize this species (fig. 14); their number is quite variable from 12 to 20.

Mucronella laqueata Norman, 1864, presents the same dietellae; it differs from it in its perforated frontal and in the absence of lyrule.

Occurrence.-Pliocene (Waccamaw marl): Waccamaw River, Horry County, South Carolina (very common).

Cotypes.-Cat. No.68617, U.S.N.M.

CYCLOCOLPOSA TENUIPARIETIS, new species.

Plate 21, figs. 1-4.

Description.--The zoarium incrusts pelecypod shalls. The zooecia are distinct, elongated, elliptical, separated by a deep furrow; the frontal is convex, surrounded by a double row of large, scattered, areolar pores, separated by pleurocystal granules. The apertura is elongate, oblique, elliptical, without cardelles. The ovicell is small, hardly salient, much embedded in the distal zooecium, with frontal smooth and fragile. Rarely a round oral avicularium is present.

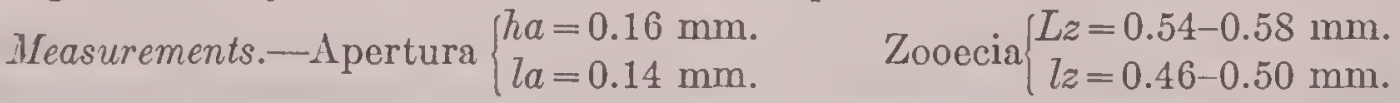

Affinities.-The presence of the ovicell absolutely disfigures this species; isolated portions of the zoarium containing only ovicelled zooecia can not be determined with certainty. The fragility of the superior wall is extreme; it does not resist fossilization; it results in a fantastic aspect difficult to comprehend. Exteriorly the pleurocyst is much reduced, and the abundance of areolar pores seems to indicate a tremocyst; the study of the interior does not permit this supposition.

This species differs from Cyclocolposa perforata in its elongate zooecia and in its very thin zooecial walls.

Occurrence.-Miocene (Duplin marl): Harvey Mills, Leon County, Florida (rare). Cotypes.-Cat. No. 68618, U.S.N.M.

CYCLOCOLPOSA(?) SPINIFERA, new species.

Plate 20, figs. $12,13$.

Description.-The zoarium incrusts oysters. The zooecia are distinct, separated by a deep furrow, somewhat elongated, much swollen; the frontal is very convex, garnished laterally with a double row of areolar pores and formed of an olocyst supporting a detachable pleurocyst. The apertura is orbicular or somewhat elongated and is surrounded by six large hollow spines. The ovicell is hyper- 
stomial, very globular, smooth, costulated on its borders; it is closed by the operculum. A very small median avicularium opens in the apertura.

$$
\text { Measurements.-Apertura }\left\{\begin{array} { l } 
{ h a = 0 . 1 5 \mathrm { mm } . } \\
{ l a = 0 . 1 2 \mathrm { mm } . }
\end{array} \text { Zooecia } \left\{\begin{array}{l}
L z=0.50 \mathrm{~mm} . \\
l z=0.35 \mathrm{~mm} .
\end{array}\right.\right.
$$

Variations.-The exterior aspect of this species is rather variable. Figure 12 represents the young zoarium which has not had time to attain its complete development. The apertura appears as elliptical and elongated; the frontal is still not completely covered by the pleurocyst and the deposit of calcite is clearly visible around each areolar pore. In figure 13 the calcification is complete; the frontal is very thick and the form of the apertura here becomes undefinable. The small median avicularium appears to be excavated in the thickness of the pleurocyst.

Occurrence.-Miocene (Yorktown formation): 1 mile west of Fort Nonsense, Gloucester County (rare), Beulahland, King and Queen County, and other localities in Virginia (rare).

Cotypes.-Cat. No. 68619 , U.S.N.M.

Genus CYCLOPERIELLA Canu and Bassler, 1920.

1920. Cycloperiella Canu and Bassler, Monograph North American Early Tertiary Bryozoa, Bulletin 106, U. S. National Museum, p. 43.

The ovicell is hyperstomial, globular, not embedded in the distal zoecium, and entirely covers the apertura. The apertura is formed of a semilunar anter and of a very concave poster. The frontal is formed of a very thin olocyst supporting a tremocyst with large widened pores.

Genotype.-Cycloperiella rubra, new species.

Range.-Miocene-Pliocene.

This genus offers the same frontal and apertural characters as Cyclicoporu Hincks, 1884. It differs from it in its ovicell never closed by the operculum. The passage of the eggs is assured by the form of the ovicell itself, which entirely covers the apertura.

CYCLOPERIELLA RUBRA, new species.

Plate 21, figs. 5-9.

Description.-The zoarium incrusts shells and frequently presents two superposed lamellae. The zooecia are elongate, a little elliptical, separated by a deep furrow; the frontal is thick, convex, and covered with large, widened tremopores. The apertura is semilunar, with a concave proximal border, and surrounded by a sort of thick and little salient peristome. The ovicell is globular, salient, covered with tremopores; it entirely covers the apertura. Its exterior orifice is irregular.

Measurements.-Apertura $\left\{\begin{array}{l}h a=0.15 \mathrm{~mm} . \\ l a=0.15 \mathrm{~mm} .\end{array} \quad\right.$ Zooecia $\left\{\begin{array}{l}L z=0.55-0.60 \mathrm{~mm} . \\ l z=0.35 \mathrm{~mm} .\end{array}\right.$

Affinities.-The zoarium often covers large surfaces; it was strongly pigmented, all the fossils are purple, indicating that their primitive tint was red. In the interior the very thin and pellicular olocyst scarcely resists fossilization, and the tremopores are clearly visible. Two very small lateral condyles serve as axis to the operculum. The orifice of the ovicell is irregular, oblique to the zooecial surface. It is difficult to comprehend how the polypide could extend its tentacles. 12184-23-Bull. $125-10$ 
It is therefore probable that after the passage of the eggs the polypide disappears by histolysis. The zooecia with calcified orifice are not rare. Sometimes a small gibbosity occurs on the frontal.

Occurrence.-Miocene (Duplin marl): Wilmington, 8 miles east of Snow Hill, 10 miles south of Greenville, and Natural Well, 2 miles southwest of Magnolia, Duplin County, North Carolina (common). Miocene (Yorktown formation): Suffolk, 3 miles southwest of Petersburg, and other localities in Virginia (common). Miocene (Bowden marl): Bowden, Jamaica (rare). Pliocene (Waccamaw marl): Waccamaw River, Horry County, South Carolina (common).

Cotypes.-Cat. Nos. 68620-68625, U.S.N.M.

\section{Genus CYCLICOPORA Hincks, 1884.}

(For description, see Bulletin 106, U. S. National Museum, p. 424.)

CYCLICOPORA MULTILAMELLOSA, new species.

Plate 46, figs. 3-6.

Description.--The zoarium is free, irregularly orbicular, striated concentrically on the inferior face and formed of many superposed lamellae. The zooecia are heaped upon each other, little raised, nonoriented, distinct, elongated, hexagonal or rectangular; the frontal is little convex, tuberous, and formed of a tremocyst with scattered pores, resting on an olocyst. The apertura is elliptical, transverse, with a concave proximal border; it is placed at one of the zooecial angles. In the immediate vicinity of the apertura there is a small orbicular avicularium sometimes transformed into a long transverse avicularium. The ovicell is globular, salient, very large, partially embedded in the distal zooecium and always closed by the operculum; it is covered by the tremocyst.

Measurements.-Apertura $\left\{\begin{array}{l}h a=0.15 \mathrm{~mm} . \\ l a=0.20 \mathrm{~mm} .\end{array} \quad\right.$ Zooecia $\left\{\begin{array}{l}L z=0.80 \mathrm{~mm} . \\ l z=0.60-0.80 \mathrm{~mm} .\end{array}\right.$

Variations.-The zooecial dimensions are quite variable; the zooecia are elongated or transverse. The characteristic of this species is the excentric position of the apertura; this and the avicularium occupy the distal portion of the zooecium. In the interior the aperture occupies its usual median position; it is therefore the irregularities of calcification which causes its exterior aspect.

Occurrence.-Pleistocene: Mount Hope, Panama Canal Zone (rare).

Cotypes.-Cat. No. 68626, U.S.N.M.

\section{CYCLICOPORA? MANSFIELDI, new species.}

Plate 19, fig. 11.

Description.-The zoarium incrusts Cellepore bryozoa. The zooecia are distinct, separated by a furrow of little depth, elongated, elliptical; the frontal is little convex and covered with large, widely spaced tremopores. The apertura is suborbicular, the proximal border being simply concave; neither cardelles nor peristome are present.

$$
\text { Measurements.-Apertura }\left\{\begin{array} { l } 
{ h a = 0 . 1 2 \mathrm { mm } . } \\
{ l a = 0 . 1 2 \mathrm { mm } . }
\end{array} \quad \text { Zooecia } \left\{\begin{array}{l}
L z=0.35 \mathrm{~mm} . \\
l z=0.25-0.30 \mathrm{~mm} .
\end{array}\right.\right.
$$


As our single specimen is without an ovicell, the generic determination must remain doubtful. This species is named in honor of Mr. Wendell C. Mansfield, of the United States Geological Survey, who has collected many interesting specimens of bryozoa for our study.

Occurrence.-Miocene (Yorktown formation): $1 \frac{1}{2}$ miles southwest Reed's Ferry, Virginia (very rare).

Holotype.-Cat. No. 68627, U.S.N.M.

CYCLICOPORA(?) GIGANTEA, new species.

Plate 37, fig. 5.

Description.-The zoarium incrusts pebbles. The zooecia are distinct, gigantic, ogival or hexagonal; the frontal is convex and formed of a tremocyst with small scattered pores surmounting an olocyst perforated by very minute pores corresponding to the tremopores. The apertura is elongate, elliptical, without lyrule or cardelles, with a concare proximal border; it is surrounded by a salient peristome, more or less thick and widened. The ovicell is hyperstomial, not embedded in the distal zooecium.

Measurements.-Apertura $\left\{\begin{array}{l}h a=0.30-0.35 \mathrm{~mm} . \\ l a=0.30-0.35 \mathrm{~mm} .\end{array} \quad\right.$ Zooecia $\left\{\begin{array}{l}L z=1.50-1.60 \mathrm{~mm} . \\ l z=0.90-1.40 \mathrm{~mm} .\end{array}\right.$

Variations.- The micrometric measurements are variable. The tremocyst is detachable and finely granular between the pores. The ovicells of our specimens are broken and we are therefore unable to classify the species without doubt.

Occurrence.-Pleistocene: Santa Monica (Tremochal Canyon), California (rare).

Holotype.-Cat. No. 68628, U.S.N.M.

Genus AIMULOSIA Jullien, 1888.

(For description, see Bulletin 106, U. S. National Museum, p. 428.)

AIMULOSIA ACULEATA, new species.

Plate 21, figs. 10-14.

Description.-The zoarium incrusts shells. The zooecia are distinct, separated by a furrow, ovoid, wide; the frontal is convex, smooth, perforated laterally by small, scattered, areolar pores; it bears on its median line a small avicularium very salient, oblique, orbicular, without pivot. The apertura is semilunar, a little elongate, with a somewhat concave proximal border; the peristome is thick, little salient, and garnished by two distal spines. The ovicell is globular, smooth, quite salient, transverse, very widely open in front of the median avicularium. Frequently there is a small triangular avicularium at the side of the apertura.

Measurements._Apertura $\left\{\begin{array}{l}h a=0.10 \mathrm{~mm} . \\ l a=0.10 \mathrm{~mm} .\end{array} \quad\right.$ Zooecia $\left\{\begin{array}{l}L z=0.50 \mathrm{~mm} . \\ l z=0.45 \mathrm{~mm} .\end{array}\right.$

Variations.-In all the species of this genus there is a very great micrometric difference between the ancestrular zooecia and the marginal ones. Our measurements are the largest that we have observed. The oral avicularium replaces an areolar pore. This is the rule in all the cheilostomatous Bryozoa. This organ is nourished in fact from the interior of the zooecia and must necessarily be in relationship with the mesenchymatous tissue. This avicularium is inconstant in its presence; sometimes it is lacking; sometimes there are two. The irregularity 
of the avicularia is one of the most tantalizing problems of bryozoology. It will remain unsolved until we know the exact physiological functions of these organs.

The apertura has no fixed measurements; it may be elongate or transverse, large or small. It appears to be in rapport with the size of the zooecium itself. The ancestrula is very small; it is reduced to its apertura; it engenders four normal zooecia and a zooeciule bearing only a salient median a vicularium. The presence of the median avicularium is a vital necessity for the zooecium and the first bud of the ancestrula is really this avicularium. The specimens from the Pliocene are still more irregular than those of the Miocene.

Affinities.-This species differs from Aimulosia brevis in its large micrometric dimensions and in the presence of areolar pores. It differs from Aimulosia radiata in its greater zooecial width, in the absence of interareolar costules, and in the much smaller areolar pores.

Occurrence.-Miocene (Duplin marl): Wilmington, North Carolina (rare); Harvey's Mills, Leon County, Florida (rare); and Muldrow's Mills, 5 miles south of Maysville (rare), South Carolina. Pliocene (Waccamaw marl): Waccamaw River, Horry County, South Carolina (rare).

Cotypes.-Cat. Nos. 68629,68630 , U.S.N.M.

AIMULOSIA BREVIS, new species.

Plate 3, figs. 5-7.

Description.-The zoarium incrusts shells. The zooecia are distinct, separated by a furrow, ovoid, very short; the frontal is convex, smooth, generally without areolar pores, terminated on the median line by a small, round, very salient a vicularium. The apertura is semielliptical; the peristome is little salient, wide, and bears two hollow spines. The ovicell is globular, salient, smooth, transverse with a very large orifice. Frequently there is a triangular avicularium at the side of the peristome.

Measurements.-Apertura $\left\{\begin{array}{l}h a=0.08 \mathrm{~mm} . \\ l a=0.08 \mathrm{~mm} .\end{array} \quad\right.$ Zooecia $\left\{\begin{array}{l}L z=0.30 \mathrm{~mm} \text {. } \\ l z=0.20 \mathrm{~mm} .\end{array}\right.$

Affinities.-The areolar pores are very small; they are easily closed by fossilization and the zooecia appear deprived of them.

This species differs from Aimulosia aculeata in its smaller micrometric measurements and in the apparent absence of areolar pores.

Occurrence.-Pliocene (Caloosahatchee marl): Shell Creek, De Soto County, Florida (rare). Lower Miocene (Bowden marl): Bowden, Jamaica (common). Lower Miocene (Bowden horizon): Cercado de Mao, Santo Domingo (rare).

Cotypes.-Cat. Nọs. 68631-68633, U.S.N.M.

AIMULOSIA RADIATA, new species.

Plate 32, fig. 5.

Description.-The zoarium incrusts shells. The zooecia are distinct, separated by a furrow, elongate, claviform; the frontal is convex, garnished laterally with large areolar pores and with interareolar costules arranged in radiating rows, and formed of a pleurocyst, slightly granular, surmounting a smooth olocyst; the median avicularium is very salient, oblique, and surmounts a mucro. The apertura is semilunar, located at the base of a short peristomie. The peristome is thick and bears two hollow spines. The ovicell is globular, very salient, smooth, very widely open before the median aricularium. 
Measurements.-Apertura $\left\{\begin{array}{l}h a=0.08 \mathrm{~mm} . \\ l a=0.10 \mathrm{~mm} .\end{array}\right.$ Zooecia $\left\{\begin{array}{l}L z=0.40 \mathrm{~mm} . \\ l z=0.20-0.30 \mathrm{~mm} .\end{array}\right.$

Affinities. - This species is very easy to recognize by its interareolar radiating costules; however, this character is much less apparent on the zooecial margins. where the pleurocystal calcification is incomplete.

Occurrence.-Pliocene (Caloosahatchee marl): Shell Creek, De Soto Count.y, Florida (very rare).

Holotype.-Cat. No. 68634, U.S.N.M.

\section{Family EURYSTOMELLIDAE Levinsen, 1909.}

Levinsen's original description is as follows:

No spines. The thick-walled and strongly calcified zooecia lack a covering membrane and have either no pores at all or 2-5 extremely large fenestrae. The broad aperture, which has a concave proximal rim, is provided with a more or less strongly chitinized operculum surrounded by a continuous marginal thickening. No avicularia. The ooecium is enclosed in a kenozooecium, the frontal wall of which is provided with a very large uncalcified part. Pore-chambers [dietellae] or groups of uniporous rosette-plates [septulae].

The two known species classed in this family are Lepralia foraminigera Hincks, 1883, and Lepralia bilabiata Hincks, 1884. Levinsen believed that the second species is probably the type of a special genus while the first is the type of the genus Eurystomella.

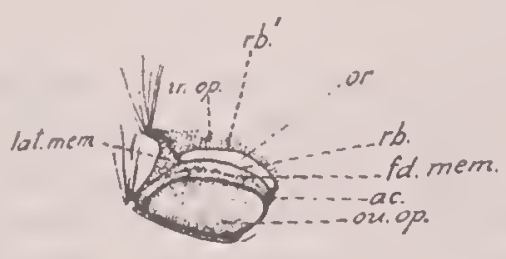

A

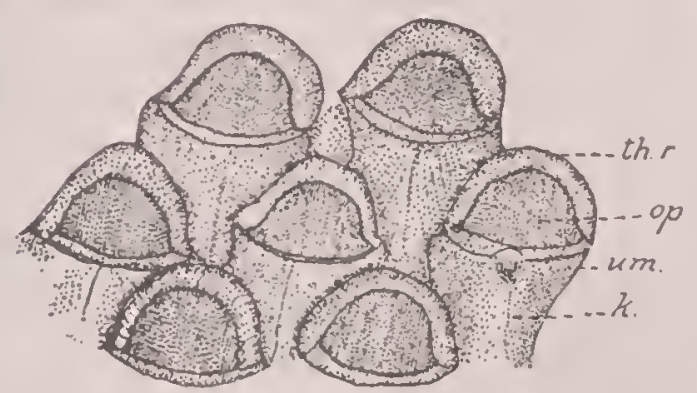

B
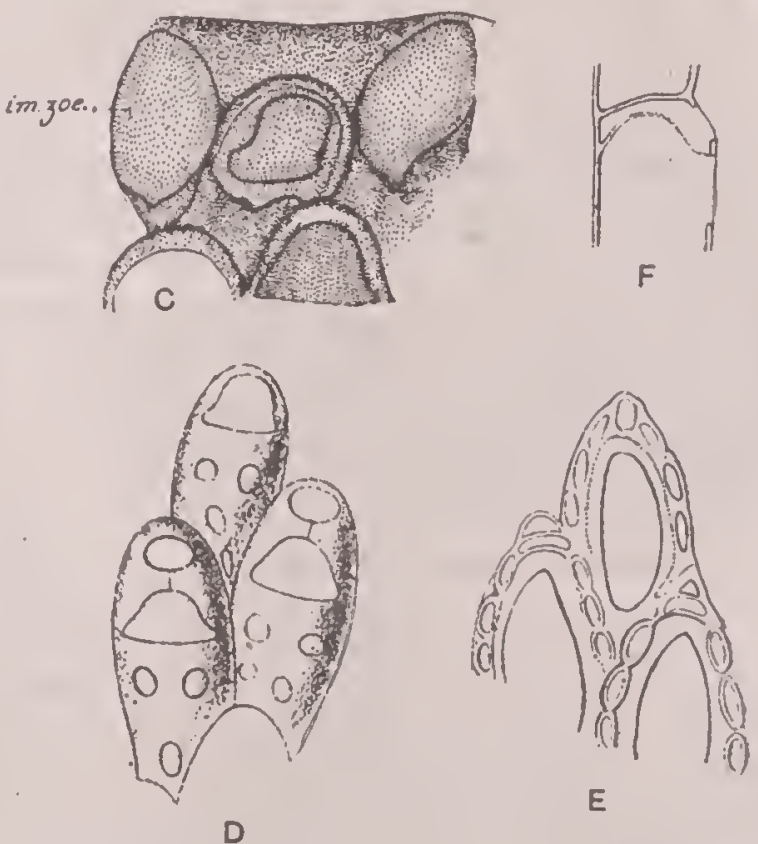

E

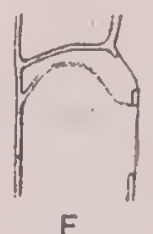

F

FIg. 26.-Genus Eurystomella Levinsen, 1909.

A-C. Eurystomella bilabiata Hincks, 1884. A. Sketch showing the operculum dissected out; rb, outer rib; $r b^{\prime}$, inner rib; in. op., inner operculum; or, orifice; lat. mem., lateral membrane; fd. mem., folded membrane; ac, accessory lip; ou. op., outer operculum. B. A few adult zooecia, $X 30$; th. $r$, thickened rim; op, operculum; um, umbo; $k$, keel. C. A few zooecia at the growing edge of the colony showing the membranous aperture of the immature zooecia (im. zoe.) (A-C, after Robertson, 1908.)

D-F. Eurystomella foraminigera Hincks, 1883. D. Two gonozooecia and an ordinary zooecium, $\times 40$. E. Three zooecia, from the basal surface, which has a large uncalcified central part, X 40 . F. A sagittal section through a zooecium with ovicell, $X 40$. The orifice of the ovicell is closed by the ectocyst. (D-F, after Levinsen, 1909.) 
Genus EURYSTOMELLA Levinsen, 1909.

1909. Eurystomella Levinsen, Morphological and systematic studies on the cheilostomatous Bryozoa, p. 314.

Characters same as for the family. The operculum closes the ovicell.

EURYSTOMELLA BILABIATA Hincks, 1884.

Plate 37, fig. 6.

1884. Lepralia bilabiata HnNcks, Polyzoa Queen Charlotte Islands, Annals and Magazine Natural History, ser. 5, vol. 13, p. 49, pl. 3, fig. 1.

1908. Lepralia bilabiata RoBertson, The incrusting Cheilostomatous Bryozoa of the West coast of North America, University of California Publications, Zoology, vol. 4, no. 5, p. 298, pl. 21, figs. 61-64.

Our fossil specimens of this species are mediocre and do not permit us to add any useful contribution to the knowledge of this remarkable species. We therefore have no modifications to add to Levinsen's description.

Occurrence.--Pleistocene: Dead Man's Island, off San Pedro, California (rare).

Habitat.-Pacific: California and Queen Charlotte Islands.

Plesiotype.-Cat. No. 68635, U.S.N.M.

Family STOMACHETOSELLIDAE Canu and Bassler, 1917.

Genus LEIOSELla Canu and Bassler, 1917.

(For description see Bulletin 106, U. S. National Museum, p. 448.)

LEIOSELLA EDAX, new species.

Plate 22, figs. 1-6.

Description.-The zoarium is free, unilamellar, often tubular; it was attached to the delicate radicells of algae. The zooecia are indistinct. The peristomice is very large, elongate, provided with a large rimule spiramen; the peristomie is deep; the apertura (in the interior) is semilunar with a concave proximal border. The ovicell is placed in the peristomie; it is widely open above the operculum; it bears a circular, very fragile frontal area. Around the peristomice there are three or four small, round, salient avicularia, with two denticles for pivot; they are sometimes transformed into large avicularia with spatulate mandibles. Another avicularium opens in to the peristomie.

$$
\text { Measurements.-Apertura }\left\{\begin{array} { l } 
{ h a = 0 . 1 5 \mathrm { mm } . } \\
{ l a = 0 . 1 2 5 \mathrm { mm } . }
\end{array} \quad \text { Zooecia } \left\{\begin{array}{l}
L z=0.40 \mathrm{~mm} . \\
l i n=0.30-0.35 \mathrm{~mm} .
\end{array}\right.\right.
$$

Affinities. - The aspect of this species is quite variable and depends solely on the number and development of the frontal avicularia. It appears very greedy for oxygen, a fact which is supported by the great thickness of its frontal wall and the activity of the calcareous secretion. Sometimes two small avicularia are replaced by a much larger one with large spatulate mandible.

The peristomie is the real seat of life of this species. An avicularum (visible from the interior) opens in to the lateral portion. The distal portion is reserved for the ovicell. Finally, the pseudo-rimule spiramen in the proximal portion is the orifice of the hydrostatic system. It is probable that the female polypide disappears by histolysis at the moment of the development of the embryos and the escape of the larva.

Occurrence.-Lower Miocene (Chipola marl): Chipola River, Calhoun County, Florida (rare).

Cotypes.-Cat. No. 68636, U.S.N.M. 
Family SMITTINIDAE Levinsen, 1909.

Genus SMITTINA Norman, 1903.

(For description see Bulletin 106, U. S. National Museum, p. 456.)

SMITTINA TRISPINOSA Johnston, 1838.

Plate 22, figs. 7-14.

1838. Lepralia trispinosa Joнnston, History of British Zoophytes, p. 324, pl. 57, fig. 7.

1889. Smittia trispinosa Jelly, A synonymic catalogue of marine Bryozoa, p. 252 (general bibliog. raphy).

1894. Smittia trispinosa Levinsen, Zoologica Danica (Danske Dyr), Heft 9, p. 70, pl. 6, figs. 10, 11.

1896. Smittia trispinosa Nevianr, Briozoi Postpliocenici di Spilinga (Calabria), Atti Accademia Gioenia di Scienze Naturali in Catania, ser. 4, vol. 9, p. 41, fig. 22.

1899. Smittia trispinosa Waters, Bryozoa from Maderia, Journal Royal Microscopical Society, p. 16.

1900. Smittia trispinosa Roвertson, Papers from the Harriman Alaskan Expedition, VI, The Bryozoa, Proceedings Washington Aacademy Sciences, vol. 2, p. 327.

1902. Smittia trispinosa CALvet, Bryozoaires marins de la region de Cette, Travaux de l'Institut de Zoologie de Montpellier, Mem. 11, p. 56.

1902. Smittia trispinosa CALveT, Bryozoaires marins des cotes de Corse, Travaux de l'Institut de Zoologie de Montpellier, Mem. 12, p. 30.

1907. Smittina trispinosa NordaAARD, Bryozoen von dem norwegischen Fischereidampfer "Michael Sars," Bergens Museums Aarbog, no. 2, p. 15.

1908. Smittia trispinosa Robertson, The incrusting cheilostomatous Bryozoa of the west coast of North America, University of California Publications, Zoology, vol. 4, pl. 22, figs. 68-70.

1910. Smittia trispinosa Osburn, Bryozoa of the Woods Hole region, Bulletin Bureau of Fisheries, vol. 30 , p. 246 , pl. 27 , fig. 65 (American bibliography).

1912. Smittina trispinosa NorngaARn, Revision av Universitets museets samling av norske Bryozoer, Kgl. norske Videnskabers Selskabs Skriften, no. 3, p. 22.

1914. Smittina trispinosa OsBurn, The Bryozoa of the Tortugas Islands, Florida, Publications of the Carnegie Institution of Washington, no. 182, p. 208.

Variations.-This species is extremely variable and many varieties are known. The varieties arborea Levinsen and lamellosa Smitt appear to be peculiar to the boreal regions. The varieties munita Hincks, bimucronata Hincks, nitida Verril, japonica Ortmann, etc., have no particular geographic extension and they generally accompany the type. The varieties, of which we have not cited the bibliography, are established either on the zoarial aspect or on the form of the avicularian mandibles; that is to say, on very secondary characters. Calvet, 1902, has shown that these characters themselves are rather characters of variations.

The detailed study of the variations would be desirable and would permit perhaps the discovery of the cause of them, which would be very important from the biologic point of view. It is probable that the richness of the waters in planktonic elements, the swiftness of the currents, the nature of the substratum, the agitation of the waters, and the nature of the bottom are the causes of the variations of which it is important to establish exact limits.

The geographic distribution of this species is universal; it has been discovered in all the explored seas. According to the known rules, the geological distribution must be correlative. But it is not so; only Waters and Neviani have mentioned fossil specimens.

The constant characteristic of this species is its very regular mode of gemmation (fig. 10) operating alternately between the walls which are absolutely recti- 
linear and deprived of septules. The pseudo-rimule of the peristomice has no avicularium as in almost all other species of the genus. This avicularium is generally placed on the line of the areolar pores and sometimes on the frontal; it is unequally developed and almost always triangular on our fossils. The lyrule is very small; it is more or less visible according to the development of the lateral lips of the peristomice.

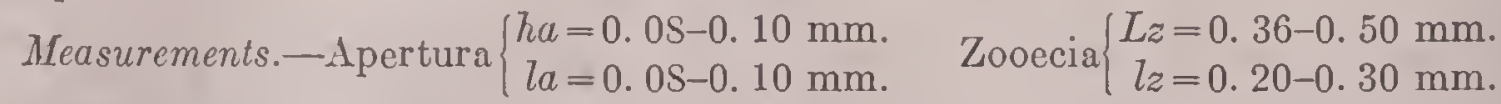

Occurrence.-Miocene (Duplin marl): Wilmington, North Carolina (common). Pliocene (Waccamaw marl): Waccamaw River, Horry County, South Carolina (rare). Pliocene (Caloosahatchee marl): Shell Creek, De Soto County (common), and Monroe County, Florida (common). Pleistocene: Vero (rare), Simmons Bluff, Yonges Island, Charleston County, South Carolina (common), and Daytona, Florida (rare.)

Geological distribution.-Miocene of Australia (Waters); Quaternary of Sicily (Neviani).

Habitat.-Cosmopolitan to a depth of 160 meters.

Plesiotypes.-Cat. Nos. 68637-68640, U.S.N.M.

SMITTINA MALEPOSITA, new species.

Plate 31, figs. 10, 11.

Description.-The zoarium incrusts shells. The zooecia are distinct, separated by a salient thread, little elongate, hexagonal, poorly oriented; the frontal is little convex and formed of a granular pleurocyst surrounded by a row of areolar pores separated by very short costules. The apertura is semilunar with a very short proximal lyrule; the peristomie is of little depth and the peristomice is suborbicular. 'The ovicell is large, globular, finely perforated. On the median line of the frontal there is a small thin avicularium the beak of which is directed toward the bottom.

$$
\text { Measurements.-Apertura }\left\{\begin{array} { c } 
{ h a = 0 . 1 0 \mathrm { mm } . } \\
{ l a = 0 . 1 0 \mathrm { mm } . }
\end{array} \quad \text { Zooecia } \left\{\begin{array}{c}
L_{z}=0.40 \mathrm{~mm} . \\
l_{z}=0.32 \mathrm{~mm} .
\end{array}\right.\right.
$$

Affinities.-This species is quite close to Smittina trispinosa Johnston, 1838. It is distinguished from it by its somewhat larger peristomice and by the place of its avicularium, always placed in the vicinity of the median line of the zooecium. The position of this avicularium is everywhere rather variable, but its presence is constant. There is therefore a group of Smittina in which the avicularium is not directly supported on the lyrule. We do not believe that this character should be generic, for it does not appear to correspond to an essential and different function.

Occurrence.-Pliocene (Caloosahatchee marl): Shell Creek, De Soto County, Florida (very rare). Pleistocene or Recent: Vero, Florida (rare).

Cotypes.-Cat. Nos. 6S641, 6S642, U.S.N.M.

SMITTINA OPHIDIANA Waters, 1877.

Plate 3 , fig. 3.

1879. Smittina reticulata, var ophidiana Waters, On the Bryozoa (Polyzoa) of the Bay of Naples, Annals and Magazine of Natural History, ser. 5, vol. 3, p. 40, pl. 9, fig. 1.

1885. Smittina reticulata, var. ophidiana Waters, On the use of the avicularium mandible in the determination of Chilostomatous Bryozoa, Journal Royal Microscopical Society, ser. 2, vol. 5 , pl. 14, fig. 6 . 
1889. Smuttia ophidiana Waters, Bryozoa from New South Wales, Annals and Magazine of Natural History, ser. 6, vol. 4, pl. 3, fig. 19.

1903. Smittia ensifera Jullien, Bryozoaries provenant des Campagnes de l'Hirondelle (1886-1888), Resultats des Campagnes Scientifiques du Prince de Monaco, fasc 23, p. 102, pl. 12, fig. 4.

1904. Smuttia ophidiana Waters, Resultats Voyage Belgica, Zoologie Bryozoa, p. 66.

1907. Smittia ophidiana Calvet, Expédition scientifiques du Travailleur et Talisman, Bryozoaires, p. 433 (bibliography).

Affinities.-This species is very close to Smittina marmorea but differs from it in the presence of costules and of areolar pores close together (and not scattered punctations) and the constant presence of two frontal pores.

Occurrence.-Miocene (Bowden marl) : Bowden, Jamaica (very rare)..

Geographic distribution.-Mediterranean at Naples; Atlantic at the Azore Isles (80-130 meters).

Plesiotype.-Cat. No. 68643, U.S.N.M.

\section{SMITTINA GRANDICELLA, new species.}

Plate 37, figs. 10-12.

Description.-The zoarium incrusts shells in one or more layers. The zooecia are distinct, separated by a furrow, elongate, elliptical, large; the frontal is convex and formed of an olocyst surmounted by a pleurocyst. The apertura is semielliptical; the lyrule is short and wide; the peristome is little salient, hardly indented in the proximal portion, and bears three distal spines.

Measurements.-Apertura $\left\{\begin{array}{l}h a=0.12-0.13 \mathrm{~mm} . \\ l a=0.13-0.15 \mathrm{~mm} .\end{array} \quad\right.$ Zooecia $\left\{\begin{array}{l}L z=0.55 \mathrm{~mm} . \\ l z=0.32-0.40 \mathrm{~mm} .\end{array}\right.$

Affinities.-This species much resembles Smittina trispinosa Johnston, 1838, for it often bears a large avicularium on the line of areolar pores; it is distinguished from it in its large zooecial dimensions and in the much less regular arrangement of the zooecia. The gemmation is identical, but the lines of the nonseptular walls are less rigorously rectilinear and often sinuous (fig. 12). The beak of the avicularium is round and salient.

Occurrence.-Pleistocene: Santa Monica (Rustic Canyon), California (rare). Cotypes.-Cat. No. 68644, U.S.N.M.

\section{SMITTINA DISCOIDEA, new species.}

Plate 38, figs. 1-7.

Description.-The zoarium is unilamellar, discoidal, very large; the lower face is concentrically wrinkled and the nonseptular walls are visible in the form of radial costules somewhat salient. The zooecia are little distinct, elongate, more

or less marginate; the frontal is very little convex and formed of an olocyst surmounted by a detachable pleurocyst with large interareolar costules. The apertura is semilunar; the lyrule is short and lamellose; the peristome is not salient, and the peristomie is excavated in the thickness of the frontal wall. The ovicell is globular, salient, deeply embedded in the distal zooecium; it is surrounded by a little salient collar. On the line of the areolar pores there is an enormous triangular avicularium with pirot or with condyles of which the beak is acuminate, salient, and pointed upward. 


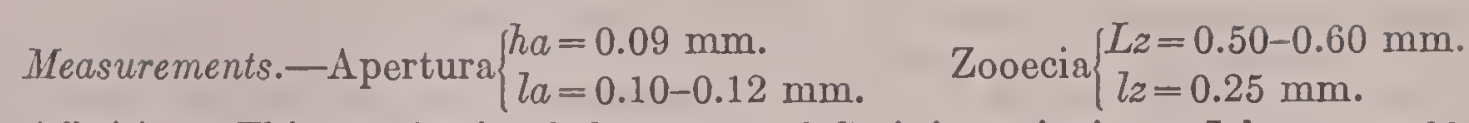

Affinities.-This species is of the group of Smittina trispinosa Johnston, 1838, in all its characters; it differs from it in the size, the form, and the direction of its avicularium. This avicularium is sometimes interzooecial (fig. 2). We are ignorant of the causes which result in the variations in sizc, direction, and form of the avicularia. These biologic variations are still to be studied. On the ovicelled zooecia the large avicularium is of ten transformed into two smaller ones (fig. 3). In the interior (fig. 7) the lyrule is laterally accompanied by two kinds of condyles, probably replacing the small cardelles.

Occurrence.-Pleistocene: Santa Monica (Rustic Canyon), California (common). Cotypes.-Cat. No. 68645, U.S.N.M.

SMITTINA CALIFORNIENSIS Robertson, 1908.

Plate 37, figs. 7-9.

1903. Smittia californiensis RoвERTSON, The incrusting cheilostomatous Bryozoa of the west coast of North America, University of California Publications Zoology, vol. 4, p. 303, pl. 22. fig. 71 .

Measurements.-Apertura $\left\{\begin{array}{l}h a=0.12 \mathrm{~mm} . \\ l a=0.12 \mathrm{~mm} .\end{array}\right.$ Zooecia $\left\{\begin{array}{l}L z=0.70 \mathrm{~mm} \text {. } \\ l z=0.30 \mathrm{~mm} .\end{array}\right.$

Variations.-We do not know all the variations of Miss Robertson's species; we are therefore not exactly certain of our determination. However, our specimens bear the principal characters. The peristome is little salient; it frequently bears two large lateral lips, leaving between them a false rimule (fig. 7). We have found some zooecia bearing a large, lateral avicularium; the latter is replaced by two smaller, thin avicularia whose beak is turned toward the bottom (figs. 8,9 ,) or indeed one toward the top and the other toward the bottom: The interareolar costules are thin (fig. 7) or very thick (fig. 8). The interzooecial avicularium bears a rectilinear pivot. The zoarium is bilamellar while that in Miss Robertson's species is incrusting.

Occurrence.-Pleistocene: Santa Barbara, California (rare).

Habitat.-Pacific, off California.

Plesiotypes.—Cat. No. 68646, U.S.N.M.

SMITTINA(?) BREVIS Cana and Bassler, 1919.

Plate 2, figs. 20, 21.

1919. Smittina? brevis CANU and BAssler, Geology and Paleontology of the West Indies, Bryozoa, Publication of the Carnegie Institution of Washington, No. 291, p. 93, pl. 2, fig. 2.

Description.-The zoarium is bilamellar with fronds somewhat compressed. The zooecia are little distinct, elongate, elliptical; the frontal is convex and very short and it bears below a large salient avicularium with rounded beak. The apertura is elliptical and deep. The ovicell is globular, little salient, ornamented by a fragile circular area; it opens into the peristomie.

Affinities.-This species is quite unique and difficult to classify. We have put it in Smittina because the ovicell opens into the peristomie formed by the thicken- 
ing of the frontal walls; but it does not really belong to this genus because it has no lyrula nor oral avicularium and because the apertura is not semilunar.

Occurrence.-Lower Miocene (Bowden horizon): Cercado de Mao, Santo Domingo (rare).

Holotype.-Cat. No. 68647, U.S.N.M.

SMITTINA PORIFERA Iincks, 1884.

Plate 38, fig. 9.

1884. Porella marsupium forma porifera Hincks, Report on Polyzoa of Queen Charlotte Islands, Annals Magazine Natural History, ser. 5, vol. 13, p. 50 (sep. 24), pl. 4, fig. 4.

1887. Porella marsupium, var. porifera Waters, Tertiary Cheilostomatous Bryozoa from \$New Zealand, Quarterly Journal Geological Society London, vol. 42, p. 63.

Description.-The zoarium is incrusting. The zooecia are distinct, swollen, separated by a deep furrow, very convex, perforated by some pores widely spaced. The frontal is a pleurocyst garnished laterally with six large areolar pores, of which the two superior ones are sometimes changed into avicularia. The apertura is deep, hidden by the peristomie and by a small, salient, orbicular, oral avicularium. The peristome is thin and bears four small spines which are often replaced by a small distal orbicular avicularium (rarely two). There is a very small lyrula hidden by the frontal avicularium. The ovicell is globular, salient, smooth; it opens above the operculum by a very large opening.

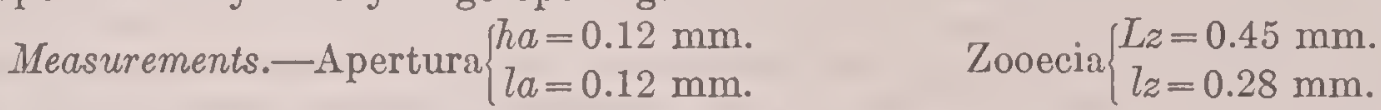

The avicularium chamber forms a frontal gibbosity perforated by four large pores. The latter characterize the species, for they do not exist in Porella marsupium MacGillivray.

Occurrence.-Pleistocene: Santa Monica (Long Wharf Canyon), California (rare). Geological distribution.-Pliocene of New Zealand (Waters).

Habitat.-Queen Charlotte Islands (Hincks).

Plesiotype.-Cat. No. 68648, U.S.N.M.

Genus PORELla Gray, 1848.

(For description, see Bulletin 106, U. S. National Museum, p. 479.)

PORELla BELLA Busk, 1860.

Plate 1, fig. 12.

1860. Lepralia bella Busk, Zoophytology, Quarterly Journal Microposcopical Science, vol. 8, pl. 27, fig. 2, 3.

1873. Escharella landsborovi Suitr, Floridan Bryozoa, pt. 2, Kongl. Seven. Vet. Akad. Hand., vol. 11, no. 4, p. 60, pl. 10, figs. 201, 202.

1880. Smittia bella Hincks, British Marine Polyzoa, p. 352, pl. 42, figs. 9, 10.

1919. Porella bella Canu and Bassler, Geology and Paleontology of the West Indies, Bryozoa, Publications of the Carnegie Institution, no. 291, p. 93, pt. 1, fig. 15.

We are not certain that Busk's species is identical with that of Smitt, as the former author represents it, but is evident that the characters of our Antigua fossil, although it is poorly preserved, are in harmony with Smitt's figures. Following are the measurements of this fossil.

$$
\text { Apertura }\left\{\begin{array} { l } 
{ h a = 0 . 1 6 \mathrm { mm } . } \\
{ l a = 0 . 2 0 \mathrm { mm } . }
\end{array} \quad \text { Zooecia } \left\{\begin{array}{l}
L z=0.90 \mathrm{~mm} . \\
l z=0.70 \mathrm{~mm} .
\end{array}\right.\right.
$$




\author{
Occurrence.-Oligocene (Antigua formation): Rifle Butts, Antigua, Leeward \\ Islands (rare). \\ Habitat.-Shetland Islands. Waters off Florida (185 meters). \\ Plesiotype.-Cat. No. 68649, U.S.N.M.
}

PORELLA REVERSA Ulrich and Bassler, 1904.

Plate 23, figs. 5-10.

1904. Lepralia ? reversa Ulrich and Bassler, Maryland Geological Survey, Miocene, p. 426, pl. 113, figs. 1, 2.

The original description is as follows:

Zoarium forming parasitic patches, several centimeters in diameter and composed of a single layer, on shells. Zooecia oblong quadrate or subhexagonal, generally arranged in rather regular longitudinal and diagonally intersecting rows, each about $0.5 \mathrm{~mm}$. in length and $0.3 \mathrm{~mm}$. in width. Orifice rather large, rounded-quadrate, enclosed by a peristome of moderate thickness and elevation. Peristomes divided into two parts, anterior and posterior, the former either straight or slightly arcuate and not so prominent as the horseshoe-shaped portion enclosing the sides and proximal margins of the orifice. Distal extremities of the latter portion of the peristome often a little thickened and projecting slightly inward. Just behind the proximal border of the orifice there is constantly a rather small but prominently elevated and thick-walled avicularium, opening obliquely forward. Remainder of front zooecia with from one to three rows of large pores. Frequently adjoining zooecia are separated by a thin raised line. Ovicells moderately convex, rather large, with a central pore and one or two somewhat radially disposed marginal rows of smaller pores. When broken they leave a sharply defined concave space in front of the orifice, slightly exceeding the latter in size.

The division of the peristome into two parts as described is unusual and produces the probably false appearance of a reversal of the ends of the operculum that has suggested the specific name. If it could be proved that the hinge of the operculum was really on the distal side of the orifice instead of the proximal, then this species would be distinct enough to justify the erection of a new genus for its reception; but until this unusual condition can be demonstrated we think it well to regard it as related to such species as Lepralia pallasiana. We know of none resembling it closely enough to require unusual care in its discrimination.

$$
\text { Measurements.-Apertura }\left\{\begin{array} { l } 
{ h a = 0 . 1 5 \mathrm { mm } . } \\
{ l a = 0 . 1 3 \mathrm { mm } . }
\end{array} \quad \text { Zooecia } \left\{\begin{array}{l}
L z=0.45-0.55 \mathrm{~mm} . \\
l z=0.25-0.30 \mathrm{~mm} .
\end{array}\right.\right.
$$

A reexamination of the type specimen shows this species should be classed in the genus Porella. It is well characterized by its embedded aperture, by its infraoral avicularium, and by its ovicell perforated like the frontal. Finally the interior shows the parietal arrangement habitual in the Smittinidae (fig. 10).

Occurrence.-Miocene (St. Mary's formation): Cove Point, Maryland (rare). Miocene; Kuhns, Carteret County, North Carolina (rare).

Cotypes and Plesiotype.-Cat. Nos. 68650, 68651, U.S.N.M.

\title{
PORELLA COLLIFERA Robertson, 1908
}

Plate 38, figs. 10-15.

1908. Porella collifera RoBertson, The incrusting cheilostomatous Bryozoa of the west coast of North America, University of California Publications, Zoology, vol. 4, no. 5, p. 304, pl. 23,

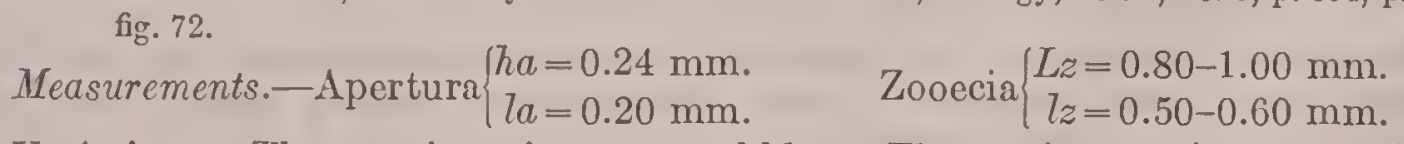

Variations.-The zoarium incrusts pebbles. The peristome is rery salient especially in the proximal portion. The oral avicularium rests on a wide but little salient lyrule; it is often only risible by a suitable inclination of the preparation 
so that the bottom of the peristome can be seen. The zooecia are sometimes bordered by a salient thread (fig. 13). The ovicell is very small (fig. 11). In the the interior the olocyst is perforated by very small pores corresponding to the large widened pores of the superposed tremocyst.

Occurrence.-Pleistocene: Santa Monica (rare) and Santa Barbara, California (common).

Habitat.-Pacific: Coronado Islands (24-29 meters).

Plesiotypes.-Cat. No. 68652, U.S.N.M.

\section{Genus PALMiCELlaria Alder, 1864.}

1861. Palmicellaria Alder, Description New British Polyzoa, Quarterly Journal Microscopical Society, new ser., vol. 4, p. 100.

The apertura is orbicular, semicircular, or semielliptical. Neither lyrula nor cardelles are present. The ovicell opens in the peristomie. The frontal is a granular pleurocyst, surrounded with areolar pores. The peristomie is much developed. Often an avicularian mucro partially hides the apertura.

Genotype.-Palmicellaria elegans Alder, 1864.

Range.-Miocene to Recent.

The known species of this genus are:

Palmicellaria elegans Alder, 1864.

Palmicellaria (Millepora) skenei Solander, 1786.

Palmicellaria (Eschara) lorea Alder, 1864.

Palmicellaria inermis Jullien, 1882.

Palmicellaria tenuis Calvet, 1907.

Structure.-The species of this genus are garnished with areolar pores and they therefore do not belong to the genus Porella Gray, 1848, as we have limited it. The absence of the lyrula and of cardelles distinguishes it from Smittina.

Historical.-For a long time, on the authority of Waters, the species of this genus have been classed in the genus Porella Gray, 1848, because the known mandibles are identical. The opercula and mandibles of Palmicellaria skenei Solander, 1786, are indeed those of Porella. The mandible of P. lorea Alder, 1864, is also that of Porella, but the operculum is semielliptical and of quite a divergent type from other Porellas. The chitinous appendages of the genotype and of the other species are unfortunately unknown.

All of the species cited having without exception the same characteristic of calcification, namely, a granular pleurocyst surrounded by areolar pores, we believe that it is necessary to maintain Alder's genus, although it does not appear to us very well marked.

PALMICELLARIA cf. INERMIS Jullen, 1882.

Plate 4, fig. 13.

Our figured specimen is too incomplete to be named with certainty, but we are introducing it to call attention to the genus in the early Miocene. This specimen is deprived of ovicell and its aperture is invisible. It approaches Palmicellaria inermis Jullien, 1882, but it differs from it in its larger micrometric measurements and in its apertura, which does not appear transverse.

Occurrence.-Miocene (Bowden horizon) : Santo Domingo.

Plesiotype.-Cat. No.68653, U.S.N.M. 
Plate 45, figs. $12,13$.

Description.-The zoarium incrusts corals. The zooecia are distinct, separated by a broad furrow, little elongated; the frontal is॰very convex, thick, covered by a tremocyst with large pores, garnished with broad radiating costules, and ending in a very salient avicularium. The apertura is semielliptical, transverse, deeply buried, partially hidden by the avicularian mucro. The ovicell is deeply embedded in the distal zooecium; it is large, little salient, similarly covered with large radiating costules.

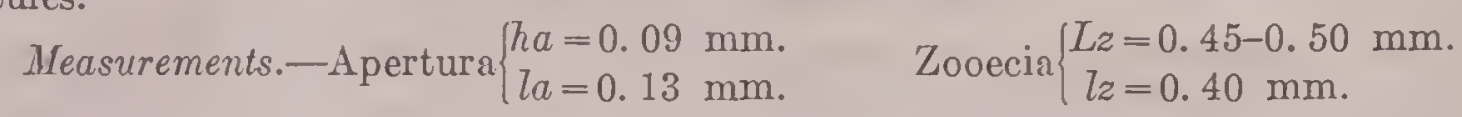

Affinities.-In the vicinity of the ancestrula the avicularian mucro is not ronstant; it is of ten replaced by small salient orbicular avicularia irregularly arranged around the apertura.

This beautiful species on account of its frontal irregularities is rery difficult to photograph. Better preserved specimens, moreover, will probably show new characters necessitating its classification in another genus. The species is certainly shorter than Lepratia corrugata MacGillivray, 1895, which has some resemblance.

Occurrence.-Pleistocene: Mount Hope, Panama Canal Zone (rare).

Cotypes.-Cat. No. 68654, U.S.N.M.

\section{PALMicellaria CONvoluta Uirich and Bassier, 1904.}

Plate 23, figs. 1-3.

1904. Palmicellaria convoluta Ulrich and Bassler, Maryland Geological Survey, Miocene, p. 427, pl. 16, figs. 2-4.

The original description of this species is as follows:

Zoarium erect, forming loose masses $3 \mathrm{~cm}$. or more in diameter, consisting of broad, bifoliate. con. voluted, anastomosing leaves, $1.0 \mathrm{~mm}$. or more in thickness. Zooecia prominent, distinct, oval, rhomboidal or hexagonal, arranged in irregular quincunx, averaging between $0.9 \mathrm{~mm}$. and $1.0 \mathrm{~mm}$. in length and about $0.45 \mathrm{~mm}$. in width; surface rather coarsely punctured; orifice terminal, the proximal edge overhung by a prominent mucro containing an avicularium the sagittate opening of which is divided into two unequal parts by a septum and lies on the abrupt distal slope of the mucro so as to be nearly or entirely concealed in a front view. When the apex of the mucro is worn or broken away the cavity of the avicularium is exposed to view as a cell immediately behind the orifice and almost equaling it in size. Ovicells small, transverse. bulbous, closely united to the cell next above.

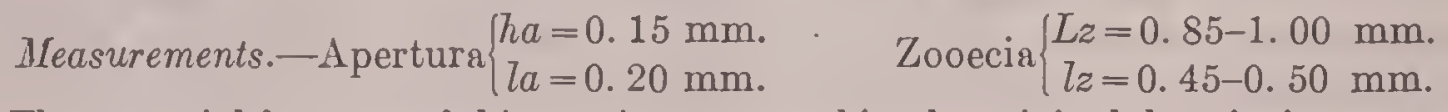

The essential features of this species are noted in the original description.

Occurrence.-Miocene (Calvert formation): Reeds, Maryland (rare).

Cotypes.-Cat. No. 68655, U.S.N.M.

\section{PALMiCellaria PUNCTATa Uirich and Bassier, 1904.}

Plate 23, fig. 4.

1904. Palmicellaria punctata Ulrich and Bassler, Maryland Geological Survey, Miocene, p. 428, pl. 116, fig. 1.

Only the type specimen of this species, a fragment of bifoliate zoarium, is known, and our studies upon it must remain incomplete. This specimen shows 
punctate zooecia with a subcircular orifice and a mucro like the preceding, but its zooecia are much smaller than Porella (Palmicellaria) convoluta Ulrich and Bassler, 1904, of the Maryland Miocene, and its mucro is less prominent. The ovicells however are relatively larger and longer.

$$
\text { Measurements.-Apertura }\left\{\begin{array}{l}
h a=0.10 \mathrm{~mm} . \\
l a=0.20 \mathrm{~mm} .
\end{array}\right. \text { Zooecia, irregular. }
$$

Occurrence.-Miocene (Calvert formation): Reeds, Maryland (very rare).

Holotype.-Cat. No. 68656, U.S.N.M.

\section{Genus RHAMPHOSTOMELLA Lorenz, 1886.}

(For description see Bulletin 106, U. S. National Museum, p. 476.)

RHAMPHOSTOMELLA LATICELLA Canu and Bassler, 1919.

Plate 5, fig. 13.

1919. Rhamphostomella laticella CANU and BASSLER, Geology and Paleontology of the West Indies, Bryozoa, Publications of the Carnegie Institution of Washington, no. 291, p. 94, pl. 5, fig. 12.

The figured specimen is the only one found; it is unfortunately incomplete and worn and does not permit a detailed description. It incrusts a shell; the areolar costules are rare or little visible. The oral avicularium is quite large, oblique, the point directed toward the bottom.

Occurence.-Lower Miocene (Bowden marl): Bowden, Jamaica (rery rare).

Holotype.-Cat. No. 68657, U.S.N.M.

RHAMPHOSTOMELLA GRANULOSA, new specles.

Plate 3, fig. 2.

Description.-The zoarium incrusts shells. The zooecia are distinct, separated by a deep furrow, elongated, elliptical; the frontal is very convex, covered with a granular pleurocyst and bordered with small areolar pores. The apertura is large, elongated, and deformed by a small, elongated, triangular avicularium arranged obliquely. The ovicell is globular, very salient, and covered also with a granular pleurocyst.

Measurements.-Apertura $\left\{\begin{array}{l}h a=0.15 \mathrm{~mm} . \\ l a=0.10 \mathrm{~mm} .\end{array} \quad\right.$ Zooecia $\left\{\begin{array}{l}L z=0.55 \mathrm{~mm} . \\ l z=0.25-0.30 \mathrm{~mm} .\end{array}\right.$

Affinities.-The zooecia are very irregular in their micrometric measurements. The areolar pores are often hidden by the pleurocyst.

This species approaches Rhamphostomella brendolensis Waters, 1891, which is often deprived of costules, but differs from it in the presence of the frontal granules.

Occurence.-Miocene (Bowden marl): Bowden, Jamaica (very rare).

Holotype.-Cat. No. 68658. U.S.N.M. 
Genus CYSTISELLA Canu and Bassler, 1917.

(For description, see Bulletin 106, U. S. National Museum, p. 479.)

CYSTISELLA AVICULIFERA, new species.

Plate 38 , fig. 8 .

Description.-The zoarium incrusts pebbles or algae. The zooecia are distinct, elongate, subelliptical, swollcn: the frontal is convex, smooth or bears an avicularian chamber rather large and somewhat salient. The apertura is semicircular and placed at the base of a deep peristomie; the peristome is thin, salient, and bears two or three orbicular avicularia. The ovicell is large, hyperstomial, convex, globular, smooth; it opens into the peristomie by a very large opening placed above the operculum.

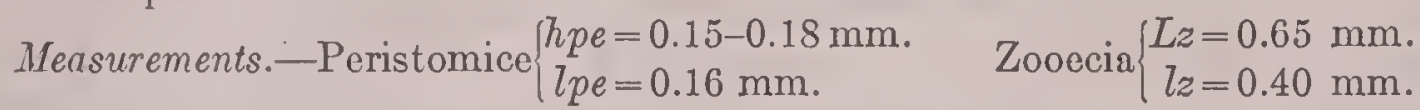

Affinities.-Our micrometric measurements are taken on the marginal zooecin; at the center of the zoarium they are much smaller, the frontal of the zooecia being much reduced there. The ancestrular zooecia appear to be erect as in the Celleporidae; this aspect is deceiving and is occasioned by the presence of small peristomial aricularia; they are perfectly oriented like the marginal zooecia but much smaller. The relative constancy of the peristomice permits us to utilize the micrometric measurements. The frontal avicularian chamber is much smaller than in the other species of the same genus; but the absence of the areolar pores leaves no doubt as to the exactness of our generic determination. The multiplicity of avicularia on a given species always reveals whether the water was calm or not very agitated. (rare).

Occurrence.-Pleistocene: Santa Barbara (rare) and Santa Monica, California

Holotype--Cat. No. 68659, U.S.N.M.

Family RETEPORIDAE Smitt, 1867.

Genus RETEPORA Imperato, 1599.

(For description, see Bulletin 106, U. S. National Museum, p. 500.)

RETEPORA DOVERENSIS UIrich and Bassler, 1904.

Plate 23, figs. 11-17.

1904. Retepora doverensis Ulrich and Bassler, Maryland Geological Survey, Miocene, p. 422, pl. 111, figs. 5-7; pl. 115, figs. 1-5.

The original description follows:

Zoarium reticulate, fenestrae of variable size, averaging $0.8 \mathrm{~mm}$. long and about $0.4 \mathrm{~mm}$. wide. Branches varying from $0.2 \mathrm{~mm}$. to $1.0 \mathrm{~mm}$. wide, usually about $0.6 \mathrm{~mm}$.; reverse solid, the surface generally smooth, occasionally minutely granulose, divided into irregular angular spaces by fine impressed or raised lines that may or may not correspond with the bases of the zooecial walls. Zooecia immersed, with oblique imbricating and slightly flaring mouths, and a narrow notch in the elevated and angular proximal border. The appearance of the celluliferous surface varies greatly in different specimens, the difference being due chiefly to the presence or absence and number of the avicularia and ovicells. The latter appear as bulbous inflations with a slit running from the center to one edge. When they occur at all it is usually in abundance. Of avicularia there are at least two sets, the larger ones occurring on the front of the zooecia, forming its highest part and causing it to appear inflated. 
Those of the smaller set occur in the depressed spaces, usually close beside the zooecial orifice, and rarely on the reverse of the branches.

This common species of the Choptank formation apparently belongs to the Retepora-cellulosa group of Waters. Though resembling several of the species of the group rather closely we could not decide that it was any nearer to one than to another. Still, having found it difficult to make thoroughly satisfactory comparisons, we will not be greatly surprised should future study prove $R$. doverensis to bẻong to some previously described species.

The peristome bears a wide, very irregular, rimule spiramen. 'The ovicell is fissured.

Occurrence.-Miocene (Choptank formation): Dover Bridge and Jones Wharf, Maryland (common).

Cotypes and plesiotypes.-Cat. Nos. 68660, 68661, U.S.N.M.

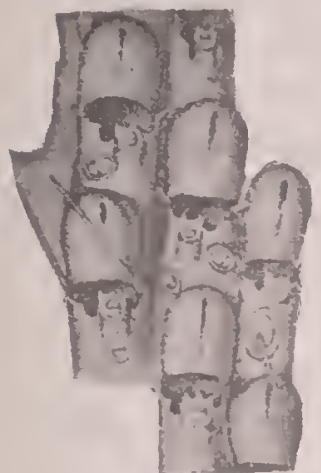

A. Retepora

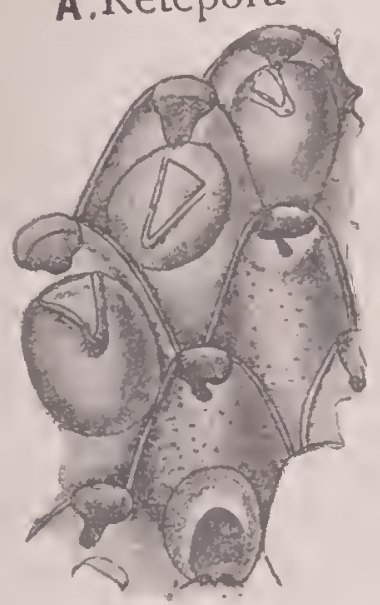

E Schizellozoon

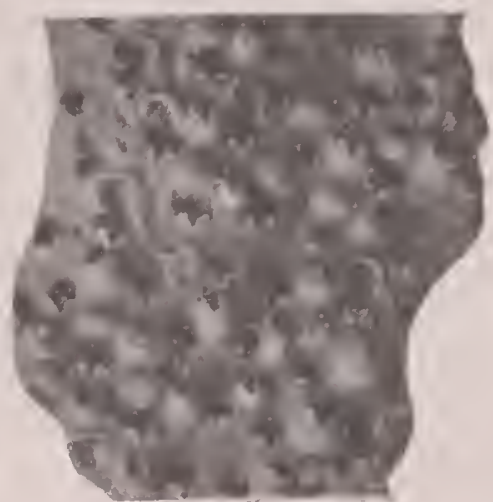

B. Phidolopora

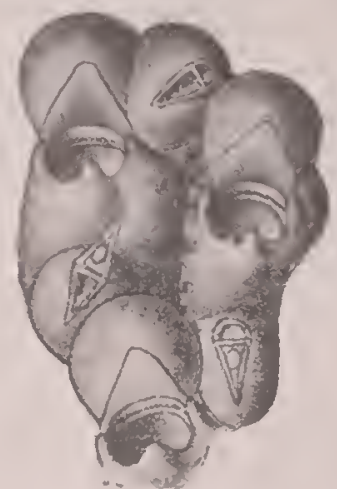

C. Rhynchozoon

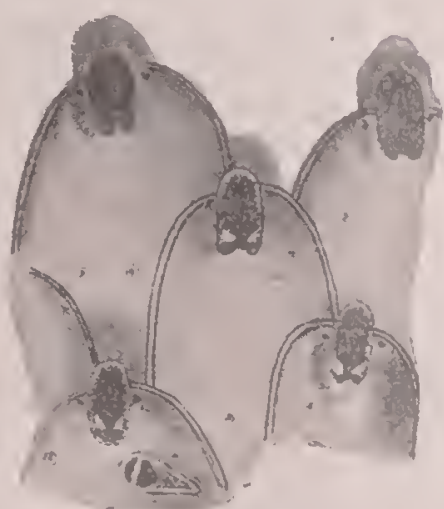

D. Hippellozoon
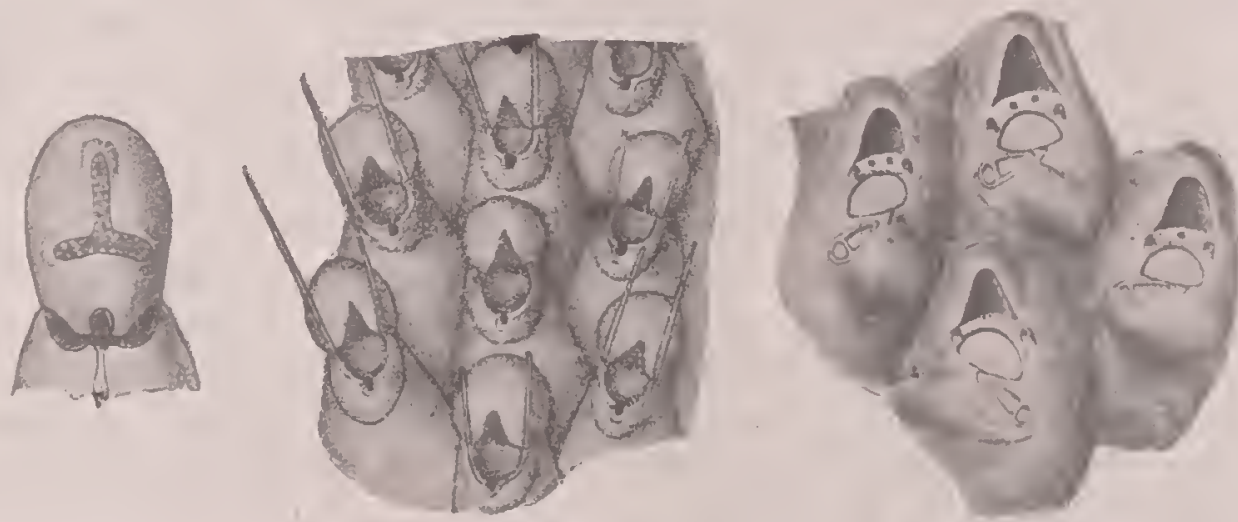

H.Lepraliella

Fra. 27.-Genera of the family Reteporidae Smitt, 1867.

A. Retcpora bcaniana King, $1846, \times 25$. Recent. (After Hincks, 1880.) B. Phidolopora labiata Gabl) and Horn, 1865, $\times 20$. Pleistocene of California. C. Rhynchozoon angulatum Levinsen, 1909 , X 55. Recent. (After Levinsen, 1909.) D. Hippellozoon novaczlandiac Wäters, $1894, \times 25$, Recent. (After Waters, 1894.) E. Schizellozoon imperati Busk, 1884, X 25. Recent. (After Waters, 1885.) F. Triphyllozoon moniliferum MacGilliviay, 1860, X 85. Recent. (After Waters, 1894.) G. Schizolheca fissa Busk, 1858, X 45. Recent. (After Hincks, 1880.) H. Lepraliella contigua Smitt, 1867. Recent. (After Levinsen, 1916.)

1218t-23-Bull. $125-11$ 


\section{Genus PHIDOLOPORA Gabb and Horn, 1862.}

1862. Phidolopora GABB and Horn, Monograph Polyzoa of the Secondary and Tertiary Formations of North America, Journal Academy National Science Philadelphia, ser. 2, vol. 5, p. 138.

The frontal of the oricell is not fissured. The aperture is semilunar, with a concare proximal border. The peristomice bears a rimule spiramen. 'The frontal is an olocyst. No labial avicularium.

Genotype--Retepora labiata Gabb and Horn, 1S62. Pleistocene, Recent.

Affinities. - The apertura is identical with that of the genus Retepora Imperato, 1859 , as Waters has limited it in 1913. The genus Phidolopora Gabb and Horn, 1862, differs from it in the absence of a fissure on the ovicell, in the replacement of the spiramen by a rimule of the peristomice, and in the absence of the labial avicularium. Moreover, the frontal is an olocyst, a character which does not exist notably in the group of Sertella Jullien, 1903. The definition of Gabb and Horn 1862, has no significance; it is even little comprehensible: "It differs from $R e$ tepora by the scattered special pores over the surface of the colony." Retepora pacifica Robertson, 1908 , belongs absolutely to the same group and show's the generic characteristics clearly.

\section{PHIDOLOI'ORA PACIFICA Robertson, 1908.}

Plate 39, figs. 1-7.

1908. Retepora pacifica RoBertson, The incrusting cheilostomatous Bryozoa of the west coast of North America, University of California Publications, Zoology, vol. 4, p. 310, pl. 24, figs. $81-84$.

Measurements.-Peristomice: $l p e=0.14-0.16 \mathrm{~mm}$.

$$
\text { Zooecia }\left\{\begin{array} { l } 
{ L z = 0 . 4 0 - 0 . 6 0 \mathrm { mm } . } \\
{ l z = 0 . 3 0 \mathrm { mm } . }
\end{array} \quad \text { Fenestrac } \left\{\begin{array}{l}
L f=1.75 \mathrm{~mm} . \\
l f=0.50 \mathrm{~mm} .
\end{array}\right.\right.
$$

Affinities.-This species differs from Phidolopora labiata Gabb and Horn, 1862, in its larger peristomice always wider than $0.14 \mathrm{~mm}$; thus the apertures appear closer together. The small tongue on the oricell mentioned by Miss Robertson is too fragile to be preserved on the fossils. The zooecia deprived of the large frontal aricularium bear some small scattered pores. In tangential section the vibices appear clearly. They are therefore formed by a very dense calcification in the entire thickness of the zoarial dorsal. Sometimes the dorsal bears radicular pores. In transverse sections the lacunae appear very irregularly arranged.

Occurrence.-Pleistocene: Santa Monica (rare), and Dead Mans Island, off San Pedro (rare), California.

Habitat.-Coast of California.

Plesiotypes.-Cat. No. 6\$662, U. S. N. M.

PHIDOLOPORA LABIATA Gabb and Horn, 1862

Plate 39, figs. 13-17.

1862. Phidolopora labiata GABB and Horn, Monograph Polyzoa of the Secondary and Tertiary formations of North America, Journal Academy Natural Sciences, Philadelphia, ser. 2, vol. 5 , p. 138, pl. 19, fig. 21.

Description.-The zoarium is reticulated; the fenestrae are narrow and elongated. The zooecia are distinct, margined by a salient thread, elongate, fusiform; the frontal is slightly convex and smooth. The apertura (visible only in the inte- 
rior) is transverse, subelliptical; the peristomice bears a rimule spiramen arranged between two salient lips. The ovicell is large, convex, smooth, buried in the distal zooecium; its orifice is very large and located in front of the two lips. Many zooecia bear a very large avicularium arranged obliquely on the frontal and provided with a curred, rery salient beak. The zooecia without aricularia bear some small scattered pores.

Measurements.-Peristomice: $l p e=0.10 \mathrm{~mm}$.

$$
\text { Zooecia }\left\{\begin{array} { l } 
{ L z = 0 . 4 6 - 0 . 6 0 \mathrm { mm } . } \\
{ l z = 0 . 2 0 - 0 . 3 0 \mathrm { mm } . }
\end{array} \quad \text { Fenestrae } \left\{\begin{array}{l}
L f=2.00 \mathrm{~mm} . \\
l f=0.30-0.75 \mathrm{~mm} .
\end{array}\right.\right.
$$

Affinities.-This species differs from Phidolopora pacifica Robertson, 1908, in the smaller dimensions of its peristomice, which measure more than $0.10 \mathrm{~mm}$. The general aspect is therefore that of bearing apertures much more scattered and in having a peristomice much smaller than the zooccial width.

The micrometric variations are extraordinary. On the same zoarium one may find zooecia $0.50 \mathrm{~mm}$. by $0.20 \mathrm{~mm}$. with zooecia 0.46 by $0.26-0.30 \mathrm{~mm}$. Frequently the peristomice of the oricelled zooecia is somewhat wider than that of the other zooecia. The ribices are also very irregular; thay are salient, but disappear easily in fossilization.

Occurrence.-Pleistocene: Dead Mans Island off San Pedro (rare), Santa Monica (common), and Santa Barbara, California (very common).

Plesiotypes.-Cat. No. 68663, U.S.N.M.

\section{Genus RHYNCHOZOON Hincks, 1891.}

(For description, see Bulletin 106, U. S. National Museum, p. 506.)

\section{RHYNCHOZOON VAUGHANI Canu and Bassler, 1919.}

Plate 2, fig. 22; plate 4, figs. 1, 2.

1919. Rhynchozoon vaughani CANU and BAssler, Geology and Paleontology of the West Indies, Bryozoa, Publications of the Carnegie Institution of Washington, no. 291, p. 94, pl. 2, fig. 23; pl. 4, figs. 1, 2.

Description.-The zoarium is unilamellar. The zooecia are large, distinct, hexagonal or claviform; the frontal is smooth, convex, surrounded by a line of small scattered areolar pores. The apertura is large, suborbicular, with a wide proximal rimule; the peristomie is deep and widened; the rery irregular peristome bears some large tubercles; the false rimule is compressed between two large tuberosities, one of which bears an oral aricularium transversely arranged.

$$
\text { Measurements.-Apertura }\left\{\begin{array} { l } 
{ h a = ? } \\
{ l a = 0 . 2 0 \mathrm { mm } . }
\end{array} \text { Zooecia } \left\{\begin{array}{l}
L z=0.60 \mathrm{~mm} . \\
l z=0.50 \mathrm{~mm} .
\end{array}\right.\right.
$$

Affinities.-This species differs from Rhynchozoon solidum Osburn, 1914, which it much resembles, in its much larger micrometric measurements and in the absence of the small frontal avicularium.

Occurrence.-Lower Miocene (Bowden horizon): Cercado de Mao, Santo Domingo (very rare).

Cotypes.-Cat. No. 68664, U.S.N.M. 
RHYNCHOZOON CURTUM, new species.

Plate 4, fig. 14.

Description.-The zoarium is unilamellar. The zooecia are distinet, separated by a deep furrow, elongated, very short, much narrowed behind; the frontal is very small, somewhat convex, surrounded with aereolar pores; it bears a small elliptical

- transverse avicularium. The apertura, hidden at the lottom of the peristomie, is little risible; it bears a wide rounded rimule. The peristome is salient, wide, formed of tuberosities smooth or perforated; it is notched in its proximal part by a triangular pseudorimule placed in the median axis of the zooecium. The ovicell is small, short, deeply buried, recumbent convex and transverse.

$$
\text { Measurements.-Opereula }\left\{\begin{array} { l } 
{ h a = 0 . 1 4 \mathrm { mm } . } \\
{ l a = 0 . 1 6 \mathrm { mm } . }
\end{array} \quad \text { Znoecia } \left\{\begin{array}{l}
L z=0.40 \mathrm{~mm} . \\
l z=0.30 \mathrm{~mm} .
\end{array}\right.\right.
$$

Affinities-This species differs from Rhynchozoon verruculatum Smitt, 1872, in its very short zooecin, in its elliptical and always aeuminate avieularium, the length of which never surpasses $0.12 \mathrm{~mm}$. In its general aspeet the peristome appears to occupy half of the zooecium, which thus reduces considerably the length of the frontal and which gives such a short appearance.

Occurrence.-Miocene (Bowden horizon): Santo Domingo.

Holotype.-Cat. No. 68665, U.S.N.M.

RHYNCHOZOON GRANDICELLA, new species.

Plate 47 , figs. 7,8 .

Description.-The zoarium inerusts shells. The zooeeia are distinet, separated by a deep furrow, large, elongated, elliptical. The frontal is a costulated pleurocyst surrounded by small areolar pores; it is covered by an avieularian chamber forming a truncated tongue above the apertura. The apertura is very oblique, transverse, with a wide proximal rimule. The peristomice is rery oblique and bears an eccentric pseudorimule to the right or left of the aricularian mucro. The oviecll is small, globular, opening into the peristomie by a wide orifiee. The ancestrular zooecia are sinaller than the ordinary ones.

$$
\text { Measurements.-Apertura }\left\{\begin{array} { l } 
{ h a = 0 . 1 5 \mathrm { mm } . } \\
{ l a = 0 . 2 0 \mathrm { mm } . }
\end{array} \quad \text { Zooecia } \left\{\begin{array}{l}
L z=0.85-0.90 \mathrm{~mm} . \\
7 z=0.60-0.70 \mathrm{~mm} .
\end{array}\right.\right.
$$

Tariations.-The apertura is visible only when the specimen is much inelined. The interareolar costules are little salient; on the zoarial margin they are visible only under special illumination.

Affinities.-This species differs from Rhynchozoon longirostris Hincks, 18s1, also provided with large zooecia, in its dimensions greater than $0.70 \mathrm{~mm}$. and in the absence of a frontal avicularium. It differs from Rhynchozoon corrugatum Thornely, 1905, also deprived of frontal avicularia in its much larger dimensions, in its interareolar costules, and in its ovicell wanting the two areas.

Occurrence.-Pleistocene: Rustic Canyon, Santa Moniea, California (rare).

Cotypes.-Cat. No. 68666, U.S.N.M. 
RHYNCHOZOON(?) LEVIGATUM, new species.

Plate 45, fig. 11.

Description. - The zoarium incrusts shells. The zooecia are distinct, elongate, oroid, separated by a furrow; the frontal is very convex, smooth or rery finely granular. The apertura is oval; the peristomice bears interiorly an excentric pseudolyrula; the peristome is thick and salient. The ovicell is globular, salient, attached to the pcristome; its orifice is large, placed in the peristomie, and can not be closed by the operculum.

Measurements. - Apertura $\left\{\begin{array}{l}h a=0.12 \mathrm{~mm} . \\ l a=0.10 \mathrm{~mm} .\end{array} \quad\right.$ Zooccia $\left\{\begin{array}{l}L z=0.50-0.75 \mathrm{~mm} . \\ l z=0.25 \mathrm{~mm} .\end{array}\right.$

Affinities.-The excentric spinule in the peristome characterizes this species. It differs from Schizoporella argentea Hincks, 1852, in the absence of a large oral avicularium. The species differs from Mucronella contorta Busk, 1882, in its nonperforated frontal. It differ's from Rhynchozoon tuberculatum Osburn, 1914, in the absence of scattered tuberosities on the frontal.

Occurrence.-Pleistocene: Mount Hope, Panama Canal Zone (very rare).

Holotype.-Cat. No.6S667, U.S.N.M.

RHYNCHOZOON VERRUCULATUM Smitt, 1872.

Plate 3, figs. 11-13.

1872. Escharella verruculata Smitr, Floridan Bryozoa, pt. 2, Kongl. Srenska Vetenskaps-Akademiens Handlingar, no. 4, p. 50, pl. 8, figs. 170-172.

1879. Cellepora vermculata Waters, On the Bryozoa of the Bay of Naples, Annals and Magazine of Natural History, ser. 5, vol. 3, p. 193, pl. 14, figs. 1-7.

1884. Escharoides vermuculata Busk, Report on Polyzoa collected by the Challenger, vol. 10, pt. 30 , p. 150.

1885. Cellepora verruculata Waters, On the use of the avicularian mandible, with additional list of the Naples fauna, Journal Royal Microscopical Society, ser. 2, vol. 5, pl. 14, fig. 37.

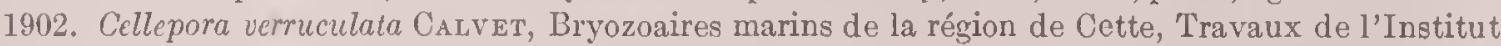
de Zoologie de L'Université de Montpellier, mem. 11, p. 66, pl. 2, figs. 6-9.

1902. Cellepora verruculata CALvet, Bryozoaires marins des côtes de Corse, Travaux de l'Institut de Zoologie de L'Université de Montpellier, mem. 12, p. 37.

1914. Cellepora verruculatum OsBurs, Bryozoa of the Tortugas Islands, Publication Carnegie Institution of Washington, no. 192, p. 214.

Measurements.-Apertura $\left\{\begin{array}{l}h a=? \\ l a=0.12 \mathrm{~mm} .\end{array} \quad\right.$ Zooecia $\left\{\begin{array}{l}L_{z}=0.45-0.50 \mathrm{~mm} . \\ l z=0.30 \mathrm{~mm} .\end{array}\right.$

Variations. - The marginal zooecia are well oriented; the central zooecia are not, which has caused the species to be classified incorrectly in Cellepora. The frontal avicularium is transverse, mucl elongated, with triangular mandible. The peristome is lobed or crowned by from three to six tubercles. One of the two lips of the pseudorimule of the peristomice often bears a small avicularium. The irregularity of this species defies all description; the absence of limits between the zooecia appears to be the cause.

We are not entirely certain that the Mediterranean species is that of Smitt; the measurements taken from Calvet's figures appear larger.

Occurrence.-Miocene (Bowden marl) : Bowden, Jamaica (ràre). Pliocene (Caloosalıatchee marl): Shell Creek, De Soto County, Florida (rare). Pleistocene: Simmons Point, Yonges Island, South Carolina (very rare).

Habitat.-Mediterranean at Naples, Cette, Corse. Atlantic: Gulf of Mexico and Tortugas Islands (24 meters). Indian Ocean: Heard Island (121 meters).

Plesiotypes.-Cat. No. 6S668, U.S.N.M. 
Family ADEONIDAE Jullien, 1903.

Genus ADEONA (Lamouroux, 1816) Levinsen, 1909.

(For description see Bulletin 106, U. S. National Museum, p. 560).

ADEONA POlzOSA Canu and Bassler, 1919.

Plate 6, figs. 22, 23.

1919. Adcona porosa Canu and Bassler, Geology and Paleontology of the West Indies, Bryozoa, Publications of the Carnegie Institution of Washington, no. 291, p. 94, pl. 6, figs. 22, 23.

Description.-The zoarium is free, bilamellar. The zooecia are little distinct, very elongate, separated by a hardly visible, salient thread; the frontal is porous, little convex, surrounded by areolar, parietal pores of which one is larger than the others. The ascopore is large, orbicular, median. The apertura and peristomice are semilunar with the proximal border somewhat concave. The gonoecia have two very large symmetrical, areolar pores and irregular, oral gibbosities. The aricularian zooecia have their opesia arranged on the lower part of a pyriform area, calcified and deep.

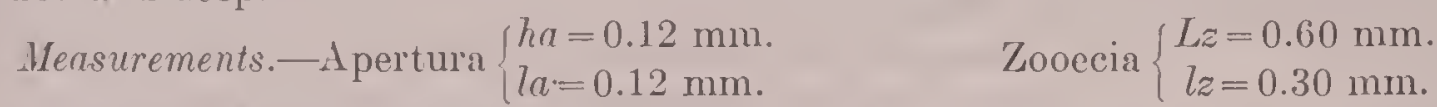

Affinities.-As we possess only the figured fragment the study of this species is necessarily incomplete. The species is rery peculiar, for there is no other one provided with a porous frontal and oral gibbosities at the gonoecia.

Occurrence.- Lower Miocene (Bowden horizon): Cercado de Mao, Santo Domingo (rare).

Cotypes.-Cat. No. 68669, U.S.N.M.

ADEONA HECKELI Reuss, 1847.

Plate 2f, figs. 1, 2.

1845. Cellepora umbilicata LoxsDALE, Report Corals Tertiary formation North America, Quarterly Journal (ieological Society, London, vol. 1, p. 507.

1847. Cellcpora heckeli Reuss, Die fossilen Polyparien des Wiener Tertiarbeckens, Haidinger's naturwissenschaftliche $\Lambda$ bhandlungen, vol. 2, p. 85 , pl. 10 , fig. 10.

1849. Lepralia violacea Joirsstox, A History of the British Zoophytes, p. 325, pl. 57, fig. 9.

1862. Multiporina umbilieata GabB and Hors, Monograph of the fossil Polyzoa of the Secondary and Tertiary formations of North America, Journal Academy of Natural Sciences of Philadelphia, ser. "2. vol. 5, p. 145, pl. 20, fig. 27 .

1880. Microporella violacea Hiscks, History of the British Marine Polyzoa, p. 216, pl. 30, figs. 1-4.

1889. Microporella hcckeli JELLY, A synonymic catalogue of the recent marine Bryozoa, p. 184 (general synonymy).

1895. Microporlla (Heckelia) violacea Neviasi, Briozoi fossili della Farnesina, Pateontographia italica, rol. 1, p. 106, (30), pl. 5, (1), figs. 27-29.

1900. Microporella heckeli CALVET, Contrilution a l'Histoire naturelle des Bryozoaires ectoprocts marins, Travaux de l'Institut de Zoologie de l'Université de Moutpellier, mem. 8, pl. 7, fig. 1; pl. 8, fig. 15 .

1901. Mieroporella (Hcekclia) violueca Neviavi, Briozoi neogenici della Calabrie, Paleontographia Italica, vol. 6. p. 177 (63), (local bibliography).

1902. Mirroporella hecklli Calvet, Bryozoaires inarins de la region de Cette, Travaux de l'Institut de Zoologie de l'Université de Montpellier, vol. 2, mem. 11. p. 39.

1902. Hicroporilla heckli CALVET, Bryozoaircs des côtes de Corse, Travaux de l'Tnstitut de Zoologie de l'Université de Montpellier, vol 2, mem. 12, p. 20.

1904. Adeoncllopsis umbilicata Ulrich and Bassier, Maryland Geological Survey, Miocene, p. 417, pl. 113, figs. 4, 5; pl. 114, fig. 5 . 
1905. Microporella (Heekelia) violacea Neviani, Briozoi fossili di Carrubare (Calabrie), Bolletino della Societa geologica italiana, vol. 23, p. 525 .

1907. Microprella heckeli Calvet, Expédition scientifique du Travailleur et du Talisman, vol. 8, p. 404 (bibliography).

1909. Adeona violaeca Levinsen, Morpholqgical and systematic studies on the cheilostomatous Bryozoa, p. 83, pl. 14, fig. 1.

1909. Reptadeonella violacea Norman, The Polyzoa of Madeira and neighboring islands, Journal Linnean Society of London, vol. 30, p. 296.

1914. Adeona violacea OsBurn, The Bryozoa of the Tortugas Islands, Florida, Publication No. 182, Carnegie Institution of Washington, p. 199.

1915. Microporella heckeli Barroso, Contribucion al conociementa de los Briozoos marinos de l'Espana,Boletin de la real sociedad espanola de Historia naturale, p. 415.

1917. Adeona heckeli Barroso, Notas sobre Briozoos, Boletin de la real sociedad espanola de Historia naturale, p. 498.

1919. Adeona heekeli CANu and BAssler, Geology and Paleontology of the West Indies, Bryozoa, Publications of the Carnegie Institution of Washington, no. 1, p. 95.

This species is better known to zoologists under the name of Microporella violacea Johnston, 1849. In 1874 Reuss abandoned his right of priority because of his mediocre figure of 1847 . Jelly, 1889 , did not recognize his withdrawal of the-name and authors have employed one or the other name according to their personal preference. On account of the size and position of the large frontal avicularium there has been created a rariety, plagiopora Busk, 1859. Osburn, 1914, has shown that on the same specimen this avicularium may be straight or oblique and that it does not necessitate the establishment of a special variety.

The American fossil specimens are very rare; they belong to the normal form with straight aricularium, long since described by Gabb and Horn under the name of Multiporina umbilicata. Of this species we have found only a single specimen in the Bowden marl which is moderately well preserved. In the Duplin marl of the Upper Miocene, however, it is more common but not so abundant as in the European Miocene and Pliocene.

Occurrence.--Lower Miocene (Bowden marl): Bowden, Jamaica (rare). Lower Pliocene (Caloosahatchee formation): Shell Creek, De Sota County, Florida (common). Upper Miocene (Duplin marl): Wilmington, North Carolina; Natural well, 2 miles southwest of Magnolia, Duplin County, North Carolína; 3 miles southwest of Petersburg, and near Powcan, King and Queen County, Virginia (common).

- Geological distribution.-Stampian of Germany (Reuss); Aquitanian of Gironde (Durergier); Miocene of Australia (Waters); Helvetian of Italy (Seguenza), of Touraine (Canu); Tortonian of Austria-Hungary (Reuss), of Italy (Seguenza, Neviana), of England (Busk); Sicilian of Rhodes (Manzoni, Pergens), of Italy (Seguenza, Neviani); Quaternary of Italy (Seguenza, Neviani).

Mabitat.-Mediterranean: Adriatic (32-89 meters), Naples (54 meters), Algeria, Cette (40-97 meters), Bonifacio (89-92 meters), Balearic Islands, shores of Spain. Atlantic: England, English Channel, Gulf of Gascony, Bay of Cadex (60-97 meters), Cape Verde Islands (118-180 meters), Madeira, Florida (56-97 meters), Tortugas (8-29 meters), Bermuda. Indian Ocean: Burmah. Pacific: Australia, China Sea and Cape Tizard (43 meters).

This species does not extend beyond the fifty-second parallel in Europe and the twenty-second in America. It is never abundant in any locality.

Plesiotypes.-Cat. Nos. 68670-68673, U.S.N.M. 
Genus BRACEBRIDGIA MacGillivray, 1886.

(For description, see Bulletin 106, U. S. National Museuni, p. 557.)

BRACERRIDGIA DEFORMIS Canu and Bassler, 1919.

Plate 8, figs. 11-16.

1919. Braccbridgia deformis CANU and Bassler, Geology and Paleontology of the West Indies, Bryozoa, Publications of the Carnegie Institution of Washington, no. 291, p. 97, pl. 3, fig. 11-16.

Description.-The zoarium is free, bilamellar, compressed, bifurcated. The zooecia are distinct, elongate, separated by a deep furrow, clariform or clliptical; the peristomice is oral or elliptical; an oblique avicularium is buricd in the peristomie; the apertura (visible only from the interior) is semilunar; the frontal is surrounded by areolar, parietal pores and on the zooecia it bears a large pore which does not perforate the wall.

$$
\text { Neasurements.-Peristomice }\left\{\begin{array} { l } 
{ \text { hpie } = 0 . 1 5 \mathrm { mm } . } \\
{ \text { lpie } = 0 . 1 2 \mathrm { mm } . }
\end{array} \text { Zooecia } \left\{\begin{array}{l}
L z=0.45-0.60 \mathrm{~mm} . \\
l z=0.25-0.30 \mathrm{~mm} .
\end{array}\right.\right.
$$

Affinities. -This species has the exterior aspect of an Adeonellopsis. The large frontal pore, however, is not a perforated area; it is invisible in the interior and its nature is unknown. The few specimens which we hare studied were, it is true, rather poorly preserred. The peristomial aricularium is rarely visible at the exterior; it is on the contrary quite constant in the interior. This interior is that of Bracebridgia; it is therefore, indeed, in this genus that it must be classified, but it is a deformed-Bracebridgia. The presence of a large frontal pore clenrly characterizes this species and clearly differentiates it from the other known species of the same genus.

Occurrence.-Lower Miocene (Bowden marl): Bowden, Jamaica (rare).

Cotypes.-Cat. No.68674, U.S.N.M.

Genus LAMINOPORA Michelin, 1842.

1842. Laminopora Michelis, Iconographie zoophytoolgique.

The apertura is very elongate; the anter is semielliptical; the poster bears a long, rounded rimule, two small cardelles separate the two latter parts; the operculum bears laterally two lateral denticles articulating on the cardelles. The frontal is a tremocyst with pores not starred. The gonoecia have no special form. Thirteen to fifteen tentacles.

Genotype.-Laminopora contorta Michelin, 1842.

Range.-Miocene-Recent.

Gemellipora arbuscula Calvet, 1907, belongs to this genus.

LAMINOPORA MIOCENICA, new species.

Plate 47 , fig. 5 .

Description.-The zoarium is bilamellar. The zooecia are distinct, separated by a deep furrow, elongated, oval, much narrowed behind, surrounded by a row of parietal dietellae; the frontal is convex, perforated by large pores; it bears a small elongated avicularium variable in form and in position. The apertura is long and narrow; the rimule is long and spear shaped. 
Measurements.-Aperture $\left\{\begin{array}{c}h a=0.15 \mathrm{~mm} . \\ l a=0.06 \mathrm{~mm} .\end{array}\right.$ Zooecia $\left\{\begin{array}{c}L z=0.65 \mathrm{~mm} . \\ l z=0.40-0.45 \mathrm{~mm} .\end{array}\right.$

Affinities.-The present new species differs from Laminopora contorta Michelin, 1842 , in the position of its aricularium below the aperture. It differs from Laminopora arbuscula Calret, 1907, in the greater length of its apertura $(0.15$ and not $0.11 \mathrm{~mm}$.), in its bilamellar zoarium and in its apertura not occupying two-fifths of the zooecial length.

'The avicularium is very irregular', sometimes straight with the beak directed above, sometimes transverse, triangular, or elliptical.

Occurrence.-Miocene (Bowden horizon): Santo Domingo (very rare).

Holotype-Cat. No. 68675, U.S.N.M.
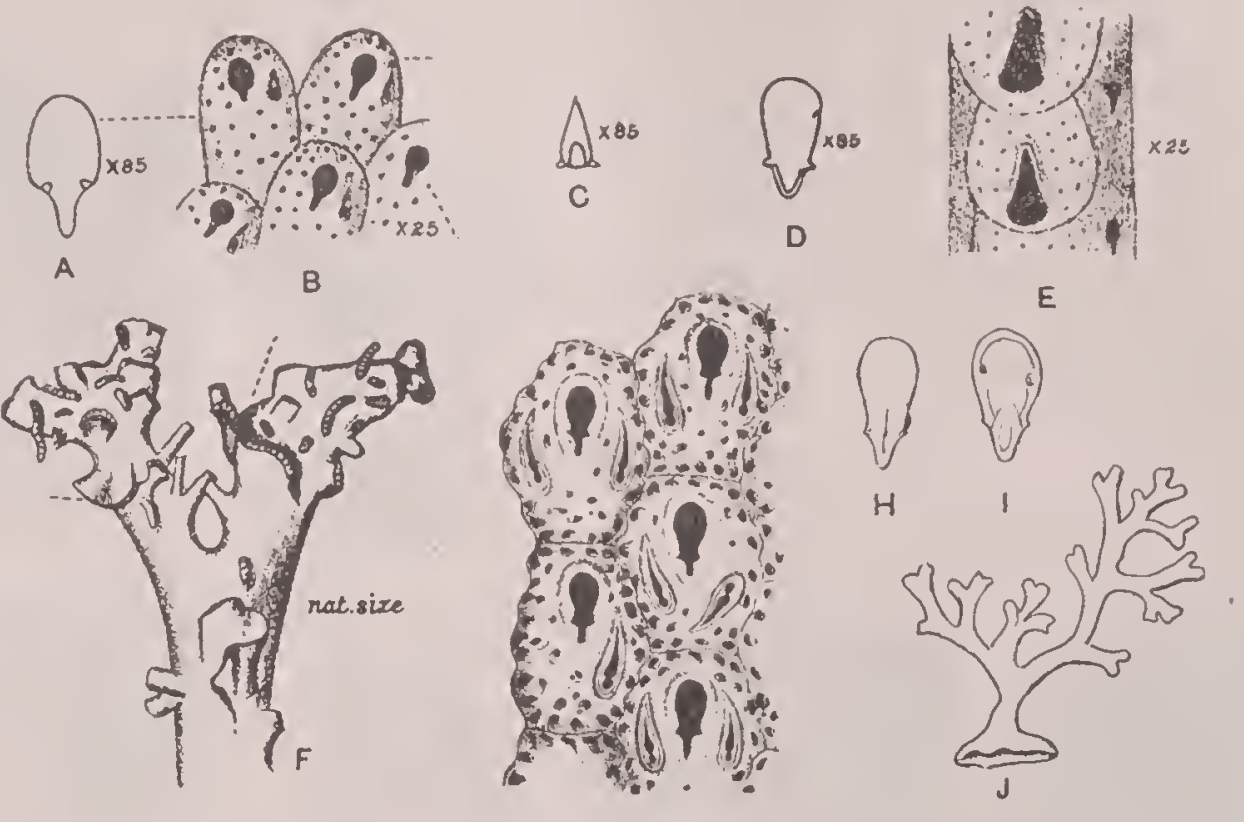

E

G

Fig. 28.-Genus Laminopora Michelin, 1842.

A-F. Laminopora contorta Michelin, 1842. $\Lambda$. Sketch of aperture, $\times 85$, showing elongated sinus. B. Zooecia, $\times 25$. C. Mandible, $\times 85$. E. Latcral view of a zoarium showing large vicarious vibracula. F. Zoarium, natural size, illustrating branching at right angles aftcr forming very short branches only. (A-F, after Waters, 1919.)

G-J. Laminopora arbuscula Calvet, 1902. G. Zooecia, $\times 45$. H. Opcrculum, $\times 90$, viewed on the outer side. I. Operculum, $\times 90$, vicwed on the inner side. J. Zoarium, natural size. (G-J, after Calvet, 1907.)

Genus ADEONELLOPSIS MacGillivray, 1886.

(For description, sec Bulletin 106, U. S. National Museum, p. 563.)

ADEONELLOPSIS COCCINELLA, new species.

Plate 24, figs. 5-8.

Description.- The zoarium is bilamellar with small irregular fronds. The zooecia are distinct, little elongate, elliptical, little convex; the frontal is perforated by four to seven stellate pores. The apertura is terminal, semilunar, with a slightly 
coneare proximal border; the peristome is thin, little salient, notehed, and bears a small very inconstant supraoral avieularium. On each side of the apertura there are two sinall straight avieularia, without pivot, the point above.

$$
\text { Measurements. A Apertura }\left\{\begin{array} { l } 
{ h a = 0 . 0 6 \mathrm { mm } . } \\
{ 7 a = 0 . 0 4 \mathrm { mm } . }
\end{array} \quad \text { Zooecia } \left\{\begin{array}{l}
L z=0.40 \mathrm{~mm} . \\
7 z=0.20 \mathrm{~mm} .
\end{array}\right.\right.
$$

Affinities.-This species is quite close to Escharipora stellata Smitt, 1872, a recent species off the eoast of Florida, in the ensemble of its characters. It differs from it in the vertical direction of the oral a vieularia, in the less low position of the latter, and in the muel smaller number of frontal perforations. Escharipora stellata MacGillivray, a recent species from Australia, is not the species of Smitt, 1872, but it is undoubtedly of the same genus.

We are absolutely ignorant of the hydrostatic system of this group called Escharipora by Sinitt, 1872. MacGillivray believed that it belonged to the Adeonidac. Lerinsen considered the stellate pores as ascopores. It has seemed to us that one of our specimens had a gonoecium with transverse apertura, but it is neecssary to await more detailed zoological study in order to classify this group of species.

Occurrence.-Lower Miocene (Chipola marl): Chipola River, Calhoun County, Floricla (rare).

Cotypes.-Cat. No.68676, U.S.N.M.

Genus ANARTHROPORA Smitt, 1867.

(For description, see Bulletin 106, U. S. National Museum, p. 430.)

Lerinsen classified this genus doubtfully in the Escharellidae, where we also placed it in our monograph on the North American Early Tertiary Bryozoa. The absence of the ovicell, the nature of the frontal, and the analogy with ecrtain species of Adeonellopsis indicate that the genus is better placed in the Adeonidae.

Family HIPPOPODINIDAE Lerinsen, 1909.

Genus METRARABDotos Canu, 1914.

(For description, see Bulletin 106, U. S. National Museum, p. 533.)

METRARABDotos Colligatum Canu and Bassler, 1919.

Plate 4, figs. 3-12.

1919. Metrarabdolos colligatum Canu and Bassier, Geology and Paleontology of the West Indies, Bryozoa, Publications of the Carnegic Institution of Washington. no. 291, p. 95, pl. 4, figs. 3-12

Description.-The zoarium is free, bilamellar, attached to algae by a small, expanded base and bent upward like a crank; the fronds are large, bifureated, but narrow. The zooccia are distinet, separated by a salient thread, long and narrow; the frontal is smooth, convex, surrounded by a line of large areolar pores often separated by short eostules. The apertura is suborbicular; the peristomice is oval with a proximal pseudorimule. There are sometimies two quite ineonstant, small, 
oral aricularia. The oriccll is cndozooecial, enormous, borne by a considerably enlarged zooccium; its frontal is garnished with radiating and granulated costules.

Measurements.--Young zooccia: Apertura $\left\{\begin{array}{l}h a=0.14 \mathrm{~mm} . \\ 7 a=0.12 \mathrm{~mm} .\end{array}\right.$

$$
\begin{gathered}
\text { Zooecia }\left\{\begin{array}{l}
L z=0.60 \mathrm{~mm} . \\
l z=0.28-0.30 \mathrm{~mm} .
\end{array}\right. \\
\text { Old zooccia : Apertura }\left\{\begin{array}{l}
h a=0.24 \mathrm{~mm} . \\
l a=0.16 \mathrm{~mm} .
\end{array}\right. \\
\text { Zooecia }\left\{\begin{array}{l}
L z=0.70 \mathrm{~mm} . \\
l z=0.24-0.30 \mathrm{~mm} .
\end{array}\right.
\end{gathered}
$$

Affinities.-The genus Metrarabdotos contains more species in America than in Europe. The present species differs from Metrarabdotos moniliferum Milne-Edwards,

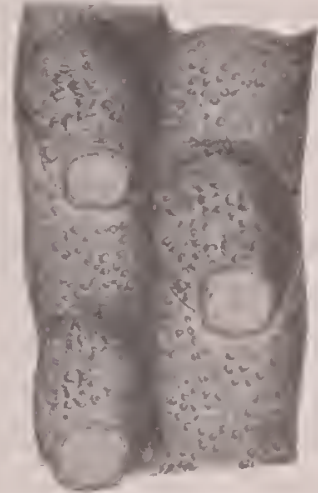

A. Hippopodina

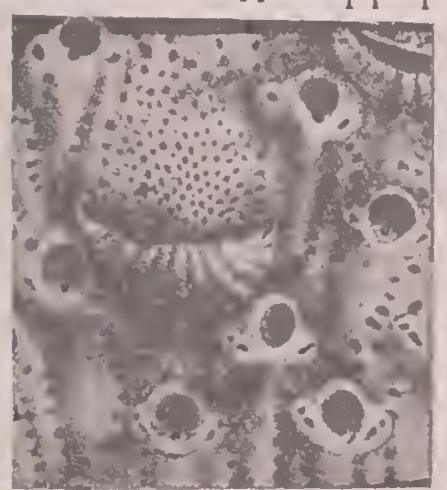

D. Metrarabdotos
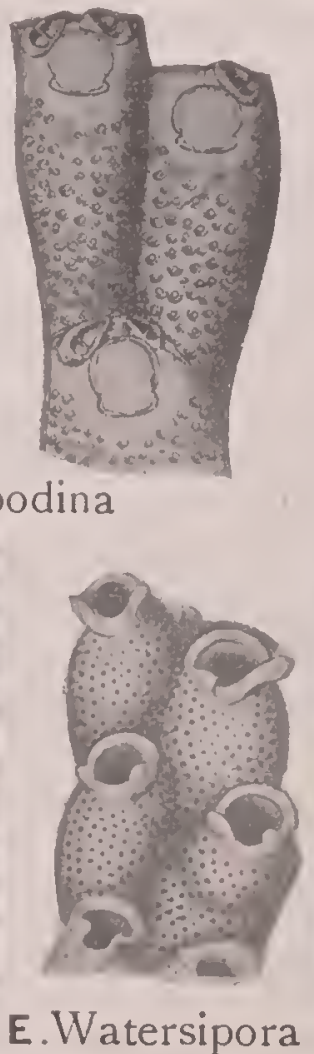

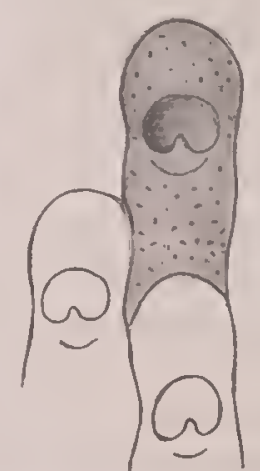

B. Cheilopora

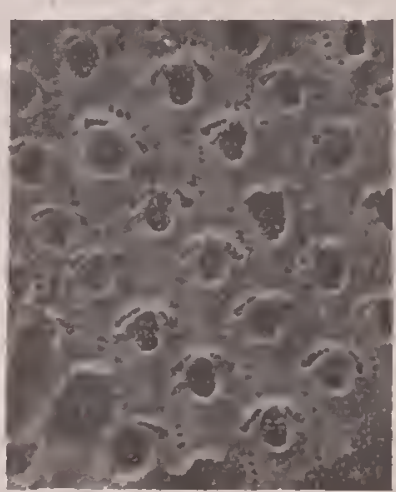

F. Hippaliosina

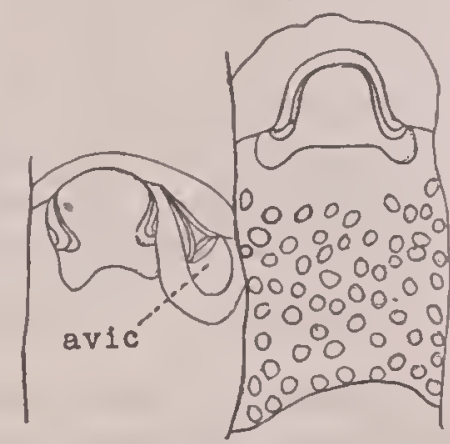

C. Cheiloporina

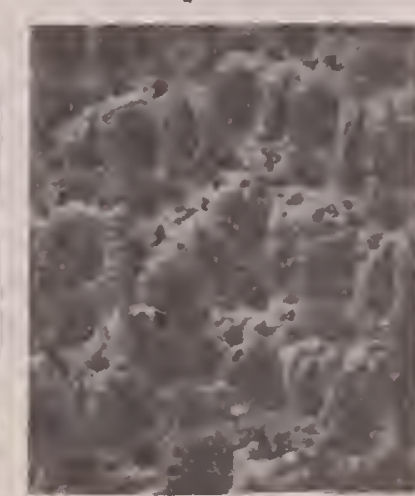

G. Tremogasterina

FIG. 29.-Genera of the Hippopodinidae Levinsen, 1909.

A. Hippopodinn Levinson, 1909; H. fceycensis Busk, 1884, X 35. B. Cheilopora Levinsen, 1909; C. sincera Smitt, $1867, \times 20$, C. Chriloporina, new genus; $C$. haddoni Harmer, 1902, X 44. D. Metrarabdotos Canu, 1914: .T. moniliferum Vilne-Edwards, X 25. F. Watersipora Neviani, 1895; W. cucullata Busk. 1853, × 35. F. Hippaliosina Canu; H. rostrigera Smitt, 1872, × 20, G. Tremogasterina Canu 1911; T. horrida, new species, $\times 20$.

1836, common in the French Mincene, in its granulaterl costules on the oricell, in the absence of a pscudolyrulc at the peristomice, and in the absence of oral avicularia. It diffcrs from Metrarabdotos grandis of the Vicksburgian, which also forms large fronds, in its greater zooecial width and in much less deep intercostular spaces 
of the ovicell. The species is quite variable and wc have figured the principal variations.

Occurrence.-Lower Miocene (Bowden horizon): Cercado de Mao and Rio Cana Santo Domingo (common).

Cotype-Cat. No. 68677, U.S.N.M.

\section{Metrarabdotos LACRYMosum Canu and Bassler, 1919.}

Plate 8, figs. 1-10.

1919. Mctrarabdotos lacrymosum CANU and BAsster, Geology and Paleontology of the West Indies, Bryozoa, Publications of the Camegie Institution of Washington, no. 291, p. 96, pl. 3, figs. 1-10.

Description.- The zoarium is free, bilamellar, bifurcated, narrow, with rectangular fronds, and fastened by a little expanded base. The zooecia are distinct, little clongate, rcctangular, surrounded by large areolar pores more or less separated by the costules. The apcrtura is oblique, semielliptical, divided in front by a rounded and perforated sinus. The oricelled zooecia are quite widle; the ovicell is endozooecial; it is little salient, finely punctate, and ornamented with interareolar costules. On-each side of the apertura there are two large, triangular, salient avicularia with their point directed upward.

$$
\text { Measurements.-Apertura }\left\{\begin{array} { l } 
{ h a = 0 . 1 8 \mathrm { mm } . } \\
{ l a = 0 . 1 4 \mathrm { mm } . }
\end{array} \quad \text { Zooecia } \left\{\begin{array}{l}
L z=0.70-0.74 \mathrm{~mm} . \\
l z=0.28-0.30 \mathrm{~mm} .
\end{array}\right.\right.
$$

Affinities.-The characteristics of this species are the two large, oral aricularia which hang from each side of the apertura like two large tears. They are very irrcgular.

This species differs from Metrarabilotos colligatum from the same genlogical horizon, in its little expanded and nonprehensile base, in its nonclaviform fronds, and in the presence of large, oral a vicularia. It differs from Metrarabdotos monitiferum Milnc-Edwards, 1S3S, in its much less costulated oricell and in the absence of a spine in the oral sinus.

Occurrence.-Lower Miocene (Bowden marl) : Bowden, Jamaica (common).

Cotypes.-Cat. No. 6867S, U.S.N.M.

\section{METRARABDotos aURiCUlatUM, new species.}

Plate 31, figs. 1-9.

Description.-The zoarium is bilamellar and formed of large, long, narrow, bifurcated fronds. The zooecia are distinct, separated by a salient thread, claviform; the frontal is narrow, little concare, surrounded by numerous areolar pores, separated by salient costules. The pcristomice bears a rather deep proximal sinus at the base of which there are two lateral condyles limiting the orifice of the compensatrix; the apertura, buried at the base of the peristomice, is elliptical, a little clongated; the peristome bears two lateral avicularia. The ovicell is endozooecial, quite lnrge; its superior wall is conrex and costulate; its apertura is large and transverse.

$$
\text { Measurements. -Apertura }\left\{\begin{array} { l } 
{ h a = 0 . 1 8 \mathrm { mm } . } \\
{ l a = 0 . 1 6 \mathrm { mm } . }
\end{array} \text { Zooecia } \left\{\begin{array}{l}
L z=0.70-0.90 \mathrm{~mm} . \\
l z=0.40 \mathrm{~mm} .
\end{array}\right.\right.
$$


Affinities.-This specics differs from Metrarabdotos colligatum and from Metrarabdotos lacrymosum in its much larger zoaria and in its larger zooecial dimensions $(L z>0.70 \mathrm{~mm}$.). It differs from Metrarabdotos monitiferum Milne-Edwards, 1838, in the absence of a pseudolyrule in the peristomice.

The two large oral avicularia occur like two lateral ears; they are rather constant but of ten are diminished and partially buried by the activity of the calcification. In some rare cases they are replaced by a single supraoral a vicularium.

Occurrence.-Pliocene (Waccamaw marl): Waccamaw River, Horry County, South Carolina (common). Pliocene (Caloosahatchee marl): Shell Crcek, De Soto County (very common), and Monroe County, Florida (very common).

Cotypes.-Cat. Nos. 68679, 68680, U.S.N.M.

\section{Genus HiPPALIOSINA Canu, 1918.}

1918. Hippaliosina $\mathrm{CAxU}_{\mathrm{A}}$, Hippaliosina, un nouveau genre de Bryozoaires, Bulletin de la Société géologique de France, ser. 4, vol. 18, p. 88.

The ovicell is endozooecial. The apertura is elongate, clliptical, divided into two parts by two triangular cardelles; the poster is smaller than the anter. The frontal is a granular pleurocyst surmounting an olocyst perforated laterally by arcolar pores. There are usually two a ricularia on each side of the apertura.

Genotype.-Hippaliosina (Escharella) rostrigera Smitt, 1872.

Range.-Rupelian-Recent.

The family Hippopodinidae is perhaps not a natural one, because the larva is not known. We classify here all the species in which the ovicell is endozooecial. Nererthcless, the genus Hippaliosina is undoubtedly very close to Hippopodina Levinsen, 1909, and Cheilopora Levinsen, 1909, which are characteristic of the family. It differs solely in the function of calcification; the tremocyst is replaced by a granular pleurocyst, accompanied by lateral areolar pores. Letrarabdotos Canu, 1914, prescnts also lateral areolar pores and a pleurocyst, but the hydrostatic function operates here through a vamna and not a rimule; moreover, the $o$ vicells are totally different.

In addition to two new recent specics from the Philippine Islands, the following species belong to this genus:

Hippaliosina (Lepralia) depressa Busk, 1852. Recent.

Hippaliosina (Escharella) rostrigera Smitt, 1872. Recent.

Hippaliosina (Lepralia) clavula Manzoni, 1871. Helvetian.

Hippaliosina brevirostris Canu, 191S. Recent.

IIippaliosina (Hemeschara) sandbergeri Reuss, 1869. Rupelian, Aquitanian.

Hippaliosina laxipora Canu, 1918. Miocene.

The genotype Hippaliosina rostrigera has been dredged nenr the twenty-second parallel a slight distance from the Tropic of Cancer, where it appears to have found its best conditions for existence. We can infer that the fossil species hare lived under similar conditions and that their presence indicates likewise the ricinity of the Tropic. In this case their geologic distribution would indicate the displacement of this line through the ages, and consequently the contraction of the equatorial 
zone. Employing the known localities we have the following table for the Northern Hemisphere:

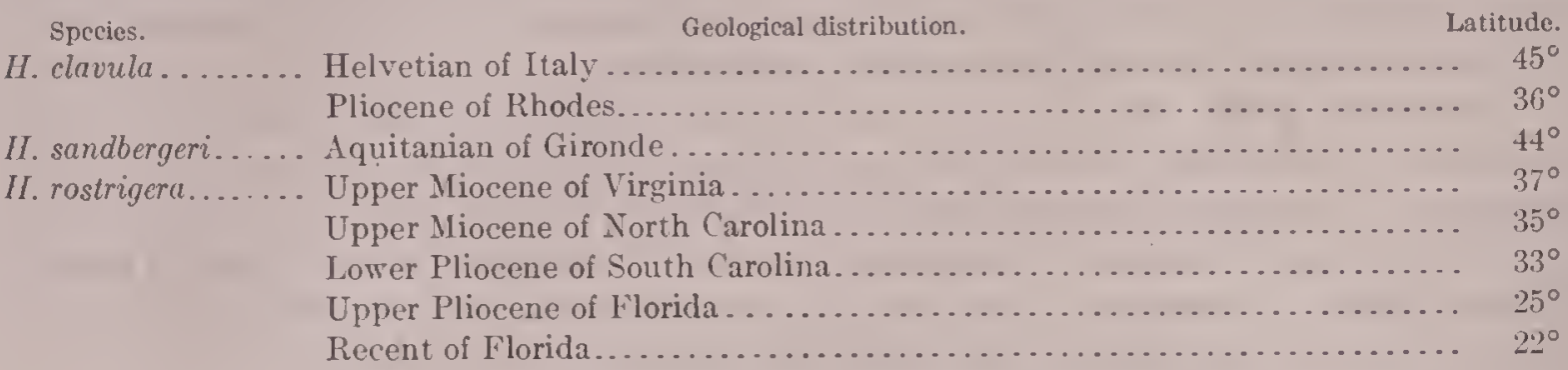

The interpretation of this table indicates in a striking fashion the rapid and continuous descent of the Tropic toward the Equator. No species of the genus exists in the faluns of Touraine (forty-ninth parallel) situated without the equitorial zone. On the contrary, the Helvetian of Italy represented by $H$. clavula was nearer

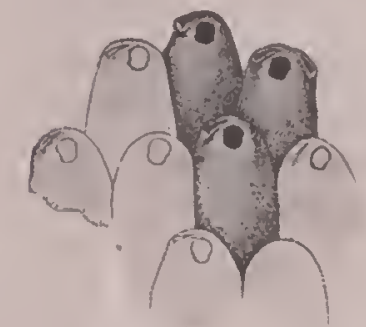

A

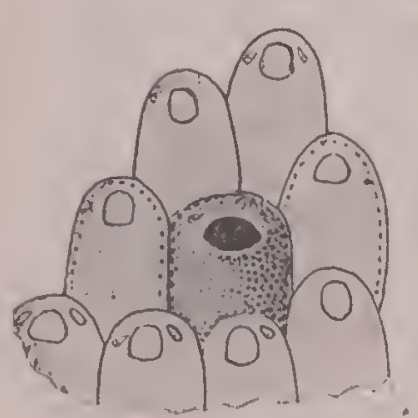

8
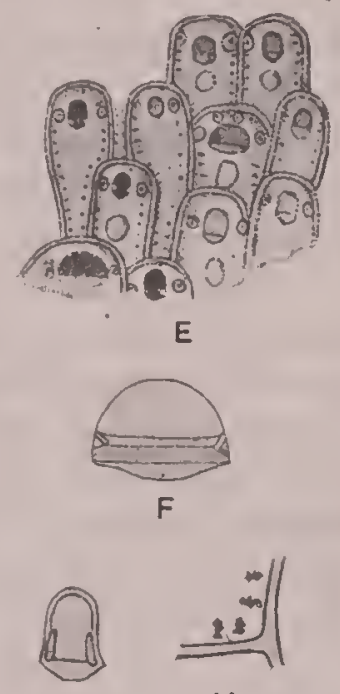

G

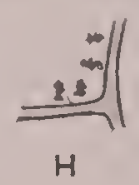

H

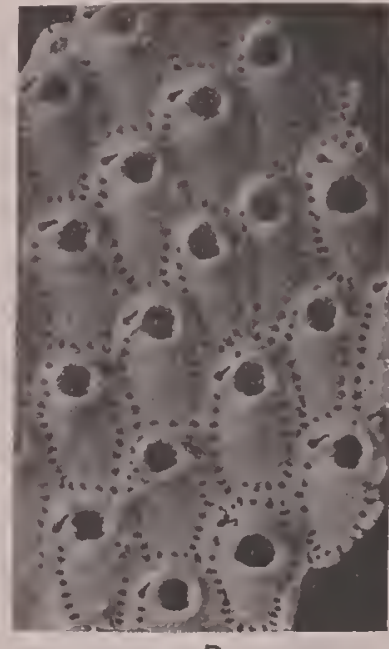

D

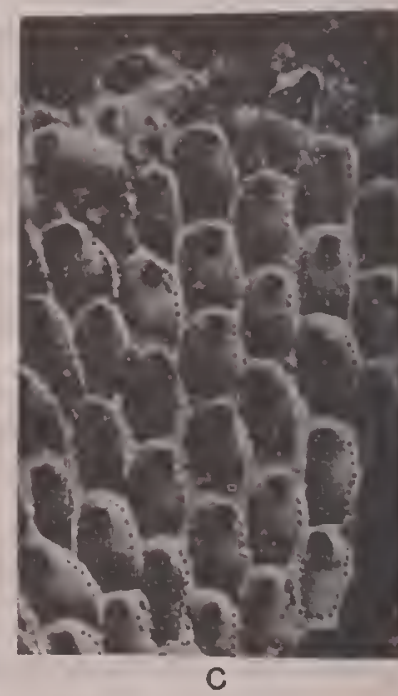

Fig. 30.-Genus Hippaliosina Canu. 1918.

A-C. IIippaliosina rostrigera Smitt, 1872. A. Ordinary zooecia. B. Group with an ovicelled zooecium. (A, B, after Smitt, 1872.) C. Interior of a fossil example, $\times 20$.

D. Hippatiosina sandbergeri Reuss, 1869. An ovicelled specimen, $X 25$, from the Aquitanian of Leognan, France.

E-H. Itippaliosina brevirostris Canu, 1918. E. Ovicelled specimen, X 25. F. Operculum of the ovicelled zooecia, $X 85$. G. Operculum of ordinary zooecia, X 85. H. Areolar pores. $X 85$. (E-H, after Waters, 1859.)

to it. This latter species does not exist in the more southern European Pliocene. H. sandbergeri, not being able to emigrate toward the south probably by the obstacle of a continental barrier, was exterminated in its place. It is probable that it will bc diseovered in more northern Oligoeene deposits.

For the Southern Hemisphere this phenomenon is less evident because of the imperfect geographie eonditions. Although the fossil species H. laxipora has been 
observed along the thirty-fifth and thirty-sixth parallels, the recent species has beell dredged only nearer the Equator from the thirty-fifth to the tenth parallels. The emigration northward toward the Equator appears thus to be a phenomenon as real as in the other hemisphere.

The bryozoa, on account of their method of life and their abundance in the marine currents, arc generally rather cosmopolitan. It is remarkable that the genus IIippaliosina las been so sensitive to external variations, and this is a new phenomenon which merits recognition.

\section{HIPPALIOSINA ROSTIIGERA Smitt, 1872.}

Plate 17, figs. 15-17.

1872. Escharella rostrigera SuITt, Floridan Bryozoa, Kongl. Svenska Vetenskaps-Akademiens Handlingar, vol 11, p. 57, pl. 10, figs. 203-205.

1918. Hippaliosina rostrigera CANU, Hippaliosiua, un nouveau genre de Bryozoaires, Bulletin de la Société géologique de France, ser. 4, vol. 18, p. 89.

Measurements (fossil specimens):

Apertura of ordi- $(h a=0.15 \mathrm{~mm}$. nary zooecia . $\{l a=0.10 \mathrm{~mm}$.

Apertura of ovi- $h a=0.16 \mathrm{~mm}$. celled zooecia $\mid l a=0.16-0.17 \mathrm{~mm}$.

$$
\begin{aligned}
& \text { Ordinary zooecia }\left\{\begin{array}{l}
L z=0.44-0.55 \mathrm{~mm} . \\
l z=0.30 \mathrm{~mm} .
\end{array}\right. \\
& \text { Oricelled zooecia }\left\{\begin{array}{l}
L z=0.50 \mathrm{~mm} . \\
l z=0.35 \mathrm{~mm} .
\end{array}\right.
\end{aligned}
$$

The ovicelled zooecia have an aperture larger and transverse and, moreover, of irregular form. Smitt has noted and has figured an elliptical aperture measuring $0.36 \mathrm{~mm}$. in width. This variation must be rather rare, for we have only observed it on the fossil specimens from the Miocene near Yorktown, Virginia. In the Australian species the small ovicelled zooecia appear to be absent. The ovicelled zooecia should not be confounded with gonoecia. The latter do not contain a polypicle, as the ovary alone occupies the interior cavity. The ovicell is little salient, little visible, but always apparent on our fossil specimens. 'The zooecia which bear them are larger.

This species has been dredged south of Florida in the vicinity of the Tropic of Cancer. The special location gives a clue to the contraction of the equatorial zone since the Oligocene period.

Geologic distribution.-Miocene (Yorktown formation): Yorktown, Suffolk, and 3 miles southwest of Petersburg, Virginia (common). Miocene (Duplin marl): Natural Well, 2 miles southwest of Magnolia, Duplin County, North Carolina (common). Pliocene (Waccamaw marl): Waccamaw River, Horry County, South Carolina (rare). Pliocene (Caloosahatchee marl): Monroe County, Florida (rare).

Habitat.- South of Florida at a depth of 56 to 59 meters.

Plesiotypes.-Cat. No. 68681-68683, U.S.N.M.

\section{Genus TREMOGASTERINA Canu, 1911.}

1911. Tremogasterina Cand, Iconographie des Bryozoaires fossiles de l'Argentine, pt. 2, Anales del Museo Nacional de Buenos Aires, vol. 21 (sec. 3, vol. 14), p. 256.

The ovicell is concealed. The frontal is perforated by a large pore and surrounded by a line of areolar pores. The apertura is semielliptical. Avicularia between the apertures. 
Genotype.-Tremogasterina problematica Canu, 1911.

Range.-Rocanean, Miocene.

In 1911 Canu discorered this remarkable and mysterious genus in the Rocanean strata of Argentina; that is to say, at the base of the Eocene. He noted the nature of the ovicell in his remarks that it opened in the interior of the zooecium. The single described species. Tremogasterina problematica, is insufficiently preserved to serve as a genotype, and as the Miocene species here described are mucl better preserred, they will give a clearer idea of the genus. The form of the aperture indicates clearly the presence of a compensatrix. Therefore, it is rather probable that the enormous frontal pore is an ascopore.

\section{TREMOGASTERINA HORRIDA, new species. ${ }^{\circ}$}

Plate 24, figs. 3,4

Description.-The zoarium is free, bilamellar, with small distorted fronds. The zooecia are distinct, very elongate, elliptical, little regular, little conrex; the frontal is perforated by a large, median orbicular pore, surrounded by a line of scattered areolar pores. The apertura is rery large, elongate, semielliptical; it presents a slight constriction at the lower third, probably at the level of the articulations. The peristome is thick and tuberous. The oricell is endozooecial, smooth, transverse, little salient; the apertura is of the same size as that of the ordinary zooecia. Between two apertures, on one or the other zooecium, there is an immense triangular avicularium, without pirot with the beak turned toward the top.

$$
\text { Measurements.-Apertura }\left\{\begin{array} { l } 
{ h a = 0 . 1 8 - 0 . 2 0 \mathrm { mm } . } \\
{ l a = 0 . 1 4 \mathrm { mm } . }
\end{array} \quad \text { Zooecia } \left\{\begin{array}{l}
L z=0.60 \mathrm{~mm} \text { : } \\
l z=0.30 \mathrm{~mm} .
\end{array}\right.\right.
$$

Opesium of the $h a v=0.14 \mathrm{~mm}$.

avicularium lav $=0.10 \mathrm{~mm}$.

$$
\text { A ricularium }\left\{\begin{array}{l}
\text { Lav }=0.30-0.40 \mathrm{~mm} . \\
\text { lav }=0.24 \mathrm{~mm} .
\end{array}\right.
$$

Affinities. - This species has a disagreeable aspect and its structure is difficult to understand. We hare only found three small specimens and we have not been able to make a good dissection. The oricell itself was not in condition to be photographed. If the frontal perforation is an ascopore, the apertura ought not to have an operculum moring on a special axis; this is not the case, the proximal border not being straight. This perforation corresponds perhaps to a special avicularium.

Occurrence.-Miocene (Choctawhatchee marl): Jackson Bluff, Ocklocknee Rirer, 25 miles southwest of Tallahassee, Florida (rare).

$$
\text { Holotype.-Cat. No. 68684, U.S.N.M. }
$$

\section{CHEILOPORINA, new genus.}

The ovicell is endozooecial; the apertura of the ovicelled zooecium is rery large. The frontal is a tremocyst. The apertura bears two cardelles and the operculum is narrowed laterally at their level. No separation between the oricell and the zooecium. Twenty-seren tentacles.

Genotype-Cheiloporina (IIippoporina) circumcincta Neviani, 1896.

Range.-Jacksonian to Recent. 
Historical.-In our monograph on the Early Tertiary Bryozoa we noted: "The genotype is deprived of cardelles. We think that the species having cardelles and a different operculum must be introduced into a new genus." Our manuscript was written in 1917. In 1918 Waters $^{7}$ stated that the operculum of Cheilopora circumcincta Neviani, 1896, is quite different from the operculum of the genotype Cheilopora sincera Smitt, 1867, and that these two species can not be maintained in the same genus. Under these conditions we are justified in creating the new genus Cheiloporina.
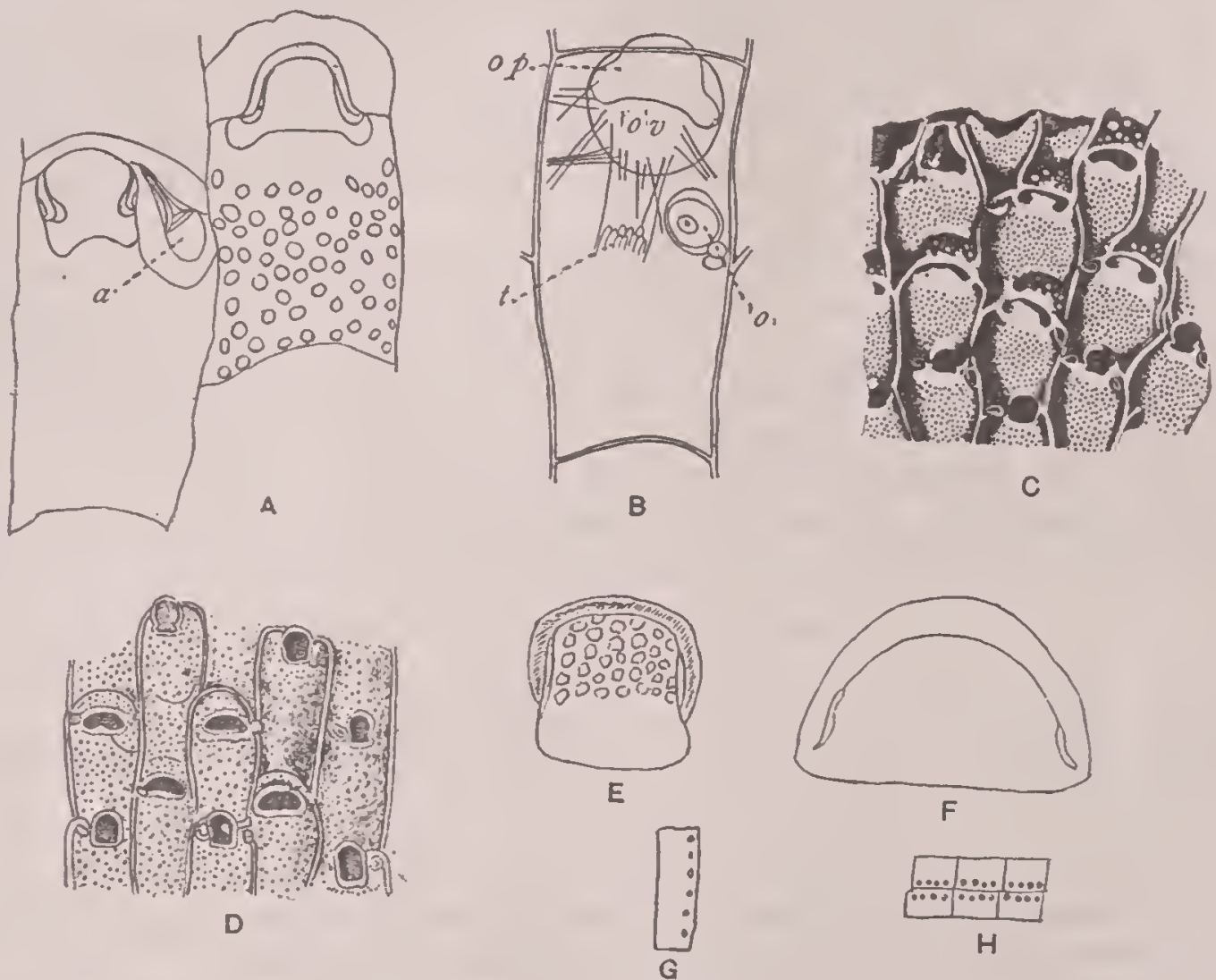

Fir. 31.-Cheiloporina, new genus.

A-H. Cheiloporina (Cheilopora) haddoni Harmer, 1902. A. Two zooecia, one ovicelled, showing an avicularium $(a)$ and the two kinds of opercula. B. Basal view of zooecium with trifoliate operculum. (After Harmer, 1902), op. operculum; $t$, tentacles; o, ovary; ov, ovisac. C. Zoarium with ovicelled zooecia, $\times 25$. (After Jullien, 1903.) D. Ovicelled zooecia, X 12. E. Operculum of ordinary zooe. cium, $\times 85$. F. Operculum of ovicelled zooecia, $\times 85$. G. Lateral wall showing septulae. H. Distal wall with septulae. (D-H, after Waters, 1918.)

All the species of Cheitopora described in the Monograph of North American Early Tertiary Bryozoa belong in reality to Cheiloporina. These are as follows: Cheilopora labiosa Ulrich, 1901; Cheilopora orbifera; C. prelucidioides; C. strictocella; C. grandis; C. transversa; C. transveroides; C. specula; and C. sulcifera Canu and Bassler.

I On some Mediterranean Bryozoa, Annals and Magazine Natural History, ser. 9, vol. 11, p. 97, pl. 12, figs. 6-10. $12184-23-B$ Bull. $125-12$ 
Family TUBUCELLARIIDAE Busk, 1884.

\section{Genus TUBUCELLARIA D'Orbigny, 1852.}

(For description, see Bulletin 106, U. S. National Museum, p. 542.)

tubucellaria punctulata Gabb and Horn, 1862.

Plate 40, figs. 1-4.

1862. Entalophora punctulata GABB and HorN, Monograph Polyzoa Secondary and Tertiary formations of North America, Journal Academy Natural Sciences, Philadelphia, ser. 2, vol. 5, p 171, pl. 21, fig. 61 .

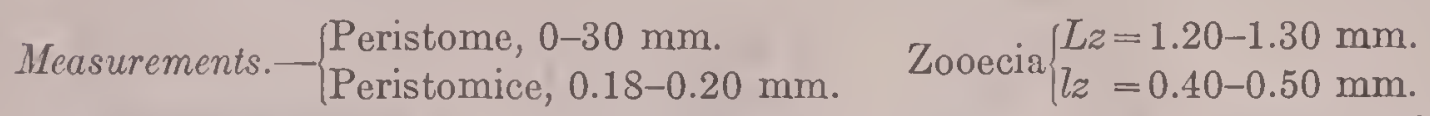

Affinities.-This species is not entirely articulated; the segments are often ramified. The peristome sometimes bears one or two small avicularia. The frontal is a tremocyst with large pores.

The exterior aspect is rather deceiving and the older American authors classified the species in Entalophora. The bifurcation of the segments confirmed this reference but the longitudinal section proves their error (fig. 4). 'The ovicell is buried in the thickness of the peristomial walls; unfortunately we have not yet had the chance to section an ovicelled zoarium.

Occurrence.-Pleistocene: Santa Barbara (very common), Santa Monica (rare), and Dead Mans Island, off San Pedro, California (rare).

Plesiotypes.-Cat. Nos. 68686-6868S, U.S.N.M.

TUBUCELlaRia PUNCTULATA, var. MINOR, new variety.

Plate 40, figs. 5,6 .

The micrometric measurements are smaller; the tremopores are smaller and more scattered.

$$
\text { Measurements.- }\left\{\begin{array} { l } 
{ \text { Peristome, } 0 . 2 4 \mathrm { mm } . } \\
{ \text { Peristomice, } 0 . 1 4 \mathrm { mm } . }
\end{array} \text { Zooecia } \left\{\begin{array}{l}
L z=1.20 \mathrm{~mm} \text {. } \\
l z=0.40 \mathrm{~mm} .
\end{array}\right.\right.
$$

- The constancy of these small micrometric measurements obliges us to separate this variety from the well-known long-ago described species.

Occurrence.-Pleistocene: Santa Barbara (rare) and Santa Monica (Tremochal Canon), California (rare).

Holotype.-Cat. No. 68689, U.S.N.M.

\section{Family PHYLACTELLIDAE Canu and Bassler, 1917.}

\section{Genus PHYLACTELLA Hincks, 1880.}

(For description see Bulletin 106, U.S. National Museum, p. 573.)

PHYLACTElla SPINOSISSIMA, var. MAJOR Hincks, 1884.

Plate 39, figs. 8, 9.

1884. Mucronella spinosissima, var. major Hrncks, Polyzoa of the Queen Charlotte Islands, Annals and Magazine Natural History, ser. 5, vol. 13, p. 53 (sep. 27); p. 213 (sep. 42).

Affinities.-In Miss Jelly's Synonymic Catalogue of Marine Bryozoa this species is considered a synonym of Mucronella peachi, var. octodentata Hincks, 1880 . We believe this arrangement is erroneous because here the ovicell is recumbent and placed 
on the collar of the zooecium (necklike of Hincks), which is characteristic of the Phylactellidae. Neither do we believe that it is identical with Mucronella spinosissima Hincks, 1881, from Australia, and Hincks himself has noted some important differences. As we have not the material at hand for comparison we are adopting Hincks name of 1884, as our fossil is identical with the variety figured by him from the Queen Charlotte Islands.

The trace of numerous spines on the peristomice is quite visible on our fossils. We have not observed the tubular system noted by Hincks, but on many of the wellpreserved zooecia we have observed the transformation of the tremopores into divergent tubules rather long and very little salient. There are eight spines on the peristome of the ovicelled zooecia.

This species differs from Phylactella collaris Norman, 1866, figured by Miss Robertson in 1908, in its oricell of less width than the zooecium and smaller in its ensemble.

Occurrence.-Pleistocene: Santa Monica (Long Wharf Canyon), California (rare).

Habitat.-Pacific: Queen Charlotte Islands.

Plesiotype-Cat. No. 68690, U.S.N.M.

Genus LAGENIPORA Hincks, 1877.

(For description see Bulletin 106, U. S. National Museum, p. 591.)

LAGENIPORA SPINULOSA Hincks, 1884.

Plate 40, fig. 7.

1884. Lagenipora spinulosa HINcks, Polyzoa of the Queen Charlotte Islands, Annals and Magazine of Natural History ser. 5 , vol. 13, p. 57 (sep. 31), pl. 3, fig. 4; p. 210 (sep. 40), pl. 9 , fig. 4 .

- 1908. Lagenipora spinulosa RoBertson, The incrusting Cheilostomatous Bryozoa of the west coast of North America, University of California Publications, Zoology, vol. 4, No. 5, p. 283, pl. 18, fig. 37.

Our figured specimen, much changed by fossilization, gives only a very poor idea of the beauty of this fragile species. The other specimens observed are equally poorly preserved, but there is no occasion to doubt their identity with this recent species.

Occurrence.-Pleistocene: Dead Mans Island, off San Pedro, California (rare).

Habitat.-Pacific: Off California.

Plesiotype.-Cat. No. 68691, U.S.N.M.

\section{LAGENIPORA(?) BREVICOLLIS, new species.}

Plate 24, fig. 9

Description.-The zoarium incrust Cellepores. The zooecia are distinct, 7 separated by a deep furrow, elongated, oriented, elliptical; the frontal is very convex and covered with tremopores. The peristome is incomplete, interrupted distally, little salient, much enlargerl in its proximal portion. The apertura hidden at the bottom of the peristome bears cardelles placed very low, and an almost straight proximal border. 
Measurements.-Apcrtura $\left\{\begin{array}{l}h a=0.10 \mathrm{~mm} . \\ l a=0.10 \mathrm{~mm} .\end{array}\right.$ Zooecia $\left\{\begin{array}{l}L z=0.50 \mathrm{~mm} . \\ l z=0.30 \mathrm{~mm} .\end{array}\right.$

Variations.-There are sometimes on the peristome two very small avicularia symmetrically placed. We have not observed the ovicell, but the distal interruption of the peristome is a sufficient reason for our generic assignment.

This species differs from Lepralia tenera Reuss, 1867, in the presence of frontal tremopores.

Occurrence.-Miocene: Kuhns, Carteret County, North Carolina (rare).

Holotype-Cat. No. 68692, U.S.N.M.

\section{Genus MASTIGOPHORA Hincks, 1880.}

(For description see Bulletin 106, U. S. National Museum, p. 586.)

MASTIGOPHORA PESANSERIS Smitt, 1873.

Plate 45, fig. 10 .

1873. Mippothoa pesanseris Smrrt, Floridan Bryozoa, pt. 2, Kongl. Svenska Vetenskaps-Akademiens Handlingar, vol. 11, No. 4, p. 43, pl. 7, figs. 159, 160 .

1880. Mastigophora dutertrei, var. pesanseris Kirkpatrick, Polyzoa of Mauritius, Annals Magazine Natural History, ser. 6, vol. 1, p. 77.

1899. Schizoporella pesanseris Waters, Bryozoa from Maderia, Journal Royal Microscopical Society, p. 11, pl. 3, figs. 7,8 .

1905. Mastigophora dutertrei, var. pesanseris Thornely, Report on Polyzoa collected by Professor Herman at Ceylon in 1892, Ceylon Pearl Oyster Fisheries, Rept. Colonial Government, vol. 4, Suppl. Rep. No. 26, p. 117.

1909. Schizoporella pesanseris Waters, Marine Biology of Sudanese Red Sea, Journal Linnean Society London, vol. 31, p. 169.

1909. Escharina pesanseris Norman, Polyzoa of Maderia and neighboring islands, Journal Linnean Society London, vol. 30, p. 302, pl. 40, fig. 7 .

1909. Escharina pesanseris Levinsen, Morphological and Systematic Studies on the Cheilostomatous Bryozoa, p. 326, pl. 18, fig. 1.

1914. Escharina pesanseris Osburn, Bryozoa of the Tortugas Islands, Florida, Publication Carnegie Institution of Washngton, No. 182, p. 207.

The generic position of this species is still doubtful. According to the operculum, Waters classified it in the S. cecili group (Arthropoma); according to the form and position of the avicularia, Levinsen classified it in Mastigophora (Escharina). He believed that the ovicell is endozooccial. If this observation be verified it will bc necessary to create a new genus for this species. Our spccimen is incrusting a coral.

Occurrence.-Pleistocene: Mount Hope, Panama Canal Zone (rare).

Habitat.-Indian Ocean: Mauritius, Nanaar ( 55 meters), Sian, Gulf of Suez (Red Sea). Atlantic Ocean: Madeira (90 meters), Tortugas Islands (12-68 meters). Plesiotype.-Cat. No. 68693, U.S.N.M.

\section{MASTIGOPHORA GRANULOSA, new species.}

Plate 3, fig. 4.

Description.-The zoarium incrusts shells. The zooecia arc distinct, separated by a deep furrow, large, elongated, and swollen; the frontal is very convex, ornamented with numerous small pores and minute granulations. The aperture is small, 
somewhat elongated, and bears a wide rimule which is rounded and deep; the peristome is wide, very little salient, and bears spines. The two vibracula are salient and orbicular, the ovicell is small, convex, smooth.

$$
\text { Measurements.-Apertura }\left\{\begin{array} { l } 
{ h a = 0 . 1 5 \mathrm { mm } . } \\
{ l _ { a } = 0 . 1 2 \mathrm { mm } . }
\end{array} \text { Zooecia } \left\{\begin{array}{r}
L z=0.60-0.75 \mathrm{~mm} . \\
l z=0.45-0.55 \mathrm{~mm} .
\end{array}\right.\right.
$$

Affinities.-This species differs from Mastigophora pesanseris Smitt, 1872, in its larger micrometric measurements, in its frontal granules larger and more apparent, and in its vibracula placed at the level of the rimule.

Occurrence.-Miocene (Bowden marl): Bowden, Jamaica (very rare).

Holotype.-Cat. No. 68694, U.S.N.M.
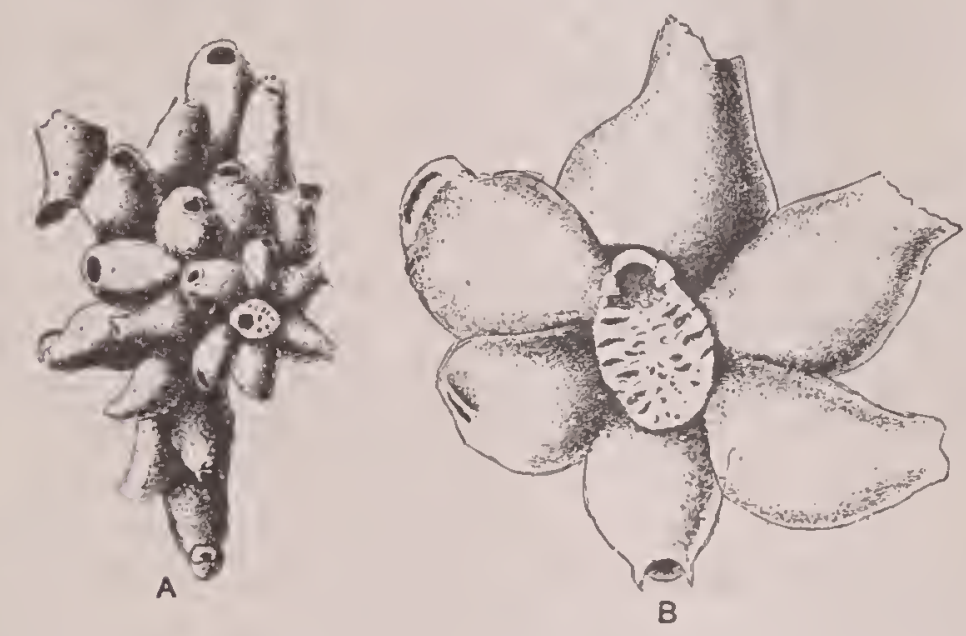

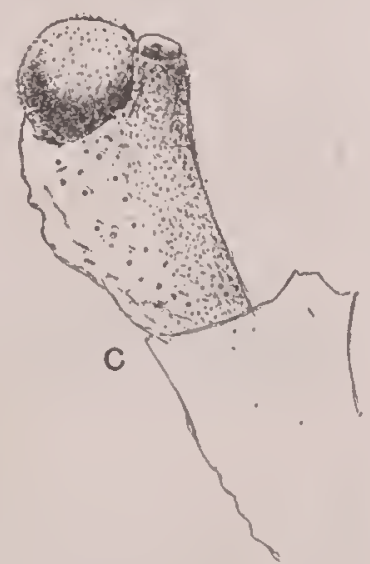

Fig. 32.-Genus Temachia Jullien, 1882.

A-C. Temachia opulenta Jullien, 1882. A. An incrusting specimen, $\times 8.5$, from the Gulf of Gascony. B. Ancestrula and ancestrular zooecia, $\times 29$. C. An ovicelled zooecium, $\times 29$.

\section{Genus TEMACHIA Jullien, 1882.}

1882. Temachia Juluien, Dragages du Travailleur, Bulletin de la Societe de France, vol. 7, p. 510.

Zooecia suberect, dilated at the base and narrowed like the neck of a bottle above; peristome split anteriorly and deprived of spines; ovicell globular with the opening corresponding to the incision in the peristome. Zooecia of origin (ancestrula) with a frontal wall entire and lattice like, with two strong lateral spines at the level of the orifice. (Translation, after Jullien.)

Genotype.-Temachia opulenta Jullien, 1882. Recent.

\section{Genus CREPIDACANTHA Levinsen, 1909.}

1909. Crepidacantha Levinsen, Morphologic and Systematic Studies on the Cheilostomatous Bryozoa, p. 266.

The zooecia, whose aperture has strong hinge teeth and a compound, wellchitinized operculum, are in the proximal half provided with 9 to 12 very long marginal spines and 8 to 11 small uniporous pore chambers (dietellae) alternating as a rule with small intermediate chambers, each of which has an uncalcified spot 
(a marginal pore) in its roof. Two frontal vibracula without a crossbar. The hyperstomial, almost free ooccia, consist of two calcificd layers, of which the ectooecium is provided with a number of porcs. (Levinsen.)

Genotype.-Crepidacantha poissoni Savigny-Audouin, 1826. Recent.
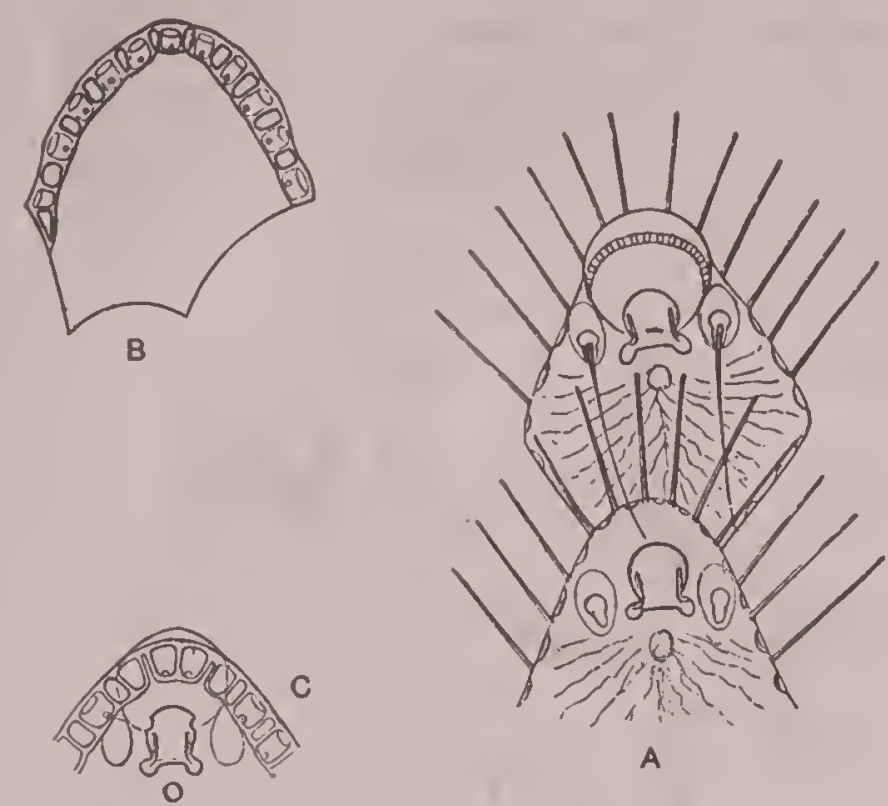

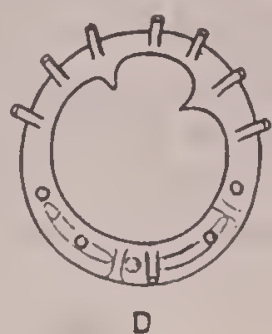

D
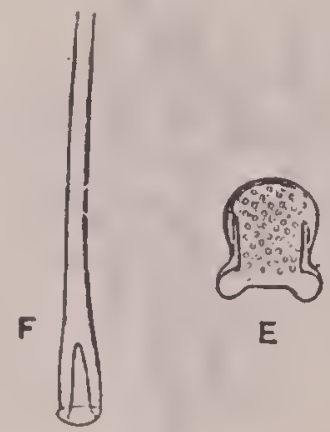

E

FIa. 33.-Genus Crepidacantha Levinsen, 1909.

A-F. Crepidacantha poissoni, var. crinispina Levinsen, 1909. A. Two zooecia, X 55. B. A zooecium seen from the basal wall. As in figure $\mathrm{C}$, dietellae alternate with intermediate spaces, $X 55$. C. The distal part of a zooecium with ovicell, seen from the basal wall, $X 55$. D. An ancestrula of another variety of the same species, $\times 175$. E. Operculum, $\times 140$. F. The proximal part of the flagellum, $\times 200$. (After Levinsen, 1909.)

\section{Family CELLEPORIDAE Busk, 1852. \\ Genus HOLOPORELLA Waters, 1909.}

For description, see Bulletin 106, U. S. National Museum, p. 604. HOLOPORELLA ALBIrostris Smitt, 1872.

Plate 7, figs. 9-14; plate 32, figs. 6-10.

1872. Discopora albirostris Smiтt, Floridan Bryozoa, pt. 2, Kongl. Svenska Vetenskaps-Akademiens Handlingar, vol. 11, no. 4, p. 70, pl. 12, figs. 233-239.

1889. Cellepora albirostris Jelly, A synonymic catalogue of the Recent Miocene Bryozoa, p. 45 (Bibliography).

1914. Holoporella albirostris Osburs, Bryozoa of the Tortugas Islands, Publication 182, Carnegie Institution of Washington, p. 215.

1919. Moloporella albirostris CANU and BASSLER, Geology and Paleontology of the West Indies, Bryozoa, Publications of the Carnegie Institution of Washington, no. 291, p. 97, pt. 1, fig. 19, pl. 7, figs. 9-14.

Measurements.-Apertura, $h a=0.14 \mathrm{~mm}$.

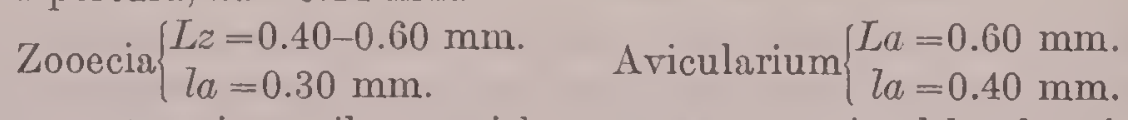

Variations.-The apertura is semilunar with a concave proximal border; it is indeed only constant in the interior (pl. 32, fig. 10). Exteriorly the peristomicc is 
quite variable; it presents very frequently an excentric pseudosinus, as in the specimens dredged by the Challenger at Heard Island. This is occasioned by the very irregular development of a spiniform mucro. The latter is very fragile and never exists on our fossils; it is scarcely visible, and then only on the deep zooecia. The frontal is smooth and garnished laterally with very small areolar pores (pl. 32, fig. 8) which are rather easily obliterated (pl. 32, fig. 7). The interzooecial avicularium is spatulate; its distribution on the zoarium is very inconsistent.

The zoarium is always attached to algae; it creeps above or indeed completely around them to form masses of 3 centimeters in diameter. The depth at which it is dredged therefore gives no indication of its hydrostatic capacities if it is not living; the disappearance of the algae buries the zoarium in the depths where it did not live. The ancestrular zooecia are oriented (pl. 32, fig. 10) and the ancestrula emits five buds. The tuberosities observed on certain zoaria come from the greater development of certain zooecial groups.

Occurrence.-Oligocene (Emperador limestone): One-third mile north of Empire, Panama Canal Zone (rare). Oligocene (Anguilla formation): Southwest side of Crocus Bay, Anguilla, Leeward Islands (rare). Lower Miocene (Bowden marl): Bowden, Jamaica (very common). Pliocene (Calooshatchee marl): Shell Creek, De Soto County, and Monroe County, Florida (very common).

Geological distribution.-Miocene of Australia; Pliocene of New Zealand.

Habitat.-Atlantic: Off Florida (24-56 meters). Indian Ocean: Heard Island (121 meters). Pacific: Off Australia (to 13 meters).

Plesiotypes.-Cat. Nos. 68695-68697, U.S.N.M.

holoporella Parvula, new species.

Plate 24, figs. 10-13.

Description.--The zoarium is free, subcylindrical, irregularly branched. The zooecia are very small, heaped upon each other, irregular, provided with a small umbo before the apertura and surrounded by some areolar pores. The apertura is very small, semielliptical, transverse, surrounded by one to four small orbicular avicularia.

Measurements.-Apertura $\left\{\begin{array}{l}h a=0.08 \mathrm{~mm} . \\ l a=0.10 \mathrm{~mm} .\end{array}\right.$

Affinities.-In its general aspect this species may easily be confounded with Holoporella maculata Ulrich and Bassler, 1904, and with Holoporella minuta, new species. It differs from both of these in its free and cylindrical zoaria (and not attached to shells), and in the presence of the small avicularia which surround the apertura.

Occurrence.-Miocene (Duplin marl): Cape Fear River, 28 miles northwest of Wilmington, North Carolina (rare).

Holotype.-Cat. No. 68698, U.S.N.M.

HOLOPORELLA ROSTRIFERA, new species.

Plate 24, fig. 14.

Description.-The zoarium incrusts shells and forms small spiny masses. The zooecia are indistinct, erect; the frontal is convex, small, surrounded by a double row of areolar pores and often with costules directed toward the frontal rostrum 
placed in front of the apertura. The apertura is somewhat elliptical, elongated; the two small cardelles are placed in the lower third. Around the apertura there are four very salient rostra $(0.30$ to $0.40 \mathrm{~mm}$.) terminated by a small, round avicularium without pivot. The ovicell is small, convex, not closed by the operculum and presents a very fragile orbicular frontal area.

$$
\text { Measurements.-Apertura }\left\{\begin{array}{l}
h a=0.17 \mathrm{~mm} . \\
l a=0.14 \mathrm{~mm} .
\end{array}\right.
$$

Affinities.-The present species differs from Holoporella subturrita in its rostra, which are free and not attached to the distal zooecium; in its frontal, which is not covered with tremopores; and in the presence of cardelles.

Occurrence.-Miocene (Yorktown formation): York River, Virginia (rare).

Holotype.-Cat. No. 68699, U.S.N.M.

\section{HOLOPORELLA SUBTURRITA, new species.}

Plate 25, fig. 9.

Description.-The zoarium incrusts shells, on which it forms small spinose masses. The zooecia are distinct, little erect, swollen; the frontal is convex and covered with tremopores. The apertura is elliptical, somewhat elongated, without cardelles. It is surrounded by four long rostra terminated by avicularia; the two distal rostra have their peduncles attached to the distal zooecium.

$$
\text { Measurements.-Apertura }\left\{\begin{array} { l } 
{ h a = 0 . 1 6 \mathrm { mm } . } \\
{ l a = 0 . 1 4 \mathrm { mm } . }
\end{array} \quad \text { Zooecia } \left\{\begin{array}{l}
L_{z}=0.60-0.80 \mathrm{~mm} \\
l z=0.36-0.40 \mathrm{~mm} \text {. }
\end{array}\right.\right.
$$

Affinities.-With its long rostra this species much resembles Holoporella turrita, Smitt, 1872, from which it differs in the two distal rostra attached to the superior zooecium, in its tremopores, and in the absence of small nonpedunculate frontal a vicularia.

Occurrence.-Miocene (Duplin marl) : 28 miles northwest of Wilmington, North Carolina (rare).

Holotype.-Cat. No. 68700, U.S.N.M.

\section{HOLOPORELLA HEMISPHERICA, new species.}

Plate 3, figs. 9, 10.

Description.-The zoarium is free, small, hemispherical, about the size of a pea. The zooecia are large, distinct, heaped upon one another; the frontal is quite convex, smooth, surrounded by some large areolar pores. The apertura is semielliptical, transverse with a concave proximal border.

Measurements.-Apertura $\left\{\begin{array}{l}h a=0.17 \mathrm{~mm} . \\ l a=0.15 \mathrm{~mm} \text {. }\end{array}\right.$

Affinities.-As we have collected only a few specimens of this small species, it is difficult to study its variations"or ized by the simplicity of its structure"and the large areolar pores which surround its broad frontal.

Occurrence.-Lower Miocene (Bowden marl): Bowden, Jamaica (rare).

Cotypes.-Cat. No.68701, U.S.N.M. 
HOLOPORELLA MASSALIS Ulrich and Bassler, 1904.

Plate 25, fig. 7 .

1904. Cellepora massalis Ulrich and Bassler, Maryland Geological Survey, Miocene, p. 428, pl. 117 , fig. 3,4 .

The original description by Ulrich and Bassler is as follows:

Zoarium massive, composed of many layers, often nodose, always rough. Zooecia erect, very irregularly arranged, four or five in $2.0 \mathrm{~mm}$; orifice circular with a thin raised peristome. Generally the peristome of each zooecium bears upon its inferior side a prominent rostrum containing a large avicularium pointing obliquely upward and outward. Surface of zooecia, excepting the peristome, coarsely punctate. Ovicells not observed.

$$
\text { Measurements.-Apertura }\left\{\begin{array}{l}
h a=0.13-0.15 \mathrm{~mm} . \\
l a=0.17 \mathrm{~mm} .
\end{array}\right.
$$

We have little to add to the description of Ulrich and Bassler and are only introducing a new photograph of the type specimen made on the same enlargement as the other species of this volume so as to better allow comparison. In the type we have observed a case of total regeneration which is very rare in the Cellepore bryozoa. This species differs from Holoporella orbifera in the very constant presence of a large frontal avicularium and in its smaller apertura.

Occurrence.-Miocene (St. Mary's formation): St. Mary's River, Maryland (rare). Miocene (Choptank formation): Greensboro, Maryland (rare). Miocene (Calvert formation): Chesapeake Beach and Plum Point, Maryland (rare).

Holotype.-Cat. No. 68702, U.S.N.M.

\section{HOLOPORELLA ORBIFERA, new species.}

Plate 25, figs. 3-6.

Description.-The zoarium is free, large, very irregular; it forms most often lobate or branched masses 2 centimeters in length. The zooecia are large, little distinct, erect; the frontal is smooth and surrounded by areolar pores. The apertura is vcry large, orbicular, without cardelles, with a concave proximal border. The oral avicularia are rare and inconstant. The interzooecial avicularia are large elliptical, with neither pivot nor denticles.

Measurements.-Apertura $\left\{\begin{array}{l}h a=0.20 \mathrm{~mm} . \\ l a=0.20-0.25 \mathrm{~mm} .\end{array}\right.$

Affinities.-This species is very easily recognized by its large oral dimensions. It can be compared only with Holoporella magnifica Osburn, 1914, now living in the water off Florida, from which it differs in the absence of the small interzooecial avicularia. Osburn unfortunately has not indicated the enlargement of his figure.

Occurrence.-Miocene (Duplin marl): Wilmington, North Carolina (rare) and Harvey's Mills, Leon County, Florida (rare). Pliocene (Waccamaw marl): Waccamaw River, Horry County, South Carolina (common).

Cotypes.-Cat. Nos. 68703, 68704, U.S.N.M.

HOLOPORELLA(?) ECHINATA, new species.

Plate 25, figs. 1, 2.

Description.-The zoarium is a globuliform mass, morc or less gibbose. The zooecia are large, salient, convex, smooth. The apertura is subcircular, the prox- 
imal border being very concare. There are two oral spines and a small oral very inconstant avicularium. On the deep zooecia the apertura only is visible.

$$
\text { Measurements.-Apertura }\left\{\begin{array}{l}
h a=0.15 \mathrm{~mm} \text {. } \\
l a=0.15 \mathrm{~mm} \text {. }
\end{array}\right.
$$

Affinities.-This species differs from Holoporella massalis Ulrich and Bassler, 1904 , in the absence of areolar pores. In the presence of two oral spines it approaches Holoporella bicornis, but differs from it in its larger micrometric dimensions and in the absence of areolar pores. It is also quite close to Cellepora tuberosa Smitt, 1872 , in the presence of a small oral avicularium and in the nature of the frontal; it differs from it in the presence of two spines and in a rery different zoarial form.

Only the figured specimen has been found. More plentiful material will later on permit a more exact study.

The absence of areolar pores may cause our generic determination to be doubted; but they are easily obliterated on the fossils.

Occurrence.-Miocene (Yorktown formation): Yorktown, Virginia (very rare).

Holotype.-Cat. No. 65705, U.S.N.M.

HOLOPORELLA BICORNIS, new species.

Plate 32, figs. 1-4.

Description.-The zoarium is formed of large shapeless masses attached to algae. The zooecia are erect, salient, very convex; the frontal is smooth, surrounded by some much-scattered areolar pores. The apertura is semilunar with a concare proximal border; the peristome is wide and bears two large spines. A small, salient avicularium terminates the median umbo. The deep zooecia have only their apertura visible. The interzooecial avicularia are rare and elliptical. Sometimes there is a vibraculum on the zooecia.

$$
\text { Measurements.-Apertura }\left\{\begin{array}{l}
h a=0.13 \mathrm{~mm} . \\
l a=0.12-0.15 \mathrm{~mm} .
\end{array}\right.
$$

Affinities.-Above many of the apertures a little pore in the form of a lunar crescent is visible; it has the aspect of vibraculum; it is placed on the distal zooecium or indeed it is interzooecial. Its function is unknown.

This species resembles Reptocelleporaria similis Tuomey and Holmes, but the figure of these authors indicates a greater number of areolar pores. It differs from Holoporella albirostris Smitt, 1S72, in the presence of two large oral spines and in the massive form of the zoarium. In each zoarium there is always a perforation which is the trace of the alga to which the zoarium was attached. This, moreover, is the most frequent habitat of the Celleporidae.

Occurrence.-Pliocene (Waccamaw marl): Waccamaw River, Horry Countv. South Carolina (rare).

Cotypes.-Cat. No. 6\$706, U.S.N.M.

\section{Holoporella umbonata, new species.}

Plate 40, figs. 8, 9.

Description.-The zoarium incrusts shells, bryozoa or algae. The zooecia are oriented, distinct, elongate, separated by a deep furrow; the frontal is convex, smooth, surrounded by pores and areolar costules; a large umbo terminated br an 
a vicularium hides the apertura. The apertura is semilunar. The ovicell is globular, transverse, smooth; it is widely open in front of the umbo and never closed by the operculum.

$$
\text { Measurements.-Zooecia }\left\{\begin{array}{l}
L z=0.50-0.60 \mathrm{~mm} . \\
l_{z}=0.25-0.40 \mathrm{~mm} .
\end{array}\right.
$$

Affinities.-The interareolar costules are easily attenuated by fossilization and are visible only on the good specimens. The ancestrular zooecia are smaller and raised.

In its exterior aspect this species is close to Cellepora pumicosa Linnaeus, 1768 ; it differs from it in the presence of the interareolar costules and in a different form of the apertura.

Occurrence.-Pleistocene: Santa Barbara (rare) and Santa Monica (Temochal Canyon), California (very rare).

Cotypes.-Cat. No. 68707, U.S.N.M.

\section{HOLOPORELLA TURRITA Smitt, 1873.}

Plate 46, fig. 1.

1873. Lepralia turrita Surte, Floridan Bryozoa, pt. 2, Kongl. Svenska Vetenskaps-Akademiens Handlingar, vol. 11, no. 4, p. 65.

1914. Holoporella turrita OsBurn, The Bryozoa of the Tortugas Islands, Florida, Publication Carnegie Institution of Washington, no. 182, p. 217 (bibliography).

Our specimen incrusts a coral. The apertura bears two small cardelles, placed in the lower third.

Occurrence.-Pleistocene: Mount Hope, Panama Canal Zone (very rare).

Habitat.-Waters off Florida (14-71 meters).

Plesiotype.-Cat. No. 68708, U.S.N.M.

\section{HOLOPORELLA AVICULIFERA, new species.}

\section{Plate 46, fig. 2.}

Description.-The zoarium incrusts corals, forming very thick masses. The zooecia are somewhat erect, convex, and formed of a tremocyst with scattered, spaced pores; the frontal bears some interareolar costules. The apertura is formed of a large anter and of a concave poster and arranged at the base of a short peristomie. There is a small avicularium in the peristomie. On the frontal some areolar pores are transformed into small orbicular aricularia.

Measurements.-A pertura $\left\{\begin{array}{l}h a=0.18 \mathrm{~mm} \text {. } \\ l a=0.20 \mathrm{~mm} \text {. }\end{array}\right.$

Affinities.-This species presents somewhat the aspect of Discopora pertusa Smitt, 1872. It differs from it in the presence of the small disseminated avicularia and in the absence of oral mucro.

Occurrence.-Pleistocene: Mount Hope, Panama Canal Zone (rare).

Holotype.-Cat. No. 68709, U.S.N.M.

\section{holoporella mucronata, new species.}

Plate 46 , fig. 7 .

Description.-The zoarium incrusts sponges. The zooecia are little erect, surrounded by a line of large, spaced, areolar pores; the little salient, areolar costules ineet at an enormous, wide, oral, very salient mucro. Two very small cardelles separate the anter from the concave poster. Some areolar pores are transformed into small orbicular or triangular avicularia. 
Measurements.-Apertura $\left\{\begin{array}{l}h a=0.13 \mathrm{~mm} . \\ l a=0.15 \mathrm{~mm} .\end{array}\right.$

Affinities.-The general aspect recalls a little that of Holoporella janthina Smitt, 1872. It differs from it in the presence of areolar pores, much scattered, and in the presence of the large oral mucro. The oral mucro does not exist on the young zooecia.

Occurrence.--Pleistocene: Mount Hope, Panama Canal Zone (very rare).

Holotype.-Cat. No. 68710 , U.S.N.M.

Genus SCHISMOPORA MacGillivray, 1888.

(For description, see Bulletin 106, U. S. National Museum, p. 598.) SCHISMOPORA BREVINCISA, new species. Plate 32, figs. 11-13.

Description.-The zoarium incrusts shells. The zooecia are erect and heaped at the center and oriented on the margin; the frontal is formed by a granular pleurocyst surrounded by soine large areolar pores. The apertura is oblique, semicircular, with a very short, rounded rimule. The interzooecial avicularium is elongate, elliptical; its opesium is very large, and its beak is quite rounded.

Measurements.-Apertura $\left\{\begin{array}{l}h a=0.15 \mathrm{~mm} \text {. } \\ l a=0.16 \mathrm{~mm} \text {. }\end{array}\right.$

Variations. - The adventitions organs are quite irregular. Besides the large interzooecial avicularium without pivot, there are still some much smaller a vicularia, almost orbicular or somewhat elongate and provided with a pivot. The medium umbo is always very short when it exists; it limits then an irregular slit which is a false rimule. The marginal zooecia are much elongated and sometimes almost cyclindrical.

Affinities.-This species differs from Discopora verruculata Smitt, 1872, in the absence of a transverse avicularium on the frontal.

Occurrence.-Pliocene (Caloosahatchee marl): Shell Creek, De Soto County, Florida (common).

Cotypes.-Cat. No. 68711, U.S.N.M.

SCHISMOPORA ABRUPTA, new species.

Plate 40, figs. 10, 11.

Description.-The zoarium incrusts shells. The zooecia are indistinct, erect; the frontal is smooth and terminated by a mucro very little salient. The apertura is semicircular, with a wide rimule short and rounded. The ovicell is deeply embedded between the adjacent zooecia; it is transverse, smooth, convex; it is widely open in a locella limited by the medium umbo, and it can not be closed by the operculum. There are numerous, small, triangular avicularia with pivot disseminated between the apertures.

$$
\text { Measurements.-Aperturn }\left\{\begin{array}{l}
h a=0.15 \mathrm{~mm} . \\
l a=0.15 \mathrm{~mm} .
\end{array}\right.
$$

Affinities.-The apertura is rarely visible; it is always deeply embedded at the base of a sort of locella. The small avicularia are sometimes more developed; they elongate, become lanceolate, and lose their pirot. In spite of the lack of precision in its exterior characters this species is not very difficult to determine, thanks to the very special appearance of its avicularia.

Occurrence.-Pleistocene: Santa Barbara, California (rare).

Cotypes.-Cat. No. 68712, U.S.N.M. 
SCHISMOPORA LANCEOLATA, new specles.

Plate 40, figs. 12-15.

Description.-The zoarium formed of small lamellar masses creeps on algae. The zooecia are distinct, erect; the frontal is thick, convex, granular, and bears rarely some areolar pores; the medium umbo is terminated by a little salient avicularium. The apertura is semicircular; it bears a triangular sinus, wide and very short. The ovicell is wide, transverse, convex, smooth; it opens into the locella by a large orifice never closed by the operculum. The incomplete zooecia are very salient. The interzooecial avicularia are large, narrow, lanceolate; the pivot is formed by two denticles. The deep zooecia have their umbo very salient, but their frontal is buried.

Measurements.-Apertura $\left\{\begin{array}{l}h a=0.15 \mathrm{~mm} . \\ l a=0.17 \mathrm{~mm} .\end{array}\right.$

Affinities.-This species is quite easy to recognize by its lanceolate avicularia and its small zoarial lamellae. It differs from Schismopora abrupta in the absence of small triangular avicularia.

Occurrence.-Pleistocene: Santa Monica (Rustic Canyon), California (rare).

Cotypes.-Cat. No. 68713, U.S.N.M.

Genus Costazzia Neviani, 1895.

For description, see Bulletin 106, U. S. National Museum, p. 603.

COSTAZZIA ROBERTSONIAE, new species.

Plate 39, figs. 10-12.

Description.-The zoarium is formed of small, globular or cylindrical masses attached to algae. The zooecia are erect, very salient; the frontal is finely porous. The apertura is pyriform; it bears a wide rimule of little depth. On the peristome there are two small avicularia. The ovicell is small, much embedded between the adjacent zooecia; it bears a small semicircular area, garnished with some large pores. The interzooecial avicularium is small, oval, with very wide beak; it is traversed by a complete pivot.

Measurements.-Apertura $\left\{\begin{array}{l}h a=0.15 \mathrm{~mm} . \\ l a=0.12 \mathrm{~mm} \text {. }\end{array}\right.$

Affinities.-The frontal is almost always smooth. Its small frontal pores are only visible on the perfectly preserved zooecia because they became very easily closed by fossilization. This species differs from Costazzia costazzi Audouin, 1828, figured by Miss Robertson and still living in the Californian waters, in its much smaller ovicell.

We dedicate this species to Miss Alice Robertson, whose work on the Bryozoa of California has been a great addition to the science of bryozoology.

Occurrence.-Pleistocene: Santa Monica (Rustic Canyon), California (rare).

Cotypes.-Cat. No. 68714, U.S.N.M.

Genus TEGMINULA Jullien, 1882.

1882. Tegminula Jullıen, Dragages du Travailleur, Bryozoaires, Bulletin Société Zoologique de France, vol. 7, p. 510.

Zooecia urceolate, standing erect irregularly one by the side of another; orifice absolutely circular, surmounted by a tubular peristome partly open in front. (Translation after Jullien.)

Genotype.-Tegminula venusta Jullien, 1882. Recent. 
We retain the ancient name Cellepora for those species, which at present can not be placed more definitely.

\section{CELlepora MiNUta, new species.}

- Plate 25, figs. 10-13.

Description.-The zoarium incrusts in thick masses gastropod mollusks; it sometimes emits irregular and ramified branches. The zooecia are small, little distinct, poorly oriented, little erect; the frontal is little convex, more or less large, surrounded by a line of small areolar pores separated by short costules and formed of a pleurocyst detachable from the subjacent olocyst. The apertura is small, suborbicular; two small cardelles, almost median, separate the anter from the somewhat smaller poster. The incomplete zooecia are rare. A very salient.small avicularium is between the apertures.

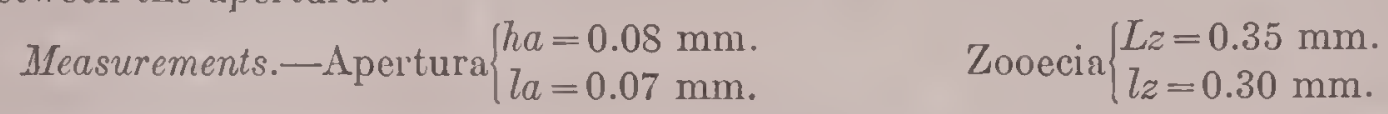

Affinities. - The phenomenon of symbiosis is characteristic of this species. It apparently can live only on a gastropod; we have not a single specimen fixed on any other substratum. The zoarium envelopes the mollusk and ends by killing it; it is rather regular and frequently presents tuberosities formed of raised zooecia. We always have trouble in understanding the selective faculty of the larvae; the latter can not really choose their substratum of fixation; is it therefore a biochemical reaction which permits them to subsist only on the shells of gastropods?

This species is quite close to Cellepora maculata Ulrich and Bassler, 1904, in its zoarium which affects the same phenomenon of symbiosis, in its small dimensions and the absence of deep zooecia. Confusion of the two is very easy, but the present species differs in the almost general presence of a single row of areolar pores and especially in the very constant occurrence of small interzooecial avicularia, which are tubular and very salient.

A sort of umbo, more or less salient, sometimes partially covers the poster. When we know the ovicell it will perhaps be necessary to place this species in a new genus.

Occurrence.-Miocene (Duplin marl): Wilmington, North Carolina (rare). Pliocene (Waccamaw marl): Waccamaw River, Horry County, South Carolina (rare).

Cotypes.-Cat. No. 68715, U.S.N.M.

CELLEPORA MACUlata Ulrích and Bassler, 1904.

Plate 25, figs. 14-20.

1904. Lepralia maculata Ulrich and Bassler, Bryozoa Miocene, Maryland Geological Survey, p. 423, pl. 114, figs, 8, 9; pl. 118, fig. 7.

Ulrich and Bassler's original description follows.

Zoarium beginning as a thin sheet on shells of small gastropoda to which other layers are added until masses as much as 2 inches in diameter result. Surface of masses generally exhiliting more or less distinct, usually elevated, clusters of zooecia slightly larger than those occupying the intermediate spaces. Zooecia convex, subovate, not sharply separated nor exhibiting any obvious plan of arrangement; when in rows a bout six occur in $2.0 \mathrm{~mm}$. Orifice not terminal but situated in the anterior half, rounded and 
expanded above, contracted below the middle, where there is a small denticle on each side, and nearly straight or curved slightly outward on the lower side; peristome simple, not elevated. Surface punctate excepting over a space just beneath the orifice that is smooth and elevated into a conical or obtuse umbo. Avicularia of two kinds and sizes, both sets very irregularly distributed. Those of the smaller set are ovate and less than half the size of the zooecial orifice, and situated in one of the corners of a zooecium; those of the larger set occupy each the place of a zooecium, have a triangular or acuminate ovate aperture considerably larger than the zooecial orifice, and have the pointed end or side strongly elevated. Ovicells immersed, somewhat smaller than the zooecia, convex, smooth centrally, punctate marginally, often with an eccentric, smooth oval space distinguished from the rest of the surface by an impressed line.

Further study of the types and other specimens show that the original description is perfectly exact. The aperture measures about $0.12 \mathrm{~mm}$. by $0.08 \mathrm{~mm}$. The frontal is garnished with a double row of areolar pores and with a detachable pleurocyst. Between the apertures there is sometimes a very small, round, nonsalient avicularium. The large interzooecial avicularium is very characteristic, but it is rather rare.

The zoarium developes into large nodose masses on gastropod shells. Cellepora minuta shows the same phenomenon of symbiosis and, although its other characters are close, its zooecia are also small and of such a kind that it is very difficult to distingush the two species. The present species differs, howevcr, from Cellepora minuta in the absence of the small, very salient avicularium arranged between the apertures and by the great frequency of the double row of areolar pores. Moreover, the zoarium is larger and more spinous than that of Cellepora minuta. We have not yet discovered the ovicell.

Occurrence.-Miocene (Calvert formation): Plum Point and other localities in Maryland (common). Miocene (Yorktown formation): Yorktown, Virginia (rare). Miocene (Choctawhatchee marl): Jackson Bluff, Ocklocknce River, 25 miles southwest of Tallahassee, Florida (very rare). Miocene (Duplin marl): Harvey's Mills, Leon County, Florida (very rare). Natural Well, 2 miles southwest of Magnolia, Duplin County, North Carolina, and Muldrows Mills, 5 miles south of Maysville, South Carolina (rare).

Cotypes and Plesiotype.-Cat. Nos. 68716-68720, U.S.N.M.

CELLEPORA CRIBROSA Ulrich and Bassler, 1904.

Plate 25, fig. 8.

1904. Cellepora cribrosa. Ulrich and Bassler, Maryland Geological Survey, Miocene, p. 429, pl. 117, figs. 5,6 .

The original description by Ulrich and Bassler is as follows:

Zoarium forming small irregular compressed masses. Zooecia very irregularly disposed, some erect, others prostrate, $0.5 \mathrm{~mm}$. to $0.7 \mathrm{~mm}$. long by $0.4 \mathrm{~mm}$. to $0.6 \mathrm{~mm}$. wide; surface strongly punctate; orifice rounded, the normal form showing a slight constriction a little below the middle, where a small tooth projects into the cavity from each side; peristome thick and more or less elevated, ringlike. Avicularia of moderate size, more or less acuminate ovate, attached to and projecting beyond the plane of the inferior side of the peristome; rarely absent. Ovicells few, known only in the broken condition in which they appear as deep semicircular excavations in front of the zooecial orifices.

Only the type specimen of this species has so far been discovered and we are unable to add anything to the original description or to place the species more accurately generically,

Occurrence.-Miocene (Calvert formation) : Reeds, Maryland (very rare).

Holotype.-Cat. No. 68721, U.S.N.M. 


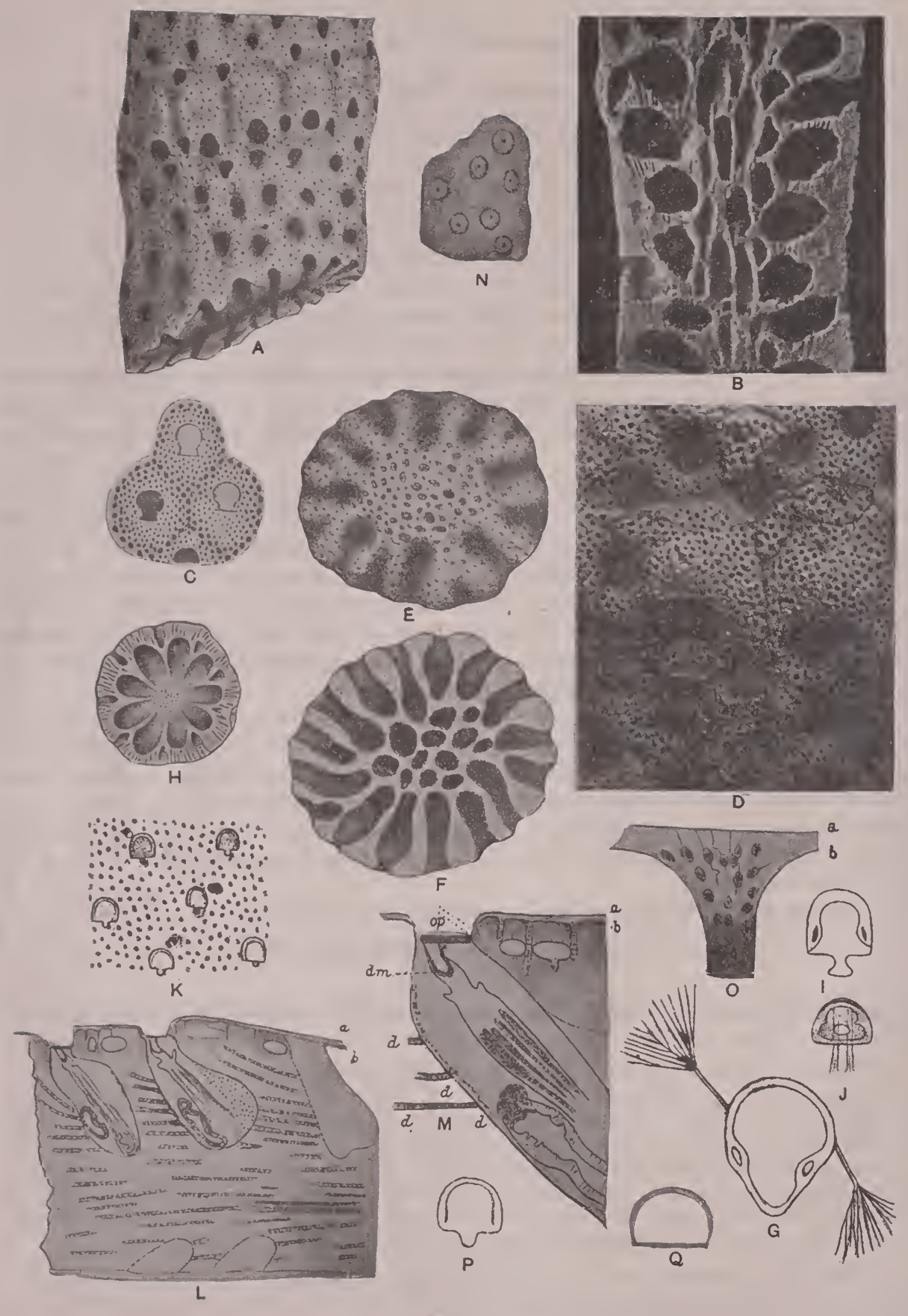

Fra. 34.-Genus Myriozoum Donati, 1750.

A-G. Myriozoum truncatum Pallas, 1766. A. Portion of a fossil zoarium with ovicelled zooecia. (After Manzoni, 1875.) B. Longitudinal section, $X 20$, showing ovicelled zooecium in upper left 
corner. C. Details of the aperture. (After D'Orbigny, 1852.) D. Portion of a recent zoarium, $\times 20$, with several ovicclled zooecia. The operculum closes the aperture. E. Extremity of a zoarium. F. Transverse section. (E, F, after Ifanzoni, 1877.) G. Operculum, $\times$ 85. (After Waters, 1878.)

H-J. Mynozoum courclatum Sans, 1850. H. Transverse section. (After Smitt, 1868.) I. Operculum, $\times 85$. J. Mandible, $\times 85$.

K-O. Myriozoum subgracile D'Orbigny, 1852. K. Portion of a zoarium with avicularia, $X 25$. L. Section of tissue, $\times 25$, showing the polypidcs in position, the covering integument ( $a=$ ectocyst) over the inner one $(b)$; also the long pore tubes which in various places have a disk separating the contents on the two sides of the disk. The oral diaphragm is seen as withdrawn. M. Section through polypidc, $X 85$, showing: $d m$, the diaphragm; op, the opcrculum, with dotted lines to show the position when partly open; $d$, disks in the porc tubes. $N$. Corering integument $(a), \times 85$. O. End of pore tube, $X 500$, slowing the covering integument $(a)$ and the inner one $(b)$. It contains some cellules of mcsenchymatous tissue; P. Operculum $\times 85$; Q. Mandible, $X 50$. (I-2 after Waters, 1900.)

\section{Family MYRIOZOIDAE Smitt, 1868.}

The frontal is thick and bears a tremocyst with tubules. Uniporous septulae or dietellae are present. The a vicularia are adventitious and bear a pirot. The ovicell is hyperstomial not adjacent to the zooecium and lodged in a nichelike depression of the distal zooecium.

According to Levinsen the genera of this family are as follows:

Haswellia Busk, 1884 (referred to the Galeopsidae by us).

Gephyrophora Busk, 1884 (Galeopsidae).

Myriozoella Levinsen, 1909.

Myriozoum Donati, 1750.

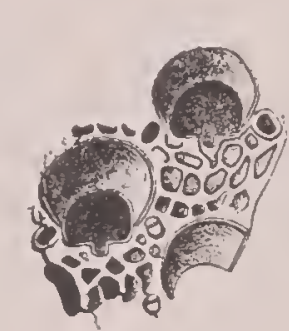

A

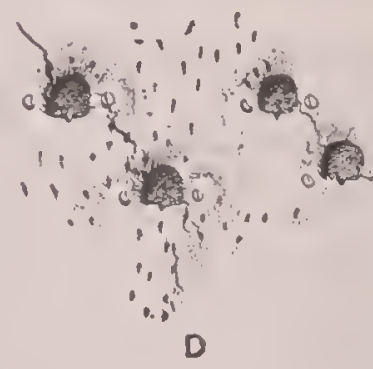

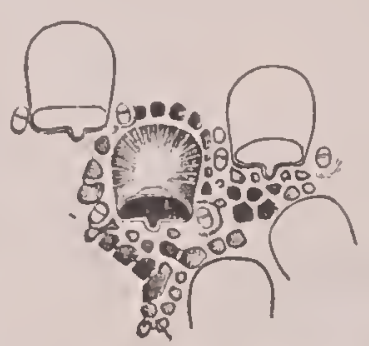

$B$
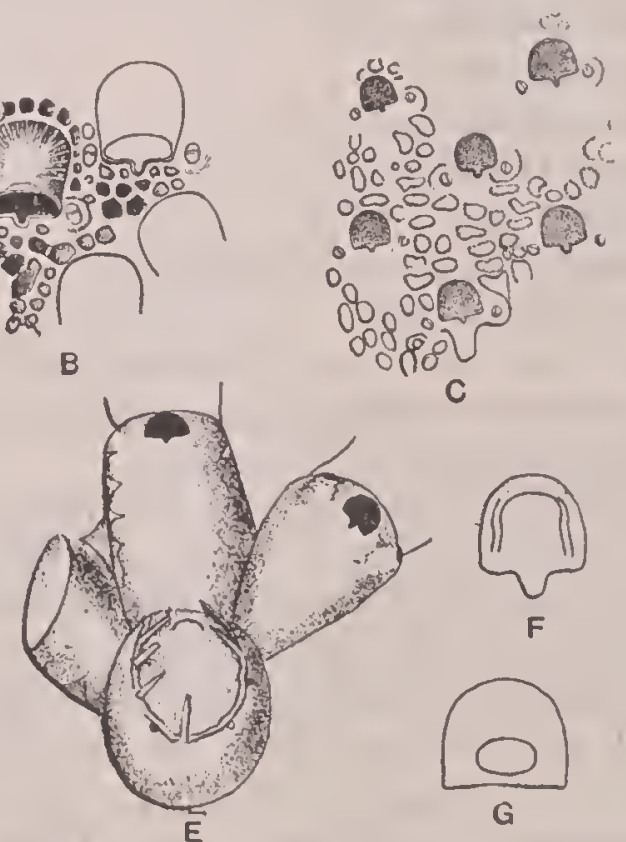

Fig. 35.-Genus Myriozoella Levinsen, 1909.

A-G. Myriozoella crustacca Smitt, 1868. A. Zooecia with peristomes and with cancellated frontal B. Zooecia showing the ovicell. C. Zooecia without peristome, $X 26.5$. (A-C, after Smitt, 1868.) D. Zooecia, $\times 26.5$, much calcified, in which the frontal is not cancellated. E. Ancestrula and ancestrular zooecia, $\times 50$. F. Operculum, $\times 85$. G. Mandible, $\times 250$. (E-G, after Waters, 1900.) 
So far as known this family is not represented in the American Tertiary, but its species, on the contrary, are of common occurrence in the Miocene and Pliocene of Europe. The larra in all of these genera is unknown and their classification necessarily remains doubtful.

Genus MYRIOZOUM Donati, 1750.

1750. Myriozoum Dosatr, Stagie della storia naturale dell' Adriatico.

The zoarium is free, cylindrical, and arborescent. Septulae are present. Sixteen tentacles.

Genotype.-Myriozoum (Millepora) truncatum Pallas, 1766.

Range.-Helvetian-Recent.

Genus MYRIOZOELLA Levinsen, 1909.

1909. Myriozoella Levinsen, Morphological and Systematic Studies on the Cheilostomatous Bryozoa, p. 297.

The zoarium is incrusting. Dietellae are present. Fifteen tentacles.

Genotype.-Myriozoella (Myriozoum) crustacea Smitt, 1868. Recent.

ORBITULIPORIDAE, new family.

The zooecia are regularly arranged vertically; the gemmation is lateral. The apertura is terminal. The ovicell is hyperstomial and forms a tube placed in a zooecium larger than usual.

The genera of this family are as follows:

Orbitulipora Stoliczka, 1861.

Stichoporina Stoliczka, 1861.

Batopora Reuss, 1867.

Mamillopora Smitt, 1872.

Sphaerophora Haswell, 1880.

Fedora Jullien, 1882.

Schizorthosecos Canu and Bassler, 1917.

Diplotaxis Reuss, 1867.

Affinities. - This new family differs from the Conescharellinidae Levinsen, 1909 , in the constant presence of an ovicell. It differs from the Myriozoidae in haring the ovicell adjacent to a zooecium.

Bistorical.-In 1917 we included the genera of this new family with the Conescharellinidae Lerinsen, 1909, but after a careful study of this latter family based upon specimens from the Philippine Islands we believe that the analogy between them is purely zoarial and that they must be separated. Their system of incubation is totally different, indicating that their larral system is also rery different.

In 1885 Koschinsky discovered in the Bavarian Lutetian a series of forms which he classed in Stichoporina Stoliczka, 1881. This error has been repeated by Waters, Kirkpatrick, Neriani, and Canu. Calvet alone, in 1907, compared Stichoporina of authors with Hamillopora Smitt, 1872. In 1919 Waters established the truth of this observation by a study of some excellent specimens and classified the principal genera as follows:

A. With a pit: Batopora, Orbitulipora, Sphaerophora, Stichoporina.

B. Without a pit: Mamillopora, Conescharellina. 
We have made only the few following changes in this classification. First, Conescharellina, provided with a peristomial ovicell, belongs to another family; second, we add the American genus Schizorthosecos as a valid genus in the first group; third, we believe it best to separate the group Fedora from Mamillopora until the type of the latter genus is better known.

The hydrostatic function of the central "pit" noted by Waters is unknown. On the inner side of Schizorthosecos and of Mamillopora there are hydrostatic cavities of different functions, for they are surmounted by ordinary but much smaller zooecia and there are many of them to a zoarium.

In this group the ancestrula engenders six zooecia and not five as in most other bryozoans. As a result of the studies of Waters in 1919 we have modified some of the generic diagnoses given in our monograph on the early Tertiary Bryozoa. The reader will find studies on the Conescharellinidae in our forthcoming monograph of the recent bryozo from the Philippine Islands.

\section{Genus BATOPORA Reuss, 1867.}

1867. Batopora REUSs, Ueber einige Bryozoen aus dem deutschen Unteroligocän, Sitzungsberichte der K. Akademie der Wissenschaften, Wien, vol. 55, Abth. 1, p. 8.

With a pit toward which the zooecia are directed. Oral aperture small $(0.09$ mm.), nearly round, but examination shows straight lower edge. Bilaminate. Primary zooecia hidden (Waters). The frontal is a granular olocyst. The zoarium is conical, never hollow and formed of two superposed lamellae.

Genotype.-Batopora stoliczkai Reuss 1867 (probably young of B. multiradiata Reuss, 1869). Stampian, Tortonian.

The known species of the genus are:

Batopora rosula Reuss, 1847. Tortonian.

Batopora scrobiculata Koschinski, 1885. Lutetian.

Batopora conica Sequenza, 18s0. Tongrian.

Batopora stoliczkai Reuss, 1867. Priabonian.

Batopora multiradiata Reuss, 1869. Priabonian.

\section{Genus ORBITULIPORA Stoliczka, 186i.}

1861. Orbilulipora Stoliczka, Oligocäne Bryozoen von Latdorf in Bernberg, Sitzungsberichte der k. Akademie der Wissenschaften, Wien, vol. 65, Abth. 1, p. 90.

With a pit toward which the zooecia are directed. Oral aperture large, with straight lower edge. Pit on the side bimultilayered (Waters). The frontal is a tremocyst. The zoarium is orbicular and formed of two layers placed back to back.

Genotype.-Orbitulipora haidingeri Stoliczka, 1861.

Range.-Bartonian, Tortonian.

The other known species of this genus are:

Orbitulipora (Cellepora) petiolus Lonsdale, 1850. Bartonian.

Orbitulipora excentrica Sequenza, 1879.

Orbitulipora lenticularis Reuss, 1869 . Tongrian. 

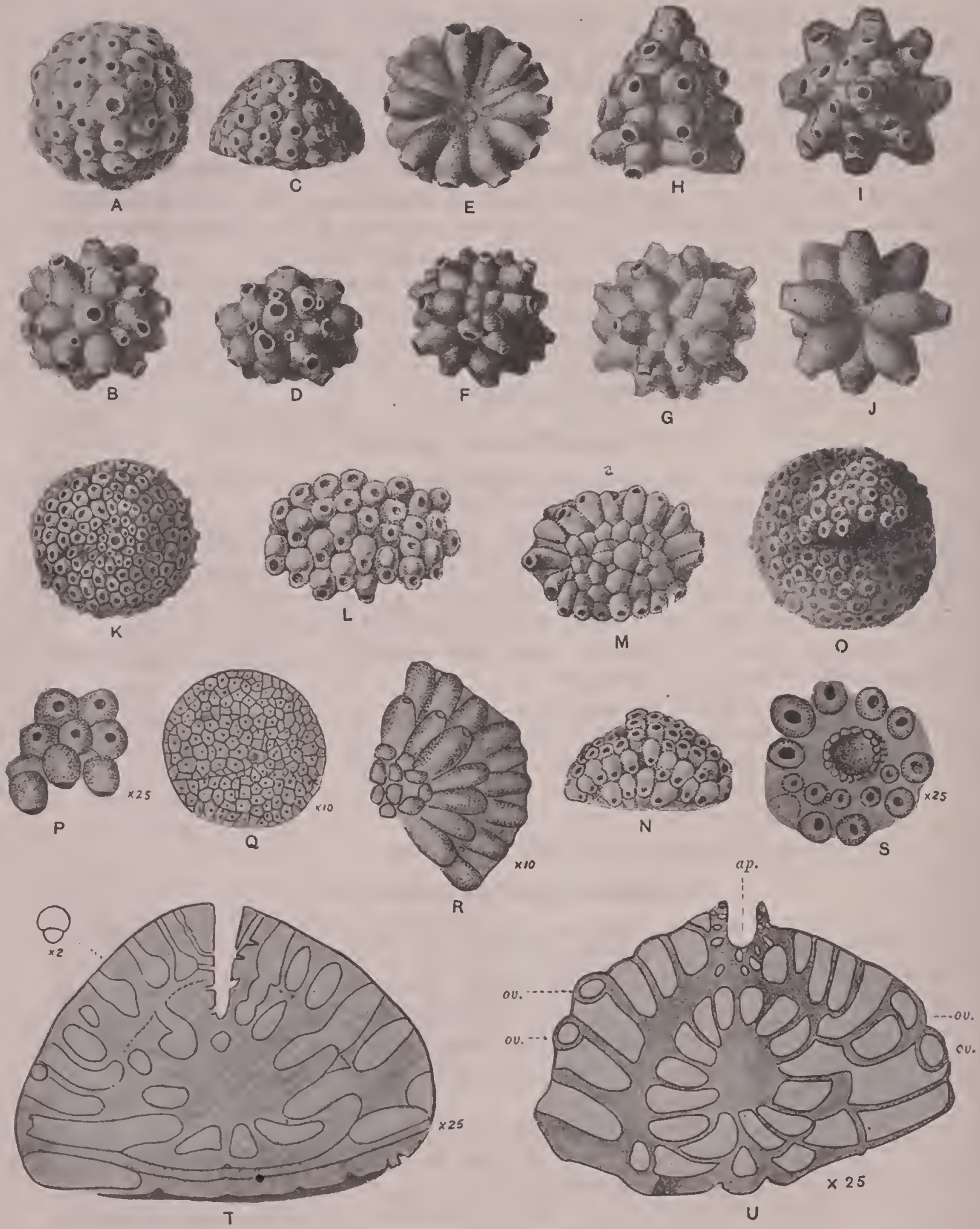

FIG. 36.-Genus Batopora Reuss, 1867.

B, D. F, G. Batopora stoliczkai Reuss, 1857. Frontal, lateral, and basal views of the zoarium. A, C, F, II, I. J. Batopora rosula Reuss, 18ti. Frontal, lateral, and basal views of two specimens from the Priabonian. (A-J, after Reuss, 1867. 
K-U. Batopora multiradiata Reuss, 1869. K. Superior face of a colony showing the central pit. $\mathrm{L}, \mathrm{N}$. Groups of ovicelled zooecia. M. Inferior face of the colony $\mathrm{K}$. O. Specimen showing a second layer. P. Group of ovicells, $\times 25$. Priabonian at Montecchio-Maggiore, Italy. Q. Specimen from Val di Lonti, Italy (Priabonian), showing a second layer from the ncighborhood of the pit, $\times 10$. R. Base showing two circles of zooecia, $X 10$. S. Summit of a colony showing the pit witl small zooecia around it as well as ordinary zooecia. T. Section showing the pit and the zooecia in a second layer around the first. From near Novezzina, Italy (Priabonian). $\times 25$; a, zoarium showing a cap formed by a second layer of zooecia, from Montecchio-Maggiorc, Italy (Priabonian). U. Meridian section showing the apical pit, the second layer and the ovicells. (After Waters, 1891.) ap, aperture; ov, ovicell.

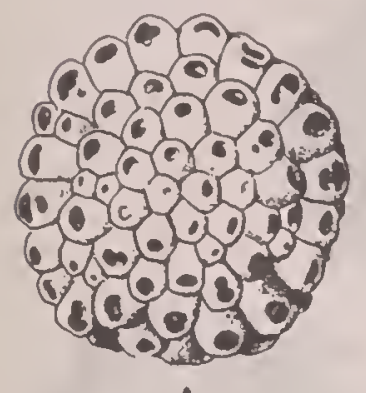

A

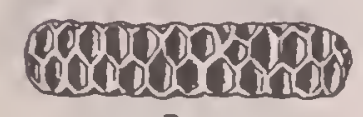

8
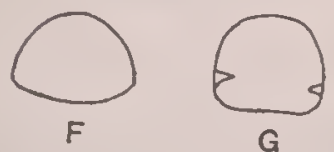
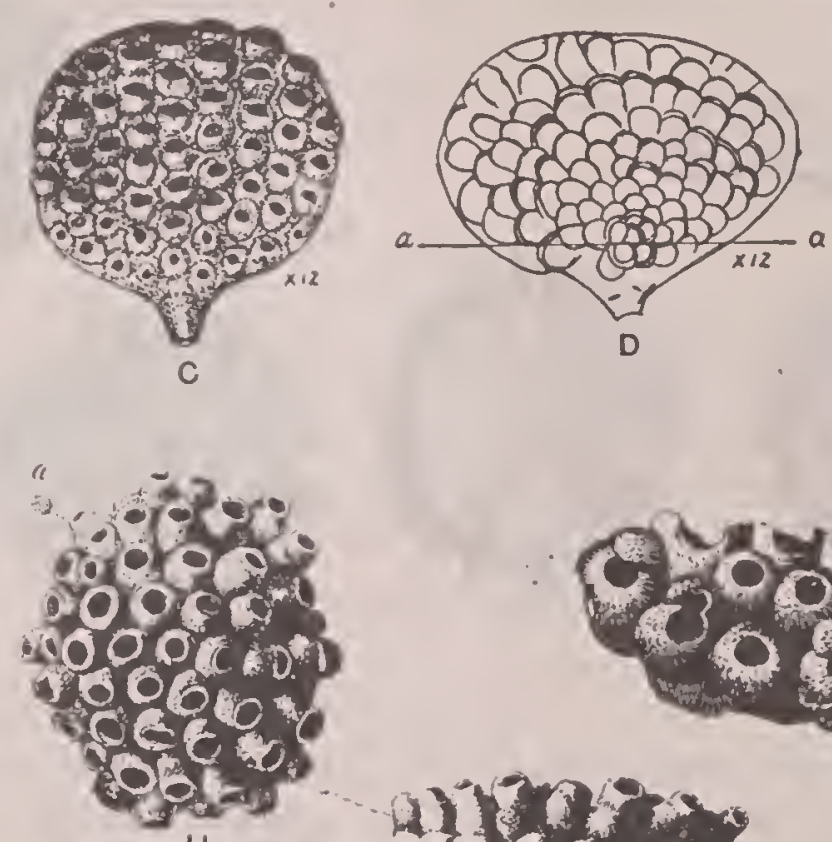

$\mathrm{H}$
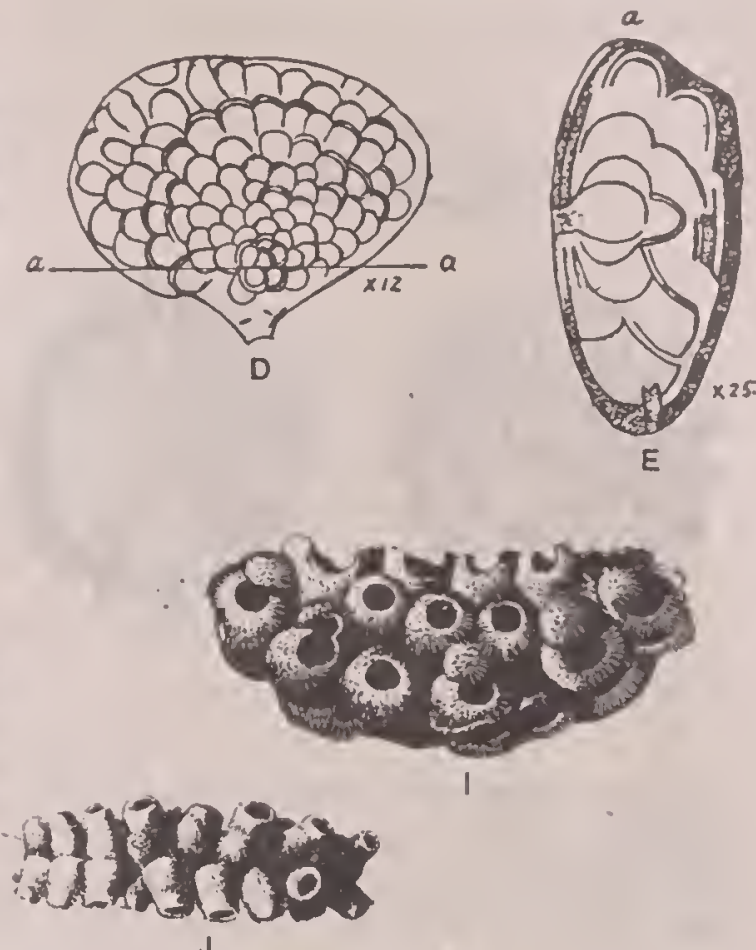

F1G. 37.-Genus Orbitulipora Stoliczka, 1861.

A, B. H-J. Orbitulipora petiolus Lonsdale, 1850. A. An entire zoarium from Latdorf. B. Transverse section showing the two lamellae placed back to back (A, B, after Stoliczka. 1851.) H. An entire bilamellar zoarium. I. Group of ovicelled zooecia. J. Lateral view of the same zoarium as $\mathrm{H}$, showing the two lamellae. ( $\mathrm{H}-\mathrm{J}$, after Reuss, 1867.)

C-E. Orbitulipora excentrica Seguenza, 1878. C. An entire zoarium showing a lateral pit, $\times 12$. D. Meridian section showing the ancestrula surrounded by 5 zooecia, $\times 12$. E. Transverse section following the line $a-a$ at right angles to $\mathrm{D}, \times 25$.

F, G. Orbitulipora lenticularis Reuss, 1869. Oral apertures, $X 85$. (C-G, after Waters, 1919.)

\section{Genus STICHOPORINA Stoliczka, 1861.}

1861. Stichoporina StoliczkA, Oligocäne Bryozoen von Latdorf in Bernberg, Sitzungsberichte der k. Akademie der Wissenschaften, Wien, vol. 65, Abth. 1, p. 92.

"With a pit towards which the zooecia are directed. Oral aperture small. Unilaminate to bilaminate? Pit central." (Waters.)

Genotype.-Stichoporina reussi Stoliczka, 1861. 
Genus SPHAEROPHORA Haswell, 1881.

1881. Sphaerophora Haswell, On some Polyzoa from the Queensland coast, Proceedings Linnean Society New South Wales, vol. 5, p. 42.

"With a pit towards which the zooecia are directed. Oral aperture $(0.12$ $\mathrm{mm}$.) with straight lower edge. Grows in all directions from the early zooecia. Pit central. Multilaminate." (Waters.)

Genotype.-Sphaerophora fossa Haswell, 1881.

Range.-Miocene, Recent.

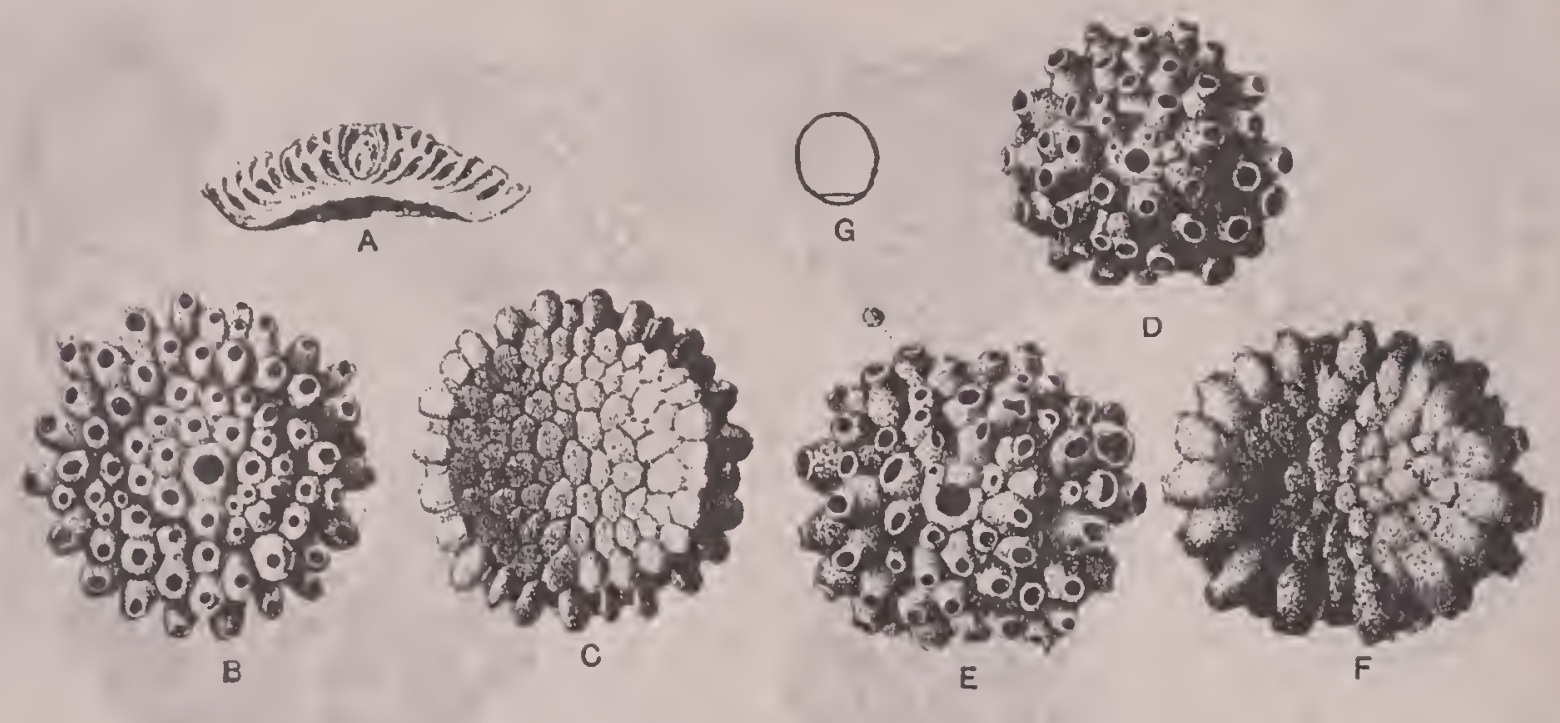

Fra. 38.-Genus Stichoporina Stoliczka, 1861.

A-G. Stichoporina reussi Stoliczka, 1861. A. Meridian section. B. Exterior side showing the central pit. C. Interior side of the same zoarium. (A-C, after Stoliczka, 1861.) D, E. Exterior side of colonies in which the central pit is surrounded by small zooecia. F. Interior side of E. (D-F, after Reuss, 1867.) G. Form of the orifice, $\times 85$. (After Waters, 1919.)

Genus SCHIZORTHOSECOS Canu and Bassler, 1917.

1917. Schizorthosecos CANU and BASSLER, A synopsis of American Early Tertiary Cheilostome Bryoz.oa, Bull. 106 U. S. National Museum, p. 74.

Completed definition.-With a pit closed externally by a perforated lamella. The zoarium is cupuliform. The apertura is oval with a rounded proximal rimule. There are numerous interzooecial zooeciules which may be transformed into avicularia, into radicular zooeciules or into compensation zooeciules.

Genotype.-Schizorthosecos (Orbitolites) interstitia Lea, 1833.

Range.-Claibornian, Jacksonian.

Genus FEDORA Jullien, 1882.

1882. Fedora Jullien, Dragages du Travailleur, Bulletin Société Zoologique de France, vol. 7 , p. 17.

Without a pit. The ovicell is hyperstomial, not closed by the operculum, arranged between two zooecia. The apertura presents an anter and a poster separated by two salient cardelles; it is elongated on the ordinary zooecia but transverse and larger on the ovicelled zooecia. The frontal is a granular pleurocyst bordered 
by very small areolar pores. There are often one or two a vicularia in the vicinity of the apertura. On the inner side the zooecia are hexagonal or fusiform, terminated by a small orbicular pore or covered with large pores.

Genotype.-Fedora edwardsi Jullien, $18 \$ 2$.

Range.-Lutetian to Recent.

The known species of this genus are as follows:

Fedora edwardsi Jullien, 1882. Recent (Atlantic).

Fedora (Stichoporina) simplex Kirkpatrick, 1890 (not Koschinsky, 1885). Recent (Indian Ocean).

Fedora (Mamillopora) smithi Calvet, 1907 (possibly F. persimplex Neviani, 1895). Recent (Atlantic).

Fedora (Discoflustrellaria) dactylus D'Orbigny, 1852. Lutetian.

Fedora (Stichoporina) simplex Koschinsky, 1885 (=Stichoporina reussi Canu, 1907). Lutetian.

Fedora (Stichoporina) protecta Koschinsky, 1885. Lutetian, Jacksonian.

Fedora (Kionidella) excelsa Koschinsky, 1885. Lutetian, Priabonian.

Fedora (Stichoporina) crassilabris Koschinsky, 1885. Lutetian.

Fedora (Cupularia) bidentata Reuss, 1869. (See Waters, 1919.) Priabonian.

Fedora (Kionidella) obliqueseriata Koschinsky, 1885. Lutetian.

Fedora (Stichoporina) persimplex Neviani, 1895. Plaisancian.

Fedora (Lepralia) minutissima Sequenza, 1880. Helvetian.

Genus MAMILLOPORA Smitt, 1873.

1872. Mamillopora Sмrтt, Floridan Bryozoa, pt. 1, Kongl. Svenska Vetenskaps Akademiens Handlingar, vol. 10, no. 11, p. 33.

Oral aperture large $(0.12 \mathrm{~mm}$.), contracted at each side. Primary zooecium erect, surrounded by six similar zooecia. Only unilaminate, showing the position of the zooecia on the under surface. (Waters.) The zoarium is cupuliform. The apertura is elliptical with two submedian cardelles. Avicularia are present. The ovicelled zooecia are much larger; their apertura is not transverse. The zooecia and their inner side are covered with tuberosities.

Genotype.-Mamillopora cupula Smitt, 1872.

The genotype of the genus is incompletely known.

We have had the good fortune to secure some recent specimens of Mamillopora dredged in the Gulf of Mexico. The species appears to be new, but it shows some interesting facts on the structure of the genus. It differs from Mamillopora cupula Smitt, 1572 , in having a much smaller and nonbilobed ovicell, in the presence of a peristomial avicularium instead of an interzooecial one, and in having analogous apertures on the ovicelled zooecia. Our specimens were unfortunately insufficient for a complete study, but nevertheless we have observed the following points:

1. The ovicell is closed by the operculum. The operculum of the ovicelled zooecia is identical with the operculum of the other zooecia but often somewhat higher.

2. On the inner, noncellular (superior) side each tuberosity is a pyriform avicularium in which the opesium, which is elliptical and without pivot, bears a small semielliptical mandible. The mandibles are quite variable in dimensions, as some are small and others are large. 
3. On the inner face there are large cavities which, as they are closed by the ectocyst, are indeed hydrostatic. We have not been able to make zoarial sections of such a nature that we can see by what mechanism the sea water enters or departs.

4. The mandibles of the oral avicularia are identical with those of the avicularia of the inner face.

5. The ovicells observed were marginal and not inserted between the other zooecia, but our specimens are insufficient to note if this is a constant character.

6. This species is very close in its dimensions to Mamillopora tuberosa Canu and Bassler, 1919, and differs only in the position of its ovicells and in the constancy of its oral avicularia.

We do not know the inner side of Mamillopora smithi Calvet, 1907. That of Mamillopora cupula Smitt, 1872, has not been figured, but Smitt speaks of "a thin layer of bladders (aborted avicularia) on the back of the zooecia," a description which appears to accord with our observation. Smitt's specimens were deprived of the ectocyst and he was not able to determine the true uature of the avicularia.

Mamillopora tuberosa Canu and Bassler, 1919.

Plate 6, figs. 16-19; plate 7, figs. 1-S.

1919. Stichoporina tuberosa CANu and BAssuer, Geology and Paleontology of the West Indies, Bryozoa, Publications of the Carnegie Institution of Washington, no. 291, p. 95, pl. 1, figs. $20-23$; pl. 6, figs. 16-19; pl. 7, figs. 1-S.

Description.-The zoarium is free, conical, hollow, with rery thick walls. The peristome is salient, ornamented with small tuberosities; it bears one or two small, elliptical avicularia with bar or denticles. The apertura is elliptical, elongated, hidden at the base of a short peristomie; it is formed of a large, semielliptical anter and of a small, concave poster, separated by two small, salient cardelles. The ovicell is large, somewhat salient, convex; it is hyperstomial and always closed by the operculum. A salient, elliptical avicularium, with two denticles serving as pivot, is placed at the base of each zooecium; it deforms the adjacent peristomes. The inner side is tuberose and bears rery large pores arranged in quincunx. On the lower face there are large pores surrounded by very small ones.

$$
\begin{array}{r}
\text { Measurements. - Apertura }\left\{\begin{array}{l}
h a=0.14 \mathrm{~mm} . \\
l a=0.10 \mathrm{~mm} .
\end{array}\right. \\
\begin{array}{r}
\text { Opesium of } \\
\text { avicularium }
\end{array}\left\{\begin{array} { l } 
{ h _ { 0 } = 0 . 1 0 \mathrm { mm } . } \\
{ l o = 0 . 0 6 \mathrm { mm } . }
\end{array} \quad \text { Avicularium } \left\{\begin{array}{l}
L a v=0.20 \mathrm{~mm} . \\
l a v=0.12 \mathrm{~mm} .
\end{array}\right.\right.
\end{array}
$$

This is a rery elegant species characterized by its peristomial tuberosities. The ancestrula is risible only in the interior of the zoarium; it is covered exteriorly by the first zooecia. All the zooecia are separated from each other by small canals which appear to end in the large, inferior pores. The oral tuberosities are hollow. The pores of the internal cavity are avicularia, of which the pivot is formed by two denticles; they are analogous with those of the external face (inferior). The internal face (and upper) bears also large carities which we believe to be liydrostatic cavities; but it nust be proved that the ectocyst is resistant enough to confine an equal amount of water. We must suppose also that these cavities are intended to counterbalance the irregularities of calcification and to assure the perfect equilibrium of the zoarial system. 
This species must not be confounded with Mamillopora cupula Smitt, 1872. It differs from it in its ovicell, which is not bilobate, and in its orarian zooecia which are not larger than the others.

Occurrence.-Lower Miocene (Gatun formation): Banana River, Costa Rica (common). Lower Miocene (Bowden horizon): Rio Cana, Rio Gurabo, and Cercado de Mao, Santo Domingo; Bowden, Jamaica (common).

Cotypes.-Cat. Nos. 68722-68725, U.S.N.M.

\section{Order CYCLOSTOMATA Busk.}

\section{Family HETEROPORIDAE Pergens and Meunier, 1886. \\ Genus CERIOPORA Goldfuss, 1827.}

(For description, see Bulletin 106, U. S. National Museum, p. 678.)

CERIOPORA VIRGINIANA, new species.

Plate 26, figs. 1-3.

Description.-The zoarium is an irregular globular mass. The tubes are polygonal; their walls are very thin. No peristomes.

Affinities.-This species may be compared only with the European species from the faluns of Touraine not yet published. Only the figured specimen has been found.

Occurrence.-Miocene (Yorktown formation): 1 mile northeast of Suffolk, Virginia (very rare).

Holotype.-Cat. No. 68726, U.S.N.M.

Family DIASTOPORIDAE Gregory, 1899.

Forma PROBOSCINA Audouin, 1826.

PROBOSCINA MESLERI, new species.

Plate 26, fig. 7.

Description.-The zoarium incrusts shells and forms long triserial branches dividing almost at a right angle. The tubes are long, convex, distinct, porous. The peristomie is perpendicular to the zooecial axis. The apertura is orbicular and the peristome is thin and sharp. The apertures are arranged in quincunx or trigeminal.

Measurements.-

Diameter of orifice . . . . . . . . . . . . . . . . . $0.10 \mathrm{~mm}$.

Diameter of the tubes. . . . . . . . . . . . . $0.12 \mathrm{~mm}$.

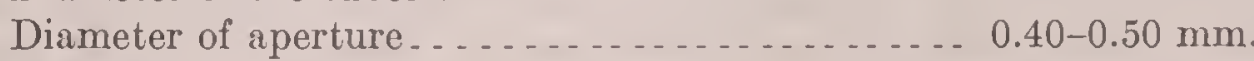

Zoarial width . . . . . . . . . . . . . . . . . . . . . . . 0.40-0.45 mm.

This species is named in honor of Mr. Rector D. Mesler, of the United States Geological Survey, who has made important collections of Miocene fossils for our study.

Occurrence.--Miocene (Duplin marl): Wilmington, North Carolina (rare).

Holotype.-Cat. No. 68727, U.S.N.M. 


\section{Forma BERENICEA Lamouroux, 1821.}

BERENICEA FLABELLUM? Reuss, I847.

Plate 27, fig. 17.

1847. Diastopora flabellum REUss, Die fossilen Polyparien des Wiener Tertiarbeckens, Iaidingers naturwissenschaftliche Abhandlungen, vol. 2, pl. 7 , fig. 9.

The specimens from the Miocene of Virginia which we have referred doubtfully as above have the general zoarial aspect of Reuss's species, but without direct comparisons we are unable to assert their identity positively. The measurenrents of the American specimens are as follows:

Measurements.-

Peristome ......................... $0.24 \mathrm{~mm}$.

Diameter of the orifice.................. $0.18 \mathrm{~mm}$.

Distance between the peristomes . . . . . . . . . $0.80-0.90 \mathrm{~mm}$.

Separation of the peristomes . ............ $0.80 \mathrm{~mm}$.

Occurrence.-Miocene (Yorktown formation): Weavers Pond, Gloucester County, and 3 miles southwest of Petersburg, Virginia (rare).

Geological distribution.-Miocene of the Vienna Basin.

Plesiotype-Cat. No. 68728, U.S.N.M.

\section{ATELESOPORA, new genus.}

Greek; Ateles, incomplete; in allusion to the lack of peristome.

The tubes are expanded and have no peristome.

This form of tubes was rather common in the Paleozoic era and during the Cretaceous, and it has been noted in many families. It is rery rare in the Tertiary formations and in the recent seas, but its study has never been undertaken seriously.

Our generic definition is incomplete, since we are ignorant of the oricell. In giving a generic name to this group, our main purpose is to call the attention of the zoologists to these singular remains of ancient periods.

ATELESOPORA IREPTANS, new species.

Plate 26, figs. 4-6.

Description.-The zoarium creeps over shells, in salient masses, more or less flabelliform. The tubes are adjacent, irregular, polygonal. The zone of growth is thick and irregular.

Occurrence.-Miocene (Duplin marl): Muldrows Mills, 5 miles south of Mayville, Sumter County, South Carolina (rare); and Natural Well, 2 miles southwest Magnolia, Duplin County, North Carolina (rare). Miocene (Yorktown formation): 3 miles southwest Petersburg, 1 mile northeast, and 1 mile west of Suffolk, 1 mile west of Fort Nonsense, Gloucester County, and Beulahland, King and Queen County, Virginia (rale).

Cotypes.-Cat. Nos. 65729-6\$731, U.S.N.M. 


\section{Family MECYNOECIIDAE Canu, 1918.}

Forma ENTALOPHORA Lamouroux, 1821.

(For remarks see Bulletin 106, U. S. National Museum, p. 734.)

ENTALOPHORA FASCICULIFERA, new species.

Plate 41, figs. 1-5.

Description.--The zoarium is free, cylindrical, with the Entalophora form of growth. The tubes are long, distinct, separated by a furrow, convex, and slightly striated transversely: at their extremity they are bont almost perpendicularly to the zoarium and are prolonged in a long, free peristomie; they are sometimes bigeminate. The peristomes are thin and widened.

Measurements:

Diameter of the little salient peristomes........... $0.14 \mathrm{~mm}$.

Length of the peristomie.................... $0.50 \mathrm{~mm}$.

Diameter of the peristome at the extremity of the long peristomies .......... $0.20 \mathrm{~mm}$.

Diameter of the tubes on the zoarium ........... $0.30 \mathrm{~mm}$.

Distance between the peristomes... . . . . . . . . . . . . $1.00 \mathrm{~mm}$.

Diameter of the branches. . . . . . . . . . . . . . . . $0.80 \mathrm{~mm}$.

Affinities.-The characteristic of this species is furnished by the presence of small bundles formed of two tubes partially joined by their peristomie. The species differs from Mecynoecia proboscidea Milne-Edwards, 1838, in its smaller micrometric dimensions and in the frequent presence of bigeminate zooecia.

Occurrence.-Pleistocene: Santa Monica (Tremochal Canyon) (rare), and Dead Mans Island, off San Pedro, California (very rare).

Cotypes.-Cat. No. 68732, U.S.N.M.

\section{Family ONCOUSOECIIDAE Canu, 1918.}

Forma FILISPARSA D'Orbigny, 1853.

FILISPARSA CLARKI, new species.

Plate 41, figs. 11-19.

Description.-The zoarium is free, compressed, bifurcated; the zooecia are placed on the anterior face; the dorsal is convex, striated longitudinally and transversally. The tubes are visible, convex, curved outward at their extremity and terminated by a rather long peristomie; the peristomes are thin, orbicular, arranged in quincunx or in oblique rows.

Measurements:

Diameter of the orifice. . . . . . . . . . . . . . $0.14 \mathrm{~mm}$.

Diameter of the peristome . _ . . . . . . . . . . . $0.18-0.20 \mathrm{~mm}$.

Zooecial diameter (on the zoarium) .. . . . . . . . . $0.24 \mathrm{~mm}$.

Distance between the peristomes . . . . . . . . . . $1.00 \mathrm{~mm}$.

Separation of the peristomes . . . . . . . . . . . . 0.76-0.80 mm. 
Affinities.-In its general aspect this species is close to Oncousoecia varians Reuss, 1869 ; it differs from it in its smaller orifice $(0.14 \mathrm{~mm}$. and not $0.20-0.28$ $\mathrm{mm}$.) and in the arrangement of its tubes, which are much less regular. The number of longitudinal series of tubes is from three to four. Very rarely a dorsal apophysis is dereloped. Although we figure the ovicell we have not been able to place this species in its natural genus because the oeciopore has not been observed.

The specific name is in honor of Dr. F. C. Clark, of Los Angeles, California, who has collected many interesting species for our study.

Occurrence.-Pleistocene: Santa Barbara (rery common), and Dead Mans Island, off San Pedro, California (rare).

Cotype.-Cat. No. 68733, U.S.N.M.

\section{FILISPARSA CLARKI, var. PARVULA, new variety.}

Plate 41, figs. 20-22.

Description.-The dimensions are smaller than in the typical form. 'The number of longitudinal series of tubes is fire.

Measurements:

Diameter of the orifice. . . . . . . . . . . . . . . . $0.14 \mathrm{~mm}$.

Diameter of the peristome . . . . . . . . . . . . . 0.16-0.18 mm.

Zooecial diameter (on the zoarium) . . . . . . . . . . . $0.20(0.24) \mathrm{mm}$.

Distance between the peristomes. . . . . . . . . . . . 0.60-0.80 mm.

Separation of the peristomes ............... . . 0.64-0.90 mm.

Variations.--The tubes are visible on the dorsal; their diameter there is 0.04 $\mathrm{mm}$. Through fossilization they disappear and the dorsal appears more or less smooth; accidentally the latter may be transrersally wrinkled.

Occurrence.-Pleistocene: Santa Barbara, California (rare).

Cotype.-Cat. No. 68734, U.S.N.M.

\section{Family CRISIIDAE Johnston, 1847.}

\section{Genus CRISIA Lamouroux, 1816.}

(For description see Bulletin 106, U. S. National Museum, p. 703.)

CRISIA SERRATA Gabb and Horn, 1862.

Plate 42, figs. 1-7.

1862. Crisia serrata Ga в в and Horn, Monograph Polyzoa of the Secondary and Tertiary furmations of North America, Journal Academy Natural Sciences Philadelphia, ser. 2, vol. 5, p. 174, pl. 21, fig. 66 .

1910. Crisia pacifica Roвertson, Cyclostomatous Bryozoa of the west coast of North America, University of California Publications, Zoology, vol. 6, p. 242, pl. 20, figs. $16,17$.

Measurements.-

Diameter of the peristome. . . . . . . . . . . 0.08-0.10 mm.

Distance between the peristomes... . . . . . . . . . 0.36-0.42 mm.

Zooecial diameter . . . . . . . . . . . . . . . . . . . 0.12 mm.

Width of a segment . . . . . . . . . . . . . . $0.46 \mathrm{~mm}$.

Diameter of the basis ramae . . . . . . . . . . 0. 0.14-0.20 mm. 
Variations.-This'species, which has been known for a long time, is very common in the post-Pliocene formations of California. When the illumination is lateral, the segments present a longitudinal and median keel very characteristic. The distance between the tubes is smaller than the zooecial width. This character is always important to consider in the determination of species of Crisia.

For reasons of equilibrium there are usually two bases ramae to every segment, one on each side. Howerer, it was not rare to find short segments having only one basis ramae.

The number of tubes per segment raries from 11 to 16 .

Affinities.-There is a rather great difference between our photographs and the drawings given by Miss Robertson of Crisia pacifica. This difference of aspect is due to fossilization; the fossils lose their translucency and the tubes are then scarcely visible.

This species has the general aspect of Crisia denticulata, but differs from it in its larger micrometric dimensions, the distance between the peristomes being $0.40 \mathrm{~mm}$. and not $0.30 \mathrm{~mm}$.

Species of Crisia are attached to floating algae. The depth at which they are dredged has no bathymetric significance.

Occurrence.-Pleistocene: Santa Barbara (very common), and Santa Monica (very common), California.

Habitat.-Pacific: Off California (2t-48 meters).

Plesiotypes.-Cat. Nos. 68735, 68736, U.S.N.M.

\section{Family TUBULIPORIDAE Johnston, 1838.}

Genus TUBULIPORA Lamarck, 1816.

(For description see Bulletin 106, U. S. National Museum, p. 753.)

TUBULIPORA FASCICULIFERA Hincks, 1884.

Plate 42, figs. 9-17.

1854. Tubulipora fasciculifera Hivcrs, Report on the Polyzoa of Queen Charlotte Islands, Annals and Magazine of Natural History, ser. 5, vol. 13, p. 206, pl. 9, fig. 6 .

Measurements.-Diameter of the peristome, $0.12 \mathrm{~mm}$.

Variations. - The fascicles are monoserial or biserial, very short, and composed of two to six tubes or more. The zoarium is generally flabelliform, more or less elongate; it creeps over algae. The ovicell is small, ramified between some fascicles only. The oeciostome is wide and little salient.

Affinities. - This species differs from Tubulipora tuba Gabb and Horn, 1862, in its very short fascicles, never composed of more than six tubes, and in its wide and little salient oeciostome.

Occurrence.-Pleistocene: Santa Barbara, California (rare),

Habitat.-Pacific: Off Queen Charlotte Islands.

Plesiotypes.-Cat. No.68737, U.S.X.M. 


\section{TUBULIPORA TUBA Gabb and Horn, 1862}

Plate 42, figs. 18-23.

1862. Semitubigera tuba GABB and Horn, Monograph Polyzoa of the Secondary and Tertiary formations of North America, Journal Academy Natural Sciences Philadelphia, ser. 2, vol.5, p. 169 , pl. 21, fig. 57

1910. Tubulipora occidentalis RoBertson, Cyclostomatous Bryozoa of the west coast of North America, University of California Publications, Zoology, vol. 6, p. 249, pl. 22, figs. 29-31.

Measurements.-Diameter of the peristome. $0.12 \mathrm{~mm}$.

Variations. - The zoarium creeps on algae, with generally flabelliform fronds; it sometimes entircly surrounds the delicate radicells and thus becomes tubular. We harc observed some specimens on other bryozoa.

The fascicles are monoserial or biserial; they have a large number of tubes, from 6 to 20; they are often arranged on each side of the zoarial axis in rather irregular order.

The oricell is large and is inserted between six or eight fascicles. The oeciostome is a very small tube, quite salient, adjacent to the first tube of a fascicle.

Affinities.-This species differs from Tubulipora fasciculifera Hincks, 1884, in its long fascicles composed of more than six tubes and in its long capillary oeciostome.

Occurrence.-Pleistocene: Santa Monica (Rustic Canyon), (rare), Dead Mans' Island, off San Pedro (rarc), and Santa Barbara (rare), California.

- Habitat.-Pacific: Off California, and the Queen Charlotte Islands.

Plesiotypc.-Cat. Nos. 68738, 68739, U.S.N.M.

\section{Genus IDMONEA Lamouroux, 1821.}

(For description, see Bulletin 106, U. S. National Museum, p. 770.)

IDMONEA DISPAR, new species.

Plate 41, figs. 6-10.

Description.-The zonrium is free, bifurcated, with subcylindrical section; the branches are undulated and at a bifurcation; they are not equal. The fascicles are alternate or almost opposite and direrge from each side of the median crest. The tubes are visible, convex, and three or four in number to a fascicle; the peristome is thin and orbicular.

Measurcments. - Width of salient fascicles . . . . . . . . $0.14 \mathrm{~mm}$.

Width of little salient fascicles. . . . . . . . . . . . $0.20 \mathrm{~mm}$.

Diameter of first zooecium (on the zoarium) . . . . $0.18 \mathrm{~mm}$.

Distance between the fascicles . . . . . . . . . . . . . 0.40-0.60 mm.

Zoarial diameter . . . . . . . . . . . . . . . . . . . . $0.80 \mathrm{~mm}$.

Affinities.-This species is quite well characterized by the inequality of the branches at the bifurcations; there is always one a little smaller than the other. mon).

Occurrencc.-Pleistocene: Santa Monica (Tremochal Canyon), California (com-

Cotypes.-Cat. No. 68740, U.S.N.M. 
IDMONEA PLANULA, new species.

Plate 26, figs. 13-15.

Description. -The zoarium is free, wide, with semielliptical scction; the dorsal is flat and striated transversally. The fascicles are salient, opposite, quite close but diverging from the median crest. The tubes are visible, separated by a little salient thread, and number three or four to a fascicle; the peristomes are thin and rectangular.

Measurements. - Width of fascicles . . . . . . . . . . $0.20 \mathrm{~mm}$.

Distance between the fascicles . . . . . . . . . . . . . . . 0.40-0.60 mm.

Diameter (on the zoarium) of the first tube..... $0.24 \mathrm{~mm}$.

Number of the tubes..................... 3- 3-4.

Width of the zoarium .................... $1.20 \mathrm{~mm}$.

Affinities.-This species has the general aspect of Idmonea petri D'Archiac, 1846. It differs from it in a greater distance bctween the fascicles (more then $0.40 \mathrm{~mm}$.) and in the larger zoarial dimensions.

Occurrence.-Miocene (Choctawhatchee marl): Jacksons Bluff, Ocklocknee River, 25 miles southwest of Tallahassee, Florida (very rare).

Holotype.-Cat. No.6S741, U.S.N.M.

\section{IDMONEA CALIFORNICA D'Orbigny, 1852.}

Plate 43, figs. $1-9$.

1852. Idmonea californicı D'Orbigny, Paleontologie francaise, Terrains crétacés, vol. 5, Bryozoaires, p. 732.

1855. Idmonea californica Conrad, Notes on Miocene and Post-Pliocene deposits of California, Proceedings Academy Natural Sciences Philadelphia, vol. 7, p. 441.

1862. Idmonea californica GABB and Horn, Monograph Polyzoa, Secondary and Tertiary formations North America, Journal Academy Natural Sciences Philadelphia, ser. 2, vol. 5, p. 168, pl. 21, fig. 56 .

1910. Idmonea californica RoBertson, Cyclostomatous Bryozoa of the west coast of North America, University of California Publications, Zoology, vol. 6, p. 253, pl. 23, figs. 39-41 (bibliography).

Measurements.-Diameter of the orifice......... $0.20 \mathrm{~mm}$.

Diameter of the pcristome . . . . . . . . . . . . $0.28 \mathrm{~mm}$.

Width of the fascicles................... $0.28 \mathrm{~mm}$.

Distance between the fascicles. . . . . . . . . . . $0.80 \mathrm{~mm}$.

Variations.-This giant species seems to be restricted to the American shores of the Pacific.

The fascicles are almost opposite. On the median axis there is a longitudinal row of isolated tubes, often closed by a calcareous diaphragm.

In tangential section the walls are perforated, but the perforations are no larger than in other species of Idmonea with small dimensions. In longitudinal section the zooecial walls appear very thick. In transverse section the tubes are rcctangular. The oricell is large, convex, placed on the median crest and finely porous. It surrounds the isolated zooecia of the median axis, which gives it the aspect of Diaperocia, but it does not surround the fascicles and its interfascicular lobes are very short.

Occurrence.-Pleistocenc: Santa Monica (rarc), Dead Man's Island, off San Pedro (very common), and Santa Barbara, California (very common).

Plesiotypes.-Cat. Nos. 6S742, 68743, U.S.N.M. 


\section{IDMONFA(?) EXPANSA Ulrich and Bassler, 1904}

Plate 26, fig. 8 .

1904. Idmonea (?) expansa Ulrich and Bassler, Maryland Geologieal Survey, Miocene, p. 404, pl. 109, figs. 6-8.

The original description was as follows:

Zoarium adnate, beginning with a single zooecium to whieh others are added rapidly until an irregular flabellate expansion is produced that with further growth becomes more or less lobate. In the older examples the lobes are seen to be due to the development of the zooecia in systens composed of two pinnate series of transverse rows springing alternately from the opposite sides of a zigzag or wavy median line. In the rows the zooecial apertures, which are rounded quadrate in shape and elevated, are in contact, with four to six in each row and this greater number in about $0.8 \mathrm{~mm}$. The furrows between the rows of apertures are often irregular, and where this in the ease the rows themselves are not continuous. When the arrangement is normal the average width of the furrows is a little less than that of the rows of apertures, allowing about four of the latter to eome within the space of $1.0 \mathrm{~mm}$. The growing margins of the expansions are oeeupied by numerous crowded angular eells, decreasing in size toward the extreme edge. Zooecial walls minutely porous.

Occurrence.-Miocene (St. Mary's formation): Cove Point, Maryland (rare). Cotypes.-Cat. No. 68744, U.S.N.M.

\section{Genus CRISINA D'Orbigny, 1852.}

CRISINA? STRIATOPORA UIrich and Bassler, 1904.

Plate 27, figs. 1-4.

1904. Crisina striatopora Ulrich and Bassler, Bryozoa, Mioeene, Maryland Geological Survey, p. 406, pl. 118, figs. 1-4.

Ulrich and Bassler's original description was as follows:

Zoarium erect, ramose, probably not exceeding $1 \mathrm{~cm}$. in height, dividing dichotomously at intervals of about $1.5 \mathrm{~mm}$.; branches subovate in eross section, thickest, uniformly eonvex and traversed longitudinally by from sixteen to twenty punetate striae on the reverse side, narrower and carrying alternating series of zooecial apertures on the obverse side. Zooeeial apertures rarely three usually four in each series, in eontact laterally, the inner one of each series largest, most prominent, and subcircuiar the outer one smallest, drawn out distally and apparently grading into the pores lying between the longitudinal ridges of the reverse side. Series of zooecia eurving first forward then slightly backward, separated by a deep interspace averaging about $0.2 \mathrm{~mm}$. in widtl; about five rows in $2.0 \mathrm{~mm}$. Over the basal part of the zoarium the zooecial apertures are covered one after the other by the growth of the striato-punetate dorsal integument.

In order to properly classify this species thin sections and the nature of the ovicell are necessary. Additional specimens are needed before further studies upon it are made.

Occurrence.-Miocene (Choptank formation): Jones Wharf, Maryland (rare). Holotype.-Cat. No. 68745, U.S.N.M. 


\section{Family THEONOIDAE Busk, 1859. \\ Genus THEONOA Lamouroux, 1821. \\ THEONOA GLOMERATA Ulrich and Bassier, 1904. \\ Plate 26, figs. 9-12.}

1904. Theonoa glomerata Úrich and BAssler, Maryland Geological Survey, Miocene, p. 406. pl. 109, figs. 4,5 .

The original description of this species was as follows:

Zoarium cake shaped when young and growing irregular with age, the under side covered with a concentrically wrinkled epitheca, the upper side with short or broken irregularly arranged celluliferous ridges separated by deep interspaces. Ridges abruptly elevated, their flattened summits usually exhibiting a double row of subangular zooecial apertures. Here and there, probably through confluence of two or more ridges, considerable clusters of apertures occur, while other groups may not contain more than three or four cells. Occasionally an irregular radial arrangement of the ridges is apparent. About four zooecial apertures in $1.0 \mathrm{~mm}$.

Occurrence.-Miocene (St. Mary's formation); St. Marys River, Maryland (rare). Cotypes.-Cat. No. 68746, U.S.N.M.

\section{Family DIAPEROECIIDAE Canu, 1918.}

Genus STATHMEPORA Canu and Bassler, 1922. fascicles.

Greek: $s t a t h m e=$ line or cord. In allusion to the rectilinear form of the

The ovicell is a vesicle traversed by the tubes of which the peristomes are much scattered. The tubes are cylindrical and grouped in linear, uniserial fascicles. Gemmation is triparietal.

Genotype.-Stathmepora flabellata, new species. Pleistocene.

STATHMEPORA FLABELLATA, new species.

Plate 43, figs. 10-17.

Description.-The zoarium is bushy and formed of bilamellar, flabellate fronds. The fascicles are uniserial, little salient, arranged perpendicularly to the zoarial margins. The tubes are visible only when they are isolated. The ovicell is an irregular vesicle pierced by fascicles whose tubes are then more adjacent.

Measurements.-

Diameter of the peristome............ $0.12 \mathrm{~mm}$.

Zooecial diameter........................ $0.18 \mathrm{~mm}$.

Distance between the peristomes . . ......... $1.00 \mathrm{~mm}$.

Separation of the peristomes............. 0. 56-0.80 mm.

Variations. - The fascicles are not exactly analogous to each other. They form, moreover, some lines with tubes adjacent like true fascicles. The basal lamella is large and the zone of growth is thick.

The ovicell is formed after the consolidation of the adjacent tubes, for the fascicles are not disarranged. If the peristomes are scattered the peristomies are long and never adjacent. It is probable that fossilization caused the long nonadjacent peristomies to disappear from the species, of which the bases alone are visible.

121S4-23-Bull. 125-14 
Affinities.-This species differs from Mesenteripora meandrina Robertson, 1910, in the oricell not placed near the zoarial margin, and in its tubes grouped in fascicles.

In spite of exterior appearances the tubes are not arranged as in Reticulipora, the axis of the apertura being placed in the longitudinal axis of the zooecia.

Occurrence.-Pleistocene: Santa Barbara (common), and Santa Ifonica (Rustic Canyon), California (rare).

Cotypes.-Cat. Nos. 68747, 68748, U.S.N.M.

\section{Genus DIAPEROECIA Canu, 1918.}

(For description, see Bulletin 106, U. S. National Museum, p. 740.)

DIAPEROECIA FLABELLATA, new species.

Plate 43, figs. $18,19$.

Description.-The zoarium is free, bilamellar and formed of flabellate fronds, and irregularly twisted. The tubes are little visible, widened at their extremity; the peristome is thin, salient, elliptical, horizontal. The ovicell is convex, smooth, traversed by 6-10 tubes; the oeciostome is crescentric and joined to an ordinary peristome.

Measurements.-

Diameter of the peristome ............... $0.15 \mathrm{~mm}$.

Distance between the peristomes. . . . . . . . . . . 0. $0.42-0.50 \mathrm{~mm}$.

Separation of the peristomes ................ 0. $0.50-0.55 \mathrm{~mm}$.

Occurrence.-Pleistocene: Santa Monica (Tremochal Canyon) (rare), and Dead Mans Island, off San Pedro, California (very rare).

Holotype.-Cat. No. 68749 , U.S.N.M.

DIAPEROECIA MILNEANA D'OrbignY, 1839.

Plate 6, figs. 20, 21.

1839. Idmonea milneana D'Orbigny, Voyage dans L'Amérique Míridionale, vol. 5, pt. 4, p. 20, pl. 9, figs. 17-21.

1919. Idmonea milneana CANu and Bassler, Geology and Paleontology of the West Indies, Bryozoa, Publications of the Carnegie Institution of Washington, No. 291, p. 99, pl. 6, figs. 20, 21.

1920. Idmonea milneana CANU and BAssLen, North American Early Tertiary Bryozoa, Bulletin 106, U. S. National Museum, p. 773, pl. 136, figs. 1-12.

This recent species has been identified in a number of Tertiary formations of Europe and in the Jacksonian and Vicksburgian of North America. So far the only discovery of it in the/ post-Oligocene strata of North America is in the Lower Mfiocene of Santo Domingo, where the single specimen here illustrated has been found.

The discovery of numerous ovicelled specimens of this species in dredgings from the Gulf of Mexico cause us to refer it generically as abore.

Occurrence.-Lower Miocene (Bowden horizon): Cercado de Mao, Santo Domingo (rare).

Plesiotype.--Cat. No. 68750, U.S.N.M. 


\section{Family LICHENOPORIDAE Smitt, 1866.}

Genus LICHENOPORA Defrance, 1823.

(For description, see Bulletin 106, U. S. National Iluseum. p. 812.)

LICHFNOPORA CALIFORNICA Conrad, 1855.

Plate 44, figs. 4-7.

?1852. Unicavea californica D'Orbiany, Paleontologie francaise, Terrains crétacés, vol. 5, Bryozoaires, p. 972.

1855. Lichenopora californica CoNran, Note on Miocene and Postpliocene deposits of California, Proceedings Academy Natural Sciences Philadelphia, vol. 7, p. 441.

1910. Lichcnopora californica RoBertson, Cyclostomatous Bryozoa of the west coast of North America, University of California Publications, Zoology, vol. 6, p. 261, pl. 25, figs. 48, 49 (bibliography).

Historical.- Cnicavea californica is thus defined by D'Orbigny, 1852: "Espèce très conrexe endessus, ayant le centre excavé, et pourvue de pores intermédiaires énormes. Madelaine, Basse Califormie." Its classification in the genus Unicavea indicates moreorer that the colony is discoidal, creeping, incrusting, provided with a single series of cellules in the rows.

Thaters, $1905,^{8}$ examined D 'Orbigny's type preserved in the Museum of Paris. He notes: "The zooecia are uniserial, slightly raised; zooecia and cancelli about the same size. This does not seem to be the Discoporella californica of Busk."

What Conrad, Gabb and Horn, Busk, and Robertson have named Lichenopora californica does not appear therefore to be the species of D'Orbigny, as the zoarium is free and the fascicles are biserial. Under these conditions we beliere it necessary to substitute the name of Conrad, 1855, for that of D'Orbigny. It is useless to change the specific name, as the specimen of D'Orbigny has not been figured.

Structure.-The structure of this species is quite constant. The zoarium is free and rery convex. The fascicles are regular and biserial. The cancelli are very large and often wider than the tubes. The ovicell is placed in the center of the zoarium and hidden by the cancelli. The oeciostome is large, orbicular, salient, placed excentrically in the vicinity of the fascicles.

Occurrence.-Pleistocene: Santa Barbara, California (rare).

Plesiotypes.-Cat. No.68751, U.S.N.M.

LICHENOPORA HISPIDA Fieming, I828.

Plate 44, figs. 1-3.

1828. Discopora hispida Fleming, History of British Animals, p. 530.

18s4. Lichenopora hispida Hrscrs, Polyzoa of Queen Charlotte Islands, Annals and Magazine Natural History, ser. 5 , vol. 13, 1. 207.

18s9. Lichenopora hispida JELLY, A synonymic catalogue of marine Bryozoa, p. 134 (general bibliography),

1901. Lichenopora hispida WHTEAves, Catalogue of the marine invertebrates of eastern Canada, Geological Survey of Canada, p. 112.

1905. Lichenopora hispida Nevian, Briozoi fossili de Carrubare, Calahria, Bollettino della Societa geologica italiana, rol. 23, p. $554(52)$.

8 Notes on some Recent Bryozoa in D'Orbigny's collection, Annals and Magazine of Natural Ifistory, ser. 7, vol. 15, p. 15. 
1907. Lichenopora hispida Calvet, Expéditions scientifiques du Travanlleur et du Talisman, Brỵozoaires, p. 466 (complementary bibliography).

1907. Lichenopora hispida NordgaA nd, Bryozoen von dem norwegischen-Fischereidampfer "Michael Sars," Bergens Museum Aarbog, p. 17.

1908. Lichenopora hisprda Canu, Les Bryozoaires du Sud-Ouest de la France, Bulletin societe geologique France, ser. 4, vol. 8, p. 3S8, pl. 7, fig. 18.

1912. Lichenopora hispida GuÉrix-Ganivet, Contributions a l'etude des Bryozoaires des côtes armoricaines, III, Bryozoaires de la région de Concarneau et de l'Archipel de Glenan, Travaux scientifiques du Laboratorie de Zoologie de Concarneau, vol. 4, p. 21.

1912. Lichenopora hispida BArroso, Briozoos de la Estaceon de Zoologia maritima de Santander, Trabajos del Museo de ciencias naturales, no. 5, p. 59.

1913. Lichenopora hispida Gú́rin-Ganivet, Bryozoaires de la mission arctique du "Jacques Cartier," Société d'oceanographie du Golfe de Gascogne, fasc. 7, p. 42.

1916. Lichenopora hispida F. Canu, Bryozoaires fossiles des Terrains du Sud-Ouest de la France, Bulletin Société géologique de France, ser. 4, vol. 15, p. 333.

1918. Lichenopora hispida NordgaArd, Bryozoa from the Arctic regions, Tromso Museums Aarschefter, vol. 40 (1917), no. 1, p. 21.

Variations.-This species appears to us as poorly defined. Generally authors have classed under this name all specimens in which the fascicles do not reach the zoarial margin, which is therefore garnished with tubes in quincunx. But the ovicells on these various specimens are not exactly similar. The fossils have lost their visor, which renders their determination still more difficult and less certain.

All the fossil species of Lichenopora resemble each other, and our determination is perhaps not good because in addition only the two figured specimens have been found and we have been unable to make any useful sections.

The ovicell does not bear cancelli in Fleming's species; and we have not observed the oeciostome.

Occurrence.-Pleistocene: Santa Barbara, California (rare).

Geological distribution.-Aquitanian of France (Canu); Helvẹtian of Italy (Seguenza), of France (Canu collection), Tortonian of Austria Hungary (Reuss); Zanclean of Italy (Seguenza); Plaisancian of England (Busk), of Italy (Manzoni); Astian of Italy (Seguenza); Sicilian of Italy (Seguenza, Neviani); Quaternary of Italy (Seguenza, Neviani).

Habitat.-Arctic Ocean: Greenland, Scandinavia (20-420 meters), White Sea, Finmark. Eastern Atlantic: North Sea, England, English Channel (240-300 meters), Gulf of Gascony. Western Atlantic: Canada. Mediterranean: At Cette (15-90 meters), Corse (40-60 meters), Marseilles, Naples, Oran (75 meters). Pacific: Australia, New Zealand, Queen Charlotte Islands.

In the great depths of the Arctic regions (420 meters) the temperature observed, according to Nordgaard, has been $+5^{\circ} \mathrm{C}$.

Plesiotype.-Cat. No. 68752, U.S.N.M.

\section{LICHENOPORA RADIATA Savigny-Audouin, 1826.}

Plate 44, fig. 10.

1826. Melobesia radiala Audour, Explication sommaires de planches de polypes de Savigny Description de l'Égypte, vol. 1, p. 235, pl. 6, fig. 3.

1889. Lichenopora radiata Jelly, A synonymic catalogue oỉ marine Byrozoa, p. 137 (general bibliography). 
1905. Lichenopora radiata Neviani, Briozoi fossili di Carrubare (Calabria), Bollettino della Societa geologica italiana, vol. 23 , p. 554 .

1910. Lichenopora radiata WATERS, Reports on the marine biology of the Sudanese Red sea, The Bryozoa, Journal Linnean Society, London, vol. 31, p. 237 (complementary bibliography).

1910. Lichenopora radiata Roвersson, Cyclostomatous Bryozoa of the west coast of North America, University of California Publications, Zoology, vol. 6, p. 262, pl. 24, figs. 46, 47.

1912. Lichenopora radiata BARroso, Bryozoos de la estación biológica marítima de Santander, Trabajos del Museo de ciencias naturales, no. 5, p. 60 .

1915. Lichenopora radiata BArroso, Contribución al conocimiento de los Briozoos marinos de España, Boletín de la real sociedad española de IIistoria natural, vol. 15, p. 419.

Our specimens agree exactly with the typical form of this widespread recent species. According to Waters, there are nine tentacles.

Occurrence.-Pleistocene: Santa Monica (Rustic Canyon), California (rare).

Geological distribution.-Miocene of Australia and New Zealand (Waters), Zanclean of Italy (Seguenza); Astian of Italy (Neviani); Sicilian of Italy (Neviani, Seguenza), of Rhodes (Pergens); Quaternary of Italy (Neviani, Waters, Seguenza).

Habitat.-Atlantic: British Channel, Gulf of Gascony (135 meters), Madeira. Mediterranean: Corse, Naples, Adriatic (32-89 meters), Majorca. Pacific: Australia, Japan, and California.

Plesiotype.-Cat. No. 68753, U.S.N.MI

\section{LICHENOPORA VERRUCARIA Fabricius, 1780.}

Plate 44, figs. 8, 9.

1899. Licheno pora verrucaria JELLY, A synonymic catalogue of marine Bryozoa, p. 138 (bibliography).

1900. Lichenopora verrucaria Robertson, Bryozoa, Harriman Alaskan Expedition, Proceedings Washington Academy Sciences, vol. 2, p. 329.

1900. Lichenopora verrucaria NordgaArd, Polyzoa, Norske Nordlave Expedition, Zoology, 11o. 27 vol. 27, p. 20.

1901. Lichenopora verrucaria Whiteaves, Catalogue of the marine Invertebrata, Canadian Geological Survey, p. 113.

1905. Lichenopora verrucaria NoRdGAARD, Hydrographical and biological investigations in Norwegian fiords, Bergen Museum, p. 173.

1906. Lichenopora verrucaria NordgaArd, Bryozoa from the Second Fram Expedition, The Society of Arts and Sciences of Kristiania, no. 8, p. 37

1910. Lichenopora verrucaria Robertson, Cyclostomatous Bryozoa of the west coast of North America, University of California Publications, Zoology, vol. 6, p. 263, pl. 25, fig. 50.

1912. Lichenopora verrucaria OsBurs, Bryozoa of the Woods Hole region, Bulletin Bureau of Fisheries, vol. 30 , p. 219 , pl. 1S, fig. 13.

1912. Lichenopora verrucaria NordgaArd, Duc d'Orléans, Campagne arctique de 1907, p. 25.

1912. Lichenopora verrucaria Guśrin-Ganivet, Contributions à l'étude des Bryozoaires des côtes armoricaines, III, Bryozoaires de la région de Concarneau et de l'Arclipel de Glenan, Travaux scientifiques du laboratoire de Zoologie de Concarneau, vol. 4, p. 22.

1918. Lichenopora verrucaria NordgaAnd, Bryozoa from the Arctic region, Tromso Mruseums Aarschefter, vol. 40, (1917), p. 21.

Variations.-The oeciostome of our ovicelled specimen was well preserved in form, very large, salient, and auricular. Unfortunately it was broken in cleaning the specimen. It was larger than the oeciostomes figured by Smitt and by Miss Robertson, and it corresponded more to Osburn's figure.

This is a polar species, as it does not pass beyond the fortieth parallel in the Atlantic and the thirtieth parallel in the Pacific. This is the first time that it has been found fossil. 

rare).

Occurrence.-Plcistocene: Santa Monica (Rustic Canyon), California (very

Mabitat.-Arctic Ocean: Finmark, Spitzberg, Kara Sea (166-216 meters), Greenland, Jean Mayen (160-1S0 meters), Sea of Barents, Iceland (162 meters). Atlantic: Scandinavia (6-24 metcrs), Denmark (13-18 meters), England, Labrador (24 meters), Canadian coast (11-97 meters), United States to the fortieth parallel. Pacific: Alaska and California.

Verrill has observed this species at 56 meters with a temperature of $6.1^{\circ} \mathrm{C}$.

Plesiotype.-Cat. No. 68754, U.S.N.M.

Family TRETOCYCLOECIIDAE Canu, 1918.

Genus TRETOCYCLOECIA Canu, 1919.

(For description, see Bulletin 106, U. S. National Museum, p. 826.)

TRETOCYCLOECIA TORTILIS Lonsdale, 1845.

Plate 28, figs. 1-12.

1845. Heteropora tortilis Lonsdale, Report on the Corals from the Tertiary formation of North America, Quarterly Journal Geological Society London, vol. 1, p. 500, text figure.

1857. Heteropora tortilis Tuonex and Holyes, Pleiocene Fossils from South Carolina, p. 16, pl. 4, figs. $15,16$.

1862. Multicrescis tortilis GabB and Horn, Monograpl Polyzoa Secondary and Tertiary formations North America, Journal Academy Natural Science Philadelphia, ser. 2, vol. 5, p. 178.

Structure.-The zoarium is rarely globular but is almost always irregularly cylindrical, branched, attached to the radicells of algac. The ovicell is suborbicular and regularly perforated by the tubes. It is rather deep and of variable dimensions. At the exterior surface the walls of the tubes are thin or thick. The mesopores are rare on certain branches, abundant in groups on others. This irregularity must correspond to conditions of equilibrium which we still do not comprchend very well.

In longitudinal sections the tubes arc cylindrical, bifurcating at all heights; their walls are resicular. The mesopores are irrcgularly distributed bctween the orifices.

In transverse sections the tubes are polygonal at the center of the zoarium. The mesopores are always rather short.

In tangential sections the zooecial walls are thick. The interior walls are strongly calcificd and appear as thin black lines separated by large clearer spaces corresponding to a less dense calcification.

This is one of the most showy species of the American Miocenc.

Occurrence.-Miocene: Torktown, Williamsburg, and 3 miles southwest of Petersburg, Virginia (common); Sinith's Goose Creek, South Carolina.

Plesiotypes.-Cat. No.68755, U.S.N.MI.

\section{TRETOCYCLOECIA AVELLANA, new species.}

Plate 27, figs, $5-11$.

Description.-The zoarium is free, spherical, born on a flat surfacc, and of the size of a hazel nut, simple or lobed. The tubes are cylindrical, branched at all 
heights, separated by a thick continuous cuticle; the orifice is polygonal with salient peristome. The ovicell is large, irregular, surrounding a score of tubes.

Variations.--The form of the zoarium is quite variable, but it is always a small globular mass simple or mammillated. It grows either on shells or on algae. The small pores observed on the surface of the zoarium are not mesopores but are young tubes in process of formation. The diameter of the normal apertures varies from 0.12 to $0.15 \mathrm{~mm}$.

In longitudinal section the zooecial walls are not vesicular; they show a long, minute canal corresponding to the disappearance of the cuticle which surrounded the tubes on a living specimen.

Affinities.--This species differs from Tretocycloecia tortilis Lonsdale, 1845, in its nonarborescent zoarial form, in the smaller zooecial diameter, and in its larger ovicell.

Occurrence.-Pliocene (Waccamaw marl): Waccamaw River, Horry County, South Carolina (very rare). Miocene (Duplin marl): One-half mile above Edenhouse Point, Chowan River, and 10 miles south of Greenville, North Carolina (rare). Cotypes.-Cat. Nos. 68756-68757, U.S.N.M.

\section{Genus PSILOSOLEN Canu and Bassler, 1922.}

1922. Psilosolen CANu and Bassler, Studies on Cyclostomatous Bryozoa, Proc. U. S. National IIuseum, vol. 61, p. 112.

There are no adrentitious tubes. The tubes are cylindrical with peripheral gemmation.

Genotype.-Psilosolen capitiferax, new species.

Range.-Pleistocene, Recent.

The ovicell is a swelling perforated by the tubes as in the Diaperoeciidae, but it is not inserted in the tubes themselves. On the contrary, the ovicell is perpendicular to the tubes and surrounds only the peristomes as in the family Tretocycloeciidae, where this new genus may be naturally classed. The ovicell is little conrex and very different from the elongated and very salient sac of the Ascosoeciidae.

It is remarkable to note again that through the geological ages it is the simplest form of the family that has persisted. The Cretaceous and Tertiary genera of this family are prorided with adventitious tubes.

PSILOSOLEN CAPITIFERAX, Canu and Bassler, 1922.

Plate 44, figs. 11-21.

1922. Psilosolen capitiferax CANu and Bassler, Studies on Cyclostomatous Bryozoa, Proc. U. S. National IIuseum, vol. 61, p. 112, pl. 13, fig. 8 .

Description.-The zoarium is free, with the form of Entalophora, more or less compressed, dichotomous; the extremity of the branches is enlarged, flattened, and bears the ovicell. The tubes are visible, separated by a furrow, convex, wrinkled transversely, somewhat widened at the summit; the peristome is thin, salient, elliptical or suborbicular. The ovicell is a swelling covering the extremity of a branch; it is perforated by a dozen tubes, some of which are closed by a finely porous diaphragm. 
Measurements.-

Diameter of the peristome . . . . . . . . . . . . 0.16-0.18 mm.

Diameter of the orifice . . . . . . . . . . . . . . . $0.12 \mathrm{~mm}$.

Distance between the peristomes . . . . . . . . . . . . 0.50-1.35 mm.

Separation of the peristomes................ . Variable.

Diameter of a tube . . . . . . . . . . . . . . . . . . 0.18-0.20 mm.

Structure.- We hare made longitudinal and meridianal sections of a number of examples, all of which show the same structure. The zoarial form is a simple compression without any relationship to the structure of the species. In longitudinal section the tubes are cylindrical with peripheral gemmation, reproducing at all heights. The exterior walls of the zoarium are thick.

The transrerse section is elliptical in consequence of the compression of the zoarium. The tubes here are of equal size as characteristic of cylindrical tubes. The rery small tubes scattered among the large ones are the tubes newly formed by peripheral gemmation which have not reached their normal diameter.

Variations.-The peristomes are not regularly placed on the zoarium; they are grouped in irregular zones as in Peripora. They are little salient, but the irregularity of the dimensions indicates the peristome was prolonged by a rery long peristomie broken by fossilization.

The tube measures its greatest width in the portion where it bends away from the zoarium. The tubes which appear exteriorly to arise from an immediately inferior tube are the shorter. Those which appear to arise from before the last row and which slip between the proximal peristomes are the longer.

The oricell located at the end of the branch is not rery salient. It is hollowed out of the zoarium itself, as is easy to rerify in the sections.

Affinities.-Our species is almost identical with Entalophora capitata Robertson, of whose rariations we are ignorant. It differs from it in its ovicell, which completely corers the end of the branch, and in the smaller micrometric dimensions (if the enlargement indicated on Miss Robertson's figures is exact).

Occurrence.-Pleistocene: Santa Barbara (very common), and Dead Mans Island, off San Pedro, California (rare).

Cotypes.- Cat. No.68758, U.S.N.MI. 


\section{BIBLIOGRAPHY OF LITERATURE ON BRYOZOA SINCE 1899.}

The following list, arranged chronologically and alphabetically under each year, gives the title of papers upon both fossil and recent bryozoa issued since the publication of the Synopsis of American Fossil Bryozoa in $1900,{ }^{9}$ in which most of the papers issued before 1899 are cited. On account of the great difficulty of securing literature during the war and since then, it is feared that the lists for the last few years are quite inadequate.

1898 .

Cand, F. Etude sur les ovicelles des Bryozoaires du Bathonien D'Occaignes. Bulletin de la Société Géologique de France, ser. 3, vol. 26, pp. 259-285, 20 figs.

1899.

Allen, E. J. On the fauna and bottom deposits near the thirty-fathom line from the Eddystone Grounds to Start Point. Journ. Mar. Biol. Assn., vol. 5, pp. 365-542; Polyzoa, pp. 511, 512, and 534 , chart 16

Gregory, J. W. Catalogue Fossil Bryozoa in Department Geology, British Museum. Cretaceous Bryozoa, vol. 1, 457 pp. $17 \mathrm{pls}$.

Lo Binnco, S. Notizie biologiche riguardanti specialmente il periode di maturita sessuale degli animali del golfo di Napoli. Mft. Stat. Neapel, vol. 13, pp. 448-573; Bryozoa, pp. 493-195.

Marion, A. F. Notes sur la Faune des Dardanelles et du Bosphore. Annales du Musée de Marseille, ser. 11, vol. 1, 1898, pp. 163-1s2.

Matzdorff, Carl. Jahresbericht über die Bryozoen für 1894, 1895, und 1896. Archiv für Naturgeschichte, vol. 60, pt. 2, pp. 89-126, 1894; issued July, 1899.

Morroe, C. E., and Teller, E. E. The fauna of the Devonian formation at Milmaukee, Wisconsin. Journal of Geology, vol. 7, pp. 272-283, lists.

Neviani, A. Briozoi, Idroidi e Foraminiferi di Ciprio, Giaffa ed Alessandria d'Egitto. Comunicazioni preventiva. Bolletino della Societa Zoologica Italiana, Rome, vol. 8, p. 66.

Odell, W. S. Notes on fresh-water Polyzoa. Ottawa Naturalist, vol. 13, pp. 107-113.

Petтy, S. L. Some Polyzoa, etc., from Walney and Bardsea, North Lancashire. Naturalist, 1899, pp. 59 and 60 .

Pfeffer, G. Über die gegenseitigen Beziehungen der arktischen und antarktischen Faurra. Verhandlungen der deutschen Zoologischen Gesellschaft, 1899, pp. 266-287.

Richard, Jules. Essai sur les parasites et les commensaux des Crustacés. Archives de parasitologie, iol. 2, pp. 548-595. List of commensal Bryozoa, pp. 575-576.

Scherren, H. Cristatella mucedo. Nature, vol. 59, p. 150. (Near London.)

Schultze, L. S. Das Verhältnis der Regeneration und Knospung zur Keimblätterlehre. Jenaische Zeitschrift für Wissenschaft, vol. 33, Bryozoa, p. 293.

Thompson, D'ArCy IV. On a supposed resemblance betrreen the Marine Faunas of the Arctic and Antarctic Regions. Proceedings of the Royal Society of Edinburgh, vol. 22, pp. 311-349.

Whitfield, R. P., assisted by Hovey, E. O. Catalogue of the types and figured specimens in the palaeontological collection of the Geological Department, American Museum of Natural History. Bulletin of the American Museum of Natural History, vol. 11, pt. 11.

WollemaN, A., and Kloos, J. H. Ueber das Vorkommen von Bryozoen und Korallen. Jahresber, Vereins für Naturwissenshaft Braunschweig: vol. 11, p. 200. 
1900.

Bidexkap, Olaf. Dic Bryozoen, I. Teil, Die Bryozoen von Spitzbergen und Koenig-Karls-Land Fauna Arctica, vol. 1, Licf 3, pp. 503-540, pls. 9-10.

Boeggild, O. B. The deposits of the sea bottom. Danish Ingolf-Expedition, vol. 1, no. 2, S9 pp., 7 maps, 6 figs.

Calvet, Louis. Contribution ì l'histoire naturelle des Bryozoaires ectoproctes marins. Travaux Institute Zoologie de l'Universite Montpellier, new ser., Memoire no. 8, 485 pp., 13 pls.

CAvu, F. Note preliminairc sur les bryozoaires de Tours. Comptes Rendus Association francaise Arancement Science, Sess. 2me, pp. 406-411.

CAxu, F. Contribution a la géologie de Romorantin Paleontologie. Bulletin Société Géologique France, ser. 3, vol. 2S, pp. 96-104, 7 figs.

CAxu, F. Revision des Brỵozoaires du Crétacé figurés par D'Orbigny, 2mc Pt. Cheilostomata. Bullctin Société Géologique France, ser. 3, vol. 28, pp. 334-463, 4 pls., 71 figs.

CAR, L. Plumatella (.Alcyonella) fungosa Pallas. (Glasnik hrvats. narav. Drustva. God., vol. 12, pp. $142-143$.

Clarke, Јонм: M. The Oriskany fauna of Becraft Mountain, Columbia County, New York. 53d Memoir New York State Yfuseum, no. 3, vol. 3, Annual Report New York State Ifuseum, 1899, vol. 2, pp. 1-12S, 9 ple., 1 map.

Davexport, C. B. On the variation of the Statoblasts of Pectinatella magnifica from Lake Michigan. American Naturalist, vol. 34, pp. 959-968, 9 figs.

Dexdr, Arthur. Cryptopolyzoon an cmendation in Nomenclature. Zoologischer Anzciger, vol. 23, no. 620 , pp. 391-392.

Gilsos, G. Exploration de la Mer sur les côtes de la Belgique en 1889. Memoires Museum Histoire naturelle Belgique, pp. 1-\$1, 3 pls. and 10 figs. (List of Bryozoa, p. 34.)

Harmer, Sidney F. On the Structure and Classification of the Cheilostomatous Polyzoa. Proceedings Cambridge Philosophical Society, vol. 11, pt. 1, pp. 11-17.

Harater, Sidney F. A revision of the genus Steganoporella. Quarterly Journal Microscopical Science, new ser., vol. $43, \mathrm{pp} .225-297,2$ pls.

Hesrel, E. Cristatella mucedo Cuv. aus der Gegend von Chemnitz und gesammelte Statoblasten desselben. Bericht der naturwissenschaftlichen Gesellschaft z11 Chemnitz, vol. 14, pp. 1xvi-lxviii.

LADENIG, Frasiz. Ueber die Knospung der ektoprokten Bryozocn. Zeitschrift für wissenshaften; Zoologie, rol. 67, p. 323-339, 1 pl.

Mapplestone, C. W. Further descriptions of the Tertiary Polyzoa of Victoria, Pt. 3. Proceedings Royal Society, lictoria, new ser., vol. 12, pp. 162-169, 2 pls.; rol. 13, pp. 1-9, 12 pls.

Nickersox, IW. S. Double Loxosomae. American Naturalist, vol. 34, pp. \$91-895, 6 figs.

Nickles, J. II., and BAssler, R. S. A synopsis of American fossil Bryozoa, including bibliography and synonymy. Bulletin 173, U.S. Geological Survey, 663 pp.

Neriasi, A. Bryozoi neozoici di alcuna localita d'Italia, pt. 6 . Bollettino della Societa Zoologica Italiana, ser. 2, rol. 1, pp. 58-68.

Neviati, A. Briozoi Terziari i Posterziari della Toscana. Bollettino della Société gèologica Italiana, rol. 19, pp. 349-375, 6 figs. in text.

Neviaxi, A. Monografia del Genere Idmonea (Bryozoa Ciclostomata). Pt. 1, Bibliografia generale. Roma, 52 pp.; pt. 2, Cap. $1^{\circ}$ Stora del Genere Roma, pp. 53-66.

Neriani, A. Revision Gencrale dei Briozoi Fossile Italia. Bollettino della Sociéta Geologica Italiana, vol. 19, p. 10-25.

Nordgatrd, O. Polyzoa. Den Norske Nordhavs. Expedition, Zool. no. 27. The Norwegian North Atlantic Expedition (1S76-1878), vol. 27, 30 pp., 1 pl., 1 map.

OrtaAx, A. E. Synopsis of the collections of invertebrate fossils made by the Princeton Expedition to Southern Patagonia. American Journal Science, ser. 4, vol. 10, pp. 368-381. (Bryozoa, p. 370.)

Prilipps, E. G. Report on the Polyzoa collected by Dr. Willey from the Loyalty Isles, New Guinea and Nerr Britain. Zoological Results, A. Willey; pp. 439-450, pls. 42-13.

ReEker, H. Ueber die Biologie der Susswasscrbryozoen. Jahrbücher des nassauischen Vereins für Naturkunde, Wiesbaden, 27 m. Proc. Verb., pp. 22-26.

REMES, II. Bermerkungen über Süsswasserbryozoen Nordmährens. Verhandlungen der $k$. $k$. Zoologisch Botanischen Gessllschait in Wien, vol. 50, pp. 1-j. 
Robertson, Alice. Papers from the Harriman Alaska Expedition, 6. The Bryozoa. Proceedings Washington Academy Science, vol. 2, pp. 315-340, 3 pls.

Robertson, Alice. Studies in Pacific Coast Entoprocta. Proceedings California Academy Science, ser. 3, vol. 2, no. 4, pp. 323-348, pl. 16.

Rogers, A. F. Occurrence of the bryozoan genus Rhabdomeson in America. Kansas University. Quarterly, vol. 9, pp. 173-174.

Rogers, A. F. New Bryozoans from the Coal Measures of Kansas and Missouri. Kansas Lniversity Quarterly, vol. 9, pp. 1-12, pls. 1-4.

Sch Epotieff, A. Die Pterobranchier des Indischen Ozeans Zoologische Jahrbuch vol. 28, Systematik, pp. 429-448, 2 pls.

TAYLon, T. H. Investigations marle at the marine Biological Laboratory, Plymouth. The Embryology" of the Polyzoa. Report 69th Meeting British Association, Dover, p. 437.

Tretiakow, D. Bryozoa und Mollusca des Wolgathals im Government Jaroslar. Transactions Société St. Petersbourg, Comptes Rendus, no. 2, pp. 111-117.

Verrill, A. E. Additions to the Tunicata and Molluscoidea of the Bermudas. Trausactions Connecticut Academy, vol. 10, pt. 2, pp. 5SS-594, pl. 70, 2 text figs.

Waters, A. W. Bryozoa from Franz-Josef Land, collected by the Jackson-Harmsworth Fxpedition in 1896-1899. Chilostomata. Journal Linneau Society London, Zoology, vol, 28, pp. 43-105, 6 pls., 3 figs.

Zsснокке, F. Die Tierwelt der Hochgebirgsseen. Denkschr. Schweiz. Gesellshaft, 400 pp., 8 pls. 4 niaps. (Bryozoa, pp. 115-119.)

1901.

ALLEx, E. J., and TODd, R. A. The fauna of the Exe Estuary. Journal Marine Biological Association, vol. 6, pp. $295-335$. Bryozoa, p. 330 .

Aliten, F. J., and Todd, R. A. The fauna of the Saleombe Estuary. Journal Marine Biological Association, new ser., vol. 6, pp. 151-210. Polyzoa, pp. 204-205.

Arnold, A. F. The sea beach at ebl, ticle, a guide to the study of the seaweeds and the lower forms of animal life found between tide marks. New York, Century Company, vol. 10, 490 pp., 600 figs. Review, American Naturalist vol. 3.5, p. 937.

BeEDe, J. W., and Rogers, A. F. Coal Measures faunal studies. Kansas Quart., vol. 9, pp. 233-254.

Blockentrorn, M. Teues zur Geologie und Palïontologie Aegyptens. Zeitschr. Deutsch. geol. ges., vol. $53, \mathrm{pp} .52-132$, pls.

CLARKE, J. M. Limestones of central and western New Lork interbedded with bituminous shales of the Marcellus stage, with notes on the nature and origin of their faunas. Bull. N. Y. Museum, vol. 49 , pt. 2, pp. 115-138, pl. 8. (Bryozoa, pp. 133 and 134.)

Corl, C. J., and Steuer, 1. Beobachtungen über das Plankton des Triester golfes in den Jahren, 1899 und 1900. Zool. anz., vol: 24, pp. 111-116, with table. (Bryozoa, p. 115.)

Cumings, E. R. I section of the upper Ordovician at Veray, Indiana. American Geologist, vol. 28, pp. $361-380,2$ pls.

Delaeid, E. Bryozoaires poederliens deteruines par le Dr. Pergens provenant du bassin America (Anstruwell-Anvers). Bulletin Société Géologique Belge, vol. 14, p. 332.

Elilot, (i. F. Scotr; I.Aurie, M.; and Murdoch, J. B. Fauna of Clyde area. (Marine Polyzod by A. (rray, Freshwater Polyzoa by M. Laurie.)

Ficheur, E. Note sur le terrain carboniferien de la region d'Igli (Sahara-Oranais). Bulletin Société Géologique France, ser. 3, vol. 28, pp. 915-926. (Bryozoa, pp. 921-922.)

Frič, A. Die thierischen Reste der Perucer Schichten. Archives Landesdf. Bohmen, vol. 11, pp: 163-180.

Gadeau de Kerville, H. Recherches sur les iaunes marine et maritime de la Normandie; $3^{e}$ voyage. Bulletin Société Rouen, vol. 2, pp. 145-22ł. (Bryozoa, pp. 206-20s; list of spp. without descriptious locality, and depth at which found.)

Grabau, 1 . W. Geology and Paleontology of Eighteen Mile Creek and the Lake Shore sections of Erie County, N. Y. Bull. Buffalo Soc. Nat. Sci., vol. 6. (Bryozoa, pp. 161-176, figs.) 
GrabaU, 1. W. Guide to the Geology and Paleontology of Niagara Falls and Vicinity. Bulletin Buffalo Society Natural Science, vol. 7, no. 1. (Bulletin New York State Museum, No. 45, vol. 9.)

Gray, A. Marine Polyzoa. Fauna Clycle Area. Handbook Natural History Glasgow, pp. 209-214.

Harmer, S. F. President's address. Bryozoa in Britain. Transactions Norfolk and Norwich Naturalists Society, vol. 7, pp. 115-137.

Herdian, W. A. Dredging Expeditions. Transactions Liverpool Biological Society, vol. 15. (Bryozoa, pp. 24, 30, and 31.)

Kukentral, W. Leitfaden für das zoologische Praktikum. (Bryozoa, pp. 92-96, 2 text figs.)

Maplestone, C. M. Further descriptions of the Tertiary Polyzoa of Victoria. Pt. 5. Procedings Royal Society Victoria, new ser., vol. 13, pp. 183-190, 2 pls., pt. 6, pp. 204-213, 2 pls.

Maplestone, C. M. On a new name Vittaticclla for the polyzoan genus Caloporella McG. Proceedings Royal Society Victoria, new ser., vol. 13, pp. 201-203.

MAYER, P. Bryozoa and Brachiopoda. Zoologische Jahresberr, 2 pp. Summary Zoologischer Anzeiger vol. 25, p. 575 .

McIntosh, W. C. The coloration of marine animals. Annals Magazine Natural History, ser. 7, vol. 7, pp. 221-240. (Coloration of Bryozoa, p. 230.)

IUdGe, C. P. A textbook of zoology. London, Ed. Arnold, viii, and $416 \mathrm{pp}$.

Neviani, A. Monografia de genere Idmonea. (Briozoo ciclostomato.) Pt. 2, Cap. 2. Storia delle specie, prima centuria Roma, pp. 67-98, with figs.

Neviasi, 1. Briozoi neogenici delle Calabrie. Paleontographia Italica, vol. 6, pp. 115-266, 4 pls.

Neviani, A. Note bibliografiche su lavori concernenti lo studio di alcuni Briozoari. Bollettino Societá Zoologica Italiana, ser. 2, vol. 11, pp. 87-92.

Neviani, Antonio. Nuovi generi e sottogeneri di Radiolari e Briozoi fossili italiana. Bollettino Societá Zoologica italiana, ser. 2, vol. 2, pp. 4l-43,

Nickerson, W. G. On Loxosoma davenporti, n. sp. An Endoproct from the New England coast. Journal of Morphology, vol. 17, pp. 351-380, pls. 32, 33.

Oppenheis, P. Die Priabonaschicten und ihre fauna. Paleontographica, vol. 47, pp. 137-348, pls. 13-21. (Bryozoa, pp. 260-276.)

Petry, S. L. Some Polyzoa, etc., of the Cumberland Coast, Naturalist, pp. 13-15.

Sardeson, F. W. Problem of the Monticuliporoidea. Journal of Geology, vol. 9, pp. 1-27, pl. A; pp. 149-173, pl.

Stenroos, K. E. Das Thierleben in Nurmijarri See. Eine faunistischbiologische Studie Acto Soc. Faun. Fenn., vol. 16, no. 1, pp. 38-50, 98-197, etc.

Sturany, R. Bryozoen. Botanik und Zoologie in Österrich in den Jahren 1850-1900. Festschrift, k. k. zool.-bot. Gessellschaft Wien, pp. 267-268.

Ruedemanx, Rudolf. Trenton Conglomerate of Rysedorph Hill, Rensselaer County, New York, and its fauna. Bulletin New York State Museum, no. 49. (Bryozoa, pp. 12-14, pls. 1, 2, 3.)

Schulz, KarL. Untersuchungen über den Bau der Bryozoen mit besonderer Ber ücksichtigung der Exkretionsorgane. Archives Naturges-Jahresb ücher, vol. 67, pt. 1, pp. 115-144, pls. 6, 7, 3 figs.

Shiplex, 1. E. The abysmal fauna of the Antarctic region. Antarctic Manual, chap. 18, pp. 241-275. (Bryozoa, p. 256.)

Shiplex, A. E., and IICBride, E. W. Zoology: an elementary textbook. Cambridge Natural Science Manuals. Biological Series. Cambridge. (Bryozoa, pp. 282-286.)

Sirth, E. A.; BelL, F. J.; and Krrkpatrick, R. A guide to the shell and starfish galleries (Mollusca, Polyzoa, Brachiopoda, Tunicata, Echinoderma, and Worms), in the British Museum (Natural History), London, printed for the Trustees, $v$ and $130 \mathrm{pp}$., figs.

Whiteaves, J. F. Catalogue of the Marine Invertebrata of Eastern Canada. Report Geological Survey Canada. (Separate publication), 272 pp. Bryozoa, pp. 91-114.

Young, Јонn. The Carboniferous Polyzoa of the Clyde Drainage Area. Elliot and others, Fauna, Flora, and Geology of Clyde Area, pp. 486, 489.

Uluer, George. Lophopus cristallinus Pall. bei Hamburg. Verhandlungen vereins naturwissenschaftlichen Unterh. Hamburg, vol. 11, pp. 195-198.

Ulrich, E. O. Maryland Geological Survey, Eocene, Bryozoa, pp. 20ॅ-222, pls. 59, 60. 
1902.

Andersson, K.A. Bryozoen während der Schwedischen Expeditionen (ins Nordliche Eismeer) 1898 und 1899 unter Léitung von Professor A. G. Nathorst und 1900 unter Leitung von Conservator G. Kolthoff gesammelt. Zoologischer Jahrbüch Abt. Systematik, vol. 15, pp. 537-560, 1 pl.

Calvet, L. Bryozoaires marins de la region de Cette. Travaux Institut Zoologie Université Montpellier, ser. 2, mém. no. 11, 103 pp., 3 pl.

Calvet, L. Bryozoaires marins des côtes de Corse. Travaux Institut de Zoologie Université Montpellier, ser. 2, mem. no. 12,52 pp., 2 pls.

Canu, F. Contributions á étude des Bryozoaires fossiles. I, Collection Campiche (Néocomien); II, Collection Dutemple (Sénonien supérieur). Bulletin Société Géologique France, ser. 4, vol. 2, pp. 10-19.

Gondra, G. E. New Bryozoa from the Coal Measures of Nebraska. American Geologist, vol. 30, pp. $337-358$, pls. 18-25.

Conte, A., and VANEY, C. Contributions a l'étude anatomique du Rhabdopleura normani Allman. Comptes Rendus Academie Science, Paris, vol. 135, pp. 63-65.

Cumings, E. R. A revision of the bryozoan genera Dekayia, Dekayella, and Heterotrypa of the Cincinnati group, American Geologist, vol. 29, pp. 197-217, 4 pls.

Forel, F. A. Le Léman, monographie limnologique, vol. 3, Lausanne. (Bryozoa, pp. 113-115, fig. 189.)

Gardiner, C. J., and Reynolds, S. H. The fossiliferous Silurian beds and associated igneous rocks of the Clogher Head district (County Kerry). Quarterly Journal Geological Society, vol. 58, pp. 226-266 and map.

Goztтe, A. Lehrbuch der Zoologie. Leipzig. Engelmann, 504 pp., 512 figs.

Harmer, S. F. Polyzoa. Encyclopedia Brittanica, vol. 31, pp. 826-839, 6 figs.

Harmer, S. F. On the morphology of the Cheilostomata. Quarterly Journal of Microscopical Science, new ser., vol. 46, pp. 263-350, 4 pls.

Herdian, W. A. Guide to the Port Erin Aquarium. (Bryozoa, pp. 85 and 86, fig.)

Hertwig, R. A manual of zoology. Translated from the 5 th German edition by Kingsley, New York, Holt \& Co., 704 pp.

Kirkpatrick, R. Polyzoa. Report Collections Natural History Southern Cross, pp. 286-289.

LABBE, A. Review of L. Calvet's Contribution a l'histoire naturelle des Bryozoaires ectoproctes marins. Thése, Paris, 484 pp., 13 pls., 1900, Annee biol., vol. 6, p. 99.

Landacre, F. L. Sponges and Bryozoans of Sandusky Bay. Ohio Naturalist, vol. 1, p. 96.

LeVAnder, K. M. Förekomsten af Bryozoo-kolonier i Nyländska skärgarden. Meddelanden Societas Fauna et Fennica, vol. 26, p. 6. (Summary, Zoologischer Anzeiger, vol. 25, p. 576.)

Levinsen, G. M. R. Studies on Bryozoa. Videnskabelige Meddelelser fra den Naturalistorisk Forening Kjobehavn, pp. 1-31. (Summary, Zoologischer Anzeiger, vol. 25, p. 358.)

Maplestone, C. M. Further descriptions of the Tertiary Polyzoa of Victoria. Pt. 7, Proceedings Royal Society Victoria, vol. 15, new ser., pp. 65-74, pls. 6-8; pt. 8, vol. 15, pp. 17-27, 2 pls.

MatzdorfF, C. Jahresbericht über die Bryozoen für 1897 und 1898. Archives für naturgeschichte, vol. 61, pp. 173-198.

Meissner, M. Liste der von Herrn Professor Semon bei Amboina und Thursday Island gesammelten Bryozoan. Semon, Zool. Forschg. Malay Archip., vol. 5, pp. 727-731 (=Denk. Ges. Jena) (n.g. Radulina).

Munthe, H. Stratigrafiska studier öfver Gotlands silurlager. Geologiska Foreningens Stockholm förhandlingar, vol. 24, pp. 221-273. (Bryozoa mentioned in the lists of spp.)

Nevisni, A. Briozoi Ctenostomi fossili. Bollettino della Societa Geologica italiana, vol. 21, pp. 216-220.

Neviani, A. I. Bryozoi pliocenici e miocenici di Pianosa raccolti dal Prof. V. Simonelli e Studiate dal Dott. G. Gioli. Bollettino della Societa Geologica Italiana, vol. 21, pp. 329-343.

Neviani, A. Rhyncopora incurvata n. sp. Bollettino della Societa Geologica Italiana, vol. 2l, fasc. 11, pp. 260-262, 3 figs.

Neviani, A. Sulla Terebripora manzonii, nella Protulophila gestroi Roverto. Bollettino della Societa Geologica I taliana, vol. 21, pp. 41-49. figs. 
Newtox, R. B., and Holiavd, R. On some fossils from the island of Formosa and Riu-Kiu (Loo Choo), Journal of the College of Science, Japan, vol. 17, art. 6, pp. 1-23, 4 pls.

Nickles, J. II. Descriptions of New Bryozon Homolrypa bassleri, n. sp., from the Warren beds of thc Lorraine group. Journal Cincinnati Society Natural History, vol. 20, no. 2, pp. 103-105, 5 fige.

Nickles, J. M. The Geology of Cincinnati. Journal Cincinnati Society Natural History, vol. 20, pp. $49-100$.

Pearsor, $\mathrm{K}$. Statoblasts of Pectinatella magnifica. Biometrika, vol. 1, p. $12 S$.

Pratt, H. S. A course in invertebratc zoology. A guide to the dissection and comparative study of invertebrate animals. Boston, Ginn \& Co.

Ortsinas, A. E. Report Princeton University Expedition to Patagonia. Vol. 4, Paleontology, pt. 2, Tertiary Invertebrates.

Reses, M. Nachträge zur Fauna von Stramberg. I. Die Fauna des rothen Kalksteins (Nicsselsdorfer Schichten). Beitrag Paleontolographica und Geologie Oesterreich Ungarns, vol. 24. (Bryozoa, p. 211.)

Rrtren, W. E. A summer's dredging on the coast of sonthern California. Science, vol. 15. (Bryozoa, p. 62.)

Robertso:; Alice. Somc obscrvations on Ascorhiza occidentalis Fewkes and related Alcyonidia. Procecdings Californin Academy Science, ser. 3, vol. 3, Zoology, pp. 99-10S, 1 pl.

Roverto, G. Briozoi, Anellidi e Spugne perforanti del neogene ligure. Paleontographia italiana, vol. S. 1901, pp. 219-234, pl. 28.

Scharfe, R. F. (Polyzoa) Report Britisl Association, p. 229

Schneider, K. C. Lehrbuch der vergleichenden Histologie der Tiere. Jena. (Bryozoa, pp. 223226, fig. 2:8.)

ThorNeley, Laura R. Polyzon from Ballycastle and Rathlin Island. Irish Naturalist, vol. 11, p. $161-162$.

Tolsacev, I. P. Une espece nouvelle des Bryozoaires du calcaire carbonifere inferieure du district de l'Altai. St. Petersburg, Travaux Societc Naturelle, vol. 33, 1.

Ulmer, Georg. Etwas n̈ber deutsche Moostierchen. Nerthus Jahrg. 4, pl). 525-529, 541-544, 11 figs.

VANeY, C., and CoNTE, A. Recherches sur le bourgeonnement de Rhabdopleura normanii All. Comptes Rendus Academie Science Paris, vol. 135, pp. 745-750.

Wanjer, Johandies. Die Faunen der obersten weissen Kreide in des libyschen Wüste. Paleontographica, vol. 30, pp. 91-151.

Wimasi, Carl. Uber die Borkholmer Schicht im Mittelbaltischen Silurgebiet. Bulletin Geological Institute, University Upsala, vol. 5, pt. 2, no. 10, pp. 149-222, pls. 5-8.

ZYKoFF, IT. Bemerkung zur Kenntnis der geographischen verbreitung der Süsswasser-Bryozoengat tung Plumatella. Zoologischer Anzeiger, vol. 25, p. 181.

1903.

Adasis, G. G.; Grity, G. II.; and White, D. Stratigraphy and paleontology of the upper Carboniferous rocks of the Kansas section. Bull. U. S. Geol. Surv,, no. 211, 123 pp.

Andersson, K. A. Eine Wiederentdeckung von Cephalodiscus (McIntosh). Zoologischer Anzeiger, vol. 26, pp. 365-369.

Barnes, J. On a fossil Polyzoan from the Mountain limestone, Castleton (Evactinopora Castleloniensis n. s.). Transactions Manchester (reological Society, vol. 2S, pt. 9, pp. 243-245, I fic.

BASSLER, R. S. The structural features of the bryozoan genus Homotrypa, with descriptions of species from the Cincinnatian gronp. Proceedings U. S. National II useum, vol. 26, pp. 565-591, pls. $20-25$.

BEEDE, J. W. Fanna of the Shawnee formation (Haworth), the Wabaunsee formation (Prosser), the Cottonwood Limestone. Coal Mensures Faunal Stndics II, J. W. Beede and Austin J. Rogers. Kansas Quarterly, vol. 1, pp. 163-1s1.

Bresson, A. Etudes sur les formations ancieunes des Hautes et Basses-Pyrénées (Haute Chainc). Bulletin Carte géologique France, vol. 14, no. 93, pp. 1-273.

Calvet, L. Descrfpton d'une nouvelle espcce de Bryozoaire Cténostome du genre Alcyonidium Iamouroux (A. brncei). Bulletin société Zoologique France, vol. 2s, pp. 33-36, 4 figs. 
Cax̃u, F. Essal sur une échelle de Bryozoaires pour l'établissment des synchronismes à grande distance. Bulletin Société Géologique France, ser. 4, vol. 3, pp. 115-117.

Caxu, F. Note sur la constance de la faune de la Craie de Villedieu. Bulletin Socíété Gélogique France, ser. 4, vol. 3. pp. 26j-26s.

Chapman, Frederick. New or little known Victorian fossils in the National Museum. II. Some Silurian Molluscoidea. Proceedings Royal Society Victoria, vol. 16, new ser., pp. 60-82, pls. 10-12.

Condra, G. E. The Coal Measures Bryozoa of Nebraska. Nebraska Geological Survey, rol. 2, pt. 1, $168 \mathrm{pp}, 21 \mathrm{pls}$

Condra, G. E. On Rhombopora lepidodendroides Meek. American Geologist, vol. 31, pp. 22-24, $1 \mathrm{pl}$.

Davenport, C. B. The animal ecology of the Cold Spring Sand Spit, with remarks on the theory of adaptation. Decennial Publications. Chicago, vol. 10, pp. 157-176, 7 figs. (Faunistic.)

Destinez, P. Faune du petit-granite $\left(\mathrm{T}_{3} \mathrm{~b}\right)$ de Belqique. Annales Société géologique Belgique, vol. 30, pt. 1, 27, pp. 71-74.

ETHERIDGE, R. A monograph of the Cretaceous invertebrate fauna of New South Wales. Memoir Geological Survey New South Wales, no. 11, vol. 12, 98 pp., 11 pls.

Faire, J. Sur les fossiles crétacés du district de Slavianosserbsk du Government d'Ekatérinoslav. Charikov, Trd. Obsc. isput, prir., 38, 2, pp. 91-173, 4 pls.

Gineste, C. L'organogénèse et l'histrogèníse au point de vue phylogénique. Trans. Lab. Aracachon, vol. 7, pp. $87-161$.

GirTy, G. H. The Carboniferous formations and faunas of Colorado. Professional Papers U. S. Geological Survey, no. 16, $546 \mathrm{pp}$.

(GrRTY, G. H.) Tabulated list of invertebrate fossils from the Carboniferous section of Kansas. Bul letin U. S. Geological Survey, no. 211, pp. 73-83.

HALL, T. S. The possibility of detailed correlation of Australian formations with those of the Northern Hemisphere. Presidential address. Melbourne. (Publication not named. Recorded from separate copy.) Bryozoa, pp. 180-182.

Hadriton, A. On the occurrence of Paludicella in New Zealand. Transactions Proceedings New Zealand Institute, vol. 35, p. 262-264.

Hayes, C. W., and Terich, E. O. Illustration sheet, U. S. Geological Survey Geological Atlas, folio 95.

Harmer, S. F. On new localities for Cephalodiscus. Zoologisclier Anzeiger, vol. 26, pp. 593-594.

Hexscher, J. Untersuchungen über die biologischen und Fischereiverhältnisse des Ǩlöntalersees. Pfäffikon-Zürich, Zwingli, ser. $8,50 \mathrm{pp} ., 1 \mathrm{pl}, 4$ figs.

Herdian, IV. A. Report of Southport meeting of the British Association. Encrusting Bryozoa forming calcareous masses on the sea bottom in the Gulf of Manaar. Science, vol. 48, p. 614.

Hrckson, S. J. (President's address to the Zoological Section.) Report British Association, 1903. (Manchester mains choked by fresh-water Polyzoa sp.)

Hrvo, W. Life zones in the British Carboniferous rocks. Report of the Committee. Report 7lst British Association, Glasgow, pp. 28s-296.

$J_{A C O B}, C$. Sur la signification du gisement cénomanien à Ichtỵosarcolithes ét à faune dù Maine de Saint Laurent près Vachères (Basses-Alpes). Coinptes Rendus Academie Science, vol. 136, pp. $703-705$.

Jords. A. Die organischen Reste in den Bohrproben von der Tiefbokrung auf dem Schlachthofe. A bhandlungen naturwissenschafteichen verein zur Bremen, vol. 17, pp. 523-541.

Jullien, Jules, and Calvet, Lou1s. Bryozoaires provenant des campagnes de l'Hirondelle (1886-88). Resultats des Campagnes scientifiques du Prince de Monaco. Fasc. 23, 188 pp., pls. 1-18, pp. 1-120, pls. 1-15 by Jullien; pp. 120-188, pls. 16-18 by Calvet.

Katzer, F. Grundzüge der Geologie des unteren 1 mazonasgebietes .(des Staates Para in Brasilien). Leipsiz. Weber, 8 vol., 296 pp., 1 pl., 261 figs.

KNUDSEN, - - (Plankton of Northern Europe.) Bulletin des resultats acquis pendant les coursee périodiques publié par le bureau du conseil avec l'assistance de M. Knudsen. Copenhagen, 19021903; no. 2, pp. 85-111; no. 3, pp. 147-170; no. 4, pp. 223-309; 1903-1904, no. 1, 62 pp. 
Korschelt, E., and HEIDER, K. Lehrbuch der vergleichenden Entwicklungsgeschichte der wirbellosen Thiere. Allgemeiner Theil. I, II. Jena, G. Fischer.

KuLczyckI, IV. Résultats des dernières explorations sur les animaux sous-marins des ocèans atlantique et indien. Kosmos, pp. 453-468.

LANG, W. D. On a fossiliferous bed in the Selbornian of Charmouth. Geological Magazine, ser. 4, vol. 10, pp. 388-392, 1 fig.

Lorie, J. Sondages en Zélande et en Brabant. Bulletin Société Belge geologie, vol. 17, pp. 203-258.

Maplestone, C. M. Further descriptions of the Tertiary Polyzoa of Victoria, pt. 9. Proceedings Royal Society Victoria, new ser., vol. 16, pt. 1, pp. 140-147, pl. 16, 17.

Nelti, B. Fossili miocenici del Macigno di Porretta. Bollittino Sociétá Géologica Italiana vol. 22, pp. 181-25?.

NordgaArd, O. Die Bryozoen des westlichen norwegens. Meeresfauna von Bergen, pp. 75-107, 2 pls.

Norman, A. M. Notes on the natural history of East Finnmark. Annals Magazine Natural History, ser. 7, vol. 11, Polyzoa, pp. 567-598, pl. 13; vol. 12, pp. 87-128, pls. 8, 9.

Ostroumoff, A. Sur le développement du cryptocyste et de la chambre de compensation. Zoologischer Anseiger, vol. 27, pp. 96-97.

Riggesbach, E. Die Selbstverstummelung der Tiere. Ergebnissne der Anatomie und Entwick lungsgeschichte, 12 (Bryozoa, pp. 828-829, Abth. 2.)

Robertsox, Alice. Embryology and embryonic fission in the genus Crisia. University of California Publications Zoology, No. 3, pp. 115-156, pls. 12-15.

Rowe, A. W. The zones of the white chalk of the English coast, 3, Devon, pp. 1-51, pls. 1-13; 4, Yorkshire, pp. 193-296, pls. 17-21. Publication Geological Association, vol. 18.

TAYLOR, T. H. Investigations made at the Marine Biological Laboratory, Plymouth. The embryology of the Polyzoa. Report 69th British Association, Dover, p. 437.

TODd, R. A. Notes on the invertebrate fauna and fish-food of the bays between the start and Exmouth. Journal Marine Biological Association, vol. 6, no. 4, pp. 541-561.

VAN BenEDEN, E. On demande de nouvelles recherches sur l'organisation et le developpement d'un Phoronis, en vue d'elucider les rapports existant entre les animaux de ce genre, les genres Rhabdopleura et Cephalodiscus, et le groupe des Enteropneustes. Bulletin Academie Belgique, pp. $1216-1232$.

1904.

Allex, E. J.; Todd, R. A.; PACE, S.; and others. Marine Biological Association. Plymouth marine invertebrate fauna, being notes of the local distribution of species occurring in the neighborhood. Compiled from the records of the laboratory of the Marine Biological Association. Journal Marine Biological Association, vol. 7, pt. 2, pp. 155-298, 1 chart.

Asi, H. If. Preliminary lists of fossil organic remains from the Potsdam, Beekmantown (Calciferous), Chazy, Black River, Trenton, Utica, and Pleistocene formations comprised within the Perth Sheet (no. 119) in Eastern Ontario. Report Geological Survey Canada, Ottawa, vol. 14, pp. 80 -90.

Axonymous Classification. Canadian Naturalist, vol. 31, pp. 210-218. (Bryozoa, p. 212, 2 figs.)

(Axonxmous.) Polyzoa as food of fishes. Pennsylvania State Department of Agriculture, Monthly Bulletin, vol. 2, no. 8, p. 243.

Axoxymous. An expanded polypide of Alcyonella stagnorum. Report Hastings Natural History Society, vol. 11, pl. opp. p. 51.

Bogojawlensti, N. W. Zur Frage uber die Vermehrung von Zoobotryon pellucidus Ehrbg. MIt. Ges. Nat. Moskau, vol. 98. Review by Adelung, Zoologische-Centralblatt, vol. 11, pp. 250-251.

Bozto., H. The paleontology of the Lancashire Coal Measures. Transactions Manchester Geological Society, vol. 28 , pt. 1, pp. 378-420; pt. 2, pp. 578-650; pt. 3, pp. 668-689.

Bonarelli, G. Appunti sulla costituzione geologica dell'isola di Creta. Atti Accademia pontifica dei Nuovi Lincei, ser. 5, vol. 3, pp. 518-548, 1 pl. 4 figs. (Bryozoa, pp. 536 and 537 by Neviani.)

Boveri, T. Ergebnisse uber die Konstitution der chromatischen Substanz des Zellkerns. Jena, 130 pp., 75 figs. Review by Fick, Zoologisches Centralblatt, vol. 11, pp. 97-99.

Calvet, Lours. Bryozoen. Ergebnisse der Hamberger Magalhaensiche Sammelreise, 1892-93, vol. 3, 45 pp. 3 pls. 
Calvet, Lours. Diagnoses de quelques especes de Bryozoaires nouvelles ou incompletement decrites de la region sub-antarctique de l'ocean Atlantique. Bulletin Soriété zoologique France, vol. 29, p. 50-59.

Calvet, Lours. La distribution géographique des Bryozoaires marins et la theorie de la bipolarite. Comptes Rendus Academie Science, vol. 138. pp. 348-387.

Canu F. Bryozoa. Pal. Univ. Pustulopora semiclausa, 6 figs., with diagnosis.

Canu, F. Bryozoaires fossiles d'Egypte, I. Bulletin institut Egypte, ser, 4, vol. 4, pp. 223-229, 2 pls., 5 figs.

Canu, F. Les Bryozoaires du Patagonien échelle des Bryozoaires pour les terrains tertiares. Memoires Société géologique France, Paleontologie, vol. 12, 110. 33, 30 pp., 5 pls., 6 figs.

CANu, F. Etude des Bryozoaires tertiares recuellis en 1855 et 1886 par $\mathrm{M}$. Ph. Thomas dans la region sud de la Tunisie. Exploration scientifique de la Tunisie, pp. 1-37, 3 pls.

CANu, F. Contributions a l'étude des Bryozoaires tertiaires, III. Description de quelques Membran ipores de Tunisie. Bulletin Société Géologique France, ser. 4, vol. 3, pp. 659-660, 1 pl.

Chrrica, C. Notes sur les Bryozoaires de Roumanie. Annales Scientifique de Universite de Jassy, vol. $3, \mathrm{pp} .4-14$.

Cla cs and Grobiex. Lelirbuch der Zoslogie, begrïdet von C. Claus neu bearbeitet von Karl Grobben. Marburg, 1904, 490 pp., 507 figs. Revjew by Scluuberg. Zoologishes Centralblatt, vol. 11, pp. 233238.

Clarke, J. II. Stratigraphic and paleontologic map of Canandaigua and Naples quadrangles. Report New York Museum, vol. 2, App. 4, and Bulletin 63, pp. 1-76. (Bryozoa, pp. 46 and 53.)

Couffox, O. Étude critique sur les falunz du Haguineau. Bulletin Société Angers, vol. 33, pp. 35-85. Cyclostomata, p. 44; Cheilostomata, p. 48; list of 36 spp.

Cumings, Edgar R. Development of some Paleozoic Bryozoa. American Journal Science, ser. 4, vol. 17 , pp. $49-78,83$ figs.

Davenport, C. B. Report on the fresh-water Bryozoa of the United States, Proceedings U. S. National Museum, vol. 27, pp. 211-221, pl. 17.

Diener, C. Himalayan Fossils. Permian fossils of the Central Himalayas. Memoirs Geological Society of India, Paleontologia Indica, vol. 15, 204 pl., pls. 1-10. (Bryozoa, p. 199.)

Dreveryasw, F. Die Fauna der Siegener Schichten von Seifen unweit Dierdorf (Westerwald). Palaeontographia $1,6,1 p$. 229-282.

Exтz, G. Az édesvizek élete. Termes. Kozl. Magyar Tars., pp. 616-636, 9 text $f . g$.

Etheridge. R. Determinations of palaeozoic and mesozoic fossils. Record Geological Survey, Victoria, vol. 1 , pt. 1, pp. 10-12.

Foerste, A. F. Silurian and Devonian limestones of Tennessee and Kentucky. Bulletin Geological Society America, XI. pl. 395-445, 8 figs.

Foerste, A. F. The Ordovician-Silurian contact in the Ripley Island area of southern Indiana, with notes on the age of the Cincinnati geanticline. American Journal Science, ser. 4, vol. 18, pp. $323-342,1 \mathrm{pl}$

Fowler, G. H. Notes on Rhabdopleura normani Allman. Quarterly Journal Microscopical Society. n. 3., vol. 48, pp. $23-31,1$ pl.

Fox-Straxgways, C. The geology of the Oolitic and Cretaceous rocks south of Scarborough. Memoir Geological Surver England and Tales, Nos. 54 and 55, pp. 1-112, 11 pls., 12 text f.gs. Lists of spp. found.

Garrard, M. A. Fresh water Polyzoa. Journal Northamptonshire Natural History Society Field Club, vol. 12 , p. 15S-164.

Girson, G. Explorations de la mer sur les côtes de la Belgique en 1899. Memoires Museum Belgique, vol. $1,81 \mathrm{pp}$.

Grabau, A. IW. Paleozoic coral reefs. Bulletin Geological Society America, vol. 14, pl. 33i-352, pls. 47 and 48 . Bryozoan reeis, p. 348 .

Grïntz, - Pflanzengeographisches und Floristisches von Chemnitz. Bericht der naturwissenschaftlichen Gesellschaft zu Chemnitz, vol. 15, p. 1, (Abhandlungen): (Alcyonella füngosa.)

HaLL, T. S. Reniarks on the deposits. Appendix to Maplestone's tabulated list. Proceedings Society Victoria, vol. 17, pt. 1, pp. 218-219.

$$
12184-23-\text { Bull. } 125-15
$$


Hayden, H. H. Memoirs of the Geological Survey of India. Mremoir Geolngical Survey, India, No. 36, pp. 1-129.

Hind, W. On the homotaxial equivalents of the Lower Culm of North Devonshire. Geological Mag. azine, vol. 1, pt. 8, pp. 397-403.

Hinde, G. J. On the zones of Marsupites in the chalk at Beddington, near Croydon, Surrey. Geological Magazine, vol. 1, pt. 10, pp. 482-487.

Holm, G. Paleontologiska notiser. Sveriges Geologiska Undersökning Serien, afh. No. 179, 104 pp., $14 \mathrm{pls}$.

Holmes, W. Murton. List of fossils collected (Surrey), P. Croydon Club, 1903 and 1904, pp. 45 and 46.

Hudleston, W. H. On the origin of the marine (halolimnic) fauna of Lake Tanganyika. Geolopical Magazine, vol. 7, pp. 337-382, 2 pls.

Hurreld, H. E. Polyzoa. Transactions Norfolk Society, vol. 7, p. 755.

Jukes-Browne, A. J. The Cretaceous rocks of Britain. The upper chalk of England. Memoir Geological Survey of the United Kingdom, 33, 566 pp. Important list of Bryozoan species, pp. 484-493.

Karaskasch, N. I. Note sur la faune contenue dans les galets de Bolschezemelskaia toundra. Protok St. Peterb. Obshch., vol. 35, No. 3, pp. 130-146. (French summary, p. 162.)

Kishinouye, K. Notes on the natural history of corals. Journal Imperial Fisheries Bureau Tokyo, vol. 14, pt. 1, 32 pp., pls. 1-9.

Kitson, A. E. Report on the Bryozoan limestone at Flinders. Record Geological Survey, Victoria, vol. 1, pt. 1, pp. 44-51. List of species found.

Kiтti, E. Geologie der Umgebung von Sarajevo. Jahrbucl geologischen Reichasant. Wien, vol. 53, pp. $515-748,3$ pls. 47 figs.

KNIPOWitsch, N. Explorations zoologiques sur le bateau casse-glace "Ermak" en été de 1901. Annales Museum Zoologique Academie St. Petersburg. vol. 6, pp. 1-20, 1 pl.

Korond, C. A. Biological survey of the waters of southern California at San Diego. Science, vol. 19, pp. 505-508.

Lamplugh, S. W.; Kilroe, J. R.; McHenry, A., Seymour, H. J.; Wright, W. B.; and Muff, H. B. The geology of the county of Belfast. Memoir Geological Survey Ireland, $166 \mathrm{pp}$.

LANG, W. D. The Jurassic forms of the "genera" Stomatopora and Proboscina. Geological Magazine, dec. 5 , vol. 1, no. 7 , pp. 315-322, text figs.

LAuterborn, R. Beiträge zür Fauna und Flora des Oberrheins und seiner Umgebung. Mittheilungen der Pollichia eines naturwissenschaft Vereins der Rheinplatz Durkheim, Jahrbuch 60, no. 19, pp. $42-130$.

Lebedinskx, G. Die Einbryonale Entwicklung der Pedicellina. Travaux Société Naturelle St. Petersbourg, Comptes Rendus, vol. 35, livr. 1, p. 468-171.

цномме. Coquilles fossiles trouvées en 1903 dans les sables de Saint-Gobain (Yprésien). Feuille de jeunes naturalists, ser. 4, vol. 34, pp. 103-106. List of spp. collected.

I.INDER, C. Étude de la faune pélagique du Lac de Bret. Revue Suisse Zool, vol. 12, pp. 144-158, pl. 4.

LINDINGER, L. Verzeichnis der in und um Erlangen beobachteten Mollusken. Anhang: Ein neurer Fundort von Cristatella mucedo Cuv. Abh. nat. Ges. Nürnberg, vol. 15, pp. 65-S4.

Lomiaxi, II. Eier und sogennante Cysten der Plankton-Expedition. Anhang: Cyphonautes. Ergebn Plankton-Expedition, vol. 4, pp. 1-61, pls. 1-7.

Lomas, J. On Polyzoa as Rock-cementing organisms. Report 73d Meeting British Association Advancement Science, pp. 663-664.

Longchamps, M. de Selys. Développement postembryonnaire et affinities des Phoronis. Memoire Academie Belgique, vol. 1, 150 pp., 7 pls. Affinities with Bryozoa, pp. 129 and 130.

Loppens, K. Sur une variété de Membranipora membranacea L., et sur quelques animeaux marins vivant dans l'eau saumatre. Annales Société Zoologique Belgique, vol. 38, Bulletin, pp. 152 and 153.

Loprens, K. Bryozoaires et Cnidozoaires nouveaux pour la faune Belge tronves par la plupart pendant l'année 1903. Bulletin Société Zoologique Belgique, vol. 39, pp. 65-67.

Luther, A. Plankyologiska och hydrofaunistiska studier i Lojo sjö under sommaren 1901. Meddelanen Société Fauna Fennica, vol. 28, A, pp. 52-55. 
Maehrenthal, F. C. v. Entwurf von Regeln der Zoologischen nomenclatur. Als Grundlage für eine Neubearbeitung der internationalen Regeln der internationalen nomenclatur. Zoologischer Anzeiger, vol. 1, pt. 2, pp. 89-138.

Maplestone, C. M. Notes on the Victorian fossil Selenariidae, and descriptions of some new species (Recent and Fossil). Proceedings Royal Society Victoria, new. ser., vol. 16, pp. 207-216, 2 pls.

Maplestone, C. M. Tabulated list of the fossil Cheilostomatous Polyzoa in the Victorian Tertiary deposits. Proceedings Royal Society Victoria, new ser., vol. 17, pp. 182-217.

Marcial, P. Recherches sur la biologie et le développement des Hyménoptères parasites, 1. La polyembryonie specifique ou germinogonie. Archives zool. exp., vol. 32 , no. 3 , pp. 257-335, pls. 9-13. Relations of germinogony to ontogeny of Bryozoa, pp. 322-324.

Matzdorf, C. Jahresbericht über die Bryozoen für 1899-1902. Archives Naturges., 1897, vol. 2, pt.3, pp. 97-146.

Meyer, E. (Affinities of Bryozoa.) Zoologische Jahrbücher Anat., vol. 21, pt. 2, pp. 21-34.

Michaelsen, W. Revision der composition Styeliden oder Polyzoinen. Mittheilungen Naturhistorischen Museum Hamburg, vol. 21, pp. 1-124, 2 pls. Affinities of Bryozoa discussed.

Munthe, H. Stratigrafiska studier öfver Gotlands Silurlager. Sveriges Geologiska Undersökning, no. $192,55 \mathrm{pp}$.

Neviani, Antonio. Appunti sui Briozoi del Mediterraneo, II. Bollettino Societiá Zoologica Italiana, anno 13, p. 1-3.

Neviani, A. Schizotheca serratimargo Hincks sp. Bollettino Societá Geologica Italiana, vo 1.23, fasc. 11, p. 270-276.

Noвre, A. Subsidios para o estudo da fauna marinha do norte de Portugal. Annales Sciencias Naturales, Porto, vol. 8, pp. 37-94. (Bryozoa, pp. 78-86.)

Nobre, A. Subsidos para o estudo da fauna marinha do sul de Portugal. Annales Sciencias Naturaes, Porto, pp. 153-160. (Bryozoa, p. 159, 18 spp.)

PARKs, W. A. Devonian fauna of Kwataboahegan River (Ontario). Bureau of Mines, Report 1904, pt. 1, Bryozoa, p. 185.

PARKs, W. A. A remarkable parasite from the Devonian rocks of the Hudson Bay slope. American Journal Science, ser. 4, vol. 18, pp. 135-144.

PArkinson, J. H. The zoning of the culm in South Germany. Geological Magazine, ser. 5, vol. 1, pp. $272-276$.

PoléNofF, B. Description géologique de partie nord-ouest de la 15me feuille du VIII zone et do la partie sud-ouest de la $15 \mathrm{me}$ feuille du VII zone de la carte générale du gouvernement Tomsk. Travaux géologique St. Petersburg, vol. 3, pp. 133-339.

Prochá́ka, V. J. Das ostböhmische Miocaen. Arch. nat. Bohmen, vol. 10, pt. 2, 173 pp., 72 fig.

RANGE, P. Das Diluvialgebiet von Lubeck und seine Dryastone nebst einer vergleichenden Besprechung der Glazialpflanzen führenden Ablagerungen überhaupt. Zeitschrift Naturwissenschaften, vol. 76, pp. 161-273, 1 pl. (Bryozoa, p. 238.)

Ransome, F. L. The geology and ore deposits of the Bisbee Quadrangle, Arizona. Professional Papers U. S. Geological Survey, 21, 112 pp. (Lists of species, pp. 36-38.)

Retzius, G. Zur Kenntnis der Spermien der Evertebraten. Biol. Untersuchen, vol. 11, pp. 1-32, pls. 1-13.

Rтсне, A. Étude stratigraphique et paléontologique sur la zone à Lioceras concavum du Mont d'Or Lyonnais. Annales Université Lyon, fasc. 14, 252 pp., 8 pls. (Bryozoa, p. 207, note of occurrence.)

Rosenfeld, G. Studien über das Fett der Mecresorganismen. Wissen-Meeresuntersuch, vol. 5, pl. 21 pp. 57-85.

Roussel, M. Tableau stratigraphique des Pyrénées. Bulletin Carte géologique France, vol. 15, no. 97 , pp. 1-116, 3 pls., 66 figs.

Rousselet, Charles F. On a new fresh-water Polyzoon from Rhodesia, Lophodella thomasi gen. et sp. nov. Journal Quekett Microscopical Club, ser. 2, vol. 9, p. 45-46, 1 pl.

Schepotieff, A. Zur organisation von Rhabdopleura. Bergens Museums Aarbok, no. 2, 21 pp., 3 pls. (Faunistic.)

Seelingero, O. Ueber die Larven und Verwandtschaftbeziehungen der Bryozoen. Archives Ver. Freunde Nat. Mecklenburg, Jahrg. 58, pp. 30-37. 
Stiasiy, Y. Beitrag zur Kenntniss des Exkretionsapparates der Entoprocta. Arbeiten zoologischen Instituten Wien, vol. 15, pp. 183-196, 1 pl.

Steckexberg, 1. Coraux et bryozoaires recueillis par N. Sibirtzen dans le government de Yladimir. Bulletin Comité Geologique, vol. 23, pp. 49i-502.

Stuckexberg, A. Anthozoen und Bryozoen des unteren Koklenkalkes von Central Russland. Memoires du Comite Geologique, new ser., vol. 54, pp. 65-109, 9 tables.

Tovla, Fraxz. Geologische Beobdachtuengen auf einer Reise in die Gegend von Silistra und in die Dobrudscha im Jahre 1S92. Jahrbuch geologischen Reichs-Anstalt, vol. 54, pp. 1-16, 3 pls.

Ulrich, E. O., and Bassier, R. S. Maryland Geological Surver, Miocene, Bryozoa, pp. 404-429, pl. 109-118.

Ulrich, E. O., and Bassler, R. S. A revision of the Paleozoic Bryozoa. I. On genera and species the Ctenostomata. Smithsonian Miscellaneous Collections, vol. 45, pp. 256-294, 4 pls., 2 figs.

Ulrich, E. O., and B.sssler, R. S. A revision of the Paleozoic Bryozoa. Pt. 2. On genera and species of Trepostomata. Smithsonian Jiscellaneous Collection, vol. 47, pp. 15-55, 9 pls.

Ussisg, N. V. Danmarks Geologi i almenfatteligt Omrids. Danmarks geologiske undersogelse, rol. 3 , pt. 2, pp. 1-359, 3 pls.

Vaхнӧғfex, E. Die Tierwelt des Südpolargebiets. Zeitschrift Gesellshaft Erdkunde zu Berlin, pp. $362-370,11$ figs.

Verrill, A. E. Additions to the Tunicata and Molluscoidea of the Bermudas. Transactions Connecticut Academy, vol. 10 , pt. 2 , pp. 58S-594, 4 figs.

Verrill, A. E. Additions to the fauna of the Bermudas irom the Yale Expedition of 1901, with notes on other species. Transactions Connecticut Academy, rol. 11, pp. 15-62, pls. 1-11. (Bryozoa, p. 54, list of species only.)

Verrill, A. E. The Bermuda Islands. Transactions Connecticut Academy; vol. 11, pl. 2, pp. 413-913

Waters, A. W. Bryozoa irom Franz-Josef Land, collected by the Jackson-Harmsworth Expedition 1896-97. Pt. 2, Cyclostomata, Ctenostomata, and Endoprocta. Journal I,innean Society London, Zoology, rol. 29, pp. 161-1S4, 3 pls.

Waters, A. W. Résultats Voyage Belgica. Zoologie, Bryozoa, $11 \pm$ pp., 9 pls., 3 figs.

Welgelt, C. L'assainissement et le repeuplement des rivières. Memoir Cour. Academie Belgique, no. 64, (Bryozoa, p. 516, fig. 83).

Wesexberg-Lind, C. Studien over Danske Soers Plankton. Specielle Del. (English summary) 223 pp. Copenhagen, 1904. (Review by Zschokke, Zoologischer Centralblatt, vol. 11, pp. 680-687.

Whteares, J. F. Preliminary list of fossils from the Silurian (Cpper Silurian) rocks of the Ekwan River and Sutton Mill Lakes, Keewatin, collected by D. B. Dowling in 1901, with descriptions of such species as appear to be new. Report Geological Survey, Canada, vol. 14, pt. F, pp. 38-59.

THнitfield, R. P. Notice of a new genus and species of Lower Carboniferous Brrozoan. American Ifuseum of Satural History, Bulletin, vol. 20, p. 469, pl. 11

Wollemaxi, A. Ein Aufschluss im Mukronatensenon bei Rotenkamp, nordwestlich von Königslutter, vol. 13. Jahresbericht Vereins für Naturwissenschaften, Braunschweig, pp. 40-42.

Wolterstrorff, WT. Beitrage zur Fauna der Tucheler Heide. Bericht über eine Zoologische Bereisung der Kreise Tuchel und Schretz in Jahre, 1900. Schr. Ges. Danzig, vol. 11, pts. 1 and 2, pp. 140-234, $1 \mathrm{pl}$,

Wood, Elvira. Marcellus (Stafford) limestones, of Lancaster, Erie County, New Fork. Report New York State Museum rol. 55, pp. 139-181. (Bryozoa, p. 156. List of species found.)

1905.

Ameghiro. F. L'Age des Formations sédimentaires de Patagonie. Critique de Hatcher. Annales Societá Argentina, vol. 51, (nos. 3 and 4) p. 65. (Bryozoa, p.'SS.)

Axoxyous. The geology of the country round Cork and Cork Harbour. Memoirs Geological Survey", Ireland. (Geology of Cork, pp. 1-126; Bryozoa, p. 27.)

Bidexkap, Olaf. Fortegnelse over de arktiske bryozoa. Bergens Museum Aarbok, no. 9, 79 pp.

Brенм, V. Zur Kenntniss der Mikrofauna des Franzensbader Torfmoordistriktes Bryozoa. Archives Hydrobiologie und Planktonkunde, vol. 1, pp. 211-233. 
Brows, E. T. Note on the pelagic fauna of the Firth of Clyde. Proceedings Royal Society of Edinburgh, vol. 25, pp. 779-791.

BuEx, Odox DE. La région méditerranéenne des Baléares. Bulletin Société Zoologique France, vol., 30 , no. 5 (Bryozoa, p. 104).

Burrows. A. W. Note on a bryozoan attached to Neptunea found in one of the Mekran nodules. Geological Magazine, ser. 2, dec. 5, rol. 2, no. 7, pp. 303-30.5, fig. 1.

Calvet, L. La station zoologique de Cette. Travaux Institut Montpellier, ser. 2, mem. no 15 (Bryozoa, list of, pp. 61-63).

Calté, L. Liste de Bryozosires marins de collections du musée Royal d'Historie naturelle de Bruxelles. Annales Société malacologique Belgique, vol. 39, pp. 1-8.

Carez, L. La géologie des Pyrénées Francaises. Feuilles de Tarbes et Luz. Groupe primaire. Système Permien. Geol. Pyrénées. Ifemoireș Carte Géologique France, Fasc. II (Bryozoa, pp. 797 and 798 ).

Crapyas, F, and McCor. Totes on fossil casts in Tertiary ironstone from Stawell. Victorian Naturalist, vol. 21, pp. 178-1S0.

Clarke, J. IT. Type specimens of paleozoic fossils in lew lork State Museum. Report New York Iruseum, vol. 56 (I-IY), and Bull.65, pp. 1-S47. (Bryozoa, pp. 94, 187, iS6, 816, S17, s21, S23, S29, $\$ 33, \$ 39, \$ 46$.

Clarke, E. Fossils oî Waitemata and Papakura series. Transactions New Zealand Institute, vol. 37, p. 413 . (Bryozoa, p. 415.$)$

Colgan, N. Notes on the invertebrate fauna of Skerries, County Dublin. Irish Naturalist, vol. 14, pp. 20.5-213. (Bryozoa, p. 209.)

Cocffor, O. Bryozosires. Étude critique sur les Faluns de Chalonnes. Bulletin Société Angers, vol. 34, pp. 165-214.

Cocffor, O. Les falunz de l'A njon et de la Louraine dans le Saumurois. Bulletin Société Angers, new ser. vol. 33, pp. 216-223. (Bryozoa, p. 21S.)

Cragri, F. W. Paleontolozy of the Malons Jurassic formation of Texas. Bulletin U. S. Geological Survey, no. 266, pp. 172, 3 pls.

Cemrigs, E. R. Development of Fenestella. American Geologist, vol. 35, pp. 50 and 51.

Cramgs, Edgar R. Development of Fenestella. AmericanJournal Science, ser. 4, vol. 20, pp. 169-177, 3 pls.

DAcqú̉, E. Beiträge zur Geologie des Somalilandes. 1 Teil, Untere Kreide. Beiträge Paleontologie und Geolozie Osterreich-Ungarns und des Orient, vol. 17, Keft 1 and 2, pp. 7-20 (2 and 3); 2 Teil, Oberer Jura, Heit 3 and 4, pp. 119-160 (with pls. 14 and 1S).

Derystghtsze, K. Otochezh po osorudovananiyn Murmanskoi Biologhicheskoi Stanju i lyetniya rasotzhina nei vzh 1904. Protok St. Petersberg Obshch, vol. 36, pt. 1 (2, 3), pp. 78-114: (Bryozoa, p. 99.)

Desiraztères, O. Notes paléontologiques sur l'Arrondissement de Segré. Bulletin Société Angers, vol. 36, pp. 123-130.

Destinez, P. Complément de la Faune des psammites du Condroz. Annales Société géologique Belgique, vol. 32, pt. 2, pp. 123-127. (Bryozoa, p. 127.)

Docglas, EARL. Some notez on the geology of southwest Montana. (Bryozoa in Carboniferous formation.) Annales Carnegie Museum, p. 419.

Dúbix, L. The history of the germ cells in Pedicellina americana. (American Society Zoology) Science, p. 331 , new ser., vol. 21.

Dublis, L. The history of the germ cells in Pedicellina americana (Leidy). Annals New York Academy Science, vol. 5, pp. 1-55, 3 pls., 2 figs.

Dúbis, L. On the Nucleoli in the Somatic and germ cells of Pedicellina americana. Biological Bulletin, vol. S, pp. $345-364,14$ figs.

Fearsides, W. G. On the geology of Arenig Fawe and Moel Llynfnant. Quarterly Journal Geological Society; vol. 61, pp. 608-637, 1 pl., 1 map, 2 figs.

Fox-Strangeways, C. Carboniferous limestone fossils from South Derbyshire. Memoir Geological Survey United Kingdom, no. 141 (Bryozoa, p. 15). 
Fox, Howard. Further notes on the Devonian rocks and fossils in the parish of St. Minver. (With notes by F. A. Bather, G. C. Crick, W. A. E. Ussher, and H. Woodward). Penzance, Transactions Royal Geological Society Cornwall, vol. 13, pp. 33-87.

Hallez, Paur. Rhéotropisme de quelques Hydroides monosiphonés et des Bugula. Comptes Rendus Academy Science Paris, vol 141, p. 840-843.

Hallez, Padu. Notes Fauniques. Bryozoaires, Archires Zoologue experimentale et generale Zool. Exp., ser. 4, vol. 3, p. 49.

Harbort, E. Die Fauna der Schaumburg-Lippeschen Kreidemulde Berlin, Abhandlungen der kgl. preussischen geologischen Jandcsanstalt, vol. 45, pp. 1-112.

Harmer, S. F. The Pterobranchia of the Siboga Expedition, with an account of other species. Siboga Expedition Monograph, no. 26, 132 pp., 14 pls., 2 figs.

Hennig, Anders. Gotlands Silur-Bryozoer, I. Arkiv för Zoologi K. Svenska Vetenskapsakademiens i Storkholm, vol. 2, no. 10, 37 pp., 2 pls., 35 figs.

Hudsos, George H. Contributions to the fauna of the Chazy limestone on Valcour Island, Lake Champlain, New York State Museum, Bulletin 80, pp. 270-295.

Johssox, CH. W. Annotated list of the types of invertebrate Cretaceous fossils in the collection of the Academy of Natural Sciences, Philadelphia. Proceedings Academy Philadelphia, vol. 57, pp. 4-28. (Bryozoa, pp. 5 and 6.)

Kaza rskir, P. Materialen zur Kenntniss d. Devon-Fauna d. Urals. Trudui Kazan Univ., vol. 34, no. 2, pp. 1-51. (Bryozoa, p. 29.)

Kesp, Helen P. Bryozoa. (Bibliography for.1905.) Zoological Record, London, vol. 42, p. 10.

KrAer, H. Dyŕelivet i Drøbaksund. Nyt magazin Naturvidenskaberne, pp. 61-89, pls. 2 and 3.

Knudsen, M. Résultats acquis pendant les courses périodiques Plankton (Norwegian, English, Belgian German, Danish, and Swedish waters). Bulletin, Conseil Permanent International pour l'exploration de la mer 1904-1905. (Cyphonautes, no. 1, d, pp. 2, 8, 10, 14, 18, 27, 30, 35, 42; no. 2.d, pp. 64, $66,72,76,79,81,83,85,86,92$; no. 3 , d, pp. $108,110,114,115,117,124$; no. 4, d, pp. $137,142,151$, $152,160,176,180$.

Lamanski, V. Die aeltesten silurischen Schichten Russlands (Etage B). St. Petersbourg, Memoires comite geologique, new ser., vol. 20.

Lana, W. D. On Stomatopora antrqua Haime and its related Ijiassic forms. Geological Magazine, dec. 5 , vol. 2 , no. 6 , pp. 258-268, table, pl. 14, text fig.

Lankester, E. R. Gn a new species of Cephalodiscus from the Antarctic Ocean. Proceedings Royal Society London, vol. 76 B, p. 400-402.

Lebedinsky, - Die Embryonal entwicklung der Pedicellina echinata Sars. Biologisches Centralblatt, vol. 25 , p. 536-548, 2 figs.

Loppens, K. Bryozoaires. Bulletin Société zoologique malacologique Belgique, vol. 39, p. 14.

Maplestone, ${ }^{4}$ C. M. Lord Howe Island Polyzoa. Proceedings Royal Society Victoria, vol. 17, pp. $386-390,2$ pls.

McINтosh, W. C. Budding in animals. Zoologist, January 1905, pp. 1-21.

Meissner, Wallerian. Ueber die Winteriauna im Kaban-Sce. Trudui Kazanskom Universitetye, vol. 39, ser. 3, 1904, pp. 1-118, 1 pl.

Merrill, G. P. (and others). Catalogue of the type and figured specimens of fossils, etc. Bulletin U. S. National Museum, no. 53, pt. 1, 1905.

Monroe, CH. E. List of fossils from Bethany, New York (Hamilton beds). Bulletin Society Wisconsin, vol. 2 , pt. 1, p. 63.

Munthe, Henr. Om den submoräna Hernögyttijan och dess Alder. Sveriges geologiska undersökning Afh. Ser C. Co., vol. 196, pp. 1-32. (Bryozoa, p. 13.)

Napgat, Dr. Seznam zkamenčlin v billém vápenci na Stramberku naizenycn. Vestnik. Ceske Ak., vol. 13, pp. 288-295. (Bryozoa, p. 291.)

Napsal, Dr. Seznam zkamenělin z cerveného vápence kopřvonǐckého. Vestuik Ceske Ak., vol. 13, pp. 360-379. (Bryozoa, p. 361.)

Neviani, A. Sulla Schizothcae serratimargo Hincks. Napoli. Annuario del Musco zoologico, Universita di Napoli, new ser. 2, no. 1, pp. 1-6. 
Neviani, A. Materiali per una bibliografia degli studi sui Bryozoi viventi e fossili dal 1800 al 1900. Bollettino Naturalista Sicna, Anno 20, pp. 104-109, 122-125; Anno 21, pp. 4-8, 29-33, 47-50, 66-67, 102,105, 139-113; Anno 22, pp. 24-28, 44-47, 53-55, 71-73, 96-98; Anno 23, pp. 11-15, 31-34, 46-50, 59-62, 75-76, 90-91, 101-102, 113, Anno 24, pp. 1-10; Anno 25, pp. 21-22.

Neviani, Antonio. Briozoi fossili di Carrubare (Calabria). Bollettino Società Geologica Italiana, vol. 23 (fasc. 3.), p. 507-555, 21 figs.

Neviani, Antonro. Di alcuni Briozoari eocenici di villatorta (Spagna). Bullettino della Societiá Geologica Italiana, vol. 24, p. 158-163.

Nickles, J. M. The Upper Ordovician rocks of Kentucky and their Bryozoa. Kentucky Geological Survcy, Bulletin no. 5,64 pp., 3 pls.

Nobre, A. Fauna Portugesa. Ectoprocta. Annuar Ac. Porto, 1903-4, p. 115.

NordgaArd, O. Hydrographical and biological investigations in Norwegian fiords. Bergen Museum, 254 pp., 21 pls. Bryozoa, pp. 164-174, pls. 3-5.

Norman, A. M. Notes on the natural history of East Finmarl.. Annals and Magazine of Natural History, ser. 7, vol. 15, pp. 341-360, pl. 27.

PeEtz, H. DE. Description géologique de la 13 feuille ( $\mathrm{A}$ zonc) de la carte generale du governement. Tomsk (feuilles; Zmélnogorsle, Bieloglasowo, Loktewsky, Sawod et Kabania). Travaux Sect, Geol. Cab. S. M. I. St. Petersburg, vol. 6, pp. 1-273.

Retzius, G. Zur Kenntniss der Spermien der Evertebraten. Biol. Untersuch., vol. 13, pp. 79102, 8 pls. (Bryozoa, pp. 89-90.)

Retzrus, G. Das sensible Nerven system der Bryozoen. Biol. Unters., new. ser., vol. 12, p. 49-54, $1 \mathrm{pl}$.

Richet, - - Génération. Dict. de Physiologie, 1905 (Bryozoa, p. 70).

Robertson, Alice. Nonincrusting Chilostomatous Bryozoa of the west coast of North America. University of California Publications, Zoology, vol. 2, no. 5, pp. 235-322, pls. 4-16.

Röмe R, F. Bericht der Senkenbergischen Naturforschenden Gesellsch. in Frankf. am. Main, 1905. Museumsbericht, No. 1. Zool. Sammlung, p. 186. Bryozoen an d. Norwegischen Küste.

Schardt u. Dubors. Descriptions Géologiques de la région des Jura Neufchätelois. Bulletin Society Neuchatel, vol. 30 (1902), p. 195. (Bryozoa, pp. 268-275, 284.)

Sмry̌ka, F. Novějši nálezy v čelechovském devonu. Vestnik Klub. Prostejove, vol. 7, pp. 53-72. (Bryozoa, p. 61.)

Thevenin, Armand." Note sur des Fossiles du Carbonifère infr. du Djebel Bechar (Sud Oranais). Bulletin Société geologique France, vol. 4, no. 6 (Bryozoa, p. 820).

Tномаs, H. J. Neue Beiträge zur Kenntniss der devonischen Fauna Argentiniens. Zeitschr. Deutsch. gcol. Ges., vol. 57, no. 11 (Bryozoa, p. 287).

Thornit, Laura R. Report on the Polyzoa collected by Professor Herman at Ceylon in 1902. Ceylon pearl oyster fisheries, Report to Col. Gov., pt. 4, suppl. Report no. 26, pp. 107-130, 1 pl.

Ulrich, E. O. Geology and general relations. In Ulrich, E. O., and Smith, W. S. T. Lead, zinc, and fluorspar deposits of western Kentucky. Professional Paper 36, U. S. Geological Survey, pp. 7-105, with plates.

Waters, A. W. Bryozoa from near Cape Horn. Journal Linnean Society London, Zool., vol. 29, pp. 230-251, pls. 28, 19.

Waters, A. W. Notes on some Recent Bryozoa in d'Orbigny's Collection. Annals and Magazine Natural History, ser. 7, vol. 15, pp. 1-16, 1 pl.

Wilson, J. Howard. The pleistocene formations of Sankaty Head, Nantucket. Journal Geology, Chicago, Illinois, vol. 13, pp. 713-33.

Young, G. W. The chalk area of N. E. Surrey. Proceedings Geological Association, vol. 19, pt. 4, pp. 188-219. (Bryozoa, p. 217.)

ZahílKa, Čenéz. Pásmo X, kridového utvaru v Pojizeri (Zone $\mathrm{X}$ of the Cretaceous of the Iser District of Bohemia). Prag, Sitz-Bcreichte Böhmen Gesellschaft Wissenschafte, no. 17, pp. 1-184.

Zrmmer, C. Pectinatella magnifica (Łeidy) in der Oder. Zoologischer Anzeiger, vol. 29, pp. 427-428.

ZyкоғF, W. Ueber das Plankton des Saisan-Sees. Bryozoa. Zoologischer Anzeiger, vol. 29, no. 15, pp. $477-482,2$ figs. 
1906.

Avwandale, N. Notes on the fresh-water fauna of India, no. 11. Affinities of Hislopia. Journal Proceedings Asiatic Society Bengal, vol. 2, pp. 59-63. 1 fig.

Apsters, C. Plankton in Nord-und Ostsce auf den deutschen Terminfahrten. 1 Teil. (Volumina 1903.) Wissenschaftliche meeresuntersuchungen, Kiel, new ser., vol. 8, Abt. Kiel, pp. 1-26 and LIX.

BAssler, R. S. The bryozoan fauna of the Rochester Shale. U. S. Geological Survey, Bulletin 292, 137 pp., 31 pls.

Bassetr, R. S. A study of the James types of Ordovician and Silurian Bryozoa (with bibliography'). Proceedings U. S. National Museum, vol. 30, pp. 1-66, pls. 1-7.

Bonnevie, Kristine. Physiologische Polyspermie. Archiv ilathematik oy Naturvidenskab, Kristiania, vol. 27 , no. 13,15 pp., 1 pl.

Boule, Marcellin, and Thévenin, Armand. Types du Prodome de paléontologie stratigraphique universelle de D'Orbigny. Annales Paleontologie, Paris, vol. 1, pp. 97-100, 165-72, 193-6.

Brydone, R. M. Further notes on the stratigraphy and fauna of the Trimmingham chalk. Geological Magazine, new scr., vol. 3, pp. 13-22, 72-78, 124-131, 289-300.

Bullen, R. A. II. Notes on some Microzoa and Mollusca from East Crete. Geological Magazine, dec. 5, vol. 3 , no. 8 , pp. 345-358, pls. $18,19$.

Calvet, Louis. Note préliminaire sur les Bryozoaires recueillis par les expeditions du Travailleur (1881-82) et du Talisman (1883). Bulletin Museum Histoire Naturelle Paris, pp. 154-166.

Calvet, L. Deuzieme note préliminaire sur les Bryozoaires récoltés par les expéditions du Travailleur (1881-82) et du Talisman (1883). Bulletin Museum Histoire naturelle, Paris, no. 12, p. 215-223.

Clarke, J. M. Percé, a brief sketch of its geology. Report New York State Museum, vol. 57, Bulletin S0, pp. 134-171.

Cossman, M. Rectifications de nomenclature (Bryocryptella n. nom for Cryptella Jullein). Rerue critique de paleozoologie, vol. 10, pp. 78-131.

('umings, E. R. The fauna of the Salem limestone of Indiana. 30th Annual Report Indiana Department of Geological and Natural Resources, pp. 1274-1296, pls. 27-40.

Darton, N. H. Geology of the Bighorn Mountains. U. S. Geological Survey, Professional Paper 51, pp. $1-129$.

Degrange-Touzin. Le Falun de Saint-Denis. Ile D'Oléron (Charente-Inferjeure), Actes Société Linneene de Bordeaux, 61, pp. 17-22.

Evans, David Cledlyn. The Ordovician rocks of Western Carmarthenshire. Quarterly Journal Geological Society, London, vol. 62, pp. 597-643.

Foerste, August F. Silurian, Devonian, and Irvine formations of East central Kentucky. Kentucky Geological Survey, Bulletin no. 7, 369 pp., 33 pl.

Gough, Lewis Henry. Plankton collected at Irish light stations in 1904. Fish. Ireland, Scientific Investigations, 1904 (1906), pp. 3-79.

Grabau, A. W. Guide to the geology and paleontology of the Schoharie Valley in eastern New York. New York State Museum, Bulletin No. 92.

Hennig, Anders. Gotlands Silur-Bryozoer 2. Arkiv. för Zoologic. K. Svenska Vetenskapsakademien, Stockholm, vol. 3, no. 10, pp. 1-62, 7 pls.

Jornsen, A. Bryozoen aus dem karnischen Fusulinenkalk. Neues Jahrbuch Min. Gcol. Pal., vol. 2, Heft 3, pp. 135-160, pls. 10, 11.

Kiduge, Hermana. Zoologische Ergebnissc einer Untersuchungsfahrt des deutschen SeefischereiVereins nach der Bäreninsel und Wcstspitzbergen ausgeführt im Sommer 1898 auf S. M. S. Olga. Bearbeitet nach Sammlungen von Dr. Hartlaub . . Wissenschaftliche Meeresuntersuchungen, new ser., vol. 8, Abt. Helgoland, p. 31-55, 10 figs.

Föhler, Walther. Süsswasser-bryozoen in geheizten Aquarien. Blätter Aquarienkunde, Magdeburg, vol. 17, p. 312 .

Kraepelin, K. Eine Süsswasserbryozoë (Plumatella) aus Java. Mittheilungen naturhistorischen Nuseum Hamberg, Jahrg. 23, p. 143-146, 3 figs.

Kupelwieser, H. Untersuchungen über den feineren Bau und die Metamorphose des Cyphonautes. Zoologie, vol. 19, Heft 47, 50 pp., 5 pls., \& figs. 
LANG, W. D. A key to the publislied figures of the Cretaceous forms of the Polyzoan genus Entalophora, Geological Magazinc, dcc. 5, vol. 3, no. 10, pp. 462-467.

Lang, W. D. The Reptant Eleid Polyzoa. Geological Magazine, dec. 5, vol. 3, no. 11, pp. 60-69, 12 tcxt figs.

LANG, W. D. Bryozon in Woods, Henry. The Cretaceous fauna of Pondoland, Cape Town. Annals South African Museum, vol. 4, pt. 7, pp. 232-286, pl. 33.

Lemorne, Paul. Études géologiques dans le nord de Madagascar. Annals Hébert, vol. 3.

Lissajous. Toarcien des environs de Macon. Macon (reprinted with corrections from Macon, Bulletin société science naturelle, vol. 2, 1902-6).

Loмicki, A. M. Mszywiol. Rozpiorka wieloksztaltna na raku stawowym. Kosmos Iwów Roczn, vol. 31, pp. 249-256, 4 figs. (Polish.)

Loppexs, K. Bryozoaires marins et fluviatiles de la Belgique. Annals Societé Zoologique malacologique Belgiquc. vol. 41, pp. 286-321, 50 figs.

Loppens, K. Bryozoaires nouveau pour la faune belgc. Bulletin Société Royale zoologique malacologique Belgique, vel. 40, p. 49.

Loppens, K. Contributions ál'étude des Bryozoaires de Belgique. Société zoologique malacologique Belgique, vol. 41, pp. 130-136.

Loprens, K. Plumatella repens L. vivant dans l'cau saumatrc. Bulletin Société Royale zoologique malacologique Belgique, vol. 40 , pp. 49,50 .

Loppens, K. Sur quelques variétés de Membranipora membranacea L. vivant dañs l'eau saumatre Annals Biol. lacustre, vol. 1, pp. 40-42, 4 figs.

Mercini, C. L' Infratius del M. Melbe presso Perugia. Pisa, Proc. verl). Soc. tosc. sc. nat., vol. 15, pp. 49,50 .

Marquand, E. D. The Zoophytes (Hydroida and Polyzoa) of Guernsey. (Including records by A. M. Norman.) Guernsey, Transactions Society Natural Science, pp. 164-176.

Mayer, Paul. Bryozoa und Brachiopoda (Bibliography for 1905). 2 vol. Jahresber., Berlin, pp. 1-3.

Neviani, A. Briozoi viventi e fossili illustrati da Ambrogio Soldani neli' opera Testaceographia ac zoophytographia parva et micoscopia (1789-1798). Bollitino Societiá Genlogica Italiana, vol. 25, pp. $765-785$.

Neviani, A. Briozoi ritenuti nova de Mitili. Bollettino Societí́ Zoologique Italiana, ser. 2, vol. 7 fasc. 4-6, pp. 184-190, 1 fig.

Nichols, A. A new Irish Polyzoon (Hypophorella expansa Ehlers). Irish Naturalist, vol. 15, p. 87.

NordgaArd, O. Bryozoa from the second Fram expedition 1898-1902. Report second Norwegian arctic expedition of the Fram, no. 8, pp. 1-44, pls. $1-4$.

Nordanard, O. Die Bryozoen des westlichen Norwegens. Bergen Museum Meeres-fauna von Bergen, pp. 73-112, 2 pls.

Norman, A. M. Grcenlandic Polyzoa. Annals Magazinc Natural History, ser. 7, vol. 17, p. 90-93.

OKa, Asajiro. Tansui-Kokemushi noirhi shin shu. (On a new species of fresh-water Polyzor.) Döbutsugaku Zasshi, Tokyo, vol. 6, 1908, pp. 307-310.

Retzius, Gustaf. Die spermien der Bryozoen. Biol. Untur., new ser., vol. 13, pp. 45-48, pl. 1, 1 fig.

PACE, R. II. On the carly stages in the devclopment of Flustrella hispida (Fabricius) and on the existence of a "yolk nucleus" in the egg of this form. Quarterly Journal Microscopical Science, vol. 50 , pp. $435-478,4$ pls.

Ridewood, W. G. A new species of Cephalodiscus, from the Cape Selas. Maritime Investigation South African Department of Agriculturc, vol. 4, pp. 173-192, 3 pls., 5 figs.

Rövier, OTto. Untersuchungen über dic Knospung. Degeneration und Rcgeneration von einigen marinen ectoprocten Bryozoen. Zeitschrift wissenschaftliche zoologie, vol. 84, pp. 446-478, 2 pls.

Sacco, Federico. Les étages et les faunas du bassin tértiaire du Piémont. Boll. geol. soc. France, vol. 5, pp. 893-916.

Sacco, Federico. La questionc eomioccnica dell'Appenino. Roma, Bollittino Sociétiá Géologica Italiana, vol. $25, \mathrm{pt} .1, \mathrm{pp} .65-127$.

Schepotiff, A. Die Pterobranchier, anatomische und histologische, untersuchunger übcr Rhabdopleura normanii Allmann und Cephalodiscus dodecalophus M. Int. 1 Teil . . . Zoologische Jahr. Abt. Anat., vol. 23, pp. $463-534,9$ pls. 
Seelifier, Oswald. Ueber die Larven und Terwandtschaftsbezichungen rlcr Bryozoen. Zeitsclirift wissenschaftliche Zoologie, vol. S4, pp. 1-7S, 4 pls., 4 figs.

Seely, H. M. Beekmantown and Chazy formations in the Champlain Vallcy. Report Geological Survey Vermont, vol. 5, pp. 174-187 with plates.

Siemiradzki, Jósef. Monografia warstw paleozoicznych Podola. Kraków. Bull. Intern. Acad., pp. 23-32.

Siemiradzki. Jóser. Die Paleozoischen Gebilde Podoliens. Ticn, Beitrg. Pal. Geol., Vest-Ung., vol. 19, pp. 173-286.

Silbermann, Sayuel. Untersuchungen über den feineren Bau von Alcyonidium mytili. Archives Naturges. Jahrg. 72, vol. 1, p. 265-310, 2 pls.

Thěvenin, A. Types du Prodome de Paleontologie stratigraphique univcrselle de D'Orbigny. Annales de paleontologie, vol. 1, pp. 1-7, pls. 8, (fig. 1) 9, (fig. 11), 12 (fig. 111).

Ulrich, E. O. Pleistocene Bryozoa. Maryland Geological Survey, Pliocene-Pleistocene, pp. 210-212, with $r$ gs.

Vadisz, M. Elemér. Über die obermediterrane Fauna von Budapest. Rákos, Földtani Közlöny Budapest, vol. 36 , pp. 256-283, 323-351, with plates.

Vaney, C., and Conte, A. Recherches sur le Rhabdopleura normanii Allman. Anatomie, bourgeonnement et affinities. Rcvuc suisse Zoologique, vol. 14 , pp. 143, 183, 4 pls.

Waters, A. IV. Bryozoa from Chatham Island and d'Urville Island, New Zcaland ... Annals Magazine Natural History, ser. 7 , vol. 17, pp. 12-23, pl. 1.

Weers, Fred Boughton. Bibliography and index of North American gcology, paleontology, petrology, and mineralogy for the years 1901-1905, inclusive. Bulletin U. S. Geological Survey, no. 301.

- Weltwer, W. Pectinatella magnifica (Leidy) bei Berlin. Archives Naturges, Jahrg. 72, vol. 1, pp. 259-264, 3 figs.

White, Harold J., Osborne and Treacher, Llewellys. The phosphatic chalk of Winterbourne and Boxford (Berkshire). Quarterly Journal Geological Society, London, vol. 62, pp. 499-522.

Whiteaves, J. F. 2. The fossils of the Silurian (Upper Silurian) rocks of Keewatin, Manitoba, the northeastern shore of Lake Winnipegosis, and the lowcr Saskatchewan River. Ottawa, Geological Survey Canada, Pal. Fossils, vol. 3, pp. 243-95.

WILcox, A. W. Locomotion in young colonies of Pectinatella magnifica. Biological Bulletin of the Marine Biological Laboratory; Woods Hole, Massachusetts, vol. 11, pp. 245-252, 2 pls.

Woons, Henry. The Cretaceous fauna of Pondoland (the Polyzoa by W. D. Lang). Cape Town, Annals South African Museum, vol. 4, pp. 275-350.

1907.

Annandale, N. The fauna of brackish ponds at Port Canning, Lower Bengal, pt. 6. Observations on the Polyzoa, with further notes on the ponds. Records of the Indian Mfuseum, vol. 1, pp. 197205,3 figs.

Axnandale, N. The fauna of brackish ponds at Port Canning, Lower Bengal, pt. 1. Introduction and preliminary account of the fauna. Record Indian Museum, Calcutta, vol. 1, pt. 1, pp. 3.5-43.

Anvandale, N. Further notes on a Polyzoon from the Himalayas. Records of the Indian Museun, vol. $1, \mathrm{pp}$. 145-14S, figs. 3 .

Annandale, N. Notes on the fresh-water fauna of India, no. 12. The Polyzoa occurring in Indian fresh and brackish pools. Journal and Proceedings Asiatic Society Bengal, vol. 3, pp. 83-93, 1 pl.

Annandale, N. Statoblasts from the surface of a Himalayan pond. Records of the Indian Museum, vol. 1, p. 177.

Arnold, RAtph. Geology and oil resources of the Summerland district, Santa Barbara County, California. (With notes and illustrations of Mollusca from the Eocene, Miocene, and Pliocene and Bryozoa from the Pliocene.) Bulletin U. S. Geological Survey, no. 321, pp. 1-93, pl.

Apstein, C. Das Plancton im Colombo-See auf Ceylon. Sammelausbeute von A. Borgert, 1904-1905 Zoologische Jahrb üch. Abtheilungen Systentatik, vol. 25, pp. 201-244.

Bather, F. A. Nathorst's use of collodion imprints in the study of fossil plants. Geological magazine, London, ser. 2 , dec. 5, vol. 4, pp. 437-440. 
Beauchasip, P. DE. Quelques observation sur les conditions d'existence des ëtres dans la Baie de Saint-Jean-de-Luz et sur la côte avoisinante. Archives zoologie expérimental et général, ser. 4, rol. 7, Notes No. I, pp. 4-16.

Bogolepow, M. Wachstum und Leben der Kolonien der Tendra zostericola au den Gläsern der Aquarien. Zoologischer Anzeiger, vol. 32, pp. 305-316, 7 figs.

Bonnevie, Kristine. Untersuchungen über Keimzellen, II. Physiologische Polyspermie bei Bryozoen. Jenaische Zeitschrift Naturwissenschaft, vol. 42, pp. 567-59s, 4 pls.

Boule, Marcelin, and Thévenin, Armand. Types du Prodome de Paléontologie Stratigraphique Universelle de d'Orbigny (Contd.). Annales Paléontologie Paris, vol.2, pt.4, pp. 161-172=25-36, pls. 23, 24, and 10.

Breni, V. Über das Vorkommen von Diaptomus tatricus Wierz. in den Ostalpen und über Diaptomus kupelwieseri nov. sp. Zugleich eine Mitteilung über die neue biologische Station in Lunz Zoologischer Anzeiger, vol. 31, pp. 319-328.

Canu, F. Les Bryozoaires fossiles des Terrains du Sud-Ouest dela France. I. Aquitanien. Bulletin Société Géologique France, ser. 4, vol. 6,pp. 510-518, pl.12, 13.

Calvet, Lours. Bryozoaires (of the Travailleur and Talisman expeditions). Expédition scientifique Travailleur et Talisman, 1906, pp. 355-495, pls. 26-30.

Chadwick, H. C. Report on the marine biological station at Port Erin. Liverpool Proceedings Transactions Biological Society, vol. 21, pp. 28-38.

Chmenkow, W. Zur Frage über den geologischen Bau der Umgebung von Chwalynsk und über die Kreide-Ablagerungen im Wolgagebiet des nördlichen Teils des Gouv. Saratow. Annuaire geologique et minèralogique de la Russie Novo Ale'rsandrija, vol. 9, pp. 115-130.

Clarke, Johñ M. Some new Devonic fossils. Bulletin New York State Museum, no. 107, pp. 153291 , with text figs.

Davies, A. Morley. Collodion as a preservative for fossils. Geological Magazine, London, ser. 2, dec. 5 , vol. 4 , pp. 524-525.

Dendy, Arthur. On the occurrence of Fredericella sultana in New Zealand. Transactions New Zealand Institute, vol. 39, pp. 221-222.

Destinez, P. Contribution a la faune du calcaire carbonifere. Liége, Annales Société gèologique Belgique, vol. 34 (1906-1907) (B 97-B 100).

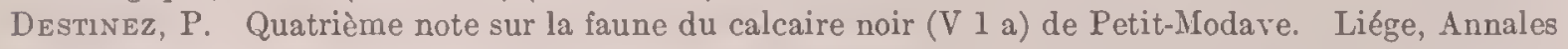
Société géologique Belgique, vol. 34 (B 62-B 64) (B 65-B 67).

Dolufus, Gustave F. Faune malacologique du miocene supériur de Beaulieu (Mayenne). (Étage redonien.) Paris, Comptes Rendus Association francaise advancement science, vol. 35 (Lyon, 1906), pt. 2, pp. 304-315.

Dublin, L. I. The history of the germ cells in Pedicellina americana. Annals New York Academy Science, vol. 17, p. 583.

FArquinar, H. Note on the bipolarity of littoral marine fauna. Wellington, Transactions New Zealand Institution, vol. 39, pp. 131-135.

Filliozat, M. Bryozoaires Crétacés de Vendome. Bulletin Société Géologique France, ser. 4, vol. 7, pp. 391-399, pl. 13, 14.

Fucrisi, A. Ancora sopra l'età del marmo giallo di Siena. Pisa, Atti societa toscana scienze naturali, vol. 23, pp. 3-7.

Girty, G. H. Descriptions of new species of Upper Paleozoic fossils from China. Proceedings U. S. National Museum, vol. 33, p. 37-48.

Gordow, C. H. Mississippian (Lower Carboniferous) formations in the Rio Grande Valley, New Mexico. American Journal Science, ser. 4, vol. 24, pp. 58-64.

Gregory, J. W. The rotiform Bryozoa of the Isle of Wight. Geological Magazine, dec. 5, vol. 4, no. 10, pp. $442-443$.

Grabau, A. W., and Smmer, H. W. North American index fossil. Bryozoa. School of Mines Quarterly, vol. 28 , no. 1, Bryozoa pp. 20-83, figs. 176-217.

Hayden, H. H. The stratigraphical position of the Gangamopteris beds of Kashmir. Record Geological Survey India, Calcutta, vol. $36, \mathrm{pp} .23-39$, pls. 4-9.

Hind, Wheelton. Life zones in British Carboniferous rocks. Part 2, The fossils of the Millstone grits and Pendleside series. Naturalist, London, pp. 17-23. 
Joly, Henry. Les fossiles du Jurassique de la Belgique avec description stratigraphique de chaque étage. Ménoires Museum Belgique, Bruxelles vol. 5, pp. 1-156, pls. 1-6.

JoNKER, H. G. Lijst van Geschriften welke handelen over of van belang zijn voor de Geologie van Nederland (1734-1906). Amsterdam, Verhandlungen Koninklijke akademie van wetenschappen, 2 d section, vol. 13, no. 2, pp. 7 and 154 .

Jukes-Browne, A. J., and Else, W. J. A list of the type fossils and figured specimens in the Museum of the Torquay Natural History Society, Plymouth. Report Devon. Association, ser. 2, vol. 9, p). 399-409.

Kammerer, Paul. Über Schlammkulturen. Archiv Hydrobiologie, Stuttgart, vol. 2, pp. 500-526.

Kammeler, PaUl. Wiedererweckung kleiner Tiere und Pflanzen aus getrocknetem Schlamm (reprint of preceding). Blätter Aquarienkunde, Magdeburg, 18, pt. 23, pp. 227-228; pt. 24, pp. 235-237; pt. 25, pp. 243-248, 3 figs.; pt. 26, pp. 25s-259.

Karakasch, N. S. Le crétacé inférieur de la Crimée et sa faune. (Russe) St. Petersbourg, Travaux Société naturelle Sect. géologique, vol. 32, 5, pp. 1-442, 454-482; Rés. franc., pp. 443-453, 28 pls.

Kellner, K. Bericht über die Embryologie von Oikopleura. Zoologischer Anzeiger, vol. 31, pp. $653-654$, 3 figs.

Kittr, Ernst. Die Triasfossilien vom Heureka Sund. Kristiania, Report of the Second Norwegian Arctic Expedition in the Fram, 1898-1902, no. 7, 11). 1-44, 3 pls.

KLuge, H. Beiträge zur Kenntnis der Bryozoen des Weissen Meeres. St. Petersburg, Bulletin Academie Science, ser. 6, vol. 1, pp. 658-659 (Russian).

KLuge, H. Zur Kenntnis der Bryozoen von West-Grönland. St. Petersburg, Bulletin Academie Science, ser. 6, vol. 1, p. 703 .

Kluge, Hermans. Kritische Erörterungen zu den bryozoologischen Arbeiten von $\mathbf{K}$. Chworostansky: Archives Naturgeschichk, Berlin, vol. 73, pt. 1, pp. 181-204.

Konler, W. Latentzustände als Trutzmittel gegan die Unbilden des Klimas (Contd). Blätter Aquarienkunde, Magdeburg, vol. 18, pt. 42, pp. 417-418.

LANG, W. D. The evolution of Stomatopora dichotomoides. Geological Magazine, dec. 5, vol. 4, no. 511, pp. 20-23, text figs. 6.

LANG, W. D. A tabular view of the Cretaceous Polyzoa of the family Idmoniidae. Geological Magazine, new ser., dec. 5, vol. 4, no. 513, pp. 122-132.

Lemoine, Paul. Les variations de facies dans les terrains sédinentaires de Madagascar. Paris, Bulletill Société géologique, ser. 4, vol. 8, pp. 30-41.

LE Roux, Marc. Recherches biologiques sur le lac d'Annecy. Annales Biol. lacustre, Bruxelles, vol. 2, pp. 220-387.

Levinsen, G. M. R. Sur la regeneration totale des Bryozoaires. Oversigtover del glgl. Darskl. videns'abernes selskavs fornandlinger, no, 4, pp. 151, 159, 1 pl.

Loppens, K. Sur les caracterès Distinctifs entre Alcyconidium gelatinosum et Alc. hirsutum. Aunals Société Zoologique malacologique Belgique, vol. 42, pp. 169-174.

LÜHE, M. Die Bryozoen Ostpreussens. Schriften. physikalisch-ökonomischen Gesellschaft Königsberg, Jahrg. 47, pp. 281-285.

LiNDiGER, L. Ein neuer Fundort von Cristatella mucedo Cuv. Abhandlungerndes naturhistorishen Gesellschaff zu Nurnberg, vol. 15, p. 84.

Matzdorff, Cart. (Jahresbericht über) Bryozoa für 1904. Archives Naturgeshichte, Berlin 67, vol.2, Heft 3, 1901 (1907), pp. 597-621.

Neltr, Brino. Il Miocene del Monte Titano nella Republica di S. Marino. Roma, Bollettino Sociétà Géologica Italiana, vol. 26 , pt. 2, pp. 239-322, pls. 8-10.

Neviani, Antonio. Di un libro poco noto sugli Zoofite a Litofiti del Mediterraneo dell' abate Francesco Maratti, Pt. I (Briozoi). Bollettino Societí Zoologique Italiana, ser. 2, vol. 8, pp. 102-118.

Nevian1, Antonio. I primo studi anatomici sui briozoi. Atti Congr. Natural. italiana, 1906, pp. 786788.

Nichols, A. R. Contributions to the natural history of Lambay. Polyzoa. Irish Naturalist, Dublin, vol. 16, Nos. 1-2, pp. \$2-83.

NordaAard, O. Bidrag til faunaeus histoire i Trondhjemsfjorden. Kgl. Norse Videnskabors Selskabs Skrifter, No. 7, 43 pp., figs. 
NordaAard, O. Bryozoen von dem norweigischen Fisehereidampfer "Miehael Sars" in den Jahren 1900-1904, gesammelt. Bergens Museum Aarbok, no, 2, 20 pp., 1 pl.

Norman, A. M. On some British Polyzoa. Annals Magazine Natural History, ser. 7, vol. 20, pp. 207212,1 pl., 1 fig.

OKa, Asajlro. Eine dritte art von Peetinatella. Zoologischer Anzeiger, vol. 31, pp. 716-718, 3 figs.

OKa, Asajiro. Zur Kenntnis der Süssirasser-Bryozoenfauna von Japan. Annotationes Zoologicae Japonenses, vol. 6, pp. 117-123, 3 figs.

PAeE, S. On an improved system of recording for use in Faunistie work. Zoologischer Anzeiger, Leipzig, vol. 32, pp. 355-391.

Poene, Franz, Einige Ergänzungen zu den Indiees neuer Gattungs und Untergattungsnamen des Zoological Record (für 1901-1905). Zoologiseher Anzeiger, Leipzig, vol, 31, pp. 705-707. vols. $37-42$.

REED, F. R. Cowper. Sedgwiek Museum notes. New fossils from Haverfordwest, 7. Geologieal Magazine, new ser. 5, vol. 4, p. 208-211, 1 pl.

Rrehard, J. Campagne scientifique de la Princesse-Aliee (1907). Liste des Stations. Monaeo, Bulletin Institut Oeean, no. 106 (1-11), map.

Richardson, Innosall. The Inferior Oolite and Contiguous Deposits of the Bath-Doulting District (with Appendiees (1) by S. S. Buekman, (2) by L. R. Richardson and J. L. Walker, (3) by L. Richardson). London, Quarterly Journal Geologieal Society, vol, 63, pt. 252, 1907, pp. 383-436, pls. $28-29,4$ pls.

Ridewood. W. G. Pterobranehia. Cephalodiseus. National Antaretie Expedition, vol. 2, no. 5, 67 pp., 7 pls., 17 figs.

Ridewood, W. G. On the development of the plumes in buds of Cephalodiseus. Quarterly Journal Mieroseopical Soeiety, vol. 51, pp. 221-252, 11 figs.

Rovle, Lıovrs. Considérations sur la faune marine du Port de Bonifaeio (Bryozoa determined by I. Calvet). Bulletin société zoologique, vol. 32 , pp. 40-45.

Rousselet, Charles. Zoologieal results of the third Tanyanika Expedition eonducted by Dr. W. A. Cunnington, 1904-5. Report on the Polyzoa. Proeeedings Zoologieal Society London, 1907, pp. $250-257,2$ pls.

Skorikov, A. Quelques faits eoneernant la biologie d'un étang situé dans le Jardin de la Tauride St. Pétersbourg. St. Petersbourg, Bulletin Acadamie Scienee, No. 10, ser. 6, 7, pp. 119-126 (Russian).

De Strfani, C. I terreni e le acque cloro-sodiehe della salute in Livorno. Pisa, Atti Socicta toscana seienze natural, vol. 23, pp. 88-124.

SteUer, Adolf. Neucre Arbeiten über Plankton mit besonderer Berücksichtigung des Zooplanktons. Wien, Verhandlungen Zoologische Botanisehen Gesellschaft, vol. 57, pp. 40, 62.

Stuekenberg, A. Die Fauna der obercarbonischen Suite des Wolgadurehbruches bei Samara. St. Petersbourg, Mémoires eomité géoloyique, ser. 2, vol. 23, 1905 (1907) (xix +144 pp.), 13 pls. (Russian with German summary, 111-14t pp.)

Thornely, Laura R. Report on the Marine Polyzoa in the eolleetion of the Indian Museum. Reeords Indian Museum; vol. 1, pp. 179-196, 8 figs.

Ulrieh and Bassler. See Welletr.

VADASz, M. Elemér. A ribieei felsómediterrán korszaki korallpad faunajaról. Uber die overmediterrane Korallenbank von Rivica. Földtani Közlöny, Geologisehe Mittheilungen, Budapest, vol. 37, pts. 9-11. (Hungarian, pp. 368-373; German, pp. 420-425.)

Verrill, Addison E. The Bermuda Islands. Pt.4, Geology and Paleontology, and pt: 5 , An account of the Coral Reefs. New Haven, Conneetieut, Transaetions Aeadeny Arts and Seience, vol. 12, pp. $45-348$, pls. $16-40$. .

VOGL, VIKToR. Adatok a fóti alsómediterran ismeretéhez. Beiträge zır Kenntnis des Untermediterrans von Fót. Földtani Közlony, Budapest, vol. 37, pt. 1-S (Hungarian, pp. 243-246; German, pp. 303-307.)

Walton, H. G. Notes on Hislopia laeustris Carter. Reeords Indian Museum, vol. 1, p. 177-178.

WAters, A. W. Tubueellaria, its species and ovieells. Journal Linnean Society London, vol, 30, pp. 126-133, 2 pls. 
Weller, Stuart. A report on the Cretaccous Paleontology of New Jersey (new species Bryozoa by Ulrich and Bassler). Geological Survey of New Jersey, Palcontology 4, text pp. 1-187, plates.

Wesenberg-Lund, C. On the occurrence of Fredericella sultana Blumenb. and Paludicella Ehrenbergii van Bened. in Greenland. Meldelelser om Grönland Köbcnhavn, vol. 34, pp. 63-75.

WIrÉN, A. Zoologicn i Uppsala 1882-1907. En aterblick Zool. Stud. tillägn. T. Tullberg (Naturvet. Students ällsk. Uppsala), pp. 1-41.

Ziegler, H. E., et alii. Zoologisches Wörterbuch. Erkklärung der zoologischen Fachausdrücke . . . pt. 1 (A. F.) xvi+20s pp.

Zimmerman, Hans. Tierwelt am Strande der blauen Adria. Eine Naturwisscnschaftliche Skizze aur Erlangung einer Ubersicht der Fauna von Rovigno (Istrien), sowie zur Einführung in die Sammeltechnik. Zs. Natw., Stuttgart, scr. 5, vol. 16, pp. 293-321.

Zsснокке, F. Ubersichtüber die Tiefenfauna des Vicrwaldstättersces. Archive Hydrobiologic Stuttgart, vol. 2 (1907), 1906, pp. 1-8.

1908.

Annandale, N. Corrections as to the identity of Indian Phylactolaemata. Records Indian Museum vol. 2, p. 110.

Annandale, N. The fauna of brackish ponds at Port Canning, Lower Bcngal. Pt 7. Further obscrvations on the Polyzoa, with the descriptions of a new genus of Entoprocta. Records of the Indian Museum, vol. 2, pp. 11-19, 7 figs.

Anvandale, N. Three Indian Phylactolaemata. Records of the Indian Museum, Calcutta, vol. 2, pt. 2, pp. 169-174.

BeUther, KarL. Beitrag zur Kenntniss der cyclostomen Bryozoen der alteren Tertiarschichten des südliclien Bayern. Paleontographica, vol. 54, Lief. 5, pp. 205-250, pls. 23, 24, and 7 text figs.

Braen, F. Die geschlechtliche Entwicklung von Fredericella sultana nebst Beobachtungen über die weitere Lebensgeschichte der Kolonien. Zoologica, Heft 52, pp. 1-37, 7 pl. 1 fig.

Braem, F. Die Spermatozoen von Paludicella und Triticella. Zoologischer Anzciger, vol 33, pp. 280-281,

Braem, F. Die Spermatozoen der Süssawasser-Bryozoen. Zoological Anzeiger, vol. 32, pp. 671-773, 2 figs.

BraEM, F. Ueber die Umwandlung plasmatischer Granula zu halbmondförmigen Körpern. Anatomische Anzeigcr, vol. 33, pp. 360-364, 1 fig.

Cavu, F. Iconographie des Bryozoaires fossiles de l'Argentine (Première partie). Anales del Museo Nacional de Buenos Aires, vol. 17 (ser. 3, vol. 10), pp. 245-34l, 13 pls.

Canu, F. Les Bryozoaires fossiles des terrains du Sud-Ouest de la France. II. Lutécien. Bulletin Société Géologique France, ser. 4, vol. 8, pp. 382, 390, pls. 6, 7 .

Chatwin, Charles P. and Withers, Thomas H. The zoncs of the chalk in the Thames Valley between Goring and Shiplake. With an appendix by George J. Hinde. London, Quartcrly Journal Geological Society, vol. 64, pp. 390-420.

Chirica, Const. Note asupra Bryozoairilor din Romania. Mem. Assoc. romana Inaintarea Rcspand St. 2 , pp. 468-474.

Clarke, John M. Early Devonic history of New York and eastern North America. New York State Museum, Mem. 9, no. 1, pp. 1-366, with plates.

Couffon, O. Le Miocène en Anjou (Supplément). Bulletin de la société études scientifiques d'Angers (Maine-et-Loire), vol. 37, pp. 49-58.

Comings, E. R. The stratigraphy and paleontology of the Ordovician rocks of Indiana. 32d Annual Report Department Geology Natural Resources Indiana, 1p. 605-1190.

Czwiklitzer, R. Dic Anatomie der Larve von Pedicellina echinata. Arbeiten zoologischen Instituten. Wien, vol. 17, pp. 157-186, pl., 2 figs.

Fillozat, Marius. Nouveaux Bryozaires cheilostomes de la Craie. Bulletin Société Géologique France, ser. 4, vol. 8, pp. 554-560, 1 pl.

Filliozat, Marius. Sur les Synchronismes Crétacés par les bryozoaires la Craie de Vendome. Bulletin Société Archéologiquc, Scientifique ct Litteraire des Vendomois, vol. 47, pp. 255-257.

Girty, G. H. The Guadalupian fauna. U. S. Geological Survey Professional Paper 58, pp. 1-649, with pls. 
Greig, M. J. Invertébrcs du fond. In Duc d'Orleans, Croisière Oceanographique dans la mer du Grönland. Bruxelles, pp. 503-567.

Hennia, Anders. Gotlands Silur-Bryozoer. 3. Arkiv. för Zoologie K. Svenska Vetcnskapsakademien Stockholm, vol. 41, no. 21, pp. 1-64, pls. 1-7.

Hopkinson, John. Dates of publication of the separate parts of Gmelin's edition (13th) of the "Srystema Naturae" of Linnacus. London, Procecdings Zoological Society, 1907, pp. 1035-1037.

Kuvge, II. Beiträge zur Kenntnis der Bryozoen des Weissen Meeres. Annals Museum Zoology, St. Petersbourg, vol. 12, pp. 215-540, 2 figs.

Kuvae, H. Zur Kenntnis der Bryozoen von West-Grönland. Annals Museum Zoology, St. Petersbourg, vol. 12, pp. 546-554.

LANG, W. D. Polyzoa and Anthozoa from the Üpper Cretaceous limestone of Needs Camp, Buffalo River. Annals South African Muscum, vol. 7, pp. 1-11, 1 pl.

Lee, G. W. Notes on fossils from Prince Charles Foreland. Proceedings Royal Physical Society Edinburgh, vol. 17, no. 4, pp. 149-166, pl. viii.

Levander, K. M. Zur Kenntniss der Verbreitung der Süsswasser Bryozoen in Finland. Meddel. Société Fauna and Flora fennica, Häft 34, pp. 97-106.

Loppens, K. Les Bryozoaires d'eau douce. Annales Biologic Lacustre, vol. 3, pp. 141-183, 31 pls.

Maplestone, C. M. Further descriptions of the Tertiary Polyzoa of Victoria, pt. 10. Proceedings Royal Society Victoria, vol. 21, new ser., pt. 1, pp. 233-239, pls. 7, 8 .

Masterman, A. S. On the Diplochorda. Pt. 5. Certain points in the structure of Tornaria. Quarterly Journal Microscopical Science, vol. 52, pp. 481-493, 1 pl.

Matzdorff, Carl. Bryozoa für 1905. (Jahresbericht) Archives Naturges schichte. Berlin, 69, vol. 2, Heft 3, 1906 (1908), XIII, pp. 1-8.

Montgomery, T. H. On the Morphology of excretory organs of Metazoa. Proceedings American Philosophical Society, vol. 47 (Polyzoa, pp. 553, 603, 604, 606).

Mourlon, Michel. Le Calcaire Carbonifère et les dépôts postprimaires qui le ecouverent dans la vallée de l'Escaut, entre Tournai et Antoine. Bruxelles, Bulletin Société géologique, vol. 22, Pr.-verb. pp. 89-105.

Nichols, A. R. Bryozoa (of Dublin district). Handbook British Association Advancement of Science, pp. 202-204.

OKa, Asajiro. Ueber eine neue Gattung von Süsswasserbryozoen (Stephanella). Annotationes Zoologicae Japonenses, vol. 6, pp. 277-285, 1 pl.

Reed, F. R. Cowper. The Devonian faunas of the northcrn Shan States. Paleontologia Indica. Memoirs Geological Survey India, Calcutta, vol. 2, no. 5, pp. 1-183, pls. 1-20.

REed, F. R., Cowper and Reynolds, H. S. Silurian fossils from certain localities in the Tortworth Inlier. Bristol, Report Naturalists Society, ser. 4, vol. 2, pp. 32-40.

Richardson, L. On the Phyllis collection of Inferior-Oolite fossils from Doulting. Gcological Magazine London, ser. 2 , dec. 5 , vol. 5, pp. 509-517.

Robertson, Alice. The incrusting Chilostomatous Bryozoa of the west const of North America. University of California Publications, Zoology, vol. 4, no. 5, pp. 253-314, pls. 14-24.

Rowe, Arthur W. The zones of the white chalk of the English coast. V. The Isle of Wight. The maps and descriptivc appendix by C. Davies Sherborn .... and a note on certain silicious nodules by G. T. Prior. London, Proceedings Geological Association, vol. 20, pp. 209-35, 2, pls. 8, 23, maps.

Sсникешітsсn, W. Die Methorisis als embryologiseher Prinzip. Zoologischer Anzeiger, vol. 33, pp. 585-598.

SMitr, Joseph. The Polyzoa-their place in naturc, with notes on some peculiarities in structure. Manchestcr, Report Microscopical Society, 1907 (1908), pp. 64-79, pls. 2-3.

Soldas, Igerna B. G. A new fresh-water Polyzoon from Soutl Africa. Annals Magazine Natural History, scr. 8, vol. 2, pp. 261-273, 8 figs.

Steinmann, Gustav, and Wilcrens, Otto. Kreide und Tertiar fossilien aus den Magellans ländern, gesammelt von der Schwedischen Expedition 1895-1897. Arkiv fur Zoologie, Stockholm, vol. 4, no. $6,118 \mathrm{pp}$.

Stiasny, G. Beobachtungen über die marine Fauna des Triester Golfes im Jahre 1907. Zoologischer Anzeiger, Leipzig, vol. 32, pp. 748-752. 
Taeger, Heinrich. Die gcologischen Tcrhältnisse des Vertesgebirges. Mit.t. Jahrb. Ungar. Geol. Ans., vol. 17, pp. 1-275, pls. 1-12.

ThÉEl, Hualarar. Om utvechlingen af Sveriges zoologiska hafsstation Kristineberg och om djurlifvet $i$ angränsandc haf och fjordar. Arkiv. Zoologie, Stockholm, vol. 4, no. 5, pp. 1-136. 5 pls., 3 inaps.

Thiébaud, Maurice. Contribution à la biologie du Lac de Saint-Blaise. Annales Biologie Lacustre, Bruxelles, vol. 3 , pp. 54-140, pls. 1-4.

Thompsox, J. Zoophytes in the Humber. Naturalist, London, p. 454.

Waters, A. M. A subfossil Polyzoon from Calcutta. Record.Indian Museum, vol. 2, p. 109-110.

Joung, George William. The chalk aren of western Surrey, London, Proceedings Geological Association, vol. 20 , pp. 422-45.5.

Zrkofr, W. Das Plancton des Flusses Irtisch und seiner Nebenflüsse Bukon u. Tabol, Zoologischer Anzeiger, Leipzig, vol. 33, pp. 103-112.

1909.

Axnandale, N. Materials for a revision of the Phylactolaematous Polyzon of India. Records of the Indian Museum, vol. 5, pp. 37-57.

Aivandale, N. A new species of Fredericella from Indian Lakes. Records of the Indian Museum, vol. 3, pp. 373-374

Axinandat, N. Preliminary note on a new genus of Phylactolaematous Polyzoa. Records of the Indiau Museum, vol. 3, pp. 279-2s0, 1 fig.

BAssLer, R. S. The Nettelroth collection of Invertebrate fossils. Miscellaneous Collections, Smitlisonian Institution, vol. 52, pp. 121-152.

Bedot,. Ir. Sur la faune de l'Archipel Malais (Résumé). Revuc Suisse Zoologique, vol. 17 pp. 143-169.

Biluard, Arsaxd. Révision des espèces types d'hydroïdes de la collection Lamouroux. Annales des Sciences naturelles, ser. 9, vol. 9, pp. 307-334.

Bloomfield, E. N. Annual notes on the local fauna, flora, etc., Hastings and E. Sussex. Nat., vol. 1, pp. 186-191.

Brydone, R. M. Notes on new or imperfectly known chalk Bryozoa (Polyzoa). Gcological Mragazine, dec. 5 , vol. 6 , pp. $337-339,398-400,3$ pls., 1 fig.

Calvet, Louts. Bryozoaires. Expédition Antarctique Francaise (1903-1905) commandée par Dr. Jean Charcot. Sciences Naturelles: documents Scientifiques, Paris, pp. 1-49, pls. 1-111.

Calvet, Louis. Voyage de MiM. M. Bedot et C. Pictet dans l'A rchipelmalais. Bryozoaires d'Amboine. Note sur Bugula dentata (Lamouroux) et Retepora denticulata Busk. Revue Suisse Zoologie Genève, vol. 14, pp. 617-621, 1 pl.

Caxv, F. Étude sur la répartition géologique des Bryozoaires. Comptes Rendus Acadenie Science, Paris, vol. 148, pp. 532-534.

Canv, F. Bryozonires fossiles des Terrains du Sud-Ouest de la France. III, Burdigalien; IV, Helvetien. Bullctin Société Géologiquc de France, ser. 4, vol. 9, pp. 442-458, pl. 15-18.

CANu, F. Les Bryozonircs fossiles du Miocène moyen de Marse-Matrouh eu Marmarique. Comptes Rendus Acadcmie Scicnce, Paris, vol. 148, pp. 959-960.

Clarke, John M. Early Devonic history of New York and eastern North America. Memoirs New York State Museum, no. 9, pt. 2 (=Report 62, 4), pp. 1-250, pls. 1-34.

Conbes, Paul. La faune halolimnique Africaine. Cosmos, Paris, vol. 61, pp. 705-707.

Davidson, W. C. The fresh-water Polyzoan Cristella mucedo from Kilmacolm. Glasgow Naturalist, vol. 2 , pp. 15,16 .

Goddard, E. J. Australian fresh-water Polyzon, pt. 1. Proceedings Linnean Society New South Wales, vol. 34, pp. $487-496,1$ pl.

Gregory, J. W. Catalogue fossil Bryozon in Department Geology British MIuseum. Cretaceous, vol. 2 , pp. 346,9 pls.

Gregory, J. W. New species of Cretaceous Bryozon. Geological Magazinc, new ser., dec. 5, vol. 6, p. 61-66.

HARMER, S. F. (Avicularia and vibracula.) Rept. 78th Meeting British Association Advancement of Science, 1908, pp. 715-731. (Presidential address.) 
Hartmeyer, Robert. Bryozoen, Moostierchen. In: Die Süsswasser fauna Deutschlands, hrsg. v. Brauer, Heft. 19, Jena, pp. 49-58.

Heath, Alice. Notes on Marine Polyzoa collected during the year June, 1908, to May, 1909. Jougual Torquay Natural History Society, vol. 1, pp. 15-16.

Hennegur, F. Sur un épithélium à fibres muscularies striées. Comptes Rendus Academie Science Paris, vol. 148, pp. 134-138, 3 figs. Un épithélium à fibres musculaires striées.' Comptes Rendus Ass. Anat. Reun., vol. 11, pp. 301-302.

Hinde, George J., and Gossling, Frank. Fossils from the chalk, exposed in a road-trench, near Croham Hurst, South Croydon. Croydon Proceedings Microscopical Natural History Cl. 1907-8 (1909), pp. 183-184.

KNıpowtsch, N. M. Rapport sur les collections zoologiques faites pour le Musée Zoologique de l'Académie Imp. des Sciences par N. M. Knipowitsch et S. A. Pavlovič dans la mer Baltique durant l'été 1908. Ann. mus. zool., vol. 14, pp. 0131-0245 avec 1 carte.

LeE, G. W. A Carboniferous fauna from Nowaja Semlja, collected by Dr. W. S. Bruce. Edinburgh Transactions Royal Society, vol. 47, pp. 143-186, pls. 1 and 11.

Leightox, Douglas, (in) Morey'o guide to the natural history of the Isle of Wight. London, William Wesley, pp. 235-239.

Levinsen, G. M. A. Morphological and systematic studies on the Cheilostomatous Bryozoa, pp. 1vii, 1-431, 27 lithographic pls., 6 text figs.

Maplestone, C. M. Polyzoa from the Gilbert Islands. Proceedings Royal Society Victoria, n. s., vol. 21 , pp. $410-419,3$ pls.

Maplestone, C. M. The results of deep sea investigations in the Tasman sea. The exposition of H. M. C. S. Miner. Polyzoa. Records of the Australian Museum, vol. 7, no. 4, pp. 267-273, pls. 7-78.

Matzdorff, Carl. Bryozoa fur 1906. (Jahresbericht) Archives Naturges., vol. 73, p. 2, Heft 3, 1907 (1909), XIII (1-15).

Moberg, JoH. Chr., and Grönwall, K. A. Om Fyledalens gotlandium. (On the gotlandium of Fyledalen, Skane.) Lund Univ. Ärsskr., new ser., 5 Afd., vol. 2, no. 1 (=Fysiogr. Sällsk. Handl., new ser., vol. 20 , no. 1, pp. i-x, 1-86, 1 map, 6 pls.

NiLus, G. Notiz über Loxosoma murmanica und Loxosoma brumpti n. sp. St. Petersburg Travaux Sociêté nat. Comptes Rendus seances, vol. 40, livr. 1, pp. 157-166; deutsch résumé, pp. 167-169.

Norman, A. M. The Polyzoa of Madeira and neighboring islands. Journal Linnean Society Zoology, London, vol. 30, pp. 275-314, pls. 33-42.

Norman, A. M. The Celtic Province: Its extent and its marine fauna. Transactions Hertford Natural History Society, vol. 14, pp. 19-32.

Parona, C. F.; Cremia C.; and Prever, P. L. La fauna coralligena del Cretaceo dei Monti d'Ocre nell' Abruzzo Aquilano. Roma, Mem. serv. descr. Carta Geol. d'It. R. Com. Geol. Regno, vol. 5, pt. 1, pp. 1-242, pls. 1-27.

Przibran, Hans. Experimental Zoologie. 2. Regeneration. Leipzig and Wien, Franz Deuticke, pp. 1-338, pls. 1-16.

Rajond, G.; Conbes, Paul; and Morin, Maurice. Études géologiques dans Paris et sabanlieue. Note sur le gite fossilifère du Guespel. Paris Comptes rendus association francaise avanc. sci., vol. 37 (1908), pp. 476-493.

Retzius, Gustaf. Weiteres zur Kenntnis der Spermien der Bryozoen. Biol. Untersuch., vol. 14, p. $75-76,1 \mathrm{pl}$.

Roaf, Herbert E. Digestive enzymes of invertebrates. London, Report British Association Advance. ment Science, 1908 (1909), pp. 746-747.

Sheppard, T. Catalogue of specimens in the "Lether" collection and of the Cornbrasl fossils in the Hull Museum. Hull Transactions Science Natural Cl. 4, pp. 71-80.

Siemiradzi, Josef. Z biory L. Zejsznera. z kieleckiego dewonu. Kraków Spraw. Komk. fizyogr. vol. 43, pp. 62-94, 2 pls. (see also Kraków Bul. Int. Acad. pp. 765-770.)

Sommer, KarL. Die fauna des Culms von Königsberg bie Giessen. Neues Jahrbucher Mineralogie, Stuttgart, vol. 28, pp. 611-660, pls. 27-30.

Sütolv, K. Sarajärven Eläimisto. Helsingfors Acta Société Fauna et Flora Fennica, vol. 29.

Walton, H. J. Large colonies of Hislopia lacustris. Records Indian Museum, vol. 3, pp. 295-296. 12184-23-Bull. 125-16 
Waters, A. W. Reports on the Marinc Biology of the Sudancse Red Sea, XII. The Bryozoa. Cheilostomata. Journal Linnean Socicty London, vol. 31, pp. 123-181, 9 pls. (See Cyclostomata in 1910.)

Weller, Stuntr. Kinderhook faunal studies 5. The fauna of the Fern Glen formation. Bulletin Gcological Society of America, vol. 20, pp. 265-332, pl. 10-15.

Zschinesche, AlFred. Untersuchungen uber dic Metamorphose von Alcyonidium mytili. Zoologische Jahrbücher, Jena, Abth. fur Anatomic, vol. 28, pp. 1-72, 5 pls.

1910.

Annandale, N. Contributions to the fauna of Yunnan based on collections made by G. Coggin Brown . B. Sc., 1909-1910. Pt. 1. Sponges and Polyzoa. Record of the Indian Museum, vol. 5, pp, 197-199.

Annandale, N. Note on a fresliwater sponge and Polyzoon from Ceylon. Spolia Zeylanica Colombo, vol. 7, pp. 63-64, 1 pl.

Banfield, Arthur. Premature hatching of Cristella mucedo. Knowledge, new ser., vol. 7, p. 487, 1 fig.

Bower, C. R., and FARMERY, G. R. The zones of the lower chalk of Lincolnshire. With a list of new records from the red clialk of the county. London, Proccedings Gcological Association, vol. 21, pp. 333-359, pl. 27.

Brydone, R. M. Notes on new or imperfectly known chalk Polyzoa. Gcological Magazine, dec. 5, vol. 7, pp. 4-6, pl. 3, pp. 76-78, pl. 8, pp. 145-147, pl. 14, pp. 258-260, pl. 21, pp. 390-392, pl. 30, pp. 481-483, pl. 36 .

BUDDENBRock, WolfGANG V. Bciträge zur Entwicklung der Statoblasten der Bryozoen. Zeitschrift wissenschaftliche Zoologie, vol. 96, pp. 477-524, 3 pls. 8 figs. Zoological Anzciger, vol. 35, pp. 534-538.

Canu, F. Bryozoaires des Terrains du Sud-Ouest de la France. 5, Lutetien; 6, Bartonien. Bulletin Société Géologique de France, ser. 4, vol. 10, pp. 840-855, pls. 16-19.

Canu, F. Bryozoaires des terrains tertiaires des environs de Paris. Annales de Paleontologie, vol. 2 (1907), pp. 57-89, 137-160, 8 pls., 8 figs.; vol. 3 (1908), pp. 61-104, 2 pls.; vol. 4 (1909), pp. 101140,4 pls; vol. 5 (1910), pp. 89-112, 4 pls.

Canu, F. Liste des Bryozoaires de la craie de Royan. Bulletin Société Géologique France, vol. 10, pp. $62-65$.

Clovgr, C. T., LeE, G. W. (and others). The geology of East Lothian, including parts of the counties of Edinburgh and Berwick. Mremoir Geological Survey Scotland, pp. 1-226; pal. app., pp. 206-217.

Drake, Henry C., and Sheprard, Thomas. Classified list of organic remains from the rocks of the East Riding of Yorkshire. Proceedings Yorkshire Geological Society, vol. 17 pp. 4-71.

FraAs, E. Der Petrefactensammler. Ein Leitfaden zum Sammeln und Bestimmen der Versteinerungen Deutschlands. Stuttgart, pp. 1-276, pls. 1-82.

Girty, G. H. New genera and spccies of Carboniferous fossils from the Fayetteville shale of Arkansas. Transactions New York Academy Science, vol. 20, pp. 189-238.

Hentschel, ERnst. Bryozoa für 1907. (Jahresbericht) Archives Naturges, Berlin, vol. 74, pt. 2, Heft 3, 1908 (1910), XIII, pp. 1-14.

Hentschel, Ernst. Bryozoa für 1908. (Jahresbericht) Archives Naturges Berlin. vol. 75, pt. 2. Heft 3, 1910, XIVa, pp. 1-9, Ber. Natg. nied. Tiere Berlin, new ser., vol. 25, 1910, pp. 1-10.

Harmer, S. F. Polyzoa. Encyclopaedia Brittanica. Ed. 11, vol. 22, pp. 42-45.

Janisevskiv, M. E. Die Fauna des Unteren Kohlenkalkes von Chabarny, Bezirk Orsk, Gouv. Orenburg. Tomsk. Izv. technol. Inst., vol. 17, no. 1, pp. 1-305, 21 pls.

Korschelt, E., und Heider, K. Lehrbuch der vergleichenden Entwicklungs-geschichte der wirbellosen Thiere. Vierter Abschnitt. Ungeschlechtliche Fortpflanzung und Regeneration. IX, Ungeschlechtliche Fortpflanzung, Jena, pp. 632-694.

Loppens, K. Catalogue des bryozoaires d'eau douce avec une note sur Victorella pavida. Annales Société malacologique Belgique, vol. 44, pp. 97-110.

Loppens, K. Fauna aquatica Europcae. Les Bryozoaires d'eau douce d'Europe. Annals Biologie lacustre, vol. 4, pp. 139-161, 16 figs. 
Maplestone, C. M. On the growth and habits of Biporae. Proceedings Royal Society Victoria, new ser., vol. 23, pp. 1-7, 1 pl.

Maplestone, C. M. On a new species of Cellepora from the south Australian coast. Proceedings Royal Society Victoria, new ser., vol. 23, pt. 1, pp. 39-41, 3 pls.

Maplestone, C. M. Observations on Parmularia obliqua and a fossil species. Proceedings Royal Society Victoria, new ser., vol. $23, \mathrm{pp} .42-43,1$ pl.

Martynow, A. Rapport préliminaire sur un voyage à station biologique de Roscoff. Prot. sèances Soc. Nat. Univ. Varsovie. Annals, vol. 22, p. 34-89.

Norman, A. M. Museum Normanianum, or a oatalogue of the invertebrata of Europe and the Arctic and North Atlantic Oceans, which are contained in the collection of the Rev. Canon A. M. Norman. XIII, Polyzoa. Durham, T. Caldcleugh \& Son.

PAcE, S., and PAcE, R. M. A bibliography and review of recent publications relating to the biology of the British and neighboring marine areas (i. e., of the North Atlantic and Arctic Oceans, Mediterranean Sea, etc.). London Bureau of British Marine Biology, ser. 2, nos. 1 and 2 (not paged titles 1-174).

Peach, B. N., Lee, G. W., and others. The geology of the neighborhood of Edinburgh. Memoirs Geological Survey Scotland, pp. 1-445; paleont. app., pp.369-412.

Reed, F. R. Cowper. Sedgwick Museum notes. New fossils from the Dufton shales. London Geological Magazine, dec. 5, vol. 7, pp. 211-220, 294-299, pls. 16, 17, 23, 24.

Richardson, L. On a fuller's earth section at Combe Hay, near Bath. London, Proceedings Geological Association, vol. 21, pp. 425-428.

Robertson, Alice. The Cyclostomatous Bryozoa of the west coast of North America. University of California Publications, vol. 6, no. 12, pp. 225-284, 8 pls.

Roenrich, O. Description d'un alcyonidium nouveau. Archives de Zoologie experimentale et generale, ser. 5, vol. 5 (notes et rev., pp. 161-167, 3 figs.

Schröder, Ouaw. Buddenbrockia plumatellae, eine neue Mesozoenart aus Plumatella repens L. und Pl. fungosa Pall. Zeitschrift Wissenschaftliche Zoologie, Leipzig, vol 96, pp. 525-537, 2 pls.

SchröDER, O. Eine neue Mesozoenart (Buddenbrockia plumatellae n. s. n sp.) und Plumatella repens L. und Pl. fungosa Pall. Sitzungberichte Heidelberger Akademie der Wissenschaften, Kl. Abh. 6, pp. 1-8.

Skorıкоv, A. S. Zoologische Un tersuchung des Wassers des Ladoga-Sees als Trinkwasser. St. Petersberg, pp. 1-123, 1 map and 1 plate.

Vinassa de Regny, Paolo. Fossili ordoviciani del nucleo centrale Carnico. Catania Mem. Accademia Gioenia scienze natural., ser. 5, mem. 12, pp. 1-48, 3 pls.

Walther, Johannes. Die Sedimente der Taubenbank im Golfe von Neapel. Abhandlungen der Kgl. Akademie der Wissenschaften zu Berlin, Abth. 3, pp. 1-49.

Waters, A. W. Reports on the Marine Biology of the Sudanese Red Sea, ... XV. The Bryozoa. (Pt. I Cyclostomata, Ctenostomata and Endoprocta). Journal Linnean Society London Zool., vol. 31 , pp. 231-256, 2 pls.

Woods, REv. F. H. Marine biology at Redcar. Naturalist, London, pp. 646, 408-410.

Willem, Vıctor. Les "Néphridies"' des Bry"ozoaires Phylactolémides. Comptes Rendus Association francaise Advancement Science, vol. 38, pp. 709-711.

Zsснокке, F. Die Tiefenfauna hochalpiner Wasserbecken. Basel, Verhandlungen der naturforschenden Gesellschaft, vol. 21, pp. 145-152.

1911.

Annandale, N. Fresh-water sponges, Hydroids and Polyzoa. Fauna of British India. Bryozoa pp. 161-251, pls. 3-5.

Annandale, N. Systematic notes on the Ctenostomatous Polyzoa of fresh water. Records of the Indian Museum, Calcutta, vol. 6, pt. 4, pp. 193-201, pl. 13.

Bassler, R. S. The early Paleozoic Bryozoa of the Baltic Provinces. Bulletin 77, United States National Museum, 382 pages, 13 pls., text figs.

BAsSLER, R. S. Corynotrypa, a new genus of tubuliporoid Bryozoa. Proceedings U. S. National Museum, vol. 39, pp. 497-527, 27 figs. 
Bassler, R. S. Bryozoa of the Middle Devonic of Wisconsin. Geological and Natural History Survey Wisconsin, Bulletin no. 21, pp. 49-67, pls. 5-11.

Braem, F. Die Variation bei den Statoblasten von Pectinatella magnifica. Archiv Entricklungs mechanik Organismcu, Leipzig, vol. 32, pp. 314-348.

Brakm, F. Beiträge zur Kcnntniss der Fauna Turkestans auf Grund des Von Pedaschcnko gesammelten Materials. VII Bryozoa und deren Parasiten. Travaux Société Nat. St. Petcrsbourg, Scct. zool., vol. 42, fasc. 2, pt. 1, Zool. et Physiol. (Victorella continentalis, n. sp.)

Braem, F. Pterobranchier und Bryozoen. Zoologischer Anzeiger, vol. 38, pp. 546-551, 2 figs.

Brydone, R. M. Notes on New or impcrfectly known chalk Polyzoa. Geological Magazine, dec. 5, vol. 8 , no. 4, pp. 153-156, pls. 9, 10.

Calvet, Louis. Diagnoses de quelques espàces nouvellesde Bryozoaires Cyclostomes. Bulletin de l'Institute oceanographique, no. 215, pp. 1-9, 6 text figs.

Calvet, Lours. Sur deux espàces nouvelles de Bryozoaires de la Méditerranéc. Archives Zoologie experimentale et generale, ser. 5 , vol. 8 , no. 3 , p. lvii-lxi, 2 figs.

Cand, F. Les Bryozoaires fossiles des Terrains du Sud-Ouest de la France. VI Bartonien (suite). Bulletin Géologiqué Société France, ser. 4, vol. 11, pp. 444-445, pls. 7, 8.

CanU, F. Inconographie des Bryozoaires fossiles de l'Argentinc, pt. 2, Anales del Museo Nacional de Buenos Aires, vol. 21 (ser. 3, f. XIV), pp. 215-292, pls. 1-12.

Fabiani, Ramiro. Palcontologia dei colli Berici. Roma, Mem. Soc., vol. 40, no. 3, 15, pp. 45-250, pls. $1-6$.

Fric, Anton. Studien im Gebiete der Böhmischen Kreideformation. Ergänzung zu Band $1 . \quad$ Illustriertes Verzeichniss der Petrefacten der cenomanen Korycaner Schichten. Archive der Naturwissenschaftlichen Landesdurchforschung von Bohmen. Prag. Vol. 15, no. 1, pp. 1-101.

Gortanı, M. Contribuzioni allo studio del Paleozoico carnico, IV. La fauna mesodevonica di Monumenz. Pl. Italiana, Pisa, vol. 17, pp. 141-228, pls. 16-20.

Guerin-Ganivet, Madame G. Contributions à l'étude des Bryozoaires des côtes armoricaines. I. Bryozoaircs provenant du Haut Fond de la Chapclle et recueilles en 1900 par l'expédition de la Vienne. Travaux scientifiques du Laboratoire de Zoologie de Concarneau, vol. 3, fasc. 2, pp. 1-12, 2 pls.

Guerin-Ganivet, Madame G. Contributions à l'étudc des Bryozoaires des côtes armoricanies. II. Bryozoaires provenant de la rade de Brest et recueillis par les freres Crouan. Travaux Scientifiqucs du Laboratoire de Zoologie de Concarneau, vol. 3, fasc. 5, pp. 1-7.

Guerin-Ganivet, Madame G. Étude préliminaire des Bryozoaires rapportés des côtes scptentrionalcs de l'Europe par l'expedition du Jacques-Cartier en 1908. Bulletin Institut oceanographique Monaco, no. 207, 27 pp.

Grrty, Georae H. The fauna of the Moorefield shale of Arkansas. Bulletin 439, U. S. Geological Survey, pp. 1-148, pls. 1-15.

Harmer, S. F. The terms Polyzoa and Bryozoa. Proccedings Linnean Society London, pp. $70-71$.

Herdman, W. A. Note on J. V. Thompson's use of the term "Polyzoa." Proceedings Linnean Society London, pp. 62, 63.

Hennig, Anders. Lc Conglomérat pleistocène à Pecten de l'ilc Cockburn. Wissenschaft. Ergebnisse der Schwed Südpolar-Expedition 1901-1903, Stockholm, 3 Lief, pp. 1-72, pls. 5.

Hurrell, H. E. Distribution of the Polyzoa in Norfolk waters. Transactions Norfolk and Norwich Naturalists Society, vol. 9, pp. 197-205.

Köhler, W. Pectinatella magnifica Leidy im Tcgeler See. Internationale Revue Hyrobilogie, - Leipzig, vol. 4, biol. Suppl. no. 5, pp. 6-7, 1 pl.

Kranz, W. Das Tertiar zwischen Castelgomberto, Montecchio. Maggiore, Creazzo und Monteviale im Vicentin. Stuttgart, Neues Jahrbuch Mineralogie, vol. 32, pp. 701-729.

Lohmann, H. Die Cyphonautes der nordischen Meere. Nordisches Plankton, Lief. 13, no. 9, pp. $31-40,8$ figs.

Lucas, Roвert. Bryozoa für 1909. (Jahresbericht) Archiv Naturgcschichte, Berlin, 76, 1910, vol. 6, Heft 1 (1911), pp. 117-143.

Maplestone, C. M. Further descriptions of the Tertiary Polyzoa of Victoria, pt. 11. Proceedings Royal Society Victoria, vol. 23, new ser., pt. 2, pp. 266-284 + 37-47. 
Maplestone, C. M. The results of deep sea investigations in the Tasman Sea. 1. The expedition of H. M. C. S. Miner. No. 5. Polyzoa, supplement. Records of the Australian Museum, vol. 8, pp. 118, 119, pls. 34, 35 .

Montensen, Tr. A new species of Entoprocta, Loxosomella antedonis, from northeast Greenland. Københaven Danmark-Ekspeditionen til Grønlands Nordøstkyst, 1906-1908, vol. 5 Nr. 8. Reprint of Meddelelser Gronland, vol. 45, pp. 399-406, pl.

Nicногs, A. R. Polyzoa from the coasts of Ireland, Fisheries, Ireland Scientific Investigations, 1910, no. 1, $37 \mathrm{pp} ., 1 \mathrm{pl}$.

Palk, Mary. On an enigmatic body in certain Bryozoa. Zoologischer Anzeiger, vol. 38, pp. 209-212, 2 figs.

PAPP, KARL. Trias-Korallen aus dem Bakony. In Resultate der wissenschaftlichen Untersuchungen des Balaton (Plattensee). Anlang, 1 volume for 1911, pp. 1-23, 1 pl., Wien.

Ritcrie, J. On an Entoproctan Polyzoon (Barentsia benedeni) new to the British fauna, with remarks on related species. Transactions Royal Society Edinburg, vol. 47, pp. 835-848, 1 pl.

Stebing, T. R. R. The terms Polyzoa and Bryozoa. Proceedings Linnean Society London, 123d session, pp. 61-62. Note on Thompson's use of the "Polyzoa" by Herdman, pp. 52-53. On Johnvaughan Thompson and his Polyzoa and on Vaunthompsonia, a genus of Sympoda, by Stebbing, p. 64-70. Note by Harmer, p. 70-71; by Waters, pp. 71-72.

Teller, Edgar F. A synopsis of the type specimens of fossils from the Paleozoic formations of Wiscon. sin. Milwaukee, Bulletin Wisconsin Natural History Society, vol. 9, pp. 170-271.

Vinassa de Regny, P. Trias-Tabulaten Bryozoen und Hydrozoon aus den Bakony. In Resultate der wissenschaftliche des Balaton (Plattensee) anhang I, volume for 1911, pp. 1-22, 2 pls.

Waters, A. W. (The terms Polyzoa and Bryozoa.) London Proceedings Linnean Society, pp. 71-72.

1912.

Agatz, Josepr. Knospung und Regeneration bei den Bryozoen. Diss. Strassburg. Bamberg (Druck v. w. Gärtner), pp. 1-30, 4 pls.

Andrussov, N. Die fossilen Bryozoenriffe der Halbinseln Kertsch und Taman. Kiev, Lief. 1,909 (pp. 1, 48 and 6 pls.); Lief, 2, 1911 (pp. 48-88 and 5 pls.); Lief. 3, 1912 (pp. 89-144 and 3 pls.).

AnNandale, N. The occurrence of Entoprocta in Indian waters. Records of the Indian Museum Calcutta, vol. 7, pt. 2, p. 205.

Annandale, N. Fauna Symbiotica Indica. No. 1, Polyzoa attached to Indo-Pacific Stomatopods. Records of the Indian Museum Calcutta, vol. 7, pp. 123-126.

Annandale, N. Fauna Symbiotica Indica. No. 3. Polyzoa associated with certain Gangetic tortoises. Records of the Indian Museum Calcutta, vol. 7, pp. 147-150.

Annandale, N., and Kemp, Sranley. Observations on the invertebrate fauna of the Kumáon Lakes, with special reference to the sponges and Polyzoa. Records of the Indian Museum Calcutta, vol. 7, pp. 129-145.

Barroso, Manuel G. Briozoos de la Estacion de Biologia Maritima de Santander. Trabajos del Museo de Ciencias naturalés, no. 5, Madrid, pp. 1-63.

BrA EM, F. Nachträgliches über die Variation der Statoblasten von Statoblasten von Pectinatella. Arch. Intro. Mech. Leipzig, vol. 35, pp. 46-55.

Brydone, R. M. Notes on new or imperfectly known chalk Polyzoa. Geological Magazine, dec. 5, vol. 9 , no. 1 , pp. $7-8$, pl. 1 ; no. 4, pp. 145-147, pl. 7; no. 7, pp. 294-296, pls. 14,15 ; no. 10, pp. $433-435, \mathrm{pl} .22$.

Calvet, Louis. Sur un Bryozoaire cténostome (Watersia paessleri n. g. n. sp.) parasitant le cormus d'une Synascidie. Comptes Rendus Academy Science, Paris, vol. 154, pp. 243-245. Apropos de Watersia paessleri, Bryozoaire parasite, p. 395.

Canu, F. Les Bryozoaires fossiles des Terrains du Sud-Ouest de la France. VI. Barton ein-Auversien. Bulletin Société Géologique France, ser. 4, vol. 12, pp. 623-630, pls. 20, 21.

Canu, F. Étude comparée des Bryozoaires Helvétiens de l'Egypte avec les Bryozoaires vivants de la Mediterranée et de la mer Rouge. Memoires de l'Institut Egyptien, vol. 6, fasc. 3, pp. 185-236, pls. 10-12.

Chapman, Frederick. Note on a collection of Tertiary limestones and their fossil contents, from King Island, Melbourne. Memorial National Museum, vol. 4, pp. 39-51, pls. 6, 7. 
Crawshay, L. R. On the fauna of the outer western area of the English Channel. Plymouth Journal Marine Biological Association, new Eer., vol. 9, pp. 292-393.

Cumings, Edgar R. Development and systematic position of the Monticuliporoids. Bulletin Geological Society America, vol. 23, pp. 357-370, pls. 19-22.

Cumings, Edgar R., and Galloway, J. J. A note on the Batostomas of the Richmond series. Proceedings Academy Science Indiana, 1911, pp. 147-167, 7 pls.

Gravier, C. Sur une éspece nouvelle de Cephalodiscus provenant de la seconde Expédition antartique française. Bulletin Histoire naturelle Paris, pp. 146-150, 1 fig.

Gravier, C. Sur la repartition geographique des especes actuellement connues du genere Cephalodiscus MacIntosh. Bulletin Museum Histoire naturelle Paris, pp. 151-153.

Gravier, C. Sur les Ptérobranches rapportés par la seconde Expédition antarctique française et sur un Crustacé parasite de l'un d'eux. Comptes Rendus Academy Science Paris, vol. 154, pp. 1458-1440

Guerin-Ganivet, G. Contributions a l'étude des Bryozoaires des côtes Armoricaines, III. Bryozoaires de la region de Concarneau et de l'Archipel de Glenan. Travaux scientifique du Laboratoire de Zoologie de Concarneau, vol. 4, pp. 1-28.

HASPER, M. On a method of rearing larvae of Polyzoa. Journal Marine Biology Association Plymouth, new ser., vol. 9 , pp. 435-436.

Holtedahl, Olaf. On some Ordovician fossils from Bootlia Felix and King William land collected during the Norwegian expedition of the Gjoa, Captain Amundsen, through the North West Passage. Kristiania Skr. Vid. selsk, vol. 9, pp. 1-11, pls. 1-4.

Lecointre, Georges. Sur quelques Bryozoaires nouveaux ou peu connus du Cénomanien du Mans. Bulletin Société Géologique, ser. 4, vol. 12, pp. 349-355, figs.

Lee, G. W. The British Carboniferous Trepostomata. Memoirs Geological Survey of Great Britains Paleontolngy, vol. 1, pt. 3, pp. 135-195, pls. 14-16.

Levinsen, G. M. R. Studies on the Cyclostomata operculata. Mémoires Academie Royale Science, et Lettres de Danemark, ser. 7, vol. 10, pp. 1-52, 7 pls., and 2 text figs. (Vid. Selsk. Skr.)

Lucas, Roвert. Bryozoa für 1910. Archiv für Naturgeschichte, Berlin, vol. 77 (1911), pt. 6, Heft 1 (1912), pp. 99-116.

Molcanov, L. A. Zur Fauna der Wirbellosen der Seliger-Sees. St. Petersburg, Der Süsswasser Naturf. Gessellschaft, vol. 3, pp. 146-153.

Nichols, A. R. Clare Island Survey, pt. 53, Polyzoa. Proceedings Royal Irish Academy, vol. 31, no. $53,14 \mathrm{pp}$.

NordgaARD, O. Revision av universitetsmuseets samling av norske Bryozoer. Kgl. norske Videnskabers Selskabs Skriften, 1911, no. 3, pp. 1-28.

Nordgar Rd, O. Bryozoaires de la Campagne arctique de 1907, de Duc d'Orleans. Bruxelles, vol 8, 42 pp., 1 map.

Osburn, RAymond C. Bryozoa from Labrador, Newfoundland, and Nova Scotia. Proceedings U. S. National Siseum, vol. 43, pp. 275-289, pl. 34, no. 1933.

Osburn, Raymond C. Bryozoa of the Woods Hole Region. Bulletin Bureau of Fisheries, vol. 30 (1910), pp. 205-266, pls. 18-31.

Ruedemann, Rudolf. The Lower Siluric shales of the Mohawk Valley. New York State Museum, Bulletin 162, pp. ]-151, pls. ]-10.

Thornely, LAura R. Marine Polyzoa of the Indian Ocean. Transactions Linnean Society London, Zoology, vol. 15, pp. 137-157, pl. 8.

Ulmer, Georg. Süsswasser-Bryozoen von Äquatorial-Afrika. (In: Wiss. Ergebnisse d. D. ZentralAfrika Expedition 1907-8, vol. 4, Lfg. 10.) Leipzig (Klinkhardt und Biermann), pp. 285-290.

Waters, A. W. A structure in Adeonella (Laminopora) contorta Michelin, with remarks on the Adeonidae. Annals Magazine Natural History, ser. 8, vol. 9, pp. 489, 500, pls. $10,11$.

1913.

Annandale, N. The Polyzoa of the Lake of Tiberias. Calcutta, Journal Asiatic Society, Bengal, vol. 9 , pp. $223-228$, pl. 7 .

Bassler. R. S. Bryozoa in Zittel's Textbook Paleontology (English edition), edited by Charles R. Eastman. Ed. 2, pp. 314-355. 
Braem, F. Die Keimung der Statoblasten von Pectinatella und Cristatella (1. Morpholog. Vorgänge). Zoologica, Stuttgart, vol. 67 (=Band 26), pp. 35-64, 5 pls.

Brydone, R. M. Notes on new or imperfectly known chalk Polyzoa. Geological Magazine, dec. 5 , vol.10, no.3, pp. 97-99; no. 5, pp.196-199, pl. 7; no. 6, pp. 248-250, pl. 8; no. 10, pp. 436-438, pl. 14.

Canu, F. Bryozoaires fossiles des terrains éocéniques du Plà de la Gargara près Aiguafrede (Lutécien). Bulletin de l'Institut Catalona d'Histoire naturelle, no. 7, pp. 1-4, pl. $2 a$.

Cand, F. Études morphologiques sur trois nouvelles familles de Bryozoaires. Bulletin Société Géologique de France, ser. 4, vol. 13, pp. 132-147, text figs.

Canu, F. Les Bryozoaires fossiles des Terrains du Sud-Ouest de la France, VII, Lutécien. Bulletin Société Géologique France, ser. 4, vol. 13, pp. 29s-303, pls. 4, 5.

CAnU, F. Contributions à l'étude des Bryozoaires fossiles. IV-XII. Pliocène d'Alger, etc. Bulletin Société Géologique France, ser. 4, vol, 13, pp. 124-131.

Cand, F. Contributions à l'étude des Bryozoaires fossiles. XIII. Bryozoaires jurassiques. Bulletin Société Géologique France, ser. 4, vol. 13, pp. 267-276, pls. 2, 3.

Cumings, E. R., and Galloway, J. J. The stratigraphy and paleontology of the Tanner's Creek section of the Cincinnati series of Indiana. Department Geology and Natural Resources Indiana, 37th Annual Report, pp. 353-478, 20 pls.

Filliozat, Marius. Sur legenre "Ceriopora" Goldfusa, 1827. Comptes rendus du Congrès des Société Savantes, pp. 154-157.

GerwerzhageN, Adolf. Beiträge zur Kenntnis der Bryozoen. 1. Das Nervensystem von Cristatella mucedo Cuv. Zeitschrift wissenschaftliche Zoologie, Leipzig, vol. 107, pp. 309-345, 3 pls.

Gerwerzhagen, Adolf. Untersuchungen an Bryozoen. (Vorl. Mitt.) Sitzungsberichte der Heidelberger Akademie der Wissenschaften, Abt. B, Abh. 9, pp. 1-16.

Girty, George H. A report on Upper Paleozoic fossils collected in China in 1903-4. Washington, D. C., Carnegie Institute Publications, no. 54 (Research in China, 3), pp. 295-334, pls. 27-29.

Guḱrin-Ganivet, G. Bryozoaires de la Mission arctique commandée par Ch. Bénard. Société d'océanographie du Golfe de Gascogne, fasc. 7, 46 pp.

HARMER, SIDNEY F. The Polyzoa of waterworks. Proceedings Zoological Society, London, pp. 426-457, pls. 62,63 .

Herwia, Ernst. Beiträge zur Kenntnis der Knospung bei den Bryozoen. Diss. Marburg (Druck v. R. Friedrich), 36 pp., 2 pls.

KetTNER, K. Ueber das neue Vorkommen der untersilurischen Bryozoen und anderen Fossilien in den Ziegelei Pernikarka bei Kossire. Bulletin Int. Acad. St. Bohème, 22 pp., 2 pls., 9 figs.

Lave, W. D. Report of a visit to the exhibits of Polyzoa and Corals in the Geological Department of the British Mruseum of Natural History. Proceedings Geologists' Association, vol. 24, pt. 3, pp. 168-173.

LARGER, Dr. RENÉ. La contre évolution ou dégénérescence par l'hérédité pathologique; cause naturelle de l'extinction des groupes animaux. Essai de paléopathologie genéralé comparée. Bulletin et Mémoires de la Société d'Anthropologie de Paris.

Maplestone, C. M. Further descriptions of the Tertiary Polyzoa of Victoria, pt. 12. Proceedings Royal Society Victoria, new ser., vol. 24, pp. 355, 356, pl. 27.

Maplestone, C. M. New or little known Polyzoa. Proceedings Royal Society Victoria, vol. 25, new ser., pp. 357-362, pl. 28.

Munroe, MAdeline. Description of some new forms of Trepostomatous Bryozoa from the Lower Carboniferous rocks of the North Western Province (of England). London, Quarterly Journal Geological Society, vol. 68, pp. 574-579.

Schröder, Olaw. Ueber einen einzelligen Parasiten des Darmepithels von Plumatella fungosa Pallas. Zoologisher Anzeiger, Leipzig, vol. 43, pp. 220-223.

Sumner, Francis B.; Osburs, Raymond C.; and Cole, Leon J. A biological survey of the waters of Woods Hole and vicinity. Section 3. A catalogue of the marine fauna of Woods Hole and vicinity. Washington, D. C., Bulletin Bureau Fisheries, vol. 31 (1911), pp. 549-794.

Ulrich, E. O., and BASsLer, R. S. Bryozoa of the middle and Lower Devonic deposits of Maryland. Maryland Geological Survey, Lower Devonic, pp. 259-290, pls. 46-51; Middle and Upper Devonian, pp. 123-124, pl. 7, figs. 7-12.

WACKERHEIM, M. Moostierchen im Aquarium (Fredericella). Blätter Aquarienkunde, Stuttgart, vol. 24, pp. 298-299. 
Waters, A. W. Marine Fauna of British East Africa and Zanzibar. Bryozoa-Cheilostomata. Proceedings Zoological Society London, 1913, pp. 458-537, pls. 64-73. (See Cyclostomata, 1914.)

WeBER, R. Plumatella repens... (Mikrophotogr. Bilder). Mikrokosmos, Stuttgart, vol. 7, pp. 105-107.

Wolfer, Otтo. Die Bryozoen des schwäbischen Jura. Paleontographica, vol. $60, \mathrm{pp} .115-173,5$ pls.

1914.

Brydone, R. M. Notes on new or imperfectly known chalk Polyzoa. Geological magazine, dec. 6, vol. 1 , no. 3 , pp. $97-99$, pl. 4 ; no. 8 , pp. $345-347$, pl. 26 ; no. 11 , pp. $480-483$, pl. 35 .

CANu, F. Bryozoaires des Terrains du Sud-Ouest de la France. VIII. Rupelien de Gaas. Bulletin Société Géologique de France, ser. 4, vol. 14, pp. 465-474, pls. 14, 15.

CANU, F. Contributions à l'etude des Bryozoaires fossiles. XIV. Bryozoaires du Stampien. Bulletin Société Géologique France, ser. 4, vol. 14, pp. 147-152, pl. 4.

Faura y Sans M. Sobre la presencia de un briozoa vivente, la "Cupularia canariensi" Busk descubierto en los terrenos miocenices de Catalana. Boletín de la Real Sociedad española de Historia natural, pp. 397, 398 .

LANG, W. D. Some new genera and species of Cretaceous Cheilostome polyzoa. Geological Magazine, dec. 6 , vol. 1, pp. 436-444, pl. 34 .

LaNG, W. D. On Herpetopora a new genus containing three new species of Cretaceous Cheilostome Polyzoa. Geological Magazine, dec. 6, vol. 1 , no. 595, pp. 5-8, pl. 2.

Osburn, Raymond C. The Bryozoa of the Tortugas Islands, Florida. Publication Carnegie Institution of Washington, no. 182, pp. 181-222, 23 text figs.

Waters, A. W. The Marine Fauna of British East Africa and Zanzibar. Cyclostomata, Ctenostomata, and Endoprocta. Proceedings Zoological Society London, 1914, pp. 831-858, pl. 1-4, text fig.

1915.

Barroso, Manuel Gerónmo. Contribución al conocimiento de los Briozoos marinos de España. Boletín de la Real Sociedad española de Historia natural, pp. 413-420.

Cumings, E. R., and Galloway, J. J. Studies of the morphology and histology of the Trepostomata or Monticuliporoids. Bulletin Geological Society America, vol. 26, pp. 349-374, pls. 10-15. (Review by Canu in Cossman's Revue Critique de Paléozoologie 1916, no. 1, p. 22.)

Girty, George H. Faunas of the Boone limestone at St. Joe, Arkansas. U. S. Geological Survey, Bulletin 598, Bryozoa, pp. 8-11.

Girty, George H. Fauna of the Batesville sandstone of northern Arkansas. U. S. Geological Survey, Bulletin 593, Bryozon, pp. 28-38.

Girty, George H. Fauna of the Wewoka formation of Oklahoma. U. S. Geological Survey, Bulletin 544, Bryozoa, pp. 44-48.

Harmer, S. F. The Polyzoa of the Siboga Expedition. Pt. I. Entoprocta, Ctenostomata, and Cyclostomata. Mono. XXVIII, Results Explorations Siboga, 180 pp., 12 pls. (Reviewed by Canu in Cossman's Revue Critique de Paléozoologie, 1916, no. 1, p. 24.)

Lang, W. D. New uniserial Cretaceous Cheilostome Bryozoa. Geological Magazine, dec. 6, vol. 2, no. 11, pp. 496-504, pl. 17.

1916.

Brydone, R. M. Notes on new or imperfectly known chalk Polyzoa. Geological Magazine, Dec. 6, vol. 3 , no. 3 , pp. $97-100$, pl. 6; no. 6 , pp. 241-243, pl. 10; no. 8, pp. 337-339, pl. 14; no. 10, pp. $433-435, \mathrm{pl} .18$.

Bassler, R. S. Bryozoa of the Upper Cretaceous deposits of Maryland. Maryland Geological Survey, Upper Cretaceous, pp. 736-745, pl. 46.

Canu F. Bryozoaires (reviews) in Cossman's Revue Critique de Paléozoologie. Vingtième année, no. 1, pp. 22-27.

Cand, F. Les Bryozoaires fossiles des Terrains du Sud-Ouest de la France. IX. Aquitanien. Bulletin Société Géologique France, ser. 4, vol. 15, pp. 320-334, pls. 3, 4.

CANU, F. Bibliographie primitive relative aux Bryozoaires. Bulletin de la Société Géologique de France, ser. 4, vol. 14, pp. 287-292. 
CAnU, F. Bibliographie paléontologique relative anx Bryozoaires du Bassin de Paris. Bulleti de la Société Géologique de France, ser. 4, vol. 14, pp. 293-305, 381-410.

(iREgory, J. II. Ige of the Norseman limestone, Western Australia. Geolngical Magazine, rer. 6, vol. 3, no. 7, pp. 320, 321, text figs.

LANG, IV. D. Revision of the "Cribrimorph" Cretaceous Polyzoa. Annals and Ilagazine Natural History, ser. 8, vol. 18, pp. 81-112.

LANe, IV. D. ('alcium earbonate and evolution in Polyzoa. (irologieal Magazine, dec, f, vol 3, no. $620, \mathrm{pl} .73-77$

Levinsen, (․ M. R. Danmark-Ekspeditionen til Grönlands Nordöstkyst, !906-1909. 1ol. 3, no. 16 ; Bryozoa, pp. 435-472, pls. 19-24.

Raymond, Pency E. Experlition to the Baltic Provinces of Russia and Scandinaria. Bulletin Museum ('omparative Zoology, Harvarl Collegre, vol. 56, no. 3, pp. 179-286, 8 pls.

Twenhofel, W. H. Expedition to the Baltic Provinces of Russia and Scandinaria, 1914. Bulletin IIuseum Comparative Zoology, Harvard University, vol. 56, no. 4, pp. 2\$9-354, 5 pls,

Waters, A. W. Some species of Crisia. Annals and Magazine of Natural History, ser. 8, vol. 18, pl. $469-477$, pl. 16

1917.

Barroso, Manufi Geronimo. Notes sobre Briozoos. Boletín de la Real Sociedarl Espanola de Historia Natural, vol. 17, pp. 494499.

Brydone, R. M. Notes on new or imperfectly known chalk Polyzoa. Geological Magazine, der. 6, vol. 4, no. 2, pp. 49-53, pl. 3; no. 4, pp. 145-148, pl. 9; nо. 11, pp. 492-496, pl. 32.

('ANu, F., and Bassler, R. S. A Synopsis of American Early Tertiary Cheilostome Bryozoa. United States National Mfuseum, Bulletin 96, pp. 1-S7, pls. 1-6.

Cave, F. Les Iryozoaires fossiles des Terrains du Sud-Ouest de la France. X. Burdigalien. Bulletin Société Géologique de France, ser. 4, vol. 16, pp. 127-152, pls. 2, 3, text figs.

Faura, Sans II., and Canu, F. Sur les Bryozoaires des terrains tertiaires de la Catalognc. Treballs de l'Institucio Catalana d'Historia Natural, vol., 1916, pl. 1-137, 9 pls.

Faura, Saxs II. Caracterización de la fauna briozoaria del lidestrichiense en el monte Perdidn (Pirineos ('entrales del alto Iragón). Boletín de la Real sociedad de Historia natural, vol. I7, pp. 191-194.

lave, W. W. The grenotypes of certain Polyzoan genera. Geological magazine, dee. 6, vol. 4, no. 4, P). 169174.

laxs, W. O). On some new ('enomanian and Turonian Polyzoa. Geological Magazine, dec. 6, rol, 1, no. 6, 197. 250 259, pl. 17

Mather, K. F. The Tertiary fauma of Wolf Island, Ontario. Ottawa Naluralist, vol. 31, pp. 33-4n, pl. 1 .

1) KADA, Falchiro. A report on the Cyclostomatous Bryozoa of Japall. Reprint from the Annotationes Zoologirae Japonenses, vol. 9, pt. 3, pp. 355-360.

1918

Barroso, Manued Gerónimo. Notas sobre Briozoos. Boletín de la Real Sociedad Espanola de Historia Natural, vol 18, pp. 206-216, 30i-309, 40i-409.

Brymone, R. M. Notes on new or imperfectly known Cretareous Polyzor. (icological Magazines dec. 6, vol. 5, no. 1, pp. 1-4, pl. 1 .

(iAvo, F. Hippaliosina, un nouveau genre de Bryozonires. Compte Rend. Sommaire des Séances la Soriété Géologique de France, no. 3, p. 40.

Canu, F. Hippaliosina. Un noureau genre de Bryozoaires. Bulletin de la Société Géologique de France, ser. 4, vol. 18, pp. 88-94.

CANU, F. Les Ovicelles des bryozoaires cyclostomes, Etudes, surquelques familles nouvelles et anciennes. Bulletin Société Gréologique de France, ser. 4, vol. 16, pp. 324-335, pl. 9.

KiNDLE, E. M., and Whitraker, E.J. Bathymetric check list of the marine invertebrates of eastern Canada. Department of the Naval Service, 8 George $Y$, sessional papers, no. 38a, pp. 229-294.

NordgaARd, O. Bryozoa from the Arctic regions. Tromso .Museums Aarshefter, vol. 40 (1917), nr. 1, pp. $1-99$

$121 S 4-23-$ Bull. $125-17$ 
NordgaArd, O. Bryozoa in the papers and collection of Dr. J. E. Gunnerus. Det Kgl. Norske Videnskabers Selskabs Skrifter, 1917, no. 5, pp. 1-5.

Waters, Arthur War. Some collections of the Littoral Marine Fauna of the Cape Verde Islands, Bryozoa. Journal Linnean Society Zoology, vol. 34, pp. 1-45, 4 pls.

Waters, Arthur Wm. Some Mediterranean Bryozoa. Annals and Magazine of Natural History, ser. 9 , vol. 2, pp. 96-102, pl. 12.

Yanagi, Naokatso, and Orada, Yarchrro. On a collection of Japanese Cheilostomatous Bryozoa, I. Annotationes Zoologicae Japanenses, vol. 9, pt. 2, pp. 407-429, pl. 6.

1919.

Barroso, Manuel Geronimo. Notas sobre Briozoos Españoles. Boletin de la Real Sociedad Espanola de Historia natural., vol. 19, pp. 200-201, 340-347.

CANU F., and Bassler, R. S. Bryozon of the Canal Zone and related areas. Bulletin U. S. National Museum, no. 103, pp. 117-122, pl. 53.

Cand, F. Etudes sur les Ovicelles de la famille du Corymboporidae Smitt, 1866 (3d contribution). Bulletin de la Société géologique de France, ser. 4, vol. 17 (1917), pp. 348, 349, pl.

Canu, F. Les Bryozoaires fossiles des terrains du Sud-Ouest de la France. XL Rupelien (=Stampien). Bulletin de la Société Géologique de France, ser. 4, vol. 17 (1917), pp. 350-361, 2 pls.

CANU, F., and Bassler, R. S. Fossil Bryozoa from the West Indies. Pub. 291, Carnegie Institution of Washington, pp. 73-102, 7 pls.

('ANU, F. Etudes sur les Ovicelles des Bryozoaires cyclostomes (2d contribution). Bulletin de la Société géologique de France, ser. 4, vol. 17 (1917), pp. 345-347, pl.

LANG, W. D. Old age and extinction in fossils. Proceedings Geologists' Association, vol. 30, pl. 102-113.

LANG, W. D. The Kelestominae; a subfamily of Cretaceous Cribrimorph Polyzoa. Quarterly Journal Geological Society, vol. 74, pp. 204-220.

LANG, W. D. The Pelmatoporinae; an essay on a group of Cretaceous Polyzoa. Philosophical Transactions of the Royal Society of London, Series B, vol. 209, pp. 191-228.

Marcus, Ernst. Notizen über einiges Material mariner Bryozoen des Berliner Zoologisclien Museums. Sitzungsherichte der Gesellschaft Naturforschender Freunde, Berlin, no. 7, pp. 255-2\$4.

Osburn, Raymond C. Bryozon of the Crocker Land Expedition. Bulletin American Museum of Natural History, vol. 40, pp. 603-624.

linassa de Regny, Paola. Fossili ordoviciani del Capolago (Seekopf) presso il Passo di Volaia (Alpi Carniche). Paleontographica Italica, vol. 21 (1915), pp. 97-116 (1-20), pl. 12, 13.

Waters, Arthur Wr. Batopora (Bryozoa) and its allies. Annals and Magazine Natural History, ser. 9 , vol. 3, pp. $79-94$, pl.

1920.

('ANU, F. Les Bryozoaires fossiles de la region des Corbiéres. Bulletin Société Geologique de France, ser. 4, 18, pp. 294-314, 6 pls.

Barroso, Manuel Geronimo. Notes sobre Briozoos Españoles, Vili. Boletin de la Real Sociedad Española de Historia Natural, vol. 20, pp. 353-362.

Canu, F., and Bassler, R. S. North American Early Tertiary Bryozon. Bulletin 106, U. S. National Museum, 2 vols., 879 pp., 162 pls.

Cand, F. Bryozoaircs Crétacés des Pyrénées. Bulletin Société Geologique de France, ser. 4, vol. 19, pp. 186-211, 2 pls.

Crrolla, F. Nota preventiva sui Bryozoi fossili di Alta villa (Palerme). Bolletino della Societa di Scienze Naturali ed Economiche, pp. 1-12.

Marcus, Ernst. Mittelmeer-Bryozoen des Berliner Zoologischen Museums, Sitzungsberichte der Gesellschaft Naturforschender Freunde, Berlin no. 2, pp. 65-108.

Okado, YaIchoro. Notes on some species of Retepora and Adeonella occurring in Japan, with descrip. tions of one new variety and five new species. Annotationes Zoologicae Japonenses, vol. 9, p. 5 . pp. 613-634, 1 pl.

Vinassa de Regny, Paola. Sulla classificazione dei Treptostomidi. Atti della Societa Italiana di Science Naturali, vol. 59, pp. 212-231. 
1921.

Barrosa Manuel Geronimo. Notas Sobre algunas especiés de Briozoos de España (Especiés del Golfo de Valencia). Real Sociedad Española de Historia Natural, vol. del 50 Ann., pp. 1-11.

BFKKER, HENDRICK. The Kuckers stage of the Ordovician rocks of N. E. Estonia. Acta et Commentationes Universitatis Dorpatensis, A. II, 1, pp. 1-92, 12 pls.

Bretnall, Rex W. Studies on Bryozoa. Records of Australian Museum, Sydney, vol. 13, no. 4, pp. $157-162$.

Cipolla, Francesco. I Briozoi Pliocenici di Altavilla presso Palermo. Giornale della Societa di Scienze Natural ed Economiche di Palermo, vol. 32, pp. 185, pls. 8.

Coryell, Horace N. Bryozoan faunas of the Stones River group of central Tennessee. Proceedings Indiana Academy of Science for 1919, pp. 261-340, 14 pls.

Duvergier, J. Note sur les Bryozoaires du Néogène de l'Aquitaine. Actes de la Société Linnéenne de Bordeaux, ser. 72 , pp. 1-41, 4 pls.

Marcus, Ernst. Bryozoen von den Juan-Fernandez Inseln in Skollsberg. C. The Natural History of Juan Fernandez and Easter Isles, vol. 3, pp. 93-124.

Marcus, ErNst. Indo-Pacifische Bryozoen aus dem Riksmuseum in Stockholm. Arkiv für Zoologi K. Svenska Vetenskapsakademien, vol. 14, no. 7, pp. 1-23, pls. 2.

Marcus, Ernst. Papers from Dr. Th. Mortensens Pacific Expedition, 1914-16. VI. Bryozoen von den Auckland-und Campbell Inseln, Saertryk af Vidensk. Medd. fra Dansk Naturh. Foren., vol. 73, pp. 85-121, 1 pl.

Marcus, Ernst. Einiges über Bau und Entwicklung der Meeresbryozoen. Schriften der zoologischen Station Büsum für Meereskunde, pp. 22-27.

Marcus, Ernst. Bryozoen. In results of Dr. E. Mjobergs Swedish Scientific Expeditions to Australia 1910-13. Köngl. Svenska Vetenskaps akademiens Handlingar, vol. 61, No. 5, pp. 1-34, 2 pls.

Marcus, ERnst. Über die Verbreitung der Meeresbryozoen. Zoologischer Anzeiger, vol. 53, pp. 205-221.

Orado, Yaichoro. Notes of some Japanese Chilostomatous Bryozoa. Annotations Zoologicae Japon enses, vol. 10, pt. 3, pp. 19-32.

Robertson, Altce. Report on a collection of Bryozoa from the Bay of Bengal and other eastern seas Records of the Indian Museum, vol. 22, pl. 1, no. 8, pp. 33-65, 11 figs.

Waters, Arthur WM. Observations upon the relationships of the (Bryozoan) Selenariadae, Conescherellinidae, etc., Fossil and Recent. Journal Linnean Society, Zoology, vol. 34, pp. 399-427, 2 plates.

1922.

Barroso, Manuel Geronimo. Notas Sobre briozoos marinos espagnoles No. X (Especies de Mahon, Baleares). Boletin de la Real Sociedad espanola de Historia Natural, vol. 22, pp. 88-101, 8 figs.

Canu, F., and Bassler, R. S. Studies on the Cyclostomatous Bryozoa. Proc. U. S. National Museum, vol. 61, pp. 1-160, 28 pls.

Cand, F. Bryozoa in Fossiles Crétacés de la cote orientale, Paleontologie de Madagascar. Annalea de Paléontologie, vol. 11, pp. 16-30, 2 pls.

Marcus, Ernst. Südafrikanische Bryozoen aus der Sammlung des Gothenburger Museum. Föteborgs Kungl. Vetenskaps och Vitterhets Samhalles Handlingar, vol 25, pp. 1-45.

Marcus, Ernst. Bryozoen von den Aru-Inseln. Abhandl. d. Senckenb. Naturf. Fesellsch., vol. 35, pp. 421-446, 2 pls.

WAters, A. W. On Mediterranean Tervia and Idmonea (Bryozoa). Annals and Magazine Natural History, ser. 9, vol. 10, pp. 1-16, 2 pls.

1923.

Borg, Folke. On the structure of Cyclostomatous Bryozoa, Arkiv för Zoologi. K. Svenska Vetenskaps-Akademien, vol. 15, no. 11, pp. 1-17.

Marcus, Ernst. Referat über die historische und moderne Auffassung des Baues und der systematischen Stellung der Bryozoengattung Adeona. Verhandlungen der zoolog.-botan. Gesellschaft in Wien, vol. 72, pp. 42-61. 


\section{APPENDIX.}

TRFMOGASTERINA TRUNCATOROSTRIS, new species.

Plate 47, Fig. 6.

Mescription.-The \%onium is bilamellar. The zooccia are distinet, separated by a furrow, clongated, elliptical; the frontal is perforated by a trifoliate orifice resulting from the coalescenee of three large pores arranged in a triangle; a large salient rounded mucro is present and is prolonged somewhat above the aperture. The aperture is large, semicircular. On each sicle there are two large, straight avicularia, with pirot, the beak of which is truncated and forms a transverse straight line. The ovicell is large salient globular, finely granular.

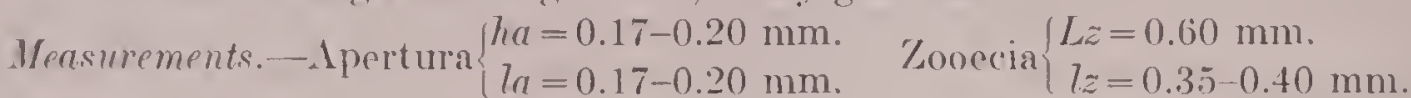

Affinities.-This new species cliffers from Tremogasterina horrida, new speeies. and T. problematica Canu, 1911, in its trifoliate frontal pore arising manifestly from the eoalescence of three pores. It approaches in its ovicell Escharipora? mucromata smitt, 1872, but differs from it in its large truncated aricularia and in its frontal pores united together. It is indeed an intermediate speries between the forms with a large single frontal pore and those with three pores in a triangle. It is also prohable that Smitt's species is also a Tremoyasterina. If the sturlies on the living speries prove this to be eorrect, Smitt's speeies enuld then be ensiclered the type of this American genus whose strueture has always remained mysterious.

Occurrence.-Miocene (Bowden horizon): Santo Domingo (very rare).

Holotype.-Cat. No.68655, U.S.N.M. 


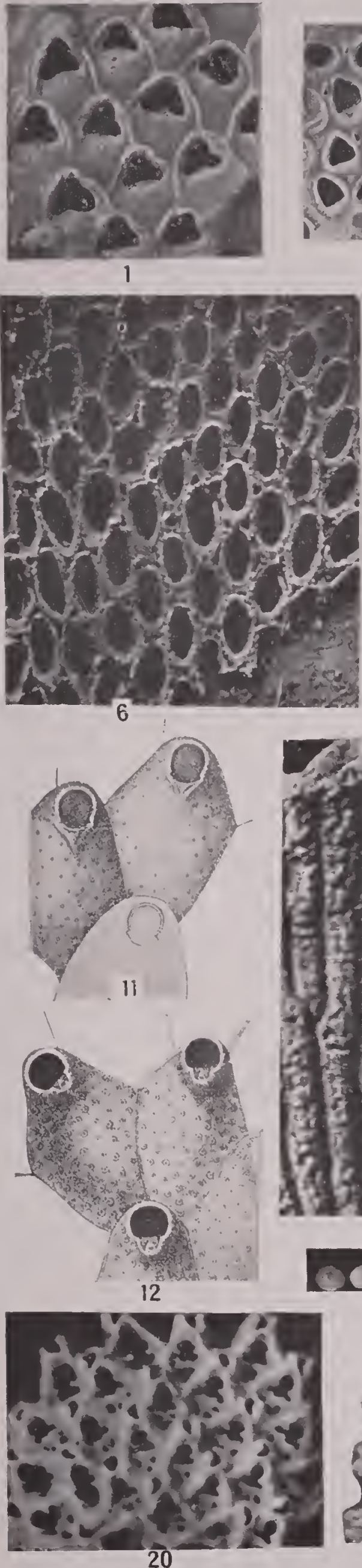
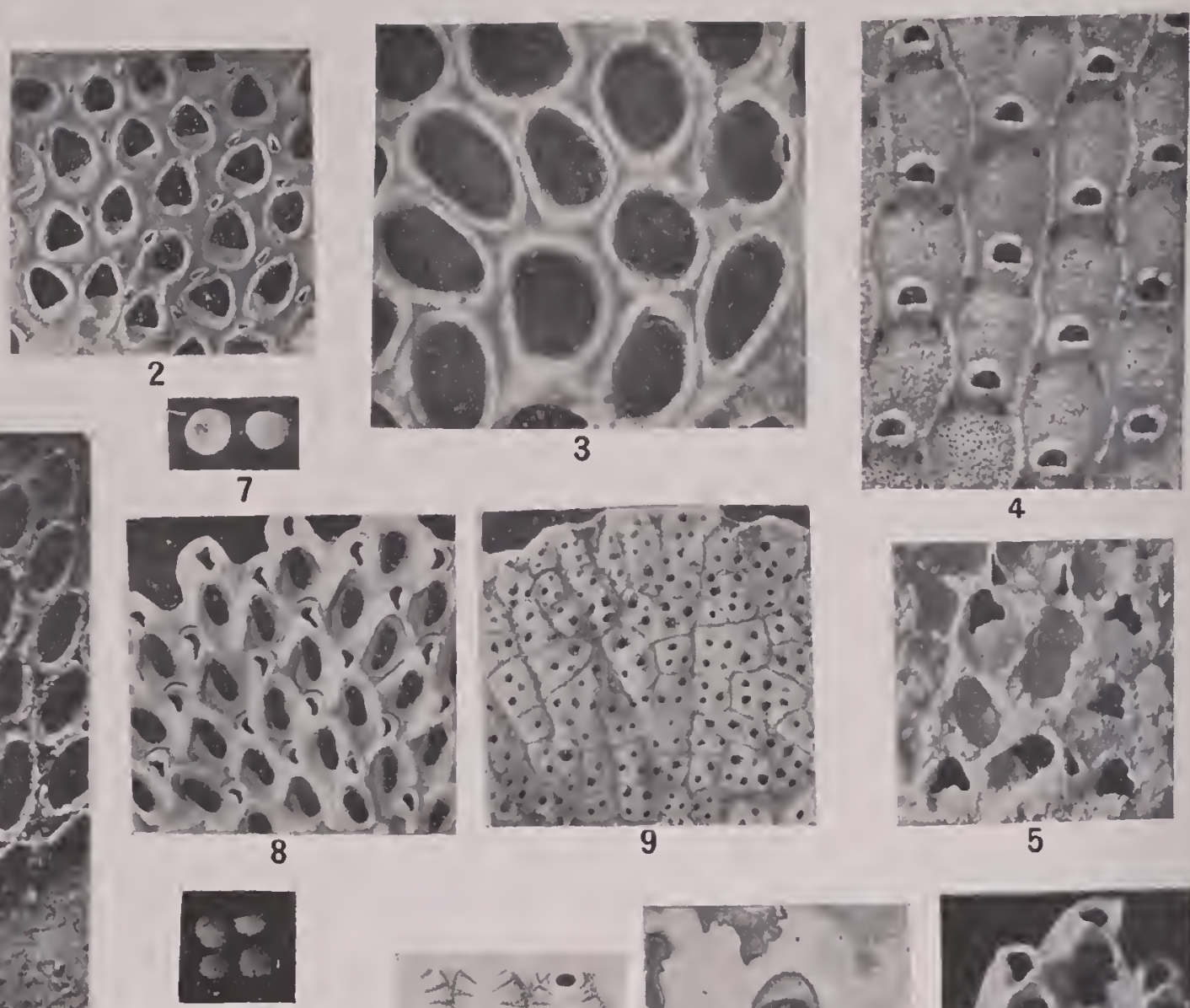

13

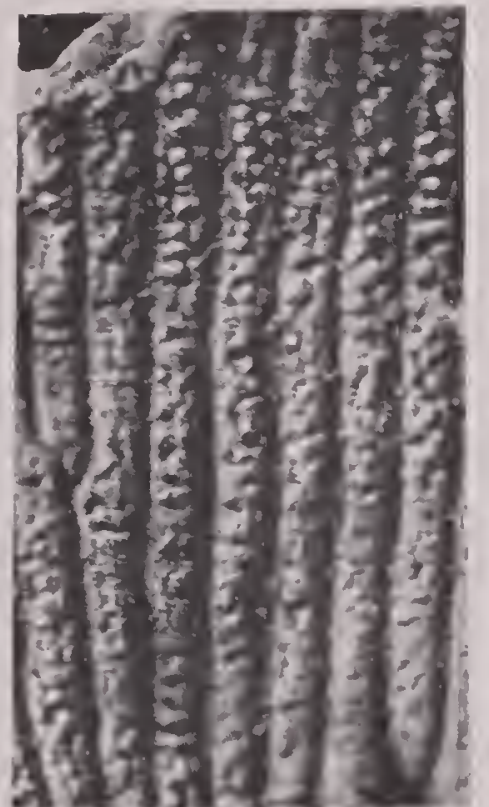

14
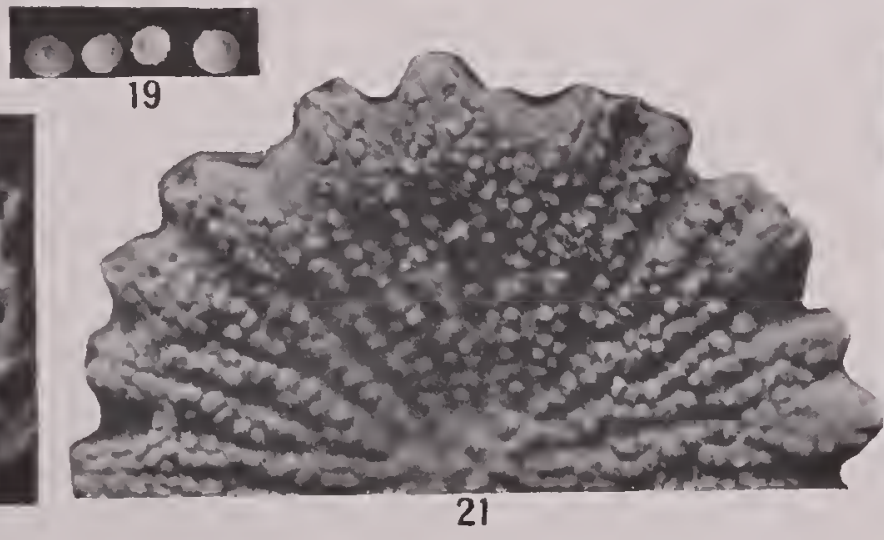

NORTH AMERICAN LATER TERTIARY AND QUATERnaRY BRYOZOA. 
PLATE 1.

Fig. 1. Floridine pyripora Canu and Bassler, 1919. (1. 56.)

Surface of the incrusting zoarim, $\times 20$, showing the large poorly defined opesiules, the pyriform opesium and the smooth salient endozooecial ovicell.

Oligocene (Antigua formation): Rifle Butts, Antigua, Lecward Islands.

Fic. 2. Callopora dumerilii Savigny-Audouin, 1826. (See also pl. 2, fig. 23; pl. 12, fig. 12.) (p. 40.)

Portion of the specimen, $\times 20$, separated by Canu and Bassler in 1919 as var. lata.

Oligocene (Anguilla formation): Soutlwest side Crocus Bay Bluff, Anguilla, Leeward Islands.

Frc. 3. Ogivalina mutabilis Canu and Bassler, 1919. (p. 37.)

The incrusting type specimen, $\times 20$, illustratiug the large, irregular opesia, small endozoocial ovicell, the small gymnocyst and the supposed avicularium.

Oligocene (Emperadol limestone): Near Empire, Panama Canal Zone.

Ficr. 4. Calpensia impressa Moll, 1803. (p. 83.)

Surface of the incrusting zoarium, $\times 20$, referred to this species.

Oligocene (Antigua formation): Carlisle marl pit, Antigua, Leeward Islands.

FIc. 5. Floridina fusifera Canu and Bassler, 1919. (p. 56.)

The incrusting type specimen, $\times 20$, exhibiting the small opesium, large, rounded opesiules, prominent polypidian convexity, large onychocellarium and small fusiform avicularia.

Oligocene (Antigua formation): Rifle Butts, Antigua, Leeward Islands.

F1G. 6. Conopeum lacroixii Busk, 1852. (p. 26.)

Portion of the incrusting zoarium, $\times 20$, showing the characteristic interopesial cavities and small tuberosities on the mural rim.

Miocene (Bowden narl): Bowden, Jamaica.

Figs. 7-9. Cupuladria canariensis Busk, 1859. (p. 28.)

7. Two of the small, free, conical zoaria, natural size.

S. The cellulliferous, convex surface, $\times 20$, illustrating the membraniporoid opesium and the vibracula.

9. Concave, basal surface, $\times 20$, showing the characteristic polygonal areas marked lyy pores.

Miocene (Gatun formation): Banana River, Costa Rica.

F1(r. 10. Puellina radiata carolinensis Gabb and Horn, 1862. (p. 90.)

rabb and Horn's illustration of this variety.

Eocene (Jacksonian) of Soutlı Carolina.

Fig. 11. Hippoporina lata Smitt, 1872. (p. 131.)

View of several zooecia, much enlarged (after Smitt).

Recent: Gulf of Mexico.

Fig. 12. Porella bella Busk, 1860. (p. 147.)

Smitt's illustration of Escharella landsborovi.

Recent: Gulf of Mexico.

Figs. 13-17. Cupularia haidingeri Reuss, 1847. (p. 77.)

13. The small discoidal zoaria, natural size.

14. The inner side, $\times 20$, showing the tuberose, lifurcating ribs.

15, 16. Portions of the celluliferous side, $X 25$, illustrating the two symmetrical condyles and the denticular processes.

17. A zooecium, $\times 50$, showirg the structure of the spinose processes which are flat, claviform, and finely denticulated.

Redonnian: Pigeon Blanc, France.

F1G. 18. Cupularia doma D'Orbigny, 1552. (See also pl. 15, figs. 1-5.) (1. 77.)

Zooecia, $\times 25$, showing the two symmetrical spinules forming condyles and three irregular ununited spinules.

Mediterranean: Oranl, Algeria. .

Figs. 19-22. Cupularia reussiana Manzoni, $1869 . \quad$ (p. 78.)

19. Several, small cupuliform zoaria, natural size.

20. Zooecia, $\times 25$, slowing the trifoliate opesium and that the condyles are not united to the spinules.

21. Inner side, $\times 20$, illustrating the large tuberosities.

22. View of zooecia, $\times 25$, in which some of the spinules are not united together.

Sicilian: Farnesina, Italy. 
Fig. 1. Membranipora vaughani Canu and Bassler, 1919. (p. 23.)

The incrusting zoarium, $\times 20$, showing the large rounded interzooecial tubercles.

Lower Miocene (Bowden horizon): Cercado de Mao, Santo Domingo.

Frgs. 2, 3. Aeanthodesia sararti forma monilifora ('anu and Bassler, 1919. (1). 32.)

The hollow cylindrical zoarium, natural size and $\times 20$. The beaded structure of the mural rim is apparent.

Lower Miocene (Bowden horizon): Cercado de Mao, Santo Domingo.

Fig. 4. Hemiseptella lata (anu and Bassler, 1919. (p. 70.)

Part of the incrusting type specimen, $\times 20$, with some zooecia showing the characteristic inferior denticle.

Lower Miocenc (Bowden horizon): Cercado de Mao, Santo Domingo.

Figs. 5-7. Nellia oculata Busk, 1852. (p. 55.)

5. Normal zooecia with tubercles, complete, $\times 25$.

6. Fragment showing large zooecia, $\times 25$; the tubercles are replaced by pores

7. View of fragment, $\times 25$, slowing two sides of the zoarium.

Lower Miocenc (Bowden lrorizon): Cercado de Mao, Santo Domingo.

Figs. 8-10. Corynostylus ellipticus Canu and Bassler, 1919. (1. 8t.)

8. Several fragments of the articulated zoarium, natural size.

9. Anterior face of zoarium, $\times 25$, showing the characteristic unilamellar growtl with two rows of zooecia.

10. Posterior face, $\times 25$.

Lower Miocenc (Bowden horizon): Cereado de Mao, Santo Domingo.

FIGS. 11-13. Corynostylus labiatus Canu and Bassler, 1919. (p. S4.)

11. Complete segment of the articulated bilamellar zoarium, natural size.

12. Photograph of the same, $X 25$. The salient opesial lip is shown.

13. Section, $\times 20$, exhibiting the interior of the zooecia in the middle row and a longitudinal scction in the outer rows.

Lower Miocene (Bowden horizon): Cercado de Mao, Santo Domingo.

Fig. 14. Thalamoporella granulata Levinsen, 1909. (p. 61.)

Small fragment, $\times 20$, identified with this recent species.

Lower Miocene (Bowden horizon): Rio Gurabo, Santo Domingo.

Figs. 15-19. Cupularia umbellata Defrance, 1823. (․ 80.)

15. The discoid zoaria, natural size.

16. Photograph of the inner tuberose side, $\times 25$.

17. Ancestrular region, $\times 25$, in which the ancestrula is covered over by a normal zooecium.

18. Ancestrular region of another zoarium, $\times 25$; the zooecia are arranged alternately and in inverted order.

19. Another view of the ancestrular region, $\times 25$ : here the ancestrula is a membraniporoid zooe. cium.

Lowcr Miocene (Bowden horizon): Cercado de Mao, Santo Domingo.

Figs. 20, 21. Smillina? brevis Canu and Bassler, 1919. (p. 146.)

20. Surface of the bilamellar zoarium, $\times 20$

21. Ovicelled zooecia of another fragment, $\times 20$.

Lower Miocene (Bowden horizon): Cercarlo de Mao, Santo Domingo.

Frg. 22. Rhynchozoon vaughani Canu and Bassler, 1919. (See also pl. 4, figs. 1, 2.) (p. 155.)

A small fragment, $\times 20$.

Lower Miocene (Bowden horizon): Cercado de Mao, Santo Domingo.

F1G. 23. Callopora dumerilii Savigny-Audouin, 1826 (see also pl. 1, fig. 2; pl. 12, fig. 12.) (p. 40.)

An example, $X 20$ showing thick mural rims and regenerated zooecia.

Lower Miocene (Bowden marl): Bowden, Jamaica. 
U. S. NATIONAL MUSEUM
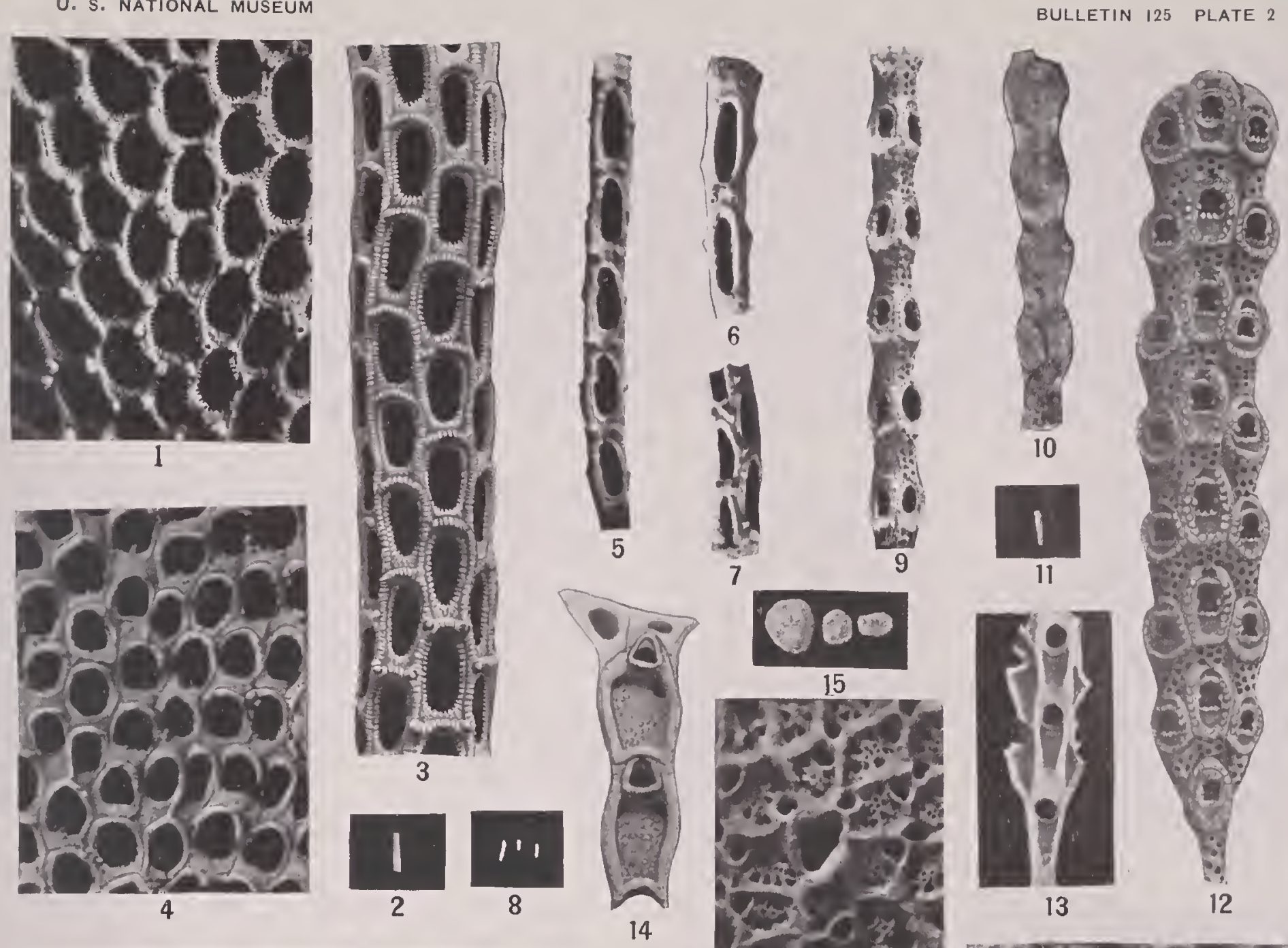

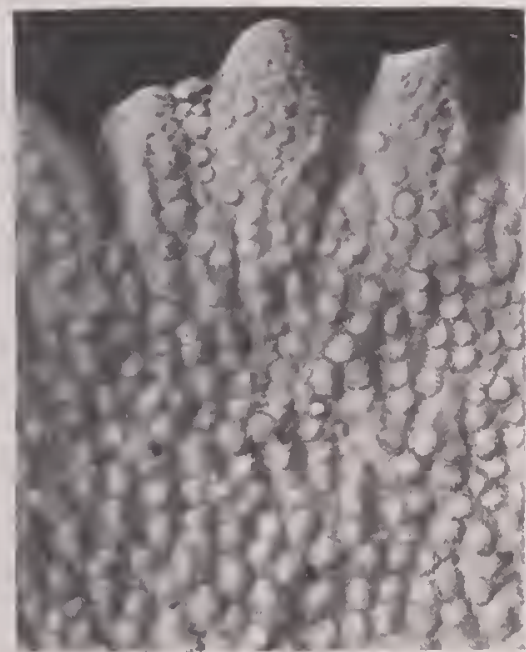

16

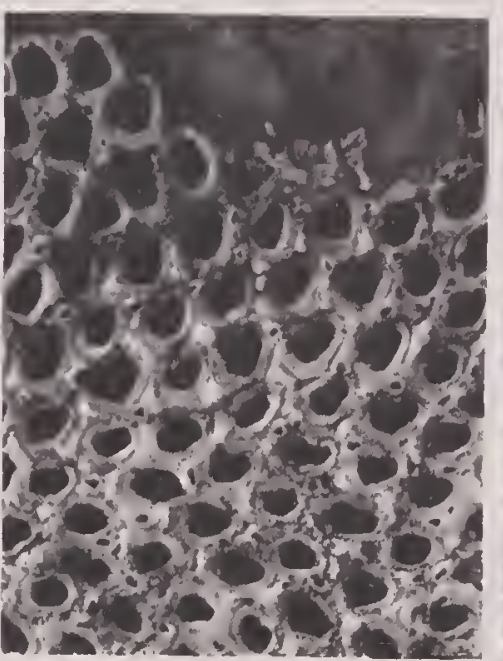

23

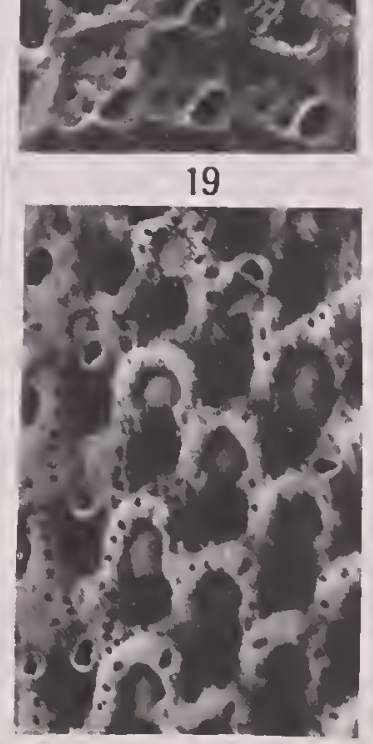

21

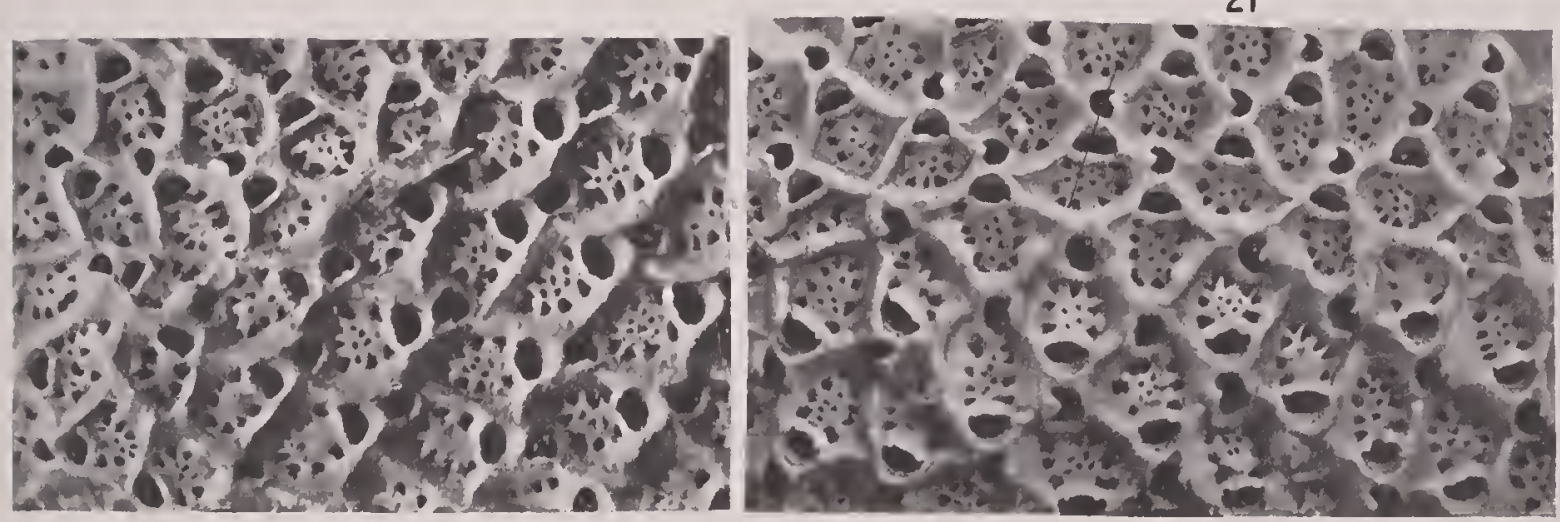

17

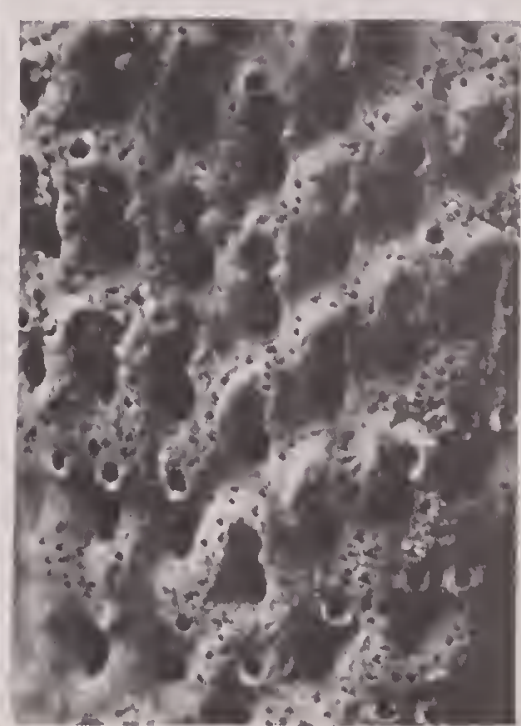

20

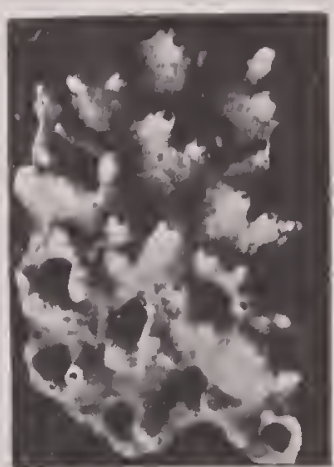

22

NORTH AMERICAN LATER TERTIARY AND QUATERNARY BRYOZOA.

FOR EXPLANATION OF PLATE SEE PAGE 240. 

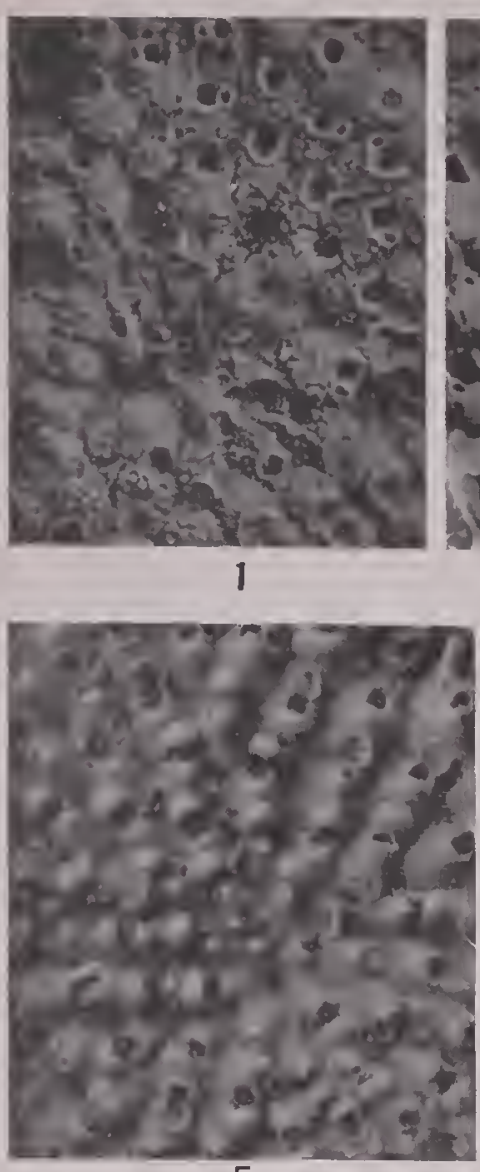

5

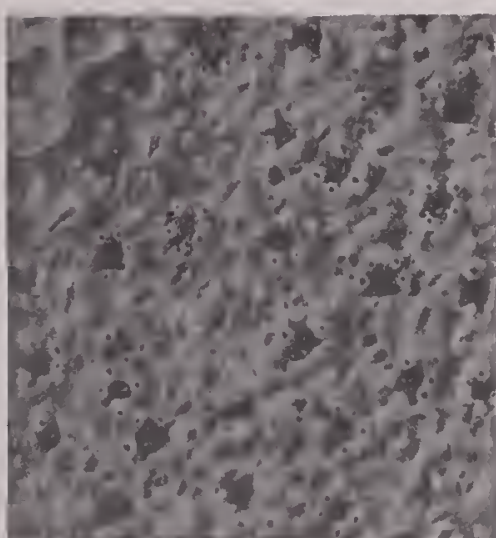

11

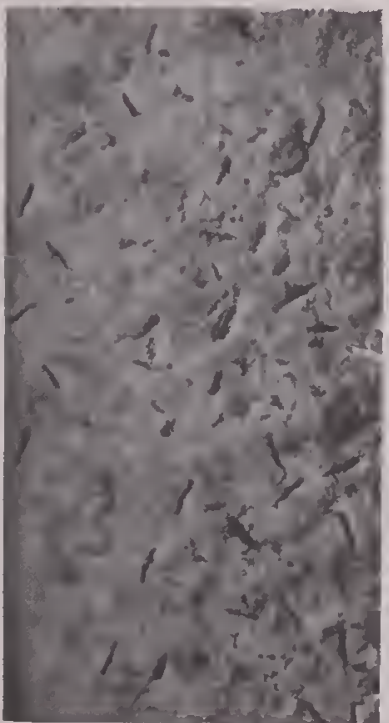

14

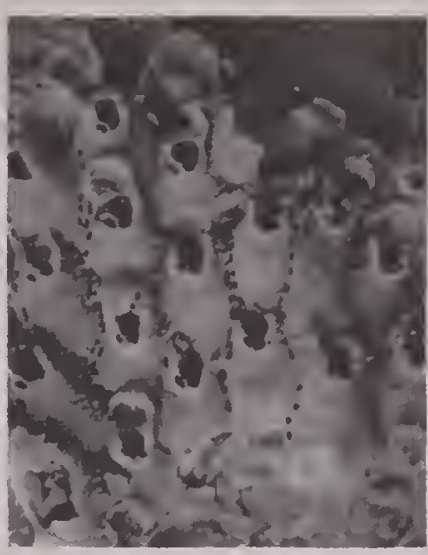

2
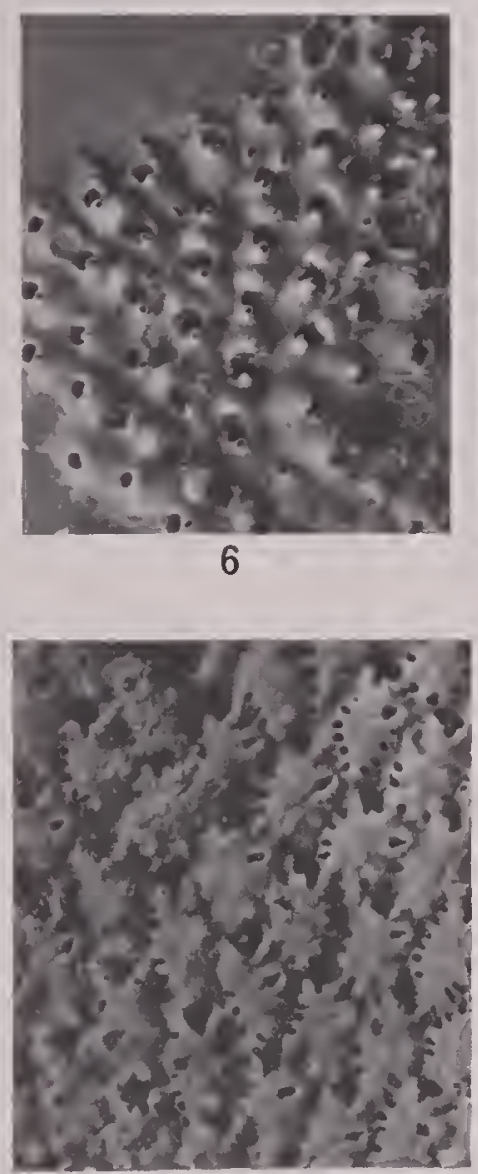

12

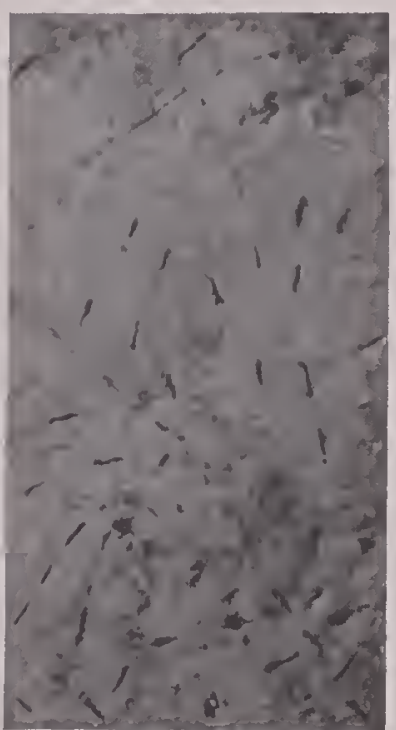

15

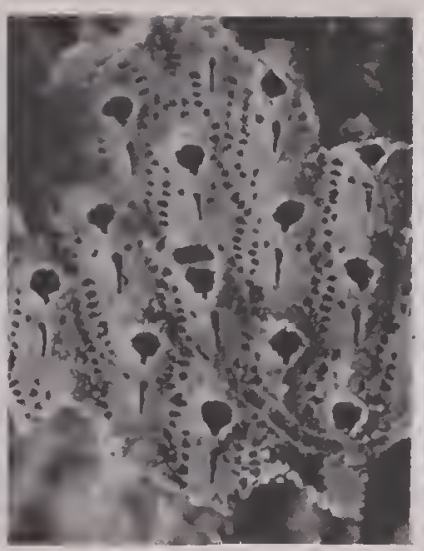

3

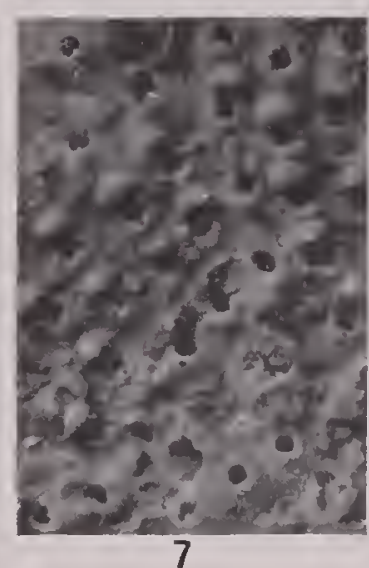

8

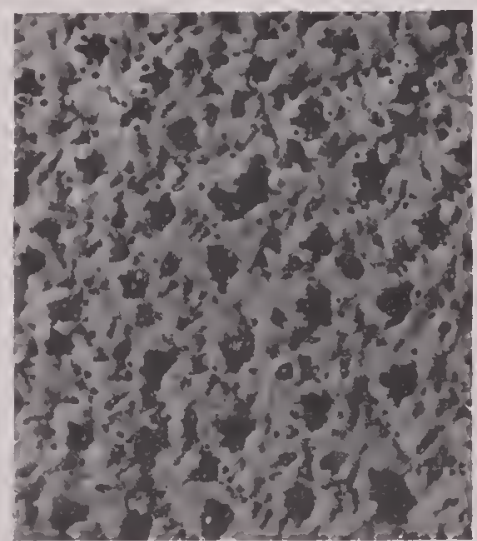

13

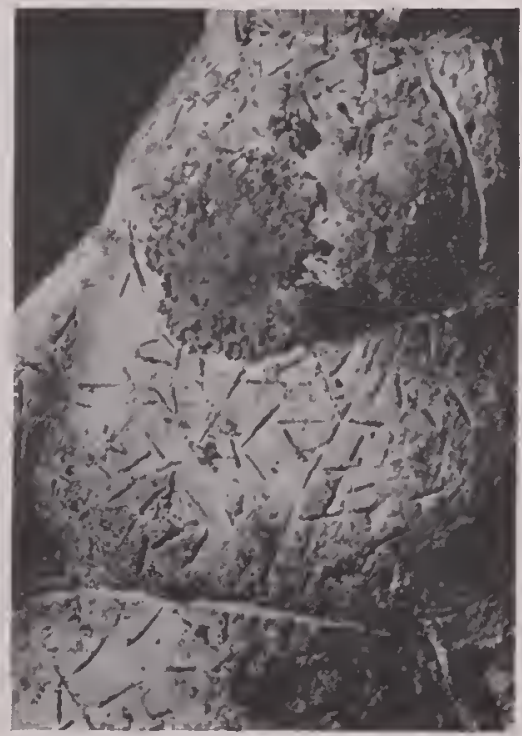

16

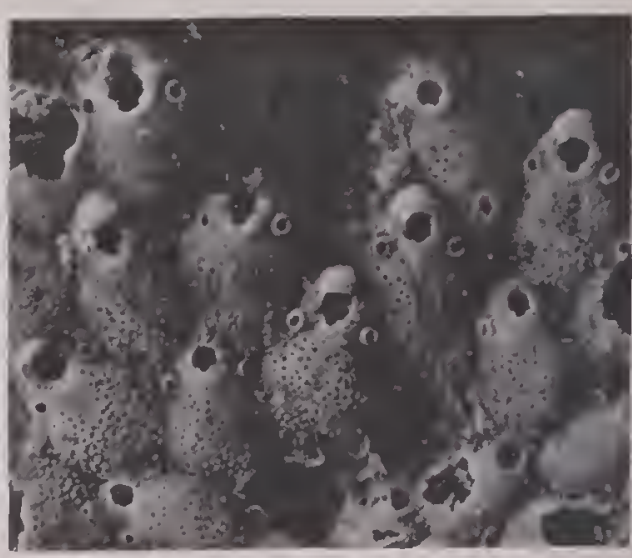

4
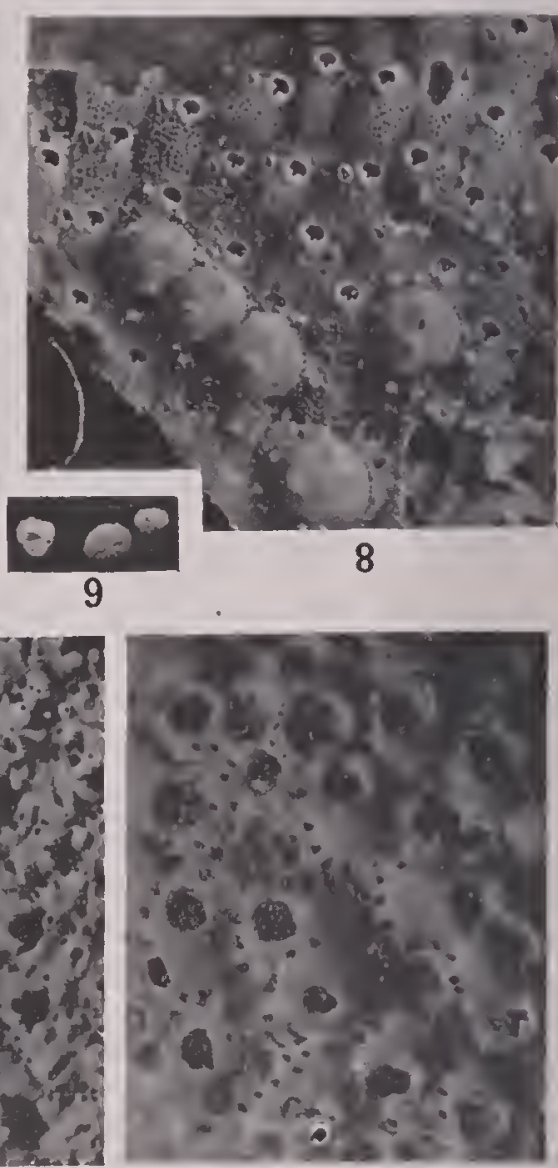

10

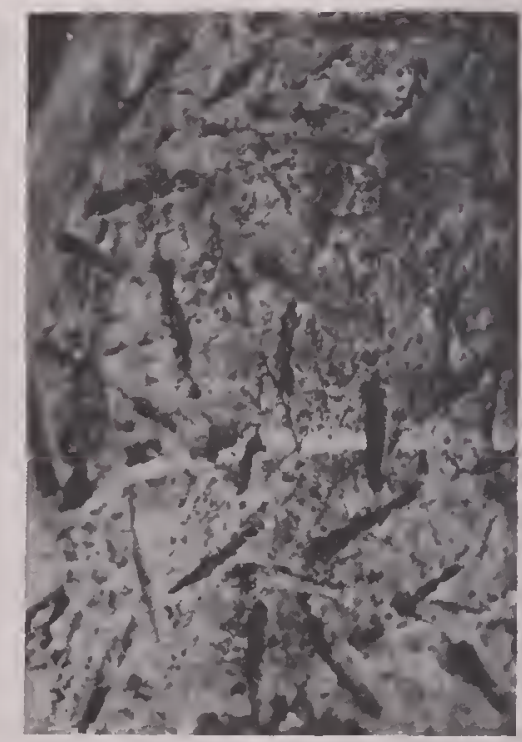

17 
Plate 3.

Fig. 1. Hippociiplosia baccata Canu and Bassler, 1920. (p. 131.)

View, $X 20$, of Miocene example of this species.

Lower Miocene (Bowden marl): Bowden, Jamaica.

Fig. 2. Rhamphostomella granulosa, new species. (p. 151.)

The incrusting zoarium, $\times 20$, showing the granular pleurocyst, small areolar pores, and the aperture with its triangular avicularium.

Lower Miocene (Bowden marl): Bowden, Jamaica.

FIG. 3. Smittina ophidiana Waters, 1877. (p. 144.)

A small incrusting zoarium, $\times 20$. The large median avicularium, two frontal pores, rectangular lateral pores, and granular ovicell are to be noted.

Miocene (Bowden marl): Bowden, Jamaica.

F1G. 4. Mastigophora granulosa, new species. (p. 172.)

Ovicelled and unovicelled zooecia of the incrusting zoarium, $\times 20$, illustrating their large size, granular surface, and the position of the vibracula at the level of the rimule.

Lower Miocene (Bowden marl): Bowden, Jamaica,

Figs. $5-7$. Aimulosia breits, new species. (p. 140.)

5. The incrusting zoarium, $\times 20$, illustrating the zooecia in the ancestrular region.

Lower Miocene (Bowden marl): Bowden, Jamaica.

6. A typical example, $\times 20$, with the usual short zooecia, bearing very salient median avicularia.

7 . Marginal portion of a zoarium, $\times 20$, exhibiting larger zooecia.

Pliocene (Caloosahatchee marl): Shell Creek, De Soto County, Florida.

FIG. 8. Stylopoma minuta, new species. (p. 104.)

Portion of the incrusting type specimen, $X 20$. The ovicell entirely covering the apertura and the small size of the zooecia are to be noted.

Lower Miocene (Bowden marl): Bowden, Jamaica.

Figs. 9, 10. Holoporella hemispherica, new species. (p. 176).

9. Several of the small, free, hemispherical zoaria, natural size.

10. Zooecia, $\times 20$, illustrating their large size and convex frontal, surrounded by large areolar pores.

Lower Miocene (Bowden marl): Bowden, Jamaica.

FIGS. 11-13. Rlymchozoon verruculatum Smitt, 1872. (p. 157.)

11. Central portion of the incrusting zoarium, $\times 20$, showing indistinct zooecia.

12. Marginal zooecia, $X 20$, with outlines well preserved.

13. Another aspect of the zoocial surface, $\times 20$.

Pliocene (Caloosahatchee marl): Shell Creek, De Soto County, Floricla.

F1GS. 14, 15. Tcrebripora sinefilum, new species. (p. 15.)

14. A normal zoarium, $\times 20$, illustrating deeply perforated old zooecia and absence of canals.

15. Portion of a young zoarium, $\times 10$, showing both the axes and the zooecia. The latter have not perforated the shell very deeply.

Lower Miocene (Bowden marl): Bowden, Jamaica.

Figs. 16, 17. Terebripora slongata, new species. (p. 15.)

16. The type specimen, $X 3$ and a small portion, $X 10$, illustrating the very large size and elongate shape of the zooecia.

Lower Miocene (Bowden marl): Bowden, Jamaica. 
PLATE 4.

Figs. 1, 2. Rhymchozoon vaughani Canu and Bassler, 1919. (See also pl. 2, fig. 22.) (p. 155.)

I. The unilamellar zoarium, $\times 20$, showing young condition in which the zooecia are distinct.

2. Old condition of zoarium, $\times 20$. The zoocia are indistinct and not oriented.

Lower Miocenc (Bowden horizon): Cercado de Mao, Santo Domingo.

Figs. 3-12. Metrarabdotos colligatum Canu and Bassler, 1919. (p. 162.)

3-5. Different aspects of the basc of the zoarium, $\times 6$.

6. Three fragments, natural size, preserving base.

7. Portion of zoarial surface, $\times 20$, with ovicells wcll prescrved.

8. Base of a zoarium, $\times 20$, showing calcification and disappearance of the apertures.

9. Broad zooccia, $\times 20$, charactcristic of the aged condition.

10. Narrow zooccia, $\times 20$, of youthful condition.

11. Normal zooecia, $\times 20$.

12. Longitudinal section, $\times 20$, exhibiting the interior of the zooccia.

Lower Miocenc (Bowden horizon): Cercado de Mao, Santo Domingo.

Fig. 13. Palmicellaria ef. inermis Ju'lien, 1882. (p. 149.)

The branching fraginent referred doubtfully to this species, $\times 20$.

Lower Miocene (Bowden horizon): Santo Domingo.

FIG. 14. Rhynchozoon curtum, new species. (p. 156.)

The unilamellar zoarium, $\times 20$, illustrating the characteristic short zooecia.

Lower Miocene (Bowden horizon): Santo Domingo.

248 


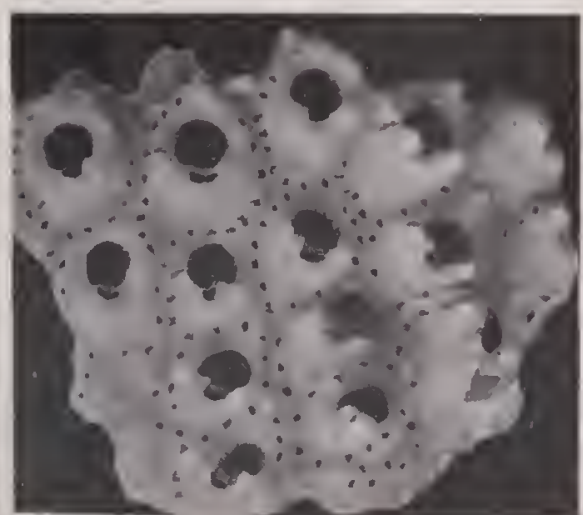

1

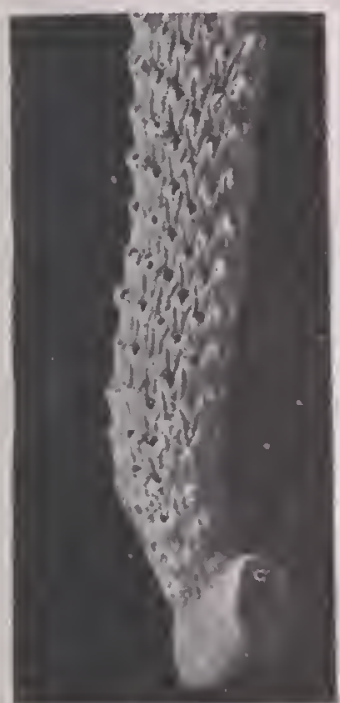

3

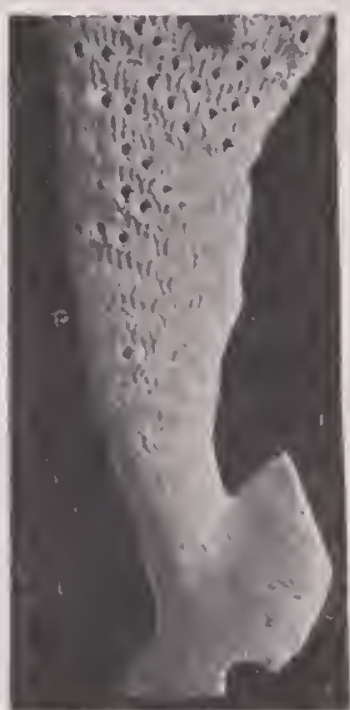

\begin{abstract}
4
\end{abstract}
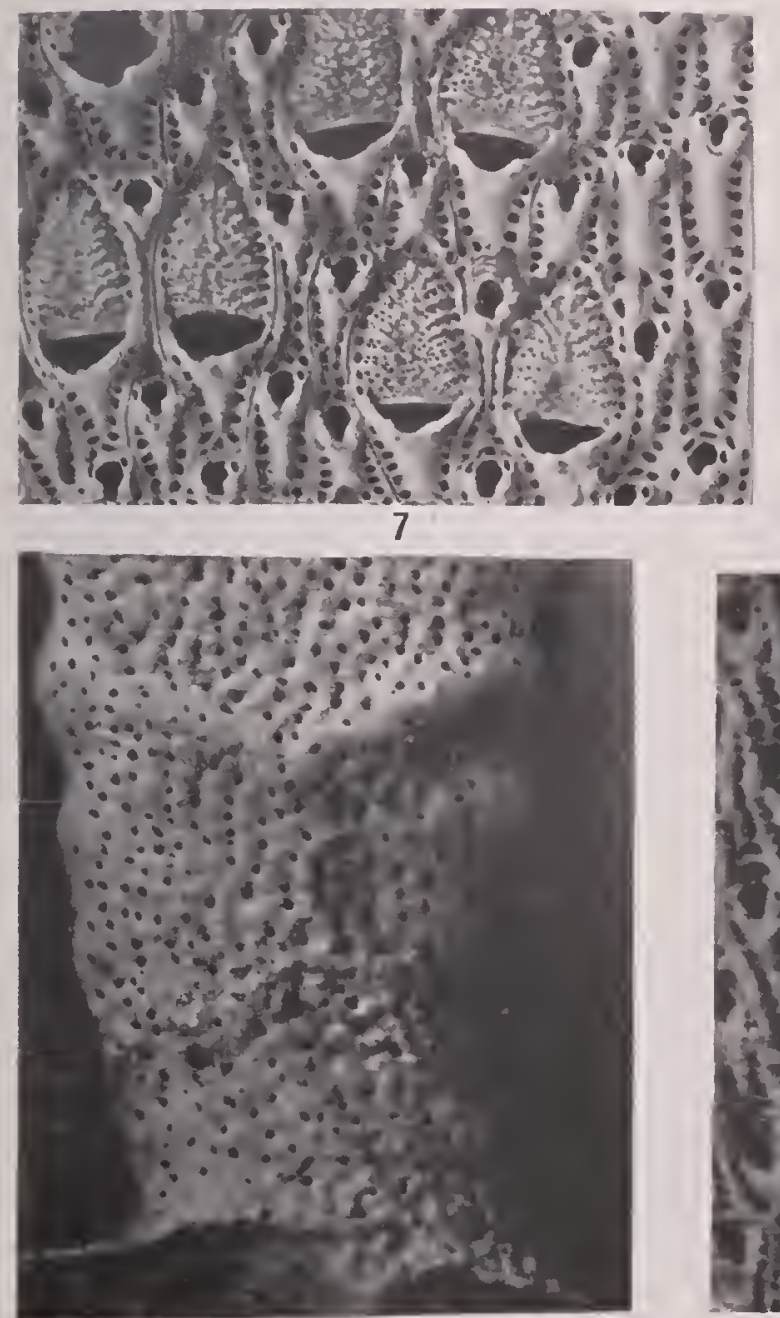

8

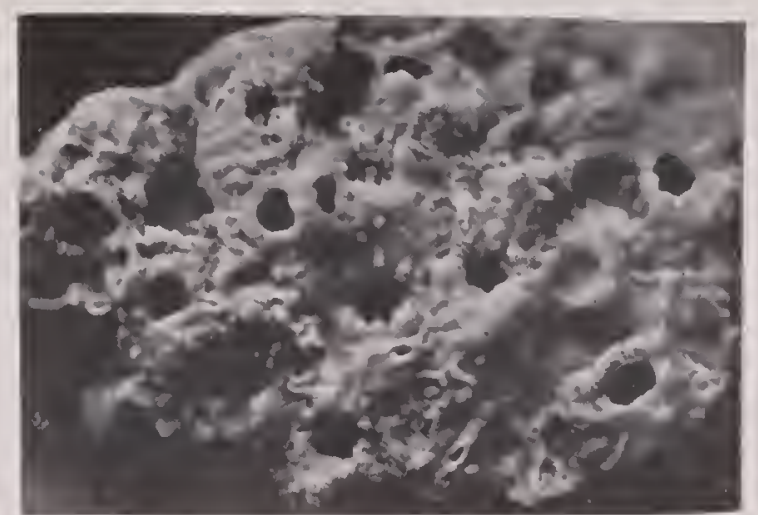

2

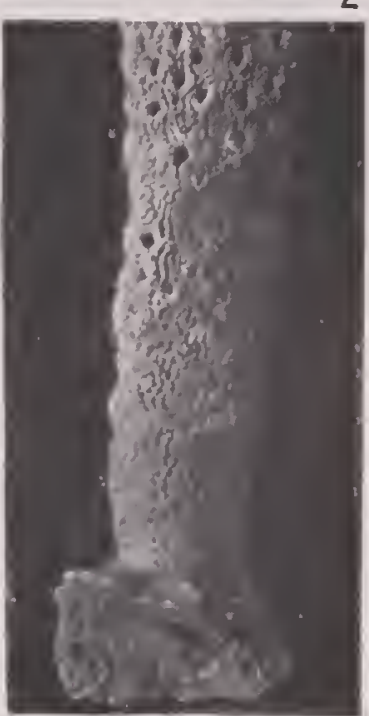

5

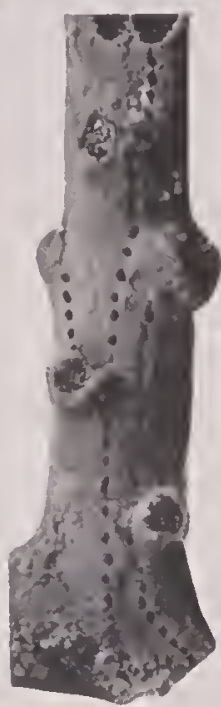

13
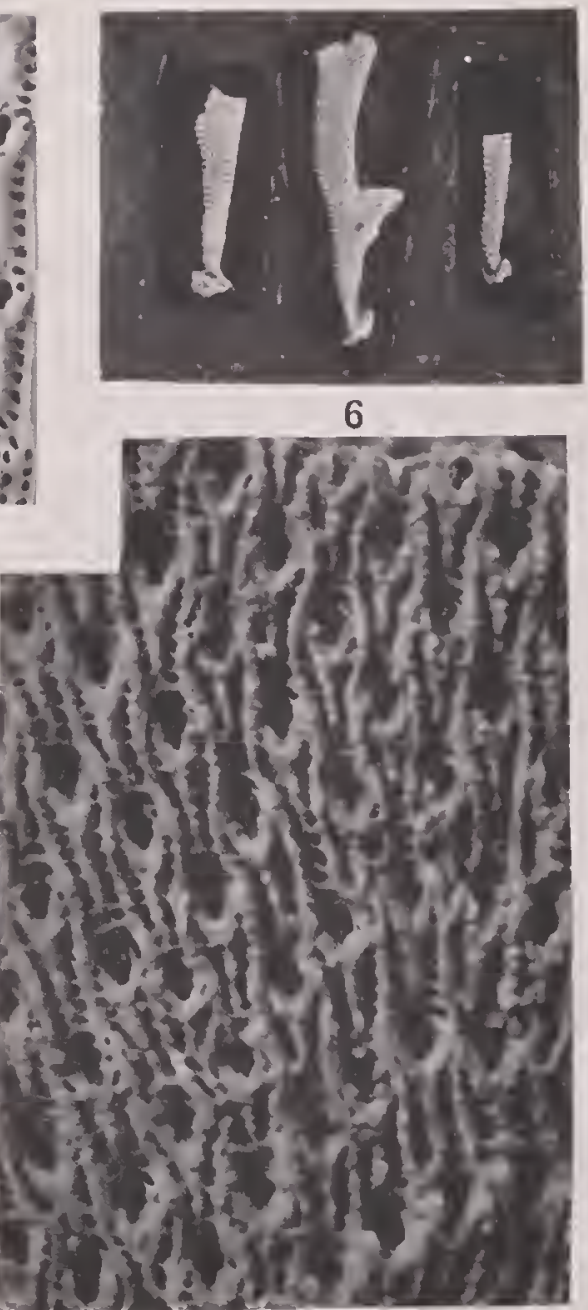

9

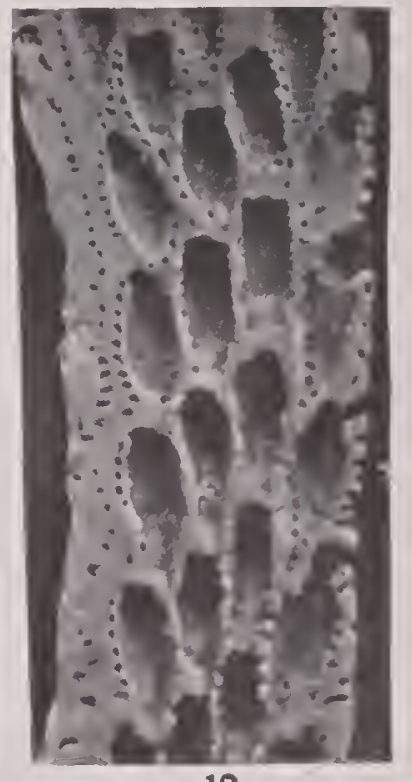

12

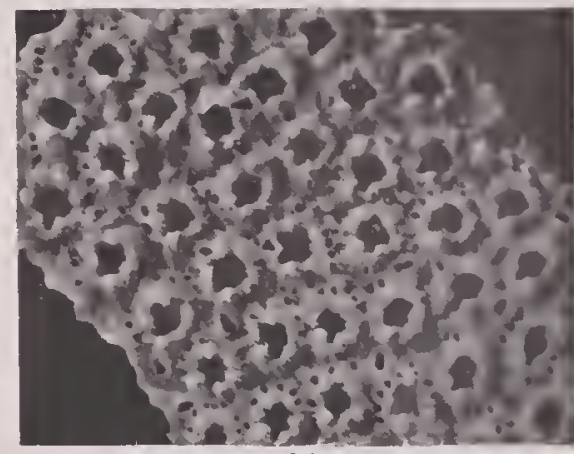

14

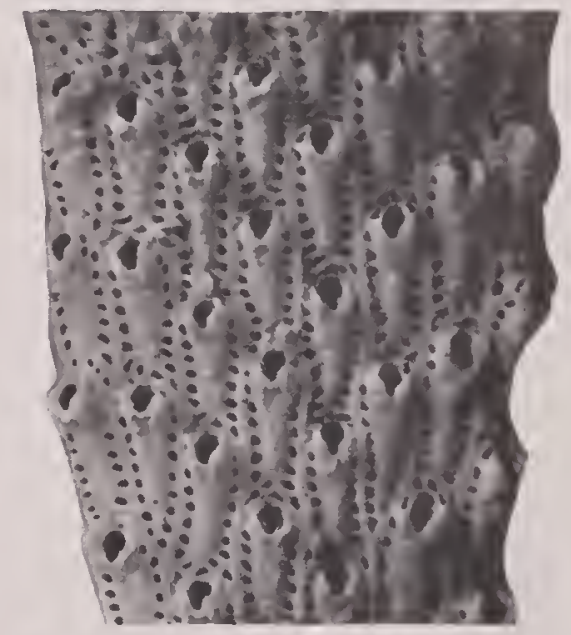

10

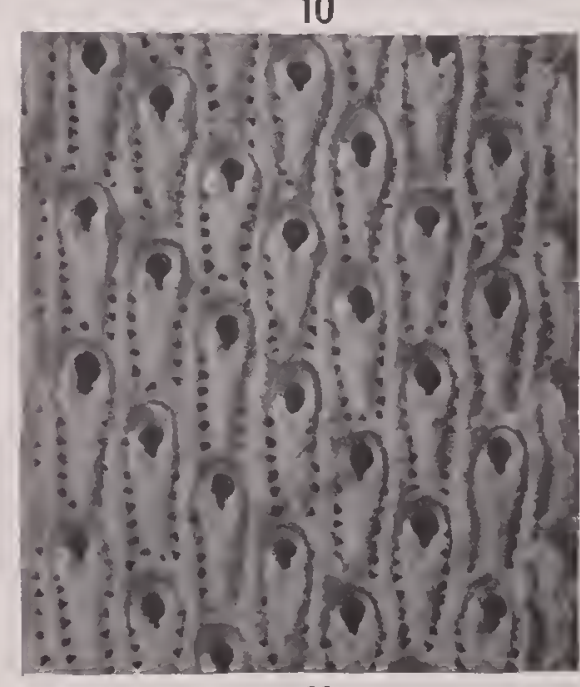

11

NORTH AMERICAN LATER TERTIARY AND QUATERNARY BRYOZOA. 


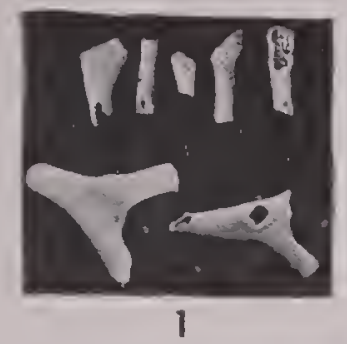

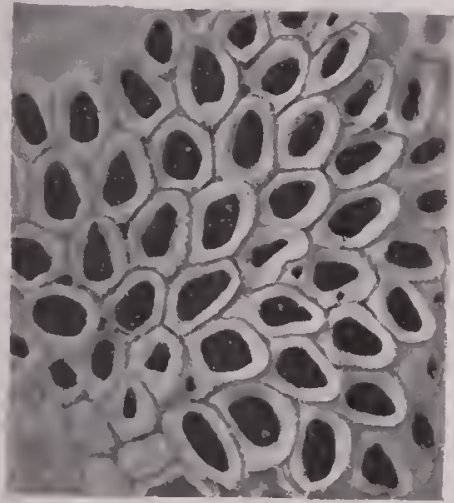

6

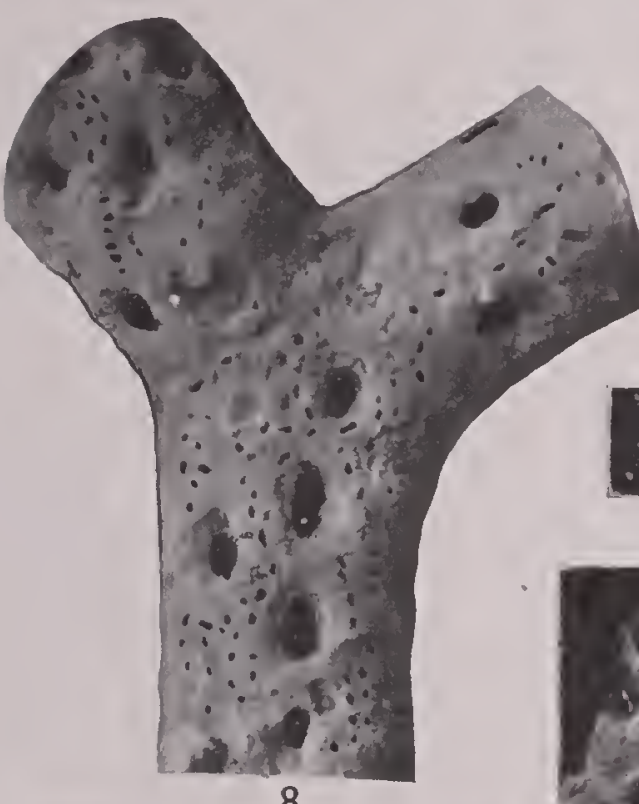

8

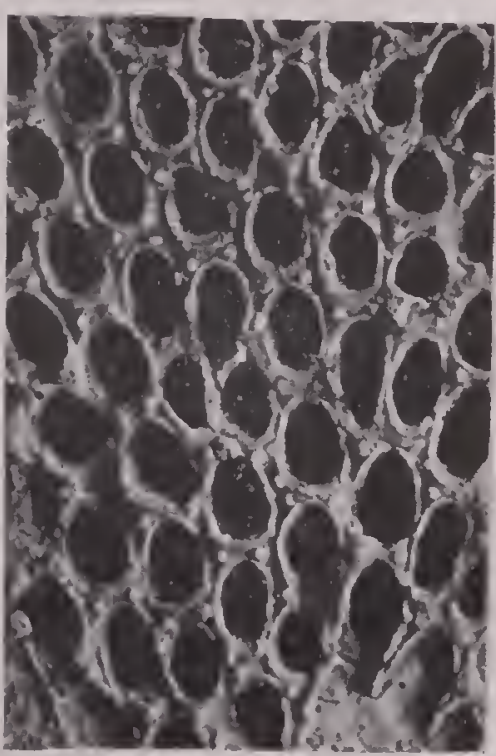

10
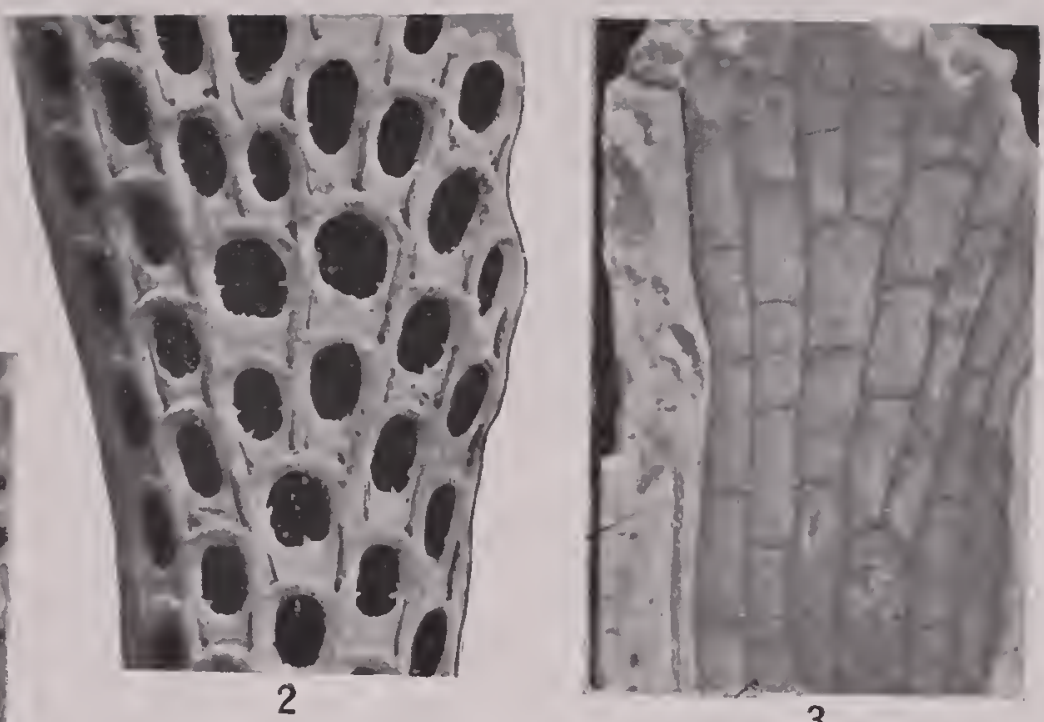

3

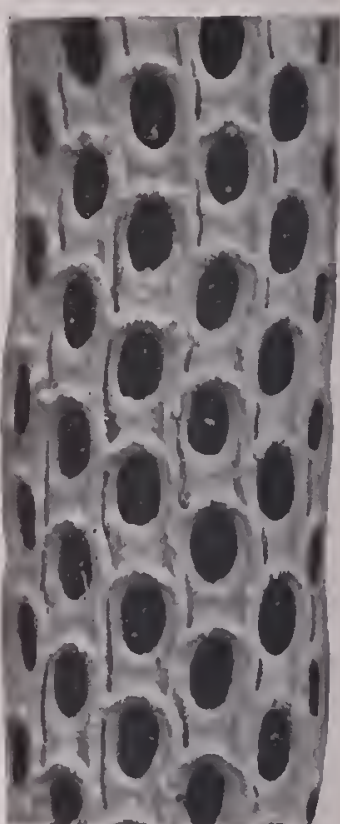
4
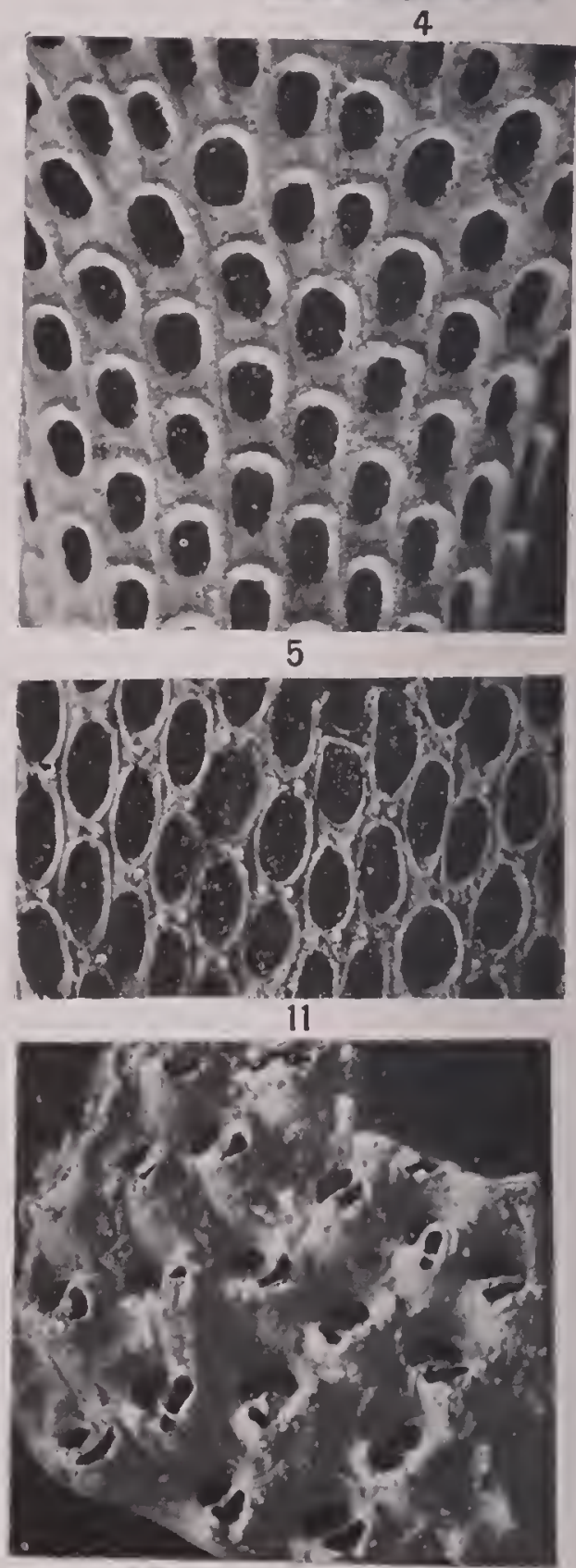

13

NORTH AMERICAN LATER TERTIARY AND QUATERNARY BRYOZOA 
Plate 5.

Figs. 1-5. Acanthodesia sutarti forma texturata Reuss, 1847. (See also pl. 46, figs. 8, 9.) (p. 32.)

1. Fragments of the unilamellar, hollow eylindrieal zoarium, natural size.

2. Zooeeia, $\times 20$, with traees of delieate spines in the opesium.

3 . Inner side of zoarium, $\times 20$, showing reetangular form of zooeeia.

4. Zooeeia, $\times 20$, with a distinet rim around the opesium.

5. Another surface, $\times 20$, showing the large size of the first zooceium of a new row.

Lower Mioeene (Bowden marl): Bowden, Jamaiea.

Fig. 6. Conopeum ovale Canu and Bassler, 1919. (p. 26.)

Aneestrular portion of the type speeimen, $\times 20$, inerusting a shell. The rare and irregular interopesial eavities, the entire, oval opesium and the flat mural rim are illustrated.

Lower Mireene (Bowden marl): Bowden, Jamaica.

Figs. 7-9. Gemelliporella punctata Canu and Bassler, 1919. (p. 111.)

7. Two fragments of the free eylindrieal zoarium, natural size.

8. An example, $\times 20$, showing the development of the tremoeyst.

9. Another fragment, $\times 20$, exhibiting the form of the aperture, ovicells (broken) and arrangement of the areolae.

Lower Mioeene (Bowden marl): Bowden, Jamaica.

Figs, 10-11. Membraniporina tenella Hineks, 1850. (p. 24.)

10. The inerusting zoarium, $\times 20$, illustrating the thin mural rim and the small tubereles on the gymnoeyst.

11. Another zoarium, $\times 20$, with narrow zooeeia.

Lower Mioeene (Bowden marl): Bowden, Jamaiea.

FIg. 12. Memiseptella grandicella Canu and Bassler, 1919. (p. 71.)

Surfaee of the inerusting zoarium, $\times 20$. The largest zooeeia eommenee a new row.

Lower Miocene (Bowden marl): Bowden, Jamaiea.

F1G. 13. Rhamphostomella laticella Canu and Bassler, 1919. (p. 151.)

The inerusting zoarium, $\times 20$. The areolar eostules are seareely visible.

Lower Mioeene (Bowden marl): Bowden, Jamaiea. 
FIG. 1. Labiopora miocenica Canu and l3assler, 1919. (p. 67.)

Fragment of the unilamellar zoarium, $\times 20$. The polypidiam tube and the small pores of the tremoeyst are visible.

Lower Miocene (Bowden horizon): Rio Gurabo, Santo Domingo.

FIG. 2. ITippomenella infratclum Canu and Bassler, 1919. (p. 132.)

Base of the bilamellar zoarium, $\times 20$. One zooecium is regenerated, being replaced by an avicularinm.

Lower Mioeene (Bowden horizon): Cerearlo de Mao, Santo Doningo.

Figs. 3-5. Schizopodrclla mutabilis Canu and Bassler, 1919. (p. 105.)

3. The tubular zoarium, natural size.

4. Surface, $\times 20$, showing indistinet zooecia.

5. Another portion of the same zoarium, $\times 20$, illustrating the shape of the zooecia

Lower Mioeene (Bowden horizon): Cercado de Mao, Santo Domingo.

Figs. 6-9. Steganoporella parvicella Canu and Bassler, 1919. (p. 62.)

6. Fragments of the unilamellar zoarium, natural size.

7. Zoarial fragment, $\times 20$, illustrating the great irregularity in the zooecia.

8. The usual zooecia, $\times 20$, witl regular arrangement.

9. The most frequent aspect of the zooeeia, $\times 20$. The polypidian tube is very fragile and often broken or altered.

Lower-Miocene (Bowden horizon): Cereado de Mao, Santo Domingo.

Figs. 10-15. Thalamoporella biperforata Canu and Bassler, 1919. (p. 62.)

10. Fragments of the bilamellar zoarium, nat ural size.

11. Specimen, $X 20$, exhibiting a well-preserved reticulocellarium.

12. An example, $\times 20$, showing the hollow tubercles worn and replaced by pores. A reticulocellarium is here present

13. Drawing showing the real form of the aperture. $\times 77$.

14. A specimen, $\times 20$, with a deformed membraniporoid zooecium near the upper eorner.

15. Another similar example, $\times 20$, with a primoserial membraniporoid zooceium along the lower edge.

J.ower Miocene (Bowden horizon): Cereado de Mao and Rio Cana, Santo Domingo.

Figs. 16-19. Mamillopora tuberosa ('anu and Bassler, 1919. (See also pl. 7, figs. 1-8.) (p. 192.)

16. Small fragments of the small, free, eonical zoarium, natural size.

17. Zoarial fragment, $\times 20$, with large zooecia.

18. Fragment, $\times 20$, with small zooecia. The tubereles are well developed.

19. Inner side of zoarium, $\times 20$.

Lower Miocene (Bowden horizon): Rio Cana, Santo Domingo.

Figs. 20, 21. Diapcroccia milneana D'Orbigny, 1839. (p. 202.)

Views of a fragment, natural size and $\times 12$, referred to this species.

Lower Mioeene (Bowden horizon): Cereado de Iao, Santo Domingo.

Figs. 22, 23. Adeona porosı Canu and Bassler, 1919. (p. 155.)

Fragment of the free bilamellar zoarium, natural size and $\times 20$.

In figure 23 , three gonoecia with their oral gibbosities are shown in the upper right-hand corner, an avicularian zoneeium in the upper left-liand corner, and ordinary zooecia with their ascopores, and small areolae in the rest of the photograpli.

Lower Miocene (Bowden horizon): Cercado de Mao, Santo Domingo. 

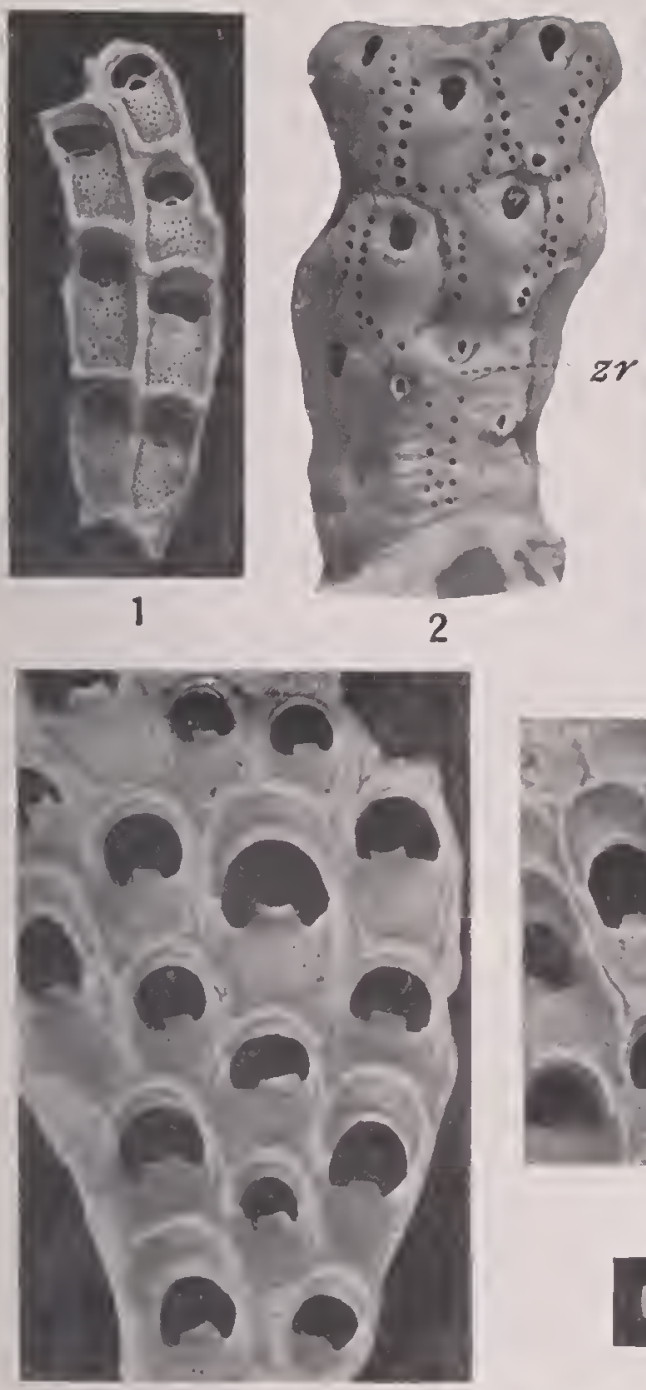

7

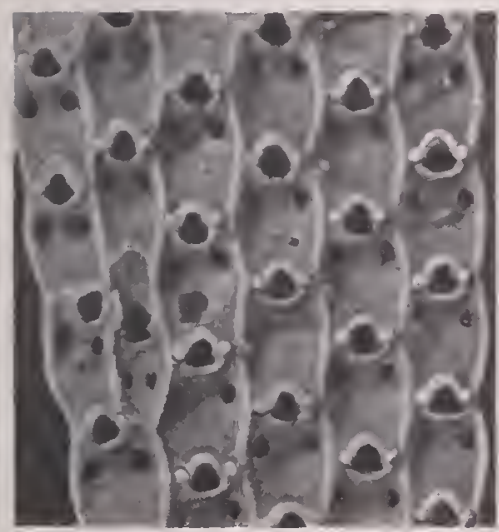

11

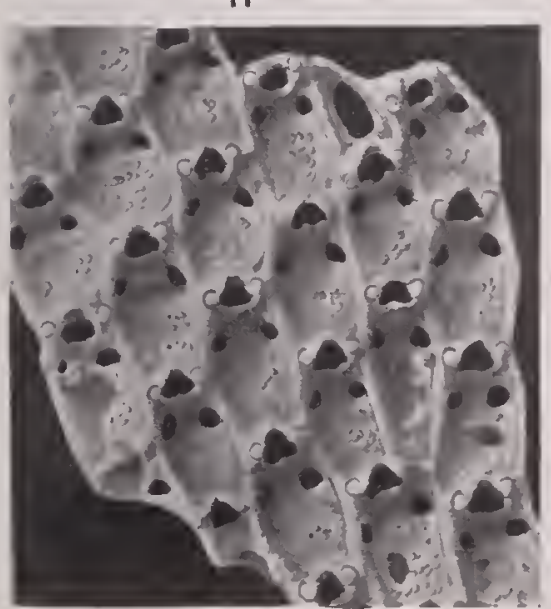

14

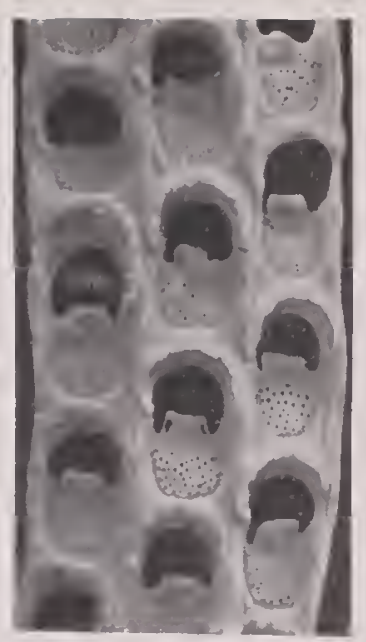

8

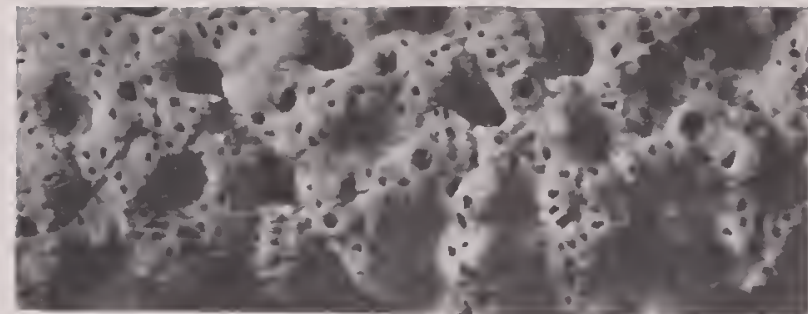

4
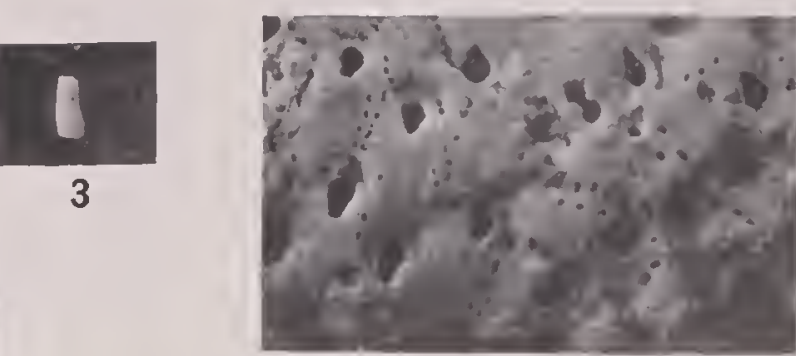

5
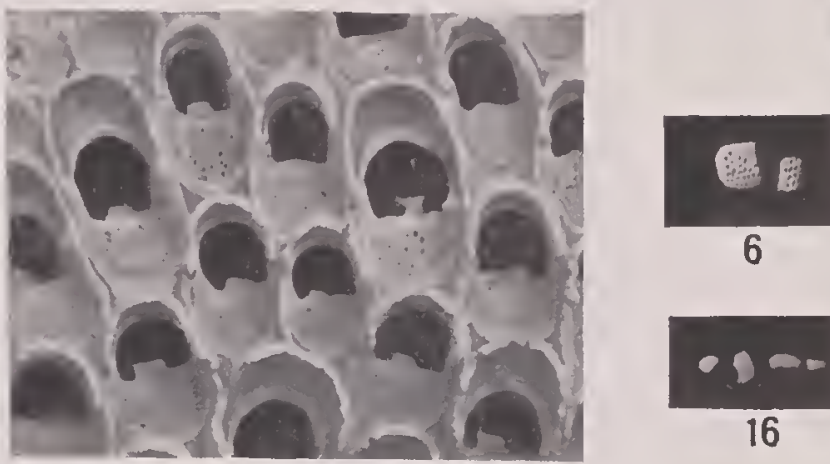

6

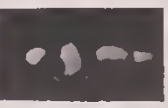

16

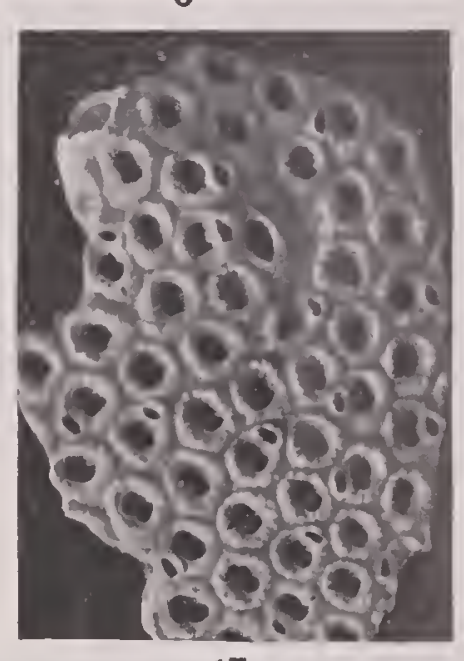

17

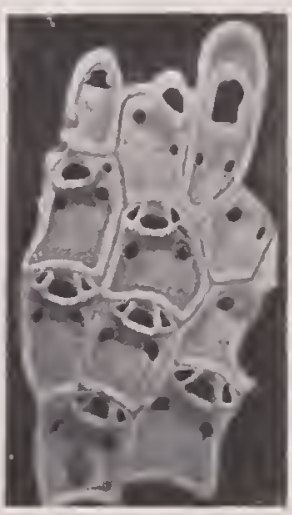

12

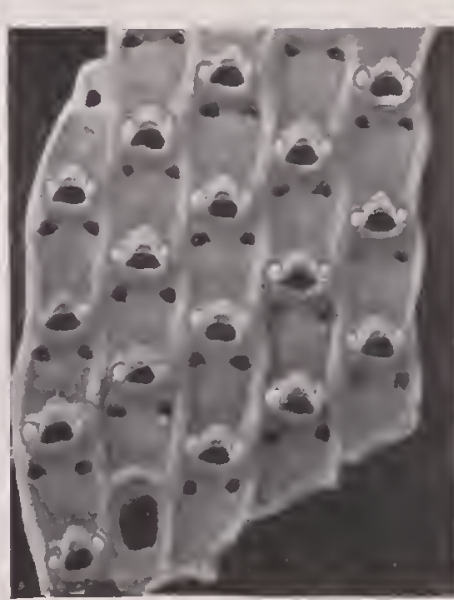

15

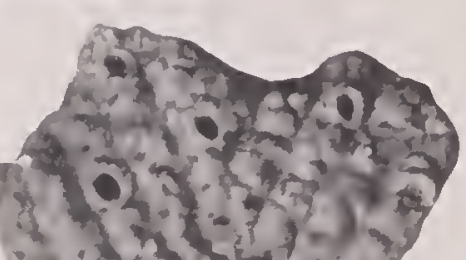

orotaty

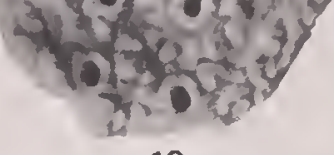

19

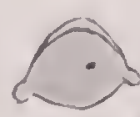

13

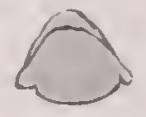

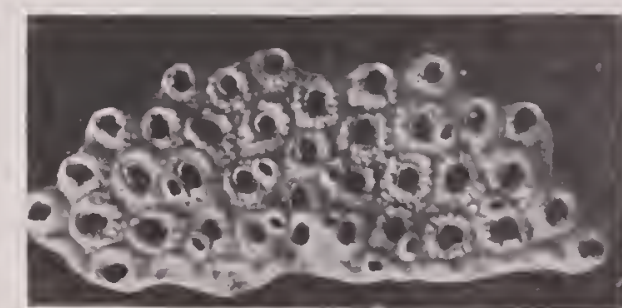

18

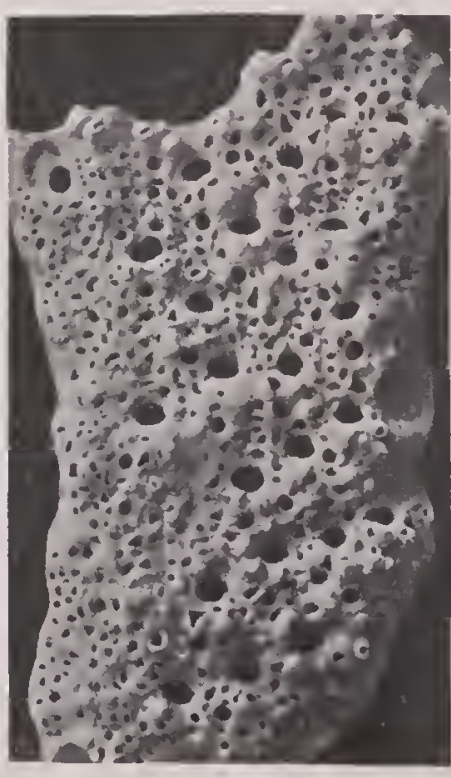

23

NORTH AMERICAN LATER TERTIARY AND QUATERNARY BRYOZOA. 

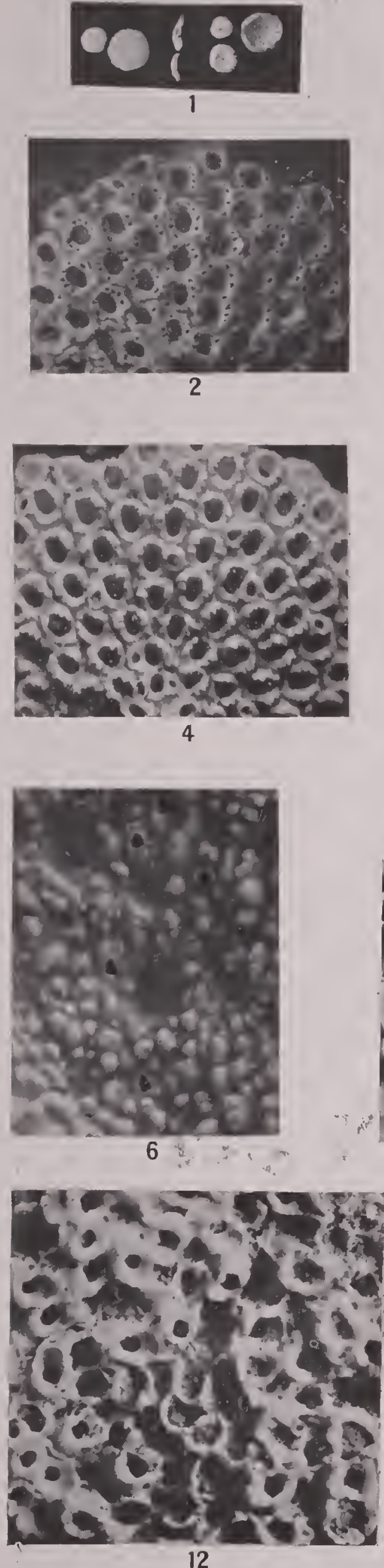
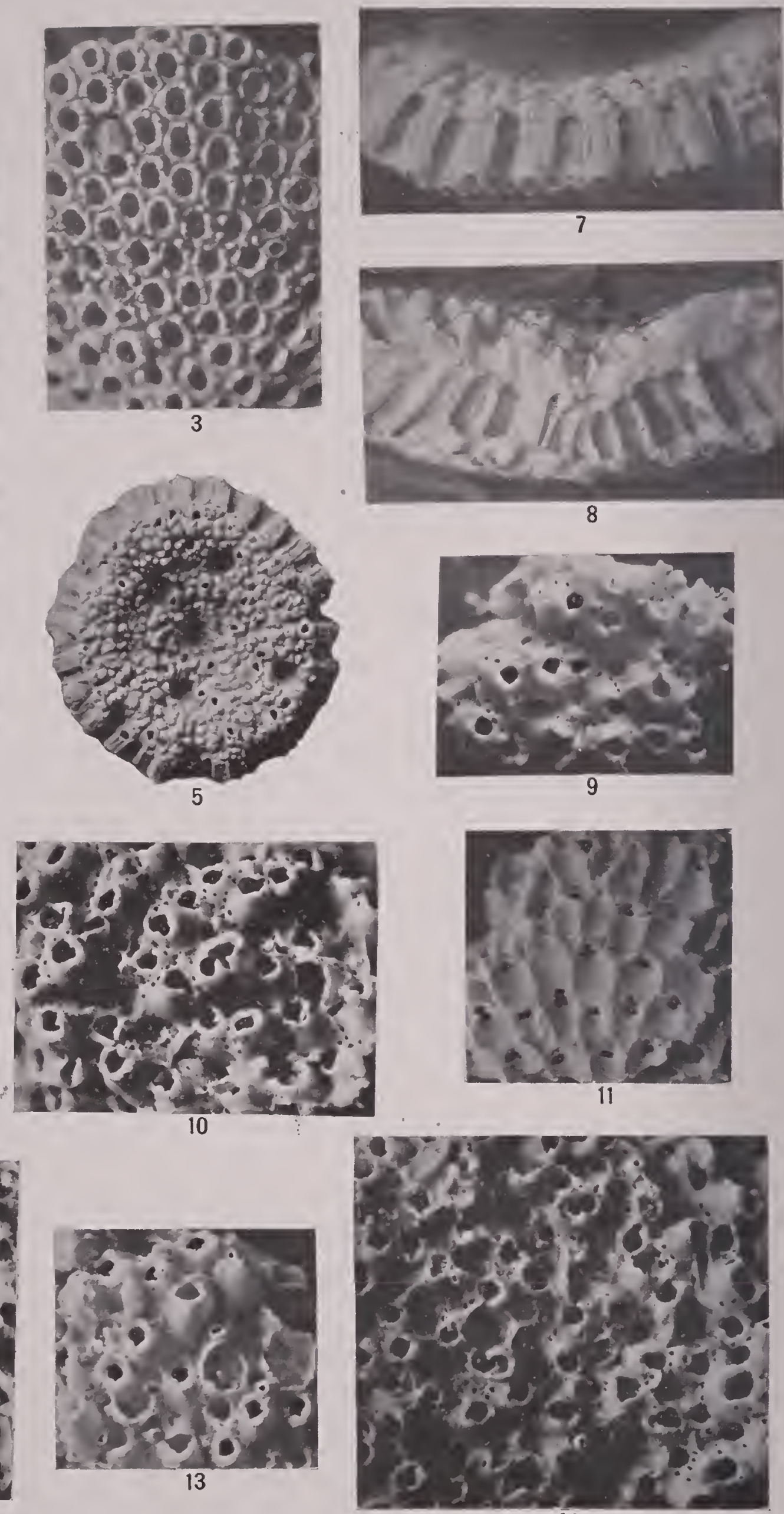

14

NORTH AMERICAN LATER TERTIARY AND QUATERNARY BRYOZOA. 
Plate 7.

F1Gs. 1-8. Mamillopora tuberosa Canu and Bassler, 1919. (Sce also pl. 6, figs, 16-19.) (p. 192.)

1. Group showing the upper, lower, and edge views of the zoarium, natural size.

2. Zoarium with weathered surface, $\times 20$, illustrating that the tubcrosities are hollow.

3. Zooecia, $\times 20$, with onc preserving the oricell, which is hyperstomial and closed by the operculum.

4. Portion of a zoarium, $\times 20$, with the tuberositics around the zooecial apertures well preserved

5. Inner surfaee of zoarium, $\times 10$. The tuberosities, aricularia, and hydrostatie (?) cavities are visible.

6. Portion of figure $5, \times 20$.

7. Edge view of fractured zoarium, $\times 20$, illustrating zooecia open.

8. Similar view, $\times 20$, but with the zooeeia elosed.

Lower Miocene (Bowden marl): Bowden, Jamaica.

Figs. 9-14. Holoporella albirostris Smitt, 1872. (See also pl. 32, figs. 6-10.) (p. 174.)

9. Fragment, $\times 20$, showing zooecia without beak with the typical form of apcrture.

10. Zooecia, $\times 20$, showing interzooeeial avicularia. The oral beak is incomplete and in process of formation.

11. Interior of zooecia, $\times 20$.

12. General aspect of the zooecia with ovicell, $\times 20$.

13. Marginal zooccia, $\times 20$. The deep zooeeia have a beak bearing a small avicularium whieh appears then as isolated.

14. Zooecia, $\times 20$, showing the different aspects of the beak when broken.

Lower Mioeene (Bowden marl): Bowden, Jamaica. 


\section{Plate 8}

Figs. 1-10. Metrarabdolos lacrymosum Canu and Bassler, 1919. (p. 164.)

1. A group of fragments, natural size.

2. Fragment, $\times 6$, showing the little expanded lase.

3. Another fragment, $\times 6$.

4. A worn branch, $\times 20$. The avicularia are absent or little apparent.

5. Zooecia, $\times 20$, with salient peristomes and large triangular a ricularia.

6. Worn zoarial fragment, $\times 20$

7. Ordinary zooecia of a branch, $\times 20$, with short, pointed triangular avicularia.

8. Ordinary zooecia, $\times 20$, with long avicularia.

9. Branch, $\times 20$, with ovicelled zooecia. The oricell is slightly costulated and its frontal is granu . lose.

10. Ovicelled zooecia, $\times 20$, with the ovicell not costulated.

Lower Miocene (Bowden marl): Bowden, Jamaica.

Figs. 11-16. Bracebridgia deformis Canu and Bassler, 1919. (1). 160.)

11. Fragments, natural size.

12. The usual aspect of the zooecia, $\times 20$. The large frontal pore does not perforate the wall.

13. Zooecia at the base of a zoarium, $\times 20$.

14. Zooecia, $\times 20$ with the large frontal pore wanting.

15. Zooecia, $\times 20$, with the peristomial avicularium slightly visible.

16. Interior of zooecia, $\times 20$. The peristomial avicularium is visible, but the frontal pore does not perforate the zooecial wall.

Lower Miocene (Bowden marl): Bowden, Jamaica. 


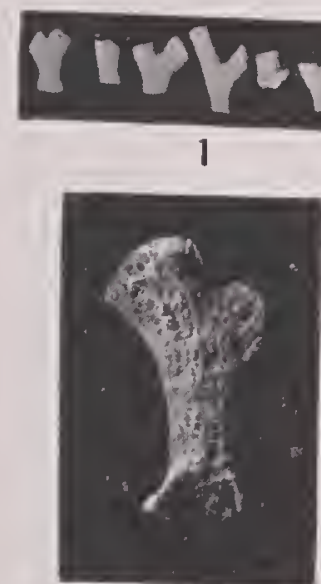

2
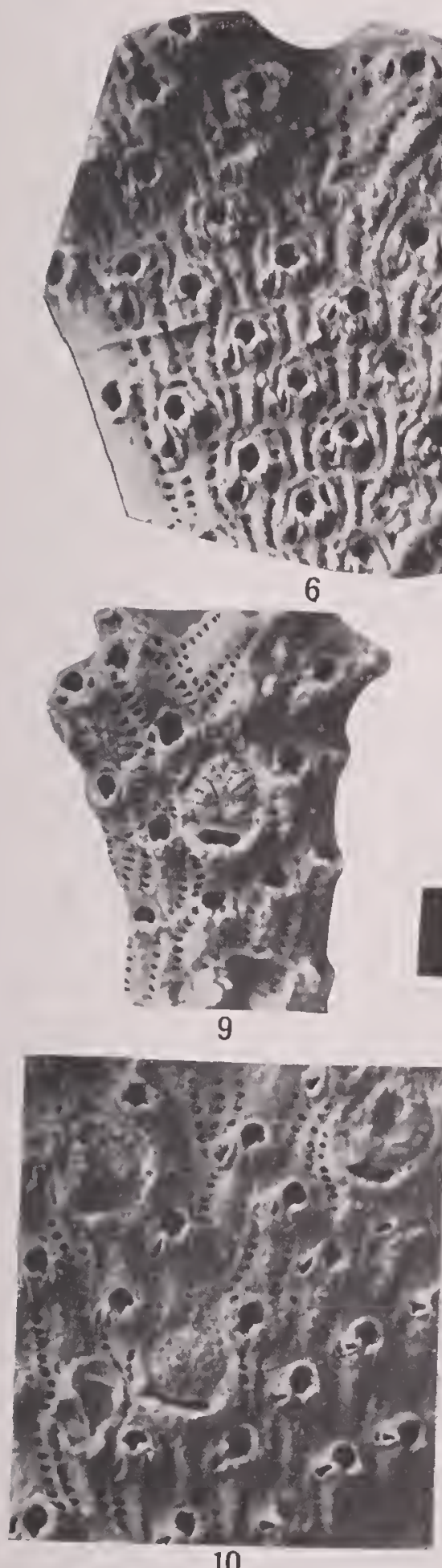

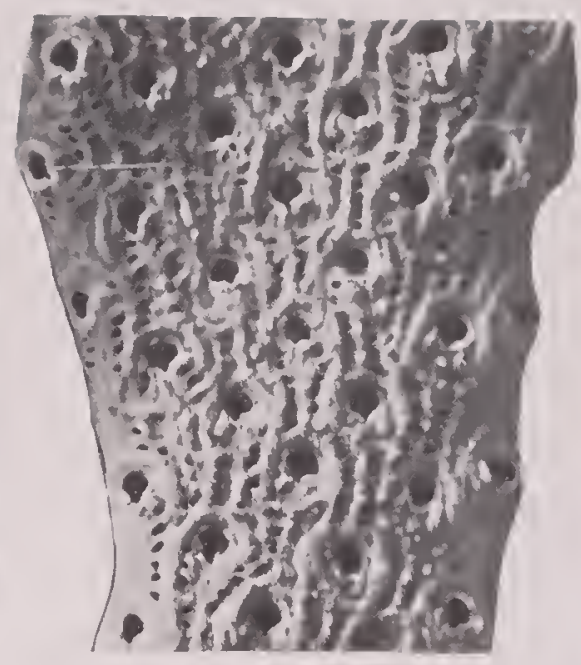

4
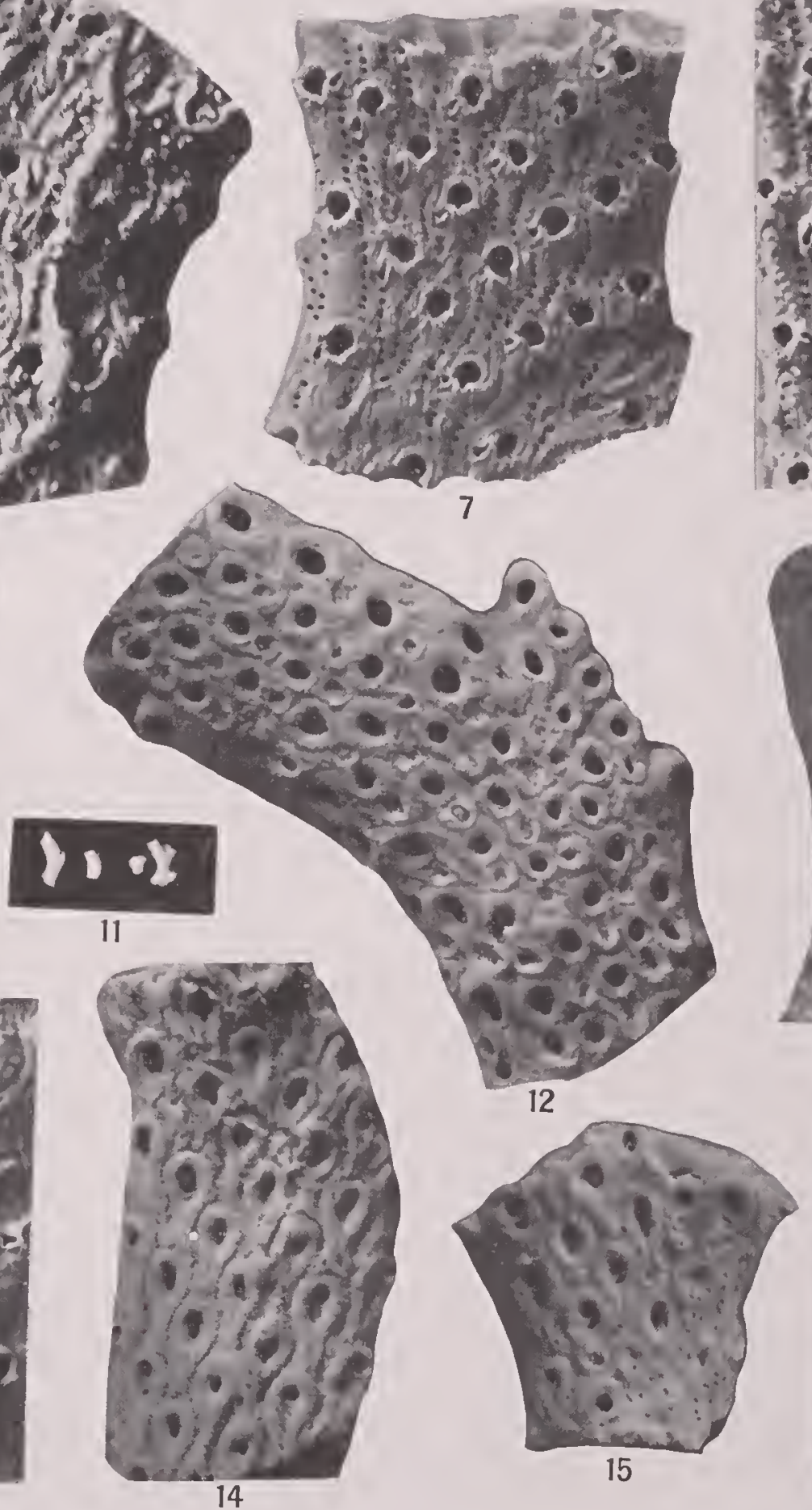

NORTH AMERICAN LATER TERTIARY AND QUATERNARY BRYOZOA.
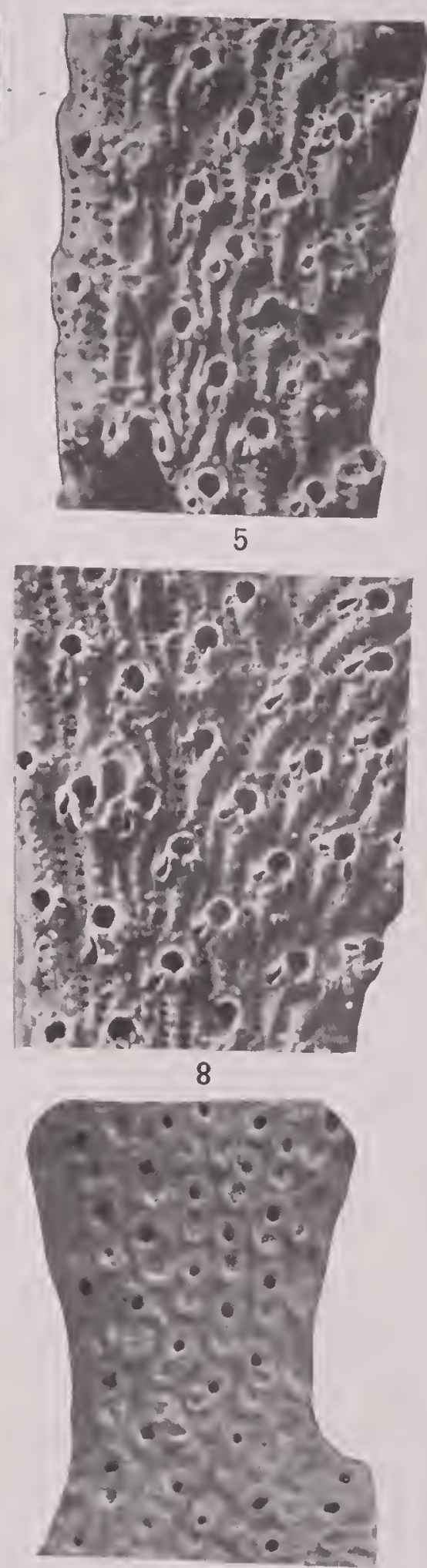

13

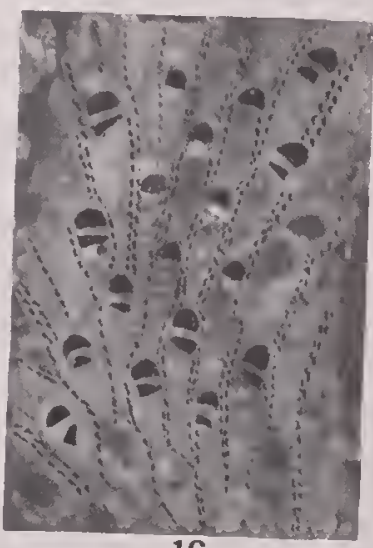

16 

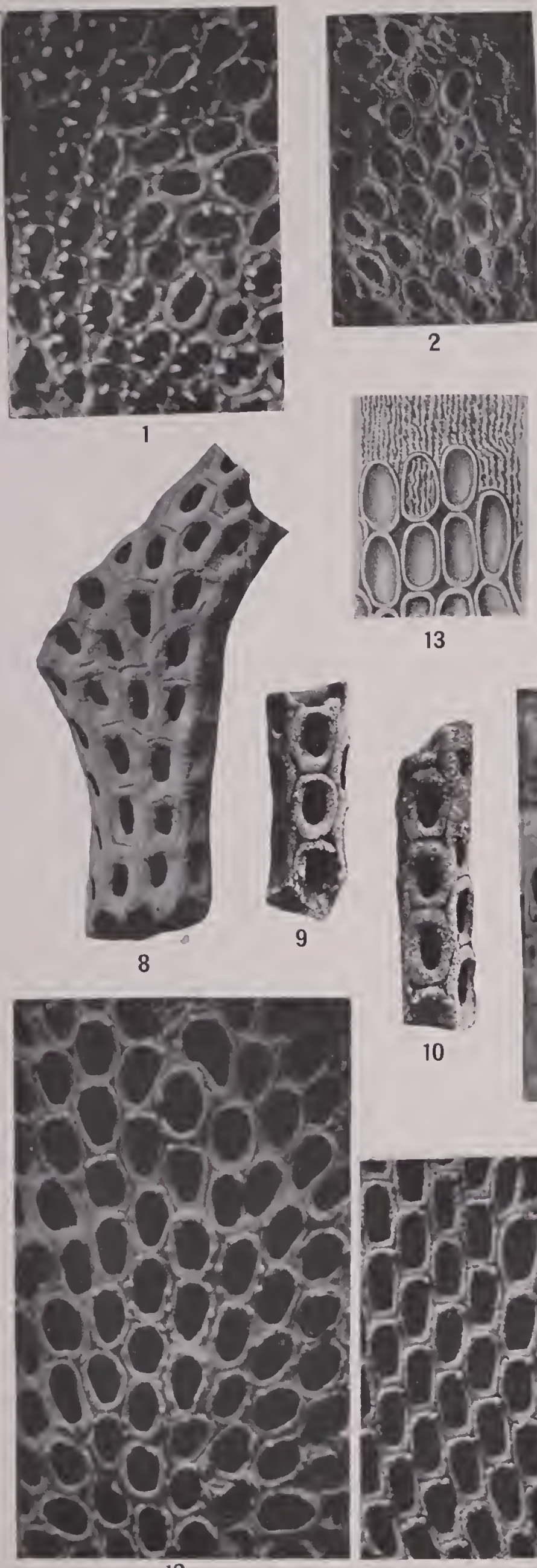

12
13

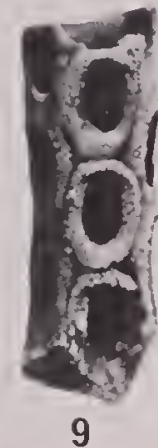

8

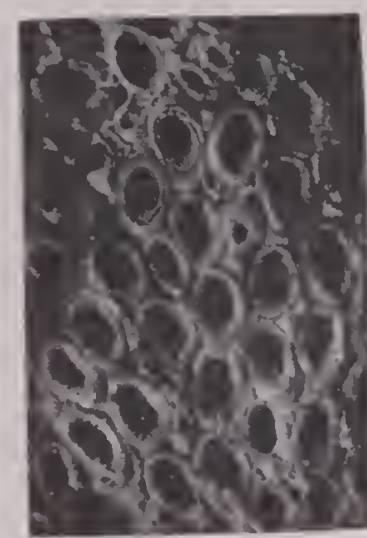

$$
2
$$

C) 1020 (1) 16$)^{\circ}$

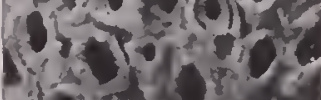
it $5 x=13$

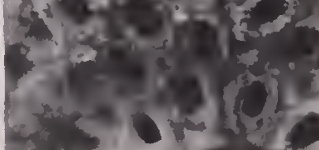
4
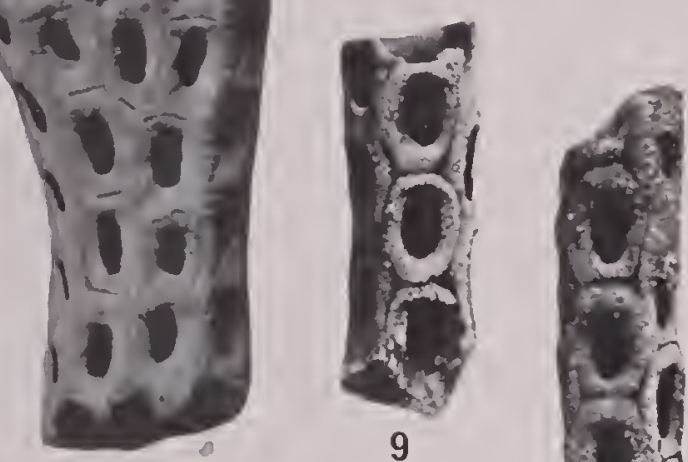
(1)

10 3 bin

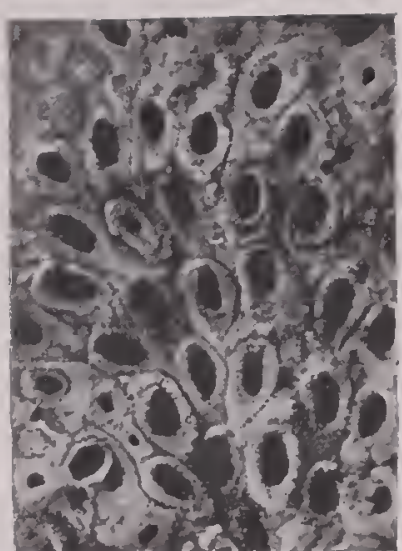

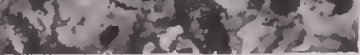

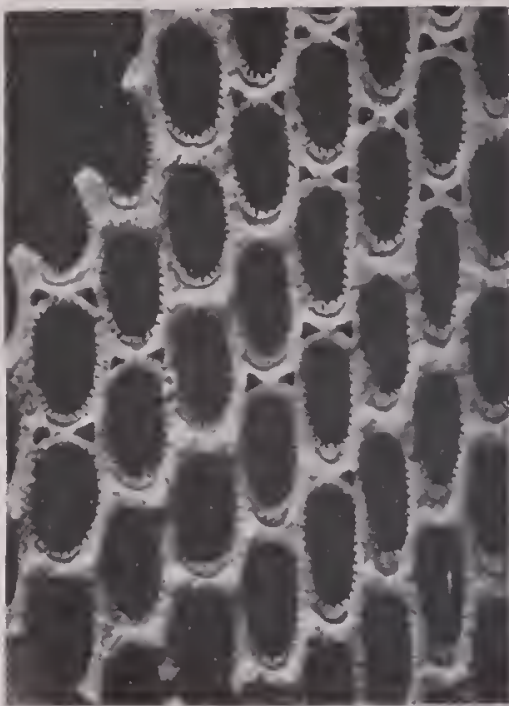

5
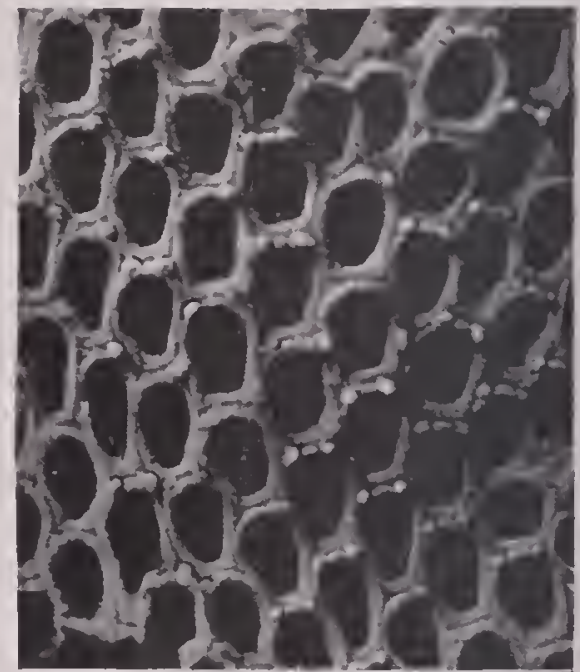

\section{8}
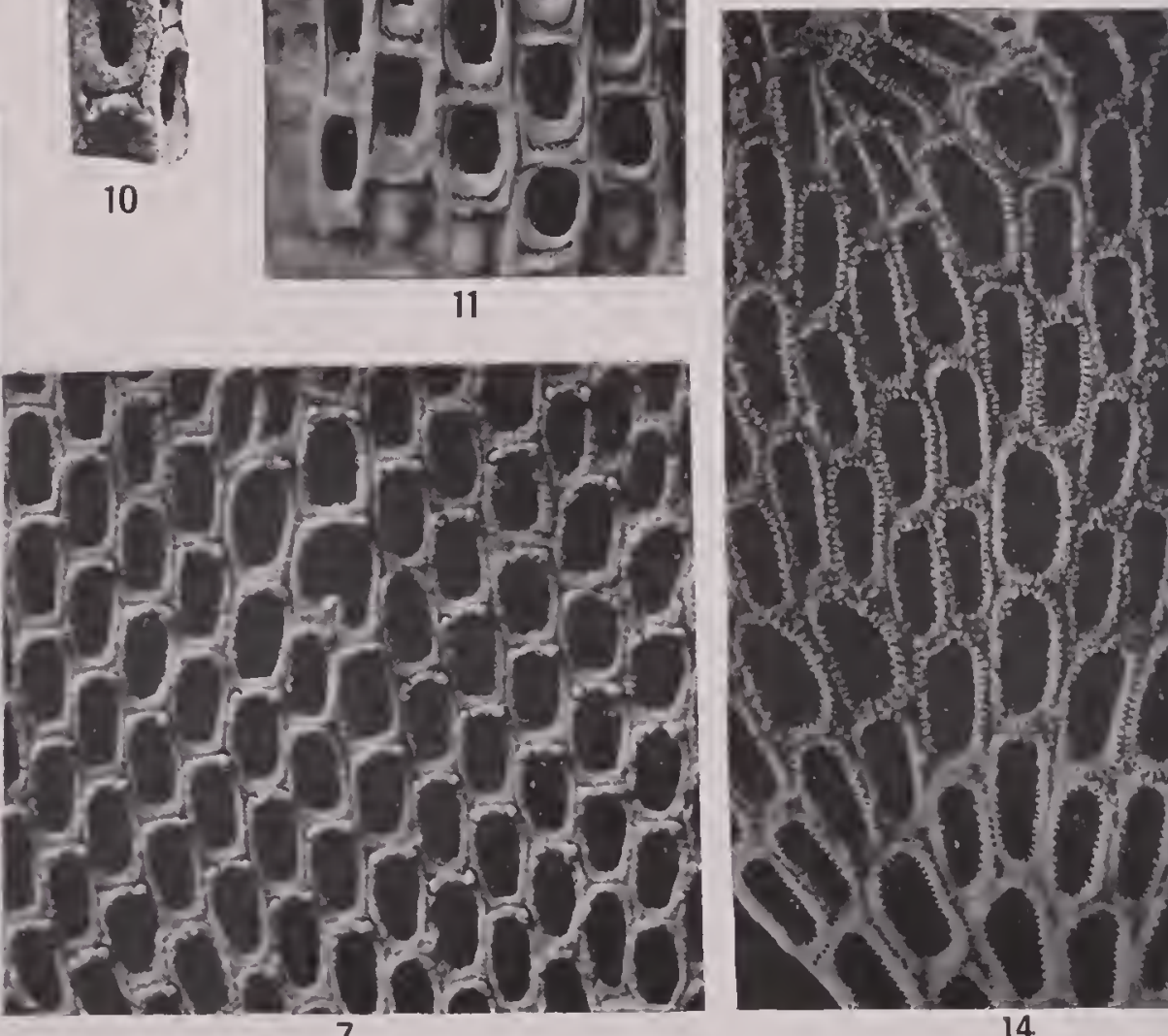

NORTH AMERICAN LATER TERTIARY AND QUATERNARY BRYOZOA. 
Plate 9.

FIG. 1. Membranipora spiculata, new species. (p. 21.)

Zooecia of the incrusting type specimen, $X 20$, showing the curved spicules.

Miocene: Kuhns, ('arteret County, North Carolina.

Figs. 2-4. Pyripora brevicaula. new species. (p. 19.)

2. Portion of the zoalium $\times 20$. showing several of the fusiform heterozooccia.

3. Another zoarium $\times 20$, illustrating the flabelliform growth. Normal and deformed zooecia are present.

4. Zooecia, $\times 20$, with several calcified ones present.

Niocene: Kuhns, Carteret County, North Carolina.

Frg. 5. Conopeum nitidulum Ulrich and Bassler, 1904. (p. 27.)

View of the type specimen $\times 20$ illustrating the small flat cryptocyst and the triangular interopesial spaces.

Miocene (Choptank formation): Pawpaw Point, Maryland.

FIGs. 6, 7. Membranipora fossulifera Uhrich and Bassler, 1904. (p. 20.)

f. An irregular specimen $\times 20$ showing the large interzooecial tubercles, the small spines on the mural rim and some zooecia without tubercles.

Miocene: Kuhns, Carteret County, North Carolina.

7. Photograph $\times 20$ of the type specimen.

The median channel between the walls, giving rise to the specific name, is apparent.

Miocene (Calvert formation): Reeds, Maryland.

Figs. 8-10. Membraniporina vincularina, new species. (p. 26.)

8. A bilamellar zoarium, $\times 20$, referred to this species.

Miocene (Yorktown formation): Petersburg. Virginia.

9,10 . The types of the species, fragments of the free rod-like zoaria, $\times 20$.

Miocene (Choctawhatchee marl): Jackson Bluif, Ocklocknee River, 25 miles southwest of Tallahassee, Florida.

Frs. 11. Acanthodesia rectangularia, new species. (p. 34.)

The incrusting type specimen $\times 20$, showing the rectangular zooecia with deep cryptocyst.

Miocene (Yorktown formation): Petersburg, Virginia.

Frg. 12. Yembranipora tuberimargo, new species. (p. 23.)

Portion of the type specimen $\times 20$ showing both ancestrula and normal zooecia: The single pair of distal tubercles and two pairs of lateral ones are quite visible on some zooecia.

Miocene (St. Mary's formation): Core Point, Maryland.

F1G. 13. Membranipora speciosa, Gabb and Horn, 1862. (p. 44.)

The original figure of this undetermined species.

Miocene? Chiriqui, Central America.

FIG. 14. ICmbraniporina baccata, new species. (p. 25.)

The incrusting, unilamellar zoarium, $\times \geq 0$, illustrating the numerous granules of the mural rim.

Miocene (St. Mary's formation): Bowler's wharf, 18 miles above Urbana, Middlesex County, Virginia. 
Figs. 1-3. Acanthodesia oblongula Clrich and Basster, 1904. (p. 34.)

1. One of the original types of this incrusting species. $\times 20$, illustrating the prominent interzooecial tubercles and the spinose processes (spicules) surrounding the opesium.

Ifiocene (Calvert formation): Plum Point, Maryland.

2. Aspecimen, $X 20$, showing the interzooecial tubercles joined.

Miocene (Choptank formation): Pawpaw Point, Maryland.

3. Another of the original types, $\times 20$, in which there are numerous spinose processes but with the interzoocial tubercles little developed.

Miocene (Choptank formation): Governor Run, Maryland.

Figs. 4-5. Tibracellina pusilla, new species. (p. 35.)

4. Ancestrular region of the incrusting zoarium, $\times 20$.

Miocene (Duplin mark): Natural Well, 2 miles southwest of Magnolia, North Carolina.

5. I well-rleveloped zoarium, $\times 20$, illustrating normal and regenerated zooccia and the small but salient vibracula.

Pliocene (Caloosahatchee marl): Shell Creek, De Soto County, Florida.

Fics. 6-7. Fibracellinu simplex, new species. (p. 35.)

6. The incrusting zoarium, $\times 20$, showing the ancestrular region. The vilracula are very rare but heterozooecia are present.

Miocene (Choctawhatchee marl): Jackson Bluff, Ocklocknee River, 25 miles southwest of Tallahassee, Florila.

7. A small zoarium, $\times 20$, showing the calcified ancestrula which engenders five zooecia. Several regenerated zooecia are present.

Miocene (Duplin marl): Natural Well, 2 miles southwest of Xagnolia, North (arolina.

Fia. 8. Conopeum germanum Uhich and Bassler. 1904. (p. 27.)

The incrusting type specimen, $\times 20$, illustrating the interopesial cavities and other characteristice.

Miocene (Cloptank formation): Dover Bridge, Maryland.

FIg. 9. Hemiseptella filimargo, new species. (p. 71)

The incrusting type specinen, $\times 20$. The salient rim separating the zooecia and the two large lateral as well as the smaller spicules of the opesium are evident.

dliocene (Yorktown formation): York River, Virginia.

Fig. 10-14. Ifembranipora flabellate Canu, 1904. (p. 20.)

10. Surface of an outer lamella, $\times 20$, with the tubercles worn away and the zooecia grouped around a false ancestrula.

llioc ene (Yorktown formation): Yorktown, Virginia.

11. Portion of a zoarium, $\times 20$, with the zooecia separated by interopesial cavities.

12. Young zooecia, $\times 20$, with thin nural rims. Other zooecia of this same zoarium are normal, tuberose or separated by interopesial cavities.

13. Zooecia, $\times 20$, with granulose mural rims

Miocene (Yorktown formation): Near Suffolk, Virginia.

14. Photograph of an inner lamella, $\times 20$, with the tubercles preserved.

lliocene (Yorktown formation) Yorktown, Virginia. 


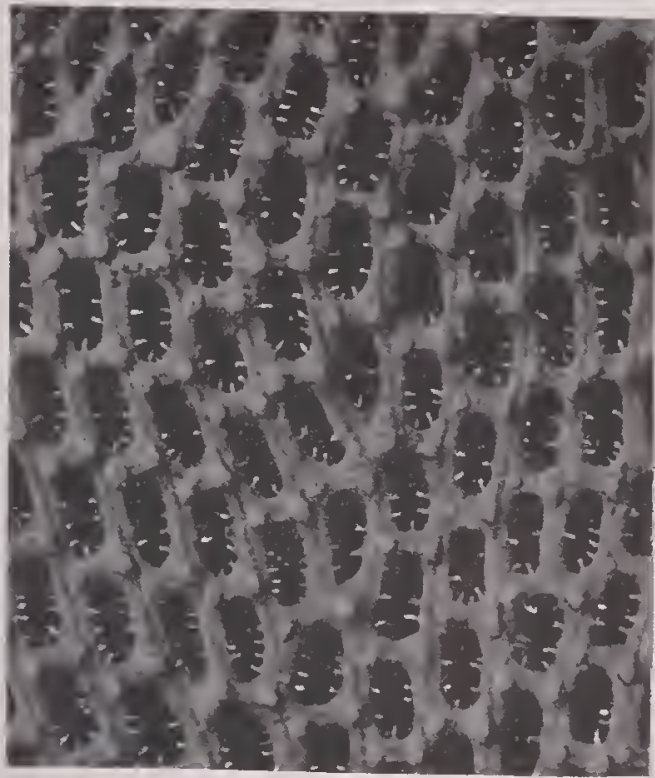

1
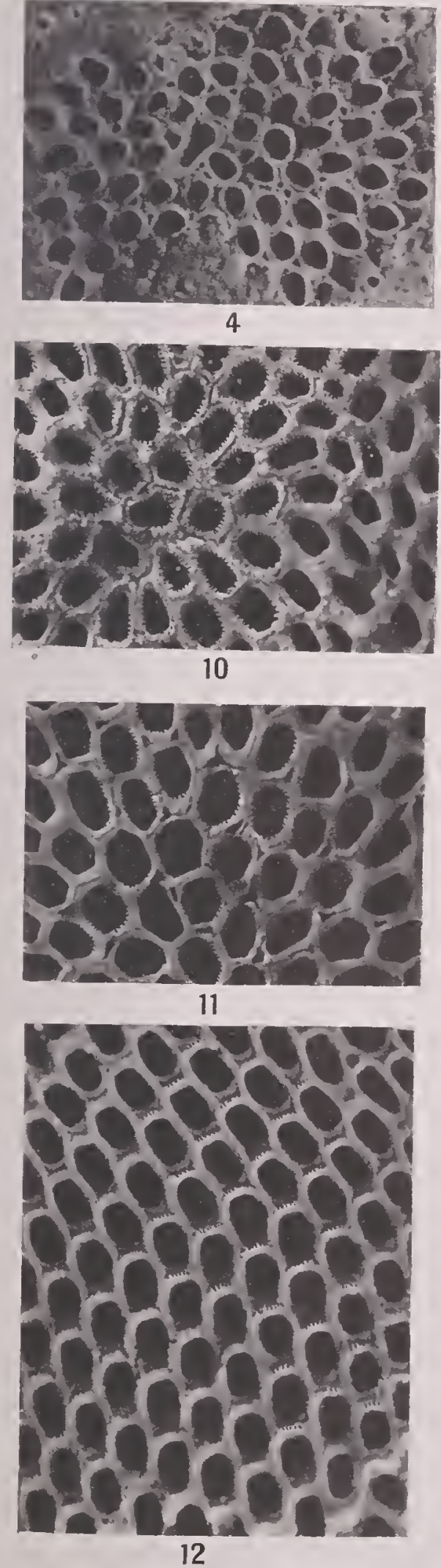

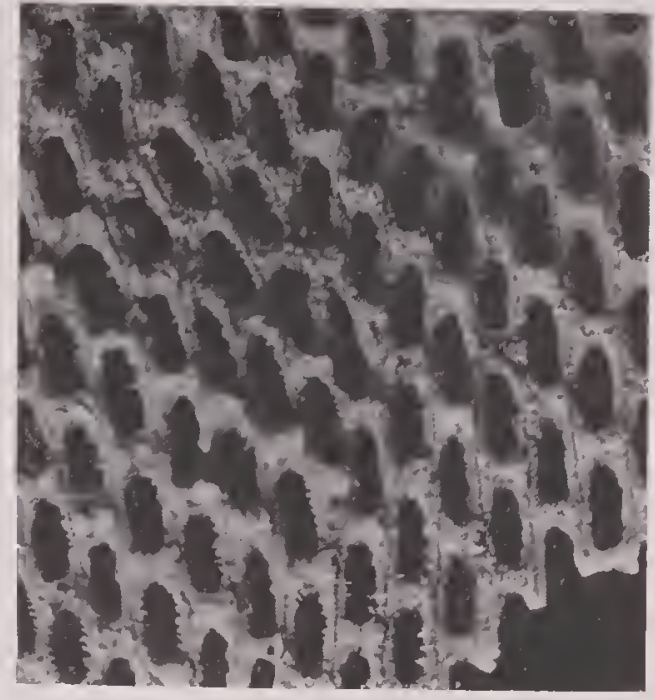

2
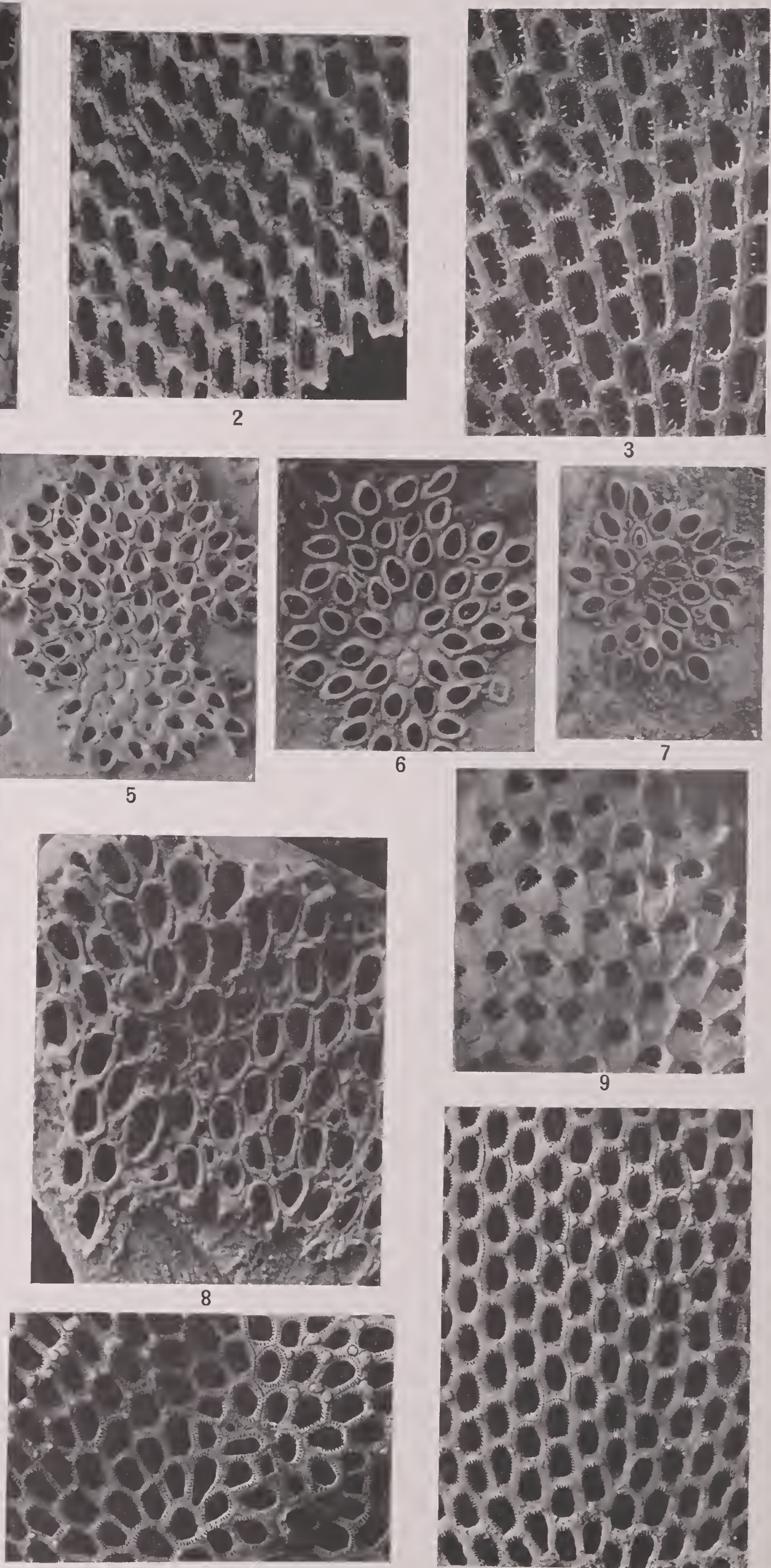

13

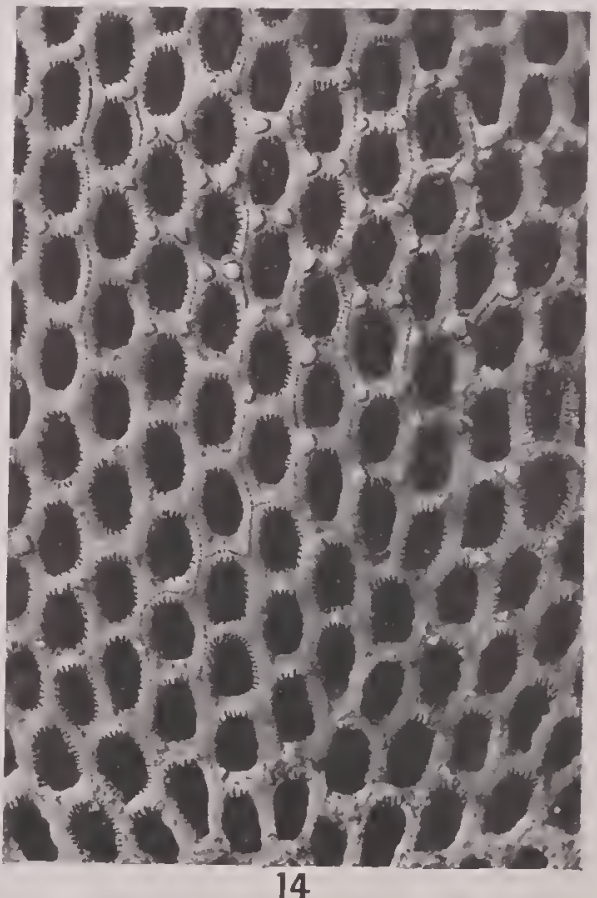



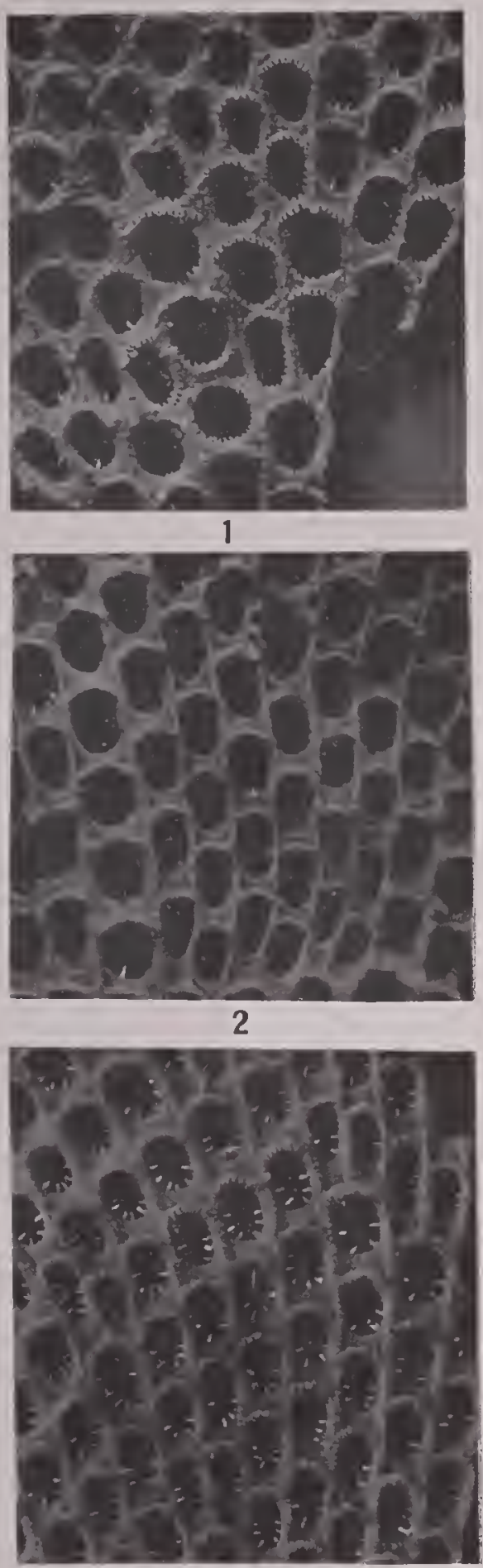

3

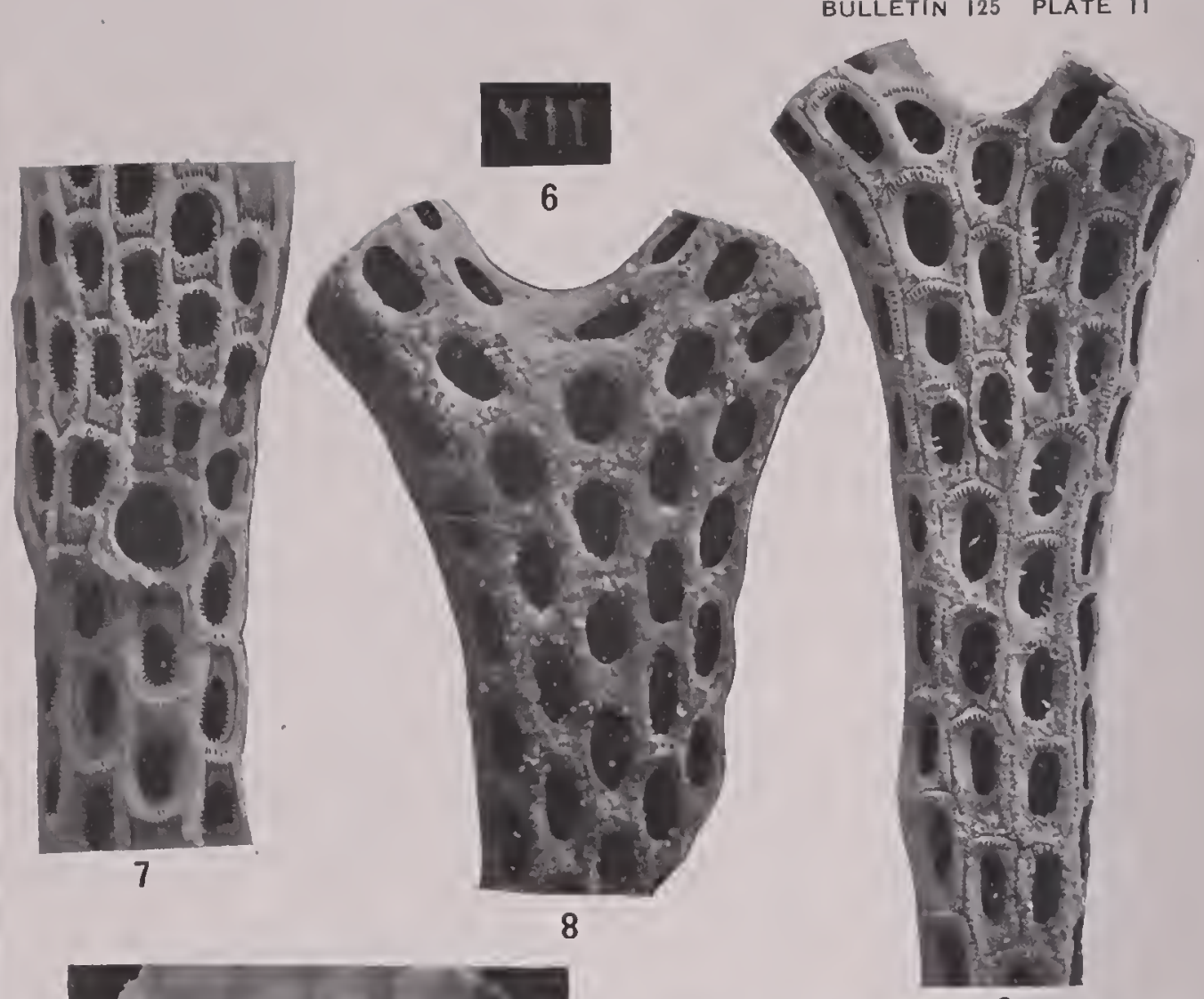

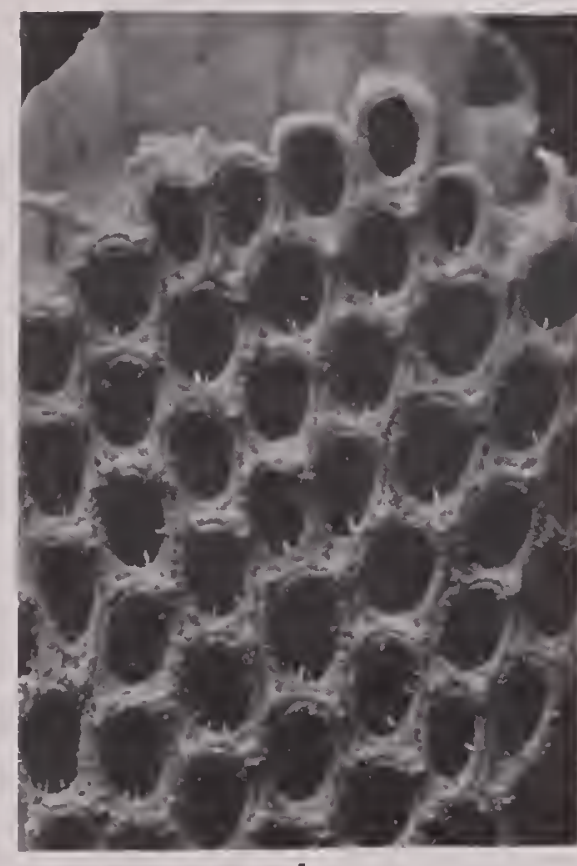

4

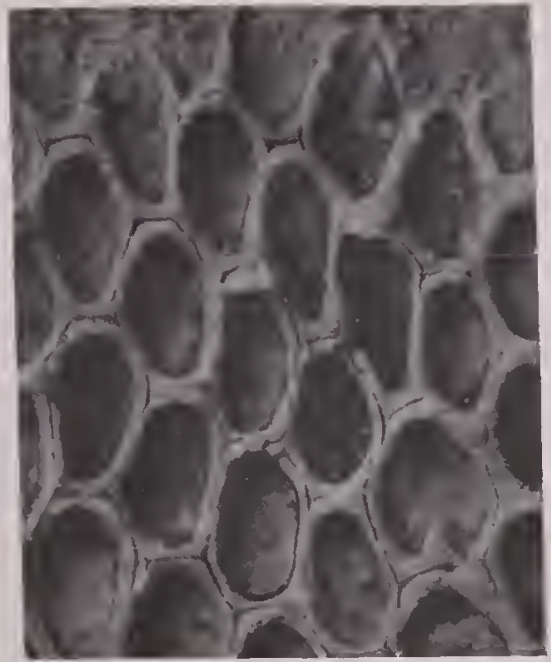

9

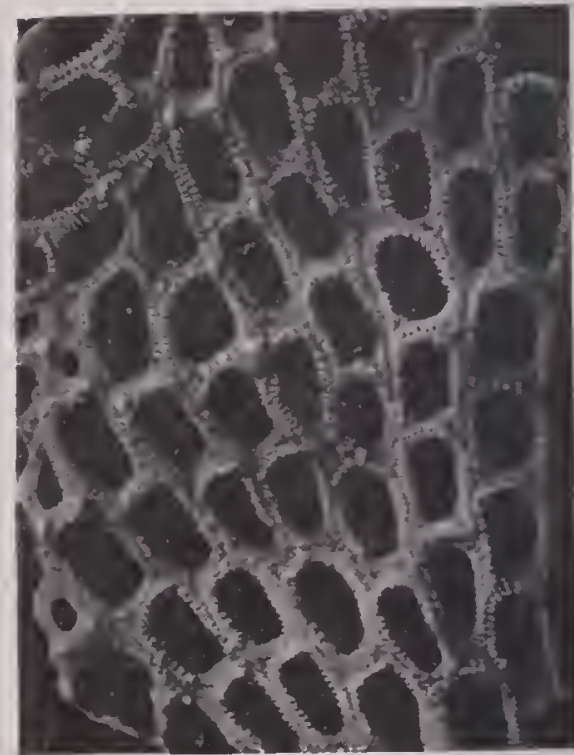

5

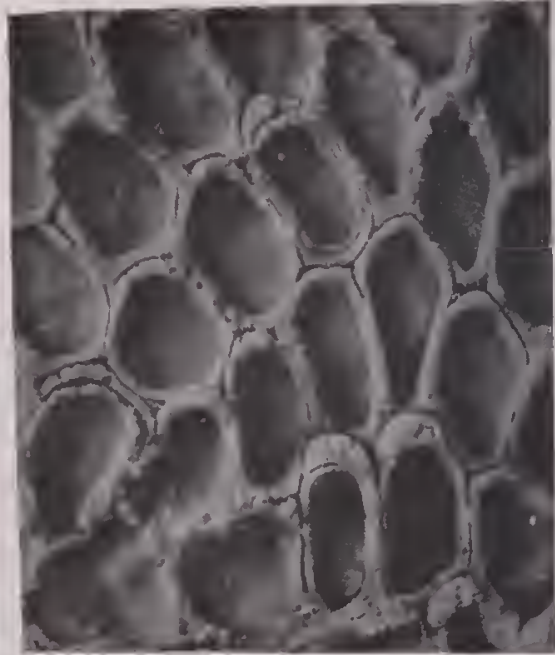

12

NORTH AMERICAN LATER TERTIARY AND QUATERNARY BRYOZOA.

FOR EXPLANATION OF PLATE SEE PAGE 266. 


\section{Plate 11.}

FIGs. 1-3. Acanthodesia savarti Audouin, 1826, forma typica. (p. 31.)

1. An incrusting specimen $\times 20$, of the typical form of the species, illustrating the considerable micrometric variations. Traces of the spicules in the opesium are visible.

Miocene: Bowler`s wharf, 18 miles above Urbana, Middlesex County, Yirginia.

2. An example $\times 20$, with young zooecia.

3. Surface of a free, multilamellar zoarium, $\times 20$, with numerous spicules, in the opesium.

Miocene (Yorktown formation): Near Suffolk, Yirginia.

FIG. 4. Acanthodesia satarti forma bifoliata Ulrich and Bassler, 1904. (p. 33.)

Surface of the bilamellar type zoarium, $\times 20$, showing the thin mural rini, the absence of the cry $p^{\text {p- }}$ tocyst, the tubercles at the angles and and spicules in the opesium.

Miocene (Choptank formation): Jones Wharf, Maryland.

Fias. 5-9. Acanthodesia savarti forma delicatula Busk, 1859. (p. 33.)

5. An incrusting example, $\times 20$, referred to this form.

Miocene: Bowler's wharf, 18 miles above Urbana, Virginia.

6. Zoarial fragments, natural size.

7. A branch, $\times 20$, on which the zooecia are developed in opposite directions.

8. Another branch, $\times 20$, in which the cryptocyst is small and the superficial ornament is obscured by fossilization.

9. A well preserved branch, $\times 20$, showing the unequal development of the cryptocyst.

Miocene (Choctawhatchee marl): Jackson Bluff, Ocklocknee River, 25 miles soutlwest of Tallahassee, Florida.

Figs. 10-12. Membrendoecium grande, new species. (p. 36.)

10. Portion of the zoarium $\times 20$, with irregular zooecia, one showing the endozooecial ovicell.

Miocene (Duplin marl): Wilmington, North Carolina.

11. Marginal, elongated zooecia, $\times 20$.

12. Another portion of the same zoarium $\times 20$, with several ovicelled zooecia.

Pliocene (Waccamaw marl): Waccamaw River, Horry County, South Carolina. 
F1øs. 1, 2. Ifembrendoccium parricapitatum, new species. (p. 36.)

1. The incrusting type specimen $\times 20$, with ancestrular, normal, ovicelled and regenerated zooecia.

Miocene (Choctawhatchee marl): Jackson Bluif, Ocklocknee River, 25 miles southwest of Tallahassee. Florida.

2. An Early Miocene specimen, $\times 20$, referred to this species.

Lower Miocene (Bowden marl): lBowden, Jamaica.

Fig. 3. Callopora parvirostris, new species. (p. 41.)

A portion of the type speeimen, $\times 20$, with normal and oricelled zooccia, exhiliting the small triangular, suberect aricnlarium.

Miocene (Calvert formation): I mile south of Parkers (reek, Calvert County. Maryland.

Figs. 4-5. Allerina cesticellu. new species. (p. 39.)

4. Aneestrular region of the incrusting zoarinm. $\times 20$, showing regenerated, calcified and ovicelled zooecia. The ovieclls have a prominent collar.

5. Another view of the same zoarium, $\times 20$, exhibiting regenerated zooecia and numerous salien $t$ spines on the zooccial walls.

Miocene (Duplin marl): Natural Well, 2 miles sonthwest Magnolia, Duplin County, North Carolina.

Fra, 6. Ogimalina parvula Litrieh and Bassler, 1904. (p. 37.)

The incrusting type specimen $\times 20$. 1 small cryptocyst and often a small convex gymnocyst are present.

Miocene (Calvert formation): Reeds, Maryland.

Fir. 7. Membraniporidra paria, new species. (p. 39.)

The imperfect type speeimen, $\times 20$, with two ovicelled zooecia.

Miocene (Choctawhatchee marl): Jackson Bluff, Ocklocknee River, 25 miles southwest of Tallahassee, Florida.

Figs, 8, 9. Dakaria torquata D'Orbigny, 1839. (p. 98.)

8. Portion of the inerusting zoarinm, $\times 20$, with ovicelled zooecia.

9. Normal zooecia, $\times 20$, illustrating the characteristic broad sinus.

Miocene (Yorktown formation): 3 miles southwest of Petersburg, Virginia.

F'1G. 10. IIippodiplosia bigibbera, new species. (p. 131.)

The incrusting zoarium. $\times 20$, showing the aperture deformed by two frontal gibbosities

Miocene (Yorktown formation): 3 miles southwest of Petersburg, Virginia.

Fir. 11. Callopora Tanecnlata, new species. (p. 41.)

The inerusting type specimen, $\times 20$, showing ovicelled aud normal zooccia, diatellas and the large lanceolate avicnlaria.

Miocene (Yorktown formation): 3 miles southwest of Petersburg. Virginia.

F1G. 12. Callopora dumerilii Savigny-Audouin, 1826. (See also pl. 1, fig. 2; pl. 2, fig. 23.) (p. 40.)

Plotograph of a specimen, $\times 20$, referred to this species

Lower Miocene (Chipola marl): Chipola River, Calhoun County, Florida.

256 

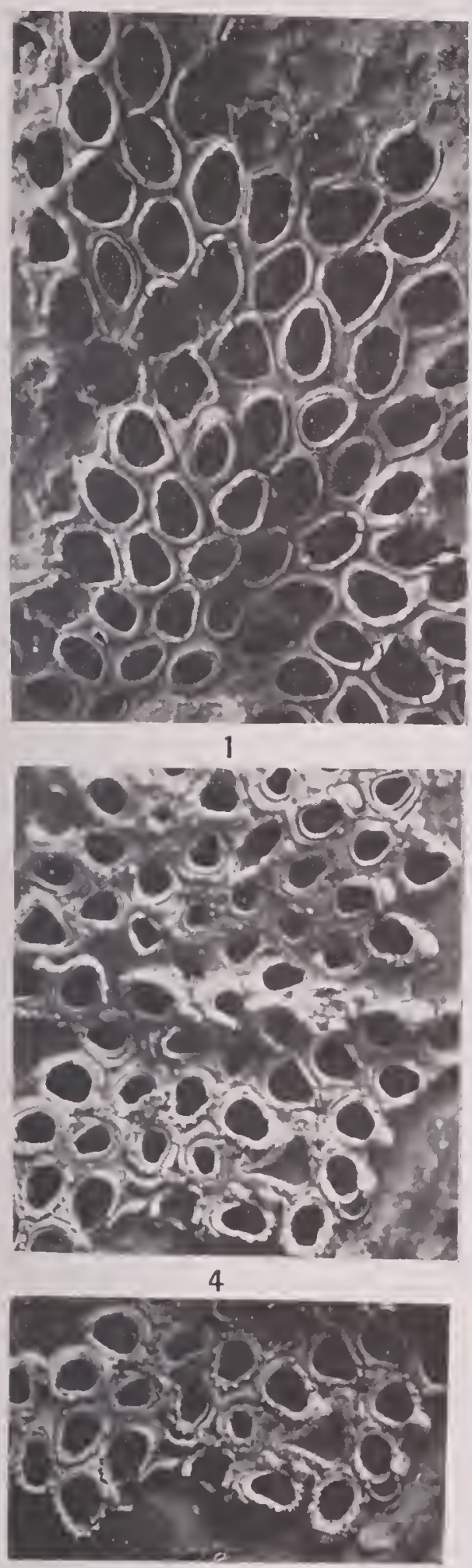

5

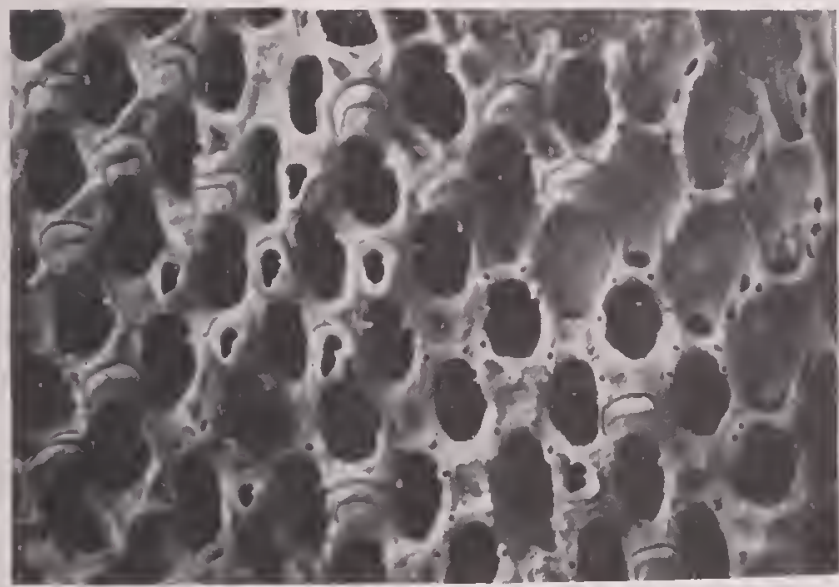

11
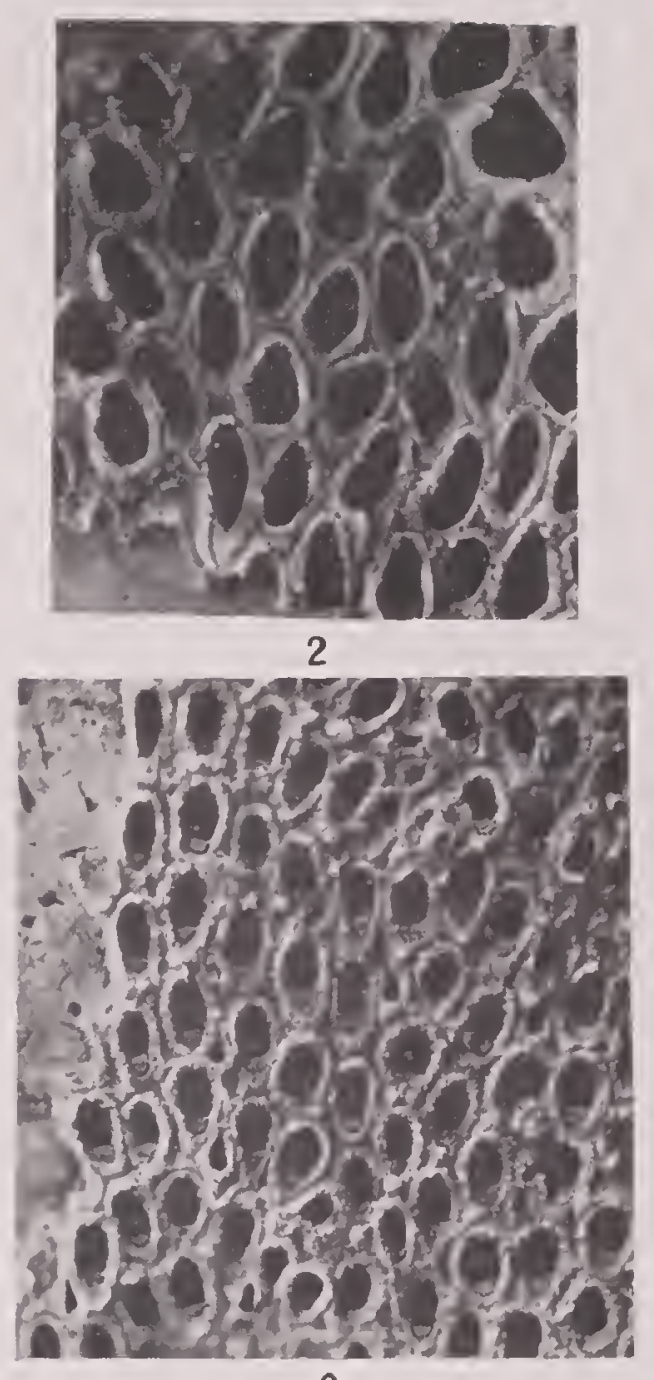

6

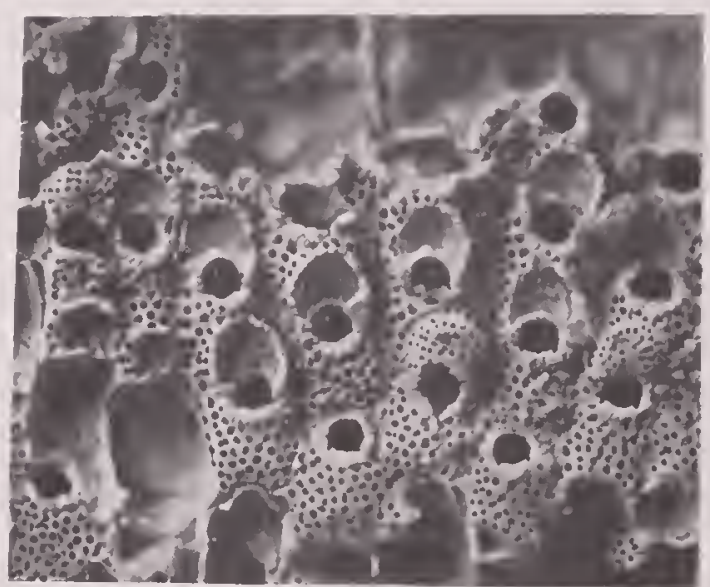

8

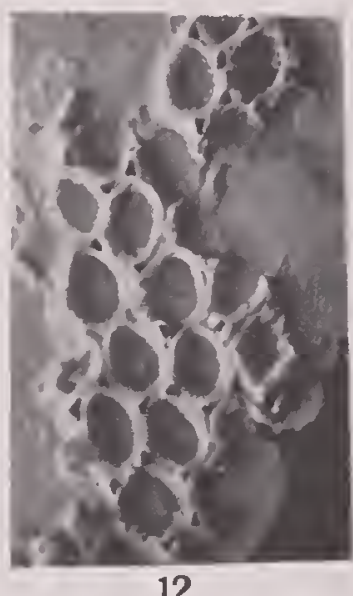

12

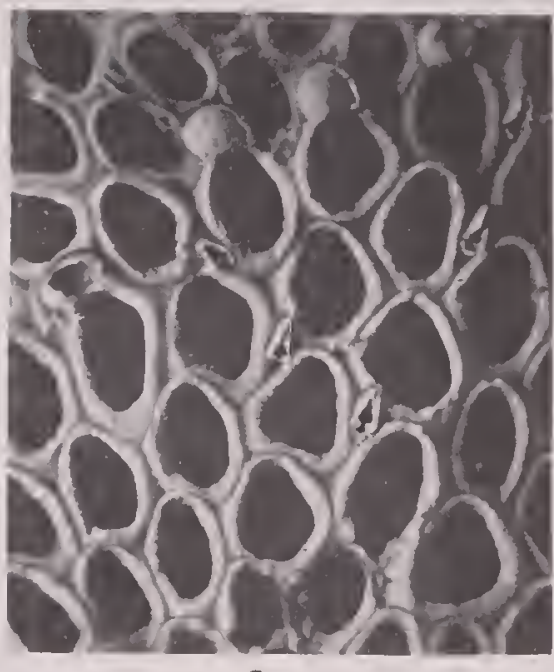

3

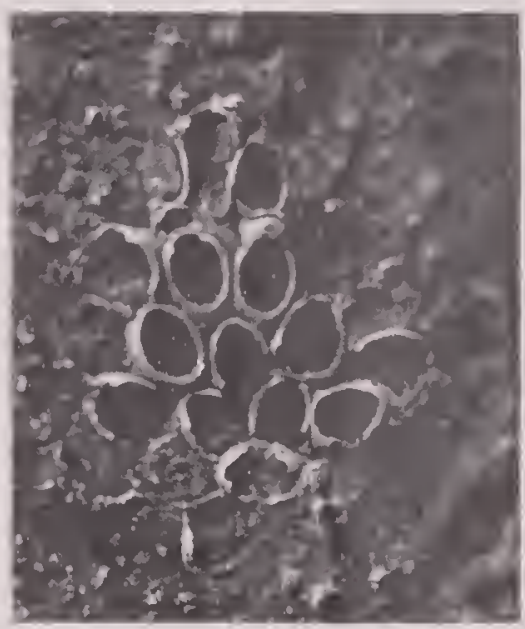

7

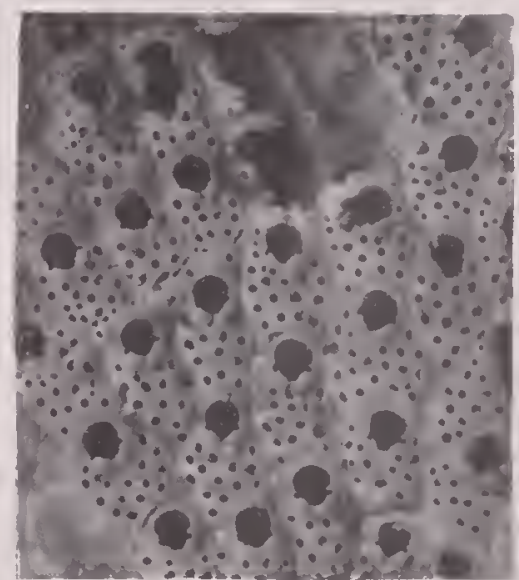

10

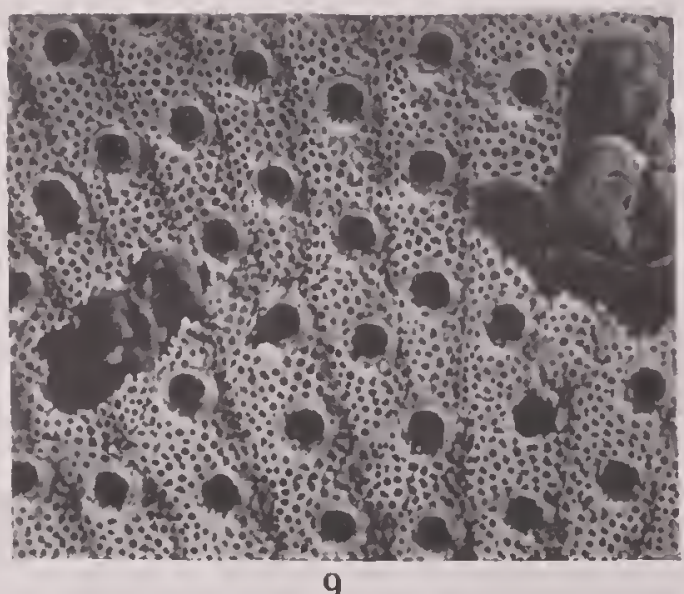



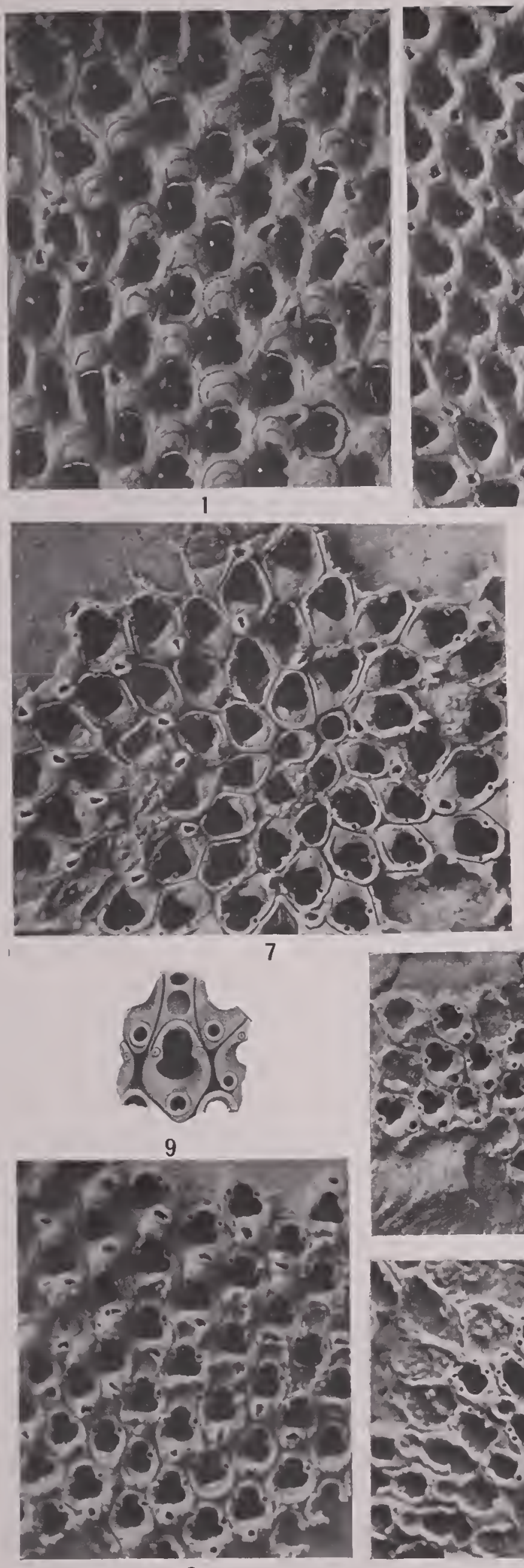

10
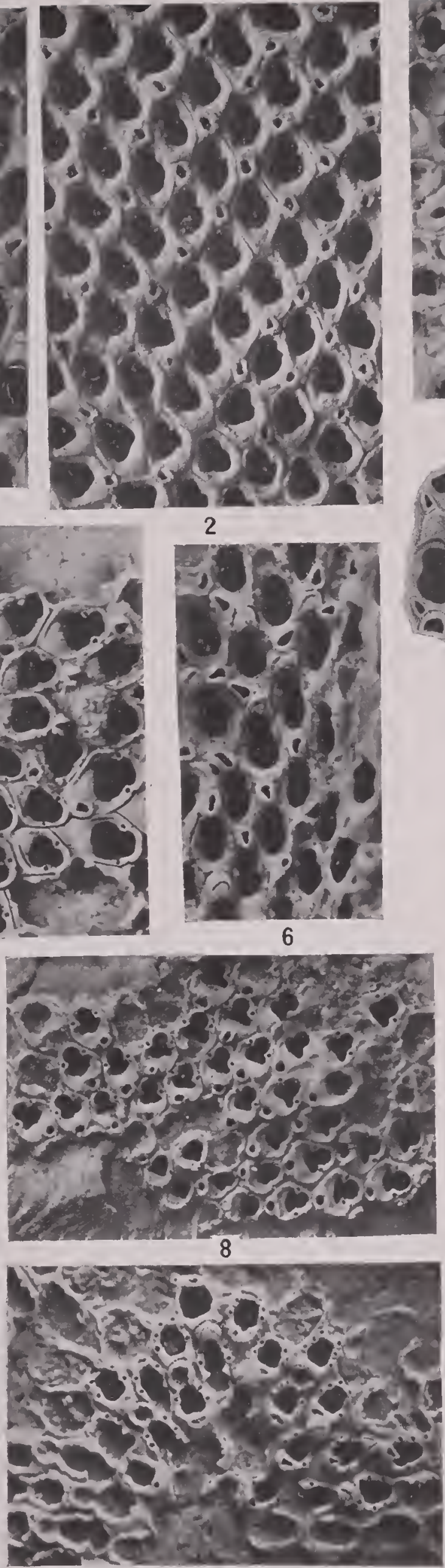

11

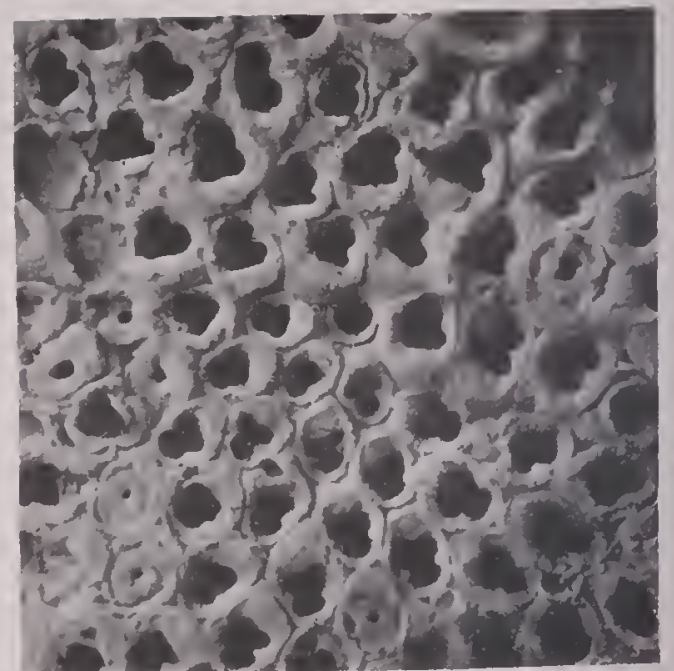

3
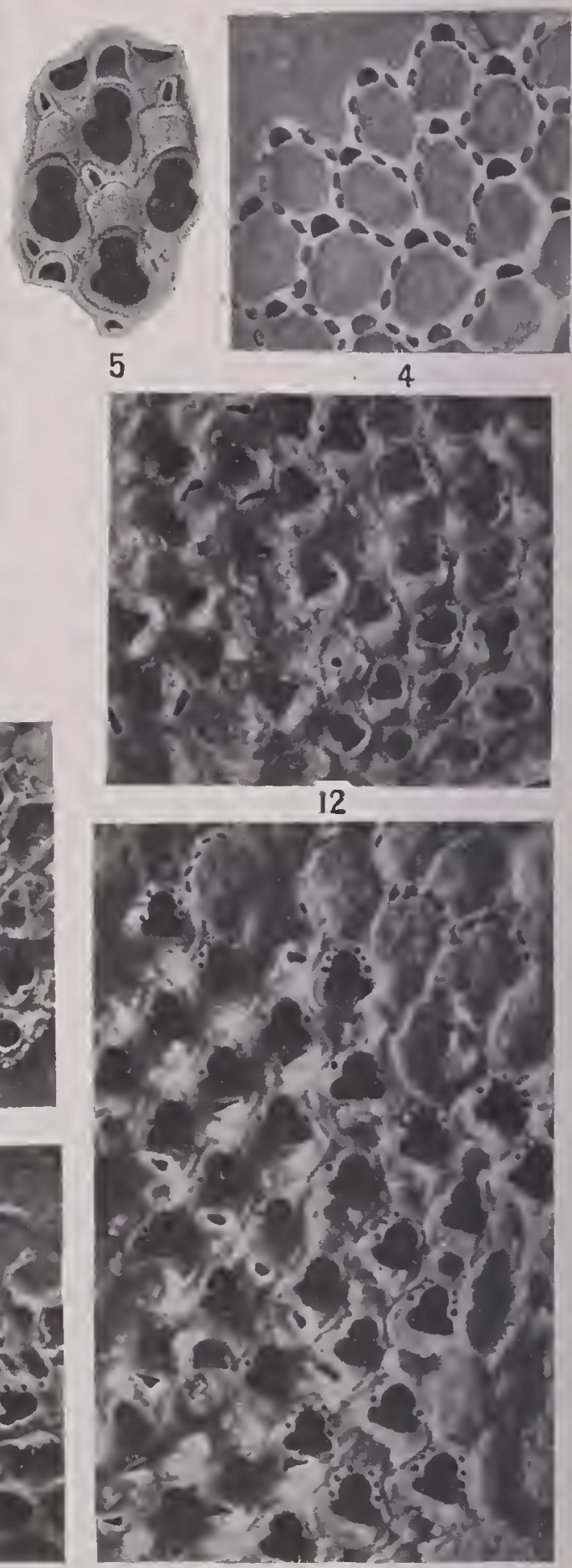

13

NORTH AMERICAN LATER TERTIARY and QUATERnaRY Bryozoa,

FOR EXPLANATION OF PLATE SEE PAGE 257 
Plate 13.

FIGs. 1-6. Amphiblestrum constrictum Ulrich and Bassler, 1904. (p. 44.)

1. Portion of the incrusting zoarium, $\times 20$, showing numerous ovicelled zooecia, a giant zooecium, and deformed primoserial zooecia.

2. Nonovicelled zooecia, $\times 20$.

3. Zoarium, $\times 20$, exhibiting the ancestrula, calcified zooecia and regenerated zooecia.

4. Worn zooecia, $\times 20$, exposing the dietellae.

Pliocene (Waccamaw marl): Waccamaw River, Horry County, South Carolina.

5. Drawing of several zooecia of the type specimens, $\times 17$.

6 . A portion of the type specimen, $\times 20$, showing zooecia with nontrifoliate opesia. The lateral condyles are replaced by serrate denticles.

Miocene (St. Mary's formation): Cove Point, Maryland.

Fig. 7. Amphiblestrum tenuiparietis, new species. (p. 45.)

The incrusting type $\times 20$, showing the ancestrula and surrounding zooecia, all with thin mural rim.

Miocene (Choctawhatchee marl): Jackson Bluff, Ocklocknee River, 25 miles southwest of Tallahassee, Florida.

Figs. 8-10. Ramphonotus agellus Ulrich and Bassler, 1904. (p. 47.)

8 . The type specimen, $\times 20$, showing the trifoliate opesium and the avicularia oriented in the zooecial axis.

9. Drawing of a zooecium of the same, more enlarged.

Miocene (St. Mary's formation): Cove Point, Maryland.

10. An example, $\times 20$, containing both ovicelled and unovicelled zooecia.

Miocene (St. Mary's formation): Bowler's wharf, 18 miles above Urbana, Middlesex County, Virginia.

Fugs. 11-13. Ramphonotus asperus, new species. (p. 46.)

11. Specimen, $\times 20$, showing ovicelled zooecia, unovicelled zooecia with 6 spines and worn zooecia exposing the dietellae.

12. The incrusting zoarium $\times 20$, illustrating the ancestrular region with several calcified zooecia.

13. Another portion of the same specimen $\times 20$, showing both ovicelled and unovicelled zooecia, and the dietellae.

Miocene (Yorktown formation) Yorktown, Virginia. 
Plate 14.

Fig. 1. Chaperia parrispina, new speeies. (p. 5t.)

The type specimen $\times 20$, illustrating the absence of large distal spines which are replaeed by very small fragile ones.

Viocene (Choctawhatehee marl): Jaekson Bluff, Oeklocknee River, 25 miles southwest of Tallahassee, Florida.

Figs. 2-4. Chaperia caminosa U7rich and Bassler, 1904. (1) 54.)

2. One of the original types, $\times 20$, with ovieelled zooecia and the salient triangular avicularium well developed.

3. Another specimen not so well preserverl, $X 20$, showing the ordinary zooecia.

4 . View of a zoarium, $\times 20$, with the ovicells l roken.

Miocene (Choptank formation): Jones Wharf, Maryland.

Fin. 5. Télumelln elongata, new species. (p.58.)

The incrusting zoarium, $\times 20$, with large, elongated zooecia, several of which show the ovicell.

Miocene (Duplin marl): Natural Well, 2 miles southwest of Magnolia, North Carolina.

Fir. 6. Florilina minima, new species. (p. 57.)

The incrusting zoarium, $\times 20$, showing both the ancestrular and marginal areas.

Miocene (Duplin marl): Natural Well, 2 miles northwest of Magnolia, North Carolina.

Figs. 7, S. Florilina regularis. new species. (p. 5i.)

7. The external layer of the lamellar incrusting yoarium, $\times 20$.

Miocene (Duplin marl): Wilmington, North Carolina.

8. A variety of this species, $\times 20$, distinguished by its slightly smaller zooecia.

Miocene (Duplin marl): Natural Well, 2 miles soutlurest of Magnolia, Duplin County, North Carolina.

Fig. 9. Ilemiseptella fistula Ulrich and Bassler, 1904. (p. 73.)

The original type, $\times 20$, showing the spicules on the inferior border.

Miocene (St. Mary's formation): St. Marys River, Maryland.

FIG. 10. IIemiseptella? lacinia Tuomey and Holmes, 1857. (p. 70.)

The original figure of this doubtful species which las not been rediscovered.

Miocene: Smith's, Goose Creek, South Carolina.

FIg. 11. Hemiseptella rectangulata, new species. (p. 74.)

Photograph of the incrusting zoarium, $\times 20$, showing the rectangular form of the zooecia, the minute spinose processes, and the absence of dietellae.

Miocene (Duplin marl): Wilmington, North Carolina.

Figs. 12, 13. Steganoporclla magnilabris Busk, 1854. (p. 63.)

12. Surface of a zoarium, $\times 20$, showing the polypidian tube and the opesiules.

13. An example, $\times 20$, with both small (a) and large (B) zooecia, and illustrating clearly the large lip under which is a polypidian tube.

Pliocene (Caloosahatchee marl): Monroe County, Florida.

258 


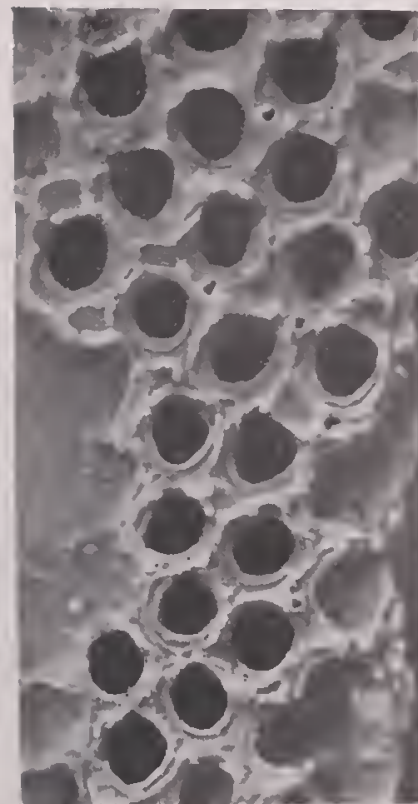

1

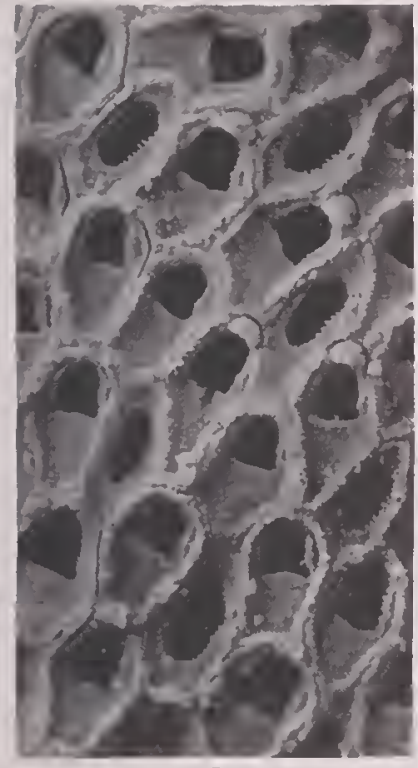

5
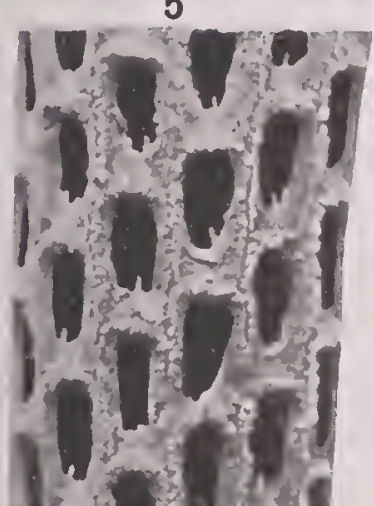

in $x^{2}+y^{4}$

in

$\cdots 3$

(3)

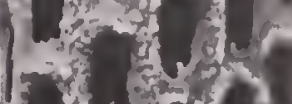

Interes

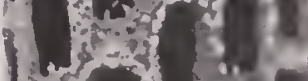

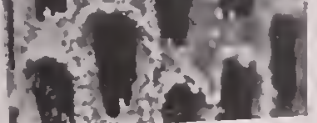

9

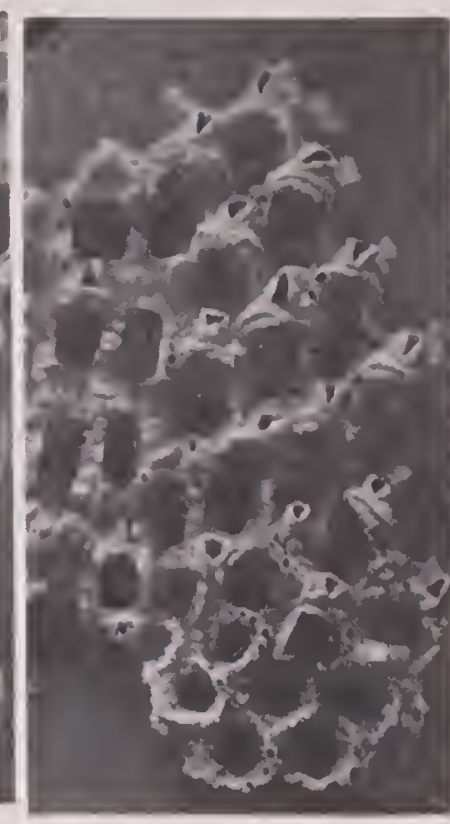

2

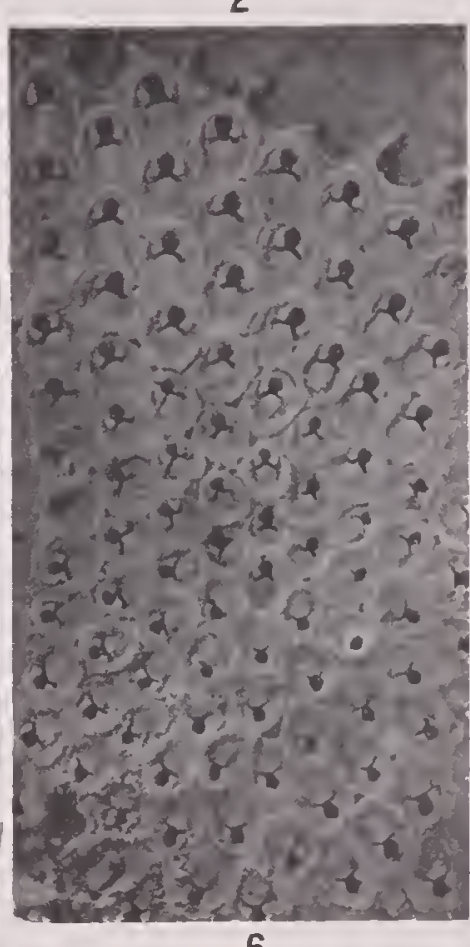

6

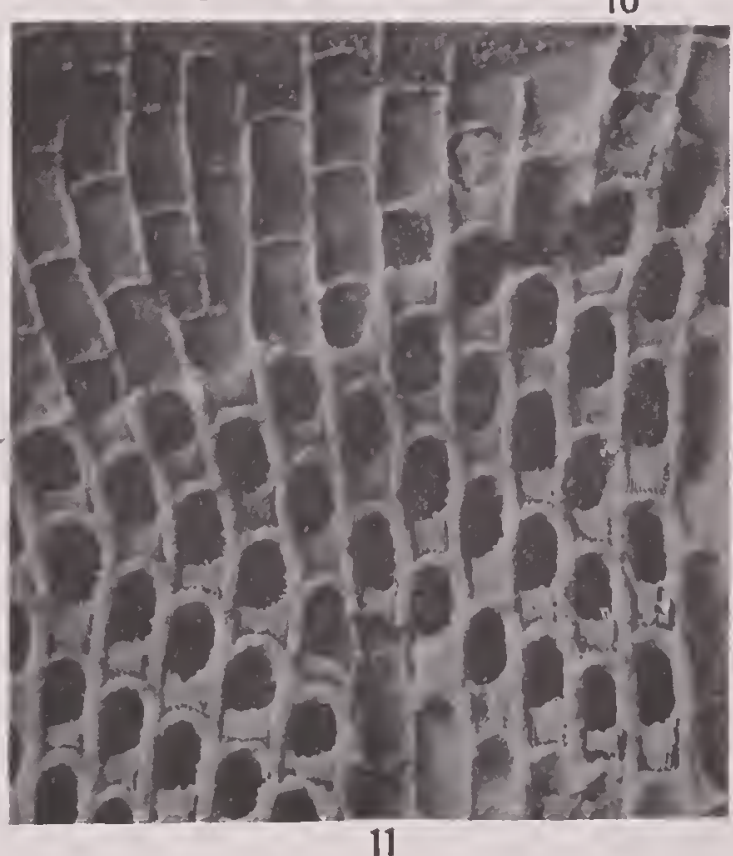

11
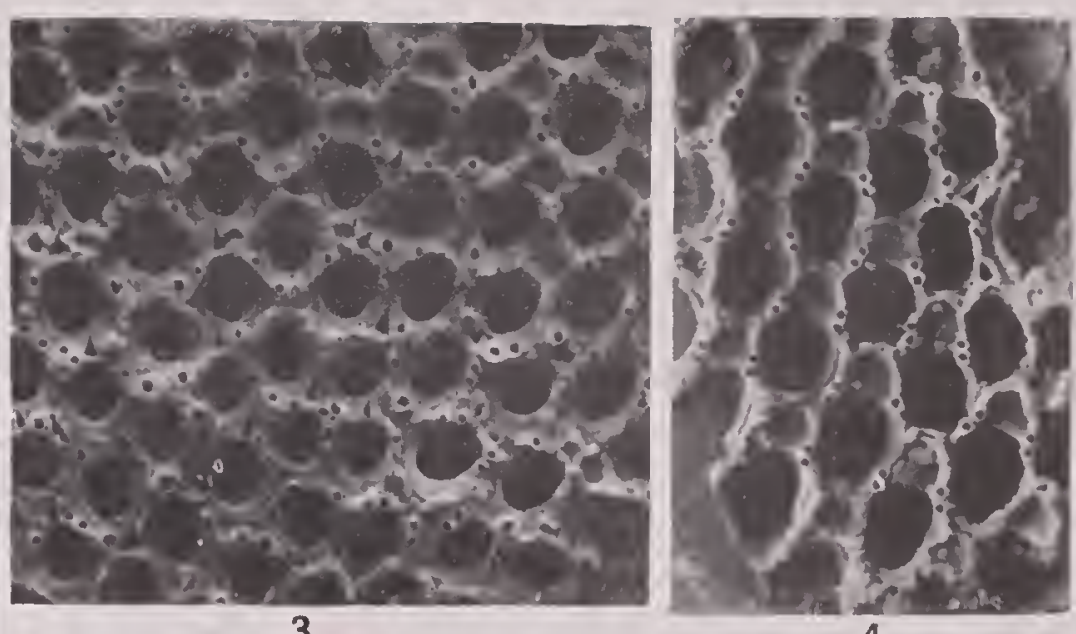

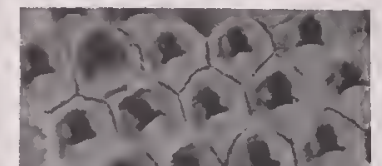

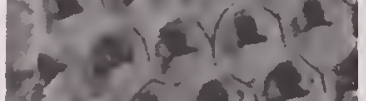

$180+2$

(2) 3 sip

सि 1010

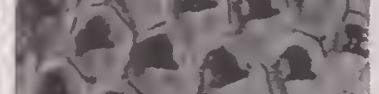

$x+2)$
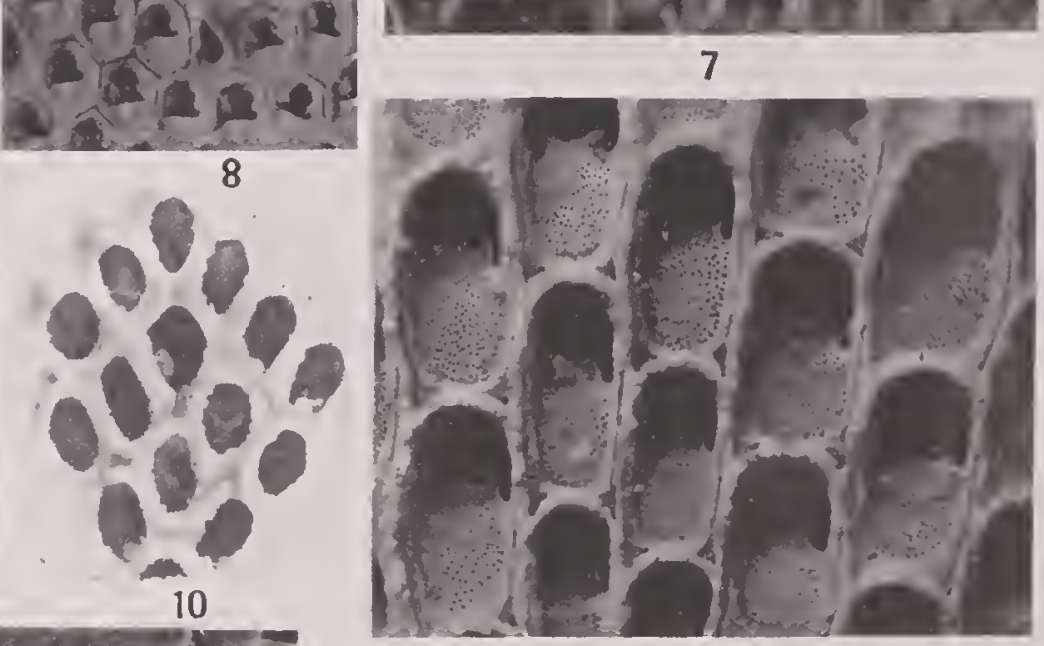

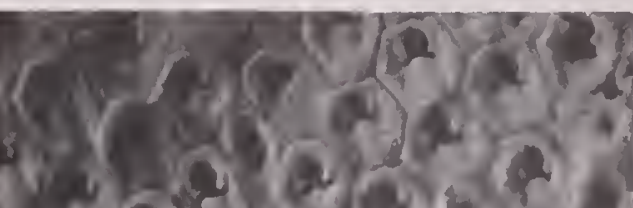

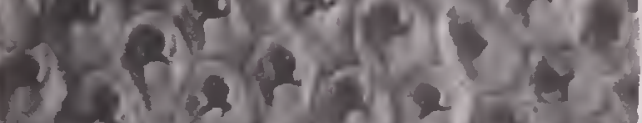

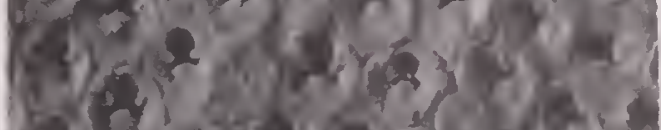
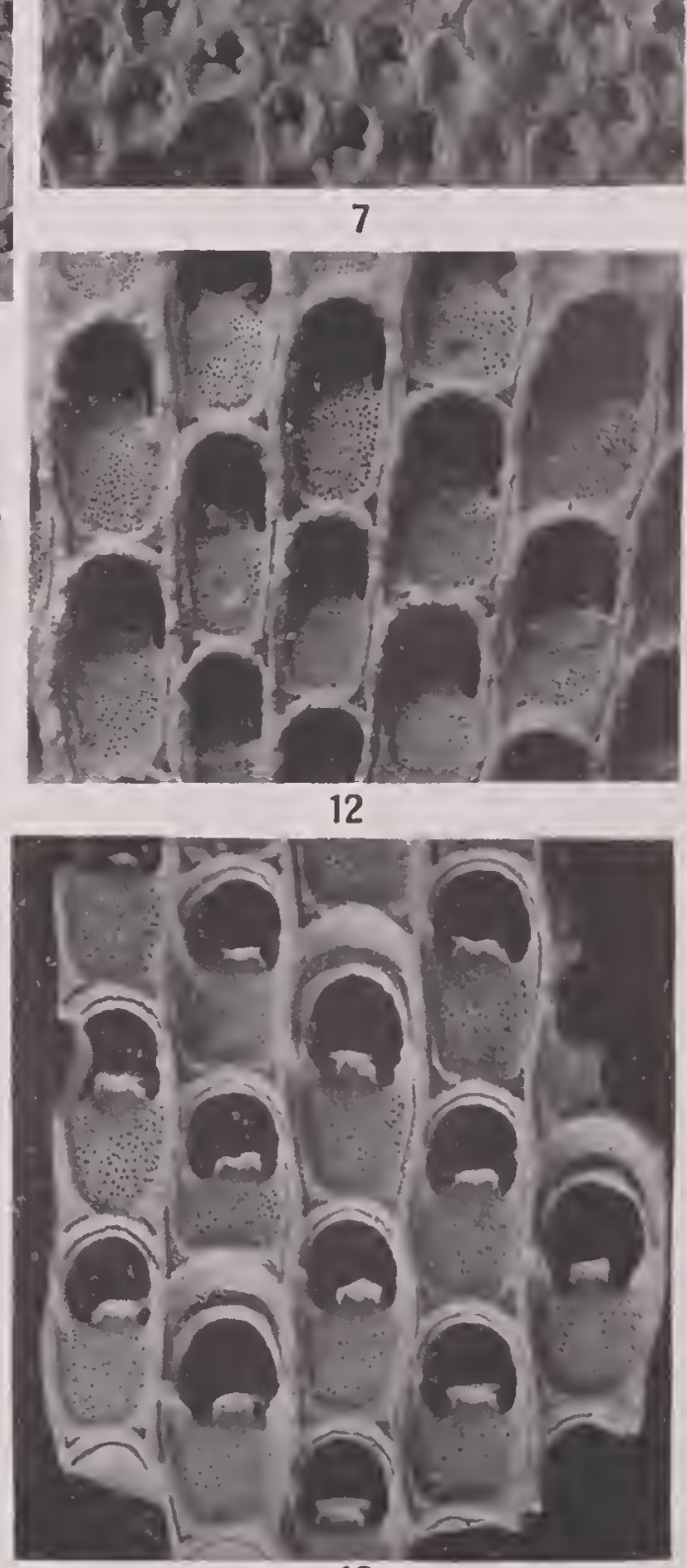

13

N'OrTH AMERICAN Later TERTIARY and Quaternary Bryozoa.

For EXPLANaTION OF PLATE SEE PAgE 258. 
U. S. NATIONAL MUSEUM

BULLETIN 125 PLATE 15
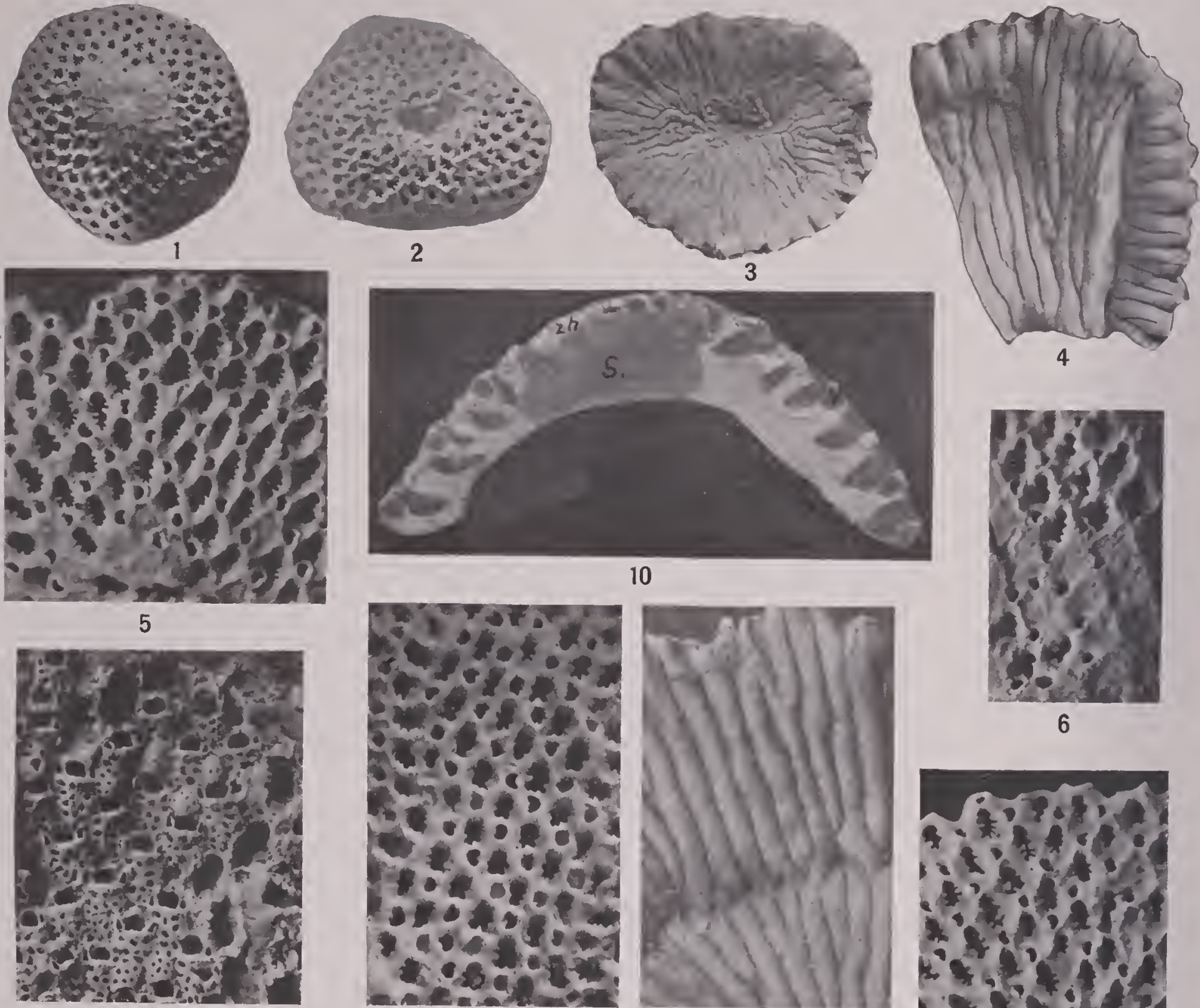

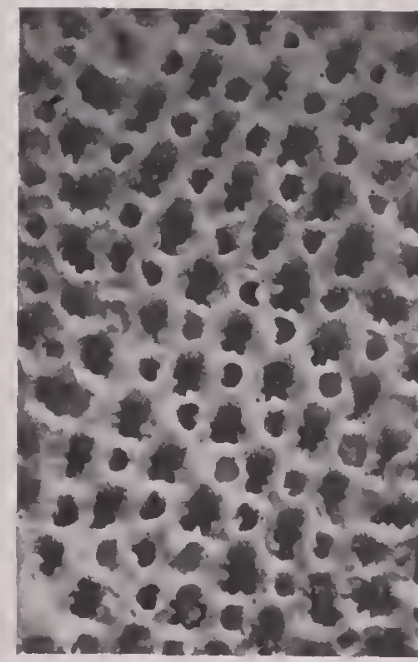

7

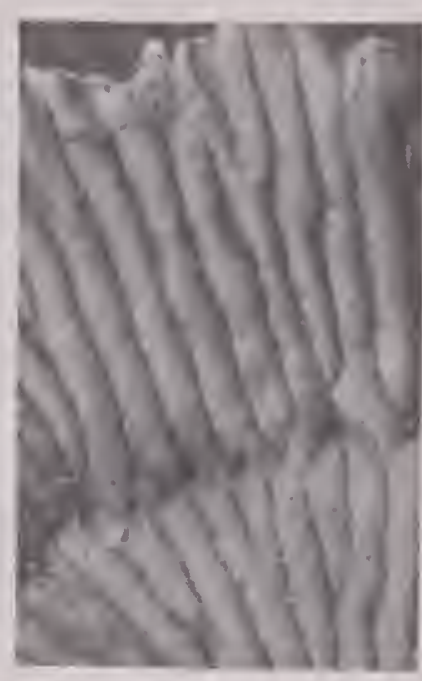

8

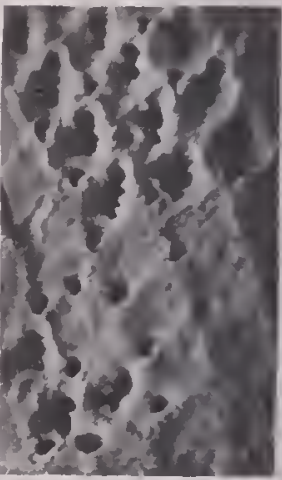

6

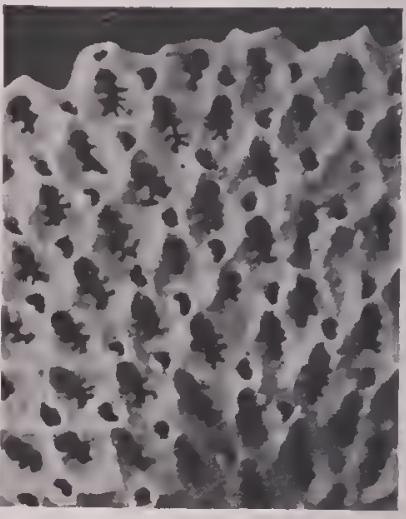

9

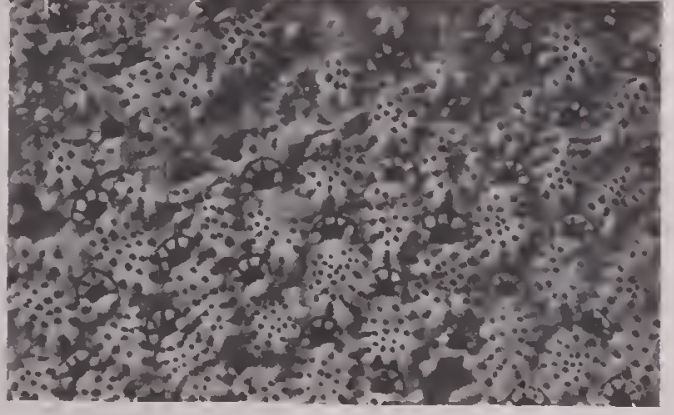

12

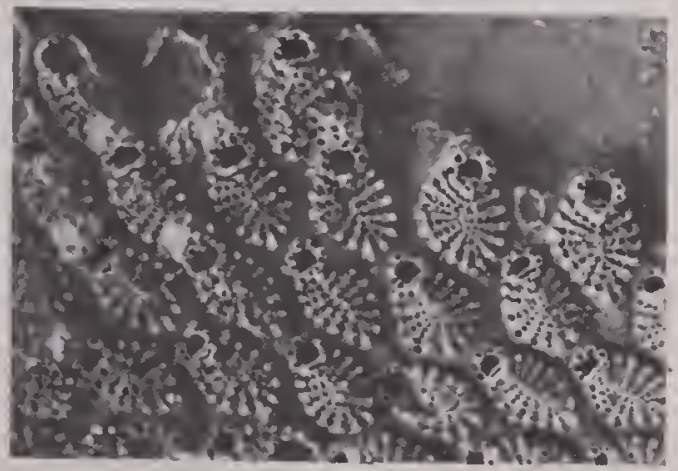

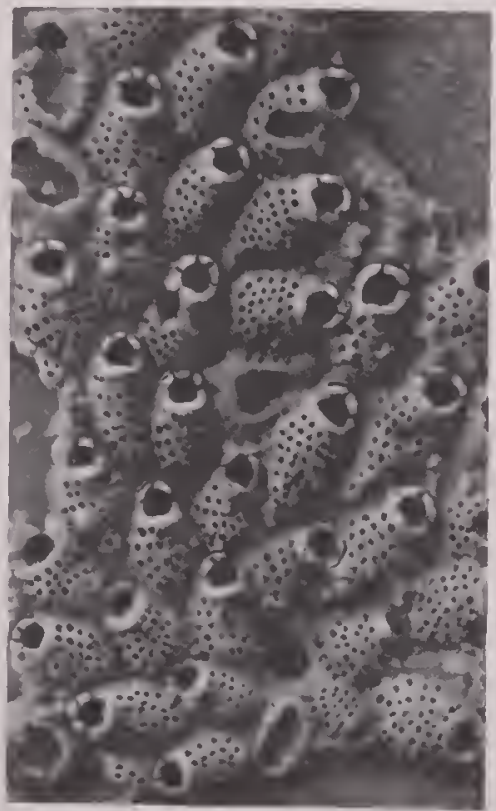

14

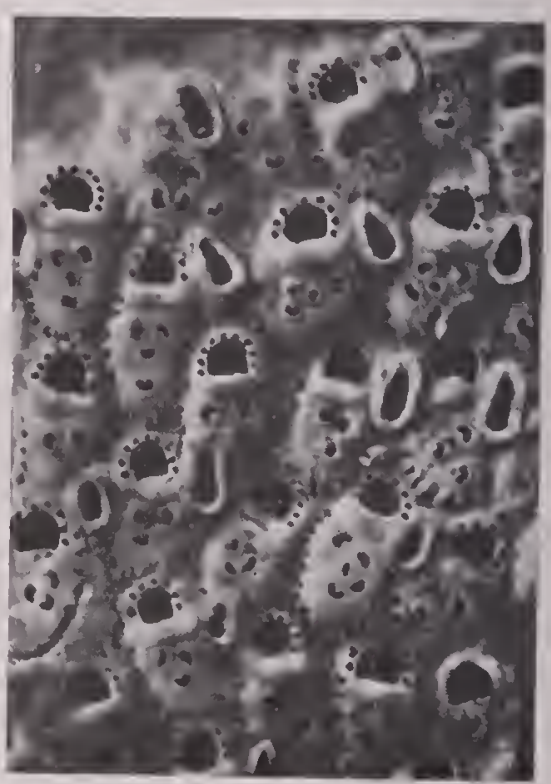

15

NORTH AMERICAN LATER TERTIARY AND QUATERNARY BRYOZOA. 


\section{Piate 15.}

Figs. 1-5. C'upularit doma D’Orbigny: 1851. (See also plate 1, fig. 18.) (p. 77.)

1. A zoarium, $\times 10$, showing the ancestrular zooecia covering the substratum. These zooecia are calcified and deprived of polypide.

2. Another zoarium $\times 10$, illustrating that the ancestrular zooecia are easily detached in fossilization.

3. Inner side of zoarium, $\times 10$, which is smooth or slightly granulated.

4. Inner (superior) side of a zoarium with hydrostatic zooecia, $\times 20$. The ribs are smoooth and are uot radially arranged. This difference in arrangement depends on the form of the substratum on which the larva fixes itself.

5. Celluliferous face $\times 20$, illustrating the form of the denticles.

Miocene (Duplin marl): Wilmington, North Carolina.

Figs, 6-10. Cupularia denticulata Conrad, 18+1. (p. 79.)

6 . Calcified ancestrular zooecia $\times 20$. The vibracula alone are visible.

7. Center of a zoarium $\times 20$, deprived of calcified zooecia.

8. Inner side of a large zoarium $\times 20$, without hydrostatic zooecia, showing the regular bifurcation of each rib.

9. Zooecia $\times 20$, illustrating the two symmetrical condyles and the vestibular arch above, the amiculated vibracula and the irregular denticles below.

10. A median section through a zoarium $\times 25$, showing the substratum $(s)$ upon which the larva became attached, the calcified hydrostatic zooecia $(z h)$ covering the substratum and the ordinary zooecia surmounted by their vibracula $(v)$.

Pliocene (Waccamaw marl): Waccamaw River, Horry County, South Carolina.

Fig. 11. Cribrilina punctata Hassall, 1841. (p. 87.)

The type specimen of Lepralia marylandica Ulich and Bassler, 1904, X 20, showing its identity with this widespread fossil and recent species.

Miocene (St. Mary's formation): Cove Point, Maryland.

Fig. 12. Puellina radiata forma scripta Reuss, 1847. (See also pl. 35, fig. 1.) (p. 89.)

A well-preserved example, $\times 20$ with wide zonecia, somewhat approaching forma rarecosta, Reuss, 1847 .

Miocene (Yorktown formation): I mile west of Fort Nonsense, Gloucester County, Virginia.

Fig. 13. Puellina innominata Couch, 1844. (p.90.)

A Miocene example of this widlespread species, $\times 20$.

Miocene (Choctawhatchee marl): Jackson Bluff, Ocklocknee River, 25 miles southwest of Tallahassee, Florida.

Fig, 14. Cribrilina ligulata, new species. (p. 88.)

The type specimen, $\times 25$, showing the ancestrula and surrounding zooecia. The spines of the peristome are transformed by coalescence into several small tongues.

Miocene (Calvert formation): 1 mile south of Parkers Creek, Calvert County, Maryland.

FIg, 15. Cribritina cuspidata, new species. (1. 88.)

The incrusting type specimen, $\times 20$ slowing the line of small lacunae, the few large lacunae and the very large triangular avicularia with rounded beak.

Miocene: Santiago, Cuba. 
FIG. 1. Trypostega renusta Norman, 1964. (p. 95.)

Plate 16.

A Miocene example of this widely distributed species, $\times 20$.

Miocene (Duplin marl): Wilmington, North Carolina.

Fig. 2. Lacerna mucronata Smitt, 1872. (p. 99.)

A fossil, incrusting example $\times 20$, referred to this recent species.

Miocene (Duplin marl): Wilmington, North Carolina.

Fig. 3. Arthropoma cormuta, new species. (p. 97.)

The incrusting zoarium, $\times 20$, showing the characteristic sinus and the frontal protulerance.

Miocene (Choctawhatchee marl): Jackson Bluff, Ocklocknee River, 25 miles southwest of Tallahassee, Florida.

FIGS. 4-9. Stephanosella biaperta Michelin, 1842. (p. 99.)

4. The incrusting zoarium, $\times 20$, illustrating the triangular aricularia.

5. A zoarium, $\times 20$, with more rounded avicularia. The tremocyst is detachable from the subjacent olocyst.

6. Interior of the zooecia $\times 20$, illustrating the form of the apertura.

Pleistocene: Rustic Canyon, Santa Monica, California.

7. An example, $\times 20$, containing both round and triangular avicularia.

Pleistocene: Los Angeles, California.

8. Surface, $\times 20$, showing sereral ovicelled zooecia.

Pleistocene: Vero, Florida.

9. A zoarium $\times 20$ showing the ancestrular zooecia and the thinness of the zooecial walls. The dietellae are very narrow.

Pleistocene: Dead Man's Island off San Pedro, California.

Fig. 10. Schizoporella cumulata Ulrich and Bassler, 1904. (1). 96.)

View of the type specimen, $\times 20$, showing the irregular arrangement and the piling up of the zooecia.

Miocene (Choptank formation): Jones Wharf, Maryland.

Figs. 11-15. Schizopodrella floridina Osburn, 1914. (p. 106.)

11. A zoarinm, natural size, composed of many lamellae.

12. Non oriented ancestrular zooecia, $\times 20$.

13. Normal aspect of the zooecia, $\times 20$. One zooecium has been regenerated with an aricularium occupying the apertura.

14. A transierse section through a muitilamellar zoarium, $\times 20$.

Miocene (Choctawhatchee marl): Jackson Bluff, Ocklocknee River, 25 miles soutluwest of Tallalassee, Florida.

15. Zooecia $\times 20$, showing the form of the apertura more clearly. Several of the apertures are closed.

Miocene (Duplin marl): Wilmington, North Carolina.

$2 \mathrm{CO}$ 

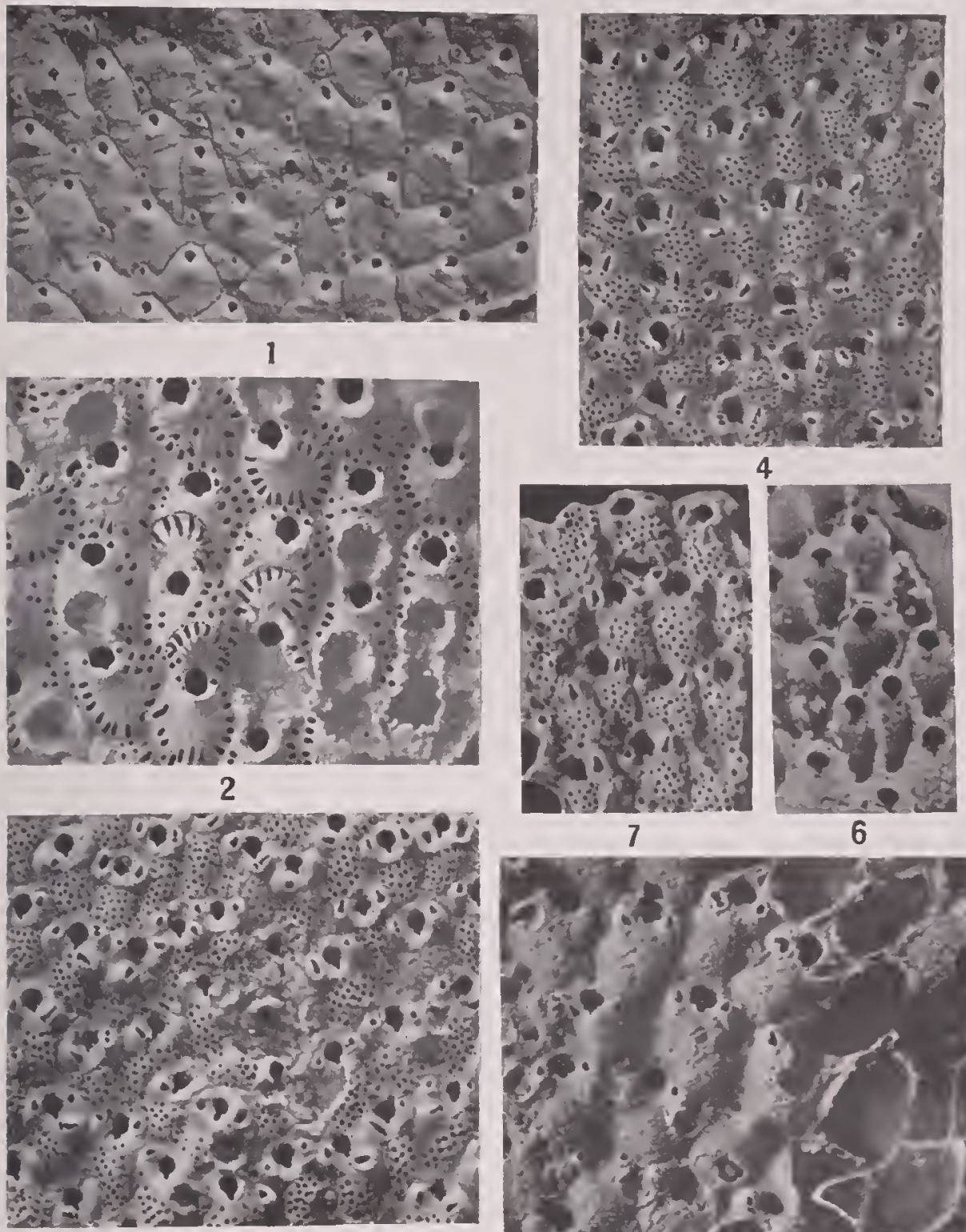

\section{5}
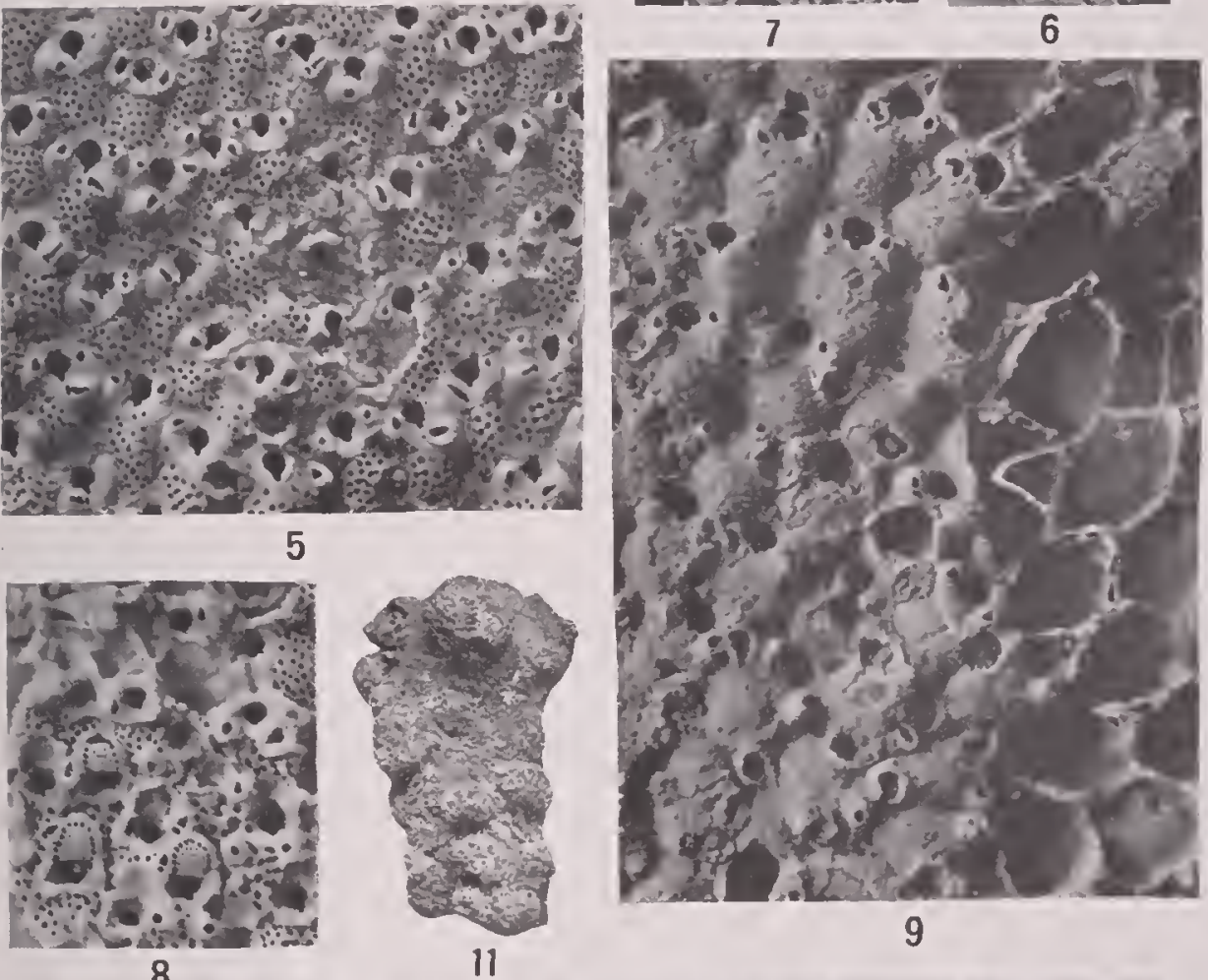
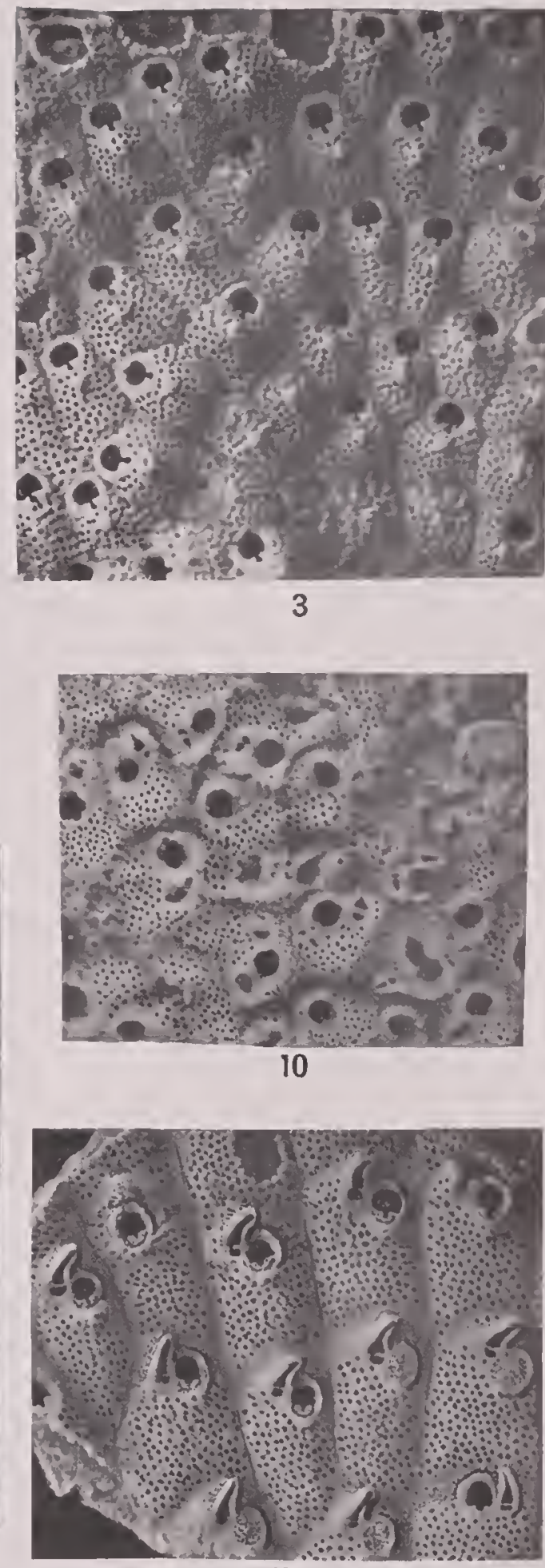

15

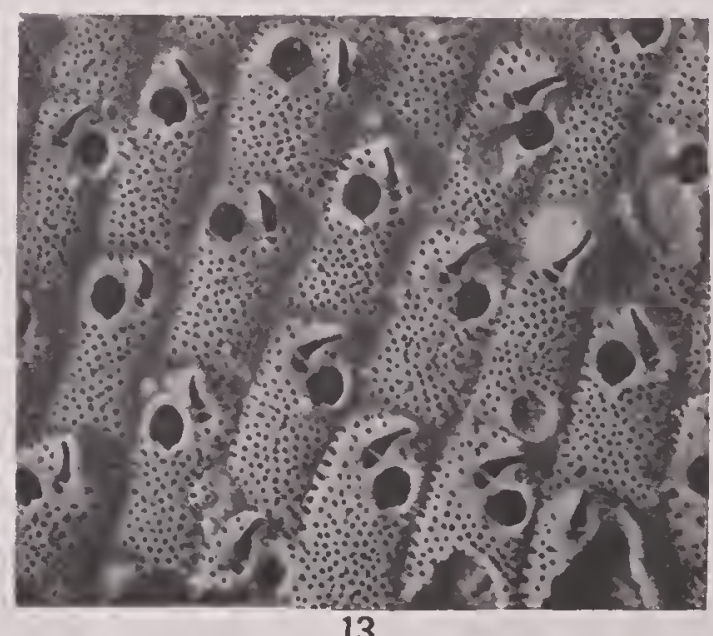

13
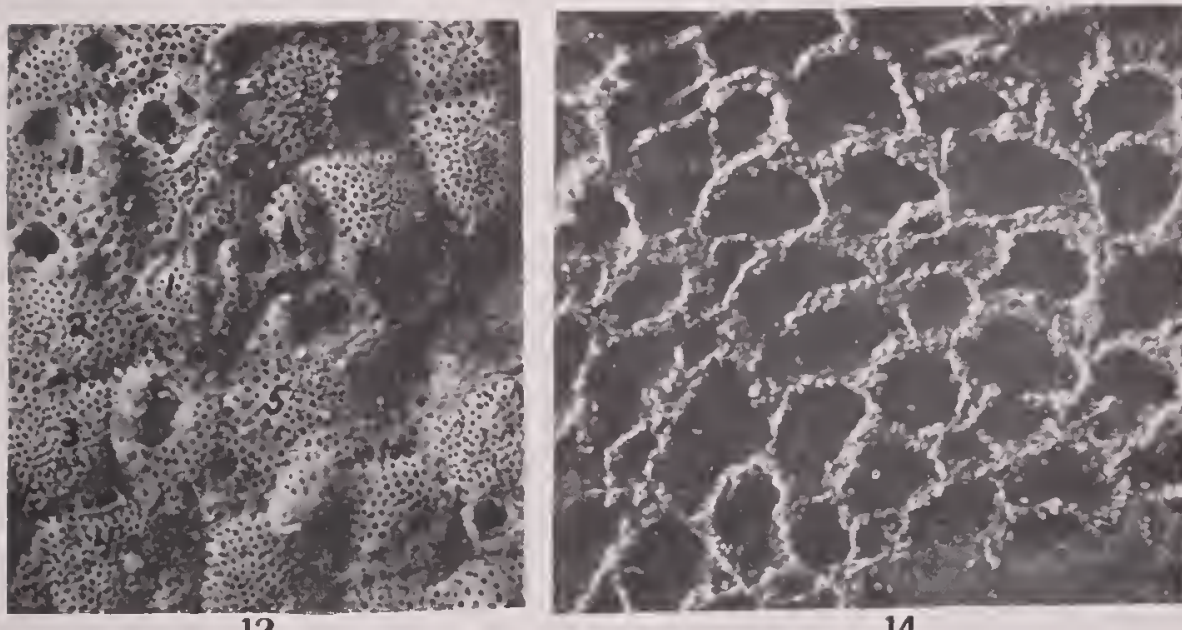

14

NORTH AMERICAN LATER TERTIARY AND QUATERNARY BRYOZOA. 

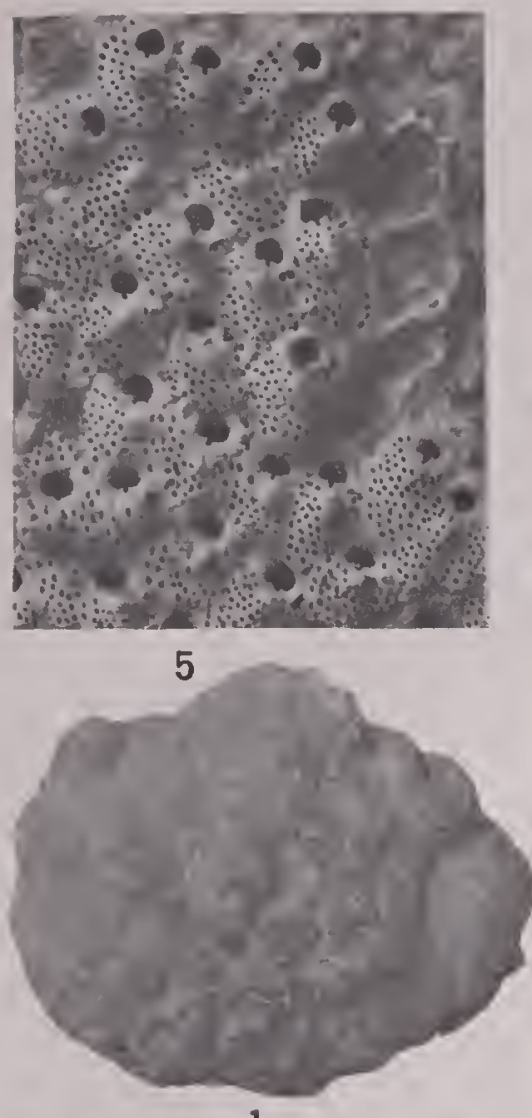

1

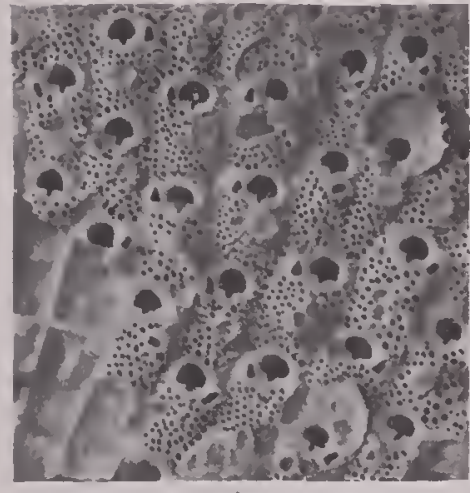

8

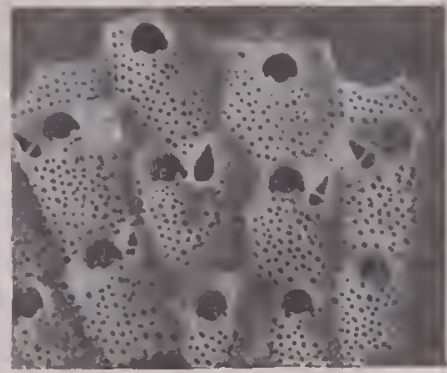

13

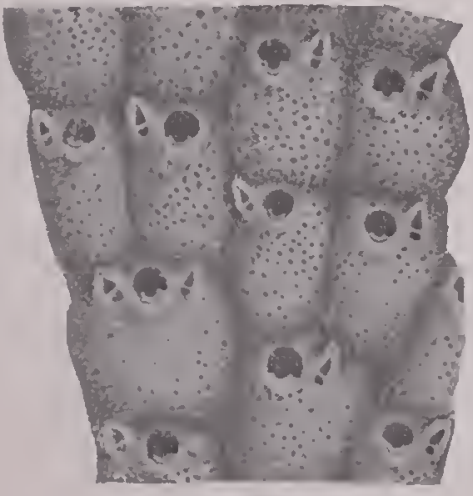

14
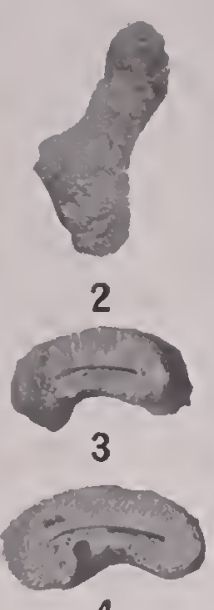

4

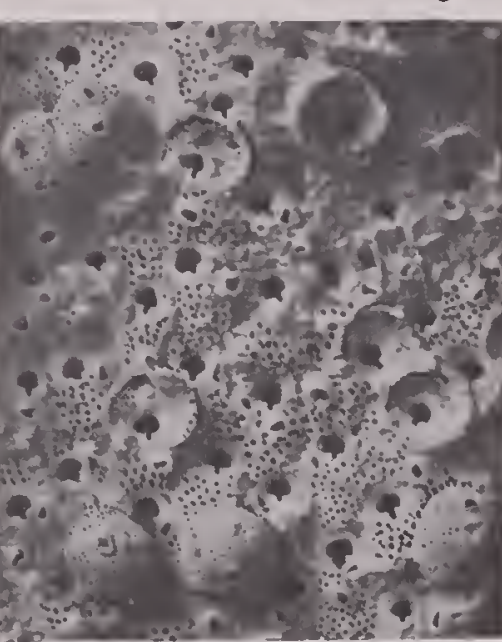

9
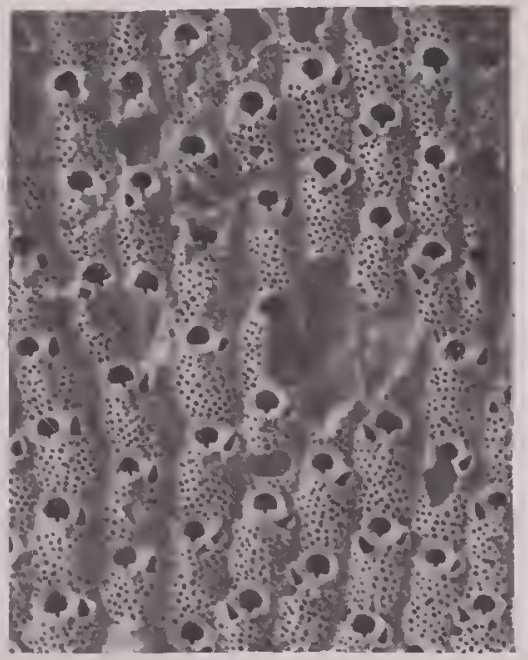

12

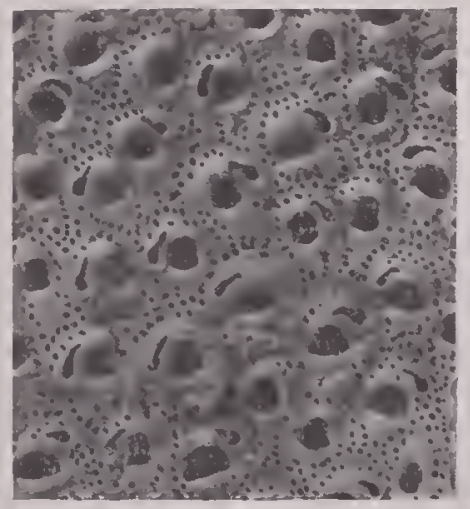

15
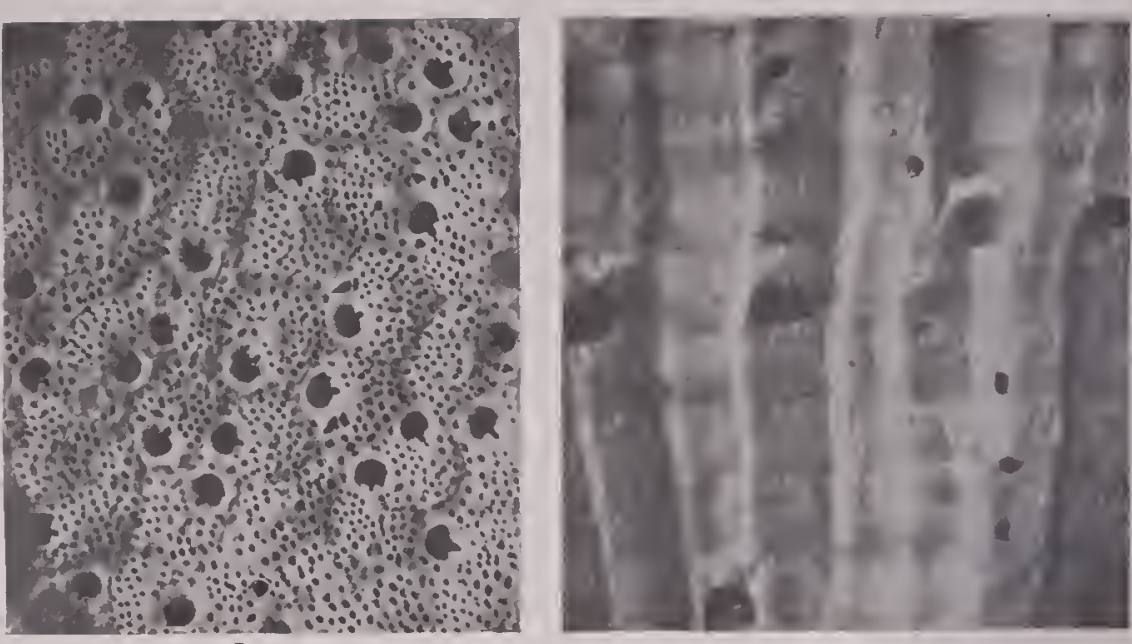

7

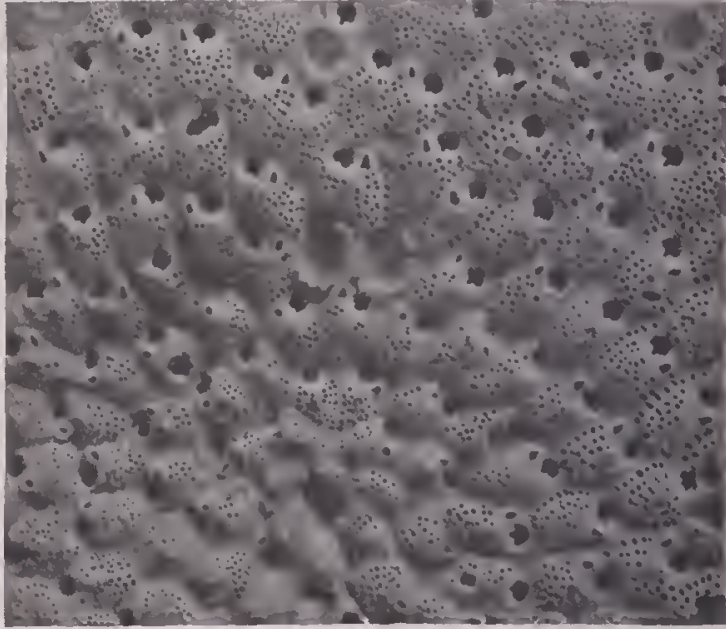

10

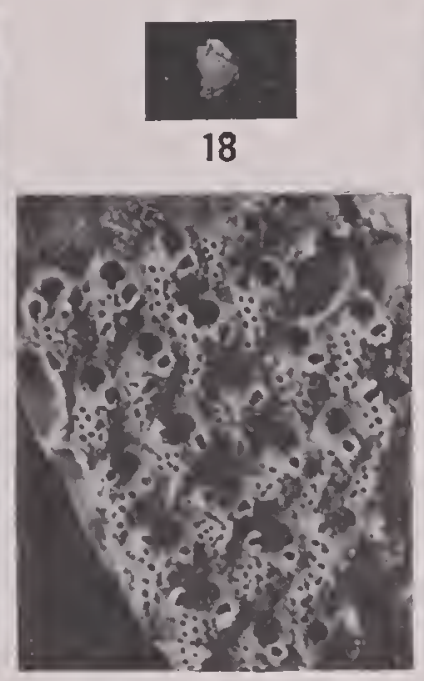

19

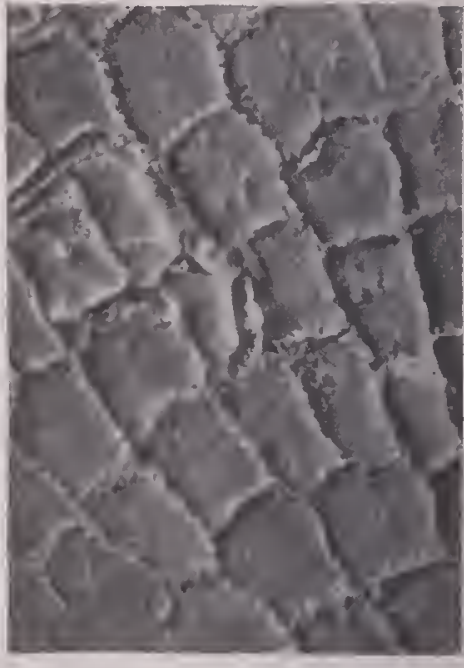

11

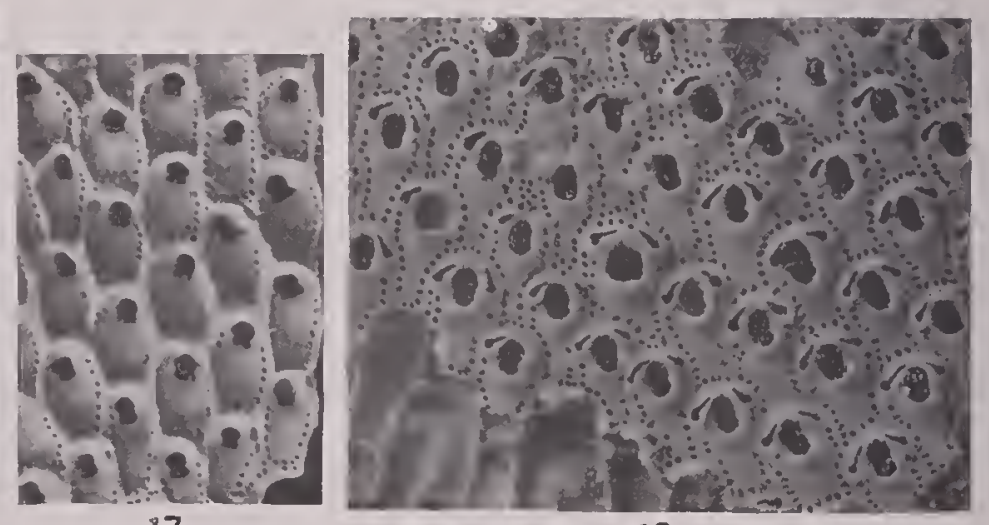

16

NORTH AMERICAN LATER TERTIARY AND QUATERNARY BRYOZOA.

For Explanation of plate see page 26 I. 
Plate 17

Figs. 1-12. Stylopoma spongutes Pallas, 1766. (p. 102.)

1, 2. Two forms of the zoarium, natural size, made up of many lamellae.

3,4 . Transverse sections of zoaria, natural size.

5. Surface $\times 20$, showing broad unovicelled zooecia.

6. Another surface $\times 20$, exhibiting nonoriented zooecia which bear conspicuous avicularia.

7. Inferior face of a lamella, $\times 20$.

Miocene (Duplin marl): Wilmington, North Carolina.

S. Normal zooecia with avicularia $\times 20$. Dietellae are not present. The broken ovicell shows the tremocyst resting on the olocyst.

9. Normal and ovicelled zooecia $\times 20$. The ovicell surrounds and conceals the apertura.

10. Ancestrular portion of a zoarium, $\times 20$.

11. Zooecial walls $\times 20$, obtained by abrasion of the surface, showing arrangement of the septules.

12. A portion of a zoarium $\times 20$, with quite elongated zooecia.

Pliocene (Caloosahatchee marl): Shell Creek, De Soto County, Florida.

Fid's. 13, 14. Schizopodrella unicornis Johnston, 1847. (p. 105.)

13. Photograph of a well-preserved Miocene specimen, $X 20$, showing the form of the apertura and the avicularia clearly.

14. Zooecia of the type specimen of Schizoporella subquadrata Ulrich and Bassler, 1904, now considered as a synonym of $S$. unicornis.

Miocene (Choptank formation): Governor Run, Maryland.

FIGS. 15-17. Hippaliosina rostrigcra Smitt, 1872. (p. 167.)

15. Zooecia, $\times 20$, of a form exhibiting only one avicularium above the aperture.

Miocene (Duplin marl): 1 mile northeast Suffolk, Virginia.

16. The normal form of the species, $\times 20$, with two avicularia.

17. Interior of zooecia, $\times 20$, illustrating the two cardelles and the olocyst.

Pliocene (Caloosahatchee marl): Monroe County, Florida.

FIas. 18-19. Schizopodrella pusilla, new species. (p. 106.)

18. The free bilamellar zoarium, natural size.

19. Surface, $\times 20$, showing the small zooecia with large tremopores.

Viocene (Choctawhatchee marl): Jackson Bluff, Ocklocknee River, 25 miles southwest of Talla. hassee, Florida. 


\section{Plate 15.}

Fias. 1-3. Schizopodrella doverensis Ulrich and Bassler, 1904. (p. 107.)

1. I Pliocene example, $\times 20$, referred to this species.

2. Ancestrular portion of a zoarium, $\times 20$, showing irregular arrangement of zooecia.

Pliocene (Calossahatchee marl): Shell ('reek, De Soto County, Florida.

3 . The incrusting type of the species, $\times 20$.

Miocene (Choptank formation): Dover Bridge, Maryland.

Fra. 4. Schizoporella latisinuata Ulrich and Bassler, 1904. (p.93.)

Photograph of the original incrusting type, $\times 20$.

Miocene (Choptank formation): Jones Wharf, Maryland.

Figs. 5, 6. Gemelliporella asper, new species. (p. 110).

5. The incrusting zoarium, $\times 20$, with oriented zooecia and showing both the large and small avicularia.

Miocene (Choctawhatchee marl): Jackson Bluff, Ocklocknee River, 25 miles southwest of Tallahassee, Florida.

6. A Pliocene example, $\times 20$, illustrating nonoriented zooecia, several of which preserve the ovicell.

Pliocene (Waccamaw marl): Waccamaw River, Horry County, South Carolina.

Figs. 7-9. Hippoporina (?) vestita, new species. (p. 130.)

7. View of the incrusting zoarium, $\times 20$, with the zocecia more distinctly marked than usual

8. An example, $\times 20$, showing at the base the calcareous pellicle covering the frontal and at the top, monstrous zooecia. All of the zooecia have indistinct outlines.

9. An example, $\times 20$, preserving some ovicelled zooecia.

Miocene (Choctawhatchee marl): Jackson Bluff, Ocklocknee River, 25 miles southwest of Tallahasse, Florida.

Fia. 10. Hippoporina gibbosa, new species. (p. 150.)

The incrusting type specimen, $\times 20$, showing the smooth frontal with its gibbosity, the shape of the aperture and the widely open ovicell.

Miocene (Duplin marl): Wilmington, North Carolina.

Fra. 11. Lepralia montifera Ulrich and Bassler, 1904. (p. 134.)

Photograph of the original type, $\times 20$.

Miocene (St. Mary's formation): St. Jlarys River, Maryland. 

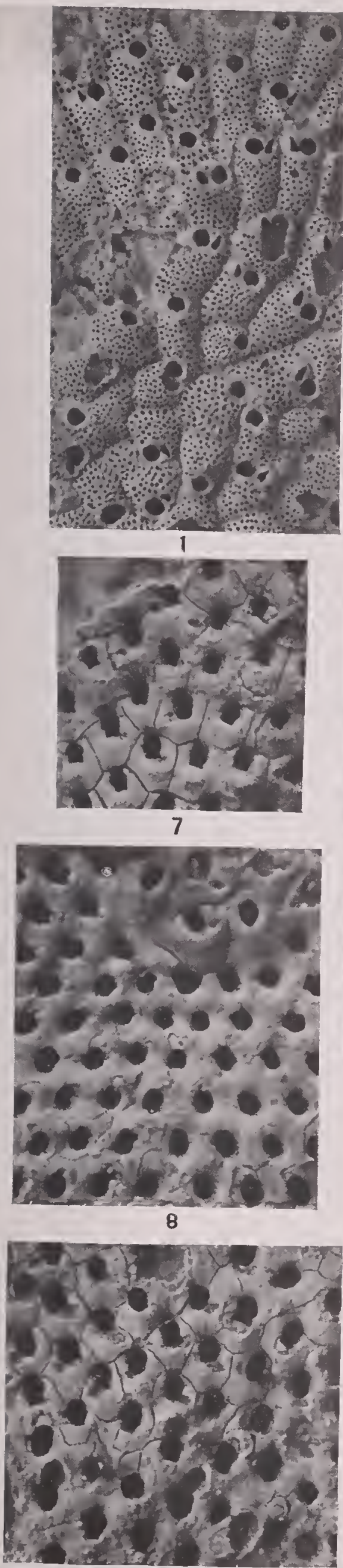

9
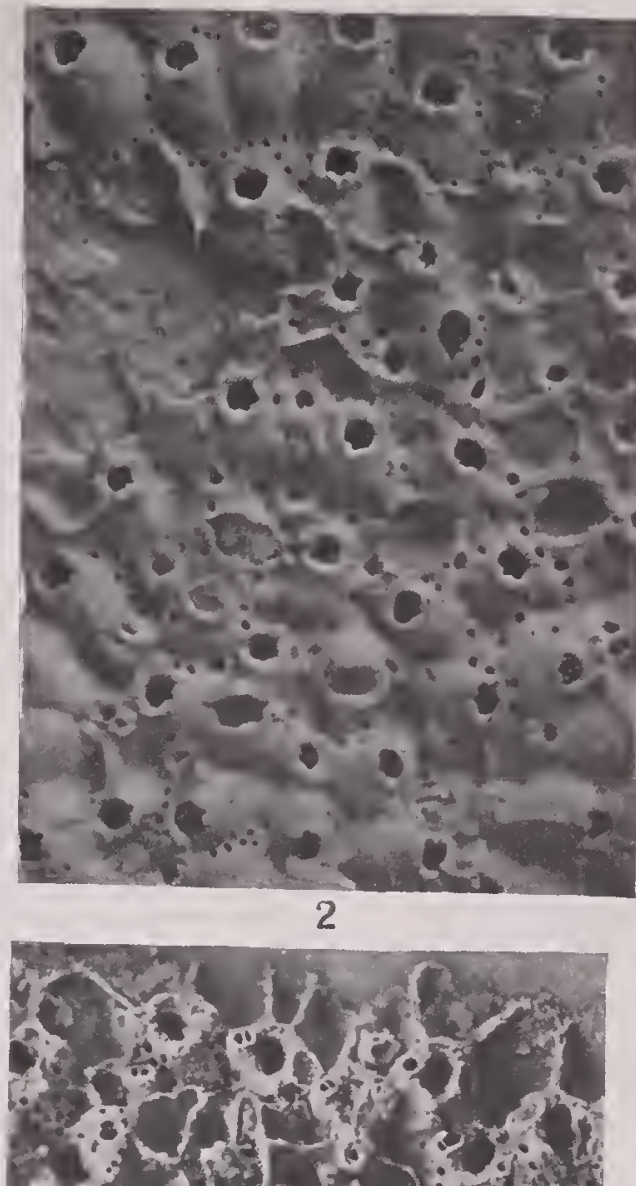
2.5. 2.2.

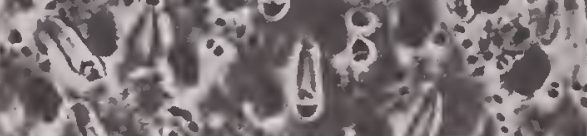
(3)

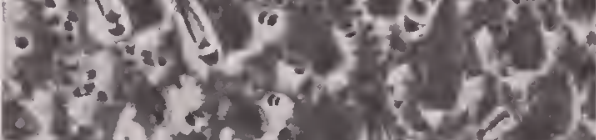

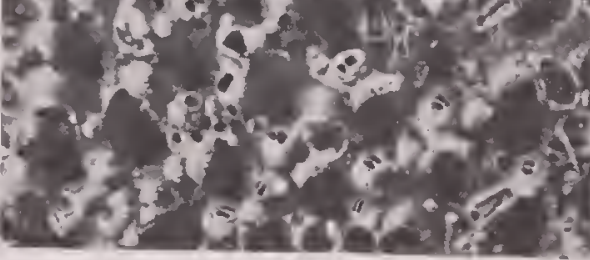
5

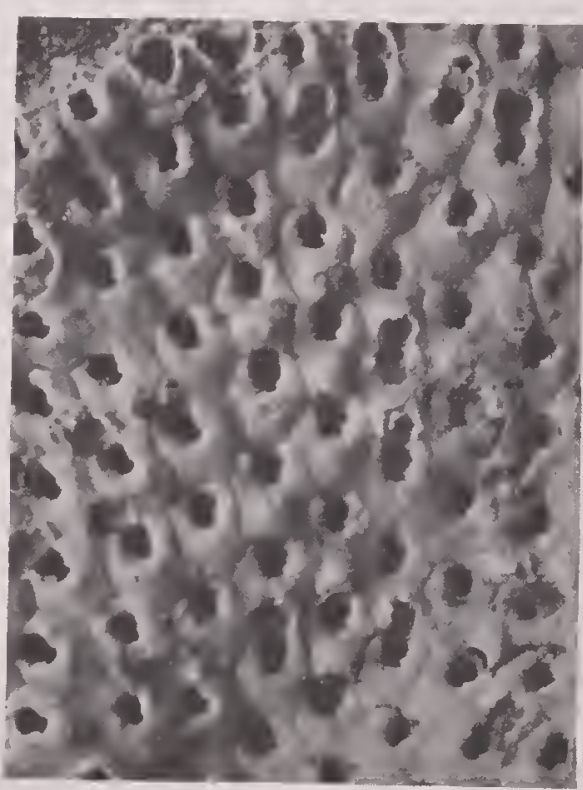

10

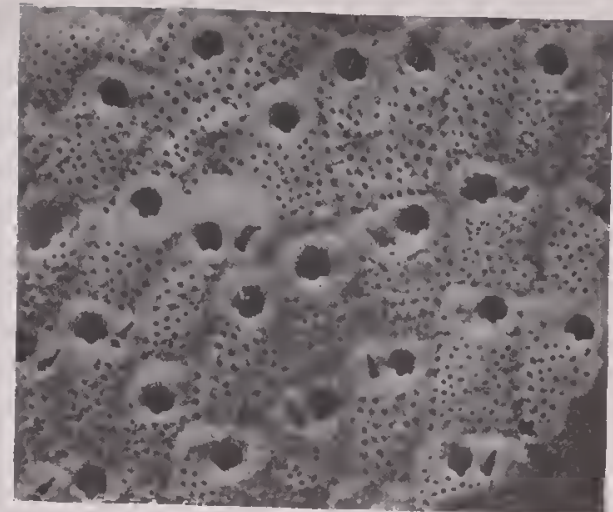

3

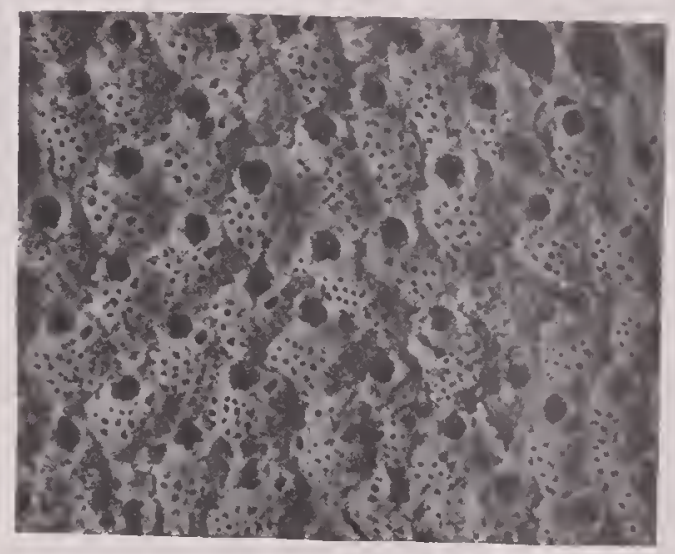

4

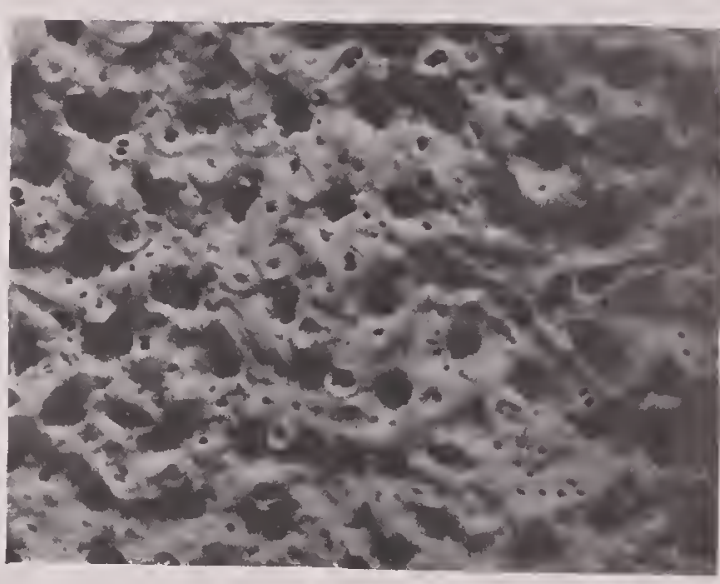

6

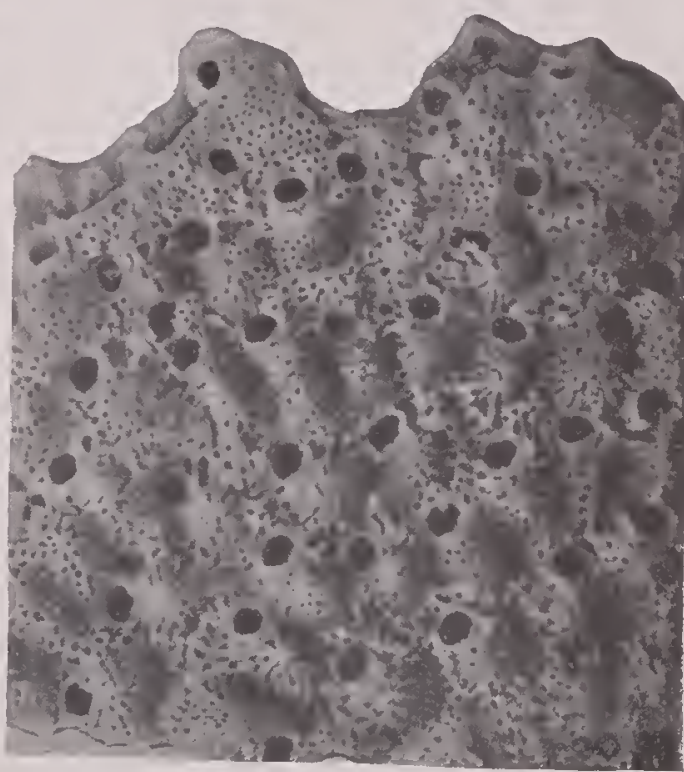

11

NORTH AmERICAN Later TERTIARY and QUaternary Bryozoa.

For EXPLANATION OF PLATE SEE PAGE 262. 


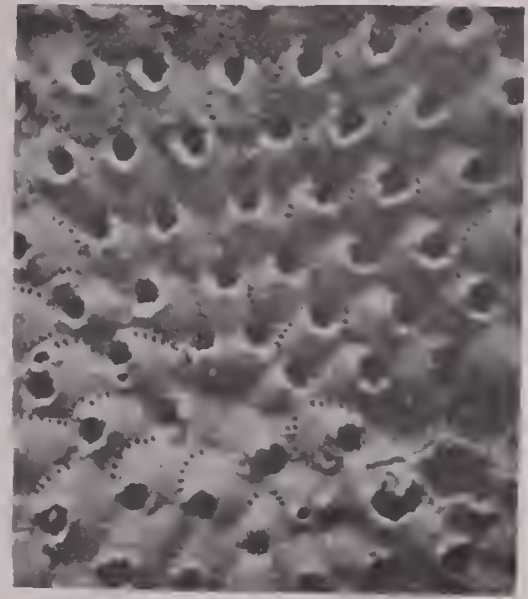

I

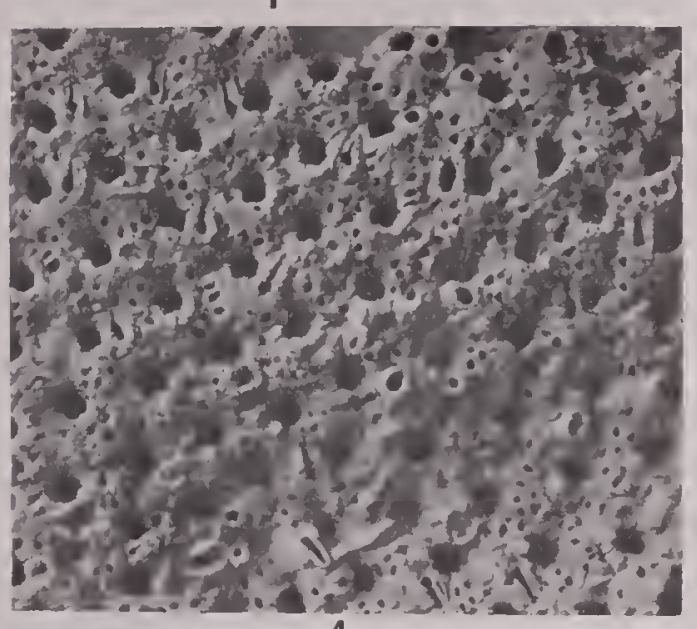
4
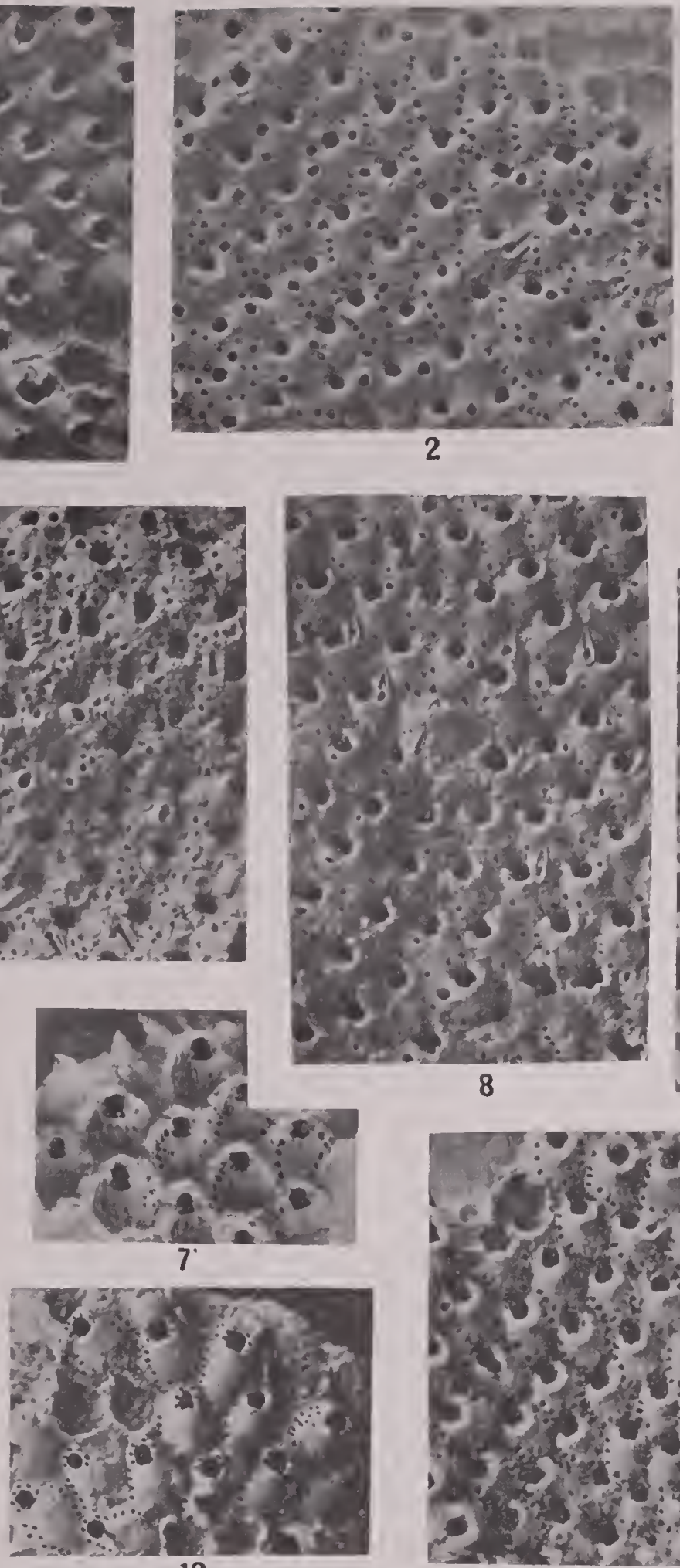

10

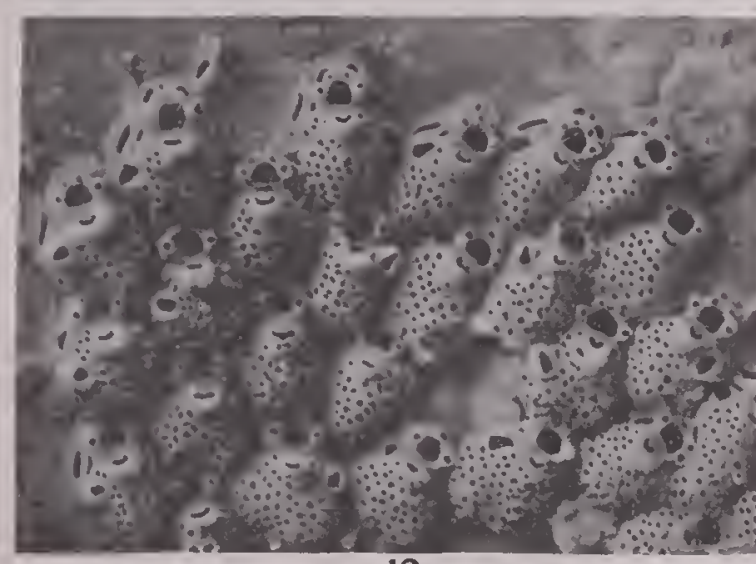

12

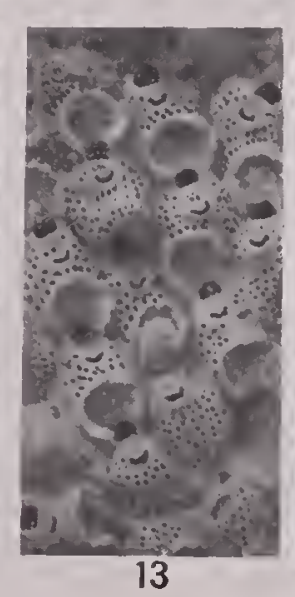

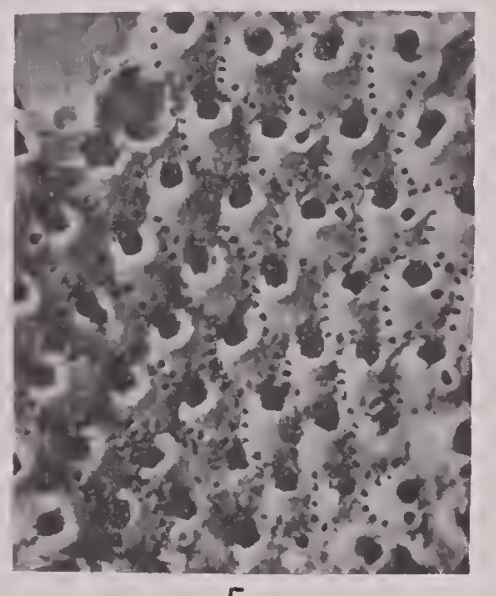

5
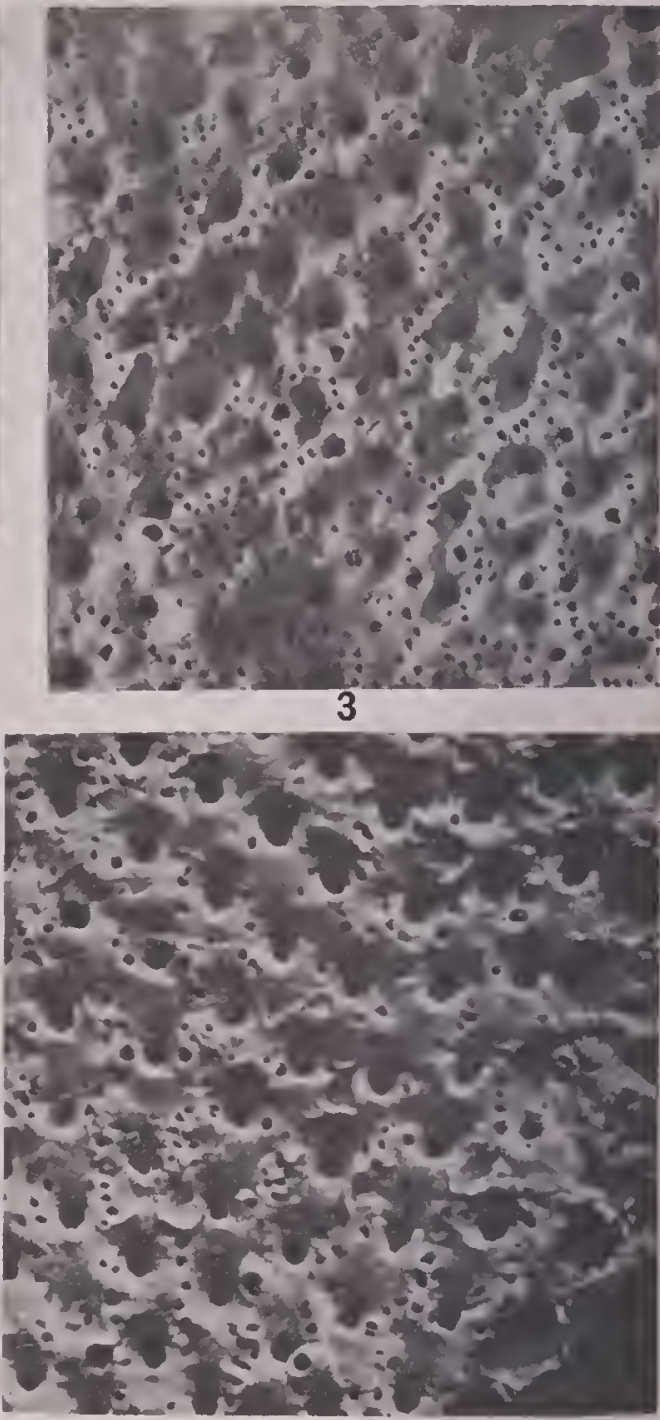

6

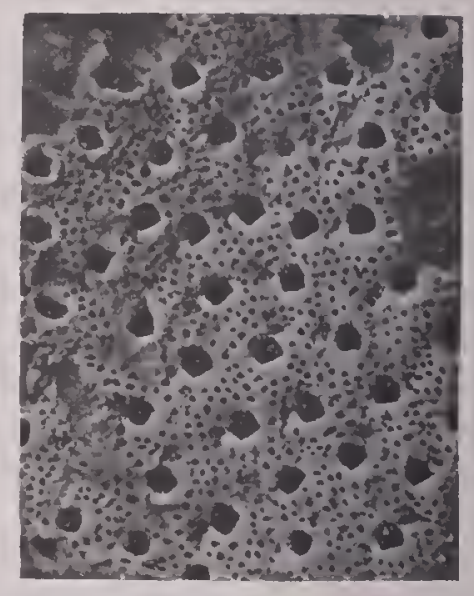

11

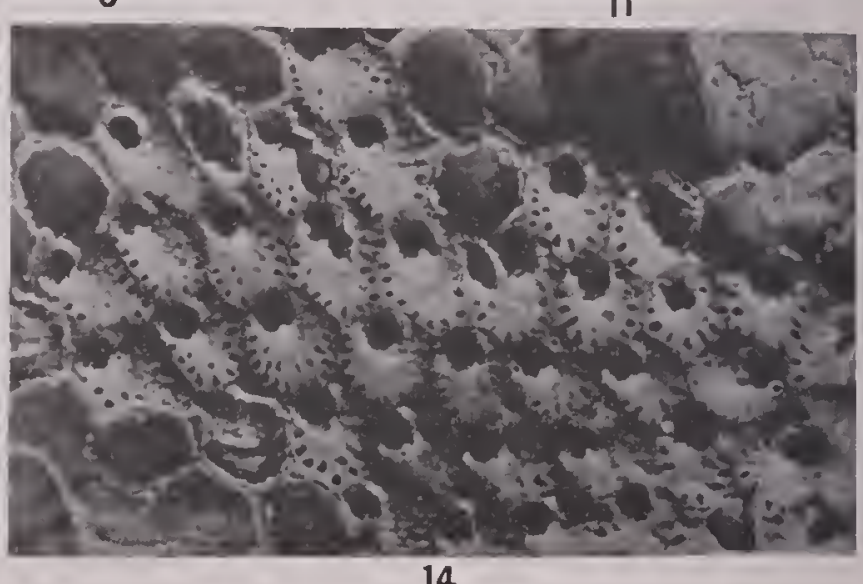

14

NORTH AMERICAN LATER TERTIARY AND QUATERnARY BRYOZOA.

For EXPLANATION OF PLATE SEE Page 263. 
Plate 19

Figs. 1-9. Gemelliporella vorax, new species. (p. 111.)

1. Ancestrular portion of the incrusting zoarium $\times 20$. The ancestrula is corered by the pleurocyst of the adjacent zooecia.

2. Zooecia, $\times 20$, with orbicular avicularia. The areolar pores and granular pleurocyst are evident.

3. A zoarium, $\times 20$, with indistinct zooecia and orbicular avicularia.

Pliocene (Waccamaw marl): Waccamaw River, Horry County, South Carolina.

4. Zooecia, $\times 20$, with large spatulate avicularia. The areolae are limited by short costules.

5. Zooecia, $X 20$, with large areolar pores and the granulated pleurocyst shown.

6. Portion of a large zoarium, $\times 20$, with indistinct zooccia and orbicular avicularia.

7 . Interior of the zooecia, $\times 20$, showing the olocyst which supports the pleurocyst.

Hiocene (Duplin marl): Wilmington, North Carolina.

8. Zooecia, $\times 20$, with both large and small avicularia.

Pliocene (Caloosahatchee marl): Monroe County, Florida.

9. A zooecia of a young zoarium, $\times 20$, with large spatulate avicularia.

Pliocene (Caloosahatchee marl): Shell Creek, De Soto County, Florida.

Frg. 10. Hippoporella spinosa, new species. (p. 132.)

The incrusting type specimen $\times 20$, showing the smooth frontal with small lateral areolar pores and the spines of the peristome.

Miocene (Yorktown formation): Yorktown, Virginia.

Fig. 11. Cyclicopora? mansfieldi, new species. (p. 13S.)

Unovicelled zooecia of the incrusting zoarium, $\times 20$, showing the suborbicular aperture and the numerous large tremopores.

Miocene (Yorktown formation): $1 \frac{1}{2}$ miles southwest of Reeds Ferry, Virginia.

Figs. 12, 13. Microporella fissurifera, new species. (p. 121.)

12. Unovicelled zooecia of the incrusting zoarium $\times 20$, exhibiting the dietellae visible along the edge of the zooecia.

Miocene (Yorktown formation): Near Macedonia Church, Essex County, Virginia.

13. Ovicelled zooecia, $\times 20$.

Miocene (Duplin marl): 10 miles south of Greenville, North Carolina.

Fig. 14. Hippoporella papulifera, new species. (p. 133.)

Unovicelled zooecia of the incrusting zoarium, $\times 20$, with distinct areolar pores and the characteristic mucro.

Miocene (Choctawhatchee marl): Jackson Bluff, Ocklocknee River, 25 miles southwest of Tallahassee, Florida. 


\section{Pl.ite 20.}

Figs. 1-6. Microporella citiata Linnaeus, 1759. (See also pl. 36, figs. 4, 5.) (p. 119.)

1. Incrusting portion of zoarium, $\times 20$, showing the typical zooecia.

2. Bilamellar expansion of the same zoarium, $\times 20$. The zooecia have large tremopores and no granules.

Miocene: Kuhns, Carteret County, North Carolina.

3. Typical zooecia, $\times 20$, with their frontal provided with granules and small tremopores.

Miocene (Choctawhatchee marl): Jackson Bluff, Ocklocknee River, 25 miles southwest of Tallahassee, Florida.

4. The original type specimen of Microporella praeciliata Ulrich and Bassler, 1904, $\times 28$, hitherto distinguished on account of its large tremopores.

5. Several zooecia of the same, further enlarged.

Miocene (Choptank formation): Jones Wharf, Maryland.

6. The type specimen of Microporella in Iata Ulrich and Bassler, 1904, now considered a synonym of $M$. ciliata.

Miocene (Choptank formation): Jones Wharf, Maryland.

Figs. 7-11. Microporella bifoliata Ulrich and Bassler, 1904. (p. 121.)

7. Photograph of the bifoliate type specimen, $\times 20$, with both ovicelled and unovicelled zooecia .

8. A drawing of two ovicelled zooecia.

9. A zooecium and an avicularium lighly magnified

10. Mature unovicelled zooecia, $\times 20$.

11. Unovicelled zooecia, $\times 20$, illustrating appearance in young specimen.

Miocene (Choptank formation): Cordova, Maryland.

FIGs. 12, 13. Cyclocolposa (?) spinifera new species. (p. 136.)

12. The incrusting zoarium, $\times 20$, with ancestrular zooecia. The pleurocyst is incompletely developed.

13. A zoarium with mature zooecia, $\times 20$, showing the very thick frontal and the globular smooth ovicell.

Miocene (Yorktown formation): 1 mile west of Fort Nonsense, Gloucester County, Virginia.

Ficis. 14, 15. Nicroporella hexagona, new species. (p. 120.)

14. The incrusting zoarium, $\times 20$, showing the strongly calcified hexagonal zooecia.

15. Another portion of the same specimen, $\times 20$, illustrating the hexagonal shape of the zooecia, the large ascopore with its salient peristome and the triangular avicularia.

Miocene (Duplin marl): Darlington Courthouse, South Carolina.

F1G. J6. Dakaria grandis, new species. (p. 97.)

The incrusting zoarium, $\times 20$.

Miocene (Yorktown formation): Yorktown, Virginia. 

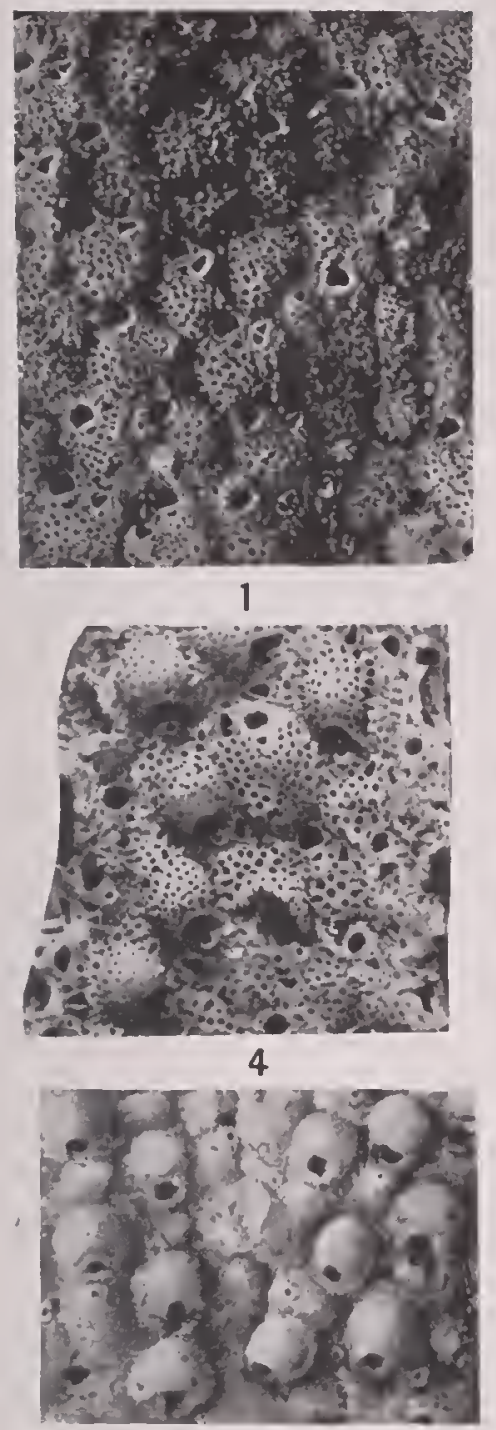

6
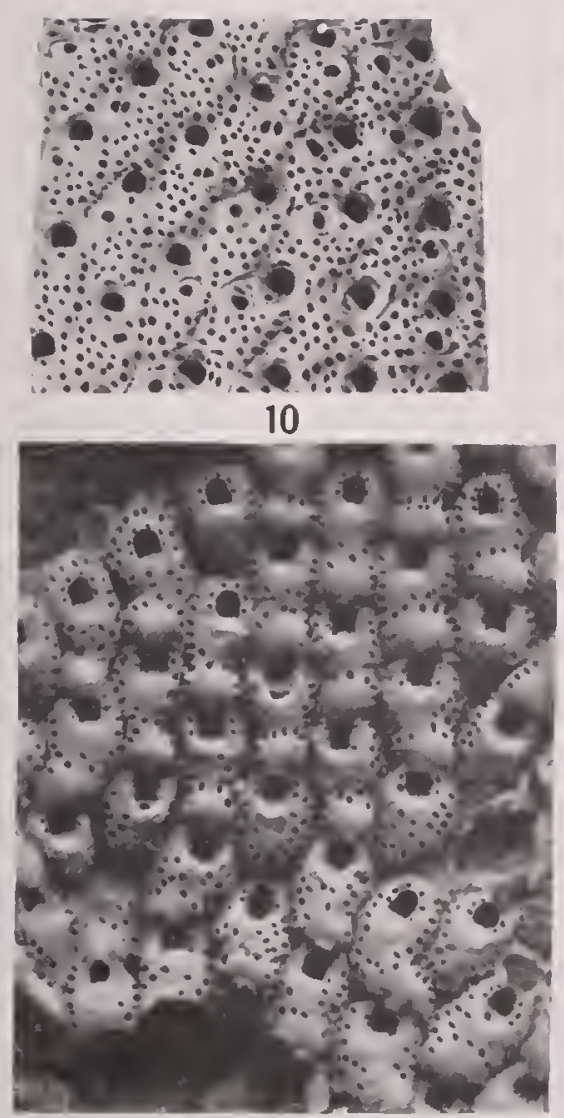

13

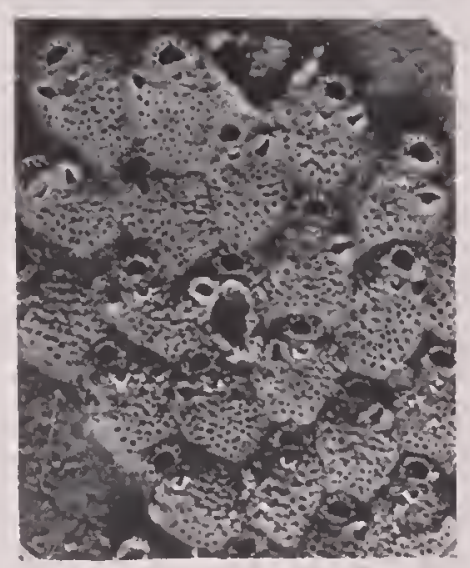

3

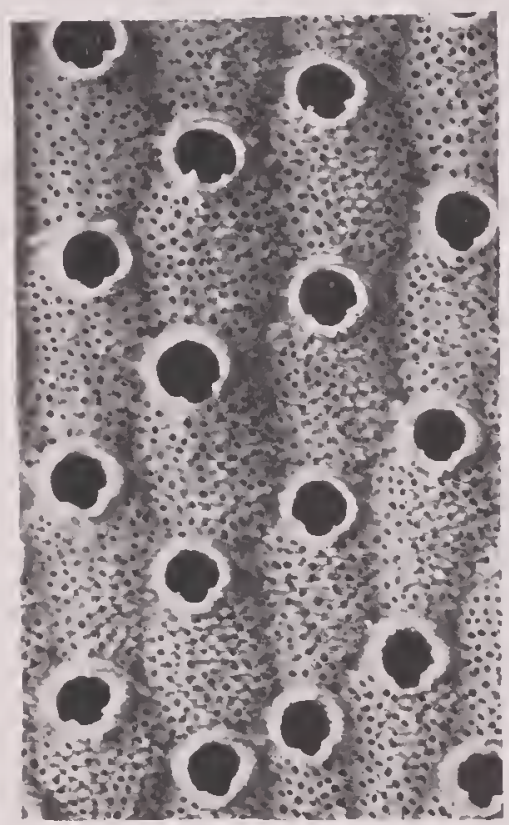
16

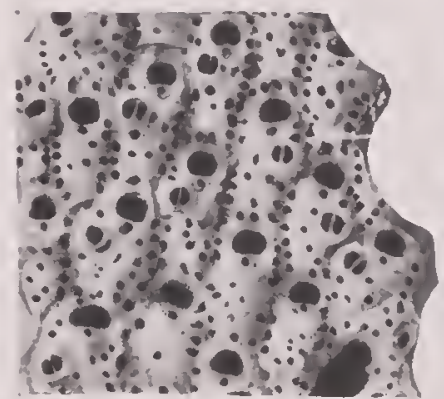

11

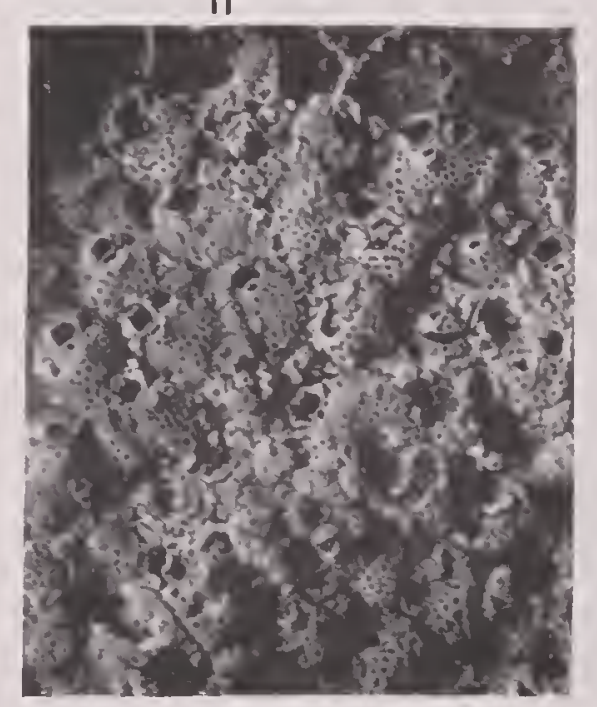

14

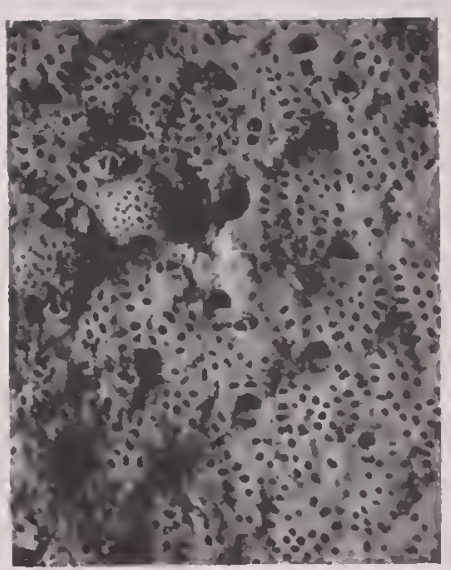

2
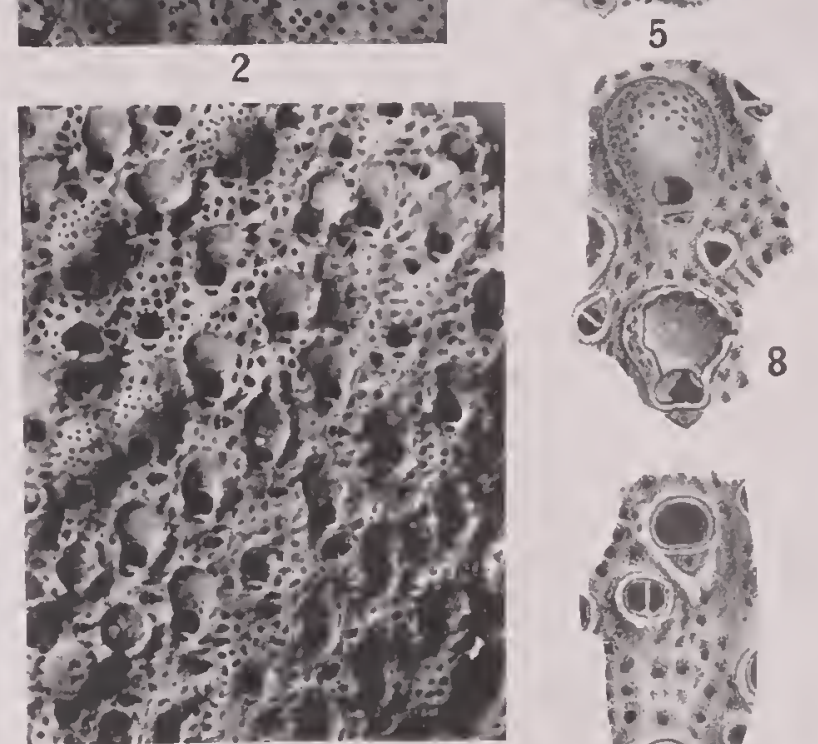

7
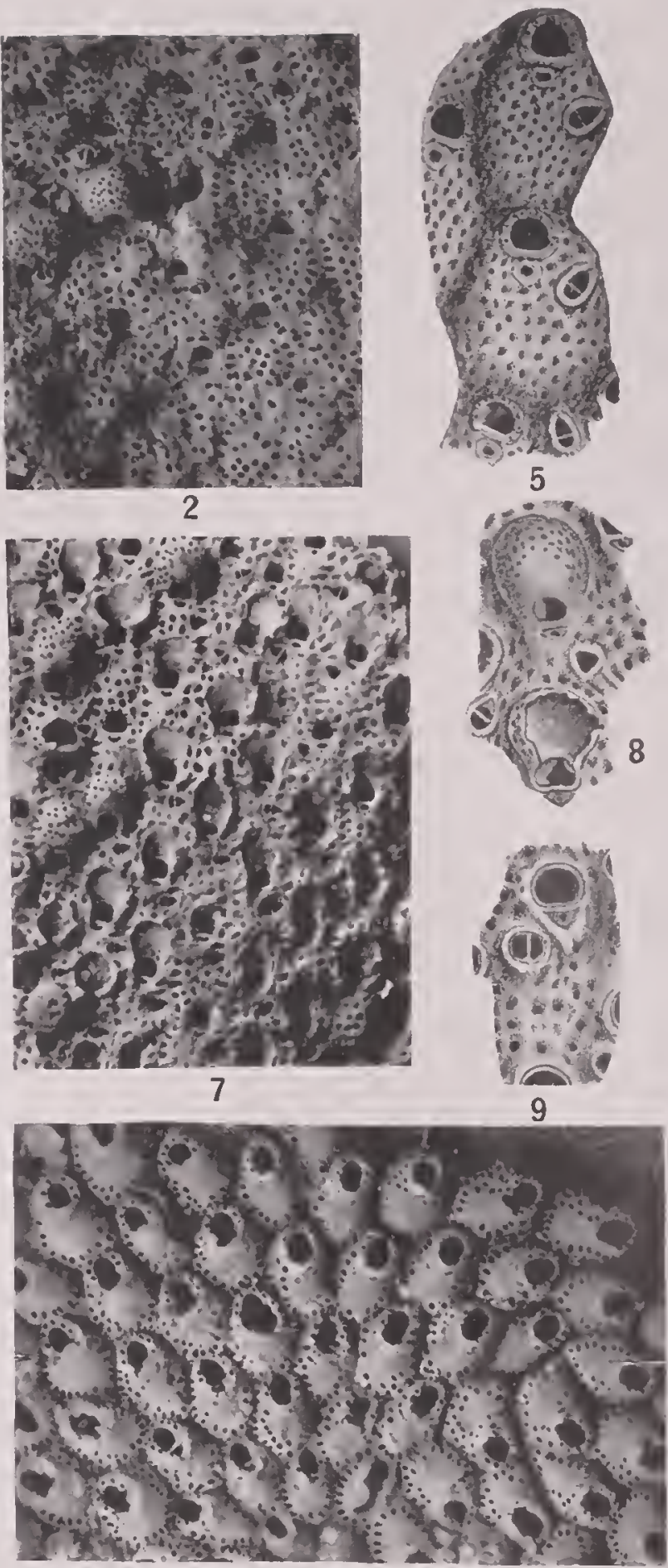

12

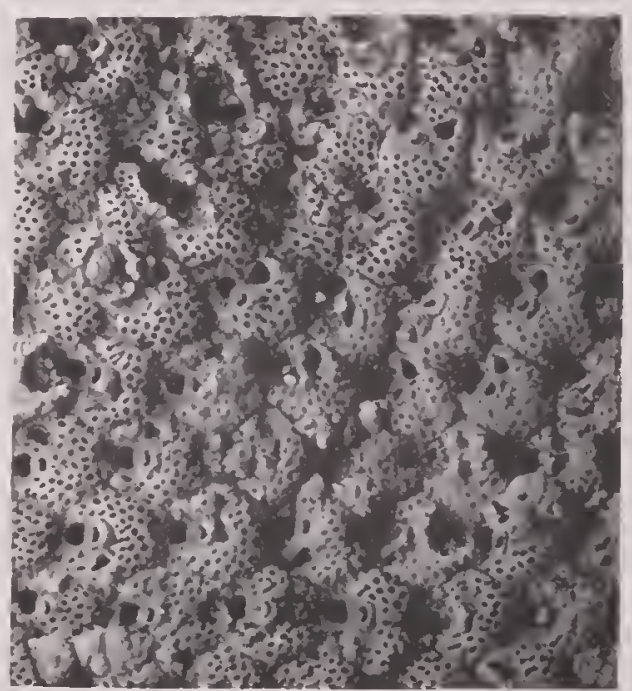

15

NORTH AMERICAN LATER TERTIARY AND QUATERNARY BRYOZOA. 

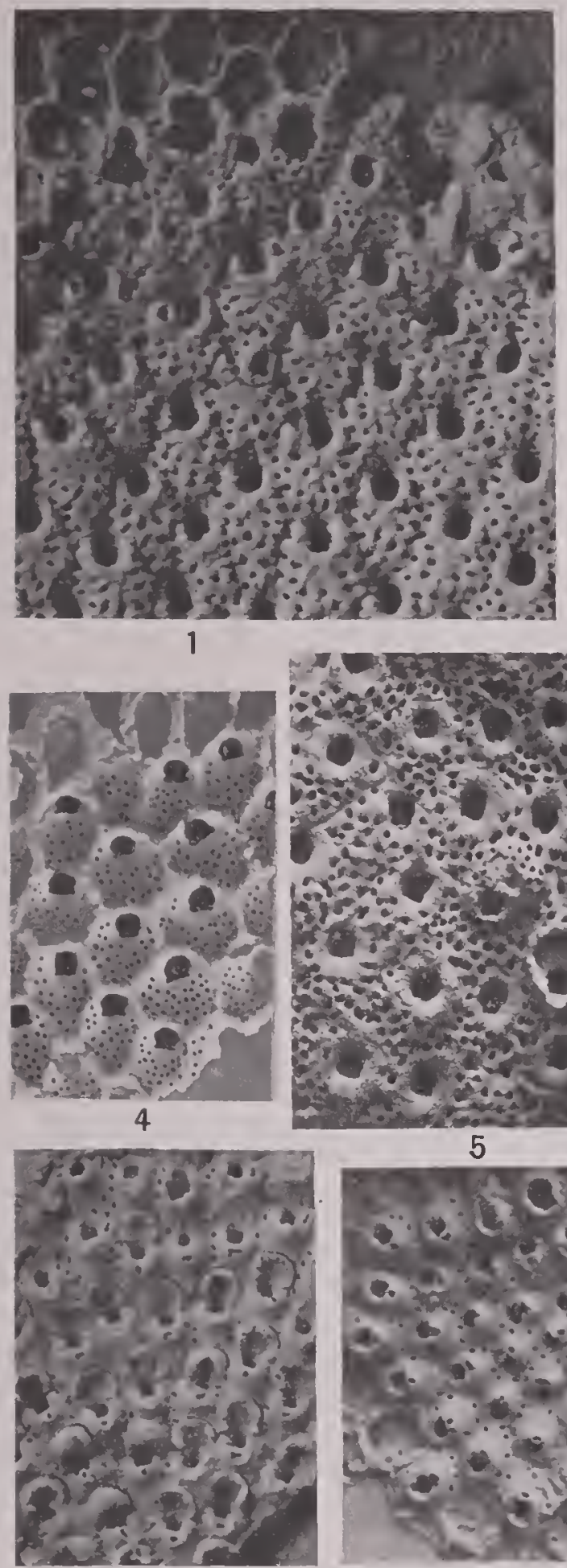

$$
10
$$

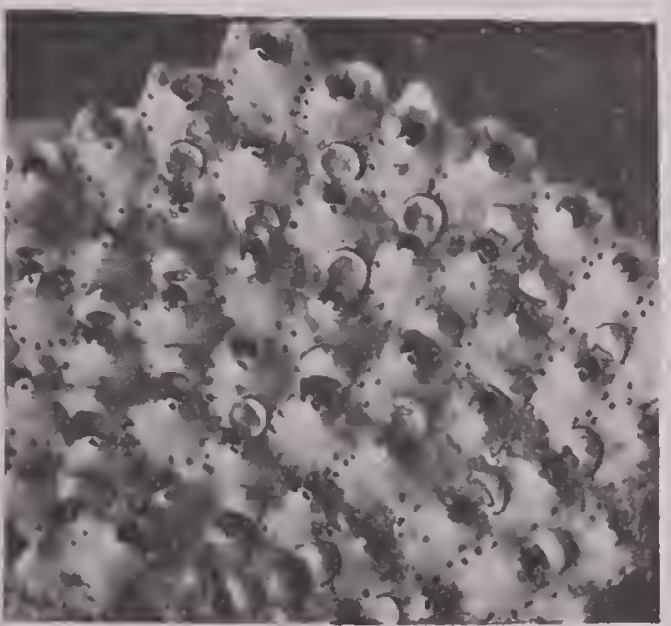

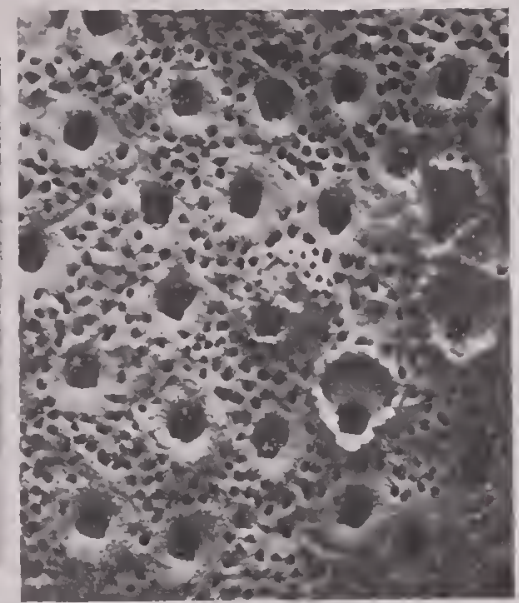

5

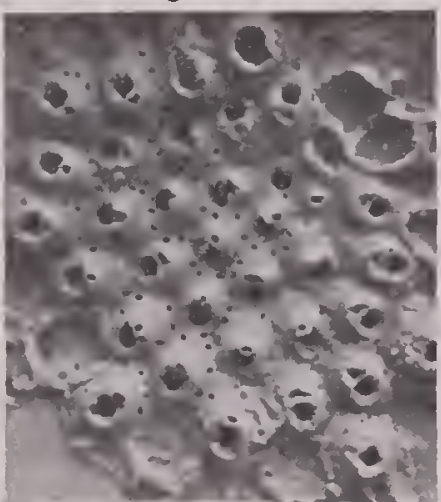

11

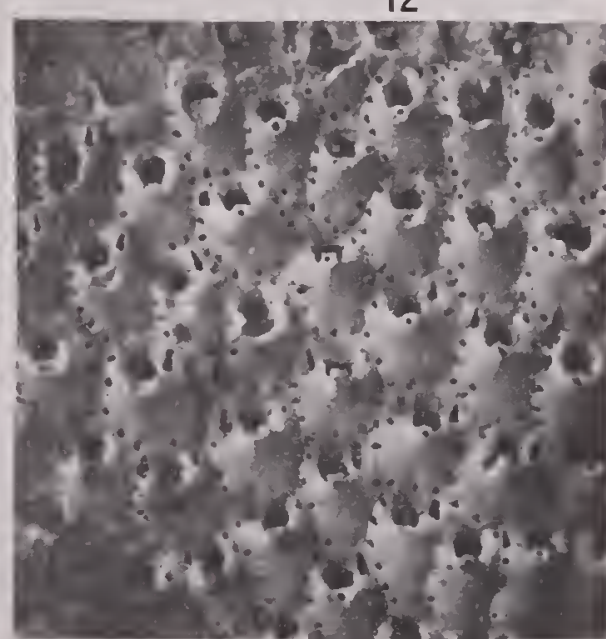

14

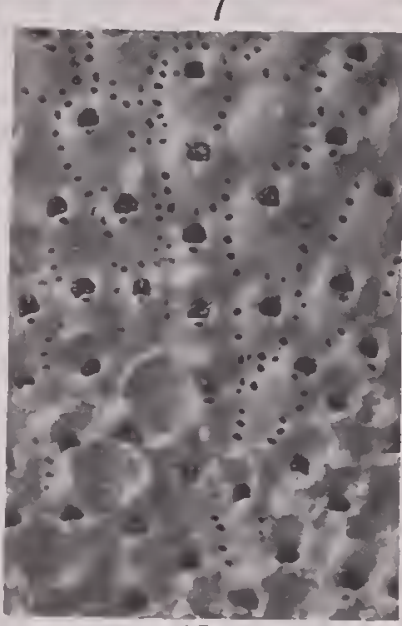

\section{2}

3.1.

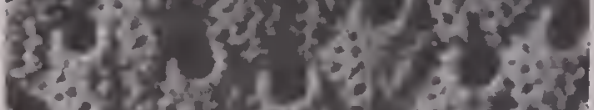
$6 \mathrm{l}^{2}+\mathrm{y}$ -

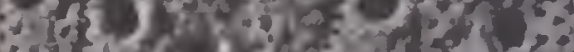

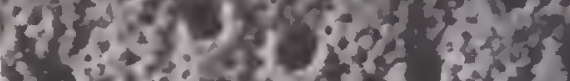

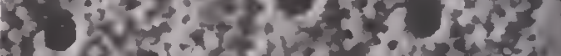

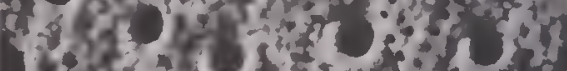

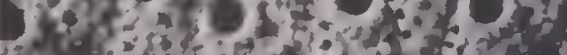

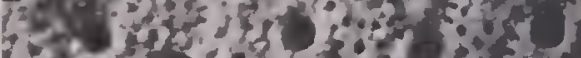

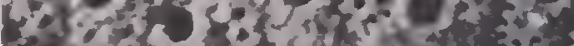

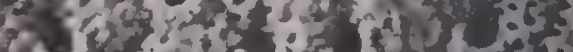

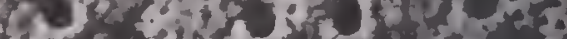

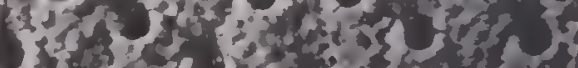

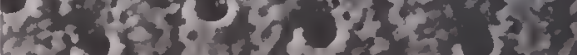

$$
3
$$
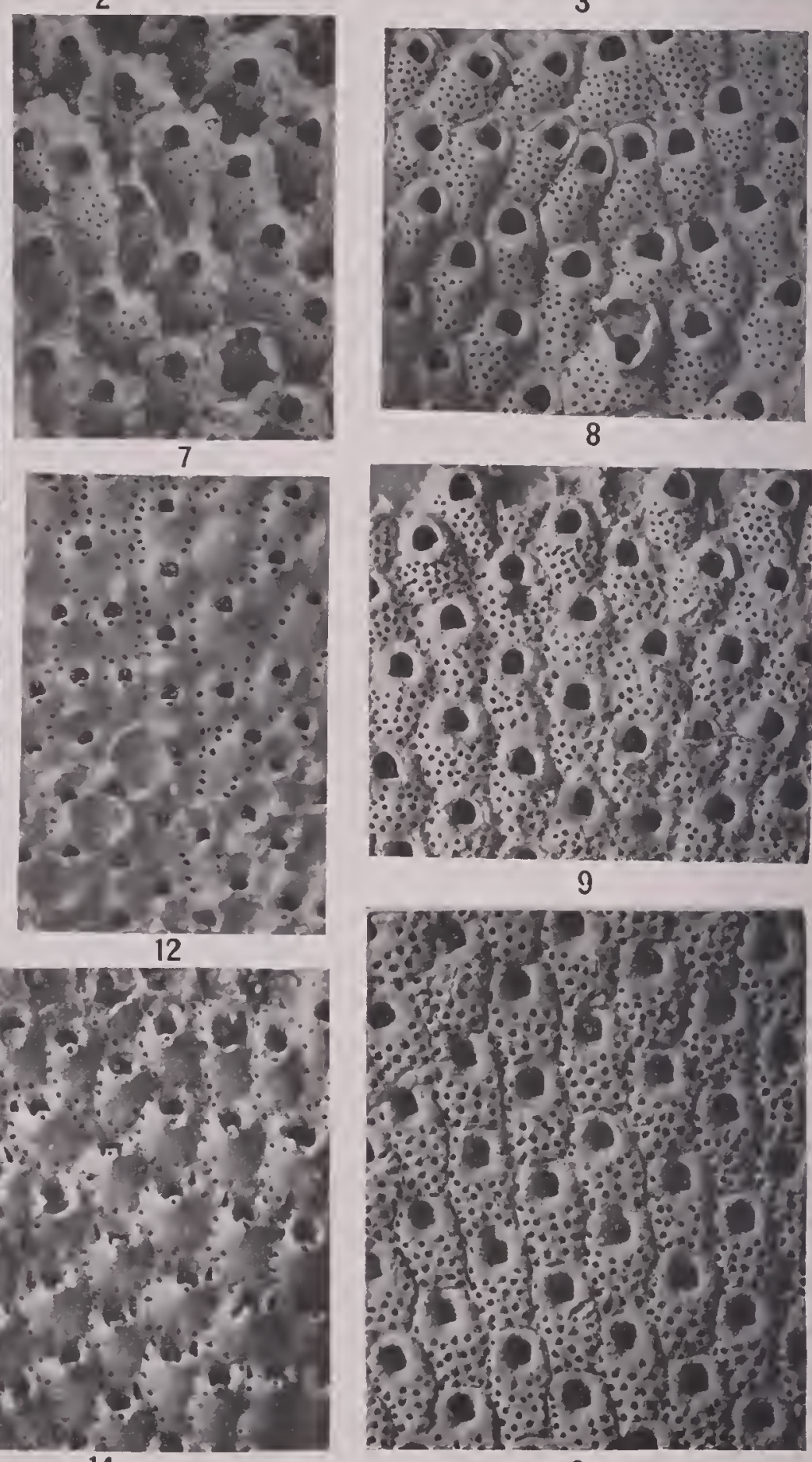

6 
Plate 21.

FIGs. 1-4. Cyclocolposa tenuiparietis, new species. (p. 136.)

1. The incrusting zoarium, $\times 20$, with some of the zooecia bearing a round avicularium. The thinness of the zooecial walls may be noted.

2. Ovicelled zooecia, $\times 20$, shoring the ovicell deeply imbedded in the distal zooecium.

3. Zooecia, $\times 20$, exhibiting regular arrangement, the two rows of areolae and the granulated pleurocyst.

4. Interior of the zooecia, $\times 20$, illustrating the condyles on each side of the apertura.

Miocene (Duplin marl): Harvey's Mills, Leou County, Florida.

FIGS. 5-9. Cycloperiella rubra, new species. (p. 137.)

5. Surface of an incrusting lamella, $\times 20$, with several ovicelled zooecia, showing that the ovicell entirely covers the apertura.

6. Normal zooecia, $\times 20$.

7. Interior of the zooecia, $\times 20$, illustrating the two lateral condyles on which the operculum oscillates.

Miocene (Duplin marl): Wilmington, North Carolina.

8. Zooecia, $\times 20$, preserving a frontal gibbosity.

Miocene (Duplin marl): $\delta$ miles east of Snow Hill, North Carolina.

9. A Pliocene example of this species, $\times 20$; the zooecia are slightly less regular than in the Miocene form.

Pliocene (Waccamaw marl): Waccamaw River, Horry County, South Carolina.

FIGs. 10-14. Aimulosia aculeata, new species. (p. 139.)

10. The incrusting zoarium with ovicelled zooecia, $\times 20$

Miocene (Duplin marl): Irarvey's Mills, Leon County, Florida.

11. The ancestrula and surrounding zooecia, $X 20$. The first zooecium is an avicularium while the other four zooecia are normal.

Miocene (Duplin marl): Muldrow's Mills, South Carolina.

12. A very irregular incrusting zoarium, $\times 20$.

Pliocene (Taccamaw marl): Waccamaw River, Horry County, South Carolina.

13. Zoarium with ovicelled zooecia, $\times 20$. The orifice of the ovicell is distinct from the apertura.

14. Broad marginal zooecia, $\times 20$, without ovicell.

Miocene (Duplin marl): Wilmington, North Carolina. 
Plate 22.

FIgs. 1-6. Lciosella edax, new species. (p. 142.)

1. Fragments of the free unilamellar zoarium, natural size.

2. A tubular zoarium, $\times 20$, with the zooecia exhibiting the large rimule spiramen.

3. Oricelled zooecia, $\times 20$.

4. Zoocia, $\times 20$, in which the small frontal avicularia are replaced by a large avicularium with spatulate mandibles.

5. A tubular zoarium, $\times 20$, showing zooecia provided with au irregular rimule spiramen and with small avicularia.

6. Interior of zooecia, $\times 20$, showing the apertura and the peristomial avicularium.

Lower Miocene (Chipola marl): Chipola River, Calhoun County, Florida.

Figs. 7-14. Smittina trispinosa Johnston, 183S. (p. 143.)

7. Unovicellel zooecia of a well preserve zo.trium, $\times 20$, with the avicularium small or absent.

8. Ancestrula and surrounding zooecia of the same zoarium, $\times 20$.

Pliocene (Waccamaw marl): Waccamaw River, Horry County, South Carolina.

9. Ancestrula region of a Miocene example, $\times 20$.

Miocene (Duplin marl): Wilmington, North Carolina.

10. An abracied surface, $\times 2$ ?, showing the alternate arrangement of the zooecia between two rectilinear axes without septulae.

11. An ovicelled zoarium, $\times 2$, in which the ovicells are broken. The alternate arrangement of the zooecia is visible.

12. Zooecia, $\times 20$, with salieat avicularia.

13. Zooecia, $\times 20$, in which the peristome is formed by two lateral salient lips.

14. Zooecia, $X 20$, with well-preserved ovicells.

Pliocene (Caloosahatchee marl): Shell Creek, De Soto County, Florida. 


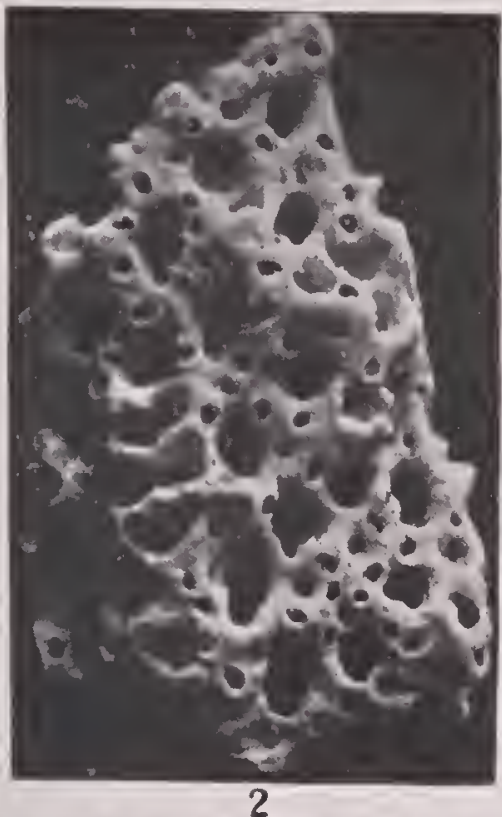

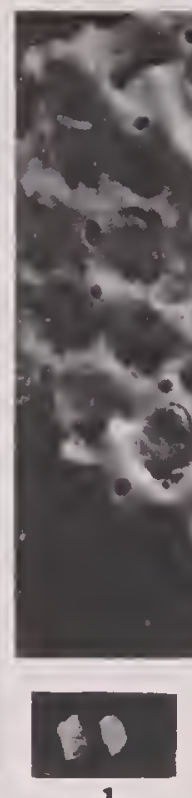

1

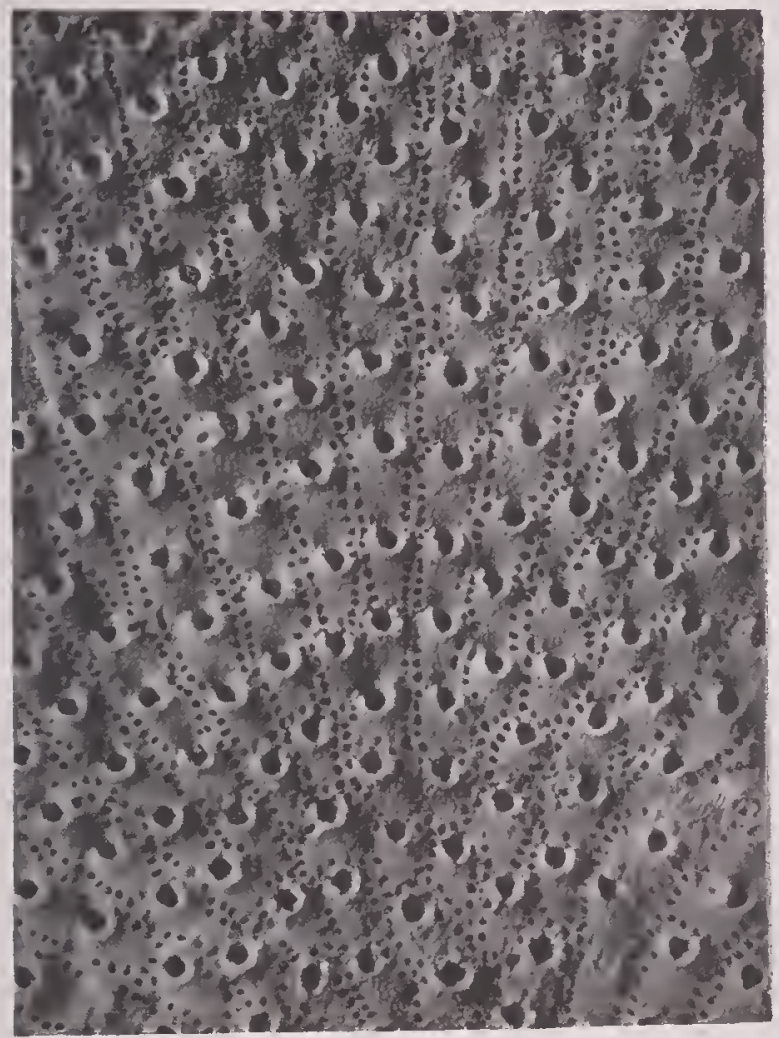$$
7
$$

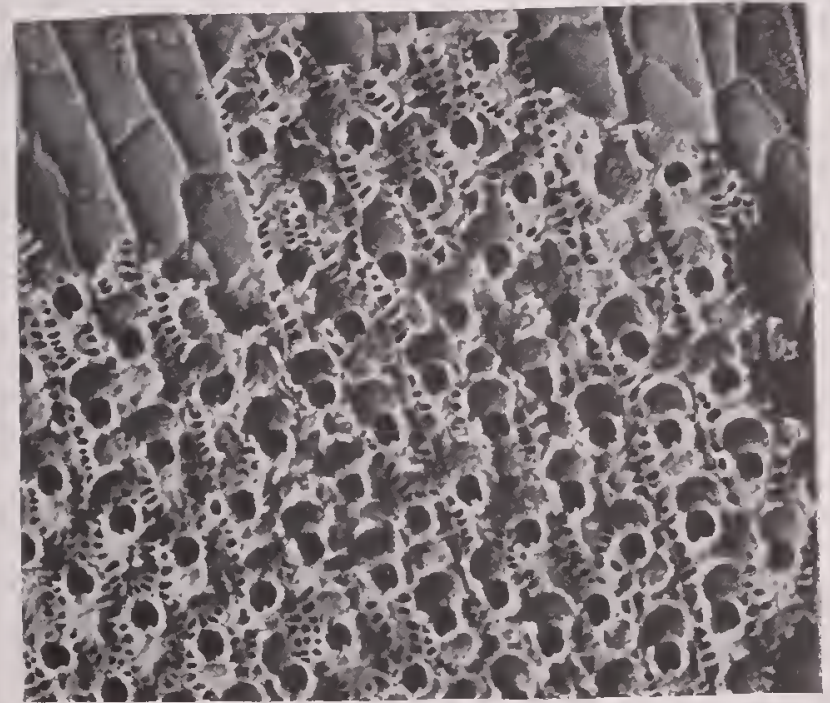

11
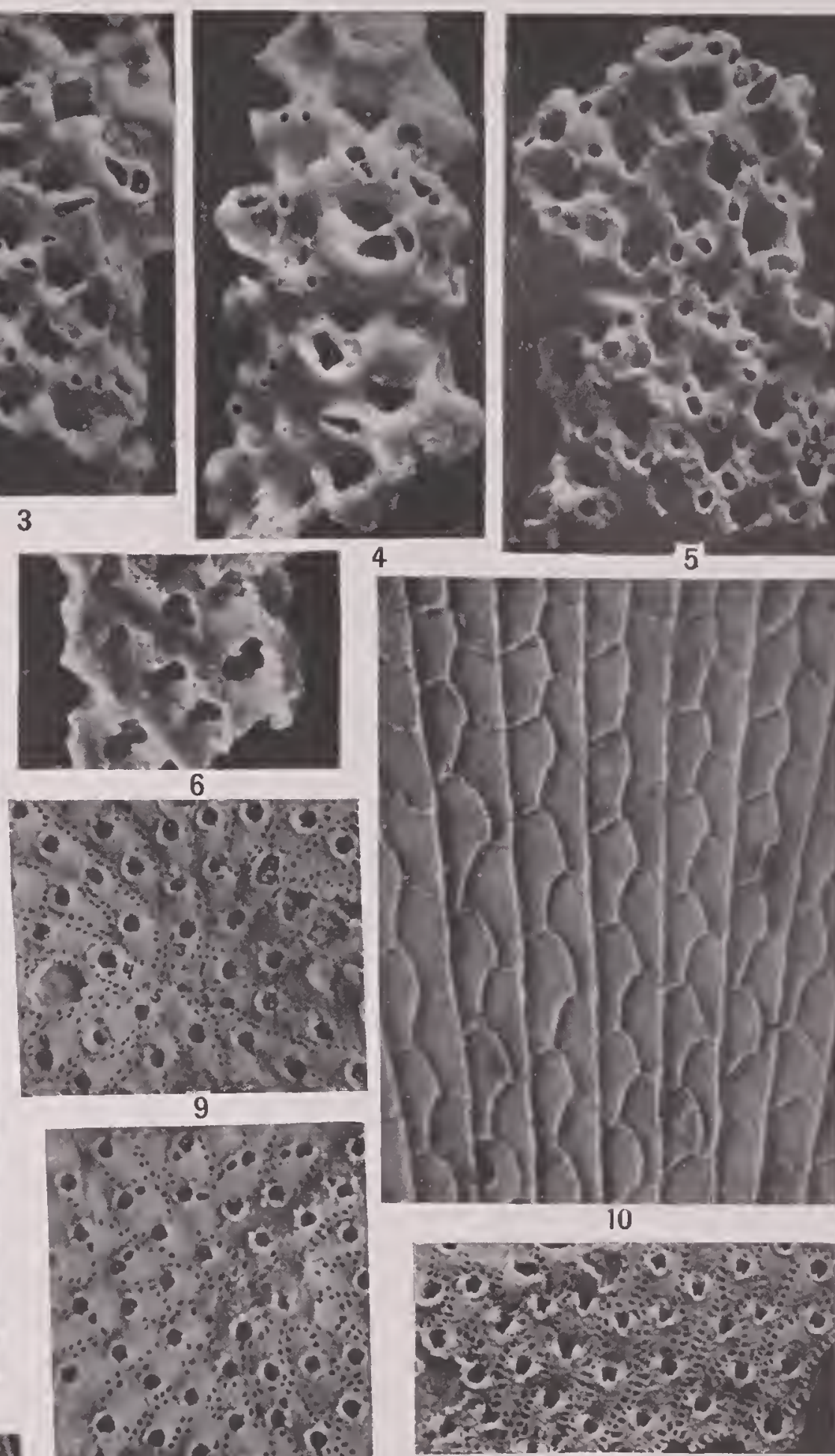

13

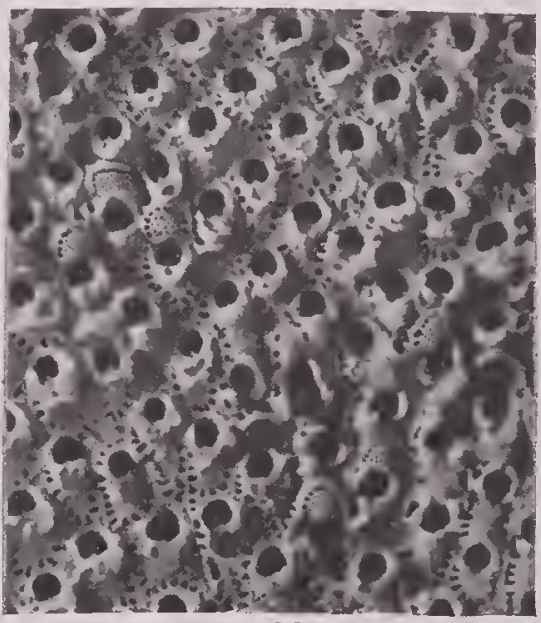

14

NORTH AMERICAN LATER TERTIARY AND QUATERNARY BRYOZOA. 


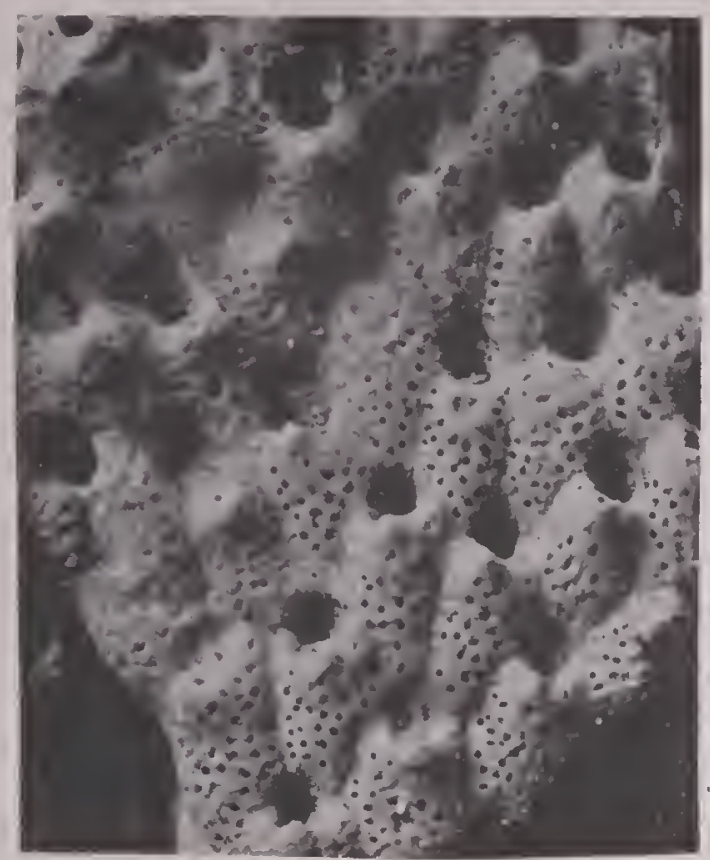

$$
2
$$

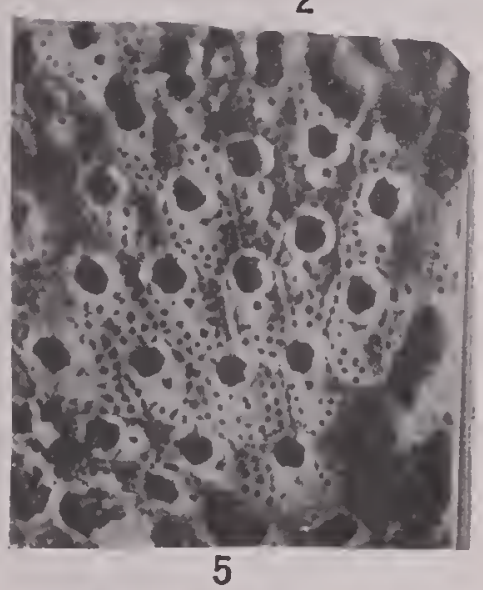

5
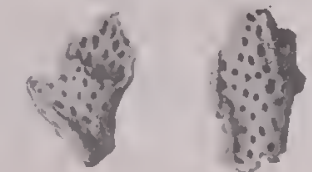

12

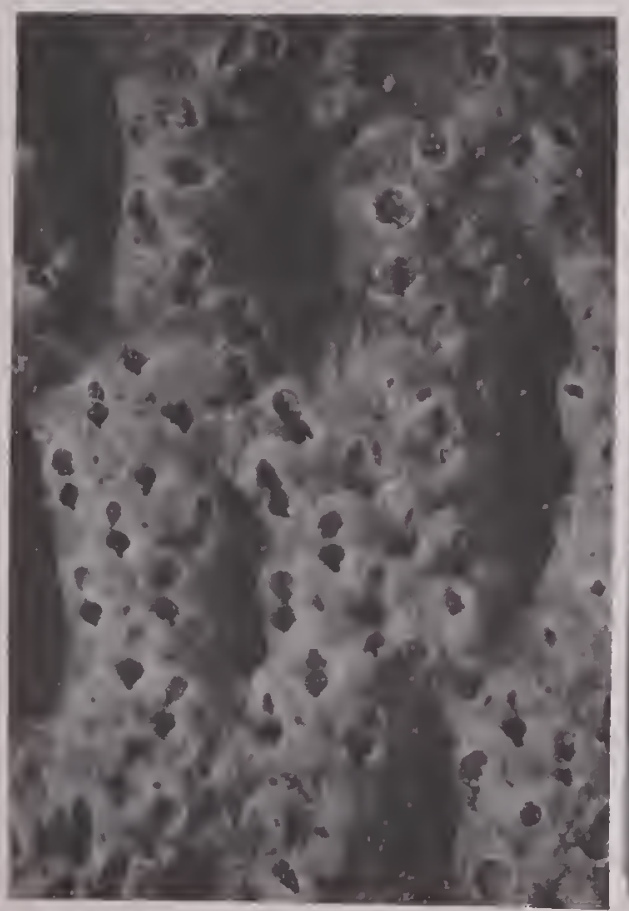

14

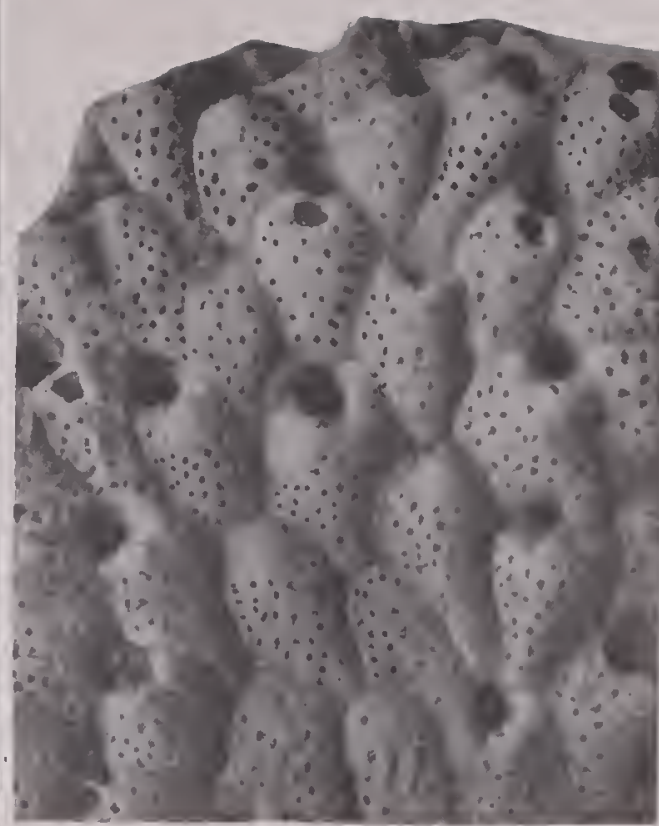

3

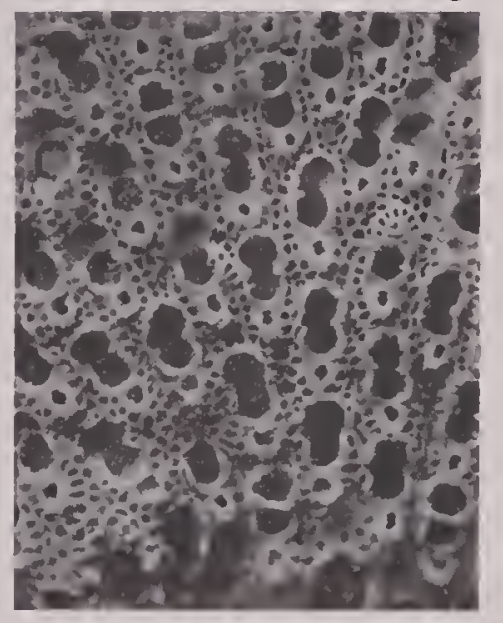

6
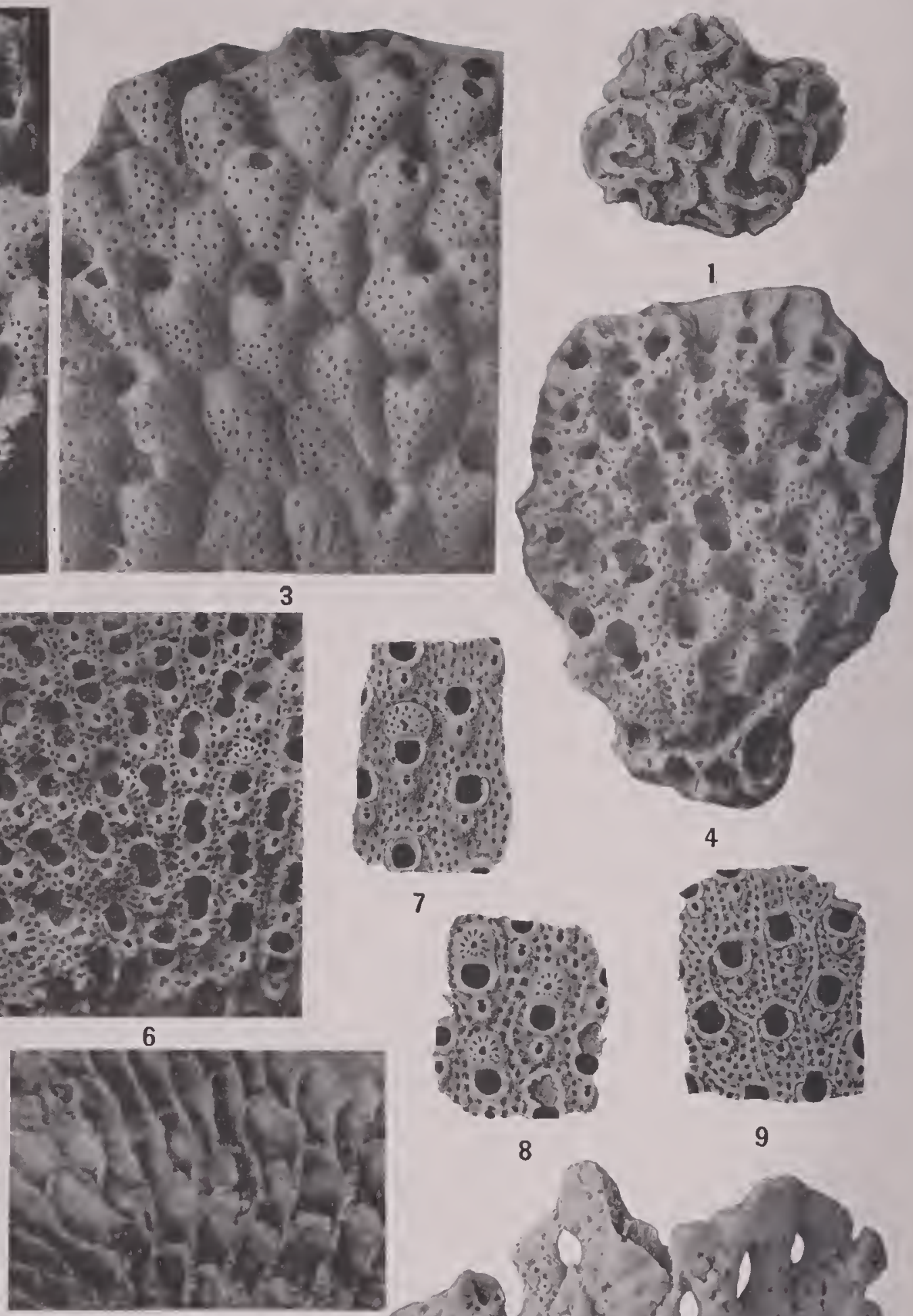

9

8

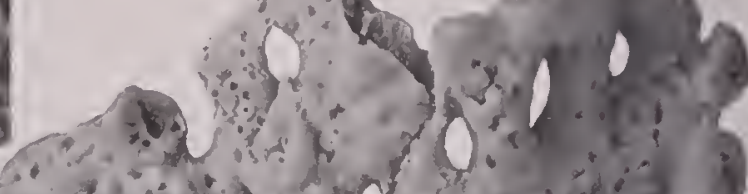

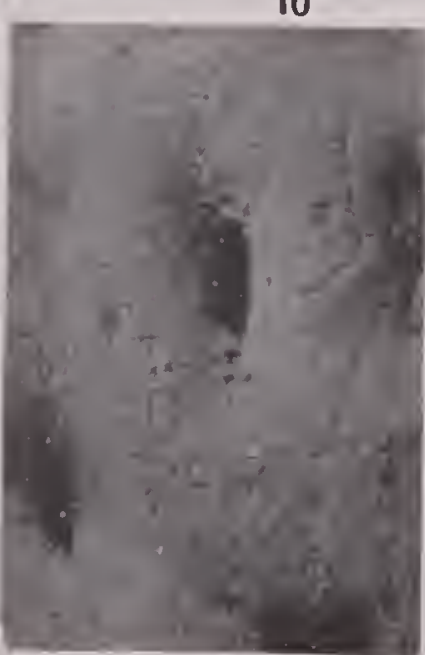

15

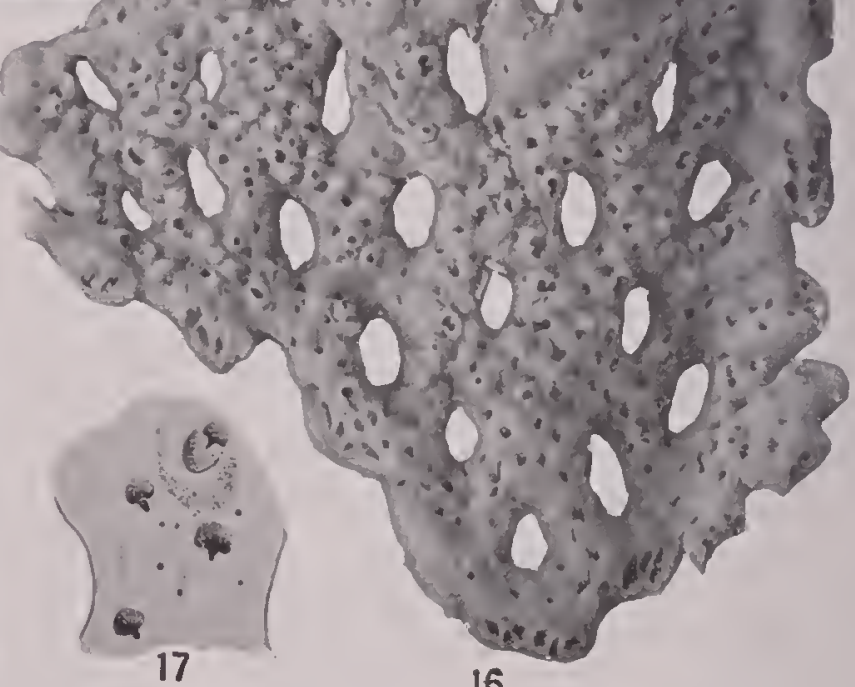

16

NORTH AMERICAN LATER TERTIARY AND QUATERNARY BRYOZOA. 


\section{Plate 23.}

FIgs. 1-3. Porella (Palmicellaria) convoluta Ulrich and Bassler, 1904. (p. 150.)

1. The convoluted, bifoliate zoarium, natural size.

2. Zooecia, $\times 20$, showing the prominent mucro and the avicularium.

3. Surface of another fragment, $\times 20$, with several closed zooecia.

Miocene (Calvert formation): Reeds, Maryland.

FIG. 4. Porella (Palmicellaria) punctata Ulrich and Bassler, 1904. (p. 150.)

The bifoliate type specimen, $\times 20$.

Miocene (Calvert formation): Reeds, Maryland.

Fias. 5-10. Porella reversa Ulrich and Bassler, 1904. (p. 148.)

5. Portion of the incrusting zoarium, $\times 20$, showing the zooecia with thin raised borders.

6. Another zoarium, $\times 20$, with ovicelled zooecia.

7. Drawing showing usual aspect of the ovicelled and unovicelled zooecia, $\times 28.5$.

8. Zooecia of a specimen with ovicells, $\times 28.5$.

9. Several zooecia, $\times 28.5$, with the boundaries well defined.

Miocene (St. Mary's formation): Cove Point, Maryland.

10. A view of the zooecial walls after abrasion of the frontal, $\times 20$.

Miocene: Kuhns, Carteret County, North Carolina.

FIGs. 11-17. Retepora doverensis Ulrich and Bassler, 1904. (p. 152)

11-13. Three specimens, natural size.

14. Portion of a type specimen, $\times 20$, showing the fissured ovicell and the wide irregular rimule spiramen.

15. Noncelluliferous side of a zoarium, $\times 20$.

16. One of the original types, $\times 8$, with ovicelled zooecia.

17. Drawing of several zooecia, $\times 30$.

Miocene (Choptank formation): Dover Bridge, Maryland. 
Plate 24

Fras. 1, 2. Adeona heckeli Reuss, 1847. (p. 158.)

1. Suriace of zoarium, $\times 29$, showing convex, young zooecia.

2. The normal aspect of the zoxrium, $\times 20$, in which the zooecia are flat.

Miocene (Duplin marl): Wilmington, North Carolina.

Figs. 3, 4. Tremogasterina horrifa, new species. (p. 168.)

3. The free, bilamellar zoarium, natural size.

4. Zooecial surface, $\times 2$, illustrating the large median orbicular pore surrounded by a line of areolar pores, and the immense triangular avicularium.

Miocene (Choctawhatchee marl): Jackson Blufi, Ocklocknee River, 25 miles southwest of Tallahassee, Florida.

Figs. 5-8. Adeonellopsis coccinella, 11ew species. (p. 161.)

5. Fragments of the bilamellar zoarium, natural size.

6. Surface of the bilamellar zoarium, $\times 20$, with poorly oriented zooecia.

7. Another surface, $\times 2$, with more regularly arranged zooecia and showing the frontal perforated by stellate pores.

S. Interior of zooecia, $\times 20$, illustrating the frontal perforations,

Lower Miocene (Chipola marl); Chipola River, Calhoun County, Florida.

Fia. 9. Lagenipora(?) brevicollis, new species. (p. 171.)

Zooecia of the incrusting zoarium, $\times 20$, illustrating the form of the apertura, the tremopores, and the occasional small avicularia.

Miocene (Duplin marl): Kuhns, Carteret County, North Carolina.

Figs. 10-13. Itoloporella parvula, new species. (p. 175.)

10. The free irregularly brancherl zoarium, natural size.

11. Surface, $\times 20$, illustrating the very small, cumulate zooecia

12. Another portion of the type, $\times 20$, showing the small umbo before the apertura more clearly.

13. Zooecia, $\times 30$, with areolar pores distinctly visible.

Miocene (Duplin marl): (ape Fear River, $2 S$ miles northwest of Wilmington, North Carolina.

F1G. 14. Holoporella rostrifera, new species. (p. 175.)

The incrusting zoarium, $\times 20$, exhibiting the erect, indistinct zooecia with the four salient rostra about the a pertura.

Ifiocene (Yorktown formation): York River, Virginia.

F1G. 15. Aetea anguina (?) Linnaeus, 1758. (p. 49.)

The incrusting network, $\times 20$, referred doubtfully to this recent species.

Pliocene (Waccamaw marl): Waccamaw River, Horry County, South Carolina.

268 


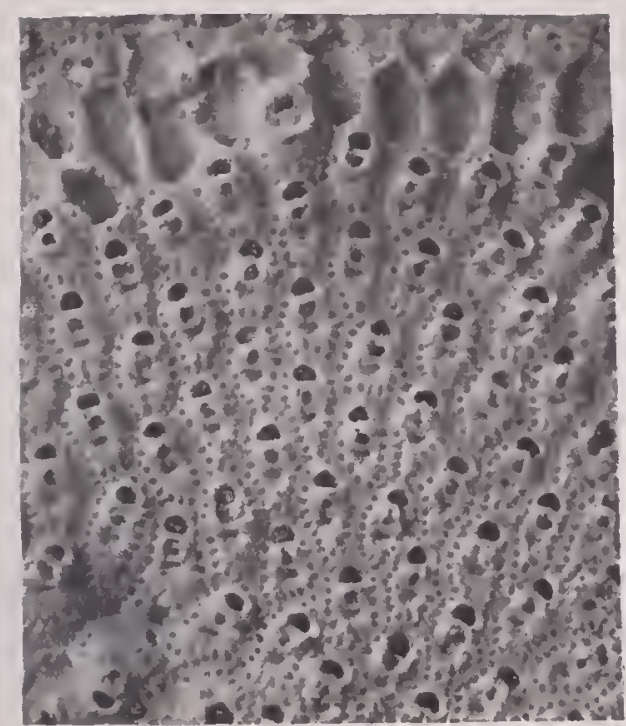
1

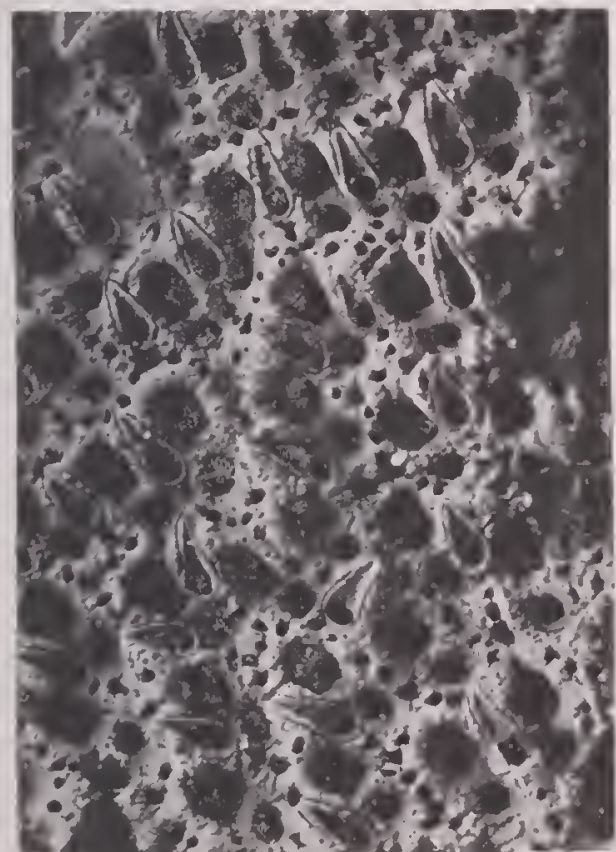
4

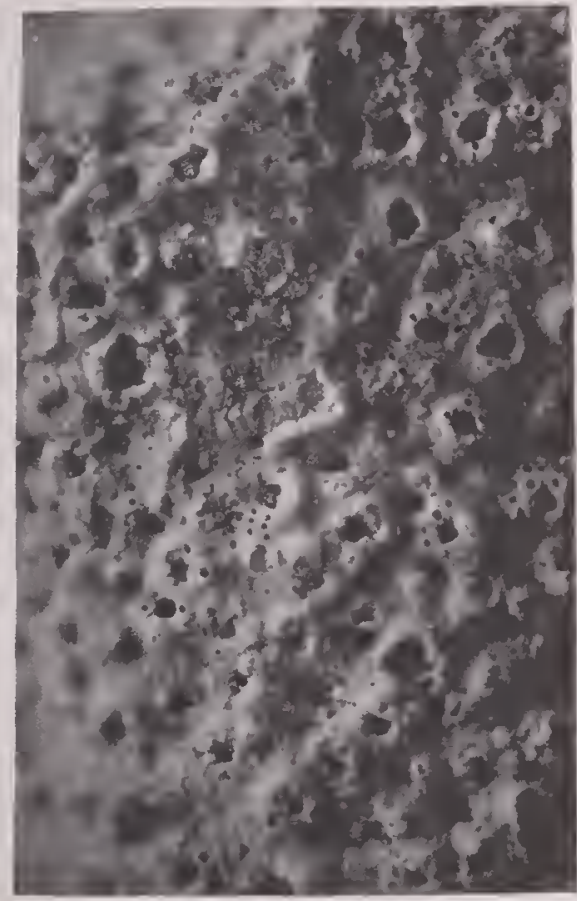

II

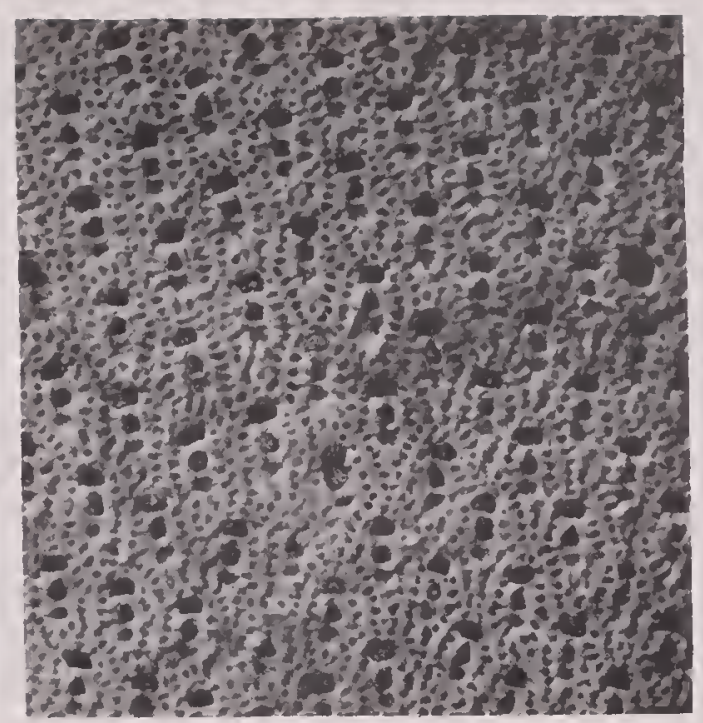

$$
2
$$

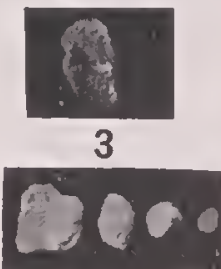

5

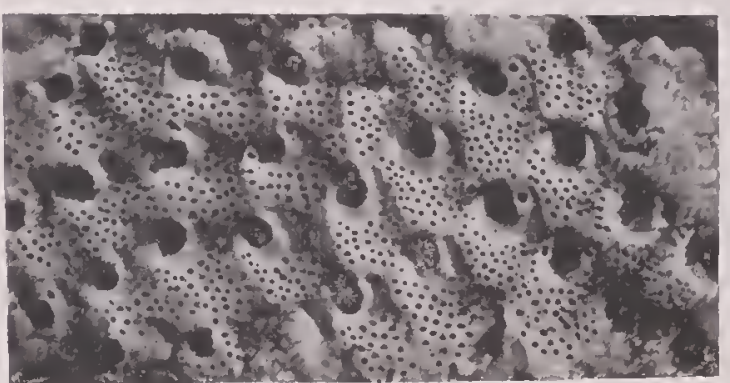

9
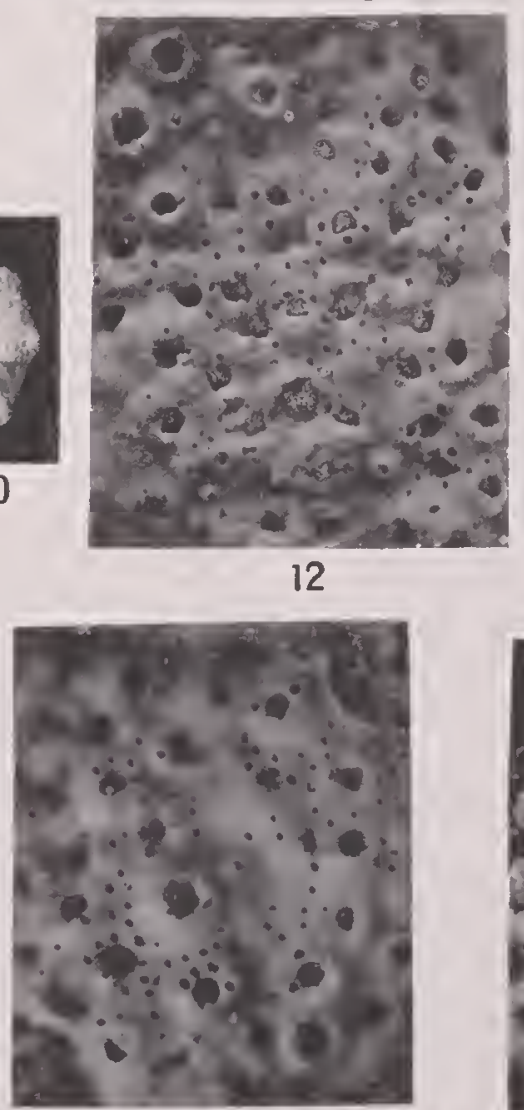

13

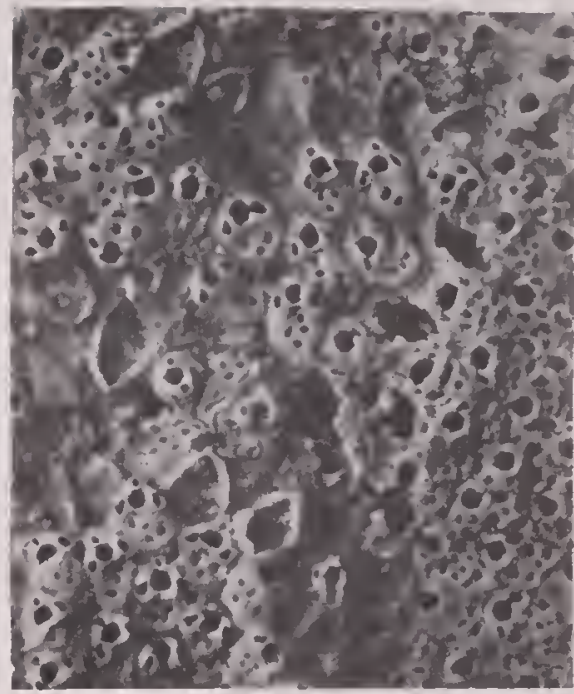

6

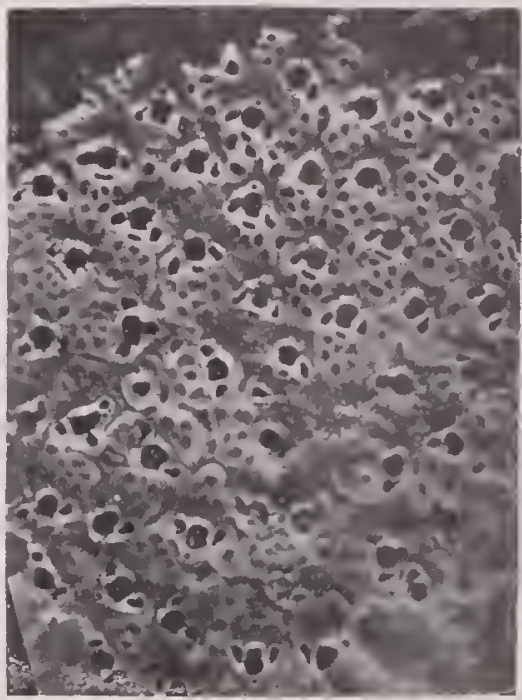

7

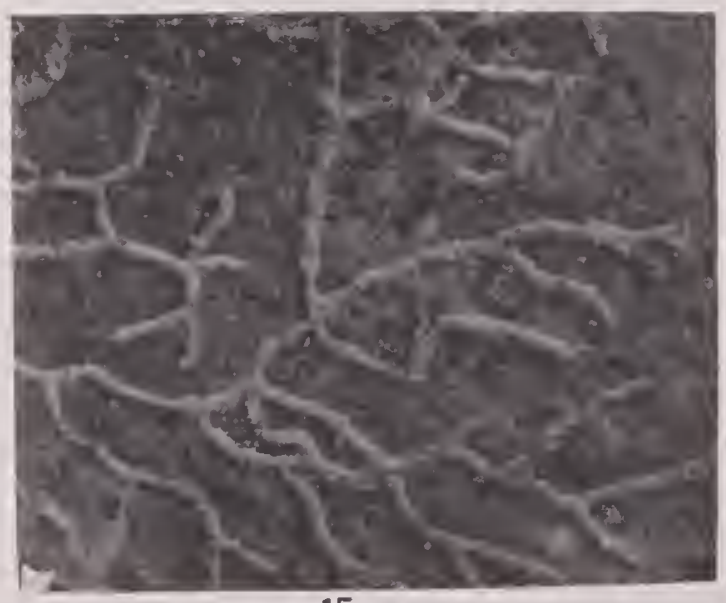

15

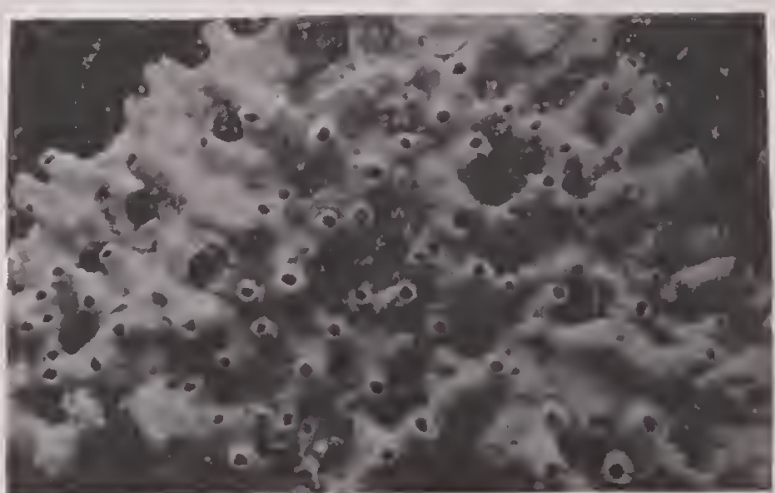

14

NORTH AMERICAN LATER TERTIARY AND QUATERNARY BRYOZOA. 


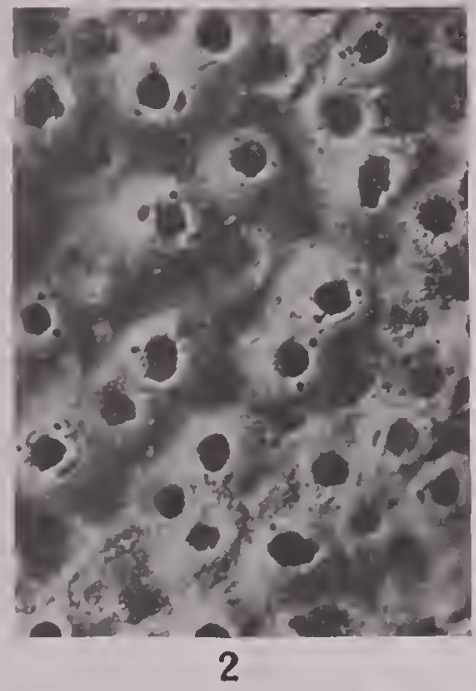

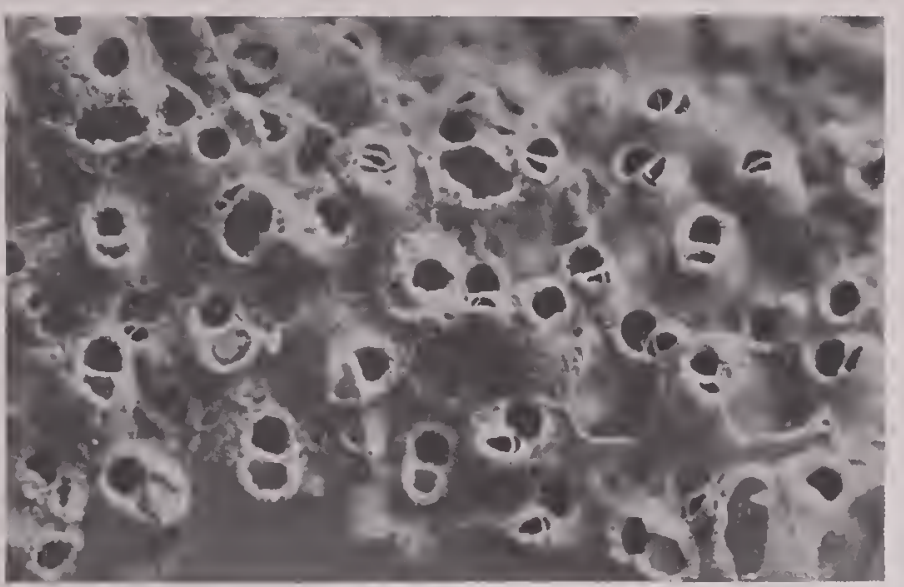
7

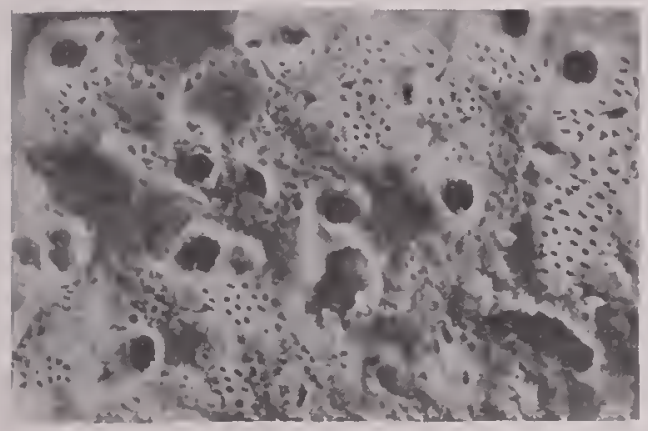

8

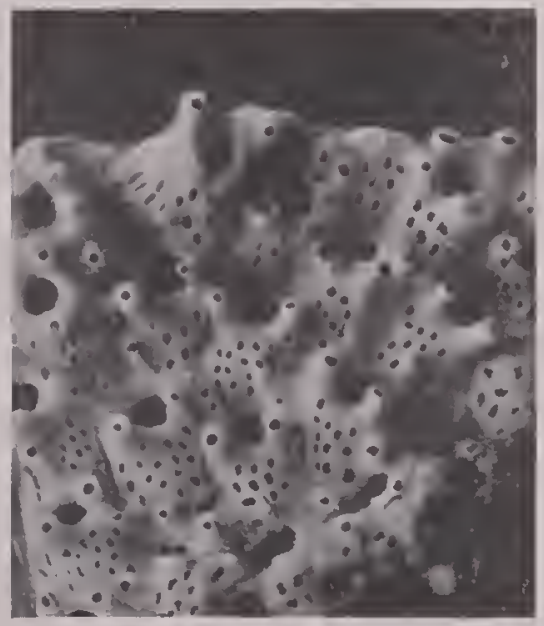

9
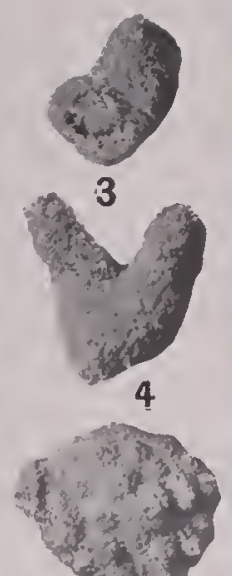

3.5

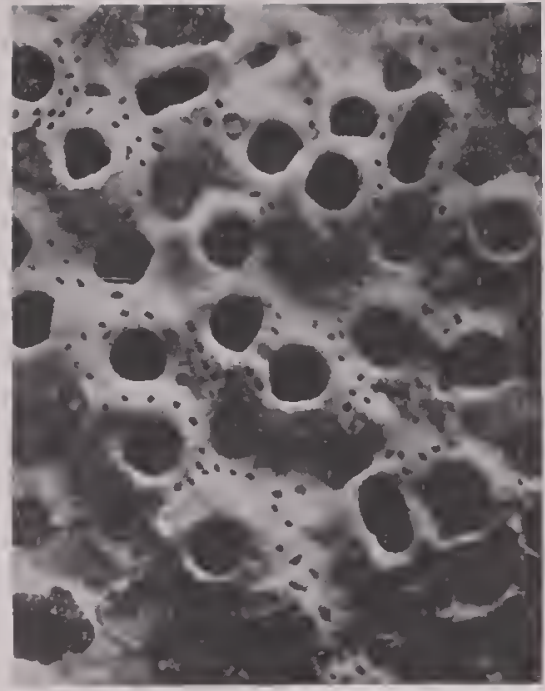

5

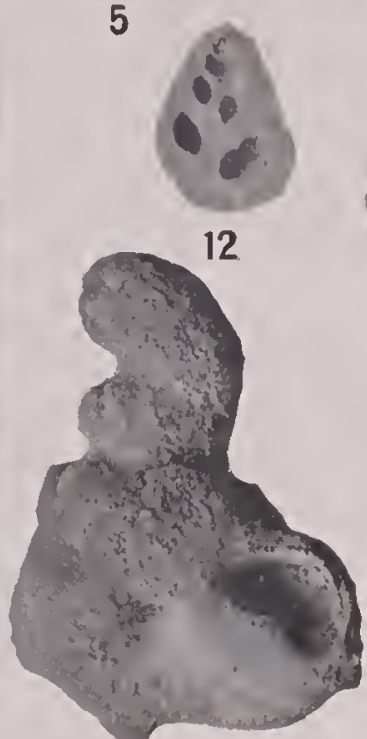

15
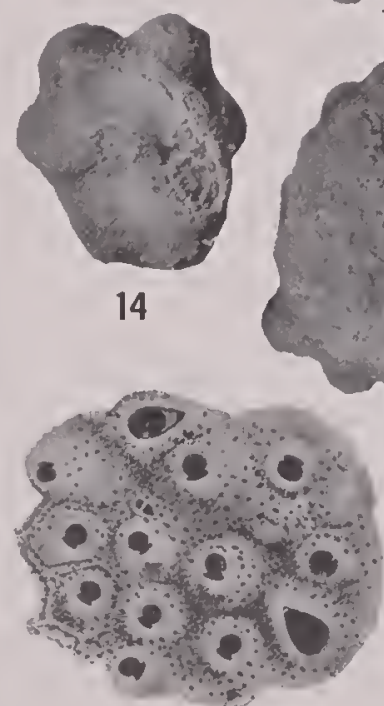

17

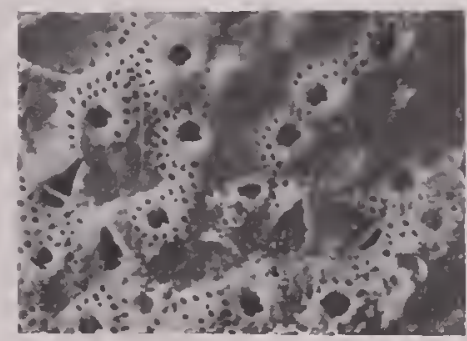

18
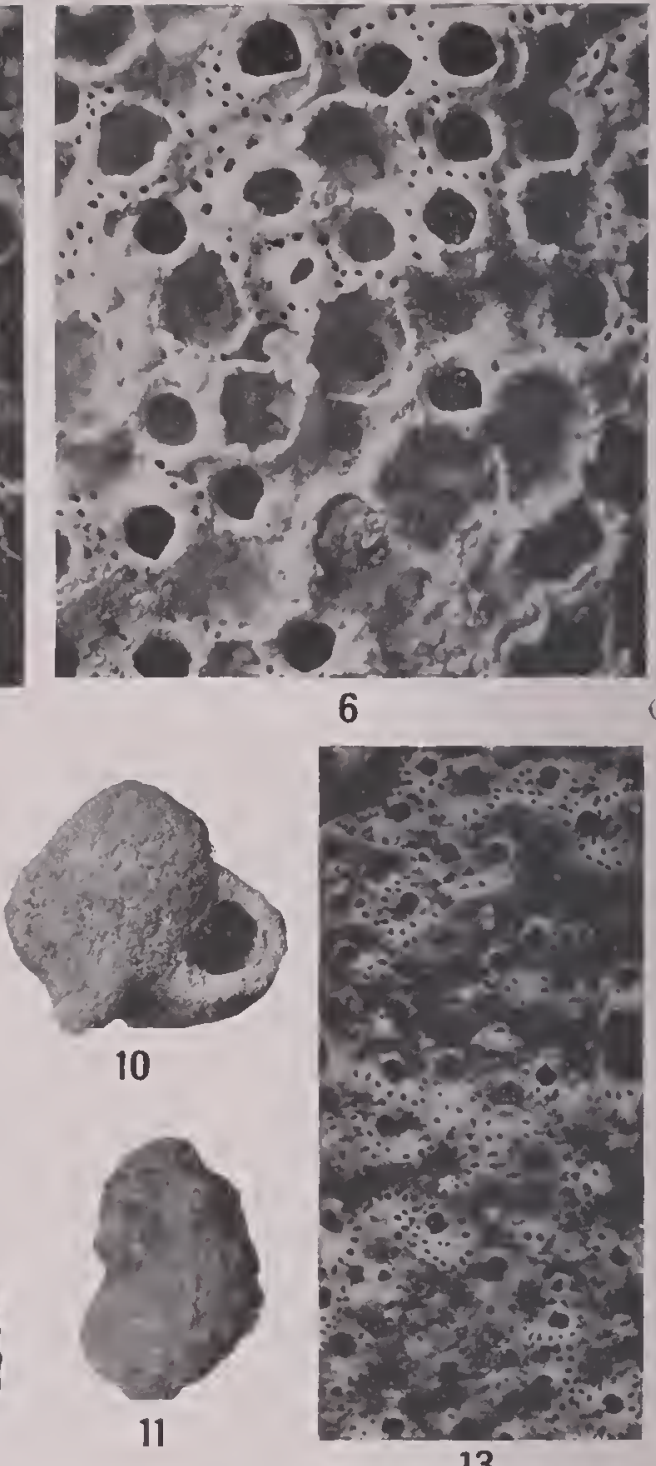

13

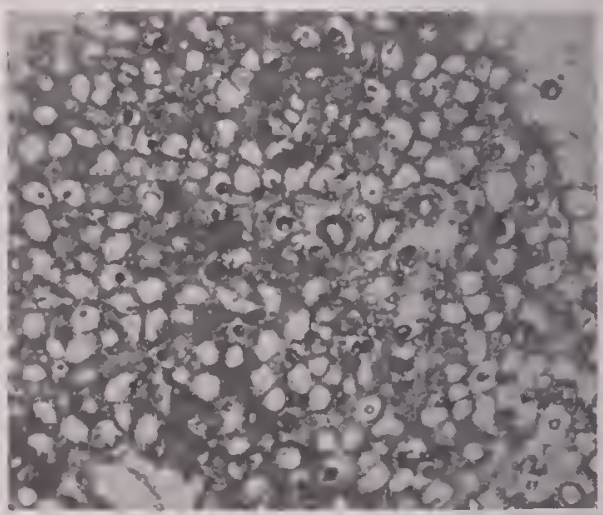

19

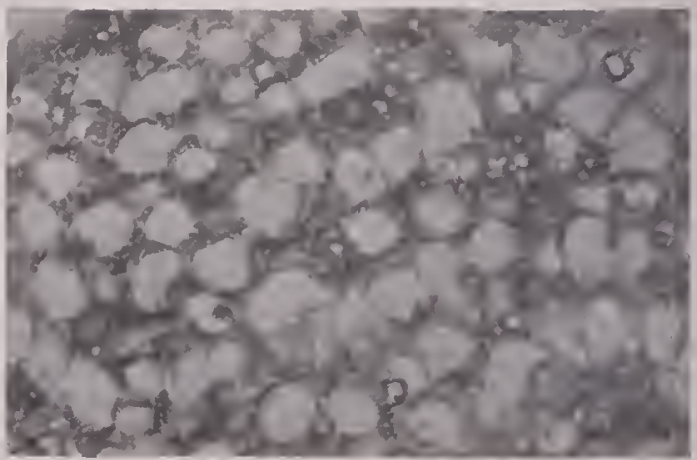

20

NORTH AMERICAN Later TERTIARY and QUaternary BRYOZOA.

For EXPLANATION OF PLATE SEE PAGE 269. 
Plate 25.

Figs. 1, 2. Holoporclla (?) echinata, new species. (1) 177.)

1. The globular zoarium, natural size.

2. Zooecia, $\times 20$, showing two oral spines and the absence of areolar pores.

Miocene (Yorktown formation): Yorktown, Virginia.

Figs. 3-6. Holoporella orbifcra, new species. (p. 177.)

3, 4. Two examples of the irregular, massive zoaria, natural size.

5 . Portion of the zoarium, $\times 20$, with large interzooecial avicularia. The areolar pores, the convex frontal, and the form of the apertura are well shown.

Pliocene (Waccamaw marl): Waccamaw River, Horry County, South Carolina.

6. Another surface, $\times 20$, illustrating the usual characters noted.

Miocene (Duplin marl): Wilmington, North Carolina.

F1G. 7. Holoporella massalis, Ulrich and Bassler, 1904. (p. 177.)

Surface of the original type, $\times 20$.

Miocene (St. Mary's formation): St. Marys River, Maryland.

F1G. S. Cellepora cribrosa Ulrich and Bassler, 1904. (p. 183.)

Photograph of the type specimen, $\times 20$.

Miocene (Calvert formation): Reeds, Maryland.

Fig. 9. Holoporella subturrita, new species. (p. 176.)

The incrusting zoarium, $\times 20$, illustrating the four prominent rostra with avicularia, about each apertura.

Miocene (Duplin marl): Twenty-eight miles northwest of Wilmington, North Carolina.

Figs. 10-13. Cellepora minuta, new species. (p. 182.)

10-12. Two zoaria, natural size, with a third cut through the middle, showing growth upon gastropod shells.

13. Surface of a zoarium, $\times 20$, illustrating the small size of the zooecia, a single row of areolar pores and the occurrence of small tubular avicularia only.

Miocene (Duplin marl): Wilmington, North Carolina.

Figs. 14-20. Cellepora maculata Ulrich and Bassler, 1904. (p. 182.)

14-16. Three zoaria, natural size, growing as usual upon gastropod shells.

17. Drawing of the surface, $\times 17$, illustrating the shape of the apertura and the two kinds of avicularia as well as the areolar pores.

18. Photograph of zooecia, $\times 20$, illustrating the large interzooecial avicularia.

19. A section through a zoarium, $\times 10$, showing the accumulation of the zooecia.

20. An enlargement of the same, $\times 25$, showing the arrangement and structure in more detail. Miocene (Calvert formation): Plum Point, Maryland. 
PLATE 26.

F1as. 1-3. Ceriopora virginiana, new species. (p. 193.)

1. The irregular globular zoarium, natural size.

2. Surface, $X 12$, showing the thin walls of the polygo:ul zooecia

3. Portion of the same, $\times 25$.

Miocene (Yorktown formation): One mile northeast of Suffolk, Virginia.

Figs. 4-6. Atelesopora reptans, new species. (p. 194.)

4. Zoaria, natural size, incrusting a shell.

5. A complete zoarium, $\times 12$, with the zone of growth showing small lobes.

6. A narrow flabellate zoarium, $\times 12$, with a thick zone of growth.

Miocene (Duplin marl): Muldrows Mills, 5 miles south of Mayville, Sumter County, South Carolina.

F1G. 7. Proboscina mesleri, new species. (p. 193.)

The type specimen, $X 12$, showing the long l,ranches with three rows of zooecia.

Miocene (Duplin marl): Wilmington, North Carolina.

FIG. S. Idmonea(?) expansa Ulrich and Bassler, 1904. (p. 200.)

The irregular, flabellate, incrusting zoarium, $\times 12$.

Miocene (St. Mary's formation): Cove Point, Maryland.

Figs. 9-12. Theonoa glomerata Ulrich and Bassler, 1904. (p. 201.)

9, 10. I large specimen, natural size, and a photograph, $X 4$.

11. A small specimen, natural size.

12. Another view of the same, $\times 4$.

Firis. 13-15. Idmonea planula, new species. (p. 199.)

13. The free zoarium, natural size.

14. Anterior sille, $\times 12$, showing the salient fascicles closely arranged and opposite to each other.

15. Posterior side of the same specimen, $X, 12$, illustrating the flat, transversely striated dorsal.

Miocene (Choctawhatchee marl): Jackson Bluff, Ocklocknee River, 25 miles southwest of Tallahassee, Florida. 


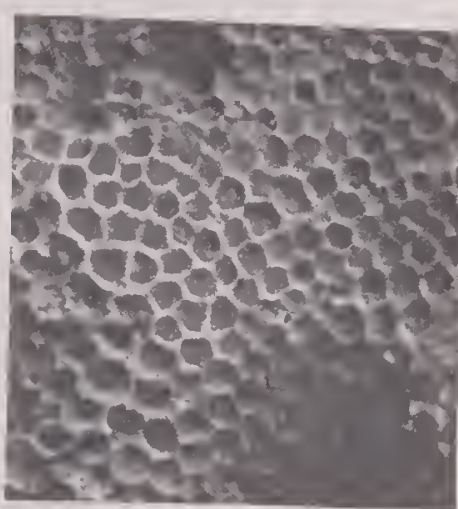

2

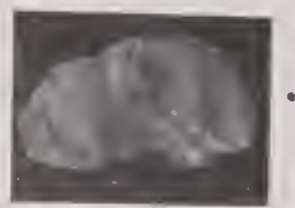

1

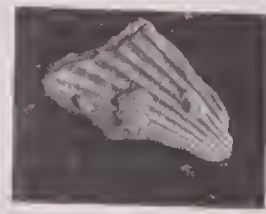

4

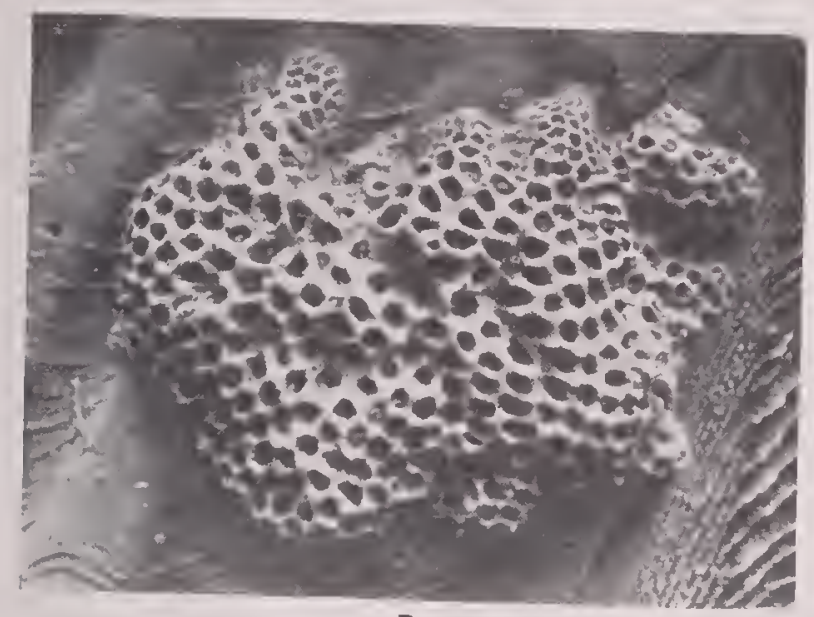

5

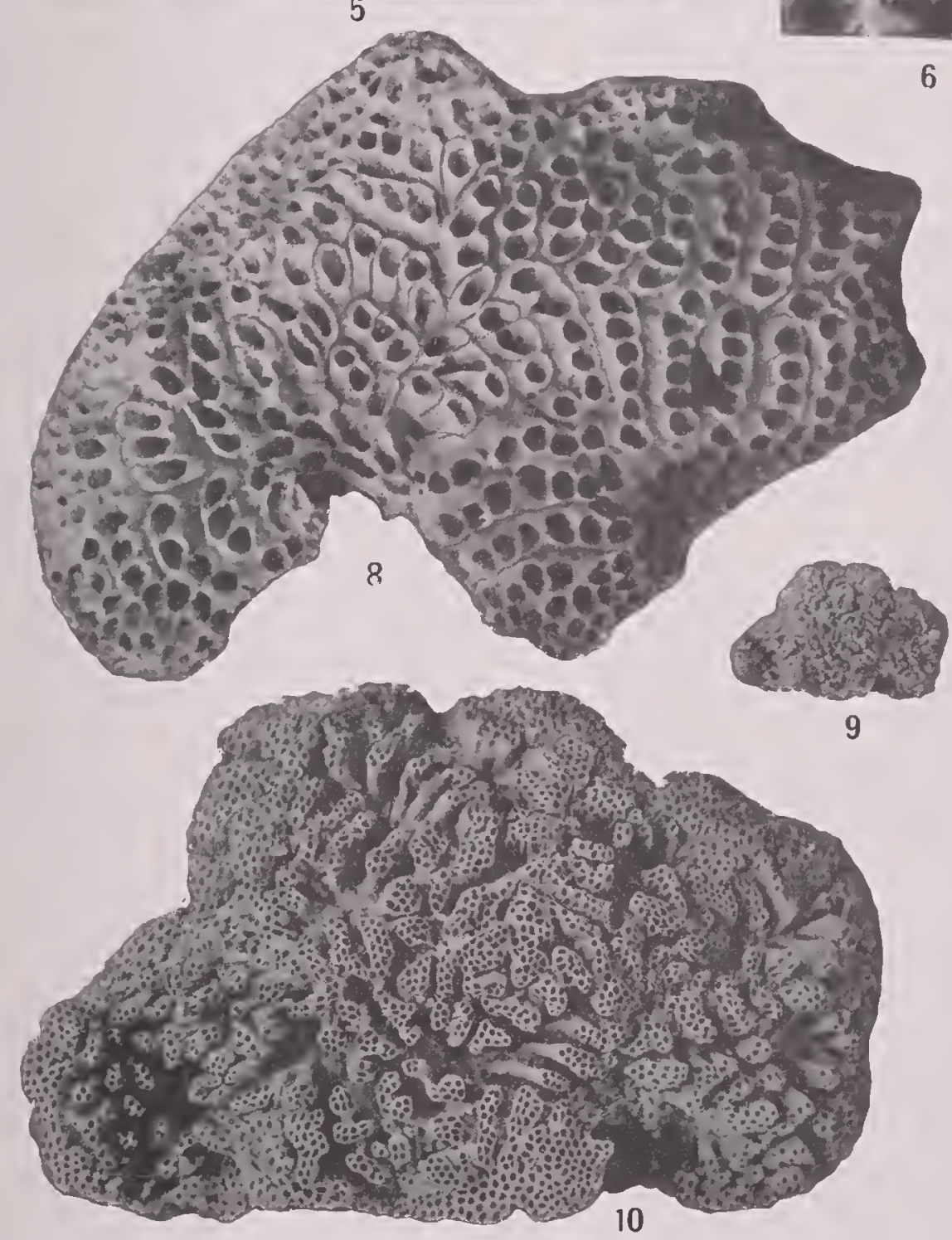

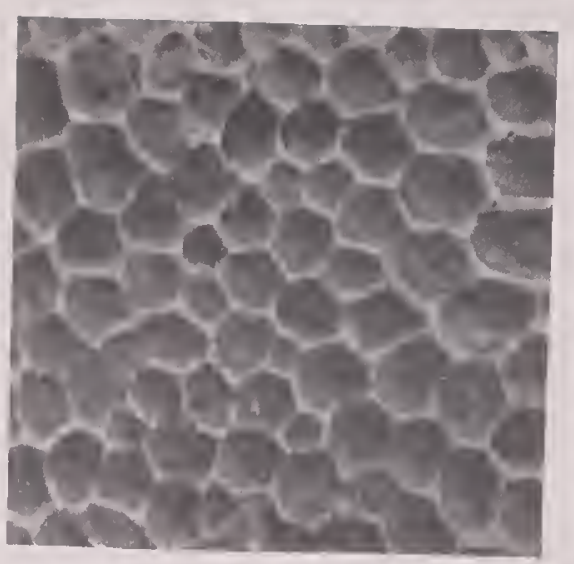

3

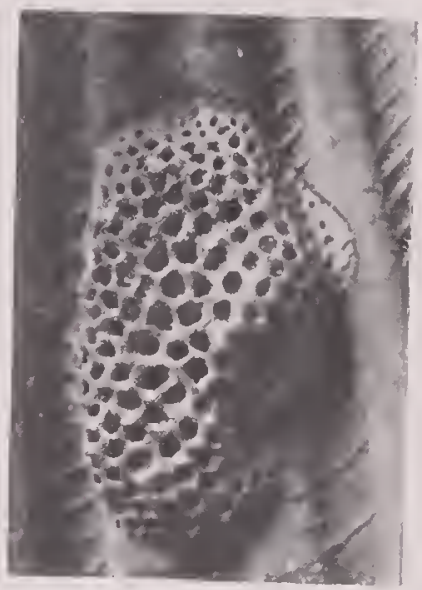

6

BULLETIN 125 PLATE 26
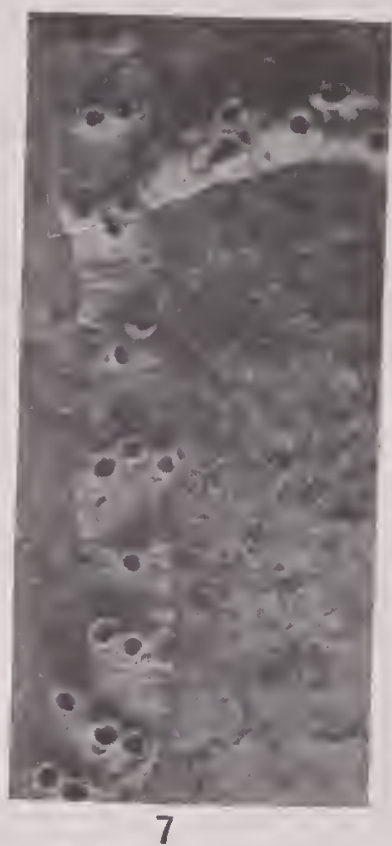

7

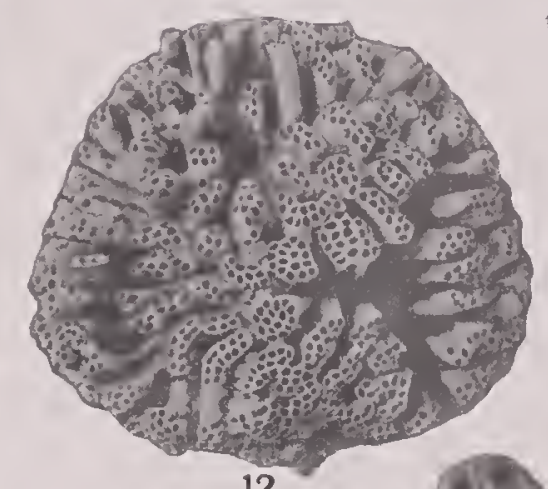

12
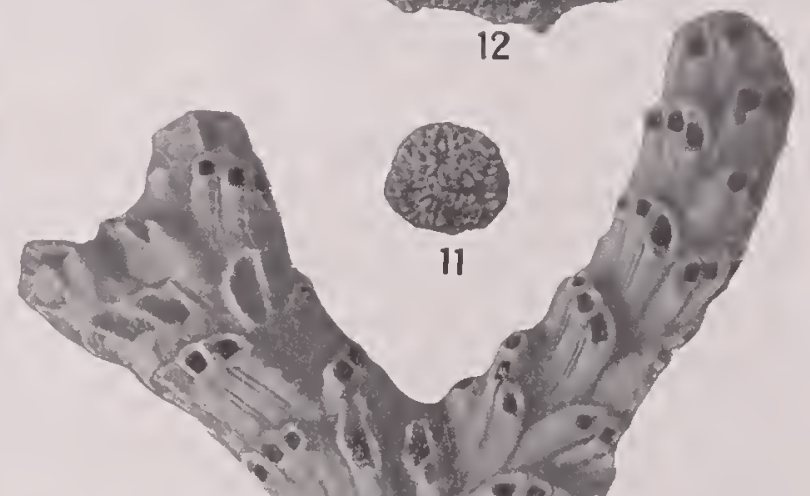

NORTH AMERICAN LATER TERTIARY AND QUATERNARY BRYOZOA. 

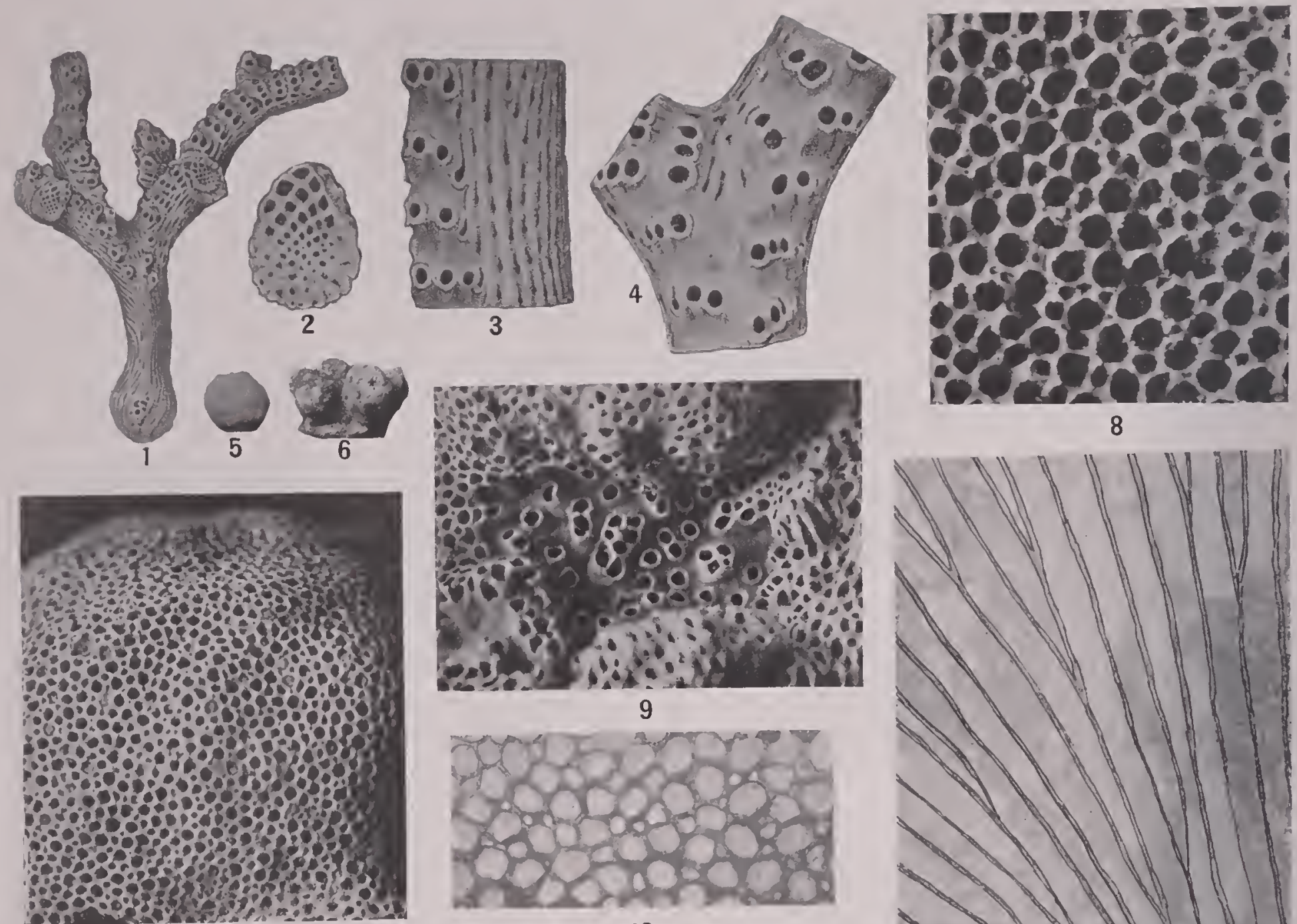

8

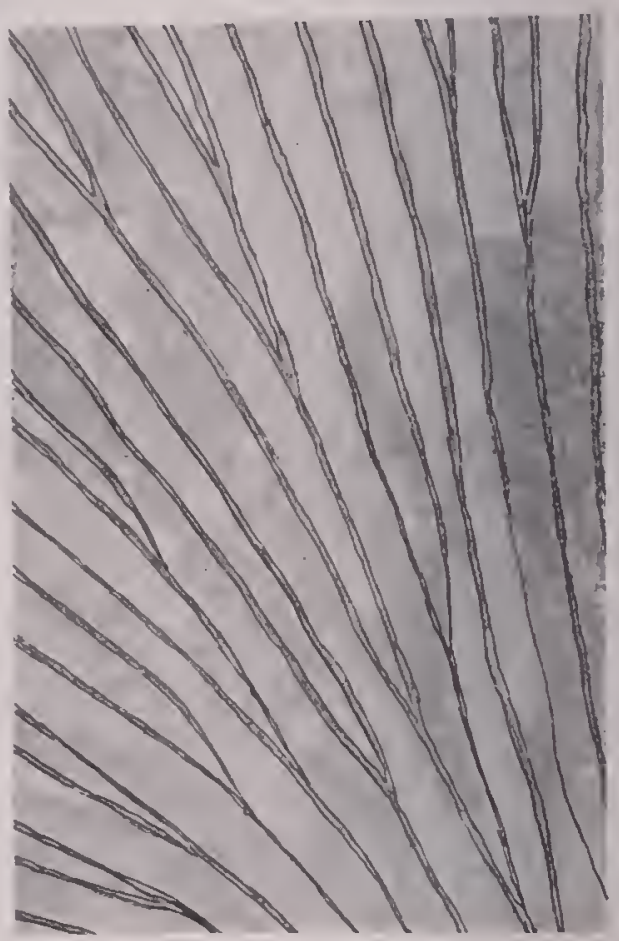

11
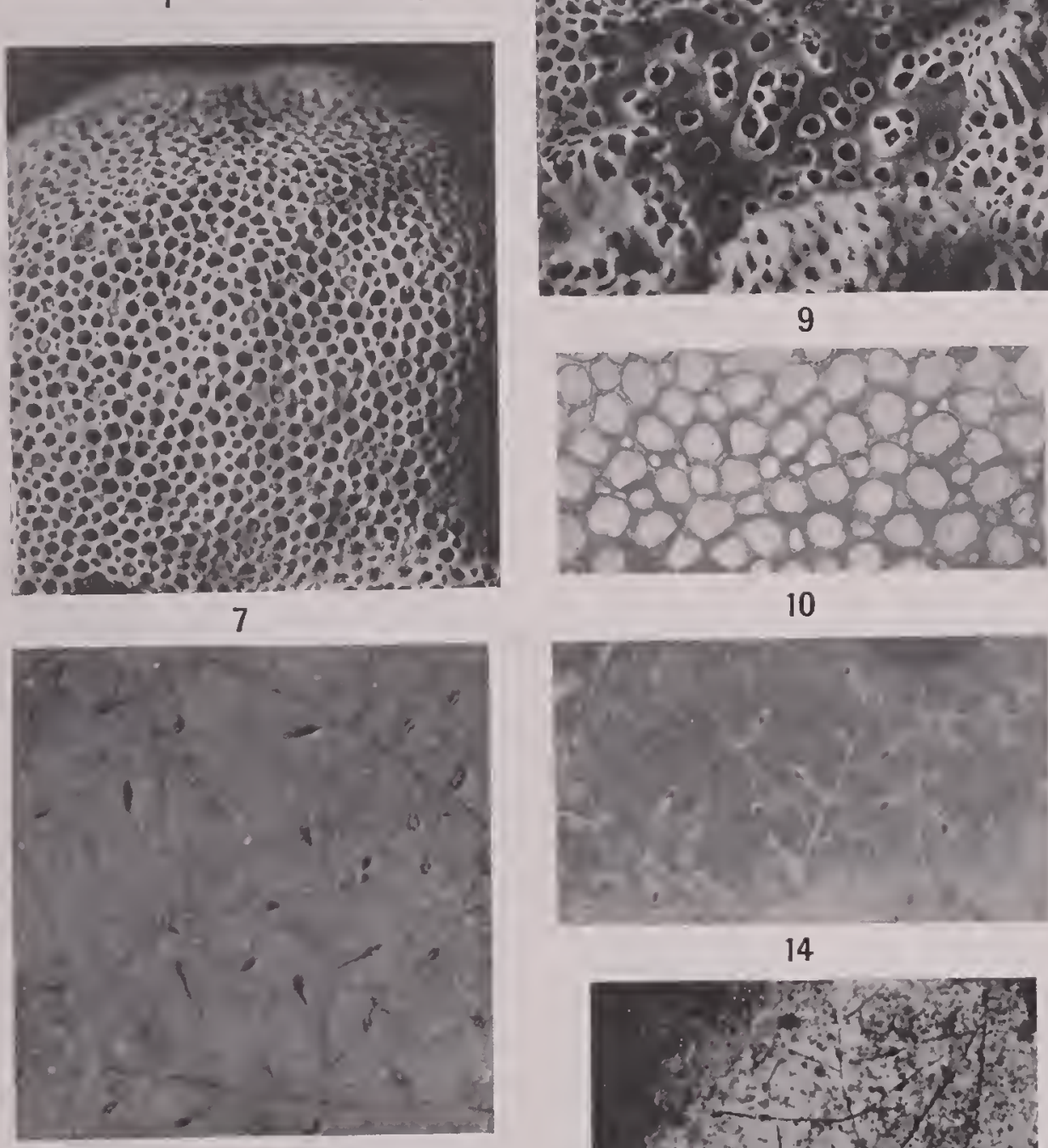

10

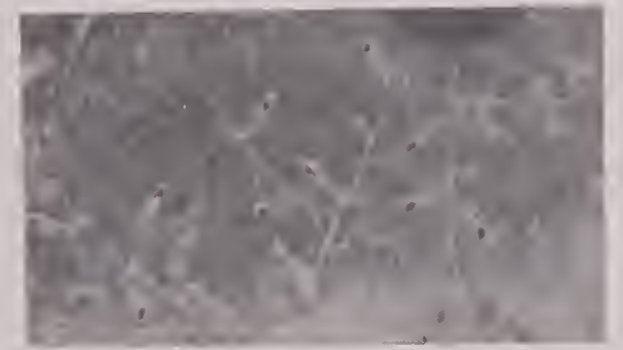

14
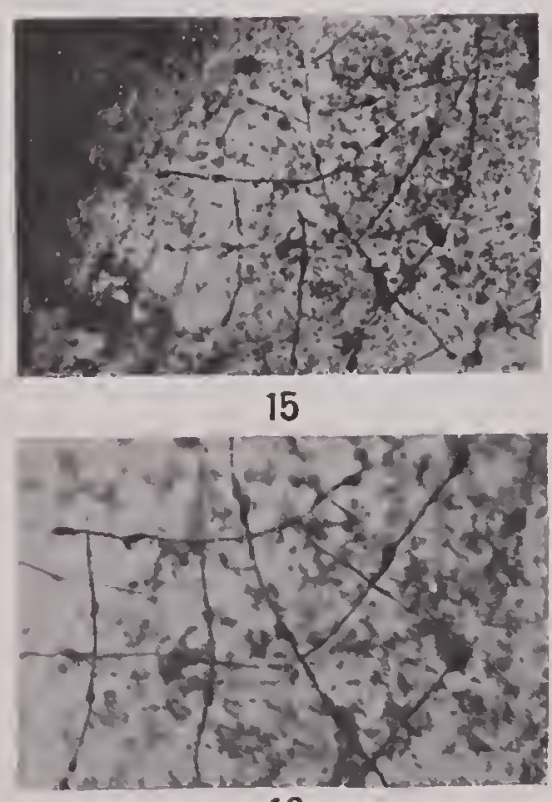

16

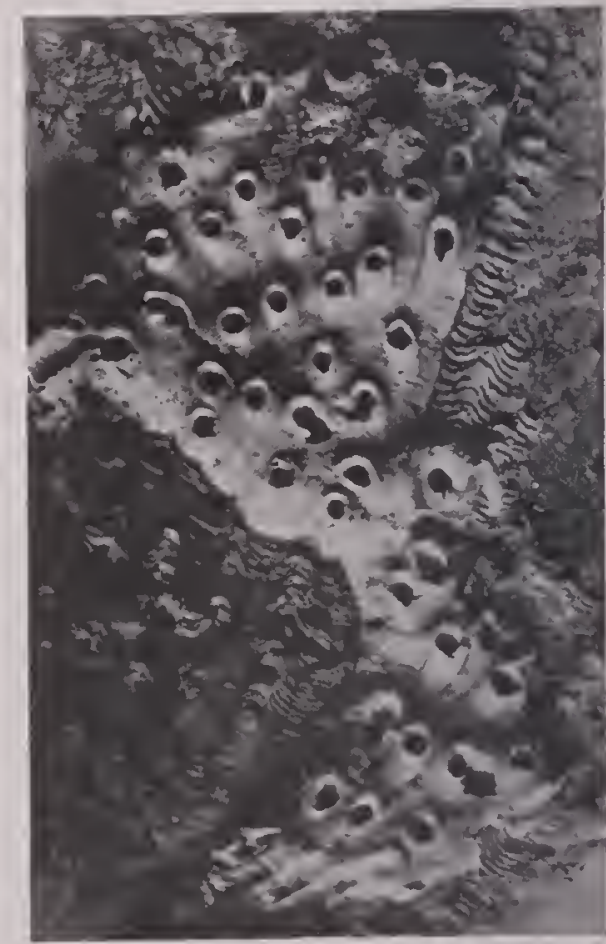

17

NORTHIAMERICAN LATER TERTIARY AND QUATERNARY BRYOZOA. 
Plate 27.

FIGs. 1-4. Crisina striatopora UTlrich and Bassler, 1904. (p. 200.)

1. The type spccimen, $\times 5$.

2. View of the end of a branch, $\times 17$.

3. Lateral view of one of the branches, $\times 23$.

4. Upper surface of the same branch, $\times 17$.

Mioccne (Choptank formation): Joncs Wharf, Maryland.

Figs. 5-11. Tretocyclocia avellana, new species. (p. 206.)

5-6. Two specimens natural size, showing variations in the frce spherical zoarium.

7. Surface of a globular specimen, $\times 12$.

8. Zoarial surface, $\times 25$.

9. Surface, $\times 12$, showing that the ovicell is large and irregular.

10. A tangential thin section, $\times 25$.

11. A longitudinal thin section, $\times 25$, showing the hollow walls and the abscnce of diaphragms. Mioccnc (Duplin marl): one-half mile above Edenhouse Point, Chowan River, North Carolina.

Figs. 12-13. Spathipora longicauda, new specics. (p. 16.)

A portion of the type specimen, $\times 20$ and $\times 10$, illustrating the clongated fusiform zooecia with a long peduncle attached to the canalicules at an angle of about $45^{\circ}$.

Miocene (St. Mary's formation): Bowler's wharf, 18 miles above Urbana, Middlesex County, Virginia.

Fig. 14. Spathipora cucullata, new species. (p. 16.)

The type specimen, $\times 20$, showing the zooccia embedded in the shell substance.

Miocene (Yorktown formation): Beulahland, Virginia.

Figs. 15-16. Terebripora parvicella, new spccics. (p. 15.)

Two vicws of the type specimen, $\times 10$ and $\times 20$, illustrating the very thin canalicules branching almost at right angles and the slightly oblique arrangement of the zooecia.

Miocene (Duplin marl): two miles southwest of Magnolia, North Carolina.

Fig. 17. Berenicea flabellum? Rcuss, 1847. (p. 194.)

The American example, $\times 12$, referred doubtfully to this European spccies.

Mioccne (Yorktown formation): Weavers Pond, Glouccster County, Virginia. 
Plite 28

Figs. 1-12. Tretocyclocin tortilis Lonsiale, 1845. (p. 206.)

1,2. Fragments of the irregularly branched, cylindrical zoarium, natural size.

3. Surface of a specimen, $X 12$, with a group of broken ovicells. The superior layer of the ovicells has disappeared in fossilization.

4. A large isolated ovicell, $X 12$, with its upper surface broken away.

5. Surface of ordinary zooecia, $\times 12$, showing the mesopores grouped together in nany parts of the branch.

6. Same surface, $\times 25$, illustrating the thickness of the zooecial walls.

7,8 . Another surface, $X 12$ and a portion of the same, $\times 25$, in which the zooecia have thin walls and the mesopores are arranged irregularly between the apertures.

9. Outer portion of longitudinal thin section, $\times 25$

10. Tangential thin section, $\times 25$.

11. Several zooecia of the same, $X 100$, showing that the iuternal walls are much calcified and are separated by a less dense tissue.

12. Portion of a transverse thin section, $\times 25$.

Miocene (Yorktown formation): Yorktown, Virginia.

272 


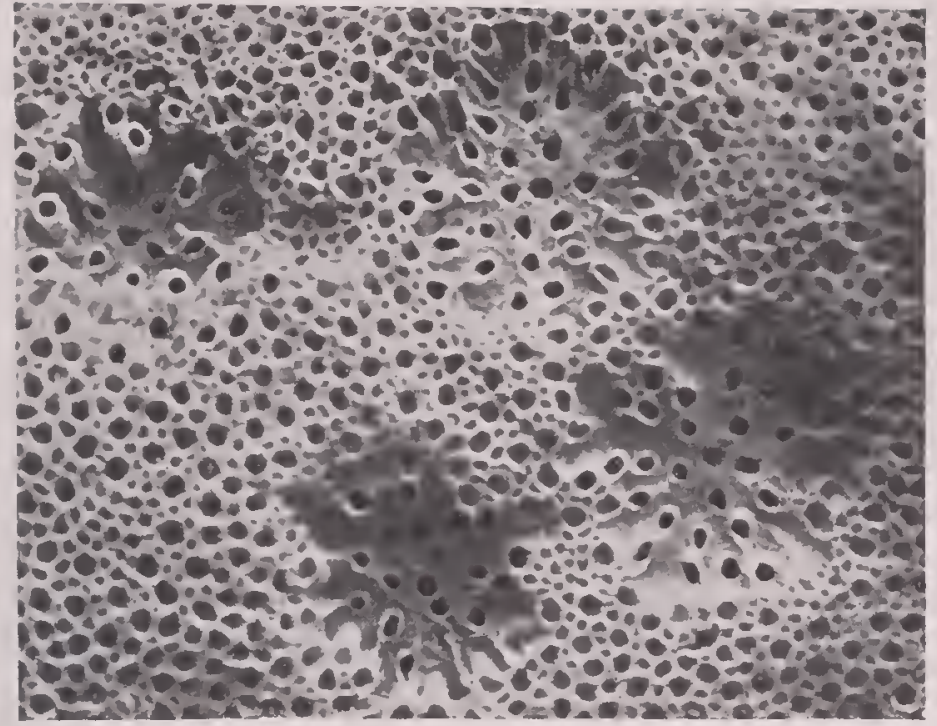

3

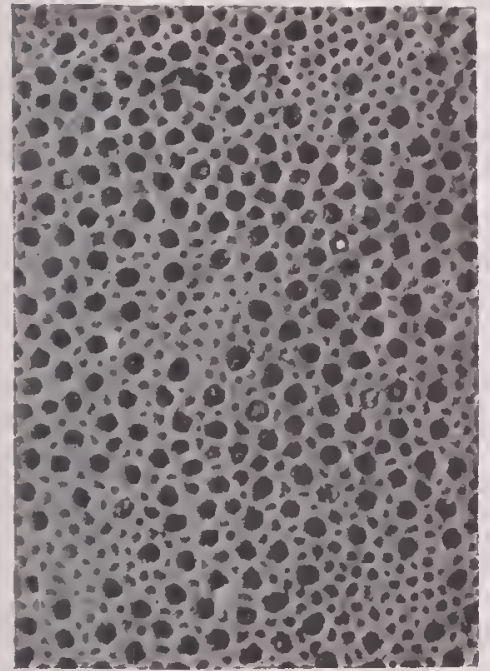

5

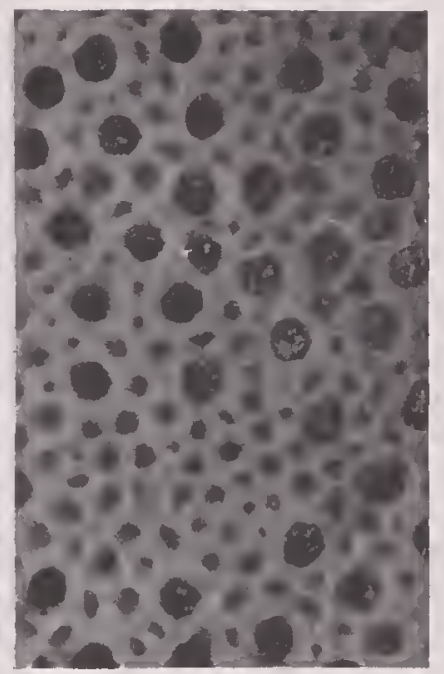

6
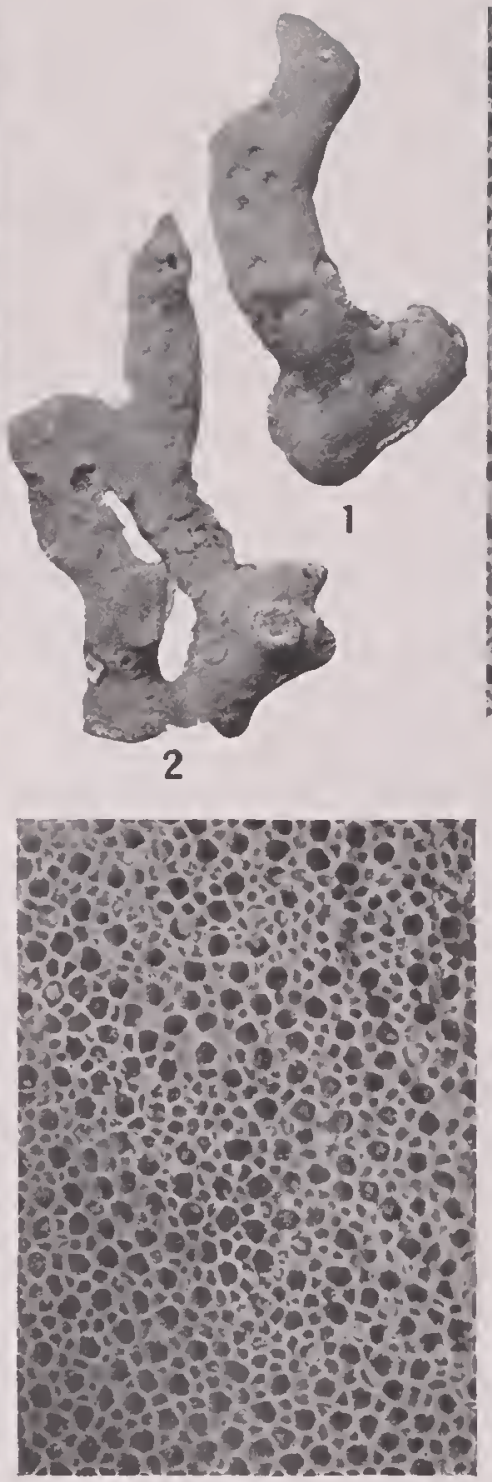

7

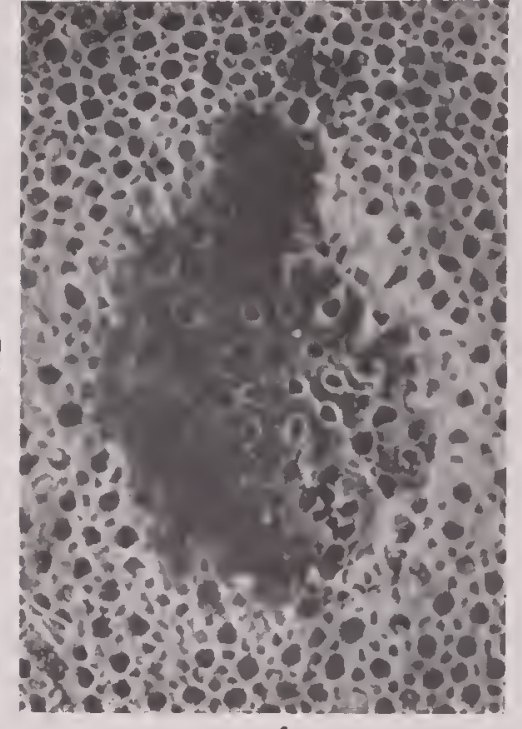

4

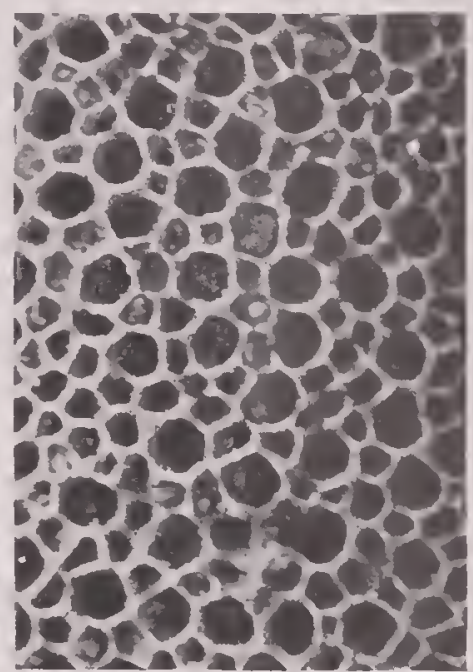

8

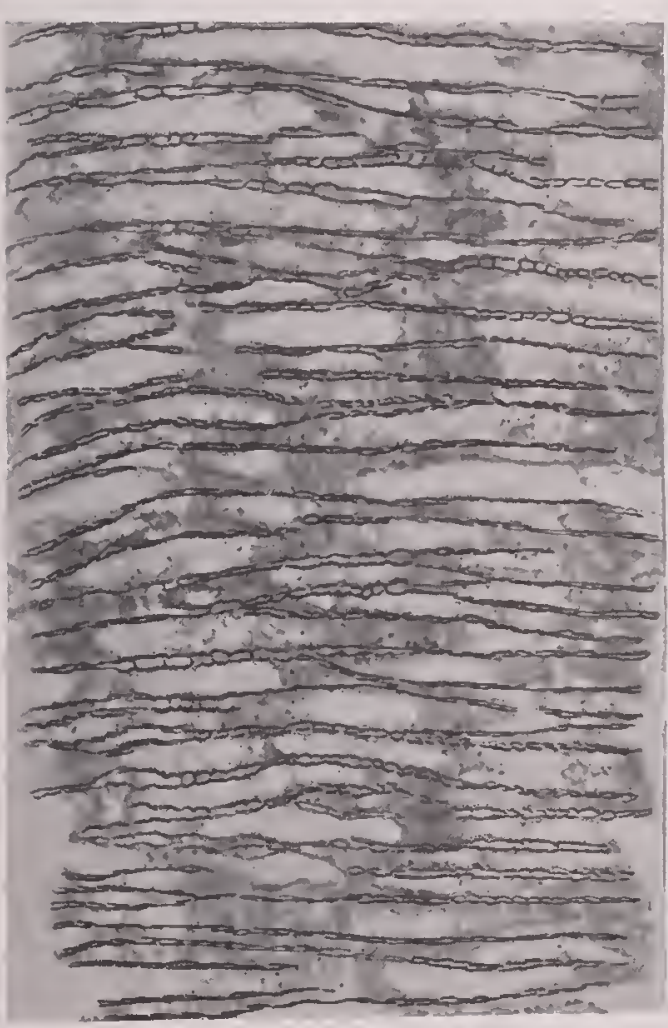

9

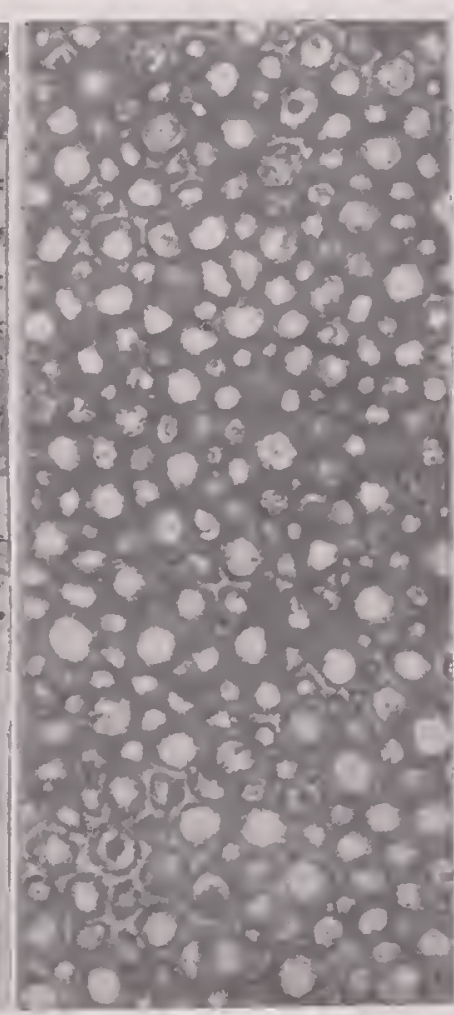

10

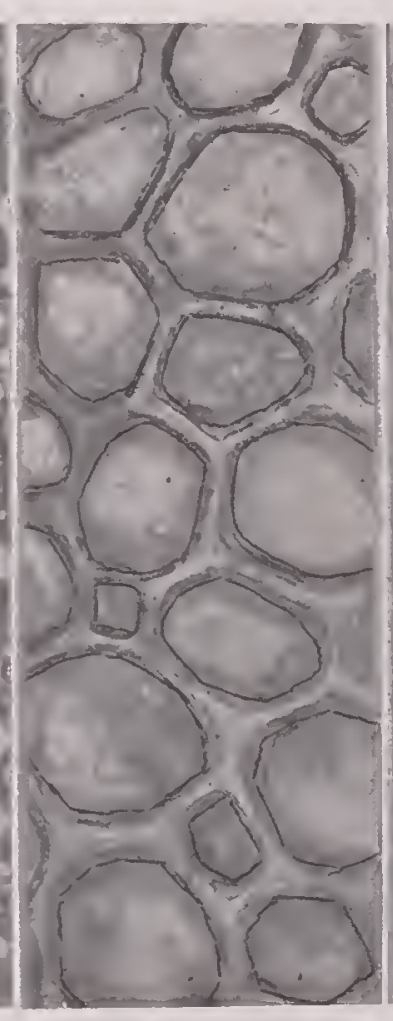

11

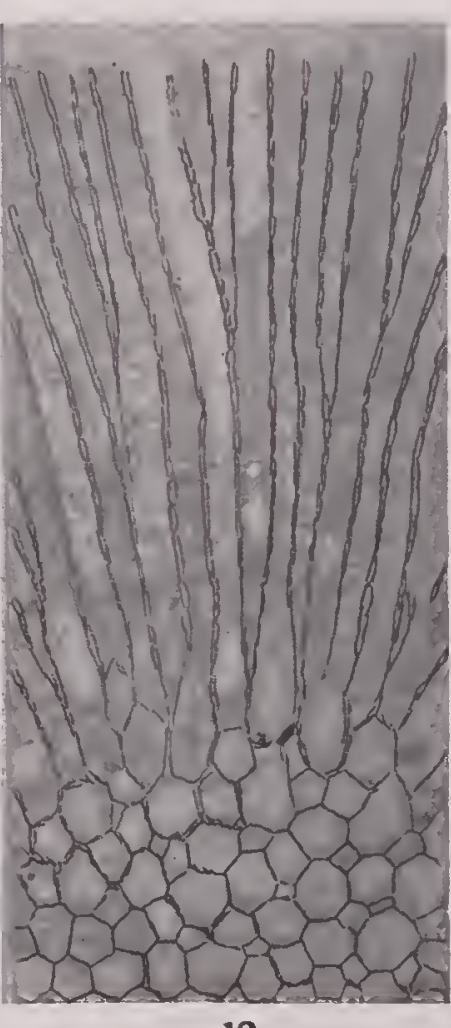

12

NORTH AMERICAN LATER TERTIARY AND QUATERNARY BRYOZOA. 

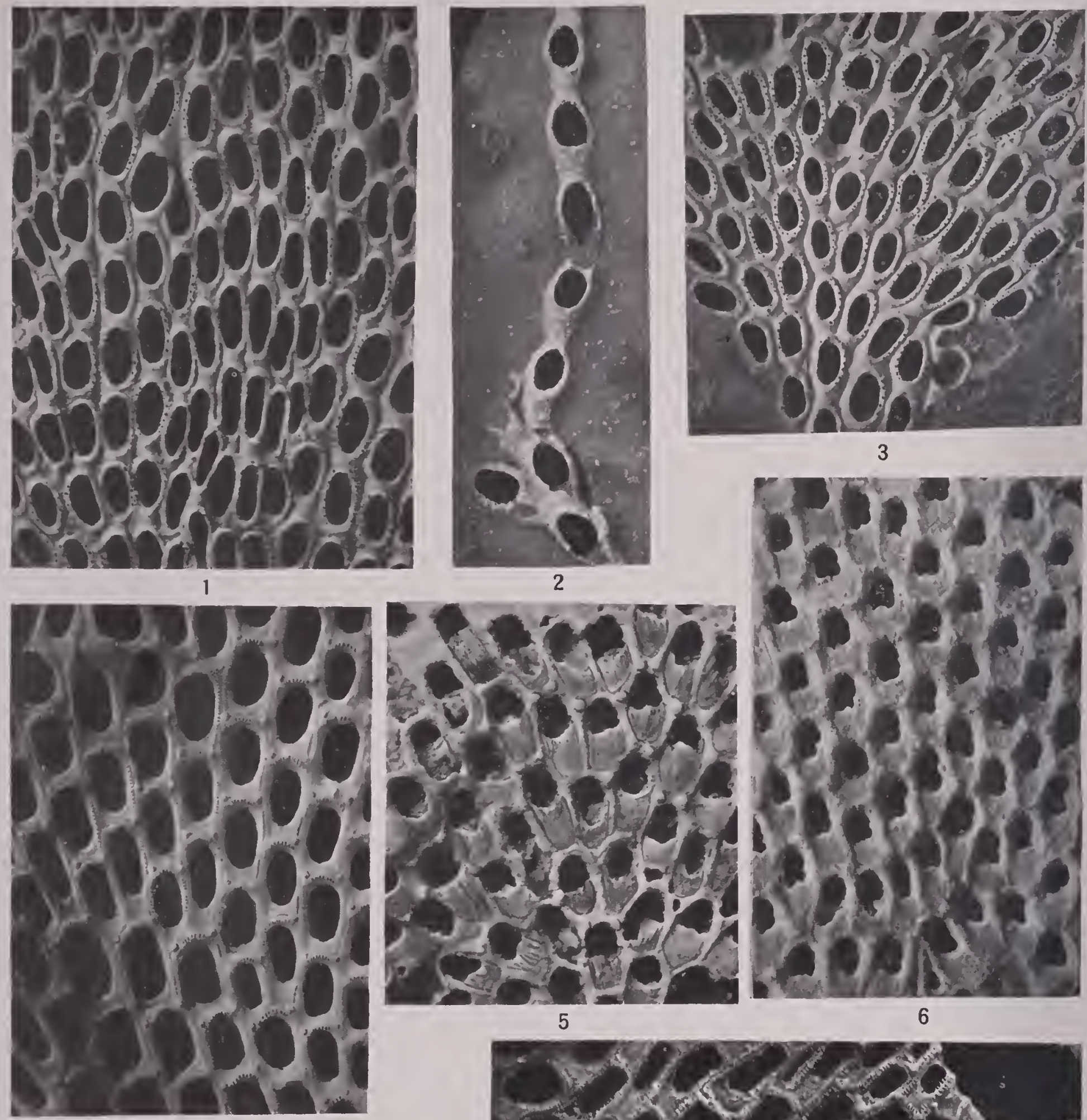

4
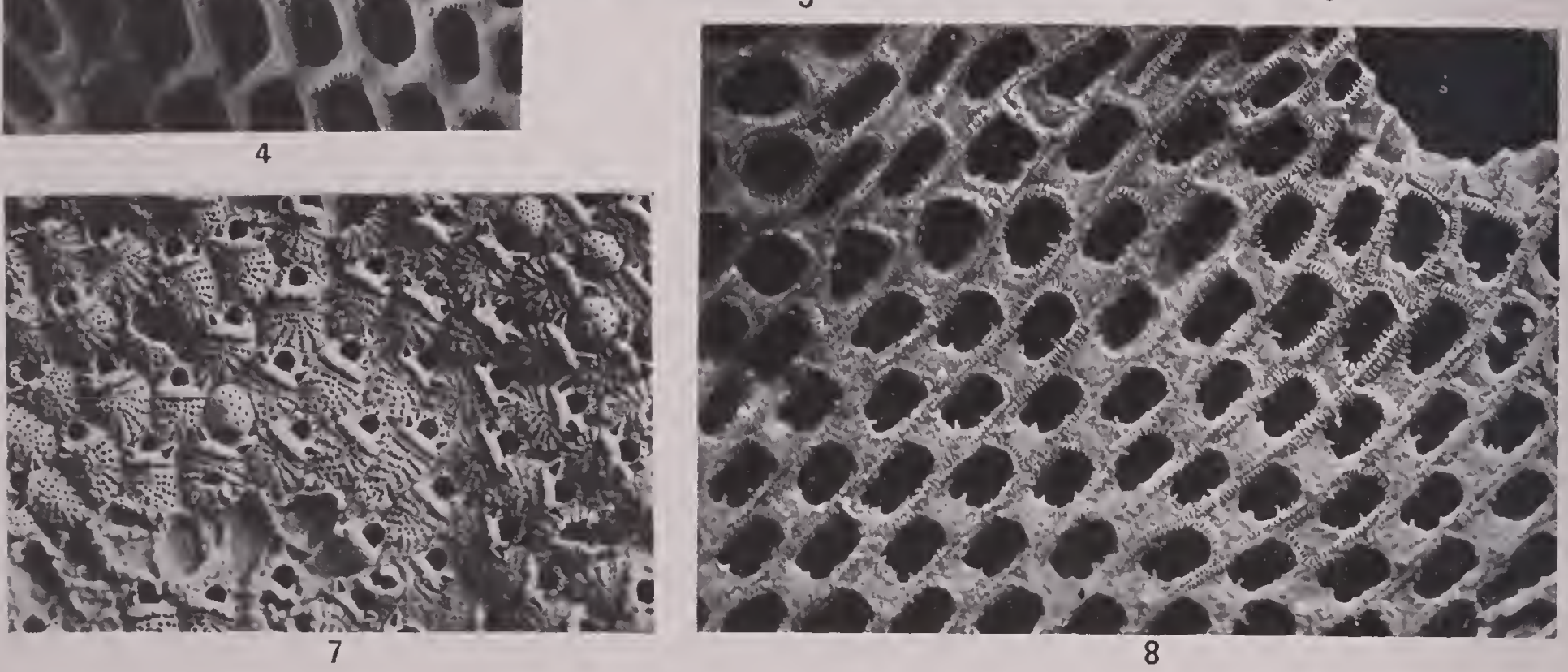

NORTH AMERICAN Later TERTIARy and Quaternary Bryozoa. 
Plate 29.

FIGs. 1-3. Eleetra monostachys Busk, 1854. (p. 17.)

1. An expanded zoarium, $\times 20$.

Pleistocene: Wailes Bluff, near Cornfield Harbor, St. Marys County, Maryland.

2. Unilinear series of zooecia, $X, 20$, with zooecia somewhat larger than usual.

Pleistocene: Santa Barbara, California.

3. A flabelliform zoarium, $\times 20$.

Pliocene (Waccamaw marl): Waccamaw River, Horry County, South Carolina.

FIG. 4. Membranipora lacroixii Audouin, 1826. (p. 22.)

The incrusting zoarium, $\times 20$, showing the finely striated mural rims and the small tubercle at each interzooecial angle.

Pliocene (Waccamaw marl): Waccamaw River, Horry County, South Carolina.

Figs. 5, 6. Hemiseptella planulata, new species. (p. 74.)

5. Portion of the incrusting zoarium, $\times 20$, somewhat worn but showing the flat cryptocyst and the tubercles at the interzooecial angles.

6. A better preserved example, $\times 20$, with the spinous processes visible.

Pliocene (Waccamaw marl): Waccamaw River, Horry County, South Carolina.

Fin. 7. Puellina crassilabiata, new species. (p. 91.)

The incrusting zoarium, $\times 20$, showing the thick transverse lip along the edge of the apertura.

Pliocene (Waccamaw marl): Waccamaw River, Horry County, South Carolina.

Fig. S. Hemiseptella granulosa, new species. (p. 74.)

The unilamellar zoarium, $\times 20$, exhibiting the characteristic irregular opesial proximal border with spinous processes and the granulose mural rim.

Miocene: Charleston, South Carolina. 
Plate 30 .

Fin. 1. Dakuria parviporosa, new species. (p. 98.)

The incrusting zoarium, $\times 2 n$, exhibiting the form of aperture and the miuute tremopores.

Pliocene (Waccamaw marl): Waccamaw River, Horry County, South Carolina.

Fins. 2, 3. Microporella tessellata Tuomey and Holmes, 1857. (p. 122.)

2. Zooecia, $\times 20$, showing a large avicularium placed lower than the apertura.

3. Ancestrular region, $\times 20$, with several worn zooecia exhibiting the dietellae.

Pliocene (Waccamaw marl): Waccanaw River, Horry County, South Carolina.

Fisis. 4, 5. Schizoportrella marginata, new species. (p. 107.)

4. Usual aspect of the incrusting zoarium, $\times 20$.

5. Zooecia, $\times 20$, with the marginal rims worn away.

Pliocene (Waccamaw marl): Waccamaw River, Horry County, South Carolina.

Fisis. 6-14. Cyclocolposa perforata, new species. (p. 135.)

6. Normal zooecia of the incrusting zoarium, $\times 20$.

7. Ovicelled zosecia, $\times 2$.

8. Portion of a zoarium, $\times 20$, showing two ancestrular arexs with their surrounding zooecia (numbered 1, 2, 3, 4, 5).

9. Ancestrular region, $\times 2$, with the ancestrula covere 1 by the pleurocyst of tie a ljace it zosezia

10. Zooecia, $\times 20$, exhibiting the olocyst and illustratiug that the pleurocyst is detachable.

11. Ancestrular region, $x 20$. The ancestrula is reduced to its apertura.

12. Interior of the zovecia, $\times 2$ ), exhihiting the olocyst

13. Worn zooecia, $\times 20$, showing the dietellae.

14. Ancestrular region, $\times 2$, with surface worn away and illustrating the arrangeneat of the zooecia around the ancestrula.

Pliocene (Waccamaw marl): Waccamaw River, Horry County, South Carolina. 


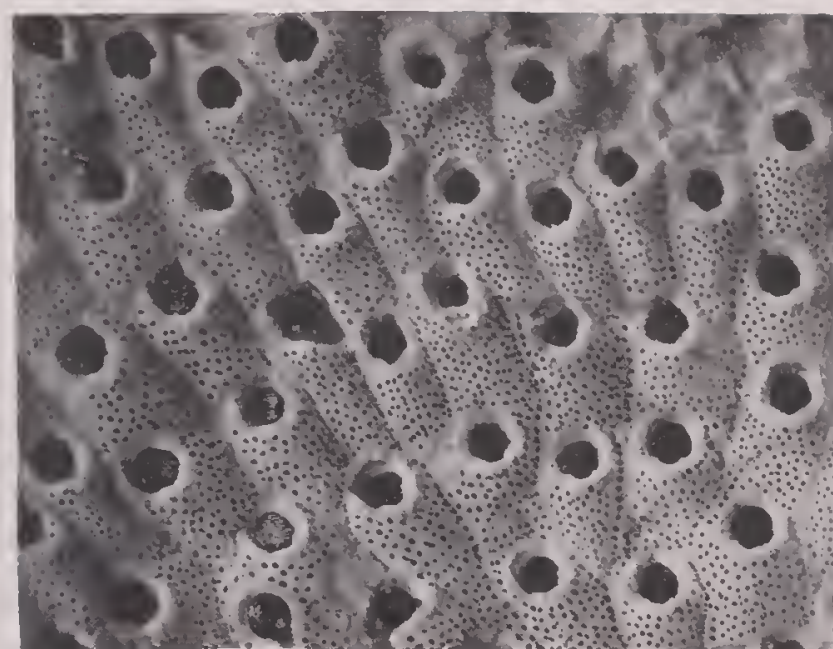

1

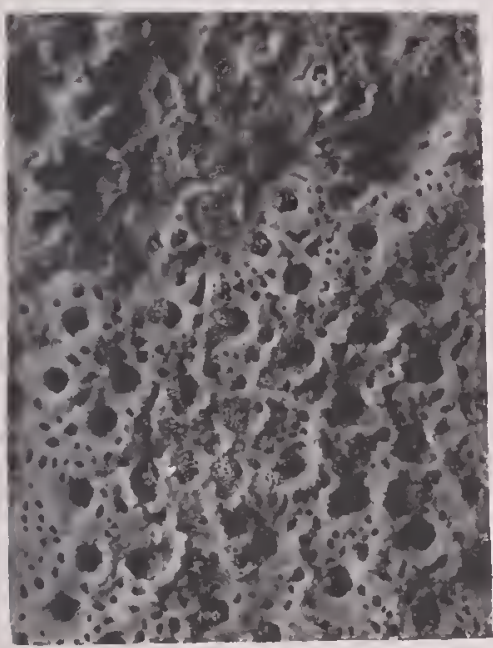

4
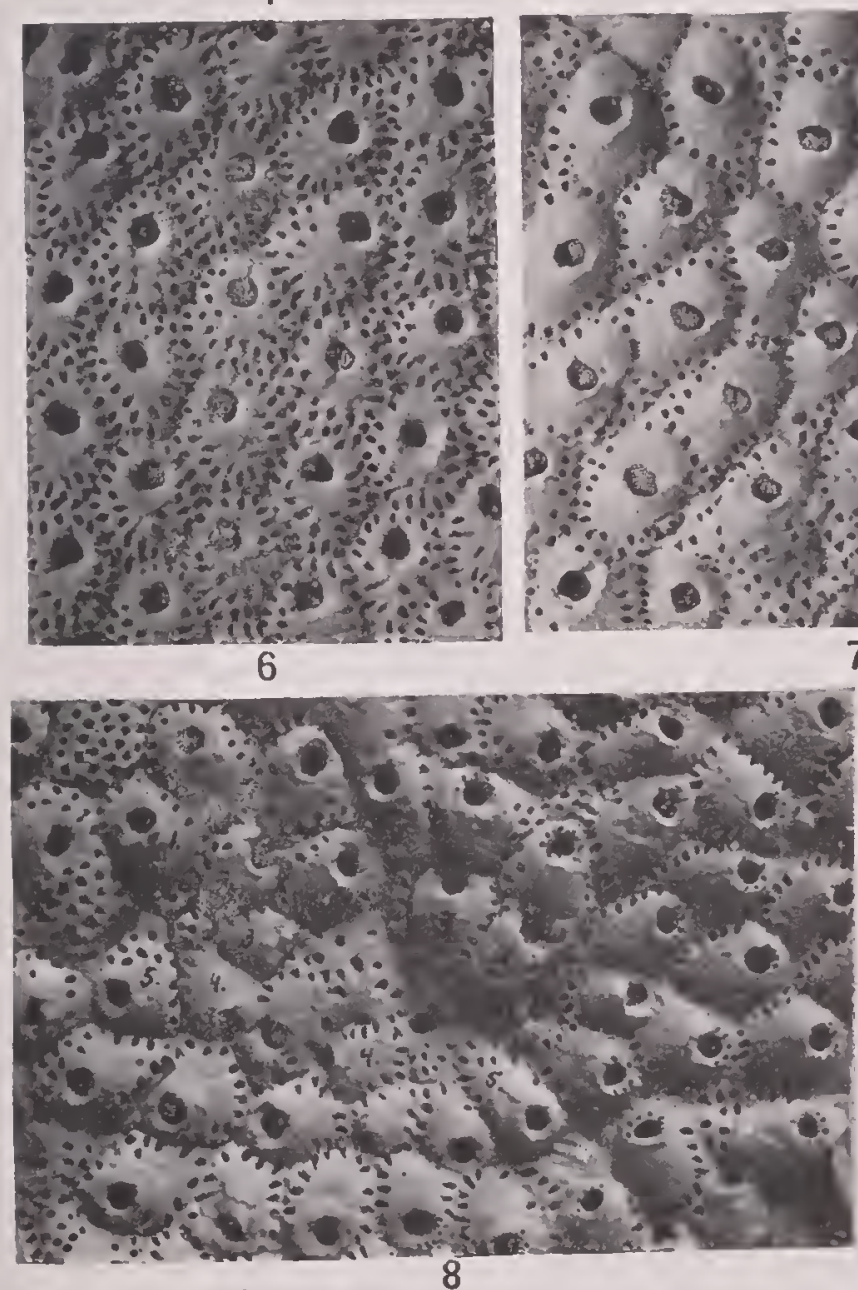

5

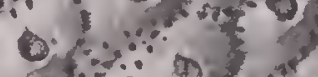

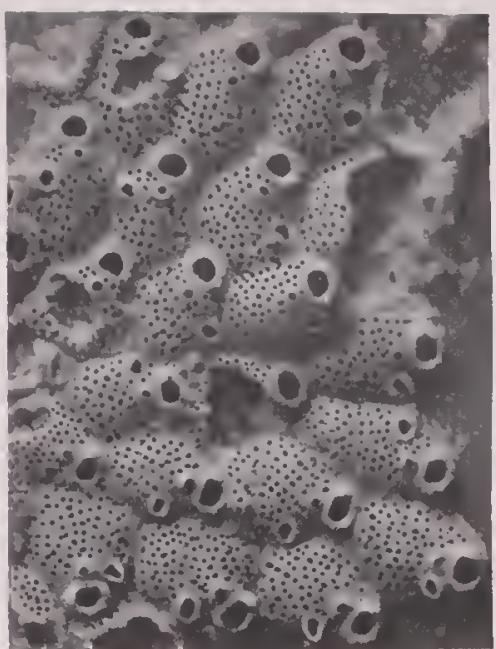

2
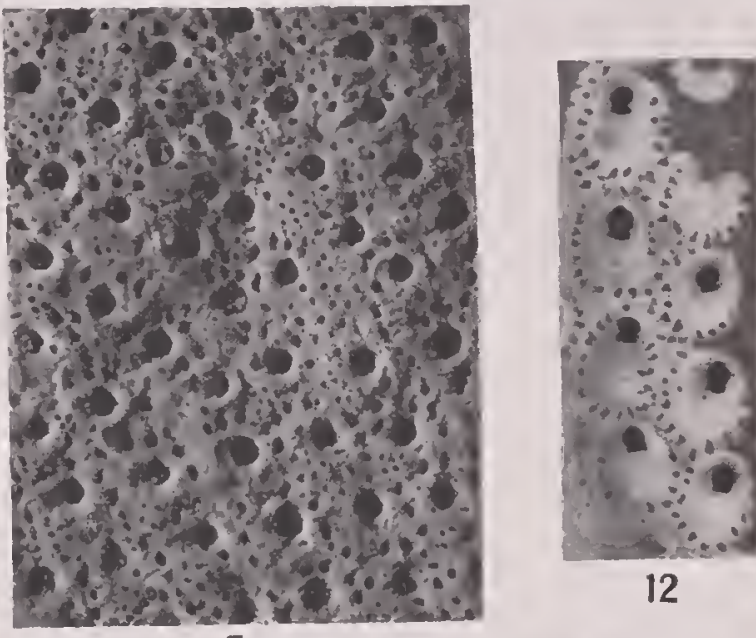

12

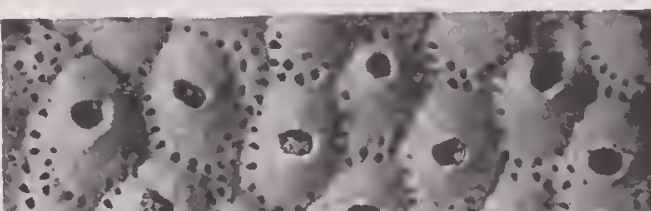

0

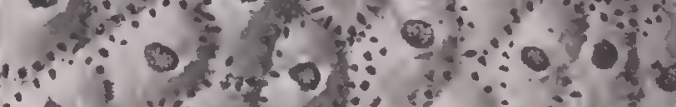

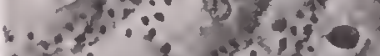

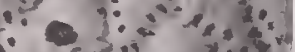

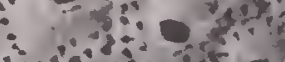
40

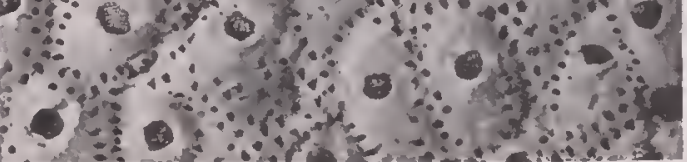

7
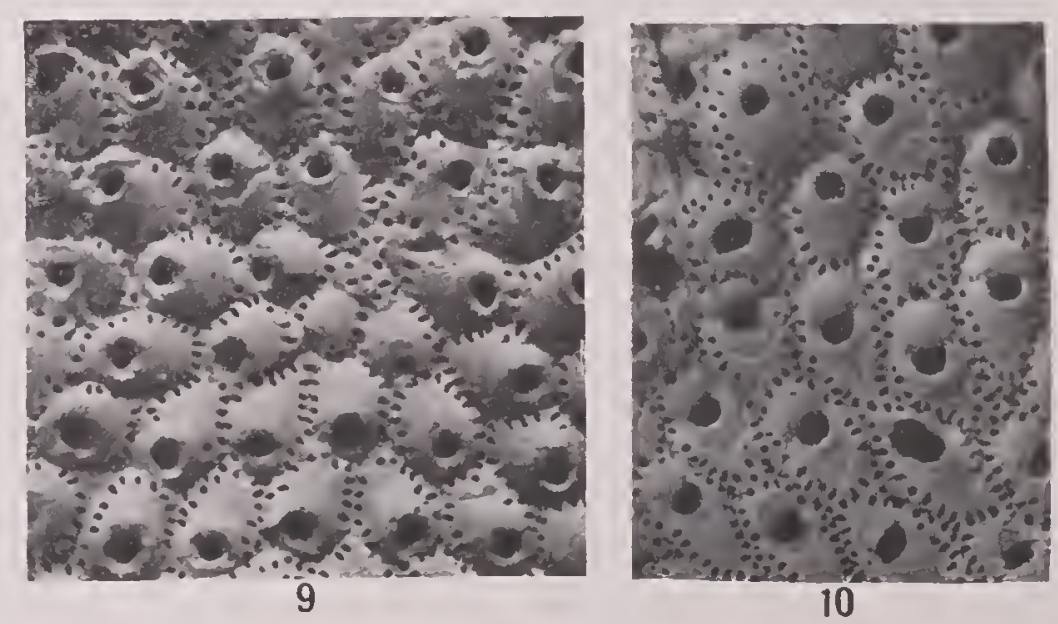


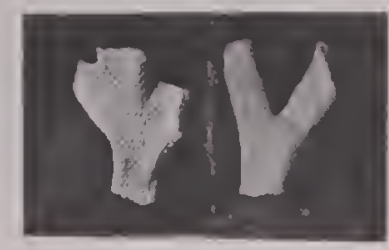

?
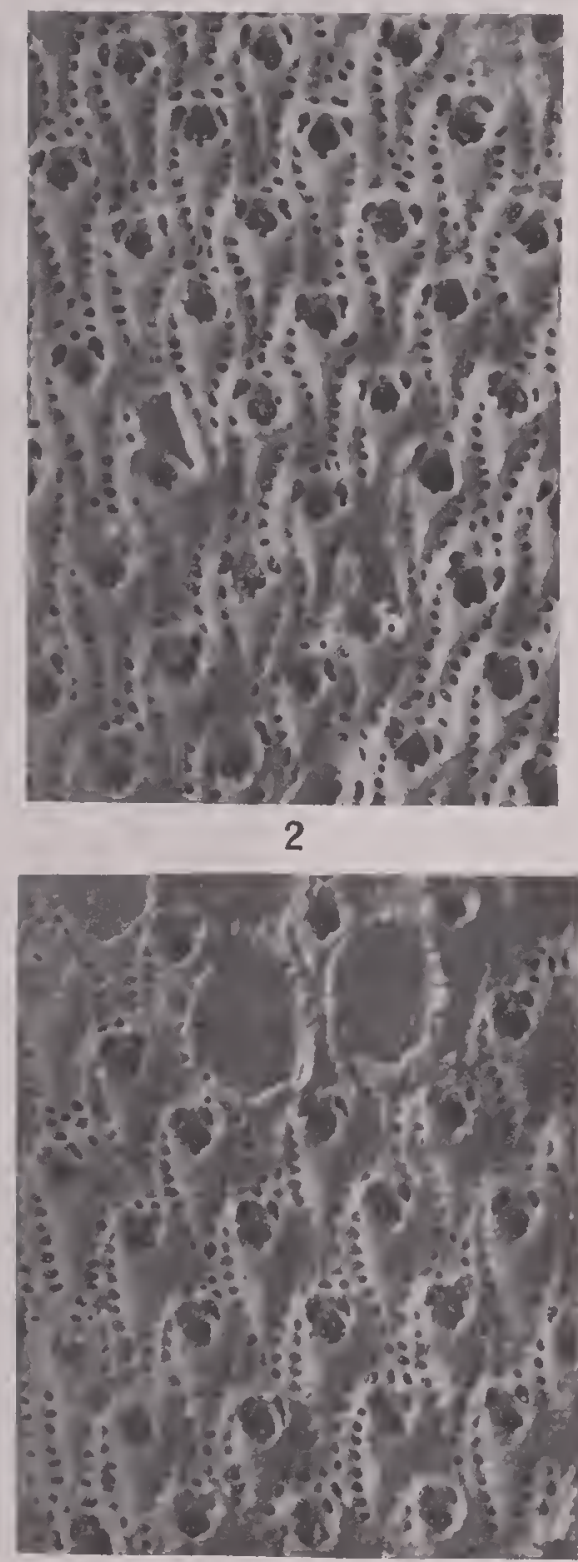

5

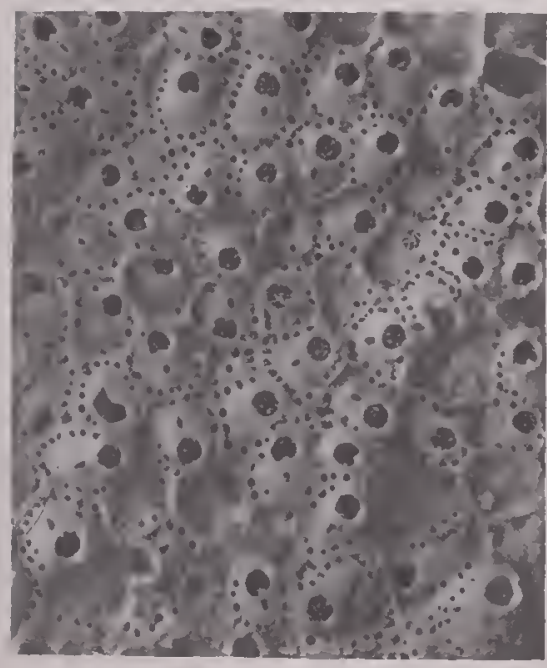

10

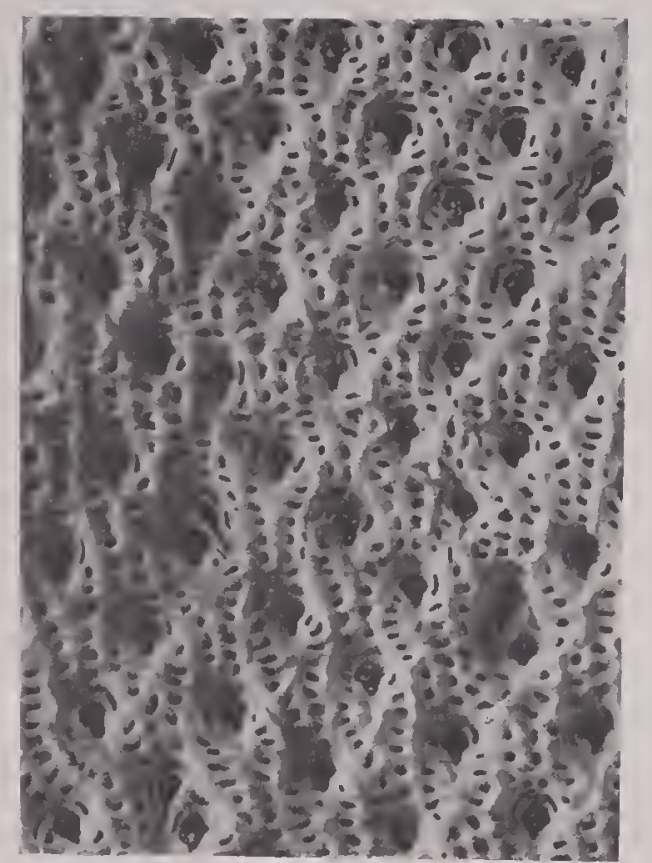

3
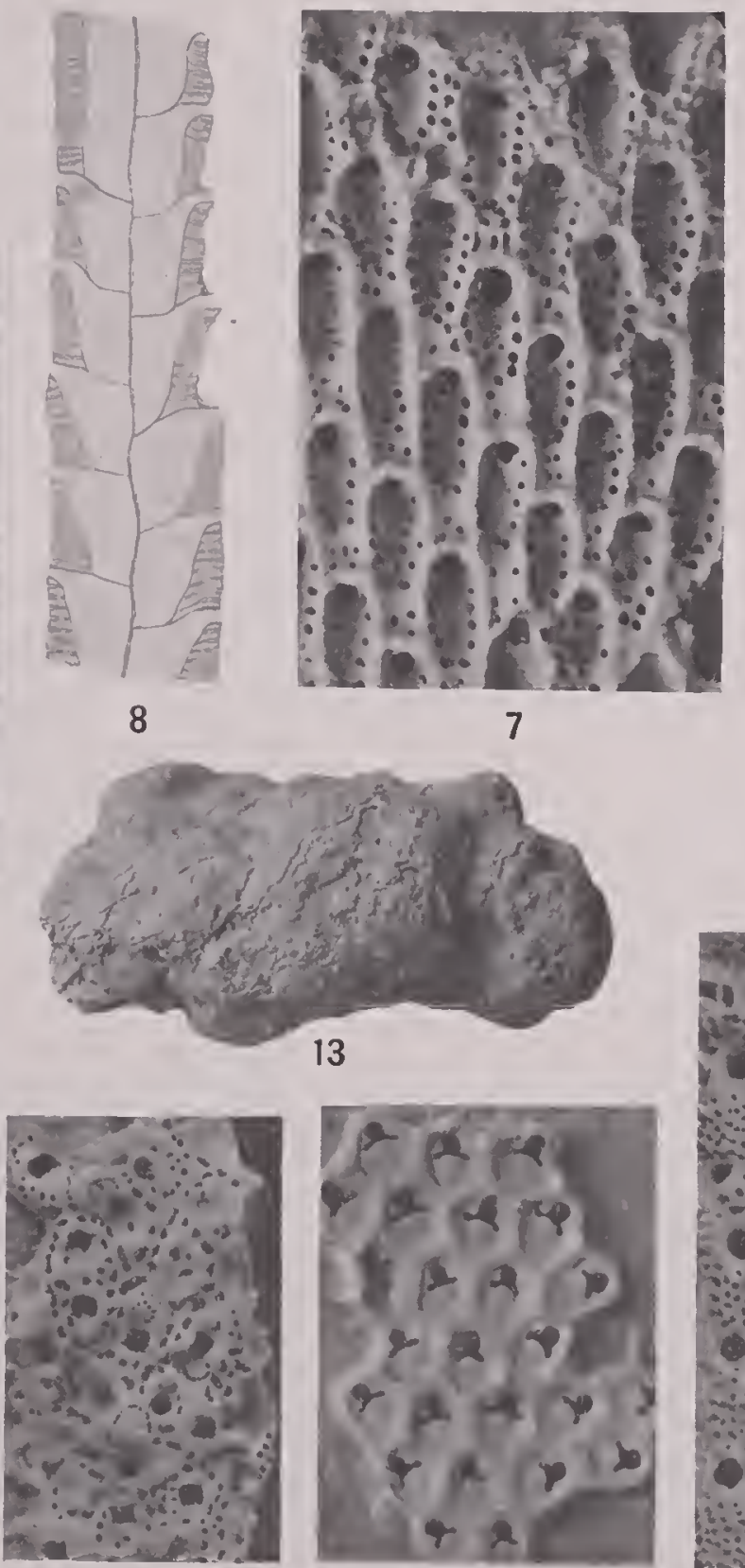

11

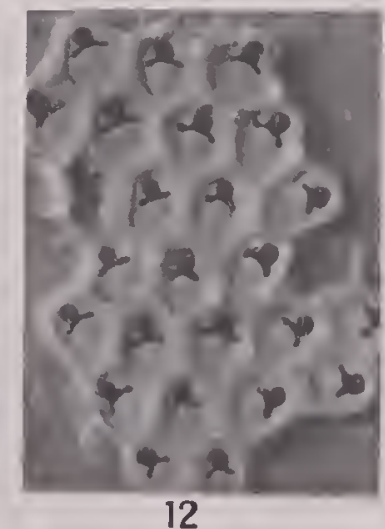

12

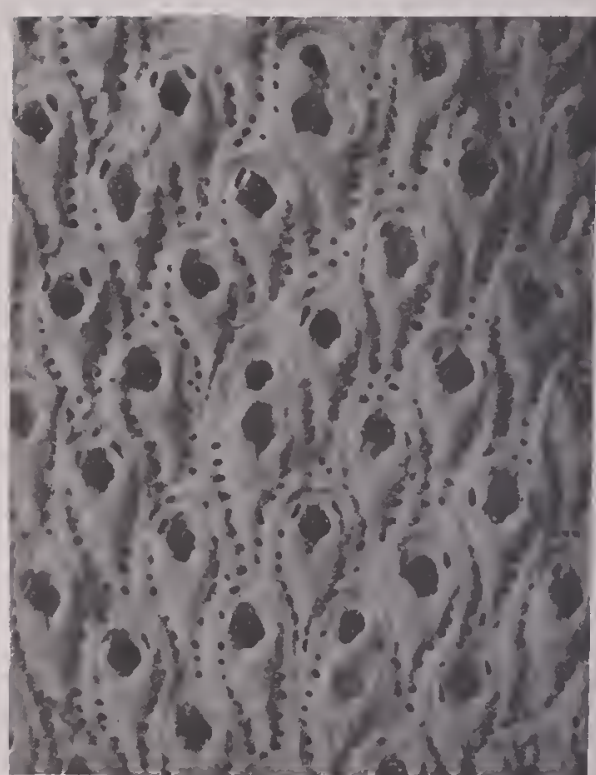

4

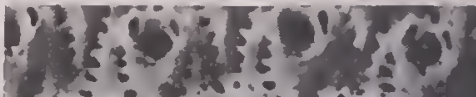

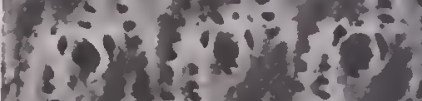

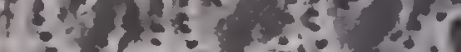

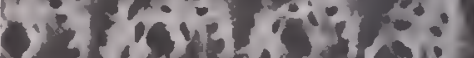

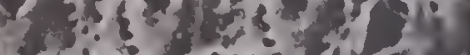

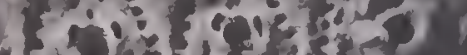

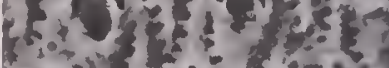

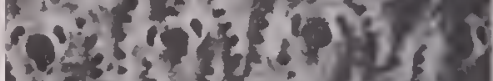
$3 \sin ^{3}$ is is ais

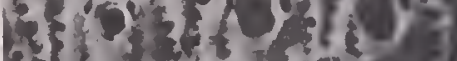
Pos d 30,9$\}$

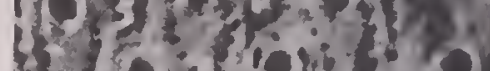
$5=\{$, is $\{:\{\}$ ?

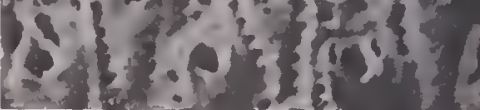
6

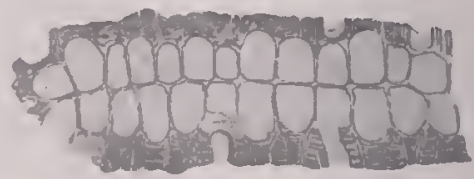

9

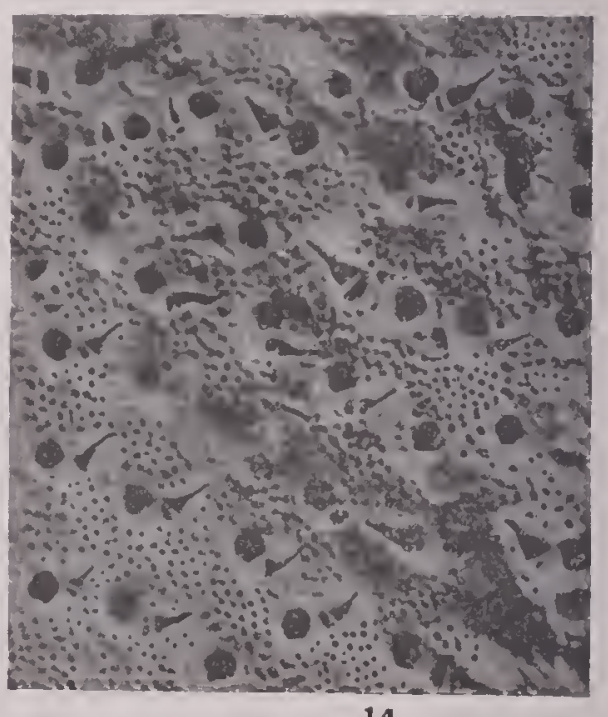
14

NORTH AMERICAN LATER TERTIARY AND QUATERNARY BRYOZOA. 
Plate 31.

Figs. 1-9. Metrarabdotos auriculatum, new speeies. (p. 164.)

1. Two fragments of the narrow bilamellar zoarium, natural size.

2. Young convex zooeeia, $\times 20$. Two zooeeia bear the large supraoral avieularium.

3. The usual aspeet of the zooeeial surface, $\times 20$. The peristomiee is deeply embedded.

4. Mueh ealcified, eonvex zooecia, $\times 20$.

5. Zoarial surface, $\times 20$, showing two broken ovieells.

6. Surface of a young zoarium, $\times 20$.

7. View of the interior of the zooeeia, $\times 20$, illustrating the areolar pores, and the subjaeent oloeyst.

8. Longitudinal thin seetion, $\times 12$

9. Transverse thin seetion, $\times 12$, exhibiting the thick zooecial walls perforated by the areolar pores.

Pliocene (Caloosahatehee marl): Shell Creek, De Soto County, and Monroe County (figs. 4-6), Florida.

FIGs. 10-11. Smittina maleposita, new speeies. (p. 144.)

10. Surface of the incrusting zoarium, $\times 20$, showing the charaeteristie poorly oriented zooeeia.

Pliocene (Caloosahatehee marl); Shell Creek, De Soto County, Florida.

11. Zooeeia, $\times 20$, several of whieh bear the large, globular, finely perforated ovieell.

Pleistocene: Vero, Florida.

F1G. 12. Floridina parvicella, new speeies. (p. 57.)

The incrusting type specimen, $\times 20$.

Pliocene (Waecamaw marl): Waecamaw River, Horry County, South Carolina.

Figs. 13,14. Schizopodrella nculeata, new speeies. (p. 104.)

13. The massive multiliamellar zoarium, natural size

14. Zooeeia, $\times 20$, showing the wide tremopores and the large, long, pointed avieularium.

Pliocene (Waceamaw marl): Waccamaw River, Horry County, South Carolina. 
Plate 32.

FIGS. 1-1. Holoporella bicornis, new species. (p. 175.)

1, 2. Two zoarial masses, natural size.

3. The usual aspect of the surface, $\times 20$.

4. Another surface, $\times 20$, illustrating occurrence of the deep zooecia.

Pliocene (Waccamaw marl): Waccamaw River, Horry County, South Carolina.

Fig. 5. Aimulosia radiata, new species. (p. 140.)

The incrusting zoarium, $\times 20$, illustrating the characteristic interareolar radiating costules.

Pliocene (Caloosahatchee marl): Shell Creek, De Soto County, Florida.

Figs. 6-10. Holoporella albirostris Smitt, 1872. (See also pl. 7, figs. 9-14.) (p. 174.)

6. The irregular, massive zoarium, natural size.

7. Usual aspect of the surface, $X 20$, showing the zooccia altered by fossilization.

8. Portion of a zoarimm, $X 20$, showing numerous interzooecial avicularia.

9. Another zoarial surface, $\times 20$, in which the areolar pores are closed and the oral sinus is limited by a spiniform umbo.

10. Interior of zooecia, $\times 20$, illustrating zooecia around the ancestrula.

Pliocene (Caloosahatchee marl): Shell Creek, De Soto County, Florida.

Figs. 11-13. Schismopnra brevincisa, new species. (p. 180.)

11. Surface of the incrusting zoarium. $\times 20$.

12. Another view, $\times 20$, showing incomplete zooecia

13. Zooecia, $\times 20$, illustrating the form of the aperture and the areolar pores.

Pliocene (Caloosahatchee marl): Shell Creek, De Soto County, Florida.

276 


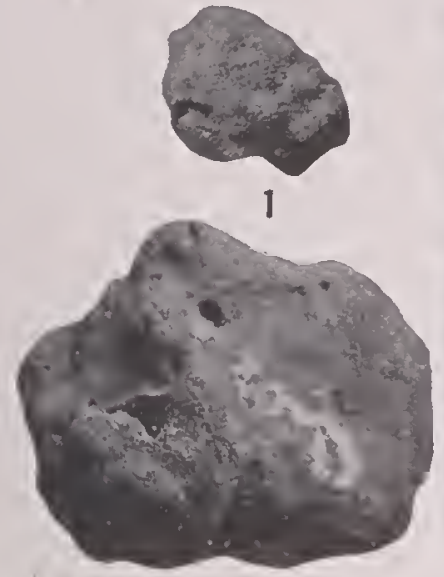

2

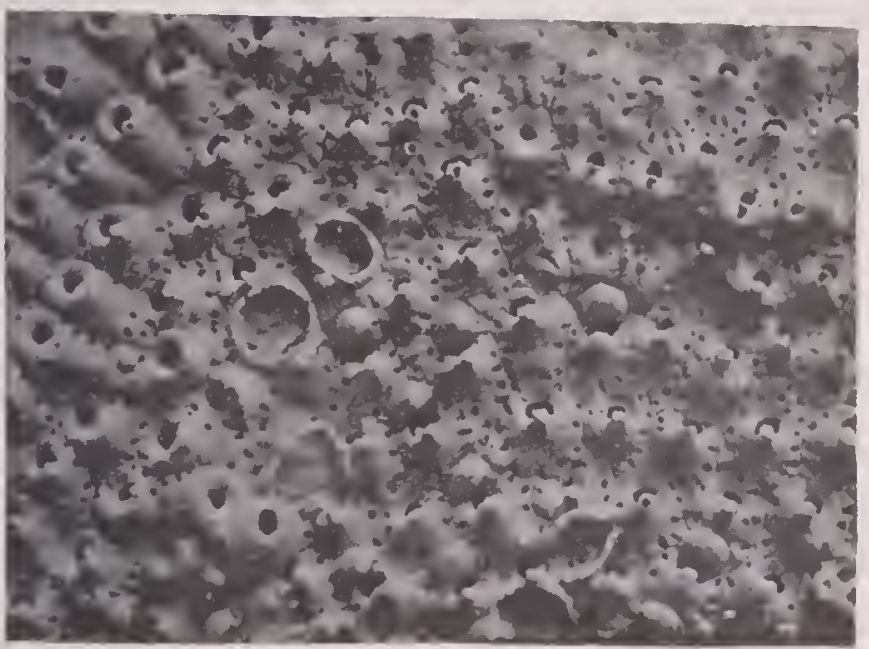

5

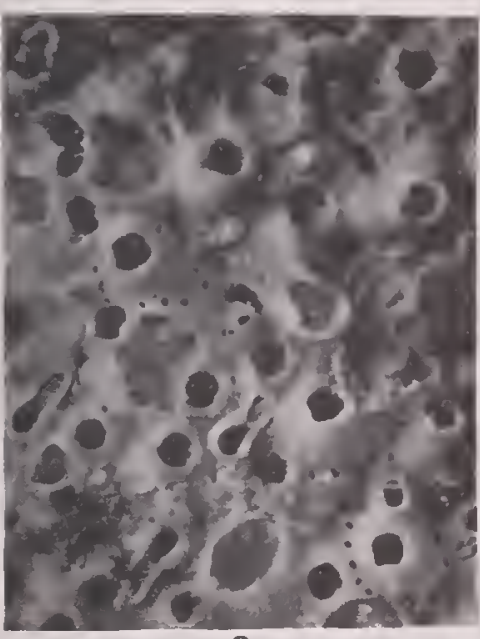

8

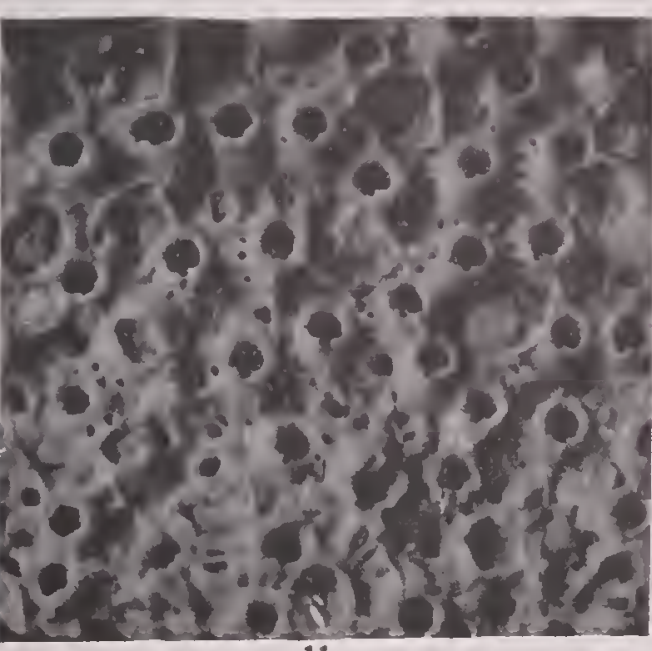

10
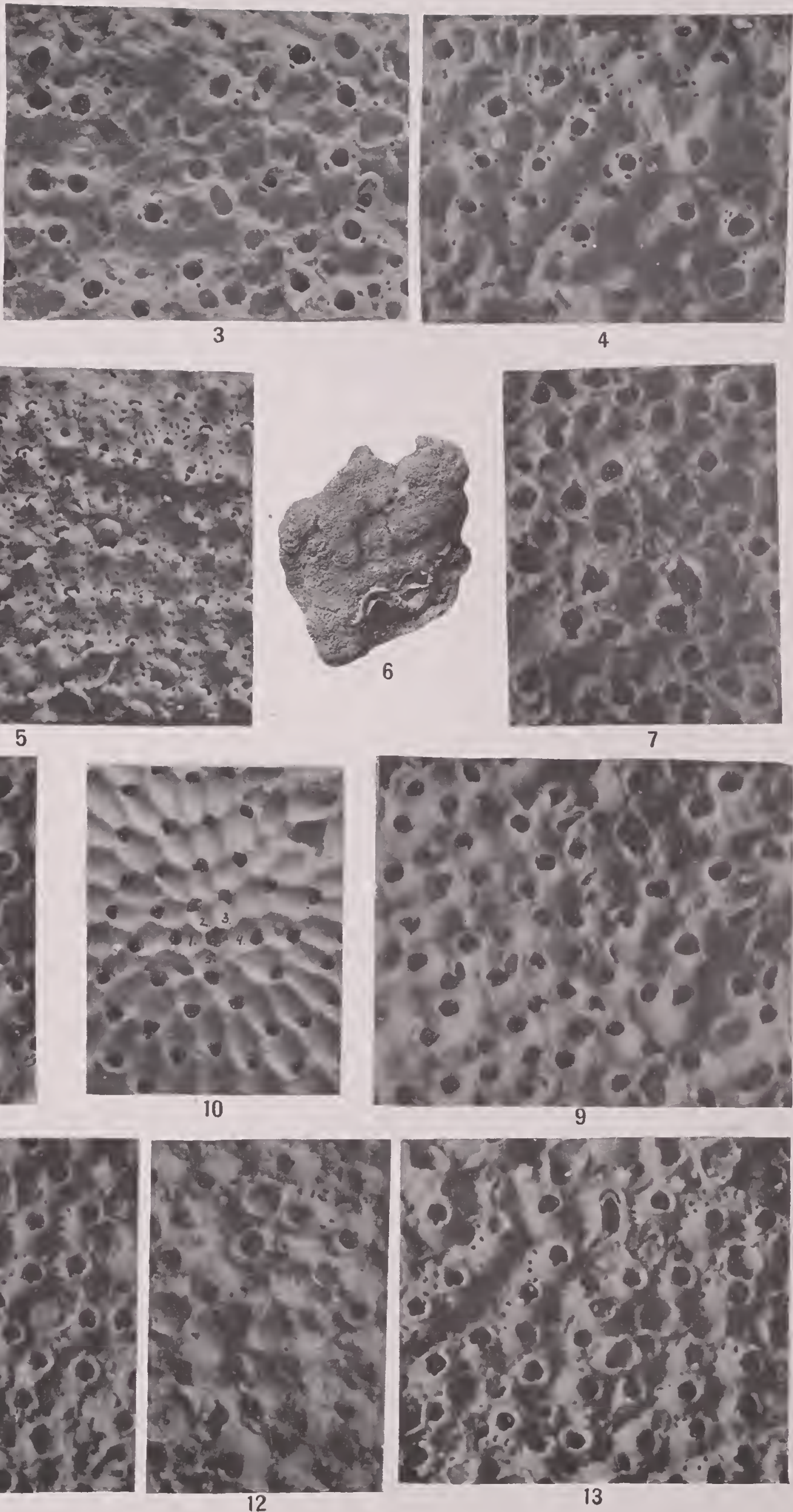

NORTH AMERICAN LATER TERTIARY AND QUATERNARY BRYOZOA. 

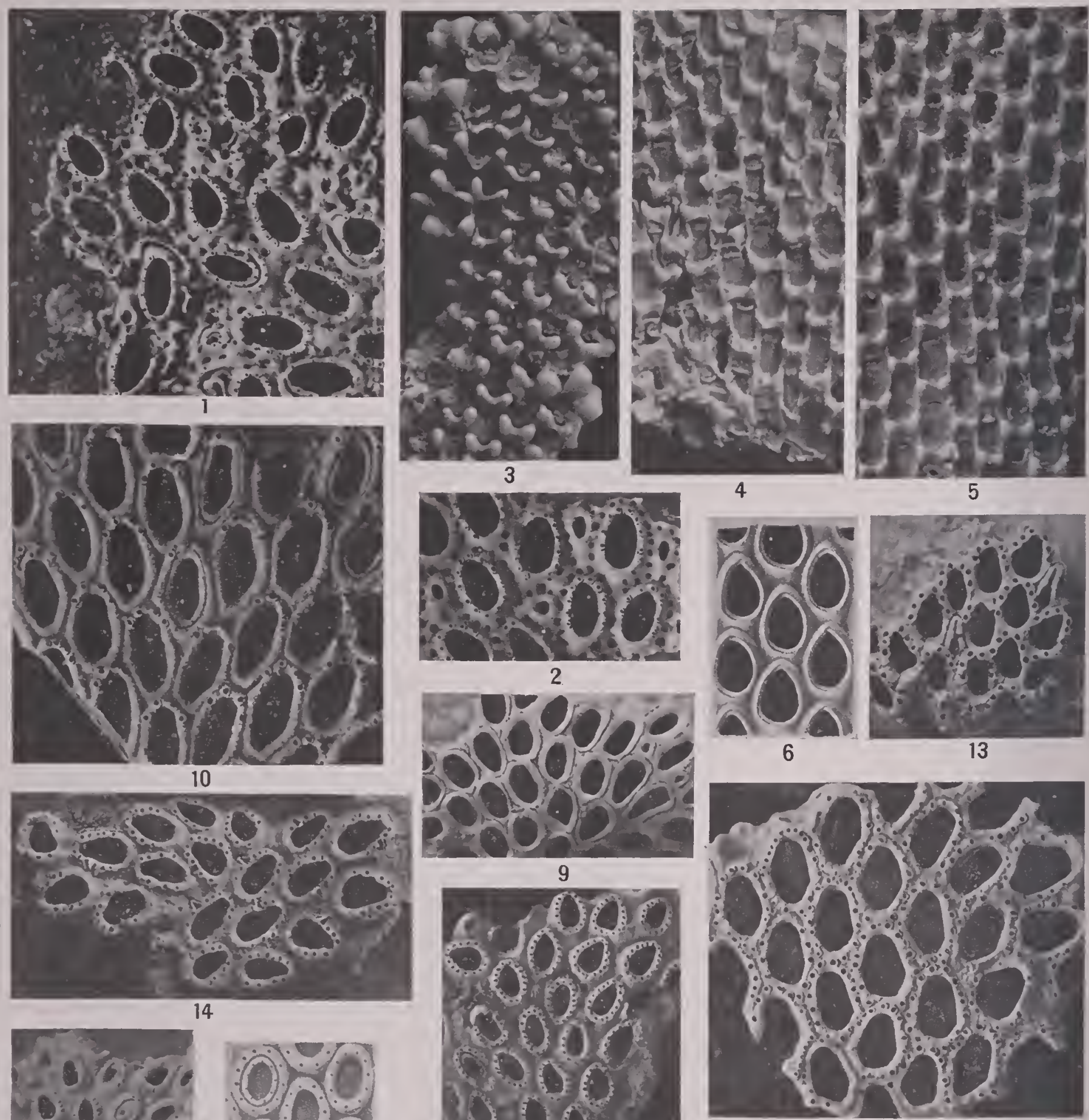

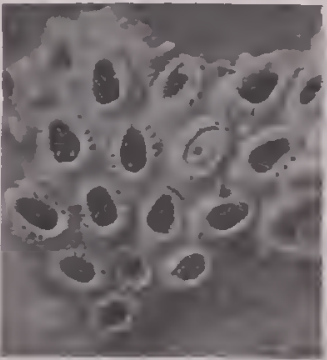

15

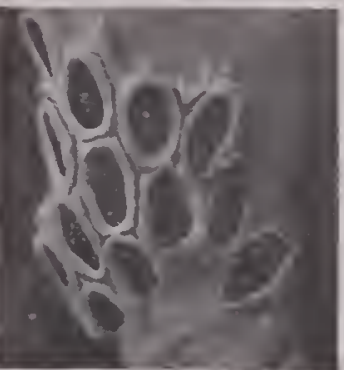

8

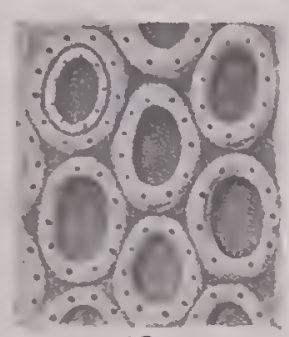

12

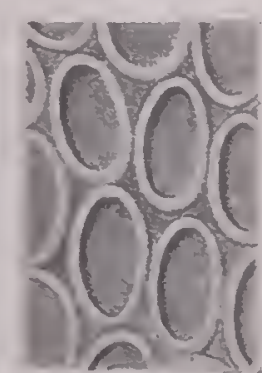

7

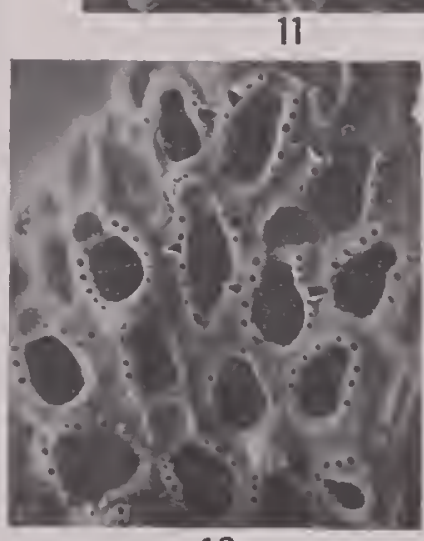

16

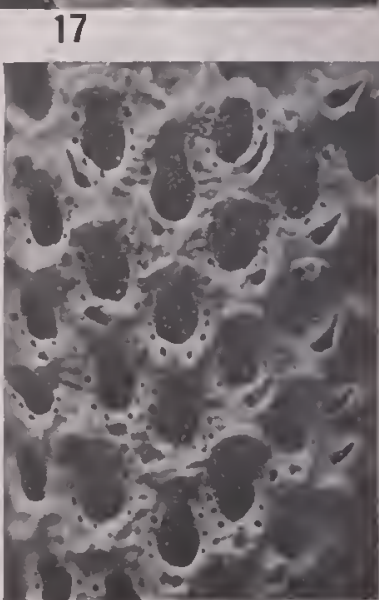

19

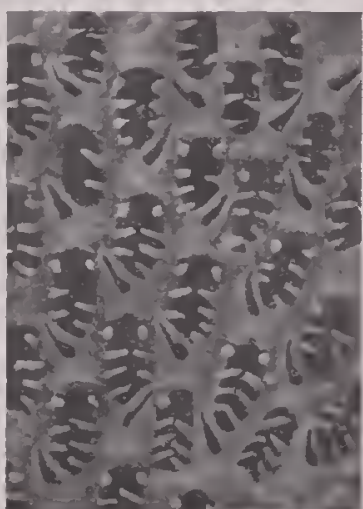

18 


\section{Plate 33.}

Figs. 1, 2. Mystriopora? areoluta, new species. (p. 19.)

1. The incrusting zoarium, $\times 20$, showing the pyriform zooecia, the zoneciules, and the interzooecial areolae.

2. Another example, $\times 20$, preserving longer zooeciules.

Pleistocene: Long Wharf Canyon, Santa Monica, California.

Figis. 3-5. Membranipora tuberculata Bose, 1802. (p. 22.)

3. A fossil example of this widespread recent species, $\times 20$, with very large tubercles.

4. Another example, $\times 20$, with the tubercles less developed and the zooecia still retaining their chitinous parts.

Pleistocene: Santa Monica, California.

5. Surface of a recent specimen, $\times 20$, showing identity with the fossil form.

Pacific Ocean: Santa Monica, California.

FIG. 6. Membraniporina californica Gabb and Horn, 1862. (p. 25.)

Original figure.

Pleistocene: Santa Barbara, California.

Figs. 7-9. Conopeum barbarensis Gabb and Horn, 1862. (p. 28.)

7. Gabb and Horn's figure of this species.

8. A small incrusting zoarium, $\times 20$, showing the simplicity of structure.

9. The incrusting zoarium, $\times 20$, showing the distinct zooecia with thin mural rim and several avicularia.

Pleistocene: Santa Barbara, California.

FIG. 10. IIincksina quadrispinosa, new species. (p. 38.)

The incrusting zoarium, $\times 20$, illustrating the large elongated zooecia with four distal spines.

Two regenerated zooecia are also shown.

Pleistocene: Rustic Canyon, Santa Monica, California.

FIG. 11. Irinchsina multispinata, new species. (p. 38.)

Zooecia, $\times 20$, of the incrusting zoarium, showing their small, elongated oval shape and the numerous hollow spines.

Pleistocene: Santa Barbara, California.

Fig. 12. Callopora multipora Gabb and Horn, 1862. (p. 44 .)

Gabb and Horn's figure of this interesting species, which has not been rediscovered.

Pleistocene: Santa Barbara, California.

FIG. 13. Callopora crassospina, new species. (p. 41.)

The incrusting type specimen, $\times 20$. The long fusiform avicularium and the six hollow spines are to be noted.

Pleistocene: Santa Barbara, Califoruia.

FIGs. 14-16. Cauloramphus triangularis, new species. (p. 48.)

14. The incrusting type specimen, $\Varangle 20$. The numerous hollow spines and the small triangular aviculariun are to be noted.

15. An example showing the ancestrular zooecia, $\times 20$.

16. An ovicelled specimen, $X 20$.

Pleistocene: Santa Barbara, California.

Fig. 17. Cauloramphus porosus, new species. (p. 48.)

The incrusting type specimen, $\times 20$, illustratıng the large distinct zooecia separated by numerous pores.

Pleistocene: Santa Barbara, California.

Figs. 18, 19. Callopora horrida Hincks, 1880. (p. 43.)

18. Unilamellar, recent zoarium, $\times 20$, with areal spines preserved

Pacific coast near Los Angeles, California.

19. Zooecia of an incrusting fossil example, $\times 20$, illustrating the large avicularia and the areal . spines.

Pleistocene: Santa Barbara, California. 
Figs. 1-3. Callopora circumclathrata Hincks, 1881. (p. 43.)

1. Well-preserved specimen, $\times 20$, with ovicells and avicularia.

2. Zoarial surface, $\times 20$, showing the zooecia, avicularia arcolar spaces, and the dietcllae.

3 . An ovicelled specimen, $\times 20$, with large avicularia.

Pleistocene: Long Wharf Canyon, Santa Monica, California.

FIG. 4. Rhamphonotus multispinatus, new spccies. (p. 47.)

The incrusting type specimen, $\times 20$, showing the two sizes of spines, a pair of large ones which constrict the opesium and numerous smaller ones.

Pleistocene: Santa Barbara, California.

Figs. 5-7. Cupularia robertsoniae, new species. (p. 82.)

5. The disk-shaped zoaria, natural size.

6. External inferior facc, $\times 20$.

7. Internal superior face, $\times 20$.

Pleistocenc: Long Wharf Canyon, Santa Monica, California.

Fig. 8-10. Chaperia galeata Busk, 1853. (p. 52.)

8. A Pleistocene example of this widespread recent and fossil species, $\times 20$.

Pleistocene: Santa Barbara, California.

9. Oricelled zooecia showing the characteristic rectilinear distal bordcr.

10. Another fragment, $\times 20$, with one completc ovicell and the spines and avicularia well shown.

Pleistoccne: Rustic Canyon, Santa Monica, California.

FIGs. 11-14. Cellaria mandibulata Hincks, 1882. (p. 86.)

11. A segment, $\times 20$, showing a large avicularian zooeciun.

12. Another fragment, $\times 20$, with an avicularian zooccium. The round orifice of the inferior zooecium is the passage for the corneous joint bearing another segment.

13. An ordinary segment, $\times 20$.

14. Several fragmentary segments, natural size.

Pleistocene: Los Angeles, California.

Figs. 15-18. Cellaria fissurifera, new species. (p. 55.)

15. A worn segment, $X 20$. The opening of the ovicell is very narrow.

16. Segment, $\times 20$, bearing zooecium with round orifice through which the chitinous joint of another segment passed.

17. Segment, $\times 20$, with rhomboidal zooecia and bearing two aricularia. The orifice of the ovicell is a narrow elongated fissure.

18. Several fragments, natural size.

Pleistocene: Rustic Canyon, Santa Monica, California.

Figs. 19, 20. Cellaria diffusa Robertson, 1905. (p. 86.)

A segment natural size and enlarged, $\times 20$, illustrating the characters of this beautiful species. The orifice of the ovicell has the characteristic proximal tongue.

Pleistocene: Rustic Canyon, Santa Monica, California. 


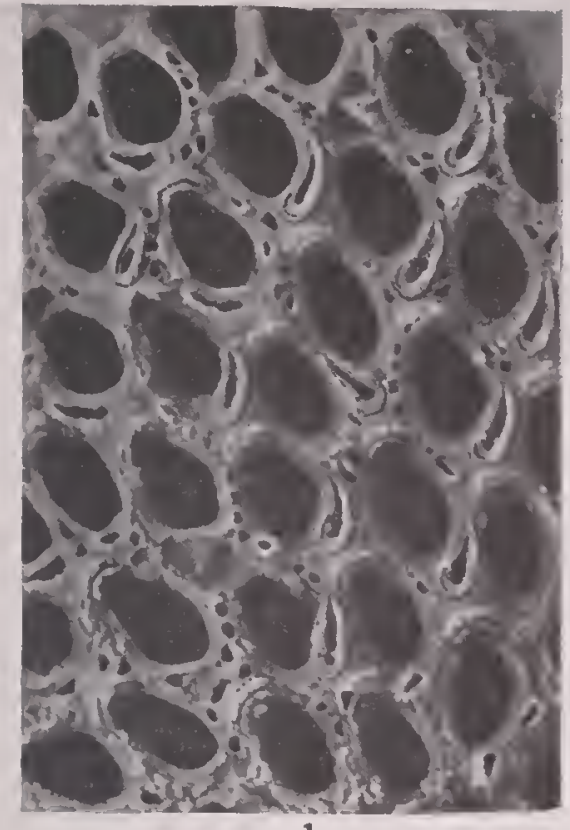

1

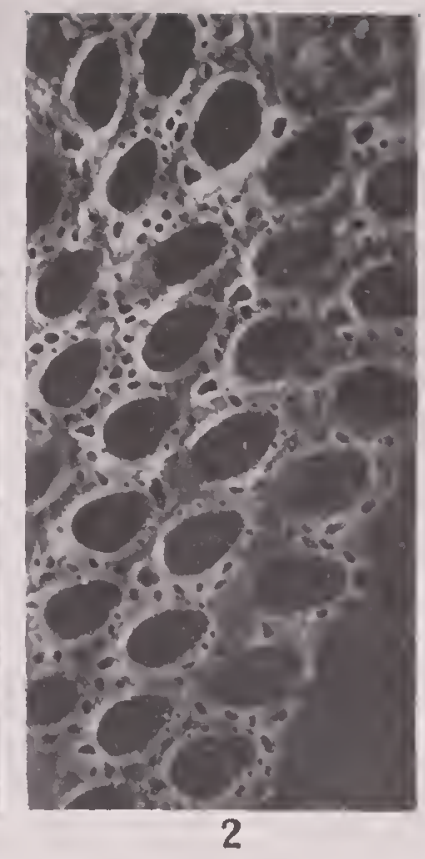

2
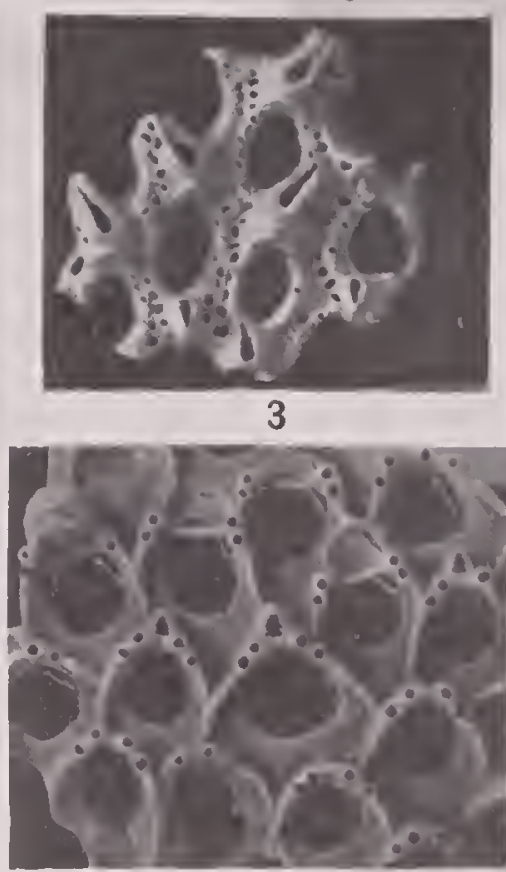

10

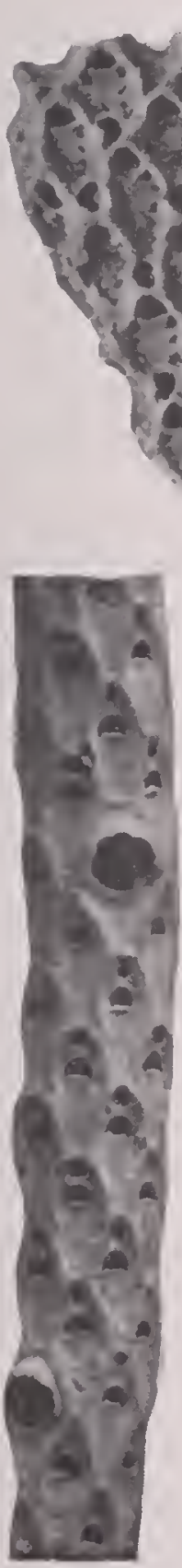

11

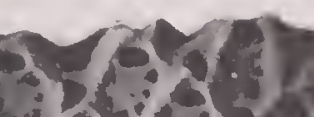
$3+1$ (1) :? s. D. de 21

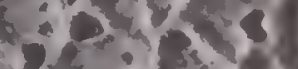
aris if 2

$\frac{12}{6}$
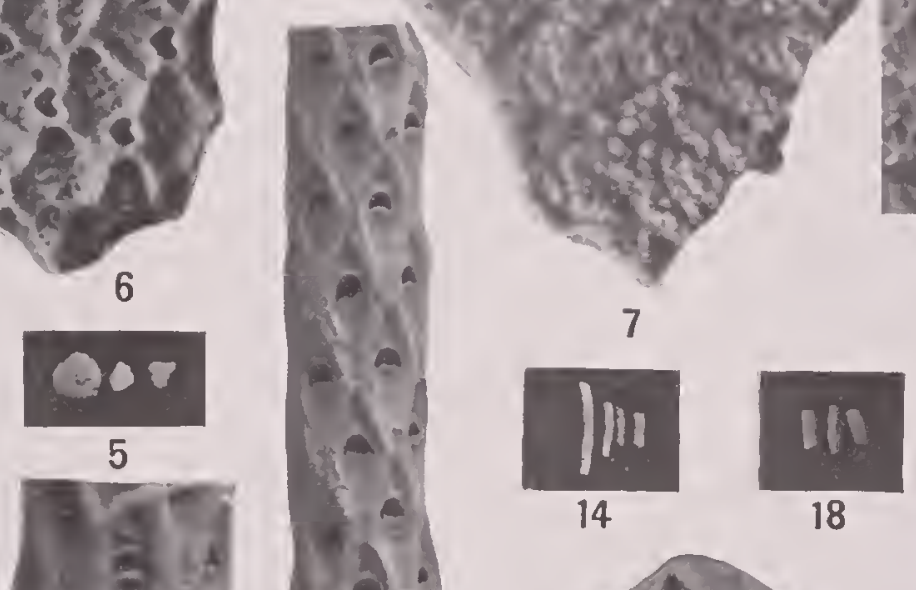

14

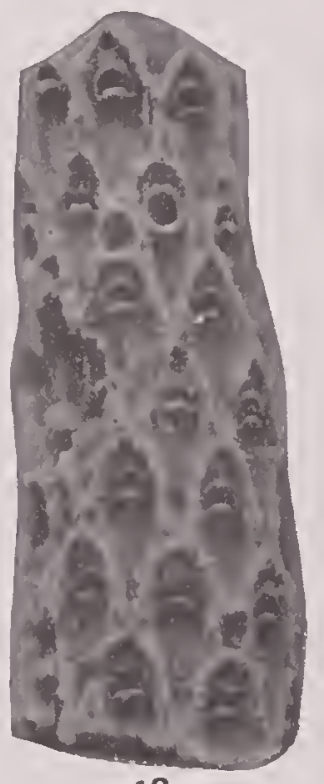

16

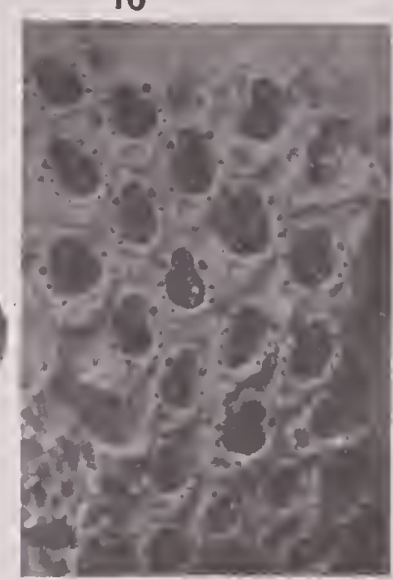

4

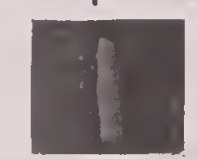

20

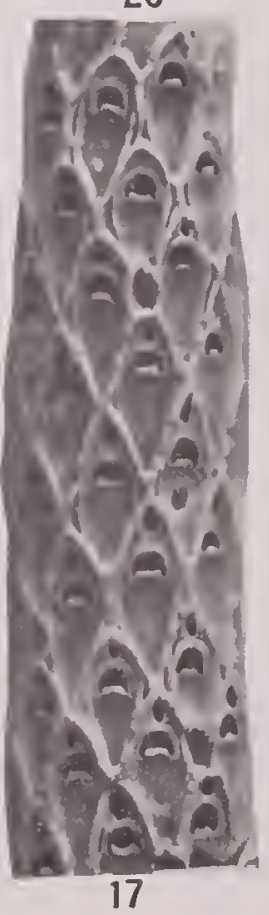

12

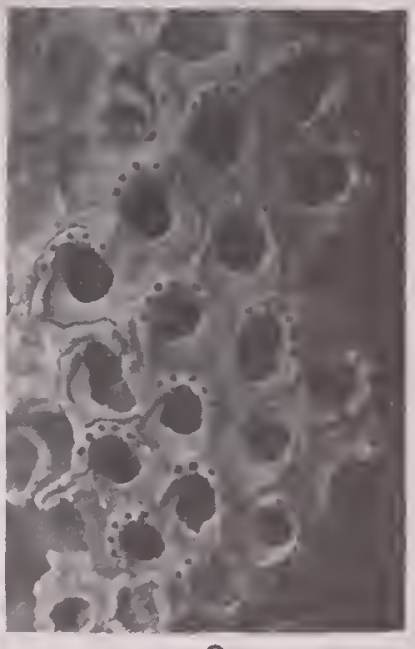

8
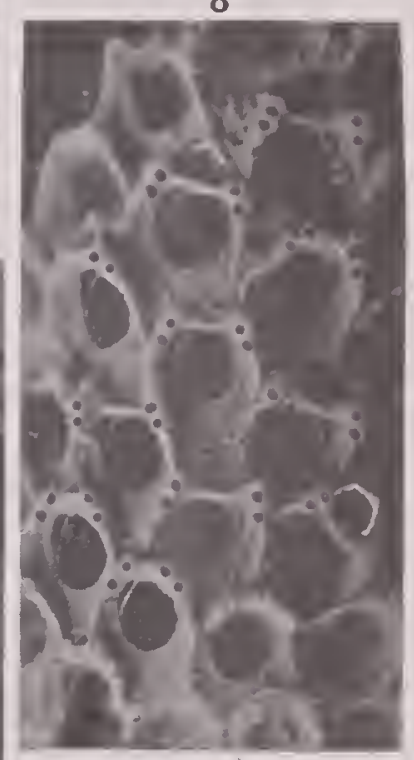

9

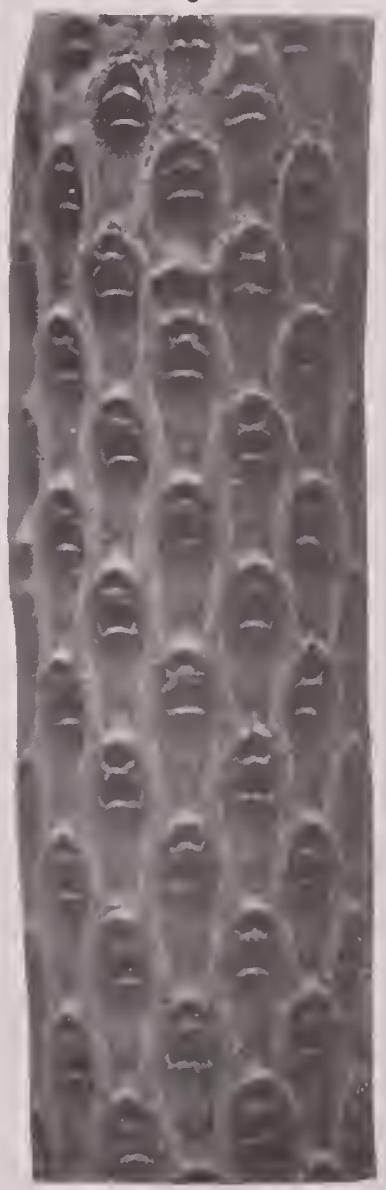

19

NORTH AMERICAN LATER TERTIARY AND QUATERNARY BRYOZOA. 


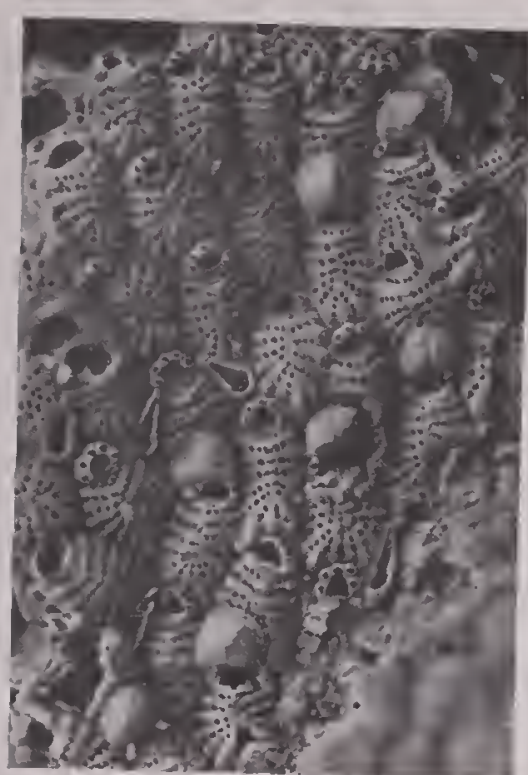

1

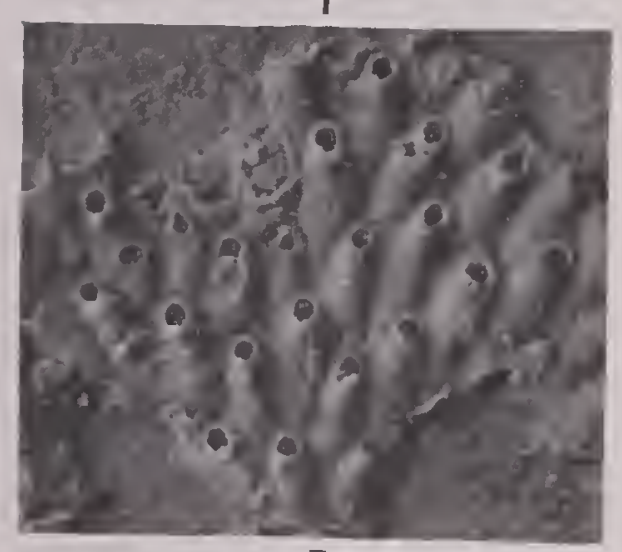

7

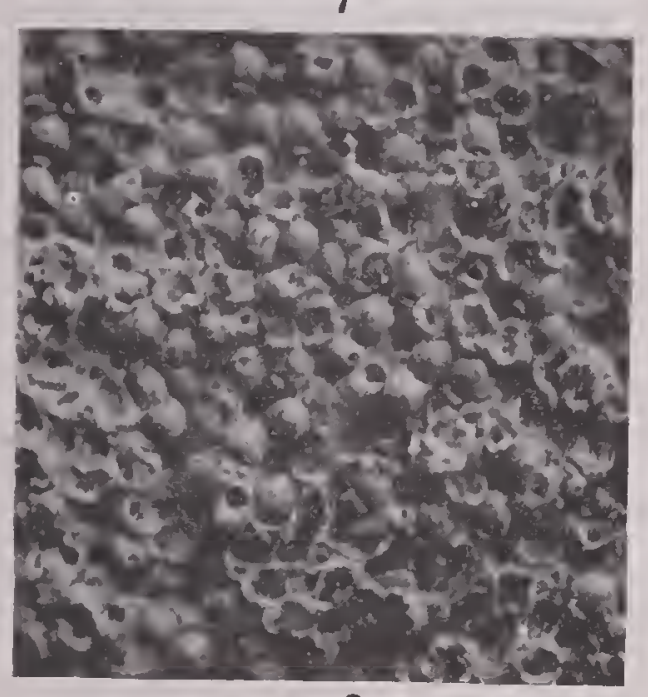

8

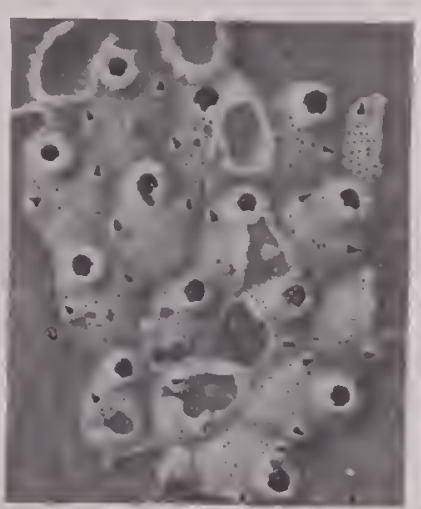

10

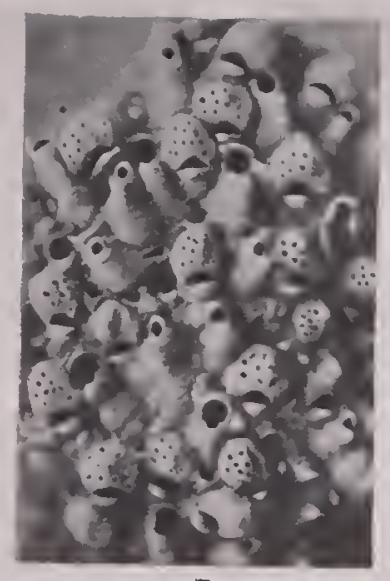

5

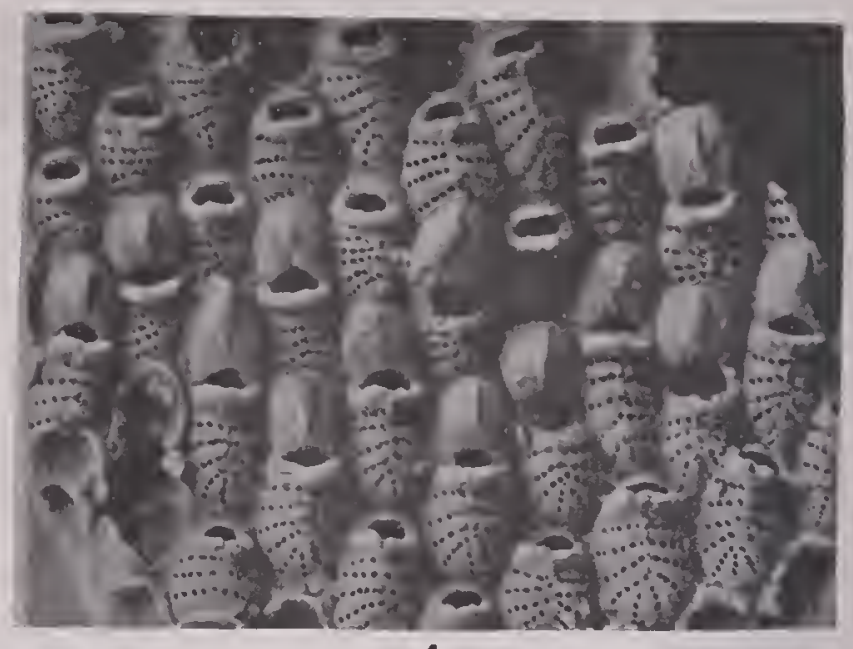

4

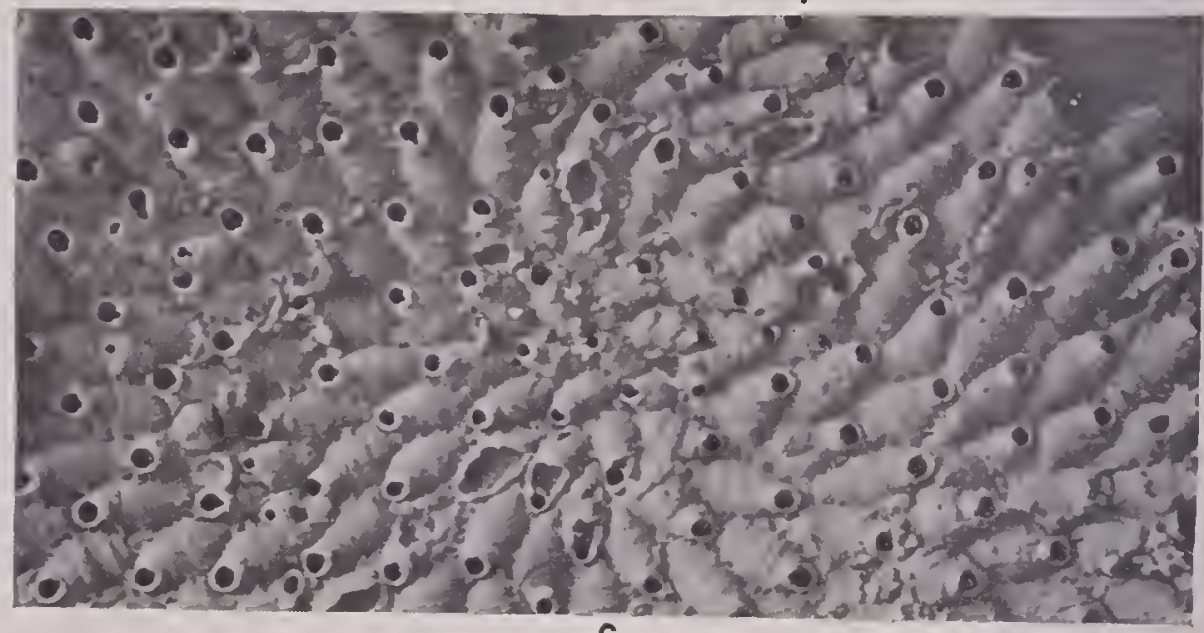

$$
6
$$

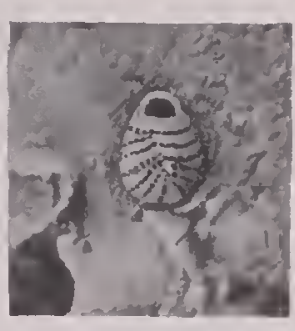

3

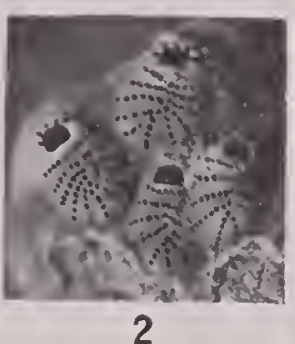

2

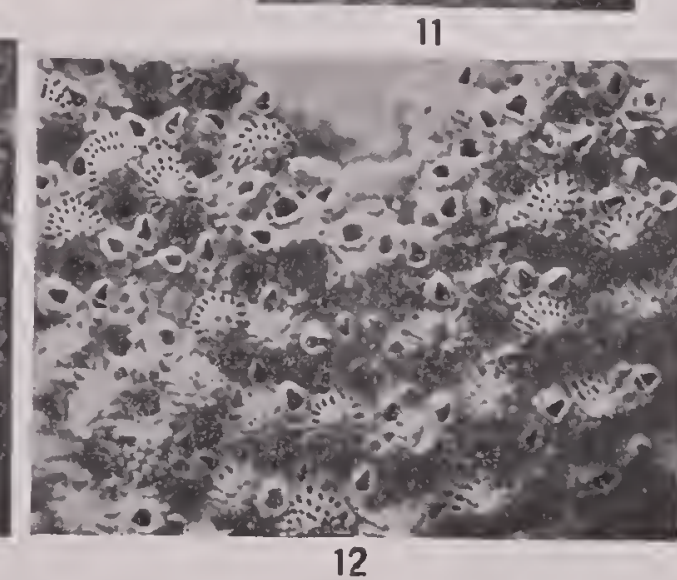

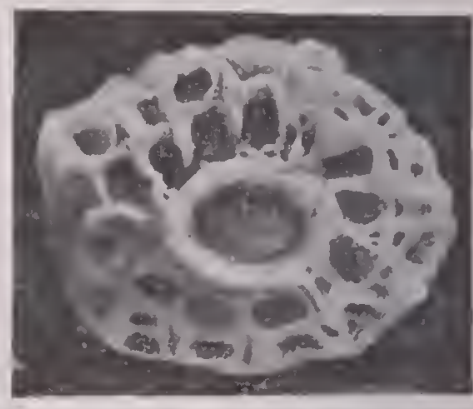

14

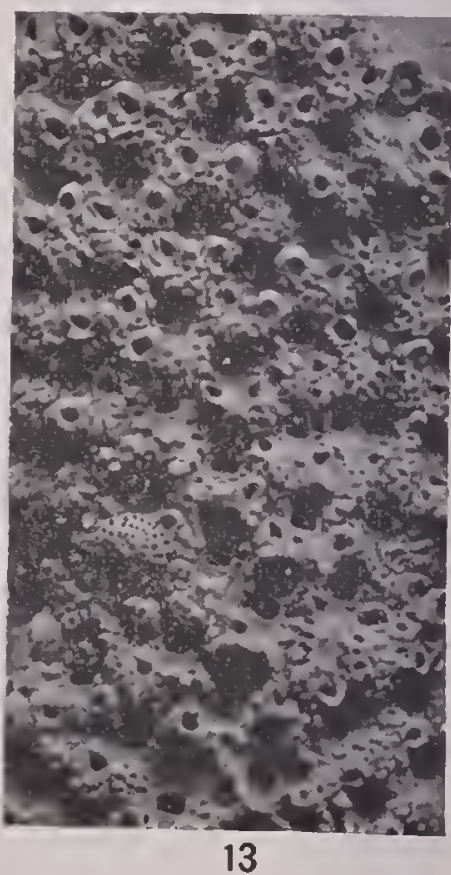

NORTHIAMERICAN LATER TERTIARY AND QUATERNARY BRYOZOA. 


\section{Plate 35.}

FIG. 1. Puellina radiata forma scripta Reuss, 1847. (See also pl. 15, fig. 12.) (p. \$9.)

Well-preserved zoarium, $\times 20$, with elongated zooecia and well-developed avicularia and spines.

Pleistocene: Santa Barbara, California.

Figs. 2, 3. Puellina heermanni Gabb and Horn, 1862. (p. 89.)

2. Several zooecia of the incrusting zoarium, $\times 20$, showing the wide costules and the oral spines.

3. A single zooecium, $\times 20$, illustrating the rectilinear proximal border of the apertura.

Pleistocene: Santa Barbara, California.

Fig. 4. Metracolposa mucronata, new species. (p. 92.)

The incrusting type specimen, $\times 20$, showing the large keeled ovicell.

Pleistocene: Santa Barbara, California.

FIgs. 5-8. Hippothoa hyalina Linnaeus, 1768. (p. 92.)

5. Portion of a zoarium, $\times 20$, illustrating the three kinds of zooecia.

Pleistocene: Santa Barbara, California.

6. A zoarium, $\times 20$, formed almost entirely of ordinary zooecia and showing the ancestrula.

7. A small incrusting patch, $\times 20$, with ordinary zooecia only.

8. A mature example, $\times 20$, in which the irregular arrangement of the male zooecia gives a celleporoid effect.

Pleistocene: Dead Mans Island, off San Pedro, California.

FIG. 9. Hippothoa hyalina, var. rugosa, new variety. (p. 94.)

Type example, $\times 20$, showing the characteristic frontal wrinkles.

Pleistocene: Santa Barbara, California.

FIG. 10. Schizolavella vulgaris Moll, 1803. (p. 108.)

The Pleistocene specimen referred to this species, $\times 20$.

Pleistocene: Santa Barbara, California.

FIG. 11. Schizomavella longirostrata Hincks, 1883. (p. 109.)

A fossil example referred to this recent species, $\times 20$. The large avicularium and the very small tremopores are shown.

Pleistocene: Santa Barbara, California.

Figs. 12-14. Trypematella papulifera, new species. (p. 135.)

12. Surface of the unilamellar zoarium, $X 20$, showing unovicelled zooecia.

13. A zoarium, $\times 20$, bearing ovicell.

14. Transverse section of the hollow tubular zoarium, $\times 20$.

Pleistocene: Rustic Canyon, Santa Monica, California. 


\section{Plate 36.}

FIc. 1. Lepralia cribrosa? Maplestone, 1900. (p. 134.)

Surface of the specimen, $\times 20$, referred to this Australian Miocene species.

Pleistocene: Rustic Canyon, Santa Monica, California.

F1Gs. 2, 3. Fenestrulina malusi Savigny-Audouin, 1826. (p. 115.)

2. Photograph, $\times 20$, showing sinall zooecia.

3. Zoarium, $\times 20$, with large zooecia, some showing the ovicell.

Pleistocene: Santa Barbara, California.

FIgs. 4, 5. Microporella ciliata Linnaeus, 1759. (See also pl. 20, figs. 1-6.) (p. 119.)

4. Zoarium, $\times 20$, exhibiting zooecia with small avicularia.

5. Zoarium, $\times 20$, in which the zooecia have large avicularia.

Pleistocene: Santa Barbara, California.

F1Gs. 6, 7. Microporella umbonata Hincks, 18\$2. (p. 123.)

6. Marginal zooecia without ovicell, $\times 20$.

7. Ovicelled zooecia of the same specimen, $\times 20$, exhibiting also the frontal umbo.

Pleistocene: Santa Barbara, California.

Figs. 8-10. Microporella californica Hincks, 18s3. (p. 123.)

8. Zooecia, $\times 20$, showing only a single but well-developed avicularium.

9. Zoarium with ovicell zooecia, $\times 20$, with a single avicularium.

Pleistocene: Long Wharf Canyon, Santa Monica, California.

10. Normal and ovicelled zooecia of a large expansion, $\times 20$.

Pleistocene: Santa Barbara, California.

FIGs. 11, 12. Microporella vibraculifera Hincks, 1883. (p. 124.)

11. A zoarium, $\times 20$, with ancestrular zooecia.

Pleistocene: Rustic Canyon, Santa Monica, California.

12. Ovicelled and normal zooecia, $\times 20$, illustrating the aricularia and the six hollow spincs.

Pleistocene: Santa Barbara, California.

Fig. 13. Microporella customata Gabb and Horn, 1862. (p. 124.)

Zoarial surface, $\times 20$, with ovicelled and normal zooecia and with the aricularium oblique to the zooecial axis.

Pleistocene: Rustic Canyon, Santa Mouica, California. 


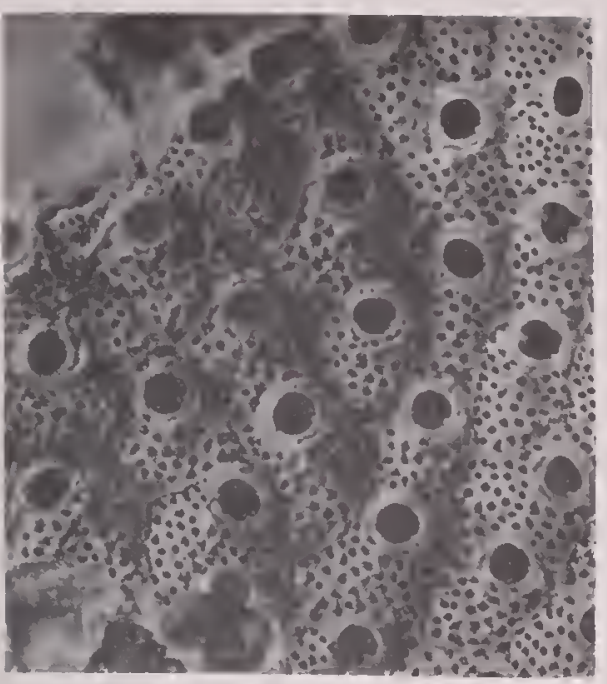

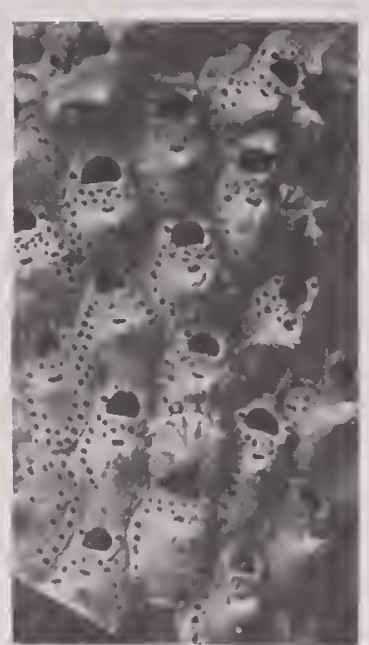

2

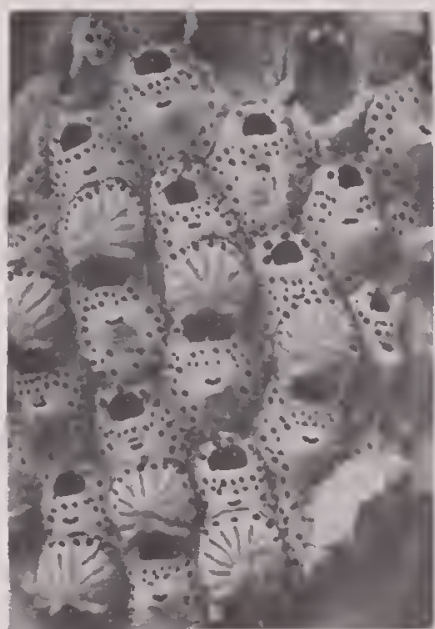

3

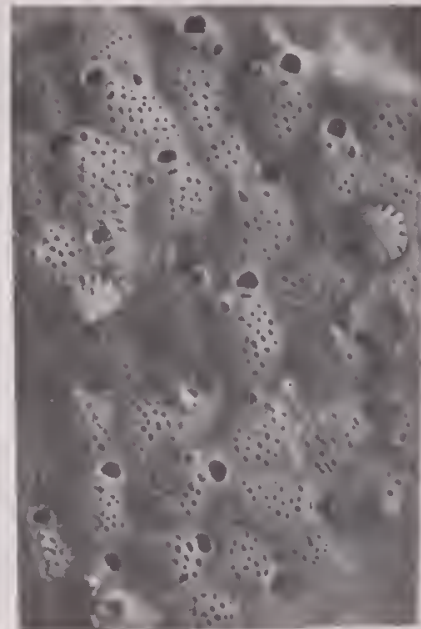

4

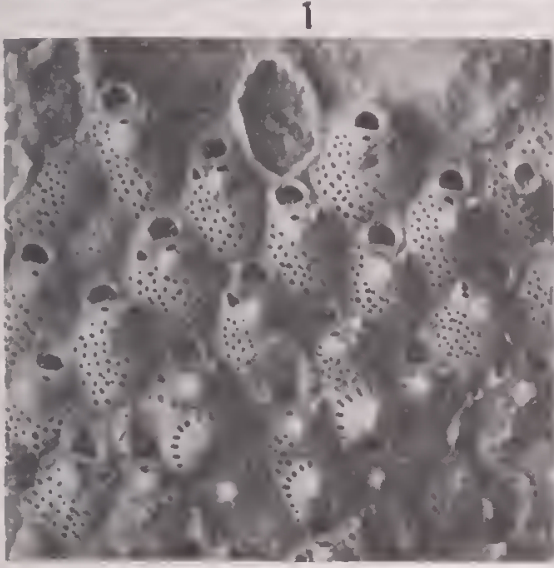

6

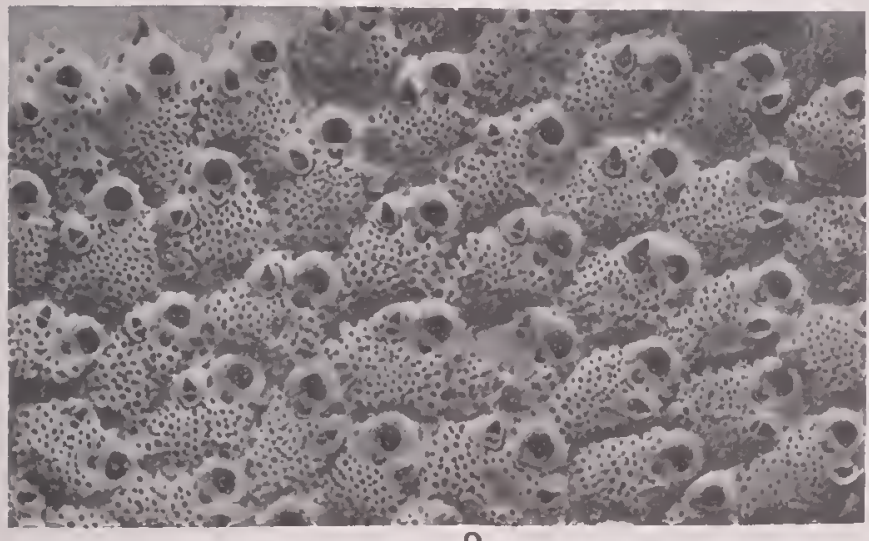

8

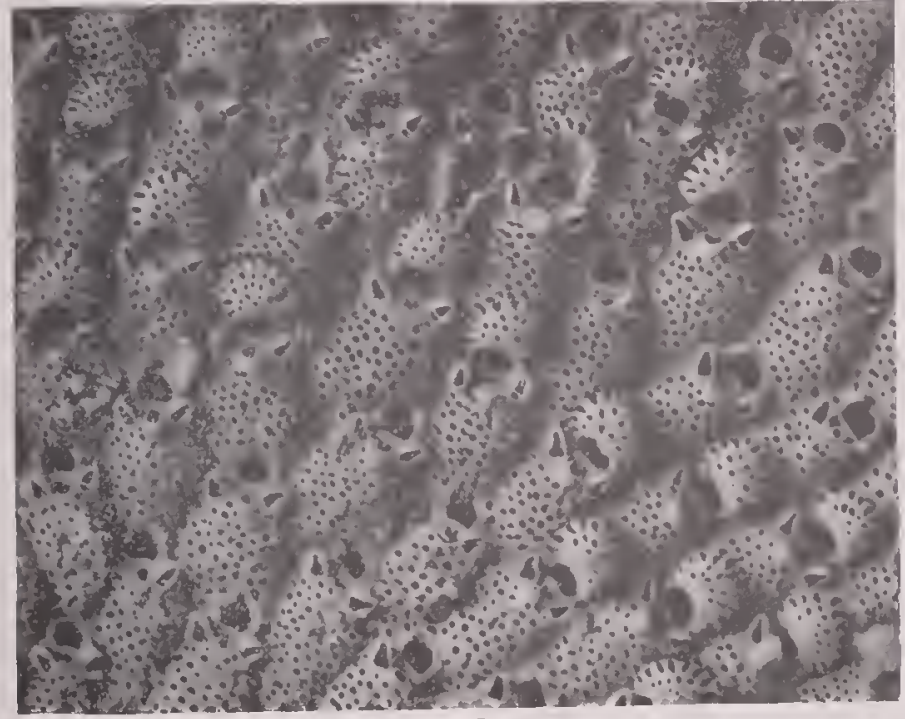

10
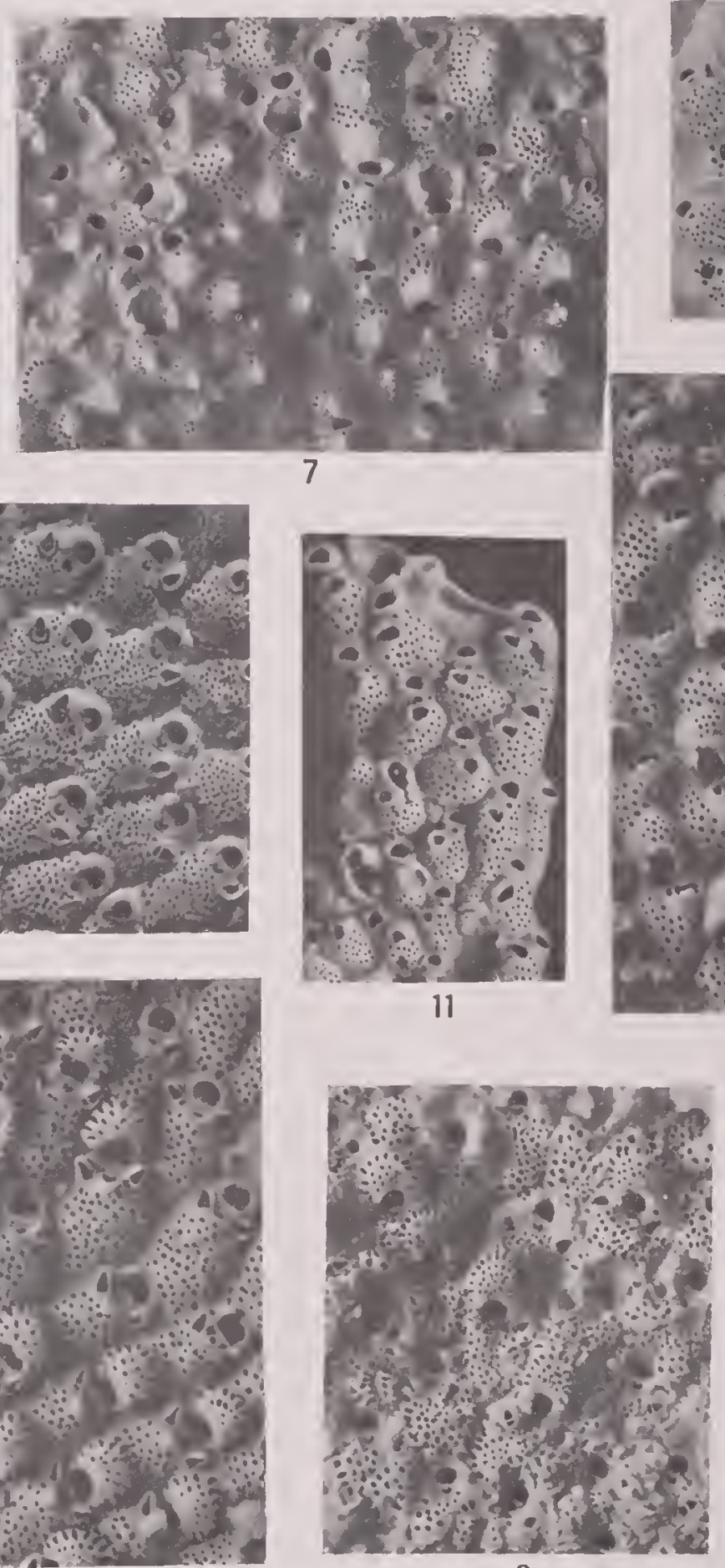

9

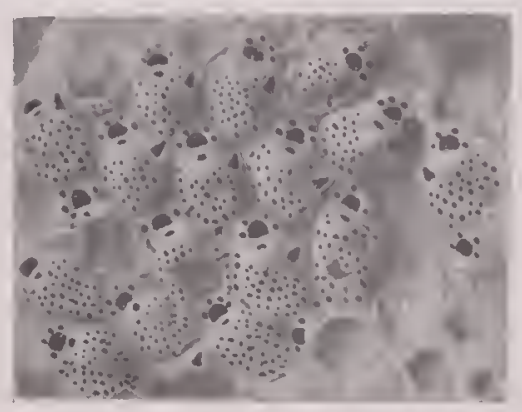

5

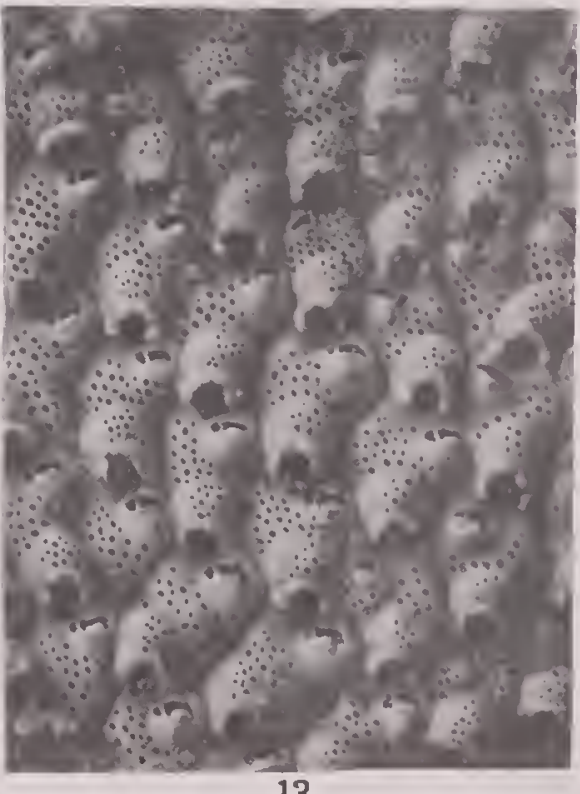

13

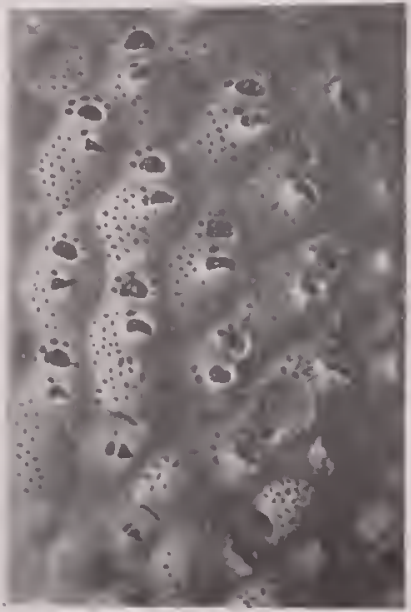

12

NORTH AMERICAN LATER TERTIARY AND QUATERNARY BRYOZOA

For explanation of plate see page 280 


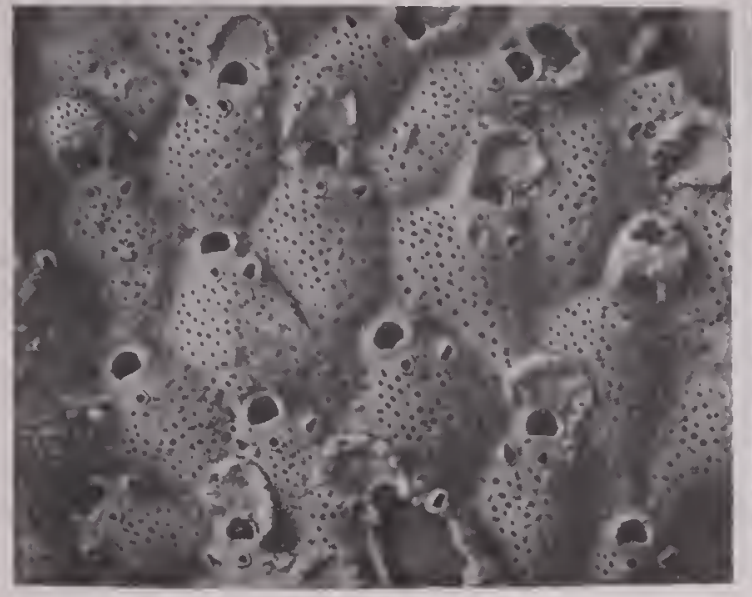

1

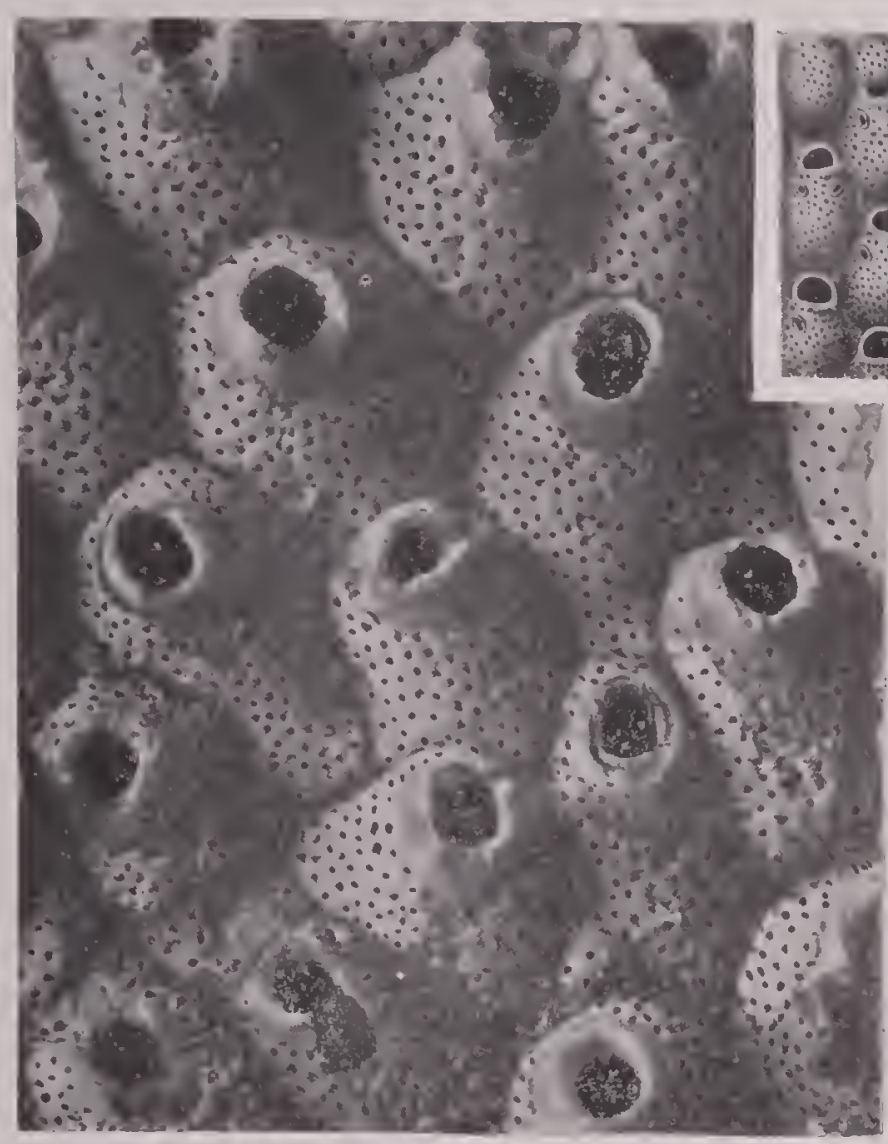

5

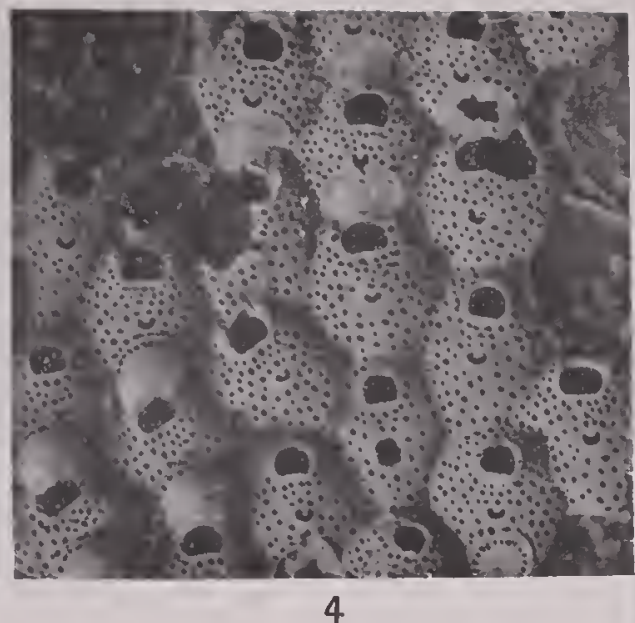

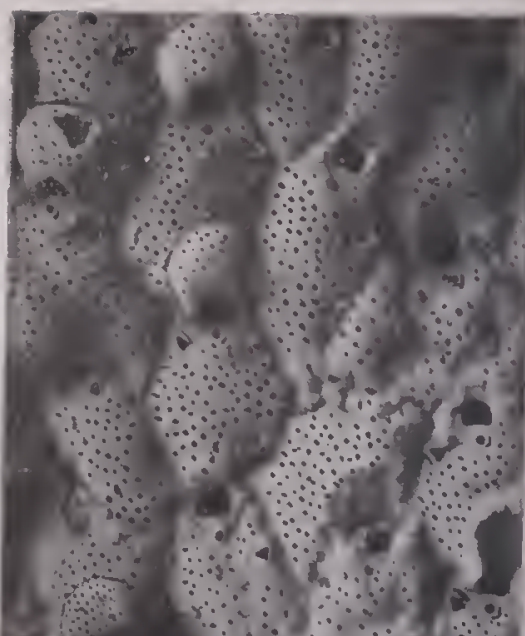

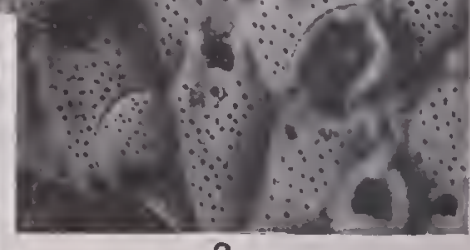

3

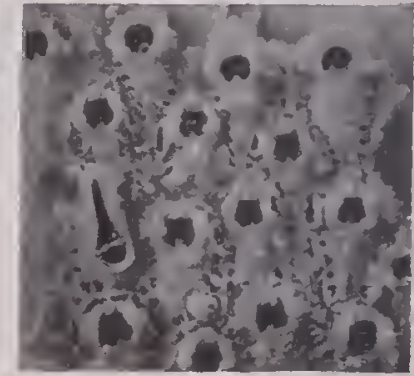

8
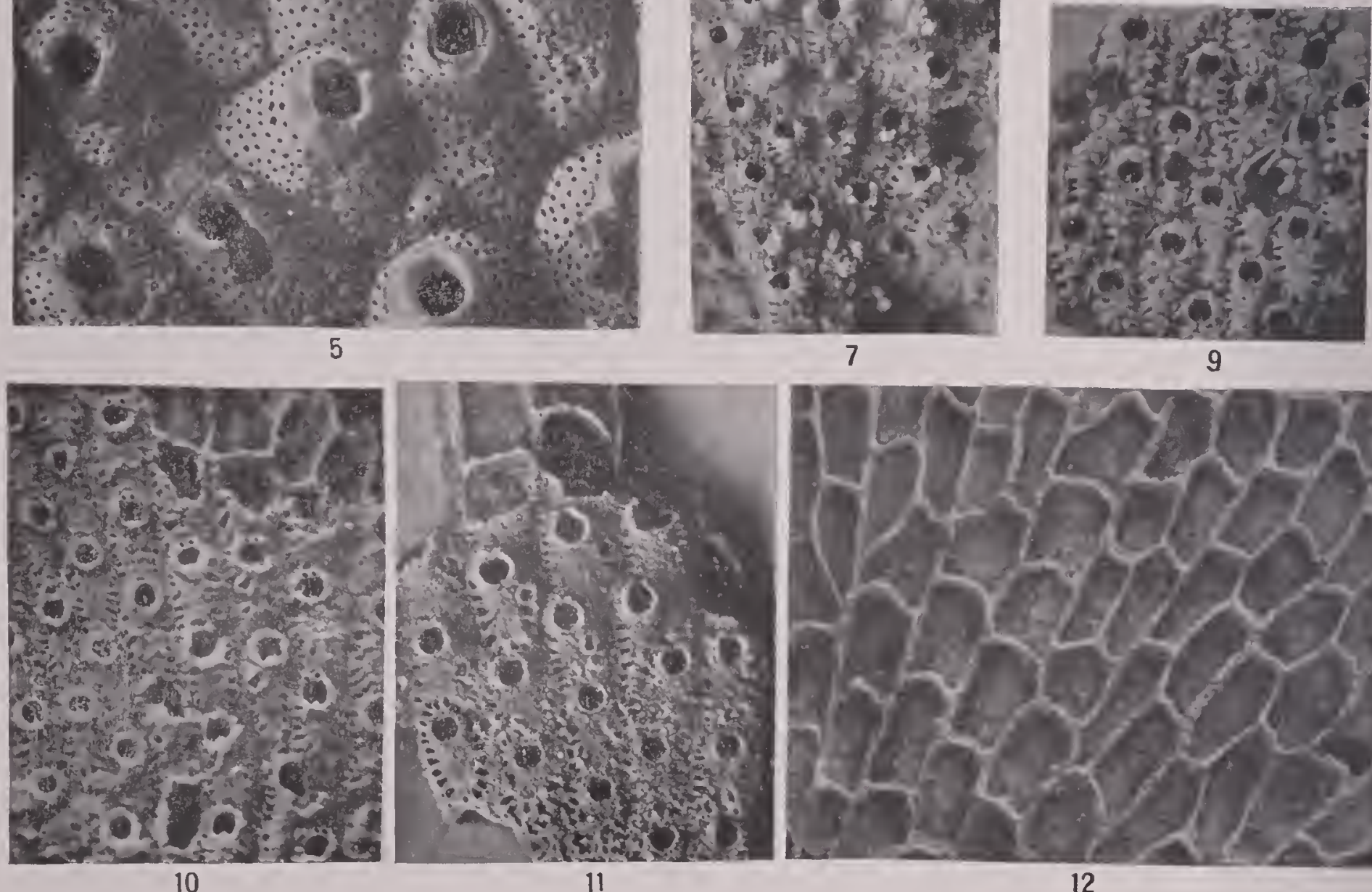

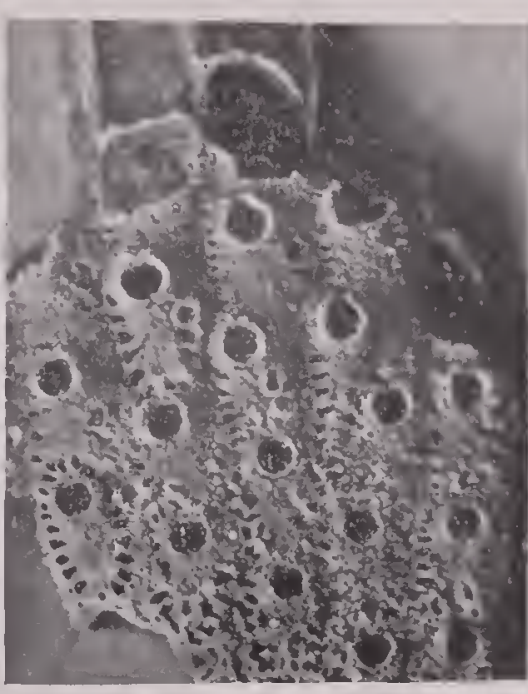

11

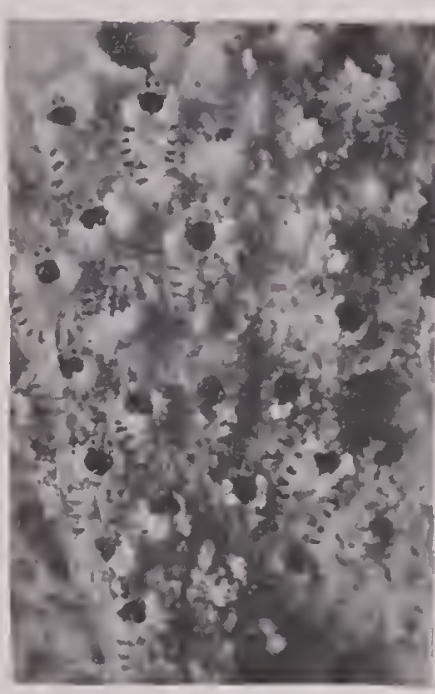

7

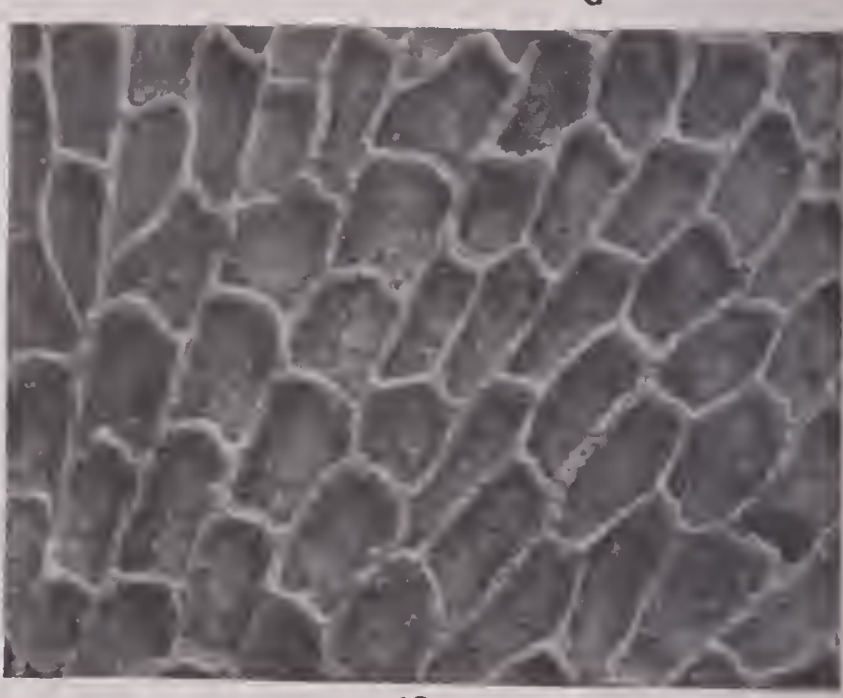

12

NORTH AmERICAN Later TERTIARy and Quaternary Bryozoa. 


\section{Plate 37 .}

Figs. 1, 2. Wicroporella heermani Gabb and Horn, 1862. (p. 125.)

1. Ordinary and ovicelled zooecia, $\times 20$. The large dimensions, granular frontal and small tremopores and avicularia are illustrated.

Pleistocene: Rustic Canyon, Santa Monica, California.

2. The original figure of the species.

Pleistocene: Santa Barbara, C'alifornia.

Fig. 3. Nicroporella gibbera, new species. (p. 126.)

Surface of the unilamellar zoarium, $\times 20$, showing the distinct, irregular, gibbose zooecia.

Pleistocene: Rustic Canyon, Santa Monica, California.

Fig. 4. Fenestrulina porosa, new species. (1) 117.)

Surface of the incrusting zoarium, $\times 20$.

Pleistocene: Long Wharf Canyon, Santa Monica, California.

FIG. 5. Cyclicopora gigantea, new species. (p. 139.)

Surface of the incrusting zoarium, $\times 20$, showing the extreme size of the zooecia.

Pleistocene: Tremochal Canyon, Santa Mfonica, California.

FIG. 6. Eurystomella bilabiata Hincks, 1S84. ( p. 142.)

A fossil specimen, $\times 20$, referred to this interesting recent species.

Pleistocene: Dead Mans Island, off San Pedro, California.

Figs. 7-9. Smittina californiensis Robertson, 1908. (p. 146.)

7. Zooecia, $\times 20$, showing thin areolar costules and the peristome formed by two lateral tuberosities.

8. Another example, $\times 20$, with two small lateral avicularia and a large interzooecial avicularium developed.

9. Surface of zooecia, $\times 20$, with the two small aricularia, one of which has the beak directed upward and the other downward.

Pleistocene: Santa Barbara, California.

Figs. 10-12. Smittina grandicella, new species. (p. 145.)

10. The incrusting zoarium, $\times 20$, showing the large distinct zooecia and the distal pores in the peristome.

11. Another example, $\times 20$, not so well preserved.

12. A zoarium, $\times 20$, with the frontal removed, illustrating the sinuous arrangement of the walls, which are without septulae.

Pleistocene: Rustic Canyon, Santa Monica, California. 
Plate 38.

liss. 1-7. Smittina discoidca, new species. (p. 145.)

1. Fragments of the unilamellar zoarium, natural size.

2. Surface, $\times 20$, showing the large interzooecial avicularium.

3. Zooecial surface, $\times 20$, with the large avicularium replaced by two small ones. Ovicelled zonecia are present.

4. Lower side, $\times 20$.

5. Another surface, $\times 20$, in which the large avicularium is unguiculate.

6. Zooecia, $\times 20$, with the large avicularia turned in different directions.

7. Interior of zooecia, $\times 20$, showing that the lyrula is accompanied by two cardelles.

Pleistocene: Rustic Canyon, Santa Monica, California.

FIg. S. Cystisella aviculifera, new species. (p. 152.)

Portion of the incrusting zoarium, $\times 20$, showing the small ancestrular zooecia and the large marginal ones.

Pleistocene: Santa Barbara, California.

FIG. 9. Smittina porifera Hincls, 1884. (p. 147.)

Zooecia of the incrusting zoarium, $\times 20$, showing the convex frontal perforated by pores.

Pleistocene: Santa Monica, California.

Figs. 10-15. Porella collifera Robertson, 190S. (p. 14S.)

10. Zoaria, natural size.

11. Ovicelled zooecia, $\times 20$.

12. Surface, $\times 20$, with one zooecium bearing a small ovicell.

13. Zooecia, $\times 20$, with a very salient peristome.

Pleistocene: Santa Monica, California.

14. Zooecia, $\times 20$, with large tremopores.

15. Interior of zooecia, $\times 20$. The oral avicularium is supported by a denticulated lyrula. Pleistocene: Santa Barbara, California.

282 

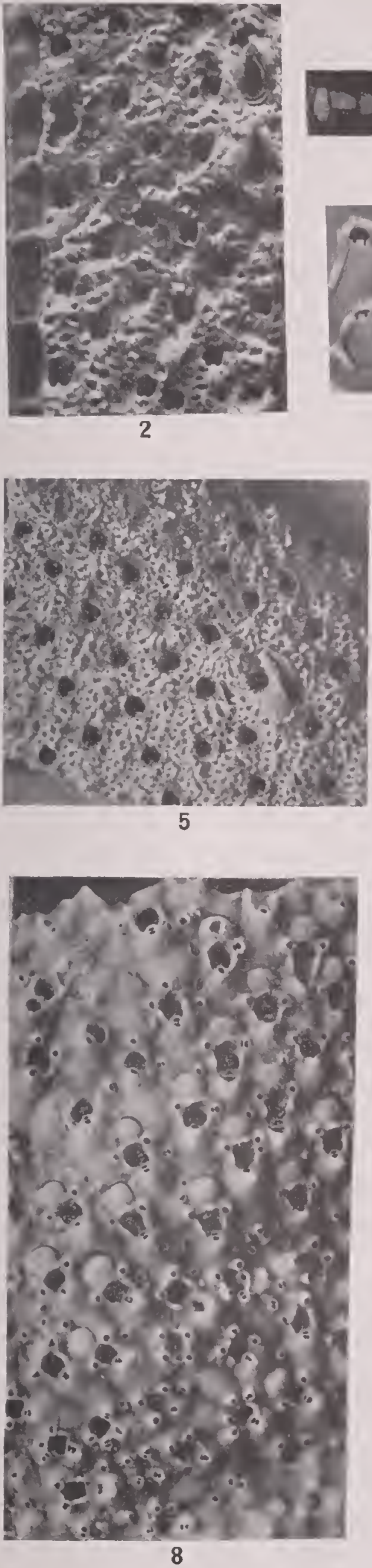
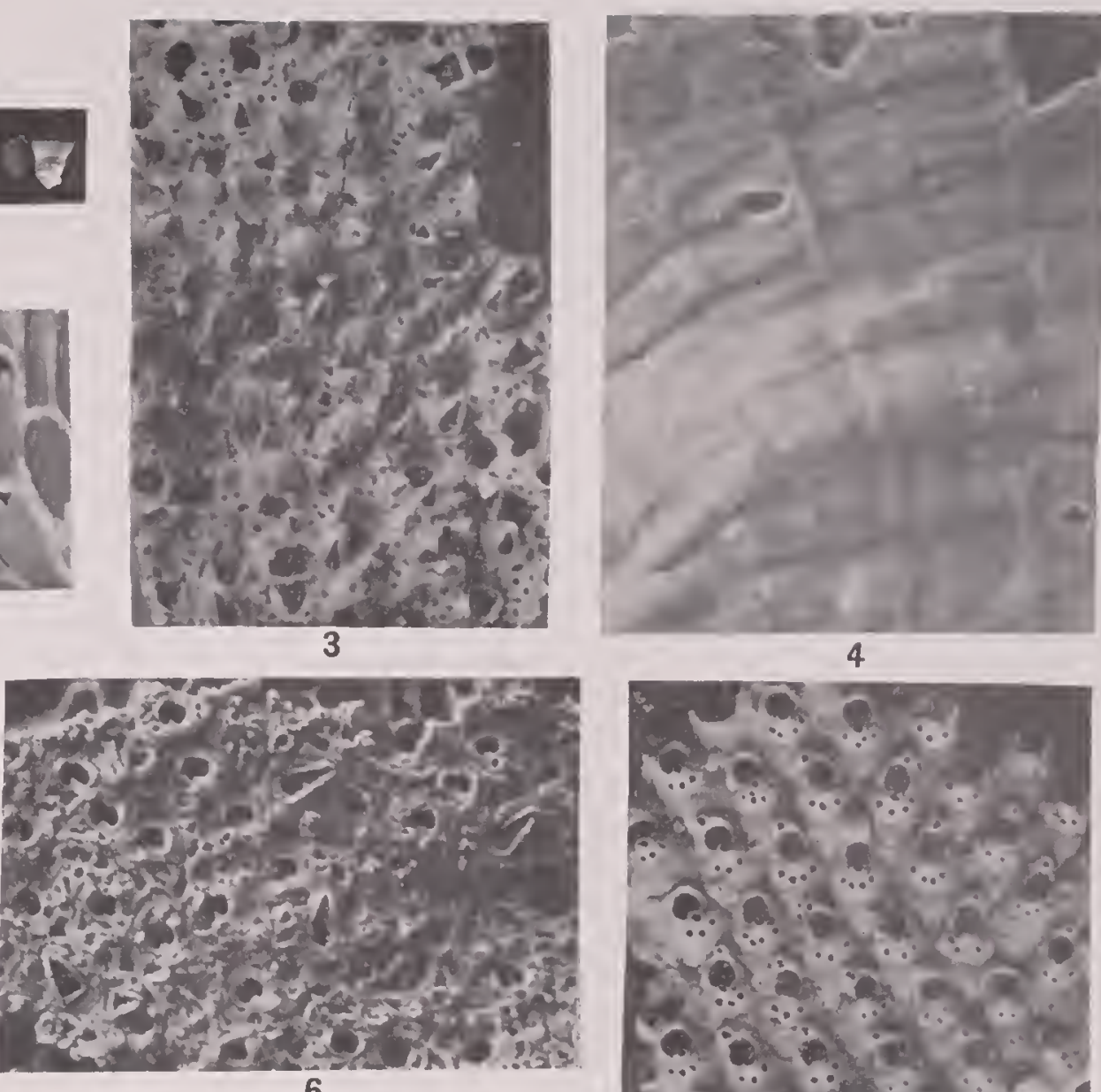

$$
6
$$

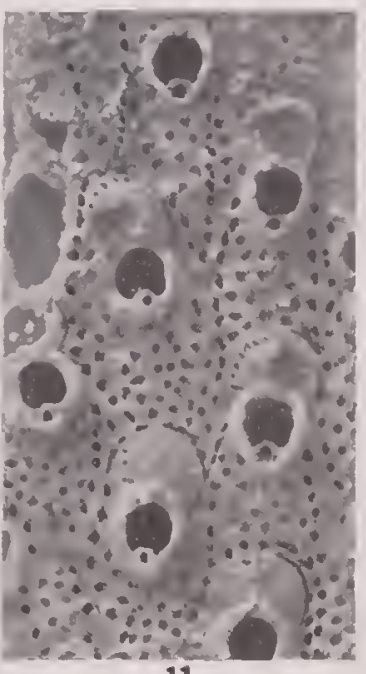

11

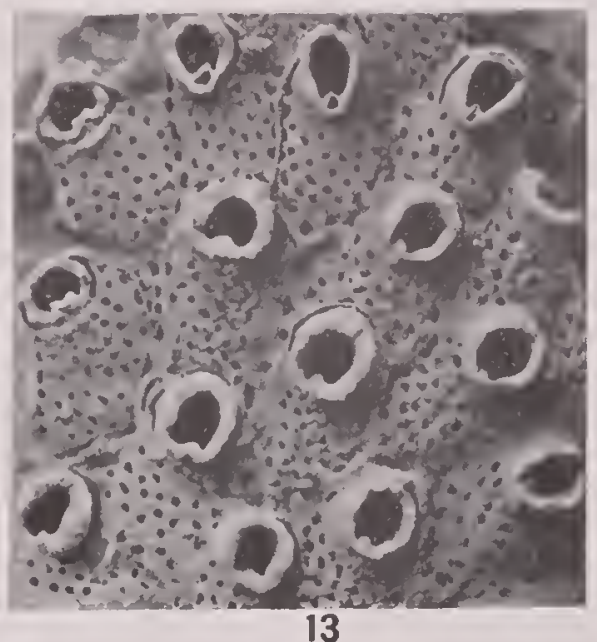

10

15
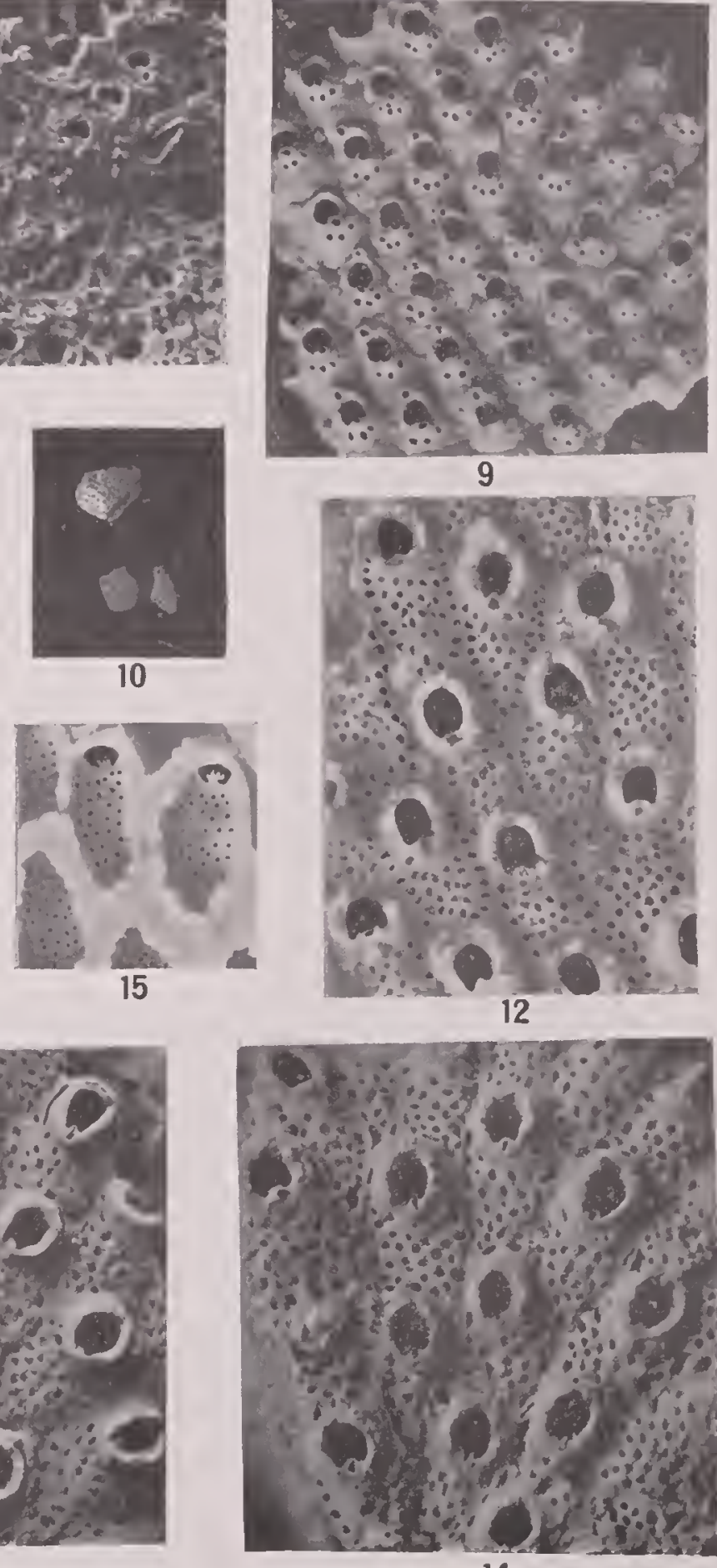


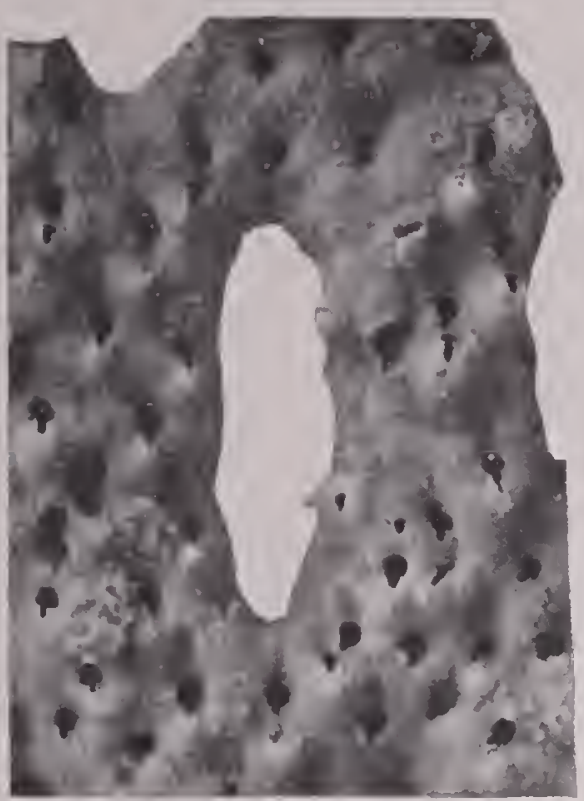

2

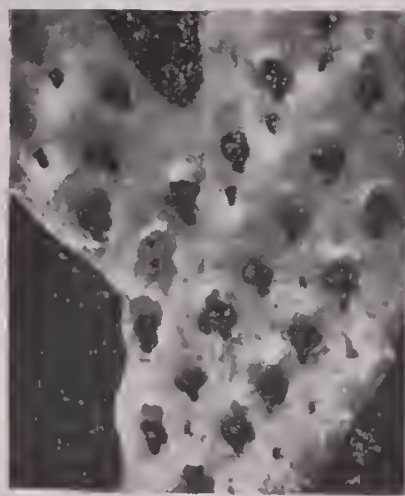

3
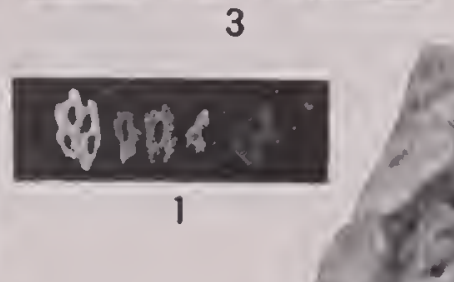

.
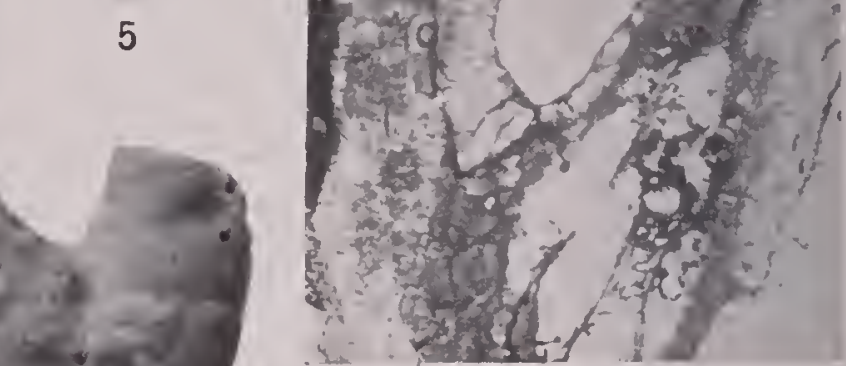

4
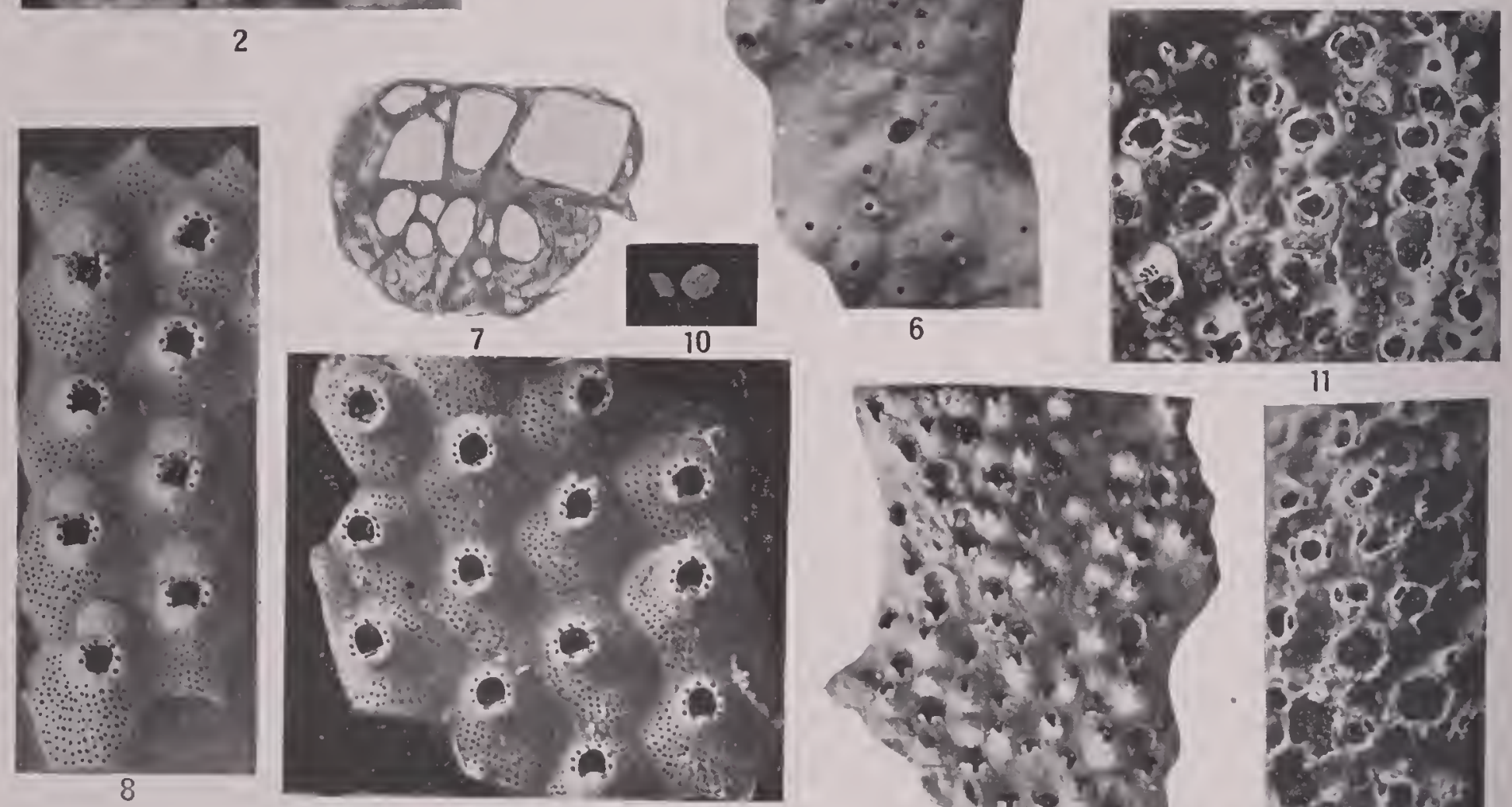

9
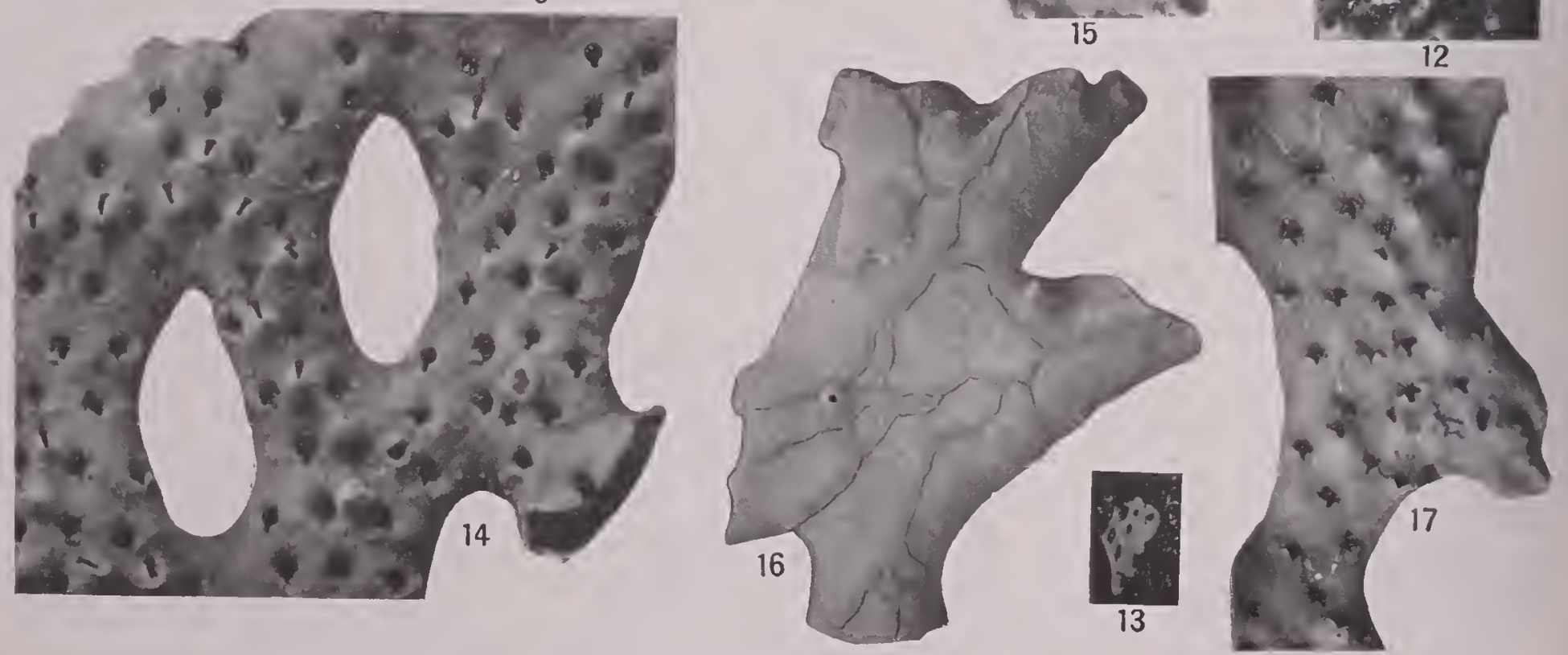


\section{Plate 39.}

FIss. 1-7. Philolopora pacifica Robertson 1908. (p. 154.)

1. Zoarial fragments, natural size.

2. Celluliferous side of fragment, $\times 20$, with the frontal avicularium well developed.

3. Another fragment, $\times 20$, in which the frontal avicularium is absent or worn away.

4. Tangential thin section of the dorsal, $\times 25$, illustrating the special calcification of the vibices.

5 . View of the interior of the zooecia, $\times 20$. ap, apertura; pic, peristomie; $d$, dietellae.

6. Dorsal side of zoarium, $\times 20$, showing some radicular pores and an avicularium.

7 . Transverse thin section, $\times 25$.

Pleistocene: Rustic Canyon, Santa Monica, California.

Figs. 8, 9. Phylactella spinosissima, var. major Hincks, 1884. (p. 170.)

8. Zooecia of the incrusting zoarium, $\times 20$, showing the recumbent ovicell.

9. A specimen, $\times 20$, with zooecia exhibiting the spines, oral mucro, and the tremopores.

Pleistocene: Long Wharf Canyon, Santa Mronica, California.

Fics. 10-12. Costazzia robertsoniae, nerr species. (p. 181.)

10. Zoaria, natural size.

11. Surface of the globular zoarium, $\times 20$, with ovicelled zooecia and interzooecial avicularia.

12. Another surface, $\times 20$, showing incomplete zooecia.

Pleistocene: Rustic Canyon, Santa Monica, California.

Figs. 13-17. Phidolopora labiata Gabb and Horn, 1862. (p. 154.)

13. The reticulated zoarium, natural size.

14. Celluliferous surface, $\times 20$, showing zooecia with large salient avicularia.

15. A fragment, $\times 20$, with ovicelled zooecia.

16. Dorsal side of a fragment, $\times 20$, illustrating the irregular vibices.

17. Another fragment, $\times 20$, with the zooecia distinctly outlined by a salient thread.

Pleistocene: Santa Barbara, California. 


\section{Plate 40.}

Figs. 1-4. Tubucellaria punctulata Gabh and Horn, 1862. (1). 170.)

1. Zoarial fragments, natıral size.

2. A ramified segment, $\times 20$.

3. Another segment, $\times 20$, illustrating the zooecial surface.

4. Longitudinal section, $\times 20$.

Pleistocene: Santa l3arbara, California.

Figs. 5, 6. Tubucellaria punctulata, var. minor, new variety. (p. 170.)

A fragment natural size, and surface of the same, $\times 20$. The smaller size of the zooecia and tremopores is evident.

Pleistocene: Santa Barhara, California.

F1G. 7. Lagenipora spinulosa Hincks, 1854. (p. 171.)

An example, $\times 20$, much changed by fossilization.

Pleistocene: Dead Mans Island, off San Pedro, California.

Figs. S, 9. Holoporella umbonata, new species. (p. 178.)

8. Zonecial surface, $\times 20$, illustrating the areolar pores.

9. Well-developed example with interareolar costules radiating from the umbo. Several ovicelled zooecia are present.

Pleistocene: Santa Barbara, California.

Figs. 10, 11. Schismopora abrupta, new species. (p. 150.)

10. Surface of the incrusting zoarium, $\times 20$, with some of the usual small avicularia transformerl into very long ones.

11. Another surface, $\times 20$. The transverse, smooth, deeply embedded ovicell and the numerous small triangular avicularia are quite visible.

Pleistocene: Santa Barbara, California.

FiGs. 12-15. Schismopora lanceolata, new species. (p. 181.)

12. The small lamellar zoarial masses, natural size.

13. Surface, $\times 20$, illustrating the triangular sinus of the apertura and the lanceolate interzooecial avicularia.

14. Ovicellet zooecia, $\times 20$. The characteristic avicularia arc also present.

15. Portion of the zooecial surface, $\times 20$, showing the incomplete zooecia.

Pleistocene: Santa Monica, California. 

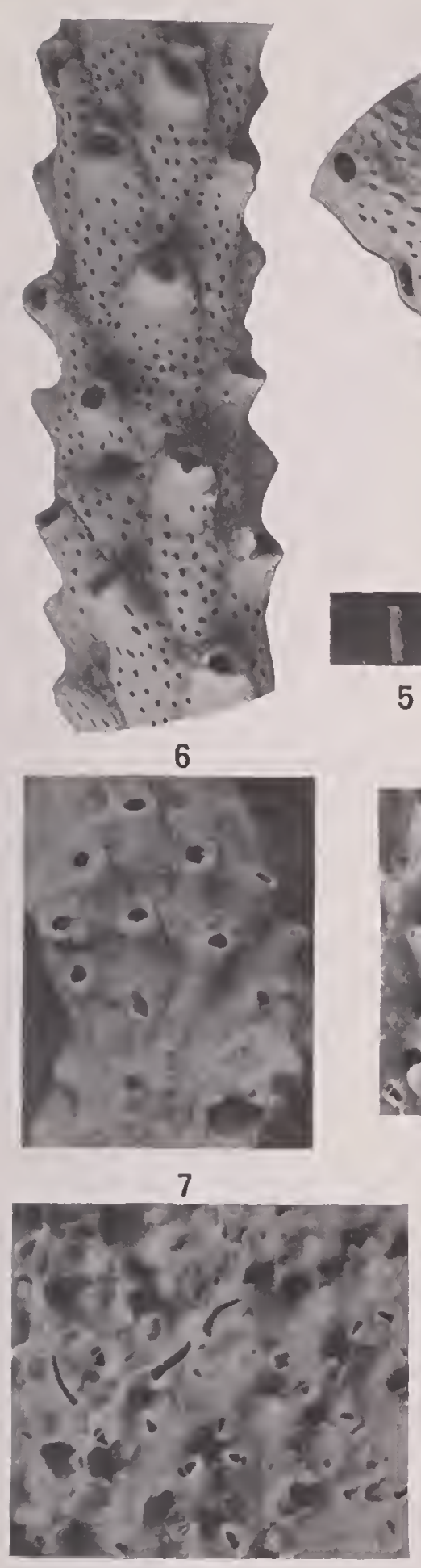

10

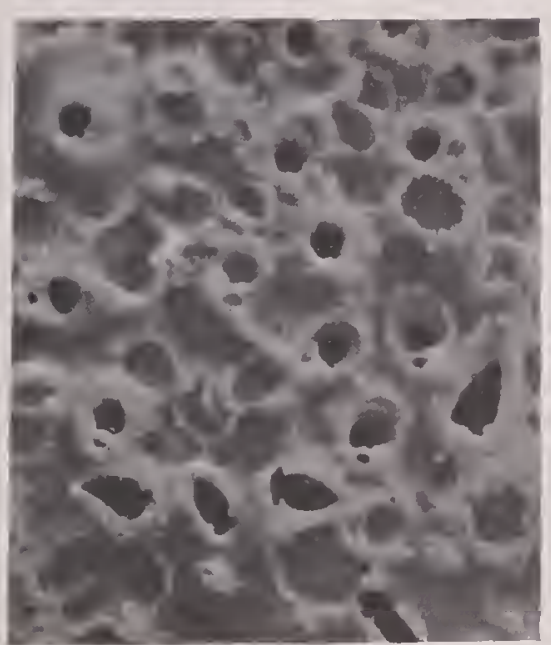

13

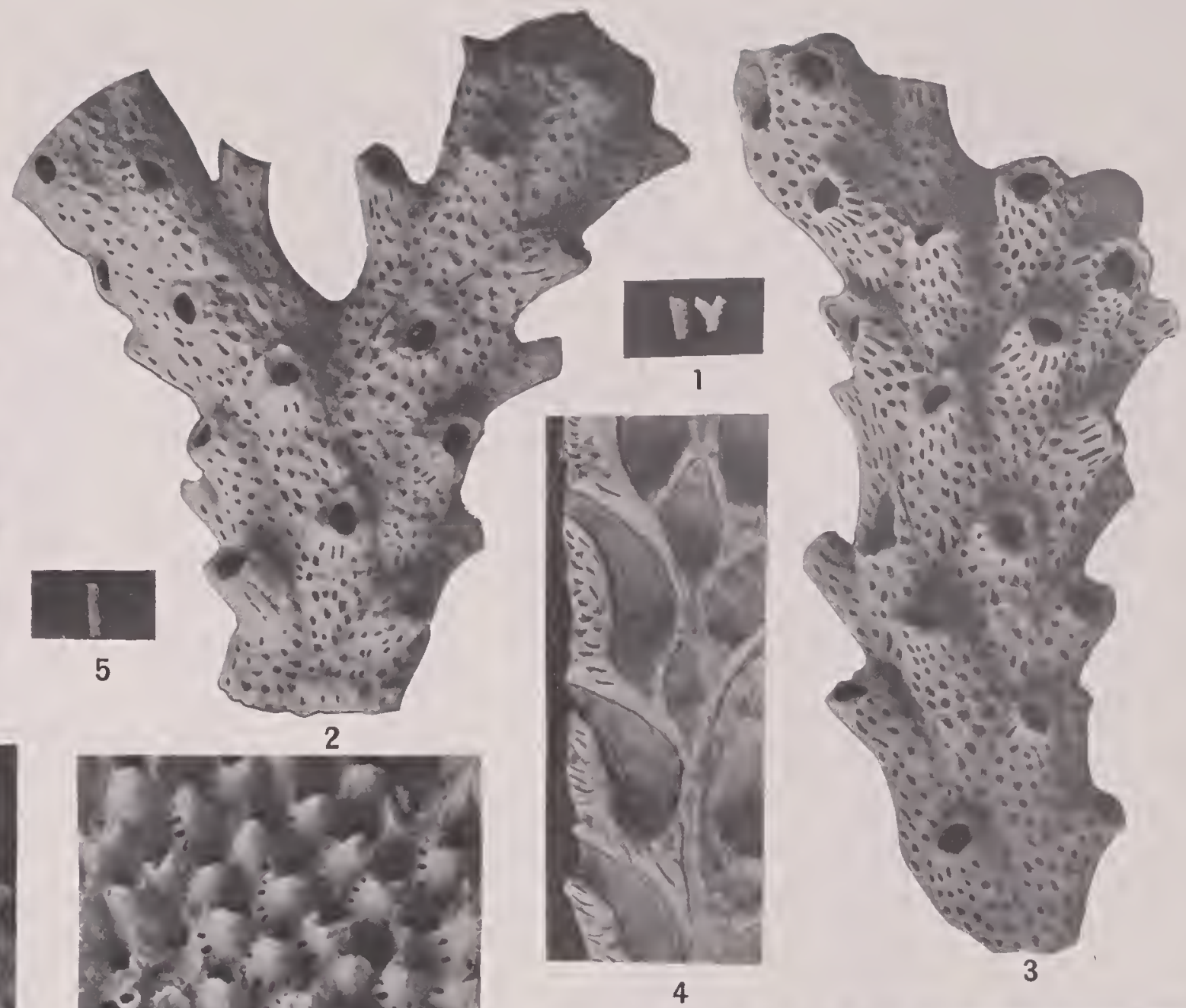

4

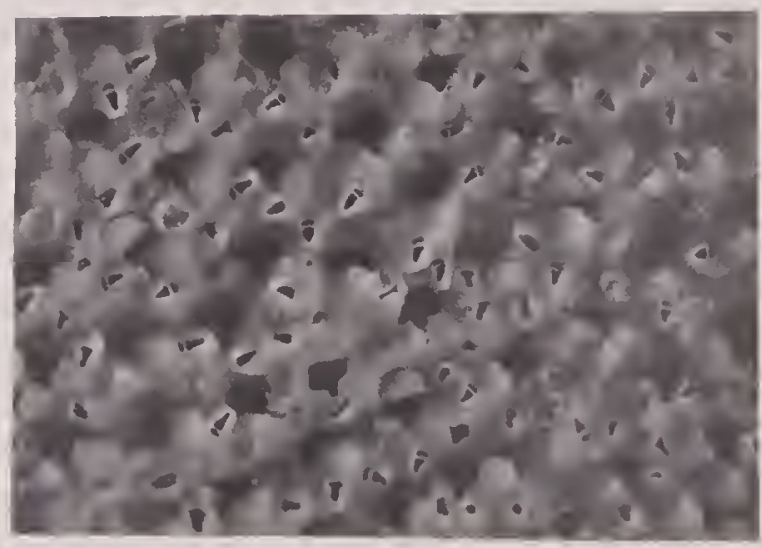

11

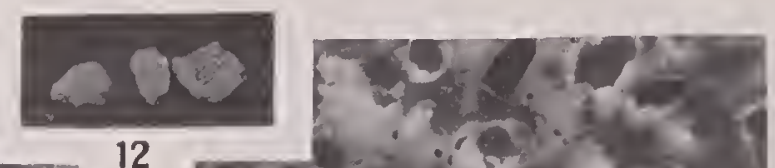

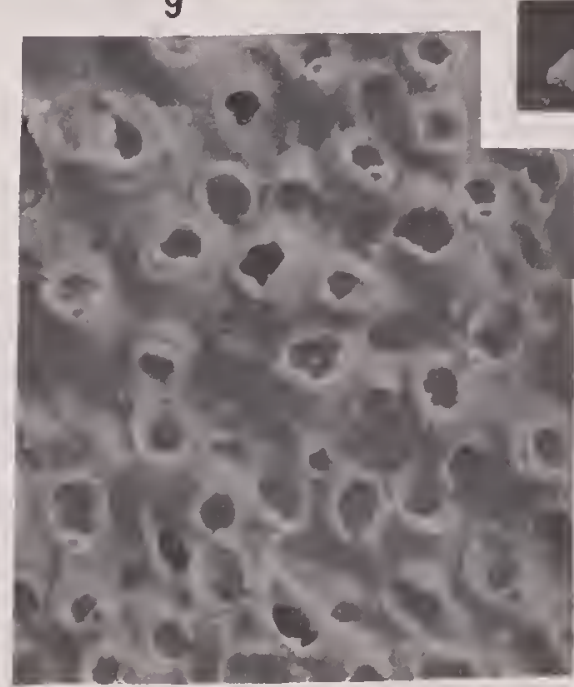

14

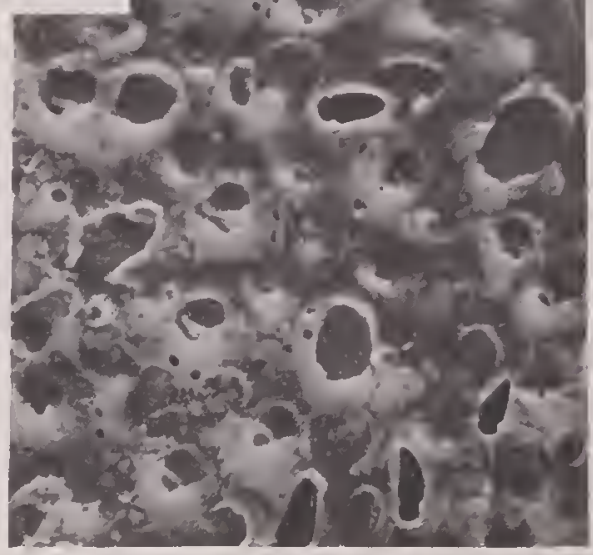

15

NORTH AMERICAN LATER TERTIARY AND QUATERNARY BRYOZOA. 


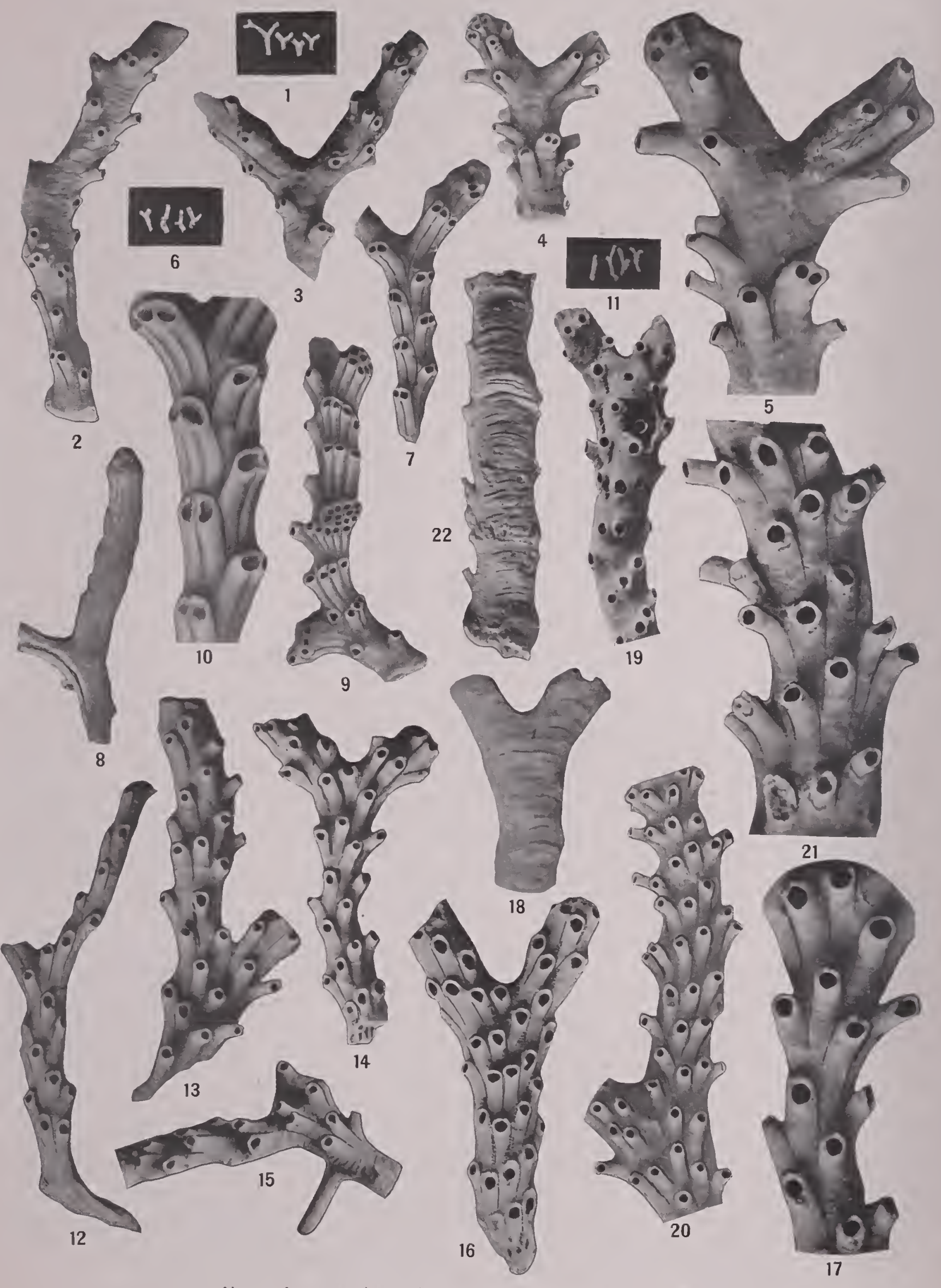

NORTH AMERICAN LATER TERTIARY AND QUATERNARY BRYOZOA. 
Plate 41.

Fisis. 1-5. Entalophora fasciculifera, new species. (p. 195.)

1. Zoarial fragments, natural size.

2. Al large example, $\times 12$, with tubes little salient.

3. A fragment, $\times 12$, showing three fascicles of two zonecia each.

4, 5. An example with long peristomes, $\times 12$, and a portion of the same, $\times 25$.

Pleistocene: Tremochal Canyon, Santa Monica, California.

Figs. 6-10. Itmonea dispar, new species. (p. 198.)

6. Fragnents, natural size.

7. Anterior (cellular) face, $\times 12$.

8. Posterior side showing longitudinal striations, $\times 12$.

9. Lateral view of a fragment, $\times 12$, hearing a small branch.

10. A portion of figure $7, \times 25$.

Pleistocene: Rustic Canyon, Santa IIonica, California.

Fics. 11-19. Filisparsa clarki, new species. (p. 195.)

11. Fragments of the zoarium, natural size.

12-14. Three examples, $\times 12$, showing different aspects of the anterior face.

15. I specimen with a dorsal apophysis, $\times 12$.

16. An example, $\times 12$, in which the peristomes are grouped in transverse and oblique rows.

17. Portion of a zoarium, $\times 25$.

15. Posterior side, $\times 12$.

19. An oricelled example, $\times 12$.

Pleistocene: Santa Barhara, California.

Figs. 20-22. Filisparsa clarki, var. partula, new variety. (p. 196.)

20, 21. Anterior side of the zoarinm, $\times 12$ and $\times 25$, showing the slightly smaller dimensions.

22. Posterior side, $\times 12$, illustrating transverse wrinkling.

Pleistocene: Santa Barhara, California. 
Plate 42.

Firs. 1-7. Crisin serrata Cabl, and IIorn, 1862. (p. 196.)

1. 'Joarial segments, natural size.

2. Characteristic segment, $\times 12$.

3. Noncelluliferous side of a segment, $\times 25$, with two ramal base's.

4. Another segment, $\times 25$, with $t$ wo ramal bases. Some of the apertures are closed by lamellae.

5. Another segment, $\times 25$.

6. A segment, $\times 25$, showing the characteristic median carina and but a single ramal hase.

Pleistocene: Rustic Canyon, Santa Monica, California.

7. I'ortion of an ovicelled segment, $\times 25$.

Pleistocene: Santa lBarbara, California.

Fig. S. Crisia, species.

Several segments, $\times 12$, still united by their corneous joints, which have not been destroyed by fossilization.

Pleistocene: Rustic Canyon, Santa Monica, California.

Fiss. 9-17. Tubuliporn fasriculifera Hincks, 1884. (p. 197.)

9 - 11. Three zoaria, $\times 12$, illustrating variations in form.

12. An example, $X 12$, showing a small lateral ovicell

13. Another ovicelled example, $\times 12$, illustrating the large oeciostome at the beginning of a fascicle.

14, 15. Two unovicolled zoaria, $\times 12$, with short fascicles.

16. Several zoaria, natural size.

17. Fragment of a zoarium, $\times 25$.

Pleistocene: Santa Barbara, California.

Ficis. 18-23. T'ubulipora tuba Gabb and Horn, 1862. (p. 195.)

18. \%oarium, natural size.

19. A young ovicellnd specimen with short fascicles, $X 12$.

20. An ovicelled example with a long capillary occiostome, $\times 12$.

21 . Surface of the same, $\times 25$, illustrating the ovicell and oeciostome

Pleistocenr: Rustic ('anyon, Santa Monica, ('alifornia.

22. An idmoneiform ovicelled specinen, $\times 12$, with long fascicles.

23. An irregular flabellate specinen, $\times 12$.

Pleistocene: Santa Barbara, California.

2 siti 


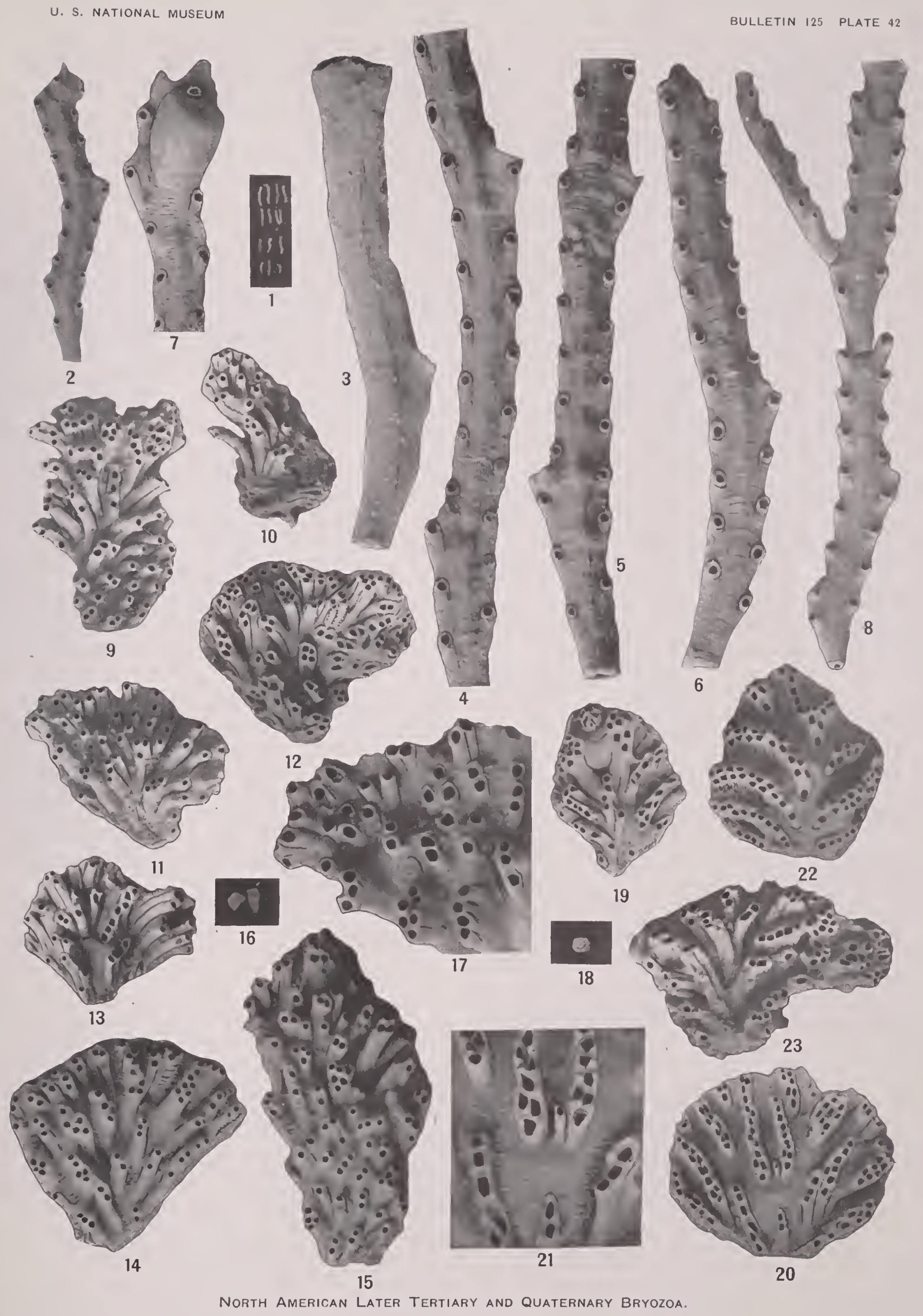



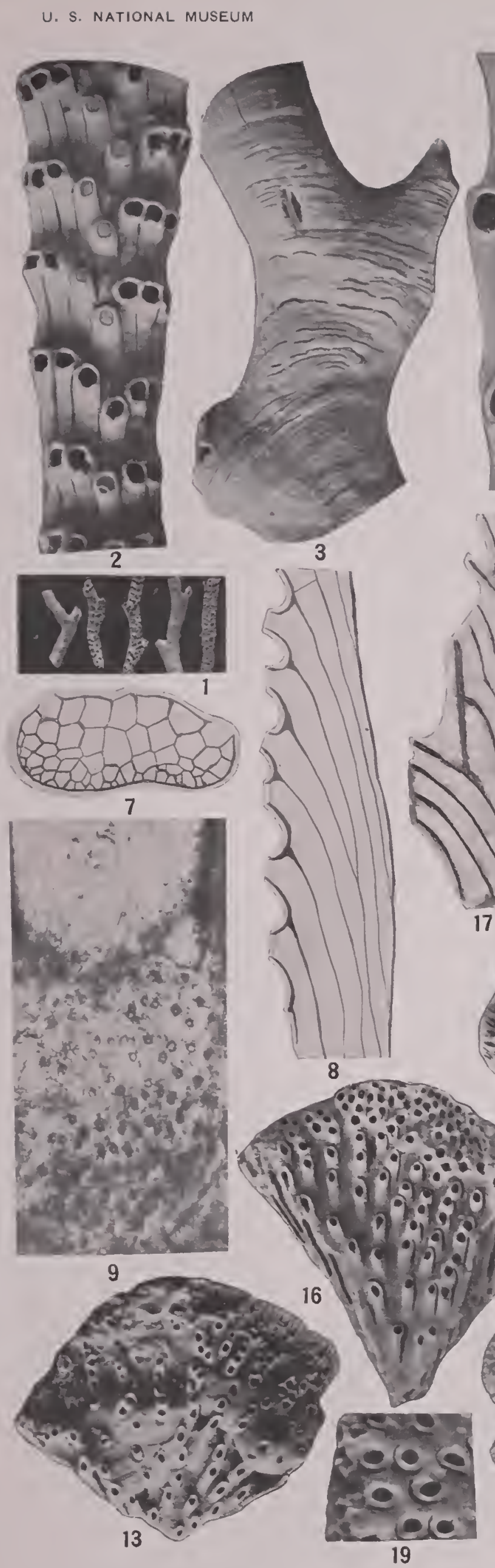
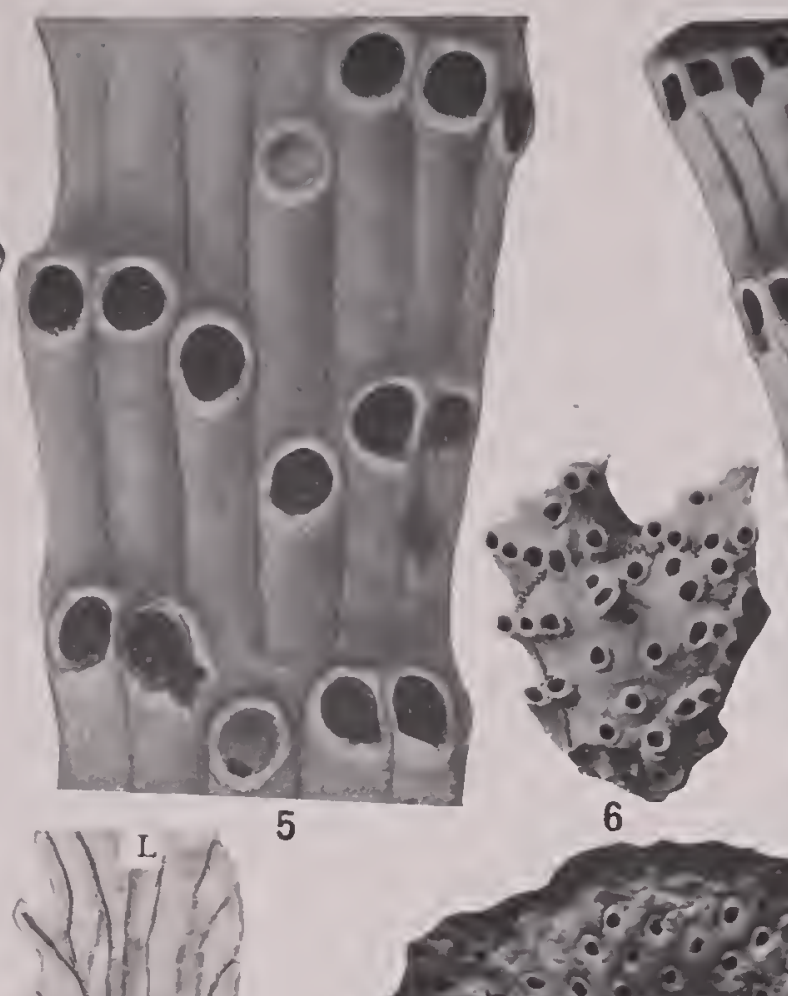

(1)
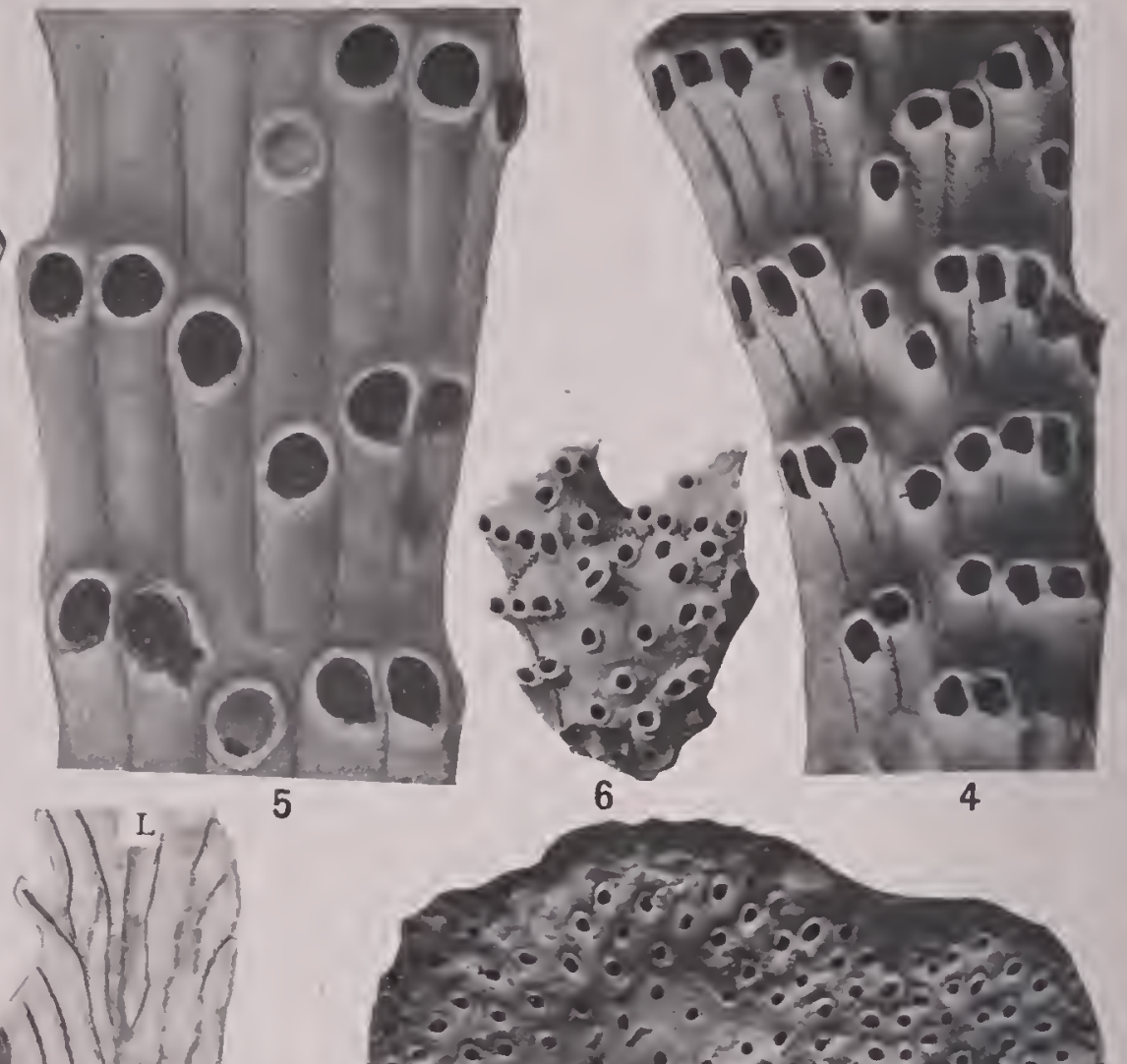

NORTH AMERICAN LATER TERTIARY AND QUATERNARY BRYOZOA.

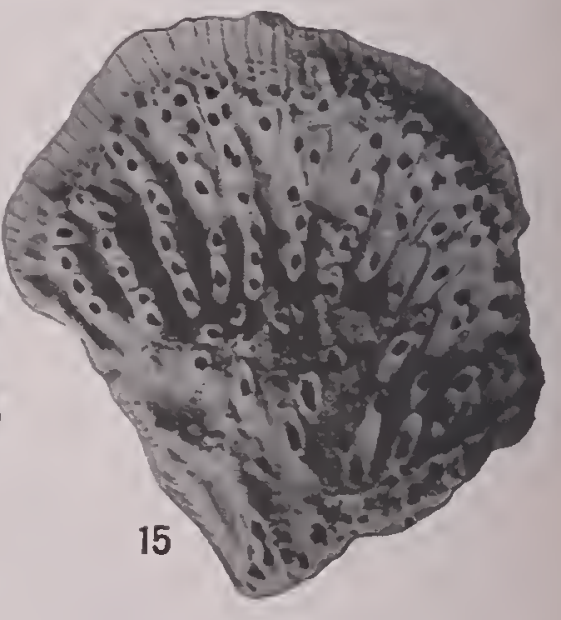

For explanation of plate see page 287. 
Plate 43.

Figs. 1-9. Idmonea californica D'Orbigny, 1852. (p. 199.)

1. Zoarial fragments, natural size.

2. Celluliferous side, $\times 12$, showing the axial zooecia isolated and closed by a diaphragm.

3. Posterior side, $\times 12$, illustrating the transverse striations.

4. Another example, $\times 12$, in which the axial zooecia are open.

5. A portion of figure $2, \times 25$.

6. An ovicelled specimen, $\times 6$.

7. Transverse thin section, $\times 12$. The tubes are polygonal.

8. Longitudinal thin section, $\times 12$.

9. Tangential thin section, $\times 100$. The inural perforations are no larger than in smaller species of the genus.

Pleistocene: Santa Barbara, California.

Figs. 10-17. Stathmepora flabellata, new species. (p. 201.)

10. Zoarial fragments, natural size.

11. A rather complete flabellate specimen, $\times 12$, with incomplete fascicles.

12. A fragment, $\times 12$, showing bifurcated fascicles.

13. A specimen with large ovicell, $\times 12$.

14. An example with broken ovicell, $\times 12$, illustrating that the peristomes are here adjacent in the fascicles.

15. An ovicelled example, $\times 12$, with a large basal lamella.

Pleistocene: Santa Barbara, California.

16. A flabellate example, $\times 12$, with a thick zone of growth.

17. Longitudinal section, $\times 25$. The tubes are cylindrical with triparietal gemmation, $L . \quad B=$ basal lamella.

Pleistocene: Rustic Canyon, Santa Monica, California.

Ficss. 18, 19. Diaperoecia flabellata, new species. (p. 202.)

18. The flabellate bilamellar zoarium, $\times 12$, with an ovicell developed.

19. Portion of the same, $\times 25$.

Plesitocene: Rustic Canyon, Santa Monica, California. 
Plate 44

Firs. 1-3. Lichenopora hispida Fleming, 1828. (p. 203.)

1. Several zoaria, natural size.

2. An example, $\times 12$, illustrating that the fascicles do not reach the zoarial margin.

3. An ovicelled example, $\times 12$, with the ovicell not entirely covered by the cancelli and slowing no occiopore.

Pleistocene: Santa Barbara, California

Fros. 4-T. Lichenopora californica ('onrad, 1855. (1. 203.)

4. Zoaria, natural size.

5. An oricelled example, $\times 12$. The oeciostome is located between two fascicles.

6. Another ovicelled example, $X 12$, showing clearly the salient oeciostome and the ovicell covered with cancelli.

7. Inferior sicle of a discoirl, free example, $\times 12$.

Pleistocene: Santa Barbara, California.

Ficis. 8-9. Lichenopora ierrucaria Fabricius, 1780. (p. 205.)

Celluliferous surfaces of two ovicelled examples, $X 12$, referred to this recent species.

Pleistocene: Rustic Canyon, Santa Monica, California.

Fir. 10. Lichenopora radiata Savigny-Andouin, 1826. (p. 204.)

An incomplete although typical zoarium of this wide spread recent species, $\times 12$. The cancelli are larger than the zooecial orifices.

Pleistocene: Rustic Canyon, Santa Monica, California.

Ficis. 11-21. I'silosolen cupitiferax, Canu and Bassler, 1922. (p. 207.)

11. A longitudinal thin section, $\times 25$.

12. A longitudinal section showing the ovicell at the end of the branch, $\times 12$.

13. Longitudinal thin section through a bifureated branch, $X 25$. The tubes are cylindrical and ramify at all heights.

14, 15. Transverse thin sections, $\times 25$.

16. An example, $X 12$, illustrating the irregular quincun $x$ arrangement of the peristornes.

17. An example, $X 12$, with the peristomes arranged in zones.

18. A portion of the same zoarial surface, $X 25$, illustrating that the tubes are visible and the peristome thin.

19. An ordinary transverse section, $\times 25$.

20, 21. Ovicelled specimens, $\times 12$, illustrating the position of the ovicell at the flattened end of the branch.

Pleistocene: Santa Barbara, Califormia. 288 


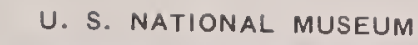

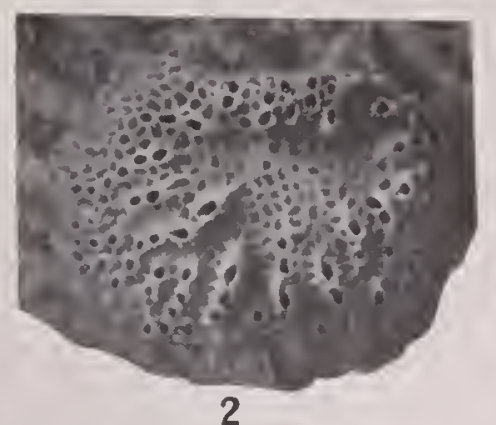
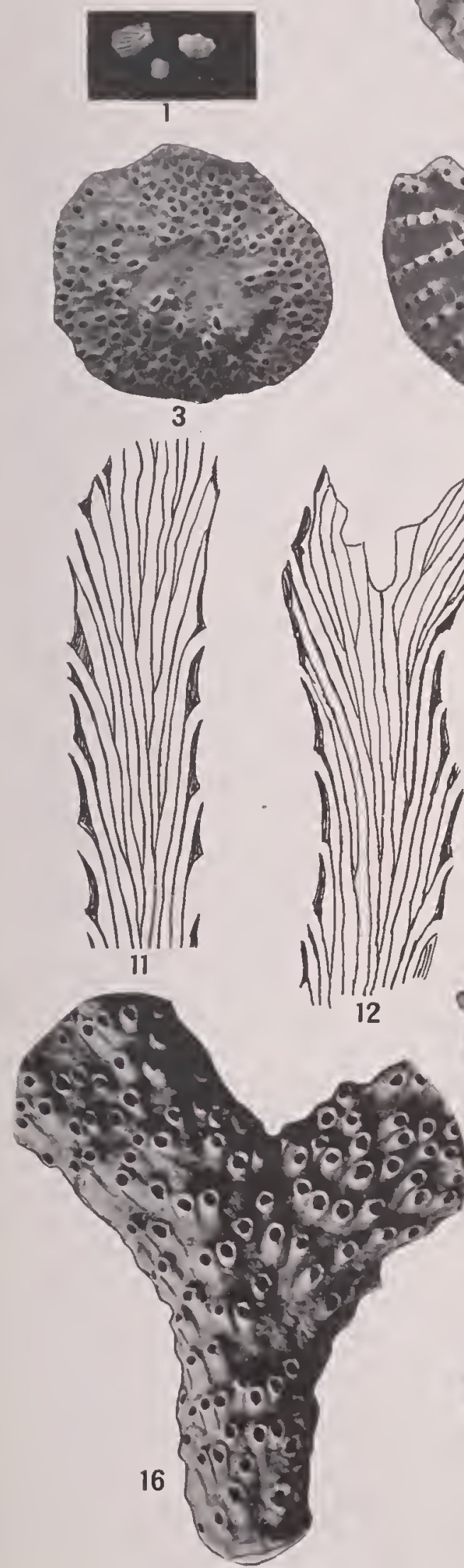
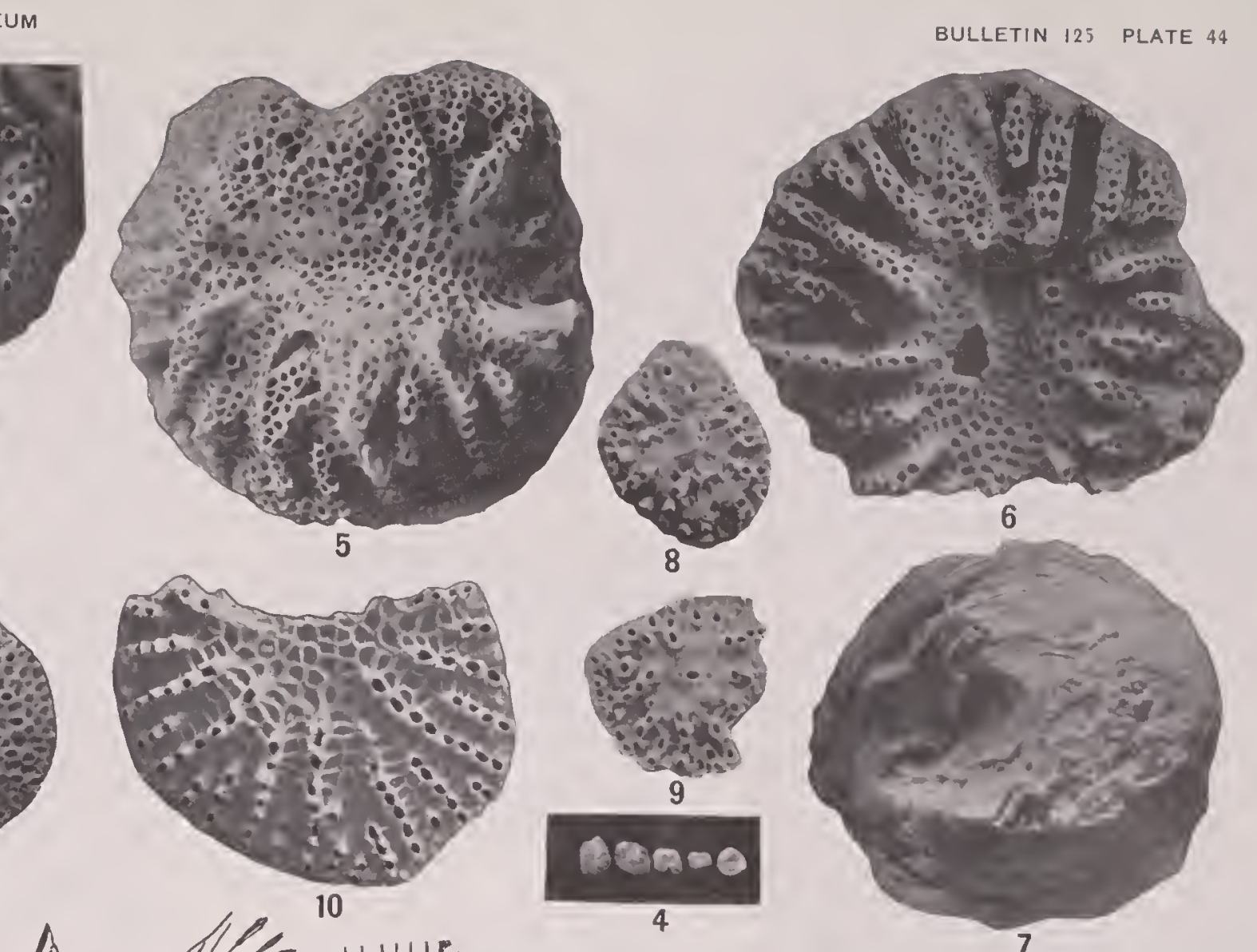

4

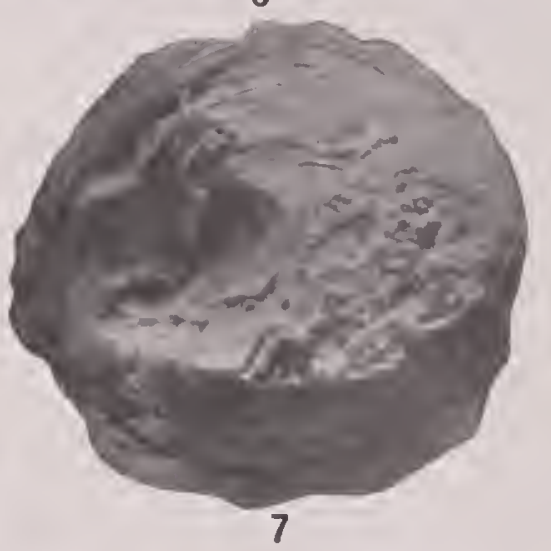

North American Later Tertiary and QuaternaRy Bryozoa.
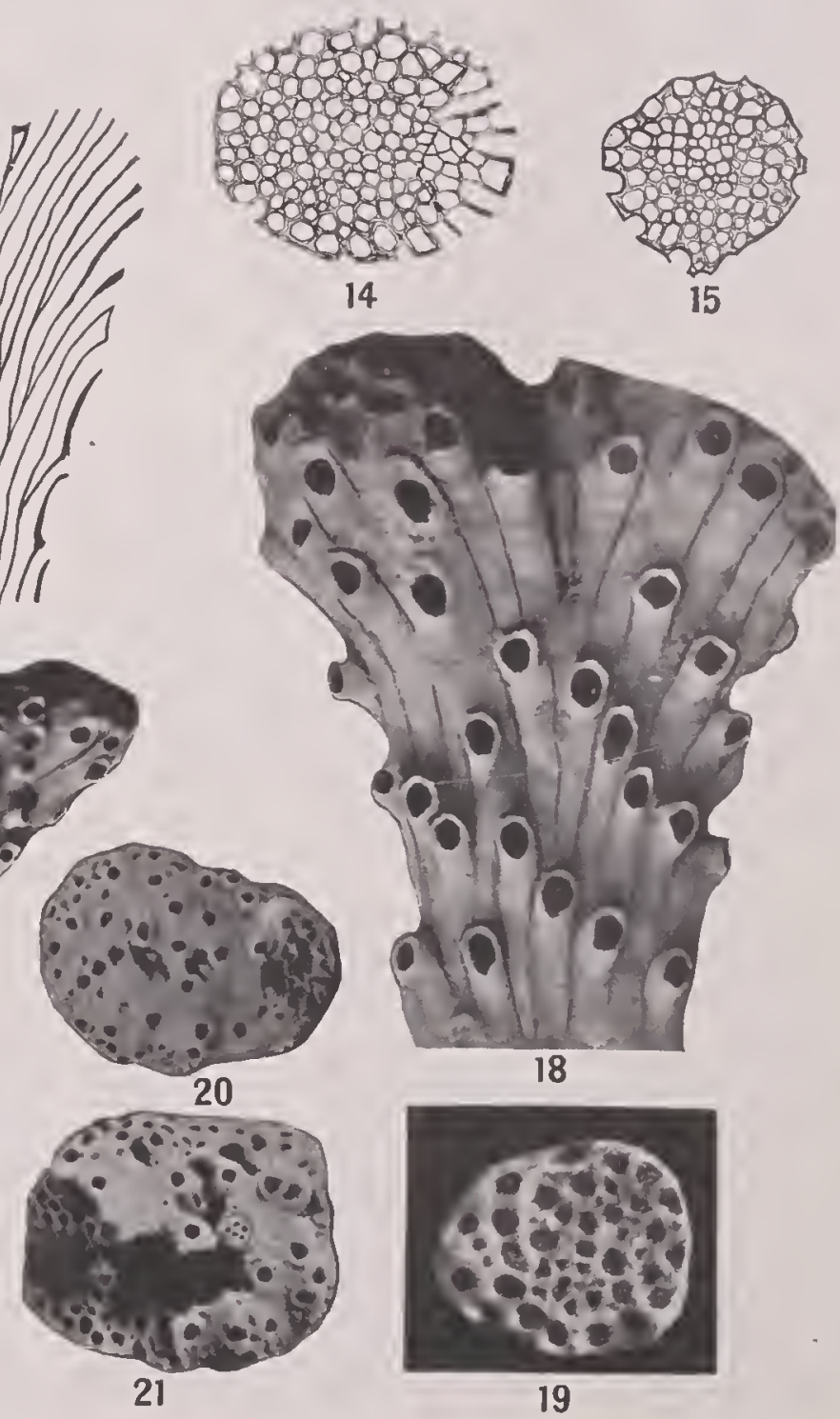

100060

a. 101

1. 11909

is 91

$0^{\circ}, \mathrm{s}$

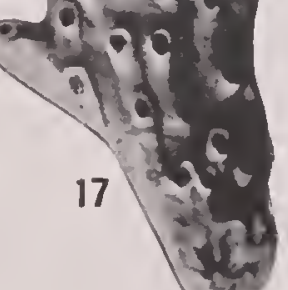

13
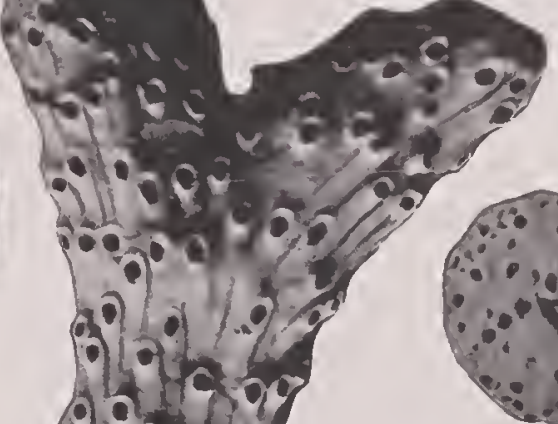

17

For EXPLANATION OF PLATE SEE PAGE 288. 

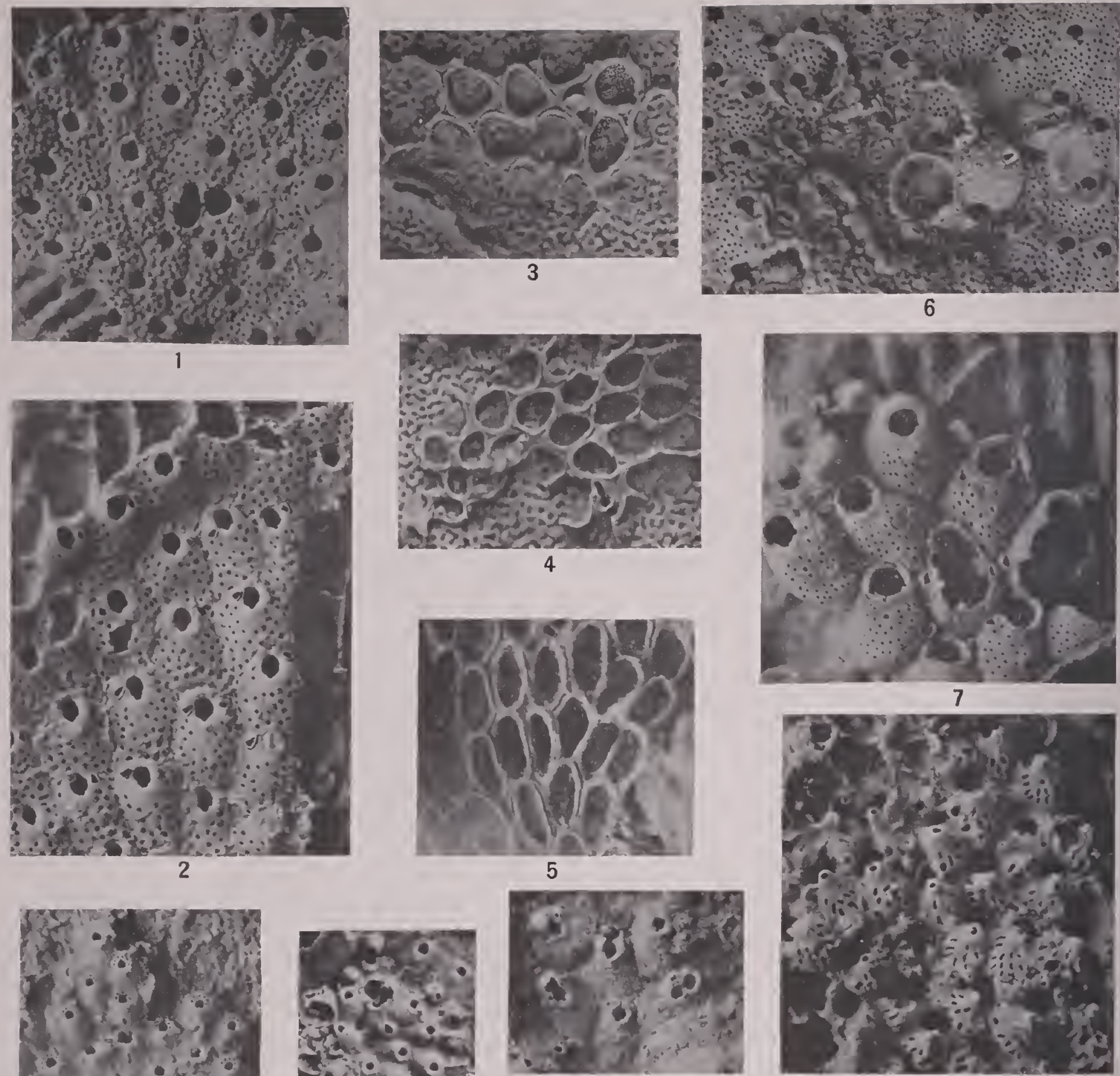

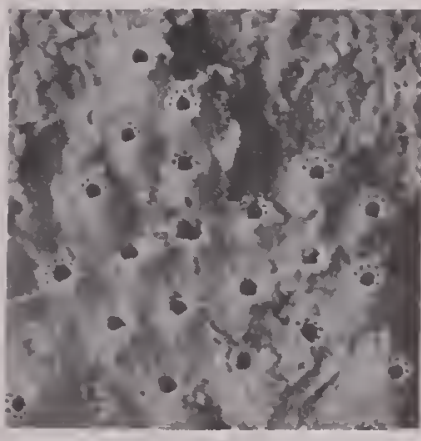

8

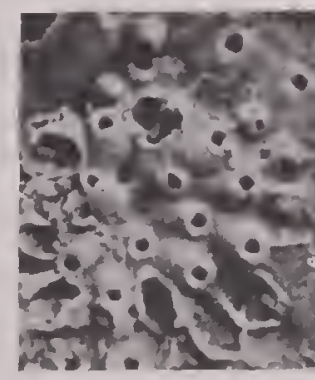

9

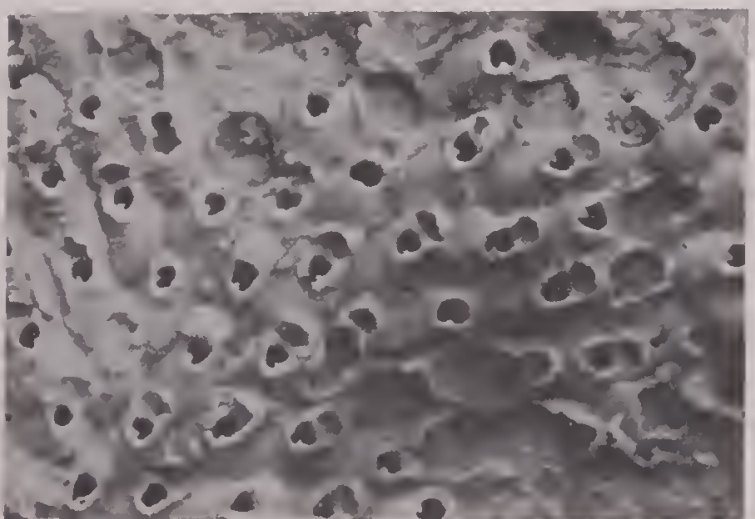

11
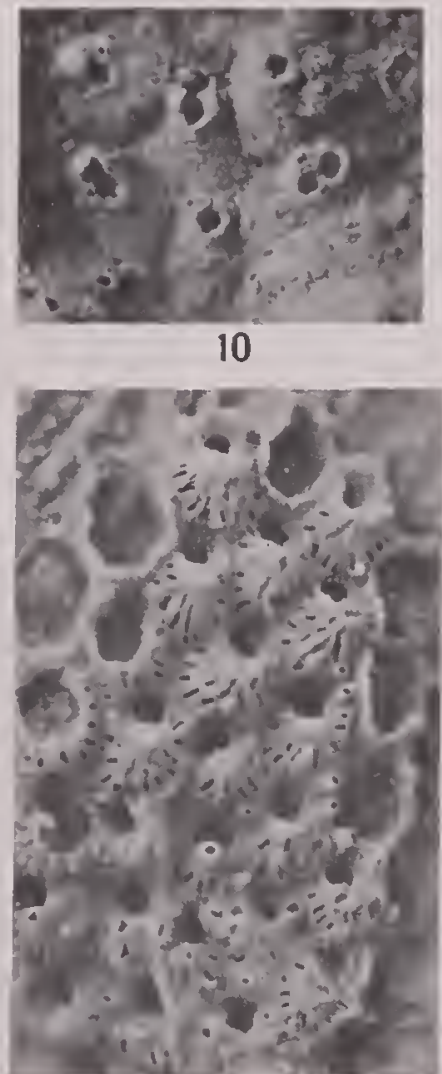

12

\section{3}

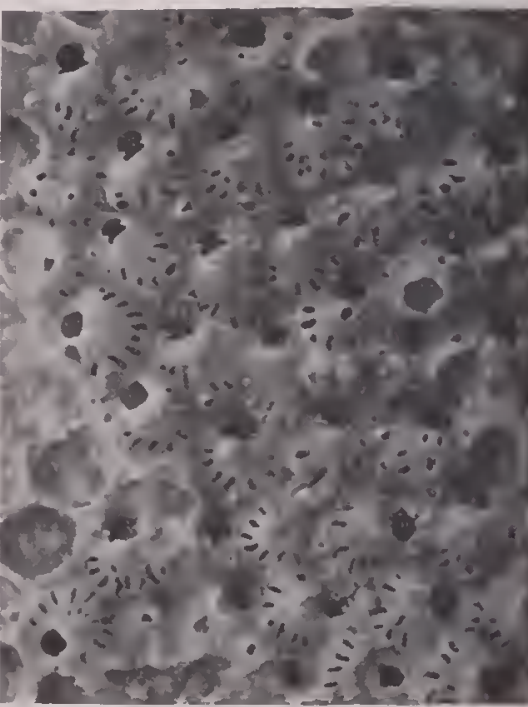

14

NORTH AMERICAN LATER TERTIARY AND QUATERNARY BRYOZOA. 
Plate: 45 .

Figs. 1, 2. Schizoporella magniporosa, new species. (p. 95.)

1. View of the incrusting zoarium, $\times 20$, showing the hexagonal zooecia with large tremopores.

2. Ancestrular portion of a zoarium, $\times 20$. The aperture of the ancestrula is very large.

Pleistocene: Mount Hope, Panama Canal Zone.

Figs. 3, 4. Callo pora guernei Jullien, 1903. (p. 42.)

3. Several marginal zooecia, $\times 20$, of a zoarium incrusting a coral.

4. Zooecia, $\times 20$, in the vicinity of the ancestrula and exhibiting an avicularium.

Pleistocene: Mount Hope, Panama Canal Zone.

Fig. 5. Callopora filum Jullien, 1903. (p. 42.)

Zooecia, $\times 20$.

Pleistocene: Mount Hope, Panama Canal Zone.

Fig. 6. Stylopoma projecta, new species. (p. 103.)

Zooecia, $\times 20$, of the incrusting zoarium, exhibiting the ovicell and the small oral avicularium characteristic of the species.

Pleistocene: Mount Hope, Panama Canal Zone.

F1G. 7. Dakaria cherereuri Jullien, 1903. (р. 97.)

Zooecia, $\times 20$.

Pleistocene: Mount Hope, Panama Canal Zone.

Figs. 8, 9. Itippoporina pusilla, new species. (p. 129.)

8. The incrusting zoarium, $\times 20$, with oricelled and badly oriented zooecia.

9. Zoarium, $\times 20$, showing the ancestrula and ancestrular zooecia.

Pleistocene: Mount Hope, Panama Canal Zone.

F1G. 10. Mastigophora pesanseris Smitt, 1873. (p. 172.)

Zooecia, $\times 20$.

Pleistocene: Mount Hope, Panama Canal Zone.

Fig. 11. Rhynchozoon lerigatum, new species. (p. 157.)

Zooecia of the incrusting zoarium, $\times 20$. The salient globular ovicell and the spinule in the peristome are shown.

Pleistocene: Mount Hope, Panama Canal Zone.

Figs. 12, 13. Porella costulata, new species. (p. 150.)

12. Zooecia of the incrusting zoarium, $\times 20$, in the vicinity of the ancestrula.

13. Normal zooecia, $\times 20$, showing the large tremopores and prominent avicularian mucro.

Pleistocene: Mount Hope, Panama Canal Zone.

Fig. 14. Ifippoporella costulata, new species. (p. 133.)

Portion of the incrusting zoarium, $\times 20$, with zooecia exhibiting areolar pores and costules.

Pleistocene: Mount IIope, Panama Canal Zone. 
Fia. 1. Holoporella turrita Smitt, 18-3. (1). 179.)

Plate 46.

The fossil example, $\times 20$, referred to this recent species.

Pleistocene: Mount Hope, Panama Canal Zone.

FIG. 2. Holoporclla ariculifera, new species. (p. 179.)

$A$ portion of the incrusting zoarium, $\times 20$. $A$ small avicularium in the peristome is risible.

Pleistocene: Mount Hope, Panama Canal Zone.

Figs. 3-6. Cyclicopora multitamellosa, new species. (p. 138.)

3 . Surface of the free orhicular zoarium, $\times 20$, illustrating the form of the zonecia and ovicell.

4. Zooecia $\times 20$, with a large transverse avicularium

5. Ordinary zooecia, $\times 20$.

6. Interior of zooecia, $\times 20$. The tremocyst is risible through the very thin olocyst.

Pleistocene Mount Hope, Panama (anal Zone.

Fig. 7. IIoloporelle muerunata, new species. (p. 179.)

The incrusting zoarium, $\times 20$, illustrating the large arcolar pores and prominent oral inucro.

Pleistocene: Mount Hope, Panama Canal Zone.

Figs. 8, 9. Acanthodesia savartii forma texturata Reuss, 184-. (See also pl. 5, figs. 1-5.) (1. 32.)

Surface of two small unilamellar examples, $\times 20$.

Pleistocene: Vero, Florida.

Fic. 10. Hemiseptella tuberosa, new species. (p. 71.)

The incrusting zoarium, $\times 20$, showing the irregular inferior border of the opesium.

Pleistocene: Simmons Bluff, Yonges Island, Charleston County, South Carolina.

Figs. 11, 12. Membranipora osburni, new species. (p. 24.)

11. The incrusting zoarium, $\times 20$, illustrating the thin, rounded mural rim, the tubercles, and the small, concave proximal cryptocyst.

Pleistocene: Mount Hoje, Panama Canal Zone.

12. Ancestrular region of a zoarium, $\times 20$, referred to this species.

Miocene (Bowden marl): Bow den, Jamaica.

Fig. 13. Terebripora pacifica, new species. (p. 15.)

The type specimen, $\times 10$, showing the small pyriform zooecia separated by one to two times their length.

Pleistocene: Santa Barbara, ('alifornia.

290 

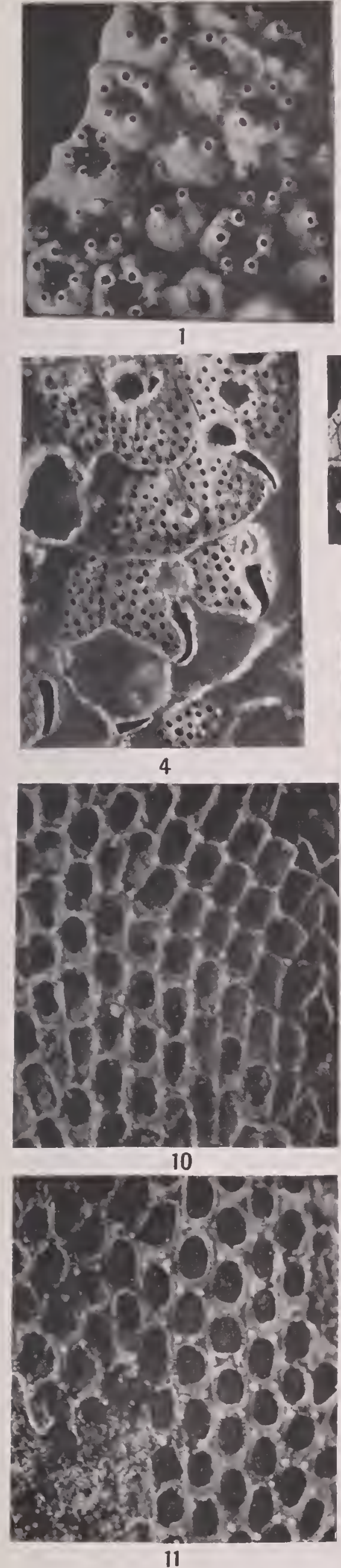

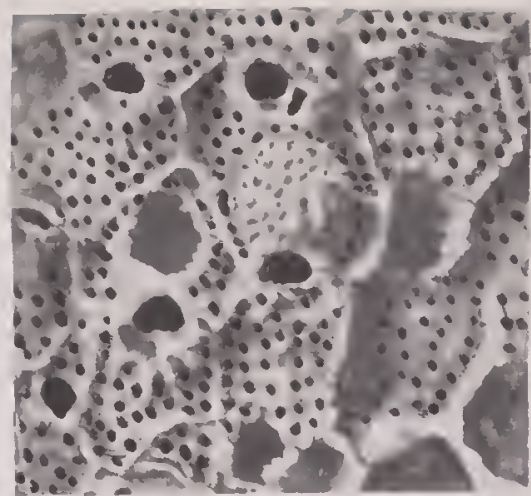

3

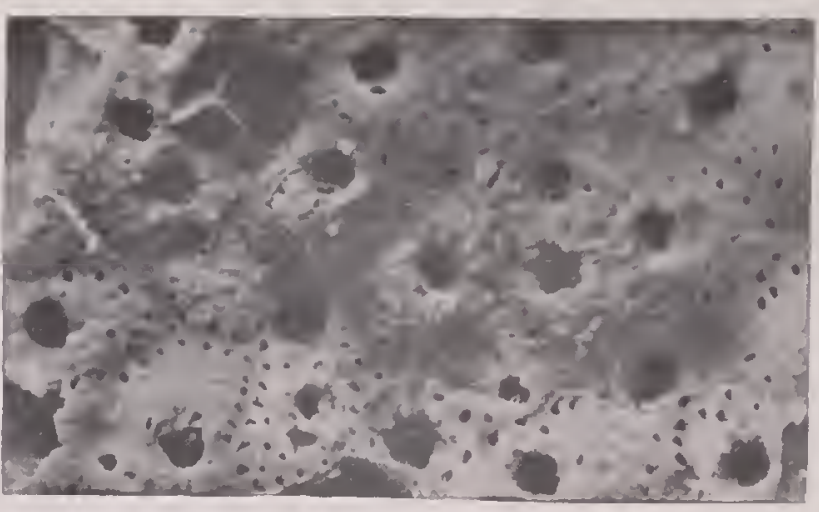

2
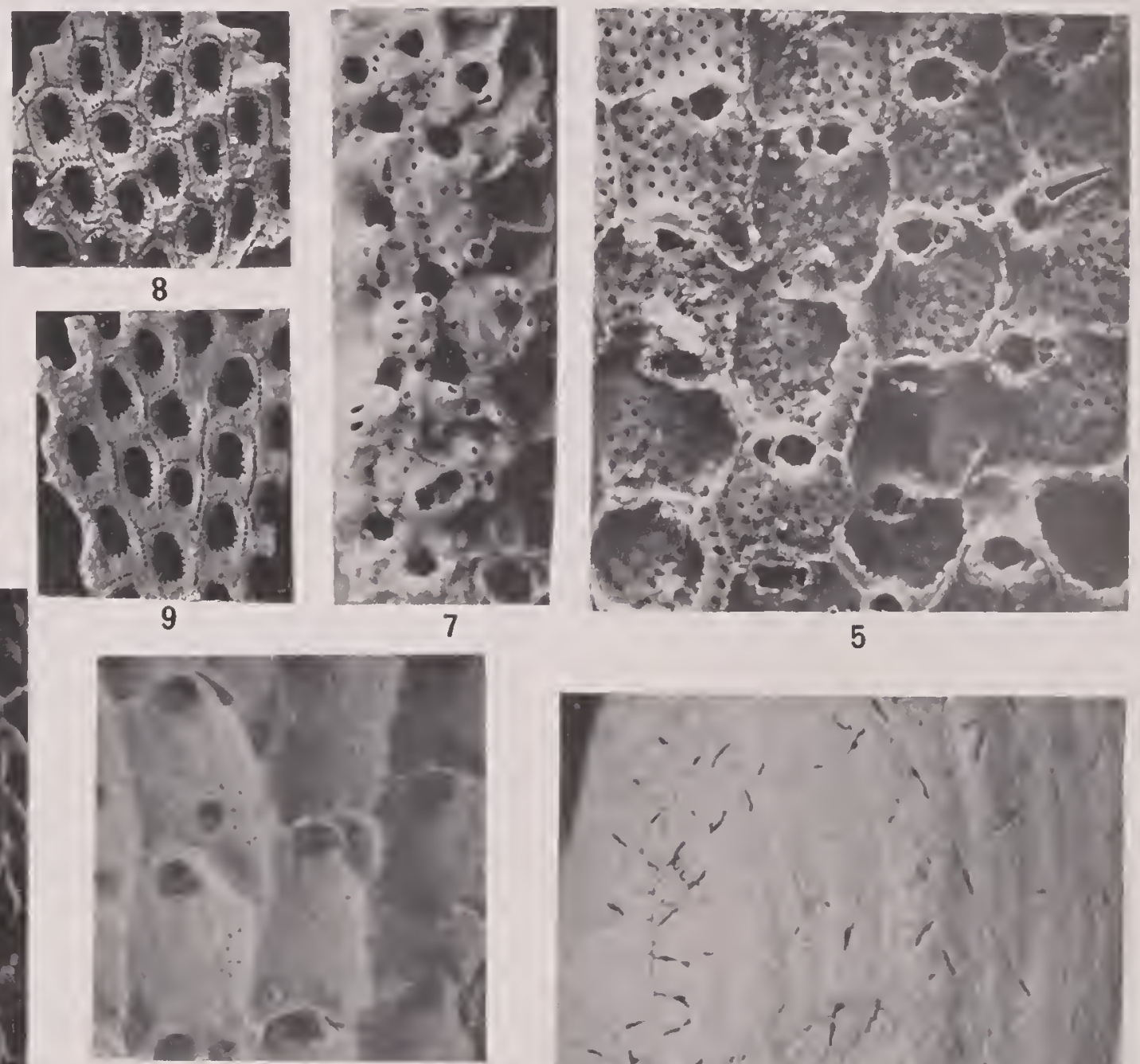

6
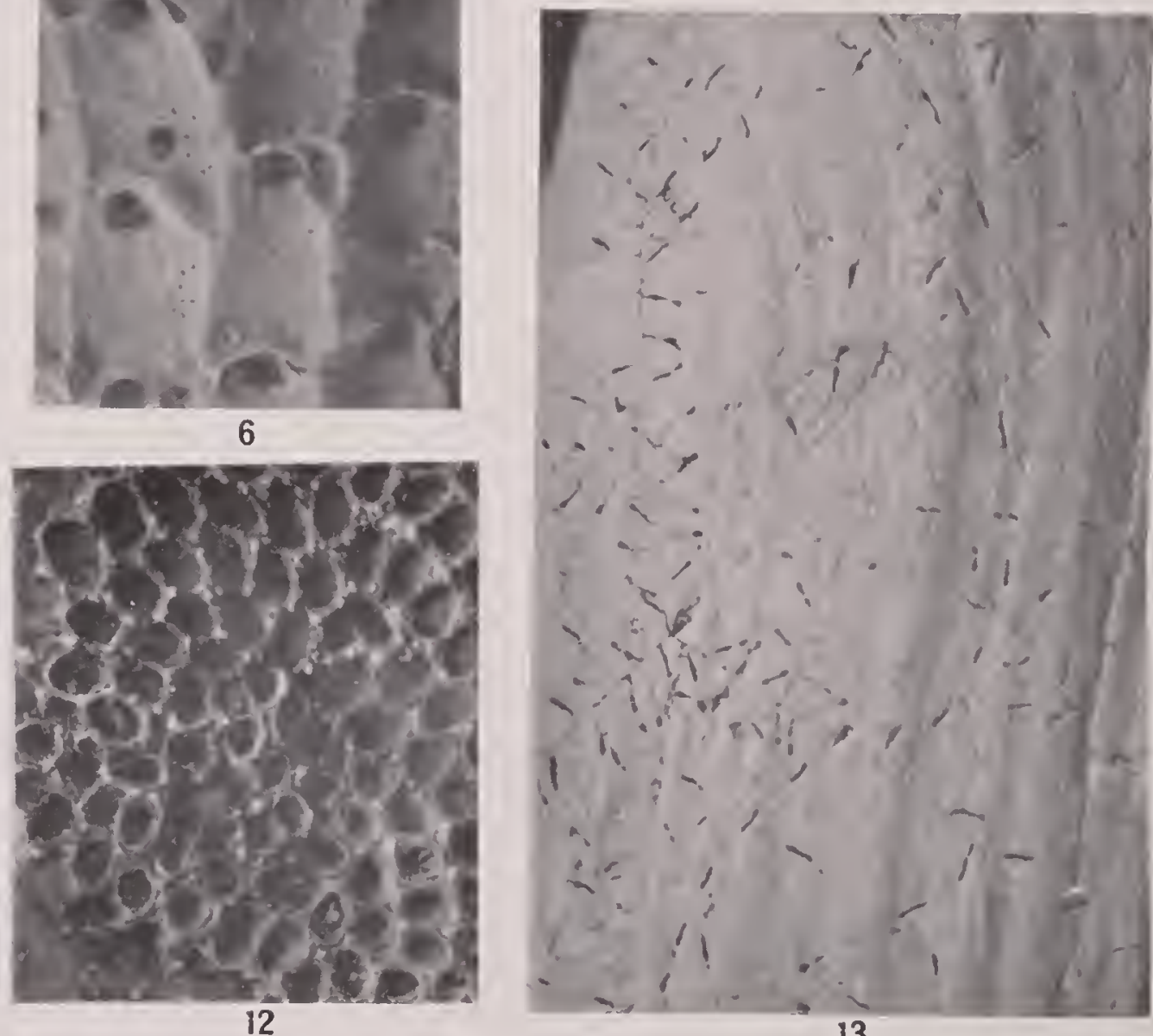

13

NORTH AMERICAN LATER TERTIARY AND QUATERNARY BRYOZOA.

FOr expLanation OF PLATE SEE PAGE 200 . 

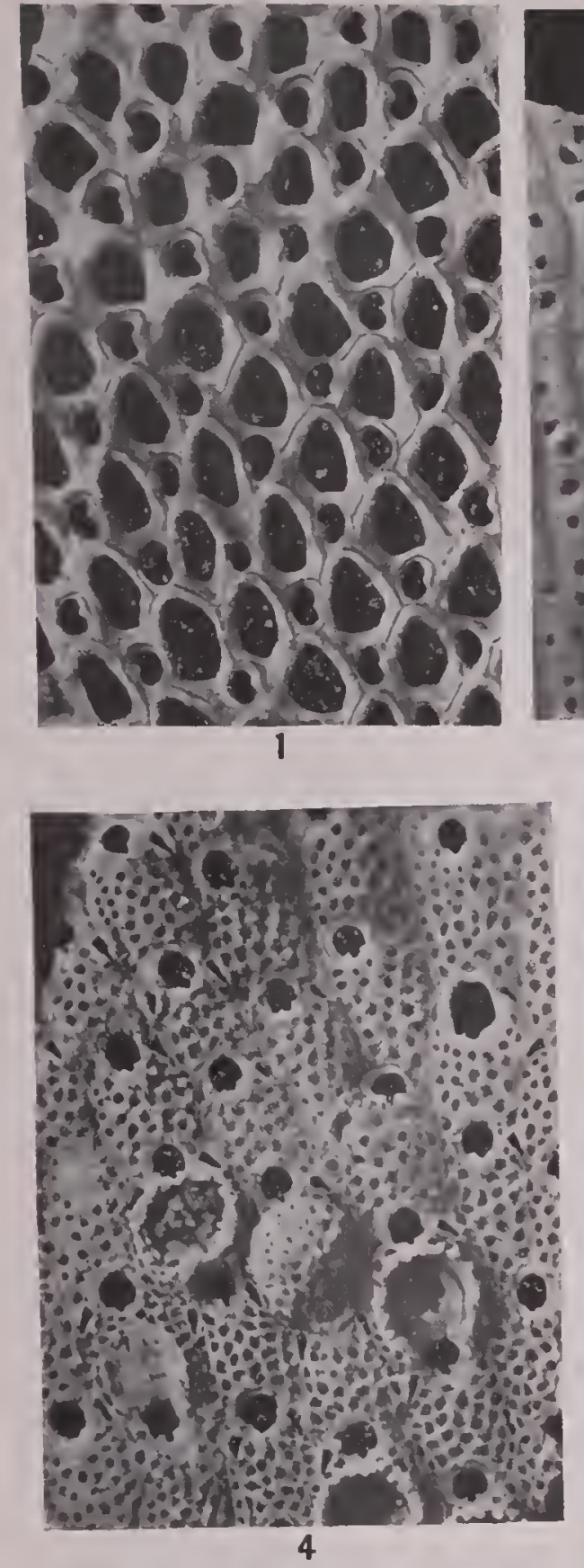
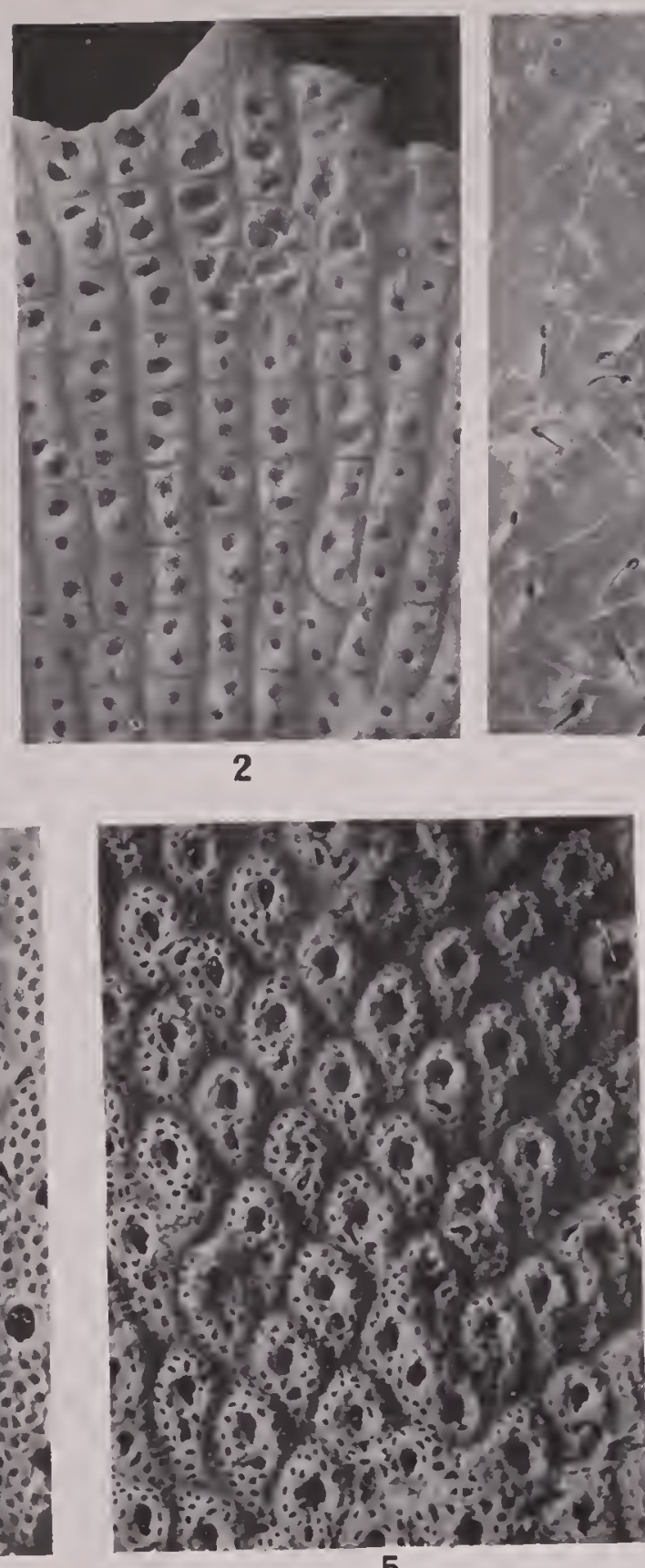

5

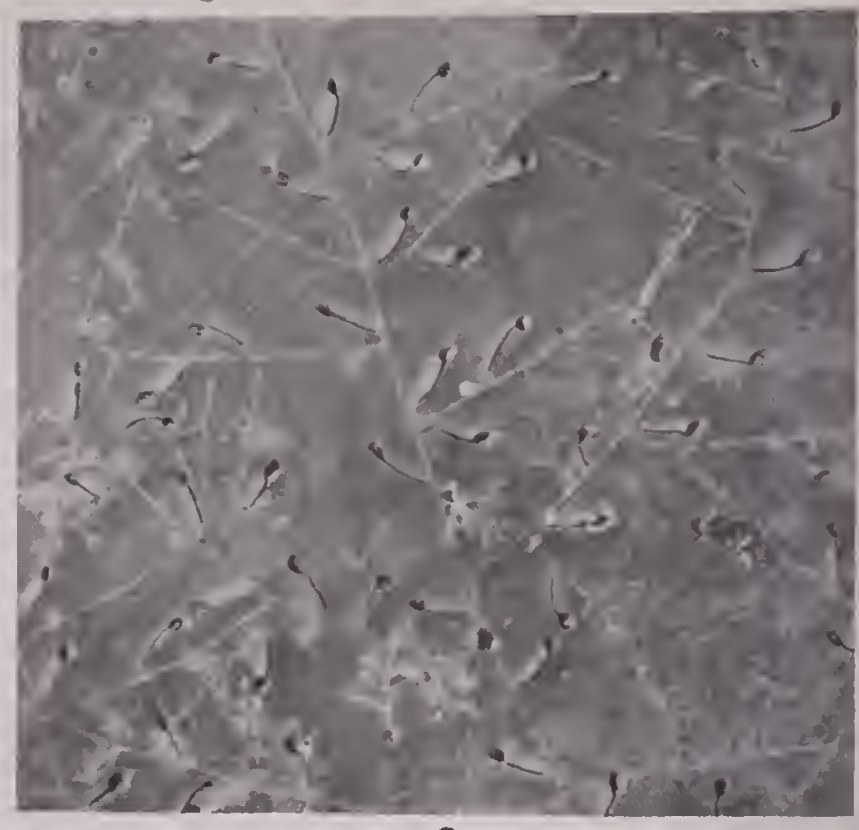

3

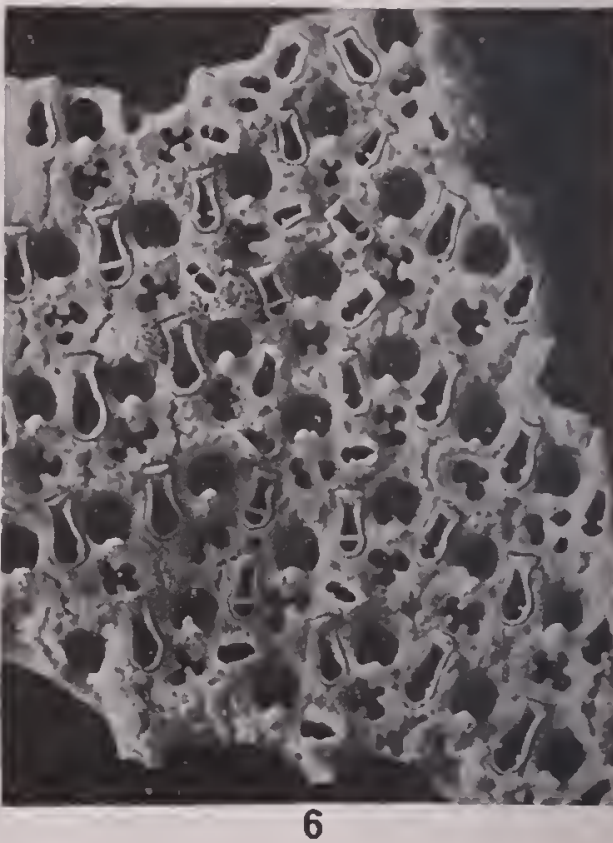

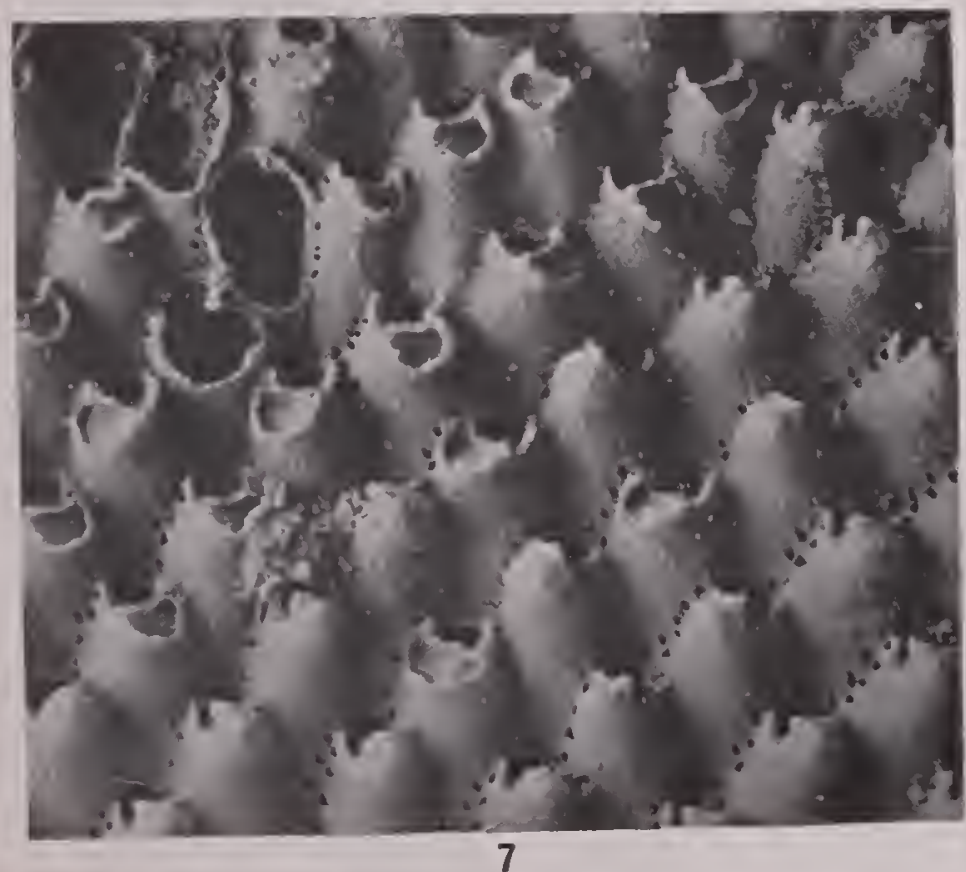

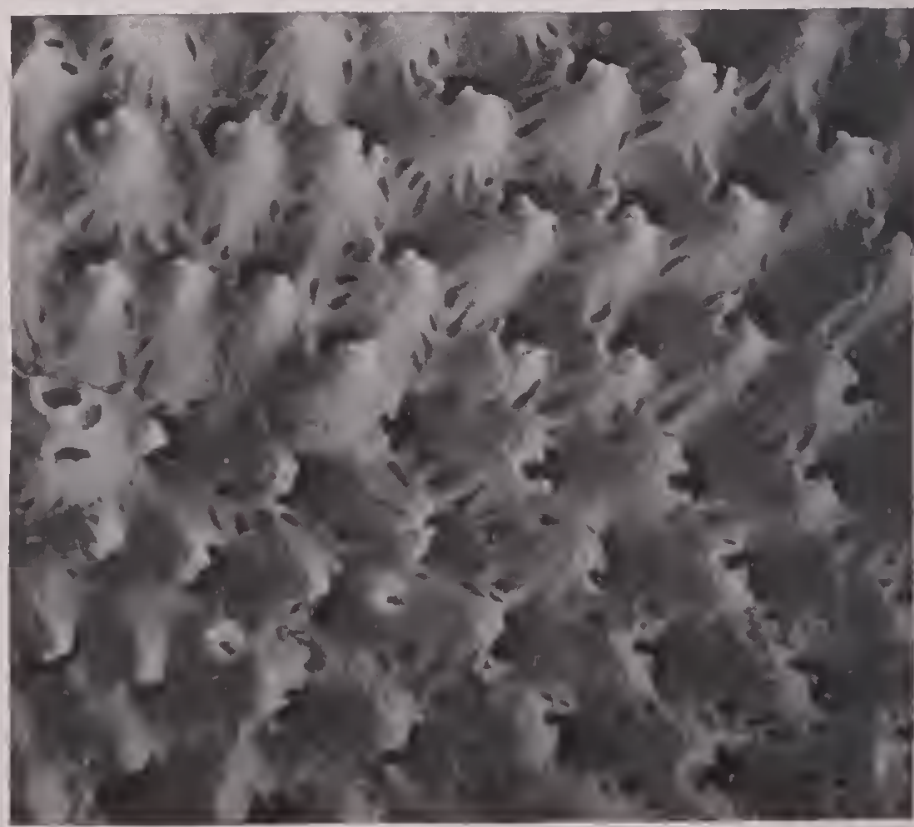

8

NORTH AMERICAN LATER TERTIARY AND QUATERNARY BRYOZOA. 


\section{Plate 47.}

Fiss. 1, 2. Cupuladria biporosa, new species. (p. 29.)

1. Celluliferous surface of the orbicular zoarium, $\times 20$, showing the wide zonecia and the large auriculate viliracula.

2. Inner face of the same zoarium, $\times 20$, with the characteristics two pores to each zooecium.

Lower Miocene (Bowden horizon): Santo Domingo.

Fir. 3. Spathipora longirima, new species. (p. 16.)

A portion of the type specimen, $\times 20$, illustrating the delicate canalicules with the attached zooecia, the apertures of which bear a long rimule.

Pliocene (Waccamaw marl): Waccamaw River, South Carolina.

Fra. 4. Stylopoma magniporosa, new species. (p. 103.)

Surface of the bilanellar zoarium $\times 20$. The large tremopores, the aricularia, and the ovicell hiding the aperture are apparent.

Lower Miocene (Bowden horizon): Santo Domingo.

FIG. 5. Laminopora miocenicu, new species. (p. 160.)

Zooecial surface, $\times 20$, with the parietal dietellae, tremopores, elongate oval zooecia, and long rimule visible.

Lower Miocene (Bowden horizon): Santo Domingo.

Fic. 6. Tremogasterina truncatorostris, new species. (p. 244.)

The bilamellar zoarium, $\times 20$, with the truncated avicularium and the large trifoliate frontal pore well preserved.

Lower Miocene (Bowden horizon): Santo Domingo.

FiGs. 7, 8. Rhynchozoon grandicella, new species. (p. 156.)

7. Marginal zooecia of the incrusting zoarium, $\times 20$, showing the pleurocyst frontal with small areolar pores and the prominent avicularian chamber.

8. Ancestrular zooecia, $\times 20$, with the costules of the frontal better developed.

Pleistocene: Rustic Canyon, Santa Lonica, California. 

INDEX.

a brupta, Schismopora.

acanthina, Chaperia

A canthodesia

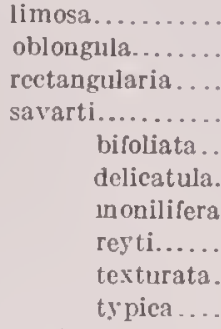

limosa.

oblongula.

rectangulari

savarti.

bifoliata.

delicatula.

inonilifera.

reyti.

texturata.

typica

aculeata, Aimulosia.

Schizopodrella..

Adeona

licckeli

porosa.

Adconellopsis.

coccinclla

umbilicata

Adconidae.

Aetea....

anguina?

agcllus, A mphiblcstrum

Aimulosia.

Ramphonotus.

$$
\begin{aligned}
& \text { aculcata. } \\
& \text { brevis... }
\end{aligned}
$$

radiata.

airensis, Inversiula (Microporella)

albirostris, Ccllcpora.

Discopora...

Ifoloporella .

albispina, Chaperia (Membranipora)

Alderina. .

cesticella

Imphiblestrum......

agellus..

constrictum.

cristatum.

tenuiparictis

amplectens, Hetrrooccium

Anarthropora.

Anasca

anglica, Hcrpetopora ...........................

anguina?, Actca.

angulatum, Rhynchozoon

annulus, A mphiblcstrum

$$
\text { Chapcria. }
$$

Membranipora.

arbuscula, Laminopora...

areolata, Mjsstriopora (?)

Arthropoma..

\begin{tabular}{|c|c|}
\hline age. & (1) \\
\hline 180 & asper, Gcmelliporclla... \\
\hline .50 & asperus, Ramphonotus... \\
\hline 30 & Aspidostoma giganteum. \\
\hline 30 & Aspidostomidae........ \\
\hline 34 & Atrlesopora.......... \\
\hline 34 & reptans..... \\
\hline 30,31 & auricularia, Selenaria....... \\
\hline 33 & auriculatum, Metrarabdotos. \\
\hline 3.3 & avellana, Tretocycloccia.... . \\
\hline 32 & aviculifera, Cystisella......... \\
\hline 31 & Holoporella........ \\
\hline 32 & baccata, Hippodiplosia.... \\
\hline 31 & Menbraniporina..... \\
\hline 139 & Batopora................... \\
\hline 104 & multiradiata... \\
\hline 1.58 & rosila........ \\
\hline 155 & stoliczkai.... \\
\hline 158 & barbarensis, Conoperum.... \\
\hline 159 & Ifembranipora. \\
\hline 161 & beaniana, Retepora........ \\
\hline 161 & bella, Lepralia....... \\
\hline 159 & Porella.... \\
\hline 155 & Smittia......... \\
\hline 49 & Berenicea flabellum?... \\
\hline 49 & biaperta, Eschara...... \\
\hline 47 & Lepralia....... \\
\hline 49 & Schizoporclla... \\
\hline 139 & Stephanosella..... \\
\hline 139 & bicornis, Holoporclla............ \\
\hline 140 & bidentata, Fedora (Cupularia)... \\
\hline 140 & Biflustra delicatula............... \\
\hline 129 & savarti................ \\
\hline 174 & bifoliata, Acanthodesia savarti................ \\
\hline 174 & 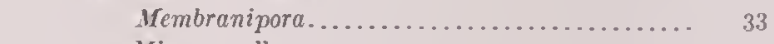 \\
\hline 174 & Microporella............................. \\
\hline 52 & bigiberra, Hippodiplosia........................ 131 \\
\hline 39 & bilabiata, Eurystomella. . . . . . . . . . . . . . 141,142 \\
\hline 39 & Lepralin........................... 142 \\
\hline 44 & bilamellata, Chaperia........................ 51,52 \\
\hline 47 & biperforata, Thalamoporella..................... 62 \\
\hline 52 & biporosa, Cupuladria........................... \\
\hline 44 & botterii, Lepralia. . ............................. \\
\hline 52 & Bracebridgia................................. \\
\hline 45 & deformis. . . . . . . . . . . . . . . . \\
\hline 18 & brevicauda, Pyripora............................. \\
\hline 162 & brevicollis, Lagenipora (?) . ....................... \\
\hline 17 & brevincisa, Schismopora...................... 180 \\
\hline 18 & brevirostris, Hippaliosina..................... 165,166 \\
\hline 49 & brevis, Aimulosia............................. 140 \\
\hline 153 & Smittina (?) $\ldots \ldots \ldots \ldots \ldots \ldots \ldots \ldots \ldots \ldots \ldots \ldots \ldots \ldots \ldots \ldots$ \\
\hline 52 & californica, Idmonea........................... \\
\hline 53 & 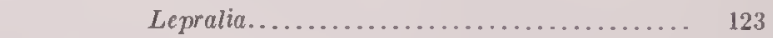 \\
\hline 52 & Lichenopora....................... \\
\hline 161 & 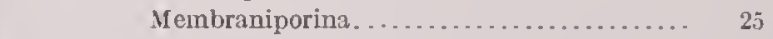 \\
\hline 19 & Microporella......................... \\
\hline 97 & Microporclla ciliata..................... \\
\hline 97 & 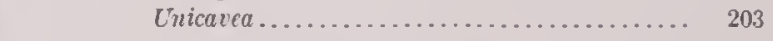 \\
\hline
\end{tabular}

$$
\text { cornuta. }
$$

$12181-23-B$ ull, 125 


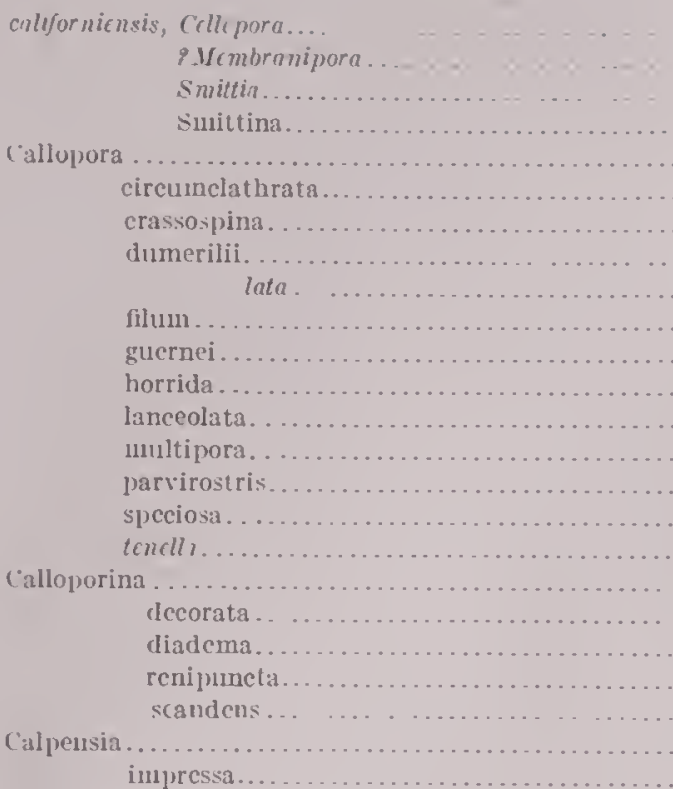

Page.

.

Chaperia............... 50,51

acanthina. ................. .. 50

altispina.................

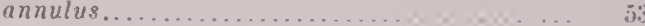

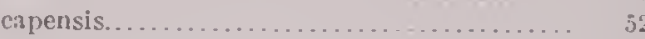

cristata.............................. 5

bilamellata..................... $\$ 1,52$

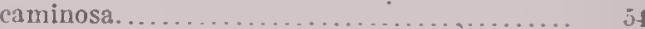

cervicornis ............................. is

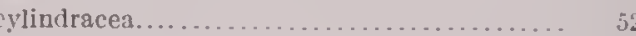

galeata............... 52

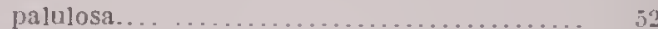

parvispina............................. if

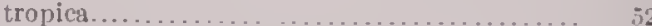

Claperiidae............................. 49

charleswortbi, Mlicerita... . . . . . . . . . .

Cheilopora sinecra............................ 163

Cheiloporina..............

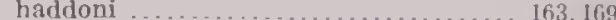

cherreuxi, Iakaria................................. ${ }_{97}^{17}$

Cianotremella gigantea....................... 85

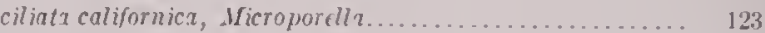

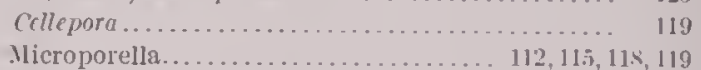

Vicroporclla (Fenestrulina)

ibraculifera, Microporella...................... 124

circumelathrata, Callopora..................... 4.3

clarki, Filisparsa... Ifembranipora .................... 13.

parrula, Filisparsa....................... 196

clarula, Hippaliosina (Lepralia)................. 165

coarctatum, $\$ 1$ ytiozoum...................... 185

coccinella, . Ideoncllopsis...................... 161

collifera, Porella............................. 14s

colligatum, Metrarabdotos..................... 162

complicata, I iplodidymia......................... 68,69

Conopcum.................................. 26

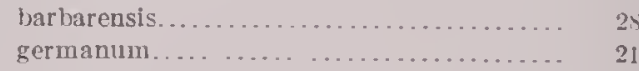

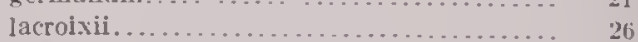

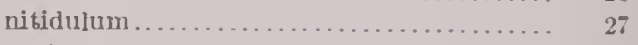

ovale........................... 26

constrictum, A mphiblestrum .....................

contigua, lepraliella........................ 153

contorta, Laminopora............................ 161

convoluta, Palmicellaria... . . . . . . . . . . . . . . . .

cornuta, Arthropoma . . . . . . . . . . . . . .

Reptescharellina.

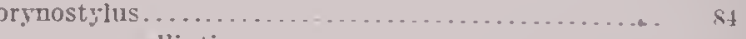

cllipticus........................... st

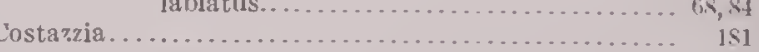

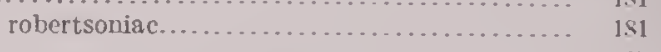

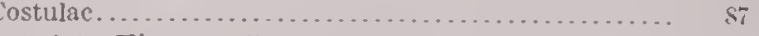

costulata, Hippoporella...................... 133 Palmicellaria ........................ 150

chsilabiata, Pucllina...............

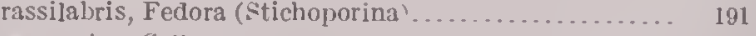

Crateropora falcata..............................

crenulata, Labiopora........................... 65

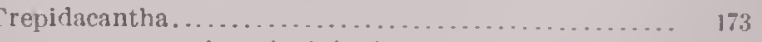

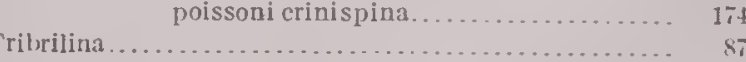
cuspidata......................... si 
Cribrilina ligulata. punetata. radiata innominata.

Cribrilinidae.

eribrosa, Cellepora 1.epralia..

erinispina, Crepidacantha poissoni

('risia

pacifica.

$$
\text { serrata. }
$$

('risidae.

rrisina

striatopora

cristata, Chaperia (Ampliblestrum).

crustacea, Myriozoella.

Ctenostomata.

euculata, Watersipora.

eucullata, Spathipora.

cumulata, Sehizoporell ...

Cupuladria

biporosa.

Cupularia canariensis.

denticulata.

dentieulata

doma..

guineensis.

haidingeri.

johnsoni.

lowei.....

multispinata.

reussiana.... . .

robertsoniac.

umbellata..

clurtun, Rliyuehozoou. .

euspidata, ('ribrilina.

(yclicopora.

gigantea.

mansfieldi.

multilanellosa.

Cyeloeolposa

perforata

spinifera....

temuiparietis

Cyeloperiella rubra.......

Cyclostomata.

cylindricea, Chaperia (Llectra)

Cystisella$$
\text { a viculifera }
$$

dactylus, Fedora (Diseoflustrellaria)

Dakaria.

$$
\begin{aligned}
& \text { chevreuxi... } \\
& \text { grandis...... } \\
& \text { parviporosa . } \\
& \text { torquata.... }
\end{aligned}
$$

deeorata, Calloporina

deformis, Bracebridyia. .

clelieatissina, Siphonoporella. .

clelieatula, Aeanthodesia savarti.

$$
\text { Biflustra. }
$$

dentata, Vembranipora.

deutieulata, Cupularia

Discoporella .

Hemiseptella

depressa, Hippaliosina (Lepralia).

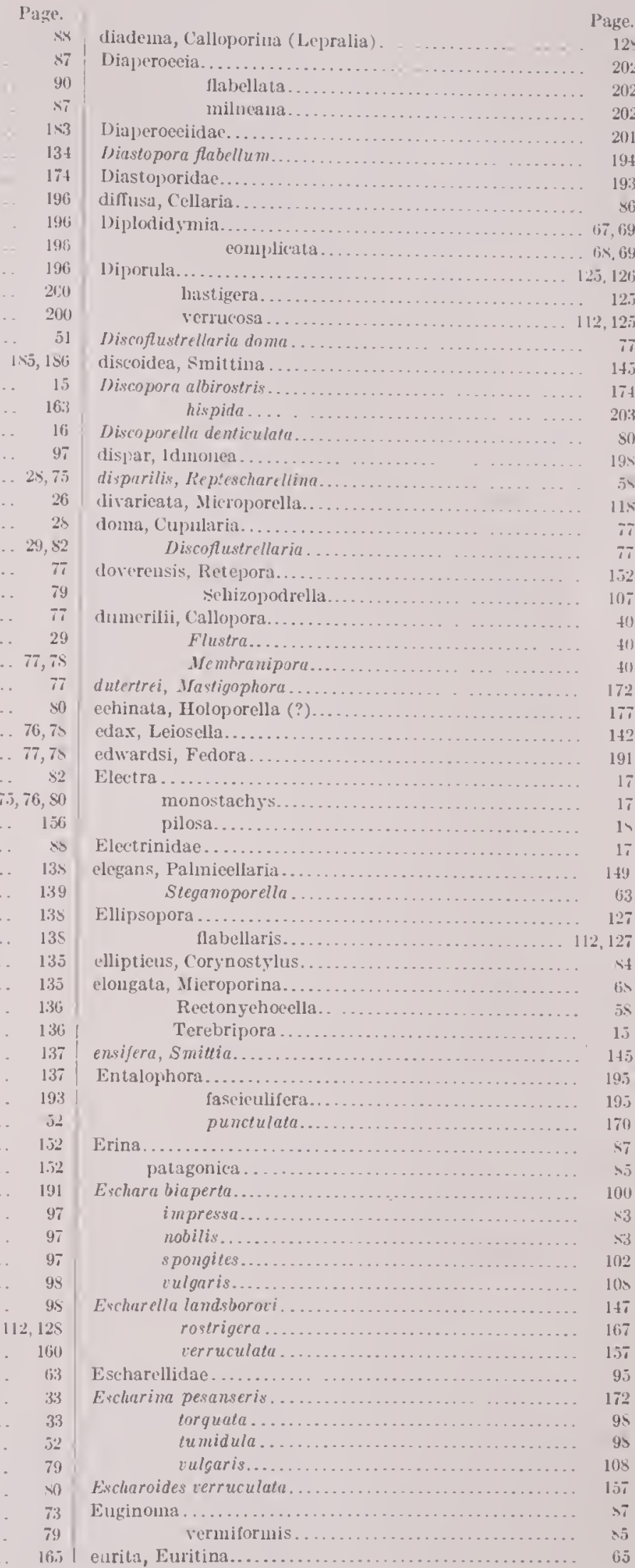

(

<. 69

2 


\begin{tabular}{|c|c|}
\hline \begin{tabular}{c}
\multicolumn{2}{c}{ Page. } \\
$\ldots \ldots$
\end{tabular} & Flustrellaria texturata. \\
\hline Eurystomella......... & Foraminella.......... \\
\hline bilabiata... & lepida......... \\
\hline . foraminigera.. & foraninigera, Eurystomella.. \\
\hline Eurystomellidae........... & fossulifera, Membranipora... \\
\hline eustomata, Mieroporella.. & fusifera, Floridina........... \\
\hline Reptoporina..... & galeata, Chaperia......... \\
\hline exeelsa, Fedora (Kionidella). & Membranipora..... \\
\hline exeentriea, Orbitulipora...... & Gemelliporella............ \\
\hline exigua, Fenestrulina (Microporeila) ... & asper...... \\
\hline exilis, Manzonella................. & $\begin{array}{l}\text { punetala.. } \\
\text { vorax...... }\end{array}$ \\
\hline xplusa, 1dmonea (?).............. & $\begin{aligned} & \text { vorax....... } \\
& \text { Gephyropliora........... }\end{aligned}$ \\
\hline falcata, Crateropora.............. & $\begin{array}{l}\text { Gephyropliora.... } \\
\text { germana, Lembrai }\end{array}$ \\
\hline Farcimia oculata........ & (n) \\
\hline tenella......... & gibbera, Mieropor \\
\hline faseieulifera, Entalophora. & gibbosa, Hip \\
\hline Tubulipora. & gigantea, Cia \\
\hline Fedora................... & $\ldots \ldots \ldots \ldots \ldots \ldots \ldots$ \\
\hline$\ldots \ldots 191$ & gigauteun, Aspi \\
\hline 191 & glomeris \\
\hline 191 & graude, Memt \\
\hline 191 & grandicella, Hemiseptella.... \\
\hline 191 & Rhynchozoon.... \\
\hline$\ldots \ldots \ldots$ & Sin \\
\hline .......... & grandis, Dakaria. . \\
\hline 191 & (n............. \\
\hline 191 & 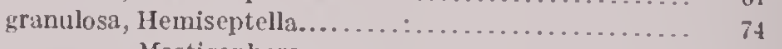 \\
\hline$\ldots \ldots+\cdots$, & (n. \\
\hline 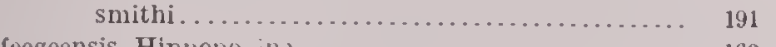 & Rhainplostomelia........................ \\
\hline feegeensis, Нippopowind . . . . . . . . . . . . . . . . . . . . . & guernei, Callopora ........................... \\
\hline 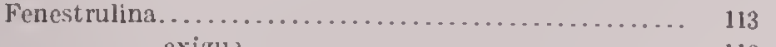 & Membranipora... \\
\hline exigua........ & guineensis, Cupularia.......................... \\
\hline$\ldots \ldots \ldots 112,115,116$ & haddoni, Cheiloporina ....................... 163,169 \\
\hline$\ldots \ldots \ldots \ldots 113,116$ & haidingeri, Cupularia.......................... 77,78 \\
\hline porosa........................... 117 & 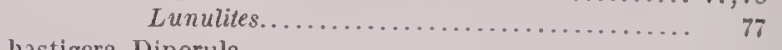 \\
\hline 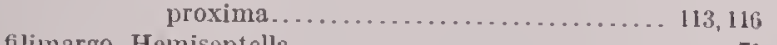 & hastigera, Diporula ............................. \\
\hline filinargo, Hemiseptella........................... 71 & Mieroporella (Diporula) .................. \\
\hline 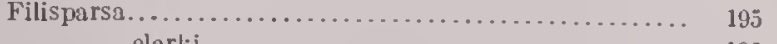 & 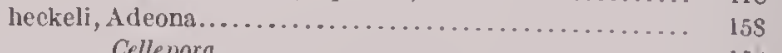 \\
\hline elarki................................... & 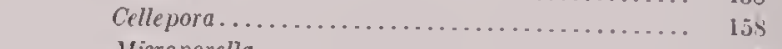 \\
\hline 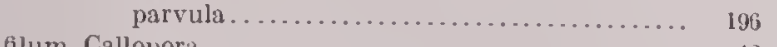 & 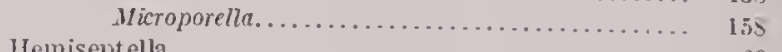 \\
\hline 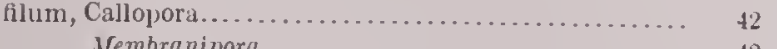 & 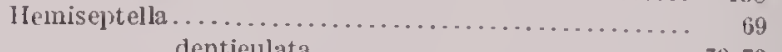 \\
\hline 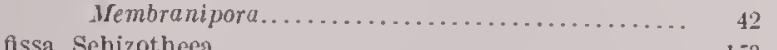 & dentieulata............ \\
\hline 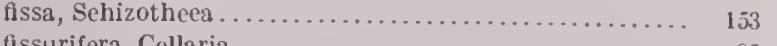 & …....... \\
\hline 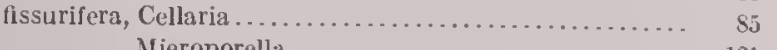 & 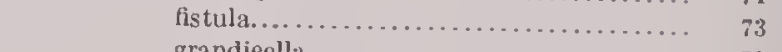 \\
\hline 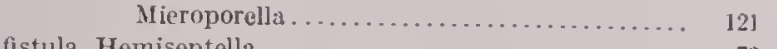 & ieellit........................... \\
\hline 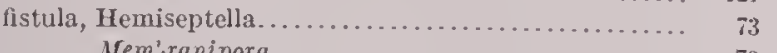 & granulosa........................... \\
\hline Memiranipora................... & labiata..................... $68,69,72$ \\
\hline flabellaris, Ellipsopora (Microporella) ........... 112, 127 & lacinia........................ 70 \\
\hline eia $\ldots \ldots \ldots \ldots \ldots \ldots \ldots \ldots \ldots \ldots \ldots \ldots \ldots+202$ & lata............................ \\
\hline (n. & elsem .............. \\
\hline 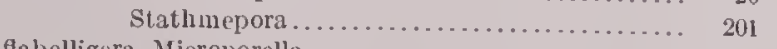 & (n) \\
\hline ….............. & (n. \\
\hline flabellum? Berenicea.. & gulata........................... \\
\hline Diastopora....... & oporoides......................... \\
\hline Floridina .................. & 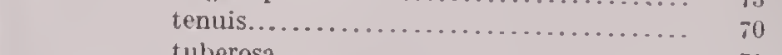 \\
\hline$\ldots \ldots \ldots \ldots \ldots \ldots$ & 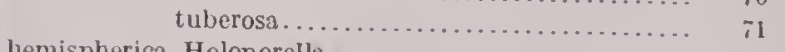 \\
\hline ................. & orella . . . . . . . . . . . . . . \\
\hline ieella..... & $\ldots \ldots \ldots+\cdots \cdots \cdots$, \\
\hline …....... & ….............. \\
\hline regularis......... & (n.............. \\
\hline floridina, Selhizopodrellı. . & 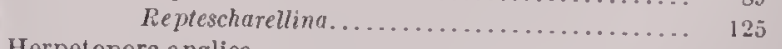 \\
\hline Flustra Dumerilii.......... & Herpetopora anglic: \\
\hline corti............... & Heterooeeium anplcetens...... \\
\hline tehuelca............. & Heteropora tortilis......... \\
\hline tuberculatı............... & Heteroporidae............. \\
\hline Flustrainorpla ................. & hexagona, Mieroporella............. \\
\hline marginata....................... 112,127 & lexagonun, Rhagasostoma .......... \\
\hline
\end{tabular}


hians, Odontionella (Membranipora)... t , ..

multispinata. quadrispinosa.

Hippaliosina. .

brevirostris

clavula......

depressa.

laxipora.

rostrigern.

sandbergeri

Hippellozoon novaezclandiae

Hippodiplosia. .

baccata.

Hippomenella . bigiberra.

infratelum.

Hippopodina feegeensis

Hippopodinidae.

Hippoporclla . .

costulata.

papulifera

spinosa

Hippoporina

gibbosa.

lata......

pusilla

vestita.

Hippothoa.

hyalina

\section{rugosa}

isabclleana.

mucronata

pesanseris.

spongites.

Hippothoidae.....

hispida, Discopora.

Lichcnopora.

Holoporella.

albirostris

aviculiferß.

bicornis..

echinata.

hemispherica

massalis.... . .

mucronata.

orbifera.

parvula.

rostrifera.

subturrita.

turrita.

umbonata

holostoma, Woodipora

horrida, Callopora....

Membranipora

Treinogasterina

llyadesi, Microporella.

hyalina, Cellepora....

Celleporella.

Hippothoa.

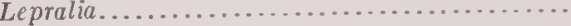

rugosa, Hippotliua.

Idmonca. ...

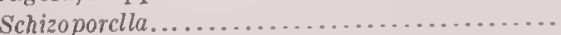

californica.

dispar...

expansa.

milneana....
Page.

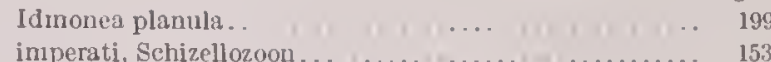

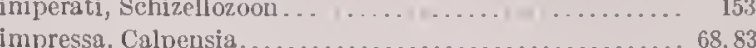

impressa, Calpensia............................ 68, 83 Eschara............................... $\quad 83$

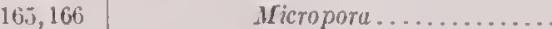

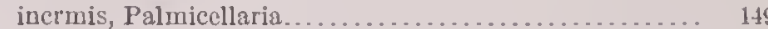

inflata, Microporclla............................. 119

informata, Cellcpora............................. 102

Reptocelle poraria

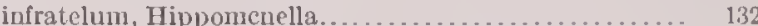

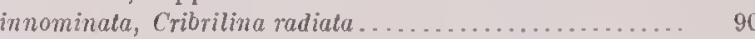

Lcpralia............................ 90

Puellina............................. 90

inversa, Inversiula............................ 112

inversa (Microporella) .......................... 129

Inversiula ................................. 113,129

airensis............................ 129

inversa..................... 112, 129

nutrix........................... 129

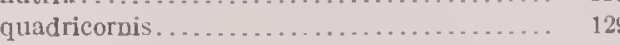

isabcllcana, Hippolhoa............................ 10

Stylopoina......................... 103

johisoni, Cupularia............................ $70,72,89$

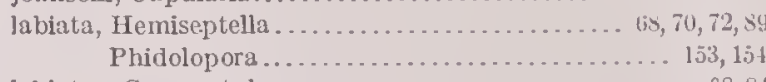

labiatus, Corynostylus .............................. 8

Labiopora ................................. 67 crenulata................................... 65 miocenica.........................

Lacerna......................................

mucronata............................ $9_{9}$

lacinia, Hemiseptella.........................

lacroixii, Conopeum............................

Membranipora.

Iacrymosum, Metrarabdotos.................... 164

Lagenipora............................. 17

brevicollis............................ 17

spinulosa.........

Laminopora .............................. 160, 16

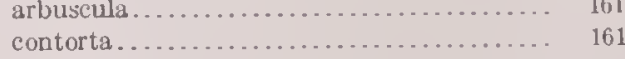

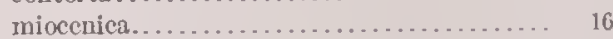

panceolata, Callopora...............................

Schismopora........................ 181

landsborovi, Escharclla........................... 147

lata, Callopora dumerilii ....................... 40

Hcmiseptella............................. T0.

Hippoporina............................. . 131

laticella, Rhamphostomella.................... 151

latisinuata, Schizoporella........................ 96

laxipora, Hippaliosina......................... 165

Leiosella................................... 142

edax................. 142

lenticularis, Orbitulipora................... . 187, 189

lepida, Foraminclla..............................

Lepralia ..................................... 133

bella................................ 147

biaperta............................... 100

bilabiata............................... 142

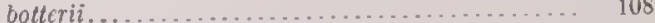

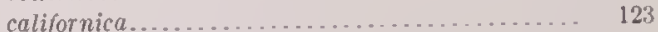

cribrosa............................... 134

hyalina. . . .........

innominatu. ........................... 90

maculata.......................... 182

marylandica.......................... $\$ 7$

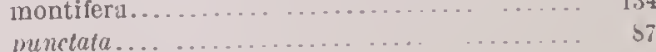




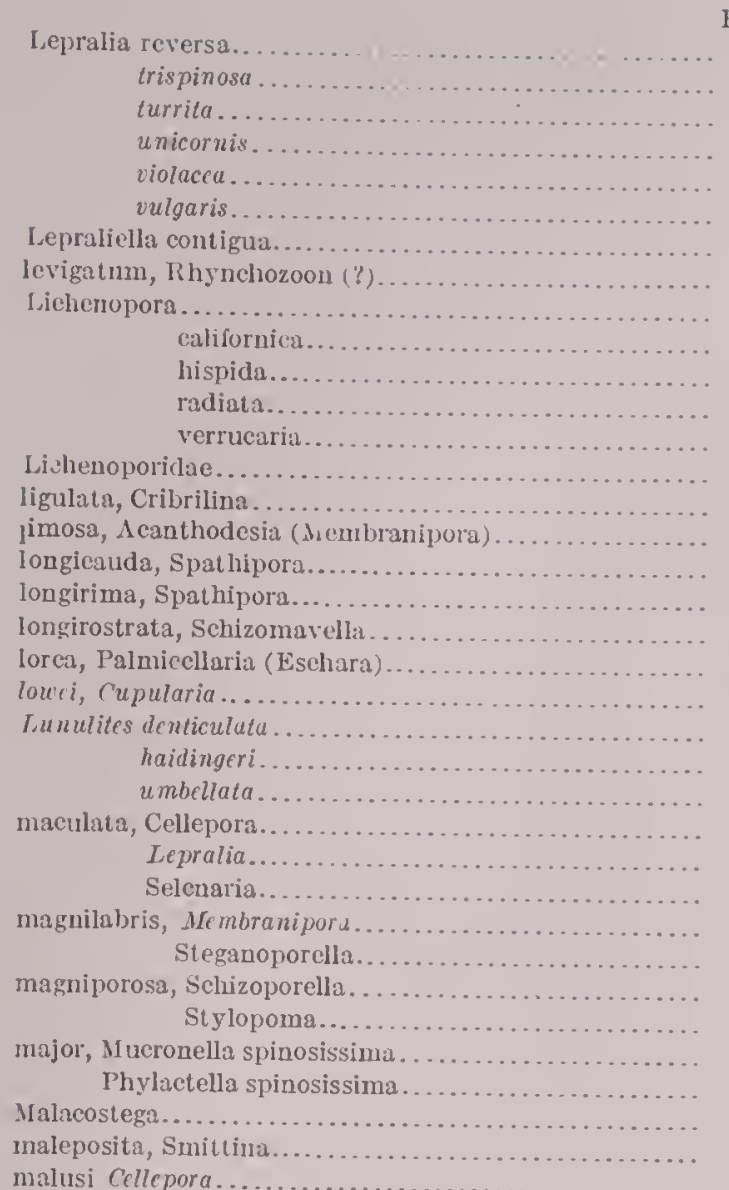

malusi Cellepora....

$$
\text { fienestrulina. }
$$$$
\text { Microporclla. }
$$$$
\text { Iamillopor }
$$$$
\text { tuberosia. }
$$

mandibulata, Cellaria.

ruansfieldi, Cyclicopora?

Manzonella.

$$
\text { exilis. }
$$

marginata, Flustramorplu

Microporella... Schizopodrella.

marsupium porifera, Porella

marylandica, Lepralia.

massalis, cellepora...

Ifastigophora.

$$
\text { Holoporella. }
$$

dutertri.

granulosa.

$$
\text { pesanscris. }
$$

Meeynocciidac...

I elicerita.

$$
\text { charlesworthi. }
$$

Mclobesia radiata.

membranacea, Membranipora...

Ientbranipora.

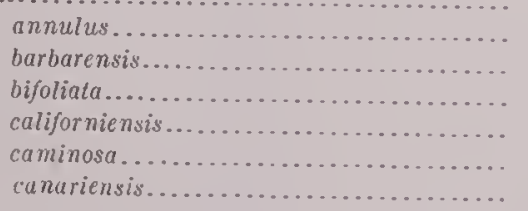

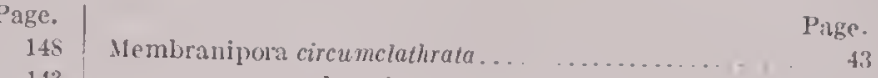

.

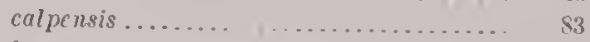

dentata.........

dumerilii.......................... th

filum..................................... th

fistula ............................

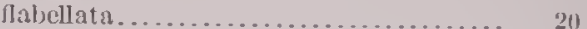

fossulifera......................... 20

gulcata..............................

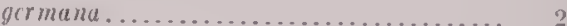

gucrnci............................ th

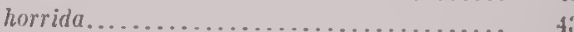

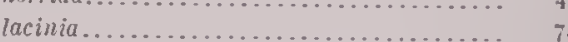

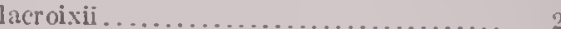

magnilabris........................ (is

membranacein.

monostaclys................................

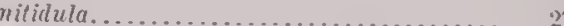

ablongula .................. 3t

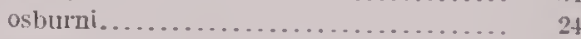

partula................................

reyti.

satarti........... 31

speciosa..........................

spiculata...........................

tchuelca......................... 2

tuberculata...............................

tnberimargo.......................

vanghani..........................

Iembraniporidra......................

parca......................... 39

baceata.

califormica

tenclia..........................

vincularina........................

Mcmbrendoecium....................... 36

grande........................

parvicapitatum................... 36

mesleri, Proboscina......................... 193

Metracolposa....................... $9_{22}$

mucronata....................... 92

Mctrarabdot os................................ 162

auriculatum.................... 164

colligatum....................... 162

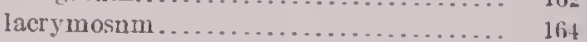

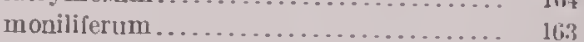

ichaelseni, Henisept clla . . . . . . . . . . . . . $70 \ldots \ldots \ldots \ldots$

icropora............. 70,73

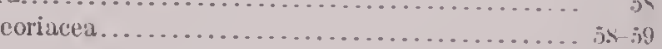

impressu .............................

icroporella ............................. 113,117

biloliat a............................... 121

ealiforuica......................... 121

ciliata..................... 112,11j,11k, 119

coronata.........................

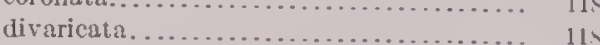

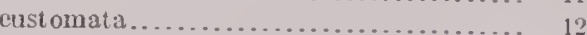

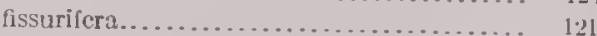

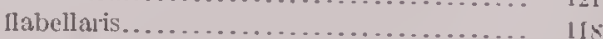

flabelligera..............................

gibbera................................

hastigera.............................

heckeli......................... 15.

hecrmanni..............................

hexagona........................ 


\begin{tabular}{|c|}
\hline 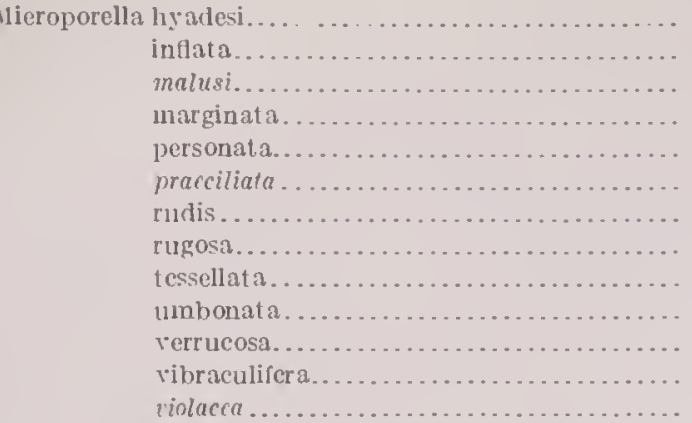 \\
\hline
\end{tabular}

Microporellac.

Mieroporina.

milneana, Diaperoecia

Idmonea.

minima, Floridina

ininor, Hemiseptella (Mcinbranipora)

minuta, Cellepora.

$$
\text { Styloporna }
$$

minutissima, Fedora (Lepralia) . .

mioecnica, Labiopor

$$
\text { Laminopora }
$$

mockleri, Mystriopora.

monilifera, Acanthodesia savarti.

moniliferum, Metrarabdotos.

Triphyllozoon

IIonostachys, Electra.

$$
\text { Membranipora }
$$

montifera, Lepralia .

inucronata, Ilippoihoa

Holoporella.

Lacerna...

Metracolposa.

Mucronclla spinosissima var major

Julticrescis tortilis.

multilamellosa, Cy clicopora.

multipora, Callopora(?)

$$
\text { Siplonella (Flustrcllaria) }
$$

Iultiporina umbilicata.

multiradiata, Batopora.

multispinata, Cupularia. .

$$
\text { Hincksina. }
$$$$
\text { Ramphonotu }
$$

nutabilis, Ogivalina.....

$$
\text { Schizopodrella }
$$

Myriozoella.

Myriozoidae.

Miyriozoum.

$$
\begin{aligned}
& \text { coaretatum } \\
& \text { subgracile. }
\end{aligned}
$$

Mystriopora

(?) areolata

möckleri

Nellia...

oculata.

nitidula, Ifembranipora.

$$
\text { Conopeum? }
$$

nobilis, Eschara.

noraezelandiae, Hippellozoon

uutrix, Inversiula. .

obliqueseriata, Fedora (Ki ionidella)
Page.

119
119

115

118

118

119

118

$11 \mathrm{~S}$
122

122
123

115

124

159
2,113

112,113

$6 \mathrm{~s}$

65
202

202
202

57

70
152

152
104

191

67

160

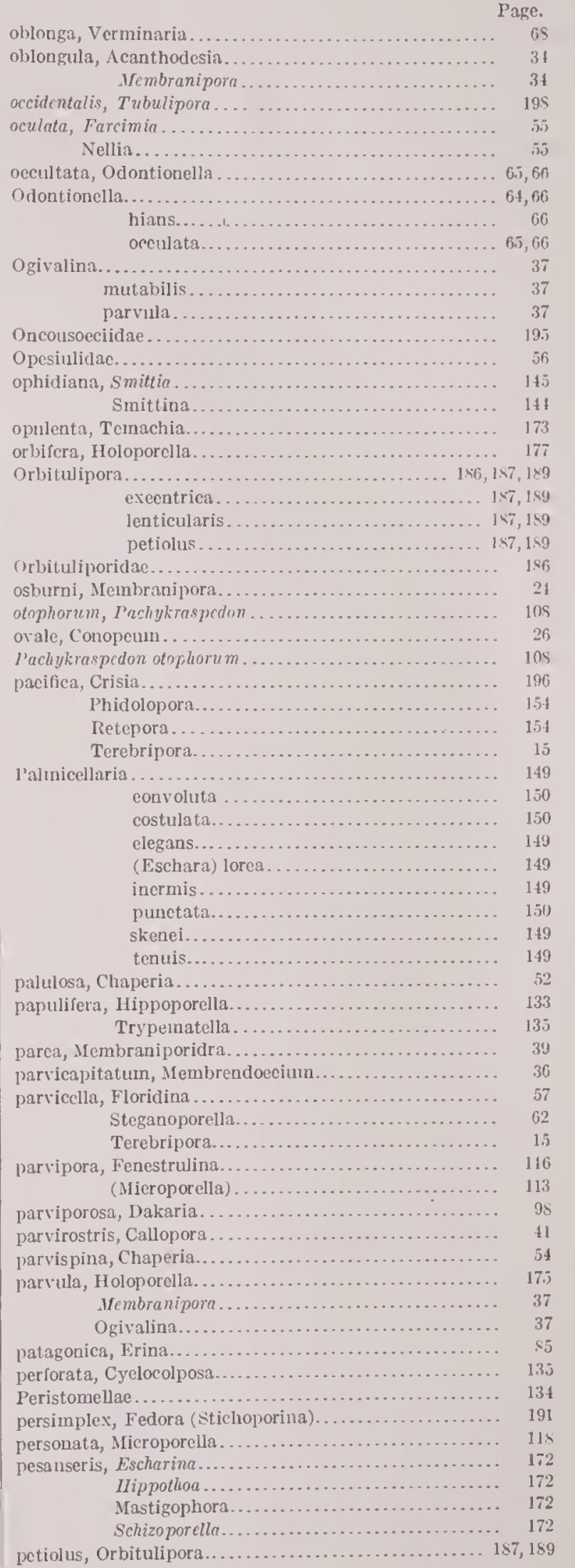




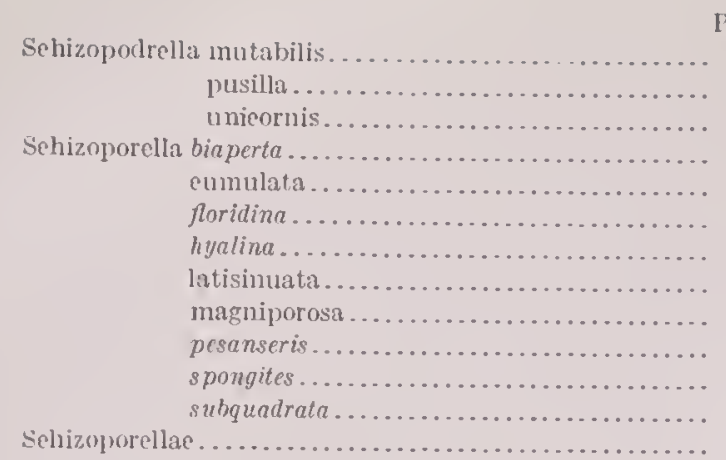

sehizorthnsecos.

Sehizotheea fissa.

seripta, Cellepora

Pucllina radiata.

Selenaria..

$$
\text { aurieularia }
$$

Semitubigera tuba

errata, Crisia

simplex, Fedora (Stielıoporina)..

$$
\text { Vibracellina. }
$$

sineera Cheilopora.

sinefilum, Terebripora.

sinuosa Cellaria.

siphonella (Flustrellaria) multipor

siphonoporella. delica tissima

skenei, Palmieellaria (Millepora)

smithi, Fedora (Mamillopora) .

Smittia bella.

$$
\begin{aligned}
& \text { californicnsis } \\
& \text { ensifera..... } \\
& \text { ophidiann... } \\
& \text { trispinosn... }
\end{aligned}
$$

Sinittina.

$$
\text { brevis }
$$

ealiforniensis.

discoidea.

grandicella

maleposita

ophidiana

porifera.

reticulata.

trispinosa

Smittiuidae.

spathipora.

$$
\begin{aligned}
& \text { enenllata.. } \\
& \text { longicauda } \\
& \text { longirima. }
\end{aligned}
$$

spreciosa, Callopora(?)

specinsa, Membranipora...

Sphacrophora...

spiculata, Membranipora.

spinifera, Cyelocolposa (?)

spinosa, Hippoporella...

spinosissima major, Mueronell

Phylactella.

spinulosa, Lagenipora

spongites, Cellepora.

Eschara...

IIippothoa.

Schizoporella

stathmepora...
Page.

105
(5)

teganoporella.

magnilabris. parvicella.

Stegmoporellidae.

biaperta...............................

stichoporina............................. I reussi ............................ 190

tubcrosa........................... 192

stomachetosellidae ................................. 192

striatopora, Crisina?............................

stylopoma..................................

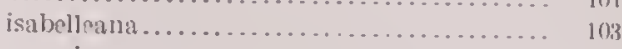

inagniporosa...................... 103

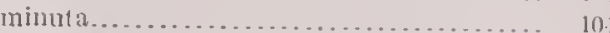

spongit.es............................ $10^{2}$

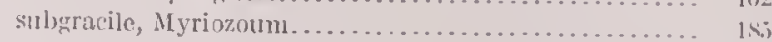

subquadrata, Schizoporella ........................

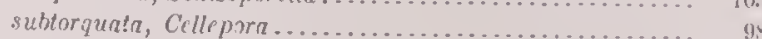

subturrita, IIoloporella....................... 176

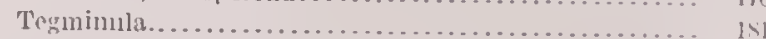

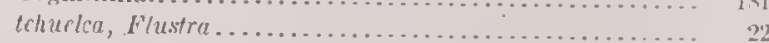

Memmamipura ......................... 22

a.................................... 17

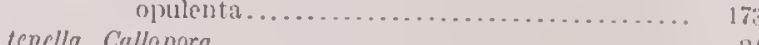

tenclln, Cullopora................................ 24

Cellarin.......................................

Farcimin .............................. 5

Membraniporina.........................

Nellin.....................................

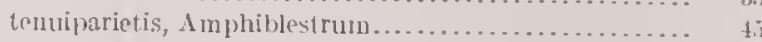

Cyeloeolposa............................

tennis, Hemiseptella (.lembranipora)................ in

Palniecllaria.............................. 149

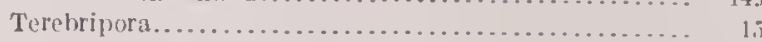

elningata.................................

pacifica.............................

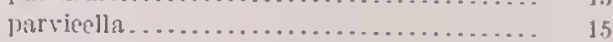

sinefilum..................................

Terehriporidac.....................................

tesselata, Cellepora.............................. ${ }_{12}$

Mieroporella......................... 122

texturata, teanthodesia savarti.................. ${ }_{32}$

Flustrcllaria..............................

Thalamoporella..................................

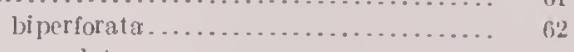

granulata...............................

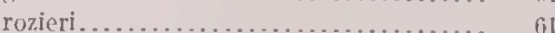

Thalamoporellidar...........................

Theonoa........................................

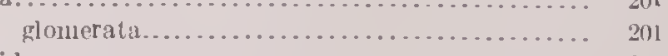

Theonoidac................................. 201

torquata, Dakaria............................ 9s

Escharina................................ 9s

tortilis, Ilctropora.......................... ${ }_{206}$

Mnlticrescis............................ 20,

Tretocycloecia......................... 206

Tiemogasteriua.................................... 167

horrida.................... $133,16 \mathrm{k}$

Tretocyelocia ............................. 206

avellana.......................... 206

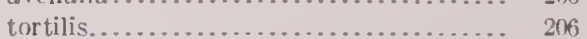

Tretoeycloedidae.................................. 20.3

triangularis, Cauloramphus...................... ts

Triphyllozoon moniliferum ...................... 153

flabellata.

12184-23- Bu11. 125-25 


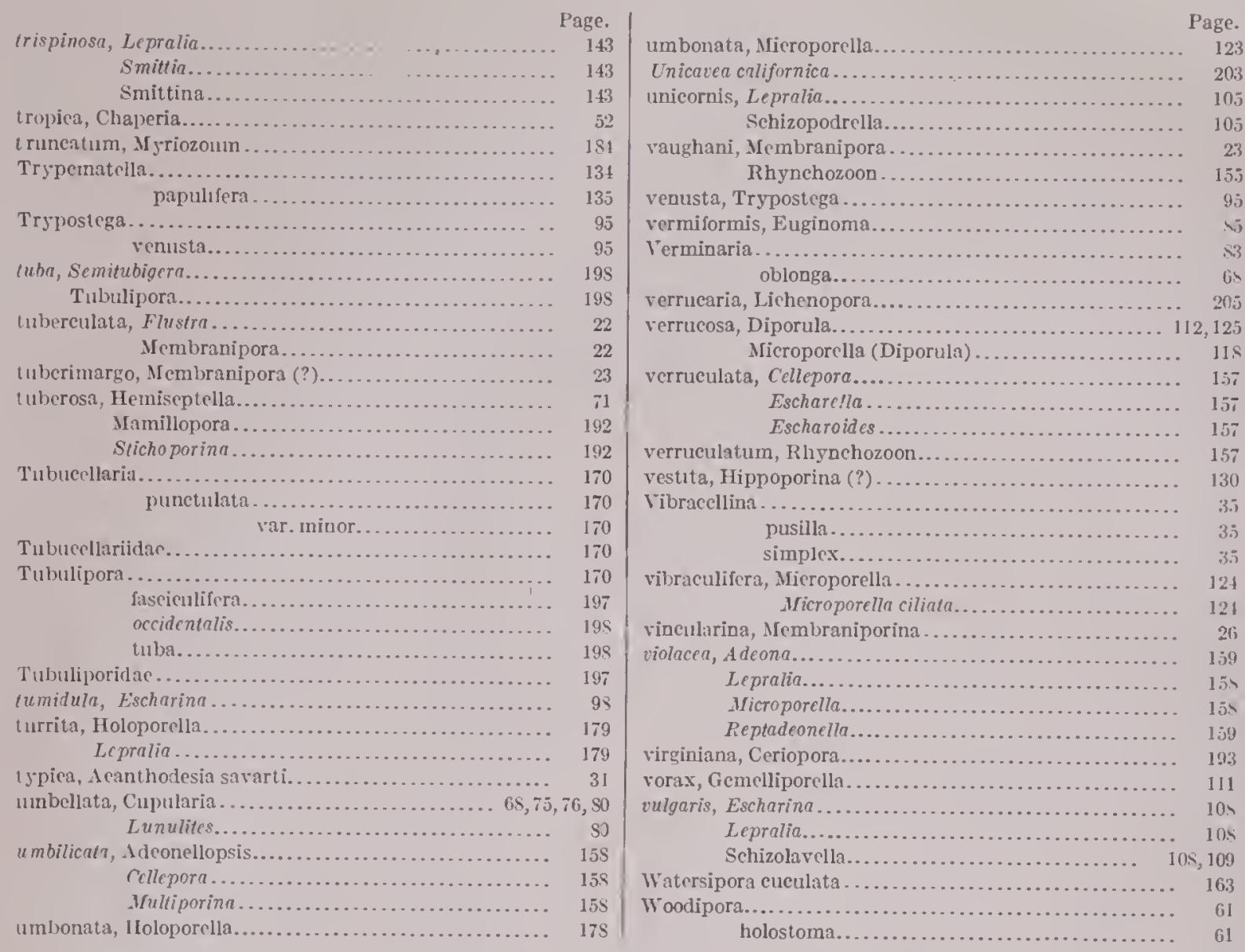

\footnotetext{
ADDITIONAL COPIES

OF THIS PUBLICATION MAY BE PROCURED FROM

THE SUPERLNTENDENT OF DOCUMENTS

GOVERNMENT PRLNTING OFF AE

WASIINGTON, D. C.

75 CENTS PER COPY

PURCHASER AGREES NOT TO RESELL OR DISTRIBUTE THIS

COPY FOR PROFIT. -PUB. RES. 57, APPROVED MAY 11, 1929
} 







